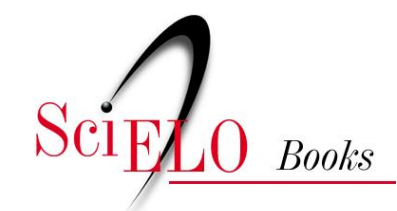

\title{
Epidemiologia nutricional
}

\author{
Gilberto Kac \\ Rosely Sichiery \\ Denise Petrucci Gigante \\ (orgs.)
}

KAC, G., SICHIERI, R., and GIGANTE, DP., orgs. Epidemiologia nutricional [online]. Rio de Janeiro: Editora FIOCRUZ/Atheneu, 2007. 580 p. ISBN 978-85-7541-320-3. Available from SciELO Books $<$ http://books.scielo.org $>$.

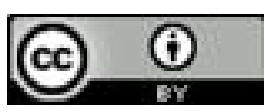

All the contents of this work, except where otherwise noted, is licensed under a Creative Commons Attribution 4.0 International license.

Todo o conteúdo deste trabalho, exceto quando houver ressalva, é publicado sob a licença Creative Commons Atribição 4.0.

Todo el contenido de esta obra, excepto donde se indique lo contrario, está bajo licencia de la licencia Creative Commons Reconocimento 4.0. 


\section{Epidemiologia Nutricional}




\section{FUNDAÇÃO OSWALDO CRUZ}

Presidente

Paulo Gadelha

Vice-Presidente de Ensino, Informação e Comunicação Maria do Carmo Leal

\section{EDITORA FIOCRUZ}

Diretora

Maria do Carmo Leal

Editor Executivo

João Carlos Canossa Mendes

Editores Científicos

Nísia Trindade Lima e Ricardo Ventura Santos

Conselho Editorial

Ana Lúcia Teles Rabello

Armando de Oliveira Schubach

Carlos E. A. Coimbra Jr.

Gerson Oliveira Penna

Gilberto Hochman

Joseli Lannes Vieira

Ligia Vieira da Silva

Maria Cecília de Souza Minayo 


\section{Epidemiologia Nutricional}

Gilberto Kac · Rosely Sichieri - Denise Petrucci Gigante

Organizadores 
Copyright (C) 2007 dos autores

Todos os direitos desta edição reservados à

FUNDAÇÃO OSWALDO CRUZ / EDITORA e EDITORA ATHENEU

ISBN: 978-85-7541-146-9

1a edição: 2007

$1^{\text {a }}$ reimpressão: 2009

Projeto gráfico e editoração eletrônica

Daniel Pose Vazquez

Revisão e copidesque

Irene Ernest Dias e Soraya Ferreira

Índice

Clarissa Bravo

Jacqueline Ribeiro Cabral

Luis Octavio Gomes de Souza

Márcio Magalhães

Miriam Junghans

Catalogação na fonte

Centro de Informação Científica e Tecnológica

Biblioteca da Escola Nacional de Saúde Pública Sergio Arouca

K11e Kac, Gilberto (org.)

Epidemiologia nutricional. / Organizado por Gilberto Kac, Rosely Sichieri e Denise Petrucci

Gigante. Rio de Janeiro : Editora Fiocruz/Atheneu, 2007.

580 p., il., tab., graf.

1.Epidemiologia Nutricional. 2.Estado Nutricional. 3.Avaliação Nutricional. 4.Obesidadeepidemiologia. 5.Gestantes. 6.Criança. 7.Adolescente. 8.Idoso. 9.Índios. I.Sichieri, Rosely. (org.) II.Gigante, Denise Petrucci. (org.) III.Título.

CDD - 20.ed. - 363.8

2009

\section{EDITORA FIOCRUZ}

Av. Brasil, 4036 - 1ำ andar, sala 112

Manguinhos

CEP 21040-361 - Rio de Janeiro, RJ

Tel.: (21) 3882-9039 e 3882-9041

Telefax: (21) 3882-9006

e-mail: editora@fiocruz.br

www.fiocruz.br/editora

\section{EDITORA ATHENEU}

São Paulo, SP

Rua Jesuíno Pascoal, 30, Santa Cecília - CEP 01224-050

Rio de Janeiro, RJ

Rua Bambina, 74 A/B, Botafogo - CEP 22251-050

Ribeirão Preto, SP

Rua Barão do Amazonas, 1435, Jardim Sumaré - CEP 14025-050

0800267753 • www.atheneu.com.br 


\section{Autores}

Adriano Marçal Pimenta

Graduado em enfermagem, mestre em enfermagem pela Escola de Enfermagem da Universidade Federal de Minas Gerais (UFMG).adrianomarcal@hotmail.com

\section{Alcides da Silva Diniz}

Graduado em medicina, mestre em oftalmologia pela Faculdade de Medicina de Ribeirão Preto, Universidade de São Paulo (USP), doutor em nutrição pela Universidade Federal de Pernambuco (UFPE), pós-doutor em nutrição pelo Prince Leopold Institute of Tropical Medicine, Antwerp, Bélgica. Professor adjunto no Departamento de Nutrição da UFPE. alcides.diniz@pesquisador.cnpq.br

\section{Alexandre G. Torres}

Graduado em nutrição pela Universidade Federal do Estado do Rio de Janeiro (UniRio), mestre em bioquímica pela Universidade Federal do Rio de Janeiro (UFRJ) e doutor em ciências de alimentos pelo Instituto de Química da UFRJ. Professor adjunto do Instituto de Química da UFRJ. torres@iq.ufrj.br

\section{Aline Cristine Souza Lopes}

Graduada em nutrição, doutora em saúde pública - concentração em epidemiologia - pela Universidade Federal de Minas Gerais (UFMG). Professora adjunta de nutrição do Departamento de Enfermagem Materno-Infantil e Saúde Pública, Escola de Enfermagem da UFMG, Grupo de Pesquisas em Epidemiologia, Observatório de Saúde Urbana. aline@medicina.ufmg.br

\section{Amanda Rodrigues Amorim}

Graduada em nutrição pela Universidade do Estado do Rio de Janeiro (Uerj), mestre e doutora pelo Instituto de Medicina Social da mesma universidade. amandara2003@yahoo.com.br

\section{Ana Marlúcia Oliveira de Assis}

Graduada em nutrição pela Universidade Federal da Bahia (Ufba), mestre e doutora em saúde pública pela Escuela de Salud Pública de México e doutora em saúde pública pela Ufba. Professora titular da Ufba. amos@ufba.com.br 


\section{Aníbal Sanchez Moura}

Graduado em ciências biológicas, doutor em ciências pela Universidade de São Paulo (USP). Professor adjunto na Universidade do Estado do Rio de Janeiro (Uerj), Instituto de Fisiologia. asmoura@uerj.br

\section{Bernardo Lessa Horta}

Graduado em medicina, doutor em epidemiologia pela McGill University. Professor adjunto no Departamento de Medicina Social da Universidade Federal de Pelotas (Ufpel).blhorta@gmail.com

\section{Bianca de Almeida Pititto}

Graduada em medicina, mestre em endocrinologia pela Universidade de São Paulo (USP). Atua em projeto de pesquisa em prevenção de diabetes nos departamentos de Medicina Preventiva e Endocrinolgia da Universidade Federal de São Paulo (Unifesp) e atua como médica no Departamento de Medicina Preventiva da Unifesp e no Laboratório Fleury. almeida.bi@uol.com.br

\section{Carlos Everaldo Álvares Coimbra Jr.}

Graduado em ciências biológicas pela Universidade de Brasília (UnB), mestre e doutor em antropologia pela Indiana University (1989) e pós-doutor pelo Five College Program in Medical Anthropology, University of Massachusetts. Pesquisador titular da Escola Nacional de Saúde Pública Sergio Arouca (Ensp/Fiocruz).coimbra@ensp.fiocruz.br

\section{Claudia Leite Moraes}

Graduada em medicina e mestre em saúde coletiva pela Universidade do Estado do Rio de Janeiro (Uerj). Professora adjunta do Departamento de Epidemiologia, Instituto de Medicina Social, Uerj, e do Mestrado em Saúde da Família da Universidade Estácio de Sá. É uma das coordenadoras do Programa de Investigação Epidemiológica da Violência Familiar (PIEVF), que congrega pesquisadores de diversas instituições de pesquisa e é sediado no Instituto de Medicina Social da Uerj.clmoraes@ims.uerj.br

\section{Claudia de Souza Lopes}

Graduada em medicina pela Universidade Federal do Rio de Janeiro (UFRJ), mestre em saúde coletiva pela Universidade do Estado do Rio de Janeiro (Uerj) e doutora em epidemiologia pela University of London. Professora adjunta do Departamento de Epidemiologia do Instituto de Medicina Social da Uerj. lopes@ims.uerj.br

\section{Cláudio José Struchiner}

Graduado em medicina pela Universidade Federal do Rio de Janeiro (UFRJ), mestre em matemática pela Associação Instituto Nacional de Matemática Pura e Aplicada e doutor em dinâmica populacional de doenças infecciosas pela Harvard University. Professor adjunto da Universidade do Estado do Rio de Janeiro (Uerj) e pesquisador titular da Fundação Oswaldo Cruz (Fiocruz). stru@fiocruz.br

\section{Cora Luiza Pavin Araújo}

Graduada em nutrição pela Universidade do Vale do Rio dos Sinos (Unisinos), mestre e doutora em saúde pública (área de epidemiologia) pela Escola Nacional de Saúde Pública Sergio Arouca (Ensp/Fiocruz). Professora adjunta na Universidade Federal de Pelotas (Ufpel). cora.araujo@terra.com.br 


\section{Daniela Saes Sartorelli}

Graduada em nutrição, doutora em saúde pública pelo Departamento de Nutrição da Faculdade de Saúde Pública da Universidade de São Paulo (FSP/USP). Professora doutora do Departamento de Medicina Social da Faculdade de Medicina de Ribeirão Preto da Universidade de São Paulo (FMRP/USP). daniss@fmrp.usp.br

\section{Denise Petrucci Gigante (organizadora)}

Graduada em nutrição, doutora em epidemiologia pela Universidade Federal de Pelotas (Ufpel) e pós-doutora na Divisão de Ciências da Nutrição da Universidade de Cornell, EUA. Professora adjunta do Departamento de Nutrição e do Programa de Pós-Graduação em Epidemiologia da Ufpel. denise.epi@gmail.com

\section{Elisa Maria de Aquino Lacerda}

Graduada em nutrição pela Universidade Federal do Rio de Janeiro (UFRJ), mestre pelo Instituto de Nutrição e doutora pela Escola Nacional de Saúde Pública Sergio Arouca (Ensp/Fiocruz). Professora adjunta da UFRJ. lacerdae@nutricao.ufrj.br

\section{Erika Aparecida da Silveira}

Graduada em nutrição pela Universidade Federal de Goiás (UFG), mestre em epidemiologia pela Universidade Federal de Pelotas (UFPel) e doutora em saúde pública - área de concentração em epidemiologia - pela Universidade Federal de Minas Gerais (UFMG). Professora adjunta da Faculdade de Nutrição e do Programa de Pós-Graduação em Ciências da Saúde da Faculdade de Medicina/UFG. erikasil@terra.com.br

\section{Gilberto Kac (organizador)}

Graduado em nutrição pela Universidade do Estado do Rio de Janeiro (Uerj), mestre em saúde pública pela Escola Nacional de Saúde Pública Sergio Arouca (Ensp/Fiocruz) e doutor em saúde pública pela Faculdade de Saúde Pública da Universidade de São Paulo (FSP/USP). Professor adjunto do Instituto de Nutrição Josué de Castro da Universidade Federal do Rio de Janeiro (INJC/UFRJ).kacetal@gmail.com ou gkac@nutricao.ufrj.br.

\section{Gloria Valeria da Veiga}

Graduada em nutrição pela Universidade Federal Fluminense (UFF), mestre em ciências dos alimentos pela Universidade Federal de Lavras (Ufla), doutora em nutrição pela Universidade Federal de São Paulo (Unifesp), pós-doutora pela Universidade do Estado do Rio de Janeiro (Uerj). Professora associada do Instituto de Nutriçãoo Josué de Castro, Universidade Federal do Rio de Janeiro (INJC/UFRJ).gvveiga@globo.com

\section{Gustavo Velásquez-Meléndez}

Graduado em ciências biológicas, doutor em saúde pública pela Faculdade de Saúde Pública da Universidade de São Paulo (FSP/USP). Professor associado do Departamento de Enfermagem Materno Infantil e Saúde Pública da Universidade Federal de Minas Gerais (UFMG). guveme@ufmg.br

\section{Iná S. Santos}

Graduada em medicina pela Universidade Federal de Pelotas (Ufpel), mestre e doutora em epidemiologia pela mesma universidade, onde atualmente é professora titular.inasantos@uol.com.br 


\section{Inês Rugani Ribeiro de Castro}

Graduada em nutrição, sanitarista, doutora em saúde pública. Professora adjunta do Departamento de Nutrição Social do Instituto de Nutrição da Universidade do Estado do Rio de Janeiro (Uerj) e sanitarista do Instituto de Nutrição Annes Dias, da Secretaria Municipal de Saúde do Rio de Janeiro. inesrrc@uol.com.br

\section{Leonor Maria Pacheco Santos}

Graduada em química pela Universidade de São Paulo (USP), doutora (Ph.D.) em patologia pela University of Tennessee, pós-graduada em ciência dos alimentos e nutrição pela Gent Universiteit, Bélgica, pós-doutora em epidemiologia pela London School of Hygiene and Tropical Medicine. Atualmente é coordenadora geral de Avaliação e Monitoramento do Ministério do Desenvolvimento Social e Combate à Fome (MDS) e pesquisadora colaboradora do Departamento de Nutrição, Faculdade de Saúde, da Universidade de Brasília (UnB). leopac@terra.com.br

\section{Luciene Burlandy}

Graduada em nutrição, doutora em saúde pública pela Escola Nacional de Saúde Pública Sergio Arouca (Ensp/Fiocruz). Professora adjunta do Departamento de Nutrição Social da Universidade Federal Fluminense (MNS/UFF).

burlandy@uol.com.br

\section{Luiz Antonio dos Anjos}

Graduado em medicina, mestre em ciências nutricionais e doutor em fisiologia do exercício pela Universidade de Illinois, EUA, com pós-doutorado pela Universidade do Arizona, EUA. Professor titular no Departamento de Nutrição Social e coordenador do Laboratório de Avaliação Nutricional e Funcional da Universidade Federal Fluminense (UFF). Pesquisador do CNPq, orientador do Mestrado em Ciências Médicas da UFF e orientador externo do Programa de Saúde Pública (mestrado e doutorado) da Escola Nacional de Saúde Pública Sergio Arouca (Ensp/Fiocruz). lanjos@ig.com.br

\section{Luiz Oscar Cardoso Ferreira}

Graduado em medicina pela Universidade Federal de Pernambuco(UFPE), mestre em epidemiologia pela London School of Hygiene and Tropical Medicine e doutor pela Universidade Federal de Pernambuco. Professor adjunto da UFPE. luizoscar@fcm.upe.br

\section{Malaquias Batista Filho}

Graduado em medicina, doutor em saúde pública pela Universidade de São Paulo (USP). Atualmente é docente do Mestrado em Saúde Materno Infantil do Instituto Materno Infantil de Pernambuco. mbatista@imip.org.br

\section{Márcia Gonçalves Ferreira}

Graduada em nutrição, doutora em saúde coletiva pela Universidade do Estado do Rio de Janeiro (Uerj). Professora adjunta do Departamento de Alimentos e Nutrição da Faculdade de Nutrição e professora do Programa de Pós-Graduação em Saúde Coletiva do Instituto de Saúde Coletiva da Universidade Federal de Mato Grosso (UFMT).

margon@terra.com.br

\section{Maria Helena Constantino Spyrides}

Graduada em estatística pela Universidade Federal do Rio Grande do Norte (UFRN), mestre em agronomia (estatística e experimentação agronômica) pela Universidade de São Paulo (USP) e doutora em saúde pública pela Escola Nacional de Saúde Pública Sergio Arouca (Ensp/Fiocruz).Professora adjunta da UFRN. spyrides@ccet.ufrn.br. 


\section{Maria Teresa Anselmo Olinto}

Graduada em nutrição, doutora em saúde coletiva pela Faculdade de Ciências Médicas da Universidade Estadual de Campinas (Unicamp). Professora titular do Programa de Pós-Graduação em Saúde Coletiva da Universidade do Vale do Rio dos Sinos (Unisinos). mtolinto@unisinos.br

\section{Maria Tereza Serrano Barbosa}

Licenciada em matemática pela Universidade Federal de Pernambuco (UFPE), mestre em estatística pela Associação Instituto Nacional de Matemática Pura e Aplicada e doutora em saúde coletiva pela Universidade do Estado do Rio de Janeiro (Uerj). Professora adjunta da Universidade Federal do Estado do Rio de Janeiro (UniRio).

terezabarbosa@unirio.br

\section{Marília Mendonça Leão}

Graduada em enfermagem, mestre em nutrição, especialista em políticas públicas. Pesquisadora associada do Observatório de Políticas de Segurança Alimentar e Nutricional da Universidade de Brasília (UnB). marilia@abrandh.org.br

\section{Marina Ferreira Rea}

Graduada em medicina, doutora em medicina pelo Departamento de Medicina Preventiva da Faculdade de Medicina da Universidade de São Paulo (DMP/FM/USP) e pesquisadora científica sênior do Instituto de Saúde (IS/SES-SP). marifrea@usp.br

\section{Marly Augusto Cardoso}

Graduada em nutrição, mestre e doutora em ciência dos alimentos e livre-docente em nutrição em saúde pública pela Universidade de São Paulo (USP). Professora associada do Departamento de Nutrição, Faculdade de Saúde Pública da USP, onde coordena o Programa de Pós-Graduação em Nutrição em Saúde Pública. Foi pesquisadora visitante do Departamento de Nutrição da Harvard School of Public Health. marlyac@usp.br

\section{Maurício Soares Leite}

Graduado em nutrição pela Universidade do Estado do Rio de Janeiro (Uerj), mestre e doutor (2005) em saúde pública pela Escola Nacional de Saúde Pública Sergio Arouca (Ensp/Fiocruz). Professor adjunto da Universidade Federal de Santa Catarina (UFSC). mauriciosleite@gmail.com

\section{Michael Eduardo Reichenheim}

Graduado em medicina pela Universidade Federal do Rio de Janeiro (UFRJ), mestre em saúde materno-infantil pela University of London, doutor em saúde pública pela University of London, pós-doutor em bioestatística pelo Institute of Public Health, University of Cambridge. Professor adjunto do Departamento de Epidemiologia, Instituto de Medicina Social, Universidade do Estado do Rio de Janeiro (Uerj) e editor associado dos periódicos científicos Cadernos de Saúde Pública e Padiatric and Perinatal Epidemiology. michael@ims.uerj.br

\section{Nádia M. F. Trugo}

Graduada em nutrição e mestre em bioquímica pela Universidade Federal do Rio de Janeiro (UFRJ), doutora em bioquímica e fisiologia da nutrição pela University of Reading, Inglaterra. Professora adjunta, aposentada, do Instituto de Química da UFRJ.trugo@iq.ufrj.br 


\section{Pedro Curi Hallal}

Graduado em educação física, doutor em epidemiologia pelo Programa de Pós-Graduação em Epidemiologia da Universidade Federal de Pelotas (Ufpel). Professor adjunto da Escola Superior de Educação Física, Programa de Pós-Graduação em Educação Física, e do Programa de Pós-Graduação em Epidemiologia da Ufpel. prchallal@terra.com.br

\section{Pedro Israel Cabral de Lira}

Graduado em medicina pela Universidade Federal de Pernambuco (UFPE), especialista em saúde pública pela Escola Nacional de Saúde Pública Sergio Arouca (Ensp/Fiocruz), mestre em nutrição pelo Instituto de Nutrición y Tecnología de los Alimentos (Inta), Universidad de Chile, e doutor em medicina pela London School of Hygiene \& Tropical Medicine, University of London. Professor associado do Departamento de Nutrição da UFPE. lirapic@ufpe.br

\section{Renata Damião}

Graduada em nutrição, doutora em ciências pelo Departamento de Endocrinologia Clínica, Universidade Federal de São Paulo, pós-doutoranda do Departamento de Medicina Preventiva, Universidade Federal de São Paulo (Unifesp-EPM). damiaorenata@hotmail.com

\section{Ricardo Ventura Santos}

Graduado em ciências biológicas pela Universidade de Brasília (UnB), mestre e doutor em antropologia biológica pela Indiana University e pós-doutor pelo Massachusetts Institute of Technology (MIT) e pela University of Massachusetts. Pesquisador titular da Escola Nacional de Saúde Pública Sergio Arouca (Ensp/Fiocruz) e professor adjunto do Museu Nacional, Universidade Federal do Rio de Janeiro (UFRJ). santos@ensp.fiocruz.br

\section{Rita Adriana Gomes de Souza}

Graduada em nutrição, mestre em epidemiologia pelo Instituto de Medicina Social da Universidade do Estado do Rio de Janeiro (IMS/Uerj). ritadriana@ims.uerj.br

\section{Rosana Salles da Costa}

Graduada em nutrição, doutora em saúde coletiva pelo Instituto de Medicina Social da Universidade do Estado do Rio de Janeiro (IMS/Uerj). Professora adjunta do Departamento de Nutrição Social e Aplicada do Instituto de Nutrição Josué de Castro da Universidade Federal do Rio de Janeiro (DNSA/INJC/UFRJ).rosana_salles@terra.com.br

\section{Rosangela Alves Pereira}

Graduada em nutrição, doutora em ciências pela Escola Nacional de Saúde Pública Sergio Arouca (Ensp/Fiocruz), professora adjunta do Instituto de Nutrição Josué de Castro da Universidade Federal do Rio de Janeiro (INJC/UFRJ). roapereira@gmail.com

\section{Rosely Sichieri (organizadora)}

Graduada em medicina pela Faculdade de Ciências Médicas de Botucatu, especialista em saúde pública, mestre em ciências (fisiologia humana) e doutora em nutrição pela Universidade de São Paulo (USP), pós-doutora em epidemiologia pela National Institutes of Health e pela Harvard School. Professora adjunta do Departamento de Epidemiologia do Instituto de Medicina Social da Universidade do Estado do Rio de Janeiro (IMS/Uerj). sichieri@ims.uerj.br 


\section{Sandhi Maria Barreto}

Graduada em medicina, Ph.D. em epidemiologia pela London School of Hygiene and Tropical Medicine. Professora adjunta da Faculdade de Medicina e vice-coordenadora do Programa de Pós-Graduação em Saúde Pública da Universidade Federal de Minas Gerais (UFMG). sbarreto@medicina.ufmg.br

\section{Sandra Roberta Gouvea Ferreira}

Graduada em medicina, livre-docente em medicina preventiva clínica pelo Departamento de Medicina Preventiva da Universidade Federal de São Paulo (EPM/Unifesp). Professora titular do Departamento de Nutrição da Faculdade de Saúde Pública, Universidade de São Paulo (FSP/USP). sandrafv@usp.br

\section{Silvia Ângela Gugelmin}

Graduada em nutrição pela Universidade Federal do Paraná (UFPR), mestre e doutora em saúde pública pela Escola Nacional de Saúde Pública Sergio Arouca (Ensp/Fiocruz). Professora adjunta da Universidade do Estado do Rio de Janeiro (Uerj).gugelmin@uerj.br

\section{Suely Godoy Agostinho Gimeno}

Graduada em nutrição, livre-docente em nutrição em saúde pública pelo Departamento de Nutrição da Faculdade de Saúde Pública da Universidade de São Paulo (FSP/USP). Professora associada do Departamento de Medicina Preventiva da Universidade Federal de São Paulo (EPM/Unifesp). suely@medprev.epm.br

\section{Tereza Setsuko Toma}

Graduada em medicina pela Universidade de São Paulo (USP), especialista em pediatria pelo Hospital Brigadeiro, em saúde pública pela USP, em lactation management education program pelo Wellstart San Diego Lactation Program (1990) e doutora em saúde pública pelo Departamento de Nutrição da Faculdade de Saúde Pública da Universidade de São Paulo (DN/FSP/USP). Pesquisadora científica do Instituto de Saúde (IS/SES-SP). ttoma@isaude.sp.gov.br

\section{Vivian Wahrlich}

Graduada em nutrição, mestre em nutrição humana pela Universidade Federal do Rio de Janeiro (UFRJ) e doutora em saúde pública pela Escola Nacional de Saúde Pública Sergio Arouca (Ensp/Fiocruz). Pesquisadora colaboradora no Laboratório de Avaliação Nutricional e Funcional da Escola de Nutrição da Universidade Federal Fluminense. walrich@terra.com.br

\section{Waleska Teixeira Caiaffa}

Graduada em medicina, pós-doutora em epidemiologia pela Johns Hopkins University. Professora adjunta de epidemiologia do Departamento de Medicina Preventiva e Social, Faculdade de Medicina, Grupo de Pesquisas em Epidemiologia, Observatório de Saúde Urbana da Faculdade de Medicina da Universidade Federal de Minas Gerais. wcaiaffa@yahoo.com.br

\section{Wolney Lisboa Conde}

Graduado em nutrição, doutor em saúde pública pela Universidade de São Paulo (USP). Professor doutor do Departamento de Nutrição e do Programa de Pós-Graduação em Nutrição em Saúde Pública da Faculdade de Saúde Pública da USP.wolney@usp.br 



\section{Sumário}

Prefácio

Apresentação

Introdução à Epidemiologia Nutricional

Gilberto Kac, Rosely Sichieri e Denise Petrucci Gigante

\section{I - Métodos em Epidemiologia Nutricional}

1. Uso e Interpretação dos Indicadores Antropométricos na Avaliação do Estado Nutricional de Gestantes

Amanda Rodrigues Amorim, Elisa Maria de Aquino Lacerda e Gilberto Kac

2. Avaliação Nutricional de Crianças

Cora Luiza Pavin Araújo

3. Referências Antropométricas

Cora Luiza Pavin Araújo

4. Avaliação Nutricional de Adolescentes

Gloria Valeria da Veiga e Rosely Sichieri

5. Antropometria como Método de Avaliação do Estado de Nutrição e Saúde do Adulto Márcia Gonçalves Ferreira e Rosely Sichieri

6. Avaliação do Estado Nutricional de Idosos

Erika Aparecida da Silveira, Aline Cristine Souza Lopes e Waleska Teixeira Caiaffa 
7. Indicadores Bioquímicos na Avaliação do Estado Nutricional Nádia M. F. Trugo e Alexandre G. Torres

8. Composição Corporal na Avaliação do Estado Nutricional

Luiz Antonio dos Anjos e Vivian Wahrlich

9. Gasto Energético: medição e importância para a área de nutrição

Luiz Antonio dos Anjos e Vivian Wahrlich

10. Métodos de Avaliação do Consumo de Alimentos

Rosangela Alves Pereira e Rosely Sichieri

11. Desenvolvimento, Validação e Aplicações de Questionários de Freqüência Alimentar em Estudos Epidemiológicos

Marly Augusto Cardoso

12. Padrões Alimentares: análise de componentes principais

Maria Teresa Anselmo Olinto

13. Desenvolvimento de Instrumentos de Aferição Epidemiológicos

Michael Eduardo Reichenheim e Claudia Leite Moraes

14. Análise de Dados com Medidas Repetidas

Maria Helena Constantino Spyrides, Cláudio José Struchiner, Maria Tereza Serrano Barbosa e Gilberto Kac

15. Intervenções Nutricionais na Infância

Iná S. Santos 261

\section{II - Problemas Nutricionais Brasileiros}

16. Epidemiologia da Desnutrição Infantil

Wolney Lisboa Conde e Denise Petrucci Gigante

17. Epidemiologia da Anemia Ferropriva

Pedro Israel Cabral de Lira e Luiz Oscar Cardoso Ferreira

18. Epidemiologia da Hipovitaminose A e Xeroftalmia

Alcides da Silva Diniz e Leonor Maria Pacheco Santos

19. Epidemiologia da Obesidade 
20. Fatores Nutricionais no Diabetes

Daniela Saes Sartorelli

21. Fatores da Dieta nas Doenças Cardiovasculares

Suely Godoy Agostinho Gimeno e Sandra Roberta Gouvea Ferreira

22. Aspectos Epidemiológicos e Nutricionais da Síndrome Metabólica

Renata Damião, Bianca de Almeida Pititto, Suely Godoy Agostinho Gimeno e Sandra Roberta Gouvea Ferreira

23. Fatores Nutricionais e Hipertensão Arterial

Gustavo Velásquez-Meléndez, Sandhi Maria Barreto e Adriano Marçal Pimenta

\section{III - Tópicos Especiais em Epidemiologia Nutricional}

24. Amamentação: evidências científicas e ações para incentivar sua prática

Marina Ferreira Rea e Tereza Setsuko Toma

25. Transição Nutricional: conceito e características

Malaquias Batista Filho, Ana Marlúcia Oliveira de Assis e Gilberto Kac

26. Epidemiologia da Atividade Física

Pedro Curi Hallal e Luiz Antonio dos Anjos

27. Obesidade e Saúde Mental: evidências e controvérsias

Claudia de Souza Lopes

28. Segurança Alimentar e Nutricional: concepções e desenhos de investigação Luciene Burlandy e Rosana Salles da Costa

29. Alimentação e Nutrição dos Povos Indígenas no Brasil

Maurício Soares Leite, Ricardo Ventura Santos, Carlos Everaldo Álvares Coimbra Jr. e Silvia Ângela Gugelmin

30. Políticas Públicas de Alimentação e Nutrição

Marília Mendonça Leão e Inês Rugani Ribeiro de Castro

31. Janelas Críticas para Programação Metabólica e Epigênese Transgeracional Aníbal Sanchez Moura

32. Efeitos a Longo Prazo da Nutrição na Infância Bernardo Lessa Horta

Índice 



\title{
Prefácio
}

\begin{abstract}
A importância da nutrição para a saúde humana é incontestável. O Relatório Mundial de Saúde publicado em 2002 pela Organização Mundial da Saúde (OMS) avaliou o impacto dos vinte principais fatores de risco para morbi-mortalidade em nível global. Nada menos de seis desses vinte fatores eram nutricionais: desnutrição infantil; sobrepeso e obesidade; baixo consumo de frutas e verduras; deficiência de zinco; anemia ferropriva e deficiência de vitamina A. O desmame precoce não foi avaliado nessa revisão, mas sem dúvida seria também incluído entre os vinte principais fatores de risco. A epidemiologia nutricional é, portanto, um campo cada vez mais importante para o controle de doenças em âmbito mundial. Essa criteriosa revisão da OMS confirma o dito popular: "você é o que você come" - ou, no caso das deficiências nutricionais, "você não é o que você não come".

A população brasileira atravessa um rápido e complexo processo de transição nutricional. Não temos aqui uma transição no sentido tradicional, em que as deficiências nutricionais são substituídas gradualmente pelo sobrepeso e obesidade, em toda a população. Nossa amplitude geográfica e diversidade ecológica, assim como a largura do fosso que separa pobres de ricos dentro de cada uma de nossas regiōes, muito contribuem para a complexidade desse processo. Os resultados de pesquisas de epidemiologia nutricional em nosso meio não cansam de surpreender. Alguns exemplos são suficientes: altas prevalências de anemia inclusive em grupos sociais privilegiados; marcada redução na duração do aleitamento materno por várias décadas, seguida de rápida retomada desta prática tão importante; a concomitância de obesidade nas mães e déficit de crescimento em seus próprios filhos; o sobrepeso de homens ricos e mulheres pobres; as marcadas alterações nas dietas tradicionais com a adoção de alimentos industrializados, muitas vezes com consequiências nefastas sobre a saúde. Esses processos apresentam temporalidades distintas em diferentes grupos sociais e nas diversas regiōes do país. Não temos aqui uma transição nutricional no sentido clássico, mas um legítimo 'vai-e-vem nutricional' em que, por exemplo, pobres engordam e ricos emagrecem.

Estou envolvido em pesquisas epidemiológicas sobre diversos tópicos há três décadas, e devo confessar que a epidemiologia nutricional é, dentro de todas as áreas em que trabalhei, aquela que considero mais complexa. Medidas antropométricas são relativamente simples de obter - embora um enorme cuidado seja necessário com a padronização dos antropometristas -, mas freqüentemente complexas de interpretar. Avaliar dieta em grandes amostras é um desafio enorme, seja por problemas de variabilidade diária e estacional, pelo próprio tamanho dos questionários, pelas distintas escolhas sobre períodos de referência, ou pela validade (ou não) da informação fornecida pelos entrevistados. Reconhecer a complexidade desta área de pesquisa
\end{abstract}


não deve desencorajar os pesquisadores - pelo contrário, deve estimular um enfoque rigoroso e criativo. Para isso, o presente livro tem um papel fundamental.

Fiquei impressionado com o escopo e rigor deste compêndio. Ao mesmo tempo, o livro combina um manual técnico - o estado da arte sobre como avaliar estado nutricional e consumo alimentar - com o que poderia ser chamado de uma 'enciclopédia nutricional brasileira', em que nossos principais problemas nutricionais são detalhadamente descritos com base na literatura científica. E a terceira parte aborda tópicos especiais de grande atualidade. O enfoque é amplo e multidisciplinar, abrangendo desde a bioquímica até as políticas nutricionais.

Outro aspecto elogiável é a reunião dos principais investigadores brasileiros na área de nutrição e saúde pública, demonstrando como nossa comunidade está coesa no objetivo de melhorar o estado nutricional de nossa população.

Os organizadores e autores precisam ser cumprimentados pela iniciativa, pois sem dúvida este volume se tornará leitura obrigatória em nossos cursos de graduação e pós-graduação em nutrição e saúde coletiva.

Cesar G. Victora

Professor titular de epidemiologia, Universidade Federal de Pelotas Membro do Comitê de Peritos em Nutrição, Organização Mundial da Saúde 


\section{Apresentação}

lassicamente, a epidemiologia estuda a distribuição e os determinantes das doenças na população. Nas últimas décadas, esta área tem se especializado cada vez mais e, com isso, vários adjetivos têm sido sugeridos. Seria a epidemiologia nutricional mais uma mera subdivisão da epidemiologia em função de determinantes específicos, ou ela teria um campo específico de conhecimento?

Entende-se que o objetivo primeiro da epidemiologia nutricional seja medir dietas como um fator de exposição na maior ou menor ocorrência de doenças. $\mathrm{O}$ alcance desse objetivo constitui-se em tarefa complexa que requer cada vez mais especialização. O escopo da epidemiologia nutricional no Brasil passou a incorporar um conceito ampliado que considera tanto o estudo de outras exposições como o de alterações nutricionais específicas. Entre as exposições, além da aferição do consumo alimentar, devem ser incluídos outros indicadores de avaliação nutricional e variáveis relacionadas ao estilo de vida que exercem influência sobre as condições de saúde e nutrição, como a prática de atividade física. Entre as alterações nutricionais, incluemse desde as deficiências como a desnutrição energético-protéica ou deficiências de micronutrientes específicos até os problemas relacionados ao excesso de peso, como a obesidade.

A delimitação conceitual e epistemológica de um campo específico de conhecimento é fundamental para o seu crescimento. Embora não seja um campo da epidemiologia assim tão recente, a epidemiologia nutricional aparece com destaque apenas no início da década de 90 do último século, após a publicação do livro Nutritional Epidemiology, em 1990, pelo professor Walter Willett, chefe do Departamento de Nutrição da Harvard School of Public Health. Apenas um ano depois é publicado, na Inglaterra, o livro Design Concepts in Nutritional Epidemiology, por Barrie M. Margetts e Michael Nelson, professores, respectivamente, do Departamento de Nutrição da Universidade de Southampton e do King's College. Em ambos os livros, a ênfase está na relação entre a dieta e doenças crônicas não transmissíveis.

No Brasil, escrever um livro contemplando a conceituação mais restrita da epidemiologia nutricional já seria um desafio. Na organização deste volume, foi necessário ir além e trabalhar com o conceito ampliado de epidemiologia nutricional, tendo em vista a realidade de ensino e pesquisa e o cenário epidemiológico e nutricional atual. Nosso objetivo foi, portanto, combinar a abordagem mais recente da relação entre consumo alimentar e o processo saúde-doença com a importante massa de conhecimento existente no Brasil relativa às doenças carenciais, seu diagnóstico e fatores associados. Para o cumprimento desse desafio, contamos com a colaboração de diversos pesquisadores. Um livro é sempre uma história com diferentes particularidades de seus autores e organizadores. A ótica na qual os vários Brasis são vistos e a pluralidade da epidemiologia nutricional explicam a variedade de temas e enfoques dos capítulos que integram este volume. 
Este livro tem como principal público-alvo alunos de graduação de nutrição e de outros cursos da área da saúde. Considerando a epidemiologia nutricional como uma especialidade no campo da epidemiologia, pretendemos, também, que chegue a alunos de pós-graduação e pesquisadores interessados no assunto.

$\mathrm{O}$ volume é composto por um texto introdutório e três grandes partes, com 32 capítulos. Na primeira parte, são apresentados e analisados métodos de mensuração do estado nutricional e do consumo alimentar. A segunda parte contém estudos sobre a epidemiologia dos problemas nutricionais brasileiros mais importantes. Os nove capítulos que compõem a terceira parte espelham, de certa forma, o conceito ampliado de epidemiologia nutricional aqui adotado.

Os capítulos metodológicos reunidos na primeira parte apresentam e discutem métodos de avaliação do estado nutricional em diferentes grupos populacionais (gestantes, crianças, adolescentes, adultos e idosos), referências antropométricas, análises bioquímicas, de avaliação do consumo alimentar e da composição corporal. Adicionalmente, há estudos sobre aferição e validação em estudos de epidemiologia nutricional, intervençôes nutricionais e estratégias de análise de dados com medidas repetidas para avaliação longitudinal do estado nutricional. Esses capítulos, de cunho mais metodológico, são importantes para uma melhor compreensão daqueles contidos na segunda parte.

A avaliação nutricional de diversos grupos populacionais tem, aqui, papel de destaque. $\mathrm{O}$ estado nutricional dos indivíduos depende do balanço entre o consumo e as necessidades fisiológicas, que variam em função da idade, o que justifica a inclusão de um capítulo específico para diferentes fases da vida. Os mais jovens e os mais velhos têm se revelado como os grupos que apresentam maior probabilidade de desequilíbrio na relação entre consumo e necessidades fisiológicas, que desencadeia distúrbios nutricionais por falta de nutrientes. Ao passo que o balanço crônico de energia pode ser captado por meio da antropometria, um método relativamente simples, a avaliação do consumo de nutrientes depende de métodos específicos mais complexos. Por esses motivos, a aferição do consumo ou a avaliação de marcadores de consumo alimentar tornam-se imprescindíveis, particularmente na compreensão do estado nutricional nos extremos da vida.

Mais recentemente, os estudos de validação e de identificação de um padrão de consumo alimentar passaram a se constituir em instrumentos de grande importância nos estudos epidemiológicos que buscam investigar a associação entre dieta e Doenças Crônicas Não Transmissíveis (DCNT). Instrumentos de investigação do consumo alimentar devem ser validados (calibrados) para a população em que se pretende aplicar o referido método, e para isso estudos de validação são uma ferramenta essencial na epidemiologia nutricional. Padrôes de consumo alimentar que podem ser considerados saudáveis têm sido explorados em vários estudos, e as técnicas que permitem defini-los foram exploradas em um dos capítulos. Análises sobre o padrão de consumo são interessantes porque podem configurar-se como forma efetiva de prevenção, diferentemente do que acontece em alguns estudos epidemiológicos que buscam identificar o efeito de um nutriente específico na determinação da cadeia causal das DCNT.

Os capítulos incluídos na segunda parte descrevem a epidemiologia dos principais problemas nutricionais brasileiros, à luz das transiçôes demográfica, epidemiológica e nutricional. É interessante observar como um estudo sobre a epidemiologia da desnutrição continua sendo tão atual e importante, embora a desnutrição não seja mais o principal problema nutricional em nosso país. Com a transição nutricional experimentada no Brasil, muitos estudiosos e pesquisadores da desnutrição no passado investigam, hoje, a epidemiologia das DCNT, com destaque para a epidemia da obesidade. A sobreposição de padrões nutricionais na população brasileira justifica a necessidade de uma descrição mais detalhada sobre a desnutrição, em concomitância com capítulos sobre a obesidade, hipertensão, diabetes, síndrome metabólica e doenças cardiovasculares, além das doenças carenciais como a hipovitaminose A e a anemia ferropriva. 
No conjunto intitulado "Problemas nutricionais brasileiros" procura-se, portanto, refletir sobre as características peculiares do Brasil. Exemplo dessas peculiaridades é a coexistência de problemas carenciais endêmicos de grande proporção, como a anemia, e a epidemia de excesso de peso observada nas últimas décadas do século XX. Trata-se, portanto, da já reconhecida sobreposição de padrões nutricionais distintos. Esse tema é discutido em capítulos dedicados a anemia, obesidade e transição nutricional.

A determinação do estado nutricional e dos fatores associados a diversas doenças com alguma gênese nutricional, como a obesidade, desnutrição, síndrome metabólica, hipertensão arterial, entre outras, merece destaque nessa parte. A atividade física consiste em um importante determinante proximal do estado nutricional e é claramente reconhecida no processo de determinação de várias DCNT. Os métodos empregados e as dificuldades encontradas na aferição desse determinante são discutidos no capítulo sobre atividade física.

Finalmente, a terceira e última parte do livro concentra os capítulos que podem ser lidos à luz do conceito ampliado da epidemiologia nutricional aqui adotado. Inclui textos que abrangem temas como a epidemiologia da amamentação no Brasil, a discussão da medida e do conceito de segurança alimentar e as políticas nutricionais públicas adotadas no país. Os estudos que a integram abordam temas da atualidade que de alguma forma retomam as origens da epidemiologia nutricional, quando as deficiências nutricionais específicas eram objeto de estudo. Os capítulos sobre origem fetal das doenças e sobre janelas de exposição na gênese das doenças apresentam conceitos e teorias que, mais recentemente, têm demonstrado como a desnutrição e a obesidade convivem nos mesmos domicílios e nos trajetos de vida, com a desnutrição em momentos específicos podendo constituir fator de risco para o desenvolvimento de algumas DCNT.

Esperamos que uma visão ampla e atualizada dos problemas nutricionais de relevância para a saúde pública possa contribuir na formulação de políticas públicas voltadas para esses problemas. Com esse conhecimento acumulado pode ser possível aperfeiçoar e desenvolver protocolos de atendimento mais adequados para uso no Sistema Único de Saúde (SUS).

Como participantes do aparelho formador de profissionais, ou como formuladores ou críticos das políticas públicas desenvolvidas, foi nosso desejo contribuir apresentando conceitos e hipóteses em uma perspectiva crítica e diacrônica, e indicando também o quanto um campo de saber se desenvolve quando se debruça sobre suas limitaçóes, o que tem de fato ocorrido com a epidemiologia nutricional. 



\title{
Introdução à Epidemiologia Nutricional
}

\author{
Gilberto Kac, Rosely Sichieri e Denise Petrucci Gigante
}

U ma breve evolução histórica do escopo da epidemiologia nutricional é aqui apresentada. Exemplos de alguns estudos clássicos que marcaram o campo nos últimos duzentos anos e abordagens da saúde pública no estabelecimento de guias alimentares no início do século XX serão utilizados, com o intuito de introduzir a temática epidemiologia nutricional. Assim, espera-se que ao longo deste texto introdutório o leitor seja capaz de identificar as tendências que marcaram o campo nos últimos dois séculos.

\section{Histórico da Epidemiologia Nutricional}

Estudos clássicos da relação entre a deficiência de certos nutrientes na dieta e o surgimento de doenças carenciais constituem a história da epidemiologia nutricional. Esses estudos, realizados há pouco mais de duzentos anos, utilizaram o método epidemiológico da época para investigar a distribuição e possíveis causas de doenças relacionadas ao consumo alimentar. No entanto, deve-se ressaltar que na época em que foram realizados a etiologia infecciosa dessas patologias ainda era investigada.

O estudo que pode ser considerado pioneiro, inaugurando a epidemiologia nutricional, foi publicado por James Lind, em 1753, no Treatise of the Scurvy in Three Parts. Os experimentos de Lind foram realizados no longínquo ano de 1747 e começaram, mais especificamente, no dia 20 de maio daquele ano no navio britânico Salisbury. Doze marinheiros da tripulação desse navio, acometidos em diferentes graus pelo escorbuto, foram incluídos no estudo de Lind. Naquela época, o escorbuto era o principal inimigo da Marinha inglesa, responsável por maior número de mortes do que nas frotas francesas ou espanholas. Em um período de vinte anos, cerca de dez mil marinheiros foram destruídos pelo escorbuto, e qualquer esforço para pôr fim a essa peste era acolhido pelo público.

James Lind teve a oportunidade de conhecer o escorbuto quando esteve no navio Salisbury durante as dez semanas de travessia do Canal da Mancha. Em 20 de maio de 1747, 12 marinheiros com sintomas similares foram acolhidos em um setor do navio destinado a enfermos e receberam a mesma dieta. Além da dieta, dois enfermos recebiam diariamente uma garrafa de cidra; outros dois recebiam 25 gotas de elixir de vitríolo; outros dois recebiam duas colheres de vinagre, três vezes por dia; outros dois recebiam água do mar; outros dois receberam duas laranjas e um limão por dia, somente por sete dias, enquanto as frutas eram disponíveis e, finalmente, os outros dois receberam semente de noz-moscada. Os resultados do experimento revelaram que os dois marinheiros que passaram a ingerir frutas frescas como laranja e limão, alimentos ricos em vitamina $\mathrm{C}$, estavam prontos para o trabalho, ao final de seis dias. Depois desse estudo de Lind, suco de 
limão passou a fazer parte da dieta dos marinheiros, e, quando necessário, em viagens mais longas, os navios mudavam sua rota para a aquisição de laranjas e limões em algum porto. Pouco tempo depois, o efeito da vitamina $C$ na prevenção do escorbuto foi confirmado com base em resultados observados na tripulação de quatro navios britânicos liderados pelo capitão James Lancaster, dos quais apenas um dispunha de alimentos ricos em vitamina C. Foi justamente nesse navio que se observaram as menores taxas de escorbuto, em comparação com os outros três. A identificação dessa relação causal foi fundamental no conhecimento da etiologia do escorbuto (Lind, 1988).

Mais de cem anos depois, aproximadamente entre os anos de 1862 e 1882, ou seja, ao final do século XIX, o médico japonês Baron Takaki, um estudioso do beribéri, buscava as causas desta doença de alta incidência, que acometia, sobretudo, a população de marinheiros e também dos soldados japoneses.

Em março de 1906, Baron Takaki apresentou três conferências no St. Thomas Hospital, de Londres, que posteriormente foram publicadas na revista médica britânica Lancet. Em sua primeira conferência, Takaki conta que 44 anos antes, ainda criança, soube por seu pai que muitos homens do Exército japonês haviam sido mortos por uma doença conhecida como beribéri, que, naquela época, já era atribuída a alguma causa relacionada com a alimentação. De 1872 a 1875, como médico da Marinha, teve oportunidade de ver centenas de casos de beribéri no Hospital Naval.

Em 1880, depois de um período de capacitação em Londres, ao retornar ao Japão como diretor-geral do Hospital Naval de Tóquio, Takaki encontrou a mesma situação de cinco anos antes em relação ao beribéri; além disso, com o incremento no número de marinheiros, houve também um aumento no número de casos da doença. Um registro de casos permitiu que fossem identificados e onde viviam os indivíduos mais afetados. Em 1883, ao investigar as condiçōes higiênicas dos barcos, quartéis e escolas que dependiam da Marinha japonesa, Takaki percebeu que horas de trabalho, alojamentos e vestimentas eram bastante similares, enquanto a alimentação apresentava diferenças importantes nesses lugares: a quantidade de nitrogênio consumida não era suficiente para compensar a eliminação dessa substância pelo organismo; a alimentação servida aos marinheiros continha grande quantidade de hidratos de carbono e a relação nitrogênio/hidrato de carbono era de 1 para 17, quando a relação recomendada era de 1 para 15 . Takaki observou que quanto maior a diferença entre essas proporçôes, maior o número de casos de beribéri.

Após receber autorização do Ministério da Marinha, Takaki propôs alterações na dieta dos marinheiros japoneses. A principal hipótese para a causa do beribéri era a de que a doença não se manifestava quando a dieta se mostrava adequada. Segundo observaçôes do pesquisador, esse fato foi evidenciado quando o navio Ryujo aportou no Havaí e diminuição importante na ocorrência da doença foi observada, sendo que ali havia suprimento de alimentos frescos. Depois de alguns anos aperfeiçoando a dieta de marinheiros, em 1885 Takaki concluiu que alguma carência na dieta era a causa do beribéri, doença que, somente algum tempo depois, foi associada à deficiência de tiamina (Takaki, 1988).

Depois de vários esforços feitos por Takaki, a alimentação na Marinha japonesa foi completamente modificada em 1890. Isso levou não somente à erradicação do beribéri, como também à diminuição de casos de outras enfermidades. Durante esse período, Takaki precisou explicar que a alimentação representava para o corpo humano o mesmo que a pólvora para pistolas e rifles.

O terceiro clássico e histórico exemplo da relação entre carência dietética e a ocorrência de doenças foi proporcionado por Joseph Goldberger, pouco tempo depois dos experimentos de Takaki. Embora a pelagra já fosse estudada há pelo menos duzentos anos, até o início do século XX sua etiologia permanecia desconhecida. Uma das potenciais causas era a dieta deficiente em algum nutriente. Com um desenho que se aproximava de um quase experimento, Goldberger comparou a distribuição de freqüência de pelagra em duas instituições que diferiam apenas na qualidade da dieta. Com base em suas observaçôes, em 4 de setembro de 1914 escreveu ao Serviço de Saúde Pública dos Estados Unidos a respeito das provas acumuladas que permitiriam concluir que 
a pelagra seria causada pela deficiência de algum elemento essencial da dieta. Anos mais tarde, a pelagra foi caracterizada como deficiência específica de niacina (Goldberger, 1988).

No documento enviado ao Serviço de Saúde Pública, Goldberger argumenta que, mesmo sendo estudada há mais de duzentos anos, a causa da pelagra ainda era desconhecida e havia dúvidas se deveria ser classificada como uma enfermidade relacionada com a alimentação ou como doença infectocontagiosa. A elevada freqüência de pelagra nos Estados Unidos havia levado à opiniāo, generalizada entre médicos e leigos, de que se tratava de uma enfermidade infecciosa. Com auxílio de outros pesquisadores, uma série de inoculaçôes de tecidos, secreções e excreções foi realizada entre pacientes graves e casos fatais de pelagra. Entretanto, até o momento em que Goldberger enviou a carta ao Serviço de Saúde Pública, nenhum resultado positivo para doença infecciosa havia sido encontrado. Contudo, chamava a atenção o fato de que, nos estudos realizados em instituições que abrigavam pessoas por um período de até vinte anos, a doença manifestava-se somente entre os internos, sendo que nenhum caso havia sido observado entre os funcionários dessas instituiçôes que viviam nas mesmas condições e, em alguns casos, muito próximos aos pacientes com pelagra.

No estudo realizado por Goldberger nas duas instituições foi possível observar que entre os indivíduos com pelagra havia menor consumo de carnes e outros alimentos protéicos de origem animal, enquanto o consumo de alimentos de origem vegetal, como milho e leguminosas, era desproporcionalmente maior. Com os resultados desse estudo, foi possível constatar que a pelagra pode ser totalmente prevenida por meio de alimentação adequada, sem apoiar qualquer idéia de que pudesse ser uma enfermidade contagiosa. Para concluir, no documento entregue ao Serviço de Saúde Pública, Goldberger argumentava que ao lado de suas observações havia demonstrações práticas de que a pelagra jamais atingira pessoas que consumiam uma alimentação mista, equilibrada e variada, como, por exemplo, as rações fornecidas às Forças Armadas, ao Exército e a exploradores.

Em 1916, dando seqüência aos estudos sobre pelagra, Goldberger revisa a literatura da época e percebe que os estudos associavam a ocorrência da doença a situaçôes de pobreza e miséria, mas conclui que nenhum dos estudos prévios permitia a comparação com a situação econômica da população em geral. Assim, decide estudar a relação de diversos fatores socioeconômicos entre um grupo de trabalhadores da indústria têxtil em sete aldeias do noroeste da Carolina do Sul. A incidência de pelagra foi investigada por meio de visitas quinzenais em busca de casos. Esses casos foram definidos pela clara presença de dermatite simétrica bilateral. Para cada uma das 747 famílias estudadas investigou-se a aquisição de alimentos adquiridos em um período de 15 dias anterior à entrevista e a renda familiar obtida por meio da informação de cada um dos membros do domicílio. Esta última informação foi completada e confirmada por dados obtidos com os funcionários administrativos da indústria têxtil, considerando-se que em $90 \%$ dos casos a renda era proveniente do salário obtido pelos empregados de tais indústrias. Os resultados desse estudo mostraram marcada relação inversa entre baixa renda e incidência de pelagra. A renda mais baixa esteve associada com menor quantidade de carne, verduras, frutas frescas, leite e derivados e maior quantidade de farinha de milho nos domicílios estudados.

James Lind, Takaki e Goldberger estão para a epidemiologia nutricional como John Snow está para a epidemiologia da cólera e para os primórdios da epidemiologia clássica. Esses estudiosos devem ser considerados pioneiros na investigação da relação entre dieta e doença. Outras informações sobre a história da epidemiologia ou sobre os estudos que deram origem ao campo podem ser obtidas em The Challenge of Epidemiology: issues and selected readings (1988).

Evoluindo no tempo, percebe-se que outros trabalhos relacionados com nutrição foram desenvolvidos na primeira metade do século XX. Um estudo realizado em 1933-1934 pelo Serviço de Saúde Pública dos Estados Unidos buscando determinar o limite de flúor recomendado demonstrou que, com exposição con- 
tinuada, a proporção de crianças sem cáries era maior entre aquelas que utilizavam água potável com maior concentração de flúor. Dessa forma, verificou-se que a composição mineral da água potável tem relação importante com a incidência de cáries dentárias em uma comunidade. Em 1945, um estudo de adição de flúor na água para prevenir cárie dentária foi iniciado. Depois de dez anos de experiências, a fluoração da água foi considerada efetiva para reduzir cárie dentária, e uma técnica segura em saúde pública.

A influência da suplementação de vitaminas durante a gestação sobre o desenvolvimento intelectual das crianças foi estudada em um ensaio clínico duplo-cego realizado entre outubro de 1945 e junho de 1948. Testes de inteligência foram aplicados em crianças de 3 a 4 anos de idade. Em um dos locais incluídos no estudo (Norfolk, Virgínia), os resultados mostraram que entre as crianças cujas mães haviam recebido suplementação de vitamina durante o último trimestre de gestação, a inteligência média avaliada por teste específico foi significativamente mais alta do que entre aquelas crianças cuja mãe havia recebido placebo. Resultados mais evidentes foram observados no grupo que recebeu tiamina, riboflavina, niacina e menos evidentes no grupo que recebeu somente tiamina ou ácido ascórbico. No entanto, não houve diferenças significativas em outra região estudada onde a dieta habitual das mulheres estava mais próxima do consumo adequado para esses nutrientes.

É importante destacar a evolução metodológica experimentada ao longo do tempo, claramente evidenciada nos desenhos de estudo dos exemplos anteriores, em que a epidemiologia nutricional estava voltada para as associaçôes entre morbidades e deficiências nutricionais.

Por sua vez, as transições epidemiológica e nutricional experimentadas por populaçôes de diversos países contribuíram em parte para que o escopo da epidemiologia fosse ampliado, passando a incluir também o efeito da dieta sobre a ocorrência de Doenças Crônicas Não Transmissíveis (DCNT). Na segunda metade do século passado, coortes incluindo um grande número de participantes e ensaios clínicos de longa duração foram estabelecidos. Nesse momento ganha importância o conceito de 'epidemiologia nutricional', que passa a ser definida como a ciência cujo objetivo é investigar o efeito da dieta sobre a ocorrência de doenças específicas.

$\mathrm{Na}$ verdade, mais do que o efeito da dieta, os primeiros estudos enfatizavam o efeito de nutrientes específicos, trazendo para as doenças crônicas o mesmo modelo de investigação das doenças carenciais. Uma importante exceção relaciona-se aos estudos do papel do excesso de peso, um dos primeiros fatores nutricionais a serem identificados e relacionados tanto com a incidência de doenças crônicas específicas como com a mortalidade geral. $\mathrm{O}$ excesso de peso torna-se um capítulo à parte nos estudos de epidemiologia nutricional, por se mostrar associado a várias DCNT.

Um marco nos estudos de epidemiologia nutricional é a constituição de coortes como a das enfermeiras americanas, iniciada em 1976, com 121.700 mulheres, que tem servido de base para testar várias hipóteses nutricionais em várias doenças que vão do câncer de mama à síndrome metabólica. Nesse período iniciam-se também os grandes ensaios como o Physicians' Health Study, de 1982, com 22.071 homens. Tratase de ensaio clínico controlado para avaliação de suplementação com betacaroteno na prevenção da doença do coração e do câncer. A principal hipótese estudada no Physicians' Health Study I (já existe o II) foi a relação entre utilização de baixas doses de aspirina e mortalidade cardiovascular. A hipótese secundária avaliou o efeito do betacaroteno na redução da incidência de câncer. $O$ modelo de desenho foi fatorial, e a parte do ensaio que avaliou o efeito da aspirina terminou antes do prazo planejado, considerando-se que os resultados foram favoráveis em relação ao infarto do miocárdio. Esses estudos permitiram testar hipóteses de diversos nutrientes como fatores de risco para as DCNT, e sua importância pode ser avaliada pelo número de publicações que são recuperadas na base de dados da Biblioteca Americana de Medicina, mais conhecida como Medline ou Pubmed. Como exemplo, utilizando-se o nome do estudo Physicians' Health Study na busca, foram identificados 67 trabalhos. O estudo das enfermeiras, por sua vez, já gerou mais de mil publicações. 
Com base nos resultados observados nessas grandes coortes, recomendações e normas nutricionais em saúde pública foram sendo estabelecidas. As guias alimentares dos Estados Unidos, embora existissem desde 1916, foram incorporadas à agenda de saúde somente no final dos anos 70, em virtude dos excessos e desequilíbrios alimentares, como explicitado no The Surgeon General's Report de 1979. A transição epidemiológica como função de mudanças alimentares é novamente reforçada pela publicação do The Surgeon General's Report on Nutrition and Health de 1998, que resume os achados dos diferentes estudos e sua relação com as DCNT.

Diferentes países, inclusive o Brasil, vêm utilizando o conhecimento da epidemiologia nutricional para orientar o setor Saúde e tentar influenciar o consumo alimentar da população. Mesmo com a grande produção científica que serve de base para a elaboração de políticas públicas na área de alimentação e nutrição, críticas são divulgadas, tanto no meio acadêmico como pela população em geral. As restrições ao consumo de ovo tornaram-se emblemáticas nesse sentido. Em relação às guias alimentares americanas, as críticas de que são objeto atualmente as consideram excessivamente influenciadas por fatores econômicos (Willett, 2001), com forte impacto do setor produtivo. Interdiçôes e escolhas alimentares aparecem em diferentes culturas e religiōes, e não se trata de uma questão atual. Todavia, propostas de políticas públicas na área de alimentação e nutrição com o objetivo de influenciar as escolhas alimentares sempre se fundamentaram em conhecimentos científicos correntes. Os recentes avanços da ciência da nutrição fazem com que mudanças na escolha alimentar ocorridas nos últimos anos e outras, ainda desconhecidas pela ciência, possam vir a acontecer, em futuro próximo.

Mais recentemente, as guias alimentares têm enfatizado uma abordagem em alimentos e padrões de consumo (Gifford, 2002) e, dessa forma, aproximam-se das reais necessidades da população. Contudo, na medida em que o conhecimento gerado pela epidemiologia nutricional transforma-se em regra social, ou norma, evidencia-se o seu caráter temporal, ou seja, as normas podem morrer, e essa possibilidade deve ser vista como um passo importante para a incorporação de novos conhecimentos pelos profissionais da saúde e pela população em geral.

\section{Referências}

DEPARTMENT OF HEALTH AND HUMAN SERVICES (DHHS). The Surgeon General's Report on Nutrition and Health. Washington: DHHS/PHS, 1988. (Publication 88-50210)

GIFFORD, K. D. Dietary fats, eating guides, and public policy: history, critique, and recommendations. American Journal of Medicine, 113, suppl. 9B: 89S-106S, 2002.

GOLDBERGER, J. Considerations on pellagra [1914]. In: The Challenge of Epidemiology: issues and selected readings. Whashington: Paho, 1988. (Scientific Publication, 505)

LIND, J. An inquire into the nature, causes, and cure of the scurvy [1753]. In: The Challenge of Epidemiology: issues and selected readings. Whashington: Paho, 1988. (Scientific Publication, 505)

STEERING COMMITTEE OF THE PHYSICIANS' HEALTH STUDY RESEARCH GROUP. Final report on the aspirin component of the ongoing Physicians' Health Study. New England Journal of Medicine, 321(3): 129-135, 1989. 
Epidemiologia Nutricional

TAKAKI, B. The preservation of health amongst the personnel of the Japanese Navy and Army [1906]. In: The Challenge of Epidemiology: issues and selected readings. Whashington: Paho, 1988. (Scientific Publication, 505)

WILLETT, W. C. Eat, Drink and Be Healthy. New York: Simon \& Schuster Source, 2001. 


\section{Parte I \\ Métodos em Epidemiologia Nutricional}





\title{
1
}

\section{Uso e Interpretação dos Indicadores Antropométricos na Avaliação do Estado Nutricional de Gestantes}

\author{
Amanda Rodrigues Amorim, Elisa Maria de Aquino Lacerda e Gilberto Kac
}

$\mathrm{O}$ diagnóstico e o acompanhamento do estado nutricional da gestante são açōes que devem fazer parte da rotina da assistência pré-natal, qualificando a atenção prestada. Essas ações têm o intuito de identificar risco nutricional no início da gestação, detectar as gestantes com ganho de peso inadequado para a idade gestacional e permitir, com base na identificação das gestantes de risco, a implementação de intervenções nutricionais adequadas a cada caso, visando a melhorar o estado nutricional materno, as condições para o parto e o peso do recém-nascido (Ministério da Saúde, 2000).

O estado nutricional materno adequado é fundamental para obter-se bons resultados gestacionais, relacionados à mulher e ao recém-nascido, pois o feto depende exclusivamente do organismo materno para o seu desenvolvimento. Entretanto, a gestação é um momento peculiar para avaliação nutricional, pois as variações, nas medidas antropométricas, são grandes e ocorrem em um curto período (WHO, 1995a, 1991).

O presente capítulo tratará da utilização e interpretação dos indicadores antropométricos na avaliação do estado nutricional de gestantes, considerando vantagens e limitações de cada um.

\section{Indicadores Antropométricos}

A antropometria é um método simples, de baixo custo e possível de ser utilizado nos serviços de saúde para diagnóstico nutricional de gestantes. Além da antropometria, indicadores bioquímicos são especialmente úteis na identificação de carência de micronutrientes como ferro e vitamina A. Contudo, o diagnóstico laboratorial de tais carências nutricionais foge ao escopo deste capítulo, sendo oportunamente abordado nos capítulos "Epidemiologia da anemia ferropriva" e "Epidemiologia da hipovitaminose A e xeroftalmia", respectivamente.

Os indicadores antropométricos mais utilizados na avaliação do estado nutricional pregresso e atual de gestantes são: peso pré-gestacional, estatura materna, perímetro do braço e da panturrilha, pregas cutâneas, Índice de Massa Corporal (IMC) pré-gestacional e ganho ponderal gestacional (WHO, 1995a, 1995b, 1991; Krasovec \& Anderson, 1991). Adicionalmente, a altura uterina e o ganho de peso são utilizados na avaliação do crescimento fetal. O Quadro 1 descreve sinteticamente os pontos de cortes utilizados para os principais indicadores antropométricos de gestantes, bem como suas vantagens e limitações. 
Quadro 1 - Descrição dos indicadores antropométricos para avaliação do estado nutricional de gestantes

\begin{tabular}{|c|c|c|}
\hline Indicador & Ponto de corte & Vantagens e limitações \\
\hline \multirow[t]{5}{*}{ Peso pré-gestacional $(\mathrm{kg})$} & $<40$ & Útil para avaliar o estado nutricional anterior à concepção. \\
\hline & \multirow[t]{4}{*}{ WHO (1991) } & $\begin{array}{l}\text { Útil para calcular o ganho de peso no início da gestação (peso } \\
\text { na primeira consulta pré-natal - peso pré-gestacional). }\end{array}$ \\
\hline & & Utilizado para calcular o ganho de peso total. \\
\hline & & Informação não está freqüentemente disponível. \\
\hline & & Sujeito a viés. \\
\hline \multirow[t]{3}{*}{ Estatura $(\mathrm{cm})$} & $140-150$ & Útil para avaliar o estado nutricional anterior à concepção. \\
\hline & \multirow[t]{2}{*}{ WHO (1991, 1995) } & $\begin{array}{l}\text { Não permite a avaliação de mudanças no estado nutricional } \\
\text { durante a gestação. }\end{array}$ \\
\hline & & $\begin{array}{l}\text { A medida pode ser comprometida quando aferida após a } \\
\text { vigésima semana de gestação devido às alterações na postura } \\
\text { materna. }\end{array}$ \\
\hline \multirow[t]{3}{*}{ Perímetro do braço $(\mathrm{cm})$} & \multirow[t]{3}{*}{$\begin{array}{l}21-23,5 \\
\mathrm{WHO}(1991)\end{array}$} & $\begin{array}{l}\text { Útil na avaliação do estado nutricional anterior à gestação, } \\
\text { principalmente na ausência da informação sobre o peso pré- } \\
\text { gestacional. }\end{array}$ \\
\hline & & De fácil obtenção e não requer equipamentos sofisticados. \\
\hline & & Medida permanece relativamente estável na gestação. \\
\hline \multirow[t]{3}{*}{ IMC pré-gestacional $\left(\mathrm{kg} / \mathrm{m}^{2}\right)$} & \multirow{2}{*}{$\begin{array}{l}\text { Baixo peso: }<19,8 \\
\text { Adequado: } 19,8-26,0 \\
\text { Sobrepeso: } 26,1-29,0 \\
\text { Obesidade: }>29,0\end{array}$} & Útil para avaliar o estado nutricional anterior à concepção. \\
\hline & & $\begin{array}{l}\text { Utilizado para determinar as recomendações de incremento de } \\
\text { peso gestacional apropriado para mulheres com diferentes níveis } \\
\text { de risco nutricional anterior à gestação. }\end{array}$ \\
\hline & IOM (1990) & Depende da informação sobre o peso pré-gestacional. \\
\hline \multirow[t]{3}{*}{ Adequação peso/estatura (\%) } & \multirow{2}{*}{$\begin{array}{l}\text { Baixo peso: }<90 \\
\text { Normal: } 90-120 \\
\text { Sobrepeso: }>120\end{array}$} & $\begin{array}{l}\text { Útil para avaliar o estado nutricional anterior à concepção } \\
\text { quando se utiliza a informação do peso pré-gestacional. }\end{array}$ \\
\hline & & Pode ser utilizado para monitorar o ganho ponderal gestacional. \\
\hline & IOM (1990) & $\begin{array}{l}\text { Necessita de um padrão de referência populacional para } \\
\text { determinar a relação adequada. }\end{array}$ \\
\hline \multirow[t]{3}{*}{ Ganho ponderal $(\mathrm{kg})$} & \multirow{2}{*}{$\begin{array}{l}\text { Baixo peso: } 12,5-18,0 \\
\text { Normal: } 11,5-16,0 \\
\text { Sobrepeso: } 7,0-11,5 \\
\text { Obesidade: } \text { mín. } 6,8\end{array}$} & Varia conforme o estado nutricional pré-gestacional. \\
\hline & & Depende da informação do IMC pré-gestacional. \\
\hline & $\operatorname{lOM}(1990)$ & \\
\hline
\end{tabular}

\section{Peso Pré-gestacional}

O peso anterior à gestação é um importante indicador antropométrico, pois está associado a diversos desfechos gestacionais. Estudos realizados em países desenvolvidos e em desenvolvimento mostram que o peso pré-gestacional tem apresentado associação com o peso ao nascer e mortalidade infantil (Krasovec \& Anderson, 1991). Embora o peso pré-gestacional e ganho de peso ponderal estejam relacionados, pesquisas mostram que o peso anterior à concepção tem um efeito independente no peso ao nascer (WHO, 1991). O peso pré-gestacional, além de ser utilizado no cálculo do ganho de peso durante a gestação, possibilita a avaliação do estado nutricional anterior à concepção por meio do cálculo do IMC pré-gestacional. Embora o peso pré-gestacional seja uma medida útil na avaliação do estado nutricional de gestantes, esta informação não está rotineiramente disponível, 
especialmente em países em desenvolvimento. Mais detalhes quanto ao peso pré-gestacional estão disponíveis no tópico 9, dedicado à interpretação de estudos sobre ganho ponderal gestacional.

\section{Estatura Materna}

A estatura materna é uma medida antropométrica que pode ser utilizada como indicador de avaliação do estado nutricional anterior à concepção, embora não permita a avaliação de mudanças no estado nutricional durante a gestação (Krasovec \& Anderson, 1991). Como a estatura em adultos é o reflexo da interação entre o potencial genético e as condiçôes ambientais (WHO, 1995b), ambos os fatores devem ser considerados na utilização da estatura como prognósticos de resultados gestacionais. A baixa estatura, em países desenvolvidos, pode indicar o risco de complicaçôes obstétricas como desproporção cefalopélvica, trabalho de parto prolongado e parto cirúrgico. Em países em desenvolvimento, a baixa estatura pode indicar risco de Crescimento Intra-Uterino Restrito (CIUR), devido às condições nutricionais desfavoráveis (WHO, 1991; Krasovec \& Anderson, 1991).

Ainda é controversa a associação entre baixa estatura e o Baixo Peso ao Nascer (BPN). Ao passo que alguns estudos demonstram que a estatura tem uma contribuição independente de outros fatores ao risco para BPN, outros estudos postulam que a associação é apenas um reflexo do efeito do peso corporal da gestante. Considerase que o ponto de corte da estatura para o prognóstico de BPN e complicações obstétricas esteja situado entre 140 e $150 \mathrm{~cm}$ (WHO, 1991).

\section{Perímetro do Braço e da Panturrilha}

O perímetro do braço, diferentemente do peso materno, é uma medida que permanece relativamente estável durante o curso da gestação. Este indicador é utilizado na avaliação do estado nutricional anterior à gestação, principalmente na ausência da informação sobre o peso pré-gestacional (Krasovec \& Anderson, 1991).

A utilização deste indicador é recomendada em locais com pouca infra-estrutura, pois a medida do perímetro do braço é de fácil obtenção, não necessitando de equipamentos sofisticados para a sua aferição. Faz-se necessário apenas o treinamento da equipe responsável pela aferição. Os pontos de corte para os resultados desfavoráveis relacionados à gestação variam de 21 a 23,5 cm, de acordo com a população avaliada (WHO, 1991).

O perímetro da panturrilha pode ser utilizado como uma medida alternativa ao perímetro do braço. Esta medida também parece ser relativamente independente da idade gestacional, permanecendo estável ao longo da gestação. A Organização Mundial da Saúde (OMS) indica que o perímetro da panturrilha aferido uma única vez durante a gestação, no primeiro contato com o serviço de saúde, parece ser uma medida promissora na identificação de mulheres sob risco de desfechos gestacionais negativos, especialmente crescimento intra-uterino restrito. Entretanto, sua aferição pode ser comprometida pela presença de edema nos membros inferiores (WHO, 1995b).

\section{Dobras Cutâneas}

A apreciação das alteraçõos nos valores de dobras tem sido amplamente utilizada na avaliação de mudanças do conteúdo de gordura corporal ao longo da gestação, na efetividade de programas de suplementação nutricional de gestantes desnutridas e na identificação de mulheres sob risco de desfechos gestacionais negativos. A aferição de dobras cutâneas durante a gestação pode ser feita em apenas um local, como, por exemplo, na região triciptal, subescapular ou na coxa, ou ainda em diversas áreas corporais, utilizando o somatório dessas pregas. A taxa de incremento da dobra cutânea da coxa ( $\mathrm{mm} / \mathrm{semana}$ ) geralmente é utilizada na avaliação da resposta a uma intervenção nutricional (WHO, 1995a). Por sua vez, a dobra cutânea triciptal é utilizada na identificação da população sob risco de BPN. Estudos revelam que a dobra cutânea triciptal está negativamente relacionada ao peso ao 
nascer, mesmo após ajustes para paridade, idade materna, idade gestacional, estatura e peso maternos e sexo da criança (Briend, 1985; Viegas, Cole \& Wharton, 1987; Neggers et al., 1984). Viegas, Cole e Wharton(1987) relatam que mulheres com aumento semanal da dobra cutânea triciptal inferior a $0,02 \mathrm{~mm}$ entre a $18^{\mathrm{a}}$ e a $28^{\mathrm{a}}$ semanas de gestação deram à luz recém-nascidos com menor peso e menor perímetro cefálico.

O somatório das dobras cutâneas é utilizado na avaliação da distribuição total da gordura subcutânea (WHO, 1986). O Institute of Medicine (IOM) dos Estados Unidos reporta que o aumento na reserva de gordura parece contribuir para o crescimento fetal, entretanto o acúmulo exacerbado de gordura corporal durante a gestação está associado à ocorrência de sobrepeso ou obesidade no período pós-parto (IOM, 1990). Segundo Atalah e Castro (2004), mulheres com gordura corporal maior ou igual a 35\% no início da gestação apresentam maior risco de complicações no parto, hipertensão, diabetes gestacional e mortalidade fetal.

Como descrito no capítulo "Antropometria como método de avaliação do estado de nutrição e saúde do adulto", a aferição de dobras cutâneas apresenta diversas limitações, que podem ser ainda maiores quando mensuradas durante a gestação. A alteração da distribuição de gordura corporal da região central (abdome) para a periférica (pernas, braços e região subescapular) para melhor acomodação do feto na cavidade abdominal pode ser considerada uma limitação específica na gestação, pois o aumento das pregas na região periférica não necessariamente representa aumento na gordura corporal total. Uma outra limitação refere-se à presença de edema nos membros inferiores, principalmente ao término da gestação.

Estudos longitudinais sobre avaliação de dobras cutâneas em gestantes sugerem que o aumento dos valores das dobras ao final da gestação reflete o aumento da retenção de líquido, e não necessariamente um incremento no conteúdo de gordura corporal. Em virtude de tais limitações, o IOM ressalta a necessidade de desenvolvimento de equações de calibração baseadas na população de gestantes, nas quais o conteúdo de gordura corporal seja mensurado utilizando-se o melhor método disponível. Entretanto, o instituto adverte que a aplicabilidade de tais equações irá variar segundo as características da população estudada - idade, cor da pele, nível de atividade física, entre outras (IOM, 1990).

\section{Índice de Massa Corporal Pré-gestacional}

O IMC pré-gestacional, definido como peso pré-gestacional $(\mathrm{kg}) /$ estatura $(\mathrm{m})^{2}$, é utilizado para a identificação de mulheres sob risco nutricional (baixo peso ou sobrepeso) no início da gestação e orienta a quantidade total de peso que, segundo as recomendações do IOM, deve ser ganho durante a gestação (IOM, 1990).

A avaliação do peso para estatura pode ser feita por meio do IMC e também pelo percentual de adequação a um padrão de referência. O IMC e o percentual de adequação peso/estatura são formas diferentes de apresentar a mesma informação. A adequação do peso para a estatura entre 90 e 120\% do padrão de referência do Metropolitan Life Insurance equivale aproximadamente a um IMC entre 19,8 e $26,0 \mathrm{~kg} / \mathrm{m}^{2}$ (limite de normalidade, segundo o IOM, 1990). Vale registrar que o ponto de corte para o IMC pré-gestacional utilizado pela OMS difere dos valores recomendados pelo IOM (WHO, 1995b). Os pontos de corte para IMC pré-gestacional preconizados pelo IOM e OMS estão apresentados na Tabela 1. 
Tabela 1 - Recomendação de ganho de peso segundo IMC pré-gestacional, proposta pelo IOM

\begin{tabular}{|c|c|c|c|c|}
\hline \multirow[t]{2}{*}{ Estado nutricional } & $\begin{array}{l}\text { IMC pré-gestacional, } \\
\text { segundo o } \mathrm{IOM}^{a}\end{array}$ & $\begin{array}{l}\text { IMC pré-gestacional, } \\
\text { segundo a } O M S\end{array}$ & Ganho de peso total ${ }^{b}$ & Taxa de ganho de pesoc \\
\hline & $\mathrm{kg} / \mathrm{m}^{2}$ & $\mathrm{~kg} / \mathrm{m}^{2}$ & $\mathrm{~kg}$ & $\mathrm{~kg} / \mathrm{semana}$ \\
\hline Baixo peso & $<19,8$ & $<18,5$ & $12,5-18,0$ & 0,5 \\
\hline Adequado & $19,8-26,0$ & $18,5-24,9$ & $11,5-16,0$ & 0,4 \\
\hline Sobrepeso & $26,1-29,0$ & $25,0-29,9$ & $7,0-11,5$ & 0,3 \\
\hline Obesidade & $>29,0$ & $\geq 30,0$ & Pelo menos 6,8 & - \\
\hline
\end{tabular}

a - Os pontos de corte adotados pelo IOM correspondem ao 90, 120 e 135 do percentual de adequação do peso/estatura do Metropolitan Life Insurance Company, dos Estados Unidos, de 1959

b - Ganho de peso recomendado na 40a semana gestacional.

c - Taxa de ganho de peso recomendada durante o segundo e terceiro trimestre gestacional.

Fonte: adaptada de IOM (1990).

\section{Estado Nutricional de Gestantes no Brasil}

O Estudo Brasileiro sobre Diabetes Gestacional (EBDG), realizado em seis capitais brasileiras entre 1991 e 1995, classificou o estado nutricional pré-gestacional de 5.314 gestantes adultas, de acordo com os pontos de corte da OMS, e encontrou uma prevalência de 5,7\% de baixo peso, 19,2\% de sobrepeso e 5,5\% de obesidade (Nucci et al., 2001). Outro estudo de coorte, com mulheres entre 15 e 45 anos, residentes no município do Rio de Janeiro, revelou uma prevalência, baseada no IMC pré-gestacional, de 20\% de baixo peso, 10,4\% de sobrepeso e 6,1\% de obesidade (Kac \& Velásquez-Meléndez, 2005). Após um acompanhamento durante nove meses de pósparto, o estado nutricional caracterizou-se por 3,2\% de baixo peso, 33\% de sobrepeso e $12,7 \%$ de obesidade (Castro, Kac \& Sichieri, 2006).

O aumento e a velocidade de aumento da prevalência de sobrepeso e obesidade são fatores preocupantes, devido ao impacto no incremento da morbi-mortalidade de mulheres em decorrência de doenças que se associam ao excesso de peso (Kac \& Velásquez-Meléndez, 2003; Prata, 1992).

O EBDG ainda revelou que a obesidade pré-gestacional e o ganho de peso excessivo na gestação aumentaram de forma independente o risco de cesariana e vários resultados adversos durante o parto vaginal (Seligman et al., 2006), e que mulheres com obesidade pré-gestacional apresentaram maior freqüência de diabetes gestacional.

\section{Altura Uterina}

A altura uterina mensura o tamanho do fundo do útero. A medida é utilizada na avaliação da idade gestacional. Como a altura uterina avalia o tamanho do útero e, indiretamente, o seu conteúdo, esta medida também pode ser utilizada como um indicador do crescimento fetal. Na prática clínica, a aferição da altura uterina na segunda metade da gestação pode ser utilizada na identificação de casos de macrossomia fetal ou CIUR (WHO, 1995b).

\section{Ganho Ponderal Gestacional}

O aumento do peso corporal durante a gravidez é um dos parâmetros mais utilizados durante o pré-natal para se observar a evolução normal da gestação (Krasovec \& Anderson, 1991; WHO, 1991; Suitor, 1997). A informação sobre o ganho de peso materno possibilita avaliar o crescimento fetal, uma vez que é mais sensível ao 
estresse nutricional agudo durante a gestação do que outros indicadores antropométricos (Krasovec \& Anderson, 1991; Yekta et al., 2006). O ganho adequado de peso reduz os riscos e resultados desfavoráveis na gestação e no parto para mãe e filho. O ganho insuficiente de peso, além do baixo peso pré-gestacional, associa-se a riscos fetais como o BPN, CIUR e a prematuridade (Thorsdottir et al., 2002; Schieve et al., 2000). A taxa de mortalidade neonatal para bebês nascidos a termo é cinco vezes maior em crianças Pequenas para Idade Gestacional (PIG), em comparação com as classificadas como adequadas para a idade gestacional (Seeds \& Peng, 1998). Por sua vez, ganho excessivo de peso, associado ou não ao sobrepeso e à obesidade, está relacionado a complicações na gestação e parto, tais como: pré-eclampsia, diabetes gestacional, macrossomia fetal, aumento da taxa de partos operatórios e incidência de distocia (Kac \& Velásquez-Meléndez, 2005; Abrams, Altman \& Pickett, 2000; Dietl, 2005; Nucci et al., 2001). Além dessas implicações, a retenção excessiva de peso no pós-parto é um dos fatores determinantes da obesidade em mulheres em idade reprodutiva (Kac et al., 2004; Linne, 2002).

Para o acompanhamento clínico do ganho ponderal, a gestação é dividida em três trimestres. O primeiro compreende as 13 semanas iniciais, o segundo engloba o período entre a $14^{\mathrm{a}}$ e a $27^{\mathrm{a}}$ semanas, e o terceiro inicia-se na $28^{a}$ semana de gestação (Ministério da Saúde, 2000). O ganho de peso durante a gestação, em geral, obedece ao seguinte padrão: pequeno aumento não linear durante o primeiro trimestre, aumento linear a partir da $13^{\mathrm{a}}-14^{\mathrm{a}}$ semana, ocorrendo o maior ganho durante o segundo trimestre, com a manutenção do padrão até a $36^{a}$ semana. A partir desse período há um decréscimo significativo na velocidade do ganho de peso (Krasovec $\&$ Anderson, 1991; Abrams, Carmichael \& Selvin, 1995). Estima-se que a média do ganho de peso total durante a gestação seja em torno de $12,0 \mathrm{~kg}$, dos quais $3,5 \mathrm{~kg}$ representariam o peso do feto a termo, 3,0 kg seriam referentes ao aumento uterino e das glândulas mamárias, do líquido amniótico e da placenta, 0,5 a 1,0 kg seriam referentes à retenção de líquido e 4,0 kg referentes ao depósito de tecido adiposo materno (Hytten, 1980).

\section{Curvas e Recomendações de Ganho de Peso}

Existem diversos tipos de curvas de peso. Em geral, consistem de um gráfico que tem a idade gestacional em semanas como abscissa e o ganho de peso em quilogramas (diferença entre peso no momento da consulta e peso pré-gestacional) como ordenada. A utilização deste instrumento é simples e de grande relevância na avaliação da evolução do estado nutricional materno durante a gestação.

Além das curvas de peso, existe um outro instrumento utilizado na avaliação do ganho ponderal gestacional, denominado curva de adequação percentual de peso para estatura. Esta curva possui a idade gestacional como abscissa e o peso materno definido como percentual de adequação como ordenada. Ambos os instrumentos requerem o conhecimento prévio dos valores normais para a população atendida e da idade gestacional (Krasovec \& Anderson, 1991).

No Brasil, a Curva de Rosso, baseada na adequação percentual de peso para estatura segundo idade gestacional, foi adotada pelo Ministério da Saúde (MS) em 1987 como instrumento gráfico de avaliação da evolução nutricional da gestante na rede pública de saúde (Ministério da Saúde, 1988). A Curva de Rosso foi construída com base em amostra de 262 mulheres norte-americanas saudáveis que deram à luz recém-nascidos vivos sem má-formação congênita (Rosso, 1985). Para fins de validação, um estudo multicêntrico foi realizado nos EUA, Chile e Brasil. O estudo constatou que, ao final da gravidez, o ganho de peso de $20 \%$ em relação ao peso ideal para estatura no início da gestação garante o crescimento fetal máximo. O estudo concluiu que a curva era um potente instrumento para diagnóstico nutricional de gestantes e para prevenir o BPN. A consistência dos primeiros resultados fez com que, no Brasil, este instrumento fosse adotado pelo MS em caráter preliminar. Este método, no entanto, não é mais utilizado por ter-se mostrado inadequado para a triagem de gestantes em risco nutricional, uma vez que confere diagnóstico positivo de baixo peso para grande proporção de mulheres com estado nutricional adequado (Coelho, Souza \& Filho, 2002). Além da superestimação da desnutrição, o instrumento de Rosso recebeu críticas por ter 
utilizado a tabela do Metropolitan Life Insurance como referência para adequação peso/estatura, e por não possibilitar a avaliação de mulheres com peso pré-gestacional acima de $130 \%$ de adequação. Nesse caso, as mulheres eram orientadas a ganhar aproximadamente $7 \mathrm{~kg}$ (Rosso, 1985).

A partir de uma pequena casuística de 43 gestantes uruguaias, o Centro Latino-Americano de Perinatologia propôs um modelo tentativo de avaliação antropométrica do estado nutricional da gestante utilizando o aumento de peso a partir de 12 semanas de gravidez, consistindo em quatro curvas correspondentes aos percentis 10, 25, 50 e 90 . Diminui-se do peso atual da gestante o peso pré-gestacional, obtendo-se o aumento de peso para a idade gestacional. O valor é registrado no gráfico do cartão da gestante. As gestantes devem se localizar entre o percentil 25 e 90 do gráfico, independentemente do IMC pré-gestacional (Fescina, 1997). O MS incorporou o método de Fescina no manual técnico de "Assistência pré-natal" (Ministério da Saúde, 2000), resultando em controvérsias por parte dos estudiosos do problema, devido ao pequeno número de observações do estudo original. Além disso, o método fundamenta-se em relações corporais de mulheres no período reprodutivo comparadas com tabelas de referência peso/idade provenientes da metade do século passado, quando a antropometria nutricional ainda não incorporava normas e padrōes hoje considerados, como, por exemplo, o IMC pré-gestacional.

Recentemente, com a intenção de corrigir as distorções observadas no método da Curva de Rosso, Atalah e colaboradores elaboraram novo instrumento baseado no IMC ajustado pela idade gestacional (Figura 1). Nas primeiras semanas de gestação, os autores adotaram os pontos de corte de IMC de 20, 25 e 30 como limites para baixo peso, sobrepeso e obesidade, respectivamente (Tabela 2). Considerando o estado nutricional no início da gestação, os autores estimaram o ganho cumulativo de peso que se associava a um menor risco para a mãe e para o feto e transformaram esse ganho em unidades de IMC. Estudo de validaçáo deste instrumento abrangendo cerca de setecentas gestantes atendidas na rede pública de saúde do Chile foi concluído recentemente, mostrando resultados favoráveis para a utilização do indicador e dos instrumentos que viabilizam seu uso - um gráfico e uma tabela com o IMC por semana gestacional (Atalah \& Castro, 2004).

Figura 1 - Acompanhamento nutricional de gestantes, proposto por Atalah

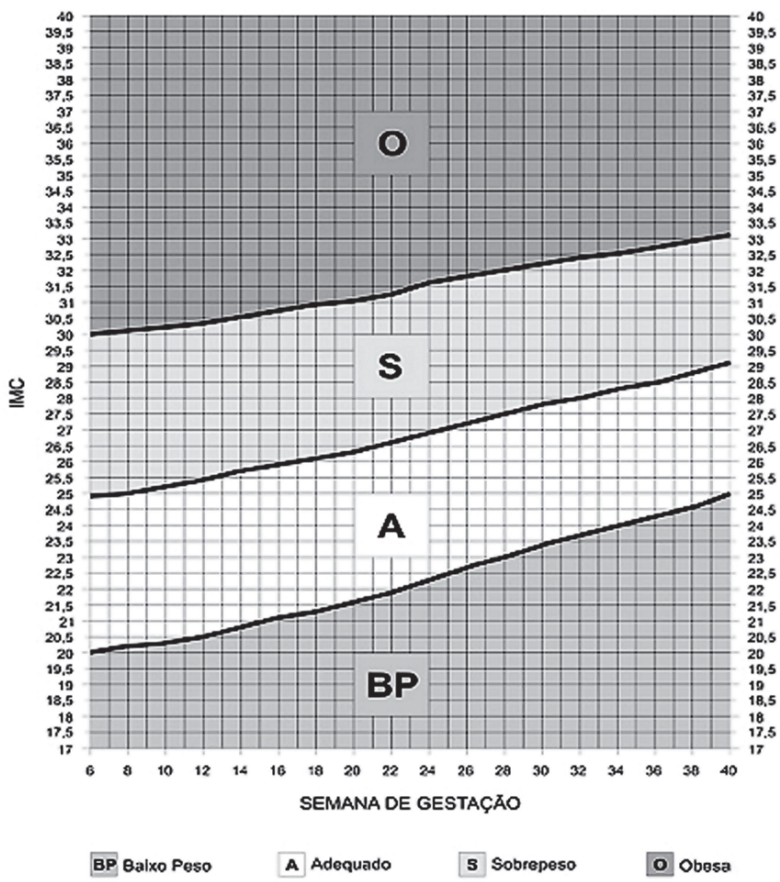

Fonte: adaptada de Atalah et al. (1997). 
Epidemiologia Nutricional

Tabela 2 - Método de avaliação do estado nutricional de gestantes segundo IMC por semana gestacional, proposto por Atalah

\begin{tabular}{|c|c|c|c|c|c|c|}
\hline \multirow{2}{*}{$\begin{array}{c}\text { Semana gestacional } \\
8\end{array}$} & \multirow{2}{*}{$\begin{array}{c}\text { Baixo peso } \\
\text { IMC } \\
19,9\end{array}$} & \multicolumn{2}{|c|}{$\begin{array}{l}\text { Adequado } \\
\text { IMC entre }\end{array}$} & \multicolumn{2}{|c|}{$\begin{array}{l}\text { Sobrepeso } \\
\text { IMC entre }\end{array}$} & \multirow{2}{*}{$\begin{array}{c}\text { Obesidade } \\
\text { IMC } \\
30,1\end{array}$} \\
\hline & & 20,0 & 24,9 & 25,0 & 30,0 & \\
\hline 9 & 20,1 & 20,2 & 25,0 & 25,1 & 30,1 & 30,2 \\
\hline 10 & 20,2 & 20,3 & 25,2 & 25,3 & 30,2 & 30,3 \\
\hline 11 & 20,3 & 20,4 & 25,3 & 25,4 & 30,3 & 30,4 \\
\hline 12 & 20,4 & 20,5 & 25,4 & 25,5 & 30,3 & 30,4 \\
\hline 13 & 20,6 & 20,7 & 25,6 & 25,7 & 30,4 & 30,5 \\
\hline 14 & 20,7 & 20,8 & 25,7 & 25,8 & 30,5 & 30,6 \\
\hline 15 & 20,8 & 20,9 & 25,8 & 25,9 & 30,6 & 30,7 \\
\hline 16 & 21,0 & 21,1 & 25,9 & 26,0 & 30,7 & 30,8 \\
\hline 17 & 21,1 & 21,2 & 26,0 & 26,1 & 30,8 & 30,9 \\
\hline 18 & 21,2 & 21,3 & 26,1 & 26,2 & 30,9 & 31,0 \\
\hline 19 & 21,4 & 21,5 & 26,2 & 26,3 & 30,9 & 31,0 \\
\hline 20 & 21,5 & 21,6 & 26,3 & 26,4 & 31,0 & 31,1 \\
\hline 21 & 21,7 & 21,8 & 26,4 & 26,5 & 31,1 & 31,2 \\
\hline 22 & 21,8 & 21,9 & 26,6 & 26,7 & 31,2 & 31,3 \\
\hline 23 & 22,0 & 22,1 & 26,8 & 26,9 & 31,3 & 31,4 \\
\hline 24 & 22,2 & 22,3 & 26,8 & 27,0 & 31,5 & 31,6 \\
\hline 25 & 22,4 & 22,5 & 27,0 & 27,1 & 31,6 & 31,7 \\
\hline 26 & 22,6 & 22,7 & 27,2 & 27,3 & 31,7 & 31,8 \\
\hline 27 & 22,7 & 22,8 & 27,3 & 27,4 & 31,8 & 31,9 \\
\hline 28 & 22,9 & 23,0 & 27,5 & 27,6 & 31,9 & 32,0 \\
\hline 29 & 23,1 & 23,2 & 27,6 & 27,7 & 32,0 & 32,1 \\
\hline 30 & 23,3 & 23,4 & 27,8 & 27,9 & 32,1 & 32,2 \\
\hline 31 & 23,4 & 23,5 & 27,9 & 28,0 & 32,2 & 32,3 \\
\hline 32 & 23,6 & 23,7 & 28,0 & 28,1 & 32,3 & 32,4 \\
\hline 33 & 23,8 & 23,9 & 28,1 & 28,2 & 32,4 & 32,5 \\
\hline 34 & 23,9 & 24,0 & 28,3 & 28,4 & 32,5 & 32,6 \\
\hline 35 & 24,1 & 24,2 & 28,4 & 28,5 & 32,6 & 32,7 \\
\hline 36 & 24,2 & 24,3 & 28,5 & 28,6 & 32,7 & 32,8 \\
\hline 37 & 24,4 & 24,5 & 28,7 & 28,8 & 32,8 & 32,9 \\
\hline 38 & 24,5 & 24,6 & 28,8 & 28,9 & 32,9 & 33,0 \\
\hline 39 & 24,7 & 24,8 & 28,9 & 29,0 & 33,0 & 33,1 \\
\hline 40 & 24,9 & 25,0 & 29,1 & 29,2 & 33,1 & 33,2 \\
\hline 41 & 25,0 & 25,1 & 29,2 & 29,3 & 33,2 & 33,3 \\
\hline 42 & 25,0 & 25,1 & 29,2 & 29,3 & 33,2 & 33,3 \\
\hline
\end{tabular}

Fonte: adaptado de Atalah et al. (1997).

Atualmente, este método foi adotado pelo MS na rotina de avaliação do estado nutricional de gestantes atendidas na rede pública de saúde. O IMC por semana gestacional tem como vantagem permitir realizar o 
diagnóstico nutricional em qualquer momento da consulta do pré-natal, possibilitando também o monitoramento do estado nutricional por meio da visualização do traçado dos valores de IMC marcados no gráfico (Figura 1). Como a previsão de ganho de peso total até o final da gestação é uma medida de muita utilidade na prática clínica, por permitir quantificar, em quilogramas, o ganho de peso desejado para a gestante e propiciar orientações nutricionais adequadas, o MS adotou, em caráter complementar ao método de Atalah, a recomendação de ganho de peso total preconizada pelo IOM em 1990 (Ministério da Saúde, 2005).

Embora a proposta de avaliação de gestantes do MS - uma combinação de dois métodos (curva de Atalah e IOM) - pareça temporariamente satisfatória, faz-se necessária a realização de um estudo multicêntrico nacional para a construção de uma curva de ganho de peso adequada para a população brasileira. Coelho, Souza e Filho (2002), em uma revisão sobre os modelos técnicos de avaliação antropométrica do estado nutricional durante a gestação utilizados nos últimos quarenta anos, afirmam que ainda é necessária a elaboração de um método mais satisfatório, desvinculado da condição peso ao nascer, como referência dominante na avaliação do instrumento.

Em âmbito internacional, apesar das recomendaçôes de ganho de peso variarem entre os países, parece haver uma tendência dos pesquisadores a utilizar a recomendação proposta pelo IOM. O ganho de peso preconizado pelo IOM varia em função da adequação do IMC pré-gestacional (Tabela 1 e Figura 2). O IOM recomenda um ganho de 11,5 a 16,0 kg para mulheres com o IMC pré-gestacional normal e um ganho de peso maior e menor para as mulheres com baixo peso e sobrepeso antes da concepção, respectivamente (IOM, 1990). Desde sua publicação em 1990, diversos estudos têm avaliado a adequação dessa recomendação (Parker \& Abrams, 1992; Keppel \& Taffel, 1993; Schieve, Cogswell \& Scanlon, 1998; Thorsdottir et al., 2002; Cogswell et al., 1995). Os estudos revelam que o ganho ponderal recomendado pelo IOM está associado a resultados favoráveis relacionados às mulheres e aos recém-nascidos.

Figura 2 - Curvas de ganho de peso, segundo IMC pré-gestacional ${ }^{A B C}$, propostas pelo IOM

A

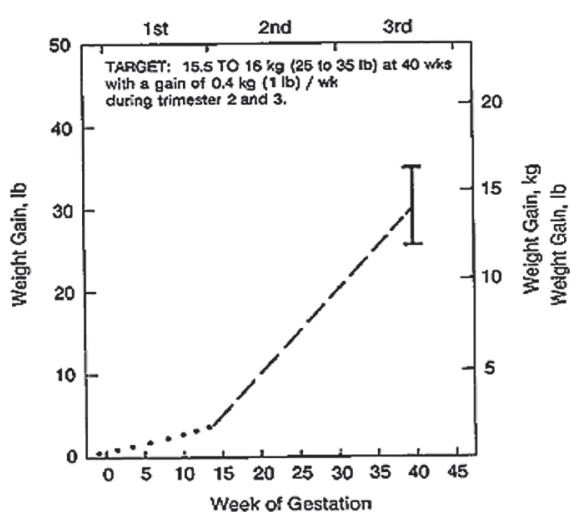

B

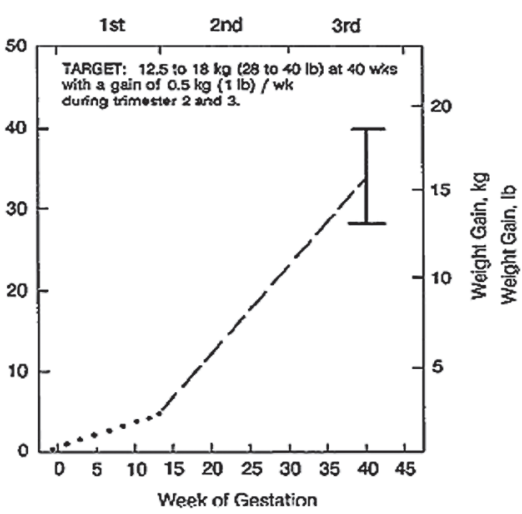

C

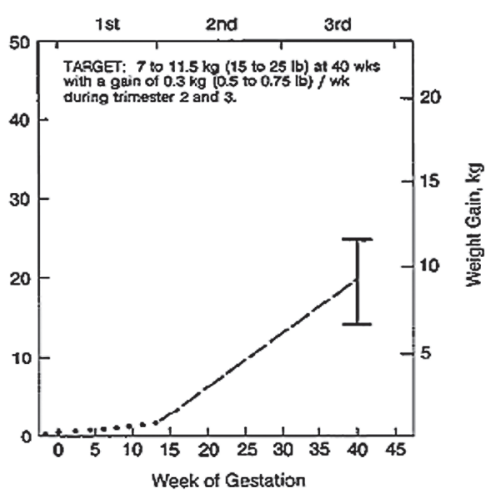

A - Assume-se um ganho de peso de 1,6 kg no primeiro trimestre e uma taxa de ganho de peso de $440 \mathrm{~g} / \mathrm{semana} \mathrm{no} \mathrm{segundo}$ e terceiro trimestres

B - Assume-se um ganho de peso de 2,3 kg no primeiro trimestre e uma taxa de ganho de peso de $490 \mathrm{~g} / \mathrm{semana}$ no segundo e terceiro trimestres.

C - Assume-se um ganho de peso de 0,9 kg no primeiro trimestre e uma taxa de ganho de peso de $300 \mathrm{~g} / \mathrm{semana}$ no segundo e terceiro trimestres.

Fonte: IOM (1990). 


\section{Indicadores de Ganho Ponderal Gestacional}

Existem vários indicadores utilizados para computar o ganho de peso gestacional. Os principais são: ganho de peso total, taxa de ganho de peso, ganho de peso total líquido e taxa líquida de ganho de peso. Em geral, o ganho de peso total é determinado pela diferença entre o peso no final da gestação e o peso no início da gestação; a taxa de ganho de peso é definida como ganho de peso total dividido pela idade gestacional em semanas, e o ganho de peso total líquido é determinado pela diferença entre ganho de peso total e o peso da criança ao nascer (IOM, 1990). Por fim, a taxa líquida de ganho de peso é calculada pela divisão do ganho de peso total líquido pela duração total da gestação em semanas. O ganho de peso total é o indicador mais utilizado; no entanto, ele não permite diferenciar os componentes do ganho de peso, como o peso do feto, as reservas de gordura materna, a massa magra materna, o volume sangüíneo e de água e outros componentes necessários para um bom resultado gestacional (Krasovec \& Anderson, 1991). Além dessa limitação, é importante notar que o ganho de peso total é influenciado pela duração da gestação. Os principais indicadores de ganho de peso, bem como suas vantagens e limitaçôes, estão descritos no Quadro 2.

Quadro 2 - Definições do ganho de peso gestacional e comentários sobre suas aplicações

\begin{tabular}{|c|c|}
\hline \multicolumn{2}{|c|}{ Ganho de Peso Total (GPT) } \\
\hline Indicador & Vantagens e limitações \\
\hline GPT $=P$ final $-P$ inicial & $\begin{array}{l}\text { Não identifica o padrão de GP. Não é útil para monitorar o GP. } \\
\text { Não permite a implementação de intervenções, pois a } \\
\text { identificação do ganho insuficiente ou excessivo de peso ocorre ao } \\
\text { término da gestação. } \\
\text { É influenciado pela duração da gestação. } \\
\text { Utilizado em pesquisas e programas de vigilância. }\end{array}$ \\
\hline Medidas & Vantagens e limitações \\
\hline GPT $=P$ final $-P$ pré-gestacional & $\begin{array}{l}\text { Quantifica o GP desde o início da gestação. } \\
\text { Difícil obtenção do peso pré-gestacional em alguns subgrupos } \\
\text { populacionais. } \\
\text { O peso pré-gestacional referido pode estar sujeito a viés. Mulheres } \\
\text { com baixo peso e sobrepeso tendem a superestimar e subestimar, } \\
\text { respectivamente, os pesos. }\end{array}$ \\
\hline GPT = P final $-\mathrm{P}$ gestacional na primeira consulta pré-natal & $\begin{array}{l}\text { O peso na primeira consulta é comumente disponível. } \\
\text { Não representa o peso pré gestacional. } \\
\text { Pode afetar o cálculo quando a informação for registrada } \\
\text { tardiamente. }\end{array}$ \\
\hline GPT $=$ P da gestante no dia do parto $-P$ inicial & $\begin{array}{l}\text { Peso no dia do parto não é rotineiramente coletado. } \\
\text { Fornece o GPT real. } \\
\text { É importante para pesquisas. }\end{array}$ \\
\hline GPT = P da última consulta pré-natal $-\mathrm{P}$ inicial & $\begin{array}{l}\text { Freqüentemente disponível. } \\
\text { Algumas vezes é obtido muitas semanas antes do parto. }\end{array}$ \\
\hline
\end{tabular}


Quadro 2 - Definições do ganho de peso gestacional e comentários sobre suas aplicações (continuação)

\begin{tabular}{|c|c|}
\hline \multicolumn{2}{|c|}{ Taxa de Ganho de Peso (TGP) } \\
\hline Indicador & Vantagens e limitações \\
\hline TGP $=(P$ data2 $-P$ data 1$) /(|G 2-| G 1)$ & $\begin{array}{l}\text { Assume um padrão de GP linear. Sabe-se que o GP no primeiro } \\
\text { trimestre não é linear. } \\
\text { A aferição do GP cumulativo em um ponto específico da gestação } \\
\text { é rotineiramente disponível na prática clínica e em pesquisas. } \\
\text { É afetado pela freqüência das mensurações. } \\
\text { Remove parcialmente a dependência do tempo. }\end{array}$ \\
\hline Medidas & Vantagens e limitações \\
\hline $\begin{array}{l}\text { TGP }=(P \text { no início do trimestre }-P \text { no final do trimestre }) / n^{\circ} \text { de } \\
\text { semanas do trimestre }\end{array}$ & $\begin{array}{l}\text { Não necessita do peso pré-gestacional. } \\
\text { O peso no início e ao final do trimestre não está sempre disponível. } \\
\text { Requer uma estimativa acurada da IG. }\end{array}$ \\
\hline $\mathrm{TGP}=\mathrm{GPT} / \mathrm{IG}$ & $\begin{array}{l}\text { A aferição da taxa de ganho de peso total é rotineiramente } \\
\text { disponivel na prática clínica. } \\
\text { Não é freqüentemente disponível em pesquisas. } \\
\text { Remove a dependência do tempo. } \\
\text { Possivelmente é não linear. } \\
\text { Requer uma estimativa acurada da duração da gestação. } \\
\text { É afetado pela qualidade da informação do peso pré-gestacional. }\end{array}$ \\
\hline \multicolumn{2}{|c|}{ Ganho de Peso Total Líquido (GPTL) } \\
\hline Indicador & Vantagens e limitações \\
\hline $\begin{array}{l}\text { GPTL = GPT - P (do recém-nascido ou dos produtos } \\
\text { da concepção ou peso materno no pós-parto) }\end{array}$ & $\begin{array}{l}\text { Assume um padrão de GP linear. Sabe-se que o GP no primeiro } \\
\text { trimestre não é linear. } \\
\text { A aferição do GP cumulativo em um ponto específico da gestação } \\
\text { é rotineiramente disponível na prática clínica e em pesquisas. } \\
\text { É afetado pela freqüência das mensurações. } \\
\text { Remove parcialmente a dependência do tempo. }\end{array}$ \\
\hline Medidas & Vantagens e limitações \\
\hline GPTL = GPT - P do recém-nascido & $\begin{array}{l}\text { A informação do peso ao nascer é freqüentemente disponível. } \\
\text { Remove a correlação do peso materno com o peso ao nascer. }\end{array}$ \\
\hline GPTL = GPT - P dos produtos da concepção & $\begin{array}{l}\text { Os pesos da placenta e do líquido amnióticos não são disponíveis. } \\
\text { Remove a correlação do peso materno com o peso do bebê e dos } \\
\text { produtos da concepção. } \\
\text { Fornece uma estimativa mais acurada. }\end{array}$ \\
\hline GPTL = P no pós-parto $-P$ pré-gestacional & $\begin{array}{l}\text { A informação do P no pós-parto não está freqüentemente } \\
\text { disponível. } \\
\text { Remove o efeito da correlação do peso materno com o peso do } \\
\text { bebê e dos produtos da concepção. } \\
\text { É influenciado pelo tempo de pós-parto (diurese). } \\
\text { Fácil mensuração. }\end{array}$ \\
\hline
\end{tabular}


Quadro 2 - Definições do ganho de peso gestacional e comentários sobre suas aplicações (continuação)

\begin{tabular}{|ll|}
\hline \multicolumn{1}{|c|}{ Taxa Líquida de Ganho de Peso (TLGP) } \\
\hline Indicador & \multicolumn{1}{c|}{ Vantagens e limitações } \\
\hline TLP = GPTL / IG & Remove o efeito da correlação do GP materno e o peso fetal. \\
& Remove dependência do tempo. \\
& Requer uma estimativa acurada da duração da gestação. \\
& $\begin{array}{l}\text { Não é útil para a prática clínica, pois o peso fetal não pode ser } \\
\text { determinado no útero e as correções não podem ser feitas durante a } \\
\text { gestação. }\end{array}$ \\
\hline
\end{tabular}

a - As variações das medidas utilizadas na composição deste indicador são as mesmas descritas para GPTL: GP Iganho de peso), GPT (ganho de peso total), GPTL (ganho de peso total líquido), IG (idade gestacional), P (peso), TGP (taxa de ganho de peso), TLGP (taxa líquida de ganho de peso).

Fonte: adaptado de IOM (1990).

\section{Interpretação de Estudos sobre Ganho Ponderal Gestacional}

Como descrito no Quadro 2, além da diversidade dos indicadores para o cálculo do ganho ponderal gestacional, também existem variações nas medidas utilizadas para computá-los. Portanto, a interpretação dos resultados de pesquisas que envolvem o ganho de peso deve levar em consideração a definição do indicador, as medidas utilizadas como peso no início e ao final da gestação, a acurácia do método empregado para o cálculo da idade gestacional e a inclusão ou não do peso fetal como parte do ganho de peso materno (IOM, 1990; Kramer et al., 1992). A decisão sobre qual medida deve ser utilizada no cálculo do ganho de peso depende fundamentalmente da disponibilidade e qualidade dos dados e dos problemas metodológicos inerentes a cada medida.

\section{Peso no Início da Gestação}

Segundo o IOM, o peso mensurado antes da concepção deve ser preferencialmente utilizado no cálculo do ganho de peso. Entretanto, como a medida não está freqüentemente disponível, o peso auto-referido pode ser utilizado como uma aproximação do peso materno anterior à gestação, desde que informado antes da $13^{a}$ semana gestacional. Apesar de o peso referido ser fortemente correlacionado ao peso corporal mensurado antes da gestação, esta medida está sujeita a viés (IOM, 1990). Mulheres com sobrepeso tendem a subestimar o peso prégestacional, e mulheres com baixo peso tendem a superestimá-lo (Stevens-Simon, Roghmann \& McAnarney, 1992). Mulheres com peso normal também são suscetíveis a informarem o peso erradamente, devido à baixa acurácia das balanças e às práticas inadequadas de mensuração (Ellison \& Holliday, 1997; Harris et al., 1997, 1998). Em face de tais limitações, Harris e Ellison (1998) advogam que o peso pré-gestacional informado não é adequado para o uso em pesquisas, mas é supostamente apropriado para o uso na prática clínica. Em contraste, estudos de validação mostram que a diferença entre o peso mensurado e o informado é pequena, aproximadamente 1-2 kg, o que permite que o dado seja utilizado em estudos epidemiológicos (Gunderson, Abrams \& Selvin, 2001). Visto que ainda não existe consenso quanto à utilização do peso informado, é aconselhável que os estudos validem o peso referido pela gestante em uma subamostra antes de usar esta informação para o cálculo do ganho de peso.

Quando o peso informado parece suspeito ou quando a gestante não se recorda do seu peso anterior à gestação, o peso mensurado durante a primeira consulta pré-natal, antes de 13 semanas, também pode ser utilizado. Embora essa medida não reflita o peso pré-gestacional, o ganho de peso durante o primeiro trimestre da 
gestação é geralmente pequeno, 1-2 kg (Krasovec \& Anderson, 1991). Contudo, as variações interindividuais devem ser levadas em consideração. Algumas mulheres são suscetíveis a náuseas e vômitos no início da gestação e podem apresentar uma perda significativa de peso durante esse período, ao passo que outras podem apresentar um ganho de peso expressivo durante o primeiro terço da gestação (IOM, 1990). Ademais, muitas mulheres iniciam o acompanhamento pré-natal tardiamente, e raramente o peso materno na primeira consulta é aferido durante o primeiro trimestre gestacional.

\section{Peso Final}

No cálculo do ganho de peso total, é crucial certificar-se de que o ganho de peso foi computado considerando a última medida de peso durante a gestação, de modo a garantir que nenhum ganho adicional de peso não tenha sido mensurado. A título de ilustração, considere um estudo que esteja avaliando a associação entre o ganho de peso insuficiente e a ocorrência de BPN. Suponha que a duração média da gestação foi de quarenta semanas e o ganho de peso total foi calculado por volta da 32a semana de gestação. Nessa situação, a associação é subestimada devido ao intervalo entre a última medida de peso e a data do parto. Presumivelmente, houve um ganho de peso adicional após a aferição do peso final (32a semana) que não foi computado. Idealmente, o ganho de peso deve ser calculado utilizando-se como medida final o peso mensurado durante a admissão na maternidade. No entanto, como esta medida não está freqüentemente disponível, na ausência de informação, sugere-se utilizar o peso final mensurado não mais que duas semanas antes do parto (Scholl et al., 1995).

\section{Idade Gestacional}

Como descrito anteriormente, a aferição correta da idade gestacional é de suma importância para a interpretação dos indicadores antropométricos e também para a avaliação do desenvolvimento da gestante e do bebê e para orientação de medidas de intervenção apropriadas, pois cada período gestacional apresenta suas peculiaridades e exige manejo clínico diferenciado.

Embora a OMS recomende a utilização da Data da Última Menstruação (DUM) como método para o cálculo da idade gestacional, tanto para fins clínicos como para as pesquisas na área (Alexander, Tompkins $\&$ Cornely, 1990), alguns autores questionam a acurácia deste indicador pela possibilidade de sangramento no primeiro trimestre ser confundido com a última menstruação e pela ocorrência de ciclos longos e/ou irregulares ampliando as diferenças entre idade da gestação e idade da concepção (Kramer et al., 1988; Savitz et al., 2002). A definição da idade gestacional baseada na DUM resulta em erro de classificação de partos prematuros, a termo e pós-termo e diagnósticos incorretos de CIUR (Kramer et al., 1988). Este erro de classificação pode, por exemplo, superestimar a taxa de ganho de peso em mulheres que tiveram partos a termo, quando a DUM indicou parto pré-termo, e subestimar a taxa de ganho de peso de mulheres que deram à luz recém-nascidos a termo, quando a DUM indicou parto pós-termo (IOM, 1990). Em função desses fatores, observa-se uma crescente indicação e utilização da ultra-sonografia (USG) para a estimação da idade gestacional do recém-nascido. No entanto, a USG deve ser realizada no início do segundo trimestre para ser considerada como um método mais apropriado para mensurar a idade gestacional (Kramer et al., 1988).

\section{Influência da Duração da Gestação}

O ganho de peso total, apesar de ser um indicador amplamente utilizado em pesquisas nacionais e internacionais, é dependente da duração da gestação. Em geral, quanto maior a duração da gestação, maior o ganho ponderal. Este fenômeno de dependência temporal deve ser considerado na apreciação de estudos sobre a associação 
entre o baixo ganho de peso gestacional e a ocorrência de partos prematuros. Visto que a prematuridade encurta o tempo de ganho de peso, deve-se ajustar o ganho de peso total pela duração da gestação, utilizando-se preferencialmente o indicador de taxa de ganho de peso (IOM, 1990).

\section{Componentes do Ganho de Peso}

$\mathrm{Na}$ apreciação do ganho ponderal, é necessária também a diferenciação entre os componentes nutricionais e não nutricionais, identificando se o aumento de peso é resultante de alterações da massa magra na reserva de tecido adiposo ou ainda do aumento do tamanho do feto, placenta e líquido amniótico. O ganho de peso total líquido permite avaliar o ganho ponderal materno retirando a contribuição dos componentes da concepção. Além disso, o ganho de peso líquido remove o viés chamado pelos epidemiologistas de part-whole correlation. Este viés ocorre quando, em um estudo, o peso do recém-nascido é incluído como variável dependente e também é um componente da variável independente - ganho de peso materno (Gunderson \& Abrams, 1999; Selvin \& Abrams, 1996).

\section{Considerações Finais}

A importância da avaliação do estado nutricional da gestante, bem como do acompanhamento do ganho de peso gestacional, reside na possibilidade de realização de intervençôes que minimizem o impacto que as alteraçôes no estado nutricional da gestante possam acarretar na saúde da mulher e do recém-nascido. Pesquisas aplicadas devem ser empreendidas a fim de desenvolver e validar não somente protocolos de atenção nutricional, como também os próprios instrumentos utilizados na avaliação antropométrica do estado nutricional de gestantes.

\section{Referências}

ABRAMS, B.; ALTMAN, S. L. \& PICKETT, K. E. Pregnancy weight gain: still controversial. American Journal of Clinical Nutrition, 71: 1.233-1.241, 2000.

ABRAMS, B.; CARMICHAEL, S. \& SELVIN, S. Factors associated with the pattern of maternal weight gain during pregnancy. Obstetrics \& Gynecology, 86: 170-176, 1995.

ALEXANDER, G. R.; TOMPKINS, M. E. \& CORNELY, D. A. Gestational age reporting and preterm delivery. Public Health Reports, 105: 267-275, 1990.

ATALAH, E. Validation of a new chart for assessing the nutritional status during pregnancy, 1999. (Mimeo.)

ATALAH, E. \& CASTRO, R. Maternal obesity and reproductive risk. Revista Médica de Chile, 132: 923-930, 2004.

ATALAH, E. et al. Proposal of a new standard for the nutritional assessment of pregnant women. Revista Médica de Chile, 125(12): 1.429-1.436, 1997.

BRIEND, A. Do maternal energy reserves limit fetal growth? The Lancet, 1: 38-40, 1985.

CASTRO, M. B. T., KAC, G. \& SICHIERI, R. Padrão de consumo alimentar em mulheres no pós-parto atendidas em um centro municipal de saúde do Rio de Janeiro, Brasil. Cadernos de Saúde Pública, 22: 1.159-1.170, 2006.

COELHO, S. K.; SOUZA, A. I. \& FILHO, M. B. Avaliação antropométrica do estado nutricional da gestante: visão retrospectiva e prospectiva. Revista Brasileira de Saúde Materno Infantil, 2: 57-61, 2002. 
COGSWELL, M. E. et al. Gestational weight gain among average-weight and overweight women: what is excessive? American Journal of Obstetrics and Gynecology, 172: 705-712, 1995.

DIETL, J. Maternal obesity and complications during pregnancy. Journal of Perinatal Medicine, 33: 100-105, 2005.

ELLISON, G. T. H. \& HOLLIDAY, M. The use of maternal weight measurements during antenatal care: a national survey of midwifery practice throughout the United Kingdom. Journal of Evaluation in Clinical Practice, 3: 3.003-3.307, 1997.

FESCINA, R. H. Nutrición materna y resultados perinatales. Clínicas Perinatológicas Argentinas, 4: 77-98, 1997.

GUNDERSON, E. P. \& ABRAMS, B. Epidemiology of gestational weight gain and body weight changes after pregnancy. Epidemiologic Reviews, 21: 261-275, 1999.

GUNDERSON, E. P.; ABRAMS, B. \& SELVIN, S. Does the pattern of postpartum weight change differ according to pregravid body size? International Journal of Obesity and Related Metabolic Disorders, 25: 853$862,2001$.

HARRIS, H. E. \& ELLISON, G. T. Practical approaches for estimating prepregnant body weight. Journal of Nurse-Midwifery, 43: 97-101, 1998.

HARRIS, H. E. et al. Methodological considerations in the design of an obstetric database abstracted from medical records. Methods of Information in Medicine, 36: 191-200, 1997.

HARRIS, H. E. et al. How accurate are antenatal weight measurements? A survey of hospital and community clinics in a South Thames Region NHS Trust. Pediatric and Perinatal Epidemiology, 12: 163-175, 1998.

HYTTEN, F. Weight gain in pregnancy. In: HYTTEN, F. \& CHAMBERLERLEIN, G. (Eds.) Clinical Physiology in Obstetrics. Oxford: Blackwell Scientific Publication, 1980.

INSTITUTE OF MEDICINE (IOM). Nutrition During Pregnancy: weight gain, nutrient supplements. Washington: National Academy Press, 1990.

KAC, G. \& VELÁSQUEZ-MELÉNDEZ, G. The nutritional transition and the epidemiology of obesity in Latin America. A transição nutricional e a epidemiologia da obesidade na América Latina. Cadernos de Saúde Pública, 19: S4-S5, 2003.

KAC, G. \& VELÁSQUEZ-MELÉNDEZ, G. Ganho de peso gestacional em uma coorte de mães e filhos. Jornal de Pediatria, 81: 47-53, 2005.

KAC, G. et al. Nine months postpartum weight retention predictors for Brazilian women. Public Health Nutrition, 7: 621-628, 2004.

KEPPEL, K. G. \& TAFFEL, S. M. Pregnancy-related weight gain and retention: implications of the 1990 Institute of Medicine Guidelines. American Journal of Public Health, 83: 1.100-1.103, 1993.

KRAMER, M. S. et al. The validity of gestational age estimation by menstrual dating in preterm, term and postterm gestations. Jama, 22: 3.306-3.308, 1988.

KRAMER, M. S. et al. Maternal nutritional and spontaneous preterm birth. American Journal of Epidemiology, 136: 574-583, 1992.

KRASOVEC, K. \& ANDERSON, M. A. Nutrición Materna y Resultados del Embarazo. Washington: Opas/ OMS, 1991. 
LINNE, Y. Factors Affecting Weight Development after Pregnancy: the Spawn (Stockholm Pregnancy and Women's Nutrition) Study, 2002. Doctoral Thesis, Stockoholm: Karolinska Institute.

MINISTÉRIO DA SAÚDE. Assistência Pré-Natal. Brasília: Centro de Documentação/MS, 1988. (Normas e Manuais Técnicos)

MINISTÉRIO DA SAÚDE. Assistência Pré-Natal. Brasília: Ministério da Saúde, 2000. (Manual Técnico, Saúde da Mulher)

MINISTÉRIO DA SAÚDE. Pré-Natal e Puerpério: atenção qualificada e humanizada. Brasília: Secretaria de Atenção à Saúde. Departamento de Ações Programáticas Estratégicas. Área Técnica de Saúde da Mulher. Ministério da Saúde, 2005. (Manual Técnico)

NEGGERS, Y. et al. The relationship between maternal skinfold thickness, smoking and birth weight in black and white women. Pediatric and Perinatal Epidemiology, 83: 462-465, 1984.

NUCCI, L. B. et al. Nutritional status of pregnant women: prevalence and associated pregnancy outcomes. Revista de Saúde Pública, 35: 502-507, 2001.

PARKER, J. D. \& ABRAMS, B. Prenatal weight gain advice: an examination of the recent prenatal weight recommendations of the Institute of Medicine. Obstetrics \& Gynecology, 794: 664-669, 1992.

PRATA, P. R. A transição epidemiológica no Brasil. Cadernos de Saúde Pública, 8: 168-175, 1992.

ROSSO, P. A new chart to monitor weight gain during pregnancy. The American Journal of Clinical Nutrition, 41: 644-652, 1985.

SAVITZ, D. A. et al. Comparison of pregnancy dating by last menstrual period, ultrasound scanning, and their combination. American Journal of Obstetrics and Gynecology, 187: 1.660-1.666, 2002.

SCHIEVE, L. A.; COGSWELL, M. E. \& SCANLON, K. S. An empiric evaluation of the Institute of Medicine's pregnancy weight gain guideline by race. Obstetrics \& Gynecology, 91: 878-884, 1998.

SCHIEVE, L. A. et al. Pre-pregnancy body mass index and pregnancy weight gain: associations with preterm delivery. Obstetrics \& Gynecology, 96: 194-200, 2000.

SCHOLL, T. O. et al. Gestational weight gain, pregnancy outcome, and postpartum weight retention. Obstetrics \& Gynecology, 86: 423-427, 1995.

SEEDS, J. W. \& PENG, T. Impaired growth and risk of fetal death: is the tenth percentile the appropriate standard? American Journal of Obstetrics and Gynecology, 178(4): 658, 1998.

SELIGMAN, L. C. et al. Obesidade e ganho de peso gestacional: cesariana e complicaçôes de parto. Revista de Saúde Pública, 40: 457-465, 2006.

SELVIN, S. \& ABRAMS, B. Analysing the relationship between maternal weight gain and birth weight: exploration of four statistical issues. Paediatric and Perinatal Epidemiology, 10: 220-234, 1996.

STEVENS-SIMON, C.; ROGHMANN, K. J. \& MCANARNEY, E. R. Relationship of self-reported prepregnant weight and weight gain during pregnancy to maternal body habitus and age. Journal of the American Dietetic Association, 92: 85-87, 1992.

SUITOR, C. Maternal Weight Gain: a report of an expert work group. Arlington: National Center for Education in Maternal and Child Health, 1997. 
THORSDOTTIR, I. et al. Weight gain in women of normal weight before pregnancy: complications in pregnancy or delivery and birth outcome. Obstetrics \& Gynecology, 99: 799-806, 2002.

VIEGAS, O. A. C.; COLE, J. J. \& WHARTON, B. A. Impaired fat deposition in pregnancy: an indicator for nutritional intervention. American Journal of Clinical Nutrition, 45: 23-28, 1987.

WORLD HEALTH ORGANIZATION (WHO). Use and interpretation of anthropometric indicators of nutritional status. Bulletin of the World Health Organization, 64: 929-941, 1986.

WORLD HEALTH ORGANIZATION (WHO). Maternal anthropometry for prediction of pregnancy outcomes: memorandum from a Usaid/WHO/Paho/MotherCare Meeting. Bulletin of the World Health Organization, 69: 523-532, 1991.

WORLD HEALTH ORGANIZATION (WHO). Maternal anthropometry and pregnancy outcomes: a WHO collaborative study. Bulletin of World Health Organization, 73, suppl., 1995 a.

WORLD HEALTH ORGANIZATION (WHO). Physical Status: the use and interpretation of anthropometry. Geneva: WHO, 1995b. (WHO Technical Report Series, 854)

YEKTA, Z. et al. The effect of pre-pregnancy body mass index and gestational weight gain on pregnancy outcomes in urban care settings in Urmia-Iran. BMC Pregnancy and Childbirth, 6: 15, 2006. 



\title{
2 \\ Avaliação Nutricional de Crianças
}

\author{
Cora Luiza Pavin Araúio
}

$\mathrm{O}$

padrão de crescimento infantil é, talvez, o melhor indicador para avaliar o estado de saúde e nutrição de crianças. Em nível populacional, a prevalência de desnutrição, por exemplo, é freqüentemente utilizada como indicador de desenvolvimento econômico e de saúde geral de uma nação (Eveleth \& Tanner, 1990). Em contrapartida, observa-se que em países emergentes a desnutrição passa a dar lugar a uma rápida elevação das prevalências de sobrepeso e obesidade. A globalização e o chamado estilo de vida ocidental podem ser os grandes responsáveis pelo acelerado aumento do excesso de peso em todo o mundo (WHO, 2000).

O crescimento infantil resulta da contínua interação entre dois tipos de fatores: os genéticos e os ambientais. Um ambiente adequado, incluindo alimentação, higiene, cuidados de saúde, afetividade, entre outros, proporciona as condições necessárias para que as crianças possam desenvolver seu potencial genético de crescimento. O monitoramento do estado nutricional de crianças desde seu nascimento é um instrumento valioso para identificar precocemente situações de risco nutricional.

Inquéritos dietéticos, determinações bioquímicas, avaliação clínica e antropometria são os principais métodos para avaliar o estado nutricional do ponto de vista clínico ou epidemiológico. Entretanto, a antropometria, que consiste na medida das dimensões corporais e da composição global do corpo humano (Jelliffe, 1968), em diferentes idades e em distintos graus de nutrição, tem sido recomendada como o principal método de avaliação do crescimento infantil. Por sua simplicidade, baixo custo, por ser um método não invasivo e apresentar boa precisão, tem sido um instrumento valioso para identificar problemas nutricionais já instalados e também na identificação precoce de situaçôes de risco nutricional. Além disso, é um método útil para o monitoramento do crescimento de crianças individualmente, além de permitir sua ampla utilização em estudos epidemiológicos que visem a determinar as prevalências de déficits nutricionais, assim como do excesso de peso.

O objetivo do presente capítulo é descrever sucintamente o instrumental necessário para avaliar o estado nutricional de crianças menores de 5 anos de idade, utilizando o método antropométrico.

\section{A Antropometria}

Medidas das dimensões corporais associadas à idade, ao sexo ou a outras variáveis antropométricas permitem conhecer o estado de saúde e de risco nutricional de indivíduos em geral, mas especialmente de crianças. 
A triagem (screening) nutricional e a monitorização do crescimento têm sido as duas principais formas de uso da antropometria. A primeira é útil para identificar quem apresenta problema nutricional e é feita uma única vez. Essa avaliação ou triagem é valiosa, mas só tem sentido realizá-la se uma ação posterior for implementada visando à solução do problema nutricional detectado. A monitorização do crescimento é o acompanhamento da evolução de índices antropométricos por um período de meses ou anos, e visa a identificar precocemente problemas nutricionais. Seu crescente uso nos programas de puericultura ajuda a identificar crianças com algum problema nutricional e, por extensão, de saúde.

Outra importante utilidade da antropometria é seu uso em estudos epidemiológicos. Nas últimas duas ou três décadas, resultados de estudos de ciclo vital (Barker, 2003; Gunnel et. al., 1998) têm ressaltado a importância de associações entre condições antropométricas, hábitos alimentares e doenças crônicas em períodos precoces da infância, da adolescência e da vida adulta. Estudos clássicos de intervenção, assim como ensaios comunitários, também utilizam a antropometria. No primeiro caso, um conjunto de indivíduos é alocado aleatoriamente em um grupo de estudo que recebe uma intervenção nutricional e comparado com outro grupo similar que não recebe a intervenção. Diferenças nos resultados entre os dois grupos indicam o efeito da intervenção. Já os ensaios comunitários permitem estudar o efeito de intervenção em nível comunitário, comparando-se os resultados com outra comunidade similar que não recebeu a intervenção E, finalmente, a antropometria é também um instrumento útil em estudos transversais, de coorte e de casos e controles que buscam investigar associaçóes entre estado nutricional e doenças.

\section{Variáveis, Índices, Indicadores Antropométricos}

Há uma grande variedade de medidas antropométricas úteis para a avaliação nutricional de crianças, individual ou coletivamente. Aqui, serão abordados os aspectos referentes à técnica de coleta das variáveis peso, comprimento e altura, perímetro cefálico e dobras cutâneas tricipital e subescapular, por serem as mais utilizadas na avaliação nutricional de crianças e pela disponibilidade de dados de referências que permitem realizar comparações.

\section{Peso}

O peso é a variável antropométrica mais usada. Em média, a criança triplica seu peso de nascimento ao final do primeiro ano de vida (WHO, 2006). Atenção a alguns detalhes técnicos na coleta desta medida é importante para que se obtenham valores com suficiente confiabilidade, ou seja, que representem o verdadeiro peso da criança. Estritamente, esta medida refere-se mais à massa corporal do que ao peso, mas o último termo tem sido popularizado. O peso é uma medida composta pelo tamanho corporal total. É importante no diagnóstico de crescimento anormal, de obesidade e de subnutrição (Lohman, Roche \& Martorell,1988).

\section{Equipamento e técnica}

O ideal é utilizar uma balança pediátrica do tipo digital. O modelo mecânico também pode ser usado, porém exige maior treinamento e prática de quem realiza a pesagem. Independentemente do tipo de balança utilizado, deve-se dispor de um conjunto de pesos-padrão $(5,10$ e $15 \mathrm{~kg})$ para a calibragem diária da balança. Para crianças maiores, de 2 anos de idade, que já conseguem permanecer de pé, recomenda-se o uso da mesma balança, digital ou mecânica, utilizada para pesar adultos.

A balança deve ser posicionada em lugar firme e nivelado, com iluminação adequada e espaço suficiente, e aferida antes de cada pesagem. Se necessário, calibrá-la. Crianças menores de 2 anos de idade devem ser pesadas completamente despidas; maiores de 2 anos devem vestir apenas roupas leves e sem sapatos. Deve-se observar que não haja nenhum objeto nos bolsos, nas mãos ou na cabeça. 
Tendo em vista que a pesagem em balança digital é extremamente simples, a técnica descrita a seguir referese à balança antropométrica, com régua para a medida de altura.

\section{Técnica}

Travar o braço da balança com movimento leve. Posicionar a criança sobre o centro da plataforma da balança e assegurar-se de que está bem segura e sem encostar-se em nada (nem na mãe ou acompanhante). Movimentar o peso grande até o provável peso da criança e destravar a balança, movimentando o peso pequeno até obter equilíbrio no fiel da balança. Em seguida, travar a balança, e só então retirar a criança. Fazer a leitura e registrar o peso em gramas ou quilogramas, imediatamente após a leitura. Com a balança travada, voltar os pesos à posição zero.

\section{Estatura}

A medida longitudinal permite avaliar o tamanho corporal total e o comprimento de ossos. É importante para o diagnóstico de déficit linear. A estatura reflete os efeitos cumulativos de eventos anteriores melhor, talvez, do que qualquer outra medida.

Neste capítulo serão utilizados os termos 'comprimento' e 'altura' para designar quando a criança foi medida 'deitada' ou 'em pé', respectivamente. 'Estatura' refere-se genericamente tanto à 'altura' quanto ao 'comprimento'.

A estatura de um indivíduo é a soma de quatro componentes: as pernas, a pélvis, a coluna vertebral e a cabeça (Jelliffe, 1968). Cada um destes segmentos apresenta particularidades em relação à magnitude e idade de aumento em suas dimensões.

O crescimento longitudinal é proporcionalmente mais lento do que o aumento de peso: em média, o comprimento aumenta $50 \%$ ao fim do primeiro ano de vida, em relação ao comprimento ao nascer (WHO, 2006). A deficiência de estatura tende a desenrolar-se de forma relativamente lenta e também se recupera lentamente. Por isso, freqüentemente não é percebida pelos pais ou responsáveis pela criança. Carência de alimentos e/ ou elevada freqüência de morbidade afetam a estatura progressivamente.

Para a tomada de medidas antropométricas, necessita-se de um antropômetro ou infantômetro, ou ainda de mesa antropométrica para a obtenção da medida deitada, e de estadiômetro ou régua da balança antropométrica para medir a criança em pé. Em locais onde não se dispõe de equipamentos específicos é possível realizar a coleta de medidas de boa qualidade, utilizando-se uma fita métrica e um esquadro, cuja preparação e técnica poderão ser encontradas mais adiante, neste capítulo.

\section{Comprimento}

É uma medida que requer cuidados especiais e, idealmente, requer dois antropometristas. Entretanto, dependendo do grau de exigência quanto à confiabilidade da medida, um antropometrista com prática pode realizar o trabalho. Recém-nascidos automaticamente dobram os joelhos, exigindo que o antropometrista aplique leve pressão sobre os joelhos para mantê-los esticados, e só então realizar a leitura da medida. Crianças maiores podem ser inquietas e não cooperativas. A visualização da mãe ou do acompanhante pode ajudar, se estes aparentarem calma. Outra estratégia é manter no ambiente alguns brinquedos que despertem o interesse da criança.

As crianças nascem com aproximadamente $49,5 \mathrm{~cm}$ em média (WHO, 2006). Ao final do primeiro ano, a altura média é de $74 \mathrm{~cm}$. Nunca mais, durante o resto da vida pós-natal, ocorrerá semelhante velocidade de crescimento. No segundo ano de vida, o crescimento é de aproximadamente $12 \mathrm{~cm}$, ou seja, a metade. 
A Tabela 1 apresenta os valores médios de crescimento por trimestres durante o primeiro ano de vida de meninos e meninas, separadamente.

Tabela 1 - Médias de comprimento ao nascer e ganhos de comprimento $(\mathrm{cm})$, entre meninos e meninas

\begin{tabular}{|c|c|c|c|c|c|c|}
\hline \multirow{2}{*}{ Idade } & \multicolumn{3}{|c|}{ Meninas } & \multicolumn{3}{|c|}{ Meninos } \\
\hline & Mediana $(\mathrm{cm})$ & $\begin{array}{l}\text { Ganho por } \\
\text { trimestre }(\mathrm{cm})\end{array}$ & Desvio-padrão & Mediana $(\mathrm{cm})$ & $\begin{array}{l}\text { Ganho por } \\
\text { trimestre }(\mathrm{cm})\end{array}$ & Desvio-padrão \\
\hline Ao nascer & 49,1 & - & 1,8627 & 49,9 & - & 1,8931 \\
\hline $1^{\circ}$ trimestre & 59,8 & 10,7 & 2,1051 & 61,4 & 11,5 & 2,0444 \\
\hline $2^{\circ}$ trimestre & 65,7 & 5,9 & 2,2664 & 67,6 & 6,2 & 2,1403 \\
\hline 3o trimestre & 70,1 & 4,4 & 2,4157 & 72,0 & 4,4 & 2,2433 \\
\hline $4^{\circ}$ trimestre & 74,0 & 3,9 & 2,5750 & 75,6 & 3,6 & 2,3762 \\
\hline Ganho no 1ํano de vida & & 24,9 & - & - & 25,7 & \\
\hline
\end{tabular}

Fonte: WHO (2006).

\section{Técnica}

Solicitar à mãe ou responsável que retire os sapatos e meias da criança, assim como roupas volumosas, particularmente fraldas. Retirar também adornos da cabeça. $\mathrm{O}$ antropômetro deve ser colocado sobre uma superfície plana e firme, como uma mesa forte. Solicitar à mãe ou acompanhante que deite a criança de costas sobre o antropômetro e permaneça próxima a sua cabeça para mantê-la calma. Assegurar-se de que a cabeça da criança esteja bem encostada na cabeceira do antropômetro. Pedir ao segundo antropometrista ou à mãe ou acompanhante que coloque as mãos sobre o queixo da criança, a fim de garantir que a cabeça permaneça encostada e que o pescoço não esteja encolhido. A cabeça deve estar posicionada observando-se o Plano de Frankfurt (plano originado pela união dos pontos 'orifício do ouvido' e o 'canto externo do olho' formando um ângulo de $90^{\circ} \mathrm{com}$ a prancha do antropômetro) (Lohman, Roche \& Martorell, 1988). Colocar o braço e o cotovelo sobre os joelhos e pernas da criança, forçando-os suavemente contra o aparelho. Com a mão deste mesmo braço, puxar os pés em direção ao joelho até que as plantas dos pés formem ângulo de $90^{\circ}$ em relação à superfície horizontal do antropômetro. Com a outra mão, deslocar o cursor até tocar a planta dos pés da criança. Os pés devem estar paralelos ao anteparo móvel do aparelho. Se a criança estiver muito agitada, será necessário forçar, com cuidado, empurrando os joelhos para baixo. Fazer a leitura da medida com precisão de $1 \mathrm{~mm}$. Registrar imediatamente.

\section{Altura}

É a medida linear total de crianças maiores de 2 anos de idade. A técnica apresentada a seguir refere-se à coleta da medida utilizando-se a régua antropométrica da balança. A balança deve estar posicionada em lugar firme, plano e com iluminação adequada. Solicitar à mãe ou acompanhante que retire os sapatos e qualquer tipo de adorno da cabeça da criança. 
Técnica

Com a balança travada, posicionar a criança no centro da plataforma. A criança deve permanecer ereta, com a cabeça erguida (Plano de Frankfurt) (Lohman, Roche \& Martorell, 1988). Os braços devem estar pendentes ao longo do corpo, os pés levemente afastados e os calcanhares encostados no plano vertical da régua. Apoiar o ramo horizontal da régua sobre o centro da cabeça. Pressionar de modo a tocar a cabeça e não apenas os cabelos. Cuidar para que a criança não se encolha quando o ramo horizontal tocar sua cabeça. Fazer a medida nesta posição e registrá-la imediatamente em centímetros, com precisão de $1 \mathrm{~mm}$.

\section{Medida de altura com fita métrica e esquadro}

Prender a fita métrica, não extensível, com fita adesiva, numa parede ou porta bem lisa. A parede não deve ter rodapé. O lugar deve ser suficientemente iluminado para permitir uma boa leitura. Marcar um ponto na parede ou porta, a partir de $50 \mathrm{~cm}$ do chão. A fita métrica deve ser fixada com fita adesiva transparente, a partir desse ponto marcado, com a escala invertida, ou seja, tendo os números menores para baixo, aumentando na medida em que vai subindo pela parede ou porta. Para assegurar-se de que a fita está perpendicular ao solo, utilizar um prumo, que pode ser feito com qualquer objeto suficientemente pesado (mas pequeno), preso na extremidade de um fio comprido. A fita métrica deve ficar bem aderida na parede ou porta em, pelo menos, três diferentes pontos. Desenhar a planta dos pés numa folha de papel e fixá-la no chão com fita adesiva, de modo a orientar a criança sobre onde pisar.

\section{Técnica}

Posicionar a criança de costas para a parede ou porta, em frente à fita métrica e sobre o desenho fixado no chão. Manter os calcanhares e as costas (ombros e nádegas) encostados na parede ou porta, cuidando para que a criança não dobre os joelhos. A cabeça deve estar posicionada no Plano de Frankfurt (Lohman, Roche \& Martorell, 1988). Apoiar o esquadro contra a parede ou porta e sobre a fita métrica. Descê-lo suavemente até tocar a cabeça da criança, pressionando levemente, de modo a comprimir apenas os cabelos e não modificar sua posição. A leitura deve ser feita em posição lateral ao indivíduo, de modo a obter o melhor ângulo para visualizar a escala métrica. Registrar o valor da medida antes de retirar a criança. Assegurar-se de que após cada medida a fita métrica mantém-se na posição correta.

\section{Circunferência Cefálica}

É uma medida que compóe a antropometria infantil por estar estreitamente relacionada ao tamanho do cérebro (Lohman, Roche \& Martorell, 1988). Pode ser usada como um índice de desnutrição crônica durante os primeiros 24 meses de vida. Entretanto, além dos 2 anos o crescimento cefálico é tão lento que sua medida perde a utilidade (Gibson, 1990), embora, após os 3 anos, o cérebro ainda aumente cerca de 30\% (Lohman, Roche \& Martorell, 1988). A Tabela 2 mostra as médias de circunferência cefálica e velocidade de aumento por semestre, desde o nascimento até os 36 meses. Os dados apresentados são do WHO Child Growth Study (WHO, 2006). Ao passo que nos seis primeiros meses de vida a circunferência cresce cerca de 1,4 cm ao mês, dos 30 aos 36 meses essa velocidade cai drasticamente para $0,1 \mathrm{~cm} / \mathrm{mês}$. 
Tabela 2 - Circunferência cefálica e velocidade de crescimento ( $\mathrm{cm} / \mathrm{mês})$, do nascimento aos 36 meses de idade, segundo o WHO Child Growth Study

\begin{tabular}{ccc}
\hline Idade (meses) & Média de circunferência cefálica $(\mathrm{cm})$ & Média de velocidade de crescimento $(\mathrm{cm} / \mathrm{mês})$ \\
\hline Nascimento & 34,2 & \\
\hline 1 & 36,4 & 1,43 \\
\hline 3 & 40,0 & \\
\hline 6 & 42,8 & 0,37 \\
\hline 9 & 44,4 & 0,18 \\
\hline 12 & 45,5 & 0,10 \\
\hline 18 & 46,6 & \\
\hline 30 & 47,7 & \\
\hline 36 & 48,4 & \\
\hline
\end{tabular}

Fonte: WHO Child Growth Study (2006).

\section{Técnica}

Utilizar uma fita métrica estreita (7 mm ou menos), flexível e inextensível. O antropometrista posiciona-se ao lado esquerdo da criança e deve remover touca ou qualquer adorno que a criança tenha no cabelo. A cabeça é mantida no Plano de Frankfurt, olhando para frente. Passar a fita métrica em volta da cabeça, no sentido da esquerda para a direita, e transferir o início da fita para a mão esquerda, de modo que ela passe completamente em volta da cabeça e cruze em frente aos olhos do antropometrista. Cruzar a fita de modo que o ponto zero fique no nível superior em relação à outra extremidade da fita. Posicionar a fita frontalmente na altura imediatamente superior às sobrancelhas. Procurar o ponto mais posterior do occipital, de modo a obter o maior perímetro. A fita métrica deve passar na mesma altura da cabeça, nas duas laterais, direita e esquerda. A fita deve estar levemente apertada, o suficiente para comprimir o cabelo. Com o dedo médio posicionado na parte posterior da cabeça, o antropometrista deve mover a fita para cima e para baixo até obter o maior perímetro. Fazer a leitura neste ponto e registrar imediatamente o valor da medida com precisão de $1 \mathrm{~mm}$ (Ex.: 39,8 cm).

\section{Dobras Cutâneas}

A medida de dobras cutâneas tem por finalidade estimar a gordura corporal total por meio de valores de gordura subcutânea em um ou mais pontos do corpo. Entretanto, a precisão das estimativas varia conforme sexo, idade, estado nutricional e grupo étnico (Gibson, 1990). Roche e colaboradores (1981) descobriram que a medida de dobra cutânea tricipital é a que melhor estima gordura corporal em crianças. Portanto, é a mais indicada quando apenas uma medida de dobra cutânea for usada.

Os pontos mais apropriados para as medidas dependem da finalidade do estudo, da idade e dos indivíduos a serem examinados (a distribuição da camada de gordura varia com a idade mesmo na primeira infância), do sexo, da precisão com que se localiza o ponto, da homogeneidade da espessura de gordura e de pele em uma dada região corporal. 
Técnica

O aparelho utilizado para a tomada da medida é o plicômetro (skinfolder caliper), e as medidas devem ser feitas no lado esquerdo (Lohman, Roche \& Martorell, 1988). Além dessa recomendação, a tomada da medida no lado esquerdo justifica-se também pelo fato de que as medidas de dobras cutâneas tricipital e subescapular, para a construção da nova referência de crescimento da OMS (WHO, 2006), foram coletadas no lado esquerdo das crianças.

É aconselhável demonstrar o plicômetro na palma da própria mão, da mãe e da criança, antes de iniciar a medição. Deve-se tomar cuidado para que a criança não se mova bruscamente enquanto a medida estiver sendo tomada, pois, se a dobra cutânea escapar, poderá causar dor. Com os dedos polegar e indicador da mão esquerda, eleva-se uma dobra de tecido adiposo subcutâneo, aproximadamente $1 \mathrm{~cm}$ acima do ponto sobre o qual o plicômetro deverá ser aplicado. A distância entre os dedos e o ponto da medida é necessária para que a pressão dos dedos não afete o valor da medida. A quantidade de tecido elevada deve ser suficiente para formar uma dobra de lados paralelos. É necessário cuidado para que apenas pele e tecido adiposo sejam elevados. A quantidade de pele e tecido adiposo a ser elevada depende da espessura da camada de tecido adiposo subcutâneo naquele ponto. Quanto maior a espessura da camada de tecido adiposo, maior separação entre os dedos polegar e indicador será necessária. A dobra é mantida entre os dedos até que a leitura seja concluída.

O plicômetro é segurado com a mão direita enquanto a dobra é elevada com a esquerda. As garras do aparelho são posicionadas sobre o ponto marcado, perpendicularmente à dobra cutânea elevada. A liberação da pressão deve ser gradual, para evitar desconforto. A medida é feita em mais ou menos quatro segundos e, depois, a pressão do plicômetro é liberada. Se o aparelho exercer pressão por um tempo maior do que esse, uma medida menor será obtida, porque os fluidos serão forçados a deixar os tecidos. Duas medidas devem ser feitas, alternadamente entre os diferentes pontos. A diferença entre cada uma das duas medidas no mesmo ponto não deve exceder $1 \mathrm{~mm}$. Usar a média. Se a diferença exceder a $1 \mathrm{~mm}$, deve-se realizar mais uma medida e escolher as duas mais próximas, cuja diferença não exceda este valor. Repetir até três vezes e, se não conseguir, suspender a tomada desta medida e tentar outro dia. A medida deve ser registrada de acordo com a precisão do aparelho (1 ou $2 \mathrm{~mm}$ ). Crianças que ainda não ficam em pé podem ser medidas sentadas no colo da mãe ou responsável.

\section{Dobra cutânea tricipital}

A medida é feita no ponto médio posterior do braço esquerdo. Para marcá-lo, a criança deve dobrar o braço, com o cotovelo formando um ângulo reto $\left(90^{\circ}\right)$. Localizar o acrômio (extremo superior do braço) e o olécrano (extremo inferior do cotovelo). Colocar a fita métrica no extremo superior e estendê-la até o extremo inferior. Dividir essa distância por dois e, com uma caneta, marcar este ponto do braço (ponto médio). Estender o braço da criança, desfazendo o ângulo reto do cotovelo.

\section{Técnica}

Manter o braço suspenso e relaxado. Com os dedos polegar e indicador, levantar uma dobra de tecido, $1 \mathrm{~cm}$ acima do ponto já marcado. Aplicar o plicômetro sobre o ponto marcado, fazer a leitura e registrar imediatamente o valor da medida.

\section{Dobra cutânea subescapular}

O ponto a ser medido fica imediatamente abaixo do ângulo inferior da escápula do lado esquerdo. Para localizá-lo, palpar a escápula correndo os dedos para baixo e lateralmente à coluna vertebral até que o ângulo mais inferior da escápula seja identificado. A movimentação do braço esquerdo ajuda a localização. A medida deve ser tomada com o braço estendido. Marcar este ponto com a caneta. 


\section{Técnica}

Levantar uma dobra de pele e tecido adiposo com os dedos polegar e indicador posicionados $1 \mathrm{~cm}$ acima e lateralmente à marca anterior. A dobra deve ser oblíqua à coluna vertebral. Aplicar as hastes do plicômetro sobre a marca, mantendo a dobra cutânea elevada pelos dedos polegar e indicador. Fazer a leitura e registrar imediatamente.

\section{Confiabilidade das Medidas Antropométricas}

Um requisito fundamental para se obter resultados confiáveis na avaliação nutricional é conseguir informações e dados os mais exatos possíveis. Todos os esforços devem ser feitos para que os resultados obtidos representem o mais fielmente possível o estado nutricional da criança ou grupo de crianças em estudo.

Com relação às medidas antropométricas, podem-se identificar três principais fontes de erros: o equipamento, a técnica de medida e a posição da criança a ser medida.

\section{Quanto ao Equipamento}

É indispensável trabalhar com equipamento de boa qualidade e que permita realizar calibração periódica. Por exemplo, uma balança que não consegue repetir uma medida, com uma precisão de, pelo menos, $100 \mathrm{~g}$ em duas pesagens consecutivas, não é recomendável para uso. Deve-se lembrar que mesmo pequenas diferenças no peso ou na estatura de crianças podem afetar negativamente os resultados finais em estudos de prevalência, assim como na avaliação individual. Sendo assim, para avaliar crianças menores de 5 anos de idade, é recomendável uma balança com precisão de, no mínimo, $100 \mathrm{~g}$ e uma escala com intervalos de $1 \mathrm{~mm}$ para a determinação da estatura. É necessário ainda dispor de um conjunto de pesos-padrão e barra com dimensão conhecida para a aferição diária dos equipamentos utilizados. Se, eventualmente, for identificado algum problema com os equipamentos, perde-se apenas o trabalho de um dia.

\section{Quanto à Técnica da Medida}

É recomendável ter à mão um manual com a descrição das técnicas de coleta das medidas antropométricas. Tanto no atendimento individual quanto em trabalho de pesquisa, não é raro que diferentes pessoas realizem a coleta das medidas. Por isso, é importante que todos utilizem os mesmos métodos de coleta. Não sendo assim, corre-se o risco de coletar uma medida de comprimento, por exemplo, menor do que aquela obtida em visita anterior. Uma vez que a criança não diminui de tamanho, ficará patente que em um ou outro momento a medida foi erroneamente coletada ou mal registrada.

\section{Quanto à Criança a Ser Medida}

$\mathrm{O}$ antropometrista deve estar atento para que a criança esteja posicionada corretamente. Recém-nascidos e crianças com menos de 6 meses de idade tendem a dobrar os joelhos e esticar a ponta dos pés, exigindo, por isso, muita atenção do antropometrista. Outro detalhe importante refere-se ao vestuário. Crianças entre 2 e 5 anos devem ser medidas com o mínimo possível de roupas. Convém elaborar uma tabela com pesos das roupas mais usadas pelas crianças e, depois de coletada a medida, subtrair o peso da roupa. 


\section{Tipos de Erros}

Erros ocorrem na realização de qualquer medida. Algumas são particularmente difíceis de coletar (dobras cutâneas, altura e comprimento) e outras, mais fáceis (peso). Todo empenho deve ser feito para minimizar esses erros. Escolha de bons equipamentos, uniformização de técnicas e treinamento exaustivo dos antropometristas são estratégias úteis para a obtenção de medidas confiáveis. Mesmo após treinamento, é preciso identificar objetivamente quando o entrevistador pode ser considerado apto para iniciar a coleta das medidas. Para definir esse momento, deve-se usar um teste que permita identificar se os erros cometidos pelos antropometristas estão dentro de níveis considerados aceitáveis.

Dois tipos de erros podem ocorrer na tomada de medidas: erro aleatório (falta de precisão) e erro sistemático (falta de exatidão ou validade). Para identificar e medir a magnitude desses erros, usa-se uma técnica denominada "padronização" (Habicht, 1974). A aplicação desse teste deve ser uma etapa preliminar ao início da coleta das medidas. Detalhes sobre essa técnica poderão ser encontrados no capítulo "Antropometria como método de avaliação do estado de nutrição e saúde do adulto" e em publicação do Ministério da Saúde (Brasil, 2002).

\section{Classificação do Estado Nutricional de Crianças}

Para avaliar o estado nutricional de uma criança ou um grupo delas, é imprescindível a definição de alguns elementos que, reunidos e devidamente interpretados, fornecerão o diagnóstico nutricional. Esses subsídios são: índices e indicadores antropométricos, critério de classificação e tabela de referência de crescimento.

\section{Índices Antropométricos}

Para classificar o estado nutricional de crianças, são necessárias, pelo menos, informações sobre peso, estatura, idade e sexo. A combinação dessas variáveis dá origem aos índices antropométricos, sendo os principais a estatura-para-idade, o peso-para-idade e o peso-para-estatura. Os dois primeiros índices devem levar em consideração a idade e o sexo; o último independe da idade, mas deve ser relacionado ao sexo. Idealmente, devem-se usar os três índices para a avaliação nutricional individual ou de grupos. Entretanto, é preciso estar ciente de que cada um deles reflete distintas combinaçôes do processo biológico (WHO, 1995). Além disso, os determinantes dos desvios nutricionais, segundo cada índice, podem ser também distintos. Portanto, é perfeitamente possível detectar problema nutricional com base em um índice, e normalidade em relação a outro.

\section{Estatura-para-idade}

É um índice que reflete o crescimento linear. O déficit de estatura-para-idade deve ser interpretado como resultante de um processo de falha em alcançar o potencial genético de crescimento devido a deficientes condições de saúde e/ou nutrição. Todavia, a expressão "desnutrição crônica" deve ser evitada, pois os determinantes da falha de crescimento podem resultar de um processo contínuo de longo prazo, como também podem ser conseqüência de um evento isolado, no passado (WHO, 1995).

O déficit de crescimento evidencia-se ao redor de 3 meses de idade e diminui de velocidade aos 3 anos, sendo que, a partir dessa idade, o crescimento em altura segue paralelo à referência (WHO, 1995).

Excesso de estatura ou comprimento para a idade não se configura, a priori, como problema nutricional, mas deve ser investigado clinicamente, como uma possível ocorrência de distúrbio endócrino (WHO, 1995). 


\section{Peso-para-estatura}

Este índice proporciona informações tanto de déficit quanto de excesso de peso em relação à estatura. Uma característica importante desse déficit é que pode desenvolver-se muito rapidamente e, em condições favoráveis, pode ser também rapidamente recuperado. O termo "desnutrição aguda" deve ser evitado (WHO, 1995), e talvez o mais adequado seja denominá-lo de "emaciação", que significa emagrecimento. A prevalência de emaciação no Brasil como um todo pode ser considerada baixa, usualmente inferior a 5\% (Monteiro \& Cervini, 1992), embora vestígios desse déficit possam ainda existir em regiōes e grupos específicos. A prevalência de emaciação é maior entre 12 e 24 meses de idade, quando as doenças diarréicas são mais freqüentes (WHO, 1986).

Peso-para-estatura é também o índice recomendado para avaliar sobrepeso em crianças menores de cinco anos de idade (WHO, 1995). O índice resulta do excesso de peso em relação à estatura da criança, ou seja, uma desproporção entre peso e estatura. Alguns estudos mostram que crianças com a relação peso-para-estatura no limite superior da normalidade têm maiores probabilidades de se tornarem adultos obesos (Wright et al., 2001). Outros estudos relatam associaçōes entre sobrepeso na infância e riscos aumentados de apresentar diabetes, hipertensão arterial, problemas cardiovasculares e alguns tipos de câncer na vida adulta (James, 2005).

\section{Peso-para-idade}

É o índice antropométrico mais utilizado para avaliar ou monitorar o estado nutricional, por sua simplicidade e fácil compreensão mesmo por pessoal não técnico. Embora o peso seja muito sensível às modificações nutricionais, representa um processo de nutrição global. O déficit de peso em relação à idade, observado em um único momento, não deixa claro se o processo que levou à desnutrição é recente ou de longo prazo. Por sua vez, o excesso de peso para a idade, por não considerar a estatura da criança, pode levar a classificá-la, equivocadamente, como portadora de sobrepeso, quando a criança também apresenta elevada estatura para sua idade.

\section{Indicadores do Estado Nutricional}

Para que um índice possa ser utilizado para descrever o estado nutricional de crianças, deve estar associado a um ponto de corte, a partir do qual as crianças são classificadas como eutróficas, portadoras de déficit ou de excesso de peso ou estatura. Por exemplo: comprimento-para-idade abaixo de dois Desvios-Padrão (DP) da mediana (peso-para-idade $<-2 \mathrm{DP}$ ).

\section{Critérios de Classificação}

Há pelo menos dois tipos de distribuições para classificar o estado nutricional de crianças e que apresentam equivalências entre si: distribuições normal e percentil. Por exemplo: um DP corresponde aproximadamente ao percentil 15,8. As duas distribuiçôes são as mais utilizadas tanto para o diagnóstico nutricional como para o monitoramento do crescimento; por isso, apenas estas serão abordadas neste capítulo.

\section{Distribuição ou curva normal}

Para melhor explicar a curva normal, será utilizada como exemplo a distribuição dos valores de altura de uma população de meninos clinicamente saudáveis, com 4 anos de idade (Figura 1). A 'distribuição normal' apresenta como característica a simetria em torno do valor médio ( $\mathrm{DP}=0$ ), ou seja, ambos os lados, abaixo e acima do valor médio, são iguais. Assim sendo, entre - 1 e + $1 \mathrm{DP}$, encontram-se aproximadamente $68 \%$ dos valores de altura de uma população considerada normal; entre - 2 e +2 DP, encontram-se cerca de $95 \%$ dos 
valores e entre - 3 e + 3 DP, aproximadamente 99\%. Pode-se deduzir, então, que abaixo de - 1 DP e acima de + 1 DP há cerca de $32 \%$ dos valores de altura; abaixo de - 2 e acima de + 2 DP encontram-se quase $5 \%$ e, finalmente, abaixo de -3 e acima de +3 DP está aproximadamente $1 \%$ dos valores.

Figura 1 - Distribuição normal

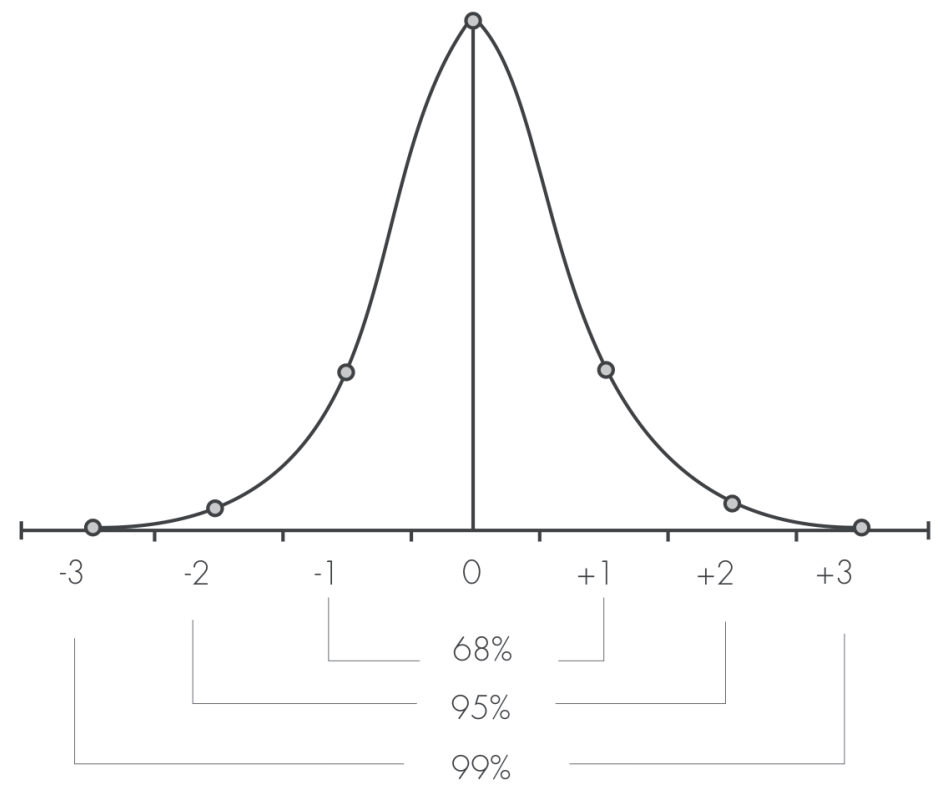

O Quadro 1 apresenta os critérios de classificação de déficit e sobrepeso para crianças menores de cinco anos de idade, segundo a Organização Mundial da Saúde (OMS).

Quadro 1 - Critérios de classificação do estado nutricional para crianças menores de 5 anos de idade

\begin{tabular}{|ccc|}
\hline Índice & Critério $\left(\mathrm{DP}{ }^{*}\right)$ & Situaçãonutricional \\
\hline Estatura-para-idade & $<-2$ & Déficit linear \\
\hline \multirow{2}{*}{ Peso-para-estatura } & $<-2$ & Emaciação \\
\cline { 2 - 3 } & $>2$ & Sobrepeso \\
\hline \multirow{2}{*}{ Peso-para-idade } & $<-2$ & Baixo peso \\
\cline { 2 - 3 } & $>2$ & Excesso de peso \\
\hline
\end{tabular}

* DP = Desvio-padrão.

Fonte: WHO (1995).

Este tipo de classificação é especialmente útil, porque permite conhecer a freqüência esperada de altura abaixo ou acima de determinado ponto de corte da curva normal. Exemplificando: definindo-se - 2 DP como ponto de corte, espera-se que, numa população normal, ou seja, isenta de déficit linear, encontre-se cerca de $2,3 \%$ de crianças com alturas abaixo de - 2 DP que, por razões 'genéticas', são aquelas que apresentam as menores alturas da distribuição. Modificando-se esse ponto de corte para - $1 \mathrm{DP}$, passa-se a esperar 15,8\% de crianças 
cujas alturas encontram-se abaixo desse ponto de corte. Assim, conhecendo-se as freqüências esperadas a partir de determinado ponto de corte, é possível concluir que, por exemplo, déficit linear de $14 \%$ encontrado em um estudo de prevalência é extremamente alto, se o ponto de corte utilizado foi - 2 DP. A prevalência de $14 \%$ representaria um déficit seis vezes maior do que o valor esperado (2,3\%) a partir da distribuição normal. $\mathrm{O}$ mesmo raciocínio é válido também para os índices peso-para-idade e peso-para-estatura.

\section{Cálculo do Desvio-Padrão}

Em algumas situações é necessário conhecer o desvio-padrão exato de cada criança, e não apenas saber se está abaixo ou acima de determinado valor. Esse cálculo é muito simples, e para realizá-lo será necessário medir a altura da criança, o valor da média e do desvio-padrão correspondentes ao seu sexo e idade. A seguir, encontra-se a fórmula para o cálculo e um exemplo.

$$
D P_{\text {exato }}=\frac{\text { altura da criança - altura média correspondente ao seu sexo e idade }}{\text { desvio-padrão correspondente ao seu sexo e idade }}
$$

$$
\begin{aligned}
& \text { Ex.: Menina, } 4 \text { anos de idade, altura medida de } 96,9 \mathrm{~cm} . \\
& \text { Procurar na Tabela }(\mathrm{WHO}, 2006) \text { : } \\
& \text { Altura média }=102,7 \mathrm{~cm} \\
& D P=4,3075 \\
& D P_{\text {exato }}=\frac{96,9-102,7}{4,3075} \\
& D P_{\text {exato }}=-1,3465
\end{aligned}
$$

\section{Distribuição Percentil}

É a outra forma de representar os valores de distribuição de uma variável antropométrica qualquer. Para explicar esta distribuição, será utilizada novamente a variável altura. Imagine cem meninos de 4 anos de idade, saudáveis e em perfeito estado nutricional. Esses cem meninos serão enfileirados por ordem crescente de altura: o menino de menor altura ocupará a posição de número 1 e aquele de maior altura será o último, que corresponderá à posição de número 100 (Figura 2). Entre o primeiro e o último, existem 98 meninos. $\mathrm{O}$ menino que ocupa a posição 50 está posicionado exatamente no meio de todos os demais. Assim, a altura do menino na posição 50 divide a distribuição ao meio: ou seja, metade dos meninos tem alturas inferiores àquela da posição 50 e a outra metade apresenta alturas superiores. Por essa razão, a altura correspondente à posição 50 corresponde à 'mediana', numa distribuição percentil. A posição que cada menino ocupa, conforme sua altura, corresponde a um determinado percentil. Assim, o valor da altura do menino que ocupa a posição 3 corresponde ao percentil 3 de altura, e assim sucessivamente.

Da mesma forma como na distribuição normal, também a distribuição percentil permite saber a freqüência esperada acima ou abaixo de cada percentil. Por exemplo, sabe-se que abaixo do percentil 3 há $3 \%$ de valores de altura, assim como acima do percentil 97 também há 3\% de valores de altura. 
Figura 2 - Distribuição percentil

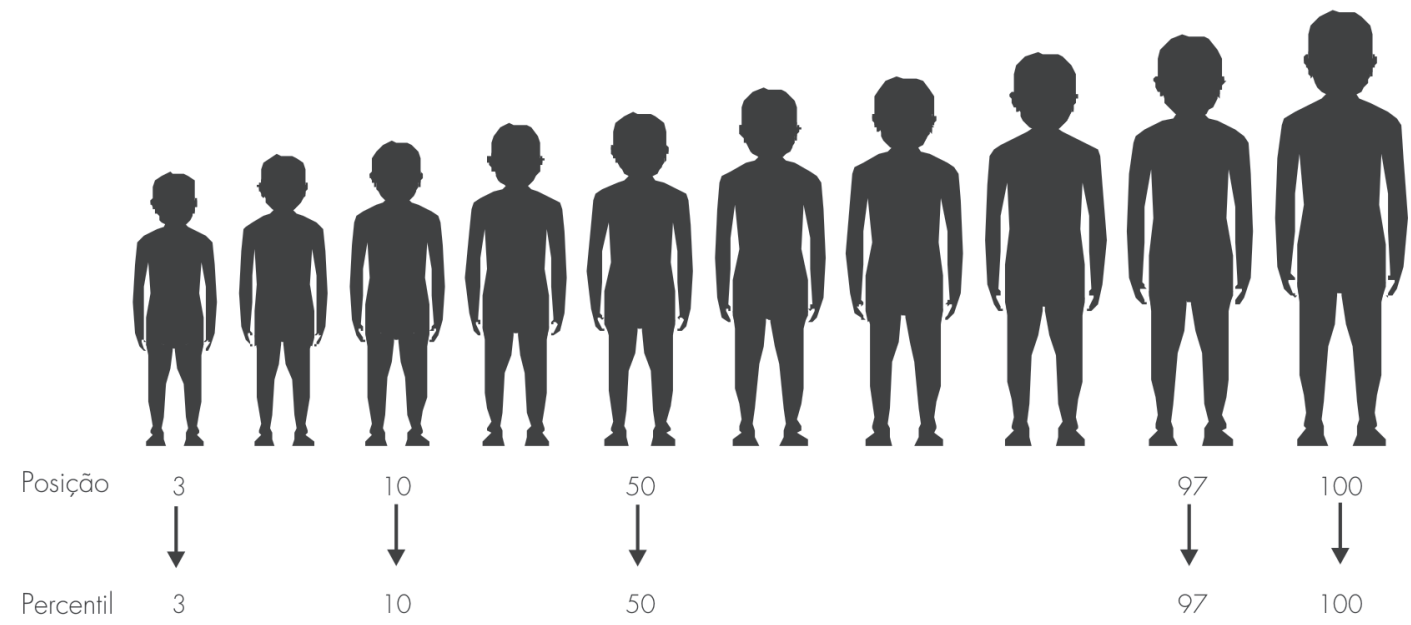

\section{Equivalência entre as Distribuições Normal e Percentil}

Em algumas situações pode ser necessário comparar prevalências de déficits ou de sobrepeso, originadas de critérios diferentes para avaliar o estado nutricional. Isso pode ser feito desde que se leve em consideração a equivalência entre os valores esperados do problema nutricional, de acordo com a distribuição e os pontos de corte adotados. Abaixo, na Tabela 3, encontram-se as equivalências entre alguns valores das duas distribuições que podem auxiliar nessa comparação.

Tabela 3 - Equivalências entre as distribuições normal e percentil

\begin{tabular}{ccccc}
\hline Situação nutricional & Percentil & Desvio-padrão & Desvio-padrão & Percentil \\
\hline \multirow{2}{*}{ Déficit } & 10 & $-1,28$ & -3 & 0,13 \\
\cline { 2 - 5 } & 3 & $-1,88$ & -2 & 2,28 \\
\cline { 2 - 5 } Excesso & 1 & $-2,33$ & -1 & 15,80 \\
\cline { 2 - 5 } & 99 & $+2,33$ & +1 & 84,20 \\
\cline { 2 - 5 } & 97 & $+1,88$ & +3 & 97,72 \\
\hline
\end{tabular}

Fonte: WHO (1995).

\section{Referência de Crescimento}

Um ponto importante da avaliação nutricional de crianças é a definição da referência ou padrão de crescimento a ser adotada para a comparação dos valores antropométricos. No capítulo 3, "Referências antropométricas", este assunto será abordado em detalhes, e portanto pretende-se, aqui, apenas sugerir a referência a ser utilizada.

Em abril de 2006, a OMS fez o lançamento oficial da nova referência de crescimento para ser usada por crianças, desde o nascimento até os 5 anos de idade (WHO, 2006). Até o momento, foram disponibilizadas curvas referentes aos índices, estatura-para-idade, peso-para-idade, peso-para-estatura e Índice de Massa Corporal (IMC) separadamente para meninos e meninas. $\mathrm{O}$ novo padrão de crescimento tem, pelo menos, três virtudes 
particularmente importantes: a) foi elaborado com base na observação de crianças que recebiam aleitamento materno até pelo menos 4 meses de idade e alimentos complementares a partir de 4-6 meses de idade; b) sua elaboração contou com a participação de crianças de seis diferentes regióes do mundo; c) o estudo que o originou incluiu apenas crianças que viviam em condiçôes ambientais adequadas, proporcionando-lhes oportunidade de um crescimento ótimo, ou seja, de alcançar seu potencial genético de crescimento.

Assim, a nova referência representa o crescimento infantil normal em condições ambientais ótimas. Por isso, deve ser usada para avaliar crianças de qualquer país, independentemente de etnia, condição socioeconômica e tipo de alimentação.

O sítio da OMS (www.who.int/childgrowth) apresenta um software para avaliar o estado nutricional individual em um determinado momento ou para o monitoramento, e ainda para grupos de crianças. Permite visualizar graficamente o estado nutricional e emite relatório com os resultados. A OMS, entretanto, não sugere pontos de cortes a serem utilizados, e deixa a atribuição de defini-los aos ministérios da Saúde dos países que adotarem a nova referência.

\section{Considerações Finais}

Dentre os numerosos métodos para determinar o estado nutricional de crianças menores de 5 anos de idade, a antropometria tem-se destacado por sua simplicidade, baixo custo, aceitabilidade pela população geral e por sua capacidade de permitir a identificação precoce de riscos nutricionais individualmente ou em grupos populacionais. Contudo, para cumprir tal papel, é fundamental que os profissionais da saúde estejam familiarizados com o instrumental necessário à realização de triagens ou diagnóstico nutricional. Isso inclui a coleta de medidas antropométricas confiáveis, a correta seleção e interpretação de índices, bem como a utilização de referência ou padrão de crescimento a ser adotada.

\section{Referências}

BARKER, D. The midwife, the coincidence, and the hypothesis. British Medical Journal, 20-27(327): 1.428$1.430,2003$.

BRASIL. Ministério da Saúde. Secretaria de Políticas de Saúde. Departamento de Atenção Básica. Saúde da Criança: acompanhamento do crescimento e desenvolvimento infantil. Brasília: Ministério da Saúde, 2002. (Cadernos de Atenção Básica, 11)

EVELETH, P. B. \& TANNER, J. M. Worldwide Variation in Human Growth. 2. ed. Cambridge: Cambridge University Press, 1990.

GIBSON, R. Principles of Nutritional Assessment. New York, Oxford: Oxford University Press, 1990.

GUNNELL, D. J. et al. Leg length and risk of cancer in the Boyd Orr cohort. British Medical Journal, 14(317): 1.350-1.351, 1998.

HABICTH, J. P. Estandardización de métodos epidemiológicos cuantitativos sobre el terreno. Boletín de la Oficina Sanitaria Panamericana, Mayo 1974: 375-84.

JAMES, W. P. T. The challenge of obesity and its associated chronic diseases: International Obesity Task Force and The London School of Hygiene and Tropical Medicine. In: UNITED NATION SYSTEM/ STANDING COMMITTEE ON NUTRITION. Overweight and Obesity: a new nutrition emergency? United Kingdom: Lavenham Press, 2005. (SCN News, 29) 
JELLIFFE, D. B. Evaluación del Estado de Nutrición de la Comunidad. Ginebra: Organización Mundial de la Salud, 1968.

LOHMAN, T. G.; ROCHE, A. F. \& MARTORELL, R. Anthropometric Standardization Reference Manual. Champaign: Human Kinetcis Books, 1988.

MONTEIRO, M. F. G. \& CERVINI, R. Perfil Estatístico de Crianças e Mães no Brasil: aspectos de saúde e nutrição de crianças no Brasil, 1989. Rio de Janeiro: Fundação IBGE, Unicef/Inan, 1992.

ROCHE, A. F. et al. Grading body fatness from limited anthropometric data. American Journal of Clinical Nutrition, 34: 2.831-2.838, 1981.

WHO. Obesity: preventing and managing the global epidemic. Report of a WHO Consultation. Geneva: WHO, 2000. (WHO Technical Report Series, 894)

WHO CHILD GROWTH STANDARDS. Length/height-for-age, weight-for-age, weight-for-length, weightfor-height and body mass index-for-age: methods and development. Geneva: Department of Nutrition for Health Development/WHO, 2006. Disponível em: <http://www.who.int/childgrowth/standards/hc for_age/en/index.html>. Acesso em: 24 jul. 2007.

WHO EXPERT COMMITTEE. Physical Status: the use and interpretation of anthropometry. Geneva: WHO, 1995. (WHO Technical Report Series, 854)

WHO WORKING GROUP. Use and interpretation of anthropometric indicators of nutritional status. Bulletin of World Health Organization, 64(6): 929-941, 1986.

WRIGHT, C. M. et al. Implications of childhood obesity for adult health: findings from thousand families cohort study. British Medical Journal, 323: 1.280-1.284, 2001. 



\title{
3 \\ Referências Antropométricas
}

\author{
Cora Luiza Pavin Araúio
}

\section{$V_{\text {ant }}$}

árias tentativas têm sido feitas no sentido de sumarizar o crescimento humano (Tanner, 1985). Parte das dificuldades ocorre porque as medidas antropométricas usualmente tomadas são complexas. Por exemplo, a estatura é uma medida resultante dos tamanhos de diversos segmentos corporais: pernas, tronco e cabeça, tendo cada uma delas diferentes curvas de crescimento. Entretanto, a utilização de curvas de crescimento para comparações de valores individuais ou de grupos de indivíduos é uma forma importante de obter informação sobre o crescimento de um indivíduo ou a situação nutricional de grupos populacionais.

O primeiro registro de crescimento humano foi feito por Montbeillard quando transcreveu na forma de gráfico a estatura de seu único filho, medida a cada seis meses, desde o nascimento até os 18 anos de idade (17591777). É o mais antigo registro longitudinal de que se tem conhecimento (Tanner, 1985).

A avaliação nutricional de crianças, jovens, adultos e idosos é um instrumento de muita utilidade na saúde pública. A medida do crescimento na infância, por meio do uso de gráficos, é um dos mais importantes indicadores básicos para avaliar o bem-estar de crianças, individual ou coletivamente. Se um indivíduo está fora dos limites de normalidade de uma adequada referência de crescimento, esse 'indivíduo' deve ser tratado clínica e individualmente. No entanto, se um grupo populacional está fora dos padrões de normalidade, então é a 'população’ que deve ser tratada com melhores cuidados de saúde, medidas de saneamento, mais emprego, melhor acesso a alimentos saudáveis e menos discriminação (Eveleth \& Tanner 1990).

Parece haver unanimidade sobre a importância fundamental da utilização de referência ou padrão de crescimento para avaliar e acompanhar a situação nutricional da criança e de populações. Contudo, desde os anos 70 do último século, quando os gráficos de crescimento começaram a ser mais amplamente utilizados, tem havido constantes debates sobre a necessidade de desenvolver curvas de crescimento específicas para cada país ou sobre a possibilidade de se aceitar universalmente uma única referência. $\mathrm{O}$ principal argumento entre aqueles que defendem o uso de referências próprias para cada país baseia-se, principalmente, no entendimento de que o crescimento, mesmo nos primeiros anos de vida, depende predominantemente da influência das características étnicas do indivíduo (Eveleth \& Tanner, 1990). Em contrapartida, alguns estudos (Habicht et al., 1974; Goldstein \& Tanner, 1980) mostram que nos primeiros cinco anos de vida a influência étnica e genética sobre o crescimento é menor do que aquelas devidas ao meio ambiente, reconhecidamente associadas ao nível socioeconômico, tais como práticas de alimentação, cuidados de saúde, morbidade, entre outros fatores. 
O pressuposto básico para que um conjunto de dados antropométricos possa ser usado para avaliar o crescimento infantil é que as crianças incluídas na amostra não estejam expostas a situações ambientais adversas que comprometam o alcance de seu potencial genético de crescimento, mesmo durante sua gestação. $\mathrm{O}$ atendimento aos requisitos referentes a cuidados básicos de alimentação e saúde durante os primeiros anos de vida é condição essencial para um crescimento ótimo. A conseqüência da exposição precoce a um ambiente saudável é que crianças de diferentes etnias e regiōes do mundo crescem de forma muito similar, enquanto crianças de mesma etnia, mas de diferentes condiçôes socioeconômicas, podem apresentar importantes diferenças nas medidas antropométricas, especialmente em relação à estatura ou ao comprimento (genericamente aqui denominados de 'estatura'). Nas curvas de comprimento de crianças até 2 anos de idade do Brasil, Gana, Índia, Noruega, Oman e Estados Unidos (Figura 1), pode-se observar que o crescimento linear dessas crianças, participantes do Estudo Internacional Multicêntrico (EIMCC) para elaboração de curvas de crescimento, é muito similar (WHO, 2006c).

Figura 1 - Médias de comprimento de crianças menores de dois anos de idade do Brasil, Gana, Índia, Noruega, Oman e Estados Unidos. EIMCC para elaboração de curvas de crescimento

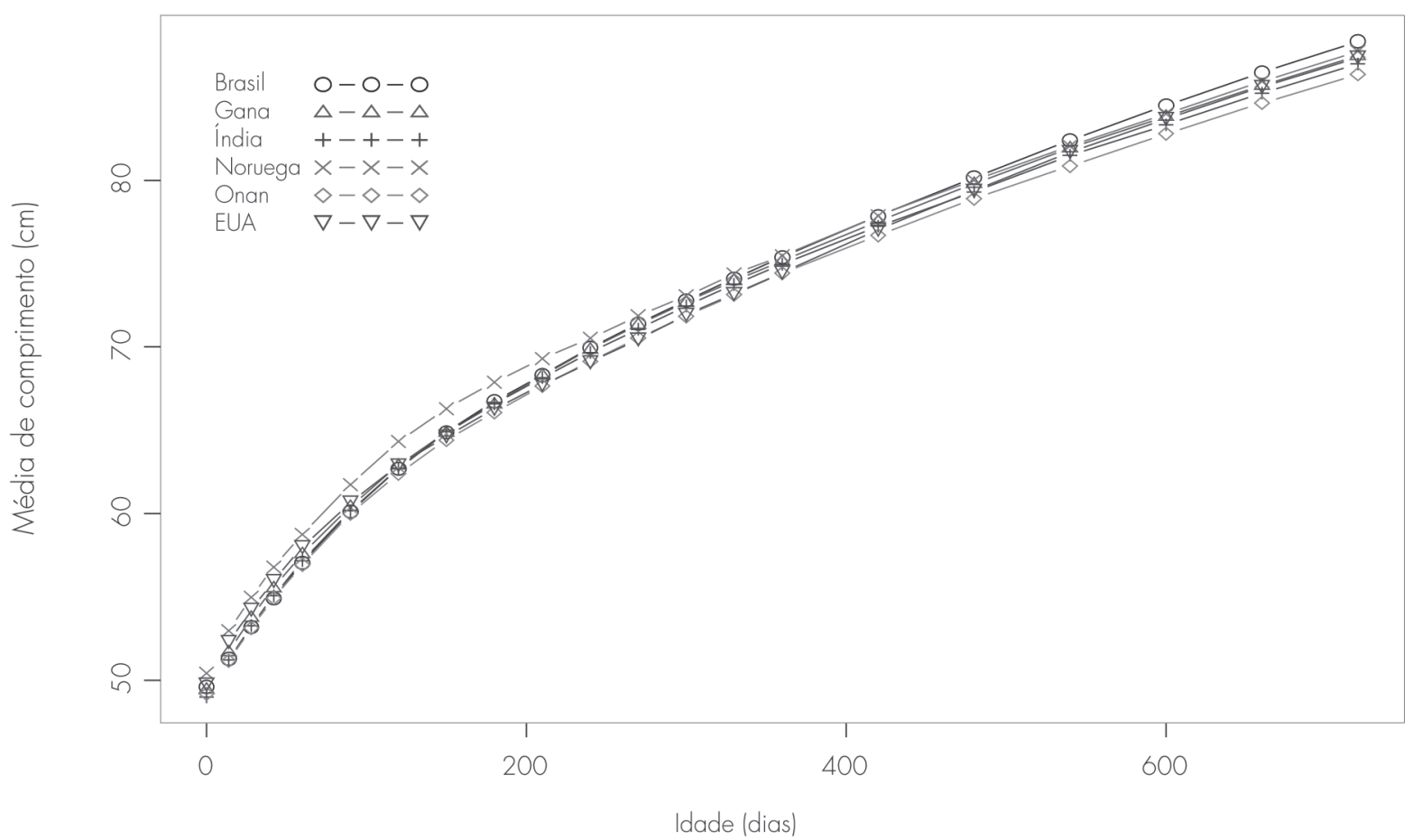

Fonte: WHO (2006a).

É preciso salientar, entretanto, que quanto mais próximo do período da adolescência ( $\geq 10$ anos de idade), menor vai se tornando a influência do meio ambiente sobre o crescimento e maior vai se tornando a influência das características genéticas. Apesar dessa inversão, o efeito do meio ambiente nunca cessa completamente, porém atua com menor força de determinação comparativamente ao fator genético.

Esta discussão, aparentemente irrelevante, é fundamental na argumentação favorável ao uso de uma única referência de crescimento para avaliar crianças de até 5 anos de idade da maioria das regiōes do mundo (WHO Expert Committee, 1995). 
Um outro aspecto que tem sido objeto de discussão desde que os gráficos passaram a ser utilizados relacionase com as definições de 'referência' e 'padrão'(WHO Expert Committee, 1995). Embora esta seja uma discussão mais acadêmica do que prática, é conveniente esclarecer a sutil diferença entre os dois termos. Entende-se como 'referência' o conjunto de dados que proporciona uma base para efetuar comparações, nesse caso, antropométricas, ao passo que o termo 'padrão' incorpora o conceito de 'norma' ou 'modelo', ou seja, inclui um valor de julgamento sobre crescimento ideal a ser seguido por crianças individualmente. Dito de outra forma, uma referência deve ser usada para finalidades meramente descritivas da população. Diferentemente, um padrão envolve o julgamento da magnitude dos 'desvios da normalidade'. Referências são tradicionalmente consideradas 'descritivas', ao passo que padrão apresenta características 'prescritivas'.

Com base no exposto, todos os conjuntos de dados até então disponíveis deveriam estar sendo usados apenas como referência de crescimento infantil, uma vez que as informações coletadas não atendiam aos requisitos para que pudessem ser usadas como padrão de crescimento. Em meados da década de 1990, a Organização Mundial da Saúde (OMS) reuniu vasto conjunto de evidências científicas que justificou sua decisão de iniciar o planejamento de um estudo para a construção de novas curvas de crescimento. O estudo então proposto deveria contemplar os rigorosos critérios para que o conjunto de dados assim gerado pudesse ser utilizado como um padrão de crescimento para avaliar crianças menores de 5 anos de idade, de todas as regiôes do mundo. $\mathrm{O}$ EIMCC para construção das novas curvas de crescimento (WHO, 2006b) será abordado com mais detalhes a seguir.

O objetivo deste capítulo é apresentar algumas das referências de crescimento em uso e enfatizar a justificativa e características das novas curvas de crescimento da OMS parcialmente lançadas em abril de 2006.

\section{Referências de Crescimento}

A utilização de referências de crescimento para avaliar o estado nutricional de crianças não é recente. Vários conjuntos de dados antropométricos foram utilizados ao longo do século passado, sendo as referências de Harvard, do Reino Unido (Gibson, 1990) e as do National Center for Health Statistics, 1977 (NCHS, 1978) e do Center for Disease Control and Prevention (CDC, 2000) as mais conhecidas. Recentemente, algumas curvas do novo padrão de crescimento da OMS (WHO, 2006c) foram disponibilizadas (www.who.int/childgrowth/en).

\section{Referência de Harvard}

Os dados da referência de Harvard (Jelliffe, 1968; Tanner, 1985) foram derivados de amostras pequenas obtidas em estudos transversais que incluíram crianças norte-americanas, brancas, de classe média, das cidades de Boston e Iowa. As amostras assim obtidas não eram representativas e foram consideradas satisfatórias numa época em que não havia nada melhor. Os gráficos foram construídos nas décadas de 1930 e 1940 e apresentam os percentis segundo os índices peso-para-idade, peso-para-estatura e estatura-para-idade do nascimento até os 36 meses de idade, separadamente para meninos e meninas. Reuniu também informações sobre peso-para-idade e estatura-para-idade para meninos e meninas dos 2 aos 18 anos de idade. A medida linear de crianças menores de 36 meses foi feita em posição deitada.

\section{Referência do Reino Unido}

A referência compilada por James Tanner e colaboradores (Tanner, 1985), nos anos 60 do último século, teve origem nas crianças de Londres. Amostra de estudantes, de 5 a 16 anos de idade, foi selecionada aleatoriamente entre os escolares de Londres. Do nascimento até os cinco anos e meio de idade, os dados basearam-se em 
cerca de oitenta crianças para cada sexo, seguidas longitudinalmente, e apresentam os índices peso-para-idade e estatura-para-idade. O comprimento (deitado) foi medido até os 2 anos, e daí em diante foi medida a estatura (em pé). Dos cinco anos e meio até 15 anos e seis meses de idade, os dados foram coletados transversalmente, e a amostra incluiu cerca de mil meninos e mil meninas para cada ano de idade, selecionados aleatoriamente entre os escolares de Londres. Dos 16 anos e meio até os 20 anos de idade, os dados foram coletados longitudinalmente e foram obtidos entre trinta jovens participantes do Estudo de Crescimento Harpenden. A escala de idade dos gráficos é apresentada em décimos de anos, e não em meses (Gibson, 1990). Essas amostras deveriam permitir avaliar e acompanhar o estado nutricional de qualquer criança de origem européia ou africana, de países desenvolvidos e clima temperado. Segundo seus idealizadores, com alguma cautela, essa referência também poderia ser aplicada para crianças de famílias de boas condiçōes educacionais e nutricionais de países em desenvolvimento (Tanner, 1985).

\section{Referência do Centro Nacional de Estatísticas de Saúde dos Estados Unidos (NCHS-1977)}

Em 1975, o Centro de Controle de Doenças (CDC) dos Estados Unidos elaborou a referência NCHS (NCHS, 1978), com base na reunião dos dados de quatro estudos, todos eles incluindo apenas crianças norteamericanas. O segmento de 0-23 incluiu as crianças do estudo longitudinal realizado pelo Instituto de Pesquisas Fels, cujos dados foram coletados entre 1929 e 1975. Uma característica importante das crianças nascidas nesse período é que sua alimentação era predominantemente à base de fórmulas lácteas e, conseqüentemente, a prática do aleitamento materno era considerada rara. A medida linear das crianças nessa idade foi o comprimento (medida da criança deitada). A partir dos 2 e até 18 anos de idade, a referência NCHS incluiu os dados de três estudos representativos da população norte-americana conduzidos entre 1960 e 1975. A estatura das crianças e adolescentes foi feita com os indivíduos em pé. Uma das limitações desse conjunto de dados foi a utilização de amostras independentes. Do ponto de vista teórico, uma referência de crescimento deveria incluir indivíduos de uma mesma população para toda a faixa etária de abrangência (WHO Expert Committee, 1995).

Em 1978, a OMS passou a recomendar a referência NCHS/CDC (NCHS, 1978) para uso internacional. Desde então, diversos países-membros da OMS passaram a utilizar a mesma referência, possibilitando comparaçôes entre a situação nutricional de crianças de diversas regióes do mundo. Em 1980, o CDC desenvolveu um programa de computador para realizar a avaliação nutricional, com base nos dados de peso, estatura, idade e sexo. A versão mais atual desse programa (Epiinfo, 2002) permite avaliar o estado nutricional conforme percentuais da mediana, percentis e escores Z para peso-para-idade, estatura-para-idade, peso-para-estatura e Índice de Massa Corporal (IMC).

Por haver consideráveis diferenças nas idades médias de ocorrência da puberdade entre diferentes populações, o grupo de especialistas em antropometria da OMS não recomenda o uso de dados de peso e estatura para comparações de estado nutricional de grupos de adolescentes com idade superior a 10 anos, embora as tabelas e curvas apresentem essas informações (WHO Expert Committee, 1995; Gibson, 1990).

\section{Referência do Centro Nacional de Estatísticas de Saúde dos Estados Unidos (NCHS-2000)}

A nova referência de crescimento do CDC (Kuczmarski et al., 2000) representa as crianças que vivem nos Estados Unidos. Inclui cerca de $14 \%$ de crianças negras, refletindo a proporção na população norte-americana de 1980. A amostra reproduz também a distribuição da freqüência de amamentação na população infantil norteamericana. Os gráficos incluem um conjunto de curvas de crescimento de crianças desde o nascimento até os 36 
meses de idade e de crianças e adolescentes de 2 a 20 anos de idade; para crianças até os 36 meses, apresenta as curvas de peso-para-idade, comprimento-para-idade, peso-para-comprimento e perímetro cefálico-para-idade; para crianças e adolescentes, estão disponíveis os gráficos de peso-para-idade, estatura-para-idade e índice de massa corporal-para-idade. Foram elaborados também os gráficos de peso-para-estatura para crianças entre 77 e 121 centímetros, correspondente às idades entre 2 e 5 anos (Kuczmarski et al., 2000).

Os dados que deram origem às curvas de crescimento CDC-2000 foram obtidos em cinco estudos nacionais ocorridos entre 1963 e 1994, sendo o mais recente deles o Terceiro Estudo para Investigação de Saúde e Nutrição - NHANES III (2007). Os dados foram coletados em entrevistas domiciliares e em exames físicos padronizados realizados no interior de uma unidade móvel devidamente equipada (Ogden et al., 2002). As curvas de crescimento do CDC 2000 excluem as crianças nascidas de muito baixo peso $(<1.500 \mathrm{~g})$.

\section{Novas Curvas de Crescimento da Organização Mundial da Saúde - 2006}

Uma abrangente revisão sobre usos e interpretação de curvas de crescimento realizada por especialistas em antropometria da OMS, em 1993, concluiu que a referência NCHS-OMS, recomendada para uso internacional a partir dos anos 70 do último século, não representava adequadamente o crescimento de crianças, especialmente nos primeiros meses de vida, e postulou a necessidade de novas curvas de crescimento. Em 1994, a Assembléia Mundial de Saúde referendou essa recomendação, e em 1997 foi iniciado o EIMCC para elaboração de novas curvas para avaliar o crescimento e desenvolvimento de crianças em todo o mundo (WHO, 2006c).

As novas curvas de crescimento da OMS incluem dados antropométricos de peso, estatura (comprimento e estatura), perímetros cefálico e braquial e dobras cutâneas tricipital e subescapular, coletadas tendo por base um componente longitudinal (0-24 meses) e outro transversal (18-71 meses). Em uma das visitas também foram coletadas as medidas de peso e estatura do pai e estatura da mãe. O peso da mãe foi coletado em cada uma das vinte visitas hospitalares e domiciliares.

O novo padrão de crescimento apresenta os dados nas formas de percentil e desvios-padrão. Do ponto de vista epidemiológico, há marcadas diferenças entre as novas curvas e o NCHS-OMS, particularmente nos primeiros meses de vida: as prevalências de déficits lineares serão maiores durante a infância, e a subnutrição (déficit de peso-para-idade) também será mais elevada até os 12 meses de idade, decrescendo posteriormente. Déficits de peso-para-comprimento também se mostrarão mais elevados durante o primeiro ano de vida quando utilizadas as novas curvas da OMS. Da mesma forma, serão mais elevadas as prevalências de sobrepeso, sendo que a magnitude das diferenças variará de acordo com a idade, o sexo e o estado nutricional da população a ser avaliada.

As novas curvas são um conjunto de dados que representam a melhor descrição de crescimento fisiológico de crianças saudáveis, menores de 5 anos de idade, que cresceram em condições ambientais ótimas e podem ser usadas para avaliar crianças de qualquer parte do mundo, independentemente de etnia, condição socioeconômica e tipo de alimentação (WHO, 2006c).

\section{Justificativas para a Elaboração de Novas Curvas de Crescimento}

O Comitê de Especialistas da OMS concluiu que os problemas encontrados na referência NCHS-OMS eram suficientemente fortes para recomendar sua substituição, sendo que sua principal preocupação residia no tipo de práticas de alimentação infantil. Além desse, os outros problemas também detectados em relação ao NCHS-OMS (Garza \& De Onis, 2004) foram:

- Falta de representatividade e excesso de homogeneidade da amostra - Os dados do Instituto Fels usados para a representação de crianças nos dois primeiros anos de vida vinham de amostra de uma 
única comunidade, de um país desenvolvido cuja coleta de dados fora feita mais de cinqüenta anos antes. A uniformidade étnica, ambiental e socioeconômica poderia conduzir a uma variabilidade mais baixa do que seria encontrada em circunstâncias menos restritivas.

- Freqüência de medidas - As medidas de peso e comprimento coletadas pelo estudo do Instituto Fels foram obtidas ao nascer, 1, 3, 6, 9, 12, 18 e 24 meses de idade. A baixa freqüência de medidas fez com que a precisão de ajuste das curvas fosse particularmente difícil nos primeiros seis meses de vida, quando a velocidade de crescimento é mais intensa.

- Tamanhos amostrais variáveis - A amostra do Instituto Fels incluiu 156 meninos e 142 meninas ao nascer. Entretanto, as amostras variaram entre 274 meninos e 251 meninas com 1 mês de idade até 472 e 463 aos 18 meses, sem nenhuma razão para tais diferenças. Tendo em vista que os valores nas idades extremas apresentam estimativas menos precisas em relação aos valores centrais, amostra pequena ao nascer era uma preocupação.

- Procedimentos obsoletos para os ajustes das curvas - As técnicas de ajustes das curvas do NCHSOMS foram consideradas obsoletas em relação aos conhecimentos atualmente existentes na área de computação.

- Disjunção da curva de comprimento-estatura aos 24 meses - Há marcada discrepância na estimativa de estatura na idade imediatamente antes e após os 24 meses. As curvas de comprimento baseadas na amostra do Instituto Fels são aproximadamente $1,8 \mathrm{~cm}$, ou meio desvio-padrão, maior do que as curvas baseadas no comprimento da amostra representativa da população de crianças norte-americanas aos 24 meses de idade. Esses problemas também afetam as curvas de peso-paraestatura.

Com base na identificação desses problemas relacionados ao NCHS-OMS, o Comitê de Especialistas da OMS fez as seguintes recomendações em relação às discussões sobre novas curvas de crescimento:

- Uma nova referência é necessária para melhorar as condutas em relação à nutrição infantil.

- A população de referência deverá refletir as atuais recomendações de saúde, especialmente considerando o freqüente uso da referência como padrão de crescimento.

- O valor prático de uso da referência baseada em crianças que seguem as recomendações de cuidados de saúde em geral e especialmente de alimentação deve ser considerado ao longo de toda a extensão do conjunto de dados.

Tendo em vista as consideraçôes aqui mencionadas, as novas curvas de crescimento deveriam apresentar as seguintes características: participação de crianças de vários países, incluindo os menos desenvolvidos; fundamentação em populações saudáveis, sem restrições de crescimento; tamanho e procedimento amostral adequados; disponibilização dos dados brutos para o conhecimento de interessados.

A principal característica do novo padrão de crescimento é a identificação do aleitamento materno como norma biológica e o reconhecimento da criança amamentada como modelo normativo para o crescimento e desenvolvimento (WHO, 2006c).

Alguns aspectos importantes devem ser ainda ressaltados com relação ao novo padrão de crescimento. O primeiro refere-se à sua natureza 'prescritiva'. A amostra do estudo foi composta apenas por crianças saudáveis, que seguiram as recomendaçôes de uma alimentação adequada, especialmente com relação ao aleitamento materno, que cumpriram a rotina de imunização e cujas mães atenderam aos cuidados pré-natais; além disso, essas 
crianças pertenciam a famílias de boas condições socioeconômicas, o que proporcionava um ambiente sem restriçôes para que pudessem atingir seu potencial genético de crescimento. Por todas essas razóes, a nova referência pode ser interpretada como uma norma ideal de crescimento, ou seja, indica como as crianças devem crescer. Outro aspecto é que crianças nascidas com baixo peso $(<2.500 \mathrm{~g})$ não foram excluídas da amostra, tendo em vista que é provável que, em populações com boas condições socioeconômicas, tais crianças representem aquelas pequenas, mas normais. Sua exclusão distorceria artificialmente os percentis mais baixos. E, finalmente, pela primeira vez os dados coletados para a elaboração das novas curvas de crescimento foram planejados exclusivamente para essa finalidade, tendo sido observados todos os requisitos teóricos para sua construção.

\section{Metodologia do Estudo}

Seis países representando as principais regiōes geográficas do mundo participaram do estudo (De Onis et al., 2004): Brasil (América do Sul), Gana (África), Índia (Ásia), Noruega (Europa), Oman (Oriente Médio) e Estados Unidos (América do Norte). Os principais critérios para a seleção dos países foram:

- Condição socioeconômica que não prejudicasse o crescimento: dados epidemiológicos mostrando baixa taxa de mortalidade infantil e prevalências de déficits peso-para-idade, comprimento-paraidade e peso-para-comprimento inferiores a 5\% nas idades entre 12 e 23 meses.

- Baixa altitude: $<1.500$ metros.

- População com baixa mobilidade que permitisse o acompanhamento das crianças e famílias por 24 meses.

- Pelo menos 20\% das mães deveriam manifestar desejo de seguir as recomendações alimentares: os investigadores de cada país deveriam ser capazes de demonstrar previamente que pelo menos $20 \%$ das mães elegíveis seguiriam as recomendaçôes alimentares.

- Possibilidade de implementar um sistema de apoio à lactação: uma equipe de apoio ao aleitamento materno e introdução adequada de alimentos complementares deveria acompanhar a mãe e a criança desde a primeira visita hospitalar até que a criança completasse 12 meses de idade.

- Existência de uma instituição de pesquisa, colaboradora da OMS: o estudo deveria ser conduzido por instituição que demonstrasse comprovada experiência em epidemiologia, particularmente em estudos longitudinais e em antropometria.

Os critérios individuais para a seleção e inclusão das crianças (De Onis et al., 2004) foram: a) não apresentar restrições econômicas, ambientais e de saúde que prejudicasse o crescimento normal; b) mães deveriam manifestar o desejo de seguir as recomendaçôes da OMS-Unicef em relação às práticas alimentares; c) apenas crianças nascidas a termo - idade gestacional $\geq 37$ semanas (259 dias) e < 42 semanas ( 294 dias); d) parto único; e) ausência de morbidade importante; f) mães não fumantes, antes e após o parto.

Tendo em vista a baixa prevalência de aleitamento materno exclusivo até os 6 meses de idade em todo o mundo, o comitê de especialistas responsável pela condução do estudo multicêntrico estabeleceu um critério mais flexível em relação às práticas de alimentação para as crianças do estudo (De Onis et al., 2004). O Quadro 1 apresenta as recomendaçôes alimentares da OMS-Unicef vigentes à época do início do estudo. 
Quadro 1 - Recomendações sobre práticas alimentares nos primeiros anos de vida, segundo a OMSUnicef e critério operacional para as crianças participantes das novas curvas de crescimento

\begin{tabular}{|ll|}
\hline Recomendações OMS-Unicef* & Critérios operacionais para o estudo multicêntrico \\
\hline Aleitamento materno exclusivo até 4-6 meses de idade & $\begin{array}{l}\text { Aleitamento materno exclusivo** ou predominante*** até, pelo menos, } \\
\text { os } 4 \text { meses de vida }\end{array}$ \\
\hline Introdução de alimentos complementares aos 4-6 meses & Introdução de alimentos complementares a partir dos 6 meses \\
\hline Aleitamento parcial até os 24 meses & Aleitamento materno parcial até, pelo menos, os 12 meses \\
\hline
\end{tabular}

* Recomendações alimentares vigentes em 1997.

* * Aleitamento materno exclusivo: criança que recebia apenas leite materno de sua mãe ou ama-de-leite, ou leite materno extraído, e nenhum outro líquido ou sólido com exceção de gotas ou xaropes de vitaminas, suplementos minerais ou medicamentos.

*** Aleitamento materno predominante: a fonte alimentar predominante é o leite materno. Entretanto, as crianças poderiam receber também água e bebidas à base de água (adoçadas ou flavorizadas, chás ou infusões), suco de frutas, solução de sais de reidratação oral, gotas ou xaropes na forma de vitaminas, minerais ou medicamentos. Exceto suco de frutas e água adoçada, nenhum outro líquido alimentar é permitido sob essa definição.

Fonte: De Onis et al. (2004).

\section{Desenho do Estudo}

Conforme recomendações para construção de curvas de crescimento (WHO Expert Committee, 1995), o estudo incluiu um componente longitudinal (0-24 meses) e outro transversal (18-71 meses) (Figura 2).

Figura 2 - Desenho do EIMCC para elaboração de curvas de crescimento

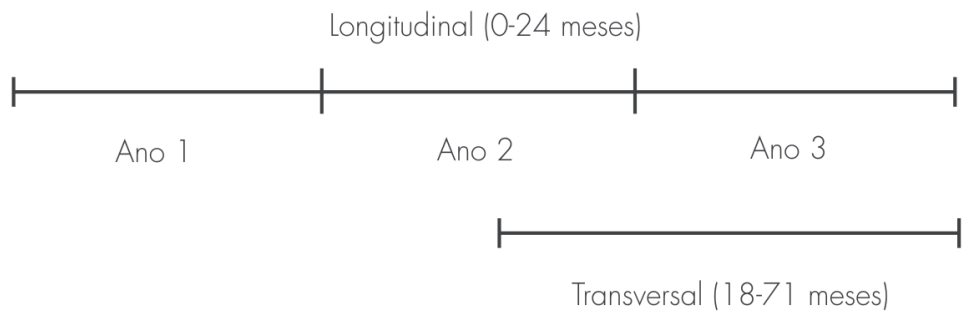

Fonte: De Onis et al. (2004).

\section{Estudo Longitudinal}

A etapa longitudinal incluiu 21 visitas: uma hospitalar e vinte domiciliares (Tabela 1). A utilização deste tipo de estudo permitirá a construção de curvas de velocidade de crescimento. $\mathrm{Na}$ visita hospitalar, as mães que preenchiam os critérios de inclusão eram informadas sobre o estudo e convidadas a participar. Na visita seguinte (14 dias), as mães que, mesmo dissimuladamente, manifestassem pouca vontade de participar do estudo, ou apresentassem evidência de que algum critério de participação não era atendido (por exemplo, ausência de água encanada no domicílio ou já ter sido introduzido outro leite não materno de forma irreversível ou, ainda, a mãe ter começado a fumar), eram excluídas da amostra e a criança era substituída por outra. As demais, que permaneceram no estudo após essa visita, foram consideradas perdas de seguimento, mas não foram substituídas. 
Tabela 1 - Freqüência de visitas e medidas coletadas durante o estudo longitudinal, conforme a idade das crianças. EIMCC para elaboração de curvas de crescimento

\begin{tabular}{|c|c|c|c|}
\hline Medidas & Idades & Freqüência & No de visitas \\
\hline \multirow{4}{*}{ Peso, comprimento e perímetro cefálico } & Nascimento & Única & 1 \\
\hline & Semanas 2-8 & Quinzenal & 4 \\
\hline & 3-12 meses & Mensal & 10 \\
\hline & $14-24$ meses & Bimestral & 6 \\
\hline \multirow{2}{*}{ Perímetro braquial e dobras cutâneas } & 3-12 meses & Mensal & 10 \\
\hline & $14-24$ meses & Bimestral & 6 \\
\hline
\end{tabular}

Fonte: De Onis et al. (2004).

Das 13.741 mães-crianças dos seis países entrevistadas no hospital, 1.743 (12,7\%) foram selecionadas para participar do estudo longitudinal. A Tabela 2 mostra os motivos para as exclusões do estudo longitudinal, conforme o país.

Tabela 2 - Motivos para exclusões na amostra longitudinal por país. EIMCC para elaboração de curvas de crescimento

\begin{tabular}{lccccccc}
\hline & Brasil & Gana & Índia & Norvega & Oman & EUA & Todos \\
\hline Triagem total (n) & 4.801 & 2.057 & 692 & 836 & 4.957 & 398 & 13.741 \\
\hline Total de exclusões (n) & 4.407 & 1.681 & 310 & 402 & 4.428 & 123 & 11.351 \\
\hline Motivos para exclusão $(\%))^{\prime}$ & & & & & & & \\
\hline Residir fora da área do estudo & 24,9 & 11,4 & 6,2 & 14,2 & 31,2 & 0,0 & 22,8 \\
\hline Nascimentos múltiplos & 2,2 & 0,8 & 0,0 & 2,9 & 1,3 & 0,8 & 1,5 \\
\hline Morbidade perinatal & 6,1 & 1,3 & 1,7 & 12,2 & 5,0 & 5,8 & 5,1 \\
\hline Nascimento pré ou pós-termo & 8,7 & 1,5 & 4,5 & 6,2 & 6,5 & 3,3 & 6,3 \\
\hline $\begin{array}{l}\text { Inobservância das } \\
\text { recomendações alimentares }\end{array}$ & 1,0 & 0,2 & 6,1 & 1,2 & 6,7 & 14,1 & 3,6 \\
\hline Mãe fumante & 19,0 & 0,1 & 0,4 & 9,2 & 0,6 & 1,5 & 7,5 \\
\hline Baixa condição socioeconômica & 54,3 & 74,2 & 24,4 & 0,0 & 47,3 & 0,8 & 48,4 \\
\hline $\begin{array}{l}\text { Dificuldade de comunicação } \\
\text { devido ao idioma }\end{array}$ & 0,0 & 0,0 & 0,0 & 0,8 & 14,0 & 4,3 & 5,6 \\
\hline
\end{tabular}

'O percentual de exclusões pode exceder 100\%, pois alguns indivíduos podem ter sido excluídos por mais de um critério.

Fonte: WHO (2006a).

\section{Estudo Transversal}

O componente transversal foi realizado para a coleta de dados de crianças de 18-71 meses, para minimizar tempo e custos se o estudo longitudinal fosse estendido até os 71 meses de idade. Além disso, nesse grupo etário, o crescimento é mais linear do que entre crianças mais novas. $O$ estudo transversal iniciou aos 18 meses, para permitir uma sobreposição de medidas por um período de seis meses (18-24 meses) com o estudo longitudinal, 
proporcionando informação sobre a transição da medida de comprimento (deitado) para a estatura (em pé), melhorando a junção dos dois conjuntos de dados (WHO, 2006c). Apesar de os dados coletados incluírem crianças de até 71 meses de idade, as curvas foram construídas para uso em crianças de até 60 meses, de modo a permitir estimativas mais confiáveis nas últimas faixas de idade.

Tendo em vista o grande número de crianças requerido para o estudo transversal, os estudos norte-americano e brasileiro realizaram uma combinação de estudo transversal-longitudinal, em que cada criança foi medida até duas vezes (EUA) ou até três vezes (Brasil).

\section{Controle de Qualidade}

Para assegurar a qualidade das medidas e das informações obtidas pelos seis países, rigorosos procedimentos de controle de qualidade foram implementados. Além das rotinas usuais para controle de qualidade, foram adotados, com o maior rigor científico possível, os seguintes procedimentos:

- Uso de formulários pré-testados e uniformizados com guias do entrevistador detalhados.

- Versão e retroversão dos formulários utilizados nos idiomas de cada país.

- Visitas regulares às equipes de trabalho de cada um dos seis países.

- Intenso treinamento para a coleta das medidas antropométricas por especialistas internacionais e visita anual desses especialistas com a finalidade de realizar teste de padronização dos antropometristas.

- Sessões de padronização a cada dois meses, com avaliação dos erros intra e interobservadores (De Onis, Onyango \& Van den Broek, 2004).

- Uso de equipamentos de coleta de medidas antropométricas de alta precisão, calibrados diariamente.

- Repetição de $10 \%$ de todas as entrevistas, realizada por telefone.

- Rigoroso monitoramento das datas de visitas, incluindo a realização de visitas atrasadas, adiantadas e perdas.

- Avaliação periódica dos valores das medidas, incluindo a análise de valores extremos e de dígitos terminais.

Quadro 2 - Especificações dos equipamentos para coleta das medidas antropométricas utilizados pelos seis países participantes do Estudo Internacional Multicêntrico para elaboração de curvas de crescimento

\begin{tabular}{|c|c|c|c|c|}
\hline Medida antropométrica & Marca & Amplitude & Precisão & Características \\
\hline Comprimento & Harpenden Infantometer & $(30-110 \mathrm{~cm})$ & $1 \mathrm{~mm}$ & Portátil, com mostrador digital \\
\hline Estatura & $\begin{array}{l}\text { Harpenden Portable } \\
\text { Stadiometer }\end{array}$ & $(65-206 \mathrm{~cm})$ & $1 \mathrm{~mm}$ & $\begin{array}{l}\text { Especialmente desenvolvido para o estudo } \\
\text { Usado para medir a estatura de crianças > } \\
2 \text { anos e adultos }\end{array}$ \\
\hline Peso & $\begin{array}{l}\text { Unicef Eletronic Scale } \\
890 \text { or Uniscale }\end{array}$ & $0-150 \mathrm{~kg}$ & $100 \mathrm{~g}$ & $\begin{array}{l}\text { Balança eletrônica, com tara, o que } \\
\text { permite pesar a criança no colo da mãe }\end{array}$ \\
\hline $\begin{array}{l}\text { Perímetros cefálico e } \\
\text { braquial }\end{array}$ & $\begin{array}{l}\text { CMS Weighing } \\
\text { Equipment Ltd. England }\end{array}$ & $0-200 \mathrm{~cm}$ & $1 \mathrm{~mm}$ & $\begin{array}{l}\text { Trena de metal flexível, não extensível, } \\
\text { largura de } 7 \mathrm{~mm} \text {, com início da tira sem } \\
\text { escala para assegurar a melhor precisão } \\
\text { da leitura }\end{array}$ \\
\hline $\begin{array}{l}\text { Dobras cutâneas tricipital e } \\
\text { subescapular }\end{array}$ & $\begin{array}{l}\text { Holtain/Tanner-Whitehouse } \\
\text { Skinfold Caliper }\end{array}$ & $0-40 \mathrm{~mm}$ & $0,2 \mathrm{~mm}$ & Pressão de $10 \pm 2 \mathrm{~mm}^{2}$ \\
\hline
\end{tabular}

Fonte: De Onis, Oyango \& Van den Broek (2004). 


\section{O Estudo Multicêntrico no Brasil}

A América do Sul foi representada no estudo multicêntrico para elaboração das curvas de crescimento pelas crianças de Pelotas, RS, o primeiro local a iniciar o estudo, no dia 1o de julho de 1997. Um dos requisitos para a seleção das crianças era pertencer a famílias cuja renda fosse suficiente para proporcionar um ambiente saudável, de modo que pudessem crescer e alcançar seu potencial genético de crescimento, desde os primeiros anos de vida. Para definir qual o ponto de corte de renda familiar a ser adotado como critério de inclusão na amostra, foram analisados os dados da coorte das crianças nascidas em Pelotas em 1993. Essa análise mostrou que, entre crianças pertencentes a famílias cuja renda familiar mensal era igual ou superior a seis salários mínimos mensais, a prevalência de déficit comprimento-para-idade aos 12 meses de idade era de 2,5\%, similar ao esperado pela referência NCHS-OMS (NCHS, 1978). Assim sendo, esse ponto de corte foi definido para a elegibilidade das crianças da amostra brasileira.

Outro aspecto característico do estudo brasileiro diz respeito às práticas de aleitamento materno. Conhecimentos prévios ao estudo multicêntrico mostravam que as taxas de início e continuidade do aleitamento materno eram baixas, mas passíveis de serem melhoradas substancialmente com adequado apoio a esta prática. Assim, uma equipe de três enfermeiras, com amplo conhecimento sobre aconselhamento à lactação, acompanhou cada criança selecionada para participar do estudo desde o nascimento até os 12 meses de idade. A primeira visita das enfermeiras ocorreu ainda no hospital e, posteriormente, aos 5, 15, 30 e 45 dias, e aos 2, 3, 4, 6, 8, 10 e 12 meses de idade. Visitas extraordinárias eram realizadas quando algum problema fosse identificado. Nas idades de 7, $9 \mathrm{e}$ 11 meses, contatos telefônicos com as mães eram feitos para avaliar se a prática de aleitamento materno estava indo bem. Caso necessário, novas visitas extras eram realizadas.

$\mathrm{Na}$ primeira visita hospitalar, as mães eram motivadas a amamentar seus filhos por meio de orientações sobre as vantagens do aleitamento materno tanto para as crianças como para elas mesmas. A partir daí, a mesma enfermeira realizava as visitas posteriores, fortalecendo a formação de vínculo com a mãe e a criança. Em cada uma das visitas domiciliares, as enfermeiras observavam uma mamada e, sempre que necessário, orientavam quanto à posição correta da criança no colo da mãe. Orientações sobre a extração do leite materno também eram dadas em todas as visitas, no caso de a mãe precisar se afastar da criança por algumas horas. Aos seis meses de idade da criança, as mães eram orientadas a introduzir alimentos complementares corretamente. Além disso, havia sempre uma enfermeira em sistema de plantão telefônico para orientação e, se necessário, realização de visita domiciliar mesmo à noite, em fins de semana e feriados.

Com a finalidade de visualizar o efeito desse aconselhamento intensivo, foram comparadas as prevalências de aleitamento materno exclusivo (apenas leite materno) e predominante (leite materno mais água, chá ou suco) entre as crianças do EIMCC e as crianças da coorte de nascimento de 1993, que apresentavam características similares, especialmente em relação à condição socioeconômica. Embora outros fatores pudessem também explicar as diferenças de prevalências encontradas no intervalo de cinco anos entre os dois estudos, é plausível acreditar que o aconselhamento e o estímulo ao aleitamento materno proporcionados pela equipe de apoio à lactação foram decisivos na melhora observada: as crianças do estudo multicêntrico mostraram prevalências de aleitamento materno exclusivo, aos 3 meses, de $56,8 \%$, contra $12,7 \%$ da coorte de 1993 . Inversamente, o aleitamento materno predominante foi de $16,9 \%$ e $28,2 \%$, respectivamente para as crianças do estudo multicêntrico e da coorte 1993. Essa comparação permitiu concluir que as mães postergaram a introdução de outros alimentos, aumentando a prevalência de aleitamento materno exclusivo e diminuindo a prevalência de aleitamento materno predominante (Albernaz, Giugliani \& Victora, 1998). 


\section{Considerações Finais}

O uso de referências de crescimento para avaliar o estado nutricional de crianças tem sido um instrumento valioso para identificar crianças sob risco nutricional e monitorar o crescimento e desenvolvimento nos primeiros anos de vida pós-natal. Entretanto, até 2006, as referências utilizadas eram conjuntos de dados adaptados, geralmente baseados em amostras etnicamente homogêneas. Em 2006, a OMS disponibiliza os primeiros conjuntos de curvas de crescimento para uso internacional, planejado e implementado especificamente para a avaliação nutricional de crianças entre 0 e 5 anos de idade.

A construção das novas curvas de crescimento exigiu cuidados extremos desde seu planejamento e análise dos dados até sua implementação. Os atuais conhecimentos científicos para a construção de curvas de crescimento foram aplicados desde a seleção dos locais de estudo, na coleta de informaçôes, até a reunião e tabulação dos dados antropométricos.

A uniformização de técnicas e equipamentos e o controle de qualidade em todas as etapas do estudo foram medidas adotadas para assegurar a rigorosa qualidade dos dados coletados.

As novas curvas da OMS podem ser usadas como um padrão para avaliar o crescimento de crianças menores de 5 anos de idade e devem ser usadas para crianças de qualquer parte do mundo, independentemente de etnia, condição socioeconômica ou padrão de alimentação.

\section{Referências}

ALBERNAZ, E.; GIUGLIANI, E. R. J. \& VICTORA, C. G. Supporting breastfeeding: a successful experience. Journal of Human Lactation, 14(4): 283-285, 1998.

CENTER FOR DISEASE CONTROL AND PREVENTION (CDC). National Center for Health Statistics. 2000 CDC growth charts: United States. Disponível em: <www.cdc.gov/growthcharts>. Acesso em: 23 fev. 2007.

DE ONIS, M.; ONYANGO, A. W. \& VAN DEN BROEK, J. Measurement and standardization protocols for anthropometry used in the construction of a new international growth reference. Food and Nutrtition Bulletin, 25(1), suppl. 1: S27-36, 2004.

DE ONIS, M. et al. The WHO Multicentre Reference Study: planning, study designs, and methodology. Food and Nutrtition Bulletin, 25(1), suppl. 1: S15-S26, 2004.

EPIINFO 2002. CENTER FOR DISEASE CONTROL AND PREVENTION (CDC). Database and statistics software for public health professionals. Disponível em: <www.cdc.gov/epiinfo>. Acesso em: 23 fev. 2007.

EVELETH, P. B. \& TANNER, J. M. Worldwide Variation in Human Growth. 2. ed. Cambridge: Cambridge University Press, 1990.

GARZA, C. \& DE ONIS, M. Rationale for developing a new international growth reference for the WHO Multicentre Growth Study Reference. Food and Nutrition Bulletin, 25(1), suppl. 1: S5-13. 2004.

GIBSON, R. Principles of Nutritional Assessment. New York, Oxford: Oxford University Press, 1990.

GOLDSTEIN, H. \& TANNER, J. M. Ecological considerations in the creation and the use of child growth standards. The Lancet, 1: 582-585, 1980.

HABICHT, J. P. et al. Height and weight standards for preschool children: how relevant are ethnic differences in growth potencial? The Lancet, 1: 611-614, 1974. 
JELLIFFE, D. B. Evaluación del Estado de Nutrición de la Comunidad. Ginebra: OMS, 1968.

KUCZMARSKI, R. J. et al. CDC growth: United States. Advance Data, 8(314): 1-27, 2000.

NATIONAL CENTER FOR HEALTH STATISTICS (NCHS). NCHS Growth Curves for Children, Birth-18 Years. Washington: US Department of Health, Education and Welfare, 1978. (Vital and Health Statistics Series, 11, Publication PHS 78-1650)

NATIONAL HEALTH AND NUTRITION EXAMINATION SURVEY III (NHANES III). NHANES Data Files. Disponível em: <http://www.cdc.gov/nchs/about/major/nhanes/nh3data.htm>. Acesso em: 23 fev. 2007.

OGDEN, C. L. et al. Center for Disease Control and Prevention 2000 growth charts for the United States: improvements to the 1977 National Center for Health Statistics 1977. Pediatrics, 109(1): 45-60, 2002.

TANNER, J. M. Fœtus into man: physical growth from conception to maturity. 3. ed. London: Open Books, 1985.

WHO. MULTICENTRE GROWTH REFERENCE STUDY GROUP. Enrolment and baseline characteristics in the WHO Multicentre Growth Reference Study. Acta Padiatrica, suppl. 450: 7-15, $2006 \mathrm{a}$.

WHO. MULTICENTRE GROWTH REFERENCE STUDY GROUP. Assessment of differences in linear growth among populations in the WHO Multicentre Growth Reference Study. Acta Pediatrica, suppl. 450: 56-65, 2006b.

WHO. CHILD GROWTH STANDARDS. Length/height-for-age, Weight-for-age, Weight-for-length, Weight-forheight and Body Mass Index-for-age: methods and development. Geneva: WHO Department of Nutrition for Health Development, 2006c.

WHO EXPERT COMMITTEE. Physical Status: the use and interpretation of anthropometry. Geneva: WHO, 1995. (WHO Technical Report Series, 854) 



\title{
4 \\ Avaliação Nutricional de Adolescentes
}

\author{
Gloria Valeria da Veiga e Rosely Sichieri
}

\begin{abstract}
A
adolescência é definida pela Organização Mundial da Saúde (OMS) como a faixa etária compreendida entre 10 e 19 anos (WHO, 1995). Caracteriza-se por intenso crescimento e desenvolvimento e por alterações morfológicas e fisiológicas complexas, nas quais a nutrição desempenha um importante papel. Durante a adolescência, o indivíduo adquire $25 \%$ de sua estatura final e 50\% do seu peso definitivo (Heald, 1979).

Os adolescentes podem ser considerados um grupo de risco nutricional por diversas razões, destacando-se a inadequação da dieta no tocante ao aumento das necessidades energéticas e de nutrientes para atender à demanda do crescimento. Há muitas evidências de que os adolescentes concentram suas escolhas em alimentos de alta densidade energética, porém pobres em nutrientes (Hunag et al., 1994; Watt \& Sheiham, 1996; Andrade, Pereira $\&$ Sichieri, 2003) incentivados por propagandas e modismos que estimulam o consumo de tais alimentos (Zaida, 1992). Esses hábitos podem contribuir tanto para o baixo peso e desnutrição quanto para o excesso de peso e obesidade, assim como para o aparecimento precoce de alterações metabólicas associadas ao excesso de gordura corporal.

Nesse contexto, a avaliação do estado nutricional de adolescentes tem uma importância fundamental para a detecção precoce de distúrbios nutricionais.
\end{abstract}

\section{Crescimento e Maturação Sexual}

Os requerimentos nutricionais na adolescência estão diretamente relacionados com composiçãao corporal, atividade física, sexo e estágio puberal. Em função da aceleração rápida no crescimento, os adolescentes têm suas necessidades de energia, proteínas e carboidratos aumentadas, assim como de minerais como ferro, cobre, cálcio e zinco, em decorrência do aumento da massa muscular, expansão do volume sangüíneo e aumento da massa óssea (Eisenstein, 1995).

O processo de crescimento e desenvolvimento na adolescência tem três etapas distintas: a) Fase de início de estirão de crescimento que, geralmente, começa entre 10 e 13 anos nas meninas e entre 12 e 15 anos nos meninos; b) Fase de pico máximo de crescimento, com duração média de 24 a 36 meses, em que o ganho em estatura chega a atingir, aproximadamente, 8 a $9 \mathrm{~cm}$ por ano nas meninas e cerca de $10 \mathrm{~cm}$ por ano nos meninos; c) Fase de desaceleração de crescimento, em que pode ocorrer ainda um incremento de 5 a $8 \mathrm{~cm}$ na estatura (Eisenstein, 
1995). Após a fase de pico máximo de crescimento, o ganho em estatura ainda pode continuar, em média, até os 17 anos de idade nas meninas e até 21 anos nos meninos (Bianculli, 1985).

Há grandes variações entre indivíduos (Duarte, 1993) e entre populações (Eveleth, 1986) quanto ao desenvolvimento puberal. Indivíduos da mesma idade podem estar em fase diferente de crescimento e, conseqüentemente, de ganho de peso e estatura. Dessa forma, os índices antropométricos que são associados à idade, tais como peso-para-idade (P/I) e estatura-para-idade (E/I), tão comumente utilizados para avaliar crianças menores de 10 anos, são de mais difícil interpretação nesta faixa etária. A maturação sexual, representada pelo desenvolvimento das gônadas, dos órgãos reprodutores e dos caracteres sexuais secundários, torna-se de fundamental importância na avaliação do crescimento, desenvolvimento e estado nutricional do adolescente (Colli, 1989).

A avaliação da maturação sexual pode ser feita com base nas pranchas de Tanner (1962), que indicam cinco estágios de desenvolvimento de mamas (M1 a M5) e de pêlos pubianos para o sexo feminino, e de genitália (G1 a G5) externa e de pêlos pubianos para o sexo masculino. A descrição detalhada de cada um desses estágios, com ilustração fotográfica, pode ser encontrada em Colli, Coates \& Guimarães (1993). No estágio M1, fase de préadolescência, ocorre elevação das papilas mamárias; em M2, a mama já aparece como uma pequena elevação sem separação dos contornos; e de M3 a M5, ocorre aumento da mama e definição dos contornos da aréola e papilas. Para o desenvolvimento masculino, o estágio G1 corresponde a uma genitália infantil; em G2, há aumento do escroto e dos testículos, sem aumento do pênis, e em G3 já ocorre aumento do pênis. Para o sexo feminino, o marcador do estirão do crescimento é a fase M2, que é o aparecimento da mama, e para o sexo masculino o marcador inicial é o aumento da genitália (G3).

A OMS recomenda a utilização de dois eventos de maturação sexual para cada sexo: um como marcador do início do estirão do crescimento (M2 para meninas e G3 para meninos), e outro como indicador de que a velocidade máxima de crescimento já ocorreu (menarca para as meninas e voz adulta para meninos) (WHO, 1995). Com base nesse critério, é possível observar os diferentes estágios (Quadro 1).

Quadro 1 - Estágios de desenvolvimento segundo sexo

\begin{tabular}{|c|c|c|}
\hline & \multicolumn{2}{|c|}{ Sexo masculino } \\
\hline \multirow[t]{2}{*}{ Voz adulta } & \multicolumn{2}{|c|}{ Estágio G3 } \\
\hline & Sim & Não \\
\hline Sim & Pós-pubescente: completou a maior parte do crescimento. & Não costuma acontecer. \\
\hline \multirow[t]{2}{*}{ Não } & Pubescente: iniciou, mas não completou o estirão. & Pré-pubescente: não iniciou o estirão. \\
\hline & \multicolumn{2}{|c|}{ Sexo feminino } \\
\hline \multirow[t]{2}{*}{ Menarca } & \multicolumn{2}{|c|}{ Estágio M2 } \\
\hline & Sim & Não \\
\hline Sim & Pós-pubescente: completou a maior parte do crescimento. & Não costuma acontecer. \\
\hline Não & Pubescente: iniciou, mas não completou o estirão. & Pré-pubescente: não iniciou o estirão. \\
\hline
\end{tabular}

Fonte: WHO (1995).

A idade da menarca é um marcador importante da desaceleração do crescimento para as meninas. Esse evento ocorre, geralmente, de 12 a 18 meses após o início do estirão de crescimento (WHO, 1995, 2006). Para os meninos, a identificação da voz do adolescente como marcador de fase de desaceleração do crescimento é muito subjetiva e pode implicar erro de classificação. 
Há grande variação na média da idade da menarca entre populações, que pode variar de 12,5 anos em países desenvolvidos a 15 anos ou mais em países menos desenvolvidos (Becker, 1993). Entre os vários fatores que podem estar envolvidos nessa variação, o estado nutricional é considerado o mais importante (Bongaarts \& Cohen, 1998). Crianças mais bem-nutridas apresentam idade da menarca mais precoce do que aquelas com desnutrição, e uma gradual redução na idade da menarca tem sido observada com as melhoras progressivas nas condições socioeconômicas e nutricionais nos últimos duzentos anos em sociedade ocidentais (WHO, 2006). No Brasil, a idade média da menarca é de 13,2 anos, segundo a Pesquisa Nacional sobre Saúde e Nutrição PNSN (Inan, 1990).

Em estudos epidemiológicos, a avaliação física para identificação do estágio de maturação sexual nem sempre é viável, pois exige profissional devidamente capacitado (geralmente médico) e ambiente reservado e apropriado. A auto-avaliação é uma alternativa que já foi validada em adolescentes norte-americanos, franceses e brasileiros, em estudos que mostraram uma boa correlação $(\mathrm{r} \sim 0,80)$ entre a auto-avaliação e aquela realizada por profissional qualificado (Duarte, 1993; Saito, 1993).

\section{Dificuldades na Interpretação dos Índices e Indicadores Antropométricos}

O método antropométrico, principalmente os índices que associam as medidas de peso e estatura, tem sido o mais usado em estudos populacionais de avaliação nutricional em todas as faixas etárias. Nas fases de crescimento, a antropometria tem uma importância fundamental, já que o crescimento físico e a maturação sexual dependem, principalmente, de condiçôes nutricionais ótimas. Entretanto, em virtude da variabilidade individual no processo de crescimento na adolescência, independentemente da idade cronológica, a interpretação das relações entre as medidas corporais nesta faixa etária é bem mais complexa do que quando usadas para avaliação de crianças.

A dificuldade se inicia na construção de curvas de valores de referência para os índices, como, por exemplo, o peso-para-estatura (P/E), amplamente utilizado para crianças, já que o peso vai variar em função do estágio de maturação sexual, e não apenas da estatura do adolescente. Em 1997, o National Center for Health and Statistics (NCHS) publicou as distribuições de percentis da população americana para os índices antropométricos E/I e P/I para meninos e meninas de 1 mês a 18 anos. No entanto, não existem os valores de P/E para meninas e meninos com estatura acima de $137 \mathrm{~cm}$ e $145 \mathrm{~cm}$, respectivamente, a fim de evitar o risco de incluir dados de peso e estatura de crianças pubescentes, que sofrem acentuadas mudanças das proporçôes corporais (Hamill et al., 1979).

Posteriormente, o Center for Disease Control - CDC (Kuczmarsky et al., 2000) divulgou as novas curvas, também da população americana, com distribuição de valores para P/I e E/I até 20 anos, e para o índice P/E apenas para crianças até $120 \mathrm{~cm}$.

Em adolescentes, a apreciação do índice $\mathrm{P} / \mathrm{E}$ associado à avaliação de maturação sexual é particularmente importante, visto que adolescentes da mesma idade podem apresentar estaturas diferentes e o seu peso deve estar proporcional à estatura atingida, e não à idade propriamente dita. Dessa forma, o uso das curvas de P/I tem pouca validade porque ignora a contribuição da estatura (Himes \& Dietz, 1994). O P/I pode sugerir um déficit ponderal nem sempre verdadeiro para aqueles adolescentes que são baixos para a idade e também se encontram em percentis baixos de P/I, mas com peso proporcional para sua estatura. Em contrapartida, naqueles que alcançam os percentis mais altos de estatura o P/I pode superestimar o excesso de peso.

Particularmente para avaliação de obesidade, o índice P/E seria o mais adequado, pois apresenta maior correlação com a porcentagem de gordura corporal do que o P/I (Roche, 1984), mas a ausência da distribuição destes valores nas referências internacionais dificulta a utilização daquele índice para estudos epidemiológicos. 


\title{
Vantagens e Limitaçōes do Índice de Massa Corporal e Critérios para Diagnóstico de Excesso de Peso e Baixo Peso
}

\begin{abstract}
A falta de curvas de referência de valores de P/E e a reconhecida importância de avaliar a relação destas medidas na adolescência motivaram os estudos sobre a aplicabilidade dos diferentes índices de peso e estatura nesta faixa etária. O Índice de Massa Corporal (IMC) referente à relação do peso em kg dividido pelo quadrado da estatura em metro é um dos índices mais populares na avaliação nutricional de adultos, por apresentar uma boa correlação com o peso (valores de $r$ geralmente superiores a 0,80 ) e uma baixa correlação com a estatura (geralmente $\mathrm{r}$ em torno de 0,10) (Anjos, 1992). Vários estudos demonstraram que, também na adolescência, o IMC apresenta uma boa correlação com outras medidas mais específicas de adiposidade (Lazarus et al., 1996; Ellis, Abrams \& Wong, 1999). Em 1994, nos Estados Unidos, um comitê de especialistas (Expert Committee on Clinical Guidelines for Overweight in Adolescent Preventive Services) sugeriu que valores específicos de IMC, de acordo com a idade e sexo, fossem usados como critério para triagem de adolescentes com sobrepeso (Himes \& Dietz, 1994). Além da alta correlação com a gordura subcutânea e total nesta faixa etária, o fato de ser este um índice fácil de calcular, ter referência para comparaçôes e ainda permitir a continuidade do critério usado para avaliação de adultos foi razão adicional para essa escolha.

Posteriormente, a OMS (WHO, 1995) endossou a proposta do comitê americano, e em 1997 uma forçatarefa criada nos Estados Unidos, a International Obesity Task Force (IOTF), indicou o IMC como a medida mais razoável para fins de comparação de estudos internacionais sobre prevalência de sobrepeso e obesidade em adolescentes (Bellizzi \& Dietz, 1999). Apesar dessas recomendações, o uso do IMC em adolescentes ainda é um tema bastante controverso. Algumas limitaçôes do índice sugerem cautela no seu uso. A massa corporal, estimada pelo IMC, por exemplo, avalia, além da gordura corporal, a massa livre de gordura, que é muito maior nos meninos.

A compleição corporal e o comprimento relativo das pernas em relação ao tronco também interferem neste índice (Garn, Leonard \& Hawthoene, 1986), o que limita a sua interpretação para avaliar obesidade. O IMC não reflete as grandes mudanças na composição corporal que ocorrem na adolescência, com maior acúmulo de gordura nas meninas e de massa muscular nos meninos (Anjos, 1992). Os resultados obtidos em 1.540 adolescentes estudantes de uma escola privada de Niterói, Rio de Janeiro, refletem claramente esse fenômeno, pois verificouse que a média de IMC aumentou de $19,5 \mathrm{~kg} / \mathrm{m}^{2}$ para $22,6 \mathrm{~kg} / \mathrm{m}^{2}$ em meninos, e de $18,1 \mathrm{~kg} / \mathrm{m}^{2}$ para $21,0 \mathrm{~kg} / \mathrm{m}^{2}$ para meninas dos 10 aos 17 anos, ao passo que a média de gordura corporal, avaliada pela bioimpedância elétrica, aumentou de $21,1 \%$ para $28,3 \%$ nas meninas e reduziu-se de $17,1 \%$ para $16,2 \%$ nos meninos (Veiga, Dias \& Anjos, 2001).
\end{abstract}

Adicionalmente, a correlação do IMC com a estatura, apesar de baixa, é significativa durante a adolescência (Fung et al., 1990), o que consiste em outra limitação para o uso deste índice na fase de crescimento, já que variará não apenas em função de ganho de massa e gordura corporal, mas também em função do ganho em estatura. A escolha da melhor referência e dos pontos de corte para indicar adolescentes com excesso ou déficit de gordura corporal e que indiquem riscos à saúde ainda está em discussão.

A referência proposta pelo comitê americano de especialistas (Himes \& Dietz, 1994) e adotada pela OMS (WHO, 1995) foi a curva de valores de percentis de IMC apresentada por Must, Dallal e Dietz (1991) a partir de dados do National Health and Nutrition Examination Survey (NHANES I, 1971-74). Com base nessa curva, o comitê adotou os percentis 85 e 95 como pontos de corte para classificar 'risco de sobrepeso' e 'sobrepeso', respectivamente, tomando o cuidado de não classificar obesidade apenas com base em um índice de peso e estatura. A OMS propôs classificar como obesos os adolescentes que apresentassem, simultaneamente, IMC acima do P 85 e valores de dobras cutâneas tricipital e subescapular acima do percentil 90 da curva de percentis de jovens americanos (Johnson et al., 1981). Como nem sempre a avaliação de dobras cutâneas é viável em 
estudos epidemiológicos ou na prática clínica, de modo geral utiliza-se o valor acima do percentil 95 como critério para classificar obesidade.

Em 2000, foram divulgadas as curvas de crescimento revisadas pelo Center for Disease Control and Prevention - CDC (Kuczmarsky et al., 2000), nas quais foi incluída a curva de percentis de IMC para idade de 2 a 20 anos, com ampliação dos estudos populacionais que serviram de base de dados (NHANES II, 1976-80 e NHANES III, 1988-94). Essa referência tem sido amplamente utilizada em estudos epidemiológicos de avaliação nutricional de adolescentes.

Devido à elevada prevalência de obesidade nos Estados Unidos, os valores de IMC nos percentis 85 e 95 são muito altos, e a utilização de jovens americanos como referência pode subestimar a extensão do problema em países onde a prevalência é mais baixa. Por exemplo, o valor de IMC no percentil 95 de adolescentes brasileiros do sexo masculino entre 17 e 18 anos é, aproximadamente, $25 \mathrm{~kg} / \mathrm{m}^{2}$, e para os americanos é $31 \mathrm{~kg} / \mathrm{m}^{2}$ (Anjos, Castro \& Veiga, 1998). Isto significa que só consideraríamos com obesidade os adolescentes que atingissem valores de IMC acima de $31 \mathrm{~kg} / \mathrm{m}^{2}$, subestimando a prevalência do problema na nossa população, como confirmado em estudantes de escolas privadas (Veiga, Dias \& Anjos, 2001) e de escolas públicas (Vieira et al., 2006). Entre os meninos, essas diferenças chegaram a atingir 20 pontos percentuais (Veiga, Dias \& Anjos, 2001) e foram bem menores entre as meninas (em torno de 4 a 8\%), indicando que os valores de IMC nos percentis mais altos das meninas brasileiras já estão próximos e quase tão altos quanto os das americanas.

A classificação de baixo peso não implicaria grandes diferenças, considerando que os valores de IMC nos percentis mais baixos (P 5) são bem semelhantes entre jovens brasileiros e americanos (Anjos, Castro \& Veiga, 1998). Conclusão similar foi obtida no estudo de Conde e Monteiro (2006) com base nos dados da Pesquisa Nacional sobre Saúde e Nutrição (PNSN).

É questionável ainda utilizar como referência para países em desenvolvimento valores de IMC de populações cujos jovens alcançaram seu potencial genético de crescimento. Nos países menos desenvolvidos, a baixa estatura, como conseqüência de agravos nutricionais pregressos, pode estar associada à maior gordura corporal (Sichieri, Siqueira \& Moura, 2000). Adicionalmente, as diferenças étnicas na distribuição e acúmulo de gordura corporal e no momento de início e velocidade do processo de maturação sexual também são fatores limitantes na internacionalização da referência americana e de pontos de corte uniformes de IMC para classificar indivíduos segundo estado nutricional (Malina \& Katzmarzyk, 1999).

A IOTF recomendou a elaboração de curva de valores de IMC baseadas em dados de outros países e a utilização de pontos de corte para a classificação de sobrepeso e obesidade em adolescentes que fossem correspondentes aos valores associados com morbidade utilizados para adultos (Bellizzi \& Dietz, 1999).

Cole e colaboradores (2000) divulgaram a curva baseada em dados populacionais obtidos em estudos realizados em seis países (Brasil, Reino Unido, Hong-Kong, Holanda, Singapura e Estados Unidos). Nesta proposta, com base em um critério estatístico, determinou-se, para cada sexo e idade entre 2 a 18 anos, qual o valor de IMC que corresponderia ao IMC de $25 \mathrm{~kg} / \mathrm{m}^{2}$ (para identificar sobrepeso) e $30 \mathrm{~kg} / \mathrm{m}^{2}$ (para identificar obesidade) aos 18 anos de idade. Há perspectiva de que esta seja uma alternativa mais válida para comparações internacionais e menos influenciada pelas variaçôes nos pontos de corte estritamente estatísticos, que podem ocorrer em função das alterações de peso na população de referência e das diferenças na prevalência de obesidade em cada país. Apesar de bastante atraente, essa proposta, que tem sido referida como "internacional", ainda carece de estudos de avaliação de desempenho, já que as populações utilizadas na sua construção ainda não representam a população mundial e não se sabe se os valores associados à morbidade em adultos terão o mesmo significado de risco para crianças e adolescentes. Conde e Monteiro (2006) elaboraram curvas brasileiras do IMC de crianças e adolescentes com base nos dados da PNSN, utilizando metodologia similar à utilizada por Cole e colaboradores (2000), e os valores para sobrepeso são aproximadamente uma unidade de IMC menores do que na curva internacional. 
Também com base nos dados da PNSN realizada em 1989, Anjos, Castro e Veiga (1998) divulgaram curvas segundo percentis de IMC para cada idade e sexo da população brasileira de 0 a 25 anos.

$\mathrm{Na}$ Tabela 1 são apresentados os valores de IMC nos percentis 85 e 95, segundo as duas referências americanas - Must, Dalal \& Dietz, 1991; CDC -, uma curva brasileira - Anjos, Castro \& Veiga, 1998 - e valores correspondentes ao IMC $25 \mathrm{~kg} / \mathrm{m}^{2}$ e $30 \mathrm{~kg} / \mathrm{m}^{2}$ aos 18 anos, segundo a referência "internacional" - Cole et al., 2000. Verifica-se que nas duas referências americanas os valores são semelhantes em ambos os sexos e não se diferenciam muito da referência internacional, embora esta tenha uma tendência a valores mais elevados, principalmente nos mais jovens. Os valores de IMC da população brasileira são sempre mais baixos.

Tabela 1 - Valores de IMC $\left(\mathrm{kg} / \mathrm{m}^{2}\right)$ nos percentis (P) 85 e 95, segundo duas referências americanas e uma curva brasileira e correspondentes ao IMC $25 \mathrm{~kg} / \mathrm{m}^{2}$ e $30 \mathrm{~kg} / \mathrm{m}^{2}$ aos 18 anos, segundo referência internacional

\begin{tabular}{|c|c|c|c|c|c|c|c|c|}
\hline \multirow[b]{2}{*}{ ldade } & \multicolumn{4}{|c|}{ Sobrepeso ${ }^{1}$} & \multicolumn{4}{|c|}{ Obesidade ${ }^{2}$} \\
\hline & $\begin{array}{c}\text { Must, Dallal } \\
\text { \& Dietz }\end{array}$ & $\begin{array}{l}\text { CDC } \\
\text { US }\end{array}$ & Cole et al. & $\begin{array}{c}\text { Anjos, } \\
\text { Castro \& } \\
\text { Veiga }\end{array}$ & $\begin{array}{c}\text { Must, Dallal } \\
\text { \& Dietz }\end{array}$ & $\begin{array}{l}\text { CDC } \\
\text { US }\end{array}$ & Cole et al. & $\begin{array}{c}\text { Anjos, } \\
\text { Castro \& } \\
\text { Veiga }\end{array}$ \\
\hline \multicolumn{5}{|c|}{ Masculino } & \multicolumn{4}{|c|}{ Masculino } \\
\hline 10 & 19,6 & 19,4 & 19,8 & 18,0 & 22,6 & 22,2 & 24,0 & 20,0 \\
\hline 11 & 22,4 & 20,2 & 20,5 & 18,7 & 23,7 & 23,2 & 25,1 & 21,3 \\
\hline 12 & 21,1 & 21,0 & 21,2 & 19,1 & 24,9 & 24,2 & 26,0 & 22,0 \\
\hline 13 & 21,9 & 21,9 & 21,9 & 20,1 & 25,9 & 25,2 & 26,8 & 21,9 \\
\hline 14 & 22,8 & 22,6 & 22,6 & 20,8 & 26,9 & 26,0 & 27,6 & 22,4 \\
\hline 15 & 23,6 & 23,5 & 23,3 & 21,7 & 27,8 & 26,8 & 28,3 & 23,8 \\
\hline 16 & 24,5 & 24,2 & 23,9 & 22,5 & 28,5 & 27,6 & 28,9 & 24,1 \\
\hline 17 & 25,3 & 24,9 & 24,4 & 22,6 & 29,3 & 28,3 & 29,4 & 24,3 \\
\hline 18 & 25,9 & 25,7 & 25,0 & 23,3 & 30,0 & 29,0 & 30,0 & 25,1 \\
\hline \multicolumn{5}{|c|}{ Feminino } & \multicolumn{4}{|c|}{ Feminino } \\
\hline 10 & 20,2 & 20,0 & 19,9 & 18,6 & 23,2 & 23,0 & 24,1 & 21,0 \\
\hline 11 & 21,2 & 20,9 & 20,7 & 19,8 & 24,6 & 24,1 & 25,4 & 22,8 \\
\hline 12 & 22,2 & 21,7 & 21,7 & 20,9 & 26,0 & 25,3 & 26,7 & 23,4 \\
\hline 13 & 23,1 & 22,6 & 22,6 & 22,2 & 27,1 & 26,3 & 27,7 & 24,3 \\
\hline 14 & 23,9 & 23,4 & 23,3 & 23,3 & 28,0 & 27,3 & 28,6 & 26,0 \\
\hline 15 & 24,3 & 24,0 & 23,9 & 23,6 & 28,5 & 28,1 & 29,1 & 26,0 \\
\hline 16 & 24,7 & 22,7 & 24,4 & 24,3 & 29,1 & 28,9 & 29,4 & 26,6 \\
\hline 17 & 25,2 & 25,2 & 24,7 & 24,6 & 29,7 & 29,6 & 29,7 & 27,7 \\
\hline 18 & 25,6 & 25,7 & 25,0 & 24,6 & 30,2 & 30,3 & 30,0 & 28,2 \\
\hline
\end{tabular}

1 - Correspondente ao P 85 para Must, Dallal e Dietz (1991), CDC (Kuczmarsky et al., 2000) e Anjos, Castro e Veiga (1998) e ao valor de referência de Cole e colaboradores (2000) equivalente ao IMC $25 \mathrm{~kg} / \mathrm{m}^{2}$ para adulto.

2 - Correspondente ao P 95 para Must, Dallal e Dietz (1991), CDC (Kuczmarsky et al., 2000) e Anjos, Castro e Veiga (1998) e ao valor de referência de Cole e colaboradores (2000) equivalente ao IMC $30 \mathrm{~kg} / \mathrm{m}^{2}$ para adulto.

Fonte: Veiga et al. (2004). 
Como seria de esperar, variações nos pontos de corte de cada referência influenciam nos valores de prevalências de sobrepeso e obesidade. Em jovens americanos, as estimativas geradas com o uso da referência de Cole e colaboradores (2000) foram mais baixas do que aquelas observadas com o uso da curva do CDC, principalmente nos mais jovens (Flegal et al., 2001). O mesmo ocorreu em estudo com dados populacionais de crianças de 6 a 18 anos da China, Rússia e Estados Unidos, onde foram comparadas as prevalências obtidas com a utilização das referências de Cole e colaboradores (2000) e de Must, Dallal e Dietz (1991). Nesse estudo, embora a concordância entre as duas classificaçóes tenha sido excelente (estatística Kappa >0,8), principalmente para os adolescentes (Wang \& Wang, 2000), as prevalências utilizando a referência de Cole e colaboradores (2000) foram menores do que quando se usou a referência do CDC. Em contrapartida, em adolescentes estudantes de escolas públicas de Niterói, Rio de Janeiro, principalmente naqueles acima de 16 anos, as prevalências utilizando a referência de Cole e colaboradores (2000) foram maiores do que quando se usou a referência do CDC (Vieira et al., 2006).

O desempenho do IMC para identificar adolescentes com excesso de gordura corporal tem sido também investigado comparando-se os critérios propostos de classificação de sobrepeso e obesidade com medidas específicas de gordura corporal. Uma revisão detalhada sobre esses estudos foi publicada anteriormente por Veiga e colaboradores (2004). De modo geral, os estudos demonstraram alta especificidade e baixa sensibilidade, independentemente dos pontos de corte de IMC testados. Entretanto, os pontos de corte obtidos com base em curva nacional e na própria população estudada são mais sensíveis do que os valores das referências americanas e da chamada "internacional" (Vieira et al., 2006).

Apesar das limitações, o IMC continua sendo usado como um bom indicador de gordura corporal em adolescentes, e a utilização de pontos de corte de IMC mais baixos gerados da distribuição de valores nacionais pode resultar em maior acurácia na identificação de jovens em risco de obesidade. A baixa sensibilidade dos pontos de corte das referências americanas e "internacional", as quais chegam a identificar até $60 \%$ de adolescentes com excesso de gordura corporal como eutróficos (Vieira et al., 2006), pode retardar a busca de medidas preventivas efetivas.

Adicionalmente, é importante que os estudos de validação do IMC como índice de obesidade investiguem a sua capacidade de predizer riscos presentes e futuros para a saúde. Apesar das evidências da associação entre valores elevados de IMC com alterações metabólicas de risco para doenças cardiovasculares (Ronnemaa et al., 1991; Steinberger et al., 1995; Teixeira et al., 2001; Oliveira, Veiga \& Sichieri, 2001; Coronelli \& Moura, 2003) e diabetes mellitus (Pinhas-Hamiel et al.,1996; ADA, 2000), estabelecer pontos de corte que levem em conta tal associação é difícil nesta faixa etária em que a morbidade não é ainda tão freqüente.

$\mathrm{O}$ uso do IMC para investigação de baixo peso tem sido pouco explorado na literatura. A OMS propõe o percentil 5 da referência de Must, Dallal e Dietz (1991) como critério para definição de magreza (WHO, 1995). Considerando-se ainda a questão do déficit de crescimento em função de condiçôes ambientais adversas que podem comprometer a estatura do indivíduo, a avaliação do índice E/I também tem sido recomendada para esta faixa etária, e proposto o percentil 3 ou valores abaixo de - 2 z-escore da curva de referência (NCHS) como ponto de corte para classificação de déficit de estatura (WHO, 1995). As curvas revisadas do CDC têm sido as mais utilizadas.

\section{Epidemiologia das Alterações Nutricionais na Adolescência: sobrepeso e obesidade, baixo peso, morbidades associadas ao sobrepeso e obesidade, déficit de estatura}

O excesso de peso (ou sobrepeso, como denominado em vários estudos) tem sido o problema nutricional mais investigado na adolescência. $\mathrm{O}$ aumento na prevalência de excesso de peso, particularmente nas últimas duas décadas, foi relatado em vários países desenvolvidos (Thomsen, Ekstrom \& Sorensen, 1999; Hulens et al., 
2001; Magarey, Daniels \& Boulton, 2001; Moreno et al., 2000; Tremblay, Katzmarzyk \& Willms, 2002) e principalmente nos Estados Unidos (Flegal \& Troiano, 2000), onde se registrou um aumento na obesidade em até 10 pontos percentuais no período de 1988 a 1999-2000, atingindo cerca de 15,5\% dos jovens do país, e com o excesso de peso chegando a 30,4\% (Ogden et al., 2002).

No Brasil, a comparação dos estudos nacionais desenvolvidos nos períodos de 1974-75, 1989 e 1996-97 revelou que a prevalência de sobrepeso em adolescentes triplicou em vinte anos, passando de aproximadamente 4\% para 13\% nas regiōes Sudeste e Nordeste (Wang, Monteiro \& Popkin, 2002; Veiga, Cunha \& Sichieri, 2004). Em meninos, houve um aumento de 2,6\% para $11,8 \%$ e em meninas de 5,8\% para $15,3 \%$. Para os meninos do Sudeste, os valores de IMC no percentil 85 em 1997 foram maiores do que o percentil 95 em 1975, de forma que o aumento neste último percentil variou de 2,9 a 7,4 unidades, semelhante ao descrito para adolescentes americanos (Veiga, Cunha \& Sichieri, 2004).

$\mathrm{Na}$ região Sudeste, o sobrepeso, em 1997, foi verificado em $17 \%$ de meninos e meninas, ao passo que na região Nordeste estas proporçôes foram de 5\% entre os meninos e 12\% entre as meninas. Em meninos de 17 anos no Sudeste, o sobrepeso chegou a 20,2\% (Magalhães \& Mendonça, 2003). A tendência de aumento é nitidamente maior nos meninos, a partir do estudo de 1989, ao passo que nas meninas, particularmente acima de 14 anos da região urbana do Sudeste, constata-se até uma redução (16,4\% para 14,5\%). Este aumento maior em meninos do que em meninas também foi observado na Finlândia (Kautiainen et al., 2002) e no Canadá (Tremblay, Katzmarzyk \& Willms, 2002).

A prevalência de sobrepeso em adolescentes observada na pesquisa de 1997 no Brasil foi mais baixa do que a descrita para a Espanha (18,1\%) (Rios et al., 1999), Estados Unidos (25\%) (Troiano \& Flegal, 1998) e Canadá (entre $26,7 \%$ e 33\%) (Tremblay, Katzmarzyk \& Willms, 2002). As meninas brasileiras, no entanto, apresentaram freqüência de sobrepeso maior do que as da Finlândia (9,8\%) (Kautiainen et al., 2002) e semelhante à das australianas (15,8\%) (Tremblay, Katzmarzyk \& Willms, 2002), usando-se o mesmo critério de diagnóstico.

Os resultados divulgados recentemente, baseados na análise dos dados da última Pesquisa de Orçamento Familiar (POF 2002-2003, IBGE, 2006), confirmam a tendência de aumento do excesso de peso entre adolescentes brasileiros. A prevalência encontrada foi de $16,7 \%$ (pouco mais de $2 \%$ foram diagnosticados como obesos), ainda um pouco maior entre os meninos (17,9\%) do que entre as meninas $(15,4)$. As regiōes Sul, Sudeste e Centro-Oeste são as mais afetadas e, dentro de cada região, o problema é maior no meio urbano do que no meio rural. Essas diferenças regionais e por estrato de residência são mais marcantes entre os meninos do que entre as meninas. A associação entre excesso de peso e renda familiar foi bem evidente, com maiores freqüências nos estratos de maior renda, particularmente entre os meninos.

Apesar de no Brasil a relação entre nível socioeconômico e prevalência de sobrepeso entre os adolescentes ainda ser direta, a evidente tendência de redução entre as meninas de nível de renda mais alto e residentes nas regiōes mais ricas do país sugere que, ao menos para o sexo feminino, a relação inversa observada nos Estados Unidos já esteja ocorrendo no nosso país.

Os dados da POF 2002-2003 revelam estabilidade na freqüência de adolescentes com déficit de IMC para idade (<- 2 z-escore da distribuição de valores de IMC com base na PNSN), como indicador de baixo peso ou desnutriçãao, que ficou entre $2,4 \%$ e $4,8 \%$, nos dois sexos. Considerando o critério de definição de baixo peso como IMC para idade abaixo do percentil 5 da referência NCHS (WHO, 1995), a prevalência encontrada para os jovens brasileiros (cerca de 7\%) é baixa. Países como Índia (53\%), Nepal (36\%) e Benin (23\%) apresentaram as maiores prevalências de baixo peso em adolescentes, entre 11 países investigados (WHO, 2006).

A tendência de aumento de sobrepeso e redução de baixo peso observada no Brasil segue o mesmo padrão da China e dos Estados Unidos, e é inverso ao verificado na Rússia, onde se constatou, durante a depressão econômica, declínio de sobrepeso e aumento de baixo peso em jovens (Wang, Monteiro \& Popkin, 2002). 
O aumento do excesso de peso em adolescentes no Brasil tem sido associado ao aparecimento precoce de alteraçôes metabólicas de risco para doenças cardiovasculares tais como resistência à insulina, diabetes mellitus tipo 2 e a síndrome metabólica (Lima et al., 2004; Silva, Miranda \& Chacra, 2005; Alvarez et al., 2006).

Os componentes da síndrome metabólica mais evidenciados em adultos, conforme registrado no capítulo 22, "Aspectos epidemiológicos e nutricionais da síndrome metabólica”, também já estão presentes em adolescentes obesos, tais como hipertensão arterial, hiperinsulinemia e/ou resistência à insulina, intolerância à glicose e/ou hiperglicemia e diabetes mellitus tipo 2 e dislipidemia caracterizada por hipertrigliceridemia e baixas concentrações de High Density Lipoprotein Cholesterol (HDL-C) no sangue (Molnár, 2004), além do acúmulo excessivo de gordura na região central do organismo que, provavelmente, precede as demais alterações.

Não existe ainda uma definição aceita universalmente para a síndrome metabólica em adolescentes, o que dificulta a comparação das prevalências encontradas nos diferentes estudos. De modo geral, as propostas para adultos foram adaptadas para esta faixa etária, sendo as mais utilizadas as adaptações das propostas do National Cholesterol Education Program Adult Treatment Panel III (NCEP-ATPIII, 2001) e da Organização Mundial da Saúde (Alberti \& Zimmet, 1998).

No Brasil, dois estudos recentes foram desenvolvidos para avaliar a síndrome metabólica em adolescentes. No primeiro, de âmbito mais clínico, Silva, Miranda e Chacra (2005) avaliaram 99 adolescentes com história familiar para diabetes tipo 2 e verificaram que $6 \%$ apresentavam síndrome metabólica. Nos obesos, que correspondiam a $23 \%$ da amostra, essa proporção foi quatro vezes maior, atingindo $26 \%$ dos adolescentes. Encontraram ainda cerca de $24 \%$ com obesidade, $22 \%$ com resistência à insulina, $18 \%$ com hipertensão arterial e $8 \%$ com hipertrigliceridemia e com baixas concentrações de HDL-C. O segundo estudo epidemiológico, desenvolvido por Alvarez e colaboradores (2006), foi pioneiro no Brasil em descrever o perfil de resistência à insulina avaliada pelo Homeostatic Model Assessment - Insulin Resistance (índice Homa-IR). Em uma amostra probabilística de 388 adolescentes do sexo feminino, de 12 a 19 anos, estudantes da rede estadual de ensino da cidade de Niterói, estado do Rio de Janeiro, os autores verificaram síndrome metabólica em 3,2\% do total das adolescentes, em $21 \%$ das que apresentavam sobrepeso e em $0,14 \%$ naquelas sem sobrepeso. No grupo com sobrepeso, a prevalência foi seis vezes maior naquelas que se encontravam no último tercil do índice Homa-IR, quando comparadas às que estavam no primeiro tercil. $\mathrm{O}$ Homa-IR associou-se inversa e significativamente com o HDL-C $(\beta=-1,03 \mathrm{mg} / \mathrm{dL} \mathrm{p}<0,001)$, independentemente do IMC e da idade.

Em adolescentes dos Estados Unidos, a prevalência de síndrome metabólica foi de 4\% (Cook et al., 2003); $32 \%$ entre os obesos e 7,1\% naqueles com sobrepeso (Duncan, Li \& Zhou, 2004). Weiss e colaboradores (2004) observaram freqüências de $49,7 \%$ e $38,7 \%$ em jovens ingleses severa e moderadamente obesos, respectivamente.

Quanto à freqüência de déficit de E/I (<- 2 z-escore da referência NCHS, WHO, 1995), como indicador de desnutrição, as tendências no Brasil são inversas às observadas para o excesso de peso. Segundo os dados da POF 2002-2003 (IBGE, 2006), houve declínio na prevalência de baixo E/I (33,5\%, 20,5\% e 10,8\% no sexo masculino e $26,3 \%, 16,9 \%$ e $7,9 \%$ no sexo feminino) em todos os estratos de renda avaliados, embora as prevalências sejam até quatro vezes maiores quando comparados os estratos de renda mais baixa com os de renda mais alta.

\section{Considerações Finais}

Diante da complexidade da avaliação nutricional de adolescentes, particularmente quanto à interpretação dos índices antropométricos, o grande desafio para pesquisas futuras é a determinação de critérios universais, mas que também levem em consideração as grandes variaçōes individuais em função do sexo, idade, maturação sexual e 
etnia. Apesar das limitações apontadas, os resultados dos estudos realizados no Brasil indicam o risco de adolescentes com sobrepeso desenvolverem resistência à insulina e, conseqüentemente, síndrome metabólica, o que pode representar um importante fator de risco para diabetes tipo 2 e doenças cardiovasculares na vida adulta.

Enfatizou-se neste capítulo a avaliação nutricional populacional. Um outro importante enfoque e ainda mais complexo é a utilização dos indicadores e a definição de pontos de corte para avaliação individual. A OMS estabelece critérios de acompanhamento clínico e de intervenções que enfatizam mais o acompanhamento do estado nutricional do que o diagnóstico pontual de déficits ou excesso pondero-estaturais (WHO, 1995).

Particularmente em relação ao IMC, é importante que sejam investigados os pontos de corte mais sensíveis e específicos e com melhor valor preditivo positivo para identificar riscos de morbidade, presentes e futuros, tanto em relação ao baixo peso quanto ao excesso de peso. A aplicação deste índice na prática clínica deve ser sempre complementada com outras medidas de composição corporal e informações adicionais sobre a história nutricional do indivíduo, além da avaliação do estagiamento maturacional, indispensável na avaliação nutricional de adolescentes.

\section{Referências}

ALBERTI, K. G. M. M. \& ZIMMET, P. Z. Definition, diagnosis and classification of diabetes mellitus and its complications. Part 1: Diagnosis and classification of diabetes mellitus, provisional report of a WHO consultation. Diabetic Medicine, 15: 539-553, 1998.

ALVAREZ, M. M. et al. Insulin resistance in Brazilian adolescent girls: association with overweight and metabolic disorders. Diabetes Research and Clinical Practice, 74(2): 183-188, 2006.

AMERICAN DIABETES ASSOCIATION (ADA). Consensus Statement. Type 2 diabetes in children and adolescents. Diabetes Care, 22: 381-396, 2000.

ANDRADE, R. G.; PEREIRA, R. A. \& SICHIERI, R. Consumo alimentar de adolescentes com e sem sobrepeso no município do Rio de Janeiro. Cadernos de Saúde Pública, 19(5): 485-495, 2003.

ANJOS, L. A. Índice de massa corporal $\left(\mathrm{kg} / \mathrm{m}^{2}\right)$ como indicador do estado nutricional de adultos: uma revisão da literatura. Revista de Saúde Pública, 26: 431-436, 1992.

ANJOS, L. A.; CASTRO, I. R. R. \& VEIGA, G. V. Distribuição dos valores de índice de massa corporal da população brasileira até 25 anos de idade. Revista Panamericana de Salud Pública, 3: 164-173, 1998.

BECKER, S. The determinants of adolescent fertility with special reference to biological variables. In: GRAY, R. (Ed.) Biomedical and Demographic Determinants of Reproduction. Oxford: Clarendon Press, 1993.

BELLIZI, M. C. \& DIETZ, W. H. Workshop on childhood obesity: summary of the discussion. American Journal of Clinical Nutrition, 70: 173S-175S, 1999.

BIANCULLI, C. N. Physical growth and development in adolescents. In: PAN AMERICAN HEALTH ORGANIZATION/WORLD HEALTH ORGANIZATION. The Health of Adolescents and Youth in the Americas. Washington: Paho/WHO, 1985. (Scientific Publication, 489)

BONGAARTS, J. \& COHEN, B. Introduction and overview. Studies in Family Planning, 29: 99-105, 1998.

COLE, T. J. et al. Establishing a standard definition for child overweight and obesity worldwide: international survey. British Medicine Journal, 20: 1-6, 2000. 
COLLI, A. S. Endocrinologia Pediátrica: aspectos fisicos e metabólicos do recém-nascido ao adolescente. Nuvarte Setian. São Paulo: Sarvier, 1989.

COLLI, A. S.; COATES, V. \& GUIMARĀES, B. E. M. Monitorização do crescimento e desenvolvimento físico. In: COATES, V.; FRANÇOSO, L. A. \& BEZNOS, G. W. Medicina do Adolescente. São Paulo: Sarvier, 1993.

CONDE, W. L. \& MONTEIRO, C. A. Body mass index cutoff points for evaluation of nutritional status in Brazilian children and adolescents. Jornal de Pediatria, 82(4): 266-272, 2006.

COOK, S. et al. Prevalence of a metabolic syndrome phenotype in adolescents: findings from the Third National Health and Nutrition Examination Survey, 1988-1994. Archives of Pediatrics \& Adolescent Medicine, 157: 821-827, 2003.

CORONELLI, C. L. S. \& MOURA, E. C. Hipercolesterolemia em escolares e seus fatores de risco. Revista de Saúde Pública, 37: 24-31, 2003.

DUARTE, N. F. S. Maturação física: uma revisão da literatura, com especial atenção à criança brasileira. Cadernos de Saúde Pública, 9, supl. 1: S71-84, 1993.

DUNCAN, G. E.; LI, S. M. \& ZHOU, X. H. Prevalence and trends of a metabolic syndrome phenotype among U.S. adolescents, 1999-2000. Diabetes Care, 27: 2.438-2.442, 2004.

EISENSTEIN, E. Nutricion y salud en la adolescencia. In: MADDALENO. M. et al. La Salud del Adolescente y del Joven. Washington: WHO, 1995. (Publicación Científica, 52)

ELLIS, K. J.; ABRAMS, A. S. \& WONG, W. W. Monitoring childhood obesity: assessment of the weight/ height ${ }^{2}$ index. American Journal of Epidemiology, 150: 939-945, 1999.

EVELETH, P. B. Population differences in growth. Environmental and genetic factors. In: FALKNER, F. \& TANNER, J. M. (Eds.) Human Growth: a comprehensive treatise. 2. ed. New York: Plenum Press, 1986.

FLEGAL, K. M. \& TROIANO, R. P. Changes in the distribution of body mass index of adults and children in the US population. International Journal of Obesity, 24: 807-818, 2000.

FLEGAL, K. M. et al. Prevalence of overweight in US children: comparison of growth charts from the Center for Disease Control and Prevention with other reference values for body mass index. American Journal of Clinical Nutrition, 73: 1.086-1.093, 2001.

FUNG, K. P. et al. Properties and clinical implications of body mass indices. Archives of Disease Child, 65: 516$519,1990$.

GARN, S. M.; LEONARD, W. R. \& HAWTHOENE, V. M. Three limitation of body mass index. American Journal of Clinical Nutrition, 44: 996-997, 1986.

HAMILL, P. V. et al. Physical growth: National Center for Health Statistics percentiles. American Journal of Clinical Nutrition, 32: 607-629, 1979.

HEALD, E. P. The adolescent. In: JELLIFFE, D. B. \& JELLIFFE, E. F. P. Human Nutrition: a comprehensive treast. v. 2 - Nutrition and Growth. New York: Plenum Publishing Corp., 1979.

HIMES, J. H. \& DIETZ, W. H. Guidlines for overweight in adolescent preventive services: recomendation from an expert committee. American Journal of Clinical Nutrition, 59: 307-316, 1994. 
Epidemiologia Nutricional

HULENS, M. et al. Trends in BMI among Belgian children, adolescents and adults from 1969 to 1996. International Journal of Obesity, 25: 195-199, 2001.

HUNAG, Y. L. et al. What do college students eat? Food selection and meal patterns. Nutrition Research, 14(8): 1.143-1.153, 1994.

INSTITUTO BRASILEIRO DE GEOGRAFIA E ESTATÍSTICA (IBGE). Pesquisa de Orçamentos Familiares - POF 2002-2003. Antropometria e análise do estado nutricional de crianças e adolescentes no Brasil. 2006. Disponível em: http://www.ibge.gov.br>.

INSTITUTO NACIONAL DE ALIMENTAÇĀO NUTRIÇÃO (INAN). Perfil de Crescimento da População Brasileira de 0 a 25 Anos. Brasília: MS/Inan, 1990.

JOHNSON, C. L. et al. Basic Data on Anthropometric Measurements and Angular Measurements of the Hip and Knee Joints for Selected Age Groups 1-74 Years of Age. Washington: US Departament of Health and Human Services, National Center for Health Statistics, 1981. (Vital and Health Statistics Series, 11, Publication PHS 81-1669)

KAUTIAINEN, S. et al. Secular trends in overweight and obesity among Finnish adolescents in 19771999. International Journal of Obesity, 26: 544-552, 2002.

KUCZMARSKY, R. J. et al. CDC Growth Charts: United States advance data from vital and health statistics, $n$. 414. Hyattsville: National Centers for Health Statistics, 2000.

LAZARUS, R. et al. Adiposity and body mass indices in children: Benn's index and other weight for height indices as measures of relative adiposity. International Journal of Obesity, 20: 406-412, 1996.

LIMA, S. C. V. C. et al. Perfil lipêmico e peroxidação de lipídios no plasma em crianças e adolescentes com sobrepeso e obesidade. Jornal de Pediatria, 80: 23-28, 2004.

MAGALHÃES, V. C. \& MENDONÇA, G. A. S. Prevalência e fatores associados a sobrepeso e obesidade em adolescentes de 15 a 19 anos das regiōes Nordeste e Sudeste do Brasil, 1996 a 1997. Cadernos de Saúde Pública, 19: 129s-139s, 2003.

MAGAREY, A. M.; DANIELS, L. A. \& BOULTON, J. C. Prevalence of overweight and obesity in Australian children and adolescents: reassessment of 1985 and 1995 data against new standard international definitions. Medical Journal of Australia, 174: 561-564, 2001.

MALINA, R. M. \& KATZMARZYK, P. T. Validity of the body mass index as an indicator of the risk and presence of overweight in adolescents. American Journal of Clinical Nutrition, 70(1): 1.315-1.365, 1999.

MOLNÁR, D. The prevalence of the metabolic syndrome and type 2 diabetes mellitus in children and adolescents. International Journal of Obesity and Related Metabolism Disorder, 28: 570-574, 2004.

MORENO et al. Trends in body mass index and overweight prevalence among children and adolescents in the region of Aragón (Spain) from 1985 to 1995. International Journal of Obesity and Related and Metabolism Disorder, 24: 925-931, 2000.

MUST, A.; DALLAL, G. E. \& DIETZ, W. H. Reference data for obesity: 85 th and 95 th percentiles of body mass index $\left(\mathrm{wt} / \mathrm{ht}^{2}\right)$ and triceps skinfold thickness. American Journal of Clinical Nutrition, 53: 839-846, 1991.

NATIONAL CHOLESTEROL EDUCATION PROGRAM (NCEP). Executive Summary of the Third Report 
of the National Cholesterol Education Program. Expert panel on detection, evaluation, and treatment of high blood cholesterol in adults (Adult Tretment Panel III). Jama, 285: 2.486-2.497, 2001.

OGDEN, C. L. et al. Prevalence and trends in overweight among US children and adolescents, 19992000. The Journal of the American Medical Association, 288: 1.728-1.732, 2002.

OLIVEIRA, C. L.; VEIGA, G. V. \& SICHIERI, R. Anthropometric markers for cardiovascular disease among overweight adolescents. Nutrition Research, 21: 1.335-1.345, 2001.

PINHAS-HAMIEL, O. et al. Increase incidence of non-insulin-dependent diabetes mellitus among adolescents. The Journal of Pediatrics, 128: 608-615, 1996.

RIOS, M. et al. Prevalence of childhood overweight in Northwestern Spain: a comparative study of two periods with a ten year interval. International Journal of Obesity, 23: 1.095-1.098, 1999.

ROCHE, A. F. Anthropometric methods: new and old, what they tell us. International Journal of Obesity, 8: 509-523, 1984

RONNEMAA, T. et al. Serum insulin and other cardiovascular risk indicators in children, adolescents and young adults. Annals of Medicine, 23: 67-72, 1991.

SAITO, M. I. A avaliação nutricional na adolescência a escolha do referencial. Jornal de Pediatria, 69(3): 165175, 1993.

SICHIERI, R.; SIQUEIRA, K. S. \& MOURA, A. S. Obesity and abdominal fatness associated with undernutrition early in life in a survey in Rio de Janeiro. International Journal of Obesity: 24(5): 614-618, 2000.

SILVA, R. C. Q.; MIRANDA, W. L. \& CHACRA, A. R. Metabolic syndrome and insulin resistance in normal glucose tolerant Brazilian adolescents with family history of type 2 diabetes. Diabetes Care, 28: 716-718, 2005.

STEINBERGER, J. et al. Relationship between insulin resistance and abnormal profile in obese adolescents. The Journal of Pediatrics, 126: 690-695, 1995.

TANNER, J. M. Growth at Adolescence. 2. ed. Oxford: Blackwell Scientific Publications, 1962.

TEIXEIRA, P. J. et al. Total and regional fat and serum cardiovascular disease risk factors in lean and obese children and adolescents. Obesity Research, 9: 432-442, 2001.

THOMSEN, B. I.; EKSTROM, C. T. \& SORENSEN, T. I. A. Development of the obesity epidemic in Denmark: cohort, time and age effects among boys born 1930-1975. International Journal of Obesity, 23: 693-701, 1999.

TREMBLAY, M. S.; KATZMARZYK, P. T. \& WILLMS, J. D. Temporal trends in overweight and obesity in Canada, 1981-1996. International Journal of Obesity, 26: 538-543, 2002.

TROIANO, R. P. \& FLEGAL, K. M. Overweight children and adolescents: description, epidemiology, and demographics. Pediatrics, 101: 497-504, 1998.

VEIGA, G. V.; CUNHA, A. S. \& SICHIERI, R. Trends in overweight among adolescents living in the poorest and richest regions of Brazil. American Journal of Public Health, 94: 1.544-1.548, 2004.

VEIGA, G. V.; DIAS, P. C. \& ANJOS, L. A. Comparison of American and Brazilian BMI distribution curves in 
Epidemiologia Nutricional

the assessment of overweight and obesity in a sample of middle-class Brazilian adolescents. Revista Panamericana de Salud Pública, 10: 79-85, 2001.

VEIGA, G. V. et al. Índice de massa corporal na avaliação de sobrepeso e obesidade em crianças e adolescentes: concordâncias e controvérsias. Nutrire: Revista da Sociedade Brasileira de Alimentação e Nutrição, 28: 109-124, 2004.

VIEIRA, A. C. R. et al. Desempenho de pontos de corte do índice de massa corporal de diferentes referências na predição de gordura corporal em adolescentes. Cadernos de Saúde Pública, 22(8): 1.681-1.690, 2006.

WANG, Y. \& WANG, J. Q. Standard definition of child overweight and obesity worldwide. Britsh Medical Journal, 321: 1.158-1.159, 2000.

WANG, Y.; MONTEIRO, C. A. \& POPKIN, B. M. Trends of obesity and underweight in older children and adolescents in the United States, Brazil, China and Russia. American Journal of Clinical Nutrition, 75: 971977, 2002.

WATT, R. G. \& SHEIHAM, A. A dietary patterns and changes in nner city adolescent. Journal of Human Nutrition and Dietetics, 9(6): 451-461, 1996.

WEISS, R. et al. Obesity and the metabolic syndrome in children and adolescents. New England Journal of Medicine, 350: 2.362-2.374, 2004.

WORLD HEALTH ORGANIZATION (WHO). Physical Status: the use and interpretation of anthropometry. Geneva: WHO, 1995. (WHO Technical Report Series, 854)

WORLD HEALTH ORGANIZATION (WHO). Nutrition in Adolescence: issues and challenges for the health sector. Geneva: WHO, 2006. (WHO Discussion Papers on Adolescence)

ZAIDA, G. A criança, os comerciais de televisão e a cultura alimentar: uma análise crítica. Educação e Sociedade, 43: 505-521, 1992. 


\title{
5
}

\section{Antropometria como Método de Avaliação do Estado de Nutrição e Saúde do Adulto}

\author{
Márcia Gonçalves Ferreira e Rosely Sichieri
}

\begin{abstract}
A antropometria se destaca, entre os demais métodos utilizados para a avaliação nutricional de adultos, como um bom preditor das condiçôes de saúde, nutrição e sobrevida. Nos estudos populacionais, ressalta-se sua grande vantagem de possibilitar a aferição acurada de medidas das dimensões corporais de forma simples e a um baixo custo, uma vez que os instrumentos utilizados nas mensurações podem ser transportados com certa facilidade.

Apesar de sua simplicidade, a falta de padronização na avaliação antropométrica pode comprometer a qualidade dos dados pela introdução de erros sistemáticos e aleatórios relacionados ao avaliado, ao antropometrista e aos instrumentos utilizados na coleta das informaçōes. Portanto, assim como ocorre em outras áreas das ciências, a avaliação antropométrica deve ser realizada criteriosamente e utilizando técnicas de medição amplamente testadas.

A maioria dos métodos antropométricos usados na avaliação da composição corporal baseia-se em um modelo no qual o corpo é constituído por dois compartimentos quimicamente distintos: o compartimento de gordura e a massa livre de gordura (Gibson, 1990). As medidas antropométricas são avaliações realizadas diretamente no indivíduo, em algum ponto anatômico, ou na superfície corpórea como um todo. A combinação de medidas gera os índices antropométricos. Os indicadores, por sua vez, são construídos com base nos índices, relacionando-se ao seu uso e aplicação (WHO, 1995).
\end{abstract}

\section{Padronização na Coleta de Dados Antropométricos e Fontes de Erro na Mensuração}

A coleta de dados antropométricos exige a padronização da técnica de aferição dos antropometristas e dos instrumentos utilizados na avaliação.

\section{Padronização da Técnica de Aferição}

O pesquisador responsável deve disponibilizar para o trabalhador de campo um manual que contenha instruções detalhadas sobre todos os procedimentos que serão necessários, a fim de garantir a confiabilidade das medidas que estão sendo realizadas. Passos para aferição: a) As medições devem ser realizadas num ambiente o 
mais confortável possível para os sujeitos; b) A equipe de campo deve contar com o antropometrista e um assistente, que auxiliará na tomada das medidas, além de se encarregar das anotações dos dados; c) $\mathrm{O}$ avaliado deve manter-se de pé, com o corpo relaxado, braços ao longo do corpo, pés levemente separados; d) Deve-se solicitar ao indivíduo que fique com o mínimo de roupa possível (ex.: trajes de banho) e sem sapatos; e) $\mathrm{O}$ avaliado não deve usar qualquer penteado ou adorno na cabeça (rabo de cavalo, coque, boné, arco ou outros acessórios); f) O indivíduo não deve estar usando relógios, correntes, pochetes, cintos ou portar telefone celular; g) Os resultados das mediçôes devem ser anotados imediatamente após sua obtenção, para evitar erros de registro dos dados. Instruções detalhadas sobre aferição de medidas antropométricas estão disponíveis no manual de Lohman, Roche e Martorell (1988).

\section{Padronização dos Antropometristas}

No treinamento do antropometrista deverão ser incluídas noções sobre a anatomia básica do corpo humano, uma vez que as marcações e medições são feitas com base na identificação de sítios anatômicos específicos. A falta de uniformidade nos procedimentos é uma das principais causas de viés na coleta de dados antropométricos.

A validade dos dados coletados depende, segundo Habicth (1974), da precisão e exatidão conseguidas pelo antropometrista durante as medições. A precisão é a capacidade do antropometrista de obter o mesmo valor cada vez que realiza a medida antropométrica no mesmo indivíduo. Essa capacidade depende do treinamento, e para algumas medidas, a exemplo da aferição de dobras cutâneas, o processo pode ser demorado. A exatidão se refere à habilidade do antropometrista em se aproximar o máximo possível da medida real do indivíduo que está sendo avaliado.

Para identificar em que momento o treinamento se encontra em nível satisfatório, Habicth (1974) propôs uma técnica relativamente simples. Elege-se um indivíduo que será o padrão-ouro (geralmente é o supervisor). Em seguida, supervisor e treinandos registrarão medidas repetidas dos mesmos indivíduos (pelo menos dez pessoas). As medidas em diferentes locais devem ser feitas em série, para evitar que a segunda medição seja influenciada pela primeira. Os antropometristas que estão sendo treinados não devem ter acesso aos resultados obtidos pelo padrão-ouro. Os dados obtidos são registrados em folhas separadas, cujos valores serão comparados quanto à precisão e exatidão. Após treinamento, a preocupação inicial é com a precisão das medidas dos antropometristas. É mais fácil o treinando concordar com ele mesmo em medidas repetidas do que atingir o valor obtido pelo padrão-ouro (confiabilidade entre e intra-antropometrista).

A padronização proposta por Habicth (1974) consiste no seguinte procedimento: cada treinando repete a medida duas vezes para dez observaçôes diferentes, e a soma dos quadrados das diferenças para o mesmo antropometrista define a confiabilidade intra-individual (o autor chamou esta aferição de precisão), ao passo que a soma dos quadrados das diferenças entre dois antropometristas para a mesma observação define a confiabilidade entre indivíduos (o autor chamou esta aferição de exatidão). Quando um antropometrista atinge uma confiabilidade intra-individual menor do que duas vezes a confiabilidade intra-individual do supervisor, ele é considerado preciso; quando ele apresenta uma confiabilidade entre indivíduos menor do que três vezes a confiabilidade intra-individual do supervisor, o treinando é considerado padronizado. Os dados podem ser dispostos na folha de cálculo como:

$\mathrm{a}=$ primeira medição

$\mathrm{b}=$ segunda medição

$\mathrm{d}=\mathrm{a}-\mathrm{b}$

$\mathrm{d}^{2}=$ é a precisão - obtida pela soma das diferenças entre a primeira e a segunda medições elevadas ao quadrado 
$s=$ soma de $\mathrm{a}+\mathrm{b}$ do examinador

$\mathrm{S}=$ soma de $\mathrm{a}+\mathrm{b}$ do supervisor

$\mathrm{D}=s-\mathrm{S}$

$\mathrm{D}^{2}$ = é a exatidão - cada par de medidas é somado, sendo calculadas as diferenças das somas entre o avaliador em treinamento e o supervisor (padrão-ouro). As diferenças são elevadas ao quadrado e seu somatório calculado

Os resultados são analisados dentro dos seguintes critérios:

1) O somatório de $\mathrm{d}^{2}$ do supervisor será o menor, supondo-se que ele seja o mais competente dos antropometristas.

2) O somatório do avaliador em treinamento tem relação inversa com a precisão, e assim não deve exceder o dobro do somatório de $\mathrm{d}^{2}$ do supervisor.

3) O somatório de $\mathrm{D}^{2}$ tem relação inversa com a exatidão, não devendo exceder o triplo de somatório de $\mathrm{d}^{2}$ do supervisor.

Figura 1 - Folha de cálculo para teste de padronização

Nome do examinador:

Data:

Medida:

\begin{tabular}{|c|c|c|c|c|c|c|c|c|}
\hline \multicolumn{5}{|c|}{ Precisão } & \multicolumn{4}{|c|}{ Exatidão } \\
\hline Individual & $\mathrm{a}$ & b & d & $d^{2}$ & $\mathrm{~s}$ & $S$ & $\mathrm{D}$ & $\mathrm{D}^{2}$ \\
\hline 1 & & & & & & & & \\
\hline 2 & & & & & & & & \\
\hline 3 & & & & & & & & \\
\hline 4 & & & & & & & & \\
\hline 5 & & & & & & & & \\
\hline 6 & & & & & & & & \\
\hline 7 & & & & & & & & \\
\hline 8 & & & & & & & & \\
\hline 9 & & & & & & & & \\
\hline 10 & & & & & & & & \\
\hline Somas & & & & & & & & \\
\hline
\end{tabular}

Fonte: adaptada de Habicth (1974).

\section{Padronização dos Instrumentos}

Todos os instrumentos utilizados na avaliação antropométrica devem ser padronizados e regularmente calibrados. A correta aferição de medidas antropométricas depende da integridade e do bom funcionamento dos 
equipamentos utilizados. A manutenção dos instrumentos contribui em muito para a qualidade das medidas obtidas e deve ser feita por órgãos competentes ou firmas autorizadas.

\section{Fontes de Erro na Mensuração de Medidas Antropométricas}

A presença de erros na mensuração das medidas pode ocorrer em função de:

1) Erro introduzido pelo antropometrista: esta variabilidade pode ocorrer pela falta de treinamento, pelo manejo inadequado dos instrumentos de medida e por erros de leitura e registro dos dados.

2) Erro devido ao avaliado: são variações nas medidas que se referem à variabilidade biológica e a outras características intrínsecas do indivíduo. Ex.: variações de peso e estatura em diferentes períodos do dia, presença de edema etc.

3) Erro devido ao instrumento: instrumentos mal calibrados ou defeituosos contribuem para a variabilidade nas medidas.

Há também o erro intrínseco a uma medida, como é o caso da grande variabilidade observada na aferição de dobras cutâneas (Gibson, 1990). Mensurar dobras cutâneas é uma tarefa difícil, que exige treinamento intenso e paciência do avaliador.

Todos esses erros podem ser minimizados pelo treinamento e checagem dos antropometristas, padronização de técnicas e refinamento dos instrumentos (Lohman, Roche \& Martorell, 1988). A realização de mais de uma medida, adotando-se a média como valor final (média de duas ou mais leituras, dependendo da variabilidade da medida), é uma estratégia que contribui substancialmente para a melhoria da precisão, uma vez que o impacto do erro aleatório é reduzido pela repetição.

\section{Principais Medidas Antropométricas Utilizadas na Avaliação de Adultos}

\section{Peso}

O peso representa a somatória de todos os componentes corpóreos, refletindo a massa corporal total. Raras vezes é utilizado isoladamente nas avaliações de adultos, sendo mais freqüentemente combinado à estatura. O peso corporal é uma das medidas biológicas que se obtêm com maior precisão em estudos epidemiológicos, possuindo alto grau de reprodutibilidade. No entanto, a medida pode ser afetada por alterações na hidratação e pela ingestão alimentar recente (Willett, 1998). O peso de adultos pode variar até cerca de $2 \mathrm{~kg}$, durante o dia (Gordon, Chumlea \& Roche, 1988). Os valores mais estáveis são os obtidos regularmente pela manhã, após 12 horas de jejum e com a bexiga vazia. Como nem sempre é possível padronizar o tempo da avaliação, é importante registrar a hora do dia em que foi realizada. Valores para o peso podem ser obtidos por meio de balanças mecânicas ou digitais portáteis, que tenham precisão de aproximadamente cem gramas. Como a medida é pouco variável, recomenda-se uma única mensuração. Antes da pesagem, o antropometrista deverá certificar-se de que a balança está tarada. A medida deve ser tomada estando o avaliado com o corpo ereto e a cabeça erguida, com o peso distribuído igualmente nos dois pés, os braços estendidos ao longo do corpo. A manutenção periódica das balanças é essencial, assim como sua calibração.

O peso referido tem sido utilizado em alguns estudos epidemiológicos. Geralmente, há uma boa concordância entre o peso medido e o peso informado. Nos Estados Unidos, a correlação observada entre o peso referido e o peso aferido para adultos de ambos os sexos pode chegar a 0,99 (Willett, 1998). Palta e colaboradores 
(1982) observaram uma concordância elevada entre peso referido e a medida direta obtida de americanos adultos, havendo maior freqüência de subestimação entre as mulheres. Na população japonesa, também têm sido evidenciadas altas correlaçóes entre peso e estatura informados, comparados aos aferidos, em ambos os sexos (Wada et al., 2005). No Brasil, estudo realizado por Fonseca e colaboradores (2004) também mostrou uma alta associação entre o peso informado e o peso aferido em homens e mulheres (coeficiente de correlação intraclasse = 0,977), tendo sido observada uma leve subestimação em ambos os sexos.

\section{Estatura}

A estatura é o maior indicador da superfície corporal total e do comprimento dos ossos, exercendo uma importante influência sobre o peso corporal (Gordon, Chumlea \& Roche, 1988). A estatura final de um indivíduo sofre a influência de fatores genéticos e ambientais. Em países onde a desnutrição é um problema de saúde pública, a estatura é um poderoso indicador de deficiência nutricional (Sichieri, Pereira \& Ascheiro, 2000).

Em estudos epidemiológicos, é um indicador particularmente útil porque pode refletir a influência da dieta pregressa, que dificilmente pode ser avaliada de outra forma (Willett, 1998). A estatura sentada tem sido utilizada em estudos epidemiológicos como marcador de desnutrição pregressa e de risco de obesidade na idade adulta (Velásquez-Meléndez et al., 2005).

Assim como o peso, a estatura de adultos também pode variar durante o dia. Geralmente, valores maiores de estatura são obtidos pela manhã, podendo haver redução da medida em até $1 \%$ durante o transcurso do dia (Norton et al., 2000). A medida da estatura é mais variável do que a medida do peso, por isso recomenda-se a realização de pelo menos duas mensurações, adotando-se a média como valor final. Quando a diferença entre as duas aferiçōes for superior a $0,5 \mathrm{~cm}$, as duas medidas devem ser refeitas.

O estadiômetro é o instrumento utilizado para aferir estatura. Durante a medição, o indivíduo deverá ser posicionado de forma ereta, a cabeça deverá estar erguida, com os olhos mirando um plano horizontal à frente, de acordo com o plano horizontal de Frankfurt, com a coluna vertebral e calcanhares encostados na parede sem rodapé ou porta, joelhos esticados, pés juntos e braços estendidos ao longo do corpo.

A estatura referida também tem sido utilizada em estudos epidemiológicos envolvendo adultos. Em geral, a concordância entre estatura aferida e informada também é elevada, porém menor do que a encontrada para o peso, segundo estudos realizados em diversas partes do mundo, inclusive no Brasil (Willett, 1998; Fonseca et al., 2004). É mais comum notar-se superestimação para a estatura informada, principalmente entre homens.

\section{Dobras Cutâneas}

A medida de dobras cutâneas (ou pregas cutâneas) é um procedimento muito utilizado para estimar a gordura corporal subcutânea. No entanto, apresenta limitações como: 1) O tecido subcutâneo não é uniformemente distribuído pelo corpo, e, por isso, faz-se necessário tomar mais de um sítio na avaliação; 2) Nem todos os depósitos de gordura corporal podem ser acessados pelo adipômetro (ex.: gordura intra-abdominal e intramuscular); 3) A reprodutibilidade de medidas de dobras cutâneas é a menor dentre a de todas as medidas antropométricas. Em indivíduos muito magros e em obesos, a acurácia da medida é ainda mais prejudicada (Willett, 1998; Norton et al., 2000). A padronização dos antropometristas utilizando o método proposto por Habicht (1974) pode ser de difícil aplicação, pois uma ou poucas medidas muito discrepantes têm uma influência muito grande nas medidas de concordância. Sichieri, Fonseca e Lopes (1999) mostraram que o coeficiente de correlação intraclasse pode ser mais adequado para a padronização dos antropometristas na mensuração das dobras cutâneas.

O treinamento exigido para que o indivíduo se torne um bom avaliador de dobras cutâneas é intenso. $\mathrm{O}$ avaliador precisa adquirir habilidade suficiente para detectar exatamente a porção de tecido que deve ser 
pinçada. É importante certificar-se de que somente a pele e o tecido adiposo subcutâneo estão sendo pinçados, e de que o tecido muscular subjacente não está sendo pressionado. Se houver dificuldade na aferição, deve-se solicitar ao avaliado que faça contração do músculo para facilitar a separação dos tecidos. Adicionalmente, a localização incorreta dos sítios representa importante fonte de erro. A utilização de marcas sobre a pele, que podem ser feitas com o auxílio de uma caneta demográfica nos pontos anatômicos a serem avaliados, reduz esse erro.

Dada a grande variabilidade da medida de dobras cutâneas, recomenda-se que o procedimento de aferição de cada sítio seja feito por três vezes, considerando-se a média obtida nas mensurações como valor final. Se a diferença entre pelo menos duas medidas for maior que $1 \mathrm{~mm}$, deve-se desprezar as medidas e repeti-las. $\mathrm{O}$ antropometrista deve ser treinado para efetuar as avaliações de sítios diferentes em série, e de forma sucessiva, ou seja, primeiramente ele deve completar toda a primeira série de avaliaçōes, depois realizar a segunda série completa, passando em seguida à terceira. Trata-se de uma estratégia para evitar o erro sistemático.

As dobras cutâneas mais comumente avaliadas são: a tricipital, a bicipital, a subescapular e a suprailíaca. As duas primeiras são mais usadas para representar a distribuição periférica da gordura, ao passo que as duas últimas geralmente representam depósitos centrais da gordura corporal (Willett, 1998). A somatória de dobras cutâneas (quatro sítios) pode também ser utilizada para estimar a densidade corporal. Para calculá-la, pode-se utilizar as equações de regressão que serão discutidas no capítulo 8 , "Composição corporal na avaliação do estado nutricional".

Procedimentos a serem observados na aferição das dobras cutâneas em quatro sítios específicos (Harrison et al., 1988; Norton et al., 2000):

a) Dobra cutânea tricipital: solicitar que o indivíduo flexione o braço em direção ao tórax, formando um ângulo de $90^{\circ}$. Com auxílio de uma fita apropriada, determinar o ponto médio do braço, marcando-o com a caneta demográfica. $\mathrm{O}$ ponto médio do braço está localizado entre a projeção lateral do processo acromial da escápula e a margem inferior do olécrano da ulna. Solicitar que o indivíduo fique com o braço estendido ao longo do corpo, com a palma da mão voltada para a coxa. Esta prega se toma com o polegar e o dedo indicador esquerdos, na marca do ponto médio, na superfície mais posterior do braço, sobre o tríceps. O local marcado deverá poder ser visto de costas, indicando que é o ponto mais posterior do tríceps. O avaliador, suavemente, pega uma dobra de pele e tecido subcutâneo entre os dedos e o polegar, aproximadamente $1 \mathrm{~cm}$ abaixo do nível marcado, pinçando a pele e o tecido adiposo subcutâneo.

b) Dobra cutânea bicipital: esta prega se toma com o polegar e o indicador esquerdos, na marca sobre a linha média, verticalmente ao eixo longitudinal do braço, na sua parte mais anterior, sobre o bíceps. O avaliado deve estar com o braço relaxado e a articulação do ombro com uma leve rotação externa.

c) Dobra cutânea subescapular: solicitar ao indivíduo que fique de pé, com os braços estendidos ao longo do corpo. Tocar com o polegar esquerdo o ângulo inferior da omoplata para determinar o ponto inferior mais protuberante. Quando for difícil identificar esse ponto, solicitar que o indivíduo leve o braço flexionado para trás. Dois centímetros abaixo deste ponto, tomar a prega com o polegar e o indicador esquerdos no local marcado, em uma direção que se desloca lateralmente e em forma oblíqua para baixo, a partir da marca subescapular, em um ângulo (de aproximadamente $45^{\circ}$ ), determinado pelas linhas naturais da prega e da pele.

d) Dobra cutânea suprailíaca: esta prega se toma imediatamente acima da crista ilíaca, na estatura da linha ilioaxilar, obliquamente. Solicitar ao avaliado uma leve abdução dos braços, ou que cruze o braço acima do peito e coloque a mão direita sobre o ombro esquerdo. Alinhar os dedos da mão esquerda sobre a crista ilíaca, pressionando para dentro de maneira que os dedos se movam sobre a 
crista ilíaca. Substituir os dedos pelo polegar esquerdo e posicionar o dedo indicador a uma distância suficiente por cima do polegar, de modo que esta posição constituirá a dobra a ser medida.

\section{Circunferências ou Perímetros}

Embora o termo mais adequado para referir a medida seja perímetro, estas medidas são normalmente denominadas circunferências. Medidas de circunferências têm sido utilizadas principalmente para a avaliação do padrão de distribuição da gordura corporal de adultos. As circunferências da cintura e do quadril são as mais usadas para esse fim, sendo a cintura avaliada isoladamente ou em combinação com a circunferência do quadril, pela determinação de uma razão entre elas, comumente denominada Razão Cintura/Quadril ou Relação Cintura/ Quadril (RCQ).

A reprodutibilidade da medida de circunferências é maior do que a observada para as dobras cutâneas. O instrumento usado na medição é uma trena ou fita flexível, inelástica, com cerca de $0,7 \mathrm{~cm}$ de largura (Callaway et al., 1988). O posicionamento inadequado da fita e diferenças na tensão aplicada por diferentes avaliadores são as principais causas de baixa reprodutibilidade da medida. A fita deve ser colocada firmemente em torno do sítio a ser medido, porém sem comprimir o tecido adiposo subcutâneo. A tensão da fita sobre o local a ser medido deve ser constante, não devendo haver folgas entre a pele e a fita.

Erros de medida também podem ocorrer se as aferições de circunferências do tronco forem feitas em diferentes fases da respiração. Circunferências devem ser aferidas duas vezes e considerada a média das avaliações. Existem limites aceitáveis para diferenças entre medidas repetidas em indivíduos saudáveis. No caso das circunferências da cintura e do quadril, essa diferença não deve ser maior que $1 \mathrm{~cm}$ (Callaway et al., 1988). Se essa diferença é excedida em duas medições de um mesmo avaliador ou entre avaliadores, as medidas devem ser repetidas. Os procedimentos a serem observados nas aferições são:

a) Circunferência da cintura: pode ser aferida em quatro sítios anatômicos diferentes, e todos eles apresentam reprodutibilidade elevada (Wang et al., 2003). No entanto, a circunferência da cintura medida no nível da menor curvatura abdominal (na altura da cintura natural) parece estar mais associada com a adiposidade visceral, avaliada por tomografia computadorizada (Lean, Han \& Morrisson, 1995; Clasey et al., 1999). Deve-se ressaltar que o local de aferição é fundamental para definir os pontos de corte de normalidade. A medida deve ser tomada obedecendo-se aos seguintes procedimentos: o sítio a ser avaliado deve estar livre de roupas. Deve-se solicitar ao indivíduo que mantenha os pés juntos, os braços estendidos e levemente afastados do corpo, e o abdome relaxado. $\mathrm{O}$ avaliador deve posicionar-se de frente para o avaliado e localizar a menor curvatura abdominal, circundando-a com a fita. A medida não deve ser obtida de frente, mas sim em uma posição mais lateral à direita. No momento da mensuração, é interessante que o antropometrista conte com o auxílio de um assistente para garantir o posicionamento correto da fita. Na ausência do assistente, pode-se utilizar um espelho para certificar-se de que a fita está bem posicionada, sem provocar compressão do tecido subcutâneo, nem desnivelá-la. Deve-se pedir ao indivíduo que inspire e, em seguida, expire totalmente. A medida deve ser feita neste momento, ao final da expiração. A leitura será realizada no $0,1 \mathrm{~cm}$ mais próximo, onde o valor da medida cruza a marca zero da fita.

b) Circunferência do quadril: reflete a quantidade de tecido adiposo da região pélvica. Em combinação com a circunferência da cintura, constitui um bom marcador da gordura visceral (RCQ). O indivíduo deverá estar usando apenas a roupa íntima durante a medição. A medida deve ser aferida no nível da extensão máxima das nádegas, onde se encontra a maior protuberância dos músculos glúteos. Este ponto geralmente coincide com a sínfise púbica. Para a tomada da medida, o 
antropometrista deverá ficar de joelhos, de forma a ter uma visão lateral e ampla da região das nádegas. A fita deverá ser colocada ao redor do quadril, em seu maior diâmetro. Deve-se solicitar ao indivíduo que permaneça em pé, ereto, com os braços levemente afastados do corpo e os pés juntos. Os glúteos devem estar relaxados, não contraídos. O antropometrista deve contar com o auxílio de um assistente ou utilizar um espelho. O procedimento para a leitura é o mesmo descrito para a circunferência da cintura.

\section{Principais Índices Utilizados na Avaliação Antropométrica de Adultos}

\section{Avaliação da Adiposidade Total}

O Índice de Massa Corporal (IMC - peso em quilogramas e estatura em metros quadrados) continua sendo o índice mais utilizado para avaliar a gordura total em estudos epidemiológicos.

Vários estudos têm mostrado a utilidade do IMC como marcador de risco de morbidade e mortalidade. O poder preditivo do IMC pode ser comprovado por meio de estudos de revisão sistemática e de metanálise, baseados principalmente em estudos de coortes prospectivas (Whitlock, Lewington \& Mhurchu, 2002; Zhou, 2002). A curva de morbidade e mortalidade associada ao IMC tem sido descrita como em formato 'J ou U'. O menor risco ocorre para valores de IMC entre 20 e $30 \mathrm{~kg} / \mathrm{m}^{2}$, embora haja variaçôes importantes segundo a idade, raça e sexo (Paeratakul et al., 2002; Fontaine et al., 2003; Flegal et al., 2005).

Os pontos de corte para o IMC utilizados como referência são aqueles preconizados pela Organização Mundial da Saúde (OMS) e apresentados na Tabela 1.

Tabela 1 - Classificação do estado nutricional de adultos de acordo com o Índice de Massa Corporal (IMC)

\begin{tabular}{ll}
\hline Classificação & $\mid M C\left(\mathrm{~kg} / \mathrm{m}^{2}\right)$ \\
\hline Baixo peso & $<18,5$ \\
\hline Normal & $18,5-24,9$ \\
\hline Sobrepeso & $25,0-29,9$ \\
\hline Obesidade grau I & $30,0-34,9$ \\
\hline Obesidade grau II & $35,0-39,9$ \\
\hline Obesidade grau III & $>40,0$ \\
\hline
\end{tabular}

Fonte: WHO (1998).

\section{Avaliação do Padrão de Distribuição da Gordura Corporal}

Nas últimas décadas, considerável atenção tem sido dada ao papel exercido pelo padrão de distribuição da gordura corporal na morbidade e mortalidade, independentemente da adiposidade total. As diferenças na localização da gordura corporal são marcadas, principalmente, por características relacionadas ao sexo: o homem tende a um maior acúmulo de gordura na região abdominal, ao passo que a mulher concentra maior quantidade de 
tecido adiposo na região glútea (Vague, 1956). A localização abdominal da gordura é mais importante do que a massa total de tecido adiposo para o desenvolvimento de várias doenças e será discutida no capítulo 22, "Aspectos epidemiológicos e nutricionais da síndrome metabólica”.

Não há consenso com relação ao marcador antropométrico mais confiável para avaliar depósitos abdominais de gordura. A circunferência da cintura tem sido mais utilizada por sua maior praticidade. Em populações caucasianas, essa medida, isoladamente, parece ser a mais efetiva na avaliação do risco de desenvolvimento de doenças crônicas não transmissíveis. Contudo, em muitos estudos em que a cintura foi considerada o melhor preditor de risco, o efeito da adiposidade total não foi removido. Essa condição é essencial, dada a elevada correlação existente entre indicadores de adiposidade total (IMC, percentual de gordura) e cintura.

No Brasil, alguns estudos que avaliaram desfechos diferentes vêm mostrando a superioridade da RCQ em relação à cintura como marcador da gordura abdominal. A primeira pesquisa brasileira a mostrar tais evidências foi um estudo transversal, de base populacional, realizado na população adulta da cidade do Rio de Janeiro (Pereira, Sichieri \& Marins, 1999). Os resultados revelaram uma elevada correlação da cintura com o IMC, e a RCQ foi mais eficiente na predição da hipertensão arterial. Um outro estudo realizado no Rio de Janeiro, entre adolescentes com sobrepeso, analisou o papel de marcadores antropométricos no risco cardiovascular, encontrando resultados semelhantes para a correlação entre IMC e cintura. A RCQ foi melhor preditor de High Density Lippoprotein (HDL) e da relação colesterol total/HDL entre os adolescentes (Oliveira, Veiga \& Sichieri, 2001).

Em Salvador, Pitanga e Lessa (2005) evidenciaram a maior eficácia da RCQ para discriminar o risco coronariano elevado. Um outro estudo brasileiro conduzido por Lemos-Santos e colaboradores (2004) analisou o poder preditivo da cintura e da relação cintura/quadril nas dislipidemias em estudo transversal de doadores de sangue. Potenciais fatores de confusão foram controlados, inclusive a adiposidade total representada pelo percentual de gordura corporal ou pelo IMC, em modelos separados. O percentual de gordura corporal mostrou-se mais eficiente que o IMC na remoção do efeito da adiposidade total. As correlações entre índices de adiposidade total e de localização de gordura foram maiores entre indivíduos mais jovens (20-30 anos) quando comparados aos mais velhos (31-59 anos). A RCQ mostrou-se mais independente da adiposidade total, uma vez que as correlaçôes observadas foram menores (em torno de 0,50 para os mais jovens e 0,40 para os mais velhos). As correlações entre IMC e percentual de gordura com a cintura variaram em torno de 0,90 para os mais jovens e 0,83 para os mais velhos. Os resultados mostraram que apenas a RCQ foi preditora da relação colesterol/HDL elevada, e que a cintura mostrou-se um bom marcador de hipertrigliceridemia.

Vale ressaltar que muitos estudos que elegeram a cintura como melhor marcador antropométrico de risco, especialmente do risco cardiovascular, não controlaram outros importantes confundidores dessa associação, tais como o tabagismo, o consumo de álcool e a prática de atividade física. Isso poderia explicar, pelo menos em parte, algumas das controvérsias da literatura.

Apesar das divergências, continuam sendo utilizados como referência os pontos de corte preconizados pela OMS para a cintura e relação cintura/quadril (WHO, 1998).

\section{Limitações da Avaliação Antropométrica}

A principal limitação do IMC está relacionada ao fato de não separar os compartimentos de gordura e massa magra. Esta restrição dificulta a sua utilização como marcador de adiposidade individual, porém, em populações, o IMC pode ser considerado um bom marcador de adiposidade total. Uma outra limitação do IMC é a sua incapacidade de detectar o aumento percentual da gordura corporal que ocorre com o avanço da idade (WHO, 1995), embora tal aumento aconteça em fases iniciais do processo do envelhecimento, havendo uma ligeira redução em idades muito avançadas (ZHU et al., 2003). 
A maior dificuldade para a identificação dos melhores marcadores antropométricos e seus respectivos pontos de corte reside nas diferenças observadas na composição corporal das populações. O IMC e a circunferência da cintura parecem ser bons preditores de risco em populações caucasianas. No entanto, para outras populaçôes que diferem com relação às proporçôes corporais e à constituição física, tanto o IMC quanto a cintura podem não ser tão apropriados (WHO, 1998), o que dificulta o desenvolvimento de pontos de corte universais para os indicadores de distribuição de gordura (WHO, 1995).

Os resultados de investigações conduzidas nos últimos anos em amostras populacionais de países asiáticos constituem um bom exemplo da limitação do uso de padrões de referência baseados em medidas antropométricas obtidas de caucasianos. Chineses, japoneses e outras populaçóes asiáticas vêm apresentando elevado percentual de gordura corporal para um IMC relativamente baixo. Metanálise realizada por Deurenberg, Yap e Staveren (1998) confirma essa evidência. Corroborando esses achados, Zhou (2002), em seu estudo de metanálise, demonstrou que os pontos de corte apropriados para identificar sobrepeso e obesidade em chineses adultos são 2427,9 e $28 \mathrm{~kg} / \mathrm{m}^{2}$, respectivamente. Da mesma forma, os pontos de corte para indicadores da centralização de gordura associados a maior risco de morbidade entre esses indivíduos vêm se mostrando menores do que aqueles preconizados pela OMS (Deurenberg-Yap, Chew \& Deurenberg, 2002; Lin et al., 2002; Zhou, 2002; Ito et al., 2003).

Os pontos de corte para marcadores antropométricos identificados em estudos brasileiros são menores do que os preconizados pela OMS, pelo menos com relação aos indicadores de localização de gordura. Na Tabela 2 são apresentados alguns desses resultados.

Tabela 2 - Melhores pontos de corte para a circunferência da cintura e Relação Cintura/Quadril (RCQ) identificados em estudos brasileiros

\begin{tabular}{|c|c|c|c|c|}
\hline Fonte & Sujeitos & Desfecho & $\begin{array}{c}\text { Marcador de } \\
\text { localização de gordura }\end{array}$ & Ponto de corte \\
\hline \multirow{2}{*}{ Pereira, Sichieri \& Marins (1999) } & 1.414 homens & \multirow{2}{*}{ Hipertensão arterial } & \multirow{2}{*}{$R C Q$} & $0,90-0,95$ \\
\hline & 1.868 mulheres & & & $0,80-0,85$ \\
\hline \multirow{4}{*}{ Pitanga \& Lessa (2005) } & \multirow{2}{*}{391 homens } & \multirow{4}{*}{$\begin{array}{l}\text { Risco coronariano } \\
\text { elevado }\end{array}$} & Cintura & $88 \mathrm{~cm}$ \\
\hline & & & $R C Q$ & 0,92 \\
\hline & \multirow{2}{*}{577 mulheres } & & Cintura & $83 \mathrm{~cm}$ \\
\hline & & & $R C Q$ & 0,83 \\
\hline \multirow{3}{*}{ Ferreira et al. (2006) } & \multirow{3}{*}{1.235 homens } & \multirow{2}{*}{ Hipertrigliceridemia } & Cintura & $85 \mathrm{~cm}$ \\
\hline & & & $R C Q$ & 0,90 \\
\hline & & $\begin{array}{c}\text { Relação colesterol/ } \\
\text { HDL elevada }\end{array}$ & $R C Q$ & 0,89 \\
\hline
\end{tabular}

\section{Referências}

CALLAWAY, C. W. et al. Anthropometric Standardization Reference Manual. Champaign: Human Kinetics Books, 1988.

CLASEY, J. L. et al. The use of anthropometric and Dual-energy X-ray Absorptiometry (DXA) measures to estimate total abdominal and abdominal visceral fat in men and women. Obesity Research, 7(3): 256-264, 1999. 
DEURENBERG-YAP, M.; CHEW, S. K. \& DEURENBERG, P. Elevated body fat percentage and cardiovascular risks at low body mass index levels among Singaporean Chinese, Malays and Indians. Obesity Reviews, 3 : 209-215, 2002.

DEURENBERG, P.; YAP, M. \& VAN STAVEREN, W. A. Body mass index and percent body fat: a meta analysis among different ethnic groups. International Journal of Obesity and Related Metabolic Disorders, 22(12): 1.164-1.171, 1998

FERREIRA, M. G. et al. Acurácia da circunferência da cintura e da relação cintura/quadril como preditores de dislipidemias em estudo transversal de doadores de sangue de Cuiabá, Mato Grosso, Brasil. Cadernos de Saúde Pública, 22(2): 307-314, 2006.

FLEGAL, K. M. et al. Excess deaths associated with underweight, overweight, and obesity. The Journal of the American Medical Association, 293(15): 1.861-1.867, 2005.

FONSECA, M. J. M. et al. Validade de peso e estatura informados e índice de massa corporal: estudo pró-saúde. Revista de Saúde Pública, 38(3): 392-398, 2004.

FONTAINE, K. R. et al. Years of life lost due to obesity. The Journal of the American Medical Association, 289(2): 187-193, 2003.

GIBSON, R. S. Principles of Nutritional Assessment. New York: Oxford University Press, 1990.

GORDON, C. C.; CHUMLEA, W. C. \& ROCHE, A. F. Stature, recumbent length, and weight. In: LOHMAN, T. G.; ROCHE, A. F. \& MARTORELL, R. Anthropometric Standardization Reference Manual. Champaign: Human Kinetics Books, 1988.

HABICHT, J. P. Estandarización de métodos epidemiológicos cuantitativos sobre el terreno. Boletín de la Oficina Sanitaria Panamericana, 76(5): 375-384, 1974.

HARRISON, G. G. et al. Skinfold thicknesses and measurement technique. In: LOHMAN, T. G.; ROCHE, A. F. \& MORTORELL, R. Anthropometric Standardization Reference Manual. Champaingn: Human Kinetics Books, 1988.

ITO, H. et al. Detection of cardiovascular risk factors by indices of obesity obtained from anthropometry and dual-energy X-ray absorptiometry in Japanese individuals. International Journal of Obesity, 27: 232-237, 2003.

LEAN, M. E.; HAN, T. S. \& MORRISON, C. E. Waist circumference as a measure for indicating need for weight management. British Medical Journal, 311: 158-161, 1995.

LEMOS-SANTOS, M. G. F. et al. Waist circumference and waist-to-hip ratio as predictors of serum concentration of lipids in Brazilian men. Nutrition, 20: 857-862, 2004.

LIN, W. Y. et al. Optimal cut-off values for obesity: using simple anthropometric indices to predict cardiovascular risk factors in Taiwan. International Journal of Obesity, 26: 1.232-1.238, 2002.

LOHMAN, T. G.; ROCHE, A. F. \& MARTORELL, R. Anthropometric Standardization Reference Manual. Champaign: Human Kinetics Books, 1988.

NORTON, K. et al. Técnicas de medición en antropometría. In: MAZZA, J. C. Antropométrica. Rosario: Biosystem Servicio Educativo, 2002. 
OLIVEIRA, C. L.; VEIGA, G. V. \& SICHIERI, R. Anthropometric markers for cardiovascular disease risk factors among overweight adolescents. Nutrition Research, 21: 1.335-1.345, 2001.

PAERATAKUL, $S$. et al. The relation of gender, race and socioeconomic status to obesity and obesity comorbidities in a sample of US adults. International Journal of Obesity, 26: 1.205-1.210, 2002.

PALTA, M. et al. Comparison of self-reported and measured height and weight. American Journal of Epidemiology, 115(2): 223-230, 1982.

PEREIRA, R. A.; SICHIERI, R. \& MARINS, V. M. R. Razão cintura/quadril como preditor de hipertensão arterial. Cadernos de Saúde Pública, 15(2): 333-344, 1999.

PITANGA, F. J. G. \& LESSA, I. Indicadores antropométricos de obesidade como instrumento de triagem para risco coronariano elevado em adultos na cidade de Salvador, Bahia. Arquivos Brasileiros de Cardiologia, 85: 26-31, 2005.

SICHIERI, R.; FONSECA, V. M. \& LOPES, C. S. Como medir a confiabilidade de dobras cutâneas. Revista Brasileira de Epidemiologia, 2: 82-89, 1999.

SICHIERI, R.; PEREIRA, R. A. \& ASCHEIRO, A. Short stature and hypertension in the city of Rio de Janeiro, Brazil. Public Health Nutrition, 3(1): 77-82, 2000.

VAGUE, J. The degree of masculine differentiation of obesities: a factor determining predisposition to diabetes, atherosclerosis, gout, and uric calculous disease. American Journal of Clinical Nutrition, 4(1): 20-34, 1956.

VELÁSQUEZ-MELÉNDEZ, G. et al. Relationship between sitting-height-to stature ratio and adiposity in Brazilian women. American Journal of Human Biology, 17(5): 646-653, 2005.

WADA, K. et al. Validity of self-reported height and weight in a Japanese workplace population. International Journal of Obesity, 29(9): 1.093-1.099, 2005.

WANG, J. et al. Comparisons of waist circumferences measured at 4 sites. American Journal of Clinical Nutrition, 77: 379-384, 2003.

WHITLOCK, G.; LEWINGTON, S. \& MHURCHU, C. N. Coronary heart disease and body mass index: a systematic review of the evidence from larger prospective cohort studies. Seminars in Vascular Medicine, 2(4): 369-381, 2002.

WILLETT, W. Nutritional Epidemiology. New York: Oxford University Press, 1998.

WORLD HEALTH ORGANIZATION (WHO). Physical Status: the use and interpretation of anthropometry. Geneva: WHO, 1995. (WHO Technical Report Series 854)

WORLD HEALTH ORGANIZATION (WHO). Obesity: preventing and managing the global epidemic. Geneva: WHO, 1998. (WHO Technical Report Series, 894)

ZHOU, B. F. Cooperative Meta-analysis Group of the Working Group on Obesity in China. Predictive values of body mass index and waist circumference for risk factors of certain related diseases in Chinese adults: study on optimal cut-off points of body mass index and waist circumference in Chinese adults. Biomedical Environmental Sciences, 15(1): 83-96, 2002.

ZHU, S. et al. Percentage body fat ranges associated with metabolic syndrome risk: results based on the Third National Health and Nutrition Examination Survey (1988-1994). American Journal of Clinical Nutrition, 78: 228-235, 2003. 


\title{
6
}

\section{Avaliação do Estado Nutricional de Idosos}

\author{
Erika Aparecida da Silveira, Aline Cristine Souza Lopes e Waleska Teixeira Caiaffa
}

$U_{n}$ ma das maiores conquistas do século XX foi o aumento da longevidade como conseqüência do desenvolvimento, da modernização e progresso científico elevando a quantidade de idosos na população global. Ao mesmo tempo, houve também redução da fertilidade, que atua diminuindo o número de jovens em uma população. Com a atuação dessas duas forças demográficas, a proporção de pessoas idosas aumentou e continua aumentando. Essa mudança na configuração populacional, conhecida como transição demográfica, ocorreu de forma gradual em países desenvolvidos, possibilitando avanços sociais e políticos que se refletem nas condições de vida dos idosos. Em contraste, essa transição tem ocorrido de forma acelerada nos países em desenvolvimento. No Brasil, a população de idosos, que era de 5,1\% em 1970 e de 8,6\% (14,5 milhões) em 2000, de acordo com o último censo, poderá alcançar, em 2025, 15\% do total da população (Carvalho \& Garcia, 2003).

O envelhecimento populacional traz vários desafios políticos, econômicos e sociais para o setor Saúde. No Brasil, diferentemente de países desenvolvidos, no que diz respeito à ausência de associação entre nível socioeconômico e saúde do idoso, há forte associação entre menor renda domiciliar per capita e pior condição de saúde, pior função física e menor uso de serviços de saúde (médicos e dentistas) entre idosos (Lima-Costa et al., 2003).

Do ponto de vista biológico, o envelhecimento é um processo contínuo que se inicia por volta dos 30 anos, como consequiência de mecanismos genéticos, fisiológicos e das interações socioambientais e do estilo de vida. Esse processo se inicia no nascimento, acarretando mudanças progressivas no organismo como um todo que levam à perda de adaptabilidade e ao aumento da susceptibilidade a doenças, com importante impacto na determinação da morbi-mortalidade (Harris, 2005; Bales \& Ritchie, 2006). Do ponto de vista nutricional, o declínio natural das funções fisiológicas, as restrições dietéticas decorrentes de doenças específicas e o uso constante de vários medicamentos levam à menor eficiência na absorção e no metabolismo de nutrientes (César, Wada \& Borges, 2005; Harris, 2005). Problemas físicos, sociais e emocionais podem interferir no apetite ou afetar a disposição para o preparo de alimentos e o consumo de uma dieta adequada, fazendo com que padrões alimentares desta faixa etária contribuam para possíveis níveis de inadequação tanto do consumo de alimentos quanto do estado nutricional (Acuña \& Cruz, 2004).

Como resultado de múltiplos fatores fisiológicos, sociais, psicológicos e econômicos, os idosos estão sob especial risco nutricional. A avaliação do estado nutricional neste grupo populacional é fundamental para detectar precocemente dificuldades e distúrbios alimentares, identificando indivíduos e grupos com maior risco nutricional, com o objetivo de estabelecer intervençôes apropriadas para prevenir ou reduzir os danos à saúde (WHO, 1995). 


\section{Consumo Alimentar e de Nutrientes}

A alimentação exerce papel fundamental na promoção, manutenção e recuperação da saúde, cabendo à segurança alimentar e nutricional garantir o acesso regular e permanente a alimentos de qualidade em quantidade suficiente. No entanto, com o envelhecimento, a insegurança alimentar torna-se mais freqüente, em função de fatores que limitam o consumo de alimentos. Entre eles estão as alteraçôes fisiológicas e da cavidade bucal, fatores econômicos e psicossociais, restrição da mobilidade e institucionalização (Campos, Monteiro \& Ornelas, 2000; Arbonés et al., 2003; Gollub \& Weddle, 2004; Acuña \& Cruz, 2004; Brasil, 2004; Marin-León et al., 2005; Cardoso et al., 2006; Menezes \& Marucci, 2006).

\section{Alterações Fisiológicas}

Algumas alterações fisiológicas interferem no consumo de alimentos dos idosos, influenciando no suprimento de suas necessidades nutricionais. Entre as principais estão: comprometimento da percepção sensorial, xerostomia, redução da sensibilidade à sede e saúde bucal (Campos, Monteiro \& Ornelas, 2000; Acuña \& Cruz, 2004).

A interação de processos sensoriais tais como paladar, olfato, visão e audição com outras estruturas e vias neurais pode afetar o comportamento alimentar por alterações no controle do apetite e da saciedade. A visão reduzida pode estar associada à diminuição do apetite, por dificultar o reconhecimento dos alimentos. E a dificuldade em detectar sabores primários tais como doce, salgado, amargo e ácido predispõe o idoso a adoçar e salgar mais os alimentos (Campos, Monteiro \& Ornelas, 2000; Arbonés et al., 2003; Cambraia, 2004).

A xerostomia, caracterizada pela inibição do fluxo salivar, pode afetar o consumo de alimentos por promover cáries, dificultando a mastigação e a deglutição (Campos, Monteiro \& Ornelas, 2000; Arbonés et al., 2003). Idosos também apresentam risco importante de desidratação em função da redução da sensibilidade à sede, das limitações físicas que dificultam o acesso a líquidos, além do medo de ingerir líquidos em função da incontinência urinária e do uso de diuréticos e laxantes (Campos, Monteiro \& Ornelas, 2000; Arbonés et al., 2003).

\section{Saúde Bucal}

A perda dos dentes associada às infecçôes na cavidade periodontal ocasiona dor e dificuldades para mastigar e deglutir, alterando o consumo de alimentos (Campos, Monteiro \& Ornelas, 2000; Acuña \& Cruz, 2004; MacMillan \& Wong, 2004). Além disso, o uso de prótese dentária reduz a eficiência da mastigação em aproximadamente $75-85 \%$, o que leva à diminuição do consumo de carnes, frutas e vegetais frescos (Campos, Monteiro \& Ornelas, 2000). Em estudo sobre a saúde bucal e ingestão de nutrientes, verificou-se que o consumo de fibras, proteína, cálcio, ferro não-heme, niacina e vitamina $C$ foi significativamente menor em edêntulos do que em não edêntulos, evidenciando a importância de um bom estado dentário para uma dieta balanceada e um estado nutricional satisfatório (Marcenes et al., 2003).

\section{Fatores Econômicos e Psicossociais}

A população brasileira apresenta número expressivo de idosos de baixa renda, e quanto menor a renda familiar maior o nível de insegurança alimentar (Gollub \& Weddle, 2004; Marín-León et al., 2005).

A solidão e o isolamento social também podem favorecer a alimentação inadequada, por desestimularem a aquisição e o preparo de alimentos. O idoso pode relatar aumento do consumo de alimentos industrializados, como doces e massas, ou de fácil preparo, como chás e torradas, em detrimento de outros mais saudáveis (Campos, Monteiro \& Ornelas, 2000; Arbonés et al., 2003; Brasil, 2004). 


\section{Restrição de Mobilidade}

A restrição da mobilidade e a coordenação motora comprometida afetam a aquisição e o preparo de alimentos, tornando o idoso dependente de cuidados (Campos, Monteiro \& Ornelas, 2000; Arbonés et al., 2003; Payette, 2005; Toral, Gubert \& Schmitz, 2006).

\section{Institucionalização dos Idosos}

Em tempos de alta prevalência de Doenças Crônicas Não Transmissíveis (DCNT) associada a baixa renda, abandono familiar e dependência por cuidados externos, tem aumentado a demanda dos idosos por instituiçóes geriátricas. Apesar de ser responsabilidade das instituiçôes manter o controle higiênico-sanitário adequado e o planejamento de refeições que atendam às necessidades nutricionais dos idosos, muitas não o fazem (Menezes, Marucci \& Holanda, 2005; Menezes \& Marucci, 2006; Toral, Gubert \& Schmitz, 2006). Estudo realizado em instituições geriátricas do Distrito Federal identificou refeições nutricionalmente inadequadas e condições higiênicas e estruturais precárias (Toral, Gubert \& Schmitz, 2006).

Além disso, idosos asilados podem apresentar consumo alimentar excessivo ou insuficiente de alguns nutrientes. Em estudos realizados entre idosos asilados, observaram-se altos índices de sobrepeso e obesidade (Santos et al., 2004; Cardoso et al., 2006).

Todos esses fatores limitam o consumo alimentar de idosos, devendo ser observados e minimizados, a fim de favorecer uma boa alimentação e um bom estado de nutrição e saúde.

\section{Hábitos Alimentares e Envelhecimento}

Os processos de urbanização e globalização facilitaram a propagação de hábitos alimentares inadequados, favorecendo as altas prevalências de DCNT. De acordo com a Pesquisa de Orçamento Familiar (POF) 20022003, parece haver uma tendência ao decréscimo do consumo e produção de alimentos de origem vegetal e aumento do consumo dos de origem animal. Entre as famílias brasileiras, independentemente de renda e região, persiste o alto consumo de açúcar, principalmente refrigerantes, e o baixo consumo de frutas, hortaliças e gordura (IBGE, 2004a).

A transição nutricional, decorrente de mudanças no padrão alimentar, e o sedentarismo trouxeram grande impacto para a saúde e o estado nutricional dos idosos. É elevado o consumo de produtos industrializados com alto valor energético, tais como doces e massas, ou de fácil preparo e baixo valor energético, como chás e torradas (Campos, Monteiro \& Ornelas, 2000). Com o comprometimento da saúde oral, também ocorre a redução do consumo de vegetais e frutas frescas, por serem considerados mais perecíveis, caros, além de necessitarem de preparo (Rugg-Gunn, 2001). Entretanto, fatores culturais e a presença de cuidadores favorecem hábitos alimentares mais saudáveis (Siviero et al., 2002).

Em pesquisa realizada para identificar o hábito alimentar de idosos em três regiōes de São Paulo, verificou-se que mais de $90 \%$ dos indivíduos ingeriam feculentos, arroz, pão e macarrão. Cerca de $70 \%$ ou mais consumiam feijão, carne de boi, aves, leites e ovos, e mais de $85 \%$ consumiam frutas, verduras, folhosos e legumes, principalmente nos estratos socioeconômicos mais elevados (Najas et al., 1994).

Já entre idosos institucionalizados, verificou-se baixo consumo de frutas e hortaliças, sendo a oferta média destes de 60\% e 53\% da recomendação, respectivamente (Toral, Gubert \& Schmitz, 2006). Verificou-se também adequação igual ou superior a 100\% para alimentos que são fontes protéicas e baixa oferta dos grupos de açúcares e doces, e pães e massas. O consumo de óleos e gordura, na mesma pesquisa, foi de $120 \%$ da recomendação (Toral, Gubert \& Schmitz, 2006). De leite e derivados, apesar de serem importantes fontes protéicas, constatou-se 
em instituições asilares de Fortaleza, CE, que a maioria dos idosos apresentava ingestão insuficiente, o que pode se dever à alta diluição do leite servido (Menezes, Marucci \& Holanda, 2005).

A mudança no padrão alimentar dos idosos traz preocupações importantes, principalmente ao se considerar a alta prevalência de DCNT. Esta tendência atual reflete a necessidade de intervençôes nutricionais urgentes, as quais podem ser dificultadas pelos hábitos arraigados decorrentes do envelhecimento (Brasil, 2006).

\section{Perfil Dietético dos Idosos Brasileiros}

No Brasil, estudos epidemiológicos do consumo alimentar e de nutrientes entre idosos são escassos e não ocorrem de forma sistemática. O Estudo Multicêntrico sobre Consumo Alimentar, realizado em cinco cidades brasileiras - Rio de Janeiro, Campinas, Curitiba, Goiânia e Ouro Preto -, mostrou alto percentual de idosos com consumo inadequado de nutrientes. O consumo de proteínas apresentou inadequação, com maior ingestão desse nutriente, principalmente entre a população estudada no Rio de Janeiro e em Goiânia. Quanto aos ácidos graxos saturados, houve inadequação das recomendações, com maior consumo principalmente em Curitiba. Com relação ao cálcio, nota-se consumo insuficiente, principalmente em Goiânia, sendo o sexo feminino o de maior inadequação em todas as regiōes (Galeazzi, Domene \& Sichieri, 1997).

Estudos observam uma tendência de consumo de dietas hiperprotéicas e hiperlipídicas entre idosos. No Estudo Multicêntrico, Goiânia foi o município que apresentou a maior prevalência de inadequação do consumo de proteínas, e em Ouro Preto $17 \%$ da população idosa apresentaram baixa ingestão (Galeazzi, Domene \& Sichieri, 1997). Por sua vez, o consumo de ácidos graxos saturados e colesterol no Rio de Janeiro apresentou redução, sendo a ingestão de colesterol cerca de 30\% menor (Galeazzi, Domene \& Sichieri,1997). Para Toral Gubert e Schmitz (2006), a oferta dos grupos alimentares fonte de proteínas apresentou adequação igual ou superior a 100\%, e a oferta do grupo de óleos e gorduras atingiu 120\% de adequação. Já para Cardoso e colaboradores (2006), idosos relataram elevada ingestão protéica, estando o consumo lipídico dentro dos níveis recomendados. Lopes e colaboradores (2005), em estudo realizado entre idosos residentes em Bambuí, MG, relataram elevado consumo de lipídios, ressaltando os ácidos graxos saturados.

Em geral, idosos relatam baixa ingestão de micronutrientes em conseqüência da redução do consumo de vegetais e frutas (Toral, Gubert \& Schmitz, 2006). No entanto, alguns estudos demonstram resultados distintos (Velásquez-Meléndez et al., 1997; Santos et al., 2004), A seguir, estão descritas informaçōes referentes ao consumo de minerais e vitaminas entre idosos institucionalizados e não institucionalizados.

Estudos sobre consumo alimentar têm encontrado importante inadequação na ingestão de cálcio entre idosos, apesar de sua importância na prevenção da osteoporose. No Estudo Multicêntrico, a prevalência de inadequação do consumo de cálcio foi bastante elevada ( $90 \%$ entre as mulheres), sendo que em Ouro Preto idosos apresentaram maior prevalência de deficiência (Galeazzi, Domene \& Sichieri, 1997). Lanzillotti e colaboradores (2003) observaram que $86 \%$ das mulheres com osteopenia e $84,8 \%$ das com osteoporose apresentaram baixa ingestão de cálcio proveniente de produtos lácteos. Essa deficiência no consumo de cálcio - assim considerada em relação às elevadas recomendaçoos nutricionais propostas - pode se dever à intolerância à lactose decorrente da idade, a fatores antinutricionais como os ácidos oxálico e fítico, e ao consumo de cafeína (Lanzillotti et al., 2003; Santos et al., 2004; Lopes et al., 2005; Menezes, Marucci \& Holanda, 2005; Cardoso et al., 2006).

Idosos residentes no Rio de Janeiro relataram redução da ingestão de ferro (Galeazzi, Domene \& Sichieri, 1997). Lopes e colaboradores (2005), por sua vez, encontraram baixa adequação do consumo de ferro para $36,9 \%$ dos idosos e consumo excessivo em 38,1\%, e Velásquez-Meléndez e colaboradores (1997) verificaram que apenas 30\% do ferro ingerido eram de origem animal. Entre idosos institucionalizados, a ingestão de ferro esteve elevada nos estudos realizados por Santos e colaboradores (2004) e por Cardoso e colaboradores (2006), e dentro das recomendações de acordo com Menezes, Marucci e Holanda (2005). 
Estudos têm demonstrado o consumo insuficiente de zinco (Santos et al., 2004; Lopes et al., 2005); em estudo realizado por Lopes e colaboradores (2005), todos os idosos apresentaram consumo abaixo do adequado. Em contrapartida, César, Wada e Borges (2005) relataram aporte de zinco adequado, principalmente proveniente do consumo de carnes.

Quanto às vitaminas, idosos relataram consumo inadequado de riboflavina, tiamina e niacina, em função da reduzida ingestão de cereais integrais, vísceras, entre outros alimentos (Velásquez-Meléndez et al., 1997; Coelho et al., 2002; Cardoso et al., 2006). Já para a vitamina A, o consumo deficiente foi encontrado por Lopes e colaboradores (2005) e Velásquez-Meléndez e colaboradores (1997), em estudos entre idosos não institucionalizados. No entanto, Coelho e colaboradores (2002) e Cardoso e colaboradores (2006) observaram ingestão acima da adequação entre idosos internados em instituições geriátricas.

A alta ingestão de vitamina C foi encontrada em alguns estudos (Velásquez-Meléndez et al., 1997; Santos et al., 2004), em função da freqüente ingestão de frutas e vegetais fontes desse mineral (Coelho et al., 2002). No entanto, Lopes e colaboradores (2005) observaram baixo consumo de vitamina C, condição que poderia ser agravada pelo uso de alguns medicamentos.

Apesar dos poucos estudos sobre o consumo alimentar realizado entre idosos, é possível identificar uma inadequação importante para a maioria dos nutrientes, caracterizada pelo consumo tanto excessivo quanto insuficiente (Velásquez-Meléndez et al., 1997; Lopes et al., 2005). Ressalta-se, contudo, que esses estudos apresentam diferenças metodológicas importantes que dificultam a comparação. Utilizam diferentes métodos dietéticos, tabelas de composição de alimentos e referências para as recomendações nutricionais, além de trabalharem, em sua maioria, com grupos específicos, como idosos institucionalizados, que apresentam limitações ainda mais importantes para relatar informaçōes (Velásquez-Meléndez et al., 1997; Lopes et al., 2005; Menezes \& Marucci, 2006).

\section{Métodos de Avaliação do Consumo Alimentar: limitações e alternativas}

Dentre os métodos mais utilizados para avaliar o consumo alimentar, estão o Recordatório 24 Horas (R24), o registro alimentar, o Questionário de Freqüência Alimentar (QFA), o Questionário Semiquantitativo de Freqüência Alimentar (QSFA), a História Dietética (HD - combinação do R24 com um QFA) e a pesagem direta dos alimentos, os quais estão descritos no capítulo 10, "Métodos de avaliação do consumo de alimentos".

Os métodos de avaliação do consumo alimentar, quando aplicados em idosos, podem apresentar limitações importantes. A primeira delas, e talvez a mais importante, é a memória. Idosos têm a memória comprometida, principalmente do tipo recente, dificultando recordar os alimentos e tamanhos de porçôes consumidos. A maioria dos métodos de avaliação de consumo alimentares é dependente da memória, sendo que o R24 está associado principalmente à perda da memória recente por referir-se ao período de 24 horas, tipo de memória ainda mais comprometida em idosos (Pereira, 2005).

Outra limitação enfrentada é a dificuldade em quantificar o tamanho das porções consumidas, principalmente entre os homens. Tal limitação é importante para o QSFA, R24, HD e registro alimentar. Esse aspecto pode ser ainda mais relevante quando o idoso não está habituado a servir suas próprias refeições.

Esses problemas relativos à memória e à estimação do tamanho de porções podem ser minimizados se forem utilizadas réplicas de alimentos ou álbuns de fotografias com medidas caseiras (Gibson, 1990).

O comprometimento das capacidades visual e auditiva também pode dificultar a aplicação de métodos de avaliação do consumo alimentar. Idosos com reduzida audição podem ter dificuldades em responder às entrevistas, sendo o registro alimentar e a pesagem direta de alimentos boas alternativas nesses casos (Pereira, 2005). 
Aqueles com dificuldade na visão podem ter problemas ao redigir o registro e, nesse caso, os métodos que utilizam entrevista ou pesagem direta de alimentos são recomendados.

$\mathrm{O}$ registro alimentar exige que o indivíduo tenha boa habilidade de leitura e escrita. Trata-se de uma limitação importante, pois, de acordo com a Pesquisa Nacional por Amostra de Domicílios (PNAD, 20042005), idosos brasileiros têm em média 3,5 anos de estudo (IBGE, 2004b). O registro, quando aplicado por sete dias, é considerado como representativo da ingestão habitual de alimentos. No entanto, é inviável para o idoso ou o cuidador realizar as anotaçóes por longos períodos.

Para indivíduos sem escolaridade e/ou com dificuldades motoras, deve-se recorrer aos cuidadores para redigir os dados ou utilizar R24 e o QSFA, que são dependentes da adequada aplicação por entrevistadores treinados (Wengreen et al., 2001).

Todos os métodos, com exceção da pesagem direta de alimentos, apresentam limitações referentes à informação por parte dos indivíduos investigados. Idosos com comprometimento mental podem fornecer informações com pouca qualidade, o que inviabiliza a realização de inquéritos dietéticos. Na presença de comprometimento mental ou deficiência cognitiva importante, deve-se recorrer ao cuidador para relatar ou redigir as informaçôes referentes ao consumo alimentar.

Ao aplicar os métodos de avaliação de consumo alimentar em idosos, deve-se considerar, além da análise qualitativa e quantitativa, as peculiaridades desta faixa etária. Dessa forma, é necessário avaliar a memória e a atenção limitadas, presença de doenças crônicas e mentais, condições socioeconômicas, além das alterações fisiológicas. Em contrapartida, idosos possuem hábitos alimentares específicos, arraigados e monótonos, que facilitam sua participação em inquéritos dietéticos (Pereira, 2005).

\section{Avaliação Antropométrica e Composição Corporal}

A escolha do método de avaliação antropométrica a ser utilizado em idosos depende não só do que se pretende como da presença de morbidade, de deficiência física e dos recursos e tecnologias disponíveis, e sobretudo das alterações fisiológicas decorrentes do envelhecimento que provocam mudanças nas dimensões e na composição corporal. As principais alterações fisiológicas são a redução da estatura, da massa magra (músculos, ossos, vísceras) e da quantidade de água corporal, e o aumento e redistribuição de gordura, que diminui nos membros e passa a se concentrar no abdome (WHO, 1995).

\section{Perfil Antropométrico da População Idosa Brasileira}

Mesmo com o crescente envelhecimento populacional observado no Brasil e no mundo e com os idosos constituindo importante grupo de risco nutricional, ainda são escassas as pesquisas populacionais sobre o perfil antropométrico deste grupo etário. No âmbito nacional, três pesquisas avaliaram a situação nutricional da população com 20 ou mais anos: o Estudo Nacional de Despesa Familiar (Endef, 1974-1975), a Pesquisa Nacional sobre Saúde e Nutrição (PNSN, 1989) e a Pesquisa de Orçamentos Familiares (POF, 2002-2003). Porém, os resultados dessas pesquisas são publicados, quase sempre, agregando os resultados de adultos e idosos, com poucos resultados específicos para a faixa etária de 60 ou mais anos (IBGE, 1977, 2004a; Inan, 1990).

Nos 15 anos decorridos entre o Endef e a PNSN, verificou-se grande alteração da situação nutricional de adultos e idosos, com aumento da prevalência de excesso de peso e obesidade e decréscimo do déficit de peso. No entanto, considerando período mais recente, 13 anos entre a PNSN e a POF, observa-se que essas alterações ocorreram apenas no sexo masculino. Tais comparações são realizadas após padronização das prevalências para a distribuição etária da população brasileira em cada sexo (IBGE, 1977, 2004a; Inan, 1990). 
As informações antropométricas apresentadas a seguir seguem as recomendações da Organização Mundial da Saúde (OMS) para o Índice de Massa Corporal (IMC), sendo déficit de peso IMC $<18,5 \mathrm{~kg} / \mathrm{m}^{2}$, excesso de peso IMC $\geq 25 \mathrm{~kg} / \mathrm{m}^{2}$ e obesidade, IMC $\geq 30 \mathrm{~kg} / \mathrm{m}^{2}$ (WHO, 1995).

Análise do banco de dados da PNSN realizado por Tavares e Anjos (1999) revela na população de 60 ou mais anos uma prevalência de déficit de peso de $7,8 \%$ e $8,4 \%$, de excesso de peso de $24,7 \%$ e $32 \%$ e obesidade de $5,7 \%$ e $18,2 \%$ em homens e mulheres, respectivamente. O déficit de peso aumentou com a idade, atingindo maiores patamares na faixa etária de 75 a 79 anos, $17 \%$ de homens e $14 \%$ de mulheres, e diminuindo a partir dos 80 anos. Entre os homens, a prevalência de obesidade se reduziu com a idade, atingindo 6,8\% dos idosos entre 60 e 65 anos e 1,2\% com 80 ou mais anos. A mesma tendência foi observada entre as mulheres, porém iniciando mais tarde (Tavares \& Anjos, 1999).

O déficit de peso foi mais freqüente em áreas rurais das regiōes Centro-Oeste/Nordeste (em mulheres) e Sudeste/Centro-Oeste (em homens), nas classes de menor renda e escolaridade e piores condiçôes de moradia. A obesidade atingiu prevalência de 20,3\% entre mulheres idosas residindo em áreas urbanas, chegando a 23,3\% nas regióes Sudeste e Sul. A prevalência de obesidade em idosas residentes em áreas rurais foi de $11 \%$. Exceto para a região Sul, observou-se menor prevalência de obesidade em idosas nas áreas rurais. Nos homens, essas prevalências foram de 7,3\% e 2,4\%, em áreas urbana e rural, respectivamente. Inversamente ao déficit de peso, a obesidade alcançou maiores prevalências nos grupos de maior renda, maior escolaridade e melhores condiçõos de moradia (Tavares \& Anjos, 1999).

Entre a PNSN desenvolvida em 1989 e a POF de 2002-2003, realizou-se no Brasil a Pesquisa de Padrões de Vida (PPV, 1996-1997), com amostra populacional apenas das regiōes Nordeste e Sudeste. Comparando-se as prevalências apresentadas no Gráfico 1, observa-se que o déficit de peso diminuiu em ambos os sexos, a prevalência de excesso de peso aumentou entre homens e não se alterou entre as mulheres, e a obesidade manteve-se estável entre os homens, reduzindo-se entre as mulheres.

Gráfico 1 - Prevalência de déficit de peso, excesso de peso na população com 60 ou mais anos de idade, por sexo - Brasil, 1989 e 1996-97

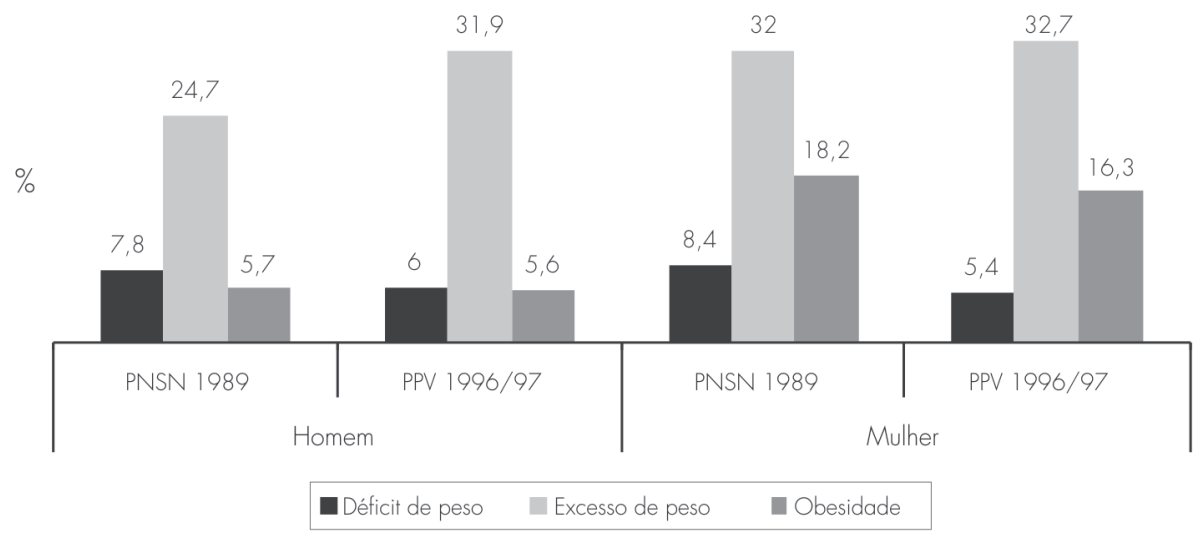

PNSN - Pesquisa Nacional sobre Saúde e Nutrição, 1989.

PPV - Pesquisa de Padrões de Vida, 1996-97, população das regiões Nordeste e Sudeste.

Fonte: dados apresentados por Tavares e Anjos (1999) e Campos e colaboradores (2006).

Com relação à renda, observaram-se resultados semelhantes aos da PNSN, ou seja, associação inversa com déficit de peso e direta com obesidade (IBGE, 1998; Campos et al., 2006). 
Dados da POF 2002-2003 evidenciam que apenas no grupo etário de 75 anos ou mais o déficit de peso em idosos excedeu os $5 \%$ compatíveis com proporção populacional de indivíduos constitucionalmente magros, ou seja, não indicativa de exposição à desnutrição, com prevalência global estimada de $6,7 \%$, sendo $8,9 \%$ no sexo masculino e 4,9\% no feminino. Para o excesso de peso, a prevalência aumentou com a idade, atingindo 53,9\% da população de 55 a 64 anos, diminuindo a partir dessa faixa etária para 49,1\% e 38,5\% nos idosos de 65 a 74 anos e 75 anos e mais, respectivamente. A prevalência de obesidade na população brasileira também aumentou com a idade, atingindo $17,1 \%$ na faixa etária de 55 a 64 anos, decrescendo para $14 \%$ na categoria de 65 a 74 anos, e para 10,5\% naqueles com 75 anos e mais. $\mathrm{O}$ aumento na prevalência de obesidade e excesso de peso ocorreu de forma mais rápida entre os homens do que entre as mulheres, e a prevalência de excesso de peso declinou entre os homens a partir de 55 anos e mulheres a partir de 65 anos (IBGE, 2004a).

Em estudo realizado na população idosa de Bambuí, MG, a prevalência de obesidade (IMC $\geq 30 \mathrm{~kg} / \mathrm{m}^{2}$ ) foi de $12,8 \%$, estando associada ao sexo feminino e ao sedentarismo. Já o déficit de peso (IMC $\geq 20 \mathrm{~kg} / \mathrm{m}^{2}$, critério adotado especificamente nesse estudo) foi associado ao sexo masculino e à ocorrência de duas ou mais internações no último ano, atingindo prevalência de 14,8\% nos homens. Nesse estudo também foram observadas maiores prevalências de obesidade entre os de maior renda familiar e de déficit de peso entre os de menor renda (Barreto, Passo \& Lima-Costa, 2003).

\section{Antropometria em Idosos}

Medidas antropométricas simples e de custo acessível, aplicáveis tanto no nível individual quanto populacional, são utilizadas na avaliação do estado nutricional do idoso, como peso, estatura, IMC, circunferências e dobras cutâneas (WHO, 1995). Devido à inexistência de padrões de referência para as medidas antropométricas em idosos nos países em desenvolvimento, a OMS recomenda a utilização dos dados de referência do Third National Health and Nutrition Examination Survey (NHANES III 1988-1994) constituída com base em uma amostra de idosos não institucionalizados. Kuczmarski, Kuczmarski e Najar (2000) apresentam tabelas com os percentis de dobra cutânea tricipital, circunferência do braço, circunferência muscular do braço, peso, estatura e IMC para homens e mulheres a partir dos 50 anos, conforme dados do NHANES III. Essas medidas devem ser aferidas seguindo padronização específica, conforme descrito no capítulo 5, "Antropometria como método de avaliação do estado de nutrição e saúde do adulto".

\section{Peso}

Em idosos, medidas em série do peso corporal podem ser consideradas um indicador simples e adequado sobre a mudança do estado nutricional do ponto de vista da avaliação clínica individual. A perda ou ganho de peso involuntário é um sinal de advertência importante que deve ser considerado pelo profissional da saúde (Harris, 2005; Bales \& Ritchie, 2006), devendo este, inclusive, orientar seus pacientes para que fiquem atentos à evolução do seu próprio peso e informem qualquer mudança involuntária.

Importante destacar que, também em idosos, a obesidade ou adiposidade, implicando risco cardiovascular, pode ser mascarada pelo peso relativamente normal, porém com massa gorda aumentada e massa livre de gordura diminuída (Roubenoff et al., 2000). Da mesma forma, parâmetros normais de peso não indicam necessariamente que não há perda de tecido muscular, ou seja, o peso não permite distinguir entre as variações de massa muscular, gordura corporal e presença de edema (Bales \& Ritchie, 2006). A perda de tecido muscular e a presença de edema são bastante comuns em idosos, principalmente nos hospitalizados (Harris, 2005). 
Em pacientes idosos, obter o peso corporal nem sempre é fácil, principalmente entre aqueles mais frágeis. Quando houver essa dificuldade, é possível estimar o peso por meio de equações como a proposta por Chumlea e colaboradores, em 1988:

$$
\begin{aligned}
& \text { Homem }[(0,98 \times C P)+(1,16 \times A)+(1,73 \times C B)+(0,37 \times \text { DSE })-81,69] \\
& \text { Mulher }[(1,27 \times C P)+(0,87 \times A)+(0,98 \times C B)+(0,4 \times D S E)-62,35]
\end{aligned}
$$

Sendo CP circunferência da panturrilha, CB circunferência do braço, AJ altura do joelho e DSE dobra cutânea subescapular.

Deve-se considerar que a estimativa do peso conforme proposta por esses autores requer quatro medidas corporais e apresenta elevada margem de erro. No entanto, não está descrita na literatura, até o momento, outra pesquisa que tenha desenvolvido equação mais acurada.

\section{Estatura}

Durante o envelhecimento, a estatura declina progressivamente como conseqüência de compressão dos discos intervertebrais, achatamento das vértebras, cifose torácica, escoliose, osteoporose, achatamento do arco plantar e arqueamento de membros inferiores (Perissinoto et al., 2002). Tal declínio inicia-se por volta dos 40 anos, mas a velocidade dessa redução ainda não está claramente estabelecida. O Euronut Seneca Study encontrou uma redução de um a dois centímetros em quatro anos, enquanto Perissinoto e colaboradores a quantificaram em dois a três centímetros por década.

Sempre que possível, deve-se usar a estatura do paciente antes dos 50 anos como estatura de referência, buscando evitar os efeitos supracitados. Porém, essa informação deve vir de fonte confiável, considerando o viés de informação em pacientes idosos (Bales \& Ritchie, 2006). Em idosos acamados, amputados ou com curvatura espinhal, a estatura pode ser estimada por meio da envergadura do braço, da estatura recumbente e da Altura do Joelho (AJ). Para as medidas da estatura recumbente e da envergadura do braço, são relatadas dificuldades relacionadas à rigidez das articulações, que dificultam o correto posicionamento durante sua tomada (Chumlea et al., 1998).

A envergadura do braço é a distância do meio da fúrcula esternal até a ponta do dedo médio, medida com o braço levantado em posição horizontal para o lado. A medida deve ser feita em ambos os lados, e então a estatura pode ser calculada (WHO, 1999): Estatura $=[0,73 \times(2 \times$ a metade da envergadura dos braços $)]+0,43$.

Quanto à estimativa da estatura a partir da $\mathrm{AJ}$, várias fórmulas foram desenvolvidas com base em dados do NHANES III, conforme sexo e etnia/raça para pessoas com 60 ou mais anos. Algumas dessas equaçóes podem ser observadas na Tabela 1 (página seguinte).

Entretanto, tais equações podem não ser aplicáveis em outras populações, conforme avaliaram MendozaNúnez e colaboradores (2002) em amostra de idosos mexicanos. A estatura média de méxico-americanos, nas quais se baseiam as equaçóes de Chumlea e colaboradores (1998), difere significativamente dos valores de referência em homens e mulheres mexicanos. A equação para estimar estatura $(\mathrm{cm})$ de idosos mexicanos proposta por Mendoza-Núnez e colaboradores (2002) para homens é 52,6 + (2,17 $\times \mathrm{AJ} \mathrm{cm})$ e para mulheres, $73,7+(1,99 \times \mathrm{AJ} \mathrm{cm})-(0,23 \times$ idades em anos $)$. 
Tabela 1 - Equações para predizer estatura $(\mathrm{cm})$ por etnia/raça em homens e mulheres, conforme dados do NHANES III

\begin{tabular}{|c|c|c|}
\hline Sexo & Grupo étnico/raça & Equações \\
\hline \multirow[t]{3}{*}{ Masculino } & Não-hispânico branco & $78,31+(1,94$ AJ) - $(0,14$ idade $)$ \\
\hline & Não-hispânico negro & $79,69+(1,85$ A $)-(0,14$ idade $)$ \\
\hline & México-americano & $82,77+(1,83$ AJ) - (0, 16 idade $)$ \\
\hline \multirow[t]{3}{*}{ Feminino } & Não-hispânico branco & $82,21+(1,85$ Al) $-(0,21$ idade $)$ \\
\hline & Não-hispânico negro & $89,58+(1,61$ AJ) $-(0,17$ idade $)$ \\
\hline & México-americano & $84,25+(1,82$ AJ) - (0,26 idade) \\
\hline
\end{tabular}

AJ: altura do joelho

Fonte: baseada em Chumlea et al. (1998).

\section{Índice de Massa Corporal}

Com o peso e a estatura calcula-se o Índice de Massa Corporal (IMC), que é amplamente utilizado na avaliação do estado nutricional tanto em adultos quanto nos idosos. No entanto, há várias críticas e questionamentos, principalmente para a faixa etária de 60 ou mais anos, sobre a capacidade desse índice de estimar a gordura corporal, a adiposidade central e ainda classificar obesidade em pessoas de diferentes idades, sexo e composição corporal. Ainda assim, seu uso é recomendado pela OMS e por diversos autores, pois apresenta vantagens como baixo custo, facilidade de aplicação, pequena variação intra e interavaliador, alta correlação com peso corporal e baixa correlação com estatura, associação com doenças cardiovasculares, diabetes, alguns tipos de câncer e correlação com mortalidade. Até o momento, o IMC é considerado um bom indicador do estado nutricional em estudos epidemiológicos e em rastreamento de grupos de risco em adultos (WHO, 1997; Santos \& Sichieri, 2005). Entretanto, não há consenso sobre o ponto de corte mais adequado para o IMC em idosos, sendo os mais utilizados o critério recomendado pela OMS (WHO, 1997) e o critério de Lipschitz (1994).

Na Tabela 2 podem ser observados os diferentes critérios de IMC para a classificação do estado nutricional em idosos. A recomendação da OMS (WHO, 1997) foi utilizada em pesquisas nacionais como a PNSN e a POF 2002-2003; no entanto, há críticas sobre o uso dos mesmos pontos de corte de IMC para adultos e idosos, já que ocorrem mudanças na composição corporal associadas ao processo de envelhecimento, tais como diminuição da massa livre de gordura (massa óssea, músculos, vísceras e água) e redistribuição e aumento da gordura corporal. Apesar de ser descrita uma boa correlação entre o IMC e a porcentagem de gordura corporal, menores valores do coeficiente de correlação são encontrados a partir dos 60 anos. Com o aumento e a redistribuição de gordura concentrando-se na região abdominal, o IMC subestima a obesidade, definida como o aumento da gordura corporal, e principalmente a adiposidade central. Assim, recomenda-se que o IMC em idosos não seja utilizado como único estimador de obesidade (WHO, 1997; Landi et al., 2000; Perissinotto et al., 2002; Cervi, Franceschini \& Priori, 2005).

O critério de classificação preconizado por Lipschitz (1994) assemelha-se ao proposto pelo Center of Disease Control (CDC) e utilizado no NHANES III 1988-1994, que acrescenta diferenças entre homens e mulheres idosas, porém sem distinção para categorias com diferentes níveis de risco, ou seja, baixo peso, sobrepeso e obesidade (CDC/NSCH, 1991). Segundo Cervi, Franceschini e Priori (2005), essa classificação leva em consideração as mudanças na composição corporal que ocorrem com o envelhecimento e a vulnerabilidade dos idosos 
à desnutrição, uma vez que estes apresentam maior porcentagem de gordura e de massa magra, além de perda do tecido livre de gordura, quando comparados com os indivíduos adultos. Recentemente, o Nutrition Screening Initiative (NSI) adotou o mesmo ponto de corte de Lipschitz para excesso de peso, porém com valor superior na classificação do baixo peso (Harris, 2005).

São necessárias ainda pesquisas que ajudem a esclarecer pontos de corte do IMC para idosos considerando a composição corporal, principalmente a partir de uma base populacional brasileira, pois, além das variações para idade e sexo, o grupo étnico é outro fator de variabilidade importante.

Tabela 2 - Diferentes critérios de pontos de corte de IMC para avaliação do estado nutricional em idosos

\begin{tabular}{cccl}
\hline \multirow{2}{*}{ Critérios/Referência } & \multicolumn{3}{c}{ Classificação $\mid \mathrm{MC}\left(\mathrm{kg} / \mathrm{m}^{2}\right)$} \\
\cline { 2 - 4 } & Baixo peso & Eutrofia & \multicolumn{1}{c}{ Excesso de peso } \\
\hline CDC, 1991 & & $>27,3$ mulheres \\
& & 27,8 homens \\
\hline Lipchitz, 1994 & $<22$ & 22 a 27 & $>27$ \\
\hline WHO, 1997* & $<18,5$ & 18,5 a 24,9 & $\begin{array}{l}25 \text { a 29,9 sobrepeso } \\
\geq 30 \text { obeso }\end{array}$ \\
\hline Harris, 2005 & $<24$ & 24 a 27 & $>27$
\end{tabular}

* Mesmo critério utilizado para indivíduos adultos.

Fontes: CDC/NCHS (1991) e WHO (1997).

\section{Dobras Cutâneas}

As dobras cutâneas estimam a massa corpórea de gordura auxiliando a avaliação da duração e gravidade da desnutrição, pois o tecido adiposo é uma reserva calórica que fornece energia durante o jejum ou a baixa ingestão de nutrientes. É um método que exige bastante técnica e experiência do avaliador, principalmente no indivíduo idoso, em função da baixa elasticidade dos tecidos, que dificulta separar o tecido subcutâneo do muscular (Frank $\&$ Soares, 2002). A perda de elasticidade e a compressibilidade dos tecidos ocorrem devido à redução do tecido muscular e à perda de água corporal.

Com a redução do tecido muscular e a redistribuição de gordura com maior acúmulo na região intraabdominal, a dobra cutânea triciptal, a circunferência do braço e a área muscular do braço diminuem com a idade, principalmente em mulheres (Santos \& Sichieri, 2005). Apesar de as dobras cutâneas se correlacionarem fortemente com tecido adiposo total, em idosos elas não têm boa correlação com tecido adiposo visceral (Bales $\&$ Ritchie, 2006).

\section{Circunferências}

As circunferências contribuem na avaliação mais completa do estado nutricional do idoso, fornecendo informações sobre a composição e adiposidade corporal. É possível medir uma série de circunferências corporais. Contudo, no idoso as mais utilizadas são o braço, a panturrilha, a cintura e o quadril. Estas duas últimas são utilizadas para o cálculo da relação cintura-quadril (Acuña \& Cruz, 2004; Harris, 2005; Santos \& Sichieri, 2005). A padronização da tomada dessas medidas bem como os pontos de corte para circunferência da cintura e relação cintura-quadril no idoso são os mesmos do adulto. Recentemente, em idosas, a relação cintura-quadril > 0,97 foi identificada como preditor de mortalidade total, o que não foi observado para o IMC e circunferência da cintura (Cabrera et al., 2005). 
A comparação das medidas antropométricas com exames de diagnóstico por imagens, como a ressonância magnética e a tomografia computadorizada, mostra que a circunferência da cintura foi a variável antropométrica que apresentou melhor correlação com o tecido adiposo visceral (Harris, 2005; Bales \& Ritchie, 2006). Assim, a medida da circunferência da cintura é uma maneira simples e prática de avaliar a distribuição de gordura abdominal. No entanto, vários grupos étnicos diferem entre si quanto à magnitude de risco associado com a elevada circunferência da cintura. Portanto, a categorização do risco usando a circunferência da cintura deverá ser específica para cada população e dependerá do nível de obesidade e da presença de outros fatores de risco para doença cardiovascular e diabetes mellitus (WHO, 1997). Até o momento, não há relato de pontos de corte de circunferência da cintura específicos para idosos, nem estudos específicos para a população de idosos brasileira.

A circunferência do braço reflete a composição corpórea total, e a área muscular do braço é utilizada para estimar a massa corpórea magra. No entanto, tais estimaçôes podem ser diferentes em homens e mulheres. Santos e Sichieri (2005) encontraram redução da circunferência e área muscular do braço com a idade em idosos do sexo masculino, ao passo que, entre as idosas, a redução foi na área de gordura do braço, dobra subescapular e tricipital. Em contrapartida, a circunferência da panturrilha tem sido considerada a medida mais sensível para avaliar a massa muscular do idoso, apresentando-se como uma medida superior à área muscular do braço. Essa medida é recomendada para monitorar a perda de massa muscular em idosos de ambos os sexos. Circunferência da panturrilha inferior a $31 \mathrm{~cm}$ indica perda de massa muscular (WHO, 1995).

Sobre classificação do estado nutricional em idosos por meio de indicadores antropométricos, IMC, relação cintura-quadril, circunferência da cintura e dobras cutâneas, o que fica claro é a falta de consenso (WHO, 1997).

\section{Avaliação Laboratorial e Bioquímica}

A avaliação bioquímica é parte da avaliação nutricional do idoso, e pode detectar precocemente deficiências nutricionais em níveis subclínicos como quadros de desnutrição e anemia, além de dislipidemias, entre outros. Alterações no estado nutricional podem ocorrer lentamente, e as alterações antropométricas somente se manifestarão a posteriori. Conforme a deficiência nutricional se desenvolve, várias adaptações orgânicas são feitas para que as funções fisiológicas normais não sejam afetadas. Os exames bioquímicos são medidas objetivas e sensíveis do estado nutricional que permitem o seguimento, ao longo do tempo, de intervençôes nutricionais. Os principais são: hematócrito, hemoglobina, linfócitos totais, proteínas séricas (albumina, pré-albumina, transferrina, proteína transportadora de retinol), índice creatinina-estatura, 3-metil histidina urinária, dosagens de vitaminas e minerais e balanço nitrogenado (Harris, 2005; Bottoni et al., 2000).

Entre as dosagens séricas de micronutrientes, as mais relevantes são a de vitamina A, C e E, ferro, zinco e selênio. A maioria dos estudos brasileiros tem sido realizada em populações pediátricas, enfocando principalmente a vitamina A, sendo raros os estudos em outras faixas etárias da população sadia. Haller e colaboradores (1996) encontraram concentrações bioquímicas de vitamina $\mathrm{E}$ abaixo do recomendado em 1,1\% dos idosos. MacNeill e colaboradores (2002) encontraram deficiências de vitamina C entre idosos do sexo masculino, que se revelaram maiores naqueles com 80 ou mais anos.

Não há um único exame bioquímico universalmente aceito para a avaliação do estado nutricional de idosos. A transferrina e a albumina são exemplos de proteínas afetadas por fatores não nutricionais, como processos inflamatórios e diversas enfermidades. Publicação recente ressalta a concentração de leptina como importante marcador biológico, por apresentar boa sensibilidade e especificidade na avaliação nutricional de idosos com doenças agudas (Bouillanne et al., 2006). A pesquisa nela relatada buscou identificar os parâmetros biológicos leptina, IGF-1 (fator de crescimento semelhante à insulina Tipo I), IGFBP-1 (IGF Binding Protein-1), IGFBP-3 e proteína-C reativa $(\mathrm{PCr})$ - mais relacionados com os marcadores antropométricos de desnutrição. Entre estes, a concentração de leptina foi o único parâmetro biológico relacionado ao estado nutricional avaliado por meio do 
IMC e de dobras cutâneas. Em idosos com déficit de peso, as concentraçôes de leptina foram mais baixas que nos demais (Bouillanne et al., 2006).

Resultados desses exames devem ser interpretados com especial atenção, pois o idoso pode apresentar algumas alterações bioquímicas decorrentes do próprio processo de envelhecimento, do uso de medicamentos e da presença de enfermidades de ordem não nutricional que podem influenciar os resultados. Dessa forma, destaca-se mais uma vez a importância da avaliação nutricional de idosos baseada em diferentes parâmetros, combinando dados antropométricos, clínicos e história dietética, entre outros (Gariballa \& Sinclair, 1998; Kamimura et al., 2002).

Além de avaliar deficiências nutricionais específicas, os exames laboratoriais também são utilizados para triagem e monitorização do risco de DCNT relacionadas à nutrição, como diabetes, hipertensão arterial, síndrome metabólica e doença cardiovascular. Maiores detalhes sobre métodos bioquímicos de avaliação do estado nutricional estão descritos no capítulo 7, "Indicadores bioquímicos na avaliação do estado nutricional".

\section{Avaliação Clínico-Nutricional}

Na prática clínica, tanto em nível hospitalar quanto ambulatorial, a anamnese tem um importante papel na avaliação nutricional do idoso e, quando adequadamente conduzida, identifica aspectos importantes do estado de saúde do indivíduo. $\mathrm{Na}$ anamnese ou história clínica, os principais pontos a serem levantados são: a) dados sociodemográficos; b) capacidade funcional, de locomoção e nível de independência; c) antecedentes clínicos como doenças crônicas e cirurgias; d) uso de medicamentos, de álcool, tabaco e drogas ilícitas; e) perda e variação de peso; f) história dietética; g) alterações no padrão alimentar, presença de disfagia e saúde oral; h) sintomas ou doenças gastrointestinais como vômitos, constipação, diarréia, anorexia e gastrite; i) demanda metabólica, verificando fatores que aumentam as necessidades energéticas, como infecções, traumas, queimaduras e sépsis (Harris, 2005; Acuña \& Cruz, 2004).

Em pacientes idosos, qualquer porcentagem de perda de peso é considerada clinicamente importante. Considera-se perda de peso grave quando superior a $2 \%$ em uma semana e $5 \%$ em um mês (Blackburn $\&$ Bistrain, 1977). A Perda Ponderal Recente (PPR) é calculada com a fórmula \% PPR = PU - PA/PU x 100, sendo PU peso usual e PA peso atual. O baixo peso $\left(\mathrm{IMC}<18,5 \mathrm{~kg} / \mathrm{m}^{2}\right)$ foi identificado como preditor independente de mortalidade total em idosas, principalmente naquelas com até 80 anos, em estudo de coorte prospectiva (Cabrera et al., 2005).

Sobre a avaliação da capacidade funcional, mudanças recentes nos hábitos e na rotina diária de trabalho e lazer devem ser averiguadas. Outros fatores que devem ser investigados pelo profissional da saúde são: depressão, demência, perda recente do cônjuge, isolamento e diminuição da mobilidade.

É importante verificar, antes de iniciar a anamnese, se o idoso apresenta algum distúrbio ou limitação cognitiva. Em caso positivo, a anamnese deverá ser respondida pela pessoa que mais convive com ele. Entre os métodos para detecção da capacidade cognitiva, existem os mais complexos, que devem ser aplicados por profissionais capacitados para realizar avaliação neuropsicológica, e aqueles mais simples e rápidos (duração: de 5 a 10 minutos), como o Mini-Exame de Estado Mental, que pode ser aplicado por qualquer profissional da saúde (Folstein, Folstein \& McHugh, 1975).

O exame físico deve complementar a história clínica, com o objetivo de identificar sinais de carências nutricionais específicas. A desnutrição é um sério problema entre pacientes idosos internados e institucionalizados, que faz aumentar a permanência hospitalar, o desenvolvimento de complicações e a mortalidade (Waitzberg \& Ferrini, 2000; Harris, 2005). Dessa forma, o profissional da saúde deve estar atento aos sinais de depleção nutricional durante o exame físico. 
No idoso, os sinais clínicos detectados no exame físico podem ser decorrentes de alterações fisiológicas próprias do processo de envelhecimento, de alguma doença de ordem não nutricional ou da própria depleção do estado nutricional, o que lhe confere baixa especificidade para a identificação de carências nutricionais. Um exemplo é a cegueira noturna, cuja causa é a deficiência de vitamina A, mas no idoso pode ser a catarata (Coelho \& Fausto, 2002). A perda de peso e a diminuição do tecido adiposo e do tônus muscular são importantes, porém devem ser interpretadas com cuidado. $\mathrm{O}$ exame físico somente deve ser interpretado em conjunto com dados da avaliação bioquímica, da história clínica, da antropometria ou de outro método que tenha sido empregado.

\section{Métodos Conjuntos de Avaliação Nutricional}

Os métodos de avaliação nutricional são diversos; no entanto, não existe um instrumento preciso para avaliar o estado nutricional de idosos. Torna-se, assim, essencial a abordagem conjunta de indicadores que possibilitem uma avaliação nutricional mais fidedigna.

Há vários métodos que utilizam conjuntamente componentes das avaliações clínica, bioquímica, antropométrica, da composição corporal e da ingestão dietética. Entre esses, serão descritos no Quadro 1 a Avaliação Global Subjetiva, a Mini-Avaliação Nutricional e o Questionário Payette.

\section{Avaliação Nutricional Subjetiva Global}

Com intuito de viabilizar a avaliação nutricional de indivíduos acamados, em 1987, Detsky e colaboradores padronizaram a Avaliação Global Subjetiva (AGS). A AGS, inicialmente, era utilizada apenas para pacientes cirúrgicos, mas atualmente é aplicada em vários outros grupos, incluindo idosos (Detsky et al.,1987; Pereira, 2005).

A AGS é um método simples, de baixo custo, facilmente aplicável, já validado, e pode ser realizado rapidamente à beira do leito. $\mathrm{O}$ método associa informaçóes sobre alteração na ingestão de nutrientes, digestão e absorção, além de efeitos na função e na composição corporal. O questionário, composto por anamnese dirigida e exame físico simplificado, aborda questões referentes a mudanças no peso habitual nos últimos seis meses e nas últimas duas semanas; alterações de hábitos alimentares e sua duração; presença de sintomas e sinais gastrointestinais, como náuseas, vômitos, diarréia e anorexia; avaliação da capacidade funcional. De acordo com o diagnóstico de base do paciente determina-se o grau de demanda metabólica, e o exame físico, realizado por inspeção e palpação, busca identificar mudanças na composição subcutânea, massa muscular e presença de edemas. A classificação da AGS consiste do conceito A, para bem nutrido; B, com suspeita de desnutrição ou moderadamente desnutrido; C, para gravemente desnutrido (Barbosa Silva, 2000).

A AGS pode ser utilizada de maneira seletiva e complementar aos métodos convencionais utilizados para o diagnóstico nutricional de idosos hospitalizados ou institucionalizados. Em estudo realizado em instituições geriátricas dos Estados Unidos utilizando a AGS, identificou-se relação importante com mortalidade e readmissão hospitalar. Além disso, evidenciou-se que, se associada a medidas bioquímicas e antropométricas, a AGS pode melhor determinar a mortalidade e morbidade entre idosos desnutridos residentes em instituições geriátricas (Barbosa Silva, 2000; Pereira, 2005).

Mas o método apresenta limitações. Ele depende do nível de consciência do paciente; baseia-se unicamente em critérios qualitativos, dificultando a detecção de pequenas alterações do estado nutricional; por ser um método subjetivo, sua precisão diagnóstica depende bastante do treinamento do observador; há dificuldades em acompanhar a evolução dos pacientes devido à ausência de critérios quantitativos (Barbosa Silva, 2000; Pereira, 2005). 


\section{Quadro 1 - Métodos conjuntos de avaliação nutricional}

\begin{tabular}{|c|c|c|}
\hline Método & Objetivo & Variáveis \\
\hline \multirow[t]{3}{*}{$\begin{array}{l}\text { Avaliação Nutricional } \\
\text { Subjetiva Global (AGS) }\end{array}$} & \multirow[t]{3}{*}{$\begin{array}{l}\text { Avaliar o risco nutricional de pacientes } \\
\text { cirúrgicos e outras condições clínicas. }\end{array}$} & $\begin{array}{l}\text { Anamnese dirigida: mudança de peso habitual nos últimos seis } \\
\text { meses e duas semanas; alterações de hábitos alimentares; } \\
\text { presença de sintomas e sinais gastrointestinais; capacidade } \\
\text { funcional. }\end{array}$ \\
\hline & & Demanda metabólica. \\
\hline & & $\begin{array}{l}\text { Exame físico - inspeção e palpação: mudanças na composição } \\
\text { subcutânea, massa muscular e edemas. }\end{array}$ \\
\hline \multirow[t]{4}{*}{$\begin{array}{l}\text { Mini-Avaliação Nutricional } \\
\text { (MAN) }\end{array}$} & \multirow[t]{4}{*}{$\begin{array}{l}\text { Facilitar triagem e diagnóstico nutricional } \\
\text { de idosos sob risco de desnutrição. }\end{array}$} & $\begin{array}{l}\text { Antropometria: IMC, \% perda peso, circunferências do braço e } \\
\text { da panturrilha. }\end{array}$ \\
\hline & & $\begin{array}{l}\text { Avaliação global: estilo de vida, mobilidade, uso de } \\
\text { medicamentos, estresse agudo, problemas neuropsicológicos, } \\
\text { entre outros. }\end{array}$ \\
\hline & & $\begin{array}{l}\text { Avaliação dietética: número de refeições, ingestão de alimentos } \\
\text { e líquidos, autonomia para se alimentar. }\end{array}$ \\
\hline & & Auto-avaliação: percepção da saúde e nutrição. \\
\hline \multirow[t]{2}{*}{ Questionário Payette } & \multirow{2}{*}{$\begin{array}{l}\text { Avaliar idosos que apresentam risco } \\
\text { nutricional e necessitam de assistência } \\
\text { nutricional. }\end{array}$} & Antropometria: peso referido e medido, estatura e IMC. \\
\hline & & $\begin{array}{l}\text { Outras questões: perda de peso no último ano, magreza, artrite } \\
\text { que interfira nas atividades diárias, problemas visuais, apetite, } \\
\text { estresse psicológico recente e ingestão usual no desjejum. }\end{array}$ \\
\hline
\end{tabular}

\section{Quadro 1 (continuação)}

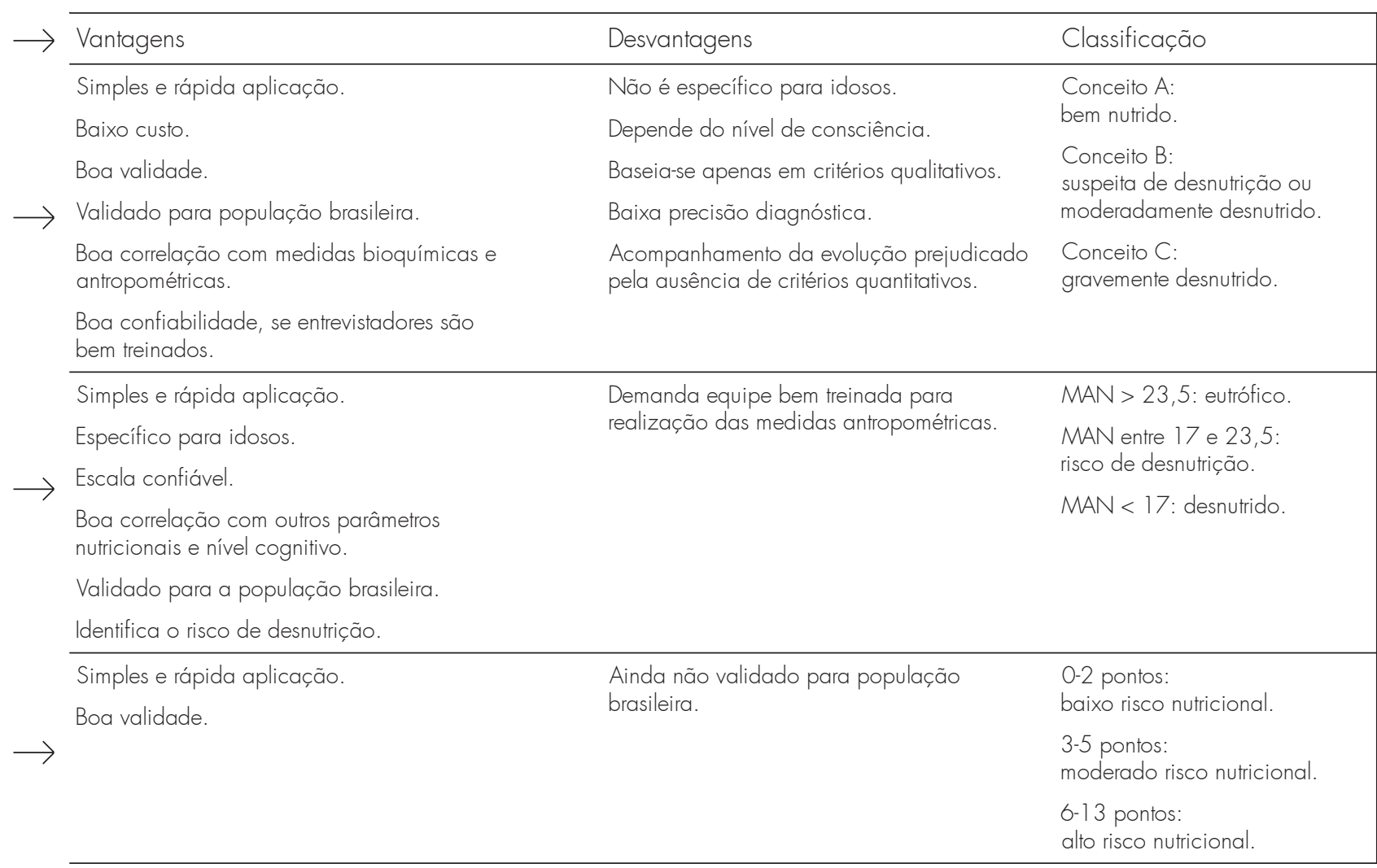




\section{Mini-Avaliação Nutricional (MAN)}

A Mini-Avaliação Nutricional (MAN) tem sido validada e utilizada desde o início da década de 1990, objetivando facilitar a triagem e o diagnóstico nutricional de idosos sob risco de desnutrição (Vellas et al., 1999; Guigoz, 2006). Embora o método tenha sido desenvolvido para idosos doentes, tem sido validado para indivíduos saudáveis (Kuzuya et al., 2005).

O instrumento consiste em perguntas simples e de rápida aplicação, abordando medidas antropométricas (IMC, percentual de perda de peso, circunferência do braço e da panturrilha), avaliação global (estilo de vida, medicaçôes utilizadas, mobilidade, presença de estresse agudo, presença de problemas neuropsicológicos, entre outros), avaliação dietética (número de refeições, ingestão de alimento, ingestão de líquidos e autonomia para alimentar-se sozinho) e auto-avaliação (autopercepção da saúde e nutrição). O método classifica o idoso, conforme os escores, como eutrófico (MAN > 23,5), em risco de desnutrição $(17 \geq \mathrm{MAN} \leq 23,5)$ ou desnutrido $(\mathrm{MAN}<17)$ (Vellas et al., 1999; Guigoz, Lauque \& Vellas, 2002; Coelho \& Fausto, 2002; (Pereira, 2005).

A MAN é um método prático, não invasivo, de rápida aplicação, e apresenta escala confiável. É capaz de detectar melhor o risco de desnutrição e a desnutrição precoce, porque aborda aspectos físicos e mentais que afetam o estado nutricional do idoso, além de apresentar alta correlação com outros parâmetros nutricionais (Vellas et al., 1999, Pereira, 2005; Guigoz, 2006).

Em estudo realizado com idosos japoneses com estado de saúde precário, observou-se boa correlação da MAN com medidas antropométricas e marcadores bioquímicos, incluindo albumina sérica e colesterol total, constatando-se ser este um instrumento útil para determinar o estado nutricional de idosos japoneses frágeis (Kuzuya et al., 2005). Entretanto, outro estudo realizado com idosos hospitalizados de Ottawa, no Canadá, constatou sensibilidade de apenas 57\%, provavelmente devido ao sistema de pontuação, que confere menor importância à perda de peso involuntária, à escala do IMC, além de não utilizar dados bioquímicos (Azad, Murphy \& Amos, 1999).

\section{Questionário de Payette}

O método Payette permite avaliar pessoas idosas que apresentam risco nutricional e necessitam de assistência para adequar sua ingestão alimentar. É um questionário curto, sensível e específico, facilmente aplicável por profissionais da saúde (Robichaud et al., 2000). Foi validado em uma amostra de 145 idosos que recebiam serviços de home care, usando como referência três recordatórios 24 horas não consecutivos. $\mathrm{O}$ instrumento apresentou sensibilidade de $78 \%$ e especificidade de $77 \%$, além de boa precisão para identificar idosos em risco de desnutrição (Payette, 2005).

O questionário consiste em dados antropométricos (peso referido e medido, estatura e IMC), questóes sobre magreza, perda de peso no ano anterior, presença de artrite que interfira nas atividades diárias, problemas de visão, bom apetite, presença de estresse psicológico recente e ingestão usual no desjejum. A cada resposta se atribui uma pontuação, classificando o idoso, ao final, como de baixo risco nutricional (0-2 pontos), de moderado risco nutricional (3-5 pontos) e de alto risco nutricional (6-13 pontos). Para cada classificação, há recomendações específicas: a) baixo risco nutricional - monitorização dos fatores de risco; b) moderado risco nutricional - monitorização da dieta (avaliação da ingestão de alimentos e orientação nutricional); c) alto risco nutricional - aumento da ingestão de alimentos, com orientação para o preparo das refeições e encaminhamento para o nutricionista (Payette, 2005). 


\section{Considerações Finais}

No Brasil, o desconhecimento da situação nutricional na terceira idade diante da nova realidade demográfica do país, caracterizada pelo aumento absoluto e relativo da população de idosos, exige a realização de investigações sistematizadas nesta área. Tais investigações envolvem diversas abordagens. Estas vão desde a questão metodológica de como medir a dieta e da definição de parâmetros antropométricos mais específicos e acurados, passando pelo entendimento do efeito produzido por aquilo que as pessoas comem (ou informam que comem), até a formulação de um modelo biológico relevante que faria um elo da biologia molecular com os dados obtidos em estudos epidemiológicos de base populacional. Somente assim se poderá alcançar um atendimento de melhor qualidade, com enfoque na prevenção de doenças crônicas e na melhora da qualidade de vida dos idosos, principalmente daqueles com processos patológicos já instalados.

\section{Referências}

ACUÑA, K. \& CRUZ, T. Avaliação do estado nutricional de adultos e idosos e situação nutricional da população brasileira. Arquivos Brasileiros de Endocrinologia \& Metabologia, 48(3): 345-361, 2004.

ARBONÉS, G. et al. Nutrición y recomendaciones dietéticas para personas mayores. Grupo de trabajo 'Salud pública’ de la Sociedad Española de Nutrición (SEN). Nutrición Hospitalaria, 18(3): 109-137, 2003.

AZAD, N.; MURPHY, J. \& AMOS, S. S. Nutrition survey in an elderly population following admission to a tertiary care hospital. Canadian Medical Association Journal, 161(5): 511-515, 1999.

BALES, C. W. \& RITCHIE, C. S. The elderly. In: SHILS, M. E. et al. Modern Nutrition in Health and Disease. 10. ed. Philadelphia: Lippincott Williams \& Wilkins, 2006.

BARBOSA SILVA, M. C. G. Avaliação subjetiva global. In: WAITZBERG, D. L. Nutrição Oral, Enteral e Parenteral na Prática Clínica. 3. ed. São Paulo: Atheneu, 2000. v. 1.

BARRETO, S. M.; PASSO, V. M. A. \& LIMA-COSTA, M. F. F. Obesity and under weight among Brazilian elderly: the Bambuí health and aging study. Cadernos de Saúde Pública, 19(2): 605-612, 2003.

BLACKBURN, G. L. \& BISTRAIN, B. R. Nutritional and metabolic assessment of the hospitalized patient. Journal of Parenteral and Enteral Nutrition, 1: 11-22, 1977.

BOTTONI, A. et al. Avaliação nutricional: exames laboratoriais. In: WAITZBERG, D. L. Nutrição Oral, Enteral e Parenteral na Prática Clínica. 3. ed. São Paulo: Atheneu, 2000.

BOUILLANNE, O. et al. Leptin a new biological marker for evaluating malnutrition in elderly patients. European Journal of Clinical Nutrition, 61(5): 647-654, 2006.

BRASIL. Ministério da Saúde. Princípios e Diretrizes de uma Política de Segurança Alimentar e Nutricional. Brasília: MS, 2004.

BRASIL. Ministério da Saúde. Guia Alimentar para a População Brasileira: promovendo a alimentação saudável. Brasília: MS, 2006.

CABRERA, M. A. S. et al. Relação do índice de massa corporal, da relação cintura-quadril e da circunferência abdominal com a mortalidade em mulheres idosas: seguimento de 5 anos. Cadernos de Saúde Pública, 21(3): 767-775, 2005. 
CAMBRAIA, R. P. B. Aspectos psicobiológicos do comportamento alimentar. Revista de Nutrição, 17(2): 217 $225,2004$.

CAMPOS, M. A. G. et al. Estado nutricional e fatores associados em idosos. Revista da Associação Médica Brasileira, 52(4): 214-221, 2006.

CAMPOS, M. T. F. S.; MONTEIRO, J. B. R. \& ORNELAS, A. P. R. C. Fatores que afetam o consumo alimentar e a nutrição do idoso. Revista de Nutrição, 13(3): 157-165, 2000.

CARDOSO, M. R. V. et al. Avaliação do estado nutricional e consumo alimentar de idosos em uma instituição asilar do município de Lavras/MG. Nutrição Brasil, 5(2): 64-69, 2006.

CARVALHO, J. A. M. \& GARCIA, R. A. The aging process in the Brazilian population: a demographic approach. Cadernos de Saúde Pública, 19(3): 725-733, 2003.

CENTERS FOR DISEASE CONTROL (CDC)/PREVENTION NATIONAL CENTER FOR HEALTH STATISTICS (NCHS). National Health and Nutrition Examination Survey (NHANES III). Atlanta: National Heart, Lung and Blood Institute, 1991.

CERVI, A.; FRANCESCHINI, S. C. C. \& PRIORI, S. E. Análise crítica do uso do índice de massa corporal para idosos. Revista de Nutrição, 18(6): 765-775, 2005.

CÉSAR, T. B.; WADA, S. R. \& BORGES, R. G. Zinco plasmático e estado nutricional em idosos. Revista de Nutrição, 18(3): 357-365, 2005.

CHUMLEA, W. C. et al. Prediction of body weight for the nonambulatory elderly from anthropometry. Journal of the American Dietetic Association, 88: 564-568, 1988.

CHUMLEA, W. C. et al. Stature prediction equations for elderly non-Hispanic white, non-Hispnic Black, and Mexican-American persons developed from NHANES III data. Journal of the American Dietetic Association, 98(2): 137-142, 1998.

COELHO, A. K. \& FAUSTO, M. A. Avaliação pelo nutricionista. In: MACIEL, A. Avaliação Multidisciplinar do Paciente Geriátrico. Rio de Janeiro: Revinter, 2002.

COELHO, M. A. S. C. et al. Avaliação da dieta oferecida nos abrigos de idosos do município do Rio de Janeiro. Revista Digital Buenos Aires, 8(49): 10-20, 2002.

DETSKY, S. A. et al. What is subjective global assessment of nutritional status? Journal of Parenteral and Enteral Nutrition, 11: 8-13, 1987.

FOLSTEIN, M. F.; FOLSTEIN, S. E. \& MCHUGH, P. R. Mini-mental state: a practical method for grading the cognitive state of patients for the clinician. Journal of Psychiatric Research, 12: 189-198, 1975.

FRANK, A. A. \& SOARES, E. A. Metodologia aplicada na investigação do perfil nutricional de idosos. In: FRANK, A. A. \& SOARES, E. A. (Orgs.) Nutrição no Envelhecer. São Paulo: Atheneu, 2002.

GALEAZZI, M. A. M.; DOMENE, S. M. A. \& SICHIERI, R. Estudo multicêntrico sobre consumo alimentar. Cadernos de Debate, vol. especial, supl. 47, 1997.

GARIBALLA, S. E. \& SINCLAIR, A. J. Nutrition, aging and ill health. Bristish Journal of Nutrition, 80: 7-23, 1998.

GIBSON, R. S. Principles of Nutritional Assessment. New York: Oxford University Press, 1990. 
GOLLUB, E. A. \& WEDDLE, D. O. Improvements in nutritional intake and quality of life among frail homebound older adults receiving home-delivered breakfast and lunch. Journal of the American Dietetic Association, 104: 1.227-1.235, 2004.

GUIGOZ, Y. The Mini Nutritional Assessment $\left(\mathrm{MNA}^{\circledR}\right)$. Review of the literature: what does it tell us? Journal of Nutrition, Health \& Aging, 10(6): 466-487, 2006.

GUIGOZ, Y.; LAUQUE, S.; VELLAS, B. J. Identifying the elderly at risk for malnutrition: the Mini Nutricional Assessment. Clinics in Geriatric Medicine, 18(4): 737-757, nov. 2002.

HALLER, J. et al. Changes in the vitamin status of elderly Europeans: plasma vitamins A, E, B6, B12, folic acid and carotenoids. Seneca investigators. European Journal of Clinical Nutrition, 50, suppl. 2: S32-S46, 1996.

HARRIS, N. G. Nutrição no envelhecimento In: MAHAN, L. K. \& ESCOTT-STUMP, S. Alimentos, Nutrição e Dietoterapia. São Paulo: Roca, 2005.

INSTITUTO BRASILEIRO DE GEOGRAFIA E ESTATÍSTICA (IBGE). Estudo Nacional de Despesas Familiares: 1974-1975. Rio de Janeiro: IBGE, 1977.

INSTITUTO BRASILEIRO DE GEOGRAFIA E ESTATÍSTICA (IBGE). Pesquisa sobre Padrões de Vida: 19961997. Rio de Janeiro: IBGE, 1998.

INSTITUTO BRASILEIRO DE GEOGRAFIA E ESTATÍSTICA (IBGE). Coordenação de Índices de Preços. Pesquisa de Orçamentos Familiares 2002-2003: primeiros resultados. Brasil e grandes regiōes. Rio de Janeiro: IBGE, 2004a.

INSTITUTO BRASILEIRO DE GEOGRAFIA E ESTATÍSTICA. Pesquisa Nacional por Amostra de Domicílios, PNAD. Rio de Janeiro: IBGE, 2004b.

INSTITUTO NACIONAL DE ALIMENTAÇĀO E NUTRIÇÃO (INAN). Pesquisa Nacional sobre Saúde e Nutrição, PNSN, 1989 - Arquivo de Dados da Pesquisa. Brasília: Inan/Ministério da Saúde, 1990.

KAMIMURA, M. A. et al. Avaliação nutricional. In: CUPPARI, L. Nutrição: nutrição clínica no adulto. São Paulo: Manole, 2002.

KUCZMARSKI, M. F.; KUCZMARSKI, R. J. \& NAJJAR, M. Descriptive anthropometric reference data for older Americans. Journal of the American Dietetic Association, 100(1): 59-66, 2000.

KUZUYA, M. et al. Evaluation of Mini-Nutritional Assessment for Japanese frail elderly. Nutrition, 21: 498503, 2005.

LANDI, F. et al. Body mass index and mortality among hospitalized patients. Archives of Internal Medicine, 160(17): 2.641-2.644, 2000.

LANZILLOTTI, H. S. et al. Osteoporose em mulheres na pós-menopausa, cálcio dietético e outros fatores de risco. Revista de Nutrição, 16(2): 181-193, 2003.

LIMA-COSTA, M. F. et al. Desigualdade social e saúde entre idosos brasileiros: um estudo baseado na Pesquisa Nacional por Amostra de Domicílios. Cadernos de Saúde Pública, 19(3): 745-757, 2003.

LIPSCHITZ, D. A. Screening for nutritional status in the elderly. Primary Care, 21(1): 55-67, 1994.

LOPES, A. C. S. et al. Consumo de nutrientes em adultos e idosos em estudo de base populacional: Projeto Bambuí. Cadernos de Saúde Pública, 21(4): 1.201-1.209, 2005. 
MACMILLAN, A. S. \& WONG, M. C. M. Emotional effects of tooth loss in community-dwelling elderly people in Hong Kong. International Journal ou Prosthodontics, 17(2): 172-176, 2004.

MCNEILL, G. et al. Predictors of micronutrient status in men and women over 75 years old living in the community. British Journal of Nutrition, 88(5): 555-561, 2002.

MARCENES, W. et al. The relationship between dental status, food selection, nutrient intake, nutritional status, and body mass index in older people. Cadernos de Saúde Pública, 19(3): 809-816, 2003.

MARÍN-LEÓN, L. et al. A percepção de insegurança alimentar em famílias com idosos em Campinas, São Paulo, Brasil. Cadernos de Saúde Pública, 21(5): 1.433-1.440, 2005.

MENDOZA-NÚNEZ, V. M. et al. Equations for predicting height for elderly Mexican Americans are not applicable for elderly Mexicans. American Journal Human Biology, 14: 351-355, 2002.

MENEZES, T. N. \& MARUCCI, M. F. N. Oferta e consumo alimentar de idosos residentes em instituições geriátricas: diferenças no valor energético total. Fortaleza/Ceará. Nutrire, 31(2): 1-11, 2006.

MENEZES, T. N.; MARUCCI, M. F. N. \& HOLANDA, I. M. M. Ingestão de cálcio e ferro alimentar por idosos residentes em instituições geriátricas de Fortaleza, CE. Revista Saúde.com, 1(2): 100-109, 2005.

NAJAS, M. S. et al. Padrão alimentar de idosos de diferentes estratos socioeconômicos residentes em localidade urbana da região Sudeste, Brasil. Revista de Saúde Pública, 28(3): 187-191, 1994.

PAYETTE, H. Nutrition as a determinant of functional autonomy and quality of life in aging: a research program. Canadian Journal of Physiology and Pharmacology, 83: 1.061-1.070, 2005.

PEREIRA, C. A. Avaliação nutricional na terceira idade. In: MAGNONI, D.; CUKIER, C. \& OLIVEIRA, P. A. Nutrição na Terceira Idade. São Paulo: Sarvier, 2005.

PERISSINOTTO, E. et al. Anthropometric measurements in the elderly: age and gender differences. Bristish Journal of Nutrition, 87: 177-186, 2002.

ROBICHAUD, L. et al. A preventive program for community-dwelling elderly risk of functional decline: a pilot study. Archives of Gerontology and Geriatrics, 30: 73-84, 2000.

ROUBENOFF, R. et al. Journal of Gerontology: medical sciences, 55: M757-60, 2000.

RUGG-GUNN, A. J. Nutrition, diet and oral health. Journal of the Royal College of Surgeons of Edinburgh, 46(6): 320-328, 2001.

SANTOS, D. M. \& SICHIERI, R. Índice de Massa Corporal e indicadores antropométricos de adiposidade em idosos. Revista de Saúde Pública, 39(2): 163-168, 2005.

SANTOS, L. C. et al. Indicadores do estado nutricional de idosos institucionalizados. Nutrição Brasil, 3(3): 168$173,2004$.

SIVIERO, J. et al. Aspectos relacionados ao hábito alimentar e estilo de vida de idosos acima de 80 anos e de seus familiares cuidadores em Veranópolis, RS. Revista de Medicina da PUCRS, 12(4): 342-350, 2002.

TAVARES, E. L. \& ANJOS, L. A. Perfil antropométrico da população idosa brasileira. Resultados da PNSN. Cadernos de Saúde Pública, 15(4): 759-768, 1999.

TORAL, N.; GUBERT, M. B. \& SCHMITZ, B. A. S. Perfil da alimentação oferecida em instituições geriátricas do Distrito Federal. Revista de Nutrição, 19(1): 29-37, 2006. 
VELÁSQUEZ-MELÉNDEZ, G. et al. Consumo alimentar de vitaminas e minerais em adultos residentes em área Metropolitana de São Paulo, Brasil. Revista de Saúde Pública, 31(2): 157-162, 1997.

VELLAS, B. et al. The Mini-Nutritional Assesment (MNA) and its use in grading the nutritional state of elderly patients. Nutrition, 15(2): 116-122, 1999.

WAITZBERG, D. L. \& FERRINI, M. T. Exame físico e antropometria. In: WAITZBERG, D. L. (Org.) Nutrição Oral, Enteral e Parenteral na Prática Clínica. 3. ed. São Paulo: Atheneu, 2000.

WENGREEN, H. J. et al. Comparison of a picture-sort food-frequency questionnaire with 24-hour dietary recalls in an elderly Utah population. Public Health Nutrition, 4(5): 961-970, 2001.

WORLD HEALTH ORGANIZATION (WHO). Physical Status: the use and interpretation of anthropometry. Report of a WHO expert committee. Geneva: WHO, 1995.

WORLD HEALTH ORGANIZATION (WHO). Obesity: preventing and managing the global epidemic of obesity. Report of the WHO Consultation. Geneva: WHO, 1997.

WORLD HEALTH ORGANIZATION (WHO). Management of Severe Malnutrition: a manual for physicians and other senior health workers. Geneva: WHO, 1999. 



\title{
Indicadores Bioquímicos na Avaliação do Estado Nutricional
}

\author{
Nádia M. F. Trugo e Alexandre G. Torres
}

\begin{abstract}
$\mathrm{I}$ ndicadores bioquímicos, assim como indicadores funcionais e clínicos, que estão relacionados com a ingestão e metabolismo de componentes de alimentos (nutrientes e não-nutrientes) são utilizados na epidemiologia nutricional como biomarcadores de exposição e de estado nutricional. Como o estado nutricional é dinâmico e resulta direta ou indiretamente da ingestão alimentar, os indicadores bioquímicos de estado podem ser usados para representar a exposição recente ou de longo prazo (habitual) a um determinado nutriente. Porém, ao passo que para alguns nutrientes pode-se estabelecer uma associação entre os indicadores bioquímicos de estado nutricional e a ingestão, para muitos nutrientes não existe uma associação clara. Em contrapartida, alguns biomarcadores refletem adequadamente a ingestão de nutrientes, mas não são bons indicadores de estado nutricional. A seleção de indicadores bioquímicos a serem utilizados em estudos de epidemiologia nutricional deve ser feita em função das questões específicas a serem investigadas, uma vez que para cada nutriente pode haver vários indicadores de estado, mas cada um deles pode estar se referindo a diferentes aspectos do metabolismo e utilização pelo organismo daquele nutriente em particular.

Os indicadores bioquímicos representam medidas objetivas de estado nutricional que, diferentemente de métodos de avaliação do consumo alimentar por meio de inquéritos alimentares (capítulos 10 e 11), não estão sujeitos a vieses na entrevista e na obtenção de dados. No entanto, os métodos bioquímicos também apresentam limitações e podem estar sujeitos a erros. A escolha entre os diferentes métodos depende do nutriente cuja exposição será avaliada, mas geralmente a complementação de métodos dietéticos e bioquímicos pode fornecer informações mais completas e abrangentes.

Neste capítulo serão abordados o uso de indicadores bioquímicos na avaliação do estado nutricional e as aplicações de indicadores bioquímicos e de outros biomarcadores relevantes na epidemiologia nutricional.

\section{Indicadores Bioquímicos na Avaliação de Estado Nutricional}

\section{Indicadores Bioquímicos Estáticos e Funcionais}

A compreensão do significado biológico dos indicadores bioquímicos de estado nutricional depende do conhecimento da função e da utilização (absorção, transporte, metabolismo e excreção) do nutriente no organismo. Os indicadores bioquímicos podem representar diferentes níveis de nutrição, que variam desde um estado
\end{abstract}


ótimo, quando há amplas reservas no organismo, até um estado de deficiência clinicamente manifesta, quando estão presentes alteraçôes morfológicas e funcionais e sinais e sintomas clínicos característicos da deficiência. O extremo oposto, representado por níveis excessivos ou tóxicos de nutrientes, pode também ser avaliado por indicadores bioquímicos. A evolução da deficiência de nutrientes no organismo até a deficiência clínica passa por níveis intermediários de depleção característicos do estado subadequado, também chamado de marginal ou subclínico.

A velocidade com que ocorre a depleção nutricional e os diferentes níveis de depleção variam para cada nutriente, dependendo dos mecanismos homeostáticos e adaptativos que controlam sua utilização no organismo, do tamanho das reservas, da gravidade do decréscimo da ingestão ou da privação alimentar, do aumento da necessidade por modificação do estado fisiológico (crescimento, gestação, lactação) e de perdas por doenças.

Para alguns nutrientes, há conhecimento suficiente e métodos disponíveis para determinar um ou mais indicadores, correspondentes a um ou mais níveis de estado nutricional, como é o caso do folato e do ferro. No entanto, para vários outros nutrientes isso ainda não é possível, devido a limitações técnicas e/ou de conhecimento. Os níveis de depleção do estado nutricional de ferro e de folato e seus indicadores serão usados adiante como exemplos do uso de indicadores bioquímicos na avaliação do estado nutricional.

Vantagens importantes do uso de indicadores bioquímicos na avaliação da exposição e do estado nutricional são a possibilidade de determinar efeitos da exposição ao nutriente a curto, médio e longo prazos e a detecção de estados marginais em um ou mais estágios de depleção. Os estados nutricionais marginais são geralmente mais prevalentes do que estados de deficiência clínica e podem estar relacionados com uma série de alteraçôes funcionais que representam uma situação desvantajosa para o organismo. Além disso, a capacidade de alguns indicadores para identificar estados marginais contribui para o entendimento de sua participação no desenvolvimento de doenças crônicas. A combinação de dois ou mais indicadores bioquímicos é desejável para a avaliação do estado nutricional e fornece informaçôes mais completas e precisas.

Os indicadores bioquímicos de estado nutricional podem ser classificados como "estáticos" ou "funcionais" (Solomons, 2003). Na avaliação de estado de um determinado nutriente no organismo, os indicadores bioquímicos funcionais e estáticos podem representar um mesmo nível ou diferentes níveis de estado nutricional.

Os indicadores bioquímicos estáticos compreendem a avaliação quantitativa do teor de um nutriente, de seus metabólitos ou de outros componentes relacionados (proteínas de reserva ou de transporte, complexos macromoleculares), os quais representam adequadamente concentrações teciduais ou reservas do nutriente no organismo (Fidanza, 1999). Esses indicadores são determinados em amostras de sangue (sangue integral, plasma ou soro, eritrócitos, leucócitos, plaquetas), principalmente, e também em urina, unhas, cabelos e outros tecidos, como, por exemplo, o tecido adiposo. A escolha do tipo de amostra depende da informação que se pretende obter (estado recente ou de longo prazo, reservas, pool disponível para troca, entre outros) e também do nutriente de interesse, pois o mesmo tipo de amostra pode não fornecer a mesma informação para diferentes nutrientes.

Os indicadores funcionais representam uma categoria mais ampla, que inclui as funçôes bioquímicas de um nutriente e funções comportamentais e fisiológicas do organismo, as quais não só dependem da disponibilidade adequada do nutriente, mas resultam de uma integração mais abrangente de processos homeostáticos, de sistemas e de distribuição do nutriente no organismo como um todo. Podem ser classificados de acordo com o sistema que está sendo avaliado (hemodinâmica, integridade estrutural, transporte, imunidade, funcionamento do sistema nervoso, biologia reprodutiva, capacidade física) ou por tipo de teste (testes in vivo e in vitro de funçōes, respostas induzidas e testes de sobrecarga, atividades e respostas espontâneas de órgãos e tecidos, testes de desempenho) (Solomons, 2003).

Alguns indicadores funcionais, assim como os indicadores bioquímicos estáticos, requerem análises bioquímicas em amostras biológicas e, portanto, podem ser classificados como indicadores bioquímicos funcionais. 
Grande parte dos indicadores funcionais é de indicadores não bioquímicos, não invasivos, o que representa uma grande vantagem em relação aos testes bioquímicos estáticos e funcionais, que, na sua maioria, dependem da obtenção de amostras de sangue. Contudo, os indicadores funcionais não bioquímicos podem apresentar várias limitações, tais como baixa especificidade, maior dificuldade em estabelecer faixas de normalidade, dificuldade de interpretação e maior influência de variáveis de confusão (Fidanza, 1999). Neste capítulo, serão abordados somente os indicadores funcionais bioquímicos, os quais refletem a integridade de um sistema bioquímico ou processo fisiológico que é dependente do nutriente de interesse. Os testes bioquímicos funcionais geralmente envolvem a determinação de atividade de enzimas e de metabólitos que participam das vias nas quais o nutriente desempenha alguma função. Testes bioquímicos funcionais baseados em técnicas de biologia molecular poderão constituir uma nova abordagem com potencial para aplicação na avaliação do estado nutricional, como, por exemplo, expressão de enzimas ou proteínas dependente de nutrientes, expressão de proteínas reguladoras da homeostasia e modulação nutricional de elementos reguladores da expressão gênica (Solomons, 2003).

Uma das principais dificuldades do uso de indicadores bioquímicos na avaliação do estado nutricional é a definição das faixas de normalidade para cada indicador. Para alguns indicadores, essas faixas podem estar bem definidas, com base em evidências científicas, ao passo que para a maioria das outras existem definições apenas tentativas. Para muitos, não há consenso. Uma vez conhecida a distribuição dos valores de um indicador para uma população saudável e com estado nutricional adequado, estabelecem-se estatisticamente os pontos de corte para os valores que representem excesso ou deficiência. Esses valores de referência podem ainda variar de acordo com a faixa etária, estado fisiológico, gênero e características genéticas, e ter sido estabelecidos apenas para uma ou algumas dessas situações. A determinação de indicadores bioquímicos e sua aplicação para avaliação do estado nutricional estão em constante evolução, em função do aprofundamento do conhecimento sobre a função e utilização de nutrientes no organismo e do desenvolvimento e aperfeiçoamento de métodos analíticos. Dessa forma, as faixas de normalidade e os pontos de corte estão sujeitos a constantes reavaliações.

Exemplos de testes bioquímicos estáticos e funcionais para avaliação do estado nutricional, para diferentes nutrientes, são apresentados na Tabela 1 e no Quadro 1, respectivamente.

Tabela 1 - Principais indicadores bioquímicos estáticos de nutrientes selecionados e seus níveis de referência mais utilizados na avaliação do estado nutricional ${ }^{a}$

\begin{tabular}{|c|c|c|c|c|}
\hline Nutriente & Indicador (unidade) & Aceitável & $\begin{array}{l}\text { Risco moderado } \\
\text { de deficiência }\end{array}$ & $\begin{array}{c}\text { Alto risco de } \\
\text { deficiência }\end{array}$ \\
\hline Vitamina A & Retinol plasma ou soro $(\mu \mathrm{mol} / \mathrm{L})$ & $>0,70$ & $0,35-0,70$ & $<0,35$ \\
\hline Vitamina D & 25-hidroxicolecalciferol soro (nmol/L) & - & - & $<12,5$ \\
\hline \multirow{2}{*}{ Vitamina $\mathrm{E}$} & $\alpha$-tocoferol plasma ou soro $(\mu \mathrm{mol} / \mathrm{L})$ & $>16,2$ & $11,6-16,2$ & $<11,6$ \\
\hline & $(\mu \mathrm{mol} / \mathrm{mmol} \text { colesterol) })^{b}$ & - & - & $<2,2$ \\
\hline Tiamina & Tiamina urina $(\mu \mathrm{g} / 24 \mathrm{~h})$ & $>66$ & $27-66$ & $<27$ \\
\hline Riboflavina & Riboflavina urina ( $\mu \mathrm{g} / \mathrm{g}$ creatinina) & $>80$ & $27-80$ & $<27$ \\
\hline Biotina & Biotina plasma (nmol/L) & $>1,0$ & $0,5-1,0$ & $<0,5$ \\
\hline \multirow{2}{*}{ Folato } & Folato plasma ou soro $(\mathrm{nmol} / \mathrm{L})^{c}$ & $>11$ & $6,8-11$ & $<6,8$ \\
\hline & Folato eritrócitos $(\mathrm{nmol} / \mathrm{L})^{\mathrm{c}}$ & $>360$ & $315-360$ & $<315$ \\
\hline \multirow{2}{*}{ Vitamina $B_{12}$} & Cobalamina plasma ou soro (pmol/L) & $>150$ & $110-150$ & $<110$ \\
\hline & Transcobalamina soro (pmol/L) & - & - & $<15$ \\
\hline
\end{tabular}


Tabela 1 - Principais indicadores bioquímicos estáticos de nutrientes selecionados e seus níveis de referência mais utilizados na avaliação do estado nutricional ${ }^{a}$ (continuação)

\begin{tabular}{|c|c|c|c|c|}
\hline Nutriente & Indicador (unidade) & Aceitável & $\begin{array}{l}\text { Risco moderado } \\
\text { de deficiência }\end{array}$ & $\begin{array}{l}\text { Alto risco de } \\
\text { deficiência }\end{array}$ \\
\hline \multirow{2}{*}{ Vitamina C } & Ácido ascórbico plasma $(\mu \mathrm{mol} / \mathrm{L})$ & $>17,0$ & $11,4-17,0$ & $<11,4$ \\
\hline & Ácido ascórbico sangue $(\mu \mathrm{mol} / \mathrm{L})$ & $>28$ & $17-28$ & $<17$ \\
\hline \multirow{3}{*}{ Ferro } & Ferritina soro ou plasma $(\mu \mathrm{g} / \mathrm{L})$ & $>100$ & $<20$ & $<12$ \\
\hline & Ferro soro $(\mu \mathrm{mol} / \mathrm{L})$ & - & $<20,0$ & $<10,7$ \\
\hline & $\begin{array}{l}\text { Capacidade total de ligação de } \\
\text { ferro soro }(\mu \mathrm{mol} / \mathrm{L})\end{array}$ & - & - & $<71,6$ \\
\hline Zinco & Zinco plasma $(\mu \mathrm{mol} / \mathrm{L})$ & $9-22$ & & $<9,0$ \\
\hline \multirow{2}{*}{ Cobre } & Cobre soro ou plasma $(\mu \mathrm{mol} / \mathrm{L})$ & $13-22$ & & \\
\hline & Ceruloplasmina $(\mu \mathrm{mol} / \mathrm{L})$ & $2-4$ & & \\
\hline \multirow{2}{*}{ Selênio } & Selênio plasma $(\mu \mathrm{mol} / \mathrm{L})$ & $0,76-1,52$ & $0,63-0,75$ & $0,25-0,38$ \\
\hline & Selênio eritrócitos ( $\mu \mathrm{mol} / \mathrm{L})$ & $1,13-2,41$ & & $\sim 0,45$ \\
\hline
\end{tabular}

Fontes: adaptada de a - Fidanza (1999) e Van den Berg et al. (1993); b - Thurnham et al. (1986); c - Bailey et al. (2001).

Quadro 1 - Exemplos de indicadores bioquímicos funcionais de nutrientes selecionados e classificação de acordo com o tipo de teste utilizado na avaliação do estado nutricional

\begin{tabular}{|c|c|c|}
\hline Tipo de teste & Nutriente & Indicador \\
\hline \multirow{5}{*}{$\begin{array}{l}\text { Atividades enzimáticas: } \\
\text { resposta à adição } \\
\text { de co-fatores }^{a}\end{array}$} & Tiamina & Transcetolase em eritrócitos (tiamina pirofosfato) \\
\hline & Piridoxina & Transaminases em eritrócitos (piridoxal-5-fosfato) \\
\hline & Riboflavina & Glutatião redutase em eritrócitos (FAD) \\
\hline & Zinco & Fosfatase alcalina em soro \\
\hline & Selênio & Glutatião peroxidase em eritrócitos \\
\hline \multirow{3}{*}{$\begin{array}{l}\text { Metabólitos ou componentes cujos } \\
\text { níveis podem ser alterados pela } \\
\text { deficiência do nutriente }{ }^{b}\end{array}$} & $\begin{array}{l}\text { Folato (também cobalamina } \\
\text { e/ou piridoxina) }\end{array}$ & Aumento da homocisteína em plasma ou soro \\
\hline & Folato & $\begin{array}{l}\text { Aumento da excreção de ácido formiminoglutâmico na } \\
\text { urina após teste de sobrecarga com histidina }\end{array}$ \\
\hline & Vitamina $B_{12}$ & $\begin{array}{l}\text { Aumento de ácido metilmalônico em plasma (ou soro) } \\
\text { e na urina após teste de sobrecarga com valina }\end{array}$ \\
\hline Integridade estrutural & Vitamina $E$, selênio & Fragilidade de eritrócitos (grau de hemólise) \\
\hline \multirow[t]{2}{*}{ Miscelânea } & Folato & $\begin{array}{l}\text { Teste de supressão da deoxiuridina em células da } \\
\text { medula óssea ou em linfócitos }\end{array}$ \\
\hline & Retinol & $\begin{array}{l}\text { Dose-resposta relativa; dose-resposta relativa } \\
\text { modificada (di-hidroxi retinol) }\end{array}$ \\
\hline
\end{tabular}

a - Aumento na atividade in vitro acima de um determinado valor de atividade, em relação ao valor inicial, pode ser indicativo de deficiência.

b - Função dependente do nutriente em questão ou relacionada com a regulação homeostática das reservas do nutriente.

Fontes: baseado em Solomons (2003) e Fidanza (2003). 
Os pontos de corte relacionados na tabela são aqueles mais utilizados na interpretação do estado nutricional de indivíduos adultos e sobre os quais há maior consenso. Esses valores podem ser diferentes para diferentes faixas etárias e conforme gênero, gestação e lactação, dependendo do nutriente e do indicador. A sensibilidade do indicador e a exatidão de seus valores de referência variam bastante para cada nutriente.

\section{Fatores Relacionados com a Utilização de Métodos Bioquímicos na Avaliação Nutricional}

Os métodos bioquímicos para avaliação do estado nutricional são considerados bastante objetivos, pois comparados aos métodos de avaliação de consumo alimentar, principalmente por meio de inquéritos alimentares, não são afetados pela qualidade da informação obtida nas entrevistas.

No entanto, vários fatores podem afetar os indicadores bioquímicos e devem ser identificados e controlados nas análises estatísticas. Esses fatores podem ser biológicos, tais como idade, gênero, características genéticas, estado fisiológico e hormonal, interação metabólica com outros nutrientes, infecções e processos inflamatórios. Podem também ser fatores ambientais/comportamentais, tais como alcoolismo, tabagismo e contaminação ambiental (Hunter, 1998; Potischman, 2003).

Além disso, fatores de natureza técnica relacionados com a coleta, manuseio e análise em laboratório das amostras contribuem para a variabilidade dos resultados obtidos com o uso de indicadores bioquímicos (Hunter, 1998). A redução ou eliminação desses fatores permite não somente o decréscimo da variabilidade como também uma interpretação correta dos resultados, e deve ser alcançada por uma adequada padronização e controle de métodos em todas as etapas, desde a coleta de amostras até a análise laboratorial (Blanck et al., 2003).

A escolha do indicador bioquímico e do método de análise laboratorial deve levar em conta sua 'especificidade', a 'sensibilidade' e a 'representatividade'.

$\mathrm{Na}$ avaliação de uma resposta de indicador bioquímico à ingestão de um nutriente e à variação do estado nutricional do indivíduo, a sensibilidade corresponde à capacidade de variação dos níveis do indicador no organismo em função das variações na ingestão e no nível de estado nutricional, respectivamente, ao passo que a especificidade está relacionada com uma resposta específica, ou seja, para aferi-la é preciso que a variação dos níveis do indicador do nutriente no organismo não responda também a outros nutrientes e componentes de alimentos e outros fatores de confusão (Hunter, 1998).

Em termos laboratoriais, a sensibilidade de um método é definida como a modificação da resposta em função da modificação na concentração, na quantidade absoluta ou na propriedade da substância analisada (analito). Métodos sensíveis também apresentam baixos limites de detecção, ou seja, a menor concentração ou quantidade absoluta do analito que pode ser detectada com certeza razoável. A exatidão de um método pode ser definida como a fidedignidade com a qual este mede a quantidade do analito. Já a sua especificidade define a capacidade de análise do analito, especialmente na presença de outros analitos com propriedades químicas semelhantes ou de substâncias que podem nele interferir. A especificidade do método analítico pode afetar tanto sua precisão quanto sua exatidão. Métodos laboratoriais analíticos modernos, com alta sensibilidade, especificidade, precisão e exatidão, estão atualmente disponíveis para a determinação de uma ampla gama de indicadores bioquímicos.

Os valores de referência (faixas de normalidade e pontos de corte) dos indicadores bioquímicos na avaliação do estado nutricional devem ser representativos da população em estudo e deveriam, idealmente, ser estabelecidos para essa população (Hunter, 1998). Entretanto, tal nível de representatividade não é viável na maior parte dos estudos. A avaliação do estado nutricional do indivíduo e de populaçóes muitas vezes é feita por comparação com os valores de referência conhecidos para outras populações que apresentem características o 
mais próximas possível daquelas da população em estudo. No caso de populações, pode-se estabelecer o desvio da distribuição em relação à população de referência ou à prevalência de indivíduos cujos valores estão abaixo ou acima dos pontos de corte.

Uma vez definidos o indicador bioquímico e o método analítico laboratorial que serão utilizados, devese tomar vários cuidados, desde a coleta de amostras até a análise laboratorial, para evitar degradação do componente a ser medido, interferência de outros compostos e erros analíticos, que irão comprometer os resultados e sua interpretação.

Os protocolos de coleta, transporte, armazenamento e manuseio das amostras devem ser padronizados. Tais procedimentos devem ser cuidadosamente planejados, levando-se em conta o tipo de amostra (sangue, urina e outros), a estabilidade dos componentes a serem medidos e a interferência de outros compostos (Blanck et al., 2003; Potischman, 2003; Wild et al., 2001). Para alguns nutrientes, como o folato, a vitamina A e os carotenóides, a proteção contra exposição à luz é essencial. Os nutrientes antioxidantes (vitaminas $\mathrm{C}$ e E, carotenóides), a vitamina $\mathrm{A}$ e os ácidos graxos insaturados são passíveis de degradação por oxidação na presença de oxigênio molecular. Dessa forma, a armazenagem de amostras para análise futura de tais componentes deve ser feita com a presença de um antioxidante (como o $\mathrm{BHT}$ e/ou o pirogalol) e em atmosfera de nitrogênio. Para a dosagem de elementos-traço (por exemplo, zinco, selênio, ferro) e ácidos graxos, cujas concentrações em fluidos biológicos é baixa e/ou a possibilidade de contaminação externa é alta, deve-se proceder à lavagem apropriada e escolha adequada do tipo do material a ser utilizado para evitar a contaminação e também a interferência de outros componentes que possam prejudicar a análise. A estabilidade térmica dos componentes a serem medidos (vitaminas, proteínas e enzimas de maneira geral) também deve ser levada em consideração e, portanto, a temperatura na qual as amostras são recolhidas, armazenadas e manuseadas também deve ser adequada. A armazenagem de amostras em baixas temperaturas também reduz a perda de componentes suscetíveis à oxidação. Quando há variação sazonal na disponibilidade de alimentos, as amostras dos casos e dos controles deverão ser obtidas simultaneamente. No caso dos biomarcadores cujas concentraçóes no sangue ou na urina variam ao longo do dia, as amostras devem ser obtidas pela manhã, após jejum noturno. Em alguns casos, a coleta do volume total de urina produzido durante um período de 24 horas é mais indicada. Quando não for possível adotar esses procedimentos, deve-se controlar o momento da coleta.

\section{Uso de Indicadores Bioquímicos na Avaliação do Estado de Folato e Ferro}

\section{Folato}

O folato, sob a forma de diferentes coenzimas, atua em reações de transferência de unidades de carbono (metil, formil, metenil), que são essenciais para a metilação de biomoléculas (proteínas, DNA, RNA, fosfolipídios), a síntese de nucleotídeos e a interconversão de aminoácidos (Bailey et al., 2001).

Os estágios seqüenciais da deficiência de folato no organismo humano e os diferentes indicadores que podem representar cada um desses estágios já estão bem definidos (Herbert, 1999). No início da depleção, que corresponde a um balanço negativo de folato, porém com reservas teciduais ainda adequadas, há decréscimo da concentração de folato no soro (plasma também é usado). Com a continuidade do balanço negativo, as reservas decrescem e há diminuição da concentração de folato em eritrócitos, que ocorre paralelamente à depleção de folato no fígado, o principal órgão de reserva de folato no organismo. Ambos, folato no plasma e em eritrócitos, são indicadores bioquímicos estáticos. Paralelamente, há aumento da excreção urinária de Formimino-glutamato (Figlu) após uma dose oral de sobrecarga de histidina. O Figlu é um metabólito intermediário da conversão de histidina em glutamato, dependente de folato. Este indicador funcional, no entanto, não é específico para a 
deficiência de folato, pois uma percentagem dos pacientes deficientes em vitamina $B_{12}$ também apresenta elevada excreção de Figlu.

Com o avanço da deficiência, há prejuízos metabólicos e funcionais que podem ser representados por alteraçôes em indicadores funcionais, como a hipersegmentação (aumento do número médio de lobos) dos neutrófilos e valores anormais no teste de supressão da incorporação do uridilato ao DNA pelo timidilato em suspensão ou cultura de células. Esses primeiros estágios são considerados marginais ou subclínicos. Com o agravamento da depleção, pode ocorrer deficiência clínica, que é classicamente caracterizada pela anemia megaloblástica, com o baixo nível de hemoglobina no sangue acompanhado pelo aumento do volume corpuscular médio, devido ao aumento do volume dos eritrócitos (macrocitose). A anemia megaloblástica também ocorre na deficiência de vitamina $\mathrm{B}_{12}$, e suas características hematológicas são indistinguíveis da deficiência de folato. O diagnóstico diferencial deve ser feito por meio dos indicadores bioquímicos específicos para cada uma dessas vitaminas.

As concentrações de folato no soro ou plasma e em eritrócitos são os indicadores mais utilizados para avaliação do estado nutricional quanto ao folato. $\mathrm{O}$ folato no soro reflete melhor o balanço de folato a curto prazo (cerca de 1 a 2 dias) e, portanto, flutua mais com a ingestão recente. Entretanto, o folato em eritrócitos reflete a sua disponibilidade para incorporação celular durante a hematopoiese e representa uma integração de sua ingestão por um período mais prolongado, cerca de 120 dias precedentes, o que corresponde à meia-vida dos eritrócitos. Dessa forma, o folato em eritrócitos é considerado um melhor indicador de estado do que o folato no soro, porque é mais representativo do folato nos tecidos (Mason, 2003).

Os pontos de corte classicamente empregados para caracterizar deficiência de folato são as concentrações abaixo de $3 \mathrm{ng} / \mathrm{ml}(6,8 \mathrm{nmol} / \mathrm{L})$ para folato no soro e de $140 \mathrm{ng} / \mathrm{ml}(315 \mathrm{nmol} / \mathrm{L})$ para folato em eritrócitos, que são bons preditores do risco de anemia, ao passo que concentraçôes de 3 a 4,8 ng/ml (11 nmol/L) e de 140 a 160 $\mathrm{ng} / \mathrm{ml}(360 \mathrm{nmol} / \mathrm{L})$, respectivamente, são consideradas deficiência marginal (Bailey et al., 2001). No entanto, há um consenso crescente de que esses pontos de corte provavelmente deverão ser modificados e que indicadores atualmente promissores deverão ser validados, ou que novos indicadores e métodos devem ser desenvolvidos para avaliar o estado de folato (Mason, 2003). Alteraçôes mais sutis no estado de folato têm conseqüências funcionais e clínicas importantes, e o que atualmente se considera como deficiência marginal de folato, que é mais prevalente do que a anemia megaloblástica, pode ser redefinido.

Um indicador funcional para avaliação do estado de folato que atualmente desperta muito interesse é a concentração de homocisteína no soro ou em plasma. Embora seja um indicador sensível, não é um indicador específico para o estado de folato. A elevação da concentração de homocisteína sérica ou plasmática é um indicador não só da depleção de folato como também de vitamina $\mathrm{B}_{12}$ (McKinley, 2000; Selhub, 2006), porque ambos participam como cofatores na reação de remetilação da homocisteína à metionina. $\mathrm{O}$ aumento da concentração de homocisteína pode ocorrer antes que as concentrações de folato no plasma e em eritrócitos e a concentração de vitamina $\mathrm{B}_{12}$ no plasma decresçam para os valores considerados indicativos de deficiência (McKinley, 2000; Refsum et al., 2006).

A concentração de homocisteína é inversamente relacionada com a concentração de folato no plasma, mesmo quando os níveis de folato variam em uma faixa considerada adequada (Refsum et al., 2006; Rosa, Pereira \& Trugo, 2004). Outros determinantes do aumento da homocisteína, tais como insuficiência renal crônica, hipertensão, consumo elevado de álcool e cafeína, tabagismo, idade ( $>55$ anos) e estado de vitamina $\mathrm{B}_{6}$ (Refsum et al., 2006), devem ser controlados quando se pretende avaliar o estado de folato utilizando a concentração de homocisteína. Contudo, faixas normativas de referência e pontos de corte de concentração de homocisteína para caracterizar deficiência de folato não foram ainda claramente estabelecidos. Neste caso, esses parâmetros podem ser diferentes daqueles utilizados para definir hiperhomocisteinemia como fator de risco para doenças cardiovasculares oclusivas. 
Polimorfismos nos genes que codificam enzimas envolvidas no metabolismo do folato podem influenciar o estado de folato e a concentração de homocisteína plasmática (Refsum et al., 2006; Van der Linden et al., 2006). Uma das mais estudadas é a mutação $677 \mathrm{C} \rightarrow$ T no gene da enzima 5,10-metilenotetrahidrofolato redutase (MTHFR), que catalisa a conversão de 5,10-metilenotetrahidrofolato em 5-metiltetrahidrofolato, o co-substrato para metilação da homocisteína a metionina pela enzima metionina sintase. Vários estudos mostram que os portadores do genótipo $\mathrm{T} / \mathrm{T}$, quando comparados com portadores dos genótipos $\mathrm{C} / \mathrm{T}$ ou $\mathrm{C} / \mathrm{C}$, apresentam menores níveis de folato plasmático e maiores níveis de homocisteína, especialmente em associação com baixos níveis de folato no plasma (Refsum et al., 2006), e apresentam melhores respostas à suplementação ou à ingestão dietética elevada de folato (Fohr et al., 2002; Silaste et al., 2001). Na gestação, o genótipo materno T/T, principalmente quando associado a um estado inadequado de folato e níveis elevados de homocisteína, aumenta o risco de defeitos do tubo neural nos fetos (Van der Linden et al., 2006).

\section{Ferro}

A maior parte do ferro corporal exerce papel estrutural e funcional no grupamento heme, que está presente em proteínas envolvidas na ligação e transporte de oxigênio, como a hemoglobina e a mioglobina, e em hemeenzimas que participam de processos integrados de transporte de elétrons. Diversas enzimas não-heme que contêm ferro também participam do transporte de elétrons e de vários processos bioquímicos, tais como regulação gênica e regulação do crescimento e diferenciação celular. Como o ferro é um nutriente essencial, mas é também potencialmente tóxico, complexos processos regulatórios envolvendo diversas proteínas atuam para atender às demandas celulares e evitar o seu acúmulo excessivo (Beard, 2001).

Assim como para o folato, diferentes níveis da deficiência de ferro no organismo e seus respectivos indicadores estão bem definidos. Os três níveis de deficiência de ferro são a depleção das reservas de ferro, a deficiência funcional de ferro e anemia por deficiência de ferro (Hambidge, 2003).

O indicador mais sensível das reservas de ferro é a concentração de ferritina sérica ou plasmática, que é proporcional à quantidade de ferro estocada na ferritina intracelular. Níveis plasmáticos menores que $12 \mu \mathrm{g}$ de ferritina/L são indicativos de reservas de ferro depletadas. Fatores como presença de infecção, processos inflamatórios e outras doenças causam aumento na concentração de ferritina plasmática, uma vez que a ferritina é uma proteína de fase aguda. Outros indicadores estáticos, como a transferrina e a capacidade total de ligação de ferro no plasma, também se encontram elevados na depleção das reservas de ferro, porém são indicadores menos sensíveis e confiáveis.

No nível da deficiência funcional de ferro, os indicadores clássicos são a saturação da transferrina sérica, que normalmente é de 30-35\% e cujo valor abaixo de $15 \%$ é indicativo de deficiência, e a concentração de protoporfirina nos eritrócitos, que aumenta devido à insuficiência de ferro para completar a síntese de hemoglobina. Um indicador sensível e específico para a deficiência funcional de ferro é a concentração de receptores de transferrina sérica, que está aumentada quando há suprimento insuficiente de ferro. Esta forma solúvel no plasma é liberada proporcionalmente ao número de receptores de transferrina na membrana celular, o qual aumenta em função da necessidade de ferro intracelular. Contudo, os dados ainda são limitados para estabelecer pontos de corte para este indicador.

O nível correspondente à deficiência clínica de ferro, que é a anemia microcítica e hipocrômica, se caracteriza por baixos níveis de hemoglobina $(<12 \mathrm{~g} / \mathrm{dL}$ de sangue em adultos), o indicador utilizado para definir anemia, cuja alteração, no entanto, não é específica para a deficiência de ferro. Uma vez que a deficiência de outros nutrientes, como folato, vitamina $\mathrm{B}_{12}$ e proteína, e outros fatores, tais como infecções e inflamações crônicas, hemoglobinopatias e gestação, também afetam a concentração de hemoglobina, outros indicadores de estado, preferencialmente a ferritina, devem ser usados para caracterizar a anemia por deficiência de ferro 
(Hambidge, 2003; Hunter, 1998). Outras manifestaçôes da deficiência de ferro são as alterações nos sistemas imune e neural, na regulação térmica e no metabolismo energético, que muitas vezes ocorrem simultaneamente e podem ou não estar associadas à anemia. Algumas dessas alterações podem ser utilizadas como indicadores funcionais do estado de ferro (Beard, 2001).

\section{Aplicações de Indicadores Bioquímicos em Epidemiologia Nutricional}

\section{Uso de Biomarcadores na Avaliação da Exposição Nutricional}

Os biomarcadores de exposição nutricional podem representar a ingestão de nutrientes ou de componentes alimentares não nutrientes, tais como colesterol, flavonóides e outros compostos fenólicos, que apresentam ação biológica relacionada com o risco e/ou a prevenção de doenças (Wild et al., 2001). Nesse contexto, os indicadores bioquímicos de estado nutricional podem ser usados como biomarcadores de ingestão de nutrientes, através do consumo habitual de alimentos e/ou uso de suplementos, e para a validação de instrumentos de avaliação de ingestão dietética. Além disso, os biomarcadores de exposição podem ser usados em estudos para avaliar a resposta à intervenção nutricional. Em muitos casos, os biomarcadores são uma alternativa importante aos métodos de avaliação de consumo alimentar quando sua medida por tais métodos é difícil ou impossível (Potischman, 2003). É o que acontece, por exemplo, quando há grande variação dos teores de um componente no mesmo alimento, dependendo das características de plantio, processamento, armazenamento e preparo, e quando há pouca fidelidade no relato de consumo e dificuldade em estabelecer porções consumidas.

Os biomarcadores, sejam eles indicadores de estado nutricional ou não, são válidos para avaliar a exposição quando apresentam uma relação direta sensível e específica com a ingestão do nutriente ou substância bioativa que estão sendo investigados. Além disso, deve-se considerar se o biomarcador apresenta integração temporal, ou seja, se reflete um efeito cumulativo da dieta, possibilitando avaliar exposição mais prolongada ou de longo prazo (habitual; semanas, meses ou anos), ou se reflete apenas exposição de curto prazo (recente; horas ou dias) (Hunter, 1998; Potischman, 2003).

As principais limitaçôes do uso de biomarcadores de exposição nutricional são: a) a magnitude da correlação entre os níveis do biomarcador em amostras de sangue, urina ou tecidos e a ingestão do nutriente em questão depende do grau de controle homeostático (saturação na absorção, excreção do excesso, controle hormonal) do nutriente, da faixa de ingestão da população estudada, da adaptação metabólica, de características genéticas e da existência de outros determinantes; b) a relação entre a ingestão de um nutriente e seus biomarcadores, muitas vezes representados por seus níveis sanguíneos, raramente é linear e geralmente sofre atenuação de resposta em função do aumento da ingestão, podendo atingir um platô e, portanto, perdendo sensibilidade (Hunter, 1998).

A utilização de indicadores bioquímicos de estado como biomarcadores para avaliação da exposição nutricional será exemplificada neste tópico com nutrientes selecionados pelo seu interesse epidemiológico e pelos contrastes de associações pouco ou muito evidentes que seus indicadores apresentam com a ingestão.

\section{Folato e Ferro}

Os indicadores bioquímicos do estado de folato, folato no plasma e folato em eritrócitos refletem adequadamente a exposição, pois respondem bem à suplementação (McKinley, 2000) e à fortificação de alimentos (Pfeiffer et al., 2005), mesmo em indivíduos com estado nutricional adequado, e apresentam boas associações com a ingestão dietética quando esta varia numa faixa ampla (Pfeiffer et al., 2005; Selhub, 2006). Como mencionado 
anteriormente, o folato no plasma é mais sensível à ingestão recente e o folato em eritrócitos reflete bem a ingestão habitual (Mason, 2003). O folato no plasma pode ser também um marcador para ingestão de frutas e vegetais em populações que não consomem alimentos fortificados (Brevik et al., 2005) A homocisteína no plasma também responde bem à suplementação e fortificação de alimentos com folato e apresenta associação inversa com a ingestão dietética de folato (Homocysteine Lowering Trialists' Collaboration, 2005; Selhub, 2006).

Por sua vez, os indicadores bioquímicos do estado de ferro, de maneira geral, embora possam responder bem à suplementação e à fortificação de alimentos em condições adequadas, especialmente em populações com deficiência de ferro, não apresentam boas correlações com a ingestão dietética de ferro (Hunter, 1998). Isso ocorre possivelmente porque muitos fatores dietéticos influenciam sua biodisponibilidade, tais como a forma com que o ferro se encontra nos alimentos (forma heme ou não-heme) e a presença de nutrientes e outros componentes alimentares que dificultam (cobre e manganês, fitatos, polifenóis, ácido oxálico) ou facilitam (vitamina C, ácidos orgânicos, peptídios contendo cisteína) sua absorção (Heath \& Fairweather-Tait, 2002). Além disso, alguns indicadores, como o ferro sérico, a saturação da transferrina e a capacidade total de ligação de ferro, apresentam alta variabilidade a curto prazo (minutos e horas) (Hambidge, 2003).

\section{Vitamina A e Carotenóides}

A concentração de retinol no plasma ou soro não é um indicador sensível de ingestão nem de estado de vitamina $A$, uma vez que é homeostaticamente bem regulada em função principalmente da mobilização das reservas hepáticas. Em populações com reservas hepáticas adequadas, o retinol plasmático não apresenta associação com a ingestão de vitamina A e pode apresentar apenas uma fraca associação com o uso de suplementos. Entretanto, em populaçôes cuja ingestão habitual de vitamina A é baixa e que, portanto, possuem pequenas reservas hepáticas e baixos níveis de retinol plasmático, a resposta deste biomarcador ao aumento de ingestão e, principalmente, à suplementação com vitamina A é mais marcante (Solomons, 2001; Thurnham \& NorthropClewes, 1999).

O retinol plasmático é um indicador importante do estado de vitamina A no organismo quando as reservas hepáticas estão bastante depletadas. Concentrações de retinol no plasma $<10 \mu \mathrm{g} / \mathrm{dL}(0,35 \mu \mathrm{mol} / \mathrm{L})$ são consideradas como deficientes, e de 10 a $20 \mu \mathrm{g} / \mathrm{dL}(0,7 \mu \mathrm{mol} / \mathrm{L})$ como marginais (Van den Berg et al., 1993). No entanto, o decréscimo dos níveis de retinol plasmático não está associado apenas com uma diminuição nas reservas, podendo também ser um reflexo da diminuição na síntese e liberação hepática de proteína ligante de retinol (RBP, do inglês Retinol Binding Protein), a proteína transportadora de retinol no plasma, o que pode ocorrer nas deficiências de proteínas e de zinco e em processos infecciosos e trauma (Thurnham \& NorthropClewes, 1999).

A concentração de retinol no leite materno vem sendo considerada um melhor e mais sensível indicador de estado de vitamina A em nutrizes (Underwood, 1994) e é também mais sensível à ingestão dietética e ao uso de suplementos de vitamina A do que o retinol plasmático (Rice et al., 2000). Sugere-se que concentrações menores que $30 \mu \mathrm{g} / \mathrm{dL}(1,1 \mu \mathrm{mol} / \mathrm{L})$ de retinol no leite materno seriam insuficientes para atingir níveis adequados de reservas hepáticas de retinol nos lactentes, a fim de evitar deficiência de vitamina A após o desmame (Underwood, 1994).

Outros indicadores bioquímicos utilizados para avaliação de estado de vitamina A, como a proteína ligante de retinol no plasma e testes de dose-resposta relativa (testes funcionais), também não são sensíveis à ingestão dietética e a variaçôes de estado em populações com reservas adequadas, sendo mais importantes para determinar estado e respostas à ingestão e suplementação em populações com reservas depletadas (Bahl et al., 2002). No caso de ingestão excessiva, ou hipervitaminose, a concentração de ésteres de retinila no plasma é um melhor indicador de estado do que o retinol, pois a concentração do primeiro aumenta de forma mais acentuada (Hunter, 1998). 
Embora não se tenham estabelecido indicadores de estado para carotenóides, a utilização de biomarcadores de ingestão destas substâncias é de interesse crescente, devido à sua ação antioxidante e a outras ações que desempenham no organismo, independentemente do papel de alguns deles como próvitamina A. Vários estudos sugerem que os carotenóides desempenham papel protetor contra Doenças Cardiovasculares (DCV), degeneração da mácula e alguns tipos de câncer (Solomons, 2001). Uma vez que os carotenóides são transportados nas lipoproteínas plasmáticas e seus níveis plasmáticos apresentam correlação com os níveis de colesterol, é desejável que as concentrações de carotenóides no plasma sejam também expressas em relação ao colesterol. As concentrações plasmáticas de carotenóides, ao contrário do retinol, não apresentam regulação homeostática estrita e são mais sensíveis à ingestão dietética e, principalmente, de suplementos (Thurnham \& Northrop-Clewes, 1999). De maneira geral, as concentrações de carotenóides no plasma e no tecido adiposo são biomarcadores adequados para a ingestão alimentar. Porém, as correlações observadas variam substancialmente, dependendo do carotenóide avaliado (El-Somehy et al., 2002).

O $\beta$-caroteno é um dos carotenóides mais estudados. Dentre aqueles com atividade de provitamina A ( $\beta$ caroteno, $\alpha$-caroteno e $\beta$-criptoxantina), é o que apresenta maior eficiência de conversão em vitamina $A$ no organismo. Porém, essa conversão apresenta alta variabilidade, mesmo entre indivíduos com estado adequado de vitamina A, e parece ser mais eficiente em indivíduos deficientes em vitamina A (Tang, Dolnikowski \& Russel, 2003). A concentração de $\beta$-caroteno no plasma é sensível à ingestão e apresenta capacidade de integração temporal por várias semanas, ou seja, reflete a exposição não apenas recente, mas também por períodos mais prolongados. Dependendo da dose e do tempo de suplementação, têm sido relatados aumentos de até vinte vezes na concentração de $\beta$-caroteno no plasma de diferentes grupos populacionais (Hunter, 1998; Mayne et al., 1998). A suplementação materna com $\beta$-caroteno também aumenta sua concentração no leite (Canfield et al., 1997), que por sua vez apresenta correlação com o $\beta$-caroteno no plasma materno (Canfield et al., 1997; Meneses \& Trugo, 2005). O $\beta$-caroteno no plasma também é sensível à ingestão de alimentos ricos em $\beta$-caroteno, mas as respostas são mais discretas do que as observadas para o uso de suplementos, mesmo utilizando-se quantidades equivalentes, o que pode estar relacionado principalmente com a menor biodisponibilidade dos carotenóides na matriz alimentar (Van het Hof et al., 2000). Associações relativamente boas entre concentrações plasmáticas e estimativas de ingestão por vários métodos de avaliação de consumo alimentar têm sido relatadas para o $\beta$-caroteno (Hunter, 1998; Thurnham \& Northrop-Clewes, 1999).

\section{Vitamina E}

A ingestão alimentar qualitativa e quantitativa de vitamina $\mathrm{E}$ (tocoferóis e tocotrienóis) é difícil de avaliar com métodos de consumo alimentar, principalmente por meio de inquéritos, devido à dificuldade de relatar e quantificar as suas fontes dietéticas. Os óleos vegetais, especialmente, têm teores e composição de vitamina E que variam amplamente, dependendo do tipo de óleo, do processamento, do tempo de armazenamento e da adição de antioxidantes (Potischman, 2003).

Os tocoferóis são potentes antioxidantes que reduzem a peroxidação lipídica, protegendo e contribuindo para a integridade de membranas celulares, onde apresentam também papel estrutural. $\mathrm{O} \alpha$-tocoferol é a forma mais ativa biologicamente e, além de sua ação antioxidante e estrutural, atua também na transcrição de genes e na inibição da proliferação celular, da agregação de plaquetas e da adesão de monócitos (Morrisey \& Sheehy, 1999). A maior abundância relativa de $\alpha$-tocoferol nas lipoproteínas plasmáticas e nos tecidos, apesar de o $\gamma$ tocoferol ser a principal forma de vitamina $\mathrm{E}$ nos óleos utilizados na dieta ocidental, é explicada pela maior oxidação do $\gamma$-tocoferol no organismo e pela presença no fígado da proteína de transferência de $\alpha$-tocoferol $(\alpha$ TTP) que seletivamente o direciona para as lipoproteínas de densidade muito baixa (VLDL) aí sintetizadas, 
em detrimento do $\gamma$-tocoferol. Uma outra $\alpha$-TTP, presente no fígado e em diversos tecidos, é responsável pela distribuição intracelular preferencial de $\alpha$-tocoferol (Dutta-Roy, 1999). Como os tocoferóis são transportados pelas lipoproteínas, suas vias de captação pelos tecidos estão relacionadas com o metabolismo das lipoproteínas (Mardones \& Rigotti, 2004) e seus níveis plasmáticos apresentam correlação com o colesterol e os triacilgliceróis (Morrisey \& Sheehy, 1999). Portanto, as concentrações plasmáticas de tocoferóis são também expressas em relação às concentrações desses componentes para evitar distorções devido às variações dos mesmos (Hunter, 1998). O $\alpha$-tocoferol plasmático é utilizado como indicador bioquímico estático de estado de vitamina $\mathrm{E}$, e níveis menores que 11,6 $\mu \mathrm{mol} / \mathrm{L}$ são considerados deficientes, ao passo que níveis maiores que 16,2 $\mu \mathrm{mol} / \mathrm{L}$ são considerados adequados (Morrisey \& Sheehy, 1999).

Os níveis de $\alpha$-tocoferol no plasma e em eritrócitos são moderadamente sensíveis à ingestão, respondendo bem a níveis elevados de suplementação, porém apresentando fraca associação com a ingestão dietética quando esta última é avaliada por inquéritos alimentares (El-Sohemy et al., 2001; Hunter, 1998). A vantagem do uso dos níveis em eritrócitos é que não precisam ser corrigidos pelos níveis de lipídios plasmáticos. Correlações significativas do $\alpha$-tocoferol no plasma com a ingestão têm sido observadas em estudos populacionais somente, ou principalmente, quando usuários de suplementos são incluídos na análise (ElSohemy et al., 2001; Hunter, 1998). Correlações da ingestão de $\alpha$-tocoferol com seu conteúdo no tecido adiposo, cujos níveis refletem exposição em prazos bem mais longos (anos) do que no plasma ou eritrócitos, também são fracas e pioram quando são excluídos os indivíduos usuários de suplementos (El-Sohemy et al., 2001; Hunter, 1998).

Há um crescente interesse na avaliação da ingestão e na utilização de $\gamma$-tocoferol circulante e nos tecidos como biomarcador de ingestão. Este tocoferol inibe a peroxidação lipídica induzida por peroxinitrito mais efetivamente que o $\alpha$-tocoferol, protegendo a lipoproteína de baixa densidade (LDL) da oxidação e o endotélio vascular, além de apresentar outros efeitos mais potentes que o $\alpha$-tocoferol (Devaraj \& Traber, 2003). Estudos recentes têm mostrado que, ao contrário do $\alpha$-tocoferol, os níveis de $\gamma$-tocoferol no plasma e no tecido adiposo são bons biomarcadores de ingestão, mesmo excluindo os usuários de suplementos (ElSohemy et al., 2001). Os níveis de $\gamma$-tocoferol e as razões $\gamma$-tocoferol/ $\alpha$-tocoferol no plasma também têm sido sugeridos como possíveis marcadores de riscos nutricionais, pois apresentam associação inversa com escolhas alimentares saudáveis, como, por exemplo, consumo de alimentos ricos em micronutrientes, fibras e lipídios poliinsaturados (Bates, Mishra \& Prentice, 2004).

\section{Lipídios e Ácidos Graxos}

Há evidências de que a ingestão total de lipídios pode estar associada com o desenvolvimento de doenças crônicas, especialmente alguns tipos de câncer e DCV (Willett, 1998a, 1998b). Entretanto, apesar do esforço de pesquisadores da área, ainda não existe um biomarcador para a ingestão habitual de gordura. Trabalhos recentes indicam que a composição em Ácidos Graxos (AG) de certos compartimentos corporais pode ser dependente da ingestão de gordura total (King, Lemaitre \& Kestin, 2006).

King, Lemaitre e Kestin (2006) sugerem que a composição em AG da membrana de eritrócitos e em fosfolipídios e ésteres de colesterol plasmáticos pode ser um biomarcador da ingestão total de lipídios. Entretanto, a validade da composição tecidual em AG como biomarcador da ingestão total de gordura, embora interessante e promissora, necessita de mais estudos para identificar, quantificar e padronizar os efeitos de possíveis variáveis de confusão, como a ingestão de AG individuais, a ingestão total de energia ou o balanço energético e a ingestão de carboidratos em diferentes grupos populacionais. A ausência de biomarcadores para a ingestão de gordura total pode causar certas dificuldades na interpretação de resultados de composição tecidual em AG, pois não se pode afirmar se o principal determinante do conteúdo de certo AG em determinada amostra biológica é a quantidade 
relativa (g/100g de AG totais) ou absoluta ( $\mathrm{mg} / \mathrm{dia}$ ) deste AG na dieta, ou seja, se a ingestão total de lipídios interfere na resposta-medida (Hunter, 1998). Dessa forma, controlar as análises estatísticas pela ingestão total de gordura é apropriado para aumentar a capacidade de interpretação dos resultados.

A concentração plasmática de colesterol total, especialmente de colesterol associado à lipoproteína de baixa densidade (LDL-C), está associada com o desenvolvimento de DCV oclusivas (Jones \& Kubow, 1999). Contudo, exceto quando a ingestão de colesterol é relativamente baixa se comparada com a dieta ocidental típica, a concentração plasmática de colesterol total e de LDL-C não é determinada pela ingestão deste lipídio. Nessas circunstâncias, seu principal determinante parece ser o metabolismo hepático de colesterol, que, por sua vez, é influenciado pela ingestão de AG saturados, transinsaturados e poliinsaturados (AGPI), especialmente os das séries n-3 e n-6 (Jones \& Kubow, 1999). Assim, não existe um biomarcador para a ingestão de colesterol que seja sensível a alterações na sua ingestão para qualquer nível de ingestão e que seja específico, isto é, cuja resposta dependa exclusivamente da ingestão deste lipídio. Entretanto, as concentrações plasmáticas de colesterol total e de LDL-C são biomarcadores clínicos do risco de desenvolvimento de DCV.

Em contraste com a ingestão de gordura total e de colesterol, para os quais não há um biomarcador específico e sensível em amplas faixas de ingestão, para a ingestão de certos AG individuais existem biomarcadores que respondem à ingestão destes nutrientes a curto, médio e longo prazos (Hunter, 1998). Há grande interesse em avaliar a ingestão de diversos AG individuais, como os das séries n-6 e n-3 de AGPI, pois a composição em AG da dieta influencia a composição das membranas celulares e de outros compartimentos corporais de lipídios (Arab, 2003), e possivelmente é um determinante do desenvolvimento de doenças crônicas, tais como DCV, diabetes mellitus e câncer, além de influenciar o desenvolvimento neonatal (Gibson \& Makrides, 1998; Pontes et al., 2006).

$\mathrm{O}$ interesse em biomarcadores de ingestão de AG específicos está muito relacionado com a dificuldade de avaliar qualitativa e quantitativamente a sua ingestão por meio de inquéritos alimentares (Cantwell, 2000). Além das dificuldades inerentes ao uso de inquéritos alimentares, como os vieses nas entrevistas e na obtenção dos dados e a variação à qual está sujeita a composição dos alimentos, há outras dificuldades especialmente importantes para a avaliação da ingestão de AG individuais (Cantwell, 2000). Boa parte da gordura total da dieta ocidental urbana não é visivelmente separável do alimento, porque faz parte da matriz do alimento in natura ou porque, quando adicionada durante o processamento industrial ou doméstico, se incorporou à matriz do alimento. Essa característica dos lipídios alimentares torna ainda mais difícil a avaliação de sua ingestão alimentar quando a freqüência de alimentação em estabelecimentos comerciais é elevada. Recentemente, Cantwell (2000) fez, por meio de inquéritos alimentares, uma revisão detalhada sobre os fatores que afetam a avaliação da ingestão de AG individuais.

A composição tecidual em AG não sintetizados endogenamente, ou cuja síntese é limitada, é usada como biomarcador de sua exposição (Hunter, 1998). São exemplos: AG da série n-6, 18:2n-6 (óleos vegetais: milho, girassol, algodão e soja), 20:3n-6 e 20:4n-6 (carnes de aves e mamíferos, ovos); AG da série n-3, 18:3n-3 (óleos vegetais: canola, linhaça e soja), 20:5n-3, 22:5n-3 e 22:6n-3 (peixes e óleos de peixes marinhos, algas marinhas); AG trans, especialmente os ácidos elaídico (18:1, $\Delta$ 9trans, gordura vegetal hidrogenada) e transvaccênico (18:1, $\Delta$-11trans, lacticínios); ácido linoleico conjugado (CLA; 18:2, $\Delta$-9cis, $\Delta$-11trans e 18:2, $\Delta$-10trans, $\Delta$-12cis; produtos de ruminantes); AG de cadeia ímpar, como pentadecanóico (15:0) e heptadecanóico (17:0), ou ramificada (laticínios).

O conteúdo tecidual dos AG não sintetizados endogenamente, mencionados no parágrafo anterior, apresenta associação com sua ingestão ou com a ingestão de suas fontes alimentares principais e, por isso, tem sido usado como biomarcador de exposição em estudos observacionais (Garland et al., 1998; Hunter, 1998) e em estudos experimentais para avaliar a adesão à suplementação com certos AG (Henderson et al., 1992; Hunter, 1998) ou a alguma dieta específica que envolva alterações na ingestão de AG (Hunter, 1998; Tynan et al., 1995). Para os AG sintetizados endogenamente (monoinsaturados ou saturados, de cadeia par, com 16C ou mais), a 
validade da composição em AG de amostras biológicas como biomarcador de sua ingestão é questionável.

A validade da composição em AG de amostras biológicas como biomarcador da ingestão destes nutrientes é influenciada por seu metabolismo. O metabolismo de um determinado AG depende de sua estrutura química e do compartimento metabólico onde está localizado. Portanto, estes fatores devem ser considerados quando a composição tecidual nesses nutrientes é usada como biomarcador de sua ingestão. $\mathrm{O}$ fígado e o tecido adiposo humanos podem sintetizar AG como o palmítico (16:0), o esteárico (18:0) e o oléico (18:1n-9). Além disso, os AGPI, especialmente os n- 6 e n-3, podem ter sua cadeia dessaturada e alongada, resultando na síntese endógena de AG poliinsaturados de 20 e 22 carbonos, tais como 20:3n-6 e 20:4n-6; 20:5n-3, 22:5n-3 e 22:6n-3, a partir dos AG essenciais linoleico (18:2n-6) e $\alpha$-linolênico (18:3n-3), respectivamente. Portanto, o conteúdo tecidual de 20:4n-6 pode estar associado com a ingestão habitual de 18:2n-6. Por isso, muitas vezes esses AG são considerados em conjunto, como série (n-6 e n-3).

O metabolismo de AG é extremamente competitivo: a maior parte dos AG compete entre si pelas mesmas enzimas e proteínas ligantes. Assim, a ingestão elevada de determinados AG pode prejudicar o estado de outros AG. Alguns exemplos deste tipo de interação metabólica acontecem na conversão de AG essenciais em seus derivados mais insaturados de cadeia mais longa, na conversão de AGPI com 20 carbonos em eicosanóides (prostaglandinas, leucotrienos, tromboxanos, entre outros) e na incorporação de AG em membranas biológicas, entre outros. Revisōes abrangentes sobre o metabolismo de AG estão disponíveis na literatura (Gurr, Harwood \& Frayn, 2002; Jones \& Kubow, 1999).

As diferentes classes de acil-lipídios (triacilgliceróis, fosfolipídios, ésteres de colesterol e AG não esterificados), assim como diferentes fluidos biológicos (plasma, soro ou leite), células (células ou elementos sangüíneos) ou tecidos corporais (tecido adiposo) podem ser consideradas diferentes compartimentos metabólicos de AG e representam níveis de ingestão de AG em diferentes escalas temporais, de curto, médio e longo prazos (Katan et al., 1997). A renovação (Hunter, 1998; Katan et al., 1997) dos AG componentes dos triacilgliceróis no plasma de jejum (VLDL) é relativamente rápida, com meia-vida de cerca de um a dois dias, e por isso a composição deste compartimento pode ser usada como biomarcador da ingestão recente de AG. A composição dos fosfolipídios e ésteres de colesterol plasmáticos responde mais lentamente à ingestão de $\mathrm{AG}$ e apresenta meia-vida de cerca de sete dias. Em seguida, respondem as composiçóes de membranas de eritrócitos e plaquetas, com meia-vida de cerca de trinta dias. O compartimento metabólico mais estável e cujos AG apresentam meia-vida mais longa (cerca de dois anos) entre os já investigados é o tecido adiposo. Assim, a composição em AG do tecido adiposo é considerada o biomarcador da ingestão habitual de AG a longo prazo e o que apresenta associação mais forte com a ingestão de boa parte dos AG (Hunter, 1998). Portanto, a escolha da amostra biológica a ser obtida para determinação da composição em AG deve considerar a escala de tempo segundo a qual se deseja estimar a exposição. Os AG Não Esterificados (AGNE, ou livres) do plasma de jejum são provenientes da hidrólise de triacilgliceróis no tecido adiposo e representam compartimento metabólico de AG disponíveis para captação tecidual no período pós-absortivo. A composição em AGNE não representa um biomarcador de ingestão de AG, embora possa ser usada como ferramenta auxiliar na compreensão do metabolismo e do estado nutricional em AG (Torres et al., 2006).

Além da cinética de renovação dos compartimentos metabólicos de AG, outro aspecto relevante a se considerar na escolha da amostra a ser obtida é a especificidade da resposta de cada compartimento metabólico à ingestão dos AG de interesse. A especificidade da resposta está relacionada com características intrínsecas das vias de síntese e degradação dos lipídios corporais e com o metabolismo das células e/ou tecidos usados. Assim, a resposta das classes de lipídios à ingestão de AG é relativamente específica (Hunter, 1998). 


\section{Uso de Biomarcadores na Investigação de Risco de Doenças Crônicas}

Os biomarcadores de exposição a nutrientes e compostos bioativos de alimentos (não-nutrientes) podem ser utilizados em investigações de epidemiologia nutricional como alternativas para os inquéritos alimentares ou como fonte de dados complementares ao inquérito (Bingham, 2002; Hunter, 1998). Os biomarcadores contribuem especialmente quando a ingestão do nutriente é de difícil avaliação, como, por exemplo, os AG, a vitamina $\mathrm{E}$ ou compostos fenólicos antioxidantes. Entretanto, quando os biomarcadores são avaliados isoladamente, sem dados de ingestão alimentar obtidos de inquéritos, pode ser difícil, ou mesmo impossível, elucidar as associações entre enfermidades e a alimentação habitual (Willett, 1998a), que consistem no principal objetivo comum de investigaçôes de epidemiologia nutricional. Essa limitação está relacionada com as limitações dos próprios biomarcadores, discutidas anteriormente. Contudo, quando usados conjuntamente com inquéritos alimentares, os biomarcadores podem contribuir no desenvolvimento de hipóteses científicas consistentes e melhorar as estimativas da contribuição quantitativa da alimentação habitual para o risco de desenvolvimento de doenças específicas em certos grupos populacionais (Bingham, 2002). Este autor sugere que o uso de biomarcadores deve se tornar rotina na epidemiologia nutricional. Exemplos de biomarcadores de exposição nutricional que podem ser usados para investigar o risco de desenvolvimento de DCV e de osteoporose serão apresentados nesta seção.

\section{Doenças Cardiovasculares (DCV)}

As DCV constituem a principal causa de morte em diversos países industrializados e em áreas urbanas de países em desenvolvimento (Lotufo \& Lolio, 2000; Willett, 1998a). Entre os determinantes de DCV, destaca-se a alimentação habitual. A alimentação apresenta associação com o desenvolvimento de DCV através de diversos mecanismos bioquímicos que, em sua maioria, estão relacionados com a formação da placa de ateroma e com a oclusão arterial (Grundy, 1999). A presença de partículas de LDL oxidadas na camada subendotelial e seu reconhecimento por macrófagos dão início a mecanismos bioquímicos complexos que culminam com a formação da placa de ateroma. Dessa forma, índices bioquímicos associados com a elevação da concentração plasmática de LDL-C e com sua susceptibilidade à oxidação têm sido usados como biomarcadores para investigar o risco de desenvolvimento de DCV (Grundy, 1999).

A ingestão de Ácidos Graxos Poliinsaturados (AGPI) contribui para a redução da concentração plasmática de LDL-C (Harris, 1997), e os ácidos graxos EPA e DHA reduzem o risco de infarto do miocárdio, independentemente da concentração plasmática de lipoproteínas (Breslow, 2006). Portanto, a concentração tecidual de AG das séries n-6 e n-3 pode ser usada como biomarcador para o risco de desenvolvimento de DCV. Há evidências de que o risco de desenvolvimento de DCV é maior entre grupos de indivíduos com menores conteúdos teciduais de EPA e DHA (Harris, Assaad \& Poston, 2006).

Apesar da existência de biomarcadores relacionados com a exposição e/ou o metabolismo lipídico que são válidos para o estudo do risco de desenvolvimento de DCV, ainda não foi possível definir pontos de corte. É possível que a dificuldade de definição de pontos de corte para esses biomarcadores esteja associada com diversos fatores, tais como o complexo metabolismo de lipídios, a existência de outras variáveis relacionadas com as DCV que não tenham sido controladas nos estudos e a complexidade das próprias DCV.

Os AGPI constituem um alvo freqüente de espécies reativas, e sua oxidação faz parte do processo de formação da placa de ateroma. Dessa forma, o efeito da ingestão de AGPI sobre a aterosclerose é bimodal, pois em baixos níveis de ingestão a concentração plasmática de LDL-C pode aumentar, mas quando a ingestão de AGPI é elevada pode aumentar a susceptibilidade da LDL à oxidação (Lapointe, Couillard \& Lemieux, 2006). Portanto, a associação entre biomarcadores de AGPI n-3 e n-6 com as DCV deve ser considerada conjuntamente com biomarcadores 
de componentes pró e antioxidantes, e vice-versa. É possível que essa relação dos AGPI e dos compostos pró e antioxidantes com as DCV seja uma das principais justificativas para a controvérsia na epidemiologia nutricional destas doenças (Willett, 1998a). Diversos trabalhos que investigaram estes componentes isoladamente encontraram resultados inconsistentes (Lapointe, Couillard \& Lemieux, 2006; Willett, 1998a). Trabalhos prospectivos futuros, nos quais biomarcadores de AG, anti e pró-oxidantes de alimentos e sua respectiva ingestão sejam determinados, poderão contribuir para a estimativa de pontos de corte para grupos populacionais.

O risco de desenvolvimento de DCV relacionado com o dano oxidativo pode ser investigado com base em biomarcadores de antioxidantes e em dano oxidativo e/ou de fatores que contribuem para a formação de espécies radicais (pró-oxidantes). Entre os biomarcadores de antioxidantes de origem alimentar estão os níveis plasmáticos de vitaminas E e C, carotenóides e compostos fenólicos (Van den Berg et al., 1993). Berg e colaboradores (1993) sugeriram níveis plasmáticos ótimos de antioxidantes que contribuem para a prevenção de doenças crônicas: $\alpha$-tocoferol $>30 \mu \mathrm{mol} / \mathrm{L}$, ácido ascórbico $>50 \mu \mathrm{mol} / \mathrm{L}, \beta$-caroteno $>0,4 \mathrm{~mol} / \mathrm{L}$ e retinol $>2,5 \mu \mathrm{mol} / \mathrm{L}$. Entre os nutrientes pró-oxidantes, o ferro apresenta papel importante, pois pode participar de reaçóes de geração de espécies reativas de oxigênio. $\mathrm{O}$ estado de ferro, medido pela concentração plasmática de ferritina, apresenta associação positiva com a concentração plasmática de LDL oxidada (Ikeda et al., 2006) e com a espessura e a prevalência de placa de ateroma (Wolff et al., 2004).

A associação entre DCV e os biomarcadores relacionados com o estresse oxidativo ainda é motivo de debate. Quando possível, esses biomarcadores devem ser considerados em conjunto e com biomarcadores de AGPI, como discutido anteriormente, para que se alcancem resultados mais conclusivos. Além disso, fatores que sabidamente contribuem para a formação de espécies reativas, como o tabagismo e o consumo de álcool, devem ser controlados. Em ensaios prospectivos controlados de amostragem aleatória, a suplementação com $\beta$-caroteno aumentou o risco de desenvolvimento de câncer de pulmão entre fumantes (Cooper, Eldridge \& Peters, 1999).

Além dos biomarcadores de exposição relacionados com a LDL e sua oxidação, diversos estudos prospectivos de coorte e de caso-controle identificaram a hiperhomocisteinemia como um fator de risco independente para DCV oclusivas (McKinley, 2000). Entretanto, ainda é motivo de debate se este aminoácido participa diretamente do mecanismo de formação da placa de ateroma (Selhub, 2006) ou se é o folato, cujo estado nutricional é um dos principais determinantes da homocisteinemia plasmática, que tem efeito protetor (Morrison et al., 1996). Embora não haja um consenso sobre a concentração de homocisteína a partir da qual o risco de desenvolvimento de DCV estaria inequivocamente elevado, sugere-se que $15 \mu \mathrm{mol} / \mathrm{L}$ possa ser usado como ponto de corte para a hiperhomocisteinemia (Refsum et al., 2006). Valores de homocisteinemia superiores a este limite estão associados com risco elevado de desenvolvimento de DCV e de outras doenças crônicas.

\section{Osteoporose}

A osteoporose caracteriza-se por uma redução na densidade mineral óssea que reduz a resistência mecânica dos ossos e aumenta o risco de fraturas. Os ossos podem ser vistos como um grande reservatório de cálcio, e a osteoporose resulta da perda crônica de cálcio ósseo, quando o indivíduo permanece em balanço negativo deste mineral por longos períodos. A osteoporose apresenta determinantes genéticos e ambientais, dos quais se destaca a alimentação habitual. A influência da alimentação habitual sobre a densidade óssea manifesta-se principalmente em sua influência sobre o metabolismo ósseo e a homeostase de cálcio. Há evidências de que a ingestão habitual de cálcio, o estado nutricional para vitamina $\mathrm{D}$ e possivelmente a ingestão de frutas, hortaliças e proteínas animais podem estar associados com o risco de desenvolvimento de osteoporose (Prentice, 2004). Assim, biomarcadores da exposição nutricional a estes componentes podem contribuir para o estudo da epidemiologia nutricional da osteoporose. 
O efeito preventivo da ingestão de frutas e hortaliças sobre o desenvolvimento da osteoporose está relacionado com a alcalinização de fluidos corporais que resulta na redução da reabsorção óssea de cálcio, na alcalinização da urina e na redução da excreção urinária de cálcio. Por sua vez, a ingestão de carnes e grãos aumenta a produção endógena de ácido e tem efeitos inversos, aumentando a perda de cálcio ósseo ao longo do tempo (Prentice, 2004). Ainda não existe um biomarcador válido para a ingestão de alimentos relacionados com o metabolismo ácido-básico, entretanto seu desenvolvimento pode acrescentar informações relevantes em estudos da epidemiologia nutricional da osteoporose.

A concentração sérica de 25-hidroxicolecalciferol [25(OH)D3] tem sido considerada um marcador bioquímico funcional do estado de vitamina $\mathrm{D}$, e há evidências de que concentraçôes inferiores a $80 \mathrm{nmol} / \mathrm{L}$ estão associadas com redução na eficiência da absorção de cálcio, osteoporose e maior risco de fraturas (Heaney, 2004).

Não há um bom biomarcador de ingestão habitual para o cálcio, pois este mineral está sujeito a eficiente controle homeostático. A concentração de cálcio na urina de 24 horas pode ser usada como biomarcador da ingestão deste mineral, porém deve ser normalizada pela concentração de creatinina na urina e, além disso, pode variar em resposta à ingestão recente de cálcio e sódio (Hunter, 1998).

\section{Referências}

ARAB, L. Biomarkers of fat and fatty acid intake. Journal of Nutrition, 133: 925S-932S, 2003.

BAHL, R. et al. Vitamin A supplementation of women postpartum and of their infants at immunization alters breast milk retinol and infant vitamin A status. Journal of Nutrition, 132: 3.243-3.248, 2002.

BAILEY, L. et al. Folate. In: BOWMAN, B. A. \& RUSSEL, R. M. Present Knowledge in Nutrition. 8. ed. Washington: Ilsi Press, 2001.

BATES, C. J.; MISHRA, G. D. \& PRENTICE, A. $\alpha$-Tocopherol as a possible marker for nutrition-related risk: results from four National Diet and Nutrition Surveys in Britain. British Journal of Nutrition, 92: 137-150, 2004 .

BEARD, J. L. Iron biology in immune function, muscle metabolism and neuronal functioning. Journal of Nutrition, 131: 568S-580S, 2001.

BINGHAM, S. A. Biomarkers in nutritional epidemiology. Public Health and Nutrition, 5: 821-827, 2002.

BLANCK, H. M. et al. Laboratory issues: use of nutritional biomarkers. Journal of Nutrition, 133: 888S-894S, 2003.

BRESLOW, J. L. N-3 Fatty acids and cardiovascular disease. American Journal of Clinical Nutrition, 83: 1.477S$1.482 S, 2006$.

BREVIK, A. et al. Plasma concentration of folate as a biomarker for the intake of fruit and vegetables: the Hordaland Homocysteine Study. American Journal of Clinical Nutrition, 81: 434-439, 2005.

CANFIELD, L. M. et al. $\beta$-Carotene in breast milk and serum is increased after a single $\beta$-carotene dose. American Journal of Clinical Nutrition, 66: 52-61, 1997.

CANTWELL, M. M. Assessment of individual fatty acid intake. Proceedings of the Nutrition Society, 59: 187$191,2000$.

COOPER, D. A.; ELDRIDGE, A. L. \& PETERS, J. C. Dietary carotenoids and certain cancers, heart disease, and age-related macular degeneration: a review of recent research. Nutrition Reviews, 57: 201-214, 1999. 
DEVARAJ, S. \& TRABER, M. G. $\alpha$-Tocopherol, the new vitamin E? American Journal of Clinical Nutrition, 77: 530-531, 2003.

DUTTA-ROY, A. K. Molecular mechanisms of cellular uptake and intracellular translocation of $\alpha$-tocopherol: role of tocopherol-binding proteins. Food and Chemical Toxicology, 37: 967-971, 1999.

EL-SOHEMY, A. et al. Population-based study of $\alpha$ - and $\alpha$-tocopherol in plasma in adipose tissue as biomarkers of intake in Costa Rican adults. American Journal of Clinical Nutrition, 74: 356-363, 2001.

EL-SOHEMY, A. et al. Individual carotenoid concentrations in adipose tissue and plasma as biomarkers of dietary intake. American Journal of Clinical Nutrition, 76: 172-179, 2002.

FIDANZA, F. Biochemical assessment. In: SADLER, M.; STRAIN, J. J. \& CABALLERO, B. Encyclopedia of Human Nutrition. 1. ed. Oxford: Academic Press, 1999. v. 3.

FIDANZA, F. Importance of measuring nutritional status. In: CABALLERO, B.; TRUGO, L. C. \& FINGLAS, P. M. Encyclopedia of Food Sciences and Nutrition. 2. ed. Oxford: Academic Press, 2003. v. 7.

FOHR, I. P. et al. 5, 10-Methylenetetrahydrofolate reductase genotype determines the plasma homocysteinelowering effect of supplementation with 5-methyltetrahydrofolate or folic acid in healthy young women. American Journal of Clinical Nutrition, 75: 275-282, 2002.

GARLAND, M. et al. The relation between dietary intake and adipose tissue composition of selected fatty acids in US women. American Journal of Clinical Nutrition, 67: 25-30, 1998.

GIBSON, R. A. \& MAKRIDES, M. The role of long chain polyunsaturated fatty acids (LCPUFA) in neonatal nutrition. Acta Paediatrica, 87: 1.017-1.022, 1998.

GRUNDY, S.M. Nutrition and diet in the management of hyperlipidemia and atherosclerosis. In: SHILS, M. E. et al. Modern Nutrition in Health and Disease. 9. ed. Baltimore: Williams \& Wilkins, 1999.

GURR, M.; HARWOOD, J. \& FRAYN, K. N. Lipid Biochemistry. 5. ed. London: Blakwell Publishing, 2002.

HAMBIDGE, M. Biomarkers of trace mineral intake and status. Journal of Nutrition, 133: 948S-955S, 2003.

HARRIS, W. S. N-3 Fatty acids and serum lipoproteins: human studies. American Journal of Clinical Nutrition, 65: 1645S-1654S, 1997.

HARRIS, W. S.; ASSAAD, B. \& POSTON, W. C. Tissue omega-6/omega-3 fatty acid ratio and risk for coronary artery disease. American Journal of Cardiology, 98: 19I-26I, 2006.

HEANEY, R. P. Functional indices of vitamin D status and ramifications of vitamin D deficiency. American Journal of Clinical Nutrition, 80: 1706S-1709S, 2004.

HEATH, A. L. M. \& FAIRWEATHER-TAIT, S. J. Clinical implications of changes in the modern diet: iron intake, absorption and status. In: WORWOOD, M. Bailière's Best Practice and Research: clinical hematology, 15: 225-241, 2002.

HENDERSON, R. A. et al. Effect of fish oil on the fatty acid composition of human milk and maternal and infant erythrocytes. Lipids, 27: 863-869, 1992.

HERBERT, V. Folic acid. In: SHILS, M. E. et al. Modern Nutrition in Health and Disease. Baltimore: Williams \& Wilkins, 1999. 
HOMOCYSTEINE LOWERING TRIALISTS' COLLABORATION. Dose-dependent effects of folic acid on blood concentrations of homocysteine: a meta-analysis of randomized trials. American Journal of Clinical Nutrition, 82: 806-812, 2005.

HUNTER, D. Biochemical indicators of dietary intake. In: WILLETT, W. Nutritional Epidemiology. 2. ed. Oxford: Oxford University Press, 1998.

IKEDA, Y. et al. Association between serum ferritin and circulating oxidized low-density lipoprotein levels in patients with type 2 diabetes. Endocrinology Journal, 53: 665-670, 2006.

JONES, P. J. H. \& KUBOW, S. Lipids, sterols, and their metabolites. In: SHILS, M. E. et al. Modern Nutrition in Health and Disease. Baltimore: Williams \& Wilkins, 1999.

KATAN, M. B. et al. Kinetics of the incorporation of dietary fatty acids into serum cholesteryl esters, erythrocyte membranes, and adipose tissue: an 18-month controlled study. Journal of Lipid Research, 38: 2.012-2.022, 1997.

KING, I. B.; LEMAITRE, R. N. \& KESTIN, M. Effect of a low-fat diet on fatty acid composition in red cells, plasma phospholipids, and cholesterol esters: investigation of a biomarker of total fat intake. American Journal of Clinical Nutrition, 83: 227-236, 2006.

LAPOINTE, A.; COUILLARD, C. \& LEMIEUX, S. Effects of dietary factors on oxidation of low-density lipoprotein particles. Journal of Nutritional Biochemistry, 17: 645-658, 2006.

LOTUFO, P. A. \& LOLIO, C. A. Tendências de evolução da mortalidade por doenças cardiovasculares: o caso do estado de São Paulo. In: MONTEIRO, C. A. Velhos e Novos Males da Saúde no Brasil: a evolução do país e de suas doenças. 2. ed. São Paulo: Hucitec, Nupens/USP, 2000.

MARDONES, P. \& RIGOTTI, A. Cellular mechanisms of vitamin E uptake: relevance in $\alpha$-tocopherol metabolism and potential implications for disease. Journal of Nutritional Biochemistry, 15: 252-260, 2004.

MASON, J. B. Biomarkers of nutrient exposure and status in one-carbon (methyl) metabolism. Journal of Nutrition, 133: 941S-947S, 2003.

MAYNE, S. T. et al. Effect of supplemental $\beta$-carotene on plasma concentrations of carotenoids, retinol, and $\alpha$ tocopherol in humans. American Journal of Clinical Nutrition, 68: 642-647, 1998.

MCKINLEY, M. C. Nutritional aspects and possible pathological mechanisms of hyperhomocysteinaemia: an independent risk factor for vascular disease. Proceedings of the Nutrition Society, 59: 221-237, 2000.

MENESES, F. \& TRUGO, N. M. F. Retinol, $\beta$-carotene and lutein+zeaxanthin in milk of Brazilian nursing women: associations with plasma concentrations and influences of maternal characteristics. Nutrition Research, 25: 443-451, 2005.

MORRISON, H. I. et al. Serum folate and risk of fatal coronary disease. Journal of the American Medical Association, 275: 1.893-1.896, 1996.

MORRISSEY, P. A. \& SHEEHY, P. J. A. Optimal nutrition: vitamin E. Proceedings of the Nutrition Society, 58: 459-468, 1999.

PFEIFFER, C. M. et al. Biochemical indicators of B vitamin status in the US population after folic acid fortification: results from the National Health and Nutrition Examination Survey 1999-2000. American Journal of Clinical Nutrition, 82: 442-450, 2005. 
PONTES, P. V. et al. N-6 and n-3 Long-chain polyunsaturated fatty acids in the erythrocyte membrane of Brazilian preterm and term neonates and their mothers at delivery. Prostaglandins Leukotrienes and Essential Fatty Acids, 74: 117-123, 2006.

POTISCHMAN, N. Biologic and methodologic issues for nutritional biomarkers. Journal of Nutrition, 133: 875S-880S, 2003.

PRENTICE, A. Diet, nutrition and the prevention of osteoporosis. Public Health and Nutrition, 7: $227-$ 243, 2004.

REFSUM, H. et al. The Hordaland Homocysteine Study: a community-based study of homocysteine, its determinants, and associations with disease. Journal of Nutrition, 136: 1.731S-1.740S, 2006.

RICE, A. M. et al. Evaluation of serum retinol, the modified-relative-dose-response ratio, and breast milk vitamin A as indicators of response to postpartum maternal vitamin A supplementation. American Journal of Clinical Nutrition, 71: 799-806, 2000.

ROSA, G.; PEREIRA, S. E. A. \& TRUGO, N. M. F. Longitudinal change in plasma total homocysteine during pregnancy and postpartum in Brazilian women and its relation with folate status and other factors. International Journal for Vitamin and Nutrition Research, 74: 95-101, 2004.

SELHUB, J. The many facets of hyperhomocysteinemia: studies from the Framingham cohorts. Journal of Nutrition, 136: 1.726S-1.730S, 2006.

SILASTE, M. L. et al. Polymorphisms of key enzymes in homocysteine metabolism affect diet responsiveness of plasma homocysteine in healthy women. Journal of Nutrition, 131: 2.643-2.647, 2001.

SOLOMONS, N. W. Vitamin A and carotenoids. In: BOWMAN, B. A. \& RUSSEL, R. M. Present Knowledge in Nutrition. 8. ed. Washington: Ilsi Press, 2001.

SOLOMONS, N. W. Functional tests. In: CABALLERO, B.; TRUGO, L. C. \& FINGLAS, P. M. Encyclopedia of Food Sciences and Nutrition. 2. ed. Oxford: Academic Press, 2003. v. 7.

TANG, G.; DOLNIKOWSKI, G. G. \& RUSSELL, R. M. Short-term (intestinal) and long-term (postintestinal) conversion of $\beta$-carotene to retinol in adults as assessed by a stable-isotope reference method. American Journal of Clinical Nutrition, 78: 259-266, 2003.

THURNHAM, D. I. \& NORTHROP-CLEWES, C. A. Optimal nutrition: vitamin A and carotenoids. Proceedings of the Nutrition Society, 58: 449-457, 1999.

THURNHAM, D. L. et al. The use of different lipids to express serum tocopherol-lipid ratios for the measurement of vitamin E status. Analytical and Clinical Biochemistry, 23: 514-520, 1986.

TORRES, A. G. et al. Polyunsaturated fatty acids and conjugated linoleic acid isomers in breast milk are associated with plasma non-esterified and erythrocyte membrane fatty acid composition in lactating women. British Journal of Nutrition, 95: 517-524, 2006.

TYNAN, M. B. et al. Erythrocyte membrane fatty acid composition as a marker of dietary compliance in hyperlipidaemic subjects. Atherosclerosis, 117: 245-252, 1995.

UNDERWOOD, B. A. Hypovitaminosis A: international programmatic issues. Journal of Nutrition, 124: 1.467S1.472S, 1994. 
VAN DEN BERG, H. et al. Flair Concerted Action n. 10 status paper. International Journal for Vitamin and Nutrition Research, 63: 247-316, 1993.

VAN DER LINDEN, I. J. M. et al. Genetic variation in genes of folate metabolism and neural-tube defect risk. Proceedings of the Nutrition Society, 65: 204-215, 2006.

VAN HET HOF, K. H. et al. Dietary factors that affect the bioavailability of carotenoids. Journal of Nutrition, 130: 503-506, 2000.

WILD, C. P. et al. A critical evaluation of the application of biomarkers in epidemiological studies on diet and health. British Journal of Nutrition, 86: S37-S53, 2001.

WILLETT, W. Diet and coronary heart disease. In: WILLETT, W. Nutritional Epidemiology. 2. ed. New York: Oxford University Press, 1998a.

WILLETT, W. Dietary fat intake and cancer risk: a controversial and instructive story. Seminars in Cancer Biology, 8: 245-253, 1998b.

WOLFF, B. et al. Association between high serum ferritin levels and carotid atherosclerosis in the Study of Health in Pomerania (Ship). Stroke, 35: 453-457, 2004. 



\title{
8
}

\section{Composição Corporal na Avaliação do Estado Nutricional}

\author{
Luiz Antonio dos Anjos e Vivian Wahrlich
}

\begin{abstract}
A medição da composição corporal é útil em diversas áreas, mas tem sua aplicação mais visível na área da nutrição e das ciências do movimento humano com vistas à manutenção da saúde e à melhora no desempenho físico. Este capítulo enfoca o aspecto nutricional da avaliação da composição corporal, particularmente no que concerne à avaliação do estado nutricional. Para revisões mais profundas dos vários aspectos relativos à composição corporal, os leitores podem consultar excelentes livros-texto recentes sobre o assunto (Heymsfield et al., 2005; Heyward \& Wagner, 2004).

A medição da composição corporal é importante não só para investigar o indivíduo em um exame clínico como também em estudos epidemiológicos (Buskirk, 1987). Do ponto de vista nutricional, a medição da composição corporal é importante na descrição do crescimento, desenvolvimento, maturação e envelhecimento normal e patológico; no monitoramento das mudanças que ocorrem durante a gravidez e o aleitamento; no fornecimento de bases de referência de variáveis fisiológicas; como guia para atletas antes, durante e após competições/temporadas; na identificação de padróes associados a doenças.
\end{abstract}

\section{Conceituação}

Composição corporal pode ser definida como a expressão do Peso Corporal (PC) em dois ou mais componentes (Anjos, 1998) baseados em modelos anatômicos ou químicos obtidos por meio de análises de dissecação de cadáveres. No modelo anatômico, o corpo é dividido em tecidos dissecáveis, como pele, músculo, ossos e órgãos. O modelo químico, mais desenvolvido experimentalmente e, portanto, mais utilizado, é baseado na informação dos componentes químicos, como gordura, água e proteína dos tecidos, obtida por meio da dissecação de cadáveres (Clarys et al., 1999). Os componentes são seis: água, mineral ósseo (75\% do total), mineral extra-ósseo, proteína, gordura e glicogênio (1\% do PC). Tipicamente, esse modelo é simplificado para dois componentes somente: a gordura e o Peso Livre de Gordura (PLG), ou também, como é chamado, Peso Magro (PM). Tecnicamente, e como foi descrito originalmente por Behnke (1959), o PM é maior do que o PLG, pois aquele inclui uma certa quantidade (2-3\%) de gordura essencial no organismo (Lohman, 1992). Entretanto, os dois termos são usados como sinônimos atualmente, apesar da diferença sutil (Lohman \& Going, 1998).

Com o propósito de organizar o estudo da composição corporal, Wang, Pierson e Heymsfield (1992) propuseram um modelo no qual a composição do corpo humano é representada em cinco níveis com componen- 
tes distintos, que somados correspondem ao PC total. Nesse modelo, os níveis são: atômico, molecular, celular, tecido-sistemas e corpo inteiro. O nível atômico inclui os elementos como oxigênio, carbono, hidrogênio, nitrogênio, cálcio e fósforo, que compõem mais de $98 \%$ do PC. No nível molecular, há seis componentes principais, como a água, lipídio, proteína, carboidrato, minerais ósseos e extra-ósseos (minerais do tecido mole). Com base nesses componentes, podem ser criados vários modelos que permitem incluir de dois até seis componentes. O modelo mais simples, e por isso o mais utilizado, inclui a expressão do PC em apenas dois componentes: o Peso de Gordura (PG) e o PM (ou peso, ou tecido, livre de gordura - PLG). A forma mais comum é expressar o PG em função do PC total (ou seja, percentual de gordura corporal - \%GC), em vez do valor absoluto (kg) do PG ou do PLG.

O nível celular representa as células, o fluido extracelular e os sólidos extracelulares, e tem grande importância para o entendimento dos processos fisiopatológicos das doenças. No nível tecidual, os três componentes do nível celular são organizados em tecidos, órgãos e sistemas. Nesse nível, o PC é resultante do somatório do tecido muscular, tecido conectivo, tecido epitelial e tecido nervoso. O quinto e último nível representa o corpo inteiro e diz respeito ao formato, à dimensão e às características físicas que podem ser descritas tendo em vista as dimensões corporais como a estatura, o comprimento dos segmentos, as circunferências, as dobras cutâneas, o volume corporal e o PC. Assim, o PC é o somatório dos pesos referentes a cabeça, pescoço, tronco, membros superiores e inferiores.

Do ponto de vista teórico, os métodos de composição corporal in vivo podem ser baseados em propriedades, em componentes ou em combinação de ambos (Wang et al., 1995; Lohman \& Going, 1998). No primeiro caso, parte-se de uma propriedade mensurável (por exemplo: volume corporal) para se chegar a um componente desconhecido (gordura corporal), por meio de relaçôes matemáticas entre a propriedade e o componente. Nos métodos baseados em componentes, parte-se de um componente conhecido (estimado por meio de um método baseado em propriedade) para se chegar ao componente desconhecido. Por exemplo, o PLG pode ser estimado pela Água Corporal Total (ACT), assumindo-se que a hidratação do PLG de adultos é fixo e conhecido (@73\%). Nos métodos combinados, quantifica-se um componente desconhecido por meio tanto de uma propriedade mensurável quanto de um componente conhecido.

\section{Breve Histórico}

O estudo da composição corporal na Idade Moderna inicia-se no século XIX, quando Liebig (1803-1873), químico alemão, constatou que substâncias contidas nos alimentos eram também encontradas no corpo humano e que os fluidos corporais continham mais sódio e menos potássio do que os tecidos (Shen et al., 2005). Até cerca de 1950, três áreas interdependentes do estudo da composição corporal foram desenvolvidas (Wang et al., 1999): 1) os pressupostos teóricos para a área; 2) as metodologias de avaliação; 3) os estudos das alterações da composição corporal na saúde e na doença.

A primeira área tinha como objetivo obter dados quantitativos dos componentes corporais obtidos por meio de necropsia, que era o único meio de obter os dados de composição corporal. Os achados desses estudos possibilitaram identificar o tamanho dos órgãos e seus conteúdos de água corporal, gordura, nitrogênio, minerais e minerais-traço. A segunda área tinha como objetivo a medição da composição corporal in vivo. Entre as metodologias desenvolvidas nesse período, destacam-se a estimativa do músculo esquelético por meio da excreção da creatinina urinária (Talbot, 1938), a medição da ACT com métodos de diluição (Wang et al., 1999), a medição do ${ }^{40} \mathrm{~K}$ (Forbes, 1987) e o desenvolvimento da técnica da pesagem hidrostática para estimar o PLG e a gordura corporal com base no princípio de Arquimedes (Behnke, Feen \& Welham, 1942). Ainda é digna de nota a descrição de modelos antropométricos para se estimar a musculatura total corporal desenvolvidos por Matiegka (1921). 
Os achados da terceira área do estudo da composição corporal dizem respeito aos efeitos do crescimento e nutrição nos componentes do corpo humano. Nesse período, destaca-se o conceito de maturidade química, proposto por Moulton (1923), segundo o qual os valores da composição dos componentes do corpo se alteram durante a infância e adolescência até atingirem os valores encontrados nos adultos. Em relação à nutrição, evidenciou-se que o jejum ou a ingestão alimentar reduzida induziam à perda de nitrogênio (Shen et al., 2005).

A partir da solidificação dos pressupostos teóricos e do desenvolvimento das metodologias, ocorreu um grande desenvolvimento de estudos, estimulados por diversos simpósios, particularmente os internacionais de estudos de composição corporal in vivo, dos quais o mais recente foi realizado em Roma, em outubro de 2002 (De Lorenzo, 2003). Esses avanços levaram um grupo de pesquisadores a iniciar, em 2003, uma publicação internacional devotada especificamente à área: International Journal of Body Composition Research.

As pesquisas publicadas mais recentemente evidenciam que o enfoque na área, além do aprimoramento das técnicas de medição, está concentrado na descrição das diferenças étnicas, na associação com patologias, no desenvolvimento de valores de referência/pontos de corte para o diagnóstico da obesidade e na validação de métodos clínicos de acompanhamento de intervenções em diversas doenças, particularmente da obesidade (De Lorenzo, 2003; Deurenberg \& Deurenberg-Yap, 2003; Pierson, 2003).

\section{Métodos de Medição da Composição Corporal}

\section{Técnicas Consideradas Padrão-Ouro}

A evolução das metodologias de avaliação da composição corporal permitiu o desenvolvimento de modelos com cada vez mais compartimentos. O modelo mais simples (dois compartimentos) envolve a medição do PG; o de três componentes inclui, em geral, a medição adicional da ACT; e o de quatro inclui, ainda, a medição do mineral ósseo.

Os métodos considerados padrão para o modelo de dois compartimentos baseiam-se na medição: da densidade corporal (densitometria), avaliada por meio da pesagem hidrostática; do nível de hidratação do indivíduo, avaliado por meio da determinação da ACT; da quantidade de potássio corporal total, avaliado pela eliminação do ${ }^{40} \mathrm{~K}$. Esses métodos são considerados padrão porque partem de princípios teóricos sólidos distintos e apresentam resultados bastante semelhantes entre si, o que permite que um método valide o outro.

\section{Densitometria Corporal}

A densitometria corporal, ou peso hidrostático, é considerada o método principal da avaliação da composição corporal em laboratório, apesar de seus princípios serem criticados principalmente por se basearem em dissecação de cinco cadáveres (Martin \& Drinkwater, 1991). O método determina a Densidade Corporal (DC) com base no princípio de Arquimedes, em que o volume de um corpo é igual ao deslocamento de água deste quando submergido. A proporção do PC submerso e fora d'água indicará, portanto, a DC total.

Recentemente, desenvolveu-se um método mais simples para medir a DC, sem a necessidade de pesar o indivíduo embaixo da água. O método, pletismografia de deslocamento de ar, ficou recentemente popularizado pelo Bod Pod, um sistema que consiste em uma câmera hermeticamente fechada em que cabe um indivíduo, na qual a relação pressão-volume é usada para estimar o volume do corpo (Going, 2005) com o indivíduo dentro da câmara em relação à câmara vazia. Esse sistema é particularmente útil em indivíduos que têm dificuldade de ser pesados embaixo da água (crianças, idosos, portadores de alguma deficiência), mas pode ser inconveniente para indivíduos claustrofóbicos. 
Assumindo-se que os vários componentes têm densidades diferentes e que estas são conhecidas e constantes (densidade do PG e do PM como 0,9 e 1,1 kg/L, respectivamente) (Siri, 1956), pode-se estimar a proporção de gordura corporal (\%GC) por meio de algumas equaçôes, mais freqüentemente a de Siri (1956): \%GC = [(4,95/ DC) - 4,50] x 100, e a de Brožek e colaboradores (1963): \%GC = [(4,570/DC) - 4,142] x 100. A crítica a esse método dirige-se aos pressupostos de que as proporçóes e as densidades dos componentes do PLG são constantes, o que não é verdadeiro para todos os indivíduos. Crianças, por exemplo, apresentam menor proporção quanto ao conteúdo mineral e maior quantidade de água (Lohman, Boileau \& Slaughter, 1984). Já em idosos, há diminuição do peso ósseo, peso muscular e da água corporal (Heymsfield et al., 1989). Em ambas as situações, a aplicação das equaçōes de Siri (Baumgartner et al., 1991; Deurenberg, Westrate \& Van de Hooy, 1989) ou de Brožek (1956) tendem a superestimar o \%GC.

\section{Hidrometria (ACT)}

A medição da Água Corporal Total (ACT) é realizada pela diluição de isótopos da água, seja radioativa ou estável. Os isótopos estáveis são mais freqüentemente usados, pois não representam risco para os indivíduos e podem ser utilizados com segurança em crianças (Schoeller, 2005). Neste método, uma quantidade conhecida do isótopo é administrada por via oral ou intravenosa. Após um período de equilíbrio, dispersão do isótopo na água corporal, são coletadas amostras dos fluidos corporais (saliva, urina ou sangue) para medir o aparecimento do respectivo isótopo (Jebb \& Elia, 1993). Para a estimativa da composição corporal é necessário assumir que a hidratação do PLG é constante, sendo que para adultos saudáveis, geralmente, equivale a 73,8\% (Brožek et al., 1963). Sabendo-se a quantidade de ACT, pode-se estimar o PLG, e, por diferença, o PG.

\section{Potássio 40 (potássio corporal total)}

$\mathrm{O}{ }^{40} \mathrm{~K}$ é um isótopo do potássio que ocorre naturalmente e é eliminado pelo organismo. Ao assumir-se que a eliminação de ${ }^{40} \mathrm{~K}$ é proporcional à quantidade de PLG, a medição da eliminação do ${ }^{40} \mathrm{~K}$ pode ser usada para determinar o PLG e, por diferença, o PG (Forbes, 1987). Os valores médios da razão entre potássio corporal total e o PLG equivalem a $59,6 \mathrm{mmol} / \mathrm{kg}$ para mulheres e $64,8 \mathrm{mmol} / \mathrm{kg}$ para homens (Ellis, 2005). Apesar de ser um método não invasivo, rápido e que não requer muito dos indivíduos em avaliação, há poucos contadores de ${ }^{40} \mathrm{~K}$ disponíveis devido ao seu alto custo e porque, geralmente, são restritos a laboratórios para pesquisas nucleares.

\section{Técnica com Potencial de se Tornar Padrão-ouro: Dexa (absorptiometria de raios X de dupla energia)}

Métodos que incorporam outros compartimentos estão sendo desenvolvidos, mas em sua maior parte estão em fase de pesquisa e ainda com pouco uso na prática. Entre esses, o mais promissor é a medição do compartimento mineral por meio da absorptiometria de raios X de dupla energia (Dexa), que apresenta potencial de tornar-se um método-ouro (Mazess et al., 1990).

A Dexa, além de avaliar o conteúdo mineral ósseo, também avalia a gordura e o tecido mole magro. Geralmente, a informação do conteúdo mineral ósseo é utilizada em modelos de multicompartimentos para a determinação da composição corporal. O princípio do método consiste no escaneamento transversal do corpo inteiro em feixes de raios X (baixa e alta energia) em fatias de aproximadamente um centímetro. Como a atenuação da radiação da gordura pura e do tecido magro sem mineral diferem, é possível, a cada pixel da fatia do corpo escaneada, determinar a gordura e o tecido magro (Lohman \& Chen, 2005). 
A maior vantagem do método é que ele pode ser utilizado em indivíduos de qualquer idade, devido à baixa exposição à radiação. Porém, é conveniente que não seja aplicado em gestantes. Em mulheres em idade fértil, é recomendado fazer um teste para verificar uma possível gravidez antes de realizar a medição no Dexa. A desvantagem do método é que indivíduos muito altos ou obesos podem não caber na área de escaneamento. Além disso, para as pessoas com peso superior a $100 \mathrm{~kg}$ ou as que apresentem a raiz quadrada da razão entre peso e estatura maior do que 0,72 , a estimativa da composição corporal tem menor acurácia, porque os coeficientes de atenuação para o tecido mole e mineral ósseo dependem da espessura do indivíduo (Lohman \& Chen, 2005).

\section{Técnicas Utilizadas em Campo}

É evidente que os métodos-padrão não podem ser utilizados em grande número de indivíduos. Assim, as estimativas de composição corporal são realizadas por meio de métodos mais simples (por exemplo, antropometria e bioimpedância), considerados métodos duplamente indiretos, por precisarem ser validados contra um outro método indireto, os métodos considerados padrão-ouro, ou seja, a densitometria corporal, ACT e medição do ${ }^{40} \mathrm{~K}$ (Clarys et al., 1999).

\section{Antropometria}

À utilização das informações antropométricas para o diagnóstico nutricional tem-se chamado antropometria nutricional (Brožek, 1956). A antropometria nutricional em grupos de crianças é baseada, principalmente, na avaliação do crescimento, ao passo que em adultos ela se faz na estimativa da composição corporal, por meio, principalmente, de medições de dobras cutâneas, perímetros e das medidas de dimensão corporal, como peso e estatura (Lohman, 1991).

Para avaliar o grau de acurácia na predição do \%GC ou do PLG, por qualquer método que seja, Lohman (1992) propôs um sistema arbitrário baseado no Erro-Padrão da Estimativa (EPE). Nesse sistema, há uma escala progressiva que vai desde o método ideal, que tem um $\mathrm{EPE}=2 \%$ para a estimativa do \%GC em homens e mulheres, até o método que não seria recomendado quando o EPE fica em $5 \%$. Um método que dê estimativas de \%GC com EPE entre 3 e 3,5\% seria considerado de bom a muito bom.

Em geral, a estimativa do \%GC pelo PC e estatura, medidas que podem ser usadas isoladamente ou em conjunto, fornece EPE entre 3,5 e 5\% (Bellisari \& Roche, 2005), o que demonstra que se deve ter cautela no seu uso em estudos de composição corporal. Em geral, as estimativas de \%GC por meio de dobras cutâneas e bioimpedância apresentam menor EPE (entre 3 e 3,5\%), mas deve-se sempre tentar usar as equaçóes apropriadas para a população em estudo.

\section{Dobras Cutâneas}

A utilização de dobras cutâneas parte do pressuposto de que: 1) elas fornecem uma boa estimativa da gordura subcutânea; 2) a distribuição da gordura subcutânea e a gordura corporal interna são semelhantes em todos os indivíduos do mesmo sexo; e 3) as medidas de gordura subcutânea em vários locais podem ser usadas para estimar a gordura corporal total (Heyward \& Stolarczyk, 1996).

Assim, sítios são escolhidos, as medidas de dobras cutâneas realizadas e aplicadas em uma equação previamente estabelecida em grupos de indivíduos para estimar inicialmente a DC, para então, utilizando-se da equação de Siri ou Brožek, se estimar o \%GC (Lohman, 1981). Embora existam dezenas de equações, as mais utilizadas internacionalmente são as de Durnin e Womersly (1974) na área de nutrição e as de Jackson e Pollock (1978), 
para homens, e Jackson, Pollock e Ward (1980) para mulheres, na área de ciências do movimento, por elas serem consideradas, em princípio, equações generalizáveis.

Entretanto, validações conduzidas em amostras da população brasileira indicaram que nem todas as equações são apropriadas (Petroski \& Pires-Neto, 1995, 1996). Por exemplo, a equação de Jackson, Pollock e Ward (1980) mostrou-se adequada na estimação tanto da DC quanto do \%GC em uma amostra de 281 mulheres jovens (média de 27,5 anos de idade), de Santa Maria (RS) e Florianópolis (SC). Da mesma forma, a equação de Jackson e Pollock (1978) mostrou-se adequada para a estimação do \%GC na amostra de 304 homens (média de 30,2 anos de idade) das mesmas regiōes. No entanto, as equaçôes de Durnin e Womersley (1974) superestimaram o \%GC tanto em mulheres quanto em homens das duas amostras de brasileiros. Essa discrepância pode ser explicada, em parte, pelo fato de as amostras dos estudos brasileiros serem de universitários e, assim, mais parecidas com a amostra que originou as equaçōes de Jakcson e Pollock (1978) e Jackson, Pollock e Ward (1980). Na verdade, das dez equações para mulheres e das 13 equações para homens 'generalizáveis', testadas na amostra de Santa Maria e Florianópolis, apenas três (tanto em homens quanto em mulheres) não mostraram valores de DC estimados significativamente diferentes do valor medido, o que indica adequação das equações.

De fato, há consenso de que se deve escolher uma equação de predição de DC que tenha sido desenvolvida em uma população que se assemelhe com a população para a qual se deseja estimar a composição corporal. Quanto a este aspecto, Heyward e Stolarczyk (1996) apresentam uma revisão extensa que pode servir como guia para a escolha das equações mais apropriadas para diferentes grupos etários, étnicos e que tenham características de atividade física diferenciada.

\section{Peso Corporal e Estatura}

Os valores de Peso Corporal (PC) e Estatura (EST) são normalmente expressos como índices, mais freqüentemente como o Índice de Massa Corporal (IMC) calculado como PC/EST ${ }^{2}$, com o PC em quilogramas e a EST em metros (Anjos, 1992). O IMC é utilizado por apresentar correlação alta com indicadores de adiposidade (Cronk \& Roche, 1982; Micozzi et al., 1986); associação com morbi-mortalidade (Anjos, 1992) e correlação alta com massa corporal (geralmente superior a 0,80 ) e baixa com estatura (geralmente inferior a 0,10 , sendo algumas vezes negativa (Anjos, 1998). Para sobrepeso, utiliza-se normalmente o ponto de corte de IMC $\geq 25 \mathrm{~kg} / \mathrm{m}^{2}$ e IMC $\geq 30 \mathrm{~kg} / \mathrm{m}^{2}$ para obesidade (WHO, 2000). Para baixo peso, utiliza-se o valor de $18,5 \mathrm{~kg} / \mathrm{m}^{2}$, sendo considerado adequado o valor entre 18,5 e $25 \mathrm{~kg} / \mathrm{m}^{2}$. Esses pontos de corte devem ser usados apenas em indivíduos com 20 anos ou mais de idade (Anjos, 1994).

É fundamental lembrar que o IMC não expressa a composição corporal dos indivíduos e que, na verdade, com o avanço da idade, a relação entre o IMC e indicadores da composição corporal, como, por exemplo, o \%GC, varia bastante (Anjos, Boileau \& Geeseman, 1991). Para um mesmo IMC, os valores de \%GC são bastante inferiores nos indivíduos jovens em comparação aos indivíduos mais idosos (Figura 1). Esse fato desautoriza a utilização de valores de IMC maiores para definir adequação em indivíduos idosos, como já sugerido na literatura (Anjos, 1992). 
Figura 1 - Valores médios de \%GC e IMC $\left(\mathrm{kg} / \mathrm{m}^{2}\right)$ em função da idade de uma amostra de mulheres (A) e homens (B) norte-americanos
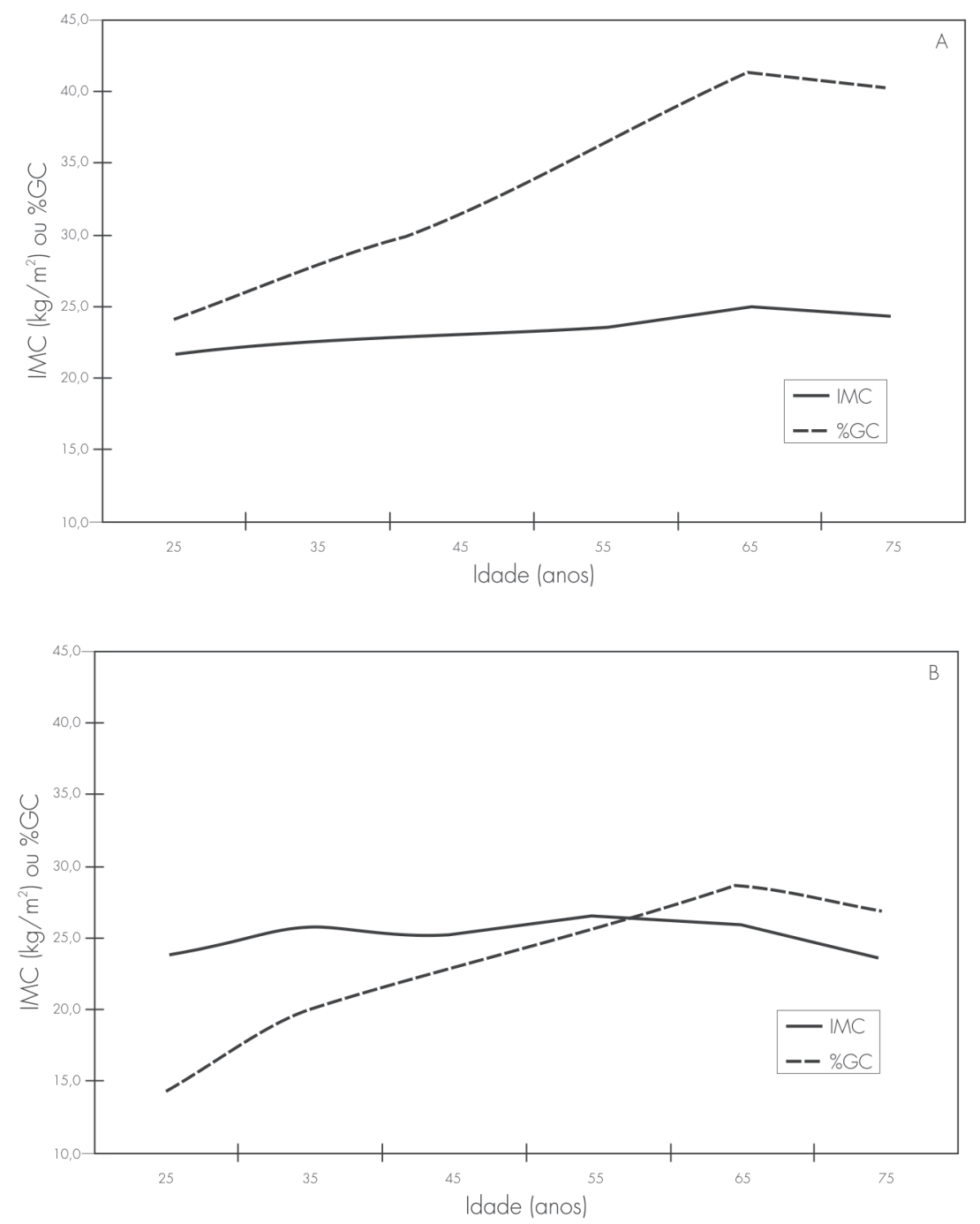

Fonte: desenhada com base em dados gentilmente cedidos pelo prof. Richard A. Boileau, do Laboratório de Pesquisa em Aptidão Física, Departamento de Cinesiologia, Universidade de Illinois.

\section{Bioimpedância}

Impedância é a oposição à passagem de corrente elétrica, sendo função da resistência e reatância, mas, como a resistência é muito maior do que a reatância (oposição à passagem da corrente causada pela capacitância da membrana celular) a $50 \mathrm{kHz}$, utiliza-se o valor da resistência na estimação da composição corporal (Lukaski et al., 1986).

O uso da impedância na avaliação da composição corporal parte do pressuposto de que o corpo humano é um cilindro perfeito com comprimento e área transversal uniformes, o que não é totalmente verdade. Assume-se, então, que o corpo humano seja composto por cinco cilindros conectados em série, e não por um cilindro único. 
Assumindo-se um cilindro perfeito, a impedância $(Z)$ à corrente é relacionada diretamente ao comprimento do condutor e inversamente à sua área transversal (Diaz et al., 1989). Tipicamente, utiliza-se a freqüência de sinal de $50 \mathrm{kHz}$ na medição e a estatura ao quadrado dividida pela resistência como estimador da composição corporal (Lukaski, 1987). Contudo, há várias equaçôes na literatura e muitas desenvolvidas em modelos de apenas dois componentes. Utilizando dados de composição corporal com vários componentes de vários laboratórios, Sun e colaboradores (2003) propuseram equações específicas para serem usadas em estudos epidemiológicos, particularmente com os dados do terceiro NHANES (sigla em inglês para o Inquérito Nacional de Saúde e Nutrição norte-americano).

O método da bioimpedância parte do princípio de que a condutividade elétrica é diferente entre o tecido magro e gordo, ou seja, os tecidos podem agir como condutores ou condensadores, e de que a corrente caminha em direção à menor resistência. Usando freqüências baixas $(\sim 1 \mathrm{kHz})$, a corrente só passa pelo fluido extracelular. Quando se usam frequiências mais altas $(500 \mathrm{a} 800 \mathrm{kHz})$, a corrente penetra na célula e passa pelo fluido intracelular. Já que a gordura é um fraco condutor, então a impedância do corpo todo (a $50 \mathrm{kHz}$ ) reflete o volume dos compartimentos de água e músculo do PLG e do volume de água extracelular.

O método é seguro, mas não deve ser utilizado em indivíduos com marca-passo. Até recentemente, só havia disponíveis aparelhos com quatro eletrodos, os quais eram ligados no punho e tornozelo dos indivíduos em avaliação, que precisavam ficar deitados. Atualmente, já há evoluções que permitem que a medição possa ser realizada com o indivíduo em pé numa balança (Wahrlich et al., 2005) ou um método mais simples, em que o indivíduo segura os eletrodos com as mãos esticadas (Lintsi, Kaarma \& Kull, 2004), tornando a medida muito mais simples de realizar. Devido a críticas segundo as quais esses sistemas mediam apenas a impedância dos membros inferiores, caso da balança, ou superiores, no outro caso, várias empresas desenvolveram uma balança em que o indivíduo também segura os eletrodos com as duas mãos quando se faz a medição, um sistema com oito eletrodos (Pietrobelli et al., 2004; Oshima \& Shiga, 2006).

Para a medição, devem-se observar os seguintes aspectos de padronização: não se alimentar ou beber quatro horas antes; urinar até trinta minutos antes; não realizar exercício intenso até 12 horas antes; não consumir álcool até 48 horas antes; não usar diurético até sete dias antes e manter a temperatura ambiental $\cong 35^{\circ} \mathrm{C}$.

Além da medição da resistência e reatância, alguns aparelhos fornecem o ângulo de fase, medida que parece promissora na avaliação, monitoramento e prognóstico de várias condições clínicas (Barbosa-Silva et al., 2005).

A comparação entre as vantagens e desvantagens de cada um dos métodos é resumida no Quadro 1.

Quadro 1 - Vantagens e desvantagens dos métodos para estimativa da composição corporal

\begin{tabular}{|c|c|c|c|}
\hline Componente/Propriedade & Método/Técnica & Medida/Vantagem & Desvantagem \\
\hline \multirow[t]{5}{*}{ Densidade } & \multirow[t]{5}{*}{$\begin{array}{l}\text { Pesagem hidrostática } \\
\text { BodPod }\end{array}$} & $\begin{array}{l}\text { Mede a gordura corporal e peso livre de } \\
\text { gordura simultaneamente. }\end{array}$ & $\begin{array}{l}\text { Assume que a composição do } \\
\text { peso livre de gordura é constante. }\end{array}$ \\
\hline & & $\begin{array}{l}\text { Baixo custo comparado a outros métodos } \\
\text { (exceto BodPod). }\end{array}$ & $\begin{array}{l}\text { Difícil de medir em crianças e } \\
\text { idosos. }\end{array}$ \\
\hline & & Pode ser repetido com freqüência. & \multirow[t]{3}{*}{ Claustrofobia (BodPod). } \\
\hline & & $\begin{array}{l}\text { Mais fácil de realizar em crianças e idosos } \\
\text { (BodPod). }\end{array}$ & \\
\hline & & Não oferece risco. & \\
\hline \multirow[t]{3}{*}{ Água Corporal Total (ACT) } & \multirow[t]{3}{*}{ Técnicas de diluição } & Estima os volumes de fluido corporal. & \multirow[t]{3}{*}{ Exposição à radiação (trítio). } \\
\hline & & Exame de sangue em alguns métodos. & \\
\hline & & $\begin{array}{l}\text { São necessários fatores de correccão para } \\
\text { espaços de água por }{ }^{2} \mathrm{H}_{2} \mathrm{O} \text { e }{ }^{3} \mathrm{H}_{2} \mathrm{O} \text {. }\end{array}$ & \\
\hline
\end{tabular}


Quadro 1 - Vantagens e desvantagens dos métodos para estimativa da composição corporal (continuação)

\begin{tabular}{|c|c|c|c|}
\hline Componente/Propriedade & Método/Técnica & Medida/Vantagem & Desvantagem \\
\hline \multirow[t]{5}{*}{ Isótopo } & \multirow[t]{5}{*}{ Contagem de ${ }^{40} \mathrm{~K}$} & Não oferece risco. & \multirow{2}{*}{$\begin{array}{l}\text { Equipamento caro e de uso } \\
\text { restrito. }\end{array}$} \\
\hline & & \multirow{4}{*}{ Pode ser repetido com freqüência. } & \\
\hline & & & $\begin{array}{l}\text { Calibração necessária para } \\
\text { tamanho e geometria corporal. }\end{array}$ \\
\hline & & & $\begin{array}{l}\text { Variações do conteúdo de K nos } \\
\text { tecidos. }\end{array}$ \\
\hline & & & Tempo de medição longo. \\
\hline \multirow[t]{4}{*}{ Atenuação dos raios $X$} & \multirow{4}{*}{$\begin{array}{l}\text { Dexa } \\
\text { (Absorptiometria } \\
\text { de raios X de } \\
\text { dupla energia) }\end{array}$} & \multirow{2}{*}{$\begin{array}{l}\text { Estima o conteúdo mineral ósseo, gordura e } \\
\text { tecido mole livre de gordura do corpo inteiro } \\
\text { ou de regiões do corpo. }\end{array}$} & Caro. \\
\hline & & & \multirow{3}{*}{$\begin{array}{l}\text { Difícil de medir em indivíduos } \\
\text { muito obesos. }\end{array}$} \\
\hline & & Pequena exposição à radiação. & \\
\hline & & Necessita de pouca cooperação do indivíduo. & \\
\hline \multirow[t]{2}{*}{ Impedância } & \multirow[t]{2}{*}{ Bioimpedância } & \multirow[t]{2}{*}{ Rápido, barato e menor erro intra-observador. } & $\begin{array}{l}\text { Certos modelos requerem que a } \\
\text { medida seja feita com o } \\
\text { indivíduo deitado. }\end{array}$ \\
\hline & & & $\begin{array}{l}\text { Cuidados prévios como } \\
\text { hidratação adequada. }\end{array}$ \\
\hline \multirow[t]{4}{*}{ Gordura subcutânea } & Antropometria & Baixo custo. & \multirow{2}{*}{$\begin{array}{l}\text { Necessidade de muito } \\
\text { treinamento. }\end{array}$} \\
\hline & \multirow[t]{3}{*}{ (Dobra cutânea) } & \multirow[t]{3}{*}{ Pode ser utilizado em estudos de campo. } & \\
\hline & & & Baixa precisão em obesos. \\
\hline & & & $\begin{array}{l}\text { Em idosos há maior } \\
\text { compressibilidade. }\end{array}$ \\
\hline
\end{tabular}

\section{Modificações da Composição Corporal no Ciclo de Vida}

A estimativa da composição corporal por métodos considerados padrão-ouro (hidrometria, densitometria e ${ }^{40} \mathrm{~K}$ ) baseia-se no pressuposto de que a composição do PLG é constante não só em seres humanos adultos como em outros mamíferos adultos (Wang et al., 1999). Porém, esse princípio pode ser violado quando aplicado a crianças, adolescentes e idosos, uma vez que a composição do PLG sofre alterações durante os processos de maturação (Fomon et al., 1982; Forbes, 1987) e envelhecimento (Deurenberg, Westrate \& Van de Hooy, 1989; Visser, 2003).

A partir da infância, a composição do PLG varia, chegando à maturação química que, segundo alguns autores, ocorre na adolescência (Forbes, 1987). Mas, para outros, isso só ocorre na vida adulta (Boileau et al.,1984). No decorrer do primeiro ano de vida até 10 anos, verificam-se diminuição entre a razão do fluido extracelular e da ACT e aumento da contribuição do músculo e da massa óssea no PLG (Fomon et al., 1982). O aumento da proporção de massa muscular e conteúdo mineral ósseo modifica a densidade do PLG, assim como a água corporal, que está quase que exclusivamente associada a este componente. A água, por sua vez, é o principal componente a exercer influência na densidade do PLG, ou seja, quanto maior a quantidade de água menor será a densidade, já que a densidade da água é muito mais baixa que a das proteínas e minerais (Boileau et al., 1984). Do nascimento até a pré-adolescência, verifica-se diminuição da hidratação do PLG com o respectivo aumento da DC (Fomon et al., 1982), porém os valores não equivalem àqueles estabelecidos para adultos. Lohman (1992) verificou que pré-adolescentes apresentavam maior proporção de água no PLG (76,6\%) e menor conteúdo de mineral (5,8\%) quando comparados com os valores estabelecidos para adultos (73,8 e 6,8\%, respectivamente). Portanto, a densidade do PLG será menor do que em adultos, e a aplicação do modelo adulto em crianças levará a uma superestimativa da quantidade de gordura corporal. 
Já no envelhecimento, ocorre a alteração da composição do PLG devido, em grande parte, à diminuição da massa muscular e, principalmente, à perda do conteúdo mineral ósseo, que é mais acentuada em mulheres (Deurenberg, Westrate \& Van de Hooy, 1989; Visser et al., 2003), fazendo com que a densidade do PLG seja menor do que a encontrada no adulto jovem. Além desses fatores, parece que a quantidade e a distribuição de ACT pode modificar-se no processo do envelhecimento (Forbes, 1987). Sabe-se que a diminuição da musculatura é acompanhada pela diminuição proporcional da água corporal. Entretanto, a questão da influência do envelhecimento na hidratação do PLG ainda é objeto de controvérsia, pois há estudos demonstrando alterações significativas da proporção de água no PLG em indivíduos mais idosos (Hewitt et al., 1993; Virgili, D’Amicis \& FerroLuzzi, 1992), ao passo que outros evidenciam pouca alteração na hidratação do PLG com o avançar da idade (Schoeller, 1989). Assim, recomenda-se cautela na aplicação do modelo de dois compartimentos em idosos, pois fatores como a diminuição da massa muscular, dúvidas quanto à hidratação da PLG e a diminuição do conteúdo ósseo comprometem os pressupostos teóricos desse modelo. Devido a isso, o modelo de quatro compartimentos é o mais recomendado para utilização em idosos, por levar em consideração a variabilidade da composição do PLG (Baumgartner et al., 1991).

\section{Aplicação da Composição Corporal no Diagnóstico Nutricional de Populações}

\section{Pontos de Corte Utilizados para Diagnóstico Nutricional}

Apesar do desenvolvimento e aprimoramento das técnicas de medição da composição corporal, ainda permanecem dúvidas quanto ao estabelecimento de pontos de corte da quantidade de GC associada a riscos de doenças a serem usados clinicamente. Isso se deve, em parte, à carência de dados acurados da composição corporal em grandes estudos populacionais (Lohman \& Going, 1998). Tal aspecto é particularmente importante na definição da obesidade, visto esta condição ser, em geral, associada a um excesso de GC que traga repercussões ao indivíduo. Tipicamente, usam-se valores de gordura corporal em torno de 10-20\% para homens e 20-30\% para mulheres, por serem os valores encontrados, em média, em estudos conduzidos em amostras de conveniência, tipicamente adultos jovens (Lohman, 1992; Lohman, Houtkooper \& Going, 1997), em laboratórios de avaliação da composição corporal no hemisfério Norte.

Em 1993, um grupo de especialistas da Associação Dietética Americana e Canadense sugeriu valores de \%GC considerados aceitáveis (ADA/CDA, 1993): 20-25\% para mulheres e entre 15 e 18\% para homens. A obesidade seria diagnosticada quando o \%GC fosse maior do que 30 e $25 \%$ para homens e mulheres, respectivamente. A definição desses valores baseou-se em experiência de especialistas, e não em dados epidemiológicos sólidos.

Usando os pontos de corte de IMC de 19 e $25 \mathrm{~kg} / \mathrm{m}^{2}$ para a menor morbi-mortalidade, Abernathy e Black (1996) propuseram os valores de peso saudável iguais a percentuais de GC entre 12 e 20\% para homens e 20 e $30 \%$ para mulheres.

Em uma amostra grande de indivíduos da Suíça (2.735 homens e 2.490 mulheres entre 15 e 98 anos de idade), Kyle e colaboradores (2001) forneceram dados de referência de composição corporal (\%GC, PG e PLG) em percentis selecionados, usando a bioimpedância como método de avaliação. Os valores do percentil 95 do \%GC aumentaram com o passar da idade, saindo de 24,4\% nos mais jovens (15-24 anos) e chegando a 33,4\% nos homens mais idosos (85 anos ou mais). Os valores para as mulheres das mesmas faixas etárias variaram de 34,9 a $46,9 \%$.

Baseando-se na conversão dos dados de dobras cutâneas em \%GC na amostra representativa da população americana (NHANES), Lohman, Houtkooper e Going (1997) propuseram pontos de corte diferenciados segundo 
a faixa etária e sexo para a obesidade: $22 \%$ em homens adultos jovens; $25 \%$ para os homens de meia-idade; $23 \%$ para os idosos. Os valores para as mulheres foram, respectivamente, 35, 38 e $35 \%$.

Outros autores usam alternativas diferentes para estabelecer esses pontos. A mais prática parece ser encontrar o valor de \%GC relativo a pontos de corte de outras medidas antropométricas bem estabelecidas, como, por exemplo, o IMC. Usando essa estratégia, Lohman (1992) sugeriu o uso dos valores de $25 \%$ e 32\% de GC para homens e mulheres, tomando como base os valores de 27,8 e $27,3 \mathrm{~kg} / \mathrm{m}^{2}$ de IMC, critério usado para sobrepeso na população americana à época (Kuczmarski \& Flegal, 2000). Usando os pontos de corte de IMC atualmente recomendados (WHO, 2000) para baixo peso $\left(<18,5 \mathrm{~kg} / \mathrm{m}^{2}\right)$, sobrepeso $\left(\geq 25 \mathrm{~kg} / \mathrm{m}^{2}\right)$ e obesidade $\left(\geq 30 \mathrm{~kg} / \mathrm{m}^{2}\right)$, Gallagher e colaboradores (2000) estabeleceram valores de \%GC para norte-americanos e asiáticos em função da idade. Por exemplo, para mulheres norte-americanas, os valores variaram de 39 a $42 \%$ de GC, e entre 25 e $30 \%$ para os homens em função da faixa etária. No estabelecimento dessa relação, a etnia parece ser um importante fator (Fernández et al., 2003; Gurrici et al., 1998; He et al., 2001), o que, aliás, vem fazendo com que se questione a prática, atual, de basear-se nos valores universais de IMC para a classificação do estado nutricional (Blew et al., 2002; Evans et al., 2006) ou mesmo o uso isolado de IMC (De Lorenzo et al., 2003).

De fato, análise preliminar de dados sobre a relação entre IMC e \%GC em amostra probabilística de adultos de Niterói indicou valores sempre maiores do que os propostos por Gallagher e colaboradores (2000) tanto para homens quanto para mulheres e todos os pontos de corte de IMC (Anjos, Wahrlich \& Vasconcelos, 2006).

Williams e colaboradores (1992), por sua vez, analisando os dados do estudo Bogalusa, observaram que valores de \%GC iguais a 25 e 30 para meninos e meninas, respectivamente, estimados por dobras cutâneas, estavam associados com maior risco de doenças cardiovasculares (pressão arterial, colesterol total e lipoproteína de baixa densidade), mesmo quando controlados pela idade, raça e gordura no tronco, o que fez os autores recomendarem esses pontos de corte como critério para crianças e adolescentes.

Recentemente, McCarthy e colaboradores (2006) desenvolveram curvas de referência de gordura corporal (\%GC), baseadas em dados obtidos por bioimpedância em uma amostra grande de crianças e adolescentes (5-18 anos) inglesas. Baseando-se nos valores de IMC para idade sugeridos para diagnóstico de obesidade em crianças da IOTF (sigla em inglês para a Força-Tarefa Internacional de Obesidade), Cole e colaboradores (2000) encontraram valores de \%GC mais próximos e estabeleceram nomenclaturas para tal: baixa gordura ( $<2$ percentil); normal (entre o percentil 2 e o 85); excesso de gordura (entre o percentil 85 e 95) e obesidade (acima do percentil 95).

\section{Considerações Finais}

Foram apresentados, aqui, os métodos tradicionais utilizados como referência na medição da composição corporal, o Dexa - atualmente cogitado como o novo método padrão-ouro, apesar de haver necessidade de mais estudos para validá-lo - e os métodos de campo mais usados. Sem dúvida, o estudo da composição corporal teve grandes avanços nas últimas décadas, com o desenvolvimento de modelos de multicomponentes melhorando as estimativas dos componentes corporais. Entretanto, permanece o desafio de desenvolver técnicas com mais acurácia aplicáveis em estudos epidemiológicos no intuito de melhor diagnosticar alteraçôes nutricionais como a obesidade, hoje baseada principalmente no IMC, que não reflete a composição corporal dos indivíduos. Também, na perspectiva da saúde pública, a determinação da composição corporal em grupos específicos, como os idosos, pode ser importante na identificação e na prevenção da osteoporose, doença que compromete a autonomia desses indivíduos. 


\section{Referências}

ABERNATHY, R. P. \& BLACK, D. R. Healthy body weights: an alternative perspective. American Journal of Clinical Nutrition, 63: 448S-451S, 1996.

AMERICAN DIETETIC ASSOCIATION (ADA)/CANADIAN DIETETIC ASSOCIATION (CDA). Position of the American Dietetic Association and the Canadian Dietetic Association: nutrition for physical fitness and athletic performance for adults. Journal of the American Dietetic Association, 93: 691-696, 1993.

ANJOS, L. A. Índice de massa corporal (kg.m-2) como indicador do estado nutricional de adultos: uma revisão da literatura. Revista de Saúde Pública, 26: 431-436, 1992.

ANJOS, L. A. O índice de massa corporal só deve ser usado em indivíduos com mais de 20 anos de idade. In: SIMPÓSIO INTERNACIONAL DE CIÊNCIAS DO ESPORTE, XIX, 1994, São Paulo. Anais... São Caetano do Sul: Celafiscs, 1994.

ANJOS, L. A. Avaliação nutricional de adultos em estudos epidemiológicos. In: VERAS, R. P. et al. (Orgs.) Epidemiologia: contexto e pluralidade. Rio de Janeiro: Editora Fiocruz, 1998.

ANJOS, L. A.; BOILEAU, R. A. \& GEESEMAN, R. Uso do índice de massa corporal (IMC) como indicador do estado nutricional de população idosa. In: CONGRESSO BRASILEIRO, IX, JORNADA PAULISTA, III, CONGRESSO LATINO-AMERICANO DE GERIATRIA E GERONTOLOGIA, VII E CONGRESSO LATINO-AMERICANO DE GERONTOLOGIA, I, 1991, São Paulo.

ANJOS, L. A.; WAHRLICH, V. \& VASCONCELLOS, M. T. L. Association between body mass index and percent body fat in a household survey in Niterói, Rio de Janeiro, Brazil. Obesity Reviews, 7, suppl. 2: 60, 2006.

BARBOSA SILVA, M. C. G. et al. Bioelectrical impedance analysis: population reference values for phase angle by age and sex. American Journal of Clinical Nutrition, 82: 49-52, 2005.

BAUMGARTNER, R. N. et al. Body composition in elderly people: effect of criterion estimates on predictive equations. American Journal of Clinical Nutrition, 53: 1-9, 1991.

BEHNKE, A. R. The estimation of lean body weight from skeletal measurement. Human Biology, 31: 295-315, 1959.

BEHNKE, A. R.; FEEN, B. G. \& WELHAM, W. C. The specific gravity of healthy men. Journal of the American Medical Association, 118: 495-498, 1942.

BELLISARI, A. \& ROCHE, A. F. Anthropometry and ultrasound. In: HEYMSFIELD, S. B. et al. Human Body Composition. 2. ed. Champaign: Human Kinetics, 2005.

BLEW, R. M. et al. Assessing the validity of body mass index standards in early postmenopausal women. Obesity Research, 10: 799-808, 2002.

BOILEAU, R. A. et al. Hydration of the fat-free body in children during maturation. Human Biology, 56: 651666, 1984.

BROŽEK, J. Body Measurements and Human Nutrition. Detroit: Wayne State University Press, 1956.

BROŽEK, J. et al. Densitometric analysis of body composition: revision of some quantitative assumptions. Annals of the New York Academy of Science, 110(Part I): 113-140, 1963. 
BUSKIRK, E. R. Body composition analysis: the past, present and future. Research Quarterly for Exercise and Sport, 58: 1-10, 1987.

CLARYS, J. P. et al. Human body composition: a review of adult dissection data. American Journal of Human Biology, 11: 167-174, 1999.

COLE, T. J. et al. Establishing a standard definition for child overweight and obesity: international survey. British Medical Journal, 320: 1.240-1.243, 2000.

CRONK, C. E. \& ROCHE, A. F. Race and sex-specific reference data for triceps and subscapular skinfold and weight/stature. American Journal of Clinical Nutrition, 35: 347-354, 1982.

DE LORENZO, A. Preface. Acta Diabetologica, 40: S1-S2, 2003.

DE LORENZO, A. et al. How fat is obese? Acta Diabetologica, 40: S254-S257, 2003.

DEURENBERG, P. \& DEURENBERG-YAP, M. Validity of body composition methods across ethnic population groups. Acta Diabetologica, 40: S246-S249, 2003.

DEURENBERG, P.; WESTRATE, J. A. \& VAN DE HOOY, K. Is an adaptation of Siri's formula for the calculation of body fat percentage from body density in the elderly necessary? European Journal of Clinical Nutrition, 49: 401-403, 1989.

DIAZ, E. O. et al. Bioimpedance or anthropometry? European Journal of Clinical Nutrition, 43: 129-137, 1989.

DURNIN, J. V. G. A. \& WOMERSLEY, J. Body fat assessed from total body density and its estimation from skinfold thickness measurements on 481 men and women age from 16 to 72 years. British Journal of Nutrition, 32: 77-92, 1974.

ELLIS, K. J. Whole-body counting and neutron activation analysis. In: HEYMSFIELD, S. B. et al. Human Body Composition. 2. ed. Champaign: Human Kinetics, 2005.

EVANS, E. M. et al. Is the current BMI obesity classification appropriate for black and white postmenopausal women? International Journal of Obesity, 30: 837-843, 2006.

FERNÁNDEZ, J. R. et al. Is percentage body fat differentially related to body mass index in Hispanic Americans, African Americans, and European Americans? American Journal of Clinical Nutrition, 77: 71-75, 2003.

FOMON, S. J. et al. Body composition of reference children from birth to age 10 years. American Journal of Clinical Nutrition, 35: 1.169-1.175, 1982.

FORBES, G. B. Human Body Composition. New York: Springer-Verlag, 1987.

GALLAGHER, D. et al. Healthy percentage body fat ranges: an approach for developing guidelines based on body mass index. American Journal of Clinical Nutrition, 72: 694-701, 2000.

GOING, S. B. Hydrodensitometry and air displacement plethysmography. In: HEYMSFIELD, S. B. et al. Human Body Composition. 2. ed. Champaign: Human Kinetics, 2005.

GURRICI, S. et al. Relationship between body fat and body mass index: differences between Indonesians and Dutch Caucasians. European Journal of Clinical Nutrition, 52: 779-783, 1998.

HE, M. et al. Body fat determination by dual energy X-ray absorptiometry and its relation to body mass index and waist circumference in Hong Kong Chinese. International Journal of Obesity, 25: 748-752, 2001. 
HEWITT, M. J. et al. Hydration of the fat-free body mass in children and adults: implications for body composition assessment. American Journal of Physiology, 265: E88-95, 1993.

HEYMSFIELD, S. B. et al. Body composition in elderly subjects: a critical appraisal of clinical methodology. American Journal of Clinical Nutrition, 50: 1.167-1.175, 1989.

HEYMSFIELD, S. B. et al. Human Body Composition. 2. ed. Champaign: Human Kinetics, 2005.

HEYWARD, V. \& STOLARCZYK, L. M. Applied Body Composition Assessment. Champaign: Human Kinetics, 1996.

HEYWARD, V. \& WAGNER, D. Applied Body Composition Assessment. Champaign: Human Kinetics, 2004.

JACKSON, A. S. \& POLLOCK, M. L. Generalized equations for predicting body density of men. British Journal of Nutrition, 40: 497-504, 1978.

JACKSON, A. S.; POLLOCK, M. L. \& WARD, A. Generalized equations for predicting body density of women. Medicine \& Science in Sports \& Exercise, 12: 175-182, 1980.

JEBB, S. A. \& ELIA, M. Techniques for the measurement of body composition: a practical guide. International Journal of Obesity, 17: 611-621, 1993.

KUCZMARSKI, R. J. \& FLEGAL, K. M. Criteria for definition of overweight in transition: background and recommendations for the United States. American Journal of Clinical Nutrition, 72: 1.074-1.081, 2000.

KYLE, U. G. et al. Fat-Free and fat mass percentiles in 5225 healthy subjects aged 15 to 98 years. Nutrition, 17: 534-541, 2001.

LINTSI, M.; KAARMA, H. \& KULL, I. Comparison of hand-to-hand bioimpedance and anthropometry equations versus dual-energy X-ray absorptiometry for the assessment of body fat percentage in 17-18year-old conscripts. Clinical Physiology and Functional Imaging, 24: 85-90, 2004.

LOHMAN, T. G. Skinfold and body density and their relation to body fatness. A review. Human Biology, 53: 181-225, 1981.

LOHMAN, T. G. Anthropometric assessment of fat-free body mass. In: HIMES, J. H. Anthropometric Assessment of Nutritional Status. New York: Wiley-Liss, 1991.

LOHMAN, T. G. Advances in Body Composition Assessment: current issues in exercise science. Champaign: Human Kinetics Publishers, 1992. (Monograph, 3)

LOHMAN, T. G. \& CHEN, Z. Dual-energy x-ray absorptiometry. In: HEYMSFIELD, S. B. et al. Human Body Composition. 2. ed. Champaign: Human Kinetics, 2005.

LOHMAN, T. G. \& GOING, S. B. Assessment of body composition and energy balance. In: LAMB, D. R. \& MURRAY, R. Exercise, nutrition, and weight control. Perspective in Exercise Science and Sports Medicine, 11: 61-105, 1998.

LOHMAN, T. G.; BOILEAU, R. A. \& SLAUGHTER, M. H. Body composition in children and youth. In: BOILEAU, R. A. Advances in Pediatric Sport Sciences. Champaign: Human Kinetics, 1984.

LOHMAN, T. G.; HOUTKOOPER, L. B. \& GOING, S. B. Body fat measurement goes high tech: not all are created equal. ACSM Health \& Fitness Journal, 1: 30-35, 1997. 
LUKASKI, H. C. Methods for the assessment of human body composition: traditional and new. American Journal of Clinical Nutrition, 46: 537-556, 1987.

LUKASKI, H. C. et al. Validation of tetrapolar bioelectrical impedance method to assess human body composition. Journal of Applied Physiology, 60: 1.327-1.332, 1986.

MARTIN, A. D. \& DRINKWATER, D. T. Variability in the measures of body fat: assumptions or technique? Sports Medicine, 11: 277-288, 1991.

MATIEGKA, J. The testing of physical efficiency. American Journal of Physical Anthropology, 4: 223-230, 1921.

MAZESS, R. B. et al. Dual-energy x-ray absorptiometry for total-body regional bone-mineral and soft-tissue composition. American Journal of Clinical Nutrition, 51: 1.106-1.112, 1990.

MCCARTHY, H. D. et al. Body fat reference curves for children. International Journal of Obesity, 30: 598-602, 2006.

MICOZZI, M. S. et al. Correlations of body mass indices with weight, stature, and body composition in men and women in NHANES I and II. American Journal of Clinical Nutrition, 44: 725-731, 1986.

MOULTON, C. R. Age and chemical development in mammals. Journal of Biological Chemistry, 57: 79-97, 1923.

OSHIMA, Y. \& SHIGA, T. Within-day variability of whole-body and segmental bioelectrical impedance in a standing position. European Journal of Clinical Nutrition, 60: 938-941, 2006.

PETROSKI, E. L. \& PIRES-NETO, C. S. Validação de equações antropométricas para a estimativa da densidade corporal em mulheres. Revista Brasileira de Atividade Fisica e Saúde, 1(2): 65-73, 1995.

PETROSKI, E. L. \& PIRES-NETO, C. S. Validação de equações antropométricas para a estimativa da densidade corporal em homens. Revista Brasileira de Atividade Física e Saúde, 1(3): 5-14, 1996.

PIERSON, R. N. A brief history of body composition: from F. D. Moore to the new Reference Man. Acta Diabetologica, 40: S114-S116, 2003.

PIETROBELLI, A. et al. New bioimpedance analysis system: improved phenotyping with whole-body analysis. European Journal of Clinical Nutrition, 58: 1.479-1.484, 2004.

SCHOELLER, D. A. Changes in total body water with age. American Journal of Clinical Nutrition, 50: 1.176S$1.181 S, 1989$.

SCHOELLER, D. A. Hydrometry. In: HEYMSFIELD, S. B. et al. Human Body Composition. 2. ed. Champaign: Human Kinetics, 2005.

SHEN, W. et al. Study of body composition: an overview. In: HEYMSFIELD, S. B. et al. Human Body Composition. 2. ed. Champaign: Human Kinetics, 2005.

SIRI, W. E. The gross composition of the body. Advances in Biological and Medical Physics, 4: 239-280, 1956.

SUN, S. S. et al. Development of bioelectrical impedance analysis prediction equations for body composition with the use of a multicomponent model for use in epidemiologic surveys. American Journal of Clinical Nutrition, 77: 331-340, 2003.

TALBOT, N. B. Measurement of obesity by the creatinine coefficient. American Journal of Diseases of Children, 55: 42-50, 1938. 
VIRGILI, F.; D’AMICIS, A. \& FERRO-LUZZI, A. Body composition and body hydration in old age estimated by means of skinfold thickness and deuterium dilution. Annals of Human Biology, 56: 19-28, 1992.

VISSER, M. et al. One-and two-year change in body composition as measured by DXA in a population-based cohort of older men and women. Journal of Applied Physiology, 94: 2.368-2.374, 2003.

WAHRLICH, V. et al. Comparison of estimated percentage body fat and fat-free mass in adults by a leg-to-leg bioimpedance with dual-energy X-ray absorptiometry. International Journal of Body Composition Research, 3: $147-152,2005$.

WANG, Z. M.; PIERSON, R. N. \& HEYMSFIELD, S. B. The five-level model: a new approach to organizing body-composition research. American Journal of Clinical Nutrition, 56: 19-28, 1992.

WANG, Z. M. et al. Systematic organization of body-composition methodology: an overview with emphasis on component-based methods. American Journal of Clinical Nutrition, 61: 457-465, 1995.

WANG, Z. M. et al. Hydration of fat-free body mass: review and critique of a classic body-composition constant. American Journal of Clinical Nutrition, 69: 833-841, 1999.

WILLIAMS, D. P. et al. Body fatness and risk for elevated blood pressure, total cholesterol, and serum lipoprotein ratios in children and adolescents. American Journal of Public Health, 82: 358-363, 1992.

WORLD HEALTH ORGANIZATION (WHO). Obesity: preventing and managing the global epidemic. Geneva: WHO, 2000. (WHO Technical Report Series, 894) 


\title{
9 \\ Gasto Energético: medição e importância para a área de nutrição
}

\author{
Luiz Antonio dos Anjos e Vivian Wahrlich
}

$\mathrm{O}$ dados sobre o sobrepeso/obesidade na população brasileira demonstram um crescimento na sua prevalência nas últimas três décadas do século XX. Apesar da carência de dados detalhados sobre a ingestão energética e, particularmente, do Gasto Energético (GE) (Anjos, 1999), é evidente que a população se apresenta em um quadro de balanço energético positivo (Mendonça \& Anjos, 2004), decorrente, possivelmente, de mudanças no consumo alimentar, com aumento no fornecimento de energia pela dieta e redução no GE das atividades cotidianas e ocupacionais, configurando um 'estilo de vida ocidental contemporâneo'.

Há uma ampla variação no GE, dependendo da ocupação, atividade de lazer e propensão individual para atividade física (Åstrand \& Rodahl, 1986), e as mulheres, em geral, tendem a ser menos ativas no lazer do que os homens, e as crianças mais ativas do que adultos (Anjos, 2000; Crespo et al., 1999).

Atualmente, considera-se que nos países mais desenvolvidos o gasto energético das atividades ocupacionais tenha menor importância no GE diário total, em função da diminuição do custo energético para a realização dessas atividades, causada pelo desenvolvimento tecnológico, que, caracterizado pela maior utilização de equipamentos, reduz o esforço do trabalhador. Entretanto, mesmo nesses países, ainda há alguns setores econômicos que exigem atividades manuais laborativas de maior intensidade. Nos países menos desenvolvidos, as atividades ocupacionais têm grande importância na determinação do GE total (Anjos, 1999). Medir apenas o GE de lazer leva à subestimação do GE total, especialmente nos indivíduos com ocupações intensas.

O presente capítulo descreve os métodos de medição do GE e revisa os principais usos de sua avaliação em estudos nutricionais, apresentando, sempre que possível, dados de estudos brasileiros.

\section{Conceituação}

O GE total diário pode ser entendido como a produção total de calor pelo indivíduo, incluindo o calor usado para a evaporação da água (Garrow, 1974). Seus componentes são: a Taxa Metabólica Basal (TMB), a atividade física e a ação dinâmica específica (ou termogênese) dos alimentos.

A TMB é a energia necessária para a manutenção das funçôes vitais (atividade mínima total das células do corpo em repouso em estado de vigília) e representa o principal componente do GE, podendo variar de $50 \%$ (indivíduo muito ativo fisicamente) até 70\% (indivíduo sedentário) do GE total diário (Wahrlich \& Anjos, 2001a). A TMB é medida em condições padronizadas: pela manhã, ao acordar, em repouso, relaxado, porém em 
estado de vigília e em posição supina, em jejum de no mínimo 12 horas, após 6 a 8 horas de sono, com o indivíduo não tendo realizado exercício físico intenso no dia anterior ao teste. A medida deve ser feita em ambiente tranqüilo, sem ruídos, com baixa luminosidade e com a temperatura da sala controlada. Na prática clínica e em estudos populacionais, a TMB não é medida, e sim estimada por equações de predição que parecem superestimar a TMB da população em geral e, particularmente, as que vivem nos trópicos (Wahrlich \& Anjos, 2000).

A Atividade Física (AF), como definida no capítulo 26, "Epidemiologia da atividade física", é entendida como qualquer movimento corporal produzido pelo músculo esquelético (Caspersen, Powell \& Christenson, 1985) que resulte em custo energético superior à taxa metabólica basal. A AF é o componente de maior variação do GE, podendo corresponder a $10 \%$ do total em indivíduos confinados ao leito a até $50 \%$ em atletas (Montoye et al., 1996). A dimensão e a composição corporal, o sexo, a idade, a intensidade e duração da atividade física, o nível de aptidão física do indivíduo e a hereditariedade são os fatores responsáveis pela variação interindividual.

A termogênese dos alimentos refere-se à energia necessária para a realização dos processos metabólicos (absorção, transporte, armazenamento e metabolização) que ocorrem após a ingestão alimentar e totaliza, para uma dieta mista, aproximadamente $10 \%$ do GE total diário, mas sofre influência do tipo de dieta: carboidratos ( 5 a 10\% de energia) ou gorduras requerem menos (5\%), e uma dieta exclusivamente protéica requer mais (10 a 35\%) (Bursztein et al., 1989).

A unidade apropriada para expressar o GE é o joule (energia gasta para deslocar $1 \mathrm{~kg}$ à distância de 1 metro pela força de 1 newton). No entanto, tipicamente utiliza-se o calorie (quantidade de calor necessária para elevar $1 \mathrm{~g}$ de água $1^{\circ} \mathrm{C}$, de 14,5 a $15,5^{\circ} \mathrm{C}$ ). Para fazer a conversão de uma unidade para outra, usam-se os seguintes fatores: $1 \mathrm{kcal}=4,184 \mathrm{~kJ}$ ou $1 \mathrm{~kJ}=0,239 \mathrm{kcal}$.

\section{Métodos de Medição}

Há uma carência de informações sobre o GE em populações que vivem em países em desenvolvimento (Anjos, 1999), devida, em parte, à sofisticação e ao alto custo da técnica da Água Duplamente Marcada (ADM), método considerado, atualmente, como padrão para as medições do GE diário (Schoeller, 1999). Existem, entretanto, alternativas menos sofisticadas, igualmente válidas e mais baratas para estimar o GE (Wareham et al., 1997). De qualquer jeito, e para qualquer uso que se tenha em mente, a medição do GE deve ser realizada da forma mais exata possível, já que seu uso é cada vez mais importante em investigações sobre a relação entre a nutrição e a saúde nas populações modernas.

\section{Calorimetria Direta e Indireta}

\section{Calorimetria Direta}

A calorimetria direta baseia-se na determinação da perda de calor pelo corpo, utilizando-se de uma câmara calorimétrica, que consiste em um cômodo hermeticamente fechado e arejado, contendo um sistema no qual há circulação de água com temperatura conhecida e cuja variação entre o ponto de entrada e de saída expressará o calor produzido pelo organismo durante sua permanência no interior da câmara (Murgatroyd, Shetty \& Prentice, 1993). Para obter-se informações confiáveis, é necessário que o indivíduo em avaliação permaneça um período longo dentro da câmara, para que o calor emanado de seu corpo possa ser medido. Isso faz com que as medidas não possam ser expressas por atividades específicas, já que haverá uma defasagem entre a produção do calor e sua medição. O calor produzido pelo corpo é captado pela alteração na temperatura da água circulante, e o calor perdido pela evaporação e pela ventilação é estimado pela captação da água que se condensa no interior da câmara. 
O primeiro calorímetro humano foi construído por Atwater, no final do século XIX, e atualmente existem muito poucas unidades em funcionamento no mundo (Webb, 1985). Apesar de ser considerado o métodopadrão para a avaliação do gasto energético, este método não é rotineiramente utilizado, devido a sua complexidade, alto custo e por restringir os indivíduos a um ambiente artificial, alterando suas atividades.

\section{Calorimetria Indireta}

A calorimetria indireta, que consiste na medição do consumo de oxigênio $\left(\dot{V} \mathrm{O}_{2}\right)$ e da eliminação de $\mathrm{CO}_{2}$ $\left(\dot{V} \mathrm{CO}_{2}\right.$ ), é considerada um método preciso para a estimativa do GE. Neste método o indivíduo respira por meio de uma máscara conectada a um calorímetro, onde são feitas a medição dos volumes inspirados e expirados e a análise do gás expirado e inspirado, a fim de estimar o nível de troca gasosa, basicamente o $\dot{V} \mathrm{O}_{2}$. A quantidade de energia gasta é estimada indiretamente, por meio da conversão do $\mathrm{O}_{2}$ consumido, daí o nome de calorimetria indireta, e baseia-se na análise da queima de nutrientes (Lusk, 1917). Cada nutriente utiliza determinada quantidade de $\mathrm{O}_{2}$ para sua metabolização, fornecendo quocientes respiratórios $\left(\mathrm{QR}=\dot{V} \mathrm{CO}_{2} / \dot{V} \mathrm{O}_{2}\right)$ diferentes. Os lipídios apresentam $\mathrm{QR}$ em torno de 0,7 , os carboidratos $\mathrm{QR}$ próximos a 1,0 e proteínas um QR aproximado de 0,82 a 0,85. Para cada QR não protéico existe um equivalente energético por litro de $\mathrm{O}_{2}$ consumido. Na prática, a conversão (em kcal) pode ser realizada pela equação simplificada sugerida por Weir $(1949):\left(\dot{V} \mathrm{O}_{2} \times 3,9\right)+$ ( $\left.\dot{V} \mathrm{CO}_{2} \times 1,1\right)$. Quando o $\mathrm{CO}_{2}$ não é medido, assume-se um QR de 1 e um equivalente energético de 1 litro de $\mathrm{O}_{2}$ igual a aproximadamente $5 \mathrm{kcal}$.

Este método permite o estabelecimento do custo energético das atividades minuto a minuto, visto que os dados são coletados neste intervalo de tempo. Atualmente, existem aparelhos portáteis, que podem ser carregados nas costas ou na cintura, possibilitando ao indivíduo manter suas atividades normais sem muita interferência, enquanto a troca gasosa é medida (Wahrlich et al., 2006).

\section{Marcadores Fisiológicos: água duplamente marcada, freqüência cardíaca}

\section{Água Duplamente Marcada}

$\mathrm{O}$ método da $\mathrm{ADM}$, que consiste na ingestão de água contendo os isótopos deutério $\left({ }^{2} \mathrm{H}_{2}\right)$ e oxigênio $\left({ }^{18} \mathrm{O}\right)$, permite avaliar o GE pela diferença entre o ritmo de eliminação do oxigênio marcado e do deutério na urina (Schoeller, 1999) e foi usado pela primeira vez em seres humanos no início da década de 1980 (Schoeller \& Van Santen, 1982), apesar de seu uso em pequenos animais ser muito mais antigo (Speakman, 1998).

O método é baseado no princípio de que o turnover do oxigênio é dominado tanto pelo fluxo de água no corpo como pelo oxigênio inspirado e gás carbônico expirado. Em contrapartida, o turnover do hidrogênio no corpo só é dominado pelo fluxo de água no corpo (Speakman, 1990). Portanto, a diferença dos dois turnovers significa o excesso de oxigênio que é equivalente ao gás carbônico produzido. A estimativa do GE é feita ao se medir a quantidade de $\mathrm{H}_{2} \mathrm{O}$ metabólica e, assim, extrapolar-se a quantidade de $\mathrm{CO}_{2}$ produzida no organismo. Assumindo-se um valor fixo de QR (usualmente 0,85), pode-se estimar o consumo de $\mathrm{O}_{2}\left(\dot{V} \mathrm{CO}_{2} / 0,85\right.$ ), e então o GE, ou seja, o método não deixa de ser uma estimativa de calorimetria indireta.

A aplicação do método é simples: consiste em fornecer uma dosagem conhecida da ADM para o indivíduo que terá de coletar a urina durante alguns dias. A baixa disponibilidade e o alto custo do isótopo de oxigênio $\left({ }^{18} \mathrm{O}\right)$, além da alta tecnologia necessária para análise de determinação da concentração dos isótopos, tornam este método inviável, atualmente, em estudos de larga escala.

Apesar de fornecer medida exata do GE por períodos de vários dias, este método não fornece o padrão de atividade, pois normalmente começa-se a medir seriadamente a eliminação do elemento marcado após pelo 
menos 24 horas de sua ingestão, o que faz com que se tenha o GE para intervalos de tempo grande (normalmente de vários dias, que são expressos em 24 horas). Este seria o método ideal para estudos epidemiológicos quando se quer saber o GE total diário.

\section{Método da Freqüência Cardíaca}

A relação entre Freqüência Cardíaca (FC) e GE foi observada no início do século passado por Benedict, que relatou que mudanças na freqüência do pulso estavam correlacionadas com mudanças na produção de calor (Benedict, 1915), o que o fez sugerir que a FC poderia se tornar um método prático satisfatório para a estimativa do metabolismo basal. Atualmente, sabe-se que a freqüência cardíaca de repouso é influenciada pelo nível de aptidão física, o que faz com que a predição da TMB pela FC de repouso não seja adequada. Entretanto, durante atividades, há uma relação linear entre a FC e o $\mathrm{O}_{2}$ (Bradfield, Huntzicker \& Fruehan, 1969; Spurr et al., 1988). Essa relação, normalmente obtida em um teste progressivo de carga em ergômetro, pode sofrer influência de vários fatores, como a composição corporal, a aptidão física e o estado de saúde. Quando o teste é feito várias vezes no mesmo indivíduo, sob as mesmas condiçôes, a reprodutibilidade do $\mathrm{O}_{2}$ em diferentes cargas de trabalho é boa. Contudo, pode haver variação na FC de um dia para outro, mesmo sob condições padronizadas, durante exercício com a mesma carga de trabalho, porque alguns fatores, como a temperatura e umidade ambiental, o estado emocional, dentre outros, podem alterar a $\mathrm{FC}$ sem influenciar o $\mathrm{O}_{2}$.

O método baseia-se na conversão dos valores de FC armazenados em monitores de FC durante 24 horas ou durante o período em que o indivíduo permanece acordado. O GE das 24 horas é calculado com base em uma curva de calibração individual (Spurr et al., 1988) ou predita (Rennie et al., 2001), pela extrapolação dos valores de FC de cada minuto ou por blocos de atividades.

A curva de calibração $\left(\mathrm{FC} \mathrm{x}_{2}\right)$ é composta por uma curva de repouso, baseada nas atividades sedentárias (deitado, sentado e de pé), e uma curva relativa ao trabalho muscular submáximo (Figura 1).

Figura 1 - Exemplo de uma curva de calibração Gasto Energético (GE) x Freqüência Cardíaca (FC) obtida em um indivíduo durante o repouso (deitado - D, sentado - S, de pé- P) e durante caminhada em esteira rolante com intensidade progressiva para gerar a equação mostrada na figura. A linha vertical expressa a média da maior FC durante o repouso e a menor FC durante a caminhada

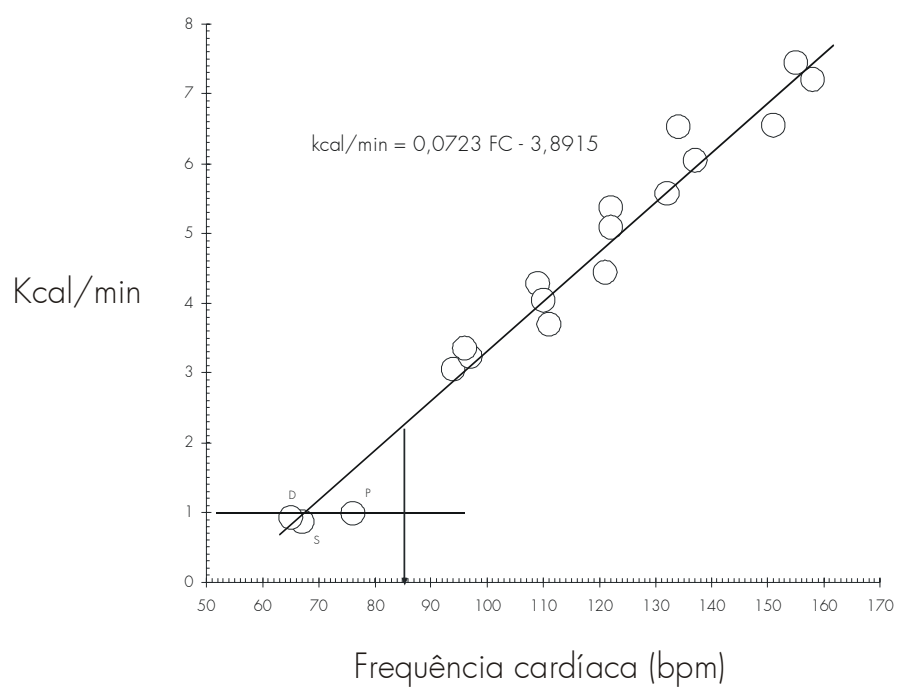

Fonte: dados inéditos dos autores. 
É importante a realização de um registro de atividades durante o dia da monitoração da FC, para que se possa parear os valores de FC com as atividades realizadas e identificar possíveis interferências e momentos de aumento da FC por outros motivos que não de atividade física.

Inicialmente, calcula-se o valor de Flexão da FC (FFC, ou Flex-HR - Flex Heart Rate, em inglês), que é, em geral, calculado como a média entre o maior valor de repouso (geralmente o valor do indivíduo de pé) e o menor valor durante o teste de carga, que no exemplo é igual a 85 batimentos por minuto (bpm), marcado pela seta vertical. Para o período da monitoração da FC em que o indivíduo estiver acordado e a FC for menor do que o FFC, utiliza-se o valor médio de GE obtido no repouso (deitado, sentado e de pé). Para o tempo em que a FC for maior do que o FFC, utiliza-se a equação de regressão dos dados do teste de carga, que, para o exemplo, seria $\mathrm{kcal} / \mathrm{min}=0,0723 \times \mathrm{FC}-3,8915$. Usando-se a equação, pode-se estimar que o GE é de 3,3385 kcal/min para a FC de 100 bpm neste indivíduo. Para o período em que o indivíduo dormiu, utiliza-se o valor de TMB medido. Assim, para cada valor de FC monitorado durante as 24 horas, pode-se estimar o GE e totalizar as 24 horas.

Essa técnica já foi validada em estudos que empregaram a calorimetria direta (Ceesay et al., 1989; Spurr et al., 1988) e a ADM (Livingstone et al., 1990; Heini et al., 1996; Davidson et al., 1997) e funciona adequadamente para grupos de indivíduos. O princípio do método, originalmente descrito por Bradfield, Huntzicker e Fruehan (1969) e formalizado por Bradfield (1971), foi popularizado pelo prof. Gerald Spurr nos estudos sobre a avaliação do estado nutricional funcional na população da Colômbia (Spurr, Reina \& Barac-Nieto, 1986; Spurr et al., 1988) e requeria uma quantidade grande de informações, principalmente a construção da curva de calibração individualizada (Bradfield, 1971, 1979) e a obtenção de um registro (diário ou entrevista) das atividades, fazendo com que muitos autores questionassem seu uso em estudos epidemiológicos. Em geral, o fisiologista do exercício precisa ter informações precisas para uma atividade realizada em ambiente controlado, mas o nutricionista, por sua vez, está interessado em obter informaçōes sobre o GE total em um determinado intervalo de tempo (Bradfield, 1971), e para tanto usa métodos menos precisos.

O grande desafio do epidemiologista é conseguir métodos simples que possam ser usados em um número grande de indivíduos com o menor erro possível. Rennie e colaboradores (2001) propuseram uma simplificação do método da estimação do GE por meio da FC, ao eliminar a necessidade de construção de uma curva de calibração individualizada. A monitoração da FC seria realizada e os valores convertidos em GE de 24 horas por meio de equações de predição populacionais com dados simples de obter: sexo, índice de massa corporal $\left(\mathrm{kg} / \mathrm{m}^{2}\right)$ e FC de repouso (sentado). Mais recentemente ainda, houve a proposta da obtenção simultânea da FC com informaçōes de movimento, por intermédio de um acelerômetro, fazendo com que o registro de atividades seja dispensado (Brage et al., 2006). Na Índia, Kurpad e colaboradores (2006) também propuseram uma simplificação: a dispensa da calorimetria indireta na curva de calibração, que, se confirmada, poderia permitir o uso do método em grande escala mesmo em lugares que não disponham de um sistema de medição da troca gasosa.

A grande vantagem do método da FC é que ele estima não só o GE diário (como no caso do método da $\mathrm{ADM}$ ), como também o gasto energético das várias atividades, podendo, assim, indicar o padrão de atividade dos indivíduos em investigação. Essa característica, associada ao seu baixo custo, vem sendo apregoada como uma excelente vantagem em estudos epidemiológicos (Wareham et al., 1997).

Usando a técnica da FFC, Anjos e Ferreira (2000) documentaram o expressivo GE em trabalhadores envolvidos na coleta de lixo domiciliar no município do Rio de Janeiro. Para uma jornada diária mediana de aproximadamente seis horas (481 minutos), os coletores de lixo domiciliar gastaram 288,4 kcal/hora (mediana), ou seja, aproximadamente $1.730 \mathrm{kcal}$ somente durante o período de trabalho. 


\section{Inquéritos}

\section{Método Fatorial}

Este método baseia-se na descrição, relato ou observação das atividades diárias e sua duração, ou seja, o orçamento do tempo. Essas informaçôes podem ser obtidas retrospectivamente por relato feito pelo indivíduo, por meio de diário de atividade ou entrevista, ou observadas e anotadas por um observador. As atividades são agrupadas por intensidade e convertidas em energia gasta empregando-se tabelas de conversão atividade/dispêndio de energia (Durnin \& Passmore, 1967). As tabelas existentes, encontradas em livros-texto de nutrição ou fisiologia do exercício, apresentam, tipicamente, valores em kcal por minuto (algumas em relação ao peso corporal) de atividades, sem levar em consideração as características individuais, como sexo, nível de aptidão física e idade.

Alternativamente, as várias atividades podem ser expressas em energia ao se multiplicar a TMB pelo tempo de atividade e pela razão GE/TMB. Essa razão pode ser expressa de três formas, dependendo do tempo da atividade: Razão de Atividade Física (RAF), quando se usa o valor do GE da TMB a cada minuto; Índice Energético Integrado (IEI), quando se utiliza um ciclo de atividade levando-se em consideração os tempos de repouso dessa atividade; Nível de Atividade Física (NAF), quando se usa o GE de 24 horas dividido pela TMB de 24 horas (FAO/WHO/UNU, 1985; Vasconcellos \& Anjos, 2003).

A expressão do GE em função da TMB tem como objetivo reduzir as diferenças individuais não contempladas com as tabelas de conversão de atividade, uma vez que sexo, idade e peso corporal são utilizados no cálculo da TMB. Assim, essa forma de expressar o GE representa vantagem em relação ao uso das tabelas de conversão que só controlam, quando o fazem, pelo peso corporal dos indivíduos.

De forma simplificada, pode-se estimar o GE total diário de indivíduos por meio da multiplicação da TMB pelo NAF, que é, atualmente (FAO/WHO/UNU, 2004), estabelecido seguindo uma classificação de estilo de vida em relação à intensidade da atividade física habitual, como será visto mais à frente. Uma forma de fatorial mais detalhada requer a obtenção de todas as atividades realizadas para se construir um orçamento de tempo gasto para cada atividade, valor que será multiplicado pelo custo energético da atividade expresso como múltiplo da TMB, ou seja, pelo IEI, como mostrado na Tabela 1.

Tabela 1 - Exemplo de orçamento de tempo (fatorial) teórico de um dia típico de um indivíduo para o cálculo do gasto energético diário

\begin{tabular}{lccc}
\hline Atividades & Tempo (horas) & |El & Cálculo da energia (Tempo $\times$ IEI $\times$ TMB) \\
\hline Dormir & 8 & 1 & (tabela) \\
\hline Trabalho & 8 & 1,4 \\
\hline Tempo residual & $?$ & 2,7 \\
\hline Atividades caseiras & $?$ & (tabela) \\
\hline Atividades discricionárias & $?$ & (tabela) \\
\hline Atividades caseiras (outras) & $?$ & (tabela) \\
\hline Socialmente desejáveis & $?$ & (tabela) \\
\hline Para melhorar/manter a aptidão física & $?$ &
\end{tabular}

Fonte: elaborada com base nas recomendações contidas em FAO/WHO/UNU (2004). 
Infelizmente, há poucos dados disponíveis sobre o IEI das várias atividades, o que limita em muito o uso deste método.

Uma outra forma de estimar o GE de atividades, amplamente utilizada pela área de ciência do movimento humano, usa os valores da atividade como múltiplo do metabolismo de repouso avaliado como MET (equivalente metabólico que é estabelecido, universalmente, como $3,5 \mathrm{~mL} \mathrm{O}_{2} / \mathrm{kg}$ peso corporal $/$ minuto). Aparentemente, a lista mais completa de códigos de METS para atividades foi compilada por Ainsworth e colaboradores (1993, 2000), no agora já clássico Compêndio de Atividades Físicas. A lista contém um vasto espectro de atividades, incluindo as cotidianas, as de lazer e as ocupacionais, e é muito mais completa do que as existentes com os valores de IEI. Nesse método, utiliza-se o valor de peso corporal do indivíduo e calcula-se o valor individual do MET por minuto. Localiza-se o valor do código de múltiplo de METs da atividade e multiplica-se tal valor pelo MET individual (ver exemplo a seguir). No entanto, há evidências de que o valor fixo de MET não é adequado para vários grupos populacionais (Byrne et al., 2005; Gunn et al., 2004). De fato, dados coletados entre 58 alunas do curso de nutrição da Universidade Federal Fluminense, Niterói, Rio de Janeiro, indicaram um valor médio de MET igual a 3,2 $\mathrm{mL} \mathrm{O}_{2} / \mathrm{kg}$ peso corporal/minuto (Anjos et al., s. d.). Nessas mulheres, observou-se que uma caminhada a $4 \mathrm{~km} / \mathrm{h}$ no plano na esteira rolante equivaleria, em média, a um GE de 2,9 kcal $/ \mathrm{min}$ ou, aproximadamente, 3,5 MET. Aparentemente, o menor valor de MET medido é compensado pelo maior valor de múltiplo de MET, já que o valor estimado de GE com base nos valores do Compêndio para essas mulheres $(2,85 \mathrm{kcal} / \mathrm{min})$ não foi, em média, diferente do medido. Isso ocorre pelo fato de o Compêndio atribuir um valor de 3 MET para a caminhada a $4 \mathrm{~km} / \mathrm{h}$ :

\begin{tabular}{|c|c|c|c|c|c|c|}
\hline MET & Peso corporal & VO2 & VO2 & $\mathrm{kcal} / \mathrm{min}$ & Número & GE \\
\hline $\mathrm{mL} \mathrm{O}_{2} / \mathrm{kg} / \mathrm{min}$ & $\mathrm{kg}$ & $\mathrm{mL} / \mathrm{min} \rightarrow$ & $\mathrm{L} / \mathrm{min}$ & por $\mathrm{LO}_{2}$ & de METs & $\mathrm{kcal} / \mathrm{min}$ \\
\hline 3,5 & 54,3 & 190 & 0,19 & 5 & 3 & 2,85 \\
\hline
\end{tabular}

É importante que mais estudos sobre o custo energético das diversas atividades sejam realizados, para se determinar a validade da estimativa do GE com base nos valores de IEI e nos códigos de MET das várias atividades descritas no Compêndio.

\section{Instrumentos Eletrônicos: acelerômetro}

O princípio teórico do acelerômetro é que a aceleração do movimento do corpo, captada pelo instrumento, é diretamente proporcional às forças musculares que a produziram e, portanto, indica o GE do movimento (Freedson \& Miller, 2000).

$\mathrm{O}$ acelerômetro consiste em uma unidade pequena que pode registrar os movimentos da parte do corpo onde eles forem colocados em um único eixo (vertical), ou nas unidades mais sofisticadas, em três eixos. As unidades mais recentes também registram simultaneamente o tempo, fazendo com que seja possível registrar a intensidade da atividade realizada (movimento/tempo). Os dados são transferidos para um computador, em que, com programas específicos, calcula-se o GE em um determinado intervalo de tempo. Em geral, não se constrói uma equação individual entre a contagem do acelerômetro e o custo de atividades, fazendo com que se dependa de equaçôes preditivas. Há diversas equações preditivas disponíveis, dependendo das características da população em estudo (Welk, 2002). Como o aparelho é usado, na maior parte das vezes, na cintura, atividades mais sedentárias e as que não impliquem deslocamentos do tronco (por exemplo, atividades realizadas sentadas) podem não ser captadas, o que faz com que haja subestimativa do GE (Bassett Jr. et al., 2000). 
Assim, este tipo de método pode ser útil para estimar movimentos que impliquem deslocamento do corpo inteiro, ou seja, caminhar, correr. Algumas unidades podem também fornecer o número de passadas realizadas, ou seja, servem também como pedômetro.

Um dos primeiros acelerômetros disponíveis comercialmente, e por esta razão bastante popularizado e ainda em uso (Iqbal et al., 2006), foi o Caltrac, desenvolvido por Henry Montoye e usado na cintura (Montoye et al., 1983). A grande crítica a esse sistema decorre do fato de ele não armazenar as informações, o que faz com que seja necessário verificar o valor mostrado no display. Além disso, o sistema tem vários botôes de controle, o que pode comprometer o seu uso em pessoas curiosas ou que, inadvertidamente, encostem nos controles. Montoye (2000) experimentou o uso do Caltrac nos três eixos do corpo, e esses dados serviram como base para o desenvolvimento de um acelerômetro de três eixos.

O grande problema deste método diz respeito a como classificar a intensidade da atividade que está sendo realizada, o que influenciará diretamente o cálculo do GE. Para tanto, alguns autores têm tentado incorporar outras medidas simultâneas, como a freqüência cardíaca, para melhorar a predição do GE (Brage et al., 2006; Johansson et al., 2006).

\section{Importância da Medida para a Área da Nutrição}

$\mathrm{Na}$ área da nutrição, o estudo do padrão de GE na população pauta-se, principalmente, na determinação dos Requerimentos Energéticos (RE) e na definição dos padrões de atividade física compatíveis com a saúde (FAO/WHO/UNU, 2004). A energia utilizada para o desempenho das funções vitais nos seres humanos é proveniente dos alimentos, cuja ingestão deve ser norteada pelo nível de sua atividade, e não pela ingestão alimentar, porque esta é bastante variável no mesmo indivíduo e os métodos para sua avaliação são pouco confiáveis. Além disso, os indivíduos podem adaptar seus níveis de atividade a ingestôes baixas (FAO/WHO/UNU, 1985). Esses são os fatores principais que levaram a Organização Mundial da Saúde (OMS) a sugerir o GE como medida para estabelecer as necessidades energéticas diárias. Além deste uso, a informação sobre o GE é importante em muitas situações clínicas e em estudos epidemiológicos, como será visto mais adiante.

Em 1985, segundo recomendação da OMS (FAO/WHO/UNU, 1985), os RE para adultos passaram a ser definidos com base no GE diário, segundo o princípio de que os RE deveriam prover energia para equilibrar o balanço energético compatível com a manutenção da composição corporal e do nível de atividade física consistentes com a boa saúde e para permitir a atividade física economicamente necessária e socialmente desejável. Essa recomendação fez com que houvesse um grande aumento em estudos sobre os componentes do GE.

Como a TMB é o maior componente do GE total diário, a sugestão foi que o custo energético das atividades fosse expresso como múltiplos da TMB (FAO/WHO/UNU, 1985; James \& Schofield, 1990) para facilitar as comparações entre populações e controlar as características individuais, tais como idade, sexo, peso corporal e estatura. Desenvolveu-se, assim, um método - chamado de fatorial simplificado - para estimativa dos RE, utilizando-se de um múltiplo da TMB, o NAF, para cada categoria definida em função da atividade ocupacional e do sexo, com base em padrōes de atividade física já descritos na literatura (Vasconcellos \& Anjos, 2003). A mais recente recomendação manteve a idéia do uso do NAF para estimar os RE, mas incorporou em seu cálculo as atividades não ocupacionais e passou a chamar esta razão de estilo de vida em relação à intensidade da atividade física habitual (FAO/WHO/UNU, 2004). Basicamente, as alterações nos valores de NAF foram: 1) não há mais distinção nos valores para mulheres e homens e 2) foi criada uma faixa, e não mais um valor fixo, para cada um dos três padrōes.

Os valores de NAF sugeridos foram: 1) 1,40 a 1,69, para os indivíduos sedentários ou com estilo de vida incluindo somente atividades leves; 2) 1,70 a 1,99, para os indivíduos com estilo de vida ativo ou moderadamente ativo; 3) 2,00 a 2,40, para os indivíduos com estilo de vida com atividades pesadas. 
Há muito poucos dados sobre os valores de NAF nas diversas populações do mundo, particularmente nas que vivem em países em desenvolvimento. Por exemplo, Vinken e colaboradores (1999) encontraram valores de NAF médio de 1,80 para 93 indivíduos (44 homens e 49 mulheres) de 18 a 81 anos de idade, ao medir o GE de 24 horas por meio de ADM e a TMB por calorimetria indireta. Os autores concluíram que os valores de NAF recomendados deveriam ser revistos, opinião que não é consensual para as sociedades afluentes (Shetty et al., 1996).

Por exemplo, Black e colaboradores (1996) revisaram as informações de 574 medições de GE por meio de ADM em populações de países ricos, chamados de afluentes, e encontraram valores médios de NAF dentro da faixa de estilo de vida moderado, com exceção dos homens na faixa de 40 a 64 anos (Figura 2). Para as populações que vivem em condições menos desenvolvidas, não há dados suficientes de GE, mas aparentemente será necessário revisar os valores de NAF (Vasconcellos \& Anjos, 2003), com base nas evidências de que os dados de atividade física (numerador) usados para seu cálculo foram subestimados (Haggarty et al., 1994; Heini et al., 1996), além da superestimativa da TMB (denominador) encontrada nessas populações (Cruz, Silva \& Anjos, 1999; Wahrlich $\&$ Anjos, 2000).

Em geral, os dados de GE obtidos por meio da mesma técnica em populações de países em desenvolvimento (Coward, 1998) indicaram valores bem maiores (Figuras 2 e 3). É importante frisar, entretanto, que os estudos disponíveis são feitos em amostras bem pequenas (perto de dez indivíduos) que gastam muita energia (fazendeiros ou população rural). São poucos os dados de populações urbanas, mais propensas a apresentar características de atividades físicas semelhantes às das populações de países desenvolvidos. No estudo feito em estudantes do Swazi, por exemplo, o valor médio de NAF foi bem baixo, perto de 1,38 (Figura 3).

Figura 2 - Valores médios do nível de atividade física $(\mathrm{NAF}=\mathrm{GE} / \mathrm{TMB})$ em amostras de indivíduos de países afluentes e em desenvolvimento

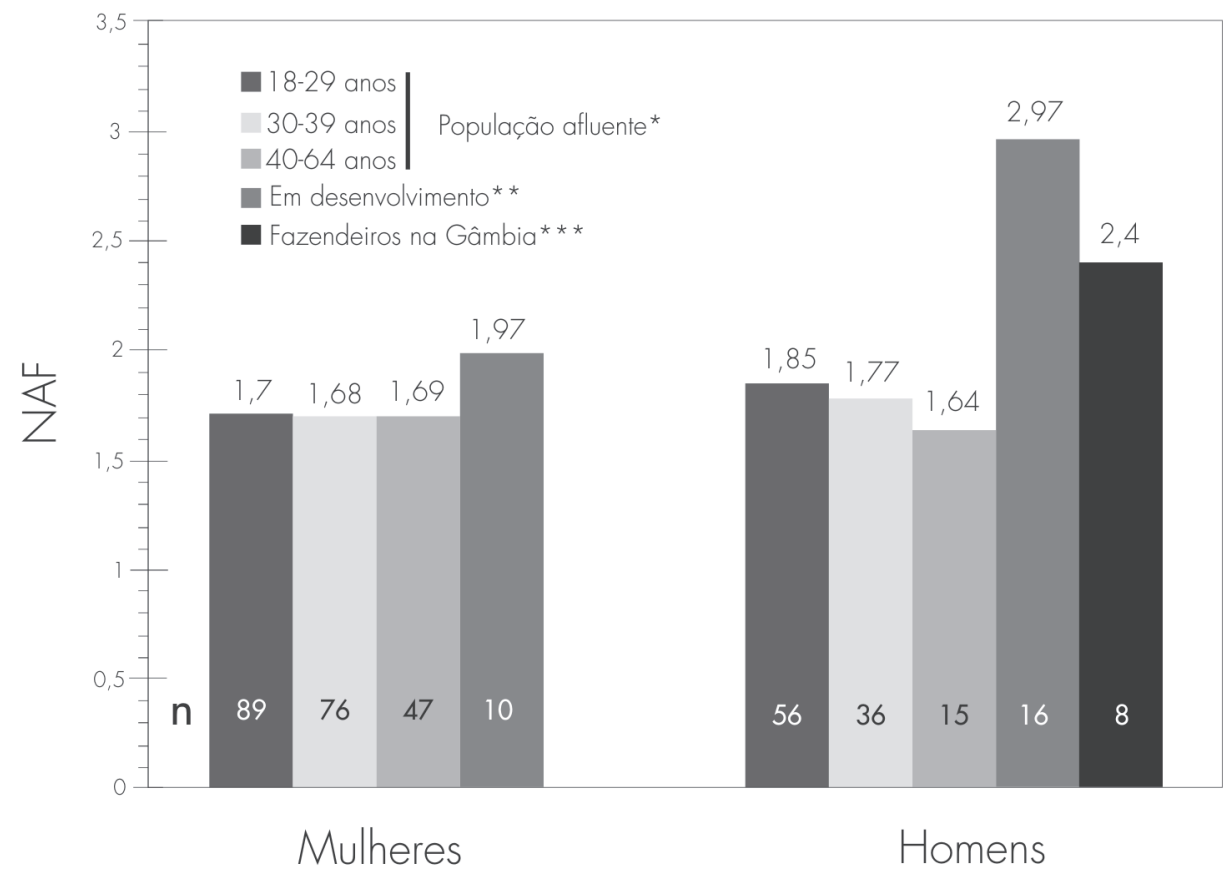

Fontes: * Black et al., 1996; ** Schulz \& Schoeller, 1994; ${ }^{* * *}$ Heini et al. 1996. 
Figura 3 - Valores médios do nível de atividade física $(\mathrm{NAF}=\mathrm{GE} / \mathrm{TMB})$ em amostras de indivíduos de países em desenvolvimento

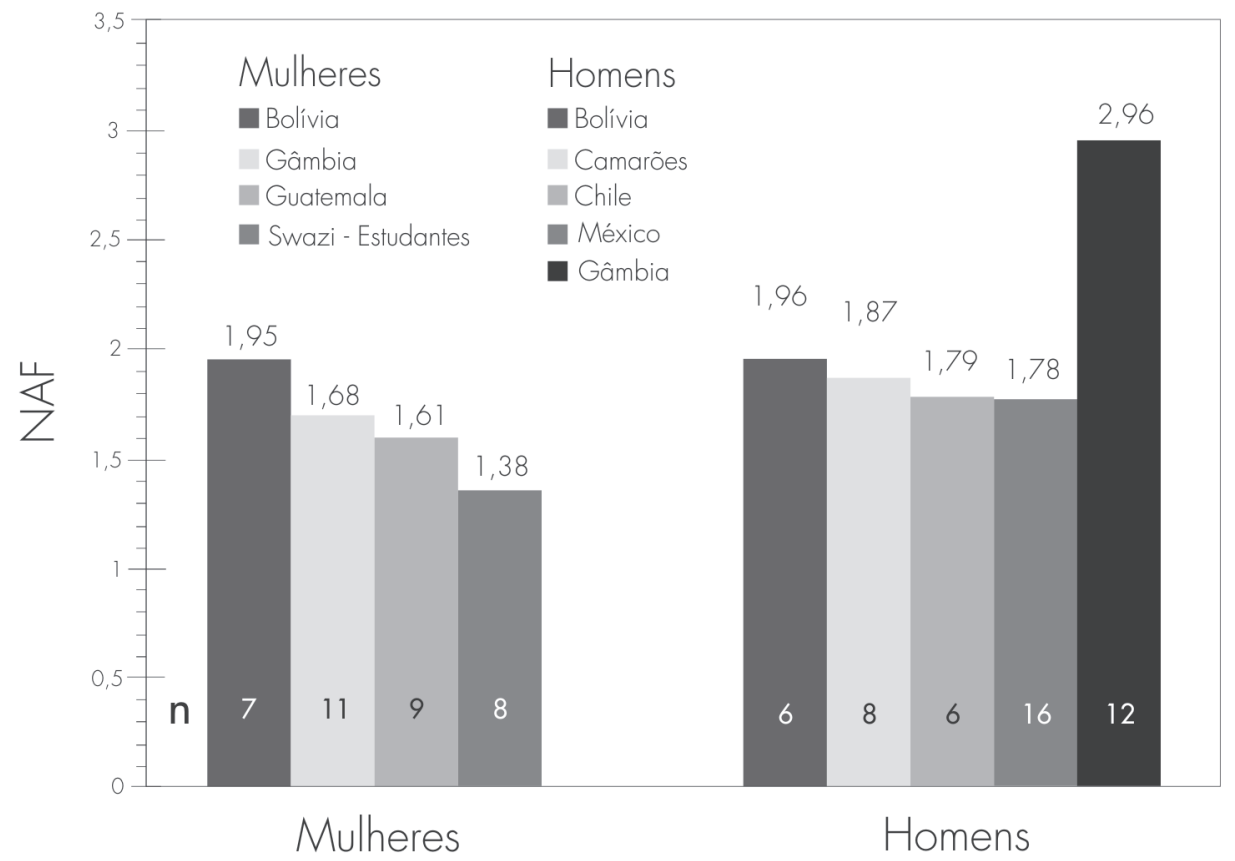

Fonte: desenhada com base em dados obtidos em Coward (1998)

$\mathrm{Na}$ verdade, pode-se estimar os valores de NAF para uma população desde que se conheçam as características do orçamento de tempo (tempo gasto realizando as diversas tarefas diárias) e se disponha dos valores corretos de IEI. Como o GE de 24 horas = TMB x NAF $=\sum_{\mathrm{i}}\left(\mathrm{t}_{\mathrm{i}} \mathrm{IEI}_{\mathrm{i}} \mathrm{TMB}_{\mathrm{i}}\right)$, pode-se concluir que o NAF $=\left(\sum_{\mathrm{i}} \mathrm{t}_{\mathrm{i}} \mathrm{IEI}_{\mathrm{i}}\right) / 24$. Ou seja, para se estimar o NAF não é preciso medir a TMB ou o GE, basta saber o tempo das atividades ( $\mathrm{t}$ ) e o valor de IEI dessas atividades. Valendo-se dessa abordagem, Vasconcellos e Anjos (2003) calcularam os valores de NAF para a população brasileira usando os dados do Estudo Nacional da Despesa Familiar (Endef). Fica evidente como os valores de NAF sugeridos para uso na população em geral eram adequados, na média, para os homens (Figura 4), mas havia uma brutal diferença entre os valores de NAF recomendados e os estimados para a população rural e urbana. Para as mulheres, as diferenças são ainda mais marcantes (Figura 5).

A aplicação dos valores de NAF na população brasileira deve ser vista com cautela, pois, além dos problemas com as tabelas de custo energético de atividades, há ainda a aparentemente superestimativa da TMB pelas equaçōes sugeridas para uso internacional, fato já documentado em segmentos da população brasileira (Anjos, 1998; Anjos et al., 1998; Cruz, Silva \& Anjos, 1999; Wahrlich \& Anjos, 2001b; Wahrlich, 2005; Wahrlich et al., 2007). Como na maioria das situações clínicas ou dos estudos epidemiológicos não se mede a TMB, deve-se confiar em equações de predição da TMB, o que, em muitos casos, pode levar a conclusões errôneas (Wahrlich \& Anjos, 2001a).

Para os casos que não é possível medir a TMB, a Organização das Nações Unidas para Agricultura e Alimentação (FAO) e a OMS passaram a sugerir na nova recomendação de RE (FAO/WHO/UNU, 2004) o uso das equações de Schofield (1985), listadas na Tabela 2, que, na ausência de outras validadas para a população brasileira, deverão ser usadas, mesmo sabendo que elas poderão superestimar a TMB em até 20\% (Wahrlich, 2005). 
Figura 4 - Coeficientes estimados de NAF na população masculina brasileira em 1975

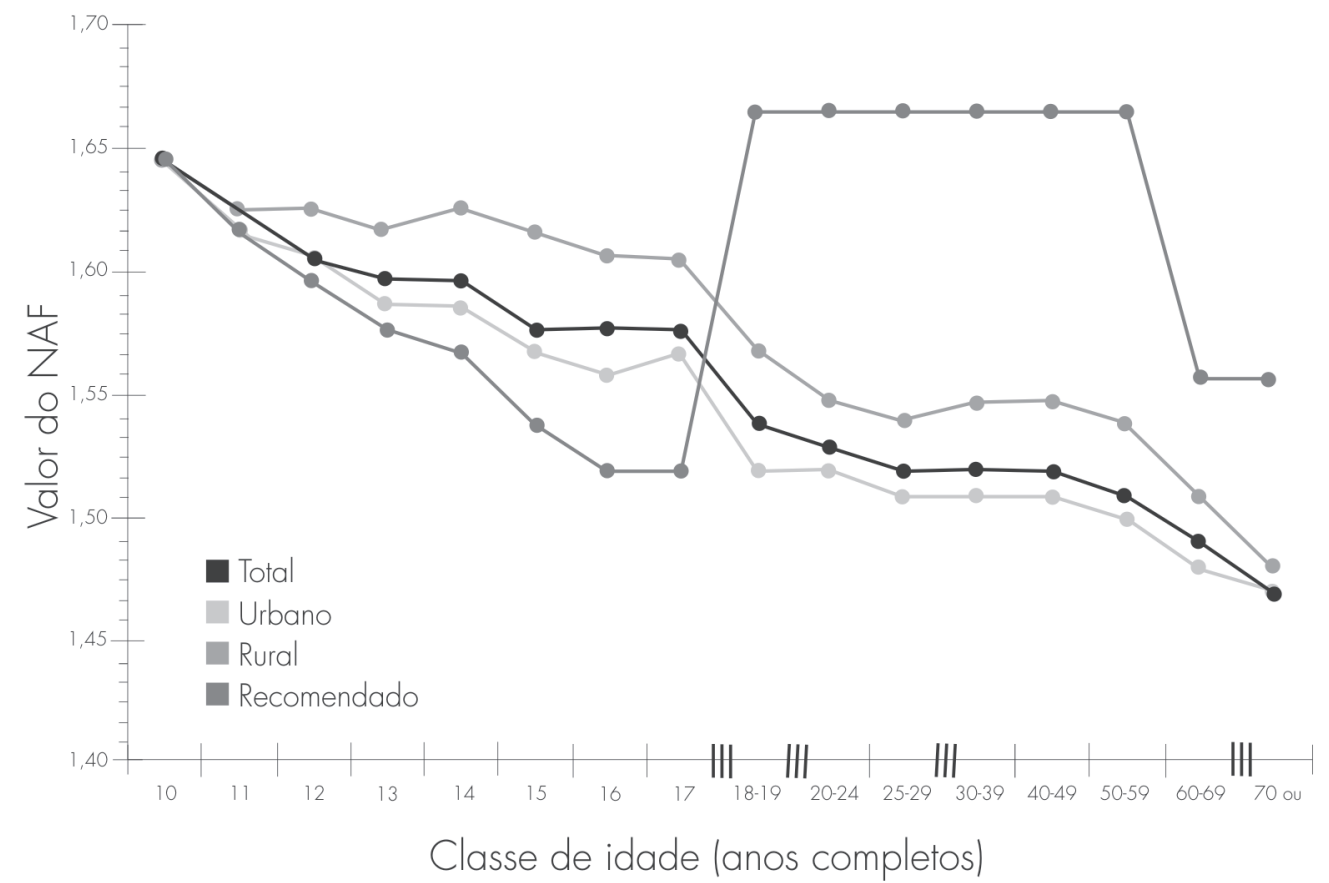

Fonte: desenhada com base em dados gerados por Vasconcellos e Anjos (2003).

Figura 5 - Coeficientes estimados de NAF na população feminina brasileira em 1975

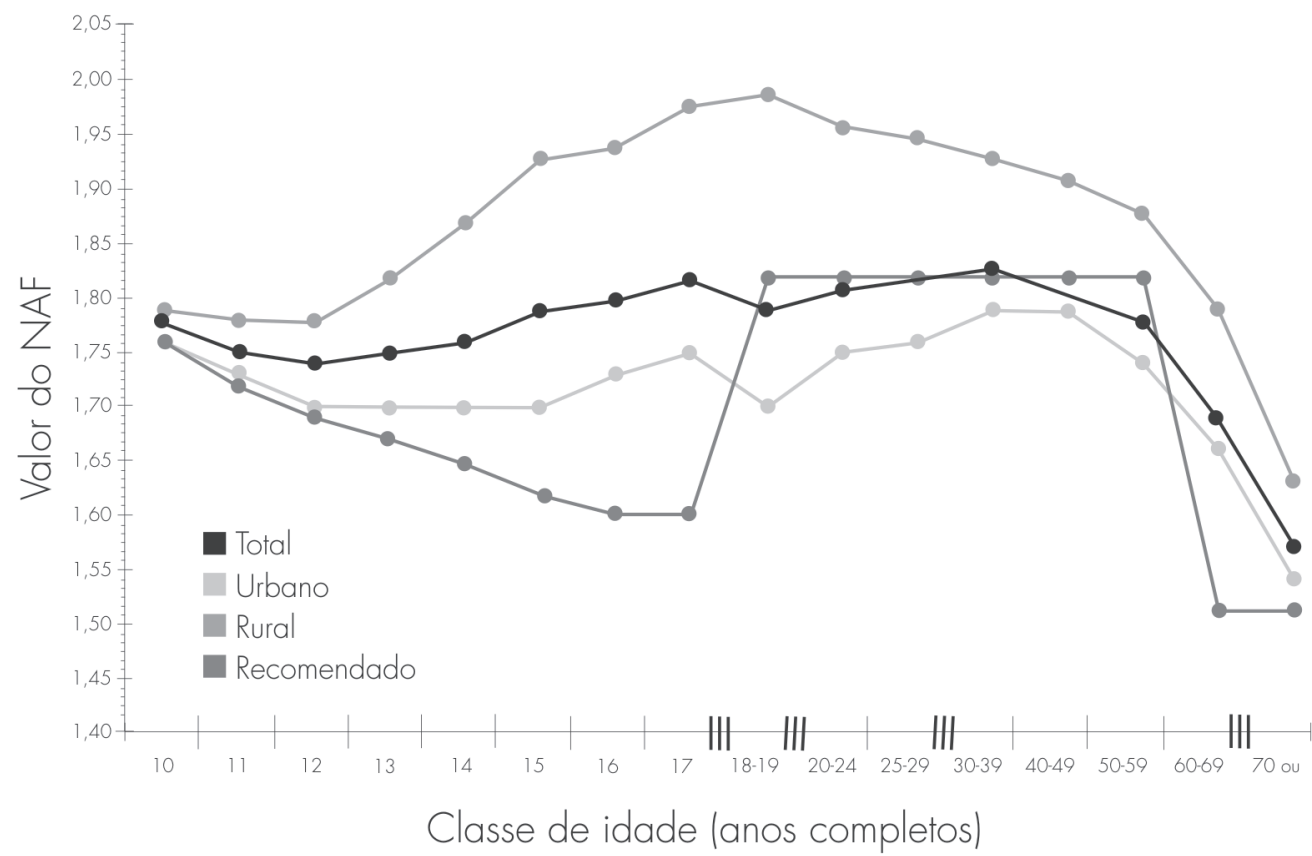

Fonte: desenhada com base em dados gerados por Vasconcellos e Anjos (2003). 
Tabela 2 - Equações para cálculo da TMB publicadas por Schofield (1985) e sugeridas para uso internacional pela FAO/WHO/UNU (2004). Peso (P) em kg

\begin{tabular}{|c|c|c|c|c|}
\hline & & Homens & & Mulheres \\
\hline Idade (anos) & $n$ & TMB (kcal/dia) & $n$ & TMB (kcal/dia) \\
\hline$<3$ & 162 & $59,512 \times P-30,4$ & 137 & $58,317 \times P-31,1$ \\
\hline $3-9,9$ & 338 & $22,706 \times P+504,3$ & 413 & $20,315 \times P+485,9$ \\
\hline $10-17,9$ & 734 & $17,686 \times P+658,2$ & 575 & $13,384 \times P+692,6$ \\
\hline $18-29,9$ & 2879 & $15,057 \times P+692,2$ & 829 & $14,818 \times P+486,6$ \\
\hline $30-59,9$ & 646 & $11,472 \times P+873,1$ & 372 & $8,126 \times P+845,6$ \\
\hline$>60$ & 50 & $11,711 \times P+587,7$ & 38 & $9,082 \times P+658,5$ \\
\hline
\end{tabular}

Até a publicação de 2004, a FAO e a OMS sugeriam que o aporte energético para os menores de 10 anos de idade fosse baseado no valor do peso corporal. Atualmente, a recomendação, para crianças acima de 1 ano de idade e adolescentes, é que se use a mesma estratégia para adultos, ou seja, basear os dados em estudos de ADM, calculando-se a TMB e multiplicando-se o valor encontrado pelo NAF. Para fins práticos, foram desenvolvidas equaçôes para a estimativa dos requerimentos energéticos baseados no valor do peso corporal (em kg), apresentadas a seguir. É importante reparar que há um componente quadrático do peso corporal $\left(\mathrm{kg}^{2}\right)$.

$$
\begin{aligned}
& \text { Meninos }(\mathrm{n}=801) \\
& G E=R E(\mathrm{kcal} / \mathrm{dia})=310,2+63,3 \mathrm{~kg}-0,263 \times \mathrm{kg}^{2} \\
& \text { Meninas }(\mathrm{n}=808) \\
& G E=\operatorname{RE}(\mathrm{kcal} / \text { dia })=263,4+65,3 \mathrm{~kg}-0,454 \times \mathrm{kg}^{2}
\end{aligned}
$$

Para crianças com menos de 1 ano de idade, foi dada a opção de calcular o RE usando-se três equações, dependendo do peso corporal e das características da alimentação das crianças:

$$
\begin{aligned}
& \text { Amamentação ( } \mathrm{n}=195) \\
& \text { GE total diário ( } \mathrm{kcal} / \text { dia })=-152,0+92,8 \times \mathrm{kg} \\
& \text { Com alimentação por fórmula }(\mathrm{n}=125) \\
& \text { GE total diário ( } \mathrm{kcal} / \text { dia })=-29,0+82,6 \text { × kg }
\end{aligned}
$$

Todos (amamentação ou alimentação por fórmula) ( $n=320$ )

GE total diário $(\mathrm{kcal} / \mathrm{dia})=-99,4+88,6 \times \mathrm{kg}$

\section{Considerações Finais}

A medição do gasto energético tem muitas aplicações para a área de saúde, mas é na determinação dos requerimentos energéticos e na avaliação da atividade física de populações que atualmente se concentra o seu uso. O método da água duplamente marcada, atualmente considerado como padrão, ainda é caro. Existem, entretanto, métodos mais simples e mais baratos e que são bastante promissores para o uso em pesquisas populacionais. 


\section{Referências}

AINSWORTH, B. E. et al. Compendium of physical activities: classification of energy costs of human physical activities. Medicine and Science in Sports and Exercise, 25: 71-80, 1993.

AINSWORTH, B. E. et al. Compendium of physical activities: an update of activity codes and MET intensities. Medicine and Science in Sports and Exercise, 32: S498-S516, 2000.

ANJOS, L. A. A taxa metabólica basal é superestimada por equações preditivas em coletores de lixo domiciliar do Rio de Janeiro. SIMPÓSIO INTERNACIONAL DE CIÊNCIAS DO ESPORTE, XXI, SÃO CAETANO DO SUL. Anais... São Caetano do Sul: Centro de Estudos de Aptidão Física de São Caetano do Sul, 1998.

ANJOS, L. A. Prevalência da inatividade física no Brasil. CONGRESSO BRASILEIRO DE ATIVIDADE FÍSICA E SAÚDE, II, 1999, Florianópolis. Anais... Florianópolis: Universidade Federal de Santa Catarina, 1999.

ANJOS, L. A. Physical activity estimates from a household survey in Brazil. Medicine and Science in Sports and Exercise, 32, suppl. 5: S188, 2000.

ANJOS, L. A. \& FERREIRA, J. A. A avaliação da carga fisiológica de trabalho na legislação brasileira deve ser revista! O caso da coleta de lixo domiciliar no Rio de Janeiro. Cadernos de Saúde Pública, 16: 785-790, 2000 .

ANJOS, L. A. et al. Basal metabolic rate cannot be estimated by current predictive equations in Brazilian college female students. Medicine and Science in Sports and Exercise, 30, suppl. 5: S263, 1998.

ANJOS, L. A. et al. Energy expenditure of walking at different intensities in Brazilian college-aged women, s. d. (Mimeo.)

ÅSTRAND, P. \& RODAHL, K. Textbook of Work Physiology: physiological bases of exercise. 3. ed. New York: Mcgraw-HillBook Company, 1986.

BASSETT JR., D. R. et al. Validity of four motion sensors in measuring moderate intensity physical activity. Medicine \& Science in Sports \& Medicine, 32, suppl. 9: S471-S480, 2000.

BENEDICT, F. G. Factors affecting basal metabolism. The Journal of Biological Chemistry, 20: 263-299, 1915.

BLACK, A. E. et al. Human energy expenditure in affluent societies: an analysis of 574 doubly-labelled water measurements. European Journal of Clinical Nutrition, 50: 72-92, 1996.

BRADFIELD, R. B. A technique for determination of usual daily energy expenditure in the field. American Journal of Clinical Nutrition, 24: 1.148-1.154, 1971.

BRADFIELD, R. B. Short-term repeatability of oxygen consumption-heart rate relationships. American Journal of Clinical Nutrition, 32: 1.758-1.759, 1979.

BRADFIELD, R. B.; HUNTZICKER, P. B. \& FRUEHAN, G. J. Simultaneous comparison of respirometer and heart-rate telemetry techniques as measures of human energy expenditure. American Journal of Clinical Nutrition, 22: 696-700, 1969.

BRAGE, S. et al. Effect of combined movement and heart rate monitor placement on physical activity estimates during treadmill locomotion and free-living. European Journal of Applied Physiology, 96: 517-524, 2006. 
BURSZTEIN, S. et al. Energy Metabolism, Indirect Calorimetry and Nutrition. Maryland: Williams \& Wilkins, 1989.

BYRNE, N. M. et al. Metabolic equivalent: one size does not fit all. Journal of Applied Physiology, 99: 1.112$1.119,2005$.

CASPERSEN, C. J.; POWELL, K. E. \& CHRISTENSON, G. M. Physical activity, exercise, and physical fitness: definitions and distinctions for health-related research. Public Health Reports, 100: 126-131, 1985.

CEESAY, S. M. et al. The use of heart rate monitoring in the estimation of energy expenditure: a validation study using indirect whole-body calorimetry. British Journal of Nutrition, 61: 175-186, 1989.

COWARD, W. A. Contributions of the doubly labeled water method to studies of energy balance in the Third World. American Journal of Clinical Nutrition, 68: 962S-969S, 1998.

CRESPO, C. J. et al. Prevalence of physical inactivity and its relation to social class in U.S. adults: results from the Third National Health and Nutrition Examination Survey, 1988-1994. Medicine \& Science in Sports \& Exercise, 31(12): 1.821-1.827, 1999.

CRUZ, C. M.; SILVA, A. F. \& ANJOS, L. A. Validação de equações preditivas da taxa metabólica basal em universitárias do Rio de Janeiro, Brasil. Arquivos Latinoamericanos de Nutrición, 49: 232-237, 1999.

DAVIDSON, L. et al. Free-living energy expenditure of adult men assessed by continuous heart-rate monitoring and doubly-labelled water. British Journal of Nutrition, 78: 695-708, 1997.

DURNIN, J. V. G. A. \& PASSMORE, R. Energy, Work and Leisure. London: Heinemann Educational Books, 1967.

FOOD AND AGRICULTURE ORGANIZATION (FAO)/WORLD HEALTH ORGANIZATION (WHO)/ UNITED NATIONS UNIVERSITY (UNU). Energy and Protein Requirements. Geneva: WHO, 1985. (WHO Technical Report Series, 724).

FOOD AND AGRICULTURE ORGANIZATION (FAO)/WORLD HEALTH ORGANIZATION (WHO)/ UNITED NATIONS UNIVERSITY (UNU). Human Energy Requirements. Rome: FAO, 2004. (Food and Nutrition Technical Report Series, 1).

FREEDSON, P. S. \& MILLER, K. Objective monitoring of physical activity using motion sensors and heart rate. Research Quarterly for Exercise \& Sport, 71: 21-29, 2000.

GARROW, J. S. Energy Balance and Obesity in Man. Amsterdam: North Holland, 1974.

GUNN, S. M. et al. Measurement and prediction of energy expenditure in males during household and garden tasks. European Journal of Applied Physiology, 91: 61-70, 2004.

HAGGARTY, P. et al. The influence of exercise on the energy requirements of adult males in the UK. British Journal of Nutrition, 72: 799-813, 1994.

HEINI, A. F. et al. Free-living energy expenditure assessed by two different methods in rural Gambian men. European Journal of Clinical Nutrition, 50: 284-289, 1996.

IQBAL, R. et al. Validating Mospa questionnaire for measuring physical activity in Pakistani women. Nutrition Journal, 5: 18, 2006.

JAMES, W. P. T. \& SCHOFIELD, E. Human Energy Requirements: a manual for planners and nutritionists. New York: FAO, Oxford University Press, 1990. 
JOHANSSON, H. P. et al. Accelerometry combined with heart rate telemetry in the assessment of total energy expenditure. British Journal of Nutrition, 95: 631-639, 2006.

KURPAD, A. V. et al. A simple method of measuring total daily energy expenditure and physical activity level from the heart rate in adult men. European Journal of Clinical Nutrition, 60: 32-40, 2006.

LIVINGSTONE, M. B. et al. Simultaneous measurement of free-living energy expenditure by the doubly labeled water method and heart-rate monitoring. American Journal of Clinical Nutrition, 52: 59-65, 1990.

LUSK, G. The Elements of the Science of Nutrition. 3. ed. Philadelphia: W. B. Saunders, 1917.

MENDONÇA, C. P. \& ANJOS, L. A. Aspectos das práticas alimentares e da atividade física como determinantes do crescimento do sobrepeso/obesidade no Brasil. Cadernos de Saúde Pública, 20: 698-706, 2004.

MONTOYE, H. J. Introduction: evaluation of some measurements of physical activity and energy expenditure. Medicine \& Science in Sports \& Medicine, 32, suppl. 9: S439-S441, 2000.

MONTOYE, H. J. et al. Estimation of energy expenditure by a portable accelerometer. Medicine \& Science in Sports \& Medicine, 15: 403-407, 1983.

MONTOYE, H. J. et al. Measuring Physical Activity and Energy Expenditure. Champaign: Human Kinetics, 1996.

MURGATROYD, P. R.; SHETTY, P. S. \& PRENTICE, A. M. Techniques for the measurement of human energy expenditure: a practical guide. International Journal of Obesity, 17: 549-568, 1993.

RENNIE, K. L. et al. Estimating energy expenditure by heart-rate monitoring without individual calibration. Medicine \& Science in Sports \& Exercise, 33: 939-945, 2001.

SCHOELLER, D. A. Recent advances from application of doubly labeled water to measurement of human energy expenditure. Journal of Nutrition, 129: 1.765-1.768, 1999.

SCHOELLER, D. A. \& VAN SANTEN, E. Measurement of energy expenditure in humans by doubly labelled water. Journal of Applied Physiology, 53: 955-959, 1982.

SCHOFIELD, W. N. Predicting basal metabolic rate, new standards and review of previous work. Human Nutrition: Clinical Nutrition, 39, suppl. 1: 5-41, 1985.

SCHULZ, L. O. \& SCHOELLER, D. A. A compilation of total daily energy expenditures and body weights in healthy adults. American Journal of Clinical Nutrition, 60: 676-681, 1994.

SHETTY, P. S. et al. Energy requirements of adults: an update on Basal Metabolic Rates (BMRs) and physical activity levels (PALs). European Journal of Clinical Nutrition, 50, suppl. 1: S11-S23, 1996.

SPEAKMAN, J. R. Principles, problems and a paradox with the measurement of energy expenditure of freeliving subjects using doubly-labelled water. Statistics in Medicine, 9: 1.365-1.380, 1990.

SPEAKMAN, J. R. The history and theory of the doubly labeled water technique. American Journal of Clinical Nutrition, 68, suppl.: 932S-938S, 1998.

SPURR, G. B.; REINA, J. C. \& BARAC-NIETO, M. Marginal malnutrition in school-aged Colombian boys: metabolic rate and estimated daily energy expenditure. American Journal of Clinical Nutrition, 44: 113126, 1986. 
SPURR, G. B. et al. Energy expenditure from minute-by-minute heart-rate recording: comparison with indirect calorimetry. American Journal of Clinical Nutrition, 48: 552-559, 1988.

VASCONCELLOS, M. T. L. \& ANJOS, L. A. A simplified method for assessing physical activity level values for a country or study population. European Journal of Clinical Nutrition, 57: 1.025-1.033, 2003.

VINKEN, A. G. et al. Equations for predicting the energy requirements of healthy adults aged 18-81 years. American Journal of Clinical Nutrition, 69: 920-926, 1999.

WAREHAM, N. J. et al. Feasibility of heart-rate monitoring to estimate total level and pattern of energy expenditure in a population-based epidemiological study: the Ely Young Cohort Feasibility Study 1994-5. British Journal of Nutrition, 78: 889-900, 1997.

WAHRLICH, V. Taxa Metabólica Basal em Adultos Residentes em Niterói, Rio de Janeiro, Brasil: estudo de base populacional, 2005. Tese de Doutorado, Rio de Janeiro: Escola Nacional de Saúde Pública Sergio Arouca, Fundação Oswaldo Cruz.

WAHRLICH, V. \& ANJOS, L. A. Basal metabolic rate of young women living in tropical and temperate regions of Brazil. Medicine \& Science in Sports \& Exercise, 32, suppl. 5: S172, 2000.

WAHRLICH, V. \& ANJOS, L. A. Aspectos históricos e metodológicos da medição e estimativa da taxa metabólica basal: uma revisão da literatura. Cadernos de Saúde Pública, 17: 801-817, 2001a.

WAHRLICH, V. \& ANJOS, L. A. Validação de equações de predição da taxa metabólica basal em mulheres residentes em Porto Alegre, RS. Revista de Saúde Pública, 35: 39-45, 2001 b.

WAHRLICH, V. et al. Validation of the VO2000 calorimeter for measuring resting metabolic rate. Clinical Nutrition, 25: 687-692, 2006.

WAHRLICH, V. et al. Basal metabolic rate of Brazilians living in the Southwestern United States. European Journal of Clinical Nutrition, 61: 290-294, 2007.

WEBB, P. Human Calorimeters. New York: Praeger Publishers, 1985.

WEIR, J. B. New methods for calculating metabolic rate with special reference to protein metabolism. Journal of Physiology, 109: 1-9, 1949.

WELK, G. J. Use of accelerometry-based activity monitors to assess physical activity. In: WELK, G. J. (Ed.) Physical Activity Assessments for Health-Related Research. Champaign: Human Kinetics, 2002. 


\title{
Métodos de Avaliação do Consumo de Alimentos
}

\author{
Rosangela Alves Pereira e Rosely Sichieri
}

\begin{abstract}
A avaliação do consumo alimentar de indivíduos e populações é considerada um passo fundamental na avaliação da saúde. Contudo, a mensuração do consumo alimentar carece de métodos que combinem facilidade na avaliação, validade e precisão, o que é compreensível, dado que esse consumo abrange todos os alimentos e bebidas ingeridos. A avaliação da ingestão alimentar deveria, portanto, incluir, além de fontes de energia ou de nutrientes, água, suplementos dietéticos e condimentos. Contudo, tais itens costumam ser, freqüentemente, omitidos em investigações sobre consumo dietético, em função das dificuldades na sua identificação e quantificação (Rutishauser, 2005). Mesmo desconsiderando-os, estimar o consumo alimentar e relacioná-lo à saúde não é uma tarefa fácil, pois, como adequadamente afirmam Willett e Buzzard (1998), a dieta que consumimos diariamente contém inúmeras substâncias, algumas das quais conhecemos e podemos quantificar, outras são grosseiramente caracterizadas e há ainda aquelas que apenas suspeitamos existir.

As seguintes categorias de compostos químicos são encontradas nos alimentos: a) nutrientes essenciais, tais como vitaminas, minerais, lipídios e aminoácidos; b) fontes de energia, especificamente proteínas, carboidratos, lipídios e álcool; c) toxinas provenientes de microorganismos, como por exemplo a aflatoxina; d) contaminantes inorgânicos, como metais e compostos sintéticos; e) substâncias formadas durante o processamento ou o cozimento, como por exemplo as aminas policíclicas aromáticas; f) toxinas naturais, como é o caso do ácido cianídrico na mandioca e de alguns alcalóides; g) outros compostos naturais, como enzimas e inibidores enzimáticos.

Uma vez que os diferentes compostos químicos encontrados nos alimentos estão altamente correlacionados, pode-se dizer que todos os indivíduos são expostos a esses fatores. Em conseqüência, o estudo de relações causais entre dieta e desenlaces deve sempre levar em conta a possível presença de confundimento residual que dificulte o estabelecimento de associaçôes causais. Mesmo com toda a dificuldade na avaliação do consumo alimentar, os métodos de investigação do consumo de alimentos são ferramentas básicas da epidemiologia nutricional. A importância da dieta na etiologia de diversas enfermidades tem sido evidenciada em pesquisas epidemiológicas, experimentos com animais e estudos laboratoriais, e sua importância justifica-se na medida em que as exposiçôes aos fatores dietéticos, por serem amplamente disseminadas, exercem impacto importante sobre as condições de nutrição e saúde. Assim, a avaliação do consumo de alimentos e a determinação do seu papel na ocorrência de enfermidades são um aspecto particular da epidemiologia nutricional, e os estudiosos vêm tentando criar instrumentos capazes de responder aos desafios impostos pela complexidade da dieta humana.
\end{abstract}


Os instrumentos para avaliação da dieta devem levar em conta a extensa variabilidade da ingestão dietética dos indivíduos e grupos humanos. A dieta varia de dia para dia, de semana para semana, e tende a sofrer modificaçôes mais profundas ao longo dos anos. Embora haja um padrão consistente subjacente na dieta individual, diversos fatores fisiológicos, culturais, econômicos e ambientais contribuem para a variação no consumo de alimentos. Por exemplo, a variação mais evidente é a mudança observada na ingestão de alimentos entre os dias de trabalho (dias da semana) e os dias de descanso (fins de semana). Outro exemplo é dado pela variação no consumo alimentar de acordo com o dia da semana entre determinados grupos religiosos. Em segmentos de baixo poder aquisitivo, o consumo alimentar pode variar entre períodos imediamente subseqüentes e outros que se distanciam da data de recebimento do salário. A proximidade de locais de abastecimento (supermercados, feiras livres, quitandas, padarias), a sazonalidade, períodos de safra e entressafra - que interferem na disponibilidade e no preço de produtos -, entre outros fatores, influenciam no consumo alimentar. Datas festivas e outras comemorações são usualmente marcadas por diferenciais no consumo alimentar. Também fatores associados às condiçôes fisiológicas, como variações hormonais e o ciclo menstrual entre mulheres, e o nível de atividade física determinam mudanças na ingestão de alimentos. Além disso, ao longo da vida, as modificações no estado fisiológico e na inserção social - por exemplo, a idade, gravidez, doenças, migrações, agregação social, casamento ou divórcio etc. - geram variações na dieta. Essas fontes de variação explicam a variabilidade intra-individual, considerada mais importante que a variação entre indivíduos.

Considere-se ainda que na sociedade urbana moderna o desenvolvimento da indústria alimentícia e a ampliação da rede de comercialização de alimentação (restaurantes, bares, lanchonetes, fast-food etc.) e a globalização têm determinado a incorporação de novos hábitos e produtos, acompanhada do desaparecimento de outros itens que eram tradicionalmente parte do hábito alimentar. Esse fenômeno repercute de forma intensa sobre a dieta habitual de grande parte da população e, certamente, sobre a dinâmica de nutrição e saúde.

Diante dessa complexidade e dinamismo, é tarefa árdua a obtenção de dados precisos sobre dieta. Além de não ser comum o relato preciso do consumo alimentar, mesmo aquele recente, os indivíduos dificilmente são capazes de indicar com exatidão os momentos em que ocorreram alterações nos seus hábitos alimentares ao longo da vida. Willett (1998) faz um contraponto entre a investigação da exposição à dieta e ao tabaco, assinalando que os indivíduos (e mesmos seus parentes e cônjuges) conseguem relatar com alta precisão e clareza quando começaram a fumar, a quantidade e a marca de cigarros fumados, as modificações no padrão de uso do tabaco ao longo dos anos, chegando ao detalhe de lembrar a data do último cigarro fumado. Em contrapartida, caracterização e quantificação precisas do consumo alimentar é quase uma impossibilidade. Alguém já experimentou questionar, em investigação sobre consumo de alimentos, quando o indivíduo comeu seu primeiro tomate, laranja ou salsicha?

Um aspecto positivo desse alto grau de complexidade na mensuração da ingestão dietética é o conhecimento mais aprofundado dos erros e da estrutura dos erros quando se estima o consumo dietético em suas múltiplas possibilidades, ou seja, os estudos podem enfocar o consumo de energia e nutrientes, de grupos de alimentos, de alimentos específicos ou de outros componentes dos alimentos que estejam relacionados a efeitos benéficos (por exemplo, isoflavonas) ou deletérios (contaminantes, pesticidas, metais pesados). A definição do foco da investigação é fundamental para a definição dos métodos e técnicas a serem empregados na obtenção e análise dos dados sobre consumo alimentar e os erros de mensuração associados. 


\section{Principais Métodos de Avaliação do Consumo Alimentar em Estudos Populacionais}

Os métodos mais utilizados na obtenção de dados sobre consumo de alimentos em pesquisas epidemiológicas são: a) folha de balanço de alimentos; b) inventário; c) Pesquisa de Orçamento Familiar (POF); d) registro ou diário alimentar; e) métodos recordatórios; f) Questionário de Freqüência Alimentar (QFA). Os itens a, b e c permitem avaliações nos agregados: países, famílias, grupos sociais e os demais propiciam avaliaçôes tanto dos agregados quanto individuais, com a ressalva de que a aplicação de um único registro ou um único recordatório de 24 horas, em geral, é adequada para a avaliação de agregados e não de indivíduos. A Figura 1 representa a aplicabilidade dos métodos de avaliação do consumo de alimentos segundo o grau de agregação desejado.

Figura 1 - Aplicabilidade dos métodos de avaliação do consumo de alimentos

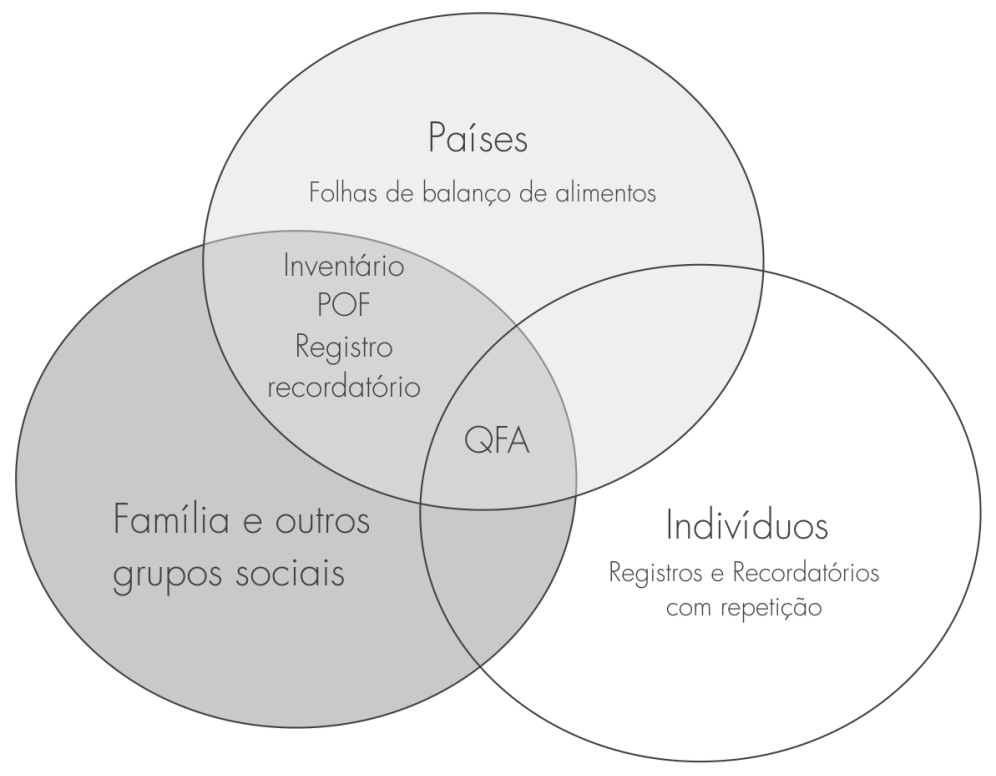

POF - Pesquisa de Orçamento Familiar

QFA - Questionário de Freqüência de Consumo de Alimentos

Contudo, resultados obtidos por diferentes métodos podem ser controversos, e sua interpretação deve considerar a possibilidade de haver fatores de confusão. Um exemplo é oferecido pelos dados de pesquisas de orçamento familiar realizadas no Brasil (Levy-Costa et al., 2005) que evidenciam a redução do consumo de energia, como representado na Figura 2, ao passo que os dados da FAO (Faostat, 2006) claramente indicam aumento da disponibilidade de energia, que era da ordem de $2.216 \mathrm{kcal}$, em 1961, e atingiu $3.001 \mathrm{kcal}$, em 2001. Uma possível explicação é o fenômeno que vem sendo reconhecido em diversos países, o incremento da proporção de refeiçôes realizadas fora do domicílio, como ilustrado na Figura 3, em que se demonstra que no Rio de Janeiro, em 1996, 50\% dos homens não realizavam o almoço em seus domicílios. 
Figura 2 - Disponibilidade de energia por pessoa e por dia, segundo Pesquisas de Orçamento Familiar (POF), desenvolvidas no Brasil (1975-2003)

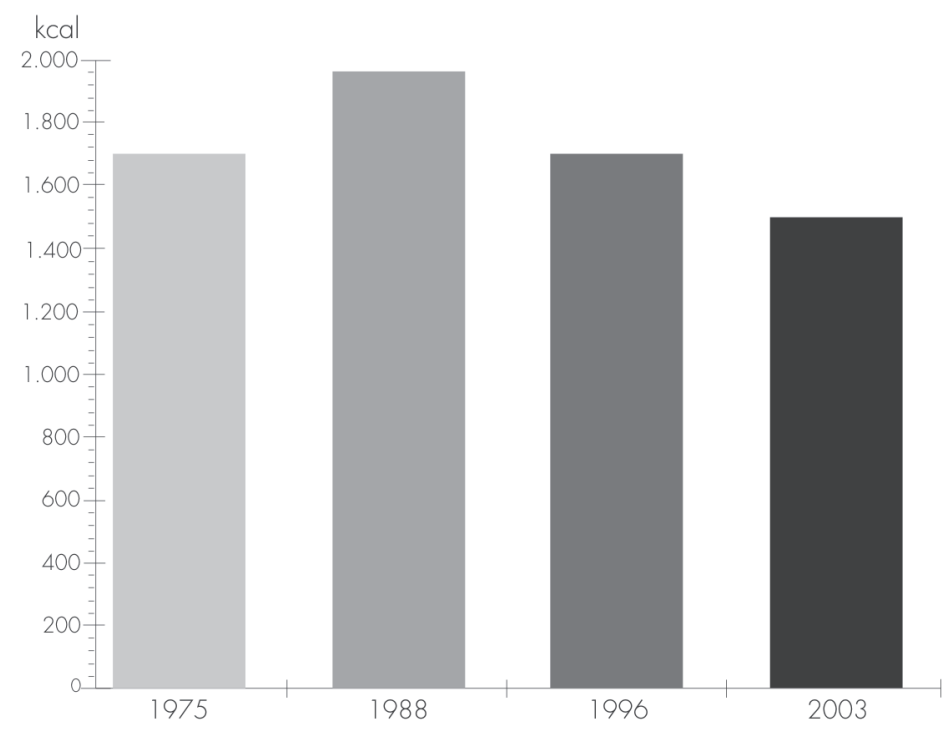

Fonte: Levy-Costa et al. (2005).

Figura 3 - Refeições realizadas no domicílio ou com alimentos levados do domicílio (\%)

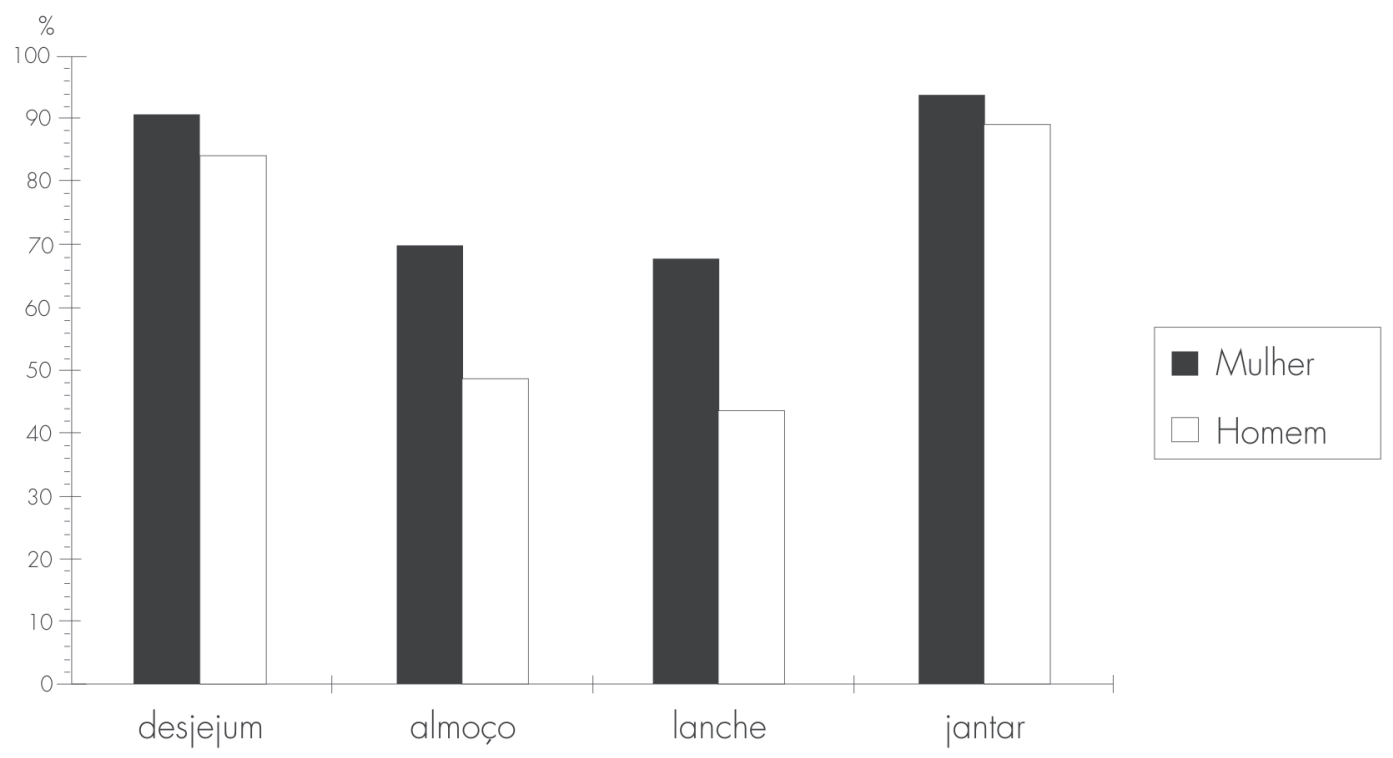

Fonte: Pesquisa de Nutrição e Saúde no Rio de Janeiro, 1996. 


\section{Folha de Balanço de Alimentos}

Por se referir à estimativa da disponibilidade de alimentos para países ou regióes, este método vem sendo utilizado em estudos ecológicos (ou de correlação), geralmente em associação com outros indicadores de saúde da população (por exemplo, taxas de mortalidade ou de incidência). Desenvolvida pela FAO (Food and Agriculture Organization, entidade ligada à Organização das Naçōes Unidas), a folha de balanço de alimentos utiliza informaçōes sobre alimentos produzidos, importados, exportados, aqueles não destinados ao consumo humano (utilizados na indústria, produção de ração etc.) e o que foi perdido no armazenamento e transporte, para estimar periodicamente as quantidades per capita de energia e nutrientes disponíveis para a população.

Energia e nutrientes disponíveis = [(alimentos produzidos + alimentos importados) - (alimentos utilizados na indústria + destinados à ração animal + exportados + perdidos no transporte/armazenamento)]

Evidentemente, com este procedimento não é possível reconhecer o que a população realmente consumiu, mas é possível identificar tendências no perfil de consumo alimentar de grandes grupos populacionais, orientar a política agrícola e de abastecimento e, eventualmente, desenvolver hipóteses etiológicas. Exemplos clássicos do uso das folhas de balanço de alimentos são os estudos que relacionaram o consumo estimado de gordura com mortalidade por câncer de mama. Sasaki, Horacsek e Kestloot (1993) analisaram dados de folhas de balanço de alimentos e de mortalidade por câncer de mama de trinta países, abrangendo o período de 1961-1986. Os autores observaram associações positivas estatisticamente significativas entre o consumo de gordura animal e vegetal e a mortalidade por câncer de mama e, para o consumo de gordura de peixe, efeito inverso. Os dados sugerem que o efeito da gordura sobre o câncer de mama poderia ser diferenciado, dependendo do tipo de gordura consumida. Obviamente, esta abordagem apresenta limitações, pois não é possível determinar se a associação observada para populações ocorre da mesma forma no plano individual; além do mais, potenciais fatores de confundimento, geralmente, não podem ser averigüados para grupos da população.

\section{Inventário}

Esta técnica tem como objetivo registrar os alimentos que são consumidos no domicílio durante um determinado período (geralmente mês, quinzena ou semana). Para tanto, são inventariados os produtos existentes no domicílio no início do período; solicita-se que sejam anotados todos os alimentos adquiridos durante o período de investigação; ao final do período, é realizado novo inventário, e o consumo de alimentos será estimado por:

[(produtos existentes no primeiro inventário + produtos adquiridos) - produtos existentes no segundo inventário]

Este procedimento também não possibilita reconhecer o consumo particular dos membros da família. Obtém-se estimativa da disponibilidade familiar de alimentos, mas não se estimam o consumo individual, pois não são consideradas as refeições realizadas fora do domícilio, a presença de outros comensais que não os membros da família, nem a participação de cada membro da família individualmente no consumo dos itens inventariados. Porém, o método do inventário pode ser útil quando se deseja avaliar fatores associados com comportamento alimentar. Rose e Richards (2004) analisaram dados de inventário de uma semana, revelando que em domicílios próximos a supermercados observou-se incremento do uso de frutas e vegetais entre beneficiários do Food Stamp Program, nos Estados Unidos, em 1996-1997. Por sua vez, Turrini e colaboradores (2001) fizeram uma composição entre o inventário domiciliar de alimentos e registros dietéticos dos membros da família em investigação de desenho seccional, de base populacional, desenvolvida na Itália entre 1994 e 1996. Os autores 
relatam que a complexidade da metodologia empregada redundou em elevada proporção de perdas; entretanto, assinalam que os dados obtidos permitiram reconhecer não somente os padrões dietéticos praticados na Itália, mas também as características particulares no consumo alimentar de homens e mulheres e nos diferentes grupos etários.

\section{Pesquisas de Orçamento Familiar (POF)}

As POF têm por objetivo estimar as despesas efetuadas pelas famílias com diferentes itens, inclusive alimentos. No Brasil, pesquisas dessa natureza vêm sendo desenvolvidas com regularidade pelo Instituto Brasileiro de Geografia e Estatística (IBGE). A POF brasileira mais recente foi realizada entre julho de 2002 e junho de 2003. Foram obtidas informações de 48.470 domicílios urbanos e rurais de todas as regiões do país. O detalhamento da pesquisa, amostragem e procedimentos são encontrados nas publicações do IBGE (IBGE, 2004) e em LevyCosta et al., 2005. Neste último levantamento, foram consideradas as despesas monetárias e não monetárias, ao passo que as POF anteriores pesquisaram somente as despesas monetárias. Para a coleta das informações relativas aos alimentos e bebidas adquiridos, as famílias registraram durante sete dias consecutivos a descrição detalhada de cada produto adquirido, a quantidade, o valor pago, a unidade de medida, o local de compra.

Pesquisas de orçamento familiar são realizadas em vários países. Na Europa, tem sido comum a prática de registrar os alimentos adquiridos pela família durante o período de referência de 14 dias (The Dafne - Data Food Networking); entretanto, em outros países, como o Reino Unido e os Estados Unidos, o registro também é feito para o período de uma semana (Byrd-Bredbenner, Lagiou \& Trichopoulou, 2000), à semelhança do Brasil.

Como discutido por Levy-Costa e colaboradores (2005), o período de referência para a coleta de dados sobre aquisição de alimentos das POFs brasileiras determina que estimativas sejam calculadas com base em agregados de famílias, uma vez que muitos dos itens incluídos na dieta são adquiridos com freqüência maior que a semanal, com exceção de frutas, verduras e alguns outros alimentos perecíveis. Outra limitação da POF está relacionada à crescente freqüência de consumo alimentar fora do domicílio, principalmente no meio urbano, como frisado anteriormente (Figura 3).

Porém, mesmo com essas ressalvas, os dados sobre aquisição de alimentos podem fornecer informações úteis sobre os hábitos alimentares de famílias. Eles permitem, ainda, avaliar o início da cadeia de consumo e estabelecer políticas públicas que podem modificar a oferta de alimentos e os padrões de compra da população. Além disso, como são realizadas com o objetivo primordial de alimentar o sistema econômico e produtivo, essas pesquisas são realizadas com freqüência e regularidade.

\section{Registro ou Diário Alimentar}

Consiste na descrição detalhada dos tipos e quantidades de alimentos e bebidas consumidas diariamente, discriminados por horário e/ou refeição. Por ser uma medida pontual, em geral o diário alimentar é repetido durante um certo número de dias, de forma contínua ou não, para a obtenção da estimativa do consumo usual. A definição do número de dias de registro alimentar é crucial e deve ser determinada em função da variabilidade intra-individual dos nutrientes de interesse no estudo e do grau de precisão desejado (Buzzard, 1998). Porém, há que se tomar cuidado, pois, quando se opta por aumentar o número de dias, corre-se o risco de reduzir a adesão. O número de dias necessários varia de população para população, dependendo da variabilidade da dieta. Em geral, três dias permitem uma boa estimativa para energia, dado que vários são os alimentos que contribuem para o consumo total de energia.

Tradicionalmente, o registro alimentar é realizado escrevendo-se em formulário apropriado, de maneira detalhada, todos os alimentos consumidos durante um ou mais dias. Por isso, para o sucesso deste método, é imprescindível a colaboração e motivação por parte do entrevistado, além de grau de escolarização que permita realizar as 
anotações, o que limita os grupos populacionais em que o método pode ser empregado. Já há estudos que descrevem a incorporação de tecnologias que permitem realizar o registro alimentar com o uso de PDA (Personal Digital Assistant) ou, como é mais conhecido, palm-top, máquinas fotográficas, gravadores, filmadoras, balanças acopladas a computadores, e até telefone celular (Burke et al., 2005; Fong \& Kretsch, 1990; Wang et al., 2002). Enquanto para alguns autores a introdução de recursos tecnológicos representou uma maneira válida e conveniente de obter dados sobre consumo de alimentos (Wang, Kogashiwa \& Kira, 2006), para outros esses recursos não contribuíram para a maior aderência ou acurácia do relato de consumo alimentar (Yon et al., 2006), apresentando resultados comparáveis aos métodos tradicionais (Beasley, Reiley \& Jean-Mary, 2005; Kaczkowski et al., 2000). Essas tecnologias podem, contudo, reduzir o tempo e o trabalho de registro do consumo de alimentos (Fong \& Kretsch, 1990, Wang, Kogashira \& Kira, 2006).

Uma das vantagens do método do registro ou diário alimentar é a eliminação do viés de memória e, por isso, para alguns autores seria um método mais preciso. Outra vantagem seria a capacidade de obter informaçóes sobre quantidade com relativa acurácia. Contudo, por se tratar de um método prospectivo, o ato de registrar pode levar o indivíduo a alterar a escolha e o consumo de alimentos - inclusive, alguns estudos relatam perda de peso durante o período de registro do consumo (Trabulsi \& Schoeller, 2001). Outras limitações referem-se, principalmente, ao custo elevado, ao tempo necessário para a obtenção dos dados e ao trabalhoso tratamento e análise destes. A obtenção de registros com qualidade requer orientação padronizada dos participantes sobre o detalhamento das informações a serem registradas, desde a maneira de informar a porção ingerida até o detalhamento de receitas, relato sobre adição de temperos, açúcar, sal, óleos e gorduras, passando pela marca e especificidades de produtos industrializados. Além disso, para garantir a adequada descrição dos alimentos consumidos e suas quantidades, um pesquisador treinado deve rever os dados registrados, junto com o indivíduo sob investigação, logo após a finalização do registro (Buzzard, 1998).

Trabulsi e Schoeller (2001) avaliaram a validade de dados de registro de alimentos, comparando-a com o daqueles obtidos mediante a estimativa do dispêndio de energia pela água duplamente marcada e observaram que, no caso do primeiro método, as características físicas e psicológicas dos indivíduos em estudo afetam a qualidade do registro. A subestimação do consumo pode se dever ao sub-relato, mas também à redução do consumo durante o período de coleta de dados. O sub-relato foi mais freqüente entre indivíduos com algum excesso de peso (medido pelo IMC [índice de massa corporal = peso/estatura ${ }^{2}$ ], circunferência da cintura e massa de gordura corporal), indivíduos com mais idade e aqueles submetidos a regime de restrição alimentar.

\section{Métodos Recordatórios}

O recordatório de 24 horas é o método mais utilizado para a obtenção de relato de consumo de alimentos. Geralmente, o relato refere-se ao período das 24 horas anteriores ou ao dia anterior à entrevista, porque se considera que este é o período em que os indivíduos são capazes de lembrar a sua ingestão alimentar com o detalhamento desejado neste tipo de investigação (Rustishauser, 2005). Entretanto, períodos maiores têm sido referidos, Schroder e colaboradores (2001) compararam o recordatório de 72 horas com o registro alimentar no mesmo período; e compararam as estimativas de consumo de nutrientes obtidas com marcadores biológicos como o nitrogênio urinário, vitamina $\mathrm{C}$ e betacaroteno plasmático e os níveis de atividade da glutationa-peroxidase, além de estimar a reprodutibilidade do método por meio de estudo de teste-resteste. Os autores consideraram que o recordatório de 72 horas fornece estimativas válidas do consumo de nutrientes e pode ser usado em estudos de avaliação do consumo dietético.

O método recordatório, tradicionalmente, baseia-se em entrevista conduzida por profissional treinado cujo propósito é obter informações que permitam definir e quantificar a alimentação consumida no período de referência, geralmente 24 horas. Em geral, a entrevista é conduzida de modo a solicitar ao entrevistado que 
recorde o consumo em ordem cronológica. Para reduzir o erro na obtenção dos dados, recomenda-se a aplicação de técnicas de entrevista que visam a melhorar a lembrança do consumo alimentar no dia anterior, como a manutenção de atmosfera apropriada para estimular a cooperação e motivar o entrevistado. Para facilitar a lembrança, pode-se solicitar um breve histórico do que foi o dia anterior e elaborar perguntas específicas

como: "V. comeu alguma coisa entre o café da manhã e o almoço?".

Uma técnica, denominada "passagens múltiplas", vem sendo utilizada mais recentemente e consiste em estimular o entrevistado a recordar os alimentos consumidos no dia anterior, em três fases distintas: a) listagem rápida; b) descrição detalhada e c) revisão. $\mathrm{Na}$ etapa da listagem rápida, solicita-se ao entrevistado que liste todos os alimentos consumidos no dia anterior, considerando qualquer estratégia de lembrança que lhe seja mais apropriada, não necessariamente em ordem cronológica; durante o relato, o entrevistador não interfere e não interrompe o entrevistado. Na segunda etapa, o entrevistador passa a sondar o entrevistado para obter informaçóes sobre outros alimentos que necessitam ser adicionados à lista, dando ao entrevistado a oportunidade de lembrar alimentos que haviam sido inicialmente omitidos. Por fim, o entrevistador revê a lista com o entrevistado, com o objetivo de completar o relato (Jonhson, Soultanakis \& Matthews, 1998).

O Departamento de Agricultura dos Estados Unidos da América (USDA) aperfeiçou o método de passagens múltiplas para a obtenção de relato de consumo de alimentos, criando o USDA Multiple Pass Method, que integra em cinco etapas a recordação da ingestão alimentar de 24 horas (Conway et al., 2003). A entrevista, feita por telefone, é desenvolvida nas seguintes etapas: a) listagem rápida dos alimentos e bebidas consumidos no dia anterior; b) uma série de questôes interpela o entrevistado a respeito de alimentos que são usualmente omitidos em recordatórios de 24 horas; c) o entrevistado responde sobre o horário em que cada alimento foi consumido, detalhando local e ocasião; d) na etapa de detalhamento, solicita-se ao entrevistado que descreva com detalhes os alimentos relatados e sua quantidade, revendo as informaçôes sobre o horário e a ocasião do consumo; e) na última, é feita revisão final das informações e sondagem sobre alimentos que tenham sido consumidos e não foram relatados. Conway e colaboradores (2003) estimaram o consumo de alimentos em mulheres americanas utilizando o USDA Multiple Pass Method, observando uma precisão de 10\% em relação ao consumo obtido por meio de registro. Rustishauser (2005) assinala que o método da passagem múltipla tem sido considerado forma mais adequada de estimulação dos processos cognitivos de lembrança do que estímulos de ordem cronológica.

Para a obtenção de dados confiáveis em inquéritos recordatórios, é fundamental a habilidade do entrevistador em estabelecer comunicação com o entrevistado, o que torna, portanto, importantíssimo o treinamento e a padronização dos entrevistadores. Também é recomendado utilizar recursos para detalhar os alimentos consumidos, como perguntar sobre os ingredientes de preparaçôes, marcas e tamanho da embalagem de produtos industrializados e, especialmente, sobre itens geralmente omitidos: balas, bebidas, doces e produtos de adição como azeite, sal, açúcar, manteiga, margarina, molhos para salada e outros temperos. Além disso, a utilização de recursos como a apresentação de utensílios, fotos ou modelos pode ajudar na estimativa das porçôes consumidas.

Nelson, Atkinson e Darbyshire (1994) assinalam que o uso de uma série de fotografias apresentando diferentes tamanhos de porçôes de alimentos foi relacionado com a redução do erro na percepção das quantidades de alimentos, ao passo que o uso de uma fotografia apenas relaciona-se com substancial subestimação das quantidades de diversos alimentos. Turconi e colaboradores (2005) também consideram que o uso de um atlas com grupos de três fotografias coloridas de cada alimento associou-se significativamente às porçôes consumidas, independentemente da idade, do sexo e do IMC, principalmente quando consideradas as estimativas para o grupo (que foram mais precisas do que para cada participante individualmente); esses autores consideraram o atlas fotográfico de alimentos como instrumento útil em estudos epidemiológicos.

As principais vantagens dos métodos recordatórios são o baixo custo, o tempo reduzido de aplicação, sua alta aceitação, o fato de não provocarem alteração nos hábitos alimentares e de não exigirem habilidades 
especiais do respondente. Os erros dos recordatórios relacionam-se com a memória e a cooperação do entrevistado e com dificuldades na estimativa das quantidades consumidas.

A qualidade da informação tanto dos diários alimentares quanto dos inquéritos recordatórios de 24 horas tem sido associada a características como sexo, idade e escolaridade. Estudos que avaliaram a validade do consumo energético estimado com base em registros ou recordatórios mostram que a subestimação do consumo é bastante disseminada (Kaczkowski et al., 2000). Trabulsi e Schoeller (2001) notam a relação inversa entre o IMC e a acurácia do relato. Entretanto, essa premissa não se confirma em todos os segmentos; por exemplo, observou-se alto grau de sub-relato entre atletas de elite, apesar dos IMC dentro dos limites de normalidade. Buzzard (1998) assinala que os grupos que mais sub-relatam o consumo são os obesos, as mulheres, os adolescentes, os idosos e os que comem mais (que em muitas ocasiōes são os que gastam mais energia). Não foram registradas diferenças entre os relatos obtidos em entrevistas pessoais e os realizados por telefone (Casey et al., 1999; Tran et al., 2000; Yanek et al., 2000).

Tanto em diários alimentares como em inquéritos recordatórios de 24 horas, a omissão de itens consumidos é mais comum que a inclusão de produtos não utilizados (Buzzard, 1998), sendo os alimentos omitidos com maior freqüência aqueles consumidos mais raramente. Além disso, itens de adição, tais como manteiga, molhos e açúcar, são habitualmente mal relatados. Quanto à estimativa das porções, a superestimação parece ser mais comum do que a subestimação (Godwin, Chambers \& Cleveland, 2004).

A reprodutibilidade de registros e recordatórios de 24 horas é muito difícil de ser avaliada devido à variabilidade intra-individual do consumo alimentar. Contudo, a reprodutibilidade da estimativa da média populacional, mesmo baseada em um único dia de consumo, é alta (Buzzard, 1998). Um único recordatório de 24 horas é um método útil para descrever o consumo médio de energia e nutrientes de grupos populacionais.

Em estudos epidemiológicos, estimar o consumo usual costuma ser mais importante que o consumo pontual. Informação sobre o consumo alimentar de apenas um dia pode ser aceitável para a estimativa de médias de consumo global (energia e macronutrientes) de grandes amostras, ou de populações com consumo muito monótono. Tanto o registro alimentar como o recordatório de 24 horas estimam o consumo atual, sendo recomendada a sua repetição quando se deseja a estimativa do consumo usual. Quando o objetivo é a determinação do risco de consumo inadequado de alimentos/nutrientes, recomenda-se a realização de múltiplos registros ou recordatórios (Bingham \& Nelson, 1997). Para micronutrientes, a variabilidade intra-individual no consumo é maior, uma vez que eles se distribuem de forma irregular entre os alimentos que compõem a dieta usual. Por conseguinte, é necessário que sejam incluídos dados de um grande número de dias. De acordo com Willett (1998), para nutrientes como colesterol, vitamina A e vitamina $C$, podem ser necessários de vinte a cinqüenta dias. Para que se obtenha medida mais precisa do consumo usual de energia e nutrientes, o ideal é que estejam representados os sete dias da semana.

\section{Questionário de Freqüência do Consumo de Alimentos (QFA)}

O QFA é um questionário no qual o respondente é apresentado a uma lista de alimentos e solicitado a relatar com que freqüência cada item é usualmente consumido em média, em número de vezes por dia, por semana ou por mês, em um dado período, geralmente, os últimos seis ou 12 meses. Os alimentos incluídos na lista são, geralmente, escolhidos por razões específicas, e teoricamente este método não permite estimar o consumo total de alimentos. Segundo Willett (1998), o QFA desenvolveu-se com base em um método de avaliação do consumo alimentar elaborado entre 1940 e 1950, nos Estados Unidos, que incluía um componente no qual o respondente deveria listar os alimentos consumidos no mês anterior. Essa listagem foi a precursora dos QFA utilizados nos dias de hoje. O QFA resultou da necessidade de avaliar o consumo de longo prazo, como uma alternativa ao registro alimentar e ao recordatório de 24 horas, que estimam o consumo pontual e se tornam dispendiosos e trabalhosos quando repetidos por longos períodos. 
O princípio subjacente aos QFA é que a estimativa da dieta habitual, praticada ao longo de semanas, meses ou anos, constitui-se como fator de exposição mais importante do que a estimativa da dieta pontual por exemplo, de um único dia, ou mesmo de alguns dias. Essa premissa justifica a utilização de informaçôes menos precisas, mas relacionadas ao consumo habitual, em detrimento da precisão de dados relativos à ingestão pontual de alimentos. É também Willett (1994) quem assinala que a variação na quantidade de alimentos consumida pelos indivíduos é determinada, em última instância, pela freqüência do consumo.

O QFA tem sido considerado o método de escolha em estudos epidemiológicos. O objetivo básico do QFA é avaliar a dieta praticada durante determinado período de tempo no passado recente, ou mesmo remoto. A preferência dos estudos epidemiológicos pelo QFA está baseada na possibilidade de medir a intensidade da exposição, permitindo classificar os indivíduos em categorias de consumo (por exemplo, alto, médio e baixo), o que possibilita estimativa da associação das categorias de consumo com o desenvolvimento de enfermidades. Além do mais, por sua praticidade tanto na obtenção quanto na análise dos dados, o QFA é adequado para extensos estudos de base populacional. O QFA não sofre o efeito da variação intra-individual e, por se tratar de método retrospectivo, não leva à alteração do padrão de consumo dos indivíduos. Portanto, embora justificável nos estudos epidemiológicos de caráter etiológico, o QFA não é o método indicado para estudos que requerem estimativas acuradas e absolutas do consumo, como é o caso de estudos descritivos do consumo alimentar e algumas investigações clínicas.

\section{Desenvolvimento do QFA}

A elaboração da lista dos alimentos do QFA é aspecto crucial no seu desenvolvimento. As alternativas são: a) a verificação em tabela de composição de alimentos dos itens que contêm teores elevados do nutriente em estudo; b) a orientação de especialistas em nutrição; c) a utilização de dados de estudos anteriores que aplicaram registro ou recordatório de 24 horas na população que se deseja investigar. Entretanto, se esses estudos são muito antigos, é necessária a sua atualização, pois podem ter ocorrido mudanças nos hábitos alimentares ao longo dos anos; d) realização de registro ou recordatório de 24 horas em amostra reduzida da população que se deseja investigar. A lista de alimentos que integra cada QFA é específica, e sua definição dependerá dos objetivos do estudo (Bingham \& Nelson, 1997). A utilização de tabelas de composição química de alimentos apresenta limitaçôes, uma vez que pode incluir alimentos com alto teor do nutriente de interesse, mas pouco consumidos pela população.

A técnica de grupo focal tem sido relatada como uma estratégia para auxiliar a construção de QFA para grupos culturais específicos (MacIntyre, Venter \& Vorster, 2000; Yaroch et al., 2000). É fundamental que a lista se constitua não só por alimentos que sejam consumidos razoavelmente por proporção considerável da população de estudo, mas cujo consumo seja variável entre os indivíduos. É quase sempre preferível que se defina uma lista ampla de alimentos, que tem a vantagem de permitir o ajuste para o consumo de energia, passo quase que obrigatório nos estudos etiológicos. Ainda que o objetivo seja investigar o consumo de algum nutriente específico, o consumo de quase todos os nutrientes é altamente correlacionado à ingestão de energia. Uma lista mais extensa, segundo Cade e colaboradores (2002), tem também a vantagem de permitir explorar hipóteses futuras, não definidas no estudo principal, ou de retornar ao mesmo grupo populacional para acompanhar mudanças na tendência de consumo de alimentos. Todavia, ocorrem situaçóes em que uma lista mais restrita pode ser o procedimento de escolha; por exemplo, quando se deseja selecionar indivíduos que mantêm consumo elevado de gorduras para a inclusão em estudo de intervenção, ou questionários de rastreamento ou com caráter educativo quando da sua aplicação (Block, 1989; Chiara \& Sichieri, 2001).

Para a definição de uma lista de alimentos com base em dados de registro ou recordatório, alguns procedimentos podem ser adotados, por exemplo, priorizando alimentos que são os que mais contribuem para o consumo de 
energia e nutrientes, escolhendo os que explicam a variabilidade interindividual do consumo (aplicando-se análise de regressão linear), ou simplesmente selecionando os que são mais freqüentemente referidos. Willett (1998) aconselha cautela na utilização da análise de regressão para a seleção dos alimentos da lista do QFA, pois alguns alimentos podem ser preditores do consumo de determinado nutriente, mas não ser diretamente responsáveis pelo aporte do referido nutriente; um exemplo é o consumo de milho, que pode estar relacionado com o consumo de colesterol, devido à adição de manteiga.

Cade e colaboradores (2002), em revisão de artigos publicados em 1998 sobre validação de QFA, observaram que o número de itens incluídos nos QFA variou de cinco a 350, com mediana de 79 itens. Os questionários que avaliavam o consumo de itens específicos eram mais curtos do que aqueles que pretendiam estimar o consumo global. Os mesmos autores sugerem que listas extensas não aumentam a validade quando comparadas com listas mais reduzidas.

Uma alternativa quando o tempo e/ou os recursos financeiros são limitados é a utilização ou modificação de questionários já existentes, particularmente aqueles desenvolvidos para populações com características similares àquelas do grupo em estudo, desde que testados quanto à reprodutibilidade e validade (Nelson, 1997). Vale lembrar que os estudos de confiabilidade podem obter correlações elevadas, porém espúrias, dado que os erros de informação costumam ser correlacionados (por exemplo, mulheres obesas consistentemente sub-relatam o consumo).

A organização da estrutura da lista de alimentos é um outro aspecto a ser considerado, pois um item pode alterar a interpretação de outro. Quando o agrupamento é realizado de modo a se adequar à estrutura conceitual dos respondentes, o relato do consumo se torna mais fácil. Cade e colaboradores (2002) recomendam apresentar itens específicos antes de itens gerais (por exemplo, refrigerante de baixa caloria precedendo refrigerante em geral).

Alimentos que são o principal foco do estudo devem aparecer próximo do começo do questionário, mas não no início propriamente dito. É provável que as respostas às primeiras perguntas estejam mais sujeitas a erro, ao passo que as últimas podem ser respondidas com menor grau de atenção (Cade et al., 2002).

Uma forma de aumentar a precisão do QFA é a inclusão de questões adicionais sobre detalhes dos alimentos usualmente consumidos, como o tipo de gordura usada no preparo de alimentos e uso de suplementos, bem como sobre o consumo de gordura visível das carnes, o consumo de açúcar e alimentos dietéticos e a freqüência de consumo de lanches (Willett, 1994).

Os QFA podem ser de três tipos: a) qualitativo: que obtém informações sobre os alimentos consumidos sem incluir dados de quantidades; b) quantitativo: quando se solicita ao respondente que descreva a porção usual de consumo de cada item da lista; tanto pode haver uma questão aberta para quantidades quanto se apresentar uma porção média para que o respondente estime se sua porção é pequena (menor que a apresentada), média (igual à apresentada), ou grande (maior que a apresentada); c) semiquantitativo: este questionário inclui uma porção média de referência para cada item alimentar, e o consumo deve ser estimado como um múltiplo dessa porção. No QFA semiquantitativo, as porções padronizadas podem ser especificadas como parte da pergunta; por exemplo, deve-se perguntar: "Com que freqüência você consome um copo de leite?" ou, alternativamente, podem ser feitas duas questôes, uma sobre freqüência do consumo e outra sobre o número de porções usualmente consumidas.

O QFA deve definir o período de referência para o consumo. Geralmente, em questionários desenvolvidos em países de zona temperada, utiliza-se o ano precedente, pois em um ano ocorre um ciclo completo de estações, o que permite capturar a variabilidade sazonal. Em geral, o questionário refere-se ao ano ou aos seis meses pregressos, pois parte-se da premissa de que o importante é o consumo usual de longo prazo.

As opções de freqüência devem ser de fácil compreensão e estabelecidas em um gradiente contínuo, variando entre cinco e dez, e organizadas de maneira crescente ou decrescente (Willett, 1998). As opçôes de freqüência podem ser as mesmas para todos os alimentos incluídos no QFA (o que é comum quando o questionário apresenta-se no formato horizontal) ou podem variar de acordo com o alimento analisado (mais freqüente quando o 
questionário tem o formato vertical). Este modelo se justifica porque há poucos alimentos que são, usualmente, consumidos mais do que uma ou duas vezes por dia. Se o questionário apresenta opções como "3-4 vezes por dia" para todos os alimentos, pode haver uma tendência de superestimação do consumo de alguns itens, levando a distorções nos resultados (Cade et al., 2002). Quando as opçôes são poucas, provavelmente ocasionam falta de informação, e se forem muitas, provavelmente geram confusão. O importante é que tenham capacidade de discriminar alimentos que são consumidos freqüentemente (tais como manteiga, açúcar, café) e aqueles que são consumidos raramente (por exemplo, fígado). Uma alternativa é deixar a opção para freqüência em aberto, mas isso complica a codificação e a digitação dos dados. Mais ainda, Subar e colaboradores (1995) observaram que o uso de opções de freqüência definidas reduz erros no preenchimento de QFA, pois todos os repondentes ficam submetidos à mesma estrutura de erro de informação.

A inclusão de categorias de freqüência e tamanhos de porçôes como respostas fechadas também reduz o trabalho e o custo com a codificação e previne erros de transcrição de dados; esta prática permite, ainda, reduzir o volume de questionários rejeitados devido a respostas incompletas ou incoerentes (Nelson, 1997).

A definição das porções não chega a ser um problema quando se trata de alimentos que têm quantidades 'naturais' (frutas, pão etc.). Quando o alimento não tem uma unidade típica, essa tarefa torna-se difícil. As porçôes padronizadas devem refletir o hábito de consumo da população estudada. Idealmente, o questionário deve permitir averiguar as diferenças nas quantidades consumidas entre indivíduos que consomem determinado alimento com uma mesma freqüência, mas em diferentes tamanhos de porçôes. Porções podem desempenhar um papel fundamental na avaliação de nutrientes que se concentram em poucos alimentos, como, por exemplo, a vitamina A.

Para fornecer informação útil sobre o tamanho da porção consumida, os indivíduos devem ser capazes de conceituar a porção média descrita no questionário e relacioná-la ao seu hábito alimentar. Entretanto, Drewnovski (2001) considera que, para o respondente, conceituar a porção padronizada e inferir sobre o seu consumo médio no período de tempo estipulado é um exercício mental difícil, cuja acurácia vem sendo contestada. Segundo Cade e colaboradores (2002), estudos de validação de QFA obtiveram coeficentes de correlação mais elevados quando os indivíduos podiam descrever o tamanho da porção consumida (coeficientes de correlação entre 0,5 e 0,6), em comparação com questionários que especificavam as porções médias (coeficientes de correlação entre 0,4 e 0,5 ) e com questionários que só estimavam o consumo qualitativo (coeficientes de correlação entre 0,2 e 0,5). Willett (1998) assinala que a inclusão da porção não acrescenta precisão ao QFA, uma vez que, quando se utiliza questionário qualitativo, o consumo de energia e nutrientes pode ser estimado utilizando-se dados de porções médias apropriados para a população em estudo.

A confiabilidade do questionário desenvolvido para adultos do Rio de Janeiro por Sichieri (1998) foi avaliada em estudo realizado com mulheres que freqüentavam os ambulatórios de ginecologia e pediatria de uma unidade primária de saúde da cidade, no período de julho de 2002 a maio de 2003. Sessenta e nove mulheres responderam ao QFA em dois momentos, com intervalo mínimo de trinta dias e máximo de dois meses. O questionário era autopreenchível e adequado para leitura óptica, com três possibilidades de resposta para porçôes de cada alimento. As concordâncias foram maiores para as freqüências de consumo do que para as porções (Quadro 1), o que indica as dificuldades envolvidas no relato das porções, ainda que o questionário apresentasse apenas três opções para descrever as porçôes usualmente consumidas. Os alimentos apresentados no Quadro 1 revelaram concordância estatisticamente significativa $(\mathrm{P}<0,05)$. 
Quadro 1 - Categorias de concordância segundo Kappa ponderado para freqüência de consumo e porções dos alimentos

\begin{tabular}{|c|c|}
\hline Concordância $^{1 ; 2}$ & Freqüência \\
\hline Reduzida & Tomate, carne de boi sem osso, frango \\
\hline Moderada & $\begin{array}{l}\text { Biscoito salgado, pipoca, }{ }^{*} \text { mamão, melancia/melão, abacate, }{ }^{*} \text { manga, limão, abóbora, vagem, cenoura, } \\
\text { manteiga/margarina, vísceras, }{ }^{*} \text { bacon/toucinho* }\end{array}$ \\
\hline Boa & $\begin{array}{l}\text { Arroz, feijão, macarrão, farinha de mandioca, }{ }^{*} \text { pão francês, biscoito doce, bolo, polenta/angu, }{ }^{*} \text { batata frita, } \\
\text { batata cozida, aipim, milho verde * inhame/cará, }{ }^{*} \text { ervilha/lentilha/grão-de-bico, alface, couve, repolho, } \\
\text { laranja/tangerina, banana, maçãa, abacaxi, maracujá, uva, goiaba, }{ }^{*} \text { chicória, }{ }^{*} \text { chuchu, pepino, }{ }^{*} \text { quiabo, } \\
\text { beterraba, couve-flor, iogurte, queijo, requeijão, }{ }^{*} \text { carne de boi com osso, }{ }^{*} \text { carne de porco, salsicha/lingüicca, } \\
\text { peixe fresco, sardinha/atum, camarão, }{ }^{*} \text { cebola, maionese, salgadinhos, }{ }^{*} \text { caramelos/balas, }{ }^{*} \text { achocolatado, } \\
\text { chocolate em barra/bombom, }{ }^{*} \text { pudim/doce, suco da fruta ou polpa, mate, }{ }^{*} \text { cerveja, }{ }^{*} \text { outras bebidas } \\
\text { alcoólicas }{ }^{*}\end{array}$ \\
\hline Muito boa & Pêra, ovo, leite, refrigerante, café \\
\hline Concordância $^{1 ; 2}$ & Porção \\
\hline Reduzida & Biscoito salgado, pepino \\
\hline Moderada & $\begin{array}{l}\text { Biscoito doce, bolo, batata frita, batata cozida, pipoca, inhame/cará, alface, laranja/tangerina, maçãa, } \\
\text { melancia/melão, abacaxi, uva, pêra, chicória, tomate, abóbora, vagem, cenoura, beterraba, carne de boi sem } \\
\text { osso, frango, salgadinho, açúcar, refrigerante, café }\end{array}$ \\
\hline Boa & $\begin{array}{l}\text { Arroz, macarrão, farinha de mandioca, aipim, ervilha/lentilha/grão-de-bico, couve, banana, mamão, abacate, } \\
\text { manga, chuchu, abobrinha, quiabo, couve-flor, ovo, queijo, carne de boi com osso, salsicha/lingüicca, pizza, } \\
\text { camarão, maionese, sorvete, chocolate em barra/bombom, suco da fruta ou polpa, mate, vinho, cerveja }\end{array}$ \\
\hline Muito boa & Feijão, goiaba, leite, iogurte, achocolatado \\
\hline
\end{tabular}

1 - Valores da estatística Kappa para as categorias de concordância: pobre: < 0,20; reduzida: 0,21-0,40; moderada: 0,41-0,60; boa: 0,61-0,80; muito boa: $\geq 0,81$.

2 - Não foram observadas concordâncias na categoria 'pobre'.

* Alimentos que $50 \%$ ou mais das mulheres referiram consumir "quase nunca" ou "nunca".

Fonte: Souza et al. (2004).

A forma de preenchimento do questionário também é um ponto a ser considerado. O autopreenchimento limita o grupo de estudo, pois sua aplicação fica prejudicada para analfabetos, idosos e crianças, ao mesmo tempo que questionários autopreenchíveis requerem mais cuidado em sua elaboração. Um dos problemas que ocorrem quando os QFA são autopreenchíveis é o elevado número de itens sem resposta, dado que os respondentes tendem a completar apenas os itens que consomem usualmente.

A análise de dados de QFA pode ser feita com a elaboração de programas computacionais. A etapa inicial consiste em converter a freqüência relatada de consumo de cada item do questionário em freqüência diária, a qual deve ser multiplicada pela quantidade relatada. O resultado é a estimativa do consumo médio diário de cada um dos alimentos da lista, no período considerado. A partir daí, com o uso de tabelas de composição química ou software de análise de dados de consumo de alimentos, estima-se o consumo de energia e nutrientes. É necessário estabelecer um critério para solucionar questōes que se apresentam quando as respostas estão incompletas. Para questionários que não excedem uma percentagem estabelecida de dados incompletos, o valor zero (alimento não consumido) pode ser usado, ou um valor médio pode ser atribuído para substituir a ausência de informação. Um programa em SAS (Statistical Analysis System) está disponível em Sichieri, 1998. 


\section{Vantagens e Limitações do QFA}

De maneira geral, podem ser consideradas vantagens dos QFA a estimativa do consumo usual, a possibilidade de classificar os indivíduos em categorias de consumo, a simplicidade na análise, o baixo custo, a economia de tempo e a não-modificação do consumo devido à avaliação.

Em contrapartida, podem ser consideradas como limitações do QFA o fato de ser dependente da memória, o trabalho envolvido no desenho e avaliação do QFA, a complexidade na entrevista e a dificuldade na precisão da quantidade consumida.

Contudo, o papel da memória sempre foi questionado, e esforços para melhorar a qualidade das estimativas dos questionários têm enfatizado o uso de técnicas cognitivas e elementos que auxiliem na recordação dos alimentos e quantidades consumidas, como o uso de fotografias e/ou medidas caseiras (Slater et al., 2003). Drewnowski (2001) afirma que as respostas aos QFA são elaboradas com base em alguma imagem subjetiva da dieta atual ou típica do respondente. Assim, o relato da dieta é baseado em uma imagem mental, o que redundaria na tendência a relatar as preferências alimentares, refletindo uma atitude, e não o comportamento dietético real.

Embora venham sendo amplamente utilizados em estudo etiológicos, os QFA vêm sofrendo críticas a partir da realização de estudos que avaliaram a sua validade utilizando o método da água duplamente marcada e excreção de nitrogênio urinário (únicos padrões-ouro disponíveis) e observaram reduzidos graus de concordância (Schatzkin et al., 2003).

\section{Aspectos Metodológicos dos Estudos de Avaliação da Dieta}

Alimentos consumidos muito freqüentemente ou muito raramente são relatados com maior acurácia, particularmente em estudos que privilegiam o consumo habitual, como é o caso dos questionários de freqüência de consumo de alimentos (Thompson et al., 1987).

Segundo Rutishauser (2005), principalmente quando se deseja averiguar a adequação do consumo de energia e nutrientes utilizando dados de consumo alimentar pontuais (como o recordatório de 24 horas e o registro alimentar), é importante que as estimativas sejam ajustadas pela variabilidade intra-individual, o que pode ser feito quando se dispõe de informações de pelos menos dois dias de consumo.

A escolha do método de avaliação vai depender do escopo da pesquisa. Um primeiro ponto é definir se as estimativas serão individuais ou para os grupos populacionais. Em seguida, é necessário definir se os dados serão utilizados para: a) descrever o padrão de consumo alimentar; b) reconhecer hábitos alimentares; c) caracterizar o consumo de energia e nutrientes; d) estimar a adequação do consumo de alimentos; e) investigar a relação entre dieta, estado nutricional e saúde.

Também é importante ter clareza dos mecanismos fisiológicos implicados no processo que se quer estudar. Por exemplo: é necessário determinar se o efeito em estudo relaciona-se com a dieta em período recente ou passado (p. ex., consumo de alimentos e desenvolvimento de neoplasias) e, portanto, definir a 'janela de tempo' em que se deseja investigar a exposição (dieta). Também importa o desenho do estudo empregado. Carece de sentido empregar um método prospectivo de obtenção de dados de consumo alimentar (como é o caso do registro alimentar) ao se desenvolver estudo caso-controle abordando efeito da dieta sobre o desenvolvimento de câncer.

Beaton (1994) afirma que não existe método que permita estimar sem erro o consumo alimentar. O erro de mensuração está presente em todos os campos da ciência que envolvem medições; são várias as fontes de erro, mas este pode ser basicamente de dois tipos: o erro aleatório e o erro sistemático. Os erros aleatórios levam ao incremento da variância dos parâmetros estimados, reduzindo a sua precisão; contudo, a replicação das medidas leva à redução desses erros; por exemplo, o efeito da variação dia a dia no consumo de alimentos pode ser reduzido 
pelo aumento do número de dias de observação. Já os erros sistemáticos, aqueles que advêm de fenômenos que não são distribuídos aleatoriamente no grupo investigado, determinam o aparecimento de vieses ou tendenciosidades nas estimativas de consumo; por exemplo, o uso de dados incorretos da composição química de um alimento específico irá alterar as estimativas de consumo e comprometer os resultados gerais do estudo.

O desafio em estudos de avaliação do consumo alimentar é compreender, mensurar e utilizar a estrutura dos erros na análise dos dados (Beaton, Burema \& Ritenbaugh, 1997). Para mensurar o erro envolvido na estimação do consumo dietético, são realizados estudos de reprodutibilidade, validação e calibração. Qualquer que seja a técnica de obtenção de dados de consumo de alimentos, é recomendado que se desenvolvam estudos para averiguar o grau de viés envolvido no grupo em estudo, pois fatores relacionados a sexo, idade, atividade física, IMC, proporção de gordura corporal e práticas alimentares têm sido relatados entre aqueles que afetam a qualidade do relato da dieta (Rutishauser, 2005; Trabulsi \& Schoeller, 2001).

Os estudos de reprodutibilidade permitem avaliar se os dados obtidos por meio de um determinado método se reproduzem ao longo do tempo através de aplicações repetidas (teste-reteste). A reprodutibilidade ou confiabilidade se refere à consistência do método na avaliação de um mesmo indivíduo em diferentes pontos no tempo, ou seja, indica se o instrumento é capaz de fornecer resultados semelhantes quando aplicado repetidas vezes (Nelson, 1997). Adicionalmente, estudos de reprodutibilidade são bastante úteis como uma avaliação preliminar a estudos de validação, por serem mais simples e permitirem uma resposta parcial sobre a validade do método. Um baixo grau de confiabilidade indica que o questionário não provê medidas válidas do consumo alimentar, porém um alto grau de reprodutibilidade não demonstra que o método é válido, mas sim que os dados são reprodutíveis ao longo do tempo (Willett \& Lenart, 1998).

Estudos de validação podem ser desenvolvidos comparando-se o método em teste com outro método que não apresente erros correlacionados. No capítulo 11 deste volume, "Desenvolvimento, validação e aplicações de questionários de freqüência alimentar em estudos epidemiológicos", é apresentada discussão aprofundada sobre os estudos de validação de QFA. Também são utilizados dados relacionados ao gasto energético ou outros marcadores biológicos que sejam reflexo do consumo de nutrientes. Dentre as medidas mais empregadas, estão o dispêndio de energia estimado pela água duplamente marcada (que é comparado ao consumo de energia relatado), a excreção de nitrogênio urinário (marcador do consumo de proteína) ou de minerais como sódio e potássio, teores plasmáticos de vitaminas e conteúdo de minerais e ácidos graxos em tecidos corporais.

Como o padrão-ouro para estimar o gasto energético, o método da água duplamente marcada, é um método dispendioso e de difícil manejo no campo, é necessário aplicar metodologias que demandem menos recursos, tempo e trabalho para analisar a plausibilidade dos relatos de consumo alimentar quanto ao conteúdo energético. Uma alternativa para identificar informaçôes plausíveis de consumo de energia é a estimativa da razão consumo de energia/taxa de metabolismo basal. Esta proposta baseia-se na equação de Goldberg e colaboradores (1991), a qual calcula os limites de concordância com 95\% de confiança da razão entre o consumo de energia/ taxa de metabolismo basal e o nível de atividade física, considerando nessa estimativa a variabilidade dos parâmetros, o período de estimativa do consumo e o número de observaçôes incluídas no estudo. Quando as estimativas de consumo de energia estão acima ou abaixo dos limites de concordância considerados, o relato é considerado improvável e tendencioso; em geral são informações eliminadas da análise dos dados.

O método da água duplamente marcada estima o gasto energético e se baseia na premissa de que a energia ingerida ou é dispendida pelo corpo ou é armazenada. Ou seja, o consumo de energia relatado, para ser válido (isto é, refletir o consumo real), deve ser igual ao gasto energético \pm mudanças nas reservas corporais de energia. Portanto, em indivíduos com peso estável, que não se encontram em fase de crescimento ativo (infância, adolescência ou gravidez), o gasto de energia estimado pelo método da água duplamente marcada deve ser igual ao consumo habitual de energia estimado pelo método de avaliação do consumo alimentar em teste (Trabulsi \& Schoeller, 2001). A principal vantagem do método da água duplamente marcada é que ele não impõe mudanças 
bruscas na rotina dos participantes do estudo, não interfere em suas atividades diárias, permitindo que mantenham o grau de dispêndio de energia habitual. Suas limitações relacionam-se com o seu alto custo, a necessidade de equipamento sofisticado para a análise dos dados (espectrometria de massa), não sendo possível incorporá-lo à rotina de validação de métodos de avaliação do consumo de alimentos. Rutishauser (2005) assinala que estudos que avaliaram estimativas do consumo energético contra a estimativa do gasto energético pela água duplamente marcada em diferentes grupos da população observaram diferenças que variaram de $-44 \%$ a $+28 \%$.

A calibração consiste em um método de reconhecimento do erro associado à estimativa da ingestão de nutrientes por um método-teste comparando-o com o método de referência. Esse procedimento permite corrigir os erros de medida provenientes do método testado e do grupo populacional investigado, podendo ser definido como o redimensionamento das medidas, que torna a ingestão obtida pelo método-teste mais próxima da ingestão real (Kaaks \& Riboli, 1997; Willett \& Lenart, 1998). Também na calibração o método de referência escolhido deve apresentar erros independentes (Lopes et al., 2003).

$\mathrm{Na}$ análise, diversos procedimentos podem ser incluídos, de modo a corrigir os efeitos dos erros. Entre tais procedimentos, incluem-se a correção de coeficientes e medidas de risco, considerando a variância intra-individual, quando métodos pontuais são utilizados (Beaton, 1997). Independentemente do método de avaliação, as análises de associaçóes da dieta com desenlaces requerem, na maioria das vezes, o ajuste para o consumo de energia (Willett, 1998).

Finalmente, não se pode deixar de levantar algumas questões sobre o uso de tabelas e programas de computador para análise da composição química dos alimentos. Sabe-se que as tabelas de composição de alimentos apresentam diferenças entre si, particularmente se os dados apresentados se referem a informaçôes obtidas em diferentes países. A escolha de uma tabela ou programa de análise de alimentos deve incorporar alguns princípios: primeiro, a tabela deve ser atualizada, não somente do ponto de vista da inclusão de novos alimentos que passam a estar disponíveis, como da diversificação dos nutrientes analisados; segundo, a tabela deve explicitar as fontes de dados, os métodos empregados na análise e o número e origem das amostras analisadas; particularmente, é interessante que os mesmos métodos tenham sido empregados nas análises de cada nutriente. A escolha de um programa de análise de composição de alimentos deve apresentar algumas características que facilitarão sua aplicação: a) o sistema deve possibilitar a inclusão de novos itens ou nutrientes; b) o sistema deve apresentar flexibilidade para a inclusão de dados com base em medidas caseiras (ou por tamanho de porção) baseadas no porcionamento habitual do país ou região a que se destina; c) os resultados provenientes da análise dos dados devem ser dispostos por alimento, refeição e dia; d) o sistema deve permitir a compilação de receitas como um item individual; e) o sistema deve permitir a transferência dos dados para outros programas de gerenciamento. Buzzard (1998) relata que a comparação do cálculo de nutrientes com base em tabelas de composição com a composição nutricional dada pela análise química mostrou que a estimativa calculada tende a ser maior que a analisada, chegando a mais de 20\% para nutrientes como vitaminas A e C, cálcio, ferro, sódio, potássio e colesterol. Contudo, essa autora assinala que, se forem incluídos mais dias de relato do consumo (pelo recordatório de 24 horas ou registro), a concordância entre analisado e calculado tende a melhorar.

\section{Uma Nova Abordagem}

Recentemente, pesquisadores do National Cancer Institute, dos Estados Unidos, desenvolveram uma nova abordagem para a avaliação do consumo alimentar (Subar et al., 2006). Os autores alegam que, embora o recordatório de 24 horas capture informação rica e importante, o método falha em mensurar adequadamente o consumo usual de alimentos que são consumidos eventualmente, mesmo quando mais de um recordatório é aplicado. Com base nessa consideração, desenvolveu-se um modelo estatístico que combina um número limitado de recordatórios de 24 horas e questóes sobre freqüência do consumo de alimentos. O elemento essencial deste 
modelo reside na noção de que o QFA representa o que falta no recordatório de 24 horas, ou seja, a possibilidade de estimar a probabilidade de consumo de itens alimentares específicos em período de tempo determinado. Em contrapartida, os recordatórios de 24 horas podem fornecer informações mais apropriadas sobre as quantidades ingeridas. A nova proposta é uma combinação de métodos, tratados de forma complementar, e vem sendo denominada Food Propensity Questionnaire ou, traduzido livremente, 'questionário sobre a propensão ao consumo de alimentos'. Na verdade, nesta metodologia não se utiliza a freqüência absoluta de consumo relatada no QFA. O que se trabalha é a informação sobre freqüência de consumo relacionada com a informação do recordatório de 24 horas, que permite estimar a probabilidade de o informante consumir um alimento em particular (Tooze et al., 2006). A análise constitui-se na elaboração de modelos estatísticos para estimar o consumo usual de alimentos consumidos eventualmente e utiliza dados sobre freqüência de consumo que exibem relação robusta e preditiva com recordatórios de 24 horas como co-variáveis, incluindo também no modelo outras co-variáveis, como sexo, idade e raça dos indivíduos investigados.

\section{Considerações Finais}

Não obstante as dificuldades importantes na avaliação do consumo de alimentos/nutrientes, a relevância dessas investigações é irrefutável. Dados obtidos em estudos epidemiológicos que pesquisam a associação entre dieta e o desenvolvimento de enfermidades têm contribuído de forma extraordinária para o conhecimento dos processos etiológicos envolvidos em doenças de reconhecido impacto para a saúde pública, além de indicarem caminhos e estratégias de prevenção e controle de muitos desses problemas. Walter Willett salienta a relevância dessas investigaçôes assinalando que, virtualmente, tudo o que se conhece sobre prevenção do câncer atualmente é originário de estudos epidemiológicos (Science Watch Interviews, 1995). Segundo esse autor, alguns achados são bastante conclusivos, como a associação entre ingestão de álcool e desenvolvimento de câncer de mama, o papel de frutas e verduras na prevenção de diversos tipos de câncer, o efeito do consumo excessivo de carne vermelha sobre determinadas neoplasias, particularmente o câncer de cólon.

Para Van Horn (2006), a confiança no relato do consumo alimentar permanece como um componente essencial da epidemiologia nutricional, e o aperfeiçoamento da qualidade dos dados coletados e da quantificação da ingestão alimentar é crucial para a determinação de associações precisas entre dieta e saúde-enfermidade. Entretanto, essa busca pela perfeição deve estar conjugada com a simplificação dos métodos e a redução do tempo e do trabalho envolvidos. De modo geral, pode-se dizer que a seleção do método de avaliação do consumo de alimentos é metade do desafio na pesquisa nutricional. Questóes decisivas se colocam diante da tarefa de analisar e interpretar as informaçôes, quando aspectos importantes devem ser considerados: a variabilidade da dieta, o tamanho amostral, a comparabilidade dos dados, o papel de fatores de confusão e a plausibilidade biológica dos achados.

\section{Referências}

BEASLEY, J.; REILEY, W. T. \& JEAN-MARY, J. Accuracy of a PDA dietary assessment program. Nutrition, 21(6): 672-677, 2005.

BEATON, G. H. Approaches to analysis of dietary data: relationship between planned analyses and choice of methodology. American Journal of Clinical Nutrition, 59, suppl.: 253S-261S, 1994.

BEATON, G. H.; BUREMA, J. \& RITENBAUGH, C. Errors in the interpretation of dietary assessments. American Journal of Clinical Nutrition, 65, suppl. 4: 1.100S-1.107S, 1997. 
BINGHAM, S. A. \& NELSON, M. Assessment of food consumption and nutrient intake. In: MARGETTS, B. M. \& NELSON, M. (Eds.) Design Concepts in Nutritional Epidemiology. Oxford: Oxford University Press, 1997.

BLOCK, G. et al. A brief dietary screen for high fat intake. Journal of Nutrition Education, 21: 199-207, 1989.

BURKE, L. E. et al. Self-monitoring dietary intake: current and future practices. Journal of Renal Nutrition, 15(3): 281-290, 2005.

BUZZARD, M. 24-hour dietary recall and food record methods. In: WILLETT, W. Nutritional Epidemiology. 2. ed. Oxford: Oxford University Press, 1998.

BYRD-BREDBENNER, C.; LAGIOU, P. \& TRICHOPOULOU, A. A comparison of household food availability in 11 countries. Journal of Human Nutrition \& Dietetics, 13(3): 197-204, 2000.

CADE, J. et al. Development, validation and utilisation of food-frequency questionnaires: a review. Public Health Nutrition, 5(4): 567-587, 2002.

CASEY, P. H. et al. The use of telephone interview methodology to obtain 24-hour dietary recalls. Journal of the American Dietetic Association, 99(11): 1.406-1.411, 1999.

CHIARA, V. L. \& SICHIERI, R. Consumo alimentar em adolescentes: questionário simplificado para avaliação de risco cardiovascular. Arquivos Brasileiros de Cardiologia, 77: 332-336, 2001.

CONWAY, J. M. et al. Effectiveness of the US Department of Agriculture 5-step multiple-pass method in assessing food intake in obese and nonobese women. American Journal of Clinical Nutrition, 77: 1.171$1.178,2003$.

DREWNOVSKI, A. Diet image: a new perspective on the food-frequency questionnaire. Nutrition Reviews, 59(11): 370-372, 2001.

FOOD AND AGRICULTURE ORGANIZATION OF THE UNITED NATIONS (FAOSTAT), 2006. Disponível em <http://faostat.fao.org/site/357/default.aspx>. Acesso em: 25 jan. 2007.

FONG, A. K. \& KRETSCH, M. J. Nutrition Evaluation Scale System reduces time and labor in recording quantitative dietary intake. Journal of the American Dietetic Association, 90(5): 664-670, 1990.

GODWIN, S. L.; CHAMBERS, E. \& CLEVELAND, L. Accuracy of reporting dietary intake using various portion-size aids in-person and via telephone. Journal of the American Dietetic Association, 104(4): 585$594,2004$.

GOLDBERG, G. R. et al. Critical evaluation of energy intake data using fundamental principles of energy physiology: derivation of cut-off limits to identify underrecording. European Journal of Clinical Nutrition, 45: 569-581, 1991.

INSTITUTO BRASILEIRO DE GEOGRAFIA E ESTATÍSTICA (IBGE). Pesquisa de Orçamentos Familiares 2002-2003: aquisição alimentar domiciliar per capita, Brasil e grandes regiôes. Rio de Janeiro: IBGE, 2004.

JOHNSON, R. K.; SOULTANAKIS, R. P. \& MATTHEWS, D. E. Literacy and body fatness are associated with underreporting of energy intake in US low-income women using the multiple-pass 24-hour recall: a doubly labeled water study. Journal of the American Dietetic Association, 98(10): 1.136-1.140, 1998.

KAAKS, R. \& RIBOLI, E. Validation and calibration of dietary intake measurements in the Epic project: methodological considerations. European Prospective Investigation into Cancer and Nutrition. International 
Journal of Epidemiology, 26, suppl. 1: S15-25, 1997.

KACZKOWSKI, C. H. et al. Four-day multimedia diet records underestimate energy needs in middle-aged and elderly women as determined by doubly-labeled water. Journal of Nutrition, 130(4): 802-805, 2000.

LEVY-COSTA, R. B. et al. Household food availability in Brazil: distribution and trends (1974-2003). Revista de Saúde Pública, 39(4): 530-540, 2005.

LOPES, A. C. S. et al. Ingestão alimentar em estudos epidemiológicos. Revista Brasileira de Epidemiologia, 6(3): 209-219, 2003.

MACINTYRE, U. E.; VENTER, C. S. \& VORSTER, H. H. A culture-sensitive quantitative food frequency questionnaire used in an African population: 1. development and reproducibility. Public Health Nutrition, 4(1): 53-62, 2000.

NELSON, M. The validation of dietary questionnaires. In: MARGETTS, B. M. \& NELSON, M. Design Concepts in Nutritional Epidemiology. 2. ed. Oxford: Oxford University Press, 1997.

NELSON, M.; ATKINSON, M. \& DARBYSHIRE, S. Food photography. I: the perception of food portion size from photographs. British Journal of Nutrition, 72(5): 649-663, 1994.

ROSE, D. \& RICHARDS, R. Food store access and household fruit and vegetable use among participants in the US Food Stamp Program. Public Health Nutrition, 7(8): 1.081-1.088, 2004.

RUTISHAUSER, I. H. E. Dietary intake measurements. Public Health Nutrition, 8(7A): 1.100-1.107, 2005.

SASAKI, S.; HORACSEK, M. \& KESTLOOT, H. An ecological study of the relationship between dietary fata intake and breast cancer mortality. Preventive Medicine, 22(2): 187-202, 1993.

SCHATZKIN, A. et al. A comparison of a food frequency questionnaire with a 24-hour recall for use in an epidemiological cohort study: results from the biomarker-based Observing Protein and Energy Nutrition (Open) study. International Journal of Epidemiology, 32(6): 1.054-1.062, 2003.

SCHRODER, H. et al. Use of a three-day estimated food record, a 72-hour recall and a food-frequency questionnaire for dietary assessment in a Mediterranean Spanish population. Clinical Nutrition, 20(5): 429-437, 2001.

SICHIERI, R. Epidemiologia da Obesidade. Rio de Janeiro: Eduerj, 1998.

SCIENCE WATCH INTERVIEWS. Risks and benefits: Harvard's Walter C. Willett on epidemiology. June, 1995. Disponível em: <www.sciencewatch.com/interviews/walter_c_willett.htm>. Acesso em: 25 jan. 2007.

SLATER, B. et al. Validação de Questionários de Freqüência Alimentar - QFA: considerações metodológicas. Revista Brasileira de Epidemiologia, 6(3): 200-208, 2003.

SOUZA, R. A. G. et al. Reprodutibilidade de questionário de freqüência de consumo de alimentos em mulheres, 2004. (Mimeo.)

SUBAR, A. F. et al. Improving food frequency questionnaires: a qualitative approach using cognitive interviewing. Journal of the American Dietetic Association, 95(7): 781-788, 1995.

SUBAR, A. F. et al. The Food Propensity Questionnaire: concept, development, and validation for use as a covariate in a model to estimate usual food intake. Journal of the American Dietetic Association, 106(10): $1.556-1.563,2006$. 
THE DAFNE - DATA FOOD NETWORKING. Disponível em: <www.nut.uoa.gr/english/dafne/ DafneEN.htm>. Acesso em: 25 jan. 2007.

THOMPSON, F. E. et al. Reproducibility of reports of frequency of food use in the Tecumseh Diet Methodology Study. American Journal of Epidemiology, 125: 658-671, 1987.

TOOZE, J. A. et al. A new statistical method for estimating the usual intake of episodically consumed foods with application to their distribution. Journal of the American Dietetic Association, 106(10): 1.575-1.587, 2006.

TRABULSI, J. \& SCHOELLER, D. A. Evaluation of dietary assessment instruments against doubly labeled water, a biomarker of habitual energy intake. American Journal of Physiology, Endocrinology and Metabolism, 281: E891-E899, 2001.

TRAN, K. M. et al. In-person vs telephone-administered multiple-pass 24-hour recalls in women: validation with doubly labeled water. Journal of the American Dietetic Association, 100(7): 777-783, 2000.

TURCONI, G. et al. An evaluation of a colour food photography atlas as a tool for quantifying food portion size in epidemiological dietary surveys. European Journal of Clinical Nutrition, 59(8): 923-931, 2005.

TURRINI, A. et al. Food consumption patterns in Italy: the INN-CA Study 1994-1996. European Journal of Clinical Nutrition, 55(7): 571-588, 2001.

VAN HORN, L. Assessing dietary intake: new ideas and better approaches. Journal of the American Dietetic Association, 106(10): 1.533, 2006.

WANG, D. H.; KOGASHIWA, M. \& KIRA, S. Development of a new instrument for evaluating individuals' dietary intakes. Journal of the American Dietetic Association, 106(10): 1.588-1.593, 2006.

WANG, D. H. et al. Validity and reliability of a dietary assessment method: the application of a digital camera with a mobile phone card attachment. Journal of Nutritional Science and Vitaminology, 48(6): 498-504, 2002 .

WILLETT, W. Future directions in the development of food-frequency questionnaires. American Journal of Clinical Nutrition, 59, suppl.: 171S-174S, 1994.

WILLETT, W. Nutritional Epidemiology. 2. ed. Oxford: Oxford University Press, 1998.

WILLETT, W. \& BUZZARD, M. Foods and nutrients. In: WILLETT, W. Nutritional Epidemiology. 2. ed. Oxford: Oxford University Press, 1998.

WILLETT, W. \& LENART, E. Reproducibility and validity of food-frequency questionnaire. In: WILLETT, W. Nutritional Epidemiology. 2. ed. Oxford: Oxford University Press, 1998.

YANEK, L. R. et al. Comparison of the effectiveness of a telephone 24-hour dietary recall method vs an inperson method among urban African-American women. Journal of the American Dietetic Association, 100(10): $1.172-1.177,2000$.

YAROCH, A. L. et al. Development of a modified picture-sort food frequency questionnaire administered to low-income, overweight, African-American adolescent girls. Journal of the American Dietetic Association, 100: 1.050-1.056, 2000.

YON, B. A. et al. Use of a personal digital assistant for dietary self-monitoring does not improve the validity of self-reports of energy intake. Journal of the American Dietetic Association, 106(8): 1.256-1.259, 2006. 


\title{
Desenvolvimento, Validação e Aplicações de Questionários de Freqüência Alimentar em Estudos Epidemiológicos
}

\author{
Marly Augusto Cardoso
}

\section{Avaliação da Dieta Habitual em Estudos Epidemiológicos}

O desenvolvimento de métodos práticos, válidos e viáveis para mensurar a dieta individual tem sido descrito como um dos principais desafios da pesquisa em epidemiologia nutricional (González \& Joan, 1997a; Willett, 1998). Informações válidas de consumo de energia e nutrientes são fundamentais para estudos epidemiológicos sobre dieta e Doenças Crônicas Não Transmissíveis (DCNT). Existem vários métodos de avaliação de ingestão alimentar, mas todos apresentam limitações (Thompson \& Byers, 1994).

Inquéritos Recordatórios de 24 horas (IR24h), registros alimentares ou história alimentar podem fornecer uma avaliação acurada da dieta habitual de um indivíduo. Entretanto, esses métodos exigem o envolvimento de grande número de entrevistadores altamente qualificados (geralmente nutricionistas treinados) e disponibilidade de tempo (Willett, 1998). Entre os métodos citados, o IR24h permite ao entrevistador colher um grande número de informações e detalhes sobre o modo de preparo e os ingredientes utilizados em receitas caseiras. Tem como vantagens a alta adesão entre os entrevistados, o baixo custo, além do fato de o entrevistado não precisar ser alfabetizado e de o hábito alimentar não se alterar quando realizado sem prévio agendamento (Slimani et al., 2000).

Em contrapartida, um único IR24h não estima a dieta habitual, pois não considera a variabilidade do consumo alimentar de um dia para outro (intra-indivíduo). A variação intra-indivíduo e entre indivíduos pode também diferir muito entre nutrientes. Para macronutrientes da dieta que apresentam pequena variação no consumo intra-indivíduo, alguns dias de avaliação do consumo alimentar são suficientes para estimar sua ingestão habitual. Já para os micronutrientes da dieta, a variação do consumo intra-indivíduos é muito maior que a variabilidade entre indivíduos, exigindo múltiplos IR24h para se alcançar uma estimativa acurada de seu consumo habitual (Nelson et al., 1989; Liu, 1994).

Questionários de Freqüência Alimentar (QFA) têm sido utilizados em estudos epidemiológicos para verificar a associação entre dieta e DCNT (Day et al., 2001). Entre as vantagens deste método, estão a aplicabilidade em um grande número de indivíduos, o baixo custo e a possibilidade de estimar a ingestão alimentar referente a um longo período - geralmente no último ano ou até mesmo por tempo maior (Ocké et al., 1997; Livingstone \& Black, 2003). No entanto, apesar de sua menor exatidão em relação a outros métodos de avaliação do consumo alimentar, o QFA classifica os indivíduos segundo quartis ou quintis de consumo, permitindo análise de tendência de risco segundo grau de exposição e diferenças entre concentrações extremas de ingestão (p. ex., para 
comparação de risco entre menor e maior quartis ou quintis de consumo alimentar). Neste aspecto em particular, por ser capaz de medir variação de consumo entre indivíduos, o QFA tem sido considerado mais adequado à estimativa de riscos. No entanto, há necessidade de avaliação de acurácia e precisão do QFA na população específica a ser estudada (Willett, 1998; Cade et al., 2002).

\section{Desenvolvimento de Questionários de Freqüência Alimentar}

Em muitas situações, a adaptação de um questionário já utilizado em estudos prévios pode ser uma alternativa para poupar tempo e recursos financeiros. No entanto, alguns aspectos devem ser considerados no processo de adaptação e/ou desenvolvimento de um QFA:

1. Qual a finalidade do QFA?

2. Qual é a população-alvo e qual o tipo de estudo?

3. Caso a validação do QFA já tenha sido realizada anteriormente, seus resultados foram satisfatórios?

As etapas iniciais de desenvolvimento de um QFA incluem seleção dos alimentos de acordo com o padrão dietético da população de estudo e identificação de porçôes alimentares adequadas às quantidades habitualmente consumidas.

A disponibilidade de dados quantitativos de consumo alimentar (registro alimentar de vários dias ou inquéritos de 24 horas) em amostra aleatória de nipo-brasileiros de São Paulo (Cardoso et al., 1997) possibilitou a construção de um QFA segundo metodologia adotada em estudos internacionais (Cardoso \& Stocco, 2000). Os alimentos identificados em registro de consumo alimentar de três dias foram agrupados segundo valor nutricional por porção alimentar e fontes de nutrientes de particular interesse (por exemplo, alimentos e preparações de origem japonesa). O tamanho das porçóes de cada item alimentar foi classificado em pequeno, médio, grande e extragrande, de acordo com a distribuição percentual dos pesos correspondentes às medidas caseiras referida nos registros alimentares. O número de itens alimentares do QFA (129) foi definido com a finalidade de captar o consumo habitual de energia e de vários nutrientes. A freqüência de consumo foi avaliada como variável contínua (exatamente como informado pelo entrevistado), com o objetivo de minimizar o erro de classificação.

A definição da lista de alimentos (quais e quantos itens) pode ser considerada crucial para o sucesso de um QFA. Um determinado alimento ou grupo de alimentos pode ser incluído em um QFA tanto por sua contribuição na ingestão habitual total como também por diferenciar o consumo entre os indivíduos. $\mathrm{O}$ consumo de fígado bovino e outras vísceras, por exemplo, pode não parecer importante, uma vez que, em geral, poucos indivíduos referem seu consumo habitual. No entanto, a presença desse item alimentar em um QFA pode identificar diferenças entre indivíduos no nível de consumo de alguns micronutrientes (vitamina A, entre outros). A variabilidade da dieta de um grupo populacional, que inclui muitos alimentos, diferentes marcas e preparações, não pode ser totalmente captada em uma lista finita de alimentos. Apesar da sobrecarga que um QFA com muitos itens alimentares pode impor ao entrevistado, entre as vantagens de uma lista ampla de alimentos está a possibilidade de avaliar o consumo alimentar ajustado pelas calorias totais da dieta - procedimento necessário para investigaçōes epidemiológicas delineadas para avaliar associação entre fatores dietéticos e risco para determinado desfecho. O número de itens alimentares de um QFA deve ser definido com base no nível de acurácia desejado e nos resultados obtidos na avaliação de validade e reprodutibilidade. 


\section{Estudos de Validação de Questionários de Freqüência Alimentar}

A análise de validade de um QFA pode ser definida pela avaliação do desempenho do instrumento, comparando-se sua estimativa de ingestão alimentar com medidas de métodos independentes considerados 'padrão-ouro'.

Como é impossível conhecer a real ingestão individual de um longo período, a validação absoluta (comparação com o real consumo) não é possível (González \& Joan, 1997a; Kaaks \& Riboli, 1997). Por essa razão, a validação relativa ou validação indireta de um QFA é geralmente realizada pela comparação de estimativas de consumo obtidas por outros métodos considerados 'padrão-ouro'. Tais métodos devem oferecer estimativas mais acuradas que o QFA a ser testado, com fontes de erros sistemáticos diferentes, e se referir ao mesmo período de tempo medido pelo questionário a ser validado (González \& Joan, 1997b). Embora existam atualmente medidas biológicas consideradas acuradas para a estimativa de ingestão habitual de energia, nitrogênio e sódio (Black et al., 1996; Kipnis et al., 2003; Shai et al., 2005), não há um método 'ideal' capaz de medir a dieta habitual como um todo.

Registro alimentar com pesagem de alimentos tem sido considerado o melhor método para estudos de validação de QFA. Apesar de o inquérito recordatório exigir menor participação do entrevistado e não influenciar os hábitos alimentares, suas fontes de erro tendem a apresentar maior correlação com erros do QFA (por exemplo, dependem da memória do entrevistado e de seu conhecimento sobre porção alimentar). Porém, quando o nível de escolaridade e o grau de motivação do entrevistado não permitirem o uso de registros alimentares, o IR24h tem sido considerado o método de escolha 'padrão-ouro' (Biró et al., 2002).

No Brasil, alguns estudos de validação de QFA foram realizados em população adulta e em adolescentes (Tabela 1, página seguinte). A avaliação do grau de acurácia aceitável de um QFA depende em grande parte da finalidade do questionário, o que dificulta a interpretação dos resultados de diferentes estudos de validação. Estimativas mais acuradas do consumo alimentar podem ser necessárias em investigaçôes com poucos indivíduos ou com propósito de vigilância e monitoramento. Para estudos de associação entre exposição dietética e um desfecho de interesse (risco de adoecer ou morrer, por exemplo), coeficientes de correlação menores que 0,3 ou 0,4 são inadequados para a detecção de associações (Cade et al., 2002). Recentemente, foram publicados alguns resultados de estudos brasileiros sobre consumo alimentar com QFA validado em relação ao risco para distúrbios da homeostase glicêmica e síndrome metabólica (Freire et al., 2005; Sartorelli et al., 2005a), sugerindo acurácia aceitável de nossos questionários para estimativa de riscos em estudos epidemiológicos. Contudo, o desempenho de nossos questionários é ainda inadequado para a avaliação de alguns nutrientes, particularmente para a estimativa de sódio, recomendando-se o uso de medidas biológicas (como excreção urinária de sódio de pelo menos 48 horas), consideradas acuradas para a estimativa de ingestão habitual desse elemento (Shai et al., 2005).

Nem todos os estudos de validação brasileiros têm incluído análise de reprodutibilidade do QFA. Em geral, esta avaliação deve ser realizada pela administração do questionário em dois momentos nos mesmos indivíduos, obtendo-se coeficientes de correlação para avaliar associação (mais utilizado) ou testes de concordância (como, por exemplo, Bland-Altman) entre as duas respostas (Cade et al., 2002). Quando coeficientes de correlação são utilizados, correlações maiores $(0,5$ a 0,7$)$ entre duas respostas têm sido observadas para intervalos de 15 dias a um mês. Quando intervalos maiores entre as duas respostas são utilizados para avaliação de reprodutibilidade do QFA, mudanças reais nos hábitos alimentares podem influenciar a variação nas respostas, comprometendo a avaliação de confiabilidade do QFA (Willett, 1998). 
Tabela 1 - Características de estudos de validação de questionários de freqüência alimentar realizados no Brasil

\begin{tabular}{|c|c|c|c|c|c|}
\hline & $\begin{array}{c}\text { Sichieri \& } \\
\text { Everhart, } 1998\end{array}$ & Cardoso et al., 2001 & $\begin{array}{c}\text { Salvo \& } \\
\text { Gimeno,2002 }\end{array}$ & Slater et al.,2003 & $\begin{array}{c}\text { Fornés, Stringhini \& } \\
\text { Elias, } 2003\end{array}$ \\
\hline N & 88 & 52 & 146 & 79 & 104 \\
\hline Grupo etário & Adultos & $21-62$ anos & $18-60$ anos & 14-18 anos & $18-60$ anos \\
\hline Sexo feminino $(\%)$ & 52,3 & 100 & 54,8 & 50,6 & 59,6 \\
\hline Escolaridade & Básico e Superior & Superior & Superior & Médio & Básico/médio \\
\hline Itens alimentares & 73 & 129 & 90 & 76 & 127 \\
\hline Período de referência & 1 ano & 1 ano & 1 mês & 6 meses & 6 meses \\
\hline Método de validação & 2 IR48h & 4 REG de 3 dias & $3 \mathbb{R} 24 h$ & 3 IR24h & $6 \mathrm{IR} 24 \mathrm{~h}$ \\
\hline $\begin{array}{l}\text { Intervalo entre as } \\
\text { entrevistas }\end{array}$ & 2 semanas & 3 meses & 15 dias & 45 dias & 1 mês \\
\hline $\begin{array}{l}\text { Variação do coeficiente } \\
\text { de correlação* }\end{array}$ & $0,18-0,55$ & $0,27-0,81$ & $0,01-0,21$ & $0,10-0,67$ & $0,25-0,76$ \\
\hline
\end{tabular}

$\mathbb{R}$ - Inquérito por técnica recordatória.

REG - Inquérito por técnica de registro do consumo alimentar.

*Coeficientes para correlação com valores de consumo alimentar ajustados pelas calorias totais e corrigidos pela variação intra-individual.

\section{Uso de Biomarcadores em Epidemiologia Nutricional}

Mais recentemente, marcadores bioquímicos têm sido utilizados em estudos de validação de métodos de avaliação de consumo alimentar (Mayne, 2003; Freedman et al., 2004). A principal vantagem é que os erros medidos pelos marcadores bioquímicos não têm relação com os erros medidos nos questionários alimentares. Portanto, correlação entre a ingestão alimentar e marcador bioquímico oferece inquestionável evidência de validação (Willett, 1998).

Alguns indicadores bioquímicos podem ser utilizados para a validação de um QFA, oferecendo boa correlação com a real ingestão alimentar, com medidas objetivas e sem viés por parte do entrevistado ou do entrevistador. Entretanto, estão também sujeitos a três fontes de erro: 1) Diferença entre a avaliação da dieta e a real ingestão; 2) Efeito da digestão, absorção, captação, utilização, metabolismo, excreção e mecanismos homeostáticos, influenciando a relação entre quantidade ingerida e a medida bioquímica; 3) Erro associado ao próprio ensaio bioquímico. Portanto, biomarcadores e avaliação da dieta não medem exatamente a mesma coisa. Os erros para medidas bioquímicas são independentes dos erros associados ao QFA (Hunter, 1998; Cade et al., 2002; Shai et al., 2005).

Existem várias abordagens para medidas de indicadores bioquímicos: a) medida direta da concentração do nutriente ou seu produto metabólico em um tecido ou fluido; b) análise funcional de atividade de enzimas específicas ou produtos derivados do nutriente relacionado com a ingestão alimentar. Neste caso, deve-se verificar se a medida encontrada é referente às reservas orgânicas do nutriente analisado que estão sendo utilizadas para manter constantes suas concentraçóes sangüíneas ou se reflete o consumo alimentar habitual e/ou recente. Esta abordagem mede preferencialmente a adequação da ingestão, já que a enzima ou o produto final derivado do nutriente em questão pode sofrer influência de diversos fatores; c) concentração de nutrientes no sangue ou urina pouco antes e em intervalos após administração de uma dose conhecida do nutriente a ser validado. Pessoas com 
deficiência do nutriente a ser testado retêm maior quantidade. $\mathrm{O}$ uso desta última abordagem em estudos epidemiológicos é limitado (Hunter, 1998).

Concentrações plasmáticas de retinol, betacaroteno e alfa-tocoferol são sensíveis à ingestão alimentar atual (Tangney et al., 1987; Stahelin et al., 1991) e têm sido sugeridos como marcadores bioquímicos de exposição a nutrientes antioxidantes (Mayne, 2003), apresentando boa correlação com consumo alimentar de frutas e vegetais (Block et al., 2001; Al-Delaimy et al., 2005). O alfa-tocoferol é transportado no sangue como parte do complexo de lipoproteína, principalmente em associação com LDL-colesterol (lipoproteína de baixa densidade). A concentração sérica de vitamina $\mathrm{E}$ apresenta boa correlação com colesterol sérico e lipídeos totais. Aparentemente, uma única medida de alfa-tocoferol no plasma, ajustado para lipídeos sangüíneos, é capaz de representar a ingestão habitual de vitamina $\mathrm{E}$ (Hunter, 1998).

Muitos biomarcadores têm sido utilizados em pesquisa clínica e epidemiológica para avaliar a adequação dietética ou o estado nutricional de um nutriente em indivíduos e populações. Exemplos típicos incluem a albumina sérica para avaliação de proteínas viscerais e ferritina sérica como indicador de reservas orgânicas de ferro. A utilidade de um biomarcador baseia-se nos determinantes fisiológicos da medida. A concentração de muitos nutrientes e biomarcadores no pool circulante é homeostaticamente regulada (cálcio sérico, por exemplo) ou pode ser fracamente relacionada ao consumo alimentar devido a produção endógena (colesterol sérico, por exemplo).

Identificação e conhecimento de fontes de erro são alguns dos desafios para pesquisa em nutrição. Não se conhece biomarcador para ingestão total de gordura, e muitos biomarcadores (betacaroteno para consumo total de frutas e vegetais, por exemplo) não estão na mesma escala de medida para os alimentos ou nutrientes avaliados e, por isso, são de pouca utilidade na avaliação de viés. Outros biomarcadores não são práticos para estudos de larga escala.

Contudo, pode-se descrever pelo menos três razões para o uso de biomarcadores nutricionais (Potischman, 2003): 1) Menor ocorrência de erros, quando comparados aos métodos de avaliação de consumo alimentar; 2) Para alguns nutrientes, dados dietéticos são inadequados devido a limitações nos dados de composição alimen$\operatorname{tar}$ (por exemplo: selênio e vitamina E), ao passo que biomarcadores do estado nutricional relativo a tais nutrientes são dispoconcentraçôes; 3) Muitos biomarcadores fornecem uma medida mais próxima do estado nutricional para alguns nutrientes do que os dados de ingestão dietética, particularmente em estudos cujo desfecho de interesse possa alterar o hábito ou a informação sobre o consumo alimentar.

Método para ajuste do consumo alimentar estimado por inquéritos de 24 horas em estudos de validação de um QFA foi recentemente proposto, utilizando-se a razão entre o indicador bioquímico e o respectivo nutriente avaliado pelo IR24h (McNaughton et al., 2005). O método foi originalmente descrito por Ocké e Kaaks (1997) como medida de validade de QFA com biomarcadores. Para determinação do coeficiente de validade da medida de um QFA, pelo menos duas medidas adicionais da dieta seriam necessárias, por exemplo, biomarcadores e inquérito de consumo alimentar de 24 horas (IR24h). Esta abordagem tem sido denominada de "método das tríades" (method of triad, em inglês), que emprega análise de correlação entre cada um dos três métodos para calcular o coeficiente de validade. A seguinte equação é utilizada para estimar o coeficiente de validação do QFA:

$$
\rho_{Q F A}=\sqrt{ } R_{Q B} * R_{Q R} / R_{B R}
$$

Onde: $\rho_{Q F A}$ é o coeficiente de validação para o QFA; $R_{Q B}$ a correlação entre QFA e o biomarcador; $R_{Q R}$ a correlação entre $Q F A$ e IR24h e $R_{B R}$ a correlação entre biomarcador e IR24h. 
Este método assume que as correlações entre as três medidas são explicadas pelo fato de estarem estas medidas linearmente correlacionadas com a ingestão verdadeira e de seus erros serem independentes. Dessa forma, o coeficiente de correlação entre o QFA e o IR24h será superestimado. Assim, recomenda-se que o valor calculado pelo método das tríades seja utilizado como limite superior do coeficiente de validação verdadeiro, ou seja, $\rho_{\text {QFA(verdadeiro) }}<\rho_{\text {QFA(tríade) }}$ e um intervalo para o coeficiente pode ser definido pelo uso da correlação entre a medida do questionário e a medida do biomarcador como uma estimativa do limite inferior do coeficiente de validade, ou seja, $\mathrm{R}_{\mathrm{QB}}<\rho_{\mathrm{QFA}(\text { (verdadeiro) }}<\rho_{\mathrm{QFA}(\text { tríade }}$ (Ocké \& Kaaks, 1997). Embora este método tenha sido proposto há cerca de dez anos, até recentemente poucos estudos de validação de QFA têm utilizado inquéritos de 24 horas e também indicadores bioquímicos (Freedman et al., 2004; McNaughton et al., 2005).

\section{Seleção e Tamanho Amostral da População em Estudos de Validação}

Em estudos epidemiológicos, a avaliação da acurácia de instrumentos de consumo alimentar pode ser realizada em subamostra representativa da população do estudo principal (Willett, 1998). Estudos de validação, nos quais um QFA é comparado a vários IR24h e marcadores bioquímicos, vêm sendo realizados dentro de grandes estudos prospectivos conduzidos em países desenvolvidos (Kaaks \& Riboli, 1997; Willett, 1998). Grupo etário, gênero, nível socioeconômico, escolaridade, raça/etnia e perfil de saúde da população podem afetar os resultados do estudo de validação (Marks, Hughes \& Van der Pols, 2006). Por essa razão, a população do estudo de validação deve apresentar características similares às da população do estudo principal.

O tamanho amostral necessário para estudos de validação de QFA dependerá do método estatístico a ser utilizado na avaliação de reprodutibilidade e validade. Cade e colaboradores (2002), em artigo de revisão sobre validação de QFA, observaram que muitos estudos utilizaram de seis a 3.750 indivíduos com mediana de 110 participantes. Nesse mesmo artigo, os autores recomendam um tamanho amostral de pelo menos cinqüenta indivíduos, e preferencialmente muito maior (cem ou mais), caso a análise estatística empregue método de BlandAltman. Em contrapartida, quando se utilizam coeficientes de correlação, o tamanho amostral dependerá da magnitude esperada para a associação entre duas medidas ou métodos.

Com base no coeficiente de correlação, assumindo-se um número suficiente de dias de informação dietética para caracterizar a dieta habitual (no mínimo dois dias para medida de variabilidade intrapessoal), um tamanho amostral entre cem e duzentos indivíduos seria suficiente. Essa estimativa é compatível com o cálculo do número de indivíduos proposto por Walter Willett (1998): para estudo de validação do QFA com inquéritos de 24 horas ou mesmo registros alimentares, recomenda-se um coeficiente de correlação mínimo de 0,4 entre QFA e o método de referência. $\mathrm{O}$ número de participantes necessário para detectar diferença nesse valor de correlação pode ser estimado com base na seguinte fórmula-padrão para tamanho amostral com transformação de coeficientes de correlação Z de Fisher:

$$
N=[(Z \alpha+Z \beta) / C]^{2}+3
$$

Onde: $N=$ total de indivíduos necessários; $Z \alpha=$ desvio-padrão para $\alpha ; Z \beta=$ desvio-padrão para $\beta ; C=0,5 \times \ln [(1+r) /(1-r)]$, sendo $\mathrm{r}=$ coeficiente de correlação esperado e $\ln =$ logaritmo natural.

Em estudos biológicos em geral, considera-se para cálculo de tamanho amostral um $\alpha$ de $5 \%$ e poder do teste $(1-\beta)$ de 80 a $90 \%$. Um poder de $80 \%$, por exemplo, significa que, se houver uma diferença de magnitude considerada no cálculo, temos $80 \%$ de chance de detectá-la. Para aplicação prática dessa fórmula, pode-se consultar 
a Tabela 2. Como exemplo, com nível de significância $(\alpha)$ bicaudal $=0,05, \mathrm{~b}=0,05$ (portanto, poder de 95\%) e coeficiente de correlação esperado de 0,35 , o número de indivíduos necessário para um estudo de validação de QFA que utilize análise de correlação seria de cem.

Tabela 2 - Tamanho amostral necessário para estudos de validação que utilizem coeficiente de correlação na análise estatística

\begin{tabular}{lllllll}
\hline$R^{*}$ & $\alpha$ bicaudal $=$ & 0,01 & & 0,05 & & \\
\hline 0,20 & 0,05 & 0,10 & 0,20 & 0,05 & 0,10 & 0,20 \\
\hline 0,25 & 436 & 365 & 287 & 319 & 259 & 194 \\
\hline 0,30 & 276 & 231 & 182 & 202 & 164 & 123 \\
\hline 0,35 & 189 & 158 & 125 & 139 & 113 & 85 \\
\hline 0,40 & 136 & 114 & 90 & 100 & 82 & 62 \\
\hline 0,45 & 102 & 86 & 68 & 75 & 62 & 47 \\
\hline 0,50 & 79 & 66 & 53 & 58 & 48 & 36 \\
\hline 0,60 & 62 & 52 & 42 & 46 & 38 & 29 \\
\hline 0,70 & 40 & 34 & 27 & 30 & 25 & 19 \\
\hline 0,80 & 27 & 23 & 19 & 20 & 17 & 13 \\
\hline
\end{tabular}

* Para estimar o tamanho amostral, siga a linha correspondente ao valor do coeficiente de correlação esperado (R), conforme valores de $\alpha$ (nível de significância estatística) e $\beta$ (probabilidade de aceitarmos hipótese nula sendo ela falsa).

Fonte: adaptada de Browner et al. (2001).

\section{Algumas Considerações Sobre a Análise Estatística de Estudos de Validação}

O método estatístico mais freqüentemente utilizado em estudos de reprodutibilidade e validade de QFA é a análise de correlação. Porém, para avaliação de reprodutibilidade, a análise de correlação não avalia concordância entre duas respostas em momentos diferentes, permitindo analisar somente o quanto essas respostas estão relacionadas. Uma vez que em estudos de reprodutibilidade se utiliza o mesmo questionário nas mesmas pessoas, é de se esperar que suas respostas sejam altamente relacionadas - mas isto não significa concordância (Bland \& Altman, 1995).

Outra limitação da análise de correlação em estudos de reprodutibilidade está no fato de que a força da correlação depende do intervalo de variação dos valores na população (que pode ser parcialmente influenciado pelo tamanho da amostra) e das características dos participantes do estudo. Quando se utiliza correlação, coeficientes de correlação de Pearson devem ser empregados em dados com distribuição normal e coeficientes de correlação de Spearman devem ser utilizados para dados que não tenham distribuição normal. Devido ao uso freqüente da correlação para avaliar reprodutibilidade de QFA, recomenda-se que seu uso seja acoplado à análise adicional de algum outro método estatístico mais adequado (Cade et al., 2002). A análise mais recomendada atualmente é o método de Bland e Altman (1999), que pode avaliar concordância entre instrumentos através de intervalos de consumo. Esse método pode determinar se há alguma diferença sistemática (viés) e qual o grau de concordância entre as duas aplicações do questionário (limites de concordância). Isso permite avaliar se a diferença entre os questionários é a mesma através dos valores de consumo e se o grau de concordância difere para níveis de consumo menores quando 
comparados aos níveis de ingestão maiores. A diferença média geral indica se um questionário tende a super ou subestimar o consumo, informando os limites de concordância (diferença média \pm 2 desvios-padrão).

Já na validação de um QFA, análises de correlação e regressão são particularmente úteis, uma vez que a investigação da associação entre diferentes métodos pode ser informativa. Coeficientes de correlação são mais comumente empregados em estudos de validação de QFA. Análise de regressão, por sua vez, é particularmente útil na calibração de um método quando comparado com outro, por exemplo, quando se comparam estimativas de consumo alimentar obtidas em um QFA com biomarcadores. Um aspecto importante é que o grau de validação 'aceitável' varia de acordo com os propósitos de um QFA. Recomendações mais recentes para estudos de validação de QFA consideram que valores baixos de correlação, por exemplo 0,3 ou 0,4, ainda que possam ser estatisticamente significativos, podem atenuar sensivelmente a estimativa do consumo verdadeiro a ponto de impossibilitar a detecção de associação em estudos sobre dieta e risco para um determinado desfecho (Cade et al., 2002).

\section{Aplicações do QFA em Estudos Epidemiológicos}

Questionários de freqüência alimentar vêm sendo desenvolvidos e utilizados em diferentes situações e tipos de estudos dietéticos. Antes de selecionar ou desenvolver um QFA, o propósito de seu uso deve ser claramente definido. Este método pode ser inadequado em situaçôes que exijam estimativa de consumo absoluto mais acurada, como, por exemplo, em estudos com poucos indivíduos e/ou para fins de vigilância e monitoramento de consumo atual.

Estudos epidemiológicos do tipo transversal sobre fatores associados à ocorrência de doenças necessitam interpretação cautelosa, pois não permitem identificar a seqüência temporal entre exposições e desfechos de interesse. Estudos de coorte prospectivos, por sua vez, são essenciais para a investigação de determinantes de morbidade e estado nutricional. Em estudos de coorte ou de intervenção, a análise de correlação entre diferenças no consumo alimentar e as alteraçōes bioquímicas tem sido indicada como método para se avaliar a acurácia de um QFA, uma vez que as diferenças de pelo menos duas dosagens sangüíneas podem atenuar a variabilidade individual de alguns indicadores bioquímicos, melhorando sua correlação com fatores dietéticos (Willett, 1998).

No Brasil, até o momento, alguns resultados da utilização de QFA em estudos prospectivos já foram publicados. Utilizando-se dados disponíveis na coorte de nipo-brasileiros de Bauru, uma análise sobre a evolução do padrão alimentar e sua correlação com mudanças no perfil de lipídeos séricos foi recentemente publicada (Castro et al., 2006). Informações sobre dieta e perfil de lipídeos séricos foram obtidas em dois inquéritos realizados em intervalo de sete anos (em 1993 e em 2000). Nos dois inquéritos, a avaliação da dieta considerou o consumo habitual de alimentos e bebidas relativo ao período de um ano anterior ao momento da entrevista alimentar. A lista de alimentos e a freqüência de consumo utilizados no QFA de 1993 se mantiveram em 2000. Após sete anos de seguimento da população nipo-brasileira de Bauru (período 1993-2000), observou-se redução do consumo alimentar de carnes vermelhas e aves, aumento do consumo de laticínios em geral (embora ainda abaixo das recomendações nutricionais), frutas e sucos de frutas. Observou-se também que o consumo de fibras da dieta (naturalmente presentes nas verduras, legumes e frutas) foi inversamente correlacionado às concentraçōes de colesterol sérico dessa população. Coeficientes de correlação de Pearson foram calculados entre as diferenças do consumo alimentar (brutas e ajustadas pelas calorias totais) e as diferenças dos valores de lipídeos séricos no intervalo de sete anos. Em geral, os coeficientes de correlação entre as diferenças de consumo alimentar e as diferenças nos lipídeos séricos foram baixos, observando-se valores significativos maiores para correlação entre a diferença no consumo bruto de carnes vermelhas e as diferenças do colesterol total e LDL colesterol $(r=0,254$ e $r=0,272$, respectivamente). No entanto, em modelos de regressão linear múltiplos, houve correlação inversa entre a diferença no colesterol sérico total e a diferença no consumo total de fibras $\left(\beta_{1}=-1,250\right.$; IC95\% - 2,061 a - 0,437), frutas e sucos de frutas $\left(\beta_{1}=-0,019\right.$; IC95\% - 0,033 a - 0,053) e vegetais $\left(\beta_{1}=-0,037\right.$; IC95\% - 0,075 a - 0,0003). 
O QFA pode também ser utilizado para detectar mudanças na dieta em resposta a algum tipo de intervenção. Com o propósito de delinear estudos de intervenção em unidades básicas de saúde, uma versão reduzida do mesmo QFA desenvolvido e validado para a comunidade nipo-brasileira foi adaptada e testada em adultos de diferente raça/ etnia. Os itens alimentares de origem japonesa foram retirados do questionário original. A lista de alimentos e o tamanho das porções alimentares foram reavaliados com base em IR24h conduzido entre 212 funcionários da Secretaria de Estado da Saúde (Ribeiro \& Cardoso, 2002). Essa versão do QFA (com 76 itens alimentares) foi então utilizada em ensaio clínico para avaliar o impacto de intervenção nutricional intensiva para mudança de estilo de vida em indivíduos com sobrepeso em Centro de Saúde-Escola em São José do Rio Preto, São Paulo (Sartorelli et al., 2005b). O programa de intervenção mostrou-se efetivo na redução do consumo de calorias, gorduras totais, gorduras saturadas, colesterol, óleos/gorduras e doces. Houve um incremento no consumo de fibra total da dieta, fibra de frutas e vegetais. Essas alterações dietéticas estimadas pelo QFA foram acompanhadas de redução no peso corporal, na pressão arterial e nas concentrações séricas de colesterol total e LDL colesterol.

Embora a versão reduzida do QFA tenha-se mostrado capaz de detectar alterações em parâmetros antropométricos e bioquímicos em estudo de intervenção nutricional, nova avaliação de acurácia e confiabilidade do QFA em população com diferente perfil socioeconômico e nível de escolaridade foi realizada em amostra aleatória de mulheres de baixa renda participantes de um estudo de casos e controles de base hospitalar. No total, foram obtidos três IR24h, conduzidos por telefone, e dois QFA (QFA1 e QFA2) para avaliação de reprodutibilidade. Ao final, 145 participantes responderam ao primeiro IR24h (34,12\% do total contatado). O segundo IR24h foi obtido aproximadamente seis meses após o primeiro IR24h $(\mathrm{n}=119)$. O terceiro IR24h foi obtido aproximadamente seis meses após o segundo IR24h, contando 94 das 119 participantes (65,5\% das participantes iniciais). Juntamente com o terceiro IR24h, foi aplicado o segundo QFA (QFA2), também por telefone. Coeficientes de correlação entre o QFA e a média de consumo alimentar obtida nos IR24h variaram de 0,18 (potássio) a 0,75 (cálcio) (Cardoso et al., 2006).

A Figura 1 apresenta uma sugestão de desenho de estudo de validação de QFA baseada em estudos brasileiros em andamento.

Figura 1 - Delineamento de estudo de validação e reprodutibilidade de um Questionário de Freqüência Alimentar (QFA)
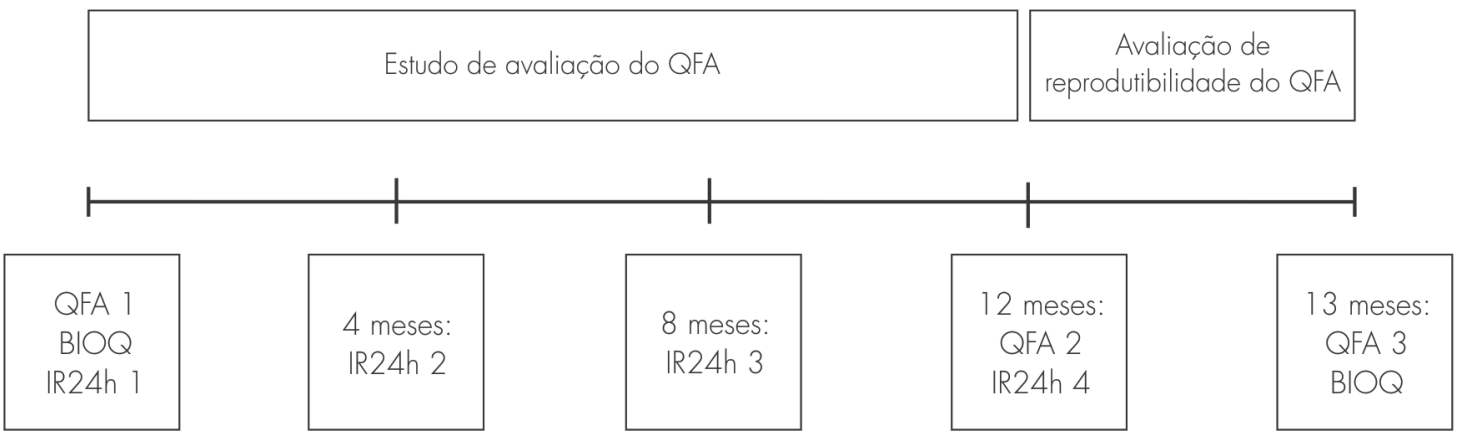

Neste exemplo, o período de referência para avaliação da dieta habitual é de um ano. No total, quatro IR24h (ou registro alimentar, dependendo das características da população de estudo) seriam obtidos ao longo de 12 meses, registrando-se eventuais variaçōes sazonais no padrão alimentar. Coleta de amostras sangüíneas para avaliação de alguns indicadores bioquímicos (BIOQ) pode ser de grande utilidade na validação do QFA para alguns micronutrientes. A reprodutibilidade do QFA pode ser avaliada logo no início ou no final do estudo. 


\section{Considerações Finais}

Informações válidas de consumo alimentar são fundamentais em epidemiologia nutricional. A escolha de método adequado à avaliação da dieta é uma decisão complexa, baseada nos objetivos da coleta de dados, no grau de acurácia desejado e nos recursos disponíveis. Questionários de Freqüência Alimentar (QFA) têm sido desenvolvidos para a estimativa de dados quantitativos da dieta habitual. Sua principal vantagem está relacionada à menor sobrecarga para o participante da pesquisa, à fácil utilização e ao baixo custo para análise quando comparados a outros métodos de avaliação da dieta. A validação de métodos de avaliação do consumo alimentar é demorada e de difícil realização, porém absolutamente necessária para o sucesso de estudos epidemiológicos.

Atualmente, muitos questionários para avaliação da dieta habitual estão sendo utilizados em uma grande variedade de investigaçōes no mundo inteiro. Considerando-se que o objetivo principal da epidemiologia nutricional é fornecer evidências científicas para a compreensão do papel da nutrição na causalidade e prevenção de doenças, a avaliação do efeito da exposição dietética por meio de técnicas e métodos adequados é fundamental para a interpretação de estudos epidemiológicos e formulação de novas hipóteses de investigação.

\section{Referências}

AL-DELAIMY, W. K. et al. Plasma carotenoids as biomarkers of intake of fruits and vegetables: individual-level correlations in the European Prospective Investigation into Cancer and Nutrition (Epic). European Journal of Clinical Nutrition, 59: 1-10, 2005.

BIRÓ, G. et al. Selection of methodology to assess food intake. European Journal of Clinical Nutrition, 56, suppl. 2: S25-S32, 2002.

BLAND, J. M. \& ALTMAN, D. G. Comparing methods of measurement: why plotting difference against standard method is misleading. The Lancet, 345: 1085-1087, 1995.

BLAND, J. M. \& ALTMAN, D. G. Measuring agreement in method comparison studies. Statistical Methods in Medical Research, 8: 135-160, 1999.

BLACK, A. E. et al. Human energy expenditure in affluent societies: an analysis of 574 doubly-labelled water measurements. European Journal of Clinical Nutrition, 50: 72-92, 1996.

BLOCK, G. et al. Which plasma antioxidants are most related to fruit and vegetable consumption? American Journal of Epidemiology, 154: 1.113-1.118, 2001.

BROWNER, W. S. et al. Estimating sample size and power: the nitty-gritty. In: HULLEY, S. B. et al. Designing Clinical Research. 2. ed. Philadelphia: Lippincott Williams \& Wilkins; 2001.

CADE, J. et al. Development, validation and utilisation of food-frequency questionnaires: a review. Public Health Nutrition, 5: 567-587, 2002.

CARDOSO, M. A. \& STOCCO, P. R. Desenvolvimento de um questionário quantitativo de freqüência alimentar em imigrantes japoneses e seus descendentes residentes em São Paulo, Brasil. Cadernos de Saúde Pública, 16: 107-114, 2000.

CARDOSO, M. A. et al. Dietary patterns in Japanese migrants to southeastern Brazil and their descendants. Journal of Epidemiology, 7: 198-204, 1997. 
CARDOSO, M. A. et al. Reproducibility and validity of a food frequency questionnaire among women of Japanese ancestry living in Brazil. Nutrition Research, 21: 725-733, 2001.

CARDOSO, M. A. et al. Evaluation of a food frequency questionnaire with multiple-day recalls and biomarkers among low-income women in São Paulo, Brazil. In: INTERNATIONAL CONFERENCE ON DIETARY ASSESSMENT METHODS, SIXTH, 2006, Copenhagen. Program \& Abstracts. Copenhagen: Diet Research Foundation, 2006.

CASTRO, T. G. et al. Association of dietary fiber with temporal changes in serum cholesterol in JapaneseBrazilians. Journal of Nutritional Science and Vitaminology, 52: 205-210, 2006.

DAY, N. E. et al. Epidemiological assessment of diet: a comparison of a 7-day dairy with a food frequency questionnaire using urinary markers os nitrogen, potassium and sodium. International Journal of Epidemiology, 30: 309-317, 2001.

FORNÉS, N. S.; STRINGHINI, M. L. F. \& ELIAS, B. M. Reproducibility and validity of a food-frequency questionnaire for use among low-income Brazilian workers. Public Health Nutrition, 6: 821-827, 2003.

FREEDMAN, L. S. et al. Adjustments to improve the estimation of usual dietary intake distributions in the population. Journal of Nutrition, 134: 1.836-1.843, 2004.

FREIRE, R. D. et al. Dietary fat is associated with metabolic syndrome in Japanese-Brazilians. Diabetes Care, 28: 1.779-1.785, 2005.

GONZALÉZ, C. A. \& JOAN, J. Relative validity and reprodutibility of a diet history questionnaire in Spain. I. Foods. International Journal of Epidemiology, 26, suppl. 1: S91-S99, 1997a.

GONZALÉZ, C. A. \& JOAN, J. Relative validity and reprodutibility of a diet history questionnaire in Spain. III. Biochemical Markers. International Journal of Epidemiology, 26, suppl. 1: S110-S117, 1997b.

HUNTER, D. Biochemical indicators of dietary intake. In: WILLETT, W. C. Nutritional Epidemiology. 2. ed. New York: Oxford University Press, 1998.

KAAKS, R. \& RIBOLI, E. Validation and calibration of dietary intake measurements in the Epic Project: metodologycal consideration. International Journal of Epidemiology, 26, suppl. 1: S15-S25, 1997.

KIPNIS, V. et al. Structure of dietary measurement error: results of the Open Biomarker study. American Journal of Epidemiology, 158: 14-21, 2003.

LIU, K. Statistical issues related to semiquantitative food-frequency questionnaires. American Journal of Clinical Nutrition, 59, suppl. 1: 262S-265S, 1994.

LIVINGSTONE, B. E. M. \& BLACK, A. E. Markers of the validity of reported energy intake. Journal of Nutrition, 133: 895S-920S, 2003.

MARKS, G. C.; HUGHES, M. C. \& VAN DER POLS, J. C. Relative validity of food intake estimates using a FFQ is associated with sex, age, and other personal characteristics. Journal of Nutrition, 136: 459-465, 2006.

MAYNE, S. T. Antioxidant nutrients and chronic disease: use of biomarkers of exposure and oxidative stress status in epidemiologic research. Journal of Nutrition, 133: 933S-940S, 2003.

MCNAUGHTON, A. S. et al. Validation of a food-frequency questionnaire assessment of carotenoid and vitamin E intake using weighed food records and plasma biomarkers: the method of triads model. European Journal of Clinical Nutrition, 59: 211-218, 2005. 
NELSON, M. et al. Between- and within-subject variation in nutrient intake from infancy to old age: estimating the number of days required to rank dietary intakes with desired precision. American Journal of Clinical Nutrition, 50: 155-167, 1989.

OCKÉ, M. C. \& KAAKS, R. J. Biochemical markers as additional measurements in dietary validity studies: application of the method of triads with examples from the European Prospective Investigation into Cancer and Nutrition. American Journal of Clinical Nutrition, 65(4), suppl.: 1.240S-1.245S, 1997.

OCKÉ, M. C. et al. The Dutch Epic Food Frequency Questionnaire. I. Description of the questionnaire, and relative validity and reprodutibility for food groups. International Journal of Epidemiology, 26, suppl. 1: S37-S48, 1997.

POTISCHMAN, N. Biologic and methodologic issues for nutritional biomarkers. Journal of Nutrition, 133, suppl. 1: 875S-880S, 2003.

RIBEIRO, A. B. \& CARDOSO, M. A. Construção de um questionário de freqüência alimentar como subsídio para programas de prevenção de doenças crônicas não-transmissíveis. Revista de Nutrição, 15: 239-245, 2002.

SALVO, V. L. M. A. \& GIMENO, S. G. A. Reprodutibilidade e validade do questionário de freqüência de consumo alimentar. Revista de Saúde Pública, 36: 505-512, 2002.

SARTORELLI, D. S. et al. Dietary fiber and glucose tolerance in Japanese-Brazilians. Diabetes Care, 28: 2.2402.242, 2005a.

SARTORELLI, D. S. et al. Beneficial effects of short-term nutritional counselling at the primary health-care level among Brazilian adults. Public Health Nutrition, 8: 820-825, 2005 b.

SHAI, I. et al. Dietary evaluation and attenuation of relative risk: multiple comparisons between blood and urinary biomarkers, food frequency, and 24-hour recall questionnaires: the DEARR Study. Journal of Nutrition, 135: 573-579, 2005.

SICHIERI, R. \& EVERHART, J. E. Validity of a Brazilian food frequency questionnaire against dietary recalls and estimates energy intake. Nutrition Research, 18: 1.649-1.659, 1998.

SLATER, B. et al. Validation of a semi-quantitative adolescent food frequency questionnaire applied at a public school in São Paulo, Brazil. European Journal of Clinical Nutrition, 57: 629-635, 2003.

SLIMANI, N. et al. Standardization of the 24-hour diet recall calibration method used in the European Prospective Investigation into Cancer and Nutrition (Epic): general concepts and preliminary results. European Journal of Clinical Nutrition, 54: 900-914, 2000.

STAHELIN, H. B. et al. Beta-carotene and cancer prevention: the Basel Study. American Journal of Clinical Nutrition, 53: 265S-269S, 1991.

TANGNEY, C. C. et al. Intra- and inter-individual variation in measurements of beta-carotene, retinol and tocopherol in diet and plasma. American Journal of Clinical Nutrition, 45: 764-769, 1987.

THOMPSON, F. E. \& BYERS, T. Dietary assessment resource manual. Journal of Nutrition, 124: 2.245S2.317S, 1994.

WILLETT, W. C. Nutritional Epidemiology. 2. ed. New York: Oxford University Press, 1998. 


\title{
Padrōes Alimentares: análise de componentes principais
}

\author{
Maria Teresa Anselmo Olinto
}

$\mathrm{O}$

perfil de morbidade e mortalidade da população brasileira tem passado por transformações que podem ser atribuídas às transições demográfica, nutricional e epidemiológica. A transição demográfica tem se caracterizado pelo aumento da proporção de pessoas com mais de 60 anos na estrutura populacional. A transição nutricional pode ser detectada pela elevação da prevalência de indivíduos apresentando sobrepeso e obesidade, com todas as suas consequiências sobre o perfil de morbi-mortalidade. Já a transição epidemiológica destaca-se nesse quadro pela redução relativa de óbitos por doenças infecciosas e pelo aumento das mortes por Doenças Crônicas Não Transmissíveis (DCNT) - doenças cardiovasculares, neoplasias, diabetes mellitus e doenças respiratórias crônicas. Assim, estudos epidemiológicos têm sido realizados para identificar fatores etiológicos que possam reduzir ou atenuar a carga produzida pelo envelhecimento da população, pelas alterações nutricionais e pela presença de DCNT. Entre os principais fatores de risco modificáveis, estão os padrôes alimentares.

Padrão alimentar pode ser definido como "o conjunto ou grupos de alimentos consumidos por uma dada população" (Garcia, 1999: 17). Na epidemiologia nutricional, esse conjunto ou grupos de alimentos são detectados por meio de métodos estatísticos de redução e/ou agregação de componentes.

Tradicionalmente, a epidemiologia nutricional dedicou-se ao estudo do efeito de nutrientes ou de um alimento específico sobre desfechos de saúde. Há evidências de que alimentos e nutrientes agem sinergicamente no risco de várias doenças crônicas (Jacobs \& Steffen, 2003). A proposta de utilizar o padrão alimentar como exposição em epidemiologia nutricional supera limitações desde a incapacidade na detecção de pequenos efeitos de simples nutrientes até a dificuldade na avaliação das intercorrelações e das interações entre os nutrientes - por exemplo, o efeito da interação entre sódio e cálcio sobre a densidade mineral óssea (Mizushima et al., 1999).

Além disso, padrões alimentares expressam melhor a complexidade envolvida no ato de se alimentar, uma vez que pessoas não consomem de forma isolada alimentos ou nutrientes. Para a epidemiologia, que tem a população como foco, o estudo dos padrôes alimentares pode melhor subsidiar a proposição de medidas efetivas de promoção da saúde por meio da alimentação (Newby et al., 2004).

A identificação de padrões alimentares pode ser feita a priori ou a posteriori (Newby et al., 2004). Na definição de padrões alimentares a priori, são propostos índices que permitem avaliar a qualidade da dieta com base em critérios conceituais de nutrição saudável e de diretrizes e recomendaçōes nutricionais. Há índices resultantes de escores da totalização de nutrientes, da totalização de alimentos ou ainda índices que resumem a adesão 
dos indivíduos a uma determinada diretriz dietética (Kant et al., 2000; Fitzgerald, Dewer \& Veugelers, 2002; Kennedy, Olls \& Callsson, 1995; Kant, 2004).

$\mathrm{Na}$ definição de padrões alimentares a posteriori, parte-se de dados empíricos de alimentos que são agregados com base em análise estatística, com posterior avaliação, ou seja, identificação de padrão alimentar. O presente capítulo aborda a identificação de padrões dietéticos por meio de métodos a posteriori. Esses métodos incluem: a escolha do instrumento para avaliar o consumo alimentar; a definição do tamanho de amostra; a coleta das informaçôes; a análise estatística dos dados e a interpretação dos resultados com a definição de nomes para os padrôes alimentares.

Na maioria dos estudos de padrão alimentar, os instrumentos utilizados para avaliar o consumo alimentar são o Questionário de Freqüência Alimentar (QFA) e o Registro Dietético (RD) (Kant, 2004). Ambos os instrumentos apresentam vantagens e desvantagens (Thompson \& Byers, 1994). O instrumento utilizado pode interferir na detecção da relação entre dieta e doença. Em algumas situações, há evidências de que o RD pode ser preferível ao QFA (Freedman et al., 2006). Além disso, no estudo dos padrões alimentares há a alternativa de utilizar dados existentes sobre disponibilidade de alimentos para determinadas populaçôes (Sichieri, Castro \& Moura, 2003).

Os métodos de avaliação de consumo estão apresentados de forma detalhada no capítulo 10, "Métodos de avaliação do consumo de alimentos”. Na utilização de QFA para a determinação dos padrões alimentares, devese ter atenção especial à definição do número e à forma de apresentação dos alimentos no QFA, assim como ao período de referência da informação. A eficiência é a melhor regra para definir o número de alimentos a serem incluídos em um QFA. Deve-se contrabalançar o tempo gasto para coletar os dados sobre os alimentos consumidos com a qualidade da informação obtida. Também se ressalta que o tempo de aplicação de um QFA terá repercussões no cronograma de execução da investigação e no tamanho da equipe necessária para aplicar o questionário na população. Na bibliografia, identificam-se estudos com QFA compostos de lista com menos de vinte alimentos e até de lista com 277 alimentos (Kumagai et al., 1999; Sevak et al., 2004).

Para a análise, interpretação e identificação dos padrōes alimentares, considera-se ideal que cada alimento seja apresentado de forma isolada no QFA, ou seja, que não se incluam dois alimentos no mesmo item - por exemplo: 'pão/bolo'. Entretanto, considerando-se a possibilidade de menor eficiência na aplicação de um questionário muito longo, recorre-se, na maioria das vezes, ao uso de QFA que contemplam no mesmo item dois ou três alimentos. Recomenda-se que o agrupamento desses alimentos seja realizado de acordo com o objetivo do estudo e suas hipóteses e, também, considerando as características nutricionais ou funcionais dos alimentos. O período de coleta de consumo alimentar pode ser referente ao último mês, ano etc. (Willett, 1998). No entanto, padrões alimentares provenientes de QFA de período curto de observação podem não contemplar as variaçóes sazonais da produção de alimentos e da própria alimentação.

\section{Procedimentos Estatísticos para a Redução dos Dados}

Em epidemiologia nutricional, os dois métodos estatísticos mais utilizados para derivar padrões são a análise de agrupamento (cluster) e a análise fatorial. Em recente revisão (Newby et al., 2004) foram identificados 58 artigos com o emprego de análise fatorial e 35 com análise de agrupamento na identificação de padrōes alimentares - artigos publicados desde 1980. A análise de agrupamento assemelha-se à análise fatorial em seu objetivo de avaliar a estrutura e de reduzir ou agrupar dados. No entanto, diferem no sentido de que a primeira agrega indivíduos (objetos) e a segunda, prioritariamente, agrega variáveis (Hair et al., 2005).

A análise fatorial reduz os dados em padrões baseados nas inter-relações (correlações) entre as variáveis, no caso, os itens alimentares. A análise de agrupamento reduz os dados e forma grupos com base em uma medida de 
similaridade em termos de distância euclidiana através de sucessivos agrupamentos de pares próximos. Assim, ao mesmo tempo que os objetos ou os indivíduos são agregados em subgrupos relativamente homogêneos, ela maximiza a heterogeneidade entre os grupos, afastando os elementos mais distantes. Esta técnica é adequada para três situações: explorar padrões alimentares quando se suspeita que a amostra não é homogênea; quando inexistem as propriedades psicométricas requeridas para a análise fatorial ou, ainda, quando a intenção do investigador é manter todos os itens alimentares propostos no instrumento, ou seja, não excluir itens. No procedimento de análise fatorial, excluem-se itens-fator por apresentarem saturação insuficiente.

Conforme o objetivo da investigação científica, a análise fatorial pode ser exploratória ou confirmatória. $\mathrm{Na}$ análise exploratória, procura-se descrever e resumir dados, agrupando-se as variáveis que são correlacionadas. Este tipo de análise é indicado na geração de hipóteses e é utilizado para o estágio investigatório de processos subjacentes para identificar qual o aspecto que os itens agrupados manifestam. Não há necessidade de se conhecer, a priori, o número de fatores. A análise confirmatória, a qual envolve técnicas estatísticas mais sofisticadas, é utilizada em estágios avançados de uma investigação científica, ou seja, no teste de uma teoria ou hipótese, partindo-se de um número conhecido de fatores. No caso dos padróes alimentares, seria utilizada em uma etapa posterior à identificação dos padrões alimentares - por exemplo, na elaboração de um instrumento de avaliação dietética.

$\mathrm{Na}$ análise fatorial, os métodos utilizados para a redução de um grande número de variáveis a um número menor são a Análise de Componentes Principais (ACP) e a Análise de Fator Comum (AFC). Tais procedimentos baseiam-se em modelos matemáticos diferentes. A ACP analisa toda a variância, tanto a compartilhada como a exclusiva, e pressupõe que não existe erro. A AFC analisa unicamente a variância compartilhada; a variância exclusiva (única) não é incluída, e alguma variância do erro é admitida (Dancey \& Reidy, 2006). A análise de componentes principais é uma técnica exploratória e a análise de fator comum tem sido utilizada para testar hipóteses, ou seja, no sentido confirmatório. Na prática, esses procedimentos podem ser utilizados nos mesmos tipos de dados oferecendo resultados similares, principalmente para grande conjunto de participantes. Para a identificação dos padrões alimentares, a análise de componentes principais tem sido utilizada com mais frequiência.

\section{Análise de Componentes Principais (ACP)}

A análise de componentes principais foi desenvolvida por Hotelling em 1933, mas, posteriormente, seu uso foi muito ampliado com o desenvolvimento da informática e dos pacotes estatísticos (López-Valcárcel, 1991). Os objetivos da Análise de Componentes Principais (ACP) são: 1) descrever de forma sintética grande número de variáveis e 2) obter índices sintéticos, os componentes, que são as dimensóes subjacentes que se identificam e podem ser nomeados.

As variáveis agrupadas em cada fator são mais fortemente correlacionadas entre si do que com as variáveis pertencentes aos outros fatores. Portanto, este procedimento possibilita que os itens de alimentos contidos no instrumento de avaliação de consumo alimentar sejam agrupados com base no grau de correlação entre eles. As etapas de análise incluem a preparação da matriz de correlação, a extração de um conjunto de fatores da matriz de correlação, a determinação do número de fatores e a rotação dos fatores para aumentar a sua interpretabilidade. A interpretação e a denominação dos fatores, no caso dos padrões alimentares, depende do significado de cada combinação das variáveis (itens de alimentos) observadas no fator e, principalmente, daqueles itens com maior carga fatorial. 
Há diversas regras para estimar o tamanho da amostra (n) necessário para garantir a realização das etapas da análise fatorial. Em uma das regras, selecionam-se no mínimo dez indivíduos para cada item alimentar contido no instrumento. Em outra, o número de indivíduos deve ser no mínimo cinco vezes maior do que o número de itens presentes no instrumento (Pestana \& Gageiro, 2005; Hair et al., 2005). Portanto, sendo K = número de itens de alimentos no instrumento, n é obtido da seguinte forma:

$$
\begin{gathered}
\text { Se } 5<K \leq 15 \Rightarrow n=10 \times K \\
\text { Se } K>15 \Rightarrow n=5 \times K
\end{gathered}
$$

Por exemplo, para um QFA que contenha vinte itens alimentares (QFA-20), o tamanho da amostra deve ser de no mínimo cem pessoas com informações válidas em todos os itens alimentares. Como os estudos epidemiológicos incluem amostras com grande número de pessoas, eles possibilitam a aplicação de QFA com listas de alimentos bem completas.

Os dados do QFA coletados na amostra, após a codificação ter sido conferida e a dupla digitação realizada com a análise de consistência, devem ser transferidos para um pacote estatístico que permita a realização da ACP. Salienta-se que, quando se aplica um QFA quantitativo, será necessário converter as porções dos alimentos para gramas ou mililitros. Para o procedimento correto da análise de componentes principais, todos os itens de alimentos devem estar com a mesma unidade de medida. A utilização de QFA qualitativo, composto apenas da lista de alimentos e uma escala de freqüência de consumo de cada item alimentar, é o método mais simplificado para a coleta, digitação e análise dos dados. Nesse caso, por exemplo, o QFA pode conter uma escala likert com as seguintes categorias: não-consumo $=0$; consumo uma vez na semana $=1$; consumo duas vezes na semana $=2$; consumo três vezes na semana $=3$; consumo de quatro a cinco vezes na semana $=4$; e consumo de seis a sete vezes na semana $=5$. Com esse tipo de escala qualitativa, não há necessidade de conversão de porções para uma unidade de medida (gramas), e os valores podem ser digitados diretamente no banco de dados e utilizados para a ACP.

Especificamente, nos procedimentos de análise dos dados deve-se iniciar com a avaliação da aplicabilidade do método de ACP. Para isso, utilizam-se os testes estatísticos de Kaiser-Meyer-Olkin (KMO) e o teste de Esferecidade de Bartlett. O KMO verifica a existência e o peso das correlações parciais. Para que o modelo fatorial seja adequado, o quociente entre o coeficiente de correlação simples e o coeficiente de correlação parcial deve se aproximar de 1, indicando um denominador de correlação parcial pequeno. Não são aceitos valores abaixo de 0,6; neste caso, deve-se utilizar outro tipo de análise. O teste de Esfericidade de Bartlett testa a hipótese nula de que a matriz de correlaçóes é igual à matriz de identidade. Um valor de p igual ou menor a 0,05 indica que os dados produzem uma matriz de identidade, concluindo-se que o modelo fatorial é adequado para a análise dos dados. Salienta-se que o teste de esfericidade de Bartlett é muito sensível ao tamanho da amostra; portanto, em amostras grandes tende-se a rejeitar a hipótese nula. Assim, na análise de banco de dados provenientes de estudos epidemiológicos é preferível utilizar o KMO.

A seguir serão apresentados resultados da análise de componentes principais com base em um QFA com vinte itens alimentares (QFA-20) aplicados em uma amostra de 1.026 mulheres adultas. Esse QFA é resultante de uma versão resumida daquele utilizado no estudo de Alves e colaboradores (2006), o qual continha setenta itens alimentares. A Tabela 1 apresenta as estatísticas de KMO e de Bartlett para a aceitação da análise fatorial nos dados provenientes do QFA-20. Observa-se que os requisitos exigidos para a análise fatorial se cumprem com KMO de 0,730 (existem pequenas correlaçóes parciais) e com o teste de esfericidade de Bartlett significativo ( $\mathrm{p}<0,001)$. 
Tabela 1 - Parâmetros estatísticos para aceitação de análise fatorial (KMO e teste de esferecidade de Bartlett) para o QFA-20 $(\mathrm{n}=1.023)$

\begin{tabular}{lc}
\hline Kaiser - Meyer - Olkin & 0,730 \\
\hline Teste de esfericidade de Bartlett & 2291,322 \\
Aprox. qui-quadrado & 190 \\
\hline Graus de liberdade & $<0,001$ \\
\hline Significância estatística &
\end{tabular}

Uma vez avaliada a aplicabilidade do método fatorial no conjunto de dados, deve-se observar, também, o percentual da variância de cada item explicada por todos os fatores juntos. Esse percentual, denominado comunalidade, pode ser interpretado como um indicador de confiabilidade do item. As comunalidades são calculadas antes e depois da extração dos fatores. Na ACP, as comunalidades iniciais são sempre iguais a 1, porque o método utiliza a variância total. Após a extração dos fatores, os resultados das comunalidades dos itens devem variar de 0 a 1 , sendo 0 quando não explicam nenhuma variância e 1 quando explicam toda a sua variância.

A Tabela 2 apresenta as comunalidades para cada item de alimento presente no QFA-20. Os resultados mostram que as proporçôes das variâncias explicadas pelos fatores (comunalidades) são todas adequadas (próximas e superiores a 0,4 ). Por exemplo, a comunalidade do item 2 igual a 0,64 indica que ele explica $64 \%$ da variância total deste com relação aos fatores extraídos. No entanto, perde $36 \%$ do poder explicativo com a interrelação com os demais itens.

Tabela 2 - Comunalidades iniciais e após a extração dos fatores por análise de componentes principais (QFA-20)

\begin{tabular}{ccc}
\hline Item alimentar & Inicial & Extração \\
\hline 13 & 1,000 & 0,512 \\
\hline 11 & 1,000 & 0,407 \\
\hline 12 & 1,000 & 0,485 \\
\hline 1 & 1,000 & 0,590 \\
\hline 10 & 1,000 & 0,495 \\
\hline 2 & 1,000 & 0,640 \\
\hline 19 & 1,000 & 0,371 \\
\hline 15 & 1,000 & 0,292 \\
\hline 16 & 1,000 & 0,508 \\
\hline 18 & 1,000 & 0,488 \\
\hline 3 & 1,000 & 0,407 \\
\hline 9 & 1,000 & 0,360 \\
\hline 6 & 1,000 & 0,495 \\
\hline 4 & 1,000 & 0,417 \\
\hline 5 & 1,000 & 0,467 \\
\hline 17 & 1,000 & 0,343 \\
\hline & & \\
\hline 17 &
\end{tabular}


Tabela 2 - Comunalidades iniciais e após a extração dos fatores por análise de componentes principais (QFA-20 - continuação)

\begin{tabular}{ccc}
\hline Item alimentar & Inicial & Extração \\
\hline 8 & 1,000 & 0,324 \\
\hline 14 & 1,000 & 0,383 \\
\hline 20 & 1,000 & 0,378 \\
\hline
\end{tabular}

No próximo passo da análise, observam-se os resultados referentes à variância total explicada (Tabela 3). Cada autovalor representa o total da variância explicada pelo fator (componente). Os autovalores estão ordenados por tamanho, e a soma dos autovalores é igual ao número de variáveis na análise. A porcentagem da variância total atribuída ao fator 1 é $15,05 \%$ e ao fator 2 é $8,79 \%$, e o acumulado para esses dois fatores é de $23,84 \%$. Os autovalores representam a proporção da variância que cada fator é capaz de reter. Cada fator (componente) que apresenta autovalor maior do que 1 é retido. $\mathrm{Na}$ Tabela 3, os cinco fatores que apresentam claramente autovalor $>1$ encontram-se grifados. No fator 6 , o autovalor foi igual a 1,070 , não sendo retido na extração. Os cinco fatores explicam $44,43 \%$ da variabilidade dos vinte itens originais.

Tabela 3 - Autovalores e porcentagem da variância total explicada antes da rotação dos fatores

\begin{tabular}{cccc}
\hline \multirow{2}{*}{ Componente } & \multicolumn{3}{c}{ Autovalores iniciais } \\
\cline { 2 - 4 } & Total & \% da variância & \% Acumulado \\
\hline 1 & 3,010 & 15,050 & 15,050 \\
\hline 2 & 1,759 & 8,793 & 23,843 \\
\hline 4 & 1,501 & 7,506 & 31,350 \\
\hline 5 & 1,388 & 6,938 & 38,287 \\
\hline 6 & 1,230 & 6,148 & 44,435 \\
\hline 7 & 1,070 & 5,352 & 49,788 \\
\hline 8 & 0,956 & 4,778 & 54,566 \\
\hline 9 & 0,893 & 4,463 & 59,029 \\
\hline 10 & 0,870 & 4,350 & 63,379 \\
\hline 11 & 0,835 & 4,175 & 71,488 \\
\hline 12 & 0,787 & 3,934 & 75,233 \\
\hline 13 & 0,749 & 3,745 & 78,953 \\
\hline 14 & 0,744 & 3,720 & 82,501 \\
\hline 15 & 0,710 & 3,548 & 85,975 \\
\hline 16 & 0,695 & 3,474 & 89,088 \\
\hline 17 & 0,623 & 3,113 & 92,144 \\
\hline 18 & 0,611 & 3,057 & 95,092 \\
\hline 19 & 0,590 & 2,948 & 2,635 \\
\hline 20 & 0,527 & 2,273 & \\
\hline
\end{tabular}


Além da utilização dos autovalores e do porcentual da variância acumulada para definir o número de fatores a serem retidos, utiliza-se o teste gráfico de Cattel (scree plot). Ele é determinado fazendo-se o gráfico dos autovalores em relação ao número de fatores em sua ordem de extração. Na Figura 1, observa-se que a explicação fatorial com cinco fatores é adequada. Salienta-se que os pontos no maior declive indicam o número apropriado de fatores a serem retidos.

Figura 1 - Gráfico de sedimentação de Cattell da análise de componentes principais (QFA-20)

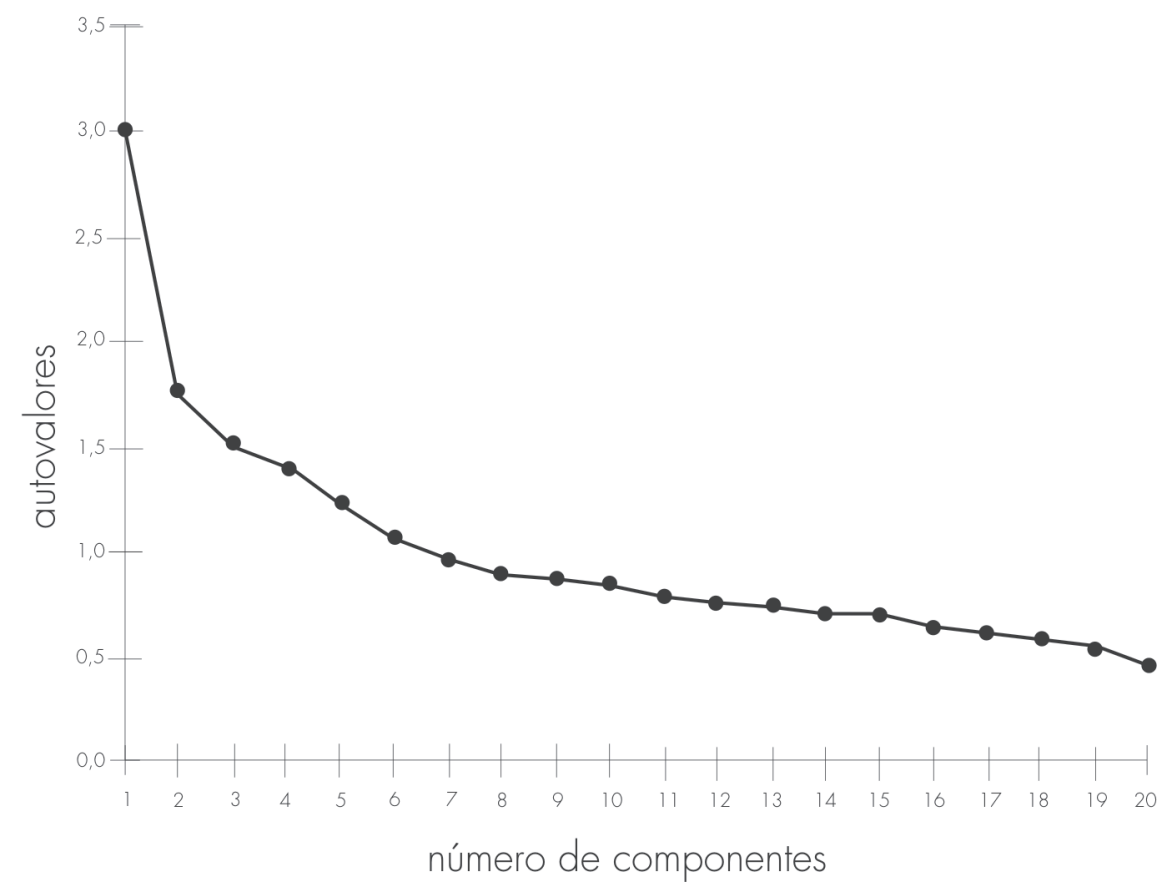

A Tabela 4 mostra o total da variância explicada após a rotação dos fatores. Embora o percentual de cada componente apresente alteração, salienta-se que o percentual acumulado dos fatores extraídos permanece o mesmo. Conforme referido anteriormente, o percentual acumulado pode contribuir para a definição do número de fatores a serem retidos. A Tabela 4 apresenta apenas os valores dos cinco fatores retidos. Entretanto, há divergências quanto ao valor satisfatório.

Tabela 4 - Autovalores e porcentagem da variância total explicada depois da rotação dos fatores

\begin{tabular}{cccc}
\hline \multirow{2}{*}{ Componente } & \multicolumn{3}{c}{ Autovalores iniciais } \\
\cline { 2 - 4 } & Total & \% da variância & \% acumulado \\
\hline 1 & 2,114 & 10,568 & 10,568 \\
\hline 2 & 1,851 & 9,257 & 19,825 \\
\hline 3 & 1,761 & 8,807 & 28,632 \\
\hline 4 & 1,719 & 8,597 & 37,229 \\
\hline 5 & 1,441 & 7,207 & 44,435 \\
\hline
\end{tabular}


A rotação de fatores é importante para gerar uma estrutura de fatores facilmente interpretável; no entanto, não melhora o grau de ajuste em relação aos dados. Há três procedimentos de rotação ortogonal (Varimax, Quartimax e Equamax) e dois procedimentos de rotação oblíqua (Oblimin direto e Promax). A rotação oblíqua pressupõe a existência de correlação entre os fatores resultantes. $\mathrm{O}$ caso mais simples de rotação é a ortogonal. A maioria dos estudos exploratórios de padrão alimentar utiliza a rotação ortogonal, ou seja, busca modelos alimentares protótipos. A vantagem da rotação ortogonal é que os fatores resultantes não são relacionados e, portanto, podem ser incluídos juntos em uma posterior análise de regressão multivariada, sem afetar o resultado de qualquer dos fatores.

Entre os vários estudos realizados recentemente para a determinação de padrões alimentares, a análise de componentes com rotação ortogonal Varimax é a mais utilizada. O objetivo da rotação é maximizar as cargas fatoriais maiores e minimizar as cargas menores. Permite, também, a visualização dos resultados da matriz, tornando-os de mais fácil interpretação. A rotação ortogonal Varimax faz com que cada fator somente apareça com as saturaçôes altas e com o menor número de variáveis (itens) possíveis.

Tabela 5 - Matriz da estrutura fatorial rotada

\begin{tabular}{|c|c|c|c|c|c|c|}
\hline \multirow{2}{*}{ Alimento } & \multirow{2}{*}{ Item } & \multicolumn{5}{|c|}{ Fator } \\
\hline & & 1 & 2 & 3 & 4 & 5 \\
\hline Couve & 13 & 0,708 & & & & \\
\hline Brócolis & 12 & 0,662 & & & & \\
\hline Abóbora e cenoura & 10 & 0,644 & & & & \\
\hline Agrião e alface & 11 & 0,631 & & & & \\
\hline Balas, sobremesas e doces & 16 & & 0,711 & & & \\
\hline Chocolate & 18 & & 0,692 & & & \\
\hline Presunto, mortadela, salame e copa & 9 & & 0,551 & & & \\
\hline Queijo & 3 & 0,341 & 0,526 & & & \\
\hline Leite integral & 1 & & & 0,766 & & \\
\hline Leite desnatado & 2 & & & $-0,740$ & & \\
\hline Açúcar & 19 & & & 0,576 & & \\
\hline Nata & 15 & & & 0,471 & & \\
\hline Melão, melancia & 6 & & & & 0,701 & \\
\hline Manga, pêra e pêssego & 5 & & & & 0,668 & \\
\hline Caqui, uva & 4 & & & & 0,627 & \\
\hline Sorvete & 17 & & & & 0,481 & \\
\hline Massa integral & 7 & & & & & 0,721 \\
\hline Soja & 14 & & & & & 0,613 \\
\hline Açúcar mascavo & 20 & & & & & 0,570 \\
\hline Peixes, sardinhas, atum enlatado & 8 & & & & & 0,379 \\
\hline
\end{tabular}

A Tabela 5 apresenta a matriz de correlação rotada com os itens alimentares e os respectivos alimentos que eles representam. Cada item aparece com as respectivas saturações (cargas) nos fatores extraídos. No exemplo do 
QFA-20, foram extraídos cinco fatores (padrões). Utilizando-se a rotação ortogonal Varimax, tem-se uma boa visualização das cargas de saturação de cada item alimentar nos fatores extraídos. Foram mantidos na matriz os alimentos cuja carga do fator apresenta-se superior a 0,30. Com essa carga já seria possível obter um poder estatístico de 80\% e um nível de significância de 0,05 em uma amostra de 350 pessoas (Hair et al., 2005).

O exemplo mostrado na Tabela 5 apresenta fatores claros com índices limpos. Mas, às vezes, os resultados podem aparecer com: 1) alguns itens que não saturam em nenhum fator por não atingir o valor mínimo estabelecido para carga (usualmente, 0,30 ); 2 ) itens que saturam em mais de um fator e 3) fatores com menos de três itens. Para cada uma dessas ocorrências, o investigador deve tomar decisões durante o planejamento da análise, ou seja, no próprio programa estatístico definem-se os parâmetros a serem seguidos.

Cabe destacar que manter e apresentar no padrão alimentar itens com cargas negativas é uma decisão a ser tomada tendo em vista o objetivo de investigação. Observa-se, por exemplo, que no fator 3 aparece o item 2 (leite desnatado) com carga negativa (Tabela 6). Ao excluir-se o item alimentar com carga negativa daquele padrão, tem-se um modelo alimentar protótipo, ou seja, apenas com os alimentos que são consumidos. Em contrapartida, a opção de manter no padrão alimentar um item com associação inversa com os outros alimentos do fator tem a vantagem de abarcar a complexidade envolvida nos hábitos alimentares. Em termos de saúde pública, essa informação pode subsidiar estratégias para recomendações nutricionais na população em estudo. Há, também, a possibilidade de um item negativo ser testado em outros fatores (ver alpha de Cronbach a seguir).

Ao final, deve-se proceder à análise de consistência interna dos fatores. $\mathrm{O}$ alpha de Cronbach é uma das medidas mais utilizadas para avaliar a consistência interna de um grupo de variáveis. Os resultados do alpha de Cronbach variam de 0 a 1 . Valores menores do que 0,6 são inaceitáveis quando se busca um construto homogêneo em termos de validação de escalas. No entanto, na busca de um padrão ou conjunto de elementos que manifestem um perfil de agregação, sem os requisitos de validar um determinado construto, os índices podem ser mais flexíveis. Os itens do mesmo fator que apresentarem correlação negativa no fator devem ser excluídos da análise, ou então verifica-se a possibilidade de um melhor agrupamento com outro fator, por meio do valor de alpha.

Nesse exemplo, em que o item 2 apresenta uma correlação negativa alta no fator 3 e diminui o alpha do fator, verificamos que, se incluído no fator 5 , ele torna-se positivo e acrescenta consistência estatística ao fator, além de congruência explicativa à sua interpretação. Além disso, deve-se testar a presença de cada item no fator. Por exemplo, se na exclusão de um item o alpha de Cronbach passa de 0,75 (razoável) para 0,8 (bom), seria melhor excluir este item do fator. Esse procedimento deve ser realizado com cada fator separadamente, e quando for necessário excluir mais de um item, é conveniente eliminar um de cada vez. Salienta-se que o investigador deve considerar que, embora alguns itens não contribuam para aumentar significativamente o alpha, eles apresentam validade de construto na melhor explicação do fator e, portanto, sua exclusão não será a decisão mais acertada.

A Tabela 6 (página seguinte) apresenta um resumo dos procedimentos realizados para testar a consistência dos padrôes. $\mathrm{O}$ alpha de Cronbach para o fator 1 é considerado razoável, e a retirada de qualquer um dos quatro itens alimentares reduz a consistência do fator. $\mathrm{O}$ mesmo ocorreu com o fator 2, embora o alpha de 0,552 seja mais fraco. Para o fator 3, observa-se que com a retirada do item 2 houve um aumento do alpha (de - 0,316 aumenta para 0,373 ), ou seja, aumenta a consistência do fator. Nesse caso, embora não seja possível observar na Tabela 6, há uma inversão de sinal tornando positivos os outros três itens alimentares remanescentes do fator. O fator 4 apresenta um alpha de 0,554 , e a retirada de algum fator, ou mesmo o acréscimo do item 2 , não melhora sua consistência. Ao final, observa-se que a inclusão do item 2 no fator 5 , além de ter aumentado o alpha de Cronbach (de 0,338 aumenta para 0,386), tornou a carga desse item positiva. 
Tabela 6 - Valores alpha de Cronbach: teste dos itens alimentares para consistência interna dos fatores

\begin{tabular}{ccccc}
\hline Fator & Alpha de Cronbach & Número de itens* & $\begin{array}{c}\text { Item que, se deletado, } \\
\text { aumenta o alpha }\end{array}$ & $\begin{array}{c}\text { Mudança de item } 2 \text { do } \\
\text { fator } 3 \text { para o fator } 5\end{array}$ \\
\hline 1 & 0,650 & 4 & Nenhum & \\
\hline 2 & 0,552 & 4 & Nenhum & \\
\hline 3 & $-0,316$ & 4 & ttem 2 & 0,373 \\
\hline 4 & 0,506 & 4 & Nenhum & 0,385 \\
\hline 5 & 0,338 & 4 & Nenhum & \\
\hline
\end{tabular}

*Todos os itens de cada fator foram testados.

Após a verificação da consistência interna, analisa-se cada fator e tenta-se explicar, teoricamente, porque esses itens se agruparam e quais os elementos comuns entre eles. Na nova configuração do fator 5 , por exemplo, observa-se que a contribuição do item 2 em termos explicativos do fator é coerente com o conteúdo dos itens. O padrão alimentar (fator 5) era composto de massa integral, soja, açúcar mascavo e peixes, portanto, há coerência na inclusão do item 2, ou seja, leite desnatado. Entretanto, a presença desse item não estava adequada ao fator 3, o qual incluía leite integral, açúcar e nata.

A busca da explicação teórica para os grupamentos formados permite que se atribuam nomes aos fatores. $\mathrm{Na}$ maioria dos estudos, os padrões alimentares são rotulados de acordo com o item alimentar de maior carga de saturação ou com a composição nutricional dos alimentos do fator. Há, também, denominação de fatores de acordo com a cultura (tradicional) ou área geográfica (Mediterrâneo). No estudo realizado no Rio de Janeiro, as cargas para o feijão e o arroz justificaram a denominação do padrão alimentar tradicional (Sichieri, 2002). Já no estudo de padrões alimentares das mulheres do sul do Brasil, os fatores foram denominados considerando-se dois critérios: a relação com as DCNT (padrão alimentar de risco ou padrão alimentar protetor) e o custo da porção dos alimentos em cada fator (Alves et al., 2006).

O Quadro 1 apresenta um exemplo para denominação dos padrões alimentares identificados com base no QFA-20 aplicando-se análise de componentes principais com rotação ortogonal Varimax. Neste exemplo, os nomes foram atribuídos de acordo com grupo de alimentos e características nutricionais. Portanto, os nomes dos padrões alimentares identificados foram: 'vegetais', 'doces e embutidos', 'calóricos', 'frutas'e 'saudáveis'. 
Quadro 1 - Exemplo de denominação para os cinco padrões alimentares identificados

\begin{tabular}{|c|c|c|c|c|c|}
\hline \multirow{2}{*}{ Alimento } & \multicolumn{5}{|c|}{ Padrão alimentar (Fatores) } \\
\hline & 1 & 2 & 3 & 4 & 5 \\
\hline $\begin{array}{l}\text { Couve } \\
\text { Brócolis } \\
\text { Abóbora e cenoura } \\
\text { Agrião e alface }\end{array}$ & Vegetais & & & & \\
\hline $\begin{array}{l}\text { Balas, sobremesas e doces } \\
\text { Chocolate } \\
\text { Presunto, mortadela, salame e copa } \\
\text { Queijo }\end{array}$ & & $\begin{array}{c}\text { Doces e } \\
\text { embutidos }\end{array}$ & & & \\
\hline $\begin{array}{l}\text { Leite integral } \\
\text { Açúcar } \\
\text { Nata }\end{array}$ & & & Calóricos & & \\
\hline $\begin{array}{l}\text { Melão, melancia } \\
\text { Manga, pêra e pêssego } \\
\text { Caqui, uva } \\
\text { Sorvete }\end{array}$ & & & & Frutas & \\
\hline $\begin{array}{l}\text { Massa integral } \\
\text { Soja } \\
\text { Açúcar mascavo } \\
\text { Peixes, sardinhas, atum enlatado } \\
\text { Leite desnatado }\end{array}$ & & & & & Saudáveis \\
\hline
\end{tabular}

\section{Considerações Finais}

A análise fatorial permite reduzir um grande número de variáveis alimentares em um número menor de fatores, identificando estruturas subjacentes, ou seja, comportamentos não observáveis diretamente, que sintetizam a complexa interação de fatores genéticos, ambientais e individuais.

Neste tipo de análise, os padrōes são derivados sem uma hipótese a priori. Assim, eles podem ser adequados para uma amostra particular, mas não necessariamente representam padrões de dietas ideais. Além disso, por serem específicos para uma amostra, os padrões derivados empiricamente podem não se repetir em outras populaçōes, o que dificulta as comparações entre os estudos. As especificidades, entretanto, refletem o comportamento alimentar real de uma população e podem fornecer informações úteis para a elaboração de diretrizes nutricionais (Jacques \& Tucker, 2001; Hu, 2002; Newby et al., 2004).

A identificação de padrões alimentares é útil na investigação da relação entre dieta e doença, principalmente quando a causa está vinculada a várias características da dieta. Porém, não seria a opção mais adequada para doenças causadas por um nutriente específico, como, por exemplo, ácido fólico e defeito do tubo neural (Hu, 2002).

Uma crítica freqüente na área da epidemiologia nutricional ao uso desta abordagem refere-se à subjetividade envolvida nas diversas etapas da análise para a redução dos fatores que vão desde a elaboração do QFA até a denominação dos fatores, a saber: quais e quantos alimentos serão incluídos no QFA; como os alimentos serão listados (individualmente ou em grupos); se em grupos, qual o critério para agrupar os alimentos; como serão inseridas as variáveis no banco de dados; qual o número de fatores a ser retido e, finalmente, que critérios serão utilizados para atribuir nomes aos padrōes alimentares (Martinez et al., 1998; Newby et al., 2004). Nenhuma dessas decisões é inócua, e qualquer mudança será de difícil controle e detecção, levando a diferentes resultados. 
Por exemplo, a escolha dos alimentos na lista do QFA é crucial e primordial na identificação de padrões alimentares, mas não menos importante é a escolha do número de fatores a serem extraídos.

Enfim, embora haja incertezas e subjetividade nas decisóes durante os processos estatísticos de redução de dados, eles têm sido fundamentais para que se possa trabalhar com a enorme quantidade de informação proveniente dos instrumentos de coleta de consumo alimentar. Além disso, a subjetividade na condução deste tipo de análise não deve ser motivo para abandoná-la, sendo recomendados maior detalhamento na descrição de todas as decisões tomadas e mais estudos de validação.

\section{Referências}

ALVES, A. L. S. et. al. Padrões alimentares de mulheres adultas residentes em área urbana no sul do Brasil. Revista de Saúde Pública, 40(5): 865-873, 2006.

DANCEY, C. P. \& REIDY, J. Estatística sem Matemática para Psicologia: usando SPSS para Windows. Porto Alegre: Artmed, 2006.

FITZGERALD, A. L.; DEWER, R. A. \& VEUGELERS, P. J. Diet quality and cancer incidence in Nova Scotia, Canada. Nutrition and Cancer, 43: 127-132, 2002.

FREEDMAN, L. S. et. al. A comparison of two dietary instruments for evaluating the fat-breast cancer relationship. International Journal of Epidemiology, 35(4): 1.011-1.021, 2006.

GARCIA, R. W. D. A Comida, a Dieta, o Gosto: mudanças na cultura alimentar urbana, 1999. Tese de Doutorado, São Paulo: Universidade de São Paulo.

HAIR, J. F. et al. Análise Multivariada de Dados. Porto Alegre: Artmed, 2005.

HU, F. B. Dietary pattern analysis: a new direction in nutritional epidemiology. Current Opinion in Lipidology, 13(1): 3-9, 2002.

JACOBS, D. R. J. \& STEFFEN, L. M. Nutrients, foods, and dietary patterns as exposures in research: a framework for food synergy. American Journal of Clinical Nutrition, 78, suppl. 3: 508S-513S, 2003.

JACQUES, P. F. \& TUCKER, K. L. Are dietary patterns useful for understanding the role of diet in chronic disease? American Journal of Clinical Nutrition, 73(1): 1-2, 2001.

KANT, A. K. Dietary patterns and health outcomes. Journal of the American Dietetic Association, 104(4): 615635, 2004.

KANT, A. K. et al. A prospective study of diet quality and mortality in women. Jama, 283: 2.109-2.115, 2000.

KENNEDY, E. T.; OHLS, J. \& CALLSON, S. The Healthy Eating Index: design and applications. Journal of the American Dietetic Association, 95: 1.103-1.108, 1995.

KUMAGAI, S. et al. Effect of food intake on all-cause mortality in the community elderly: a 7-year longitudinal study. Journal of Nutrition, Health and Aging, 3: 29-33, 1999.

LÓPEZ-VALCÁRCEL, B. G. Análisis Multivariante: aplicación al ámbito sanitario. Barcelona: SG Editores, 1991.

MARTINEZ, M. E. et al. Invited commentary. Factor analysis and the search for objectivity. American Journal of Epidemiology, 148(1): 17-19, 1998. 
MIZUSHIMA, S. et al. Preventive nutritional factors in epidemiology: interaction between sodium and calcium. Clinical and Experimental Pharmacology and Physiology, 26(7): 573-575, 1999.

NEWBY, P. K. et al. Empirically derived eating patterns using factor or cluster analysis: a review. Nutrition Reviews, 62(5): 177-203, 2004.

PESTANA, M. H. \& J. N. GAGEIRO. Análise de Dados para Ciências Sociais: a complementaridade do SPSS. Lisboa: Edições Sílabo, 2005.

SEVAK, L. et al. Validation of a food frequency questionnaire to assess macro and micro nutrients intake among South Asians in the United Kingdom. European of Journal Nutrition, 43(3): 160-168, 2004.

SICHIERI, R. Dietary patterns and their associations with obesity in the Brazilian city of Rio de Janeiro. Obesity Research, 10(1): 42-48, 2002.

SICHIERI, R.; CASTRO, J. F. \& MOURA, A. S. Fatores associados ao padrão de consumo alimentar da população brasileira urbana. Cadernos de Saúde Pública, 19, supl. 1: S47-S53, 2003.

THOMPSON, F. \& BYERS, T. Dietary Assessment Resource Manual: official publications of the American Institute of Nutrition. Journal of Nutrition, 124(11s): 2.245S-2.317S, 1994.

WILLETT, W. C. Nutritional Epidemiology. Oxford: Oxford University Press, 1998. 



\title{
Desenvolvimento de Instrumentos de Aferição Epidemiológicos
}

\author{
Michael Eduardo Reichenheim e Claudia Leite Moraes
}

$\mathrm{E}$ ste capítulo trata do desenvolvimento de instrumentos de aferição, uma área de interesse metodológico que nitidamente vai além do domínio precípuo das ferramentas e técnicas voltadas para a aferição nutricional (e que estão bem contempladas em outros capítulos deste livro). Ainda assim, este tema não é de todo estranho à área temática da epidemiologia nutricional, pois muitos de seus programas de investigação concernem a estudos de objetos que transcendem as avaliações sobre o status nutricional em si, tais como contenção alimentar (dietary restraint) (Bond, McDowell \& Wilkinson, 2001; Van Strien et al., 2006), avaliação de apetite (Wilson et al., 2005), comportamento alimentar (Burrows \& Cooper, 2002; De Lauzon et al., 2004; Wright, Parkinson \& Drewett, 2006) ou conhecimentos e educação nutricional (Vereecken, Van Damme \& Maes, 2005; Whati et al., 2005; Zinn, Schofield \& Wall, 2005). Ademais, muitos estudos da área se debruçam sobre causas e determinantes das disfunções nutricionais e, destarte, forçosamente abarcam os vários domínios afins oriundos da epidemiologia como um todo. Claramente, rigor e refinamento na incorporação de construtos e dimensões conexas também requerem rigor e refinamento na escolha e uso do respectivo instrumental de aferição.

Como o leitor perceberá, a exposição que se segue está mais fundamentada na tradição de pesquisa oriunda das áreas de psicologia e educação denominada 'conceptualização dimensional' em contraste à 'categórica'. Esta, por sua vez, é mais afeita à área médica tradicional, cuja preocupação se concentra prioritariamente em diagnósticos e tratamentos. Uma premissa estruturante da abordagem 'dimensional' é que, subjacente aos itens empíricos manifestos, existe um contínuo de intensidade e/ou gravidade do fenômeno de interesse. Assim, tendo-se identificado instrumentos de aferição acurados e confiáveis, fica subentendido ser possível 'posicionar' indivíduos (unidades de análise) ao longo do espectro latente e, do ponto de vista das relações de determinação entre fenômenos assim mensurados, ser possível também uma aproximação verossímil entre os nexos conceituais sob investigação. Além dos construtos afins à área da epidemiologia nutricional citados anteriormente, bons exemplos de variáveis latentes assim trabalhadas são o apoio social (Sherbourne \& Stewart, 1991; Chor et al., 2001), a resiliência (Wagnild \& Young, 1993; Pesce et al., 2005), a qualidade de vida (Guillemin, Bombardier \& Beaton, 1993; Teixeira-Salmela et al., 2004), a violência entre parceiros íntimos (Krug et al., 2002; Moraes \& Reichenheim, 2002) e a auto-estima (Schmitt \& Allik, 2005).

Qualquer texto sobre instrumentos de aferição necessita perpassar pela questão da validade de estudos epidemiológicos como um todo, aliás, um tema de constante preocupação e que tem gerado contínuos debates entre pesquisadores. Certos autores salientam a necessidade de detalhamento sobre as possíveis fontes de erros 
sistemáticos e aleatórios na tentativa de evitar ou minimizar vieses (Kleinbaum, Kupper \& Morgenstern, 1982; Miettinen, 1985; Steineck \& Ahlbom, 1992; Rothman \& Greenland, 1998). Outros enfatizam a necessidade de embasamento teórico-conceitual no desenvolvimento e execução de estudos epidemiológicos (Krieger \& Zierler, 1997; Pearl, 2000; Weed, 2001; Greenland \& Brumback, 2002; Luiz \& Struchiner, 2002; Rothman \& Greenland, 2005). Na tentativa de unificar os vários aspectos que perpassam a qualidade de estudos epidemiológicos, Reichenheim e Moraes (1998) propuseram seis pilares para a apreciação de validade, percorrendo as questões conceituais, operacionais, de domínio do estudo, de comparação, de mensuração e de especificação dos modelos estatísticos empregados. Dois destes pilares - validade operacional e de mensuração - são de particular interesse quando se discutem os fatores que podem influenciar a qualidade das informaçóes.

Para a compreensão da validade operacional, é preciso perceber que a epidemiologia, como outras áreas da ciência, opera nos campos teórico e empírico. A conexão entre ambos é mediada pela formulação de hipóteses que expressam as relações terminais de um modelo teórico, servindo como ponte entre este e a realidade (Almeida Filho, 1989; Krieger \& Zierler, 1997). A partir da construção desse quadro, o pesquisador organiza suas idéias em relação ao processo que está investigando, o que torna possível identificar as hipóteses de pesquisa e os nexos entre os construtos e respectivas dimensōes teóricas supostamente envolvidas. Estabelecido o modelo teóricoconceitual, definem-se os indicadores e variáveis para representar os conceitos subjacentes no nível empírico. Esta etapa requer máxima atenção e aprofundamento, pois o traslado de um quadro teórico - em si um recorte da realidade - para o plano empírico produz, inevitavelmente, ainda mais simplificaçôes. O pouco cuidado no processo de redução dos conceitos às variáveis e indicadores pode fazer com que um 'falso' representante do conceito seja incorretamente incorporado em uma análise subseqüente. Sem dúvida, a utilização de instrumentos de aferição bem desenvolvidos pode em muito contribuir para a qualidade de um estudo.

Um segundo eixo de interesse aborda os aspectos relacionados à validade da informação (ou sua falta) conseqüente ao processo de mensuração. Problemas na aferição e o seu enfrentamento têm tido atenção especial no meio epidemiológico e bioestatístico (Dunn, 1989; Carroll, Ruppert \& Stefanski, 1995; Streiner \& Norman, 2003). A abordagem tradicional parte da classificação que separa a confiabilidade da validade de um instrumento (Nunnally \& Bernstein, 1995; Streiner \& Norman, 2003). No entanto, é central explicitar o que se tem em mente ao se confrontar esses dois conceitos. Ainda que a sucessiva demonstração de confiabilidade seja útil para recomendar um instrumento de aferição a médio ou longo prazo, grosso modo, a confiabilidade diz respeito à qualidade do processo de aferição precípuo de um estudo, não sendo, portanto, uma característica estrutural ou imanente do instrumento de aferição. Trata-se de algo conjuntural e específico do processo. Pode-se pensar a confiabilidade como elemento que conota a robustez da aferição (ou sua falta) em um estudo pontual, apreendendo as pressões exercidas pelo examinador e o examinado sobre o instrumento. Pelo caráter particular dessa interação, a confiabilidade precisa ser investigada em cada pesquisa, e seus resultados são, em princípio, intransferíveis (Armstrong, White \& Saracci, 1995).

Em contraposição, diz-se que um instrumento é válido se mede o que se espera que meça em termos do objeto ou fenômeno em questão (McDowell \& Newell, 1996). Desde que se tenha em mente certa constância do domínio de aplicação, a validade pode ser considerada uma propriedade do instrumento, havendo, pois, transposição para uma população externa àquela do estudo de validação do instrumento. Todavia, é imperioso distinguir entre a validade própria do instrumento e a da informação sobre o objeto-alvo, que é finalmente apreendida no estudo epidemiológico em questão. A validade da informação como um todo depende também da confiabilidade do processo de aferição (Streiner \& Norman, 2003). Se um instrumento considerado válido a priori tem, circunstancialmente, precária estabilidade e replicabilidade em conseqüência de mau desempenho dos entrevistadores, pode haver inadequação da informação captada, a despeito do potencial positivo do instrumento utilizado (Nunnally \& Bernstein, 1995; Pett, Lackey \& Sullivan, 2003). 
Existe uma distinção entre o processo de construção de variáveis representativas de construtos/dimensões teóricas - algo estritamente relacionado à validade operacional - e o processo de aferição (mensuração) de indivíduos em si. É possível conceber uma situação em que ocorra um problema de classificação devido ao uso de uma escala (variável) construída com base em itens (indicadores) inadequados, mesmo não havendo qualquer problema na aferição. Em contrapartida, mesmo diante de uma escala satisfatoriamente concebida e desenvolvida, nada impede que haja um problema de mensuração, levando a um problema na ordenação de indivíduos que potencialmente seriam escalonados de forma acertada. Ambas as situações levam a má classificação dos sujeitos estudados, o que afeta a validade do estudo. Chama-se atenção para a necessidade de explicitação destes dois importantes aspectos - a qualidade do instrumental e de sua aplicação -, não só para garantir a validade interna de um estudo epidemiológico, mas também para permitir a comparação do próprio estudo com achados obtidos em outras pesquisas.

Cabe ressaltar que tanto questōes relacionadas à validade operacional como à validade de mensuração têm sido pouco enfatizadas na prática e até, de certa forma, encaradas com descaso por muitos pesquisadores. Freqüentemente, ênfase é dada aos problemas relacionados aos desenhos de estudo e à análise de dados. Vale indagar, no entanto, para que servem um delineamento de estudo adequado e um tratamento de dados que utilize modelagem estatística sofisticada, se a qualidade das informações colhidas deixa a desejar. Esse quadro claramente merece reversão. É central que as estratégias de coleta de informação sejam planejadas cuidadosamente e se baseiem em premissas sólidas, envolvendo tanto as nuanças relacionadas à redução de conceitos a variáveis e indicadores como as inerentes ao processo de aferição.

Sublinhando a importância que merece ser dada à 'validade operacional' em estudos epidemiológicos, alguns dos pontos que permeiam essas reflexões são visitados a seguir. Este capítulo se concentra especificamente nas questôes relacionadas ao desenvolvimento de novos instrumentos de aferição. Um outro componente central no âmbito do desenvolvimento e consolidação de ferramentas de aferição, no entanto, concerne ao processo de adaptação transcultural de instrumentos propostos e estabelecidos em outros contextos lingüístico-socioculturais. Para obter mais informações sobre as diversas abordagens teóricas e operacionais, o leitor interessado pode consultar Guillemin, Bombardier \& Beaton (1993), Herdman, Fox-Hushby \& Badia (1998), Perneger, Leplège \& Etter (1999), Behling \& Law (2000), Beaton et al. (2000) e Reichenheim \& Moraes (2002). Um componente adicional para assegurar a qualidade de informação envolve as questōes sobre a mensuração em si. Detalhes podem ser encontrados em Moser \& Kalton (1984), Bowling (1997), Reichenheim \& Moraes (2002) e Streiner $\&$ Norman (2003).

Inicialmente são abordados, aqui, alguns pontos gerais relativos ao instrumental de aferição e que visam a situar o leitor quanto à necessidade de investir em uma adaptação transcultural ou, alternativamente, partir para o desenvolvimento de um novo instrumento, o tema central do presente capítulo. Em seguida, discutem-se as etapas mais relevantes para a construção desses instrumentos.

\section{Lidando com o Instrumental de Aferição}

Estudos epidemiológicos com pretensões explicativas (determinantes, fatores de risco ou proteção, fatores etiológicos etc.), a rigor, tendem a utilizar questionários. Comumente, estes são compostos por diferentes módulos, abarcando um ou mais construtos (dimensões) ${ }^{1}$ de um modelo teórico a ser testado. Nesse sentido, cada construto implica um instrumento epidemiológico que necessita ser incorporado ao questionário. ${ }^{2} \mathrm{O}$ primeiro passo para a construção de um questionário multitemático consiste em uma detalhada revisão bibliográfica envolvendo o escrutínio dos instrumentos disponíveis sobre cada um dos construtos de interesse. A compilação do histórico de cada instrumento candidato deve conter uma apreciação sobre o grau de utilização prévia e, principalmente, uma avaliação do estágio de desenvolvimento. Para isso, é crucial examinar as evidências de adequação e suficiência da 
trajetória psicométrica ${ }^{3}$ existente até então. Essa etapa serve para indicar ao pesquisador se realmente há ou não instrumentos satisfatórios para captar o objeto em pauta e, em se tratando daqueles desenvolvidos e consolidados fora da cultura em questão, se já passaram por um processo formal de adaptação transcultural. Por contraposição, a etapa também permite sugerir que se invista em um instrumental totalmente novo.

Mediante essa primeira e laboriosa etapa, o pesquisador pode decidir se, para um determinado construto, vale a pena admitir incondicionalmente um instrumento, se é preciso iniciar um programa de investigação ancilar de adaptação transcultural, ou, no extremo dos cenários, se há necessidade de partir para a construção de um novo instrumento. Em relação à última possibilidade, não deve passar ao largo o alerta de Streiner e Norman (2003) sobre a pletora de novos instrumentos, sempre considerados 'melhores' do que os antecedentes pelos seus proponentes. Sensatamente, os autores recomendam que o desenvolvimento de um instrumento original seja sempre a última opção, dando-se prioridade aos já existentes. Tempo 'perdido' com uma boa revisão bibliográfica é tempo 'ganho', por evitar que seja preciso investir no desenvolvimento de um novo instrumento que, como o leitor poderá perceber, não é uma tarefa trivial.

Alerta à parte, há ocasiōes em que a insuficiência de instrumentos de aferição pertinentes a um ou mais construtos é genuína. Se efetivamente é necessário investir na construção de um novo instrumento, é fundamental que o processo seja o mais rigoroso possível. Como detalhado a seguir, trata-se de um processo longo e trabalhoso que requer diversas etapas, envolvendo os próprios pesquisadores, especialistas e membros da população entre a qual o instrumento será aplicado (Streiner \& Norman, 2003).

\section{Desenvolvimento de um Instrumento Novo}

As diversas etapas do processo são sucintamente apresentadas no Quadro 1. O processo se inicia com a avaliação dos conceitos que subjazem às dimensōes componentes do construto de interesse. Adaptando-se a terminologia cunhada por Wilson (2005), esta etapa do processo poderia ser chamada de 'especificação do mapa do construto'. No entanto, diferentemente do referido autor, que limita o mapa do construto a apenas uma dimensão a cada vez, sugere-se um alargamento de limites para permitir que o processo não só procure delinear o gradiente de intensidade do objeto teórico dentro de uma dimensão precípua, mas também possibilite mapear as possíveis dimensões formadoras do conteúdo do construto como um todo. Assim, faz parte desta etapa entender, debater e demarcar o que Streiner e Norman (2003) chamam de espaço de conteúdo. Efetivamente, no momento dessa primeira apresentação de um perfil dimensional, ainda se trata de uma postulada validade de face (Streiner \& Norman, 2003), cuja corroboração ou refutação terá de ainda ser estabelecida mediante evidências psicométricas em fases posteriores do processo.

Uma vez mapeado o construto, passa-se para especificação e construção de seus indicadores manifestos, isto é, dos itens que comporão o instrumento. A esta etapa Wilson (2005) chama de "desenho de itens". Mesmo se tratando do desenvolvimento de uma ferramenta original, é boa prática que o processo retome a busca bibliográfica pela qual se julgou insuficiente o histórico dos instrumentos. A crítica aos já existentes permite evitar a repetição dos mesmos erros identificados no conjunto disponível, interessando identificar o que pode ser aproveitado das experiências anteriores. Contudo, não se trata de simplesmente enxertar itens antigos. Merece ser lembrado que estes não têm um significado nominal, mas servem para representar espaços de conteúdo do construto (dimensão) subjacente. Por conseguinte, não podem ser interpretados de forma isolada. Aproveitá-los dessa forma pode acarretar problemas de validade (Nunnally \& Bernstein, 1995).

$\mathrm{Na}$ fase inicial de busca de itens, é profícuo investir em estudos qualitativos, como, entre outros, os métodos de consenso pela técnica Delphi, o processo de grupos nominais ou o de grupos focais (Dawson, Manderson \& Tallo, 1992; Denzin \& Lincoln, 1994; Krueger, 1994; Bowling, 1997). Nas situaçôes em que nada ou pouco se sabe sobre como certo construto é percebido pela população-alvo, pode-se afirmar que estudos qualitativos são 
obrigatórios. A meta é identificar os itens que melhor representem os conceitos de interesse. Várias opções devem ser propostas para que uma crítica subseqüente avalie e selecione os mais interessantes. O principal desafio é especificar um conjunto que seja suficientemente completo para garantir a validade de conteúdo, mas não tão extenso a ponto de dificultar a aceitabilidade e aplicabilidade do instrumento.

Quadro 1 - Etapas envolvidas na elaboração de um novo instrumento

\begin{tabular}{|c|c|c|c|}
\hline & Etapas $^{a}$ & \multicolumn{2}{|c|}{ Estratégia de execução } \\
\hline \multirow{4}{*}{$\begin{array}{l}\text { Especificação do mapa } \\
\text { do construto }\end{array}$} & \multirow{4}{*}{$\begin{array}{l}\text { Explicitação dos conceitos, } \\
\text { identificando-se os construtos e } \\
\text { respectivas dimensões a } \\
\text { considerar }\end{array}$} & \multicolumn{2}{|l|}{ Revisão bibliográfica } \\
\hline & & \multicolumn{2}{|l|}{ Apreciação do modelo teórico do estudo } \\
\hline & & \multicolumn{2}{|c|}{ Identificação das dimensões que compõem o construto } \\
\hline & & \multicolumn{2}{|c|}{ Identificação do possível gradiente de intensidade do objeto teórico } \\
\hline \multirow{5}{*}{$\begin{array}{l}\text { Especificação do } \\
\text { desenho de itens }\end{array}$} & & Revisão bibliográfica & \multirow{5}{*}{$\begin{array}{l}\text { Pré-teste } \\
\text { Aplicação dos protótipos a } \\
\text { indivíduos da população- } \\
\text { alvo visando a avaliar } \\
\text { aceitabilidade, compreensão } \\
\text { e impacto emocional. }\end{array}$} \\
\hline & $\begin{array}{l}\text { Proposição de itens que } \\
\text { representem as dimensões a } \\
\text { estudar }\end{array}$ & $\begin{array}{l}\text { Discussão envolvendo pesquisadores, } \\
\text { outros especialistas e indivíduos da } \\
\text { população-alvo }\end{array}$ & \\
\hline & \multirow{3}{*}{$\begin{array}{l}\text { Seleção dos itens que comporão } \\
\text { as primeiras edições do } \\
\text { instrumento (protótipos) } \\
\text { Redação das perguntas }\end{array}$} & \multirow{3}{*}{$\begin{array}{l}\text { Discussão envolvendo pesquisadores e } \\
\text { outros especialistas } \\
\text { Pesquisadores } \\
\text { Discussão envolvendo pesquisadores e } \\
\text { indivíduos da população-alvo }\end{array}$} & \\
\hline & & & \\
\hline & & & \\
\hline $\begin{array}{l}\text { Especificação do } \\
\text { espaço de desfecho }\end{array}$ & $\begin{array}{l}\text { Discussão do sistema de } \\
\text { escores/opções de respostas }\end{array}$ & $\begin{array}{l}\text { Discussão envolvendo pesquisadores e } \\
\text { outros especialistas }\end{array}$ & \\
\hline \multirow{3}{*}{$\begin{array}{l}\text { Especificação do } \\
\text { modelo de medida }\end{array}$} & \multirow{3}{*}{$\begin{array}{l}\text { Avaliação das características } \\
\text { psicométricas dos protótipos }\end{array}$} & \multicolumn{2}{|c|}{ Avaliação de validade dimensional e adequação de itens componentes } \\
\hline & & \multicolumn{2}{|c|}{ Avaliação de confiabilidade (consistência interna, estabilidade temporal etc.) } \\
\hline & & \multicolumn{2}{|c|}{ Avaliação de validade de construto e de critério } \\
\hline \multirow{2}{*}{ Decisão } & Seleção do instrumento final & \multicolumn{2}{|c|}{ Discussão envolvendo pesquisadores e outros especialistas } \\
\hline & Estudos de corroboração & \multicolumn{2}{|c|}{ Utilização do instrumento em outros contextos de pesquisa } \\
\hline
\end{tabular}

a- Modelo e nomenclatura adaptados de Wilson (2005).

Tratado esse importante aspecto, passa-se ao aprimoramento e adequação semântica dos itens, estabelecendose uma ou mais alternativas de perguntas a serem testadas em seguida. Aqui interessa alcançar uma redação objetiva, clara, simples e curta, evitando-se frases ambíguas e com múltipla significação (Moser \& Kalton, 1984; Converse \& Presser, 1986; Streiner \& Norman, 2003). A literatura recomenda que a escolha dos termos considere as particularidades da população-alvo à qual o instrumento se dirige, com destaque para os de fácil compreensão, harmônicos com a cultura em questão e sem erudição supérflua. Também tem-se enfatizado que um bom texto deve evitar assertivas 'positivas' e 'negativas' inseridas no mesmo item, jargão profissional (por exemplo, médico) e coloquialismo (gírias) indevido. Quanto à seqüência de itens, recomenda-se que os mais delicados ou constrangedores sejam colocados no final do instrumento, ainda que exceçôes possam ser encontradas em certos casos. Por exemplo, no desenvolvimento do instrumento Revised Conflict Tactics Scales, usado para avaliar violência entre parceiros íntimos, chegou-se à conclusão de que intercalar itens de diversas intensidades (gravidades) seria a melhor forma de apresentá-los aos respondentes (Straus et al., 1996).

O passo seguinte consiste em especificar o "espaço do desfecho" (Wilson, 2005), isto é, cuidar da escalonabilidade de cada item. Para atribuir o status de validade aos instrumentos, é fundamental que estes sejam capazes de posicionar as unidades de aferição (células, indivíduos, municípios etc.) dentro do espaço de conteúdo do construto (dimen- 
são) e lhes atribuir valores e/ou categorias que permitam a demarcação de distâncias e importância. Nesse sentido, vale inicialmente sintonizar a metria interna de cada item com o que estipula o 'mapa do construto' subjacente delineado em etapas anteriores. A literatura sobre o assunto está repleta de técnicas e estratégias com vista à definição de opções de resposta (por exemplo, escalas visuais analógicas, adjetivais, Likert, diferenciais semânticas). Evidentemente, um aprofundamento está além do escopo deste texto, mas o leitor pode encontrar valiosos subsídios em Moser \& Kalton (1984), Converse \& Presser (1986), Streiner \& Norman (2003) e Wilson (2005).

Conforme indica o Quadro 1, as etapas de 'desenho de itens' e de especificação do 'espaço do desfecho' contemplam uma primeira visita ao campo, para que os primeiros lotes de protótipos (propostas alternativas) sejam submetidos a uma intensa avaliação de aceitabilidade, compreensão e impacto emocional. Uma técnica interessante no pré-teste é solicitar aos respondentes que parafraseiem cada item, devendo o entrevistador anotar em uma questão adicional se houve ou não compreensão de seus termos. Essa é também uma boa oportunidade para avaliar se as opções de resposta dos itens se adéquam ou não à população-alvo. Tantas 'séries' de n (por exemplo, 30) entrevistas são realizadas até que um percentual preestabelecido de ajustamento (entendimento) em todos os itens seja alcançado (por exemplo, $\geq 90 \%$ ). Essas avaliações interinas podem ser realizadas pela própria equipe de pesquisa ou, melhor ainda, por um grupo de especialistas no assunto convocados para tal. Com base nas evidências encontradas nesse pré-teste, são escolhidos os protótipos mais promissores, que são postos à prova subseqüentemente.

Parte-se, então, para a consolidação da escala, o que Wilson (2005) chama de "modelo de mensuração". Também reconhecida sob a designação de modelagem psicométrica, esta etapa visa a avaliar os instrumentoscandidatos em diferentes perspectivas. Primeiro, quanto à pertinência dos itens em relação ao construto e às dimensões componentes. É aqui que a validade de face do espaço de conteúdo postulada durante o mapeamento do construto é ou não corroborada. Cada item é testado, não só para avaliar seu peso na formação de uma escala dimensional, mas também se e o quanto contribui de forma exclusiva a apenas uma das escalas formadoras do construto (dimensão). Para além da métrica interna de cada item, também é nesta etapa do processo que se testa e se consolida o escore composto da escala. Nesse passo, procura-se estabelecer e garantir a escalonabilidade do conjunto de itens, independentemente de se a escala é constituída por um escore calculado diretamente com base nas análises multivariadas que subjazem ao processo; por um escore obtido por meio do somatório simples ou ponderado da pontuação dos itens componentes; ou ainda por transformaçóes desses escores, tais como percentis, escores-padrão, escores padronizados ou escores normalizados (Streiner \& Norman, 2003). Também é parte integral da psicometria a avaliação da confiabilidade potencial e da validade de construto e/ou de critério de cada escala em teste.

Uma síntese dos procedimentos envolvidos nas análises psicométricas está exposta nos Quadros 2 a 5 . Devido a restrições editoriais, o conteúdo é forçosamente restritivo e não exaustivo. Entretanto, pode servir como roteiro de aplicação, não só em relação aos objetivos e métodos de análise disponíveis, mas também quanto a uma possível seqüência de procedimentos. Claramente, não há como se apresentar e discutir os prós e os contras de cada método/técnica, mas o leitor poderá notar que estes, assim como alguns outros pontos importantes, podem ser encontrados na bibliografia.

No âmbito do desenvolvimento de instrumentos de 'conceptualização dimensional', a seqüência de quadros procura, esquematicamente, apresentar três enfoques psicométricos. Tão logo se encerra a etapa de especificação do espaço de conteúdo dos itens, a primeira tarefa consiste em corroborar a validade dimensional do instrumento e a adequação dos itens componentes. O Quadro 2 oferece alguns requisitos para que se possam julgar satisfatórias as escalas (e respectivos itens) de um instrumento. Métodos multivariados estão no âmago do processo. Este se inicia com uma Análise de Fatores Exploratória (AFE) (Gorsuch, 1983; Kline, 1994; Pett, Lackey \& Sullivan, 2003; Loehlin, 2004; Skrondal \& Rabe-Hesketh, 2004), ainda que, no contexto do desenvolvimento de instrumentos, já se tenha alguma estrutura postulada a priori quanto à dimensionalidade e aos itens participantes. 
Mesmo que a conotação de exploração seja um tanto nebulosa aqui, para que se possa implementar uma Análise de Fatores Confirmatória (AFC) (Maruyama, 1998; Loehlin, 2004; Skrondal \& Rabe-Hesketh, 2004; Kline, 2005) com bases firmes, é boa prática realizar uma AFE prévia. Primeiro, para explorar se efetivamente existe a estrutura multidimensional conjeturada, e segundo, para explorar o comportamento dos itens. Evidenciada uma inadequação, nada impede que já nesse ponto da seqüência se tenha de voltar para a 'prancheta', isto é, para fases anteriores com vista ao encontro de novos e melhores itens. O processo iterativo de todo o desenvolvimento é bem nítido.

Quadro 2 - Enfoque psicométrico I. Avaliação de validade dimensional e adequação de itens componentes

\begin{tabular}{|c|c|}
\hline Objetivos & Métodos e/ou estimadores \\
\hline \multirow[t]{2}{*}{$\begin{array}{l}\text { - Estabelecer a dimensionalidade (uni ou multi) } \\
\text { postulada na etapa de formulação do mapa do } \\
\text { construto, corroborando ou refutando a validade } \\
\text { de face postulada quanto aos espaços de } \\
\text { conteúdo do construto. }\end{array}$} & $\begin{array}{l}\text { - Análise de Fatores Exploratória (AFE) usando, por exemplo, o método de } \\
\text { fatoração por eixos principais com rotação ortogonal do tipo Varimax ou oblíqua } \\
\text { do tipo Oblimin (Gorsuch, 1983; Rummel, 1988; Comrey \& Lee, 1992; Kline, } \\
\text { 1994; Pett, Lackey \& Sullivan, 2003; Loehlin, 2004; Skrondal \& Rabe-Hesketh, } \\
\text { 2004). }\end{array}$ \\
\hline & Questões centrais a observar: \\
\hline \multirow{2}{*}{$\begin{array}{l}\text { - Identificar os itens mais profícuos em cada uma } \\
\text { das escalas dimensionais, escrutinando suas } \\
\text { propriedades psicométricas e decidindo pela sua } \\
\text { manutenção ou retirada da composição escalar. }\end{array}$} & - Número de fatores extraídos. \\
\hline & $\begin{array}{l}\text { - Magnitude das cargas (loadings) de cada item nos fatores (isto é, correlação entre } \\
\text { itens e fatores). Diversos pontos de corte podem ser utilizados, por exemplo, } \\
0,40 \text {. Veja Comrey \& Lee (1992) para detalhes. }\end{array}$ \\
\hline $\begin{array}{l}\text { - Reconhecer e estabelecer o espaço do desfecho } \\
\text { de cada escala, propondo uma métrica à } \\
\text { consolidação do escore final. }\end{array}$ & $\begin{array}{l}\text { - Presença ou não de cargas cruzadas (cross-loading), o que, a princípio, deve ser } \\
\text { evitado. Estratégias de decisão podem ser encontradas em Pett, Lackey \& Sullivan } \\
\text { (2003). }\end{array}$ \\
\hline \multirow{12}{*}{$\begin{array}{l}\text { - Apresentar uma ou mais escalas alternativas } \\
\text { para cada dimensão do construto, visando à } \\
\text { testagem subseqüente (confiabilidade e } \\
\text { validade de construto/critério). }\end{array}$} & $\begin{array}{l}\text { - Análise de Fatores Confirmatória (AFC) implementada no âmbito dos modelos de } \\
\text { equações estruturais (Bollen, 1989; Maruyama, 1998; Loehlin, 2004; Skrondal \& } \\
\text { Rabe-Hesketh, 2004; Kline, 2005). }\end{array}$ \\
\hline & Questões centrais a observar: \\
\hline & - Corroboração de ausência de cargas cruzadas. \\
\hline & - Grau de ajustes de modelo. \\
\hline & $\begin{array}{l}\text { - Padrão de dimensionalidade, que pode ser de quatro tipos: estrita, forte, } \\
\text { intermediária e fraca (veja Skrondal \& Rabe-Hesketh, 2004). }\end{array}$ \\
\hline & $\begin{array}{l}\text { - Análises via modelos de Teoria de Resposta ao Item (TRI) para o caso de escalas } \\
\text { formadas por itens dicótomos ou ordinais (Hambleton, Swaminathan \& Rogers, } \\
\text { 1991; Mellenbergh, 1994; Van der Linden \& Hambleton, 1996; Cella \& Chang, } \\
\text { 2000; Embretson \& Reise, 2000; Sijtsma \& Molenaar, 2002; Streiner \& Norman, } \\
\text { 2003; De Boeck \& Wilson, 2004; Skrondal \& Rabe-Hesketh, 2004; Wilson, } \\
\text { 2005). }\end{array}$ \\
\hline & Questões centrais a observar em cada escala dimensional: \\
\hline & - Corroboração de escalonabilidade dos itens. \\
\hline & - Capacidade discriminante dos itens. \\
\hline & $\begin{array}{l}\text { - Posicionamento absoluto e relativo dos itens ao longo do contínuo da variável } \\
\text { latente (dimensão) subjacente a que a escala do instrumento aspira captar, visando } \\
\text { a identificar a presença (indesejável) ou não (desejável) de lacunas de informação } \\
\text { ao longo do espectro. }\end{array}$ \\
\hline & - Grau de informatividade coberto pelos itens ao longo da escala. \\
\hline & - Precisão de informação ao longo do espectro (contínuo) da variável latente. \\
\hline
\end{tabular}


Ainda que não explícito no Quadro 2, o método de Teoria de Resposta ao Item (TRI) (Hambleton, Swaminathan \& Rogers, 1991; Van der Linden \& Hambleton, 1996; Cella \& Chang, 2000; Embretson \& Reise, 2000; Sijtsma \& Molenaar, 2002; Streiner \& Norman, 2003; De Boeck \& Wilson, 2004; Skrondal \& Rabe-Hesketh, 2004; Wilson, 2005) é, de fato, um tipo de AFC baseado em modelos não lineares, apropriado para escalas formadas por itens dicótomos ou ordinais. Além de se alcançar uma melhor especificação do modelo estatístico, uma análise via TRI permite também apreciar algumas propriedades psicométricas atraentes e proveitosas para uma escolha conscienciosa de itens (Reichenheim, Klein \& Moraes, 2007). Como indicado no Quadro 2, a TRI permite corroborar a presença de escalonabilidade conjunta dos itens; a capacidade discriminante de cada item; o posicionamento absoluto e relativo dos itens ao longo do contínuo da variável latente (dimensão) subjacente; a abrangência da informatividade dos itens ao longo da escala e a precisão da informação ao longo do espectro (contínuo) da variável latente.

Por mais que uma análise via TRI deva ser encorajada quando se está diante de itens binários ou ordinais, vale comentar que existe alternativa para acomodá-los em análises de fatores (AFE ou AFC), que, a rigor, utilizam matrizes de correlações que assumem distribuições gaussianas. Uma opção para contornar o real problema da má especificação de modelo ao se aplicar análises de fatores 'tradicionais' a dados discretos (Gorsuch, 1983; Rummel, 1988; Jöreskog \& Sörbom, 1996) é utilizar matrizes de correlações tetracóricas ou policóricas obtidas por transformaçōes prévias à submissão à análise (Divgi, 1979; Uebersax, 2006). Essas transformaçōes necessitam ser ativamente implementadas em alguns software como, por exemplo, [R] (Fox, 2006) e Stata (StataCorp, 2005; Kolenikov, 2006), ou já são usadas como default em outros como Lisrel 8 (Jöreskog \& Sörbom, 2004).

O segundo enfoque psicométrico envolve avaliações formais de confiabilidade das escalas obtidas após a 'depuração' dos itens e satisfatória evidência de dimensionalidade (Quadro 3). O objetivo é avaliar em que medida os escores de um instrumento (isto é, das escalas componentes) estão livres de erro aleatório (Pedhazur \& Schmelkin, 1991), o que, como dito anteriormente, serve não apenas para robustecer a qualidade do estudo relacionado ao desenvolvimento do instrumento em si, mas como uma instância de adequação processual. A longo prazo, uma série de estudos usando certo instrumento e revelando consistentemente uma boa confiabilidade da mensuração (informação) acaba também atestando sua qualidade. Evidências como essas acrescentam ao histórico do instrumento e podem ser benéficas à decisão sobre qual instrumento utilizar em uma pesquisa epidemiológica.

O Quadro 3 oferece várias referências que o leitor poderá consultar para obter mais detalhes sobre a finalidade, o mérito e os procedimentos concernentes a cada tipo de confiabilidade (consistência interna; estabilidade/reprodutibilidade intra ${ }^{4}$ ou interobservador; equivalência de formulários). Cabe aqui um comentário sobre a Teoria da Generalização (TG) desenvolvida por Cronbach e colaboradores (1972), cujo objetivo principal é oferecer uma elaborada sistemática para a redução das fontes de erros aleatórios de mensuração. No caso específico de estudos de desenvolvimento de instrumentos em que diferentes tipos de confiabilidade devem ser buscados, é possível obter uma análise 'unificada', na qual os componentes de erros são decompostos e cada aspecto ("faceta", no jargão da TG) é avaliado à luz da contribuição dos outros (Cronbach et al., 1972; Shavelson \& Webb, 1991; Nunnally \& Bernstein, 1995). Por extensão, é também possível obter um coeficiente de generalização que resume a fração de erro decorrente do conjunto de abordagens.

Mesmo que tenha sido possível identificar dimensionalidade, adequação de itens (em termos de variância compartilhada, como requer a análise de fatores) e confiabilidade, a validade de uma escala precisa ser avaliada explicitamente. Afinal, se um pesquisador visando a centralmente captar um construto $\mathrm{C}_{1}$ (por exemplo, 'apoio social') inadvertidamente arrolar uma gama de itens consistentemente atinada a um outro construto $\mathrm{C}_{2}$ (por exemplo, 'resiliência'), é bem plausível que os resultados obtidos nas análises psicométricas descritas anteriormente sejam bastante satisfatórios. Mas nem por isso o instrumento traz 'embutida' automaticamente a validade sobre o construto $\mathrm{C}_{1}$ em foco. Ainda que as situaçôes no dia-a-dia das pesquisas epidemiológicas sejam bem menos claras, o exemplo lembra que escrutinar a validade de um instrumento vai além das avaliações dos componentes 
'internos' de variância, requerendo um escrutínio adicional das covariações das escalas (dimensões) com outros elementos pertencentes ao quadro teórico subjacente. Como já mencionado, assumir validade de face (dos itens) importa nas fases inicias do programa de investigação para guiar as discussões e decisões de escolha dos protótipos de instrumentos a serem mais trabalhados. Mas, diferentemente do que muitos crêem, a validade de face não é suficiente, sendo necessários estudos aprofundados para corroborá-la.

Quadro 3 - Enfoque psicométrico II. Avaliação de confiabilidade

\begin{tabular}{|c|c|}
\hline Objetivos & Métodos e/ou estimadores \\
\hline \multirow[t]{3}{*}{$\begin{array}{l}\text { - Avaliar a consistência interna das escalas } \\
\text { identificadas anteriormente. }\end{array}$} & $\begin{array}{l}\text { - Análise via coeficiente } \alpha \text { para o caso de variáveis contínuas (Cronbach, } 1951 \text {; } \\
\text { Nunnally \& Bernstein, 1995; Osburn, 2000) ou coeficiente de Kuder Richardson, } \\
\text { Fórmula } 20 \text { no caso de variáveis discretas (Kuder \& Richardson, 1937; Streiner \& } \\
\text { Norman, 2003). Estimadores alternativos são descritos em Osburn (2000). Pontos } \\
\text { de corte de decisão (adequação) são discutidos em Nunnally \& Bernstein (1995). }\end{array}$ \\
\hline & $\begin{array}{l}\text { - Correlação entre cada item e o escore total sem o mesmo - item-resto (Nunnally } \\
\text { \& Bernstein, 1995). }\end{array}$ \\
\hline & $\begin{array}{l}\text { - Percentual de aumento ou redução do coeficiente } \alpha \text { ou kr-20 à retirada de cada } \\
\text { item da escala - p. ex., 10\% (Reichenheim \& Moraes, 2006). }\end{array}$ \\
\hline \multirow{3}{*}{$\begin{array}{l}\text { - Avaliar a estabilidade temporal (reprodutibilidade } \\
\text { intra-observador e teste-reteste) das escalas } \\
\text { identificadas anteriormente. } \\
\text { - Avaliar a estabilidade (reprodutibilidade } \\
\text { interobservador) das escalas identificadas } \\
\text { anteriormente. }\end{array}$} & $\begin{array}{l}\text { - Para o caso de variáveis contínuas: análise via correlações intraclasse (Shrout \& } \\
\text { Fleiss, 1979; Shrout, 1998; Streiner \& Norman, 2003), sendo a correlação de } \\
\text { Pearson e o coeficiente de concordância de Lin (1989) tipos especiais; ou ainda, } \\
\text { o método de Bland e Altman (1986). }\end{array}$ \\
\hline & $\begin{array}{l}\text { - Para o caso de variáveis discretas (dicótomas ou policótomas): análises de } \\
\text { concordância via estimador kappa simples ou ponderado (Cohen, 1960, 1968; } \\
\text { Fleiss, } 1981 \text {; Donner \& Eliasziw, 1992); ou, alternativamente, coeficiente kappa } \\
\text { ajustado para viés e prevalência (Byit, Bishop \& Carlin, 1993). Pontos de corte de } \\
\text { decisão (adequação) são discutidos em Landis \& Koch (1977) e Shrout (1998). }\end{array}$ \\
\hline & $\begin{array}{l}\text { - Estimadores alternativos são descritos em Cicchetti \& Feinstein (1990) e em uma } \\
\text { revisão de Elmore e Feinstein (1 992). }\end{array}$ \\
\hline $\begin{array}{l}\text { - Avaliar a equivalência (de formas) das escalas } \\
\text { identificadas anteriormente. }\end{array}$ & $\begin{array}{l}\text { - Análise pelo método de half-split, que consiste em estimar de forma sistemática } \\
\text { (exaustiva) as correlações entre escores de pares de subescalas (formas paralelas) } \\
\text { formadas pela metade dos itens constituintes da escala sob escrutínio (Pelt, Lackey } \\
\text { \& Sullivan, 2003; Streiner \& Norman, 2003). }\end{array}$ \\
\hline
\end{tabular}

Vários outros tipos além da validade de face têm sido definidos, propostos, utilizados e, até certo ponto, criticados (Streiner \& Norman, 2003). Entretanto, no âmbito do desenvolvimento de instrumentos que buscam conceptualizaçôes dimensionais, talvez seja de interesse enfatizar a perspectiva dada por Streiner \& Norman (2003), na qual estabelecer a validade de um instrumento, em última instância, é estabelecer a adequação da teoria que a suporta. Estudar a validade de um instrumento é estudar a própria teoria que a embasa, em ciclos de conjecturas e refutaçôes/corroborações. É um processo continuado pelo qual se determina o grau de credibilidade a ser atribuído a uma inferência com base na 'leitura' de uma escala (Landy, 1986; Streiner \& Norman, 2003).

Os Quadros 4 e 5 (página seguinte) explicitamente discernem duas situaçôes. A primeira, exposta no Quadro 4, concerne aos objetos de pesquisa em que não há consenso sobre o que seria a referência (ou padrãoouro) de aferição para o fenômeno de interesse ou quando não é possível defini-la de forma inequívoca. Construtos como 'auto-estima' e 'resiliência' são bons exemplos. Nessa situação, é preciso acessar a validade do construto. Avaliam-se as relações entre as dimensões supostamente captadas pelas diferentes escalas do instrumento, bem como as relaçôes com outros conceitos, atributos e características ligadas à teoria geral na qual se insere o construto sob escrutínio. O encontro de associaçôes previstas ou afinadas com evidências pregressas corrobora e reforça a validade do instrumento. Avaliar o inverso também é relevante, pois constatar a inexistência de relações entre os conceitos teóricos manifestos pelas escalas em pauta e certos construtos (escalas) reconhecidamente fora do escopo 
da teoria geral envolvendo o fenômeno de interesse também fortalece a idéia de validade do instrumento. Podese constatar que a validade de construto é a epítome de validade teórica.

Quadro 4 - Enfoque psicométrico III-a. Avaliação de validade de construto

\begin{tabular}{|c|c|}
\hline Objetivos & Métodos e/ou estimadores \\
\hline \multirow[t]{6}{*}{$\begin{array}{l}\text { Avaliar a validade de construto quando } \\
\text { não há instrumento de referência } \\
\text { (padrão-ouro) para o contraste. }\end{array}$} & $\begin{array}{l}\text { - Análise exploratória de associações via tabulações envolvendo duas ou três } \\
\text { variáveis (estratificada) e usando razão de risco/prevalência ou razão de produtos } \\
\text { cruzados (odds-ratio) como estimador; ou associações via coeficiente de } \\
\text { correlações de Pearson para variáveis contínuas (Armitage \& Berry, 1994) ou } \\
\text { coeficientes de correlação não paramétricos (teste de posição de Spearman outau-b } \\
\text { de kendall) para variáveis ordinais (Blalock Jr., 1985). }\end{array}$ \\
\hline & $\begin{array}{l}\text { - Análise epidemiológica multivariável complexa encerrando o quadro teórico- } \\
\text { conceitual do qual faz parte o construto (e suas respectivas dimensões) sob } \\
\text { escrutínio (Kleinbaum, Kupper \& Morgenstern, 1982; Rothman \& Greenland, } \\
\text { 1998; Skrondal \& Rabe-Hesketh, 2004). }\end{array}$ \\
\hline & $\begin{array}{l}\text { Questões centrais a observar (Cronbach \& Meehl, 1955; Streiner \& Norman, } \\
\text { 2003): }\end{array}$ \\
\hline & $\begin{array}{l}\text { - Se e como os conceitos teóricos manifestos pelas escalas dimensionais do } \\
\text { construto se relacionam entre si. }\end{array}$ \\
\hline & $\begin{array}{l}\text { - Se e como os conceitos teóricos manifestos pelas escalas dimensionais do } \\
\text { construto em pauta se relacionam com os outros conceitos prescritos ou postulados } \\
\text { pela teoria (validade convergente). }\end{array}$ \\
\hline & $\begin{array}{l}\text { - Se os conceitos teóricos manifestos pelas escalas dimensionais do construto em } \\
\text { pauta apropriadamente 'não' se relacionam a conceitos que a teoria da qual } \\
\text { fazem parte 'não' prescreve ou postula (validade divergente). }\end{array}$ \\
\hline
\end{tabular}

Ainda que não seja impeditivo buscar a validade de construto, quando existe um instrumento, exame ou teste de referência para contrastar o 'novo' instrumento em desenvolvimento, é próprio avaliar a validade de critério. Streiner e Norman (2003) distinguem a validade concorrente da preditiva. A classificação se baseia na finalidade da proposta e depende da cronologia de realização dos testes. A validade concorrente é admissível quando já se tem o resultado de um instrumento de referência na ocasião da aplicação do instrumento em teste e permite a apreciação da validade paralelamente à sua aplicação. A validade preditiva só é possível quando as informações auferidas por meio do instrumento de referência são obtidas tempos depois da aplicação do instrumento em teste.

Comumente, estudos de validade de critério são bastante utilizados quando é de interesse maximizar custo-benefício, prever e planejar ações sanitárias, seja reduzindo o próprio instrumento considerado de referência ou propondo um completamente diferente, mas que ainda permita reter a capacidade de classificação original. Contudo, vistas na ótica precípua do contexto de desenvolvimento de um instrumento de conceptualização dimensional (e que não necessariamente pretenda ser uma redução de outro maior, nem uma ferramenta de finalidade pragmática), avaliações da capacidade discriminante das escalas de um instrumento podem ser extremamente esclarecedoras. Saber que um instrumento de aplicação em estudos epidemiológicos não só capta o contínuo da variável latente subjacente, mas também está substantivamente 'colado' ao que um exame ou instrumento de referência encontraria é claramente profícuo e atraente. Os procedimentos apresentados no Quadro 5 são exemplos a serem contemplados. 
Quadro 5 - Enfoque psicométrico III-b. Avaliação de validade de critério

\begin{tabular}{|c|c|}
\hline Objetivos & Métodos e/ou estimadores \\
\hline \multirow[t]{10}{*}{$\begin{array}{l}\text { Avaliar a validade de critério (concorrente e } \\
\text { preditiva) quando há um instrumento de referência } \\
\text { (padrão-ouro) para o contraste. }\end{array}$} & $\begin{array}{l}\text { - Para o caso de se testar uma escala de conceptualização dimensional usando-se } \\
\text { o escore completo em relação a um instrumento ou exame de referência de metria } \\
\text { contínua: }\end{array}$ \\
\hline & $\begin{array}{l}\text { - Análise via correlações intraclasse (Bartko, 1976; Shrout \& Fleiss, 1979; Shrout, } \\
\text { 1998; Streiner \& Norman, 2003), entendendo-se que se está avaliando o grau de } \\
\text { concordância do instrumento 'novo' sob escrutínio com uma medida 'infalível' de } \\
\text { referência. }\end{array}$ \\
\hline & $\begin{array}{l}\text { - Análises via correlação de Pearson também têm sido implementadas em } \\
\text { avaliações de concordância, mas seu uso nesse contexto requer alguma reserva. } \\
\text { Veja Bartko (1976), Bland \& Altman (1986) ou Streiner \& Norman (2003) para } \\
\text { detalhes. No contexto da epidemiologia nutricional, veja Willett \& Lenart (1998) } \\
\text { para uma discussão sobre este tópico. }\end{array}$ \\
\hline & $\begin{array}{l}\text { - Para o caso de se testar a escala de conceptualização dimensional usando-se o } \\
\text { escore completo em relação a um instrumento ou exame de referência de metria } \\
\text { dicółoma: }\end{array}$ \\
\hline & $\begin{array}{l}\text { - Análise via curvas ROC (Receiver Operating Characteristic analysis) (Tanner \& } \\
\text { Swets, 1954; Hanley \& McNeil, 1982; Streiner \& Norman, 2003), observando-se } \\
\text { em particular a área abaixo da curva ROC, que indica o grau de discriminação } \\
\text { da escala em teste em relação ao instrumento de referência. }\end{array}$ \\
\hline & $\begin{array}{l}\text { - Para o caso de se testar uma escala de conceptualização dimensional usando-se } \\
\text { o escore completo em relação a um instrumento ou exame de referência de metria } \\
\text { em mais de dois níveis: }\end{array}$ \\
\hline & $\begin{array}{l}\text { - Análise via curvas ROC (Tanner \& Swets, 1954; Hanley \& McNeil, 1982; Streiner } \\
\& \text { Norman, 2003) entre níveis crescentes (em gradação, por exemplo), nível } 1 \text { vs } 2 \\
+3 \text { e } 1+2 \text { vs 3) do instrumento de referência, observando-se o grau de } \\
\text { discriminação em relação a cada ponto de corte através da área abaixo da curva } \\
\text { ROC. }\end{array}$ \\
\hline & $\begin{array}{l}\text { - Uma vez identificado um grau de discriminação satisfatório do conjunto, } \\
\text { identificam-se os pontos de corte de máxima discriminação do instrumento em } \\
\text { teste, respeitando-se o número de categorias do instrumento de referência. Cria-se } \\
\text { uma variável policótoma de tantos níveis quantos os da variável de referência e } \\
\text { prossegue-se com as análises via índices de sensibilidade e especificidade (Sackett } \\
\text { et al., } 1991 \text {; Choi, 1992; Fletcher \& Fletcher, 2006) obtidas com base em tabelas } \\
\text { 2'2, formadas pelas tabulações de variáveis derivadas, tal como se procedeu nas } \\
\text { análises via curvas ROC descritas anteriormente. }\end{array}$ \\
\hline & $\begin{array}{l}\text { - Para o caso de análises via índices de sensibilidade e especificidade segundo } \\
\text { subgrupos/estratos populacionais, pode-se usar modelagem multivariável } \\
\text { (Coughlin et al., 1992). }\end{array}$ \\
\hline & $\begin{array}{l}\text { - Alternativamente aos índices de sensibilidade e especificidade simples, podem-se } \\
\text { usar (a) análises via índices de sensibilidade e especificidade corrigidos por } \\
\text { concordância aleatória (Coughlin \& Pickle, 1992); (b) o método de razão de } \\
\text { verossimilhança (Sackett et al., 1991) ou (c) o coeficiente Phi de concordância } \\
\text { (Streiner \& Norman, 2003), novamente entendendo-se que se está avaliando o } \\
\text { grau de concordância entre uma medida 'infalível' de referência e o instrumento } \\
\text { 'novo' sob escrutínio. }\end{array}$ \\
\hline
\end{tabular}


Por fim, vale lembrar que o processo de avaliação da qualidade de um novo instrumento não se esgota no primeiro estudo que o utiliza. Mesmo que as evidências iniciais tenham sugerido validade, é capital que se conheça seu desempenho em outros contextos. Uma primeira edição necessita ser continuamente posta à prova pelos profissionais interessados. A vasta gama de detalhes e opções, muitas intrinsecamente subjetivas, demanda que o aprimoramento do novo instrumento dependa de debates e negociaçóes contínuas entre pares.

\section{Notas}

1 Distingue-se, aqui, 'construto' de 'dimensão', entendendo-se que um construto pode ser composto de várias dimensões. Por extensão, entende-se que uma dimensão tem na escala o seu representante empírico que, por sua vez, tem no escore a ordenação numérica subjacente.

2 Da mesma forma, distingue-se 'instrumento' de 'questionário', convencionando chamar de questionário o conjunto de instrumentos específicos que, por sua vez, abarcam construtos/dimensões específicos.

3 Entende-se pelo termo 'psicométrica (psicométrico/psicometria)' um conjunto de avaliações quantitativas visando ao escrutínio das propriedades de mensuração de um instrumento. Apesar de ter sido inicialmente proposto e usado no contexto da psicologia e psiquiatria, o termo tem sido largamente utilizado fora dessas áreas.

4 No contexto de instrumentos de autopreenchimento ou laboratoriais, a confiabilidade intra-observador tem sido denominada 'teste-reteste'.

\section{Referências}

ALMEIDA FILHO, N. Epidemiologia sem Números: uma introdução crítica à ciência epidemiológica. Rio de Janeiro: Campus, 1989.

ARMITAGE, P. \& BERRY, G. Statistical Methods in Medical Research. 3. ed. London: Blackwell Scientific Publications, 1994.

BARTKO, J. J. On various intraclass correlation reliability coefficients. Psychological Bulletin, 83: 762-765, 1976.

BEATON, D. E. et al. Guidelines for the process of cross-cultural adaptation of self-report measures. Spine, 25: 3.186-3.191, 2000.

BEHLING, O. \& LAW, K. S. Translating Questionnaires and Other Research Instruments. Thousand Oaks: Sage Publications, 2000. v. 133.

BLALOCK JR., H. M. Social Statistics. 2. ed. London: McGraw-HillBook Company, 1985.

BLAND, J. M. \& ALTMAN, D. G. Statistical methods for assessing agreement between two methods of clinical measurement. The Lancet, 8: 307-310, 1986.

BOLLEN, K. A. Structural Equations with Latent Variables. New York: John Wiley \& Sons, 1989.

BOND, M. J.; MCDOWELL, A. J. \& WILKINSON, J. Y. The measurement of dietary restraint, disinhibition and hunger: an examination of the factor structure of the Three Factor Eating Questionnaire (TFEQ). International Journal of Obesity and Related Metabolic Disorders, 25: 900-906, 2001.

BOWLING, A. Research Methods in Health: investigating health and health services. Buckingham: Open University Press, 1997. 
BURROWS, A. \& COOPER, M. Possible risk factors in the development of eating disorders in overweight preadolescent girls. International Journal of Obesity and Related Metabolic Disorders, 26: 1.268-1.273, 2002.

BYRT, T.; BISHOP, J. \& CARLIN, J. B. Bias, prevalence and kappa. Journal of Clinical Epidemiology, 46: 423429, 1993.

CARROLL, R. J.; RUPPERT, D. \& STEFANSKI, L. A. Measurement Errors in Nonlinear Models. London: Chapman and Hall, 1995.

CELLA, D. \& CHANG, C. H. A discussion of item response theory and its application in health status assessment. Medical Care, 38, suppl. II: 66-72, 2000.

CHOI, B. C. K. Sensitivity and specificity of a single diagnostic test in the presence of work-up bias. Journal of Clinical Epidemiology, 45: 581-586, 1992.

CHOR, D. et al. Medidas de rede e apoio social no Estudo Pró-Saúde: pré-testes e estudo piloto. Cadernos de Saúde Pública, 17: 887-896, 2001.

CICCHETTI, D. V. \& FEINSTEIN, A. R. High agreement but low kappa: II. Resolving the paradoxes. Journal of Clinical Epidemiology, 43: 551-558, 1990.

COHEN, J. A coefficient of agreement for nominal scales. Educational and Psychological Measurement, 20: 37 46, 1960.

COHEN, J. Weighted kappa: nominal scale agreement with provision for scaled disagreement or partial credit. Psychological Bulletin, 70: 213-220, 1968.

COMREY, A. L. \& LEE, H. B. A First Course in Factor Analysis. Hillsdale: Lawrence Erlbaum, 1992.

CONVERSE, J. M. \& PRESSER, S. Survey Questions: handcrafting the standardized questionnaire. London: Sage Publication, 1986. v. 63.

COUGHLIN, S. S. \& PICKLE, L. W. Sensitivity and specificity-like measures of the validity of a diagnostic test that are corrected for chance agreement. Epidemiology, 3: 178-181, 1992.

COUGHLIN, S. S. et al. The logistic modeling of sensitivity, specificity and predictive value of a diagnostic test. Journal of Clinical Epidemiology, 45: 1-7, 1992.

CRONBACH, L. J. Coefficient alpha and the internal structure of tests. Psychometrika, 16: 297-334, 1951.

CRONBACH, L. J. \& MEEHL, P. E. Construct validity in psychological tests. Psychological Bulletin, 52: 281302, 1955.

CRONBACH, L. J. et al. The Dependability of Behavioral Measurement: theory of generalizability for scores and profiles. New York: Wiley \& Sons, 1972.

DAWSON, S.; MANDERSON, L. \& TALLO, V. Social and Economic Research (SER): the Focus Group Manual. Geneva: World Health Organization, 1992.

DE BOECK, P. \& WILSON, M. Explanatory Item Response Models: a generalized linear and nonlinear approach. New York: Springer, 2004.

DE LAUZON, B. et al. The Three-Factor Eating Questionnaire-R18 is able to distinguish among different eating patterns in a general population. Journal of Nutrition, 134: 2.372-2.380, 2004. 
DENZIN, N. K. \& LINCOLN, Y. S. Handbook of Qualitative Research. London: Sage Publication, 1994.

DIVGI, D. R. Calculation of the tetrachoric correlation coefficient. Psychometrika, 44: 169-172, 1979.

DONNER, A. \& ELIASZIW, M. A goodness-of-fit approach to inference procedures for the kappa statistic: confidence interval construction, significance-testing and sample size estimation [see comments]. Statistics in Medicine, 11: 1.511-1.519, 1992.

DUNN, G. Design and Analysis of Reliability Studies: the statistical evaluation of measurement errors. New York: Oxford University Press, 1989.

ELMORE, J. G. \& FEINSTEIN, A. R. A bibliography of publications on observer variability (final installment). Journal of Clinical Epidemiology, 45: 567-580, 1992.

EMBRETSON, S. E. \& REISE, S. P. Item Response Theory for Psychologists. Maheah: Lawrence Erlbaum Associates Publishers, 2000.

FLEISS, J. L. Statistical Methods for Rates and Proportions. 2. ed. New York: John Wiley \& Sons, 1981.

FLETCHER, R. H. \& FLETCHER, S. W. Epidemiologia Clínica: elementos essenciais. 4. ed. São Paulo: Artmed, 2006.

FOX, J. Polycor: polychoric and polyserial correlations, function for [R] (0.7-2). CRAN (R-project). 19 Oct. Disponível em: <www.cran.r-project.org/src/contrib/Descriptions/polycor.html>. Acesso em: 19 nov. 2006.

GORSUCH, R. L. Factor Analysis. 2. ed. Hillsdal: Lawrence Erlbaum, 1983.

GREENLAND, S. \& BRUMBACK, B. An overview of relations among causal modelling methods. International Journal of Epidemiology, 31: 1.030-1.037, 2002.

GUILLEMIN, F.; BOMBARDIER, C. \& BEATON, D. Cross-cultural adaptation of health-related quality of life measures: literature review and proposed guidelines. Journal of Clinical Epidemiology, 46: 1.417-1.432, 1993.

HAMBLETON, R. K.; SWAMINATHAN, H. \& ROGERS, H. J. Fundamentals of Item Response Theory. Newbury Park: Sage, 1991.

HANLEY, J. A. \& MCNEIL, B. J. The meaning and use of the area under a receiver operating characteristic (ROC) curve. Radiology, 143: 29-36, 1982.

HERDMAN, M.; FOX-RUSHBY, J. \& BADIA, X. A model of equivalence in the cultural adaptation of HRQoL instruments: the universalist approach. Quality of Life Research, 7: 323-335, 1998.

JÖRESKOG, K. G. \& SÖRBOM, D. LISREL 8 User's Reference Guide. Chicago: Scientific Software International, 1996.

JÖRESKOG, K. G. \& SÖRBOM, D. Interactive LISREL 8.7. Chicago: Scientific Software International, 2004.

KLEINBAUM, D. G.; KUPPER, L. L. \& MORGENSTERN, H. Epidemiologic Research: principles and quantitative methods. New York: Van Nostrand Reinhold Company, 1982.

KLINE, P. An Easy Guide to Factor Analysis. 2. ed. New York: Routledge, 1994.

KLINE, R. B. Principles and Practice of Structural Equation Modeling. 2. ed. London: The Guilford Press, 2005.

KOLENIKOV, S. Polychoric: the polychoric correlation package for Stata Statistical Software. Release, 8(1.4), 2006. Disponível em: <www.unc.edu/ skolenik/stata>. Acesso em: 10 nov. 2006. 
KRIEGER, N. \& ZIERLER, S. The need for epidemiologic theory. Epidemiology, 8: 212-213, 1997.

KRUEGER, R. Focus Groups: a practical guide for applied research. 2. ed. London: Sage Publications, 1994.

KRUG, E. G. et al. World Report on Violence and Health. Geneva: World Health Organization, 2002.

KUDER, G. F. \& RICHARDSON, M. W. The theory of estimation of test reliability. Psychometrika, 2: 151$160,1937$.

LANDIS, J. R. \& KOCH, G. G. The measurement of observer agreement for categorical data. Biometrics, 33: 159-174, 1977.

LANDY, F. J. Stamp collection versus science. American Psychologist, 35: 1.012-1.027, 1986.

LIN, L. I. K. A concordance correlation coefficient to evaluate reproducibility. Biometrics, 45: 255-268, 1989.

LOEHLIN, J. C. Latent Variable Models. An Introduction to Fator, Path and Structural Equation Analysis. 4. ed. Mahwah: Lawrence Erlbaum Associates Publishers, 2004.

LUIZ, R. R. \& STRUCHINER, C. J. Infererência Causal em Epidemiologia. Rio de Janeiro: Editora Fiocruz, 2002.

MARUYAMA, G. M. Basics of Structural Equation Modeling. Thousand Oaks: Sage Publications, 1998.

MCDOWELL, I. \& NEWELL, C. Measuring Health: a guide to rating scales and questionnaires. 2. ed. New York: Oxford University Press, 1996.

MELLENBERGH, G. J. Generalized linear item response theory. Psychological Bulletin, 115: 300-307, 1994.

MIETTINEN, O. Theoretical Epidemiology: principles of occurrence research in medicine. New York: John Wiley \& Sons, 1985.

MORAES, C. L. \& REICHENHEIM, M. E. Cross-cultural measurement equivalence of the Revised Conflict Tactics Scales (CTS2) Portuguese version used to identify violence within couples. Cadernos de Saúde Pública, 18: 783-796, 2002.

MOSER, C. A. \& KALTON, G. Survey Methods in Social Investigation. 2. ed. London: Heinemann, 1984.

NUNNALLY, J. C. J. \& BERNSTEIN, I. Psychometric Theory. 2. ed. New York: McGraw-Hill, 1995.

OSBURN, H. G. Coefficient alpha and related internal consistency reliability coefficients. Psychological Methods, 5: 343-355, 2000.

PEARL, J. Causality: models, reasoning, and inference. Cambridge: Cup, 2000.

PEDHAZUR, E. J. \& SCHMELKIN, L. P. Measurement, Design, and Analysis: an integrated approach. Illsdale: Lawrence Erlbaum, 1991.

PERNEGER, T. V.; LEPLÈGE, A. \& ETTER, J. F. Cross-cultural adaptation of a psychometric instrument: two methods compared. Journal of Clinical Epidemiology, 52: 1.037-1.046, 1999.

PESCE, R. P. et al. Adaptação transcultural, confiabilidade e validade da Escala de Resiliência. Cadernos de Saúde Pública, 21: 436-448, 2005.

PETT, M. A.; LACKEY, N. R. \& SULLIVAN, J. J. Making Sense of Factor Analysis: the use of factor analysis for instrument development in health care research. Thousand Oaks: Sage Publication, 2003.

REICHENHEIM, M. E. \& MORAES, C. L. Alguns pilares para a apreciação da validade de estudos epidemiológicos. Revista Brasileira de Epidemiologia, 1: 131-148, 1998. 
REICHENHEIM, M. E. \& MORAES, C. L. Buscando a qualidade das informaçôes em pesquisas epidemiológicas. In: MINAYO, M. C. S. \& DESLANDES, S. F. (Orgs.) Caminhos do Pensamento: epistemologia e método. Rio de Janeiro: Editora Fiocruz, 2002.

REICHENHEIM, M. E. \& MORAES, C. L. Psychometric properties of the Portuguese version of the Conflict Tactics Scales: Parent-child Version (CTSPC) used to identify child abuse. Cadernos de Saúde Pública, 22: 503-515, 2006.

REICHENHEIM, M. E.; KLEIN, R. \& MORAES, C. L. Assessing the physical violence component of the Revised Conflict Tactics Scales when used in heterosexual couples: an item response theory analysis. Cadernos de Saúde Pública, 23: 53-62, 2007.

ROTHMAN, K. J. \& GREENLAND, S. Modern Epidemiology. 2. ed. Philadelphia: Lippincott-Raven Publishers, 1998.

ROTHMAN, K. J. \& GREENLAND, S. Causation and causal inference in epidemiology. American Journal of Public Health, 95, suppl. 1: S144-S150, 2005.

RUMMEL, R. J. Applied Factor Analysis. 4. ed. Evanston: Northwest University Press, 1988.

SACKETT, D. L. et al. Clinical Epidemiology: a basic science for clinical medicine. 2. ed. Boston: Little, Brown \& Co, 1991.

SCHMITT, D. P. \& ALLIK, J. Simultaneous administration of the Rosenberg Self-Esteem Scale in 53 nations: exploring the universal and culture-specific features of global self-esteem. Journal of Personality and Social Psychology, 89: 623-642, 2005.

SHAVELSON, R. J. \& WEBB, N. M. Generalizability Theory: a primer. Newbury Park: Sage Publications, 1991.

SHERBOURNE, C. D. \& STEWART, A. L. The MOS social support survey. Social Science and Medicine, 32: 705-714, 1991.

SHROUT, P. E. Measurement reliability and agreement in psychiatry. Statistical Methods in Medical Research, 7: 301-317, 1998.

SHROUT, P. E. \& FLEISS, J. L. Intraclass correlations: uses in assessing rater reliability. Psychological Bulletin, 86: 420-428, 1979.

SIJTSMA, K. \& MOLENAAR, I. W. Introduction to Nonparametric Item Response Theory. Thousand Oaks: Sage Publications, 2002.

SKRONDAL, A. \& RABE-HESKETH, S. Generalized Latent Variable Modeling: multilevel, longitudinal, and structural equation models. Boca Raton: Chapman \& Hall, CRC, 2004.

STATACORP. tetrachoric. Tetrachoric correlations for binary variables. Program in Stata Statistical Software, Release 9. College Station (TX): Stata Corporation, 2005.

STEINECK, G. \& AHLBOM, A. A definition of bias founded on the concept of the study base. Epidemiology, 3: 477-482, 1992.

STRAUS, M. A. et al. The revised Conflict Tactics Scales (CTS2): Development and preliminary psychometric data. Journal of Family Issues, 17: 283-316, 1996.

STREINER, D. L. \& NORMAN, G. R. Health Measurement Scales. A Practical Guide to Their Development and Use. 3. ed. Oxford: Oxford University Press, 2003. 
TANNER, W. P. J. \& SWETS, J. A. A decision making theory of visual detection. Psychological Review, 61: 401409, 1954.

TEIXEIRA-SALMELA, L. F. et al. Adaptação do Perfil de Saúde de Nottingham: um instrumento simples de avaliação da qualidade de vida. Cadernos de Saúde Pública, 20: 905-914, 2004.

UEBERSAX, J. S. The tetrachoric and polychoric correlation coefficients. Statistical Methods for Rater Agreement web site. Disponível em: <http://ourworld.compuserve.com/homepages/jsuebersax/tetra.htm>. Acesso em: 11 nov. 2006.

VAN DER LINDEN, W. J. \& HAMBLETON, R. K. Handbook of modern item response theory. New York: Springer, 1996.

VAN STRIEN, T. et al. The validity of dietary restraint scales: comment on Stice et al. (2004). Psychological Assessment, 18: 89-94, 2006.

VEREECKEN, C. A.; VAN DAMME, W. \& MAES, L. Measuring attitudes, self-efficacy, and social and environmental influences on fruit and vegetable consumption of 11- and 12-year-old children: reliability and validity. Journal of the American Dietetic Association, 105: 257-261, 2005.

WAGNILD, G. M. \& YOUNG, H. M. Development and psychometric evaluation of the Resilience Scale. Journal of Nursing Measurement, 1: 165-178, 1993.

WEED, D. L. Theory and practice in epidemiology. Annals of the New York Academy of Sciences, 954: 52-62, 2001.

WHATI, L. H. et al. Development of a reliable and valid nutritional knowledge questionnaire for urban South African adolescents. Nutrition, 21: 76-85, 2005.

WILLETT, W. \& LENART, E. Reproducibility and validity of food-frequency questionnaires. In: WILLETT, W. (Ed.) Nutritional Epidemiology. 2. ed. New York: Oxford University Press, 1998.

WILSON, M. Constructing measures. An Item Response Modeling Approach. Mahwah: Lawrence Erlbaum Associates Publishers, 2005.

WILSON, M. M. et al. Appetite assessment: simple appetite questionnaire predicts weight loss in communitydwelling adults and nursing home residents. American Journal of Clinical Nutrition, 82: 1.074-1.081, 2005.

WRIGHT, C. M.; PARKINSON, K. N. \& DREWETT, R. F. How does maternal and child feeding behavior relate to weight gain and failure to thrive? Data from a prospective birth cohort. Pediatrics, 117: 1.262-1.269, 2006.

ZINN, C.; SCHOFIELD, G. \& WALL, C. Development of a psychometrically valid and reliable sports nutrition knowledge questionnaire. Journal of Science and Medicine in Sport, 8: 346-351, 2005. 



\title{
14
}

\section{Análise de Dados com Medidas Repetidas}

\author{
Maria Helena Constantino Spyrides, Cláudio José Struchiner, \\ Maria Tereza Serrano Barbosa e Gillberto Kac
}

interesse de pesquisadores em estudos epidemiológicos por acompanhar o comportamento de determinadas variáveis medidas em um mesmo indivíduo ou unidade experimental ao longo do tempo é muito comum. Estudos de crescimento infantil, ganho de peso gestacional, retenção de peso pós-parto, composição corporal, evolução de taxas hormonais em mulheres em período reprodutivo, acompanhamento da carga viral em pacientes com HIV são alguns exemplos da aplicação de medidas repetidas no tempo.

Os estudos que envolvem o acompanhamento repetido dessas medidas procuram, desde o seu planejamento, controlar ao máximo as diversas fontes de variação envolvidas no processo, buscando encontrar um padrão para o comportamento das medidas no tempo e identificar os fatores que influenciam este padrão.

Assim, a análise estatística que vai auxiliar nessa busca precisa levar em consideração que tais medidas apresentam dependência entre as observações de um mesmo indivíduo e não podem se encaixar na suposição estatística usual de que são independentes. Além disso, o outro pressuposto básico de alguns modelos estatísticos que se refere à igualdade das distribuições entre os indivíduos também não se aplica, considerando-se que há uma variabilidade individual decorrente de fatores não mensurados.

Os modelos de efeitos mistos são atualmente um dos mais importantes instrumentos para a análise de dados epidemiológicos longitudinais. Esses modelos incluem a estimação de efeitos comuns para indivíduos de um mesmo grupo (efeitos fixos) e efeitos específicos por indivíduo (efeitos aleatórios) que permitem controlar a variação existente entre indivíduos e podem ser provenientes de fontes de variação não controladas no estudo.

Esse tipo de modelagem tem recebido uma grande atenção nos últimos anos, já que seus pressupostos se ajustam mais ao grau de conhecimento biológico e à realidade dos experimentos, permitindo que a estimação dos efeitos capte mudanças nas respostas individuais do grupo estudado.

Este capítulo, inicialmente, introduz o conceito de medidas repetidas no tempo ou dados longitudinais, com subseqüente ilustração da aplicação destes estudos com um exemplo em epidemiologia nutricional. As características dos dados longitudinais abordados na seção seguinte são importantes no acompanhamento de estudos, pois alertam para as dificuldades e cuidados a serem tomados durante a coleta da informação. 


\section{Medidas Repetidas}

O que são medidas repetidas em um estudo? As observações de um desfecho ou resposta coletadas sobre uma mesma unidade experimental ou indivíduo em duas ou mais ocasiōes ou condições denominam-se medidas repetidas.

As medidas podem ser repetidas:

- apenas no tempo, ao se medir e pesar os recém-nascidos nos seus primeiros meses de vida;

- no tempo e no espaço, simultaneamente, ao se medir taxas de mortalidade infantil ou neonatal em diversos anos e em diversos bairros ou municípios, com o intuito de identificar padrões espaciais diferenciados de mortalidade;

- em distintas condições experimentais, quando um mesmo paciente é submetido a dois tipos de tratamento.

Em estudos longitudinais, os indivíduos ou unidades são monitorados em um determinado período, com o objetivo de identificar um padrão nos valores observados. As medidas repetidas no tempo de marcadores imunológicos e virológicos de pacientes com infecção do HIV, por exemplo, têm um papel importante na avaliação tanto da história natural da doença como da resposta ao tratamento. Estas medidas repetidas ao longo do tempo denominam-se dados longitudinais.

\section{Aplicação em Nutrição}

Foram acompanhadas 479 crianças em um centro de saúde do Rio de Janeiro, através de um estudo longitudinal envolvendo quatro ondas de seguimento: 0,5, 2, 6 e 9 meses. As variáveis dependentes foram o peso e o comprimento, coletados de acordo com procedimentos padronizados em todos os pontos do estudo. Os principais objetivos foram avaliar o efeito da duração da amamentação predominante sobre o perfil antropométrico e identificar os determinantes do crescimento infantil nessa coorte de crianças.

Figura 1 - Comportamento individual do peso infantil (kg) por idade, Rio de Janeiro, 1999-2001

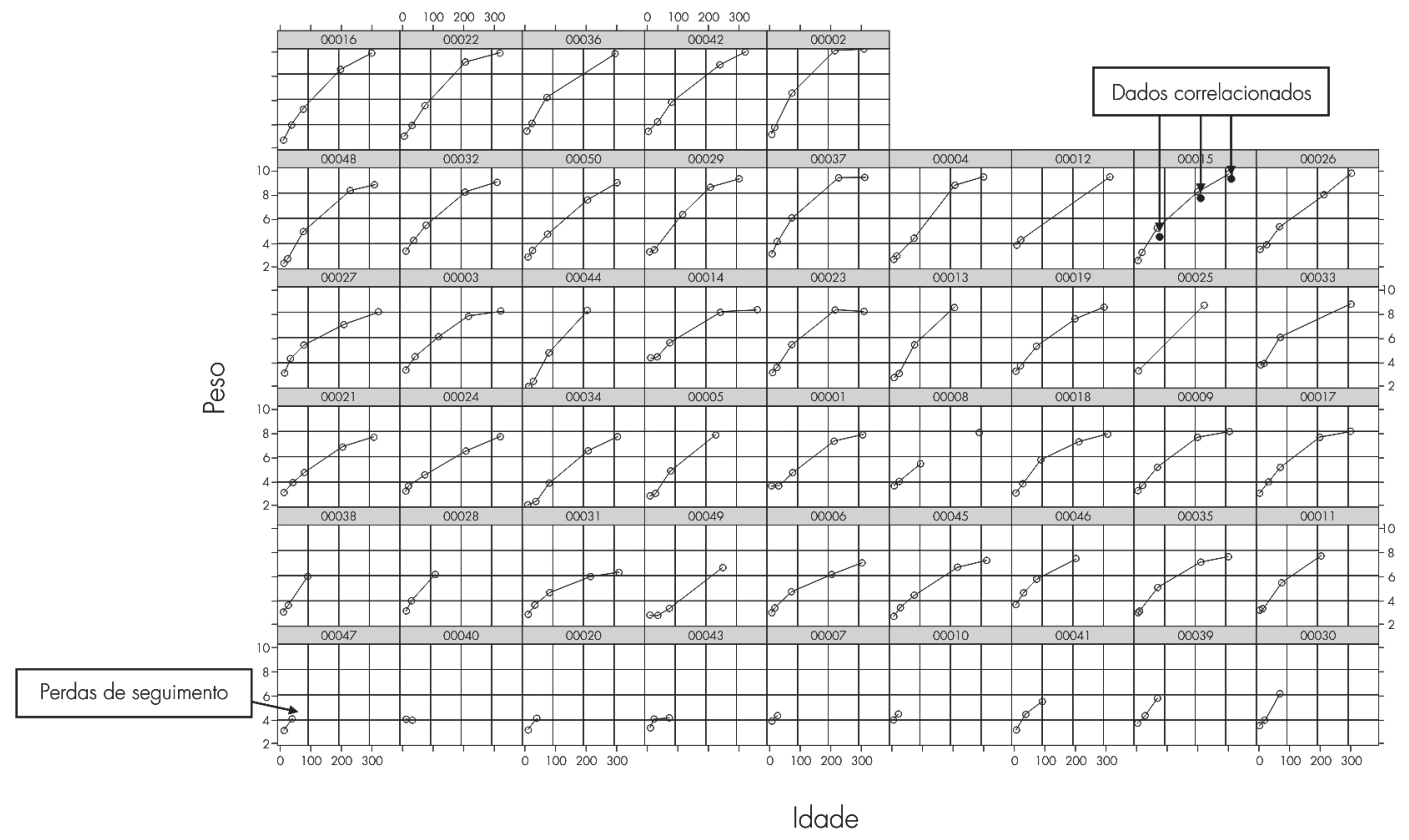


A Figura 1 apresenta o comportamento do peso de cinqüenta das 479 crianças acompanhadas desde o nascimento até os 9 meses de idade. Ao observá-la, pode-se identificar que: a) as medidas tomadas de uma mesma criança são positivamente correlacionadas, ou seja, o peso das crianças em cada um dos momentos depende muito do seu peso ao nascer; b) essa dependência decresce se os intervalos entre as medidas crescem, ou seja, há maior correlação entre os pesos aferidos no nascimento e aos 2 meses do que entre os pesos aferidos no nascimento e aos 9 meses; c) essa correlação não é a mesma para todas as crianças, ou seja, há padrões diferenciados de crescimento; d) nem todas as crianças apresentam o mesmo número de medidas, podendo haver perdas de seguimento ao longo do estudo. As perdas de seguimento podem ocorrer por preenchimento incompleto dos prontuários ou por desistência dos indivíduos ao longo do acompanhamento no estudo. A Figura 1 mostra que houve perda de seguimento de algumas crianças no estudo por não-comparecimento da mãe e da criança em certas consultas. Essas características de dados longitudinais podem ser acomodadas nos modelos de efeitos mistos.

\section{Características dos Dados Longitudinais}

A base de dados de um estudo de coorte ou longitudinal é formada por um conjunto de variáveis, por diferentes indivíduos e pelas medidas tomadas no tempo de um mesmo indivíduo. As dimensões da base de dados compreendem: a variável resposta, ou seja, o desfecho ou fenômeno que se pretende estudar, as variáveis explicativas, que são os potenciais determinantes desse desfecho, e as repetições dessas observações. Portanto, os dados estarão dispostos em uma matriz da forma 'indivíduos x medidas repetidas x variáveis'. O número de registros ou linhas da matriz corresponde ao número de indivíduos vezes o número de medidas repetidas em um mesmo indivíduo, e o número de colunas corresponde ao número de variáveis explicativas.

A base de dados Crescer.txt refere-se ao exemplo da seção "Aplicação em nutrição" e consiste de 2.395 linhas ou registros ( 479 crianças $x 5$ medidas repetidas tomadas ao longo do tempo $=2.395$ ). As colunas PesoCC, Sexo, AmPred referem-se ao peso da criança $(\mathrm{kg})$ no momento da visita ao centro de saúde, sexo da criança e tempo de amamentação predominante (dias), respectivamente.

\begin{tabular}{cccccc}
\hline NQquest & Visita & Tempo (dias) & PesoCC $(\mathrm{kg})$ & Sexo & AmPred (dias) \\
\hline 00001 & 0 & 0 & 3,77 & 2 & 0,00 \\
\hline 00001 & 1 & 20 & 3,80 & 2 & 8,00 \\
\hline 00001 & 2 & 64 & 4,90 & 2 & 8,00 \\
\hline 00001 & 3 & 190 & 7,60 & 2 & 8,00 \\
\hline 00001 & 4 & 280 & 8,20 & 2 & 8,00 \\
\hline 00002 & 0 & 0 & 3,26 & 2 & 0,00 \\
\hline 00002 & 1 & 10 & 3,80 & 2 & 10,00 \\
\hline 00002 & 2 & 61 & 6,70 & 2 & 61,00 \\
\hline 00002 & 3 & 193 & 10,40 & 2 & 180,00 \\
\hline 00002 & 4 & 291 & 10,50 & 2 & 180,00 \\
\hline 00003 & 0 & 0 & 3,41 & 1 & 0,00 \\
\hline 00003 & 1 & 26 & 4,60 & 1 & 26,00 \\
\hline 00003 & 2 & 100 & 6,30 & 1 & 39,00 \\
\hline 00003 & 3 & 189 & 8,00 & 1 & 39,00 \\
\hline
\end{tabular}




\begin{tabular}{cccccc}
\hline NQquest & Visita & Tempo (dias) & PesoCC $(\mathrm{kg})$ & Sexo & AmPred (dias) \\
\hline 00003 & 4 & 293 & 8,50 & 1 & 39,00 \\
\hline 00004 & 0 & 0 & 2,70 & 1 & 0,00 \\
\hline 00004 & 1 & 7 & 3,00 & 1 & 7,00 \\
\hline 00004 & 2 & 63 & 4,50 & 1 & 15,00 \\
\hline 00004 & 3 & 185 & 9,00 & 1 & 15,00 \\
\hline 00004 & 4 & 276 & 9,80 & 1 & 15,00 \\
\hline
\end{tabular}

..

Essa base de dados pode ser digitada em qualquer planilha eletrônica e importada para o programa estatístico que será utilizado para a análise dos dados. Por exemplo, o R é um programa de domínio público e está disponível na Internet: <http://www.r-project.org/>.

Após a leitura dos dados, é necessário informar que pertencem a uma hierarquia de grupos, ou seja, fazer corresponder a cada indivíduo ou grupo suas respectivas medidas repetidas.

A repetição de medidas em uma mesma unidade de observação permite que a modelagem capte a variação específica do indivíduo de forma separada da variação atribuída ao processo de medição e da variação no tempo intra-indivíduo. Em um modelo de regressão clássico, por exemplo, que busca explicar o peso com base na estatura ou em outras co-variáveis, toda a variabilidade da variável resposta não explicada pelas co-variáveis é atribuída a um erro aleatório com uma estrutura de co-variância extremamente simplificadora. Quando se supóe que as observações sejam independentes com mesma variabilidade, não se permite captar as diferenças entre os indivíduos, nem as correlações que porventura possam existir.

Além dessas características, a análise longitudinal deve levar em consideração que as medidas de um mesmo indivíduo apresentam uma correlação no tempo e que as observaçōes nem sempre são igualmente espaçadas. $\mathrm{Na}$ linguagem estatística, essas características vão exigir que se assumam pressupostos específicos sobre estruturas de co-variâncias. Na seção "Estrutura de variância" serão apresentadas várias estruturas de co-variância para contornar esse problema.

\section{Estrutura de Variância/Co-variância}

As medidas repetidas de um mesmo indivíduo são correlacionadas, ou seja, apresentam estruturas de dependência longitudinal que precisam ser consideradas na análise estatística.

$\mathrm{Na}$ aplicação da seção "Aplicação em nutrição", medidas repetidas de uma mesma criança são observadas ao longo do tempo (Figura 1); verifica-se que as correlaçōes entre as observações próximas são altas e, em geral, decrescem à medida que as distâncias entre estas aumentam. Na análise de medidas repetidas, a incorporação nos modelos das possíveis dependências entre as observações tomadas de um mesmo indivíduo melhora a precisão das estimativas, ou seja, é importante na redução da amplitude dos intervalos de confiança dos parâmetros estimados no modelo; ganha-se, com isso, poder de teste. Essa dependência é incorporada no modelo a partir da escolha adequada de estruturas de co-variância, com o objetivo de detectar um nível de mudança que pode não se dever apenas às flutuações aleatórias (Boscardin, Taylor \& Law, 1998). 


\section{Medidas Não Eqüidistantes no Tempo}

Outro problema freqüente com dados longitudinais é que as medidas podem não estar igualmente espaçadas no tempo, requerendo, assim, estruturas de co-variância mais específicas. Essas estruturas são semelhantes às utilizadas para dados espaciais, pois levam em consideração a distância no tempo entre as medidas. A seção "Estrutura de variância" também apresenta algumas matrizes de variância/co-variância que levam em consideração a distância de tempo ou espaço entre as medidas repetidas.

\section{Número de Medidas Repetidas por Indivíduo}

Uma das considerações que se deve fazer no planejamento de um estudo longitudinal refere-se ao número de indivíduos envolvidos na análise e ao número de medidas repetidas por indivíduo.

\section{Dimensionamento da Amostra}

A determinação do tamanho de amostra adequada para que as conclusões de um estudo sejam confiáveis é uma das preocupações dos pesquisadores em diversas áreas de conhecimento. O número de unidades experimentais, pacientes ou indivíduos, em um estudo clínico ou epidemiológico que devem ser investigadas é extremamente importante na determinação do poder do teste e, conseqüentemente, na confiança e precisão da decisão assumida pelo pesquisador.

Quando o desenho de estudo envolve medidas repetidas, o dimensionamento da amostra depende não só do número de unidades experimentais, pacientes ou indivíduos, mas também do número de observações obtidas em cada uma destas unidades experimentais. O desenho do estudo deve contemplar um tamanho de amostra adequado para detectar diferenças importantes baseadas nas hipóteses do pesquisador.

Segundo Leon (2004), um estudo conduzido sem o devido cuidado corre o risco de pecar tanto por falta quanto por excesso de unidades amostrais. Por um lado, acarretaria falha na detecção de diferenças importantes e, por outro, o estudo estaria envolvendo um número excessivo de participantes, o que contraria as normas éticas dos protocolos de pesquisa.

Em ensaios clínicos ou em estudos observacionais, o interesse do pesquisador é detectar diferenças entre grupos de participantes submetidos a tratamentos ou condições diferentes. Segundo Diggle e colaboradores (2004), na determinação do tamanho da amostra alguns aspectos devem ser considerados:

a) Erro do Tipo I, ou seja, o nível de significância $(\alpha)$ que corresponde à probabilidade de detectar diferenças significativas quando de fato estas diferenças não existem na população em estudo. Dependendo das exigências do estudo, pode-se convencionar este erro em 1\%, 5\% ou em valores maiores.

b) O Poder do Teste, o complemento do erro Tipo II ( $\beta$ ), que corresponde à probabilidade de detectar diferenças significativas quando de fato estas ocorrem na população. Costuma-se trabalhar com um poder de teste em torno de 0,80 .

c) A diferença mínima significativa $(\Delta)$ entre os tratamentos ou grupos que se deseja detectar no nível de significância $\alpha$.

d) A variância residual $\left(\sigma^{2}\right)$, ou seja, a variabilidade não explicada na resposta, e no caso de estudos longitudinais.

e) O coeficiente de correlação entre as medidas repetidas.

f) O número de medidas repetidas observadas por indivíduo. 
$\mathrm{Na}$ comparação entre tipos de tratamento ou grupos, portanto, o tamanho de amostra dependerá das exigências do pesquisador com relação a cada um desses aspectos. $\mathrm{O}$ tamanho de amostra necessário para a realização de um estudo será maior quanto mais elevado for o poder de teste estabelecido, e será inversamente proporcional à diferença mínima significativa e à correlação existente entre as medidas repetidas.

Para maiores informaçôes sobre o cálculo da amostra, consultar Vonesh \& Chinchilli (1997), Freitas (2000), Diggle et al. (2002) e Paz et al. (2005).

\section{Os Modelos Estatísticos para Medidas Repetidas}

Ao contrário dos estudos transversais, o acompanhamento de um indivíduo com base em medidas repetidas permite a descrição da evolução no tempo do desfecho de interesse e possibilita que se busque o ajuste de funçôes que representem o comportamento individual.

Os modelos de efeitos mistos constituem uma ferramenta de grande utilidade no processo de busca do entendimento do comportamento do desfecho em relação aos seus determinantes. Este tipo de modelagem aproxima-se do desenho de estudo que originou as medidas repetidas, que, em um primeiro estágio, considera as unidades amostrais selecionadas aleatoriamente da população de interesse e, em um segundo estágio, que um número de medidas seja observado em cada unidade do primeiro estágio. Os modelos de efeitos mistos têm a flexibilidade de especificar alguns efeitos como fixos (os efeitos da população) e outros aleatórios (os efeitos devido ao indivíduo), levando em consideração a correlação existente entre e intra-indivíduos (Pinheiro \& Bates, 2000; Verbeke \& Molenberghs, 2000). Os efeitos aleatórios permitem controlar a variação existente entre indivíduos e que pode ser proveniente de fontes de variação não controladas no estudo. Dessa forma, estes modelos fornecem estimativas mais precisas dos parâmetros estimados, o que torna o teste mais sensível para captar diferenças significativas.

A relação entre uma variável resposta e as explicativas descreve um comportamento que pode ser expresso por uma função linear ou não linear nos parâmetros. No primeiro caso, os modelos são chamados modelos lineares de efeitos mistos e, no segundo caso, modelos não lineares de efeitos mistos. Ao se escolher um modelo que descreva o comportamento de uma variável resposta em relação às explicativas, sempre se tem a opção de usar modelos polinomiais, que são lineares nos parâmetros. No entanto, os coeficientes dos modelos polinomiais nem sempre permitem uma interpretação biológica ou natural do processo estudado.

Os modelos não lineares são baseados em funções que buscam reproduzir o mecanismo de geração da variável resposta, por isso seus parâmetros geralmente são objeto de uma interpretação prática. Além disso, estes modelos fornecem predições mais confiáveis para a variável resposta fora do intervalo dos dados observados. Antes de ajustar um modelo estatístico, é importante observar se o comportamento da variável descreve uma função aproximadamente linear ou não linear. Neste caso, faz-se necessária a escolha de uma função que represente bem essa relação.

\section{Construção dos Modelos}

Suponha que $\mathrm{N}$ indivíduos ou unidades amostrais foram observados em uma determinada população e que tais unidades foram medidas repetidamente $n_{i}$ vezes no tempo $t_{i j}, i=1, \ldots N$ e $j=1, \ldots n_{i} . Y_{i}$ expressa o vetor resposta de interesse para o indivíduo $i$, de dimensão $n_{i}$. Se $n_{i}$ é o mesmo para cada indivíduo $\left(n_{i}=n\right)$, tem-se um total de $n \times \mathrm{x}$ observações.

O modelo de efeitos mistos pode ser entendido como uma combinação de dois estágios de análise. O primeiro estágio assume que $Y_{i}$ satisfaz um modelo de regressão estimando parâmetros que são específicos da população em estudo, ou seja, são os mesmos para todos os indivíduos observados, e são denominados efeitos 
fixos. O segundo estágio compreende a estimação de parâmetros específicos para cada indivíduo, denominados efeitos aleatórios. Isso quer dizer que os parâmetros são decompostos em uma parte fixa, que representa o comportamento médio da população observada, e uma parte aleatória específica de cada indivíduo, que é acrescentada ou subtraída da média.

O modelo linear de efeitos mistos, portanto, é dado pela equação:

$$
Y i=X_{i} \beta+Z_{i} b_{i}+\varepsilon_{i}{ }^{(1)}
$$

onde $\beta$ é um vetor p-dimensional de efeitos fixos, $b_{i}$ é um vetor de efeitos aleatórios associados ao i-ésimo indivíduo (não variando $\operatorname{com} j$ ) $\operatorname{com} b_{i} \sim N(0, D)$ sendo $D$ a matriz de variância/co-variância e $\varepsilon_{i} \sim N\left(0, \sigma^{2} l\right)$ . $X_{i}$ e $Z_{i}$ são matrizes de co-variáveis ou variáveis explicativas conhecidas com dimensões $\left(n_{i} \times p\right)$ e $(n i$ x $q)$, respectivamente. Isto é, a decomposição dos efeitos em uma parte fixa e outra aleatória permite que os coeficientes variem de indivíduo para indivíduo, tornando as estimativas individuais mais precisas (Pinheiro \& Bates, 2000; Verbeke \& Molenberghs, 2000).

\section{Conceito de Efeitos Fixos e Aleatórios}

Para ilustrar o conceito de efeitos fixos e aleatórios, suponha que a variável resposta $Y$ tenha uma relação linear com uma variável explicativa $X$. Esta relação pode ser expressa pela equação $Y_{i}=\phi_{0 i}+\phi_{1 i} X+\varepsilon_{\mathrm{i}}$, onde $\phi_{0 i}$ representa o intercepto e $\phi_{1 i}$ corresponde à taxa de crescimento de $Y$ em função dos valores que $X$ assume.

Se uma única estimativa for calculada para cada um dos parâmetros $\phi_{0}$ e $\phi_{1}$, esses valores estariam representando o comportamento médio do grupo observado sem levar em consideração as especificidades de cada unidade amostral. Considere, agora, que cada um desses parâmetros pode ser decomposto em uma parte fixa $\left(\bar{\phi}_{0}\right.$ e $\left.\bar{\phi}_{1}\right)$, representando o comportamento médio, e outra parte aleatória $\left(\phi_{0 \mathrm{i}}-\bar{\phi}_{0}\right)$ e $\left(\phi_{1 \mathrm{i}}-\bar{\phi}_{1}\right)$, correspondente ao diferencial de cada indivíduo em relação à média da população. Então, os parâmetros poderiam ser reescritos em função de $\bar{\phi}$ (média dos parâmetros individuais), da seguinte forma:

$$
Y_{i}=\bar{\phi}_{0}+\left(\phi_{0 i}-\bar{\phi}_{0}\right)+\left\{\bar{\phi}_{1}+\left(\phi_{1 i}-\bar{\phi}_{1}\right)\right\} X+\varepsilon_{i}
$$

Na versão de modelo linear de efeitos mistos, tem-se:

$$
Y_{i}=\left(\beta_{0}+b_{0 i}\right)+\left\{\left(\beta_{1}+b_{1 i}\right)\right\} X+\varepsilon_{i}
$$

Para cada indivíduo, portanto, é ajustado um modelo específico, o que melhora muito a qualidade do ajuste. A Figura 2 apresenta a interpretação gráfica dos efeitos aleatórios. Observa-se que é feita a suposição de que o conjunto de valores específicos por indivíduo em cada um dos parâmetros tem uma distribuição normal, com média zero e variância $D$. 
Figura 2 - Efeitos fixos e aleatórios de um modelo linear

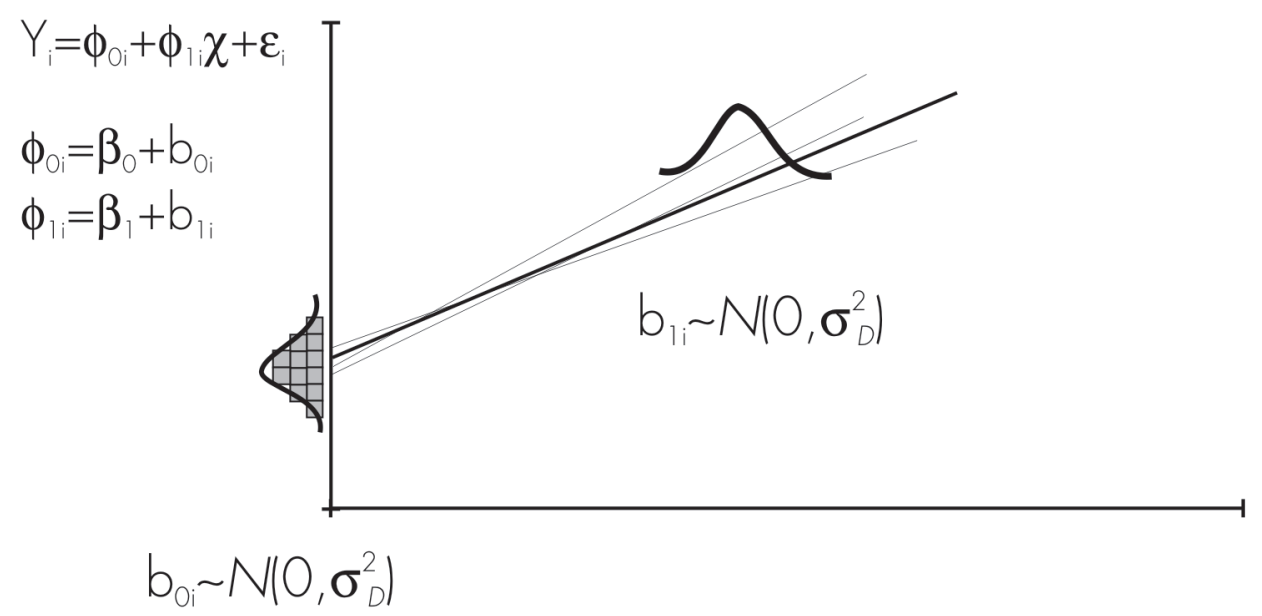

Onde os efeitos fixos $\beta$ representam os valores médios dos parâmetros na população de indivíduos e os efeitos aleatórios $b_{i}$ representam os desvios individuais.

\section{Estrutura de Variância}

Como já foi ressaltado, a análise de dados longitudinais envolvendo medidas repetidas deve levar em conta não só a variabilidade entre indivíduos, mas também a variação existente entre observações de um mesmo indivíduo. A escolha adequada de uma estrutura de variância é um passo muito importante para se fazer inferências sobre os parâmetros de um modelo de forma precisa.

No exemplo do crescimento infantil, as variações intra e entre crianças são estimadas separadamente. A variação entre grupos descreve como os coeficientes variam de criança para criança, ao passo que a intragrupo descreve a variação no ajuste de peso ou comprimento de uma mesma criança em torno de seu próprio comportamento de crescimento.

$\mathrm{Na}$ formulação do modelo, portanto, é necessária a especificação dos três componentes estocásticos que definem a estrutura de variância e que devem ser considerados:

- Efeitos aleatórios - parâmetros específicos por indivíduo (variações em torno dos parâmetros populacionais), representados pelo $b_{i} \sim \mathrm{N}(0, \mathrm{D})$.

- Erro de medida - devido ao processo de medição, representado por $\varepsilon_{(1) \mathrm{i}} \sim \mathrm{N}\left(0, \sigma^{2} \mathrm{I}\right)$.

- Correlação serial - devido ao processo estocástico variando no tempo operando intra-indivíduo, representado por: $\varepsilon_{(2) \mathrm{i}} \sim \mathrm{N}\left(0, \tau^{2} \mathrm{H}_{\mathrm{i}}\right)$.

Os erros $\varepsilon_{i j}$ do modelo podem ser, portanto, decompostos em um componente devido ao processo de medição $\left(\varepsilon_{(1) i}\right)$ e em um componente estocástico devido à correlação serial operando intra-indivíduo $\left(\varepsilon_{(2) \mathrm{i}}\right)$.

$$
\varepsilon_{i}=\varepsilon_{(1) \mathrm{i}}+\varepsilon_{(2) \mathrm{i}} \quad \varepsilon_{i} \sim N(0, \Sigma)
$$

As estruturas mais comumente utilizadas na literatura são: a matriz de co-variância uniforme ou Simétrica Composta (SC), a auto-regressiva de primeira ordem e a não estruturada. O Quadro 1 apresenta algumas características dos tipos de estruturas de variância/co-variância. Para mais informações, consultar Verbeke e Molenberghs (2000). 
Quadro 1 - Características de algumas estruturas de variância/co-variância

\begin{tabular}{|c|c|}
\hline Matriz de co-variância & Característica \\
\hline Não estruturada & $\begin{array}{l}\text { Os elementos da diagonal representam a variância calculada para cada ponto no tempo, e os } \\
\text { demais elementos correspondem às co-variâncias entre as respostas tomadas em pontos de } \\
\text { tempo distintos. Requer muitos parâmetros à medida que o número de observações por } \\
\text { indivíduo aumenta e, conseqüentemente, requer um tamanho de amostra maior. }\end{array}$ \\
\hline Uniforme ou Simétrica composta & $\begin{array}{l}\text { Assume-se que existe uma correlação positiva } \rho \text {, entre quaisquer duas medidas de um mesmo } \\
\text { indivíduo. São necessários apenas dois parâmetros, independentemente do número de } \\
\text { medidas repetidas sobre o mesmo indivíduo, porém esta estrutura assume que não somente as } \\
\text { variâncias, mas também as co-variâncias, sejam constantes. }\end{array}$ \\
\hline Auto-regressiva de primeira ordem & $\begin{array}{l}\text { Nesta matriz a correlação entre as observações sobre o mesmo indivíduo entre os instantes de } \\
\text { tempo corresponde a } \rho^{\text {ni }} \text {, ou seja, a correlação é elevada à potência equivalente ao instante } \\
\mathrm{n}_{1} \text {. As variâncias (elementos da diagonal) são consideradas constantes. Considera-se aqui que } \\
\text { cada indivíduo foi medido em intervalos de tempo igualmente espaçados. }\end{array}$ \\
\hline Poder, Exponencial e Gaussiana & $\begin{array}{l}\text { No caso em que as medidas repetidas não estão igualmente espaçadas no tempo, as } \\
\text { estruturas de co-variância têm de levar em consideração os intervalos de tempo entre } \\
\text { observações. Nessas situações, recomenda-se o uso de estruturas de co-variância } \\
\text { proporcionais aos intervalos de tempo. }\end{array}$ \\
\hline
\end{tabular}

A decisão sobre qual a estrutura de variância e co-variância mais adequada deve ser tomada com base no Critério de Informação de Akaike (Akaike Information Criterion - AIC) ou o Critério Bayesiano de Schwartz (Baysean Information Criterion - BIC). Quanto menor o valor do AIC, melhor a qualidade do ajuste.

Após a escolha da estrutura de variância e co-variância, procede-se à seleção das variáveis com base na diferença entre modelos aninhados. Um modelo com a variável que se quer testar e outro sem a variável. A diferença entre os logaritmos de máxima verossimilhança (- 2log ML) dos dois modelos aninhados tem distribuição de qui-quadrado e, comparada com seus graus de liberdade, permite testar a significância do parâmetro.

\section{Estimação dos Parâmetros}

O processo de estimação e inferência torna-se diferente da resolução de sistema de equações normais desenvolvida em modelos lineares. A solução dos sistemas não lineares não é obtida de forma explícita e requer métodos numéricos para o seu desenvolvimento. Felizmente, hoje já se dispõe de programas computacionais que possibilitam a implementação de algoritmos, como o Winbugs, o S-Plus/R e o SAS.

No caso dos sistemas lineares, a estimação de mínimos quadrados dos parâmetros é baseada em valores que minimizam a soma de quadrados dos resíduos (ou, equivalentemente, maximiza a função de verossimilhança, considerando $\varepsilon \sim N\left(0, I \sigma^{2}\right)$. Derivando a soma de quadrados dos resíduos em função dos parâmetros, obtêm-se as equações normais, que igualadas a zero fornecem as estimativas dos parâmetros (pontos de máximo ou mínimo da função). No caso de modelos de efeitos mistos, não é possível obter as estimativas dos parâmetros de uma forma fechada. Esta dificuldade pode propiciar múltiplas soluçōes. Neste caso, o processo é dito não identificável, e faz-se necessário um processo iterativo para solucionar o sistema de equações de verossimilhança, que são obtidas igualando a zero as derivadas parciais das funções de verossimilhança (função escore), com respeito aos parâmetros correspondentes ou à inclusão de restriçōes nos parâmetros.

Várias técnicas numéricas, tais como os algoritmos de Newton-Raphson ou Fisher-scoring, são utilizados. O processo começa com algumas estimativas preliminares dos parâmetros. Essas estimativas são utilizadas para calcular a Soma de Quadrado Residual (SQR) e verificar em um passo seguinte que alteraçóes devem ser feitas nos parâmetros estimados que resultem na redução da SQR. O procedimento é repetido até que nenhuma modificação nos parâmetros reduza substancialmente a soma de quadrados residual. 
Outros métodos numéricos têm sido implementados com o intuito de obter as estimativas que minimizem a soma de quadrados residual ou que maximizem a função de verossimilhança, como, dentre outros: Algoritmo de Gauss-Newton, Método do Gradiente, Método DUD (Doesn't Use Derivatives), Algoritmo Lindstrom \& Bates, Aproximação Laplaciana, Aproximação Adaptativa Gaussiana.

\section{Medidas de Diagnóstico}

Uma etapa importante no processo de construção do modelo linear de efeitos mistos é o diagnóstico sobre o ajuste do modelo. A análise de diagnóstico envolve os seguintes aspectos:

- Seleção dos efeitos que necessitam a incorporação de componentes aleatórios.

- Verificação das suposições das distribuições feitas para o modelo por meio da análise de resíduos, isto é, a diferença entre os valores observados e os estimados pelo modelo.

- Identificação de pontos que exercem alguma influência nas estimativas dos parâmetros, como os outliers ou observações extremas e os pontos influentes.

\section{Seleção dos Efeitos Aleatórios}

Um problema prático importante é a escolha dos parâmetros que necessitam um componente aleatório. Uma questão difícil é como decidir quais fatores têm coeficientes que variam entre indivíduos. A inclusão do efeito aleatório dependerá, principalmente, do delineamento do estudo. $\mathrm{O}$ exemplo da seção "Aplicação em nutrição" refere-se a um estudo planejado em blocos (grupos) no qual se busca captar os efeitos da variação aleatória em torno da média populacional.

Os efeitos aleatórios são comumente incorporados nos modelos de dados longitudinais para se considerar a heterogeneidade entre indivíduos, acomodar a dependência nas observações repetidas e estudar a estrutura de variância e co-variância que melhor acomode a dependência entre as medidas repetidas. É importante, portanto, decidir que efeitos aleatórios incluir e que estrutura de co-variância esses efeitos teriam. Suponha que para cada indivíduo fosse ajustado um modelo com coeficientes específicos.

Uma maneira de visualizar a necessidade da inclusão dos efeitos aleatórios é a construção de um gráfico com os intervalos de confiança para os coeficientes estimados para cada indivíduo (Figura 3). Veja, por exemplo, os intervalos de confiança estimados para cinqüenta das 479 crianças. Esses intervalos são obtidos por meio do ajuste de parâmetros estimados com base em regressōes individuais, estimando-se os coeficientes de cada criança e calculando-se o intervalo de confiança de cada um destes parâmetros.

A Figura 3 (página seguinte) é útil para verificar a necessidade da inclusão do efeito aleatório. O intercepto representa o peso ao nascer das crianças, e o parâmetro associado à idade corresponde à taxa de crescimento infantil de acordo com a idade. Percebe-se, na Figura 3, que há pouca variação da amplitude dos intervalos tanto para o intercepto quanto para a idade; no entanto, não ocorre interseção entre alguns dos intervalos de confiança calculados. Por exemplo, para o peso ao nascer entre as crianças de número 14 e 34 não existe interseção dos intervalos de confiança. Nesse caso, é necessário ajustar um componente aleatório para a variável idade da criança. O mesmo ocorre com a taxa de crescimento. Isso quer dizer que há um comportamento diferenciado entre as crianças com relação tanto ao peso ao nascer quanto às taxas de crescimento. 
Figura 3 - Intervalos de confiança para os coeficientes da regressão linear (intercepto e taxa de crescimento) para cada uma das cinqüenta crianças, Rio de Janeiro, 1999-2001

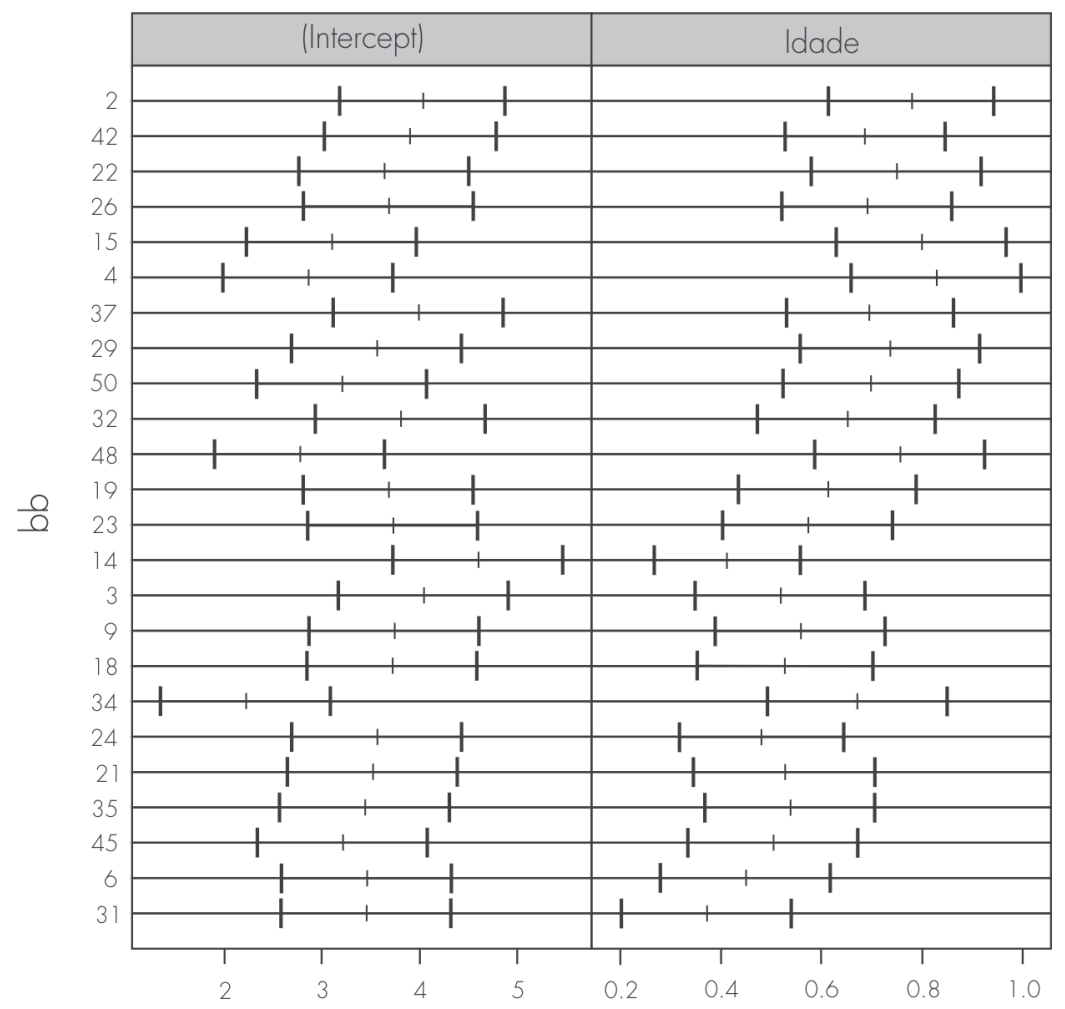

\section{Análise de Resíduos}

Antes de proceder a qualquer inferência com os parâmetros do modelo, é importante checar se os pressupostos básicos sobre as distribuições feitas para o modelo de efeitos mistos estão sendo cumpridos. Há duas suposições importantes que devem ser consideradas na análise:

1. Os erros intra-indivíduo ou intragrupo são independentes e identicamente distribuídos pela normal, com média zero e variância $\sigma^{2}$, e são independentes dos efeitos aleatórios.

2. Os efeitos aleatórios são normalmente distribuídos, com média zero e co-variância $\Psi$, e são independentes para diferentes grupos ou indivíduos.

Uma ferramenta bastante útil para a verificação do pressuposto da distribuição dos erros é o gráfico dos valores ajustados em relação aos resíduos padronizados (Figura 4). Este gráfico permite observar se a média está centrada em zero e se a variabilidade dos resíduos respeita os limites aceitáveis, que variam de -3 a 3 . Além disso, permitem identificar pontos extremos.

A Figura 4 (página seguinte) permite visualizar dois aglomerados distintos de pontos. Estes aglomerados constituem o comportamento de acordo com o sexo das crianças. Caso a variabilidade dos resíduos demonstrasse comportamentos diferenciados em cada nível do fator sexo, seria recomendável a escolha de uma matriz de variância/co-variância adequada para contornar a heterocedasticidade.

Outra maneira bastante útil de checar se o modelo está bem ajustado é construir um gráfico dos valores observados versus os valores ajustados pelo modelo que leva em consideração a variação intra-indivíduo. Quando os valores descrevem aproximadamente uma reta diagonal, indicam sucesso no ajuste. 
Figura 4 - Análise de resíduos versus valores ajustados pelo modelo linear de efeitos mistos para o peso infantil, Rio de Janeiro, 1999-2001

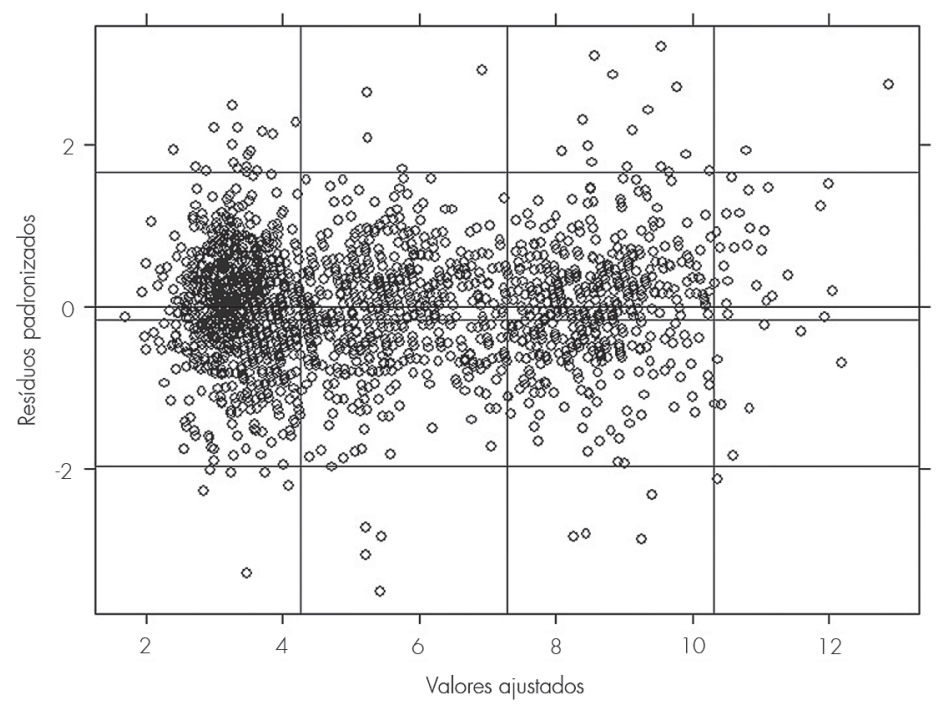

Para se verificar o pressuposto de normalidade dos resíduos, utiliza-se o gráfico conhecido por qqnorm (Figura 5). Neste tipo de gráfico, é importante verificar se as caudas não estão demasiadamente prolongadas, quebrando o comportamento linear da reta, e se esta é simétrica em torno de zero.

Figura 5 - Teste de normalidade dos resíduos do modelo linear de efeitos mistos para o peso infantil, Rio de Janeiro, 1999-2001

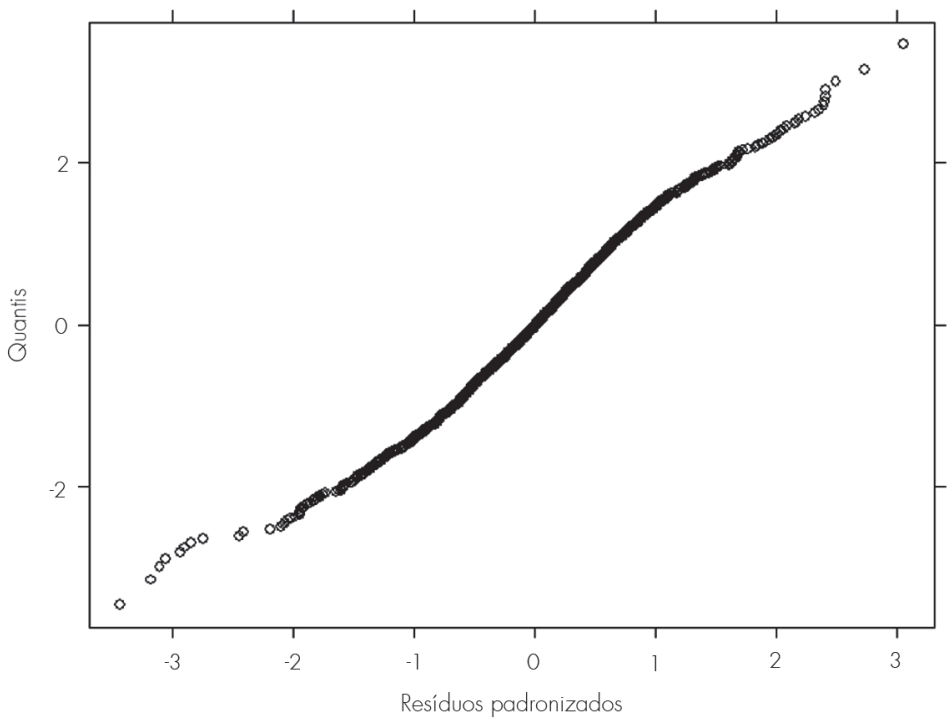

Dois tipos de gráficos são utilizados para checar a suposição de normalidade dos efeitos aleatórios: o qqnorm, para constatar a normalidade e identificar outliers, e um gráfico de dispersão dos efeitos aleatórios estimados, para testar a suposição de homogeneidade da matriz de variância e co-variância dos efeitos aleatórios. 


\section{Análise de Resultados}

Com o intuito de ilustrar e consolidar os conceitos expostos anteriormente, descreve-se nesta seção o processo de modelagem da situação prática apresentada na seção "Aplicação em nutrição". Trata-se do estudo longitudinal de crianças acompanhadas em quatro ondas de seguimento com 0,5, 2, 6 e 9 meses. A modelagem estatística foi desenvolvida por meio do programa computacional R versão 5 (2007).

\section{Situação Prática}

Para melhor compreensão sobre os parâmetros aleatórios, a Figura 6 mostra o comportamento de apenas oito crianças participantes do estudo, refletindo a variação existente no padrão de crescimento entre as crianças. Pode-se observar que o comportamento do peso de cada uma das crianças poderia ser ajustado com interceptos e coeficientes de regressão diferentes, correspondendo ao peso inicial e à taxa de crescimento, respectivamente. Isto é, cada criança apresenta um ritmo de crescimento diferente do comportamento médio populacional (linha contínua), tanto no que se refere ao peso ao nascer quanto nos ganhos de peso ao longo desses primeiros meses. O modelo de efeitos aleatórios, portanto, permite estimar a variação dos desvios individuais em torno da média populacional de cada parâmetro do modelo, fazendo com que as estimativas se tornem mais precisas.

Figura 6 - Comparação dos ajustes dos modelos com e sem efeitos aleatórios com base nos valores observados do peso infantil, Rio de Janeiro, 1999-2001

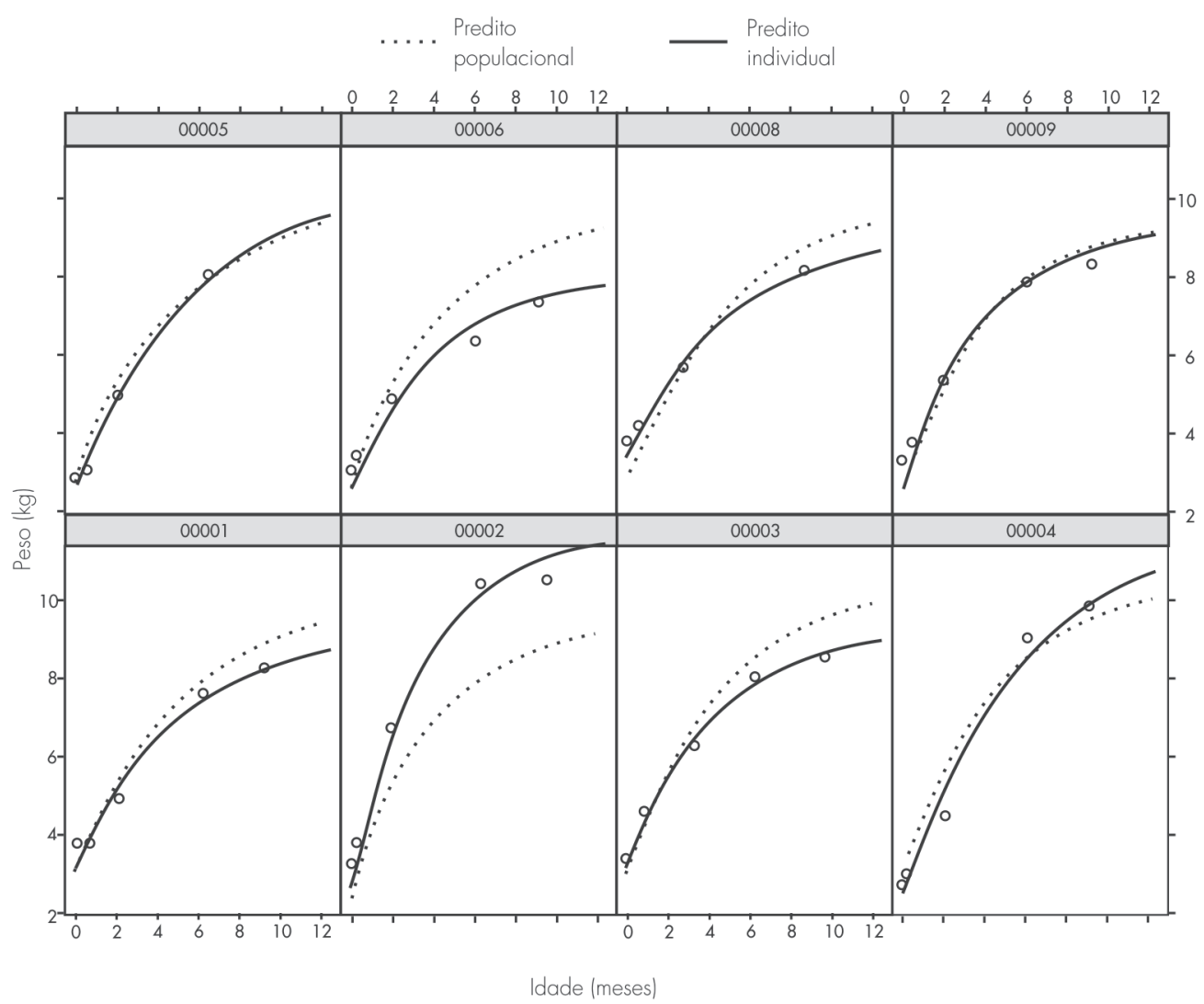


No caso em estudo, de acordo com o comportamento apresentado pelos dados longitudinais observados, assumiu-se para o crescimento infantil, nos primeiros meses de vida, o modelo de regressão assintótico para a função $f$, dada por Pinheiro e Bates (2000) como:

$$
f\left(\phi_{i j}, v_{i j}\right)=\mathrm{P}_{\text {assint. }}+\left(\mathrm{P}_{0}-\mathrm{P}_{\text {assint. }}\right) \exp \left[-\exp \left(\mathrm{Ln} \_t a x a^{*} i d a d e\right]^{(2)}\right.
$$

A interpretação dos parâmetros $\phi_{i j}$ pode ser dada da seguinte forma:

$\mathrm{P}_{\text {assint. }}$ - representa o peso assintótico, considerando-o como o peso ao final do período de estudo;

$\mathrm{P}_{0}$ - representa o peso ao nascer;

Ln_taxa - logaritmo da taxa $(\lambda)$ de ganho de peso; pressupõe-se que estas taxas de ganho de peso sejam constantes.

Nesta análise encontrou-se o modelo reduzido de regressão assintótico considerando-se apenas os parâmetros de efeitos fixos para a variável peso, o que resulta em um erro-padrão residual de 0,7689 . Ao se comparar o ajuste do modelo reduzido de efeitos aleatórios com o que ignora a estrutura agrupada (modelo de efeitos fixos), verificou-se para o ajuste do peso uma redução significativa do erro-padrão residual para 0,2667 , uma redução de $65 \%$ da variabilidade entre grupos. Isso ocorre porque a variabilidade entre grupos no modelo de efeitos fixos não é incorporada no modelo, sendo absorvida no erro-padrão residual. Além disso, observa-se na Tabela 1 que as estimativas, embora similares, apresentam erros-padrão menores no modelo que considera os efeitos aleatórios. Uma das vantagens, portanto, de se considerar os efeitos como aleatórios na modelagem é o aumento na precisão de suas estimativas.

Tabela 1 - Coeficientes estimados e erros-padrão dos modelos reduzidos com e sem efeitos aleatórios

\begin{tabular}{lcccc}
\hline & \multicolumn{2}{c}{ Modelo de efeitos fixos } & \multicolumn{2}{c}{ Modelo de efeitos mistos } \\
\hline Parâmetros & Estimativas & Erro-padrão & Estimativas & Erro-padrão \\
\hline Peso & & & & \\
\hline$P_{\text {assint. }}$ & 10,29 & 0,1492 & 10,16 & 0,1004 \\
\hline$P_{0}$ & 3,13 & 0,0293 & 3,11 & 0,0226 \\
\hline Ln_taxa & $-1,68$ & 0,0433 & $-1,62$ & 0,0196 \\
\hline Resíduo & & 0,7689 & & 0,2667 \\
\hline
\end{tabular}

$P_{\text {assint. }}$ representa o peso assintótico, considerando-o como o peso ao final do período de estudo; $P_{0}$ representa o peso ao nascer; Ln_taxa- logaritmo da taxa $(\lambda)$ de ganho de peso.

A Tabela 2 mostra que a variável sexo é significativa em todos os três parâmetros, ou seja, as meninas apresentam pesos significativamente inferiores aos dos meninos tanto ao nascer $(-0,0971)$ quanto em seu peso assintótico $(-0,3639)$ e tendem a ter taxas menores de ganho de peso $(-0,0991)$ ao longo dos primeiros meses de vida. A idade gestacional influencia apenas no peso ao nascer $(0,1338)$, ou seja, quanto maior a idade gestacional, maior é o peso da criança ao nascer, porém esta variável não influi significativamente nem sobre o peso assintótico nem sobre a taxa de crescimento infantil. $O$ tipo de parto apresenta efeito significativo $(0,0766)$ apenas sobre a taxa de crescimento, revelando que as crianças nascidas de parto cesáreo tendem a apresentar taxas de ganho de peso mais elevadas. 
É interessante observar o efeito significativo da duração da amamentação sobre o peso assintótico $(-0,2813)$ da criança e em sua taxa de crescimento $(0,0798)$. Percebe-se que, embora a taxa de crescimento seja mais elevada à medida que a duração da amamentação predominante aumenta, o peso assintótico de crianças amamentadas por mais tempo torna-se inferior. Isso quer dizer que as crianças com período de amamentação predominante mais elevado, embora tenham um ritmo de crescimento maior nos primeiros meses de vida, atingem um peso de equilíbrio menor ao final do período estudado.

Tabela 2 - Modelo não linear de efeitos mistos para a evolução do peso $(\mathrm{kg})$ de crianças menores de 1 ano, Rio de Janeiro, 1999-2001

\begin{tabular}{|c|c|c|c|}
\hline Efeitos fixos & Estimativa & Erro-padrão & Valor-p \\
\hline$P_{\text {assint }}$ (Intercepto) & 11,2074 & 0,1858 & $<0,0001$ \\
\hline$P_{\text {assint. }}$ Sexo & $-0,3639$ & 0,1887 & 0,0541 \\
\hline$P_{\text {assint. }}$ AmPred $_{\mathrm{i}}$ (mês) & $-0,2813$ & 0,0390 & $<0,0001$ \\
\hline$P_{0}$ (Intercepto) & 3,0985 & 0,0362 & $<0,0001$ \\
\hline$P_{0}$ Sexo & $-0,0971$ & 0,0254 & 0,0431 \\
\hline $\mathrm{P}_{0}$ ldade gestacional & 0,1338 & 0,0133 & $<0,0001$ \\
\hline Ln_taxa (Intercepto) & $-1,8104$ & 0,0385 & $<0,0001$ \\
\hline Ln_taxa Sexo & $-0,0991$ & 0,0357 & 0,0056 \\
\hline Ln_taxa AmPredi (mês) & 0,0798 & 0,0110 & $<0,0001$ \\
\hline Ln_taxa Tipo de parto & 0,0766 & 0,0289 & 0,0083 \\
\hline \multirow{2}{*}{ Efeitos aleatórios } & \multicolumn{3}{|c|}{ Intervalos de confiança 95\% } \\
\hline & Limite inferior & Estimativa & Limite superior \\
\hline$\sigma_{\text {assint. (Iniercepio) }}$ & 1,2512 & 1,4170 & 1,6048 \\
\hline$\sigma_{\text {po (lniercepto) }}$ & 0,3391 & 0,3766 & 0,4183 \\
\hline$\sigma_{\text {Ln_taxa (Intercepio) }}$ & 0,1312 & 0,1722 & 0,2260 \\
\hline Cor $\left[\right.$ Assint., $\left.P_{0}\right]$ & $-0,1148$ & 0,0520 & 0,2159 \\
\hline Cor[Assint.,Ln_taxa] & $-0,5666$ & $-0,3882$ & $-0,1750$ \\
\hline Cor $\left[P_{0}, L\right.$ n_taxa $]$ & 0,0393 & 0,3376 & 0,5806 \\
\hline$\sigma_{\text {residual }}$ & 0,2514 & 0,2669 & 0,2834 \\
\hline - 2 Ln-verossimilhança & 2069,34 & & \\
\hline $\mathrm{AIC}$ & 2103,35 & & \\
\hline
\end{tabular}

Os parâmetros $\sigma_{\text {intercepto }}$ e $\sigma_{\text {idade }}$ expressam os desvios em torno do peso inicial e da taxa de ganho de peso entre crianças, respectivamente. 


\section{Considerações Finais}

Estudos envolvendo a análise de medidas repetidas observadas em um mesmo indivíduo são bastante comuns em epidemiologia nutricional. Nesses estudos, as características nutricionais dos indivíduos são monitoradas ao longo do tempo, o que requer o controle da dependência entre as observações de um mesmo indivíduo. Os modelos de efeitos mistos permitem acomodar essas dependências intra e entre indivíduos por meio de estruturas de variância e co-variância apropriadas, melhorando a qualidade do ajuste e fornecendo estimativas mais precisas dos parâmetros a serem estimados. Adicionalmente, importantes avanços da informática possibilitaram a implementação de algoritmos em vários programas computacionais, como o S-Plus/R, o SAS e o Winbugs.

$\mathrm{Na}$ área da saúde, além de dados contínuos como os discutidos no presente capítulo, é comum também o interesse dos pesquisadores em investigar desfechos com distribuição discreta. Vários autores abordam técnicas para lidar com a análise longitudinal de dados discretos. Crowder e Hand (1990), Lindsey (1993) e Molenberghs e Verbeke (2005), que apresentam várias técnicas estatísticas para lidar com medidas repetidas para dados discretos, são algumas referências importantes na literatura.

\section{Referências}

BOSCARDIN, W. J.; TAYLOR, J. M. G. \& LAW, N. Longitudinal models for Aids marker data. Statistical Methods in Medical Research, 7: 13-27, 1998.

CROWDER, M. J. \& HAND, D. J. Analysis of Repeated Measures. London: Chapman \& Hall, 1990.

DIGGLE, P. J. et al. Analysis of Longitudinal Data. New York: Oxford University Press, 2002.

FREITAS, A. R. Método para estimar o tamanho amostral em análises de medidas repetidas. Pesquisa Agropecuária Brasileira, 35(4): 697-702, 2000.

LEON, A. C. Sample-Size requirements for comparisons of two groups on repeated observations of a binary outcome. Evaluation and the Health Professions, 27(1): 34-44, 2004.

LINDSEY, J. K. Models for Repeated Measurements. New York: Oxford University Press, 1993.

MOLENBERGHS, G. \& VERBEKE, G. Models for Discrete Longitudinal Data. New York: Springer-Verlag New York, 2005.

PAZ, C. C. et al. Sample size and power calculations for body weight in beef cattle. Biostatistics Research Archive, Berkeley, CA, 2005.

PINHEIRO, J. C. \& BATES, D. M. Mixed-Effects Models in S and S-Plus. New York: Spring-Verllag, 2000.

R DEVELOPMENT CORE TEAM. R: A language and environment for statistical computing. R Foundation for Statistical Computing, Vienna, Austria, 2007. ISBN 3-900051-07-0, URL. Disponível em: <http:// www.R-project.org>.

VERBEKE, G. \& MOLENBERGHS, G. Linear Mixed for Longitudinal Data. New York: Springer-Verlag, 2000.

VONESH, E. F. \& CHINCHILLI, V. M. Linear and Nonlinear Models for the Analysis of Repeated Measurements. New York: Marcel Dekker, 1997. 


\title{
Intervenções Nutricionais na Infância
}

\author{
Iná S. Santos
}

C

erca de 11 milhões de crianças morrem no mundo, a cada ano, antes de completarem o quinto ano de vida. A maioria morre no primeiro ano, $98 \%$ das quais nos países em desenvolvimento, mais da metade devido a pneumonia, diarréia, sarampo, malária e HIV/Aids. A desnutrição está presente em $54 \%$ de todas as mortes (Hill, Kirkwood \& Edmond, 2004). A alimentação complementar, iniciada aos seis meses de idade e constituída por alimentos nutritivos paralelamente à amamentação e à suplementação, fortificação ou modificação da dieta, para garantir um aporte adequado de micronutrientes, tem hoje evidência suficiente sobre sua capacidade de proteção à saúde da criança e garantia de desenvolvimento saudável (WHO, 1998).

Este capítulo aborda as intervenções nutricionais utilizadas para enfrentar o problema da desnutrição infantil e das carências nutricionais específicas de ferro e vitamina A. Para tal, foram utilizados como base os documentos de revisão publicados pela Organização Mundial da Saúde (OMS) nos últimos dez anos (WHO, 1998, 1999; Allen \& Gillespie, 2001; Hill, Kirkwood \& Edmond, 2004).

\section{Intervenções para Prevenir a Desnutrição Infantil}

\section{Intervenções que Utilizaram Alimentos Complementares Processados}

Os ensaios de eficácia considerados foram as intervenções conduzidas de forma prospectiva, randomizadas, com um grupo intervenção recebendo alimentos específicos, sob condiçôes ideais, e um grupo controle concorrente não recebendo tais alimentos. O estado nutricional das crianças ao final ou a mudança no estado nutricional ao longo do estudo foi comparado entre os dois grupos e, sendo estes semelhantes na linha de base (no início da intervenção), as diferenças observadas foram atribuídas às intervenções específicas.

Em vários países realizaram-se ensaios randomizados para avaliar o efeito de alimentos complementares processados sobre o estado nutricional. Há registro na literatura de dez ensaios de eficácia conduzidos para melhorar a alimentação complementar que incluíram crianças de 6 a 12 meses de idade. Desses, seis lograram melhorar o estado nutricional das crianças beneficiadas no tempo planejado pelo estudo. Esses estudos, conduzidos na Colômbia, Guatemala, Indonésia, Jamaica, Sudão e Gana, distribuíram alimentos como suplementos à dieta usual da criança, embora diferindo quanto ao tipo de alimento oferecido e ao mecanismo de oferta empregado: 
a) $\mathrm{Na}$ Guatemala, o estudo Incap foi realizado em dois pares de povoados, de 1969 a 1977, para avaliar o crescimento e desenvolvimento de menores de 7 anos. Era oferecido um suplemento líquido contendo quantidades altas de calorias e moderadas de proteína (atole) ou um suplemento controle contendo poucas calorias (fresco, uma bebida adocicada) (Martorell, Habicht \& Rivera, 1995; Schroeder et al., 1995). Ambos os suplementos eram enriquecidos com as mesmas quantidades de micronutrientes (tiamina, riboflavina, niacina, ácido ascórbico, vitamina A, cálcio, fósforo, ferro e fluoreto). Às mães das crianças estudadas era oferecido o mesmo suplemento durante a gestação e a lactação. O suplemento era oferecido duas vezes por dia, para todos os habitantes dos quatro povoados, em centros de alimentação do estudo.

Houve maior ganho de peso e comprimento entre as crianças com 3-24 meses de idade do grupo intervenção. Os grupos de crianças de três anos de idade diferiram apenas quanto ao comprimento. No primeiro ano de vida, o consumo de cada $100 \mathrm{kcal} / \mathrm{dia}$ do suplemento intervenção resultou em ganhos adicionais de $0,35 \mathrm{~kg}$ no peso e $0,9 \mathrm{~cm}$ no comprimento. No segundo ano de vida, esses benefícios decresceram para $0,25 \mathrm{~kg}$ e $0,5 \mathrm{~cm}$, respectivamente.

b) Na Colômbia, no final dos anos 70 do último século, famílias de comunidades pobres de Bogotá, com alto risco de terem crianças desnutridas, foram aleatoriamente selecionadas para fazer parte do grupo intervenção ou controle (Mora et al., 1981; Lutter et al., 1990). Porçôes com quantidades previamente estipuladas do suplemento eram entregues semanalmente às gestantes do grupo intervenção e suas famílias na sede de campo do estudo. A intervenção iniciava no terceiro trimestre de gestação e se mantinha até que a criança completasse 36 meses de vida. A criança índex começava a receber suplementos diretamente aos três meses de vida. $\mathrm{O}$ suplemento para menores de um ano consistia em leite em pó integral e um produto preparado centralmente pelo estudo, rico em proteína (Duryea), composto por farinha de milho, amido de milho, farinha de soja e leite em pó. O suplemento para todos os demais membros da família maiores de 1 ano de idade consistia em leite em pó desnatado, pão enriquecido e óleo vegetal. A criança suplementada também recebia 7,5-15 mg/dia de sulfato ferroso, dependendo da idade, e $60.000 \mathrm{mg}$ de retinol.

Recém-nascidos de mães suplementadas pesaram $68 \mathrm{~g}$ a mais e foram $0,5 \mathrm{~cm}$ maiores ao nascer do que os das não suplementadas, embora a diferença não fosse estatisticamente significativa. Aos três meses de idade, as crianças do grupo intervenção estavam significativamente mais pesadas e com

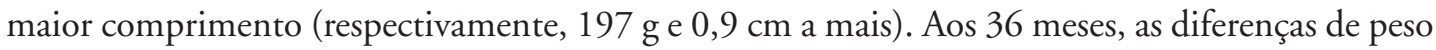
e estatura entre os grupos foram de $476 \mathrm{~g}$ e $2,2 \mathrm{~cm}$, ambas estatisticamente significativas e favoráveis à intervenção.

c) Na Jamaica, o estudo de Walker e colaboradores (1991) fornecia suplemento lácteo e/ou estímulo psicológico a crianças de 9 a 24 meses de idade, aleatoriamente selecionadas, que apresentassem escore Z de comprimento para idade (HAZ) menor que - 2 (stunted) e cujo peso ao nascer referido fosse maior que 1.800 gramas. As crianças do grupo controle poderiam ser stunted ou apresentar HAZ maior que - 1 . As crianças de ambos os grupos não eram amamentadas. O suplemento consistia em leite maternizado, que fornecia $750 \mathrm{kcal}, 20 \mathrm{~g}$ de proteína por dia, e era entregue no domicílio semanalmente, durante 12 meses. Leite em pó desnatado e cereal à base de milho eram fornecidos para o restante da família, na tentativa de reduzir a distribuição intrafamiliar do suplemento destinado à criança. Não houve efeito da estimulação psicológica sobre os desfechos nutricionais, sendo os grupos analisados de acordo com o fato de haver recebido suplementação ou não. Após seis meses de intervenção, as crianças que recebiam o suplemento apresentaram incrementos 
significativamente maiores em comprimento, peso, perímetro cefálico, perímetro braquial e prega triciptal. Após os seis meses não foram verificados benefícios. A criança suplementada ganhou aproximadamente $1,0 \mathrm{~cm}$ a mais em comprimento do que a criança controle stunted. No entanto, o HAZ do grupo suplementado (de aproximadamente - 2,0 HAZ) foi significativamente menor do que o do grupo de crianças controle não stunted. Possíveis explicações levantadas pelos pesquisadores para a melhora do crescimento somente na primeira metade do estudo incluíram diminuição de consumo do suplemento na segunda metade do programa ou maior impacto sobre crianças menores. Os autores não apresentaram resultados conforme as faixas etárias.

d) $\mathrm{Na}$ Indonésia, Husaini e colaboradores (1991) investigaram o efeito de suplementos alimentares sobre o crescimento e desenvolvimento de crianças de 6 a 20 meses de idade em creches localizadas em plantaçôes de chá. Crianças não suplementadas em creches adjacentes formaram o grupo controle. Os suplementos eram lanches oferecidos duas vezes por dia, seis dias por semana, durante três meses. Este foi o único ensaio em se usou uma combinação de alimentos sólidos e semi-sólidos em vinte tipos diferentes de lanches, que eram preparados com produtos locais (farinha de cereais e de tubérculos, pão, açúcar e óleo vegetal).

Nas creches, as crianças suplementadas consumiam cerca de $317 \mathrm{kcal}$ por dia a mais do que as não suplementadas. As crianças suplementadas ganharam 0,29 Desvios-Padrão (DP) em escore Z de peso para idade (WAZ) durante três meses de observação, ao passo que o WAZ das crianças controle diminuiu em 0,01 DP no mesmo período. Essas diferenças foram altamente significativas em termos estatísticos. Não houve diferença entre os grupos quanto à mudança em HAZ.

e) No Sudão, Vaughan e colaboradores (1981) compararam o efeito do leite em pó desnatado contra o consumo de grãos entre crianças de 6-26 meses de idade atendidas nos serviços de saúde da província de Khartoum. A cada 15 dias, durante três a seis meses, as mães recebiam $1 \mathrm{~kg}$ de leite em pó desnatado (grupo intervenção) ou o equivalente em grãos (grupo controle) para serem consumidos pela criança no domicílio. Havia trezentas crianças em cada grupo. A comparação entre os grupos mostrou que as mães do grupo intervenção continuaram amamentando mais dos que as do grupo controle e que houve maior ganho em comprimento entre as crianças que recebiam leite em pó desnatado (diferença de $0,25 \mathrm{~cm}$ por mês).

f) Em Gana, Lartey e colaboradores (1999) desenvolveram um produto alimentar (Weanimix), constituído por milho, soja e amendoim torrados, misturados e moídos, para ser adicionado ao leite. O suplemento era distribuído semanalmente para ser consumido três vezes por dia, no domicílio, durante seis meses. Foram formados cinco grupos de crianças com seis meses de idade: um recebia apenas Weanimix ( $n=53)$; outro recebia Weanimix com micronutrientes $(n=51)$; outro, Weanimix com farinha de peixe $(\mathrm{n}=52)$; outro recebia koko (espécie de mingau preparado com milho fermentado) com farinha de peixe $(n=52)$. O grupo controle foi formado por crianças de 6 a 12 meses de idade, avaliadas antes do recrutamento $(\mathrm{n}=79)$ ou após as crianças da intervenção terem completado 12 meses de idade $(\mathrm{n}=385)$.

Quando comparadas às controle, as crianças intervenção como um todo tiveram médias de WAZ aos 8, 11 e 12 meses, e de HAZ, aos 8, 10, 11 e 12 meses de idade, significativamente mais elevadas. Aos 12 meses, o WAZ médio no grupo intervenção foi de $-1,19 \pm 0,93$ e, no controle, de $-1,71 \pm$ 0,90; e o HAZ médio, de $-0,63 \pm 0,84$ e $-1,27 \pm 1,02$, respectivamente ( $\mathrm{p}<0,001$ para ambos). 
Os quatro ensaios que não obtiveram sucesso foram realizados na Tailândia; multicêntrico em quatro países (Bolívia, Congo, Nova Caledônia e Senegal); em Papua Nova Guiné e na República Popular da China:

g) Na Tailândia, no início de 1980, Gershoff e colaboradores (1988) realizaram um estudo em cinco grupos de povoados para investigar o efeito de um biscoito rico em gordura e enriquecido com micronutrientes, distribuído uma vez por dia em creches, como suplemento alimentar, durante 12 meses. Os biscoitos forneciam, aproximadamente, $300 \mathrm{kcal}$ e $6 \mathrm{~g}$ de proteína por dia, além de vários micronutrientes. Os autores relataram que o consumo de biscoitos era "alto", mas não o quantificaram. Embora as crianças do estudo fossem vários centímetros mais baixas do que as crianças tailandesas de classe média, não foi detectado impacto sobre o peso ou comprimento durante 22 meses de observação. No entanto, no grupo intervenção havia somente 16 crianças menores de um ano de idade, que eram as que mais poderiam se beneficiar da suplementação.

h) Em cada área da investigação multicêntrica realizada na Bolívia, no Congo, na Nova Caledônia e no Senegal (Simondon et al., 1996), de noventa a 127 crianças de 4-7 meses de idade foram aleatoriamente selecionadas para receber o suplemento ou fazer parte do grupo controle. Era um suplemento pré-cozido, especialmente preparado para o estudo, composto de vários cereais, farinha de soja, leite em pó, óleo vegetal e açúcar, e enriquecido com micronutrientes. $\mathrm{O}$ alimento era dado às crianças duas vezes por dia, sete dias na semana, no domićlio, pela equipe do estudo, durante três meses. $\mathrm{Na}$ residência da criança, o trabalhador de campo do estudo preparava a mistura do suplemento com a quantidade adequada de água, formando uma espécie de mingau semi-sólido, e observava enquanto a criança era alimentada. Um máximo de $200 \mathrm{kcal}$ por dia era oferecido aos menores de 4 meses de idade, e uma quantidade duas vezes maior aos mais velhos.

O consumo médio do suplemento variou de setenta a $161 \mathrm{kcal}$ por dia nos quatro locais. Várias das crianças da Bolívia, Congo e Senegal eram levemente ou moderadamente stunted aos quatro meses de idade (HAZ médio variando de - 0,5 a - 1,0). O comprimento inicial das crianças de Nova Caledônia era similar às referências internacionais. Comparadas às controle, as crianças suplementadas do Senegal ganharam mais em comprimento $(0,58 \mathrm{~cm})$ apenas dos 4 aos 5 meses de idade, e na Bolívia $(0,41 \mathrm{~cm})$, dos 5 aos 6 meses. Não houve impacto significativo da suplementação sobre o ganho de peso em nenhuma faixa etária, exceto um pequeno efeito negativo $(-0,17 \mathrm{~kg}) \operatorname{dos} 5$ aos 6 meses de idade, no Congo.

i) Em Papua Nova Guiné, Becroft e Bailey (1965), em um pequeno ensaio ( $\mathrm{n}=43$ crianças de 6-12 meses de idade), compararam o efeito da suplementação com leite em pó desnatado, pasta de amendoim e soja, pelo grupo intervenção, contra nenhum suplemento no grupo controle. Não foi verificada diferença entre os grupos após 12 meses de suplementação.

j) Na República Popular da China, Liu e colaboradores (1993) randomizaram, por vila de moradia, 226 crianças de 6 a 13 meses de idade para receber um biscoito doce enriquecido com micronutrientes (grupo intervenção) ou não enriquecido (grupo controle). O suplemento foi distribuído diariamente por três meses. Após três meses de suplementação, não foi detectado efeito sobre o crescimento.

\section{Intervenções que Utilizaram Somente Aconselhamento Nutricional}

Três intervenções, realizadas em Bangladesh (Brown et al., 1992), China (Guldan et al., 2000) e Brasil (Santos et al., 2001), utilizaram somente aconselhamento nutricional. Tais estudos tiveram como objetivo melhorar a alimentação complementar, sem deixar de incentivar a amamentação. A idade das crianças ao serem 
arroladas nos estudos variou de 0 até 18 meses (Santos, 2001), e o tempo de acompanhamento, de cinco (Brown et al., 1992) a 12 meses (Guldan et al., 2000).

Nos estudos de Bangladesh e da China, a intervenção era dirigida às mães, no domicílio, pela equipe de pesquisa. No estudo brasileiro, as recomendações nutricionais eram feitas dentro do sistema de saúde, por médicos, durante consultas pediátricas na rede de postos de saúde de Pelotas, RS. Os estudos em Bangladesh e no Brasil assemelharam-se quanto ao conteúdo das recomendações: ambos orientavam as mães sobre como enriquecer a alimentação infantil por meio do uso de alimentos locais disponíveis e acessíveis às condiçôes econômicas da família. Em Bangladesh, o aconselhamento consistia em demonstrar, no domićlio, como enriquecer a alimentação infantil por meio da adição de óleo, xarope de açúcar, leite, peixe, farinha de lentilha, vegetais e frutas da estação, além de estimular a introdução de novos alimentos e a continuação da amamentação. Eram também discutidas formas de melhorar a segurança alimentar com o armazenamento adequado e a higiene no preparo dos alimentos, lavando as mãos e recipientes antes de preparar as refeiçôes e alimentar a criança.

$\mathrm{Na}$ China, durante as visitas, os educadores nutricionais davam sugestões e conselhos sobre amamentação e alimentação complementar apropriados para a idade da criança, e distribuíam, para cada família, um guia sobre alimentação e um gráfico de peso. Além disso, esclareciam dúvidas, pesavam a criança e registravam o peso no gráfico. As mensagens visavam a melhorar a qualidade e quantidade dos alimentos complementares após os 4 meses de idade e manter a amamentação durante o primeiro ano de vida. Mensagens específicas incluíam: o leite materno exclusivo é o melhor alimento nos primeiros 4-6 meses de vida; iniciar a amamentação imediatamente após o nascimento; alimentar com mamadeira pode ser perigoso para a saúde da criança; o leite materno é de graça; a amamentação freqüente e em livre demanda é a melhor forma de amamentar; a criança necessita ser amamentada por pelo um ano; após os 4-6 meses, dar diariamente gema de ovo cozida (inicialmente misturada com um pouco de leite materno), depois, oferecer mingau de arroz e outros alimentos, para que a criança cresça bem e com saúde. Era enfatizado o emprego de alimentos preparados em casa e comumente utilizados pela família como base para o aconselhamento nutricional.

No Brasil, tendo como base as recomendaçōes gerais do programa de Atenção Integral às Doenças Prevalentes na Infância (AIDPI) (WHO, 1995a, 1995b), eram dados às mães os seguintes conselhos nutricionais: aumentar a freqüência das mamadas e das refeiçôes complementares; dar alimentos com proteína de origem animal e ricos em micronutrientes (p. ex., gema de ovo, fígado de galinha, galinha desfiada, carne moída); adicionar óleo de soja, manteiga ou margarina ao alimento da criança; aumentar a densidade energética e nutricional dos alimentos dando o grão de feijão (em vez de somente o caldo) e papa de legumes (em vez de sopa rala). As recomendações eram resumidas em um Cartão da Mãe, utilizado pelo médico durante o aconselhamento e entregue à mãe no final da consulta.

As três intervenções obtiveram impacto positivo sobre o estado nutricional das crianças, expresso em escores $\mathrm{Z}$ de peso para idade e duas também em escores $\mathrm{Z}$ de comprimento para idade (Guldan et al., 2000; Santos et al., 2001; Brown et al., 1992).

\section{Programas de Larga Escala}

Organizações internacionais e governos de países em desenvolvimento têm investido grandes volumes de recursos na tentativa de melhorar a alimentação complementar, geralmente por meio da distribuição de suplementos de produção centralizada e de baixo custo. A cobertura desses programas é variável, mas muitos foram planejados para terem alcance nacional. Caulfield, Huffman e Piwoz (1999) publicaram uma revisão sobre a experiência de 16 programas nutricionais em 14 países, a maioria dos quais era do tipo guarda-chuva, incluindo várias ações como imunizações, cuidados à saúde e monitorização do crescimento infantil. A maioria dos programas utilizou uma abordagem ampla, incluindo as práticas alimentares desde o início da amamentação até a 
completa integração da criança com os alimentos comumente utilizados pela família. Pesquisas formativas precederam a implementação desses programas, de forma a identificar práticas e crenças alimentares e a permitir o desenvolvimento de outras, melhores e aceitáveis pela população a que se dirigia. A maioria envolvia algum tipo de monitorização e avaliação. Todos os programas usaram uma variedade de abordagens de comunicação, incluindo os meios de comunicação de massa e aconselhamento face a face. Esses programas demonstraram que é possível desenvolver alimentos complementares nutricionalmente adequados em diversos ambientes culturais, aumentando o aporte calórico e, conseqüentemente, melhorando o crescimento infantil (Hill, Kirkwood \& Edmond, 2004).

No caso específico do Brasil, dois programas nutricionais marcaram presença nos últimos anos: o Programa Nacional do Leite e o Bolsa Alimentação, ambos, atualmente, incorporados pelo Programa Bolsa Família. O Programa Nacional do Leite (Brasil, 1993) distribuía, mensalmente, para crianças abaixo do percentil 10 de peso-para-idade, por intermédio dos postos de saúde, o equivalente a um litro de leite em pó integral por dia e um litro de óleo de soja, para ser adicionado ao leite. Aos demais membros da família menores de 5 anos e gestantes, era distribuído o equivalente a meio litro de leite integral por dia.

Uma avaliação do impacto do programa, em uma amostra de vinte municípios do estado de Alagoas, mostrou que o objetivo de melhorar o estado nutricional das crianças beneficiárias não estava sendo alcançado (Santos et al., 2005b). Os principais motivos para o insucesso identificados foram a descontinuidade do abastecimento do suplemento nos postos de saúde (atrasos de até dois meses seguidos), o não-cumprimento do fornecimento de suplemento para os contatos intradomiciliares menores de 5 anos e gestantes, conforme estabelecia o programa, e não-adesão das mães à adição do óleo de soja ao leite.

O Programa Bolsa Alimentação transferia renda a famílias pobres (renda per capita inferior a R \$120,00 mensais) que tivessem pelo menos um possível beneficiário (gestante e/ou nutriz e/ou criança de 6 meses a 6 anos de idade). Essas famílias recebem $R$ \$ 15,00 por beneficiário por mês, com um teto de $\mathrm{R} \$ 45,00$ por família. A avaliação do programa mostrou que seis meses após sua implementação as famílias beneficiárias gastavam 55\% do valor recebido na compra de alimentos (Ministério da Saúde, 2004). Dois anos após a implementação do programa, os índices antropométricos das crianças beneficiárias não apresentaram diferença estatisticamente significativa em comparação com o restante da população infantil da região Nordeste. Análises longitudinais mostraram que as beneficiárias, inicialmente em pior estado nutricional, ganhavam $8 \mathrm{~g}$ a mais de peso por mês do que as crianças do grupo controle (Ministério da Saúde, 2005).

\section{Resumo e Conclusões}

- Os ensaios de eficácia anteriormente descritos deixam claro que os resultados foram muito variáveis, por motivos nem sempre óbvios. A maioria dos ensaios com suplementos incluía leite em pó, com ou sem cereais, ou enriquecido com micronutrientes. Não há uma relação clara entre a composição do suplemento e o efeito sobre o crescimento infantil. $\mathrm{O}$ pequeno número de estudos, o limitado número de suplementos e a ampla variação nas idades, status nutricional no início do estudo e duração da amamentação entre as crianças participantes não permitem a realização de metanálises, nem a conclusão definitiva sobre a relação entre o tipo de suplemento e o efeito sobre o crescimento. Em três ensaios (Guatemala, Colômbia e Jamaica), o suplemento teve efeito sobre o peso e o comprimento. $\mathrm{Na}$ Indonésia, houve efeito somente sobre o peso.

- O impacto positivo da suplementação é esperado somente quando há déficit no estado nutricional da população-alvo e as práticas nutricionais são subótimas (WHO, 1998). Isso pode explicar a ausência de efeito no estudo da Nova Caledônia, onde o estado nutricional das crianças era similar 
às referências internacionais, e na Tailândia, onde as crianças recebiam as refeições em creches, nas quais o consumo de alimentos já devia ser adequado.

- A idade crítica para a suplementação parece ser entre 6 e 12 meses de idade e possivelmente, embora com menor benefício, por mais 1 a 2 anos (WHO, 1998). O aconselhamento nutricional realizado no Brasil, no entanto, teve efeito somente entre crianças com 12 meses ou mais de idade.

- Alguns estudos forneceram suplemento às gestantes e depois para seus bebês. Há alguma evidência de que bebês nascidos de mães suplementadas durante a gestação ganham mais peso e comprimento mesmo antes deles mesmos serem suplementados (Lutter et al., 1990; Kusin et al., 1992; Mora et al., 1979), mas há necessidade de mais estudos nessa área.

- Em geral, os programas de larga escala em que são distribuídos suplementos têm como populaçãoalvo crianças desnutridas identificadas através da monitorização do crescimento ou do exame clínico. Entretanto, os programas de alimentação complementar são mais apropriados para prevenir do que para tratar desnutrição (Hill, Kirkwood \& Edmond, 2004).

- Novas estratégias para controlar um problema nutricional específico deveriam ser testadas em ensaios de eficácia, nos quais a intervenção é implementada em condições ideais para determinar se o efeito biológico desejado pode ser obtido quando se tem certeza de que a intervenção realmente foi oferecida e utilizada pela população-alvo. Uma vez provado que uma nova intervenção funciona, ensaios de efetividade podem ser realizados para identificar a magnitude do impacto nutricional quando a intervenção é realizada sob as condições reais de um programa (Habicht, Victora \& Vaughan, 1999).

\section{Intervenções para Prevenir Anemia}

As intervenções de eficácia para melhorar o aporte de ferro incluem modificações na dieta, suplementação com sais de ferro e fortificação de alimentos.

\section{Suplementação com Sais de Ferro}

Ensaios randomizados, placebo-controlados, de eficácia, no primeiro ano de vida, mostraram que a suplementação melhora os níveis de hemoglobina e de ferritina (Allen \& Gillespie, 2001). No entanto, ainda é controversa a idade em que a anemia se inicia na infância, como são ainda incertos os limites de hemoglobina que a definem nessa faixa etária. Em um ensaio realizado em Honduras e na Suécia (Dewey et al., 2002) era fornecido $1 \mathrm{mg}$ de ferro/kg para crianças entre 4 e 9 meses de idade ou entre 6 e 9 meses. Todas as crianças recebiam leite materno exclusivo (todo o líquido, calorias e nutrientes eram provenientes exclusivamente do leite materno) até completar 6 meses de idade e, a partir daí, leite materno parcial (leite materno e outros alimentos líquidos, semisólidos e sólidos).

Embora as crianças de Honduras tivessem níveis de ferritina mais baixos no início do estudo, a suplementação com ferro entre 4 e 6 meses aumentou igualmente o nível de hemoglobina e ferritina nos dois grupos. A suplementação dos 6 aos 9 meses melhorou a hemoglobina e a ferritina em Honduras, mas, na Suécia, aumentou somente a hemoglobina. Os resultados sugerem que o ponto de corte de hemoglobina para diagnóstico de anemia no primeiro ano de vida pode estar alto demais, superestimando a prevalência de anemia neste grupo de idade (Allen \& Gillespie, 2001).

Nem todos os estudos verificaram aumento da hemoglobina em pré-escolares, especialmente entre os mais jovens. No México, Allen e colaboradores (2000) realizaram um ensaio randomizado entre crianças de 18 a 36 
meses de idade, das quais 70\% eram anêmicas. As crianças recebiam $20 \mathrm{mg} / \mathrm{dia}$ de ferro (grupo intervenção) ou placebo (grupo controle), durante 12 meses, sob supervisão. Após seis meses, o nível de hemoglobina foi levemente maior entre as suplementadas. Após 12 meses de suplementação, no entanto, não houve diferença entre os grupos. O nível de hemoglobina aumentou à medida que as crianças ficaram mais velhas, mas $30 \%$ em ambos os grupos permaneciam anêmicas aos 12 meses, a despeito da normalização da ferritina. A diferença entre os grupos não foi devida à maior prevalência de parasitas intestinais ou de outras doenças. O aumento da hemoglobina ocorreu entre as crianças mais bem nutridas, indicando que, possivelmente, a deficiência de outros micronutrientes tende a limitar a resposta da hemoglobina à suplementação com ferro.

Nos últimos anos, surgiu interesse em investigar a eficácia da suplementação semanal com ferro, em vez de diária, visando a melhorar a adesão dos participantes. Uma metanálise recente comparou a eficácia da administração semanal com a diária, no tocante aos níveis de hemoglobina e de ferritina (Beaton \& McCabe, 1999). Os autores concluíram que ambas são eficazes, desde que a adesão seja boa - se a adesão não for boa, a suplementação diária é mais efetiva (possivelmente porque deixar de tomar algumas doses diárias pode ser menos importante do que deixar de tomar algumas doses semanais) -, e que a duração da suplementação não influi sobre a comparabilidade da eficácia das duas abordagens (exceto entre gestantes, cuja demanda é maior e a janela de oportunidade é limitada).

\section{Aconselhamento Nutricional}

A infância, ao lado da adolescência e da gestação, é um período que requer grandes quantidades de ferro, uma vez que este micronutriente é necessário para o crescimento dos tecidos e para expansão do volume sanguíneo. A criança normal, em média, triplica o peso ao nascer no primeiro ano de vida. As necessidades diárias de ferro $(0,8 \mathrm{mg})$ no primeiro ano são quase iguais às de um homem adulto (Yip, 1997), sendo praticamente impossível atender a essa demanda sem a fortificação de alimentos (Brown, Dewey \& Allen, 1998). O volume de alimentos ricos em ferro, como fígado, por exemplo, que seria preciso consumir para atender a essa demanda é impraticável. Nos Estados Unidos, a quantidade de ferro nos alimentos infantis fortificados é sete vezes maior do que a encontrada nos alimentos não fortificados do Peru (Brown, Dewey \& Allen, 1998). Somente a suplementação ou a fortificação podem reduzir a prevalência de anemia ferropriva nessa faixa etária.

Uma maneira de melhorar a absorção de ferro dos alimentos é aumentar o consumo de vitamina C. A absorção de ferro não-heme é aumentada se os dois nutrientes forem consumidos dentro de uma hora entre um e outro (Hallberg, Brune \& Rossander, 1986). A eficácia da vitamina C dos alimentos é a mesma da vitamina C sintética. No entanto, há poucos estudos sobre a exeqüibilidade e o efeito da vitamina $\mathrm{C}$ de alimentos.

$\mathrm{Na}$ Índia (Seshadri, Shah \& Bhade, 1985), em um estudo randomizado com pré-escolares, durante dois meses, foram fornecidos suplementos de $100 \mathrm{mg}$ de vitamina $\mathrm{C}$, duas vezes por dia (almoço e jantar), ao grupo intervenção, e placebo ao grupo controle. As crianças suplementadas aumentaram o nível de hemoglobina e melhoraram a morfologia das hemácias, ao passo que as controle não apresentaram nenhuma mudança. No entanto, é praticamente impossível obter a quantidade de vitamina $\mathrm{C}$ oferecida a partir de alimentos, sendo mais factível sua adição a alimentos fortificados com ferro. No Chile, por exemplo, a adição de vitamina C ao leite em pó fortificado com ferro reduziu mais a anemia em pré-escolares do que somente o leite enriquecido (Walter et al., 1993).

A adição de carne de rês, ave, peixe ou outros animais à refeição não somente proporciona maior quantidade de ferro absorvível, mas também aumenta a absorção de ferro não-heme. O estudo de Engelmann, Sandstrom e Michaelsen (1998), na Dinamarca, com crianças de 8 meses de idade, mostrou que o alto consumo de carne de rês (27 g/dia), por dois meses, comparativamente ao baixo consumo $(10 \mathrm{~g} / \mathrm{dia})$, aumentava o nível de hemoglobina.

Uma intervenção educacional foi realizada em Pelotas com a população menor de 6 anos de idade atendida pela Pastoral da Criança (Santos et al., 2005a). As líderes do grupo intervenção foram treinadas para avaliar a alimentação das crianças e aconselhar as mães no uso de alimentos locais, de preço acessível para populações de 
baixa renda, ricos em macro e micronutrientes, cuja aceitabilidade e eficácia no crescimento infantil já haviam sido testadas em estudo anterior (Santos et al., 2001). A variação média da hemoglobina, em seis meses, não foi estatisticamente significativa, embora positiva no grupo intervenção $(0,20 \pm 2,41 \mathrm{~g} / \mathrm{dl})$ e negativa $(-0,02 \pm 1,95$ $\mathrm{g} / \mathrm{dl})$ no controle.

\section{Fortificação de Alimentos}

A fortificação de alimentos consiste em uma estratégia efetiva a longo prazo para melhorar o estado nutricional de ferro de populaçôes. Além de uma adequada biodisponibilidade do sal de ferro adicionado ao alimento, um programa de fortificação, para ser efetivo, requer a cooperação do governo, da indústria de alimentos e dos consumidores. A falta de sais de ferro com boa biodisponibilidade é o principal limitante desta estratégia. Sais de ferro como o sulfato e o fumarato são razoavelmente bem absorvidos quando adicionados a cereais, desde que o tempo de armazenamento não seja longo. Porém, os sais de ferro mais solúveis causam, ao longo do tempo, oxidação e rancificação das gorduras, além de modificação na cor do alimento. Para o tempo de validade de prateleira mais longo, é preferível fortificação com ferro reduzido, embora a absorção não seja tão boa. A absorção do ferro a partir de quelatos de aminoácidos (bisglicinato ferroso) é melhor protegida contra a ação de fitatos do que o sulfato ferroso. O bisglicinato ferroso é usado no Brasil e outros países para fortificar produtos lácteos. Quando a farinha é usada como veículo, como é o caso recente do Brasil, o grupo-alvo do programa é a população geral, embora esta estratégia não atinja os menores de 1 ano, que normalmente consomem pouco pão (Hill, Kirkwood \& Edmond, 2004).

Nos países desenvolvidos, a fortificação de alimentos complementares e de outros alimentos infantis tem sido efetiva para reduzir a deficiência de ferro (Michaelsen et al., 2000). A fortificação específica do leite em pó para ser distribuído a famílias de baixa renda no Chile também foi bem-sucedida (Stekel et al., 1986). No entanto, na maioria dos países menos desenvolvidos, em que a alimentação no primeiro ano e na infância baseiase quase que exclusivamente em alimentos produzidos localmente, o efeito da fortificação específica de alguns alimentos não costuma ser tão bom (Yip, 1997).

Uma recente revisão sobre a eficácia ou efetividade de intervenções com fortificação de alimentos, endereçadas a crianças e adolescentes, com foco sobre a anemia ou indicadores dos estoques de ferro (Assunção \& Santos, 2007) mostrou que, embora a fortificação venha sendo utilizada como uma estratégia para combater a deficiência de ferro em muitos países, a documentação sobre seu impacto na população é ainda muito limitada.

\section{Programas de Larga Escala}

\section{Programas de Suplementação}

A experiência com programas de suplementação em larga escala é muito limitada internacionalmente, e os resultados disponíveis são pouco encorajadores (Yip, 1997). Os problemas incluem baixa adesão a esquemas de uso diário de longa duração e a coexistência de deficiência de outros micronutrientes que podem prejudicar a resposta hematológica ao ferro, como suspeitado no ensaio realizado no México.

A suplementação semanal, além de tão eficaz quanto a diária na melhora dos níveis de hemoglobina de crianças com deficiência de ferro e anemia (Michaelsen et al., 2000), é provavelmente também mais factível. Há pouca informação sobre a efetividade ou factibilidade da suplementação semanal de ferro entre menores de um ano.

Formulações alternativas de ferro também têm sido desenvolvidas. Recentemente, o fumarato ferroso em pó, microcapsulado, em sachê de dose única, para ser adicionado em qualquer alimento semilíquido, foi testado por Zlotkin e colaboradores (2001). Em um ensaio randomizado conduzido em Gana, o fumarato ferroso em pó 
mostrou-se tão eficaz quanto o padrão-ouro (ferro em gotas) no tratamento da anemia entre pré-escolares. Além de não alterar o sabor ou a consistência do alimento, é fácil de usar, armazenar e transportar e aceita a adição de qualquer outro micronutriente.

\section{Programas com Alimentos}

Uma revisão sobre o impacto de programas baseados no aumento do consumo de produtos de origem animal (Ruel \& Levin, 2000) apresentou os resultados observados no Vietnã (com a promoção da criação de peixes e produção animal), no Peru (aumento da disponibilidade e promoção do consumo de fígado e outras vísceras), em Bangladesh (criação de peixes) e na Tailândia (criação de peixes e galinhas). No Vietnã, houve aumento no consumo de ferro pelas crianças, mas o status nutricional do mineral não foi analisado. No Peru, houve aumento no consumo de ferro heme e diminuição da prevalência de anemia. Em Bangladesh, não houve aumento do consumo de peixes nem impacto sobre o status em ferro. $\mathrm{Na}$ Tailândia, o consumo de ferro e vitamina $\mathrm{C}$ aumentou, como planejado.

O programa nacional de suplementação do Chile fornece leite semidesnatado fortificado com ferro a famílias de baixa renda. As mães recebem o leite nos postos de saúde, nas consultas de monitorização de peso e vacinação. A prevalência de anemia caiu de $27 \%$ para $10 \%$ entre crianças de 3-15 meses de idade (Stekel et al., 1986).

\section{Fortificação de Alimentos}

Em 1980, uma crise econômica afetou a quantidade e qualidade dos alimentos consumidos pelas famílias pobres da Venezuela, aumentando a prevalência de anemia. Em 1993, o governo venezuelano implementou um programa nacional de fortificação em que o milho pré-cozido e a farinha de trigo, que forneciam $45 \%$ das calorias diárias da população de baixa renda, foram enriquecidos com 20 e $50 \mathrm{mg}$ de ferro por kg, respectivamente. Em 1994, em Caracas, a prevalência de anemia em crianças de 7-15 anos havia caído de 19 para 9\% e a deficiência de ferro, de 37 para 16\% (Layrisse et al., 1996). Não houve grupo controle. Logo, o possível efeito de fatores externos ao programa não pôde ser descartado.

A fortificação de condimentos também tem sido realizada. $\mathrm{Na}$ Guatemala, em oito meses, em três comunidades que consumiram açúcar enriquecido com $13 \mathrm{mg}$ de ferro/100 g, houve aumento estatisticamente significativo nos estoques de ferro, em comparação a comunidades controle (Viteri et al., 1995). Na Tailândia, a fortificação do molho de peixe e, na África do Sul, a fortificação do curry, visando a atingir descendentes asiáticos, apresentaram resultados positivos sobre a hemoglobina (Garby \& Areekul, 1974).

No Peru, o programa nacional de alimentação escolar oferece biscoitos e leite enriquecidos com ferro no café da manhã. Após um ano, a prevalência de anemia caiu de 66 para 14\% (Allen \& Gillespie, 2001).

Uma avaliação do programa nacional de fortificação das farinhas de trigo e milho, recentemente implementado no Brasil, sobre a hemoglobina de crianças de até 6 anos de idade, em Pelotas, não demonstrou efetividade (Assunção et al., 2007). O consumo insuficiente de alimentos produzidos ou preparados com farinhas e a baixa biodisponibilidade dos sais de ferro utilizados para fortificação foram levantados como hipóteses para explicar o insucesso do programa entre as crianças pelotenses. 


\section{Resumo e Conclusões}

- Em uma população normal, espera-se que 2,5\% dos indivíduos apresentem anemia, a qual é considerada um problema de saúde pública somente quando essa prevalência ultrapassa os 5\%. Em uma mesma população, há cerca de duas a cinco vezes mais indivíduos com deficiência de ferro do que com anemia. Em populaçōes em que a prevalência de anemia ultrapassa $20 \%$, a prevalência de deficiência de ferro entre pessoas de mesma idade e sexo deverá estar em torno de $50 \%$. Se a prevalência de anemia ultrapassar os $40 \%$, virtualmente toda a população daquela idade e sexo deverá apresentar deficiência de ferro. Do ponto de vista da saúde pública, isso implica que, quando a prevalência de anemia ferropriva alcança níveis de 20-30\% em um determinado grupo de idade e sexo, deverá ser mais efetivo e, possivelmente, mais eficiente promover a suplementação universal com sais de ferro para todo o grupo do que rastrear indivíduos para tratamento individual (WHO, 2001).

- Vários países adotaram a suplementação no primeiro ano de vida e entre pré-escolares como política de saúde pública. Em regiōes onde a prevalência de anemia é inferior a 40\%, a recomendação é oferecer 12,5 mg de ferro elementar mais $50 \mathrm{mg}$ de ácido fólico por dia, dos 6 aos 12 meses de idade. Onde a prevalência de anemia é maior que $40 \%$, a suplementação deve ser prolongada dos 6 aos 24 meses e estendida a escolares, adolescentes e mulheres em idade reprodutiva (WHO, 2001).

- Programas nacionais de suplementação de larga escala são raros, e escassa a informação sobre sua efetividade e factibilidade (Hill, Kirkwood \& Edmond, 2004).

- A efetividade de programas baseados no consumo de alimentos ricos em ferro tem sido pouco estudada. $\mathrm{O}$ aumento isolado do consumo de vitamina $\mathrm{C}$ com base em alimentos locais não parece ser uma estratégia adequada para prevenir a ocorrência de anemia (Allen \& Gillespie, 2001). A promoção do consumo de carnes e vísceras é uma opção para aumentar o aporte de ferro absorvível.

- Nos países desenvolvidos, há uma boa evidência de que a fortificação com ferro de alimentos infantis complementares é efetiva na redução de anemia ferropriva (Michaelsen et al., 2000). A fortificação do leite em pó distribuído para famílias de baixa renda no Chile também foi bem-sucedida (Stekel et al., 1986). No entanto, na maioria das áreas menos desenvolvidas, onde a alimentação infantil é baseada principalmente em alimentos locais, é menos provável que a fortificação seja uma boa alternativa (Hill, Kirkwood \& Edmond, 2004).

- A fortificação com ferro não traz riscos adicionais à saúde. A absorção de ferro diminui naturalmente, à medida que aumentam os estoques do mineral. No entanto, uma pequena parcela da população pode ser suscetível à sobrecarga de ferro. $\mathrm{O}$ risco para indivíduos com talassemia minor ou outras hemoglobinopatias é pequeno, e o impacto da fortificação em áreas com malária deve ser monitorado (Allen \& Gillespie, 2001).

\section{Intervenções para Prevenir a Deficiência de Vitamina A}

As intervenções para melhorar o aporte de vitamina A incluem modificação da dieta e/ou criação de hortas domésticas, suplementação e fortificação de alimentos.

\section{Ensaios de Eficácia}

Uma metanálise com oito estudos randomizados, controlados, sobre o efeito da suplementação com vitamina A (Beaton, Martorell \& Aronson, 1993) mostrou uma redução de 23\% na mortalidade de crianças de 6 
meses a 5 anos de idade, em ambos os sexos. O efeito sobre a mortalidade foi maior para os casos de diarréia e sarampo. Em contraste, não há evidência de que a suplementação de crianças de 0-5 meses tenha impacto sobre a mortalidade.

Todos os estudos sobre mortalidade foram conduzidos em populações pobres, com manifestaçôes clínicas de deficiência de vitamina A. Não há relação direta entre taxas de xeroftalmia e níveis bioquímicos de deficiência (Hill, Kirkwood \& Edmond, 2004). O estudo randomizado conduzido por Barreto e colaboradores (1994), no Nordeste do Brasil, foi o único realizado em uma área sem xeroftalmia, mas com grave deficiência bioquímica, com vista a avaliar o efeito da suplementação sobre a morbidade. A suplementação com vitamina A mostrou efeito sobre a gravidade da diarréia, indicando não ser necessário que estejam presentes sinais oculares da deficiência para que ocorram benefícios às crianças suplementadas.

\section{Programas de Larga Escala}

\section{Modificação da Dieta e/ou Criação de Hortas Domésticas}

A vitamina A é encontrada como retinol no leite materno, fígado, ovos, manteiga e leite de vaca integral, e como betacaroteno (precursor da vitamina A) em vegetais de folhas verde-escuras e em frutas de cor laranja ou amarelada (como mangas). A promoção do plantio de vegetais e de técnicas de preservação, como desidratação de frutas, pode melhorar o aporte de vitamina A na dieta. No entanto, essa estratégia, se isolada, dificilmente é suficiente (Hill, Kirkwood \& Edmond, 2004). Primeiro, porque a dieta pode não conter quantidade suficiente de gordura que permita a conversão dos carotenóides em vitamina A. Segundo, porque o conhecimento sobre a biodisponibilidade da vitamina $\mathrm{A}$ em diferentes vegetais e o efeito de diferentes métodos de processamento desses alimentos (como duração e temperatura de cozimento) é ainda incompleto.

\section{Suplementação}

A vitamina A é armazenada no fígado e, ao contrário do ferro, que precisa ser consumido em bases regulares, seus estoques podem ser mantidos por 4-6 meses após a administração de altas dosagens. Em meados de 1997, a política da suplementação periódica com altas doses de vitamina A foi adotada pela maioria dos países com deficiência clínica ou subclínica documentada de vitamina A. Atualmente, cerca de um terço dos países que aderiram à suplementação com altas doses o faz juntamente com as vacinas nos dias nacionais de imunização (Unicef, 1998). Inicialmente, eram administradas 25.000 UI de vitamina A com cada uma das três doses da vacina tríplice (DTP) programadas para 6, 10 e 14 semanas de vida e com a vacina contra o sarampo (em torno do nono mês).

Um estudo multicêntrico foi realizado para avaliar o efeito da suplementação ligada à vacinação em 8.439 crianças em Gana, na Índia e no Peru, randomizadas para o grupo intervenção (vacinas e vitamina A em três doses) em comparação ao grupo controle (dose única de 100.000 UI de vitamina A aos 9 meses, junto com a vacina do sarampo). A suplementação ligada à vacinação mostrou um pequeno impacto sobre o status de vitamina A das crianças aos 6 meses de idade, comparadas às do grupo controle. Esse efeito não se manteve aos 9 meses. Não houve diferença entre os grupos quanto à mortalidade (WHO/CHD, 1998).

Atualmente, no Brasil, é administrada uma megadose de vitamina A (200.000 UI) às mães, no pós-parto imediato, para aumentar a disponibilidade da vitamina no leite materno. Às crianças é administrada uma dose de 100.000 UI para menores de 6 meses de idade, desmamadas, desnutridas ou em risco nutricional, e para todas entre 6 e 12 meses de idade. Entre 1 e 5 anos de idade, é administrada uma megadose de 200.000 UI (Ministério da Saúde, 1994). 


\section{Fortificação}

Vários países têm enfrentado a deficiência de vitamina A recorrendo à fortificação do açúcar. A Guatemala foi o primeiro país a adotar tal medida, tendo iniciado nos meados da década de 1970. Embora tenha havido uma interrupção no início dos anos 80, a avaliação de 82 povoados, em 1990, concluiu que a deficiência de vitamina A estava controlada naquele país (Unicef, 1998). Em 1998, Bolívia, El Salvador, Honduras e Filipinas passaram também a adotar essa medida.

\section{Resumo e Conclusões}

- O leite materno é a principal fonte de vitamina A no primeiro ano de vida. Crianças amamentadas apresentam menor prevalência de deficiência clínica de vitamina A, mesmo em áreas com altas prevalências.

- A suplementação em dose única alta, ao nascer, diminuiu a mortalidade nos quatro meses subseqüentes. Mas um estudo multicêntrico sobre a eficácia de altas doses de vitamina A, administradas juntamente com as vacinas de rotina, não detectou impacto sobre a mortalidade ou a morbidade das crianças do programa. A hipótese levantada pelos pesquisadores é que as doses administradas sejam muito baixas para melhorar o status de vitamina A da criança por tempo prolongado (WHO/ CHD, 1998).

- A fortificação de alimentos que alcançam os grupos populacionais com deficiência de vitamina A é outra estratégia que pode ser utilizada.

- Programas baseados em alimentos têm bom potencial para prevenção de deficiência de vitamina A. No entanto, há poucos estudos avaliando o impacto desse tipo de intervenção.

Em resumo, a redução da mortalidade na infância requer mais do que a disponibilidade e acesso a serviços de saúde bem estruturados e a equipes bem treinadas. É necessária a implementação de programas de saúde bem planejados e de eficácia comprovada. A melhoria das práticas familiares e comunitárias de cuidado infantil constitui uma das estratégias de importância-chave para a sobrevivência, redução da morbidade e promoção do crescimento e desenvolvimento saudáveis dos menores de 5 anos de idade (WHO, 1998, 1999; Allen \& Gillespie, 2001; Hill, Kirkwood \& Edmond, 2004). Essas práticas consistem em amamentação exclusiva até os 6 meses de idade; introdução de alimentação complementar aos 6 meses, com alimentos ricos em energia e nutrientes, mantendo a amamentação até os 2 anos de idade, e garantia de que as crianças recebam quantidades adequadas de micronutrientes (particularmente ferro, vitamina A e zinco), por meio da alimentação ou por suplementação.

Há, atualmente, suficiente evidência de que programas nutricionais de larga escala podem ser efetivos no crescimento e na melhoria do estado nutricional das crianças. Os fatores que contribuem para o sucesso de programas nutricionais não são exclusivos desse campo da saúde e incluem conhecimento adequado do problema nutricional na população-alvo, mobilização e participação comunitárias, treinamento de trabalhadores de campo, definição de metas programáticas, supervisão, monitoramento e avaliação de resultados (WHO, 1999). 


\section{Referências}

ALLEN L. H. \& GILLESPIE S. R. What works? A review of the efficacy and effectiveness of nutrition interventions. United Nations Sub-Committee on Nutrition and Asian Development Bank (ADB), Manila. Disponível em: <www.adb.org>. Acesso em: set. 2001.

ALLEN, L. H. et al. Lack of hemoglobin response to iron supplementation in anemic Mexican preschoolers with multiple micronutrient deficiencies. American Journal of Clinical Nutrition, 71(6): 1.485-1.494, 2000.

ASSUNÇÃO, M. C. F. \& SANTOS, S. I. Efeito da fortificação de alimentos com ferro sobre anemia em crianças: um estudo de revisão. Cadernos de Saúde Pública, 23(2): 269-281, 2007.

ASSUNÇÃO, M. C. F. et al. Efeito da fortificação de farinhas com ferro sobre anemia em pré-escolares, Pelotas, RS. Revista Saúde Pública, 41 (4): 539-548, 2007.

BARRETO, M. L. et al. Effect of vitamin A supplementation on diarrhoea and acute lower-respiratory-tract infections in young children in Brazil. The Lancet, 344(8.917): 228-231, 1994.

BEATON, G. H. \& MCCABE, G. P. Efficacy of Intermittent Iron Supplementation in the Control of Iron Deficiency Anemia in Developing Countries: an analysis of experience. Ottawa: Micronutrient Initiative, 1999.

BEATON, G. H.; MARTORELL, R. \& ARONSON, K. J. Effectiveness of Vitamin A Supplementation in the Control of Young Child Morbidity and Mortality in Developing Countries. Geneva: Administrative Committee on Coordenation, 1993. (ACC/SCN State-of-the-art Series, Nutrition Policy Discussion Papers)

BECROFT, T., \& BAILEY, K. V. Supplementary feeding trial in New Guinea Highland infants. The Journal of Tropical Pediatrics and African Child Health, 11(2): 28-34, 1965.

BRASIL. Comissão Especial para Propor Medidas de Combate à Fome, ao Desemprego e à Recessão. Plano de Combate à Fome e à Miséria: princípios, prioridades e mapa das ações de governo. Brasília, 1993. (Mimeo.)

BROWN, K.; DEWEY, K. \& ALLEN, L. Complementary Feeding of Young Children in Developing Countries: a review of current scientific knowledge. Geneva: World Health Organization, 1998. (WHO/NUT/98.1)

BROWN, L. V. et al. Evaluation of the impact of weaning food messages on infant feeding practices and child growth in rural Bangladesh. American Journal of Clinical Nutrition, 56(6): 994-1003, 1992.

CAULFIELD, L. E.; HUFFMAN, S. L. \& PIWOZ, E. G. Interventions to improve intake of complementary foods by infants 6 to 12 months of age in developing countries: impact on growth and on the prevalence of malnutrition and potential contribution to child survival. Food and Nutrition Bulletin, 20(2): 183-200, 1999.

DEWEY, K. G. et al. Iron supplementation affects growth and morbidity of breast-fed infants: results of a randomized trial in Sweden and Honduras. Journal of Nutrition, 132(11): 3.249-3.255, 2002.

ENGELMANN, M. D.; SANDSTROM, B. \& MICHAELSEN, K. F. Meat intake and iron status in late infancy: an intervention study. Journal of Pediatric Gastroenterology and Nutrition, 26(1): 26-33, 1998.

GARBY, L. \& AREEKUL, S. Iron supplementation in Thai fish-sauce. Annals of Tropical Medicine and Parasitology, 68(4): 467-476, 1974.

GERSHOFF, S. N. et al. Nutrition studies in Thailand: effects of calories, nutrient supplements, and health interventions on growth of preschool Thai village children. American Journal of Clinical Nutrition, 48(5): 1.214-1.218, 1988. 
GULDAN, G. S. et al. Culturally appropriate nutrition education improves infant feeding and growth in rural Sichuan, China. Journal of Nutrition, 130(5): 1.204-1.211, 2000.

HABICHT, J. P.; VICTORA, C. G. \& VAUGHAN, J. P. Evaluation designs for adequacy, plausibility and probability of public health programme performance and impact. International Journal of Epidemiology, 28(1): 10-18, 1999.

HALLBERG, L.; BRUNE, M. \& ROSSANDER, L. Effect of ascorbic acid on iron absorption from different types of meals. Studies with ascorbic-acid-rich foods and synthetic ascorbic acid given in different amounts with different meals. Human Nutrition Applied Nutrition, 40(2): 97-113, 1986.

HILL, Z.; KIRKWOOD, B. \& EDMOND, K. Family and Community Practices that Promote Child Survival, Growth and Development: a review of the evidence. Geneva: World Health Organization, 2004.

HUSAINI, M. A. et al. Developmental effects of short-term supplementary feeding in nutritionally-at-risk Indonesian infants. American Journal of Clinical Nutrition, 54(5): 799-804, 1991.

KUSIN, J. A. et al. Energy supplementation during pregnancy and postnatal growth. The Lancet, 340(8.820): 623-626, 1992.

LARTEY, A. et al. A randomized, community-based trial of the effects of improved, centrally processed complementary foods on growth and micronutrient status of Ghanaian infants from 6 to 12 mo of age. American Journal of Clinical Nutrition, 70(3): 391-404, 1999.

LAYRISSE, M. et al. Early response to the effect of iron fortification in the Venezuelan population. American Journal of Clinical Nutrition, 64(6): 903-907, 1996.

LIU, D. S. et al. Nutritional efficacy of a fortified weaning rusk in a rural area near Beijing. American Journal of Clinical Nutrition 57(4): 506-511, 1993.

LUTTER, C. K. et al. Age-specific responsiveness of weight and length to nutritional supplementation. American Journal of Clinical Nutrition, 51(3): 359-364, 1990.

MARTORELL, R.; HABICHT, J. P. \& RIVERA, J. A. History and design of the INCAP longitudinal study (1969-77) and its follow-up (1988-89). Journal of Nutrition, 125, suppl. 4: 1.027S-1.041S, 1995.

MICHAELSEN, K. F. et al. Feeding and Nutrition of Infants and Young Children: guidelines for the WHO European Region, with emphasis on the former Soviet countries. Copenhagen: World Health Organization, Regional Office for Europe, 2000. (WHO Regional Publications, European Series, 87)

MINISTÉRIO DA SAÚDE. Portaria ministerial n. 2.160 de 29 de dezembro de 1994. Administração de megadose de vitamina A. Brasília: MS, 1994.

MINISTÉRIO DA SAÚDE. Secretaria de Atenção à Saúde. Departamento de Atenção Básica. CoordenaçãoGeral da Política de Alimentação e Nutrição. Avaliação do Programa Bolsa Alimentação: primeira fase. Brasília: MS, 2004. (Série C. Projetos, Programas e Relatórios)

MINISTÉRIO DA SAÚDE. Secretaria de Atenção à Saúde. Departamento de Atenção Básica. Coordenação Geral da Política de Alimentação e Nutrição. Avaliação do Programa Bolsa Alimentação: segunda fase. Brasília: MS, 2005. (Série C. Projetos, Programas e Relatórios)

MORA, J. O. et al. Nutritional supplementation and the outcome of pregnancy. I. Birth weight. American Journal of Clinical Nutrition, 32(2): 455-462, 1979. 
MORA, J. O. et al. The effects of nutritional supplementation on physical growth of children at risk of malnutrition. American Journal of Clinical Nutrition, 34(9): 1.885-1.892, 1981.

RUEL, M. T. \& LEVIN, C. E. Assessing the Potential for Food-based Strategies to Reduce Vitamin A and Iron Deficiencies: a review of recent evidence. Washington: International Food Policy Research Institute, Food Consumption and Nutrition Division, 2000. (Discussion Paper, 92)

SANTOS, I. et al. Nutrition counseling increases weight gain among Brazilian children. Journal of Nutrition, 131(11): 2.866-2.873, 2001.

SANTOS, I. et al. Effectiveness of nutritional counseling provided by the Children's Mission on hemoglobin variation in under-six children. Cadernos de Saúde Pública, 21(1): 130-140, 2005 a.

SANTOS, I. S. et al. Evaluation of the impact of a nutritional program for undernourished children in Brazil. Cadernos de Saúde Pública, 21(3): 776-785, 2005 b.

SCHROEDER, D. G. et al. Age differences in the impact of nutritional supplementation on growth. Journal of Nutrition, 125, suppl. 4: 1.051S-1.059S, 1995.

SESHADRI, S.; SHAH, A. \& BHADE, S. Haematologic response of anaemic preschool children to ascorbic acid supplementation. Human Nutrition Applied Nutrition, 39(2): 151-154, 1985.

SIMONDON, K. B. et al. Effect of early, short-term supplementation on weight and linear growth of 4-7-moold infants in developing countries: a four-country randomized trial. American Journal of Clinical Nutrition, 64(4): 537-545, 1996.

STEKEL, A. et al. Absorption of fortification iron from milk formulas in infants. American Journal of Clinical Nutrition, 43(6): 917-922, 1986.

THE UNITED NATIONS CHILDREN'S FUND (UNICEF). The State of the World's Children 1998: a Unicef report. Malnutrition: causes, consequences, and solutions. Nutrition Reviews, 56(4): 115-123, 1998.

VAUGHAN, J. P. et al. An evaluation of dried skimmed-milk on children's growth in Khartoum Province, Sudan. Nutrition Research, 1(3): 243-252, 1981.

VITERI, F. E. et al. Fortification of sugar with iron sodium ethylenediaminotetraacetate (FeNaEDTA) improves iron status in semirural Guatemalan populations. American Journal of Clinical Nutrition, 61(5): 1.153$1.163,1995$.

WALKER, S. P. et al. Nutritional supplementation, psychosocial stimulation, and growth of stunted children: the Jamaican study. American Journal of Clinical Nutrition, 54(4): 642-648, 1991.

WALTER, T. et al. Effectiveness of iron-fortified infant cereal in prevention of iron deficiency anemia. Pediatrics, 91(5): 976-982, 1993.

WORLD HEALTH ORGANIZATION (WHO). Management of Childhood Illness: counsel the mother. Geneva: WHO/CDR, 1995a. (WHO/CDR/95.14.E)

WORLD HEALTH ORGANIZATION (WHO). Management of Childhood Ilness: management of the sick young infant age 1 week up to 2 months. Geneva: WHO/CDR, 1995b. (WHO/CDR/95.14.F)

WORLD HEALTH ORGANIZATION (WHO). Complementary Feeding of Young Children in Developing Countries: a review of current scientific knowledge. Geneva: WHO, 1998. (WHO/NUT/98.1) 
WORLD HEALTH ORGANIZATION (WHO). A Critical Link. Interventions for Physical Growth and Psychological Development: a review. Geneva: WHO, 1999. (WHO/CHS/CAH/99.3)

WORLD HEALTH ORGANIZATION (WHO). Iron Deficiency Anaemia: assessment, prevention, and control. A guide for programme managers. Geneva: WHO/CDR, 2001. (WHO/CDR/95.14.F)

WORLD HEALTH ORGANIZATION/CHILD AND ADOLESCENT HEALTH AND DEVELOPMENT (WHO/CHD). WHO/CHD Immunisation-Linked Vitamin A Supplementation Study Group. Randomised trial to assess benefits and safety of vitamin A supplementation linked to immunisation in early infancy. The Lancet, 352(9136): 1.257-1.263, 1998.

YIP, R. The challenge of improving iron nutrition: limitations and potentials of major intervention approaches. European Journal of Clinical Nutrition, 51, suppl. 4: S16-S24, 1997.

ZLOTKIN, S. et al. Treatment of anemia with microencapsulated ferrous fumarate plus ascorbic acid supplied as sprinkles to complementary (weaning) foods. American Journal of Clinical Nutrition, 74(6): 791-795, 2001 . 



\section{Parte II \\ Problemas Nutricionais Brasileiros}





\title{
16
}

\section{Epidemiologia da Desnutrição Infantil}

\author{
Wolney Lisboa Conde e Denise Petrucci Gigante
}

\begin{abstract}
A pesar da crescente importância na ocorrência de problemas nutricionais relacionados ao excesso de peso, a desnutrição ainda é prevalente em determinados grupos populacionais, atingindo principalmente crianças que vivem em regiōes menos desenvolvidas. Neste capítulo será descrita a distribuição da ocorrência de desnutrição infantil no Brasil e no mundo e serão abordados seus principais determinantes. Cabe destacar que, embora o termo desnutrição possa também ser usado para se referir ao excesso de peso, neste capítulo estará sendo usado como sinônimo para déficit nutricional.

Desnutrição ou baixo peso tem sido considerado como o principal fator de risco relacionado ao número de pessoas com incapacidade e o quarto fator relacionado ao número de mortes na população mundial, de acordo com dados da Organização Mundial da Saúde (OMS). Ao passo que o baixo peso atinge apenas países em desenvolvimento, nos países desenvolvidos os fatores de risco para incapacidades e mortalidade em geral estão relacionados ao excesso de peso, incluindo pressão arterial, colesterol e Índice de Massa Corporal (IMC) elevados e baixo consumo de frutas, legumes e verduras (WHO, 2002).
\end{abstract}

\section{Definição de Desnutrição}

O termo kwashiorkor tem sido aceito para nomear a desnutrição desde que foi publicado no jornal The Lancet, embora poucos saibam que sua tradução em um idioma do oeste africano seja "a doença da criança deposta" (Waterlow, 1992). No entanto, a adequada terminologia para descrever a desnutrição deve discriminar desde formas moderadas de déficit de peso até as formas severas tradicionalmente conhecidas como marasmo ou kwashiorkor (WHO, 1995).

Os termos desnutrição, subnutrição e desnutrição energético-protéica são, muitas vezes, usados indiscriminadamente para descrever valores antropométricos anormais. Sempre que possível, é recomendável que os déficits nutricionais sejam descritos conforme o parâmetro e o índice utilizados na classificação nutricional (WHO, 1995).

A definição operacional da desnutrição é, em geral, realizada com o uso de um ou mais índices que calculam a posição relativa das medidas antropométricas na distribuição de valores de referência; em seguida, pela aplicação de um ponto de corte, classifica-se o estado nutricional do indivíduo em saudável ou não. Esses índices 
são conhecidos como estatura-para-idade, peso-para-idade e peso-para-estatura e estão apresentados e descritos no capítulo 2, "Avaliação nutricional de crianças".

O crescimento linear é uma função biológica sofisticada e é, também, o produto da síntese de muitos processos fisiológicos. Por essa razão, é um dos melhores marcadores da situação geral de saúde, especialmente entre crianças menores de 5 anos. Em linhas gerais, pode-se dizer que o crescimento é a função que diferencia o estado nutricional de crianças ou adolescentes do estado nutricional dos adultos.

Déficits de estatura-para-idade descrevem falhas no crescimento linear da criança e estão ligados a prolongado consumo insuficiente de macro ou micronutrientes ou, ainda, a péssimas condiçóes de saúde. Déficits de peso-para-estatura indicam ganho inadequado de massa corporal em relação à estrutura física do indivíduo e estão ligados a processos agudos e mais recentes, traduzidos pelo catabolismo dos tecidos corporais e pela deficiência de energia. Déficits de peso-para-idade estão associados ao retardo do crescimento linear, ganho insuficiente de massa corporal ou catabolismo dos tecidos, constituindo-se, assim, em índice que pode traduzir múltiplos agravos nutricionais.

\section{Prevalências de Desnutrição no Brasil e no Mundo}

As prevalências de desnutrição em crianças menores de 5 anos de idade são apresentadas com base nos três índices antropométricos: peso-para-idade, estatura-para-idade e peso-para-estatura. Como indicado anteriormente, esses índices foram calculados pela comparação entre as medidas da criança observada e os valores antropométricos de uma população saudável, tomados como referência para aquele parâmetro. A prevalência de déficit nutricional, considerando cada um dos índices, é calculada pela proporção de crianças que se encontram abaixo de - 2 desviospadrão em relação à referência para aquele índice. Cabe destacar que, embora as novas curvas de referência estejam disponíveis desde abril de 2006, os resultados apresentados a seguir são anteriores à recomendação da OMS, e as prevalências de desnutrição foram calculadas com base na referência do National Center for Health Statistics (NCHS/WHO).

\section{Desnutrição no Brasil}

O Brasil dispõe, nas últimas quatro décadas, de grandes inquéritos de abrangência nacional com dados antropométricos. Esses dados permitem que se analise a evolução do estado nutricional de menores de 5 anos de idade de modo mais detalhado, identificando a mudança da situação nutricional nas grandes regiōes geográficas e segundo a situação do domicílio ou estratos socioeconômicos.

O último desses grandes inquéritos, a Pesquisa de Orçamentos Familiares (POF) 2002-2003, apresentou problemas na coleta dos dados antropométricos dos menores de 10 anos. Assim, não se recomenda o uso dos dados da estatura. Os dados do peso corporal devem ser utilizados com cautela, preferencialmente empregandose a correção dos valores nesta faixa etária, como descrito na própria publicação (IBGE, 2006). Por essa razão, neste capítulo a situação nutricional dos menores de 5 anos será descrita com base no índice peso-para-idade. Em 2002-2003, o índice antropométrico foi calculado com base nos valores corrigidos da medida do peso. Os dados podem diferir marginalmente daqueles oficialmente publicados, por serem produto de nova análise. 
Tabela 1 - Prevalência do déficit peso-para-idade em crianças menores de 5 anos, segundo situação do domicílio, por grandes regiōes. Brasil, 2002-2003

\begin{tabular}{lccc}
\hline & & \multicolumn{2}{c}{ Déficit peso-para-idade* $(\%)$} \\
\cline { 2 - 4 } Grandes regiões & Total & Situação do domicílio \\
\cline { 2 - 4 } & & 3,6 & Rural \\
\hline Brasil & 4,0 & 6,4 & 5,4 \\
\hline Norte & 7,4 & 4,8 & 5,3 \\
\hline Nordeste & 4,9 & 2,8 & 4,0 \\
\hline Sudeste & 2,9 & 2,6 & 2,5 \\
\hline Sul & 2,6 & 3,4 & 4,0 \\
\hline Centro-Oeste & 3,5 & \multicolumn{2}{c}{}
\end{tabular}

* Valores para o índice abaixo de - 2 escore - $z$.

Fonte: IBGE (2006).

As regiōes mais pobres do país, Norte e Nordeste, concentram os casos de déficit nutricional segundo o indicador peso-para-idade. Por outro lado, nas outras regiōes do país, a prevalência do déficit nutricional alcança valores muito próximos àqueles esperados em uma população que não sofra agravos nutricionais. ${ }^{1} \mathrm{~A}$ diferença entre as áreas urbana e rural, exceto no caso da região Sul, ainda é acentuada no Brasil. A região Norte mostrou-se a área nutricionalmente mais vulnerável do país, especialmente o Norte rural, cuja prevalência de déficit nutricional se aproxima daqueles valores observados em regiōes consideradas de prevalência moderada pela OMS (WHO, 2006). A POF 2002-2003 foi a primeira pesquisa nacional a coletar dados na área rural da região Norte (Tabela 1).

Parte das diferenças de déficit nutricional observadas entre as grandes regiōes e, internamente, segundo o local do domicílio, está ligada às grandes diferenças registradas na distribuição da renda no país. Para exemplificar, considerando apenas as famílias com crianças menores de 5 anos, a renda monetária domiciliar per capita na área rural da região Sul ( $\mathrm{R}$ \$ 290) é aproximadamente 1,3 daquela observada nas áreas urbanas das regiōes Norte ( $\mathrm{R} \$ 228)$ e Nordeste ( $\mathrm{R} \$ 219)$, em valores correntes de junho de 2003.

A estratificação da prevalência do déficit de peso-para-idade em seis faixas de múltiplos do salário mínimo per capita permite a observação da forte associação inversa entre essas duas variáveis (Tabela 2, página seguinte). A prevalência do déficit nutricional no grupo de famílias muito pobres, aquelas com renda per capita inferior a 1/4 do salário mínimo, é aproximadamente dez vezes aquela observada entre as famílias com renda per capita superior a cinco salários mínimos. O déficit nutricional no país está fortemente concentrado em crianças que vivem em famílias com renda inferior a $1 \frac{1}{2}$ salário mínimo per capita.

Inquérito nutricional realizado na região do Semi-Árido brasileiro mostrou que os programas governamentais de distribuição de renda a famílias muito pobres exercem efeito protetor sobre o crescimento infantil. O déficit de estatura-para-idade é, em média, 30\% menor entre as crianças de famílias matriculadas em programas de distribuição de renda. Na faixa entre 6 e 11 meses, idade crítica para o crescimento infantil, o déficit nutricional é $60 \%$ inferior entre as crianças de famílias matriculadas (Conde, Konno \& Monteiro, 2006).

A evolução do estado nutricional da população infantil brasileira nas últimas décadas é apresentada a seguir em figuras que descrevem a prevalência de déficits peso-para-idade entre menores de 5 anos em inquéritos nacionais realizados no país em 1974-1975, 1989, 1996 e 2002-2003. ${ }^{2}$ O índice peso-para-idade foi selecionado por ser o único disponível em todos os inquéritos. As estimativas excluem a população infantil das áreas rurais da região 
Norte, estudada apenas em 2002-2003. Nos inquéritos de 2002-2003 e 1974-1975, são utilizados valores corrigidos do peso, procedimento que leva em conta o excessivo coeficiente de variação das distribuições originais do peso, observadas nos dois inquéritos. Essa correção é necessária para que as estimativas dos inquéritos de 19741975 (Estudo Nacional de Despesas Familiares - Endef) e 2002-2003 (POF) possam ser comparadas às dos demais inquéritos (IBGE, 2006).

Tabela 2 - Prevalência do déficit peso-para-idade em crianças menores de 5 anos por grupos de idade segundo classes de rendimento monetário mensal familiar per capita. Brasil, 2002-2003

\begin{tabular}{lccc}
\hline \multirow{2}{*}{$\begin{array}{l}\text { Classes de rendimento } \\
\text { monetário mensal familiar per } \\
\text { capita (salários mínimos) }\end{array}$} & Total & \multicolumn{2}{c}{ Déficit peso-para-idade* $(\%)$} \\
\cline { 2 - 4 } & & $0-23$ & Grupos de idade (meses) \\
\hline Até $1 / 4$ & 7,4 & 5,2 & 8,8 \\
\hline Mais de $1 / 4$ a $1 / 2$ & 6,5 & 4,7 & 7,5 \\
\hline Mais de $1 / 2$ a 1 & 3,7 & 3,0 & 1,1 \\
\hline Mais de 1 a 2 & 2,6 & 3,7 & 1,9 \\
\hline Mais de 2 a 5 & 1,5 & 0,7 & 0,7 \\
\hline Mais de 5 & 0,8 & 1,0 & \\
\hline
\end{tabular}

* R \$ 200,00 - valor do salário mínimo vigente em 15 de janeiro de 2003.

* * Valores para o índice abaixo de - 2 escore -z.

Fonte: IBGE (2006).

No período de aproximadamente 14 anos que separa os inquéritos de 1974-1975 e 1989, o declínio médio observado na prevalência foi igual a 0,68 ponto percentual ao ano. No período de aproximadamente sete anos, que separa os inquéritos de 1989 e 1996, observa-se declínio médio anual na prevalência igual a 0,11 ponto percentual. Nos sete anos seguintes, que separam os inquéritos de 1996 e 2002-2003, a média do declínio na prevalência do déficit nutricional foi igual a 0,33 ponto percentual ao ano. Embora com menor intensidade nos dois últimos intervalos, a tendência de redução no déficit nutricional se manteve ao longo de todo o período analisado.

O declínio do déficit nutricional é inicialmente mais intenso nas áreas urbanas do que nas áreas rurais do país (Figura 1). Dessa forma, até 1996 observa-se o crescimento do excesso relativo de desnutrição no meio rural. Em 1996, a prevalência do déficit ponderal no meio rural (9,8\%) supera em quase duas vezes a estimada no meio urbano (5,1\%). No período mais recente, entre 1996 e 2002-2003, a tendência se inverte e o declínio é substancialmente maior no meio rural, o que aproxima as prevalências de déficits ponderais encontradas no meio urbano $(3,6 \%)$ e no meio rural $(5,7 \%)$. 
Figura 1 - Evolução da prevalência (\%) de déficits de peso-para-idade na população de crianças com menos de 5 anos de idade. Brasil, períodos 1974-1975, 1989, 1996 e 2002-2003

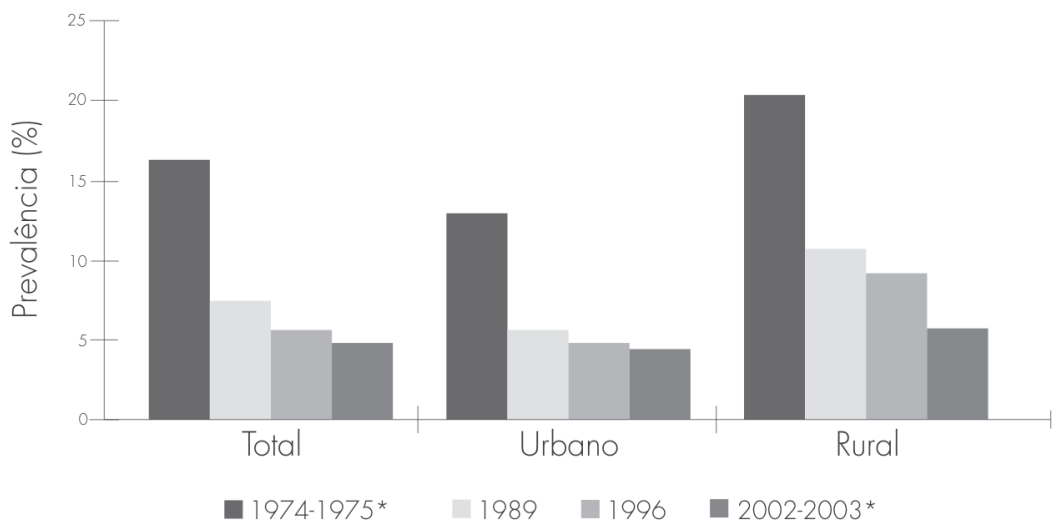

* Prevalências ajustadas para corrigir a imprecisão na mensuração e registro de peso.

Fontes: IBGE. Endef 1974-1975; Inan. PNSN 1989; Bemfam. PNDS 1996; IBGE/Diretoria de Pesquisas/Coordenação de Trabalho e Rendimento. POF 2002-2003.

Regionalmente, o declínio do déficit nutricional no país também apresenta diferentes tendências nas últimas décadas (Figura 2, página seguinte). $\mathrm{Na}$ área Centro-Sul do país (regiōes Sudeste, Sul e CentroOeste), entre 1974-1975 e 1989 ocorre intensa redução no déficit nutricional: de 10\%-12\% para cerca de 3\%-4\%. Nos períodos entre 1989 e 1996 e entre 1996 e 2002-2003, a prevalência de déficits ponderais nesse agregado regional apresenta pequenas flutuações e situa-se em torno de 3\%-4\%. Nas regiões Norte (apenas áreas urbanas) e Nordeste, a prevalência de déficits ponderais parte de valores mais altos (22\%25\%, em 1974-1975), porém o declínio é contínuo ao longo dos quatro inquéritos. Esse movimento é mais acentuado na região Nordeste, na qual o declínio relativo do déficit nutricional é mais intenso no último período.

Ao longo das décadas de 1970 e 1980, o excesso relativo de déficits ponderais na metade norte do país aumentou em relação à metade sul. Já na primeira metade da década de 1990, entre 1989 e 1996, o que se observa é uma forte tendência de redução da desigualdade Norte/Sul, e essa redução prossegue de modo particularmente claro para a região Nordeste até 2002-2003. Na região Nordeste, entre 1996 e 2002-2003 a situação nutricional dos menores de 5 anos evoluiu de forma particularmente favorável no meio rural.

A análise da evolução do estado nutricional de acordo com a renda familiar (ou do inventário de bens presentes no domicílio em 1996) pode ser realizada criando-se, em cada inquérito, cinco estratos de renda (ou bens) proporcionalmente iguais, de modo que o primeiro deles represente a fração dos $20 \%$ mais pobres, e o último a fração dos $20 \%$ mais ricos, em cada período. No período entre os dois primeiros inquéritos, o declínio do déficit nutricional é mais intenso em todos os estratos econômicos (Figura 3, p. 287). Para as crianças de maior renda (os dois estratos econômicos superiores), a prevalência do déficit nutricional em 1989 já é muito baixa (inferior aos 2,3\% esperados); assim, nos períodos subseqüentes, o déficit nutricional apenas flutua em torno das baixas freqüências alcançadas no primeiro período. Nos estratos econômicos com menor poder aquisitivo, reduz-se a intensidade observada no primeiro período, porém mantém-se a tendência de declínio até o inquérito de 2002-2003. No período mais recente, a redução do déficit nutricional é digna de nota entre as crianças situadas nos estratos mais pobres, especialmente quando comparadas àquelas dos estratos mais ricos. Entre 1996 e 2002-2003, o déficit nutricional declina de 15,5\% para 
$8,7 \%$ no quinto inferior da distribuição do poder aquisitivo (os $20 \%$ mais pobres), de $9,3 \%$ para $6 \%$, no segundo quinto, de $4,6 \%$ para $3,4 \%$, no terceiro quinto, de $3,3 \%$ para $3,2 \%$, no quarto quinto e de $2,4 \%$ para $1,5 \%$, no quinto superior da distribuição do poder aquisitivo (os $20 \%$ mais ricos).

Figura 2 - Evolução da prevalência (\%) de déficits de peso-para-idade na população de crianças com menos de 5 anos de idade segundo grandes regiōes. Brasil, períodos 1974-1975, 1989, 1996 e 2002-2003

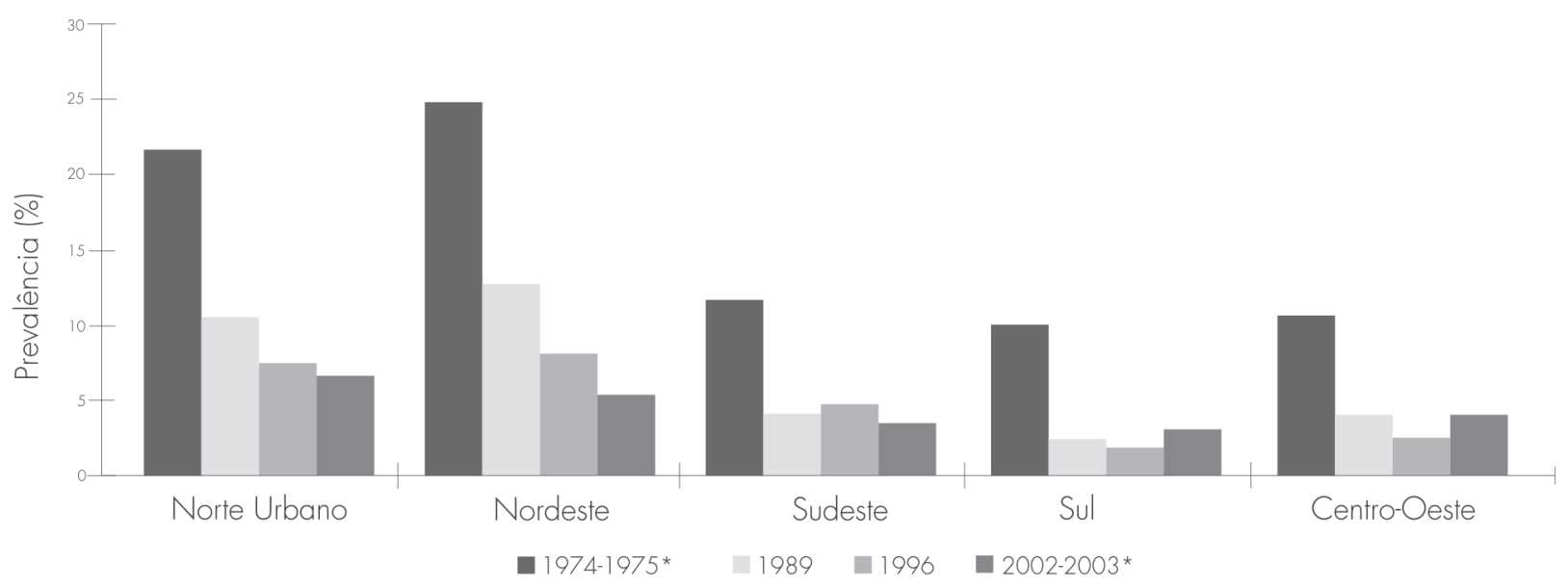

* Prevalências ajustadas para corrigir a imprecisão na mensuração e registro de peso.

Fontes: IBGE. Endef 1974-1975; Inan. PNSN 1989; Bemfam. PNDS 1996; IBGE/Diretoria de Pesquisas/Coordenação de Trabalho e Rendimento. POF 2002-2003.

A análise da evolução do estado nutricional infantil nas últimas décadas evidencia, pela primeira vez no país, o surgimento de uma clara tendência de redução das enormes desigualdades econômicas quanto à prevalência da desnutrição na infância.

\section{Desnutrição no Mundo}

Levantamentos sobre a situação nutricional realizados ainda na década de 1980, em diferentes países, são de difícil comparação, uma vez que nem sempre são utilizadas as mesmas referências, pontos de corte, índices e indicadores nutricionais. Em 1986, a OMS iniciou a padronização e sistematização de coleta de dados da situação nutricional de crianças menores de 5 anos (De Onis et al., 1993).

Em recente revisão realizada no banco internacional de dados sobre crescimento infantil da OMS, envolvendo dados de todas as regiōes em desenvolvimento, a América Latina mostrou-se a região com menores déficits nutricionais de estatura-para-idade, peso-para-idade e peso-para-estatura. O banco de dados contém informações de inquéritos antropométricos realizados em amostras probabilísticas da população de crianças menores de 5 anos de 79 países em desenvolvimento entre 1980 e 1992.

Dividindo-se o conjunto de países em quatro partes, segundo valores do indicador de déficit de peso-paraidade, no primeiro quarto estão os países com prevalências inferiores a 10\%; no segundo quarto, os países com prevalências entre 10 e 19\%; no terceiro, os países com prevalências entre 20 e 29\%; no quarto superior, estão os países com prevalências iguais ou superiores a $30 \%$ da população infantil. Esses quatro intervalos de prevalências foram denominados grupos de países com déficits ponderais relativamente baixos, moderados, altos e muito altos, respectivamente (De Onis et al., 1993). Tomando-se apenas os inquéritos mais recentes dos países da 
América Latina compilados pelo mesmo banco de dados, estariam no grupo de baixa prevalência de déficits ponderais Venezuela (6,2\%, em 2000) e Colômbia (6,7\%, em 2000); no grupo de prevalências moderadas estariam Equador (14,3\%, em 1998) e Haiti (17,2\%, em 2000). Nenhum dos países latino-americanos, com dados recentes, apresentou déficits ponderais superiores a $20 \%$ da população de menores de 5 anos (WHO, 2006).

Figura 3 - Evolução da prevalência (\%) de déficits de peso-para-idade na população de crianças com menos de 5 anos de idade segundo quintos da renda familiar per capita ou do número de bens no domicílio. Brasil, períodos 1974-1975, 1989, 1996 e 2002-2003

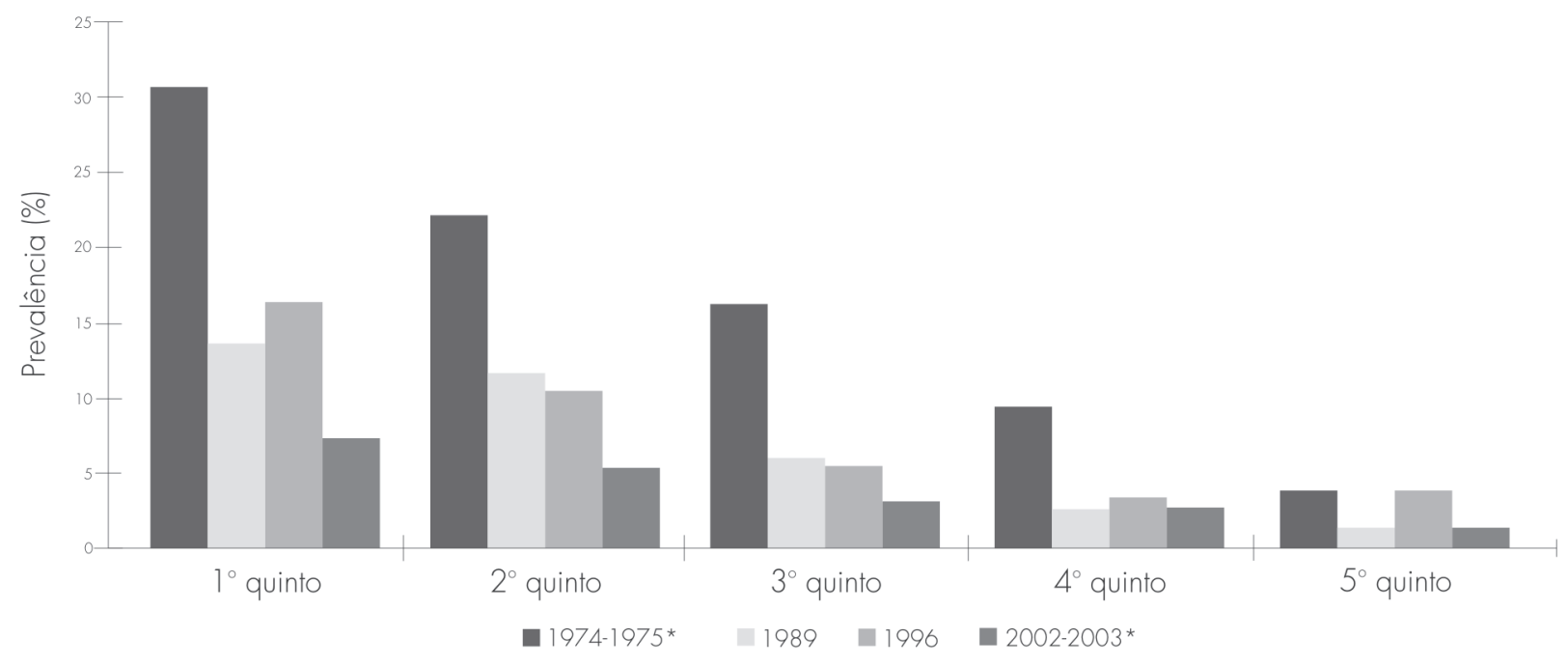

*Prevalências ajustadas para corrigir a imprecisão na mensuração e registro de peso.

Fontes: IBGE. Endef 1974-1975; Inan. PNSN 1989; Bemfam. PNDS 1996; IBGE/Diretoria de Pesquisas/Coordenação de Trabalho e Rendimento. POF 2002-2003.

Tendências nas estimativas de retardo no crescimento infantil foram analisadas com base em informações obtidas em 241 estudos, com representatividade nacional, incluídos na base de dados da OMS. Análise multinível estimando as tendências no déficit de estatura-para-idade de países em desenvolvimento, no período de 1980 a 2005, mostra um declínio de 47\% em 1980 para 33\% em 2000 em todos os países. Ao passo que houve aumento em países do leste africano, reduçôes foram observadas nos países em desenvolvimento do continente asiático, América do Sul, Caribe e norte da África. Poucas diferenças foram observadas entre países da América Central e do oeste da África. Apesar do decréscimo nas prevalências globais dos países em desenvolvimento, a desnutrição permanece como importante problema de saúde pública nesses países (De Onis, Frongillo \& Blossner, 2000). Estimativas das prevalências por regiōes são apresentadas na Figura 4. 
Figura 4 - Estimativa da prevalência de déficit de estatura-para-idade, por regióes depaíses em desenvolvimento, no período de 1980 a 2005

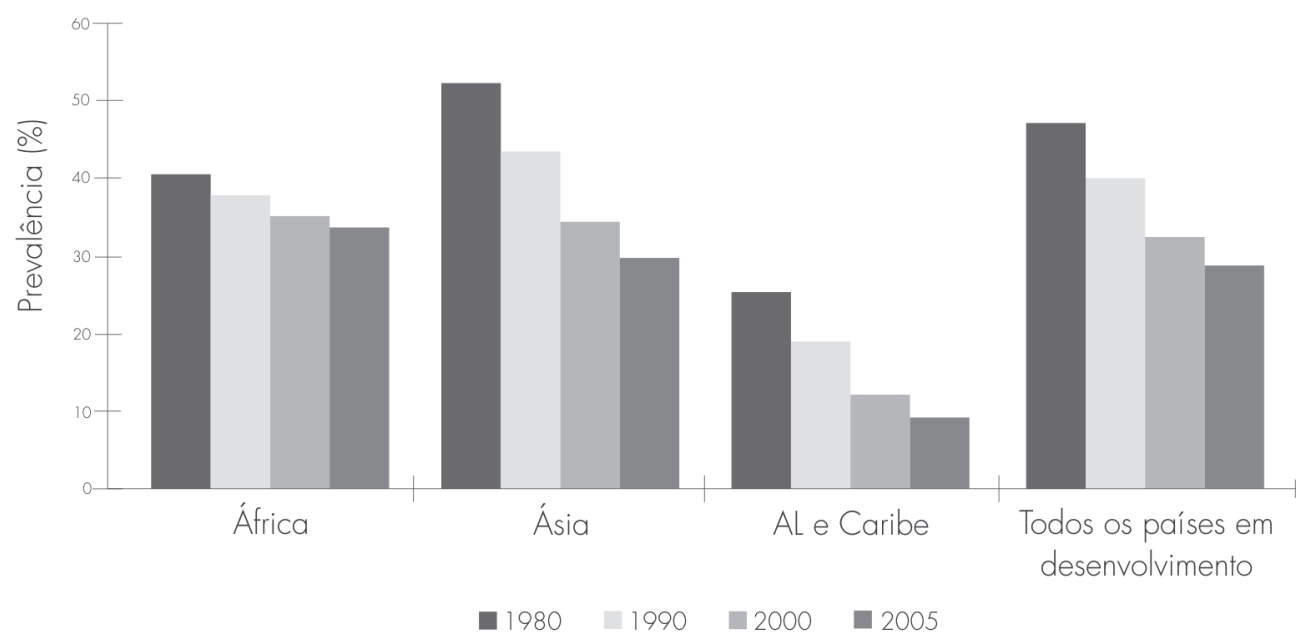

Fonte: De Onis, Frongillo \& Blossner (2000).

Outra análise, agora utilizando o índice peso-para-idade e calculando a prevalência global de desnutrição infantil de 1990 a 2015 (Figura 5), estima declínio de 36\% para o período (De Onis et al., 2004). Da mesma forma que para o déficit de estatura-para-idade, diferenças podem ser observadas entre as regióes. Ao passo que reduções nas estimativas das prevalências estão sendo observadas em países da Ásia, aumentos estão sendo estimados em países da África. Na população mundial de crianças menores de 5 anos, espera-se uma redução de cerca de cinqüenta milhões de casos de desnutrição no período de 1990 a 2015, representando uma diminuição em torno de $34 \%$, que seria menor do que a redução pela metade, estabelecida como meta para o desenvolvimento do milênio, de acordo com proposta das Nações Unidas.

Essa meta poderia ser alcançada na maioria dos países, exceção feita a algumas regiōes da África, onde se espera um aumento substancial nos casos de desnutrição em crianças (um aumento relativo dessas prevalências seria em torno de 12\%). Resultados dessas análises são apresentados na Figura 5. A redução observada em todos os países em desenvolvimento é de 36\%, na América Latina e Caribe é superior àquela proposta para as Metas do Milênio (61\%) e nos países em desenvolvimento da Ásia, um pouco inferior (47\%).

Dados de prevalência de desnutrição no mundo mostram que, ao contrário da percepção popular, a maioria das crianças com déficit de peso-para-estatura não vive na África. No entanto, em alguns países com elevadas proporçõos de mulheres e crianças contaminadas por HIV, um aumento na ocorrência desse déficit nutricional em regióes da África, seja como efeito direto da doença ou pelo impacto indireto da segurança alimentar e da atenção à criança, poderá ser observado. A maioria das crianças com déficit de peso-para-estatura vive na Ásia. Na Índia, Paquistão e Bangladesh são identificadas cerca de 5,5 milhões de crianças com déficit de peso-paraestatura, representando $78 \%$ desse déficit nutricional na população mundial de crianças menores de 5 anos (Gross \& Webb, 2006). 
Figura 5 - Estimativa da prevalência de déficit de peso-para-idade por regiōes de países em desenvolvimento, em 1990 e 2015

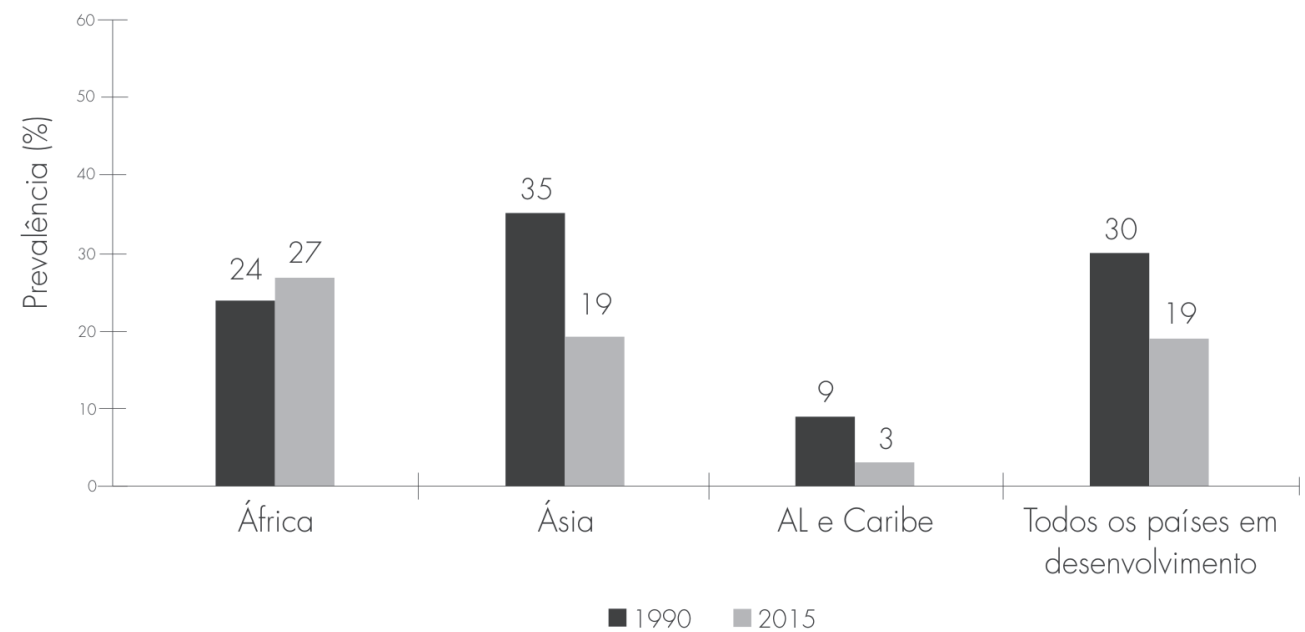

Fonte: De Onis et al. (2004).

\section{Principais Determinantes}

Os resultados dos estudos analisados, especialmente aqueles de abrangência nacional, ilustram a complexidade da determinação do estado nutricional infantil e estabelecem como principais fatores para explicar as diferenças entre os países - ou, internamente, entre as regiōes de cada país - a área de localização do domicílio (urbana ou rural) e o estrato socioeconômico no qual a criança está inserida. Subjacentes a esses fatores, observam-se o nível de desenvolvimento do país, a distribuição interna da riqueza, a estabilidade política, as prioridades nos gastos públicos, além de outras condições ambientais e culturais de cada região ou país. Entre os fatores biológicos que influenciam a desnutrição, os determinantes mais próximos são o consumo inadequado de alimentos e a presença de doenças infecciosas.

A ocorrência de desnutrição tem sido explicada em função de alguns mecanismos fisiológicos que são apresentados no Quadro 1.

Quadro 1 - Mecanismos fisiológicos relacionados com a desnutrição

\begin{tabular}{|ll|}
\hline Causa & Efeito \\
\hline Fome/anorexia & $\downarrow$ consumo energético \\
\hline Doença infecciosa/síndrome de má absorção/deficiência enzimática & $\downarrow$ absorção de nutrientes \\
\hline Uso de medicamentos/presença de morbidade & $\downarrow$ utilização de nutrientes \\
\hline Processo fisiológico/gravidez/lactação) ou patológico (febre) & $\uparrow$ necessidades energéticas \\
\hline Queimadura/lesão/presença de outra morbidade & $\uparrow$ perda de nutrientes \\
\hline
\end{tabular}

No sentido fisiológico, esses cinco mecanismos explicam como o balanço energético pode se tornar negativo. Entretanto, o que pode também ser constatado é que os principais fatores envolvidos nesse balanço energético negativo estão relacionados a fatores socioeconômicos, culturais, ambientais ou biológicos, que, por sua vez, determinam o consumo energético inadequado ou a presença de doenças que são consideradas as causas proximais da ocorrência da fome/desnutrição. 
A complexidade e a natureza dos fatores envolvidos na determinação do déficit nutricional requerem que se leve em conta na análise a cadeia causal dos determinantes do estado nutricional e o tempo decorrido entre a exposição a cada fator e a desnutrição. Assim, estimadores estatísticos que explicitem a hierarquia das causas e organizem a precedência da exposição a cada fator passam a ser ferramentas importantes nas análises da determinação do estado nutricional e nas recomendações de políticas públicas que se façam a partir delas.

Desnutrição é, freqüentemente, parte de um ciclo vicioso que inclui pobreza e doença, sendo cada um destes três componentes inter-relacionados e contribuintes da ocorrência e persistência do outro. Para romper esse ciclo, são necessárias, além das intervenções específicas na área de nutrição e saúde, mudanças sociais, políticas e econômicas que atuem sobre os determinantes mais distais da desnutrição.

Os determinantes distais não agem diretamente sobre os déficits antropométricos, e sim por meio de fatores intermediários ou proximais, que podem estar agindo por diferentes cadeias de determinação da desnutrição. Por exemplo, a pobreza e o desemprego são considerados como causas distais que, por sua vez, agem sobre a disponibilidade de alimentos no domić́lio ou o acesso a serviços de saúde, considerados determinantes intermediários e com atuação sobre as causas proximais, como o consumo inadequado de nutrientes e a ocorrência de doenças infecciosas.

Em relação às causas proximais, deve-se ressaltar que pode haver consumo deficiente de energia, proteína ou de micronutrientes e que as doenças infecciosas, por sua vez, podem levar à desnutrição por meio dos distintos mecanismos fisiológicos supracitados, seja por redução do apetite e diminuição no consumo alimentar, seja por aumento das necessidades energéticas ocasionado pelo catabolismo de nutrientes durante um processo infeccioso.

Assim como as conseqüências das doenças infecciosas sobre a desnutrição estão bem estabelecidas (Victora et al., 1990; Keusch, 2003), a influência dos déficits nutricionais sobre a ocorrência dessas doenças também tem sido descrita, demonstrando o ciclo vicioso entre desnutrição e infecção (Victora et al., 1994, 1999).

O início da desnutrição geralmente ocorre em torno do sexto mês de vida da criança, quando a transição de alimentos complementares pode ser inadequada em qualidade e quantidade e também quando ocorre maior freqüência de exposição a doenças infecciosas (Giugliani \& Victora, 2000). Entretanto, a população idosa, principalmente em regiōes menos desenvolvidas, também pode ser considerada um grupo de risco para a desnutrição (SCN, 1997b). Sendo assim, em qualquer grupo etário, a ocorrência da desnutrição pode estar relacionada a fatores biológicos, sociais, econômicos e culturais que, por sua vez, podem estar envolvidos em qualquer um dos mecanismos de determinação.

\section{Conseqüências da Desnutrição}

A fome e a desnutrição são reconhecidas como as principais causas de mortalidade por doenças infecciosas em crianças menores de 5 anos. Mais da metade das mortes por pneumonia, diarréia, sarampo, malária ou HIV/ Aids tem a desnutrição como causa básica, sendo esta, portanto, considerada responsável por mais da metade de 10,5 milhões de mortes previsíveis em crianças menores de 5 anos de idade que ocorrem a cada ano, em países menos desenvolvidos (Jones et al., 2003).

A relação entre desnutrição e mortalidade mostra que mais de cinco milhões de crianças menores de 5 anos de países em desenvolvimento morrem a cada ano como consequiência direta ou indireta da desnutrição. Desse total, cerca de $40 \%$ das mortes ocorrem na Índia (Gross \& Webb, 2006). Dados obtidos de dez estudos de coorte mostram um aumento significativo no risco de morrer associado ao déficit de peso-para-idade. Esse risco aumentado ocorreu para mortalidade por todas as causas, como também por diarréia, pneumonia, malária ou sarampo. Do total, $53 \%$ de todas as mortes em crianças foram consideradas conseqüências da desnutrição (Caulfield et al., 2004).

Além das conseqüências da desnutrição sobre a mortalidade, verifica-se que a maioria das crianças desnutridas menores de cinco anos que vivem em países menos desenvolvidos tem seu desenvolvimento motor, cognitivo 
e socioemocional afetado. Os primeiros anos de vida da criança são especialmente importantes, pois nessa fase a maior parte do desenvolvimento em todos os domínios está ocorrendo, o cérebro está se desenvolvendo rapidamente e pequenas alterações durante esse processo podem levar a grandes conseqüências estruturais e funcionais de sua capacidade. Embora poucos dados nacionais estejam disponíveis sobre o desenvolvimento de crianças menores de 5 anos de regiões menos desenvolvidas, estima-se que 200 milhões não têm sua capacidade funcional completamente desenvolvida. Embora o maior número dessas crianças viva no sul da Ásia, maiores proporçôes estão vivendo em algumas regiōes da África (Grantham-McGregor et al., 2007).

A influência da desnutrição sobre a função cognitiva na vida adulta também tem sido estudada e, embora a desnutrição seja associada com o desenvolvimento emocional e comportamental da criança, sua repercussão sobre o desenvolvimento a longo prazo ainda não foi completamente estabelecida (Caulfield, Richard \& Rivera, 2006).

Déficit de crescimento na infância também está relacionado com baixa estatura na vida adulta (Gigante et al., 2006). Algumas evidências mostram que o déficit nutricional está relacionado com a produtividade no trabalho (Martorell, 1996), a função cognitiva e a capacidade reprodutiva (Haas et al., 1996), e sua associação com mortalidade é consistente com os efeitos da situação nutricional precoce sobre a morbidade e a mortalidade na vida adulta. Conseqüências da desnutrição, desde o período intra-uterino, sobre as condições adversas na vida adulta têm sido bastante estudadas (Barker, 2004) e estão abordadas no capítulo 32, "Efeitos a longo prazo da nutrição na infância".

Uma recente revisão de estudos longitudinais em países em desenvolvimento sugere que as crianças não estão atingindo seu completo potencial de desenvolvimento, com conseqüências no desempenho escolar e na transferência da pobreza para as próximas geraçôes. Estima-se que a perda de potencial humano seja associada com mais de $20 \%$ no déficit de renda, com implicação para o desenvolvimento desses países (Grantham-McGregor et al., 2007), sendo o déficit de crescimento linear um dos quatro fatores identificados como principal causa dessa menor capacidade do desenvolvimento humano (Walker et al., 2007).

Finalmente, três principais rotas de perpetuação do ciclo da pobreza como conseqüência da desnutrição têm sido propostas. As duas primeiras, já comentadas anteriormente, estariam relacionadas a perdas diretas ou indiretas na produtividade do trabalho e do desempenho escolar por diminuição da capacidade física e da função cognitiva. Essas duas rotas refletem um custo econômico que pode ser constatado por meio de estudos que mostraram um aumento na renda em torno de $10 \%$ para cada ano de escolaridade (Vazir, Naidu \& Vidyasagar, 1998; Drewett et al., 2001), ao passo que a terceira rota de perpetuação do ciclo da pobreza está relacionada a perdas econômicas como conseqüência de gastos com saúde e um custo direto da fome/desnutrição tem sido estimado entre vinte e trinta bilhões de dólares por ano em todo o mundo (SCN, 1997a).

\section{Prevenção da Desnutrição}

Há 146 milhões de crianças desnutridas menores de 5 anos de idade vivendo em países em desenvolvimento (Editorial Global childhood malnutrition. Lancet, 367(9.521): 145, 2006). Considerando as metas para o desenvolvimento do milênio estabelecidas pelas Naçôes Unidas, diversos organismos internacionais vêm trabalhando em iniciativas de combate à fome/desnutrição no intuito de reduzir pela metade, até 2015, a proporção de indivíduos que sofrem pela fome. A redução na proporção de crianças menores de 5 com déficit de peso-para-idade é um dos principais indicadores para o alcance dessa meta. Além dessa, o sucesso no alcance de outras metas estabelecidas no desenvolvimento do milênio, como educação primária universal, redução da mortalidade infantil, melhora da saúde materna e combate à malária, HIV/Aids são dependentes da meta de fim da fome/desnutrição. Por exemplo, em relação à quarta meta do desenvolvimento do milênio, que se refere à redução de $2 / 3$ na mortalidade de crianças menores de 5 anos, sabe-se que cerca de 5 a 6 milhões de mortes poderiam ser evitadas com a prevenção da desnutrição. 
Diferentes estratégias têm sido utilizadas em programas de abrangência nacional de combate e prevenção da desnutrição em vários países em desenvolvimento. A maioria dos esforços tem focado a prevenção de doenças infecciosas que estão relacionadas com a redução do apetite, o aumento das necessidades energéticas e a perda de nutrientes (Caulfield, Richard \& Rivera, 2006), mesmo que haja evidências indicando a necessidade de uma intervenção mais efetiva com a melhoria das práticas alimentares (Becker, Black \& Brown, 1991). Uma revisão sistemática mais recente evidencia a influência do apoio dos profissionais da saúde sobre a duração do aleitamento materno (Sikorski et al., 2003), sugerindo que intervençōes podem ser efetivas em prolongar a duração do aleitamento materno, o que levaria a uma redução em torno de $13 \%$ na proporção de todas as mortes em crianças menores de 5 anos (Jones et al., 2003). Intervençôes nutricionais na prevenção da desnutrição são abordadas no capítulo 15, "Intervenções nutricionais na infância".

Ao mesmo tempo, outras intervenções também podem ser efetivas na prevenção e controle de doenças infecciosas e, conseqüentemente, sobre a desnutrição. A utilização de mosquiteiros com inseticida tem sido efetiva na diminuição da prevalência de anemia e na melhora no crescimento em regióes de elevada prevalência de malária (Lengeler, 2004). A prevenção de doença diarréica por meio de intervenções de programas de promoção de higiene em larga escala tem sido efetiva e levado à diminuição da desnutrição infantil (Checkley et al., 2004; Borghi et al., 2002).

Finalmente, no que se refere à prevenção da desnutrição, há evidências de que medidas efetivas de intervençôes nutricionais ou de controle de doenças infecciosas foram capazes de reduzir a proporção de crianças desnutridas em diferentes regiōes e países. Em contrapartida, o alcance da primeira meta de desenvolvimento do milênio - redução pela metade na proporção de desnutridos, até 2015 - tem sido discutido (Editorial Global childhood malnutrition. Lancet, 367(9.521): 145, 2006), e uma nova estratégia que posiciona a questão da sobrevivência infantil no topo da lista de prioridades está sendo proposta para o período de 2006 a 2015 (Bryce et al., 2006).

\section{Considerações Finais}

Embora o termo desnutrição possa referir-se a diferentes processos, tem sido mais frequentemente utilizado para descrever déficits nutricionais. Neste capítulo, as prevalências de desnutrição foram apresentadas para os três índices: peso-para-estatura, peso-para-idade e estatura-para-idade, sendo que cada um deles descreve um processo diferente.

As prevalências dos déficits nutricionais estão diminuindo no Brasil e no mundo; entretanto, alguns grupos populacionais, especialmente crianças menores de 5 anos e de regiões menos desenvolvidas, ainda são atingidos pela desnutrição em níveis alarmantes.

A inter-relação entre nutrição, infecção e pobreza pode ser considerada como o principal fator determinante da ocorrência de desnutrição, que, por sua vez, é uma conseqüência de fatores sociais, econômicos, políticos, culturais e biológicos, os quais, segundo um modelo hierárquico de determinação causal, atuam como determinantes distais, intermediários ou proximais. Ao mesmo tempo, as doenças infecciosas e suas influências sobre a capacidade de trabalho e a mortalidade podem ser consideradas como as principais conseqüências da desnutrição, interferindo no desenvolvimento de indivíduos e populaçôes.

Finalmente, a prevenção da desnutrição em grupos e populações específicas deve abranger desde intervenções até mudanças políticas, sociais e econômicas, com o envolvimento permanente de todos os países e dos organismos internacionais, e não apenas em situações emergenciais. 


\section{Notas}

1 Como observado no capítulo 2, em populações que não sofram agravos nutricionais a frequiência de crianças com baixo peso é inferior a $2,3 \%$.

2 Os inquéritos Estudo Nacional de Despesas Familiares (Endef), realizados em 1974-1975, estudaram 53.311 domicílios em todo o país; a Pesquisa Nacional Saúde e Nutrição (PNSN), realizada em 1989, estudou 14.458 domicílios em todo o país; a Pesquisa Nacional Demografia e Saúde (PNDS), realizada em 1996, estudou 3.629 domicílios em todo o país; a Pesquisa de Orçamentos Familiares (POF), realizada em 2002-2003, estudou 48.568 domicílios em todo o país. A POF foi a primeira pesquisa a cobrir todas as áreas em todas as grandes regiōes geográficas.

\section{Referências}

BARKER, D. J. P. The developmental origins of adult disease. Journal of the American College of Nutrition, 23(6): 588S-595S, 2004.

BECKER, S.; BLACK, R. E. \& BROWN, K. H. Relative effects of diarrhea, fever, and dietary energy intake on weight gain in rural Bangladeshi children. American Journal of Clinical Nutrition, 53(6): 1.499-1.503, 1991.

BORGHI, J. et al. Is hygiene promotion cost-effective? A case study in Burkina Faso. Tropical Medicine and International Health, 7(11): 960-969, 2002.

BRYCE, J. et al. Getting it right for children: a review of Unicef joint health and nutrition strategy for 2006-15. The Lancet, 368(9.538): 817-819, 2006.

CAULFIELD, L. E.; RICHARD, S. \& RIVERA, J. A. et al. Stunting, wasting, and micronutrient deficiency. In: JAMISON, D. T. et al. Disease Control Priorities in Developing Countries. New York: Oxford University Press, 2006.

CAULFIELD, L. E. et al. Undernutrition as an underlying cause of child deaths associated with diarrhea, pneumonia, malaria, and measles. American Journal of Clinical Nutrition, 80(1): 193-198, 2004.

CHECKLEY, W. et al. Effect of water and sanitation on childhood health in a poor Peruvian peri-urban community. The Lancet, 363(9.403): 112-118, 2004.

CONDE, W. L.; KONNO, S. \& MONTEIRO, C. A. Análise do inquérito Chamada Nutricional 2005. Cadernos de Estudos Desenvolvimento Social em Debate, 4: 29-36, 2006.

DE ONIS, M.; FRONGILLO, E. A. \& BLOSSNER, M. Is malnutrition declining? An analysis of changes in levels of child malnutrition since 1980. Bulletin of the World Health Organization, 78(10): 1.222-1.233, 2000 .

DE ONIS, M. et al. The worldwide magnitude of protein-energy malnutrition: an overview from the WHO Global Database on Child Growth. Bulletin of the World Health Organization, 71(6): 703-712, 1993.

DE ONIS, M. et al. Estimates of global prevalence of childhood underweight in 1990 and 2015. Jama, 291(21): 2.600-2.606, 2004.

DREWETT, R. et al. Malnutrition and mental development: is there a sensitive period? A nested case-control study. Journal of Child Psychological and Psychiatry, 42(2): 181-187, 2001. 
GIGANTE, D. P. et al. Early life factors are determinants of female height at age 19 years in a populationbased birth cohort (Pelotas, Brazil). Journal of Nutrition, 136(2): 473-478, 2006.

GIUGLIANI, E. R. \& VICTORA, C. G. Complementary feeding. Jornal de Pediatria, 76, suppl. 3: S253-62, 2000.

GRANTHAM-MCGREGOR, S. et al. International Child Development Steering Group: developmental potential in the first 5 years for children in developing countries. The Lancet, 369: 60-70, 2007.

GROSS, R. \& WEBB, P. Wasting time for wasted children: severe child undernutrition must be resolved in nonemergency settings. The Lancet, 367: 1.209-1.211, 2006.

HAAS, J. D. et al. Early nutrition and later physical work capacity. Nutrition Reviews, 54, suppl. 2: S41-48, 1996.

INSTITUTO BRASILEIRO DE GEOGRAFIA E ESTATÍTICA (IBGE). Pesquisa de Orçamentos Familiares 2002-2003: antropometria e análise do estado nutricional de crianças e adolescentes no Brasil. 2. ed. Rio de Janeiro: IBGE, 2006.

JONES, G. et al. How many child deaths can we prevent this year? The Lancet, 362(9.377): 65-71, 2003.

KEUSCH, G. T. The history of nutrition: malnutrition, infection and immunity. Journal of Nutrition, 133(1): 336S-340S, 2003.

LENGELER, C. Insecticide-treated bed nets and curtains for preventing malaria. Cochrane Database System Review, 2: CD000363, 2004.

MARTORELL, R. The role of nutrition in economic development. Nutrition Reviews, 54(4): S66-71, 1996.

SIKORSKI, J. et al. Support for breastfeeding mothers: a systematic review. Pediatric Perinatology and Epidemiology, 17(4): 407-417, 2003.

STANDING COMMITTEE ON NUTRITION (SCN). Update on the nutrition situation 1966. Summary of results for the Third Report on the World Nutrition Situation. SCN News, 14: 7-9, 1997a.

STANDING COMMITTEE ON NUTRITION (SCN). Assessing the nutritional vulnerability of older people in developing countries. SCN News, 15: 22-24, 1997b.

VAZIR, S.; NAIDU, A. N. \& VIDYASAGAR, P. Nutritional status, psychosocial development and the home environment of Indian rural children. Indian Pediatric, 35(10): 959-966, 1998.

VICTORA, C. G. et al. Pneumonia, diarrhea, and growth in the first 4 y of life: a longitudinal study of 5.914 urban Brazilian children. American Journal of Clinical Nutrition, 52(2): 391-396, 1990.

VICTORA, C. G. et al. Risk factors for pneumonia among children in a Brazilian metropolitan area. Pediatrics, 93(6): 977-985, 1994.

VICTORA, C. G. et al. Potential interventions for the prevention of childhood pneumonia in developing countries: improving nutrition. American Journal of Clinical Nutrition, 70(3): 309-320, 1999.

WALKER, S. P. et al. Child development: risk factors for adverse outcomes in developing countries. The Lancet, 369(9.556): 145-157, 2007.

WATERLOW, J. C. Protein Energy Malnutrition. London: Edward Arnold, 1992. 
WORLD HEALTH ORGANIZATION (WHO). Physical Status: the use and interpretation of anthropometry. Geneva: WHO, 1995. (WHO Technical Report Series, 854)

WORLD HEALTH ORGANIZATION (WHO). The World Health Report. Reducing Risks, Promoting Healthy Life. Geneva: WHO, 2002.

WORLD HEALTH ORGANIZATION (WHO). Global database on child growth and malnutrition. Geneva: WHO, 2006. Disponível em: <http://www.who.int/gdgm/p-child_pdf>. Acesso em: 29 dez. 2006. 



\title{
17 \\ Epidemiologia da Anemia Ferropriva
}

\author{
Pedro Israel Cabral de Lira e Luiz Oscar Cardoso Ferreira
}

\begin{abstract}
A epidemiologia da anemia ferropriva, por definição, deve tratar dos determinantes da distribuição deste agravo nutricional causado pela deficiência de ferro no organismo humano, que afeta, sobretudo, o desempenho de uma das funçôes mais nobres do sangue, o transporte de oxigênio. Conhecer os determinantes da distribuição da anemia ferropriva significa descrever e explicar o que é anemia ferropriva, quantos e quem são os atingidos pelo agravo nutricional, assim como saber onde, quando, como e por que grupos populacionais são afetados pela doença, com a finalidade de contribuir para o enfrentamento do problema.

Em 1990, por iniciativa das Naçôes Unidas, à frente o Fundo das Nações Unidas para a Infância (Unicef) e a Organização Mundial da Saúde (OMS), reuniram-se em Nova York representantes de oitenta países durante o Encontro Mundial de Cúpula pela Criança com a finalidade de elaborar um plano de ação para ser implementado durante a última década do século XX, visando a melhorar a saúde de crianças e mães, combater a desnutrição, o analfabetismo e erradicar as doenças que matavam milhões de crianças a cada ano. "A redução de um terço nos níveis de anemia das mulheres com relação a 1990" (Unicef, 1990) foi uma das metas estabelecidas naquele encontro, demonstrando a gravidade da situação epidemiológica da deficiência e o compromisso inadiável dos governos e organismos internacionais com o enfrentamento do problema.

Este capítulo trata, portanto, do entendimento da anemia ferropriva, abordando suas causas, consequiências e o modo de enfrentar o problema mediante o olhar epidemiológico, como um instrumento básico da saúde coletiva, enfocando primordialmente o cenário brasileiro.

\section{Histórico}

Consta da mitologia grega que Íficlo foi curado de impotência e de infertilidade com uma beberagem feita com a casca de um carvalho no qual havia sido cravada uma faca (Guimarães, 1995). Os médicos da antiga Grécia administravam água potável ou vinho, em que uma espada havia sido enferrujada, para tratar pacientes com palidez acentuada, com o propósito de passar o vigor do ferro ao doente, pois acreditavam que Marte, o deus da guerra, havia imbuído o metal de forças superiores (Hillman, 1991).

Nos meados do século XVII, mulheres jovens que apresentavam respiração difícil, palidez, palpitação, queixas gastrintestinais e perversão do apetite eram consideradas portadoras de clorose, um arcaico termo usado para definir a deficiência de ferro. Thomas Sydenham (médico inglês, considerado o Hipócrates do Ocidente)
\end{abstract}


prescrevia, na segunda metade do século XVII, limalhas de ferro banhadas em vinho para tratar moças cloróticas, iniciando assim a história biológica do ferro (Hillman, 1991).

Em 1932, Födisch observou que a quantidade de eritrócitos dos cloróticos estava diminuída, e dez anos depois Andral e colaboradores notaram que a terapêutica com ferro provocava um aumento no número de hemácias, estabelecendo-se os primórdios científicos da anemia ferropriva e de seu tratamento. Exatamente cem anos antes de Födisch, o médico francês Pierre Blaud desenvolvera uma pílula que consistia de partes iguais de sulfato ferroso e carbonato de potássio para enfrentar a clorose (Hillman, 1991).

Ainda no século XVIII, Menghini observou que pó de sangue podia ser atraído por um corpo imantado, e em 1916 Williamsom desenvolveu um método espectométrico para mensurar a concentração de hemoglobina em escala populacional, inclusive em crianças (Dallman, 1989).

No despontar do século XX, aprofundam-se os estudos sobre o metabolismo do ferro, e nos anos $40 \mathrm{Hahn}$ e colaboradores, mediante estudos com isótopos radioativos do ferro, descrevem um fenômeno de supressão de absorção do mineral em cães (Hahn et al., 1943). Na década de 1980, o fenômeno do bloqueio da mucosa é confirmado em seres humanos.

As implicações entre a deficiência de ferro e respostas a estímulos na área cognitiva passam a ser objeto crescente de interesse da investigação científica na década de 1970, com os trabalhos pioneiros de Oski e Honig (1978), estabelecendo-se a partir daí a associação entre a deficiência do mineral e o desenvolvimento cognitivo.

Estudos desenvolvidos nas duas últimas décadas, tendo como subsídio biológico a teoria do bloqueio e mediante evidências empíricas, têm apontado para uma nova possibilidade terapêutica que utilize os sais de ferro em esquemas intermitentes, mediante aplicações de uma a duas vezes por semana (Batista Filho \& Ferreira, 1996; Viteri, 1997; WHO, 2001).

\section{Conceito e Definições (pontos de corte para a classificação)}

A situação do ferro nos organismos oscila em um continuum de deficiência com ou sem anemia, para uma condição de ferro normal com variações no estoque e, finalmente, uma situação de excesso do mineral.

A deficiência de ferro é reconhecida como uma condição na qual não há ferro mobilizável nos estoques e há sinais de comprometimento da oferta de ferro aos tecidos, incluindo os eritrócitos, e é o resultado de um desequilíbrio entre a oferta, a utilização e as perdas do mineral. O estágio mais grave da deficiência de ferro está associado com a anemia. A anemia por deficiência de ferro pode ser considerada um subconjunto da deficiência de ferro e representa o extremo inferior da distribuição (gaussiana) do mineral (Wintrobe, Lukens \& Lee, 1993).

Em escala populacional, define-se anemia como o estado em que a concentração de hemoglobina no sangue está abaixo de um nível considerado ótimo. A anemia está presente (em um indivíduo) quando a concentração de hemoglobina está abaixo de dois desvios-padrão da média de uma distribuição de uma população de referência, com a mesma idade, sexo, condição de gravidez e vivendo na mesma altitude (WHO, 2001). Fatores como etnia e hábito de fumar influenciam os valores da concentração de hemoglobina. A Tabela 1 apresenta a concentração de hemoglobina abaixo da qual a anemia está presente. 
Tabela 1 - Valores de concentração de hemoglobina no sangue e de hematócrito abaixo dos quais a anemia está presente de acordo com sexo, idade e condição de gravidez, no nível do mar

\begin{tabular}{lcc}
\hline Grupos populacionais & Hemoglobina $(\mathrm{g} / \mathrm{L})$ & Hematócrito $(\%)$ \\
\hline Crianças de 6 a 59 meses & 110 & 33 \\
\hline Crianças de 5 a 11 anos & 115 & 34 \\
\hline Crianças de 12 a 14 anos & 120 & 36 \\
\hline Mulheres não-grávidas com 15 ou mais anos & 120 & 36 \\
\hline Mulheres grávidas & 110 & 33 \\
\hline Homens com 15 ou mais anos & 130 & 39 \\
\hline
\end{tabular}

Fonte: WHO (2001).

Em uma população saudável, espera-se que $2,5 \%$ das pessoas estejam abaixo do ponto de corte. Segundo a OMS (WHO, 2001), a anemia por deficiência de ferro é um problema de saúde pública quando a prevalência da concentração de hemoglobina abaixo do ponto de corte está acima de 5\% (Tabela 2).

Tabela 2 - Categorias de significância de anemia em âmbito populacional de acordo com a prevalência definida por pontos de corte de concentração de hemoglobina no sangue*

\begin{tabular}{lc}
\hline Categorias de significância em saúde pública & Prevalência (\%) \\
\hline Normal & $<5,0$ \\
\hline Leve & $5,0-19,9$ \\
\hline Moderada & $20,0-39,9$ \\
\hline Grave & $\geq 40,0$ \\
\hline
\end{tabular}

* De acordo com pontos de corte conforme a Tabela 1.

Fonte: WHO (2001).

Do ponto de vista etiológico, as anemias podem ser atribuídas à perda de sangue, à destruição excessiva de células vermelhas ou à deficiência na sua produção. Nessa classificação, a anemia por deficiência de ferro e as demais anemias carenciais (por deficiência de vitamina $\mathrm{B}_{12}$ e ácido fólico) estão incluídas nas anemias por deficiência de produção, ao passo que as talassemias e a anemia falciforme estão enquadradas nas anemias por destruição de células vermelhas (Wintrobe, Lukens \& Lee, 1993).

A classificação que leva em consideração os aspectos morfológicos da célula vermelha define as anemias como microcíticas, normocíticas e macrocíticas. Quanto à concentração de hemoglobina na hemácia, as anemias são divididas em hipocrômicas e normocrômicas. A anemia por deficiência de ferro é, por definição, hipocrômica e microcítica (Wintrobe, Lukens \& Lee, 1993).

\section{Metabolismo do Ferro}

O ferro é o quarto elemento químico mais abundante da Terra, e representa cerca de 4,7\% de sua crosta, estando presente como componente essencial em todos os organismo vivos do planeta (exceto algumas espécies de Lactobacillus). Devido a sua fartura e ao poder de catalisar reaçôes que produzem radicais livres que prejudi- 
cam as membranas celulares, proteínas e DNA, sua absorção é complexamente bem controlada (Dallman, 1989; Beard, Dawson \& Pinero, 1996).

Nos seres humanos a quantidade de ferro é menor que o peso de uma moeda de cinco centavos, cerca de 3,5 g em homens e 2,5 g em mulheres. Esse montante de ferro está biologicamente em dois compartimentos: ferro funcional presente na hemoglobina, mioglobina e enzimas, e ferro de estoque em forma de ferritina, hemossiderina e transferrina. Cerca de 60 a $65 \%$ do ferro corporal estão na hemoglobina, 10\% na mioglobina, $3 \%$ nas enzimas e o restante, 20 a 30\%, presente nas duas proteínas de armazenamento. Portanto, a mensuração da concentração de hemoglobina no sangue e da ferritina sérica refletem o conteúdo de cerca de $90 \%$ do ferro corporal (Dallman, 1989; Beard, Dawson \& Pinero, 1996).

O ferro está contido na dieta sob duas formas químicas: o ferro heme, presente em alimentos de origem animal (carnes, peixes, aves, vísceras), proveniente da hemoglobina, mioglobina e heme-enzimas, que representa cerca de $10 \%$ a $15 \%$ do mineral na dieta, e o ferro não-heme ( $85 \%$ a $90 \%$ do ferro da dieta), encontrado em alimentos de origem animal (por exemplo, algumas enzimas não-heme) e vegetal, tais como feijōes, vegetais de folhas verde-escuras (Dallman, 1989; Beard, Dawson \& Pinero, 1996).

A absorção do ferro envolve um complexo mecanismo de regulação desencadeado pelo teor de ferro da dieta, pelas necessidades orgânicas do mineral e pelo conteúdo corporal do ferro. As necessidades variam de acordo com condições fisiológicas, tais como: crescimento acelerado, gravidez e lactação e situaçôes patológicas como hipoxia, perdas sangüíneas, destruição de eritrócitos por doenças genéticas (hemoglobinopatias) ou adquiridas (doenças parasitárias e intoxicações), e ainda hábitos de vida (fumo) e a altitude da localidade. Em regra, a absorção de ferro é inversamente proporcional à quantidade de ferro estocada, e a homeostase protege o organismo contra o excesso e a deficiência de ferro (Dallman, 1989; Wintrobe, Lukens \& Lee, 1993; Beard, Dawson \& Pinero, 1996).

Diferentemente do que ocorre com outros minerais, o organismo humano não tem mecanismo de excreção de ferro. As perdas fisiológicas ocorrem pelas fezes, pelo suor e pela descamação de células, e representam cerca de $0,1 \%$ do ferro estocado e menos ainda do ferro corporal, cuja perda é de, em média, $1 \mathrm{mg}$ de ferro por dia (0,6 a $1,6 \mathrm{mg} / \mathrm{dia}$ ); sua regulação é realizada apenas pela absorção, que ocorre nas células do intestino delgado (duodeno e jejuno). O complexo mecanismo de absorção do ferro efetuado dentro dos enterócitos, apesar de muito estudado, é pouco conhecido e motivo de controvérsias (Dallman, 1989).

Em torno de $90 \%$ das necessidades do ferro orgânico em uma pessoa adulta são obtidos pela reutilização do mineral, em especial pelo reaproveitamento do ferro oriundo da hemocaterese das células vermelhas. Os 10\% complementares são obtidos por meio dos alimentos. A dieta ocidental balanceada proporciona cerca de $6 \mathrm{mg}$ de ferro heme e não-heme por 1.000 calorias (Dallman, 1989; Beard, Dawson \& Pinero, 1996).

A absorção do ferro heme é facilitada apenas pela presença de alimentos de origem animal e dificultada pela ação do cálcio (Beard, Dawson \& Pinero, 1996). A absorção do ferro não-heme depende da solubilidade do mineral (que é aumentada pelos ácidos da secreção gástrica e reduzida pela acloridia e por antiácidos presentes no estômago) e da presença de substâncias inibidoras e facilitadoras presentes na composição da dieta. Alimentos contendo fitatos (cereais, farelos, farinhas) e polifenóis (chás e cafés) e ricos em cálcio (leite e derivados) dificultam a absorção do mineral, ao passo que carnes, peixes, aves, o ácido ascórbico (vitamina C) e a vitamina A facilitam a absorção do ferro não-heme (Dallman, 1989; Beard, Dawson \& Pinero, 1996; Lynch, 1997).

As necessidades de ferro para os seres humanos variam de acordo com o grupo biológico e a presença de doenças, e a ingestão de ferro para cobrir as necessidades depende da biodisponibilidade do ferro da dieta. $\mathrm{Na}$ Tabela 3 mostram-se as necessidades biológicas diárias de ferro e a quantidade recomendada de ferro a ser ingerida, considerando uma dieta com biodisponibilidade intermediária deste mineral (WHO, 2001). 
Tabela 3 - Necessidades biológicas e recomendações diárias de ferro, de acordo com grupos biológicos

\begin{tabular}{|c|c|c|c|}
\hline Grupos & Idade (anos) & $\begin{array}{c}\text { Necessidades }^{a} \\
\text { (mg/dial }\end{array}$ & $\begin{array}{c}\text { Recomendações } \\
\text { (mg/dia) }\end{array}$ \\
\hline \multirow{4}{*}{ Crianças } & $0,5-1$ & 0,72 & 7,7 \\
\hline & $1-3$ & 0,46 & 4,8 \\
\hline & $4-6$ & 0,50 & 5,3 \\
\hline & $7-10$ & 0,71 & 7,4 \\
\hline \multirow{3}{*}{ Homens } & $11-14$ & 1,17 & 12,2 \\
\hline & $15-17$ & 1,50 & 15,7 \\
\hline & $18 e+$ & 1,05 & 11,4 \\
\hline \multirow{6}{*}{ Mulheres } & $11-14^{c}$ & 1,20 & 11,7 \\
\hline & $11-14$ & 1,68 & 27,7 \\
\hline & $15-17$ & 1,62 & 25,8 \\
\hline & $18 e+$ & 1,46 & 24,5 \\
\hline & Pós-menopausa & 0,87 & 9,4 \\
\hline & Nutriz & 1,15 & 12,5 \\
\hline
\end{tabular}

a - Mediana de necessidade total de ferro, incluindo necessidades para crescimento,

perdas basais e menstruais.

b - Recomendações de ingestão de ferro para cobrir os requerimentos de 97,5\% (média + 2 desvios-padrão) de uma população, considerando uma dieta com biodisponibilidade intermediária de ferro (12\%).

c - Mulheres não menstruantes.

Fonte: WHO (2001).

\section{Indicadores (diagnóstico populacional)}

Neste item serão considerados apenas os meios laboratoriais para o diagnóstico da anemia em âmbito populacional. Não serão abordados os métodos simplificados empregados mediante observação direta de pele e mucosas, nem os meios de investigação para diagnóstico diferencial das anemias utilizado pela clínica médica, tais como: dosagem do ferro sérico, capacidade total de ligação do ferro, saturação de transferrina e biópsia de medula óssea. A seguir, são abordadas a dosagem da concentração de hemoglobina no sangue e a dosagem da ferritina sérica, que juntas detectam cerca de $90 \%$ do ferro corporal.

O hemograma completo é o exame de sangue mais utilizado na clínica em todo o mundo, independentemente da especialidade médica. A dosagem de hemoglobina, por outro lado, é o exame mais utilizado para o diagnóstico das anemias em escala populacional e é, inclusive, utilizado para definição de anemia. Portanto, por razões conceituais e também de praticidade (atualmente, mediante aparelhos conhecidos como Hemocue, a dosagem da concentração de hemoglobina pode ser efetuada no campo de forma direta e imediata) e de universalidade, é o exame isolado que melhor se presta ao conhecimento das anemias na população. Apresenta, contudo, baixa especificidade, sendo impossível discriminar qual o tipo de anemia detectada, mas, como a anemia por deficiência de ferro é a de maior prevalência, muitas vezes se considera a prevalência da anemia como uma 'proxi' da anemia ferropriva (exceto em localidades com elevada ocorrência de malária). 
Em localidades com dificuldades de realização da dosagem da concentração de hemoglobina, costuma-se utilizar a determinação do hematócrito realizado por centrifugação. Esse exame apresenta as mesmas limitações da dosagem da concentração de hemoglobina.

Como a dosagem sérica da ferritina se correlaciona com a quantidade dos depósitos tissulares de ferro, é, portanto, um dos testes bioquímicos mais específicos para a avaliação do ferro corporal. Quando a dosagem da ferritina está baixa, isso significa que há depleção de ferro, mas, em contrapartida, se a ferritina apresenta valores normais ou elevados, isso não significa necessariamente estoques normais ou elevados, porque nos processos inflamatórios e infecciosos agudos ou crônicos, inclusive em fases subclínicas, há um aumento na produção dessa proteína. Assim, a ferritina não serve para avaliar com exatidão o esgotamento das reservas de ferro em cenários em que a saúde da população é precária. Em condições normais, considera-se que há ferropenia quando os valores estão abaixo de $15 \mu \mathrm{g} / \mathrm{L}$, e, se há presença de infecção ou inflamação, consideram-se valores acima de $30 \mu \mathrm{g} / \mathrm{L}$. O risco de sobrecarga de ferro está presente quando a ferritina está acima de $150 \mu \mathrm{g} / \mathrm{L}$ (WHO, 2001).

\section{Distribuição (tempo/lugar/pessoa)}

Segundo a OMS, a anemia, em termos de magnitude, constitui na atualidade o principal problema carencial em escala de saúde pública do mundo. Estima-se que mais de dois bilhôes de pessoas sejam anêmicas, em diferentes graus de intensidade, o que corresponde a aproximadamente um terço da população da Terra (WHO, 2001).

A deficiência de ferro, usualmente detectada pela baixa concentração de ferritina, tem sua prevalência estimada em 2,0 a 2,5 vezes superior à prevalência de anemia, atingindo aproximadamente quatro bilhões da população mundial. Em âmbito populacional, a maioria dos casos de anemia é decorrente da deficiência de ferro, exceto nas regióes onde a malária é endêmica. Os dados sobre a prevalência da deficiência de ferro são escassos, tanto em países desenvolvidos como em países em desenvolvimento (Allen \& Gillespie, 2001).

A anemia nutricional, especialmente a ferropriva, acomete as populações de quase todos os países do mundo, embora os países mais pobres sejam os mais atingidos. De acordo com as estimativas da OMS, a prevalência na África e Ásia é superior a 40\%, nas Américas a 19\% e na Europa a 10\% (Delange \& West, 2003).

Os grupos de risco são crianças e adolescentes, gestantes, mulheres em idade reprodutiva, idosos e indivíduos com dieta insuficiente em ferro quantitativa e qualitativamente. Nos países em desenvolvimento, as prevalências de anemia nesses grupos são de, no mínimo, o dobro das encontradas nos países desenvolvidos. Para os dois grupos mais vulneráveis, crianças e gestantes, estima-se uma prevalência de anemia de $20-25 \%$ nos países desenvolvidos e de 40-60\% nos países em desenvolvimento (WHO, 2001).

No Brasil, como no resto do mundo, os dados disponíveis sobre prevalência de anemia são oriundos de pesquisas, em geral, com base populacional restrita, e em específicas situações de saúde/nutrição, faixa etária, idade gestacional e métodos diagnósticos distintos, o que torna difícil a comparação entre os resultados. Entretanto, observam-se, nos últimos anos, esforços no sentido de minimizar essas limitações, mediante estudos epidemiológicos com amostras representativas e a introdução de métodos estatísticos multivariados que permitem, inclusive, análises dos determinantes da anemia.

Outro aspecto positivo diz respeito ao incremento de pesquisas visando ao diagnóstico do problema nas distintas regiōes do país, realizadas em decorrência da constatação do aumento da prevalência da anemia em crianças menores de 5 anos de idade, nas duas últimas décadas, observado no estado da Paraíba - de 19,3\% para 36,4\%, entre 1982 e 1992 (Dricot d'Ans et al., 1984; Oliveira et al., 2002) - e na cidade de São Paulo - de 35,6\% para 46,9\%, entre 1985-1986 e 1995-1996 (Monteiro \& Szarfarc, 1987; Monteiro, Szarfarc \& Mondini, 2000). A tendência temporal em ascensão, opondo-se, assim, ao paradigma da 'transição epidemiológica e nutricional', contrasta com a redução das morbidades infecciosas e parasitárias, do baixo peso ao nascer e da 
desnutrição energético-proteíca em crianças, decorrente, em parte, do aumento da cobertura da assistência materno-infantil, da melhoria do saneamento básico e da ampliação da cobertura dos programas sociais.

A III Pesquisa Estadual de Saúde e Nutrição de Pernambuco, realizada em 2006, encontrou uma prevalência de anemia de 34\% (Hb média = 11,4g/dL, DP=1,3) em menores de cinco anos de idade e de 16,7\% (Hb média = $13,1 \mathrm{~g} / \mathrm{dL}, \mathrm{DP}=1,3$ ) em mulheres em idade reprodutiva (Batista Filho et al., 2006), ao passo que a pesquisa anterior, realizada em 1997, utilizando o mesmo marco amostral e as mesmas técnicas diagnósticas, detectou uma prevalência de 46,7\% ( $\mathrm{Hb}$ média $=10,9 \mathrm{~g} / \mathrm{dL}, \mathrm{DP}=1,57)$ e $24,5 \%(\mathrm{Hb}$ média $=13,0 \mathrm{~g} / \mathrm{dL}, \mathrm{DP}=1,6)$, respectivamente (Ministério da Saúde, 1998). A consolidação e ampliação do Programa Saúde da Família e da transferência de renda por intermédio do Bolsa Família, bem como a fortificação compulsória de farinhas de trigo e milho com ferro e ácido fólico podem ser fatores que contribuíram para essa redução. Entretanto, é necessária a observação desse fenômeno em outras áreas do país para consolidar a tendência observada.

Nas Tabelas 4, 5, 6 e 7 apresentam-se as prevalências de anemia em crianças menores de 6 anos e escolares, nos últimos quarenta anos, por regiōes do país. Apesar da grande variação observada, os estudos das duas últimas décadas indicam uma prevalência de anemia em cerca de $2 / 3$ dos lactentes, com valores mais elevados no primeiro ano de vida, ao passo que para os pré-escolares observaram-se prevalências de 30-50\%. Para a população de crianças em idade escolar, os estudos são mais escassos e as prevalências oscilam entre 5 e 60\%, com predominância de valores em torno de $15-20 \%$.

Tabela 4 - Prevalência de anemia em crianças menores de 6 anos no Nordeste do Brasil, de acordo com estudos selecionados

\begin{tabular}{|c|c|c|c|c|}
\hline Fonte & Localidade & Grupo etário & Amostra $\mathrm{N}$ & Anemia \% \\
\hline ICNND, $1965^{\circ}$ & 6 estados NE & $<5 a$ & * & 31,4 \\
\hline Martins et al., 1968 & Zona da Mata, PE & $<5 a$ & 400 & 18,5 \\
\hline Batista Filho et al., $1982^{\circ}$ & Zona da Mata, PE & $<5 a$ & 59 & 14,3 \\
\hline Salzano, $1974^{\circ}$ & Interior, PE & $6-60 \mathrm{~m}$ & 310 & 47,0 \\
\hline Torres, $1982^{a}$ & Semi-Árido, PE/PB & $<b a$ & 157 & 48,0 \\
\hline Dricot d'Ans et al., 1984 & Paraíba & $0-59 m$ & * & 19,3 \\
\hline Lira et al., 1985 & Agreste, PE & $<b a$ & 976 & 38,9 \\
\hline Salzano et al., $1985^{\circ}$ & Serv. Saúde Recife, PE & $6-60 \mathrm{~m}$ & 1.306 & 55,1 \\
\hline Benigna, $1987^{\circ}$ & Pernambuco & 6-11m & 780 & 22,3 \\
\hline Mariath et al., $1988^{\circ}$ & Pernambuco & $1-4 a$ & 573 & 41,9 \\
\hline Assis et al., 1990 & Bahia & $<5 a$ & * & 22,4 \\
\hline \multirow[t]{2}{*}{ Romani et al., 1991} & Serv. Saúde Recife, PE & $6-24 m$ & 459 & 83,4 \\
\hline & & $6-72 \mathrm{~m}$ & 1.161 & 54,5 \\
\hline Governo do Pl/Unicef, 1992ª & Piauí & $2-6 a$ & 742 & 33,8 \\
\hline Assis et al., 1997 & Semi-Árido, BA & $1-72 \mathrm{~m}$ & 745 & 22,2 \\
\hline Ministério da Saúde, 1998 & Pernambuco & $6-59 \mathrm{~m}$ & 827 & 46,7 \\
\hline Perez et al., $1998^{\circ}$ & Creches Recife, PE & $<36 \mathrm{~m}$ & * & 81,0 \\
\hline
\end{tabular}


Tabela 4 - Prevalência de anemia em crianças menores de 6 anos no Nordeste do Brasil, de acordo com estudos selecionados (continuação)

\begin{tabular}{|c|c|c|c|c|}
\hline Fonte & Localidade & Grupo etário & Amostra $\mathrm{N}$ & Anemia \% \\
\hline Soares et al., 2000 & Fortaleza, CE & $<24 \mathrm{~m}$ & 110 & 60,0 \\
\hline Ferreira, Lira \& Batista Filho, 2000 & Nordeste & $12 \mathrm{~m}$ & 610 & 78,9 \\
\hline Osório et al., 2001 & Pernambuco & $6-23 m$ & 777 & 61,8 \\
\hline Gov. do Estado, SE, $2001^{a}$ & Sergipe & $6-59 \mathrm{~m}$ & 720 & 31,4 \\
\hline Oliveira et al., 2002 & Paraíba, PB & $0-59 m$ & 1.287 & 36,4 \\
\hline Ferreira et al., 2003 & Caruaru, PE & $6-23 m$ & 293 & 77,5 \\
\hline Ferreira et al., 2003 & Creches Recife, PE & $<5 a$ & 145 & 90,3 \\
\hline Assis et al., 2004 & Salvador, BA & $<5 a$ & 603 & 46,3 \\
\hline Assis et al., 2004 & Serv. Saúde Salvador, BA & $<12 \mathrm{~m}$ & 553 & 62,8 \\
\hline Lima et al., 2004 & Zona da Mata, PE & $12 \mathrm{~m}$ & 245 & 73,5 \\
\hline Spinelli et al., 2005 & 2 municípios NE & $6-12 m$ & 296 & 65,9 \\
\hline Batista Filho et al., 2005 & Semi-Árido, PB & $6-59 \mathrm{~m}$ & 502 & 37,1 \\
\hline Lira et al., 2005 & Zona da Mata, PE & $6-59 m$ & 628 & 46,3 \\
\hline Leal \& Osório, 2006 & Serv. Saúde Recife, PE & $6-23 m$ & 206 & 92,7 \\
\hline Carvalho, Lima \& Lira, 2006 & Creches Recife, PE & $6-20 m$ & 335 & 91,9 \\
\hline Batista Filho et al., 2006 & Pernambuco & $6-59 \mathrm{~m}$ & 1.406 & 34,0 \\
\hline
\end{tabular}

* Dados não disponíveis.

a - Publicações citadas em artigos de revisão e em compilações de pesquisas desenvolvidas no Brasil (Vannucci, Freitas \& Szarfarc, 1992; Devincenzi, Ribeiro \& Sigulem, 1999; Santos, 2002).

Tabela 5 - Prevalência de anemia em crianças menores de 6 anos no Sudeste do Brasil, de acordo com estudos selecionados

\begin{tabular}{|c|c|c|c|c|}
\hline Fonte & Localidade & Grupo etário & Amostra N & Anemia \% \\
\hline Sigulem et al., 1978 & São Paulo, SP & $6-59 m$ & 278 & 22,7 \\
\hline Sigulem et al., 1983a & São Paulo, SP & $<2 a$ & * & 35,0 \\
\hline \multirow[t]{2}{*}{ Guerra et al., $1983^{\circ}$} & São Paulo, SP & $6-18 \mathrm{~m}$ & 182 & 72,0 \\
\hline & & $<3 a$ & * & 38,9 \\
\hline Tone et al., 1984 & Pradópolis, SP & $4-5 a$ & 370 & 24,5 \\
\hline Monteiro \& Szarfarc, 1987 & São Paulo, SP & $<5 a$ & 902 & 35,6 \\
\hline \multirow[t]{2}{*}{ Sichieri, 1987ª } & São Paulo, SP & $<2 a$ & 307 & 57,0 \\
\hline & & $2-5 a$ & * & 26,0 \\
\hline \multirow[t]{4}{*}{ Araúio et al., 1987ª } & Belo Horizonte, MG & Pré-escolar & 130 & 21,5 \\
\hline & V. Jequitinhonha, MG & & & \\
\hline & Urbano & Pré-escolar & 67 & 23,9 \\
\hline & Rural & Pré-escolar & 52 & 34,6 \\
\hline
\end{tabular}


Tabela 5 - Prevalência de anemia em crianças menores de 6 anos no Sudeste do Brasil, de acordo com estudos selecionados (continuação)

\begin{tabular}{|c|c|c|c|c|}
\hline Fonte & Localidade & Grupo etário & Amostra N & Anemia \% \\
\hline \multirow[t]{2}{*}{ Freitas, $1990^{\circ}$} & Ribeirão Preto, SP & $<2 a$ & * & 58,2 \\
\hline & & $6 m-6$ a & 178 & 29,6 \\
\hline Rodrigues et al., 1997 & Rio de Janeiro, RJ & $12-18 \mathrm{~m}$ & 288 & 50,0 \\
\hline Torres et al., 1994 & Serv. Saúde São Paulo, SP & $6-23 \mathrm{~m}$ & 2.992 & 59,1 \\
\hline Torres et al., 1996 & Angatuba, SP & $<4 a$ & 269 & 62,3 \\
\hline Lamounier et al., 2000 & Carrancas, MG & $6 m-6 a$ & 400 & 47,2 \\
\hline Devincenzi, 1999ª & Favelas São Paulo, SP & $<36 \mathrm{~m}$ & * & 63,1 \\
\hline Monteiro, Szarfarc \& Mondini, 2000 & São Paulo, SP & $6-59 \mathrm{~m}$ & 1.256 & 46,9 \\
\hline Sigulem et al., 2001 & Favelas São Paulo, SP & $<24 \mathrm{~m}$ & * & 66,7 \\
\hline Ribeiro, 2001 & Creches São Paulo, SP & $13-14 \mathrm{~m}$ & * & 69,0 \\
\hline Almeida et al., 200 $1^{\circ}$ & Vitória, ES & $6-72 \mathrm{~m}$ & 760 & 28,6 \\
\hline Lacerda \& Cunha, 2001 & Serv. Saúde R. Janeiro, RJ & $12-18 \mathrm{~m}$ & 288 & 50,0 \\
\hline Silva, Giugliani \& Aerts, 2001 & Viçosa, MG & $<24 \mathrm{~m}$ & * & 65,0 \\
\hline Silva et al., 2002 & Serv. Saúde Viçosa, MG & $6-12 m$ & 204 & 60,8 \\
\hline Capanema, 2002 & Belo Horizonte, MG & $6 m-6 a$ & 322 & 47,8 \\
\hline Miranda et al., 2003 & Serv. Saúde Viçosa, MG & $12-60 \mathrm{~m}$ & 171 & 63,2 \\
\hline Almeida et al., 2004 & Creches Pontal, SP & $12-72 \mathrm{~m}$ & 192 & 62,5 \\
\hline Matta et al., 2005 & Rio de Janeiro, RJ & $<5 a$ & 865 & 47,3 \\
\hline Spinelli et al., 2005 & 4 municípios Sudeste & $6-12 m$ & 1.022 & 70,4 \\
\hline Bueno et al., 2006 & 20 creches São Paulo, SP & $6-75 \mathrm{~m}$ & 330 & 68,8 \\
\hline
\end{tabular}

* Dados não disponíveis.

a - Publicações citadas em artigos de revisão e em compilações de pesquisas desenvolvidas no Brasil (Vannucci, Freitas \& Szarfarc, 1992; Devincenzi, Ribeiro \& Sigulem, 1999; Santos, 2002).

Tabela 6 - Prevalência de anemia em crianças menores de 6 anos no Norte, Centro-Oeste e Sul do Brasil, de acordo com estudos selecionados

\begin{tabular}{|c|c|c|c|c|}
\hline Fonte & Localidade & Grupo etário & Amostra N & Anemia \% \\
\hline \multicolumn{5}{|l|}{ Norte } \\
\hline \multirow[t]{6}{*}{ Shrimpton et al., 1977a } & Área ribeirinha Solimões/Negro & Pré-escolar & * & 29,0 \\
\hline & Amazonas & Pré-escolar & * & 50,0 \\
\hline & Manaus, AM & Pré-escolar & 243 & 60,5 \\
\hline & 2 municípios Norte & 6-12 m & 464 & 65,3 \\
\hline & Terra indígena Suruí Rondônia/Mato Grosso & 6-59 m & 268 & 84,0 \\
\hline & 2 cidades Acre & $<6 a$ & 669 & 30,6 \\
\hline
\end{tabular}


Tabela 6 - Prevalência de anemia em crianças menores de 6 anos no Norte, Centro-Oeste e Sul do Brasil, de acordo com estudos selecionados (continuação)

\begin{tabular}{|c|c|c|c|c|}
\hline Fonte & Localidade & Grupo etário & Amostra N & Anemia \% \\
\hline \multicolumn{5}{|l|}{ Centro-Oeste } \\
\hline Schmitz, 1998 & Brasília, DF & $6 m-3 a$ & 279 & 28,7 \\
\hline Brunken, Guimarães \& Fisberg, 2002 & Creches Cuiabá, MT & $<3 a$ & 271 & 63,1 \\
\hline Hadler, Juliano \& Sigulem, 2002 & Goiânia, GO & 6-12 m & 110 & 60,9 \\
\hline Spinelli et al., 2005 & 2 municípios $\mathrm{GO}$ & 6-12 m & 447 & 60,2 \\
\hline \multicolumn{5}{|l|}{ Sul } \\
\hline \multirow[t]{2}{*}{ Turconi \& Turconi, 1992} & Bento Gonçalves, RS & $0-24 m$ & 336 & 49,1 \\
\hline & & $25-71 \mathrm{~m}$ & 224 & 29,9 \\
\hline Neuman et al., 2000 & Criciúma, SC & $<36 \mathrm{~m}$ & 476 & 54,0 \\
\hline Silva, Giugliani \& Aerts, 2001 & Porto Alegre, RS & $<36 \mathrm{~m}$ & 557 & 47,8 \\
\hline Uchimura et al., 2003 & Serv. Saúde Maringá, PR & $<12 \mathrm{~m}$ & 587 & 58,0 \\
\hline Santos et al., 2004 & Pastoral Pelotas, RS & $<6 a$ & 304 & 53,0 \\
\hline Kmetiuk, 2005 & Creches Guarapava, PR & $<6 a$ & 156 & 42,9 \\
\hline Spinelli et al., 2005 & 2 municípios Sul & $6-12 \mathrm{~m}$ & 486 & 59,7 \\
\hline
\end{tabular}

* Dados não disponíveis.

a - Publicações citadas em artigos de revisão e em compilações de pesquisas desenvolvidas no Brasil (Vannucci, Freitas \& Szarfarc, 1992; Devincenzi, Ribeiro \& Sigulem, 1999; Santos, 20021.

Tabela 7 - Prevalência de anemia em escolares, por regiōes do Brasil, de acordo com estudos selecionados

\begin{tabular}{|c|c|c|c|c|}
\hline Fonte & Localidade & Grupo etário & Amostra N & Anemia \% \\
\hline \multicolumn{5}{|l|}{ Norte } \\
\hline Silva et al., 1980 & Pará & $6-14 a$ & * & 50,0 \\
\hline \multicolumn{5}{|l|}{ Nordeste } \\
\hline ICNND, $1965^{\circ}$ & 6 estados & $6-16 a$ & $60(\mathrm{M}) / 70(\mathrm{~F})$ & $36,7 / 32,9$ \\
\hline \multirow[t]{4}{*}{ Batista Filho et al., 1982a } & Ferreiros, PE & 5-14 a & 370 & 18,6 \\
\hline & Brejo Madre Deus, PE & $5-14 a$ & 248 & 39,1 \\
\hline & Afogados de Ingazeira, PE & 5-14 a & 143 & 52,4 \\
\hline & Água Preta, PE & 5-14a & 130 & 17,7 \\
\hline Torres, $1982^{a}$ & Semi-Árido, PE & $6-10 a$ & 134 & 60,4 \\
\hline Brito, $1982^{\circ}$ & Recife, PE & $7-11 a$ & $135(\mathrm{M}) / 170(\mathrm{~F})$ & $9,6 / 8,2$ \\
\hline Silva, 1996а & Recife, PE & b-12a & 233 & 37,8 \\
\hline Ferreira, 1998 & São Lourenço, PE & $4-18 a$ & 299 & 43,1 \\
\hline Ferreira, 1998 & Zona da Mata, PE & $6-11 a$ & 130 & 70,7 \\
\hline \multirow[t]{2}{*}{ Tsuyuoka et al., 1999a } & Aracaju, SE & $4-24 a$ & 360 & 26,7 \\
\hline & & $4-8 a$ & 108 & 35,4 \\
\hline Santana, 2001 & Semi-Árido, PB & $6-12 a$ & 517 & 24,6 \\
\hline Santos et al., $2002^{\circ}$ & Maceió, AL & $6-10 a$ & 426 & 25,4 \\
\hline Pereira, Ferreira \& Batista Filho, 2003 & São João, PE & $6-14 a$ & 340 & 53,5 \\
\hline Brito et al., 2003 & Jequié, BA & $7.17 a$ & 1.709 & 32,2 \\
\hline
\end{tabular}


Tabela 7 - Prevalência de anemia em escolares, por regiōes do Brasil, de acordo com estudos selecionados (continuação)

\begin{tabular}{|c|c|c|c|c|}
\hline Fonte & Localidade & Grupo etário & Amostra N & Anemia \% \\
\hline Centro-Oeste & Cárceres, MT & & & \\
\hline Sanchez et al., 1988 & & $6-14 a$ & 1.178 & 36,1 \\
\hline \multicolumn{5}{|l|}{ Sudeste } \\
\hline Szarfarc, $1972^{\circ}$ & Vale do Ribeira, SP & $10 a$ & 284 & $12,7-63,3$ \\
\hline Ruiz et al., 1984 & Viçosa, MG & $7-14 a$ & 985 & 7,3 \\
\hline \multirow[t]{2}{*}{ Araújo et al., $1986^{\circ}$} & Belo Horizonte, MG & Escolar & 130 & 17,6 \\
\hline & V. Jequitinhonha, MG & & & \\
\hline Pedrazzani, 1988 & Urbano & Escolar & 90 & 20,0 \\
\hline Turconi, 1992 & Rural & Escolar & 55 & 18,2 \\
\hline Norton et al., $1996^{\circ}$ & São Carlos, SP & Escolar & 254 & 9,6 \\
\hline Stefanini et al., 1998` & Bento Gonçalves, RS & $6-12 a$ & 168 & 21,4 \\
\hline \multirow[t]{5}{*}{ Stefanini, $1998^{\circ}$} & Rio Acima, MG & $7-15 a$ & 332 & 36,2 \\
\hline & Osasco, SP & $6-10 a$ & 1.033 & 51,0 \\
\hline & Santos, SP & Escolar $1^{a}$ & 396 & 27.8 \\
\hline & & Escolar 5a & 207 & 11,3 \\
\hline & & Escolar $8^{\circ}$ & 94 & 5,6 \\
\hline \multicolumn{5}{|l|}{ Sul } \\
\hline Onsten et al., 1988 & Porto Alegre, RS & $7-12 a$ & 128 & 53,9 \\
\hline Uchimura, 1994 & Maringá, PR & Escolar & 344 & 31,7 \\
\hline
\end{tabular}

* Dados não disponíveis.

a - Publicações citadas em artigos de revisão e em compilações de pesquisas desenvolvidas no Brasil (Vannucci, Freitas \& Szarfarc, 1992; Devincenzi, Ribeiro \& Sigulem, 1999; Santos, 2002).

No Brasil, os estudos da prevalência de anemia em gestantes, puérperas e mulheres em idade reprodutiva são mais freqüentes nas regiōes Nordeste e Sudeste (Tabela 8). Para as gestantes e puérperas, os valores oscilam entre 30\% e 50\%, aumentando a prevalência com o avançar da gestação, e para as mulheres em idade reprodutiva observam-se prevalências de anemia entre $20 \%$ a $40 \%$. Esses resultados são sugestivos de que aproximadamente $1 / 3$ dessas mulheres inicia a gravidez com algum grau de anemia.

Embora os estudos de base populacional em idosos sejam bastante escassos, a prevalência de anemia é considerada elevada e não decorre, necessariamente, do processo biológico do envelhecimento (Daly, 2000). Segundo estimativa da OMS, na população com mais de 60 anos a prevalência da anemia em países em desenvolvimento é de 40-50\%, em contraste com os valores encontrados em países desenvolvidos, que oscilam entre $10 \%$ e 15\%, (WHO, 2001). No Brasil, os estudos são, em geral, restritos à clientela de serviços de saúde e a dados registrados em laboratórios de análises clínicas. As prevalências encontradas são discrepantes, variando de 3,2\% em idosos atendidos em ambulatório geriátrico a 52\% em internados em hospital público, ambos do município de São Paulo (Marucci \& Pinotti, 2006). 
Tabela 8 - Prevalência de anemia em mulheres em idade reprodutiva, gestantes e puérperas, por regiões do Brasil, de acordo com estudos selecionados

\begin{tabular}{|c|c|c|c|c|}
\hline Fonte & Localidade & Grupo etário & Amostra & Anemia \% \\
\hline \multicolumn{5}{|l|}{ Nordeste } \\
\hline \multirow[t]{2}{*}{ Salzano et al., $1980^{\circ}$} & Serv. Saúde PB & Gestantes & * & 36,9 \\
\hline & Serv. Saúde PE & Gestantes & * & 33,7 \\
\hline Batista Filho et al., 1982ª & Agreste, PE & Gestantes & 89 & 57,3 \\
\hline Batista Filho, $1987^{\circ}$ & Semi-Árido, PE/PB & Mulheres $>10$ a & & 36,4 \\
\hline Arruda, 1990a & Serv. Saúde Recife, PE & Gestantes & * & 30,3 \\
\hline Gov. do PI/Unicef, 1992ª & & Parturientes & * & 38,1 \\
\hline Nogueira, 1997 & Piauí & Mulheres, $10-49$ a & 809 & 26,2 \\
\hline Arruda, 1997a & Piauí & Gestantes-Adolescentes & * & 35,0 \\
\hline Ministério da Saúde, 1998 & Serv. Saúde Recife, PE & Gestantes & 1.007 & 30,9 \\
\hline Lopes, Ferreira \& Batista Filho, 1999 & Pernambuco & Mulheres, 10-49 a & 1.196 & 24,5 \\
\hline Nascimento, 2000 & Recife, PE & Mulheres 15-45 a & 484 & 42,1 \\
\hline Souza et al., 2002 & Pernambuco & Adolescentes & 559 & 21,6 \\
\hline \multirow[t]{3}{*}{ Vasconcelos, 2004} & Serv. Saúde Recife, PE & Gestantes & 316 & 55,4 \\
\hline & Sobral, CE & Gestantes $1^{\circ}$ trim. & 421 & 25,9 \\
\hline & & Gestantes $3^{\circ}$ trim. & 253 & 41,9 \\
\hline Batista Filho et al., 2006 & Pernambuco & Mulheres, 10-49 a & 1.536 & 16,7 \\
\hline \multicolumn{5}{|l|}{ Sudeste } \\
\hline \multirow[t]{2}{*}{ Szarfarc, Siqueira \& Martins, 1983} & São Paulo, SP & Parturientes & * & 52,1 \\
\hline & & Gestantes & * & 35,1 \\
\hline \multirow[t]{2}{*}{ Szarfarc, Siqueira \& Martins, 1983} & São Paulo, SP & Gestantes 17a & 507 & 37,3 \\
\hline & & Gestantes 18-19 a & 706 & 36,1 \\
\hline Szarfarc, 1985 & São Paulo, SP & Gestantes & 4.539 & 35,1 \\
\hline \multirow[t]{2}{*}{ Guerra et al., 1990} & São Paulo, SP & Gestantes $1^{\circ}$ trim. & $(363)$ & 3,6 \\
\hline & & Gestantes $2^{\circ}$ trim. & & 20,9 \\
\hline Rodriguez, Szarfarc \& Benicio, 1991 & & Gestantes $3^{\circ}$ trim. & & 32,1 \\
\hline Fujimori, Szarfarc \& Oliveira, 1996 & São Paulo, SP & Gestantes & 691 & 29,2 \\
\hline Fujimori et al., 2000 & Taboão da Serra, SP & Adolescentes & 262 & 17,6 \\
\hline \multirow[t]{2}{*}{ Rocha et al., 2005} & Serv. Saúde São Paulo, SP & Gestantes & 79 & 13,9 \\
\hline & Serv. Saúde Viçosa, MG & Gestantes & 168 & 21,4 \\
\hline \multicolumn{5}{|l|}{ Sul } \\
\hline Olinto et al., 2003 & Pelotas, RS & Mulheres, 20-49 a & 137 & 21,9 \\
\hline Fabian et al., 2007 & São Leopoldo, RS & Mulheres, 20-49 a & 252 & 21,4 \\
\hline
\end{tabular}

* Dados não disponíveis.

a - Publicações citadas em artigos de revisão e em compilações de pesquisas desenvolvidas no Brasil (Vannucci, Freitas \& Szarfarc, 1992; Devincenzi, Ribeiro \& Sigulem, 1999; Santos, 20021. 


\section{Fatores Determinantes}

Ainda que a etiologia da deficiência do ferro esteja bem estabelecida em âmbito individual (desequilíbrio entre a oferta, a demanda e as perdas), os fatores determinantes em escala populacional são múltiplos e envolvem aspectos biológicos e demográficos, socioeconômicos e culturais que se expressam de forma diferenciada, dependendo do contexto onde estão inseridos os grupos de risco.

\section{Biológicos e Demográficos}

Estes fatores estão associados aos ciclos da vida e envolvem essencialmente a idade e o sexo de acordo com o desenvolvimento fisiológico. Dentre eles estão o crescimento acelerado durante os primeiros anos de vida e o início da adolescência e da puberdade (mais fortemente nas meninas), o período reprodutivo - incluindo gravidez e amamentação - e, por fim, o período do climatério e da senectude. Em cada um desses momentos fisiológicos, as necessidades de ferro devem ser consideradas em intervençôes individuais e coletivas (Batista Filho, 1983; WHO, 1992).

\section{Socioeconômicos e Culturais}

Os estudos sobre os fatores determinantes da deficiência do ferro e da anemia, principalmente em países desenvolvidos, são escassos e, quando existem, enfocam o problema com relação às variáveis biológicas e demográficas, desconsiderando, na maioria das vezes, os aspectos socioeconômicos e culturais, os quais poderiam proporcionar subsídios para a formulação de políticas de saúde e nutrição, visando a solucionar o problema e, conseqüentemente, melhorar a qualidade de vida das populaçôes.

No âmbito da saúde coletiva, os determinantes da anemia ferropriva têm origem em uma complexa cadeia de fatores, que nos países em desenvolvimento são liderados pelas condições socioeconômicas desfavoráveis e pela escassez de políticas públicas. Assim, os estudos realizados no Brasil associam a anemia às populações de baixa renda de áreas urbanas e rurais, às condiçôes precárias de habitação e saneamento básico e à baixa escolaridade (Lira et al., 1985; Assis et al., 1997; Neuman et al., 2000; Osório, Lira \& Ashworth, 2004; Santos et al., 2004; Lima et al., 2004; Spinelli et al., 2005). Entretanto, nos estudos que utilizam análises estatísticas multivariadas, nem sempre essas associações são evidenciadas pelos modelos, possivelmente em função da homogeneidade socioeconômica e cultural das populações estudadas.

O consumo alimentar pode ser considerado o indicador que melhor representa as condições socioeconômicas e culturais de um povo. $\mathrm{O}$ aporte inadequado de ferro da dieta e a baixa biodisponibilidade do mineral, entre os diferentes grupos biológicos, destacam-se como fatores etiológicos mais relevantes.

Durante a gravidez, os requerimentos de ferro estão aumentados, principalmente no último trimestre, favorecendo o aparecimento de deficiência de ferro, especialmente em gestantes de baixa condição socioeconômica. A deficiência do mineral na dieta repercute sobre as reservas de ferro materno, aumentando a mobilização dos estoques para garantir as necessidades do feto, sendo que apenas em casos de anemia grave na gestante há repercussões negativas para o feto, com o aumento do risco de prematuridade e de baixo peso ao nascer (Stekel, 1984; Beard, 2003).

A acelerada velocidade de crescimento nos primeiros meses de vida pode reduzir as reservas do ferro antes do sexto mês, desencadeando inclusive o aparecimento de anemia; entretanto, as crianças em aleitamento materno exclusivo têm as necessidades fisiológicas plenamente satisfeitas pela elevada biodisponibilidade do mineral no leite materno, compensando desta forma sua baixa concentração (Monteiro, Szarfarc \& Mondini, 2000; Osório, 2002; Romani \& Lira, 2004). 
A introdução precoce de alimentos, além de favorecer o desmame, compromete a biodisponibilidade do ferro do leite humano, podendo ocasionar a deficiência de ferro e o surgimento de anemia nos lactentes. Para as crianças em aleitamento artificial, os riscos de anemia são maiores, tendo em vista a menor quantidade e a baixa biodisponibilidade do ferro nos alimentos oferecidos. A partir do sexto mês de vida, os requerimentos de ferro aumentam e, assim, a alimentação complementar assume papel relevante no atendimento às necessidades, ao garantir as reservas de ferro (Stekel, 1984; Osório, Lira \& Ashworth, 2004; Oliveira, Osório \& Raposo, 2006; Torres et al., 2006).

Nos idosos, vários fatores exógenos e endógenos comprometem a adequada ingestão, absorção e biodisponibilidade do ferro da dieta, propiciando maior vulnerabilidade à deficiência do mineral e à anemia ferropriva. Entre os vários fatores, destacam-se: a inadequada preservação dos dentes, a redução do pH gástrico atribuída ou não ao uso de medicamentos, as lesões e hemorragias crônicas do sistema gastrintestinal decorrentes ou não do processo de envelhecimento, assim como a presença de doenças crônicas e degenerativas que apresentam em seu quadro clínico a anorexia e a anemia, comprometendo mais intensamente os idosos das classes sociais desfavorecidas (Marucci \& Pinotti, 2006).

\section{Morbidades}

Além da inadequação do ferro da dieta e das necessidades elevadas, as doenças infecciosas e parasitárias, destacando-se as ancilostomíases, a esquistossomose e a malária, causam a anemia - as primeiras por deficiência de ferro e a malária, especialmente a falciparum, pela destruição e supressão da produção de novas células vermelhas -, sem, contudo, causar deficiência de ferro propriamente dita, porque a maior parte do ferro da exacerbada lise da hemoglobina não é eliminada do corpo (Nestel \& Davidsson, 2002).

Estudos brasileiros revelam que as parasitoses intestinais têm pouca relevância na etiologia da anemia, considerando que as prevalências da anemia apresentam tendência temporal em ascensão nas últimas décadas, ao passo que as parasitoses estão em declínio. Estudos realizados em São Paulo, Pernambuco e Bahia não têm encontrado associação entre a frequiência de parasitoses intestinais com a prevalência de anemia (Monteiro, 1988; Souza et al., 2002; Brito et al., 2003)

\section{Conseqüências}

Os sinais e sintomas clínicos da anemia são palidez, redução e perversão do apetite (pagofagia e geofagia), fadiga, fraqueza, glossite, estomatites, disfagia e palpitação, podendo, no idoso, ocasionar descompensação cardíaca. Entretanto, as conseqüências da anemia por deficiência de ferro não se limitam apenas aos sinais e sintomas mencionados e não estão restritos aos casos de anemia, mas também às situaçôes de déficits de ferro sem anemia.

\section{Gravidez, Parto e Puerpério e Mortalidade Materna e Infantil}

Nas gestantes, a anemia ferropriva grave está associada ao risco de morte materna, perdas fetais, prematuridade, baixo peso ao nascer e morte perinatal. Das mortes maternas ocorridas no pós-parto imediato, $40 \%$ são de mulheres anêmicas, e nos casos de anemia severa, o risco estimado de morte materna pode ser vinte vezes maior quando comparado com o do grupo de não anêmicas, de menor mortalidade (Rush, 2000).

As ocorrências de baixo peso ao nascer e de prematuridade apresentaram um gradiente de intensidade com a anemia, sendo o risco 4,9 e 2,0 vezes maior nos quadros maternos de anemia severa e moderada, respectivamente, quando comparado com o dos recém-nascidos de mães não anêmicas (Beard, 2003). Em outro estudo, o 
baixo peso ao nascer e a prematuridade ocorreram quando a deficiência de ferro foi observada no primeiro trimestre da gravidez, não tendo sido registrados agravos quando a anemia foi diagnosticada a partir do segundo trimestre (Scholl \& Hediger, 1994).

Há consenso na literatura sobre distribuição da concentração de hemoglobina materna e baixo peso ao nascer, ou seja, nos extremos da curva ocorrem as maiores prevalências de baixo peso ao nascer, por expansão do volume plasmático no extremo superior e pela insuficiente eritropoese e também inapropriada expansão do volume plasmático materno, no extremo inferior da distribuição (Yip, 2000).

Embora haja poucas evidências da influência da deficiência de ferro e da anemia materna no status do ferro do lactente, alguns resultados sugerem que, na depleção de ferro e anemia ferropriva moderada na gravidez, o aporte de ferro para a criança é suficiente para garantir o crescimento e a eritropoese intra-útero, mas não o é para garantir o crescimento e o desenvolvimento ao longo do primeiro ano de vida, especialmente no segundo semestre (Beard, 2003). Em estudo realizado por Sichieri e colaboradores (2006), a anemia materna não se associou com a anemia dos prematuros no nascimento e os indicadores de anemia das mães e das crianças ao nascer não influenciaram o crescimento destas últimas nos seis primeiros meses de vida.

\section{Crescimento e Desenvolvimento}

A associação entre a deficiência de ferro e o déficit de crescimento em crianças tem sido constatada quando da recuperação do crescimento linear e do ganho de peso, após suplementação de ferro tanto em países desenvolvidos como naqueles em desenvolvimento. Para os estudos de intervenção em que não foram observados impactos no crescimento, outros fatores adversos estavam envolvidos, tais como diarréias e outros processos infecciosos e fatores dietéticos (Waterlow \& Schürch, 1994; Allen \& Gillespie, 2001).

O ferro é encontrado em diferentes regiōes do cérebro humano e tem papel relevante no seu funcionamento, principalmente nos períodos de rápido crescimento neuronal (Pollitt, 1995). Na literatura médica, há registro de evidências da influência da deficiência do mineral no retardo do desenvolvimento psicomotor e na função cognitiva em lactentes, pré-escolares e escolares (Grantham-McGregor \& Ani, 2001; Lozoff \& Black, 2004).

Estudos correlacionando o desenvolvimento de crianças aos 5 anos de idade com os níveis de ferritina do cordão umbilical documentaram que aquelas nascidas com valores de ferritina abaixo da mediana pontuaram menos nos testes de linguagem e de motricidade fina quando comparadas a outras crianças (Tamura et al., 2002) e, em outro experimento, os filhos de mulheres anêmicas que foram suplementadas com ferro no período gestacional tiveram melhores escores motor e mental aos 12 meses de idade (Preziosi et al., 1997).

Crianças em idade escolar que tiveram anemia na infância apresentaram piores desempenhos em testes de inteligência (QI) e em testes para outras funçôes cognitivas quando comparadas com aquelas não anêmicas na infância, mesmo após ajuste por fatores socioeconômicos. Ademais, escolares anêmicos com baixos resultados nos testes de linguagem e matemática não melhoraram seus desempenhos nos referidos testes após a suplementação de ferro, o que sugere um efeito prolongado da deficiência no desenvolvimento infantil (Grantham-McGregor \& Ani, 2001; Lozoff \& Black, 2004).

\section{Função Imunitária}

O ferro é essencial para o funcionamento do sistema imunológico. Estudos têm evidenciado, por um lado, que a deficiência do mineral pode vir a causar efeitos adversos no sistema imune, contribuindo para o aumento de doenças infecciosas (WHO, 2001), mas, por outro lado, há evidências de que uma sobrecarga do ferro pode aumentar o risco de infecção e de neoplasias. Baseados nesses achados, alguns autores consideram que tanto a 
retenção de ferro na forma de depósito como déficits leves seriam mecanismos de defesa do organismo contra agentes agressores. Em decorrência, a anemia das infecçôes e das doenças crônicas seria uma defesa imunológica inespecífica e não necessariamente relacionada à deficiência de ferro (Kent, Weinberg \& Stuart-Macadan, 1994).

\section{Capacidade Física e Produtividade no Trabalho}

A relação da deficiência de ferro com a redução da capacidade de trabalho e diminuição da produtividade em adultos está bem estabelecida, com correlação linear positiva entre a concentração de hemoglobina e situaçôes de esforço máximo. Estudos realizados com diferentes tipos de ocupação laboral evidenciaram a recuperação rápida da capacidade de trabalho e o aumento da produtividade entre $10 \%$ e 30\%, após suplementação medicamentosa do ferro para o enfrentamento do problema (Viteri \& Torun, 1993).

Em atletas adolescentes do sexo feminino com deficiência de ferro e sem anemia, verificou-se aumento da resistência e melhor desempenho físico após suplementação do mineral, quando comparadas com aquelas do grupo placebo. Em contraste, estudos que avaliaram o efeito da deficiência de ferro e da anemia na capacidade física de trabalho e na atividade física de lazer em crianças e adolescentes não resultaram em associações consistentes. (Viteri \& Torun, 1993).

\section{Enfrentamento: prevenção e tratamento}

$\mathrm{Na}$ deficiência de ferro e na anemia ferropriva, o enfrentamento deverá proporcionar de forma efetiva o acesso ao mineral, levando-se em consideração as necessidades nutricionais e os aspectos culturais. Dito de outra forma, o paradigma norteador das açôes de enfrentamento da deficiência de ferro é o da "segurança alimentar", e significa que "todas as pessoas, em todos os momentos, tenham acesso físico e econômico a uma alimentação que seja suficiente, segura, nutritiva e que atenda às necessidades nutricionais e às preferências alimentares, de modo a propiciar vida ativa e saudável" (FAO, 1997: 123).

A erradicação da miséria e a redução da pobreza, a melhoria no acesso aos serviços de educação, saúde e saneamento e a garantia de uma alimentação saudável, diversificada, segura e de qualidade são ações públicas (governamentais e não governamentais) que permitirão em escala populacional a redução e o controle da deficiência de ferro e da sua expressão mais grave, a anemia ferropriva.

Há mais de meio século que organismos internacionais preconizam três estratégias de intervenção nutricional para enfrentar a deficiência de ferro nos diferentes grupos etários: a mudança nos hábitos alimentares, o enriquecimento de alimentos com o mineral e a suplementação medicamentosa mediante a administração de sais de ferro. Há ainda uma quarta medida: o combate a parasitoses espoliadoras de sangue, tais como malária, esquistossomose, ancilostomíase, que, no entanto, não será abordada neste capítulo (OMS, 1959; WHO, 2001).

\section{Modificação dos Hábitos Alimentares}

A mudança e a diversificação do hábito alimentar são, sem dúvida, a estratégia mais desejável e sustentável para enfrentar a deficiência de ferro e a anemia em escala populacional. Esta estratégia envolve mudanças nas condiçōes socioeconômicas (renda e escolaridade) da população e na produção, preservação, processamento, distribuição e comercialização de alimentos, assim como ações de educação alimentar e nutricional que fundamentem a escolha e preparação dos alimentos, a composição da dieta, as práticas alimentares e a distribuição intradomiciliar de alimentos, visando a assegurar uma dieta rica em ferro e em alimentos facilitadores da absorção do mineral e à redução do consumo daqueles alimentos que dificultem a sua absorção. 


\section{Fortificação}

O enriquecimento ou fortificação de alimentos é reconhecido como uma estratégia prioritária em termos de custo-benefício para enfrentar deficiências nutricionais e vem sendo adotada há mais de meio século (OMS, 1959; WHO, 2001). Desde 1940, os Estados Unidos adicionam ferro a produtos alimentares. Esta estratégia é reconhecida como a principal ação para a redução, em termos de tendência temporal, da deficiência de ferro nos países desenvolvidos (Darnton-Hill, 1998).

Em termos ideais, o alimento a ser fortificado deve ser regularmente consumido pela população-alvo em quantidades que não variem consideravelmente de um indivíduo para outro. É necessário ainda que o alimento seja produzido em escala industrial e que o produto fortificado não sofra mudanças nas qualidades organolépticas, nem no tempo de validade de consumo, nem no custo final do alimento (Stekel, 1984).

A farinha de trigo é o alimento mais utilizado como veículo de ferro, tanto em países desenvolvidos como nos em desenvolvimento e, possivelmente, o veículo mais apropriado: consumido amplamente em forma de pães, acessível a grupos vulneráveis à deficiência de ferro, processado em escala industrial, quase não sofre mudança nas características organolépticas, não sofre perdas do ferro no processo de cozimento. Alimentos como o sal de cozinha (Tailândia, Índia), arroz (Filipinas), açúcar (Guatemala), farinha de milho (Brasil e Venezuela) e certos condimentos (curry na África do Sul) também têm sido utilizados como veículos de ferro (Darnton-Hill, 1998).

Segundo Raunhardt e Bowley (1996), 14 países fazem a fortificação compulsória de farinhas de trigo: Arábia Saudita, Canadá, Chile, Costa Rica, Equador, El Salvador, Estados Unidos, Guatemala, Honduras, Nigéria, Panamá, Reino Unido, República Dominicana e Venezuela. O Brasil tornou compulsório o enriquecimento de farinhas de trigo e milho desde 2004. Para cada quilo de alimento são acrescentados $42 \mathrm{mg}$ de ferro em forma de sulfato ferroso e 1,5 mg de ácido fólico (Brasil, 2002).

Numerosas substâncias são disponíveis para fortificar alimentos com o ferro. O desafio é encontrar uma forma de ferro que seja adequadamente absorvível, estável, não altere aparência ou gosto do veículo. O ferro heme tem sido pouco utilizado, pois altera as qualidades organolépticas dos alimentos fortificados, especialmente as farinhas. Vários compostos de ferro não-heme têm sido utilizados para fortificar alimentos: sulfato e fumarato ferroso, ferro elementar, ferro-EDTA, ortofofosfato férrico. Os três primeiros são os mais utilizados. O sulfato ferroso, embora pouco estável, tem excelente absorvibilidade e elevado valor biológico, sendo adequado se o tempo entre o enriquecimento da farinha e o consumo for menor que quatro meses, como se verifica no Chile e no Brasil. Embora o tempo de estoque da farinha seja longo, o ferro metálico (o mais estável de todos e o menos absorvível deles) tem sido utilizado, como se observa na Suécia, no Reino Unido e nos Estados Unidos (Verster, 1998).

\section{Suplementação}

A suplementação com sais de ferro é a estratégia mais amplamente utilizada para controlar a anemia em países em desenvolvimento, principalmente naqueles onde as duas estratégias descritas anteriormente ainda não foram plenamente alcançadas.

A suplementação é mais largamente usada para tratar do que para prevenir a deficiência de ferro e a anemia, embora venha sendo utilizada como medida preventiva em grupos de alto risco, como pré-escolares e gestantes entre estas últimas, inclusive em países desenvolvidos (WHO, 2001).

Apesar de sua comprovada eficácia em experimentos bem controlados, na prática a sua efetividade tem se mostrado pequena, principalmente em países em desenvolvimento. A baixa efetividade tem sido atribuída a vários fatores: difícil distribuição, inadequada posologia e duração da aplicação do medicamento e baixa adesão (Viteri, 1997). Devido à necessidade de oferecer o ferro diariamente e por longo período, a distribuição e o acesso ao medicamento são o principal entrave para o bom desempenho da estratégia. Excluindo-se os adolescentes que 
podem ser alcançados nas escolas, os outros grupos biológicos são de difícil acesso, o que torna difícil atingir as coberturas necessárias.

Outro fator limitante para o êxito da suplementação consiste na baixa adesão aos sais de ferro devido aos efeitos colaterais indesejáveis, tais como náuseas, desconforto abdominal, vômitos, gosto metálico, diarréia, constipação intestinal e fezes escurecidas (Sölvell, 1970). Os efeitos colaterais estão relacionados à quantidade de ferro oferecida por dose, à freqüência das doses e ao momento de sua administração em relação às refeições. A aplicação do ferro às refeiçôes pode minimizar os incômodos, em especial os sintomas gastrintestinais altos (Viteri, 1997). $\mathrm{O}$ sulfato ferroso heptahidratado $\left(\mathrm{FeSO}_{4} \cdot 7 \mathrm{H}_{2} \mathrm{O}\right)$, contendo $20 \%$ de ferro elementar, é o sal mais recomendado por ser eficaz, bem tolerado e de baixo custo (Wintrobe, Lukens \& Lee, 1993).

O Quadro 1 apresenta um roteiro para enfrentamento da anemia por deficiência de ferro em aplicações diárias, segundo sugestão do Unicef e da OMS.

Quadro 1 - Esquema posológico em diferentes grupos biológicos para a prevenção da anemia por deficiência de ferro em escala populacional

\begin{tabular}{|c|c|c|c|}
\hline Grupos biológicos & Indicação para suplementação & Posologia & Duração \\
\hline $\begin{array}{l}\text { Crianças com baixo } \\
\text { peso ao nascer }\end{array}$ & Suplementação universal & $\begin{array}{l}\text { Fe: } 2 \mathrm{mg} / \mathrm{kg} \text { de peso } \\
\text { corporal/dia }\end{array}$ & De 2 a 23 meses de idade \\
\hline $\begin{array}{l}\text { Crianças de } 6 \text { a } 23 \\
\text { meses }\end{array}$ & $\begin{array}{l}\text { Quando não há alimentos fortificados com } \\
\text { ferro ou prevalência }>40 \%\end{array}$ & $\begin{array}{l}\text { Fe: } 2 \mathrm{mg} / \mathrm{kg} \text { de peso } \\
\text { corporal/dia }\end{array}$ & De 6 a 23 meses de idade \\
\hline $\begin{array}{l}\text { Crianças de } 24 \text { a } \\
59 \text { meses }\end{array}$ & Quando há prevalência de anemia > 40\% & $\begin{array}{l}\text { Fe: } 2 \mathrm{mg} / \mathrm{kg} \text { de peso } \\
\text { corporal/dia }\end{array}$ & 3 meses \\
\hline $\begin{array}{l}\text { Escolares acima de } \\
60 \text { meses }\end{array}$ & Quando há prevalência de anemia > 40\% & $\begin{array}{l}\text { Fe: } 30 \mathrm{mg} / \mathrm{dia} \\
\text { Ac. fólico: } 250 \mathrm{mg} / \mathrm{dia}\end{array}$ & 3 meses \\
\hline $\begin{array}{l}\text { Mulheres em período } \\
\text { fértil }\end{array}$ & Quando há prevalência de anemia > 40\% & $\begin{array}{l}\text { Fe: } 60 \mathrm{mg} / \mathrm{dia} \\
\text { Ac. fólico: } 250 \mathrm{mg} / \text { dia }\end{array}$ & 3 meses \\
\hline Gestantes & Suplementação universal & $\begin{array}{l}\text { Fe: } 60 \mathrm{mg} / \mathrm{dia} \\
\text { Ac. fólico: } 250 \mathrm{mg} / \text { dia }\end{array}$ & Durante toda a gestação \\
\hline Puérperas & Quando há prevalência de anemia > 40\% & $\begin{array}{l}\text { Fe: } 60 \mathrm{mg} / \mathrm{dia} \\
\text { Ac. fólico: } 250 \mathrm{mg} / \text { dia }\end{array}$ & 3 meses após o parto \\
\hline
\end{tabular}

Fonte: WHO (2001).

Considerando-se a baixa adesão aos sais ferro e levando-se em conta que o objetivo da administração de medicamentos é encontrar a dose mínima capaz de produzir os efeitos desejáveis sem, contudo, produzir efeitos adversos à saúde, recentes estudos têm mostrado que a administração de sais de ferro em esquemas intermitentes (uma a duas vezes por semana) apresenta resultados semelhantes aos dos esquemas diários, inclusive com a vantagem de aumentar a adesão (Batista Filho \& Ferreira, 1996; Viteri, 1997; Beaton \& McCabe, 1999). Essa modalidade posológica representa uma promissora alternativa para a aplicação dos sais de ferro em escala populacional, em particular para ações preventivas (WHO, 2001).

\section{O Enfrentamento nos Diferentes Grupos Biológicos}

Crianças menores de dois anos de idade, notadamente aquelas com baixo peso ao nascer, são consideradas o grupo biológico de maior vulnerabilidade para a deficiência de ferro. $\mathrm{O}$ incentivo ao aleitamento materno exclusivo é a medida de maior efetividade para combater a deficiência de ferro nos primeiros meses de vida. 
O reconhecimento da importância do leite materno na prevenção da deficiência de ferro deve-se não apenas a seu elevado percentual de absorção ( $49 \%$ em lactentes sadios aos seis meses) quando comparado ao do leite de gado e ao de outros alimentos, mas, sobretudo, ao fato de ser facilitador da absorção do ferro não-heme (Oski, 1985).

O uso de papas e mingaus na alimentação de crianças, preparados à base de leite e massa (cereais, raízes e tubérculos), com elevado teor de cálcio e principalmente fitatos (o maior inibidor de absorção de ferro nãoheme), contribui para a elevada prevalência da deficiência de ferro nesse grupo biológico. A substituição desses preparados por sucos de frutas e caldos de produtos de origem animal e o uso de farinhas fortificadas com o ferro podem contribuir para a redução da deficiência do mineral nesse grupo. A OMS recomenda administrar $2 \mathrm{mg} /$ $\mathrm{kg} /$ dia de ferro por duas a três semanas várias vezes ao ano, a partir de 4 a 6 meses de idade e continuando até os 24 meses (Viteri, 1997).

Experiência com pré-escolares chineses comparando a efetividade de esquemas diários, semanais e bissemanais, mediante a administração de $6 \mathrm{mg} / \mathrm{kg}$ de peso de ferro elementar, mostrou que todas as crianças anêmicas responderam de modo semelhante aos três esquemas e que, entretanto, a ocorrência de efeitos colaterais foi significativamente menor nos esquemas intermitentes (Viteri, 1997). Resultados semelhantes têm sido observados em outras localidades, sugerindo a possibilidade de se contar com mais essa medida de combate à deficiência de ferro nesse grupo etário (Monteiro et al., 2002; Cavalcanti et al., 2003; Ferreira, M. L. M. et al., 2003; Ferreira, L. O. C. et al., 2004; Lima et al., 2006; Brunken, Muniz \& Silva, 2004).

Os escolares e os adolescentes representam o subgrupo populacional em que as medidas de controle da deficiência de ferro podem apresentar as mais elevadas coberturas. Orientaçôes sobre o cardápio para a merenda escolar visando à introdução de alimentos ricos em ferro e de facilitadores da absorção do mineral e da redução de alimentos inibidores podem ser medidas de elevada efetividade. A aplicação de sais de ferro em esquemas diários ou semanais deve ser adotada quando a prevalência de anemia for moderada ou grave (Ferreira, 1998).

A OMS recomenda $60 \mathrm{mg}$ de ferro elementar por três meses ao ano como ação preventiva/curativa para a deficiência de ferro em mulheres em período fértil de populaçôes em que a prevalência de anemia é alta. Estudos conduzidos em Berkeley, na Califórnia, EUA (Viteri, 1997), e no Recife, em Pernambuco, Brasil (Lopes, Ferreira \& Batista Filho, 1999), mostraram não haver diferenças significativas entre a administração de ferro em esquemas diários e a efetuada em esquemas intermitentes, e recomendam a administração de sais de ferro na dose de $60 \mathrm{mg}$ de ferro elementar semanalmente, durante todo o ano.

Ensaios clínicos e comunitários têm mostrado sólidas evidências de que a suplementação com ferro durante a gravidez é eficiente em proteger e melhorar o estado nutricional do feto durante e após a gravidez. Desde 1990, a OMS recomenda a suplementação universal com sais de ferro para gestantes (60 mg de ferro elementar e $250 \mathrm{mg}$ de ácido fólico uma a duas vezes por dia), sendo que o esquema de duas vezes ao dia é recomendado em localidades onde a anemia é comum na gravidez (Viteri, 1997).

Estudos de campo em primíparas chinesas na província de Xinjiang (Liu et al., 1995), em grávidas da cidade de Guatemala (Viteri, 1997), em gestantes de baixo risco gravídico em Recife (Souza et al., 2004) que freqüentavam clínicas de pré-natal, comparando esquemas diários e semanais com sulfato ferroso, encontraram no controle da deficiência de ferro com aplicação dos esquemas tradicionais respostas semelhantes àquelas encontradas com aplicação dos esquemas alternativos; os esquemas intermitentes apresentaram como vantagem adicional a melhor tolerância aos sais de ferro. Tais resultados podem vir a consolidar uma alternativa na prevenção da deficiência de ferro e da anemia, que consiste na utilização de $60 \mathrm{mg}$ de ferro elementar duas vezes por semana durante todo o período gestacional e estendida ao período de lactação, isto é, até os seis meses após o parto. 


\section{Considerações Finais}

A deficiência de ferro mantém-se como um problema de saúde pública em escala mundial, com tendência temporal e geográfica em ascensão, inclusive alastrando-se em novos grupos biológicos, como as crianças menores de 1 ano de vida e os idosos. Acometendo principalmente os habitantes de países em desenvolvimento e grupos socialmente desfavorecidos dos países centrais, requer, portanto, ações em escala populacional mais efetivas do que as implementadas até hoje, para prevenir e tratar contingentes populacionais por ela atingidos.

O envelhecimento populacional e as mudanças nos hábitos de vida, tais como o sedentarismo e dietas hipercalóricas, conduziram ao fenômeno conhecido como transição epidemiológica e nutricional, que vem se acentuando nas três últimas décadas, proporcionando, por exemplo, um quadro que associa em um mesmo contexto doenças nutricionais por carência e aquelas devidas ao excesso alimentar. A condição de anemia por deficiência de ferro associada ao sobrepeso e à obesidade representa um quadro nutricional emblemático do novo padrão de adoecimento das pessoas no despontar do século XXI. Que estratégias de intervenção serão desenvolvidas para dar conta desse 'paradoxo nutricional'?

O desenvolvimento científico e tecnológico da modernidade tem proporcionado uma redução de esforços físicos nos afazeres domésticos, no deslocamento de pessoas, na agricultura, na indústria e no comércio, inclusive no lazer e entretenimento. Essa redução de esforços estaria conduzindo a uma redução nas necessidades de oxigênio tissular e, portanto, nos níveis de hemoglobina? Seria o caso de se rever os pontos de corte da concentração de hemoglobina e do nível sérico de ferritina para a definição da anemia e deficiência de ferro, levando-se em conta, inclusive, que esses critérios foram estabelecidos há mais de cinqüenta anos?

Medidas promissoras vêm sendo delineadas para o enfrentamento da anemia ferropriva, entre as quais se destacam a administração de sais de ferro em esquemas posológicos intermitentes e a adoção de medidas compulsórias para o enriquecimento de produtos alimentares de elevada aceitação popular, como fez recentemente o Brasil ao enriquecer farinhas de trigo e milho com ferro e ácido fólico. Que impacto essa medida exercerá nos grupos mais vulneráveis? Ademais, respeitando-se as questôes éticas e de desenvolvimento sustentável, o enriquecimento de alimentos com ferro mediante a engenharia genética pode representar mais uma estratégia na luta contra a anemia.

A Conferência Internacional sobre Cuidados Primários de Saúde, promovida pela OMS e Unicef em 1978, propugnou o acesso universal à saúde, a participação popular e a descentralização dos serviços de saúde. À luz da conferência, o Brasil implementou sua reforma sanitária mediante a implantação de um sistema único de saúde que tem condições de contribuir, por meio do novo modelo de atenção, isto é, do Programa Saúde da Família, para o enfrentamento eficaz da anemia por deficiência de ferro.

\section{Referências}

ALLEN, L. H. \& GILLESPIE, S. R. What works? A review of efficacy and effectiveness of nutrition interventions. ACC/SCN Nutrition Policy Paper, 19: 123, 2001.

ALMEIDA, C. A. N. et al. Fatores associados a anemia por deficiência de ferro em crianças pré-escolares brasileiras. Jornal de Pediatria, 80(3): 229-234, 2004.

ASSIS, A. M. O. et. al. Distribuição da anemia em pré-escolares do Semi-Árido da Bahia. Cadernos Saúde Pública, 13(2): 237-243, 1997.

ASSIS, A. M. O. et. al. Níveis de hemoglobina, aleitamento materno e regime alimentar no primeiro ano de vida. Cadernos de Saúde Pública, 38(4): 543-551, 2004. 
BATISTA FILHO, M. Biologia social da fome. Recife: Departamento de Nutrição da UFPE, 1983. (Mimeo.).

BATISTA FILHO, M. \& FERREIRA, L. O. C. Prevenção e tratamento da anemia nutricional ferropriva: novos enfoques e perspectivas. Cadernos de Saúde Pública, 12(3): 37-45, 1996.

BATISTA FILHO, M. et al. Avaliação da situação alimentar e nutricional e seus fatores determinantes em conglomerados urbanos e rurais do Semi-Árido do Nordeste. Recife: DN/UFPE-Imip, 2005. (Relatório CNPq)

BATISTA FILHO, M. et al. III Pesquisa Estadual sobre Situação Alimentar, Nutricional e de Saúde - Pernambuco, 2006: contexto sócio-econômico e de serviços. Recife: DN/UFPE-Imip-SES/PE, 2006. (Relatório CNPq)

BEARD, D. J. L. Does iron deficiency cause low birth weight, prematurity, anemia and mortality in early infancy? In: DELANGE, F. M. \& WEST JR., K. P. (Eds.) Micronutrient Deficiencies in the First Months of Life. Basel: Nestec Lts., Vevey/S. Karger AG, 2003. (Nestlé Nutrition Series Pediatric Program, 52)

BEARD, J. L.; DAWSON, B. S. H. \& PINERO, D. S. Iron metabolism: a comprehensive review. Nutrition Reviews, 54(10): 295-317, 1996.

BEATON, G. H. \& MCCABE, G. P. Efficacy of intermittent iron supplementation in the control of iron deficiency anaemia in developing countries. An analysis of experience: final report to the Micronutrient Initiative (the MI) and the Canadian International Development Agency (Cida), 1999.

BRASIL. Ministério da Saúde. Resolução RDC n. 344, Brasília, 13 de dezembro de 2002. Diário Oficial da Uniāo, Brasília, 18 dez. 2002.

BRITO, L. L. et al. Fatores de risco para anemia por deficiência de ferro em crianças e adolescentes parasitados por helmintos intestinais. Revista Panamericana de Salud Pública, 14(6): 422-431, 2003.

BRUNKEN, G. S.; GUIMARÃES, L. V. \& FISBERG, M. Anemia em crianças menores de três anos que freqüentam creches públicas em período integral. Jornal de Pediatria, 78 (1): 50-56, 2002.

BRUNKEN, G. S.; MUNIZ, P. T. \& SILVA, S. M. Suplementação semanal com sulfato ferroso reduz 1/3 a prevalência de anemia em pré-escolares. Revista Brasileira de Epidemiologia, 7(2): 210-219, 2004.

BUENO, M. B. et al. Prevalência e fatores associados à anemia entre crianças atendidas em creches públicas de São Paulo. Revista Brasileira de Epidemiologia, 9(4): 462-70, 2006.

CAPANEMA, F. D. Anemia em Crianças de 0 a 6 anos em Creches Conveniadas da Regional Leste da Prefeitura de Belo Horizonte: aspectos clínicos e laboratoriais, 2002. Dissertação de Mestrado, Belo Horizonte: Faculdade de Medicina, Universidade Federal de Minas Gerais.

CARVAlHO, A. G. C.; LIMA, M. C. \& LIRA, P. I. C. Avaliação da eficácia de três esquemas na prevenção e tratamento medicamentoso da anemia em lactentes de creches do Recife. Recife: DN-DMI-DFF/UFPE, 2006. (Relatório CNPq)

CASTRO, T. G. Anemia Ferropriva na Infância: prevalência e fatores associados na Amazônia Ocidental Brasileira, 2006. Tese de Doutorado, São Paulo: Universidade de São Paulo, 2007.

CAVALCANTI, N. V. et al. Comparação da efetividade do sulfato ferroso, administrado em doses bissemanais, exclusivamente, e associada à vitamina A em pré-escolares de creches públicas do Recife [Resumo]. Anais do VII Congresso de Saúde Coletiva - Abrasco, 8, supl. 2: 40-41, 2003.

DALLMAN, P. Review of iron metabolism. In: FILLER JR., L. J. Dietary Iron: birth to two years. New York: Raven Press, 1989. 
DALY, M. P. Anemia in the elderly. American Pharmacology Physician, 62: 1.565-1.572, 2000.

DARNTON-HILL, I. Overview: rationale and elements of a successful food-fortification programme. Food and Nutrition Bulletin, The United Nations University, 19(2): 92-100, 1998.

DELANGE, F. M. \& WEST JR., K. P. (Eds.) Micronutrient Deficiencies in the First Months of Life. Basel: Nestec Lts.; Vevey/S. Karger AG, 2003. (Nestlé Nutrition Series Pediatric Program, 52)

DEVINCENZI, M. U.; RIBEIRO, L. C. \& SIGULEM, D. M. Anemia ferropriva na primeira infância. Revista Diagnóstico \& Tratamento, 4(1): 49-52, 1999.

DRICOT D’ANS, C. et al. Estudo epidemiológico preliminar da desnutrição no Estado da Paraíba. João Pessoa, 1985. (Relatório Técnico Finep/CNPq), apud ARRUDA, B. K.G. A política alimentar e nutricional brasileira. CONGRESO LATINOAMERICANO DE NUTRICIÓN, 7, 1984, Brasília. Anais... México: Sociedad Latinoamericana de Nutrición, 1984.

FABIAN, C. et al. Prevalência de anemia e fatores associados em mulheres adultas residentes em São Leopoldo, Rio Grande do Sul, Brasil. Cadernos de Saúde Pública, 23(5): 1.199-1.205, 2007.

FERREIRA, L. O. C. A Ação do Sulfato Ferroso Administrado em Doses Diárias e Semanais em Escolares da Mata Sul de Pernambuco: um ensaio terapêutico, 1998. Tese de Doutorado, Recife: Centro de Ciências da Saúde, Universidade Federal de Pernambuco.

FERREIRA, L. O. C.; LIRA, P. I. C. \& BATISTA FILHO, M. Avaliação do Programa de Combate a Anemia em crianças de 6 a 24 meses nos municípios do Projeto de Redução da Mortalidade na Infância/Comunidade Solidária (PRMI) da região Nordeste do Brasil. Recife: DN/UFPE-Imip-MS, 2000. (Relatório de Pesquisa)

FERREIRA, L. O. C. et. al. Fortificação artesanal de alimentos com sulfato ferroso no controle da anemia em pré-escolares de creches públicas da cidade do Recife, 2003. In: CONGRESSO BRASILEIRO DE EPIDEMIOLOGIA, VI, 2004, Recife. Anais... Rio de Janeiro: Abrasco, 2004.

FERREIRA, M. L. M. et al. Efetividade da aplicação do sulfato ferroso em doses semanais no Programa Saúde da Família em Caruaru, Pernambuco, Brasil. Cadernos de Saúde Pública, 19(2): 375-381, 2003.

FOOD AND AGRICULTURE ORGANIZATION OF THE UNITED NATIONS (FAO). Report of the World Food Summit. Rome: FAO, 1997.

FUJIMORI, E.; SZARFARC, S. C. \& OLIVEIRA, I. M. V. Prevalência de anemia e deficiência de ferro em adolescentes do sexo feminino - Taboão da Serra, SP, Brasil. Revista Latino-Americana de Enfermagem, 4(3): 49-63, 1996.

FUJIMORI, E. et al. Anemia e deficiência de ferro em gestantes adolescentes. Revista de Nutrição de Campinas, 13(3): 177-184, 2000.

FUNDO DAS NAÇÕES UNIDAS PARA A INFÂNCIA (UNICEF). Declaração mundial sobre a sobrevivência, a proteção e o desenvolvimento da criança. In: ENCONTRO MUNDIAL DE CÚPULA PELA CRIANÇA, 1990, Nova York. Brasília: Unicef, 1990.

GRANTHAM-MCGREGOR, S. \& ANI, C. A review of studies on the effect of iron deficiency on cognitive development in children. Journal of Nutrition, 131: S649-S668, 2001.

GUERRA, E. M. et al. Prevalência de anemia em gestantes de primeira consulta em centros de saúde de área metropolitana, São Paulo, Brasil. Revista de Saúde Pública, 24(5): 380-386, 1990. 
GUIMARĀES, R. Dicionário da Mitologia Grega. São Paulo: Cultrix, 1995.

HADLER, M. C. C. M.; JULIANO, Y. \& SIGULEM, D. M. Anemia do lactente: etiologia e prevalência. Jornal de Pediatria, 78(4): 321-326, 2002.

HAHN, P. F. et al. Radioactive iron absorption by gastro-intestinal tract: influence of anemia, anoxia, and antecedent feeding distribution in growing dogs. The Journal of Experimental Medicine, 78(3): 169-188, 1943.

HILLMAN, R. S. Agentes hematopoiéticos: fatores de crescimento, sais minerais e vitaminas. In: GOODMAN, L. S. \& GILMAN, A. G. (Eds.) As Bases Farmacológicas da Terapêutica. 8. ed. Rio de Janeiro: Guanabara Koogan, 1991.

KENT, S.; WEINBERG, E. D. \& STUART-MACADAN, P. The etiology of anemia of chronic disease and infection. Journal of Clinical Epidemiology, 47: 23-33, 1994.

KMETIUK, S. F. Prevalência de Anemia Ferropriva em Crianças Matriculadas em Duas Creches Municipais de Guarapuava - PR, 2005. Dissertação de Mestrado, Ribeirão Preto: Escola de Enfermagem de Ribeirão Preto, Universidade de São Paulo.

LACERDA, E. \& CUNHA, A. J. Anemia ferropriva e alimentação no segundo ano de vida no Rio de Janeiro, Brasil. Revista Panamericana de Salud Pública/Pan American Journal of Public Health, 9(5): 294-301, 2001.

LAMOUNIER, J. A. et al. Prevalência de anemia ferropriva e parasitose intestinal em crianças de 0 a 6 anos no município de Carrancas, MG. III ENCONTRO DE EXTENSÃO DA I SEMANA DO CONHECIMENTO DA UFMG, Belo Horizonte, 2000. Anais... Belo Horizonte: Pró-Reitoria de Pesquisa da UFMG, 2000 .

LEAL, L. P. \& OSÓRIO, M. M. Comparação da acurácia do diagnóstico dos sinais clínicos e da escala de cores de hemoglobina como métodos de triagem no diagnóstico da anemia em crianças. Revista Brasileira de Saúde Materno Infantil, 6(2): 183-189, 2006.

LIMA, A. C. V. M. S. et al. Fatores determinantes dos níveis de hemoglobina em crianças aos 12 meses de vida na Zona da Mata Meridional de Pernambuco. Revista Brasileira de Saúde Materno Infantil, 4(1): 35-43, 2004.

LIMA, A. C. V. M. S. et al. Impacto do tratamento semanal com sulfato ferroso sobre o nível de hemoglobina, morbidade e estado nutricional de lactentes anêmicos. Jornal de Pediatria, 82(6): 452-457, 2006.

LIRA, P. I. C. et al. Estado nutricional de crianças menores de 6 anos, segundo posse da terra, em áreas rurais do estado de Pernambuco NE - Brasil. Archivos Latinoamericanos de Nutrición, 35(2): 247-257, 1985.

LIRA, P. I. C. et al. Avaliação da situação alimentar e nutricional e seus fatores determinantes em conglomerados urbanos e rurais da Zona da Mata de Pernambuco. Recife: DN/UFPE-Imip, 2005. (Relatório CNPq)

LIU, X. N. et al. Weekly iron supplementation is effective and safe in pregnant women. Faseb Journal, 9: A56A58, 1995.

LOPES, M. C. S.; FERREIRA, L. O. C. \& BATISTA FILHO, M. Uso diário e semanal de sulfato ferroso no tratamento de anemia em mulheres no período reprodutivo. Cadernos de Saúde Pública, 15: 799-808, 1999.

LOZOFF, B \& BLACK, M. M. Impact of micronutrient deficiencies on behavior and development. In: PETTIFOR, J. M. \& ZLOTKIN, S. (Eds.) Micronutrient Deficiencies during the Weaning Period and the First Years of Life. Basel: Nestec Lts.; Vevey/S. Karger AG, 2004. (Nestlé Nutrition Series Pediatric Program, 54) 
LYNCH, S. R. Interaction of iron with other nutrients. Nutrition Reviews, 55(4): 102-110, 1997.

MARUCCI, M. F. N. \& PINOTTI, R. Deficiência de ferro no idoso. In: BRAGA, J. A. P.; AMANCIO, O. M. S. \& VITALlE, M. S. S. (Orgs.) O Ferro e a Saúde das Populaçôes. São Paulo: Roca, 2006.

MATTA, I. E. A. et al. Anemia em crianças menores de cinco anos que freqüentam creches públicas do município do Rio de Janeiro, Brasil. Revista Brasileira de Saúde Materno Infantil. Recife, 5(3): 349-357, 2005.

MINISTÉRIO DA SAÚDE/INAN-IMIP-DN/UFPE-SES-PE. II Pesquisa Estadual de Saúde e Nutrição: saúde, nutrição, alimentação e condições sócio-econômicas no Estado de Pernambuco, 1997. Recife: MS/INAN-IMIPDN/UFPE-SES-PE, 1998.

MIRANDA A. S. et al. Anemia ferropriva e estado nutricional de crianças com idade de 12 a 60 meses do município de Viçosa, MG. Revista de Nutrição, 16(2): 163-169, 2003.

MONTEIRO, C. A. Saúde e Nutrição das Crianças de São Paulo: diagnóstico, contrastes sociais e tendência. São Paulo: Hucitec, 1988.

MONTEIRO, C. A. \& SZARFARC, S. C. Estudo das condições de saúde das crianças do Município de São Paulo (1984/85). V. Anemia. Revista de Saúde Pública, 21: 255-260, 1987.

MONTEIRO, C. A.; SZARFARC, S. C. \& MONDINI, L. Tendência secular da anemia na infância na cidade de São Paulo (1984-1996). Revista de Saúde Pública, 34, supl. 6: 62-72, 2000.

MONTEIRO, C. A. et al. A prescrição semanal de sulfato ferroso pode ser altamente efetiva para reduzir níveis endêmicos de anemia na infância. Revista Brasileira de Epidemiologia, 5(1): 71-83, 2002.

NASCIMENTO, S. F. Estado Nutricional e Anemia em adolescentes do sexo feminino no Estado de Pernambuco, 1997, 2000. Dissertação de Mestrado, Recife: Departamento de Nutrição, Centro de Ciências da Saúde, Universidade Federal de Pernambuco.

NESTEL, P. \& DAVIDSSON, L. Anemia, Iron Deficiency and Iron Deficiency Anemia: the International Nutritional Anemia Consultative Group (INACG) Steering Committee. Washington: INACG/ILSI Press, 2002.

NEUMAN, N. A. et al. Prevalência e fatores de risco para anemia no sul do Brasil. Revista de Saúde Pública, 34(1): 56-63, 2000.

NOGUEIRA, N. N. Estudo Comparativo sobre os Efeitos da Suplementação com Ferro (diferentes concentrações), Ácido Fólico e Zinco no Estado Nutricional de Adolescentes Grávidas e de seus Conceptos, 1997. Tese de Doutorado, São Paulo: Faculdade de Ciências Farmacêuticas, Universidade de São Paulo.

OLINTO, M. T. A. et al. Prevalência de anemia em mulheres em idade reprodutiva. Boletim da Saúde, 17: 135144, 2003.

OLIVEIRA, M. A. A.; OSÓRIO, M. M. \& RAPOSO M. C. F. Concentração de hemoglobina e anemia em crianças no estado de Pernambuco, Brasil: fatores sócio-econômicos e de consumo alimentar associados. Cadernos de Saúde Pública, 22(10): 2.169-2.178, 2006.

OLIVEIRA, R. S. et al. Magnitude, distribuição especial e tendência da anemia em pré-escolares da Paraíba. Revista de Saúde Pública, 36(1): 26-32, 2002.

ORELLANA, J. D. Y. et al. Estado nutricional e anemia em crianças Suruí, Amazônia, Brasil. Jornal de Pediatria, 82(5): 383-388, 2006. 
ORGANISATION MONDIALE DE LA SANTÉ (OMS). L'Anemie Ferriprive: rapport d'un groupe d'étude. Genève: OMS, 1959. (Rapports Techniques, 182)

OSKI, F. A. Deficiência de ferro: fatos e falácia. Clínicas Pediátricas da América do Norte, 2: 503-508, 1985.

OSKI, F. A. \& HONIG, A. S. The effects of therapy on the developmental scores of iron-deficient infants. The Journal of Pediatrics, 92(1): 21-25, 1978.

OSÓRIO, M. M. Fatores determinantes da anemia em crianças. Jornal de Pediatria, 78(4): 269-278, 2002.

OSÓRIO, M. M.; LIRA, P. I. C. \& ASHWORTH, A. Factors associated with Hb concentration in children aged 6-59 months in the State of Pernambuco, Brazil. British Journal of Nutrition, 91: 307-314, 2004.

OSÓRIO, M. M. et al. Prevalence of anemia in children 6-59 months old in the state of Pernambuco, Brazil. Revista Panamericana de Salud Pública, 10(2): 101-107, 2001.

PEREIRA, R. C.; FERREIRA, L. O. C. \& BATISTA FILHO, M. Anemia em escolares de uma cidade do agreste de Pernambuco em 1999 [Resumo]. In: CONGRESSO DE SAÚDE COLETIVA, VII, 2003, Brasília. Anais..., 2003.

POLLITT, E. (Ed.) Undernutrition and behavioral development in children. Journal of Nutrition, 125(8): S2.211S2.284, 1995 .

PREZIOSI, P. et al. Effect of iron supplementation on the iron status of pregnant women: consequences for newborns. American Journal of Clinical Nutrition, 66: 1.178-1.182, 1997.

RAUNHARDT, O. \& BOWLEY, A. Mandatory food enrichment. Nutriview, 1, suppl.: 1-44, 1996.

RIBEIRO, L. C. Anemia Ferropriva na Primeira Infância: controle e prevenção com doses intermitentes de ferro quelato glicinato, 2001. Dissertação de Mestrado, São Paulo: Escola Paulista de Medicina, Universidade Federal de São Paulo.

ROCHA, D. S. et al. Estado nutricional e anemia ferropriva em gestantes: relação com o peso da criança ao nascer. Revista de Nutrição de Campinas, 18(4): 481-489, 2005.

RODRIGUEZ, O. T. S.; SZARFARC, S. C.; BENICIO, M. H. A. Anemia e desnutrição maternas e sua relação com o peso ao nascer. Revista de Saúde Pública, 25(3): 193-197, 1991.

ROMANI, S. A. M. \& LIRA, P. I. C. Fatores determinantes do crescimento infantil. Revista Brasileira de Saúde Materno Infantil, 4(1): 15-23, 2004.

ROMANI, S. A. M. et al. Anemias em pré-escolares: diagnóstico, tratamento e avaliação, Recife, PE, Brasil. Archivos Latinoamericano de Nutrición, 67: 159-167, 1991.

RUSH, D. Nutrition and maternal mortality in the developing world. American Journal of Clinical Nutrition, 72 : S212-S240, 2000.

SANTANA, L. Anemia e Associação com Parasitose Intestinal e Desnutrição Energético-Protéica em Escolares de 6 a 12 anos de Idade em Região do Semi-Árido Paraibano, 2001. Dissertação de Mestrado, Recife: Centro de Ciências da Saúde, Universidade Federal de Pernambuco.

SANTOS, I. et al. Prevalência e fatores associados à ocorrência de anemia entre menores de seis anos de idade em Pelotas, RS. Revista Brasileira de Epidemiologia, 7(4): 403-415, 2004. 
SANTOS, L. M. P. (Org.) Bibliografia sobre Deficiência de Micronutrientes no Brasil 1990-2000. Brasília: Opas, 2002. v. 2a e 2b - Anemia.

SCHMITZ, B. A. S. et al. Prevalência de desnutrição e anemia em pré-escolares de Brasília (Brasil). Pediatria Moderna, 34(4): 155-164, 1998.

SCHOLL, T. O. \& HEDIGER, M. L. Anemia and iron deficiency anemia: compilation of data on pregnancy outcomes. American Journal of Clinical Nutrition, 59: S492-S492, 1994.

SICHIERI, R. et al. Ausência de associação entre indicadores de anemia ao nascimento e crescimento de Prematuros. Revista de Saúde Pública, 40(4): 641-647, 2006.

SIGULEM, D. M. et al. Anemia carencial em lactentes e pré-escolares atendidos no Centro de Saúde Escola. In: WORLD CONGRESS OF PEDIATRIC NUTRITION, III, 2001. Resumos... São Paulo: Sociedade Brasileira de Pediatria, 2001.

SILVA, L. S. M.; GIUGLIANI, E. R. J. \& AERTS, D. R. G. C. Prevalência e determinantes de anemia em crianças de Porto Alegre, RS, Brasil. Revista Saúde Pública, 35(1): 66-73, 2001.

SILVA, D. G. et al. Anemia ferropriva em crianças de 6 a 12 meses atendidas na rede pública de saúde do município de Viçosa, Minas Gerais. Revista de Nutrição, 15(3): 301-308, 2002.

SOARES, N. T. et al. Estado nutricional de lactentes em áreas periféricas de Fortaleza. Revista de Nutrição, 13(2): 99-106, 2000.

SÖLVELL, L. Oral iron therapy - side effects. In: HALBERG, L.; HARWERTH, H. G. \& VANNOTI, A. Iron Deficiency: pathogenesis, clinical aspects, therapy. London: Academic Press, 1970.

SOUZA, A. I. et al. Enteroparasitoses, anemia e estado nutricional em grávidas atendidas em serviço público de saúde. Revista Brasileira de Ginecologia e Obstetrícia, 24(4): 253-259, 2002.

SOUZA, A. I. et al. Efetividade de três esquemas com sulfato ferroso para tratamento de anemia em gestantes. Revista Panamericana de Salud Pública, 15(5): 313-319, 2004.

SPINELLI, M. G. N. et al. Fatores de risco para anemia em crianças de 6 a 12 meses no Brasil. Revista Panamericana de Salud Pública, 17(2): 84-91, 2005.

STEKEL, A. Prevention of iron deficiency. In: STEKEL, A. Iron Nutrition in Infancy and Childhood. New York: Raven Press, 1984. (Nestlé Nutrition Workshop Series, 4)

SZARFARC, S. C. Anemia nutricional entre gestantes atendidas em centros de saúde do Estado de São Paulo (Brasil). Revista de Saúde Pública, 19: 450-457, 1985.

SZARFARC, S. C.; SIQUEIRA, A. A. F. \& MARTINS, I. S. Avaliação da concentração de ferro orgânico em uma população de grávidas. Revista de Saúde Pública, 17(3): 200-207, 1983.

TAMURA, T. et al. Cord serum ferrintin concentrations and mental and psychomotor development of children at five years of age. Journal of Pediatrics, 140: 165-170, 2002.

TORRES, M. A. A. et al. Fortificação do leite fluido na prevenção e tratamento da anemia carencial ferropriva em crianças menores de 4 anos. Revista de Saúde Pública, 30(4): 350-357, 1996.

TORRES, M. A. A. et al. Anemia em lactentes de baixa renda em aleitamento materno exclusivo. Jornal de Pediatria, 82: 284-288, 2006. 
TURCONI, S. J. \& TURCONI, V. L. Anemia ferropriva: incidência em uma população infantil. Pediatria Moderna, 28: 107-112, 1992.

UCHIMURA, T. T. et al. Anemia e peso ao nascer. Revista de Saúde Pública, 37(4): 397-403, 2003.

VANNUCCI, H.; FREITAS, M. L. S. \& SZARFARC, S. C. Prevalência de anemias nutricionais no Brasil. Cadernos de Nutrição, 4: 7-26, 1992.

VASCONCELOS, A. K. B. Prevalência de Anemia em Gestantes no Município de Sobral, Ceará, 2004. Monografia de Especialização em Saúde da Família, Sobral: Universidade Estadual Vale do Acaraú - UVA.

VERSTER, A. (Ed.) Fortification of Flour with Iron in Countries of the Eastern Mediterranean, Middle East and North Africa. Alexandria: World Health Organization, 1998.

VITERI, F. E. Iron supplementation for the control of iron deficiency in populations at risk. Nutrition Reviews, 55(6): 195-209, 1997.

VITERI, F. E. \& TORUN, B. Anaemia and physical work capacity. Clinical Haematologic, 3: 82-96, 1993.

WATERLOW, J. C. \& SCHÜRCH, B. (Eds.) Causes and mechanisms of linear growth retardation. European Journal of Clinical Nutrition, 48, suppl. 1: 216, 1994.

WINTROBE, M. M.; LUKENS, J. N. \& LEE, G. R. The approach to the patient with anemia. In: LEE, G. R. et al. (Eds.) Wintrobe’s Clinical Hematology. 9. ed. London: Lea \& Febinger, 1993.

WORLD HEALTH ORGANIZATION (WHO). The Prevalence of Anaemia in Women: a tabulation of available information. Geneva: WHO, 1992. (WHO/MCH/MSM/92.2)

WORLD HEALTH ORGANIZATION (WHO). Iron Deficiency Anaemia Assessment, Prevention, and Control: a guide for programme managers. Geneva: WHO, 2001. (HO/NHD/01.3)

YIP, R. Significance of an abnormally low or high hemoglobin concentration during pregnancy: special consideration of iron nutrition. American Journal of Clinical Nutrition, 72: S272-S279, 2000. 



\title{
18
}

\section{Epidemiologia da Hipovitaminose A e Xeroftalmia}

\author{
Alcides da Silva Diniz e Leonor Maria Pacheco Santos
}

\section{Definição e Tipologia}

Uma variedade de termos tem sido usada para caracterizar o estado nutricional de vitamina A e os seus efeitos sobre a saúde. Deficiência de Vitamina A (DVA) é o termo recomendado para expressar o status inadequado de vitamina $A$, que começa quando as reservas hepáticas caem abaixo de $20 \mu \mathrm{g} / \mathrm{g}(0,07 \mu \mathrm{Mol} / \mathrm{g})$. Distúrbios da Deficiência de Vitamina A (DDVA) deve ser a expressão empregada para expressar as alterações fisiológicas secundárias à DVA. Essas alterações podem ser subclínicas, a exemplo dos distúrbios da diferenciação celular, da depressão da resposta imune, da redução da mobilização do ferro; ou clínicas, traduzidas pelo aumento da morbidade por doenças infecciosas e da mortalidade, retardo do crescimento, anemia e, principalmente, xeroftalmia. Xeroftalmia representa o epifenômeno da DDVA, sendo o termo utilizado para descrever todas as manifestaçôes clínico-oculares da DVA, que compreendem um amplo espectro de sinais e sintomas que vão desde a cegueira noturna até a ulceração corneal e a ceratomalacia (Sommer \& Davidson, 2002).

\section{Magnitude e Distribuição Espacial}

A hipovitaminose A constitui um dos principais problemas nutricionais que afligem a população dos países do Terceiro Mundo, acometendo, sobretudo, crianças na idade pré-escolar e gestantes. Esse quadro de deficiência está intrinsecamente associado ao subdesenvolvimento, concentrando-se nas camadas mais pobres e menos educadas da população (WHO, 1996). Segundo as estimativas mais recentes, cerca de 127 milhôes de crianças na idade pré-escolar têm DVA (concentrações de retinol sérico $<0,70 \mu \mathrm{Mol}$ ou citologia conjuntival anormal) e 4,4 milhões têm xeroftalmia. As cifras mostram, ainda, que 7,2 milhōes de gestantes/nutrizes apresentam concentraçôes inadequadas de retinol no soro ou no leite materno $(<0,70 \mu \mathrm{Mol} / \mathrm{L})$ e um contingente adicional de 13,5 milhões tem concentraçôes de vitamina A consideradas baixas ou marginais (0,70-1,05 $\mu \mathrm{Mol} / \mathrm{L})$. Além disso, anualmente, mais de seis milhões de mulheres desenvolvem cegueira noturna durante a gravidez (West, 2002).

A DVA tem ampla distribuição geográfica, tendo sido documentada como um problema de saúde pública em 39 países, segundo relato da Organização Mundial da Saúde (WHO, 1995). O quadro carencial, principalmente com manifestações clínicas incapacitantes, é particularmente grave na Ásia Meridional (45\% dos casos) e em grande parte do continente africano ( 25 a 35\% dos casos). As manifestaçôes subclínicas têm sido observadas 
em outros continentes, inclusive em países industrializados, nos estratos mais pobres e em pessoas idosas. Na América do Sul e Caribe, os dados até agora disponíveis são insuficientes para compor o mapa nosográfico do estado carencial. No entanto, estimativas, baseadas em dados, em sua maioria sem representatividade populacional, indicam que a DVA parece ser um problema de saúde pública no Brasil, Equador, El Salvador, Guatemala, Haiti, Honduras, Nicarágua e República Dominicana. Também parece ser freqüente em comunidades pobres da Bolívia, em algumas regiōes do México e do Peru e em grupos indígenas do Panamá.

\section{Histórico}

A xeroftalmia é uma enfermidade conhecida desde a Antigüidade. A cegueira noturna foi descrita pela primeira vez no Egito, por volta de 1500 a.C; o mais antigo texto médico conhecido no ocidente, o papyrus Ebers (1600 a.C.), prescrevia, às pessoas atingidas por essa afecção, uma dieta rica em fígado, conduta também recomendada por Hipócrates (Wolf \& Phil, 1978). Entretanto, a descrição detalhada do comprometimento corneal e a possível origem nutricional da xeroftalmia parecem ter sido registradas pela primeira vez na literatura científica pelo médico brasileiro Manuel da Gama Lobo, que em 1864 relatou a ocorrência das lesões oculares características da doença em crianças escravas no Rio de Janeiro. Segundo Gama Lobo, a ocorrência dessa síndrome ocular estaria relacionada à alimentação inadequada; de certa maneira ele previu a existência de vitaminas ao afirmar: "a causa d'esta ophtalmia é a falta de nutrição conveniente e sufficiente a que estão submettidos os escravos (...) o organismo, pobre de princípios vitaes, não pode oferecer os princípios necessários para a nutrição da córnea" (Gama Lobo, 1865: 432, 433).

No entanto, só em 1913, o professor Elmer McCollum, juntamente com a sua colega Marguerite Davis, descobriu na manteiga e na gema do ovo um fator lipossolúvel que era absolutamente necessário para o crescimento de ratos, fator este que, posteriormente, passou a ser denominado vitamina A (McCollum, 1967).

\section{Hipovitaminose A e Xeroftalmia no Brasil}

Após os achados iniciais de Manuel da Gama Lobo, seguem-se os relatos de hipovitaminose A e xeroftalmia no Brasil. Em 1883, Hilário de Gouveia documentou a existência de cegueira noturna em escravos mal alimentados (Coutinho, 1947). Após a abolição da escravatura os relatos são mais raros, exceto em épocas de escassez aguda de alimentos, como nas estiagens prolongadas na região semi-árida. Euclydes da Cunha, em Os Sertôes, descreveu a cegueira noturna como uma falsa cegueira que ocorria durante as secas (Cunha, 1995). Robalinho Cavalcanti registrou sua ocorrência na seca de 1932-33 (Cavalcanti, 1934) e Josué de Castro, em 1946, descreveu, em Geografia da Fome, a "hemeralopia e outras hipovitaminoses, comuns no Sertão nas calamidades sociais das secas" (Castro, 1967: 213). Em 1951-52, os dados do serviço de oftalmologia do Centro de Saúde de Fortaleza, CE, revelaram prevalência tão alta de xeroftalmia, a ponto de haver a recomendação da administração compulsória de vitamina A a todos os pacientes pediátricos (Leão, 1958).

Nas últimas décadas, evidências de hipovitaminose A e xeroftalmia têm sido documentadas, sobretudo, na região Nordeste, mas também, de modo esporádico, em áreas setentrionais e meridionais do Brasil. Em Florianópolis, SC, entre 1963 e 1965, foram acompanhadas 64 crianças com xeroftalmia corneal, das quais 80\% referiam história de ingestão de leite desnatado, não fortificado, doado pelo Fundo Internacional de Socorro à Infância (Fisi) (Pereira, Abreu \& Freusberg, 1966).

A epidemiologia da deficiência de vitamina A no Nordeste do Brasil foi revisada recentemente (Santos, Batista Filho\& Diniz, 1996). Estudo clínico-nutricional realizado no estado da Paraíba, em 1981-82, envolvendo as três mesorregiōes bioclimáticas do estado, demonstrou uma prevalência significativamente elevada de manchas de Bitot e de cicatrizes corneais na mesorregião do Sertão, principalmente no período da entressafra (Santos et al., 1983). 
Manifestações clínicas da xeroftalmia moderada, bem como seqüelas cicatriciais, foram também documentadas na Paraíba em crianças de 2 a 28 meses de idade, em anos subseqüentes, sobretudo na seca prolongada de 198184 (Dricot d'Ans et al., 1988). A partir de 1982, com a adoção do sistema de busca ativa de casos de xeroftalmia no Hospital Universitário de João Pessoa, vários casos de lesões oculares foram diagnosticados e acompanhados (Araújo, Diniz \& Santos, 1984).

Em 1986, evidências clínicas da xeroftalmia moderada foram também observadas no Rio Grande do Norte (Mariath, Lima \& Santos, 1989). Dados bioquímicos de Fortaleza, do interior do estado do Ceará e de Recife no período de 1987-91 demonstraram um elevado percentual de níveis séricos de retinol inadequados (McAuliffe et al., 1991). Foi também relatada a ocorrência, em 1989, de elevada prevalência de níveis séricos de retinol inadequados e de baixo consumo de alimentos fonte de vitamina A, em áreas urbanas do Semi-Árido baiano (Santos et al., 1996). Mais recentemente, estudos de base populacional realizados nos estados de Pernambuco (Andrade, 2000), Sergipe (Martins, Santos \& Assis, 2004) e na cidade de Teresina, PI (Paiva et al., 2006), revelaram prevalências igualmente elevadas de retinolemia inadequada em crianças na idade pré-escolar. Deve-se ainda ressaltar que estudos pontuais têm revelado prevalência elevada de DVA em outros grupos populacionais no estado de Pernambuco, a exemplo de escolares (Diniz et al., 2005), gestantes (Lopes et al., 2006) e idosos (Nascimento, 2005).

\section{Fisiopatologia}

\section{Absorção, Armazenamento e Transporte}

A vitamina A está presente nos alimentos sob duas formas: a vitamina A pré-formada (ésteres de retinil), de origem animal, e a provitamina A (carotenóides), de origem vegetal (IVACG, 1989). O termo 'provitamina A' engloba cerca de cinqüenta compostos possuidores de atividade biológica vitamínica, sendo o transbetacaroteno o mais importante. Os carotenóides precisam ser convertidos em vitamina A (retinol) para se tornarem biologicamente ativos. Nesse processo, devem ser levados em consideração dois aspectos igualmente importantes: a biodisponibilidade do produto, que é a fração ingerida de um nutriente disponível para ser utilizada tanto nas funções fisiológicas do organismo quanto na sua estocagem, e a bioconversão, que é a fração do nutriente biodisponível (carotenóide absorvido) convertido na forma ativa do nutriente (retinol). O produto dessas duas propriedades determina a bioeficácia do nutriente (carotenóide), que representa a eficiência com que um carotenóide de atividade provitamina A é absorvido e convertido na forma ativa retinol. O Institute of Medicine introduziu o termo Retinol Activity Equivalent (RAE), equivalente da atividade de retinol, para expressar a atividade de carotenóides em termos de vitamina A, em substituição ao termo, até recentemente usado, Equivalente de Retinol (RE), e passou a recomendar novos fatores de conversão, com base na avaliação da bioeficácia de cada carotenóide ou grupo de carotenóides. Essa nova concepção mudou radicalmente a premissa de que vegetais, especialmente aqueles com folhas verde-escuras, ricas em carotenóides provitamina $\mathrm{A}$, seriam suficientes para atender às necessidades de vitamina A do indivíduo. Dados recentes têm demonstrado que as taxas de conversão deveriam ser da ordem de $21 \mu \mathrm{g}$ de $\beta$-caroteno para atingir a mesma atividade de $1 \mu \mathrm{g}$ de retinol, e ainda maiores quando se trata de muitos outros carotenóides de atividade provitamina A (De Pee et al., 1995).

No estômago, os ésteres de retinil e os vários carotenóides sofrem a ação de enzimas proteolíticas, separamse dos alimentos e são agregados em glóbulos junto com outros lipídeos da dieta. No intestino, os ésteres de retinil são hidrolisados, incorporados às micelas formadas sob a influência de secreções biliares e posteriormente absorvidos (Sommer, 1995). Em quantidades fisiológicas, o retinol é mais eficientemente absorvido do que os carotenóides; o percentual de absorção do retinol gira em torno de 70-90\%, enquanto o dos carotenóides situa-se numa faixa de 20-50\% (Sivakumar \& Reddy, 1972). À medida que a quantidade ingerida aumenta, a eficiência na 
absorção do retinol continua alta (60-80\%), enquanto que a dos carotenóides cai acentuadamente, situando-se em patamar inferior a 10\% (Olson, 1972).

A absorção dos compostos vitamínicos parece sofrer a interferência de uma série de fatores. Dentre eles, têm sido citadas as parasitoses intestinais, sobretudo a giardíase, a ascaridíase e a estrongiloidíase (Mahalanabis et al., 1979), a diarréia aguda, ressecções intestinais e doenças pancreáticas.

A quantidade de gordura na dieta é outro fator que merece consideração quando se trata da absorção de vitamina A. A limitação na absorção de carotenóides é particularmente importante na criança jovem, cuja dieta tem pouca gordura. Este é um dado preocupante, uma vez que as fontes de vitamina A, na maioria dos países com problemas de deficiência endêmica, são constituídas essencialmente por carotenóides e não por vitamina A préformada (Underwood, 1994).

Quase todo o retinol absorvido é armazenado nas células do parênquima hepático, o que corresponde a cerca de $90 \%$ da reserva de vitamina A do organismo (Olson, 1982). Os 10\% restantes são distribuídos pelas células do sangue, medula óssea, tecido adiposo e baço. $\mathrm{O}$ retinol circula do fígado para os tecidos periféricos através de uma proteína carreadora específica, a Retinol Binding Protein (RBP), com peso molecular de 21.000, possuindo um sítio receptor para o retinol (Flores et al., 1984). Após a ligação aos receptores de membrana, o retinol entra na célula-alvo e a RBP é novamente liberada na circulação, sendo posteriormente degradada ou reciclada.

\section{Papel Fisiológico}

A vitamina A é um micronutriente essencial à manutenção de importantes funções para o metabolismo normal. No seu amplo espectro de atuação, ainda parcialmente conhecido, ressaltam-se as funçôes ligadas ao ciclo visual, à integridade das membranas biológicas, à manutenção e diferenciação epitelial, bem como à formação de glicoproteínas, à produção de muco e à resistência contra as infecções, mediada pela ação moduladora da resposta imune.

O papel da vitamina A no ciclo visual, nas membranas oculares e na produção de muco será abordado de forma mais detalhada no decorrer da descrição dos sinais e sintomas oculares da xeroftalmia.

O papel da vitamina A como moduladora da resposta imune tem sido respaldado por várias investigações, in vivo e in vitro (Chandra \& Vyas, 1989; Schmidt, 1991; Rumore, 1993), embora as conclusões de tais experimentos devam ser interpretadas com a devida reserva. Em termos genéricos, pode-se afirmar que a vitamina $\mathrm{A}$ aumenta a imunidade humoral, a concentração de anticorpos ativos, o número de células esplênicas formadoras de anticorpos e a imunidade local, além de estimular a fagocitose e a atividade dos neutrófilos polimorfonucleares e macrófagos (Schmidt, 1991).

\section{Sinais e Sintomas da Xeroftalmia}

Quando as reservas hepáticas de vitamina A são escassas, ou mesmo inexistentes, o indivíduo encontra-se em estado potencial de risco para os efeitos do quadro carencial. Uma diminuição da quantidade de vitamina A ingerida, transtornos na absorção ou um aumento da demanda metabólica podem precipitar o aparecimento de manifestações oculares típicas, que constituem a síndrome xeroftálmica (Sommer, 1995).

As principais manifestações clínicas da deficiência de vitamina A no sistema visual ocorrem principalmente em três estruturas oculares: a retina, a conjuntiva e a córnea.

O envolvimento da retina se dá por alterações tanto no nível bioquímico/funcional - cegueira noturna - quanto no nível estrutural - fundus xeroftalmicus. Apesar da prática comum de se considerar esse tipo de comprometimento de significância apenas marginal, o acometimento retiniano tem-se mostrado tão sensível e específico como indicador da hipovitaminose A quanto os sinais clínicos do segmento anterior do globo ocular (Sommer \& West, 1996). 
Figura 1 - Citologia de impressão conjuntival

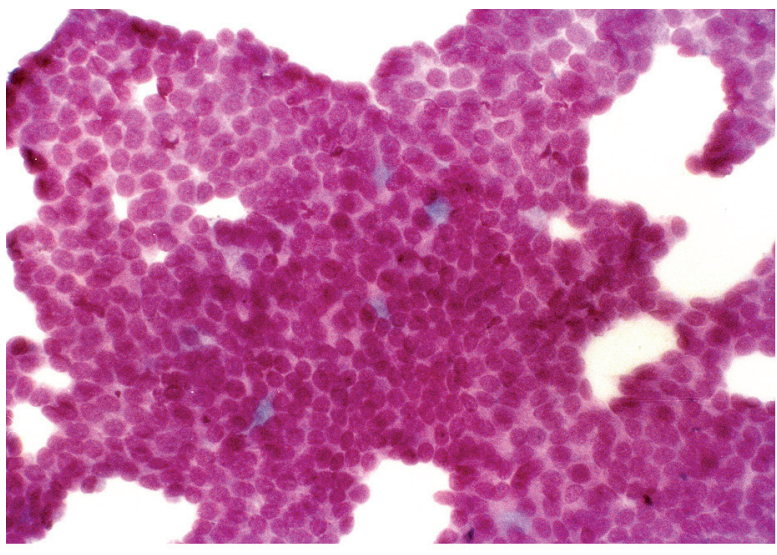

Padrão normal

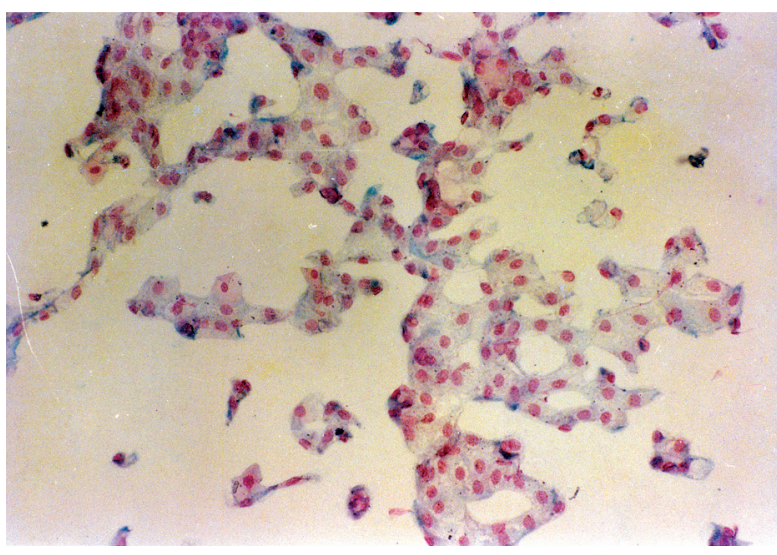

Padrão marginal $(-)$

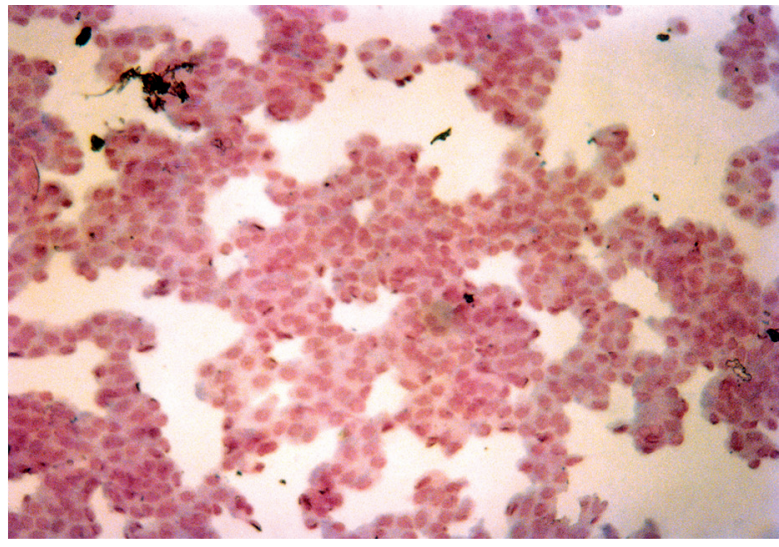

Padrão marginal $(+)$

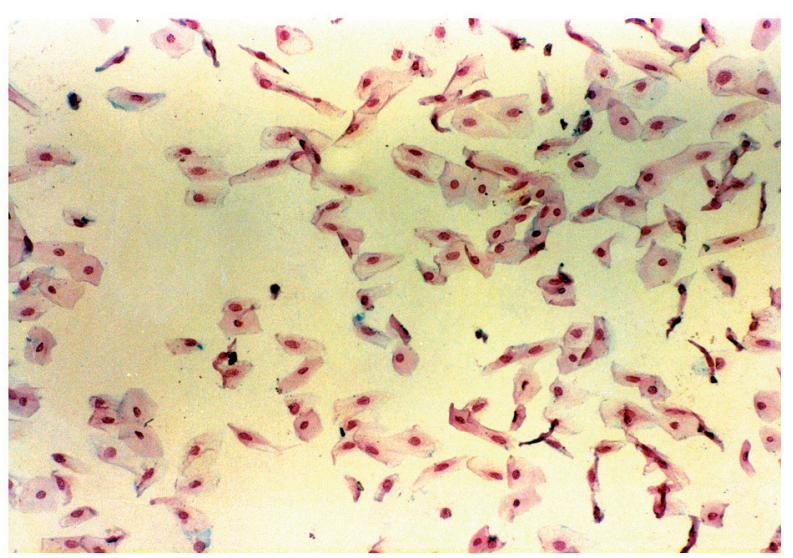

Padrão deficiente

No ciclo visual, o retinal, uma forma oxidada do retinol, está ligado a proteínas específicas, as opsinas, para formar os pigmentos visuais dos cones e bastonetes, situados na retina. No nível dos bastonetes, células funcionalmente responsáveis pela visão escotópica, encontra-se a rodopsina, formada pelo complexo retinal + opsina. A reação fotoquímica da visão tem início quando o estímulo luminoso atinge a retina. $\mathrm{Na}$ presença da luz, o 11-cisretinal assume a configuração da forma todo transretinal. Estas alteraçōes mudam a configuração geométrica do retinal e são acompanhadas de uma mudança global da molécula de rodopsina, o que funciona como um gatilho molecular, produzindo um impulso nas terminações nervosas do nervo óptico, que é, então, transmitido ao cérebro. O 11-cisretinal é também o cromóforo dos cones, essenciais para a visão fotópica e das cores, mas é a rodopsina dos bastonetes que está intrinsecamente ligada à visão noturna (Wald, 1955). Se o suprimento dietético de vitamina A é muito baixo, a cegueira noturna é um dos primeiros sintomas da síndrome xeroftálmica, uma vez que a rodopsina requer altas concentrações de 11-cisretinal para criar um filme visual altamente sensível (Underwood, 1990).

Alfred Sommer e colaboradores (1980) concluíram que a história de cegueira noturna mostrou-se um método confiável para o diagnóstico da xeroftalmia. A palavra ou expressão utilizada pela mãe para descrever a perda da visão crepuscular é um importante instrumento para o diagnóstico da extensão do problema. No entanto, os autores insistem na necessidade de se conhecer, primeiramente, o termo local apropriado, para que se possa, então, pesquisar 
o fenômeno. Outra limitação no uso da história de cegueira noturna como método de diagnóstico em estudos populacionais refere-se à dificuldade de obter dados confiáveis para crianças muito jovens (menores que 2 anos), que se constituem no grupo de maior risco à cegueira nutricional (Dricot d'Ans et al.,1988; Sommer, 1995).

A metaplasia ceratinizante do epitélio conjuntival (Figura 1, página anterior), com o desaparecimento das células mucinógenas e a conseqüente instabilidade do filme lacrimal, causam a 'xerose conjuntival' (Figura 2). Ou seja, a superfície conjuntival perde o brilho, a transparência, sofrendo um processo de espessamento e endurecimento. Pela subjetividade do sinal clínico, a xerose conjuntival, como critério isolado, não tem valor no diagnóstico da xeroftalmia. Isto se deve também ao fato de que a conjuntiva ocular é um sítio freqüentemente acometido por outras alterações morfológicas, que podem diminuir ainda mais o poder de discriminação do sinal clínico no diagnóstico da xeroftalmia.

Figura 2 - Xerose conjuntival

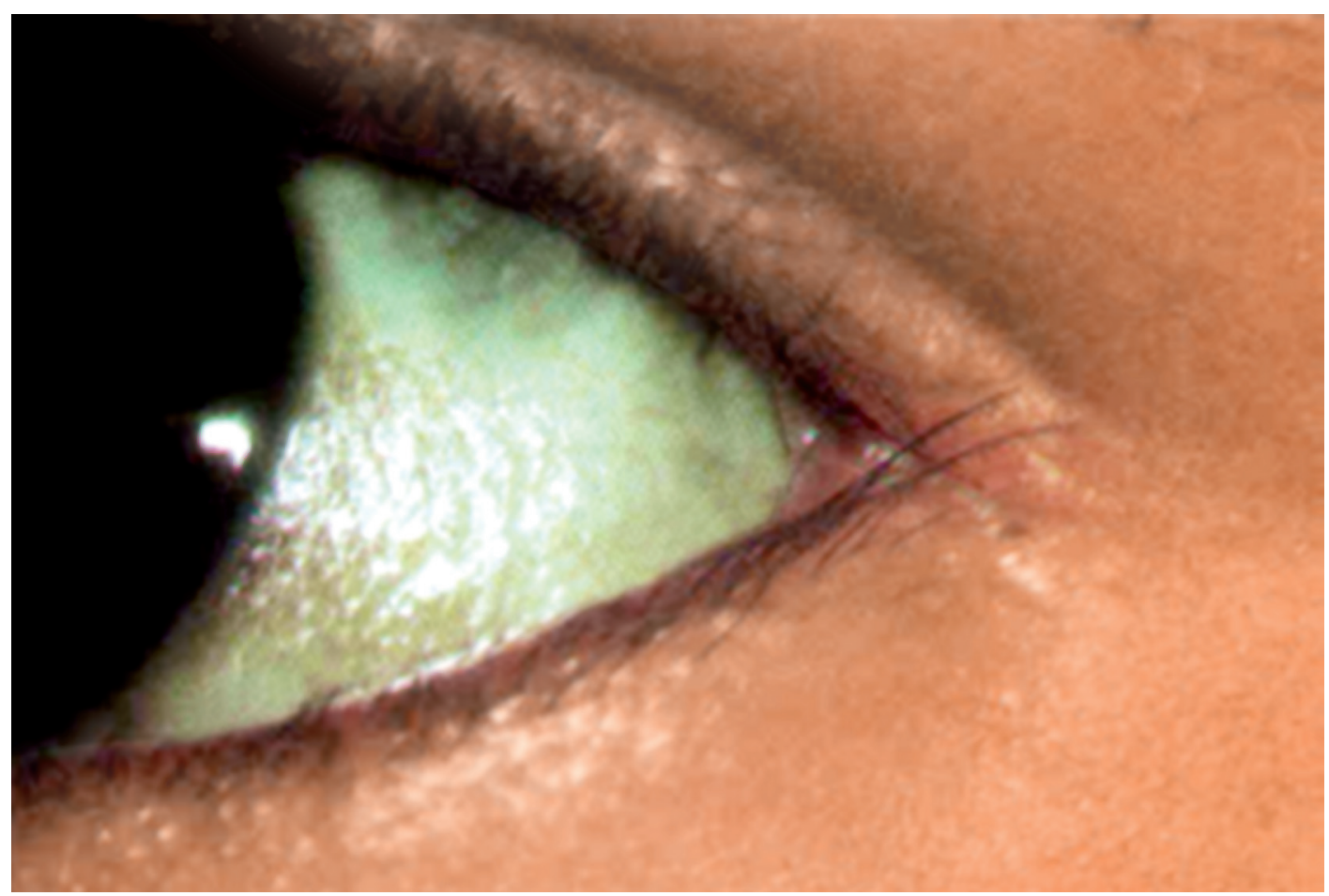

Nas áreas da conjuntiva onde a xerose é mais intensa formam-se as 'manchas de Bitot', depósitos de material espumoso ou caseoso, resultantes do acúmulo de células epiteliais descamadas, fosfolipídeos e bactérias saprófitas (Figura 3) (Sommer, 1995). São lesões assintomáticas, facilmente removíveis, exceto em alguns casos do tipo caseoso, em que a aderência à conjuntiva é maior. São formações ovaladas ou triangulares, concentradas ou dispersas, localizadas na fenda interpalpebral.

O declínio na produção do muco leva ao rompimento precoce do filme lacrimal, o que confere à córnea um aspecto áspero, seco, enrugado e sem brilho, expresso pelo sinal clínico de 'xerose corneal'. O epitélio ceratinizado é extremamente vulnerável, e a região inferior da córnea, por ser uma área mais exposta e, por conseguinte, mais desprotegida, pode sofrer um processo erosivo, com a destruição do epitélio corneano (Sommer, Green \& Kenyon, 1982). O estágio de 'erosão corneal', que cursa com fotofobia muito intensa, é a fronteira clínica a partir da qual todas as lesões corneanas subjacentes deixam uma opacidade como seqüela cicatricial (Figura 4). 
Figura 3 - Mancha de Bitot

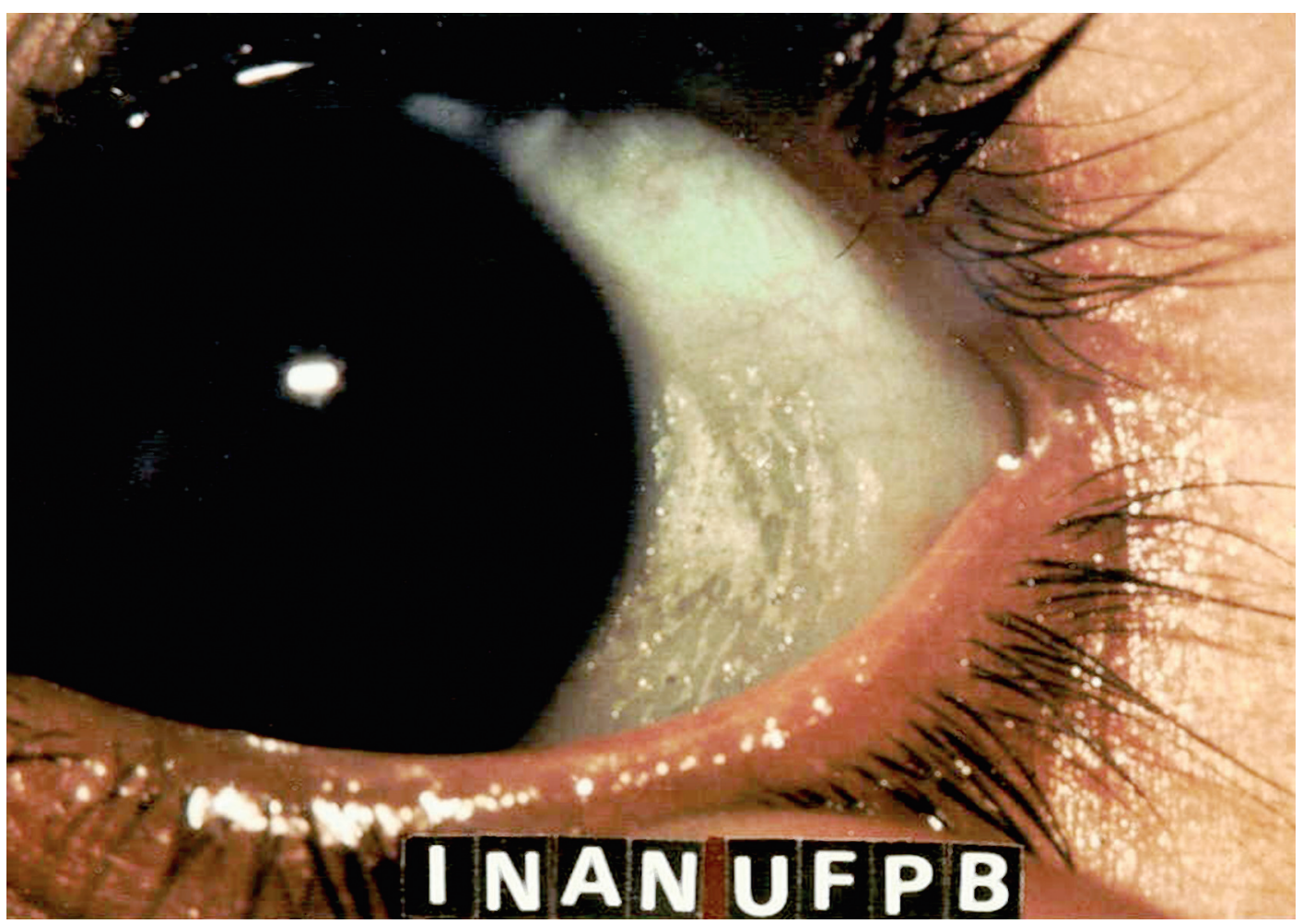

Figura 4 - Xerose corneal

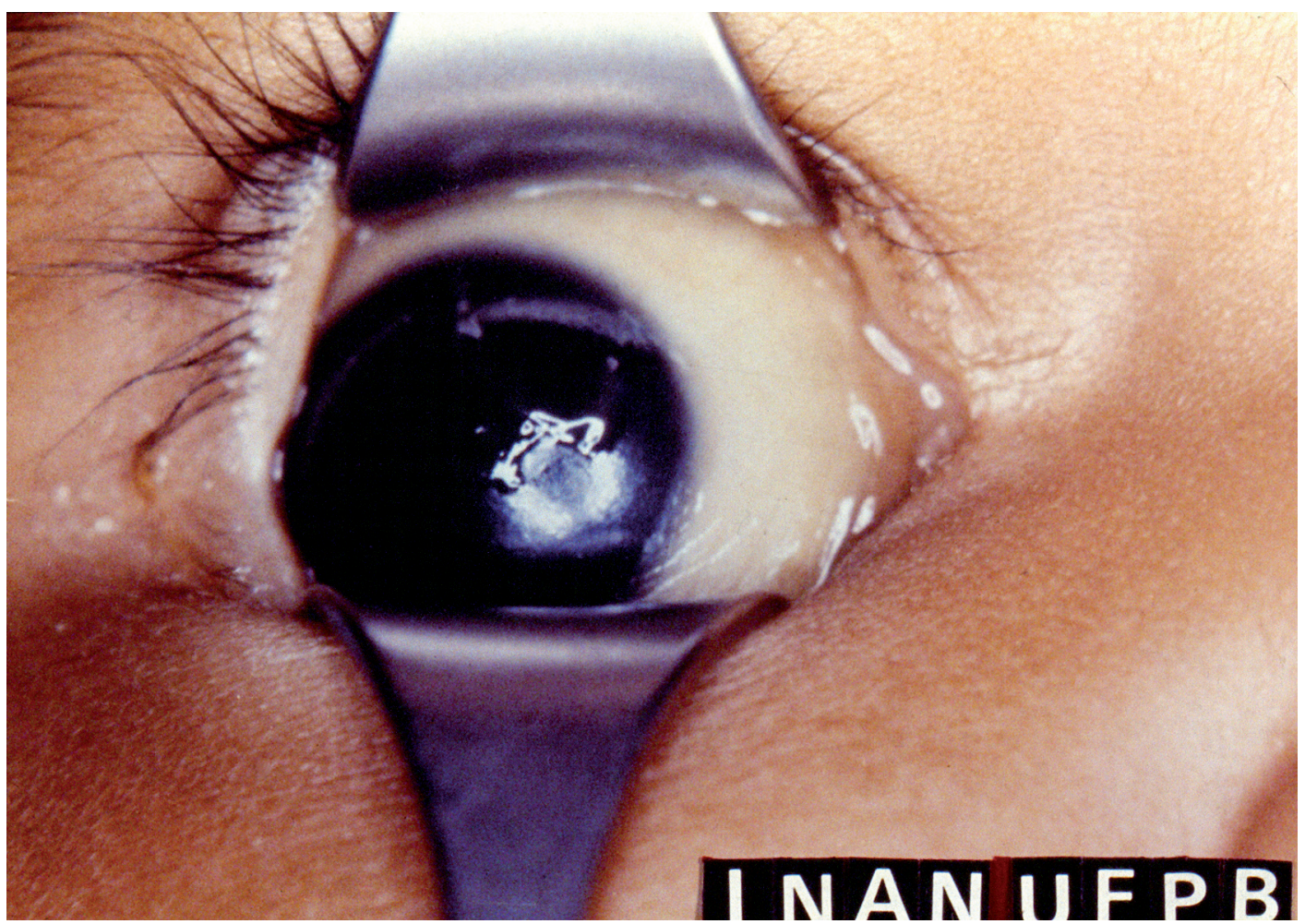


A formação de uma 'úlcera corneal', geralmente única, de forma arredonda ou ovalada e com bordas bem definidas, se constitui na lesão mais grave da síndrome xeroftálmica (Figura 5). A quebra da integridade da barreira anatômica, ocasionada pela formação ulcerosa, favorece a liberação de enzimas proteolíticas que provocam um quadro de necrose liquefativa da córnea, caracterizando a 'ceratomalácia' (Figura 6) (Sommer, 1995).

Apesar de o quadro ocular representar um processo de extrema gravidade, o olho permanece calmo, hiporeativo, sem sinais inflamatórios significativos, exceto se há uma infecção secundária concomitante. O tratamento com vitamina A é suficiente para reverter o processo xeroftálmico (Araújo, Diniz \& Santos, 1984; Sommer, Green \& Kenyion, 1982).

Quando o envolvimento corneal limita-se ao estágio de xerose, após o tratamento com vitamina A ocorre a regeneração completa da superfície ocular sem deixar seqüelas. As lesões mais graves, como ulceração e ceratomalácia, deixam cicatrizes compatíveis com a intensidade do processo. Podem ocorrer opacidades corneanas de intensidade variável - 'nébula, mácula, leucoma' (Figura 7) ou pode até desenvolver-se o 'estafiloma' (Figura 8) (Sommer, 1995), causando a cegueira total ou parcial.

Deve-se ressaltar que o comprometimento corneal e a cegueira podem preceder o envolvimento retiniano e conjuntival, a exemplo da cegueira noturna e das manchas de Bitot (Sommer, Green \& Kenyion, 1982), principalmente em crianças muito jovens, desnutridas e gravemente enfermas (Araújo, Diniz \& Santos, 1984).

Figura 5 - Úlcera de córnea

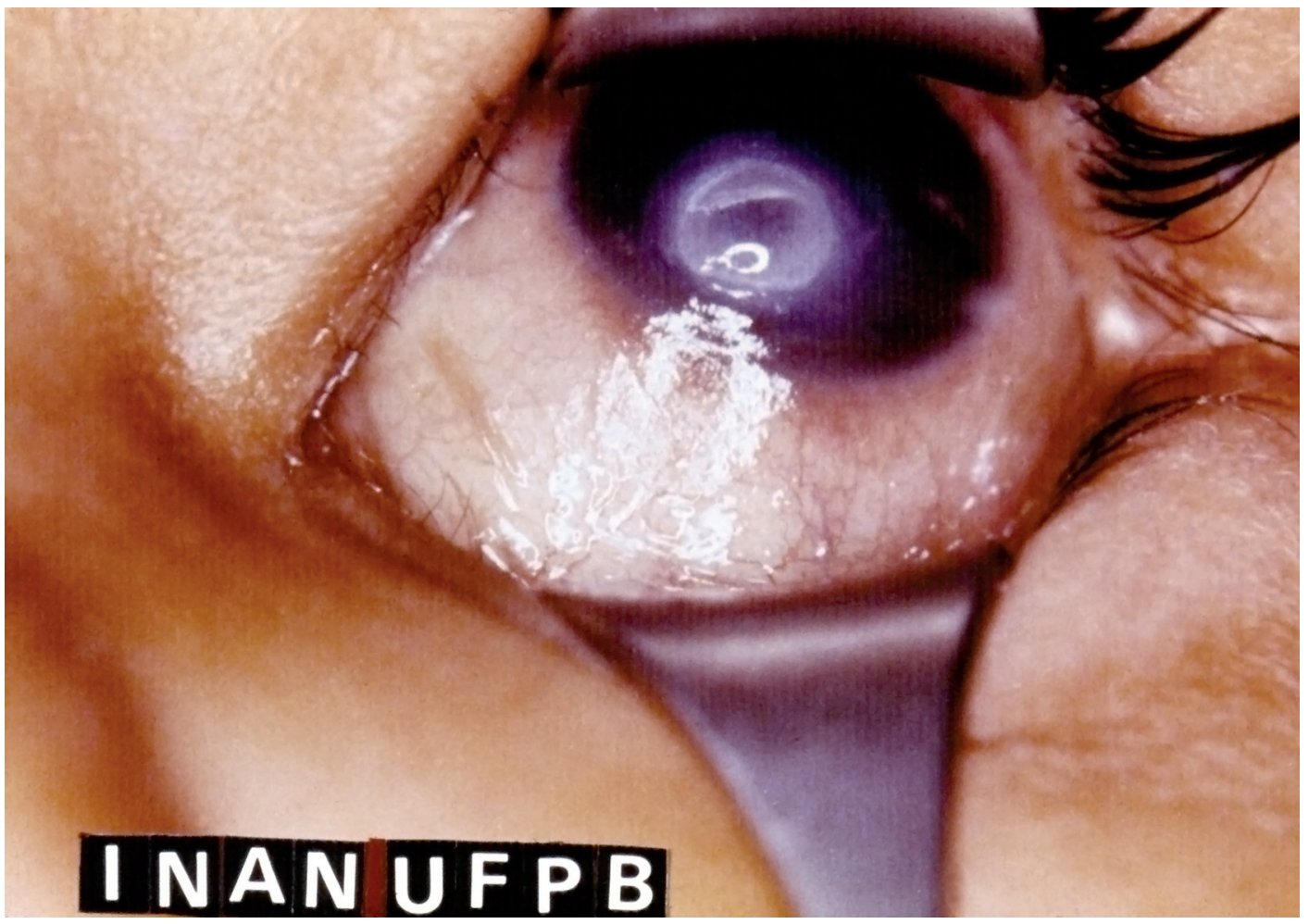


Figura 6 - Ceratomalácia

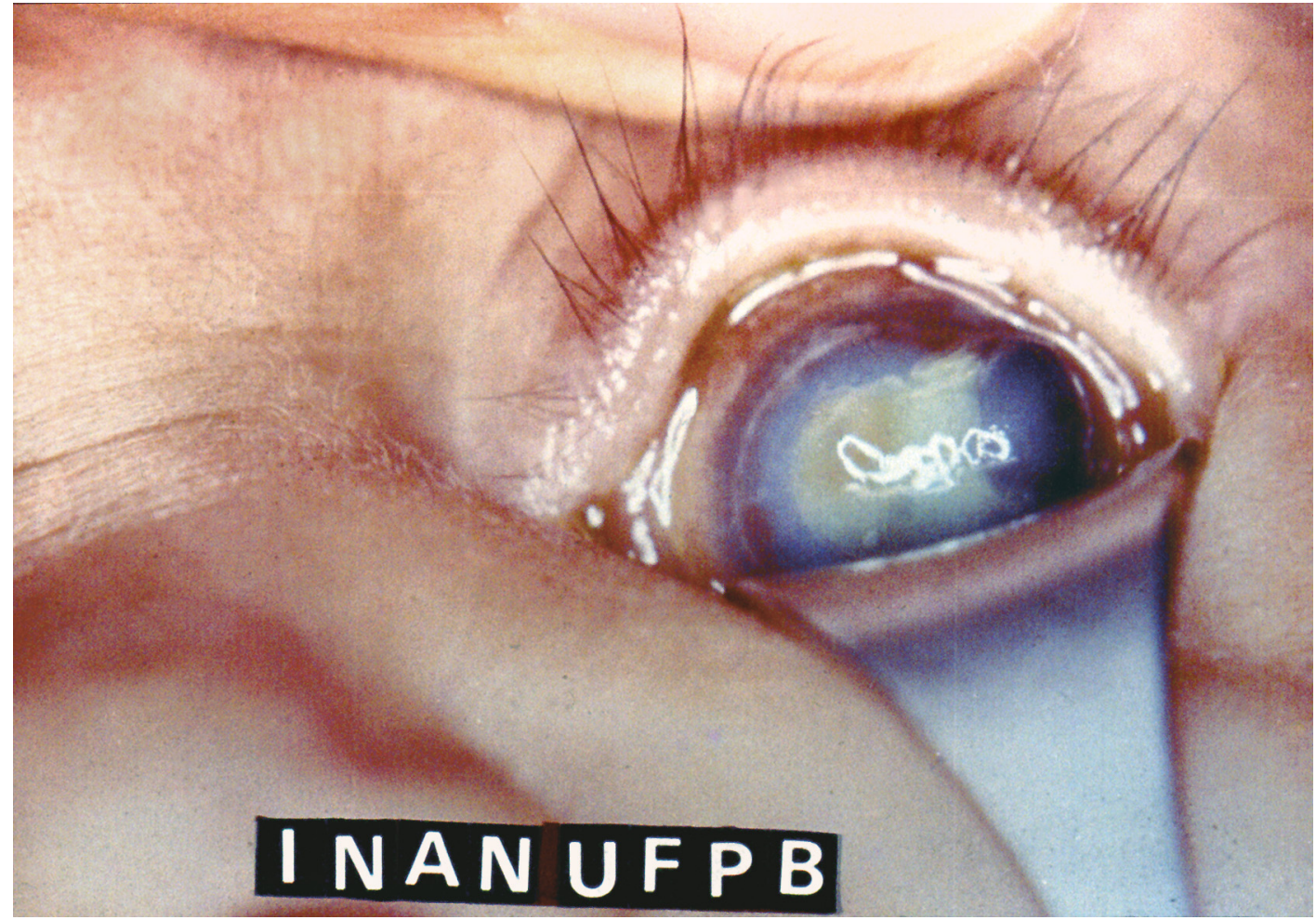

Figura 7 - Leucoma de córnea

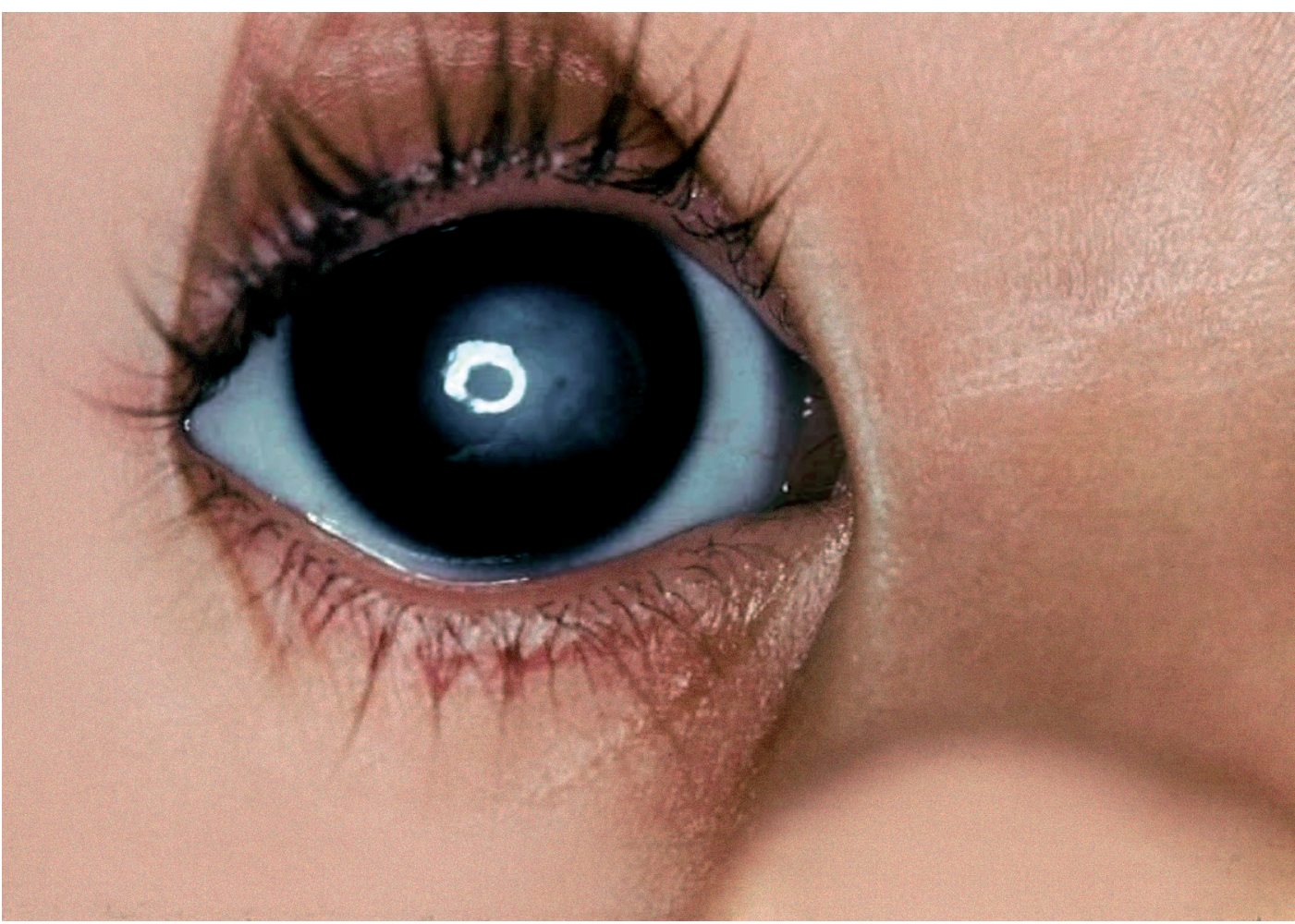




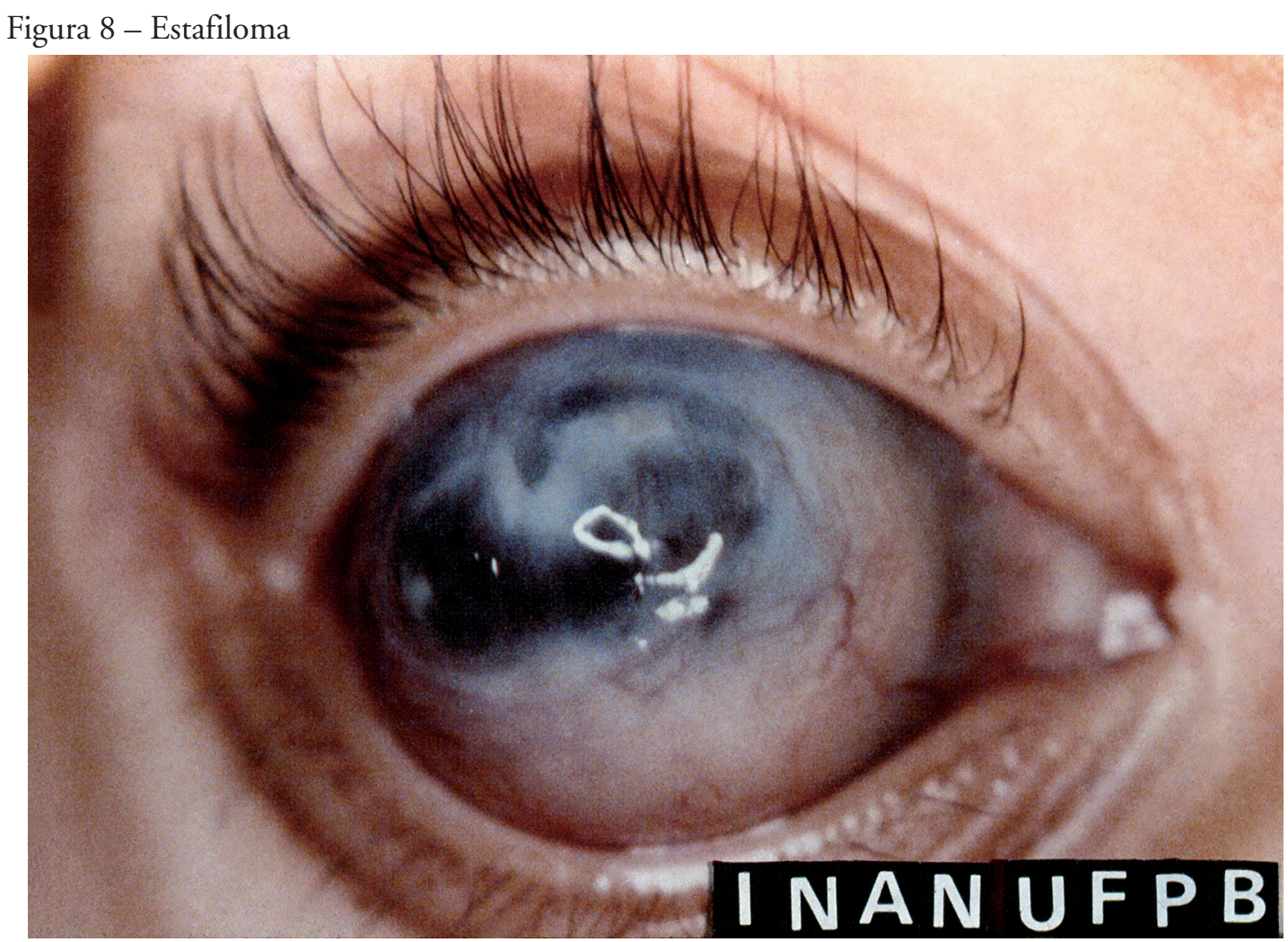

\section{Indicadores Epidemiológicos}

\section{Clínicos}

Os sinais e sintomas clínico-oculares da carência de vitamina A são, a priori, os indicadores que apresentam maior fidedignidade no diagnóstico da hipovitaminose A. No entanto, deve-se estar alerta para o fato, previamente comentado, de que algumas manifestações clínicas não são específicas do estado carencial; além do que, persistem ainda dificuldades na avaliação e padronização destes indicadores.

O diagnóstico da cegueira noturna tem se baseado, sobretudo, na história relatada pela mãe ou responsável, como já discutido anteriormente. No entanto, um caráter mais objetivo para pesquisa desta alteração funcional tem sido proposto, utilizando-se um teste rápido para estimar a curva de adaptação à obscuridade. Os resultados da adaptometria, comparados aos níveis séricos de retinol, têm sido conflitantes. Alguns autores encontraram uma sensibilidade de $95 \%$ e uma especificidade de $91 \%$ (Vinton \& Russel, 1981), enquanto outros não encontraram correlação entre os dois indicadores (Fávaro et al., 1986).

A identificação da xerose conjuntival implica uma grande carga de subjetividade, daí não ser considerada isoladamente como um sinal clínico da xeroftalmia. A importância do diagnóstico precoce da xeroftalmia estimulou o uso de corantes vitais (verde de Lissamina e rosa Bengala) no intuito de melhor caracterizar o processo xerótico, contudo os resultados foram inconclusivos (Fávaro et al., 1986). A mancha de Bitot e os sinais do comprometimento corneal devem ser diagnosticados, exclusivamente, pelo exame clínico-ocular, apoiado pelo teste terapêutico. 
A Citologia de Impressão Conjuntival (CIC) é o termo usado para descrever a técnica na qual camadas superficiais da conjuntiva ocular são removidas por meio da aplicação de um papel de filtro de acetato de celulose, para análise histológica subseqüente (Wittpenn, Tseng \& Sommer, 1986; Natadisastra et al., 1987; AmedéeManesme et al., 1987). Grande parte dos autores tem utilizado a presença/ausência de células caliciformes como critério preponderante para o diagnóstico citológico, objetivando minimizar o número de resultados falsos positivos (Natadisastra et al., 1987; Amedée-Manesme et al., 1987; Nathanail \& Powers, 1992). No entanto, estudos com animais sugerem que a ceratinização corneal precede a perda de células caliciformes e, com base nessas suposiçóes, alguns pesquisadores enfatizam a importância de se incluir, no elenco de critérios para o diagnóstico, informações tanto das células caliciformes quanto do aspecto morfológico das células epiteliais, o que conferiria maior sensibilidade ao método citológico (Nathanail \& Powers, 1992).

A leitura interpretativa dos resultados do teste citológico tem mostrado um grau elevado de reprodutibilidade intra e interobservadores (WHO, 1996). A citologia de impressão conjuntival é um método de diagnóstico pouco oneroso e, sendo um teste praticamente indolor, dispensa o uso de anestésicos tópicos, que poderiam funcionar como artefatos na interpretação microscópica das amostras. É exeqüível em trabalhos de campo e tem apresentado um grau de aderência satisfatório. Como principais limitaçōes, têm sido evidenciadas as dificuldades de realização em crianças menores de 3 anos de idade (Nathanail \& Powers, 1992) e a interferência de fatores ambientais, tais como a excessiva umidade e a alta temperatura, que poderiam afetar as propriedades do papel ou da técnica de transferência (Carlier et al., 1991).

\section{Bioquímicos}

\section{Retinol Hepático}

As concentrações de vitamina A no fígado podem ser usadas como estimativas de seu status, pois este orgão detém cerca de $90 \%$ das reservas totais dessa substância do corpo. No entanto, a biopsia hepática, na ausência de patologias, não é eticamente justificável. De acordo com Barbara Underwood (1990), essa metodologia é usada apenas nos casos objeto de diagnóstico ou pós-morte. Entretanto, é possível estimar as reservas hepáticas de vitamina por métodos indiretos. Um suprimento dietético inadequado leva a uma depressão das reservas hepáticas, com a conseqüente diminuição da taxa de liberação da vitamina $\mathrm{A}$, mantida nas reservas. A síntese de RBP continua, resultando em um acúmulo do carreador protéico pré-formado, a proteína de enlace de retinol livre na circulação (apo-RBP). A administração exógena de vitamina A provoca a liberação de Holo-RBP, em concentrações e características de tempo proporcionais à quantidade do carreador pré-formado ao nível do fígado (Loerch, Underwood \& Lewis, 1979). O teste de Resposta a uma Dose de Retinol (RDR) adota esse princípio. Após a coleta de uma amostra de sangue, em jejum, para dosagem do retinol (vitamina A no tempo zero = vitaA0), é administrada, por via oral, uma solução de palmitato de retinil (450-1000 $\mu \mathrm{g})$ e, cinco horas depois, uma nova amostra de sangue é tomada, para avaliação do nível de retinol pós-suplementação (vitA5). A RDR é calculada pela equação descrita nesta fórmula (Underwood, 1990):

$$
\text { RDR }=(\text { vitA5 - vitAO) } \times 100 / \text { vitA5 }
$$

Se o RDR for $>20 \%$, considera-se a resposta como positiva, indicativa de uma reserva hepática inadequada de vitamina A, ou seja, status marginal de vitamina A (Flores et al., 1984). Foi observado, em pacientes hospitalizados, que valores de RDR > 20\% estavam correlacionados com concentrações hepáticas de retinol < 0,70 $\mu \mathrm{mol} / \mathrm{g}(20 \mu \mathrm{g} / \mathrm{g})$ (Amedée-Manesme, Furr \& Olson, 1984).

Embora seja um teste exeqüível em trabalhos de campo (Mariath, Lima \& Santos, 1989), a necessidade de duas flebotomias tem limitado a utilização do teste em larga escala. Por outro lado, os resultados do teste podem 
sofrer a influência de infecções e, provavelmente, da adequação protéica e doenças hepáticas, em que as concentrações de RBP podem estar muito baixas para produzirem uma resposta ao teste. A desnutrição energéticoprotéica leve ou moderada, entretanto, parece não interferir nos resultados do teste (Underwood, 1990).

Uma modificação do teste RDR foi proposta. No novo procedimento (MRDR), o palmitato de retinol é substituído pelo 3,4-didehidroretinol (DR), composto natural e biologicamente ativo de vitamina $A$, que se liga à RBP, sem alterar as concentrações do retinol (R). Uma única amostra de sangue é tomada cinco horas após a administração da dose oral de 3,4-didehidroretinol (Tanumihardjo, Koellner \& Olson, 1990). A principal desvantagem operacional do MRDR reporta-se ao fato de que o composto não é disponível comercialmente.

\section{Retinol Sérico}

A dosagem do retinol sérico tem sido o teste bioquímico mais utilizado no diagnóstico do estado nutricional de vitamina A. Embora amplamente empregado e aceito pela comunidade científica, quando analisado pela cromatografia líquida de alta resolução (HPLC) tem se revelado um indicador fidedigno apenas nas situações em que as concentrações de vitamina A estão muito baixas ou em excesso (Olson, Grunning \& Tilton, 1984). Por essa razão, as concentrações de retinol sérico nas demais faixas do espectro bioquímico não têm uma boa correlação, no nível individual, com o RDR ou com os resultados de biopsia hepática (Amedée-Manesme et al., 1987).

Além disso, tem sido relatada baixa sensibilidade do retinol sérico na avaliação do status de vitamina A, nos casos de depleção moderada das reservas hepáticas (Flores et al., 1984). Sabe-se ainda que nas infecçōes, mesmo subclínicas, há uma alteração na concentração de proteínas que participam no processo de resposta da fase aguda, dentre as quais as proteínas carreadoras da vitamina A (Filteau et al., 1993).

No entanto, a grande maioria dos estudos sobre vitamina A em pacientes com infecção tem usado o retinol sérico para medir o status desta vitamina. Observou-se que em crianças com sarampo as concentrações de retinol sérico retornaram ao normal dentro de uma semana após a cura e que, ao fim de seis semanas, os níveis séricos de retinol foram similares nos grupos de crianças que receberam vitamina $\mathrm{A}$ ou não, durante o tratamento do sarampo (Coutsoudis et al., 1991). Assim, é fundamental que as concentrações de retinol sérico sejam ajustadas por marcadores do estado inflamatório, a exemplo da proteína C-reativa e da $\alpha-1$ glicoproteína, para a devida interpretação e caracterização do status de vitamina A em populaçóes que habitam em regióes tropicais, onde as infecções, principalmente subclínicas, apresentam alta endemicidade.

De forma consensual, teores de retinol sérico, em crianças menores de 5 anos, inferiores a $20 \mu \mathrm{g} / \mathrm{dL}(0,70 \mu \mathrm{Mol} /$ L) têm sido considerados baixos, e valores menores do que $10 \mu \mathrm{g} / \mathrm{dL}(0,35 \mu \mathrm{Mol} / \mathrm{L})$, deficientes. Por sua vez, concentraçōes de retinol sérico situadas na faixa acima de $20 \mathrm{mg} / \mathrm{dL}(0,70 \mu \mathrm{Mol} / \mathrm{L})$ e inferiores a $30 \mu \mathrm{gg} / \mathrm{dL}(1,05 \mu \mathrm{Mol} / \mathrm{L})$ são interpretadas, por alguns autores, como valores marginais. No entanto, para os demais grupos etários, ainda não há definição consensual de qual ponto de corte deve ser utilizado para caracterizar um status de inadequação.

\section{Retinol no Leite Materno}

As concentrações de vitamina A no leite materno têm sido consideradas indicador fidedigno do estado nutricional de vitamina A de uma população (WHO, 1996). Este indicador é utilizado na cartografia das áreas de risco e tem se comportado como um dos melhores indicadores na avaliação da eficácia de uma intervenção (Stoltzfus et al., 1993). Concentrações iguais ou inferiores a $30 \mathrm{mg} / \mathrm{dl}(1,05 \mu \mathrm{Mol} / \mathrm{L})$ são indicativas de um quadro de hipovitaminose A.

Recentemente, os indicadores que avaliam a DVA, tanto em termos de extensão quanto de severidade do problema, foram revistos. O objetivo primordial foi o de aumentar a validade de cada indicador, simplificando o diagnóstico e clarificando a interpretação. Embora os critérios anteriormente usados continuem válidos, maior 
ênfase deve ser dada aos indicadores descritos na Tabela 1, com as respectivas prevalências, acima das quais a DVA deve ser considerada como um problema de saúde pública.

Tabela 1 - Critérios de prevalência para a caracterização da deficiência de vitamina A como problema de saúde pública

\begin{tabular}{lc}
\hline Critérios & Prevalência crítica \\
\hline Clínico & \\
Crianças de 2 a 5 anos & $>1 \%$ \\
Cegueira noturna (XN) & $>0,5 \%$ \\
Mancha de Bitot (X)B) & $>0,01 \%$ \\
Xerose corneal (X2) e úlcera de córnea (X3) & $>0,05 \%$ \\
Cicatrizes corneais (XS) & $>5 \%$ \\
Mulheres em idade reprodutiva & \\
XN durante gravidez recente & $>15 \%$ \\
Bioquímico & \\
Retinol sérico $<0,70 \mu \mathrm{Mol} / \mathrm{L}(2 \mathrm{O} \mu \mathrm{g} / \mathrm{dL})$ & \\
\hline
\end{tabular}

Fonte: Sommer \& Davidson (2002).

\section{Outros Indicadores}

Indicadores novos e ainda em estágios de desenvolvimento têm sido propostos para avaliar o status nutricional de vitamina A. Dentre as novas abordagens, está a aplicação do método de diluição isotópica que, segundo Barbara Underwood (1990), é o melhor índice para avaliar o estado nutricional de vitamina A, uma vez que mede as reservas corporais globais. O método é baseado no princípio de que uma nova vitamina A marcada se mistura uniformemente com a vitamina $\mathrm{A}$ das reservas corporais. A diluição dessa vitamina A marcada no sangue, relativa à quantidade administrada, é utilizada para calcular a extensão total da quantidade de vitamina $\mathrm{A}$, assumindo-se que uma proporção constante é estocada no fígado. A metodologia é a única que direta e quantitativamente mede o status relativo de vitamina A (Underwood, 1990).

$\mathrm{O}$ inquérito de consumo de alimentos fonte de vitamina $\mathrm{A}$, embora pouco oneroso e exeqüível em trabalhos de campo, tem sofrido pesadas críticas no que diz respeito a sua precisão (Underwood, 1990). Em teoria, o histórico dietético poderia ser um indicador fidedigno do estado nutricional de vitamina $\mathrm{A}$, assumindo-se que ele é obtido pelo menos em termos semiquantitativos, que é representativo do padrão usual do consumo de alimentos em determinado período e que os requerimentos de vitamina A, tanto em nível individual quanto populacional, sejam conhecidos (IVACG, 1989). As dificuldades em obter informações quantitativas, representativas da ingestão de vitamina A, têm sido bem documentadas em populações em que o consumo provém de fontes muito variadas de alimentos. No entanto, um inquérito semiquantitativo, baseado na freqüência do consumo, pode ser utilizado para categorizar grupos de risco para um status inadequado de vitamina A. Para crianças dos países em desenvolvimento, onde $80-90 \%$ do consumo vem de carotenóides presentes em um número limitado de grupos de alimentos, o International Vitamina A Consultative Group (IVACG, 1989) elaborou um guia para proceder a esse tipo de categorização, baseado em uma tabela de composição de alimentos adaptada aos alimentos locais disponíveis. Alguns autores alertam, no entanto, para o problema da análise e interpretação dos dados dietéticos, considerando que, em vários países, as tabelas de composição de alimentos são inadequadas ou estão ultrapassadas (Santos, Batista Filho \& Diniz, 1996). 
Utilizando-se o indicador de consumo, uma região ou população é considerada em estado potencial de risco à deficiência de vitamina A quando o consumo de alimentos ricos desta substância, pelo menos três vezes por semana, ocorre em 75\% ou menos dos domicílios ou grupos vulneráveis (WHO, 1996).

$\mathrm{O}$ estado nutricional de vitamina $\mathrm{A}$ existe num continuum que vai desde a deficiência clínica à toxicidade (Diniz \& Santos, 2000). Até o presente, nenhum método isolado é suficientemente capaz de identificar o status de vitamina A. A avaliação mais confiável é feita, seguramente, quando se usa a combinação de vários métodos (Underwood, 1990). A recomendação mais atual (WHO, 1996) sugere a utilização de pelo menos dois indicadores biológicos para caracterizar a deficiência de vitamina A. No uso circunstancial de apenas um indicador biológico, este deveria ser respaldado por um conjunto de, no mínimo, quatro fatores de risco adicionais, relacionados, principalmente, a aspectos alimentares e nutricionais, demográficos e ecológicos, e sociosanitários, tais como:

$<50 \%$ de crianças menores de 6 meses em aleitamento materno exclusivo;

$\geq 30 \%$ de crianças de 0 a três anos com déficit estatural (<-2 desvios-padrão da população de referência do National Center for Health Statistics, NCHS);

$\geq 15 \%$ de crianças com baixo peso ao nascer $(<2,5 \mathrm{~kg})$;

$>75 \%$ para o coeficiente de mortalidade infantil;

> 50 \%o para o coeficiente de mortalidade na infância (1-4 anos);

$<50 \%$ de crianças com cobertura vacinal completa;

$>1 \%$ de letalidade por sarampo;

$>50 \%$ de ausência de escolaridade formal feminina;

$<50 \%$ de domicílios com água tratada.

\section{Tratamento e Prevenção}

\section{Tratamento Clínico das Formas Ativas}

As evidências clínicas da deficiência de vitamina A devem ser tratadas como uma emergência médica, sobretudo aquelas que cursam com comprometimento corneal. São recomendadas 200.000 UI (unidades internacionais) de vitamina A (110 mg de palmitato de retinol ou $69 \mathrm{mg}$ de acetato de retinol) no diagnóstico, repetindo-se a dose 24 horas depois. Uma terceira dose, quando possível, deve ser administrada ao cabo de quatro semanas. Nas crianças menores de 1 ano ou com peso inferior a $8 \mathrm{~kg}$, administra-se a metade dessa dose. No caso particular de mulheres na idade reprodutiva, recomendam-se no máximo 10.000 UI diárias durante duas semanas, em virtude do potencial risco teratogênico da megadose.

Quando coexistem a desnutrição energético-protéica e a hipovitaminose A, deve-se incluir vitamina A no esquema de recuperação nutricional, para evitar a precipitação da síndrome xeroftálmica; nessas circunstâncias reativa-se a atividade anabólica, a demanda de vitamina A é subitamente aumentada e as reservas escassas são rapidamente utilizadas. 


\section{Tratamento Preventivo}

\section{Vitamina A, Mortalidade e Diarréia na Infância}

O impacto da suplementação com vitamina A na mortalidade de crianças de 6 meses a 5 anos de idade despertou grande interesse na comunidade científica nos últimos anos. Oito estudos de intervenção, randomizados e controlados com placebo, com metodologia adequada e amostras de tamanho suficiente, foram realizados em países da Ásia e da África. Em seis desses estudos houve redução significativa na mortalidade geral das crianças suplementadas, variando de 19\% a 54\% (Sommer et al., 1986; Muhilal et al., 1988; Rahmathulah et al., 1990; West et al., 1991; Daulaire et al., 1992; Ghana Vast Study Team, 1993); nos outros dois estudos nenhum efeito foi encontrado (Vijayaraghavan et al., 1990; Herrera et al., 1992). Três metanálises independentes com os dados desses estudos de intervenção foram realizadas, duas delas por investigadores não envolvidos, direta ou indiretamente, com nenhum dos estudos originais. Os resultados das metanálises indicaram reduções médias de 23\% (Beaton et al., 1994) e de 30\% na mortalidade (Fawzi et al., 1993; Glasziou \& Mackerras, 1993).

A prevalência de uma série de indicadores na linha-base, tais como xeroftalmia, déficits ponderais e estaturais e mortalidade no grupo controle (usada como proxy da mortalidade na linha-base), não conseguiu predizer o resultado final, nem definir as condiçōes em que a suplementação iria atingir um maior benefício (Beaton et al., 1994). De modo semelhante, as diferentes periodicidades de suplementação, nos seis estudos que tiveram efeitos positivos, pareceram ser igualmente efetivas: dois estudos empregaram megadoses a cada seis meses, dois a cada quatro meses, em outro houve distribuição de pequenas doses semanais e no último foi empregado um condimento fortificado com vitamina A (monosódio glutamato), o que resultava em pequenas doses diárias. A possibilidade de um efeito farmacológico devido a megadoses da vitamina, ao invés de fisiológico, pode ser descartada com alguma confiança (Beaton et al., 1994). Quanto à mortalidade por causas específicas, dados de cinco dos seis estudos com efeitos na mortalidade puderam ser agregados para a metanálise. $\mathrm{O}$ único efeito significativo sobre a mortalidade específica foi uma diminuição de $32 \%$ nas mortes por diarréia nas crianças suplementadas, ou seja, um Risco Relativo (RR) de 0,68 ( $\mathrm{IC}_{95 \%} 0,57$ a 0,80). A interpretação, contudo, deve ser cautelosa, pois na maioria dos estudos a causa mortis era obtida por meio de anamnese com a família - "autópsia verbal" (Beaton et al., 1994).

Diversos estudos foram realizados para analisar o efeito da suplementação com vitamina A sobre a morbidade na infância, sobretudo por diarréia e infecção respiratória aguda. O efeito na prevenção da diarréia é pequeno, ou mesmo negligenciável. Apenas um dos estudos sobre morbidade, bem desenhado e com amostra adequada, mostrou uma pequena, mas significativa, redução de $6 \%$ na incidência da diarréia $\left(\mathrm{RR}=0,94 \mathrm{IC}_{95 \%}=0,90-0,98\right)$ (Barreto et al., 1994). Nos outros quatro, nenhum efeito sobre a prevalência média diária ou incidência da diarréia foi registrado (Abdeljaber et al., 1991; Rahmathullah et al., 1991; Biswas et al., 1994; Bhandari, Bhan \& Sazawal, 1994). Somente um estudo, em que a perda de seguimento pode ter comprometido a análise, encontrou resultados diferentes e intrigantes: um ligeiro aumento (significativo) na incidência tanto de diarréia como de infecção respiratória aguda (Stansfield et al., 1993).

Contudo, se considerarmos a diarréia severa, acumulam-se as evidências do impacto da vitamina A. Em um dos estudos de intervenção, a suplementação foi responsável por uma redução de $9 \%$ na incidência dos episódios de diarréia moderada $\left(\mathrm{RR}=0,91 \mathrm{IC}_{95 \%}=0,85-0,98\right)$ e de $20 \%$ no caso da diarréia severa $(\mathrm{RR}=0,80$ $\left.\mathrm{IC}_{95 \%}=0,65-0,98\right)$ nas crianças suplementadas. Foi considerado como moderado o episódio com três dias ou mais de duração e quatro ou menos dejeções líquidas ou semilíquidas em 24 horas, e como severo o episódio com três dias ou mais de duração e cinco ou mais dejeções líquidas ou semilíquidas em 24 horas (Barreto et al., 1994). No mesmo estudo, houve redução da prevalência média diária de diarréia, à medida que a definição incluía apenas os episódios mais severos, com $\geq 4, \geq 5$ e $\geq 6$ dejeções líquidas ou semilíquidas em 24 horas; as razões de 
prevalência entre crianças suplementadas e placebo foram de $0,90(\mathrm{p}=0,049), 0,80(\mathrm{p}=0,005)$ e $0,77(\mathrm{p}=$ 0,006), respectivamente. Outra pesquisa mostrou uma redução de $36 \%$ na prevalência média diária de diarréia associada com febre, somente nas crianças suplementadas na faixa etária superior a 23 meses (Bhandari, Bhan \& Sazawal, 1994). Em outro estudo, de larga escala, o efeito na severidade da diarréia foi evidenciado por uma proporção $15 \%$ menor de sinais e sintomas de desidratação no grupo suplementado, comparado com o grupo placebo $\left[\mathrm{RR}=0,85 \mathrm{IC}_{95 \%}=0,81-0,89\right]$, bem como por uma procura $12 \%$ menor de atendimento clínico ambulatorial $\left[\mathrm{RR}=0,88 \mathrm{IC}_{95 \%}=0,81-0,95\right]$ e uma freqüência $38 \%$ menor de internação hospitalar $[\mathrm{RR}=0,62$ $\left.\mathrm{IC}_{95 \%}=0,42-0,93\right]$ (Ghana Vast Study Team, 1993; Arthur et al., 1992).

\section{Estratégias de Tratamento Preventivo}

São várias as estratégias universalmente reconhecidas para controlar e eliminar as deficiências de micronutrientes na população; existem medidas de efeito a curto, médio e longo prazos (Batista Filho \& Diniz, 1993; Diniz, 2001). No entanto, até o presente, a maior ênfase tem sido dada à distribuição em massa de megadoses de vitamina A, que tem se constituído em programas institucionais, na maioria das áreas de risco. No Brasil, a suplementação tem sido implementada, desde 1983, no âmbito do Programa Nacional de Imunização (PNI) na região Nordeste (Assis et al., 2000) e, em menor escala, em nível ambulatorial, pela rede básica de saúde. Além da distribuição universal (crianças de 6 meses a 5 anos incompletos), tem sido recomendada a distribuição em grupos específicos da população (crianças com diarréia aguda e/ou prolongada, sarampo e desnutrição grave e gestantes no pós-parto imediato) (WHO, 1988).

Os riscos de toxicidade da vitamina A, em distribuição universal, têm sido um dos principais motivos de resistência a essa estratégia de intervenção (Florentino et al., 1990). A ocorrência de náusea, vômito e, eventualmente, abaulamento da fontanela, tem sido descrita; no entanto, esses efeitos colaterais desaparecem, sem tratamento específico, dentro de um ou dois dias após a ingestão do suplemento (Francisco et al., 1993). Foi publicado um estudo realizado no Brasil, com o objetivo de identificar a ocorrência e a natureza de possíveis efeitos adversos agudos da suplementação com megadoses de vitamina A (100.000 e 200.000 UI) oferecida junto com imunização em massa. Uma amostra de 852 crianças de 6 a 59 meses de idade foi acompanhada por 24 horas antes e 72 horas após a vacinação, sendo divididas em dois grupos: 416 crianças receberam vitamina A com as vacinas e 436 compuseram o grupo controle, que recebeu apenas as vacinas. Nas 24 horas que antecederam a vacinação, as crianças dos dois grupos referiram similar freqüência de diarréia, febre e vômito; contudo, a anorexia foi mais prevalente no grupo que recebeu vitamina A e persistiu durante todo o período de seguimento. Os resultados sugerem que nenhum efeito adverso agudo, em especial diarréia, vômito, febre ou anorexia, esteve associado à ingestão da vitamina A combinada à vacinação em massa, particularmente à Sabin, à DPT e à anti-sarampo (Assis et al., 2000).

As recomendações para os grupos etários, esquemas posológicos e período de administração a serem utilizadas na suplementação massiva com megadoses de vitamina A estão descritas na Tabela 2. 
Tabela 2 - Esquema de suplementação com megadoses de vitamina A em populações vulneráveis

\begin{tabular}{|c|c|c|}
\hline População & Quantidade de vitamina A a ser administrada & Período de administração \\
\hline Crianças de 0 a 5 meses & $\begin{array}{l}150.000 \mathrm{UI},{ }^{*} \text { em } 3 \text { doses de } 50.000 \mathrm{UI}, \\
\text { com intervalo de } 1 \text { mês (mínimo) entre doses }\end{array}$ & $\begin{array}{l}\text { Durante cada contato para imunização } \\
\text { por DPT }(6,10 \text { e } 14 \text { semanas) }\end{array}$ \\
\hline Crianças de 6 a 11 meses & Dose única de 100.000 Ul a cada 4-6 meses & $\begin{array}{l}\text { Qualquer oportunidade } \\
\text { (p. ex. imunização contra sarampo) }\end{array}$ \\
\hline Crianças $\geq 12$ meses & Dose única de 200.000 Ul a cada 4-6 meses & $\begin{array}{l}\text { Qualquer oportunidade } \\
\text { (p. ex. imunização antipólio) }\end{array}$ \\
\hline Mulheres no pós-parto & $\begin{array}{l}400.000 \mathrm{UI} \text { fracionadas em } 2 \text { doses de } 200.000 \mathrm{UI}, \\
\text { com, pelo menos, intervalo de } 24 \text { horas; e/ ou } 10.000 \\
\text { UI/dia ou } 25.000 \mathrm{UI} / \text { semanal }\end{array}$ & $\begin{array}{l}\text { mais rápido possível depois do parto e, } \\
\text { no máximo, } 6 \text { semanas depois; e/ou } \\
\text { durante os } 6 \text { primeiros meses após o parto }\end{array}$ \\
\hline
\end{tabular}

* UI - Unidade Internacional

Fonte: De Benoist, Martines \& Goodman (2001).

As experiências com a fortificação de alimentos mostraram resultados promissores na Ásia (Muhilal et al., 1988) e na América Central (Dary, 1994). No entanto, a adoção, em larga escala, de medidas dessa natureza, pela multiplicidade dos fatores condicionantes de sua implementação, deve ser objeto de uma análise criteriosa, baseada na realidade de cada região ou país.

Intervenções em larga escala que visam a um aumento da disponibilidade e do consumo de alimentos fonte de vitamina A são, praticamente, inexistentes; a implantação de medidas desse porte teria que abordar fatores de ordem econômica, social, educacional e cultural (Underwood, 1994). Os alimentos ricos em vitamina A pré-formada são caros, o que torna extremamente limitado o seu consumo regular pela população de risco. Frutas e vegetais são fontes importantes de betacarotenos, mais acessíveis às populaçôes de baixa renda, embora o consumo de alguns produtos, sobretudo os vegetais, sofra restrições em virtude de hábitos alimentares próprios de cada região (Santos, Batista Filho \& Diniz, 1996). A promoção do consumo em larga escala do betacaroteno seria, em princípio, a estratégia mais apropriada na abordagem da questão. O betacaroteno teria vantagem, em relação ao retinol, em termos de toxicidade, disponibilidade e custo benefício; poderia ser administrado a mulheres grávidas para aumentar as suas reservas corporais e concentrações no leite, porque é mais seguro que o retinol e não apresenta risco comprovado de teratogenicidade (Carlier et al., 1993). Não tem havido, até agora, relatos de toxicidade do betacaroteno como conseqüência de ingestão excessiva; a hipercarotenemia resulta apenas em depósito amarelado na pele.

No Brasil, o consumo do fruto da palma de buriti (Mauritia vinifera mart), uma fonte rica de carotenóides, em administração diária de $134 \mathrm{mg}$ de retinol equivalente, durante 15 dias, foi seguido de reversão das evidências clínicas e bioquímicas da deficiência de vitamina A (Mariath, Lima \& Santos, 1989).

\section{Prognóstico Clínico}

A experiência clínica tem mostrado que o tratamento com vitamina A reverte o processo xeroftálmico, mantendo, entretanto, as cicatrizes nas áreas ulceradas (Sommer et al., 1981; Araújo, Diniz \& Santos, 1984; Dricot d'Ans et al., 1988; Semba et al., 1995; Sommer \& West, 1996). Alguns autores têm enfatizado a mortalidade extremamente elevada de crianças com xeroftalmia durante a permanência no âmbito hospitalar (McLaren et al.,1965; Sommer et al., 1982; Sommer \& West, 1996). Outros pesquisadores relatam que, infelizmente, tal mortalidade continua elevada, inclusive, após a alta hospitalar. Na década de 80 havia estimativas de que cerca de dois terços das crianças com cegueira parcial ou total devido à xeroftalmia morrem ao curso de alguns meses após a instalação da deficiência visual (Menon \& Vijayaraghavan, 1980; Darton-Hill, 1988). 


\section{Considerações Finais}

Há evidências de deficiência de vitamina A entre crianças brasileiras, sobretudo em bolsões de pobreza, na região semi-árida do Nordeste e durante as secas prolongadas (Santos, Batista Filho \& Diniz, 1996; Santos, 2002). No entanto, na experiência da equipe do Hospital Universitário da Universidade Federal da Paraíba, que atendeu a maioria dos casos graves de xeroftalmia (Diniz, 1997), a mortalidade intra-hospitalar foi bastante reduzida, com apenas dois óbitos em 49 crianças tratadas entre 1982 e 1992 (Santos, 2002). O profissional da saúde deve estar atento à ocorrência, ainda que esporádica, dos sinais e sintomas dessa deficiência (Araújo, Diniz $\&$ Santos, 1984), bem como dos fatores de risco associados (WHO, 1996). Diante dos resultados que indicam reduçôes importantes na mortalidade e severidade da morbidade na infância, torna-se imperativo incluir sempre a vitamina A na agenda das políticas públicas, com o objetivo de melhorar a sobrevivência infantil.

\section{Referências}

ABDELJABER, M. H. et al. The impact of vitamin A supplementation on morbidity: a randomized community intervention trial. American Journal of Public Health, 81: 1.654-1.656, 1991.

AMEDÉE-MANESME, O.; FURR, H. C. \& OLSON, J. A. The correlation between liver vitamin A concentrations in micro-(needle biopsy) and macrosamples of human liver specimens obtained at autopsy. American Journal of Clinical Nutrition, 39: 315-319, 1984.

AMEDÉE-MANESME, O. et al. Simple impression cytology method for detecting vitamin A deficiency. The Lancet, 1(8.544): 1.263, 1987.

ANDRADE, S. L. S. Prevalência da Hipovitaminose A e Potenciais Fatores de Risco em Crianças Menores de 5 anos no Estado de Pernambuco, 2000. Tese de Doutorado, Recife: Programa de Pós-Graduação em Nutrição, Universidade Federal de Pernambuco.

ARAÚJO, R. L.; DINIZ, A. S. \& SANTOS, L. M. P. Diagnóstico e evolução de casos de ceratomalácia e xeroftalmia Jornal de Pediatria, 57(5-6): 419-424, 1984.

ARTHUR, P. D. et al. Impact of vitamin A supplementation on childhood morbidity in Northern Ghana [letter]. The Lancet, 339: 361-362, 1992.

ASSIS, A. M. O. et al. Tolerância à aplicação de megadoses de vitamina A associada à vacinação em crianças no Nordeste do Brasil. Cadernos de Saúde Pública, 16(1): 51-57, 2000.

BARRETO, M. L. et al. Effect of vitamin A supplementation on diarrhoea and acute lower-respiratory infection in young children in Brazil. The Lancet, 344: 228-231, 1994.

BATISTA FILHO, M. \& DINIZ, A. S. Combate às deficiências de micronutrientes no Brasil. Revista do Imip, 7(2): 121-125, 1993.

BEATON, G. H. et al. La suplementación con vitamina A y la morbilidad infantil em los países en desarrollo. Boletín de la Oficina Sanitaria Panamericana, 117: 506-518, 1994.

BHANDARI, N.; BHAN, N. K. \& SAZAWAL, S. Impact of massive dose of vitamin A given to preschool children with acute diarrhoea on subsequent respiratory and diarrhoeal morbidity. British Medical Journal, 309: 1.404-1.407, 1994.

BISWAS, M. L. et al. Effect of vitamin A supplementation on diarrhoea and acute lower respiratory tract infection in children. European Journal of Epidemiology, 10: 57-61, 1994. 
CARLIER, C. et al. Prevalence of malnutrition and vitamin A deficiency in the Diourbel, Fatick, and Kaolack regions of Senegal: feasibility of the method of impression cytology with transfer. American Journal of Clinical Nutrition, 53: 66-69, 1991.

CARLIER, C. et al. A randomized controlled trial to test equivalence between retinyl palmitate and beta carotene for vitamin A deficiency. British Medical Journal, 307: 1.106-1.110, 1993.

CASTRO, J. de. Geografia da Fome. 10. ed. São Paulo: Brasiliense, 1967.

CAVALCANTI, L. R. Hemeralopia, manifestação de avitaminose observada entre os flagelados da seca do Nordeste. Arquivos Brasileiros de Neurologia e Psiquiatria, 17: 16, 1934.

CHANDRA, R. K. \&VYAS, D. Vitamin A, immunocompetence and infection. Food and Nutrition Bulletin, 11: 12-19, 1989.

COUTINHO, R. O Valor Social da Alimentação. 2. ed. Rio de Janeiro: Livraria Agir, 1947.

COUTSOUDIS, A. et al. Micronutrient utilization during measles treated with Vitamin A or placebo. International Journal of Vitamin Nutrition Research, 61: 199-204, 1991.

CUNHA, E. da. Os Sertôes. 37. ed. Rio de Janeiro: Livraria Francisco Alves, 1995.

DARTON-HILL, I. Vitamin A deficiency in Bangladesh. Health Policy and Planning, 3(3): 205-213, 1988.

DARY, O. Avances en el proceso de fortificación de azúcar con vitamina A en Centroamérica. Boletín de la Oficina Sanitaria Panamericana, 117: 529-537, 1994.

DAULAIRE, N. M. P. et al. Childhood mortality after a high dose of vitamin A in a high risk population. British Medical Journal, 304: 207-210, 1992.

DE BENOIST, B.; MARTINES, J. \& GOODMAN, T. Food and Nutrition Bulletin. Special issue on vitamin A supplementation and the control of vitamin A deficiency, 22(3), 2001.

DE PEE, S. et al. Lack of improvement in vitamin A status with increased consumption of dark-green leafy vegetables. The Lancet, 346: 74-85, 1995.

DINIZ, A. S. Aspectos Clínicos, Subclínicos e Epidemiológicos da Hipovitaminose A no Estado da Paraíba, 1997. Tese de Doutorado, Recife: Universidade Federal de Pernambuco.

DINIZ, A. S. Combate à deficiência de vitamina A: linhas de ação e perspectivas. Revista Brasileira de Saúde Materno Infantil, 1(1): 31-36, 2001.

DINIZ, A. S. \& SANTOS, L. M. P. Hipovitaminose A e xeroftalmia. Jornal de Pediatria, 76, supl. 3: S311-S323, 2000.

DINIZ, A. S. et al. Trends in growth faltering, vitamin A deficiency, iron deficiency anemia among school-children of Northeast Brazil. Pediatric Research, 58(5): 1.094, 2005.

DRICOT D'ANS, C. et al. Geographic distribution of xerophthalmia in the state of Paraiba, Northeast Brazil. Ecology of Food and Nutrition, 22: 131-138, 1988.

FÁVARO, R. M. D. et al. Evaluation of rose Bengal staining test and rapid dark-adaptation test for the field assessment of vitamin A status of pre-school children in Southern Brazil. American Journal of Clinical Nutrition, 43: 940-945, 1986.

FAWZI, W. W. et al. Vitamin A supplementation and child mortality: a meta-analysis. Journal of the American Medical Association, 269: 898-903, 1993.

FILTEAU, S. M. et al. Influence of morbidity on serum retinol of children in a community-based study in Northern Ghana. American Journal of Clinical Nutrition, 58: 192-197, 1993. 
FLORENTINO, R. et al. Tolerance of pre-schooler to two dosage strengths of Vitamin A preparation. American Journal of Clinical Nutrition, 52: 694-700, 1990.

FLORES, H. et al. Assessment of marginal vitamin A deficiency in Brazilian children using the relative dose response procedure. American Journal of Clinical Nutrition, 40: 1.281-1.289, 1984.

FRANCISCO, A. et al. Acute toxicity of vitamin A given with vaccines in infancy. The Lancet, 342: 526-527, 1993.

GAMA LOBO, M. Da ophthalmia braziliana. Gazeta Médica,16: 430-434, 1865.

GHANA VAST STUDYTEAM. Vitamin A supplemntation in northern Ghana: effects on clinic attendance, hospital admissions, and child mortality. The Lancet 342: 7-12, 1993.

GLASZIOU, P. P. \& MACKERRAS, D. E. M. Vitamin A supplementation and infectious disease: a meta-analysis. British Medical Journal, 306: 366-370, 1993.

HERRERA, H. G. et al. Vitamin A supplementation and child survival. The Lancet, 340: 267-271, 1992.

INTERNATIONAL VITAMIN A CONSULTATIVE GROUP (IVACG). Guidelines for the Development of a Simplified Dietary Assessment to Identify Groups at Risk for Inadequate Intake of Vitamin A. Washington: Nutrition Foundation, 1989.

LEÃO, J. V. A desnutrição no meio pré-escolar de Fortaleza. Boletim do Instituto de Puericultura da Universidade do Brasil, 15: 172-177, 1958.

LOERCH, J. D.; UNDERWOOD, B. A. \& LEWIS, K. C. Response of plasma levels of vitamin A as an indicator of hepatic vitamin A reserves in rat. Journal of Nutrition, 109: 778-786, 1979.

LOPES, R. E et al. Prevalência de anemia e hipovitaminose A em puérperas do Centro de Atenção à Mulher do Instituto Materno Infantil Prof. Fernando Figueira, IMIP: um estudo piloto. Revista Brasileira de Saúde Materno Infantil, 6, supl. 1: S63-S68, 2006.

MAHALANABIS, D. et al. Malabsorption of water miscible vitamin A in children with giardiasis and ascariasis. American Journal of Clinical Nutrition, 32: 313-218, 1979.

MARIATH, J. G. R.; LIMA, M. C. C. \& SANTOS, L. M. P. Vitamin A activity of buriti (Mauritia vinifera Mart) and its effectiveness in the treatment and prevention of xerophthalmia. American Journal ofClinical Nutrition, 49: 849-853, 1989.

MARTINS, M. C.; SANTOS, L. M. P. \& ASSIS, A. M. O. Prevalência da hipovitaminose A em pré-escolares no Estado de Sergipe, 1988. Revista de Saúde Pública, 38(4): 537-542, 2004.

MCAULIFFE, J. et al. A deficiência de vitamina A e estratégias para o seu controle: um guia para as secretarias municipais de saúde. Fortaleza: Project HOPE, 1991.

MCCOLLUM, E. V. The paths to the discovery of vitamin A and D. Journal of Nutrition, 91(2): 11-16, 1967.

MCLAREN, D. S. et al. Xerophthalmia in Jordan. American Journal of Clinical Nutrition, 17: 117-130, 1965.

MENON, K. \& VIJAYARAGHAVAN, K. Sequelae of severe xerophthalmia a follow-up study. American Journal of Clinical Nutrition, 33: 218-220, 1980.

MUHILAL et al. Vitamin A fortified monosodium glutamate and health, growth and survival of children: a controlled field trial. American Journal of Clinical Nutrition, 48(5): 1.271-1.276, 1988.

NASCIMENTO, A. L. Estado Nutricional de Vitamina A em Idosos do Município de Camaragibe - PE, 2005. Dissertação de Mestrado, Recife: Programa de Pós-Graduação em Nutrição, Universidade Federal de Pernambuco. 
NATADISASTRA, G. et al. Impression cytology for detection of vitamin A deficiency Archives of Ophthalmology, 105: 1.224-1.228, 1987.

NATHANAIL, L. \& POWERS, H. J. Vitamin A status of youn Gambian children: biochemical evaluation and conjunctival impression cytology. Annals of Tropical Paediatrics, 12: 67-73, 1992.

OLSON, J. A. The biological role of vitamin A in maintaining epithelial tissues. Israel Journal of Medical Science, 8-9: 1.170-1.178, 1972.

OLSON, J. A. New approaches to methods for the assessment of nutritional status of the individual. American Journal of Clinical Nutrition 35: 1.166-1.168, 1982.

OLSON, J. A.; GRUNNING, D. \& TILTON, R. Liver concentrations of vitamin A and carotenoids as a function of age and other parameters of American children who died of various causes. American Journal of Clinical Nutrition 39: 903-910, 1984.

PAIVA, A. A. et al. Prevalência de deficiência de vitamina A e fatores associados em pré-escolares de Teresina, Piauí, Brasil. Cadernos de Saúde Pública, 22(9): 1.979-1.987, 2006.

PEREIRA, N. D. V.; ABREU, U L.V. \& FREUSBERG, O. Observaçōes clínicas em 64 crianças portadoras de hipovitaminose A. Arquivos Catarinenses de Medicina, 1: 1-11, 1966.

RAHMATHULLAH, L. et al. Reduced mortality among children in Southern India receiving a small weekly dose of vitamin A. New England Journal of Medicine, 323(14): 929-935, 1990.

RAHMATHULLAH, L. et al. Diarrhoea, respiratory infections and growth are not affected by a weekly low-dose vitamin A supplement: a masked, controlled field trial in children in Southern India. American Journal of Clinical Nutrition 54: 568-577, 1991.

RUMORE, M. M. Vitamin A as an immunomodulating agent. Clinical Pharmacy, 12: 506-14, 1993.

SANTOS, L. M. P. (Org.) Bibliografia sobre deficiência de micronutrientes no Brasil 1990-2000. v. 1 - Vitamina A. Brasília: Opas, 2002. Disponível em: <http://www.opas.org.br/publicmo.cfm?codigo=72>. Acesso em: 19 nov. 2007.

SANTOS, L. M. P.; BATISTA FILHO M. \& DINIZ, A. S. Epidemiologia da carência de vitamina A no Nordeste do Brasil. Boletín de la Oficina Sanitaria Panamericana, 120(5): 525-536, 1996.

SANTOS, L. M. P. et al. Xerophthalmia in the state of Paraiba, Northeast of Brazil: clinical findings. American Journal of Clinical Nutrition, 38: 139-144, 1983.

SANTOS, L. M. P. et al. Situação nutricional e alimentar de pré-escolares no Semi-Árido da Bahia: II. Hipovitaminose A. Revista de Saúde Pública, 30(1): 67-74, 1996.

SCHMIDT, K. Antioxidant vitamins and beta-carotene: effects on immunocompetence. American Journal of Clinical Nutrition, 53, suppl.: 383-385, 1991.

SEMBA, D. R. et al. The decline of admissions for xerophthalmia at Cicendo Eye Hospital, Indonesia, 19811992. International Ophthalmology, 19: 39-42, 1995.

SIVAKUMAR, B. \& REDDY, V. Absorption of labeled vitamin A in children during infection. British Journal of Nutrition, 27: 299-304, 1972.

SOMMER, A. Vitamin A Deficiency and its Consequences: a field guide to their detection and control. 3. ed. Geneva: WHO, 1995.

SOMMER, A. \& DAVIDSON, R. F. Assessment and control of vitamin A deficiency: the Annecy accords. Journal of Nutrition, 132: 2845S-2850S, 2002. 
SOMMER, A. \& WEST, K. P. Vitamin A Deficiency: health, survival and vision. New York: Oxford University Press, 1996.

SOMMER, A.; GREEN, W. R. \& KENYON, K. R. Bitot's spots responsive and nonresponsive to vitamin A. Archives of Ophthalmology, 99: 2.014-2.027, 1981.

SOMMER, A.; GREEN, W. R. \& KENYON, K. R. Clinic-histopathologic correlation in xerophthalmia ulceration and necrosis. Archives of Ophthalmology, 100: 953-963, 1982.

SOMMER, A. et al. Oral versus intramuscular vitamin A in the treatment of xerophthalmia. The Lancet, 1: 557-559, 1980.

SOMMER, A. et al. Impact of vitamin A supplementation on childhood mortality: a randomized controlled community trial. The Lancet, 1: 1.169-1.173, 1986.

STANSFIELD, S. K. et al. Vitamin A supplementation and increased prevalence of childhood diarrhoea and acute respiratory infections. The Lancet, 341: 578-582, 1993.

STOLTZFUS, R. J. et al. High dose vitamin A supplementation of breast-feeding Indonesian mothers: effects on the Vitamin A status of mother and infant. Journal of Nutrition, 123: 666-675, 1993.

TANUMIHARDJO, S. A.; KOELLNER, P. G. \& OLSON, J. A. The modified relative dose-response assay as an indicator of vitamin A status in a population of well-nourished American children. American Journal of Clinical Nutrition, 52: 1.064-1.067, 1990.

UNDERWOOD, B. A. Methods of assessment of vitamin A status. Journal of Nutrition, 1: 459-463, 1990.

UNDERWOOD, B. A. Hipovitaminosis A: epidemiologia de un problema de salud pública y estrategias para su prevención y control. Boletín de la Oficina Sanitaria Panamericana, 117: 469-505, 1994.

VIJAYARAGHAVAN, K. et al. Effect of massive dose vitamin A on morbidity and mortality in Indian children. The Lancet, 336: 1.342-1.345, 1990.

VINTON, N. E. \& RUSSEL, R. M. Evaluation of a rapid test of dark adaptation. American Journal of Clinical Nutrition 81: 1.961-1.966, 1981.

WALD, G. The photoreceptor process in vision. American Journal of Ophthalmology, 40: 18-41, 1955.

WEST, K. P. JR. Extent of vitamin A deficiency among preschool children and women of reproductive age. Journal of Nutrition, 132: 2857S-2866S, 2002.

WEST, K. P. JR. et al. Efficacy of vitamin A in reducing child mortality in Nepal. The Lancet, 338: 67-71, 1991.

WITTPENN, J. R.; TSENG, S. C. G. \& SOMMER, A. Detection of early xerophthalmia by impression cytology. Archives of Ophthalmology, 104: 237-239, 1986.

WOLF, G. \& PHIL, D. A historical note on the mode of administration of vitamin A for the cure of night blindness. American Journal of Clinical Nutrition, 31: 290-292, 1978.

WORLD HEALTH ORGANIZATION (WHO). Vitamin A Supplements: a guide to their use in the treatment and prevention of vitamin deficiency and xerophthalmia. Geneva: WHO, Unicef, IVACG, 1988.

WORLD HEALTH ORGANIZATION (WHO). Global Prevalence of Vitamin A deficiency: Micronutrient Deficiency Information System. Geneva: WHO, 1995. (Working Paper, 2)

WORLD HEALTH ORGANIZATION (WHO). Indicators for Assessing Vitamin A Deficiency and their Application for Monitoring and Evaluating Interventions Programmes: micronutrient series. Geneva: WHO, Unicef, 1996. 


\title{
19
}

\section{Epidemiologia da Obesidade}

\author{
Rosely Sichieri e Rita Adriana Gomes de Souza
}

$P_{e}$ ela primeira vez na história do planeta o número de pessoas com excesso de peso supera o de desnutridos (Roth et al., 2004). No Brasil, esse fenômeno é marcante, com aumento da prevalência em adolescentes, adultos e idosos. Heymsfield (2004) reconhece que nenhuma faixa etária ou grupo social está protegido da obesidade e identifica a atualidade da questão, visto que o tema está em todos os lugares: revistas, livros populares, textos científicos e agenda política dos governos. Infelizmente, respostas claras e precisas para a questão fundamental como manter o controle do peso ao longo da vida adulta? - não estão disponíveis.

Os estudos sobre os fatores da dieta associados à obesidade realizados nas últimas décadas do século XX priorizaram isolar componentes específicos da dieta, como, por exemplo, as gorduras, fibras ou tipo de carboidrato. Essas estratégias não se mostraram efetivas para a prevenção da obesidade, e a tônica das decisóes mais recentes, que tem sido abraçada pelos organismos internacionais e agências de saúde, é abordar, concomitantemente, tanto o consumo quanto o gasto de energia.

Combinar estratégias que visem a alterações, ao mesmo tempo, dos hábitos dietéticos e dos níveis de atividade física parece ser fundamental, na medida em que ambos são resultados da crescente industrialização e movimentação para os centros urbanos de grandes parcelas da população. Essas mudanças permitem e estimulam o acesso a um mercado crescente de produtos com distribuição globalizada e de produtos em geral, muitos deles poupadores de energia. Muitas atividades físicas foram substituídas, na sociedade moderna, pelo uso de aparelhos como os eletrodomésticos, os sistemas automatizados de controle remoto, o carro e os sistemas de controle da temperatura ambiental. A Organização Mundial da Saúde (OMS), reconhecendo que manter o equilíbrio energético é a questão fundamental no controle da obesidade, destaca o equilíbrio energético como a primeira recomendação do documento internacional conhecido como Estratégia Global (WHO, 2006). No Brasil, essa recomendação foi incorporada no guia alimentar do Ministério da Saúde (2006).

Contudo, a busca por alimentos específicos que possam associar-se à prevenção ou redução da obesidade não foi abandonada. O cálcio é um dos exemplos mais recentes nessa arena: após muita discussão sobre a hipótese de este elemento ser protetor para a obesidade, estudos em população com alto risco de excesso de peso, como os índios Pima, do Arizona, não mostraram nenhuma associação (Venti, Tatarinni \& Salbe, 2005). E recente metanálise sobre o cálcio e obesidade também não sustenta essa hipótese. 


\section{A Medida da Doença}

Observa-se no Brasil evolução crescente das prevalências de sobrepeso (Índice de Massa Corporal IMC) $\geq 25 \mathrm{~kg} / \mathrm{m}^{2}$ e de obesidade $\left(\mathrm{IMC} \geq 30 \mathrm{~kg} / \mathrm{m}^{2}\right.$ ). Para adultos, os dados mais recentes são referentes à Pesquisa de Orçamentos Familiares (POF), realizada pelo Instituto Brasileiro de Geografia e Estatística IBGE (2005). A POF de 2002-2003 realizou entrevistas em uma amostra de 48.470 domicílios. Com base nesses dados, a prevalência de sobrepeso aferida foi de $41,1 \%$, e a de obesidade em homens adultos foi de $8,9 \%$; entre mulheres esses valores foram de $40 \%$ e $13,1 \%$, respectivamente. Os dados da POF mostram que, embora as prevalências de obesidade sejam maiores no sul do país (10,1\% em homens e 15,1\% em mulheres), a tendência, comparada à observada em outras pesquisas de base populacional, foi de aumento crescente em homens em todas as regiōes do país, ao passo que entre as mulheres, exceção para aquelas do nordeste do país, observou-se tendência decrescente ou manutenção da prevalência de obesidade.

Em adolescentes, o sobrepeso também seguiu essa forte tendência de aumento. Nas áreas mais desenvolvidas do Brasil, ou seja, no Sudeste, a prevalência de sobrepeso, definida segundo a proposta do Childhood Obesity Working Group of the International Obesity Task Force, atingia, em 1997, 17\% das meninas e dos meninos, ao passo que no Nordeste a prevalência foi de $5 \%$ entre os meninos e $12 \%$ entre as meninas (Veiga, Cunha \& Sichieri, 2004).

Os dados para idosos seguem a mesma tendência, e mesmo nesta faixa etária a desnutrição, fenômeno freqüente na pesquisa do Endef de 1975, é substituída pelo excesso de peso, como mostra o deslocamento das curvas na Figura 1. Essa distribuição mostrada para mulheres de 60 a 69 anos ocorre nas outras faixas etárias e também entre os homens.

Figura 1 - Curvas do IMC para mulheres de 60-69 anos em três pesquisas nacionais: Estudo Nacional da Despesa Familiar (Endef 1974-1975) em negrito, Pesquisa Nacional de Saúde e Nutrição (PNSN 1989) em linha cheia e Pesquisa sobre Padrões de Vida (PPV 1996-1997) em pontilhado

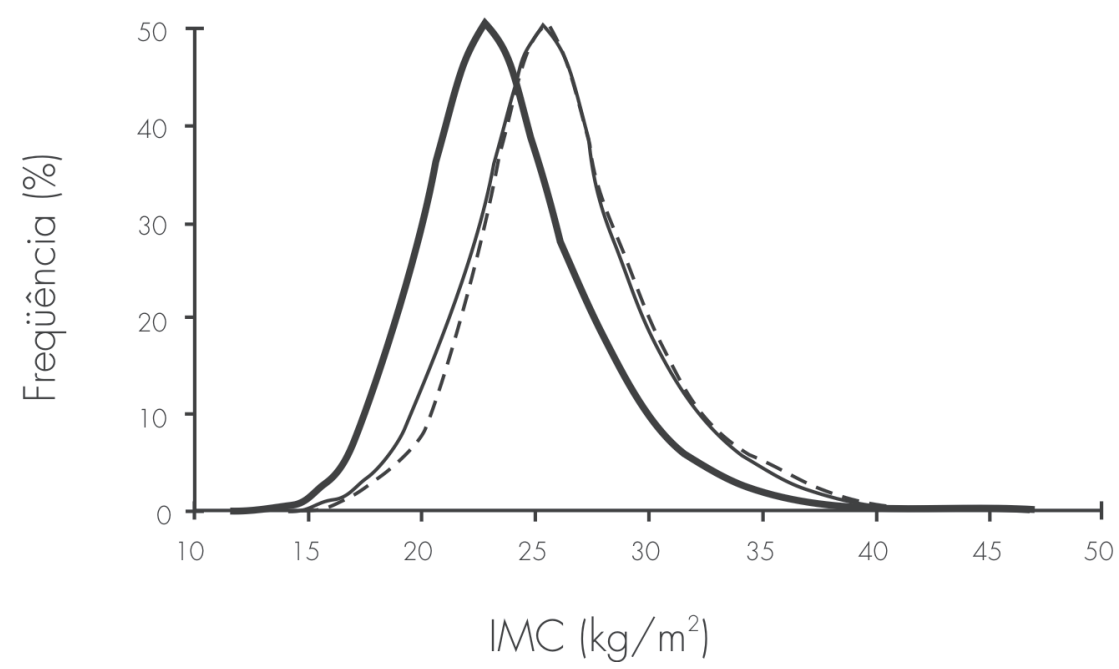

Fonte: Cunha (2002).

Os indicadores de estado nutricional, bem como a adequação do uso do IMC em adolescentes e idosos, estão discutidos nos capítulos 4, "Avaliação nutricional de adolescentes", e 6, "Avaliação do estado nutricional de idosos". 


\section{Obesidade como Epidemia}

Embora quase todo texto sobre obesidade e doenças associadas faça menção ao caráter epidêmico que ela assume, a pertinência de defini-la como epidêmica tem sido questionada. Flegal (2006) tece algumas considerações sobre esse aspecto e mostra que o uso do termo não é adequado. Segundo a autora, definir a obesidade como epidemia não auxilia a abordagem da doença, pois o que se sabe sobre o combate de epidemias não se aplica ao tratamento de doenças não transmissíveis. Um aspecto positivo dessa crítica é o fato de que ela propõe relativizar os casos de doença obesidade e pensar o ganho de peso da população como um todo. Quando se define um fenômeno para determinada população como uma epidemia, o que conta é o aumento dos casos. No fenômeno da obesidade, é mais importante entender como se dá na população o ganho de peso do que propriamente o aumento do número de pessoas com IMC acima ou igual a $30 \mathrm{~kg} / \mathrm{m}^{2}$.

Observando a Figura 1 e muitas distribuições do IMC em populaçōes, o que se verifica é um deslocamento da curva como um todo. Se a tendência fosse de deslocamento somente dos valores mais altos, essa mudança indicaria que uma parcela de maior risco estaria expressando a doença, mas, na verdade, quando a curva do IMC, indicador de obesidade, se desloca como um todo, o fenômeno é mais disseminado, indicando que o excesso de peso deve, provavelmente, ser abordado por políticas que visem à população como um todo, mais do que por ações voltadas para população de risco. Ou seja, o controle e a prevenção devem ser pensados em relação ao ganho de peso, e não em relação à obesidade. Essa não tem sido, contudo, a política adotada nos mais diversos países, e torna-se emblemático que no Brasil a cirurgia bariátrica já faça parte do rol de procedimentos reconhecidos para tratamento da obesidade, sem que haja uma definição de outras abordagens necessárias para reduzir o ganho de peso.

Ainda nessa linha de discussão voltada para a caracterização da epidemia do século, outra polêmica relacionase à carga de doença associada à obesidade. Foi também uma publicação de Flegal e colaboradores (2005) que desencadeou grande discussão ao mostrar que a obesidade causaria, nos Estados Unidos, 112.000 mortes por ano e que o sobrepeso moderado seria benéfico. As estimativas anteriores eram maiores, com números da ordem de quatrocentos mil óbitos por ano. Uma ampla análise desses resultados contraditórios foi realizada na conferência "Pesando as evidências: sobrepeso, obesidade e mortalidade nos Estados Unidos", disponível no site $<$ http:www.harvard.edu/weighingevidence>. Não é fato novo que a mortalidade de adultos está muito mais associada (medida pelo risco relativo) ao baixo peso do que ao excesso de peso (Sichieri, Everhart \& Rubbard, 1992). Por sua vez, os negros parecem ser muito menos suscetíveis ao efeito do excesso de peso sobre a mortalidade (Fontaine et al., 2003), e estudos em coortes brasileiras seriam de muito interesse na avaliação dessa questão, pela grande miscigenação da população brasileira.

Dessa discussão importa observar que a obesidade gera morbidades que não necessariamente conduzirão à mortalidade. A redução da mortalidade pode decorrer de redução dos fatores de risco associados à obesidade, como hipertensão, hipercolesterolemia e tabagismo (Gregg et al., 2005), com custos com os quais poucos sistemas de saúde poderão arcar. Particularmente, como crítica ao trabalho de Flegal e colaboradores (2005) pesa, ainda, a possibilidade de, nele, não ter sido completamente controlado o efeito de patologias pregressas e do tabagismo sobre a mortalidade. Vale assinalar que, com maior ou menor peso sobre a mortalidade, os efeitos sobre a morbidade são de grande magnitude e de altos custos para os sistemas de saúde. Para os Estados Unidos, Allison e colaboradores (1999) mostraram que somente o tabagismo excede a obesidade como fator associado à mortalidade.

Mesmo considerando possíveis exageros na atribuição de importância da obesidade para a mortalidade, é fato que o excesso de peso é um dos principais fatores de risco para hipertensão, doença cardiovascular, oesteoartrite, colelitíase e diabetes tipo 2 (Gregg et al., 2005), e a estimativa de custos diretos para o sistema de saúde no Brasil é próxima aos valores percentuais observados em países europeus (Sichieri, Nascimento \& Coutinho, 2007). 
Outra vertente de discussão sobre a questão da obesidade, segundo Campos e colaboradores (2006), reporta-se aos muitos atores que emergem e são gerados pela constatação de que vivemos uma epidemia de obesidade. Haveria, por um lado, o interesse dos que lucram com a indústria da obesidade - remédios, dietas, equipamentos - e, por outro, os que ficam segregados por sua corpulência. Como exemplo, lembremos que no episódio em que o furacão Katrina destruiu a cidade de New Orleans, em uma das áreas mais pobres dos Estados Unidos, a mídia deu grande destaque à dificuldade que os bombeiros tiveram em retirar das áreas inundadas os muitos corpos de pessoas obesas, quase todas negras. Repetidamente, os estudos mostram que a obesidade tende a se concentrar nas áreas mais pobres. Os dados da POF 2002-2003 (IBGE, 2005) indicam claramente, pelo menos em mulheres, essa situação.

\section{Fatores Associados à Obesidade}

Tanto nos países desenvolvidos quanto naqueles em desenvolvimento, a obesidade tem-se transformado em um problema de saúde pública, principalmente para a população mais jovem e entre os mais pobres. Nos Estados Unidos, taxas mais altas de obesidade e diabetes ocorrem entre os grupos de menor renda (Bassett \& Perl, 2004). Muitos são os fatores associados à obesidade. Dentre eles, os fatores ambientais são claramente reconhecidos como os mais importantes, tanto na gênese quanto, provavelmente, na prevenção do ganho excessivo de peso.

Os grãos refinados, açúcares e gorduras (fatores de risco da dieta para obesidade) estão entre as fontes de energia dietética de custo muito baixo, ao passo que legumes, hortaliças frescas e frutas (fatores de proteção) geralmente custam mais caro (Drewnowski \& Darmon, 2005).

Entre os fatores sociodemográficos associados à obesidade, idade, sexo, renda, escolaridade e raça têm sido amplamente estudados. A prevalência de obesidade aumenta com a idade. Os dados da POF para 2002-2003 (IBGE, 2005) mostram que em mulheres há um aumento muito mais acentuado até os 60 anos, quando a prevalência comparada com a da faixa etária de 20 anos é aproximadamente quatro vezes maior, atingindo os $20 \%$. Em homens, esse aumento é muito menor, passando de 3,1\% para $11 \%$ aos 40 anos e permanecendo praticamente estável até os 60 anos. A partir dos 60 anos, nos dois sexos a prevalência se reduz tanto no Brasil como em outros países. A raça negra apresenta maiores prevalências de obesidade em vários estudos realizados nos Estados Unidos e também no Brasil.

No Brasil, as associações entre renda e escolaridade com a obesidade são mais complexas. Em um estudo com funcionários de uma universidade, a escolaridade apresentou forte associação inversa com o IMC entre mulheres e não apresentou associação entre os homens. Nesse estudo, a renda não mostrou associação em ambos os sexos (Fonseca et al., 2006). Em estudo de base populacional, os resultados para as mulheres residentes na região Sudeste do Brasil foram similares aos observados nos funcionários estudados por Fonseca e colaboradores. No entanto, entre os homens foram observadas uma associação positiva com a renda e associação inversa a partir do terceiro quartil de escolaridade (Monteiro, Conde \& Popkin, 2001).

Variações socioeconômicas refletem diferenças biológicas, além de acesso a diferentes hábitos, entre eles o tabagismo, que pode afetar de forma importante a prevalência de obesidade das diferentes populaçõos. Variações socioeconômicas refletem também a possibilidade de desnutrição em fases de rápido crescimento, que parece estar associada à obesidade. A desnutrição na infância como fator de risco para a obesidade será explorada nos capítulos 16, "Epidemiologia da desnutrição infantil", e 31, "Janelas críticas para programação metabólica e epigênese transgeracional". 


\section{Fatores Ambientais}

Apesar da reconhecida importância dos fatores ambientais em relação à obesidade, pouquíssimas são as intervenções no meio ambiente de longa duração que tenham se mostrado efetivas. Discute-se a dificuldade no desenvolvimento dessas ações em função da falta de uma clara compreensão de que ações de modificação comportamental e ambiental seriam mais facilmente implementadas e de maior impacto em relação à obesidade (Johnson-Taylor \& Everhart, 2006).

Nesse contexto, ocupam papel de destaque as preocupaçôes, estudos e intervençôes entre crianças e adolescentes. A mais plausível explicação para o aumento da obesidade nessa faixa etária são a redução de atividade física nos tempos ditos modernos e um modelo de estilo de vida familiar pouco saudável, que estimula o superconsumo de alimentos (Suter \& Ruckstuhl, 2006).

A escola é considerada um ambiente privilegiado para a promoção de estilos de vida saudável (Warren et al., 2003). Adicionalmente, escola e estudantes podem ser vetores de mudanças na família, como foi muito explorado na campanha antitabagista. Para a prevenção da obesidade, foram testados muitos programas entre crianças escolares, mas poucos alcançaram resultados estatisticamente significativos na prevenção de ganho de peso (Atkinson \& Nitzke, 2001). Normalmente, esses programas têm focos múltiplos, incluindo atividade física e comportamento alimentar.

Nos Estados Unidos e na Europa, esses programas foram capazes de modificar os conhecimentos e até mesmo influenciar mudanças na compra de alimentos, mas redução da prevalência de sobrepeso não tem sido alcançada (Gortmaker et al., 1999; Sahota et al., 2001; University of York, 2002). Condutas sedentárias, como assistir à televisão, têm se mostrado positivamente associadas ao desenvolvimento da obesidade, tanto entre crianças como em adultos. A televisão contribui muito para a inatividade (Gortmaker et al., 1996), gera um gasto de energia similar à taxa metabólica de repouso e associa-se, ainda, com alterações no consumo alimentar (Dietz \& Gortmaker, 2001). O fato de assistir à TV influencia na escolha de alimentos e aumenta o consumo de lanches e bebidas de alto valor calórico (Baur \& O’Connor, 2004).

Além disso, a propaganda veiculada pela televisão influencia na escolha do alimento, particularmente entre as crianças. Os alimentos são um dos itens mais propagandeados em programas de televisão para crianças e representam $27,5 \%$ de todos os anúncios. Uma análise do conteúdo de tais propagandas mostrou que a maioria desses alimentos contém muita gordura, açúcar e/ou sal (Almeida, Nascimento \& Quaioti, 2002). Os comerciais sobre alimentos têm efeitos imediatos sobre as preferências das crianças, como mostrou um ensaio randomizado controlado realizado com pré-escolares nos EUA (Borzekowski \& Robinson, 2001). Uma a duas exposições de dez a trinta segundos por dia influenciaram as preferências alimentares de crianças de 2 a 6 anos.

O padrão dietético de crianças, que é determinado, primeiramente, pela família, sofre forte influência da televisão e, com o crescimento, outros fatores culturais e sociais levarão à criação dos hábitos alimentares (Ramos \& Stein, 2000). Um estudo sobre o consumo de base populacional no município do Rio de Janeiro, RJ (Veiga \& Sichieri, 2006) avaliou a concordância da alimentação de pais e filhos e mostrou que há uma forte associação, particularmente para refrigerantes. Entre pais e filhos adolescentes de menor renda, a concordância no consumo é quase perfeita e, com o aumento de renda, essa associação fica mais fraca.

Alguns pedagogos sugerem que escolas já têm muito para fazer e que prevenção de obesidade não deveria ser principalmente focalizada na escola (Sutton, 2004). Porém, em países como o Brasil, a escola é um dos poucos estabelecimentos públicos que alcançam a maioria da população de menor nível socioeconômico.

A busca de alternativas de intervenção em adolescentes e suas famílias é ainda corroborada pela observação de que, sejam obesos ou não, grande parte da população não atinge as recomendações de alimentação saudável. Pesquisa de base populacional no Rio de Janeiro observou hábitos alimentares pouco saudáveis, tanto em crian- 
ças com sobrepeso como em crianças com IMC normal (Andrade, Pereira \& Sichieri, 2003). Nesse estudo, verificou-se alto consumo de açúcar, doces, refrigerantes e batata frita, e consumo de frutas e vegetais muito abaixo do recomendado. Reduzido consumo de frutas e verduras entre as famílias brasileiras foi claramente evidenciado pela POF de 2003 (Levy-Costa et al., 2005).

\section{Consumo de Açúcar e de Bebidas Açucaradas}

O aumento de consumo de refrigerantes no Rio de Janeiro, comparando-se os dados de consumo diário de 1975 a 1996 per capita, passou de $28 \mathrm{ml}$ para $103 \mathrm{ml}$, ou seja, foi da ordem de 400\% (Sichieri, 1998). O limite máximo de $10 \%$ para a proporção de calorias provenientes de açúcar, incluindo os refrigerantes, é ultrapassado em todos os inquéritos, ainda que se note algum declínio na última década, quando são comparadas as últimas POF (Levy-Costa et al., 2005). Esse declínio pode estar associado a maior consumo de açúcar, com a alimentação fora do domicílio.

O consumo freqüente de refrigerantes parece estar associado ao ganho de peso (Ludwig, Peterson \& Gortmaker, 2001). Uma possível explicação para isso é que os efeitos fisiológicos da ingestão de energia sobre a saciedade são diferentes para líquidos e para alimentos sólidos. Carboidratos ingeridos na forma líquida promoveriam um balanço energético positivo maior (Ludwig, Peterson \& Gortmaker, 2001; Dimeglio \& Mattes, 2000).

Cavadine, Siega-Riz e Popkin (2002), analisando a tendência de consumo de bebidas nos Estados Unidos, mostraram que parte dos refrigerantes foi substituída por sucos com alta adição de açúcar e que sucos e refrigerantes aumentam, ao passo que o consumo de leite diminui. Tendo em vista possíveis intervençôes, essa observação é muito pertinente, pois, com a grande crítica hoje existente em relação aos refrigerantes e sem uma regulação ou parceria da indústria de alimentos, é possível reduzir os refrigerantes sem, contudo, reduzir o consumo de açúcar adicionado às bebidas.

Um ensaio clínico randomizado, conduzido na Inglaterra entre escolares, mostrou que um programa educativo para redução do consumo de refrigerantes, mesmo alcançando apenas uma modesta redução de consumo em 12 meses, resultou em uma diferença média de 8\% na freqüência de sobrepeso entre os grupos experimental e controle (James et al., 2004). O principal foco do estudo foi a redução da ingestão calórica global pela substituição de refrigerantes por bebidas não calóricas, e muitas estratégias foram desenvolvidas para incorporar essa mensagem. Não obstante, em uma coorte de escolares de baixo nível socioeconômico não foi observada associação do consumo de refrigerantes e sucos com o ganho de peso (Newby et al., 2004), mas outros estudos longitudinais conduzidos nos Estados Unidos observaram aumento do IMC e maior prevalência de sobrepeso associados ao consumo de refrigerante (Ludwig, Peterson \& Gortmarker, 2001; Berkey et al., 2004, StriegelMoore et al., 2006).

Em adultos, a ingestão de refrigerantes e sucos observada na Women's Health Initiative, coorte dos Estados Unidos, bem como na coorte das enfermeiras americanas, associou-se com ganho de peso (Schulze et al., 2004).

O papel de refrigerantes no ganho de peso explica-se pelo menor controle do consumo de energia na forma de líquidos (Van Wymelbeke et al., 2004). Nos Estados Unidos, as campanhas negativas em relação aos refrigerantes levaram a uma pequena redução no seu consumo e à sua substituição por um consumo maior de sucos com grande adição de frutose (Cavadini, Siega-Riz \& Popkin, 2002).

A ingestão de refrigerantes é influenciada pelo consumo de amigos e pais, e estudos prospectivos mostraram um efeito positivo de mudanças no estilo de vida familiar na redução de obesidade em crianças. Os educadores também têm um papel importante de apoio às escolhas feitas pelas crianças. Mudanças positivas de fatores de risco cardiovasculares em estudantes foram obtidas incluindo-se tópicos de saúde nas atividades escolares, com ampla participação dos professores (Johnson et al., 2003). 
A Estratégia Global para Alimentação Saudável, Atividade Física e Saúde (EG) da OMS preconiza, entre suas várias recomendaçôes dietéticas para populações e indivíduos, "limitar o consumo de açúcares livres". As bebidas são ricas em açúcares livres, principalmente os xaropes de milho ricos em frutose nos Estados Unidos e a sacarose no Brasil. Essas bebidas contêm grande quantidade de calorias e não levam à redução do consumo de alimentos sólidos em quantidade correspondente. Dessa forma, promovem um balanço positivo de energia na dieta e também parecem reduzir o controle do apetite.

Outro mecanismo por meio do qual o açúcar de adição poderia promover o ganho excessivo de peso decorre da sua densidade de energia. A densidade de energia dos alimentos parece ser o principal fator associado ao consumo excessivo de energia nos alimentos com grande adição de açúcar. A densidade energética refere-se à quantidade de energia fornecida por grama de peso do alimento. Prentice e Jebb (2003) mostraram que muitos alimentos oferecidos em cadeias de fast-food têm densidades em torno de $263 \mathrm{kcal} / 100 \mathrm{~g}$. Esse valor é $65 \%$ maior do que o da densidade da dieta típica britânica e $145 \%$ maior do que o da dieta africana. Segundo os autores, os mecanismos regulatórios não estão aptos a controlar esse excesso de calorias por grama de ingestão, o que induz ao chamado consumo passivo excessivo. Produtos que fornecem mais de 1,5 kcal por grama de peso são considerados de densidade energética elevada (Rolls et al., 1999). Andrade, Pereira e Sichieri (2003) fornecem as densidades energéticas de vários itens alimentares consumidos com freqüência por adolescentes brasileiros.

Dados do Brasil, em uma análise ecológica da POF segundo capitais, mostraram associação estatisticamente significativa entre consumo de açúcar e de refrigerantes com a prevalência de obesidade em mulheres adultas (Lobato, 2006).

Encontrar fatores ambientais associados à obesidade que possam ser incorporados por indivíduos, famílias, escolas etc. poderia facilitar a prevenção do ganho de peso, embora poucos estudos tenham combinado intervenções. Uma dessas intervençôes, combinando escola e família, com vinte semanas de duração, mostrou resultados positivos (Warren et al., 2003). Reduzir o consumo do açúcar de adição pode ser um desses elementos de intervenção combinada. Considerando que há um ambiente muito obesogênico, é intuitivo imaginar que o ganho de peso decorre de hábitos alimentares inadequados de toda a família.

\section{Outras Fontes de Superconsumo de Calorias}

No Brasil, tem sido observada alta freqüência de consumo de doces, biscoitos e batatas fritas (Andrade, Pereira \& Sichieri, 2003; Fontanive, Costa \& Soares, 2002; Levy-Costa et al. 2005). Esse padrão de consumo tem sido associado com uma alta prevalência de obesidade. Os dados da Pesquisa de Padrões de Vida (PPV) de 1997 (IBGE, 1997) mostraram que no Brasil o consumo de açúcar é particularmente alto no Sudeste rural: cerca de $100 \mathrm{~g} /$ dia per capita. No Sudeste urbano e Nordeste, esse consumo ficou ao redor de $80 \mathrm{~g} / \mathrm{dia}$, ao passo que o consumo de biscoitos foi de aproximadamente $20 \mathrm{~g} /$ dia na área urbana e de $15 \mathrm{~g} / \mathrm{dia}$ na área rural. Massas e produtos de cereais altamente refinados, como pão, bolos e biscoitos, apresentaram maior consumo nas áreas com menor consumo de açúcar. Esses alimentos processados têm índices glicêmicos altos e, em particular, os biscoitos e as batatas fritas figuram ainda entre as principais fontes de ácidos graxos trans, um componente da dieta que, na sua maior parte, deve ser evitado. Nos dados da POF (Levy-Costa et al. 2005), os biscoitos participam com porcentagem maior de calorias do que os diversos tipos de macarrão em quase todas as regiōes do país.

\section{Considerações Finais}

Dados epidemiológicos descritivos do fenômeno obesidade, combinados a estudos de intervenção, são fundamentais para orientação das condutas individuais e coletivas de tratamento e prevenção. Os dados recentes mostram que a redução da obesidade não será alcançada com uma ou duas ações. Estratégias ambientais devem 
ser estudadas de forma tão ou mais enfática que os marcadores genéticos. É necessário avaliar estratégias que possam mostrar eficácia, principalmente entre grupos de menor nível socioeconômico e utilizando desenhos prospectivos.

Para países em desenvolvimento, onde a carga e os custos associados a doenças crônicas relacionadas à obesidade são crescentes, a prevenção primária de obesidade pode ser obrigatória. Além disso, um padrão dietético inadequado não é privilégio de pessoas com sobrepeso. Em adolescentes, fica evidente que o consumo alimentar aquém da recomendação para frutas, hortaliças, leite e feijōes independe da presença de sobrepeso (Andrade, Pereira \& Sichieri, 2003). Família, escola e comunidade, independentemente de seu estado nutricional, precisam implementar hábitos alimentares saudáveis. Neste cenário em que a ingestão de refrigerante aumentou mais que $400 \%$ nas últimas três décadas no Brasil, havendo muitas marcas de refrigerante disponíveis de custo muito baixo e dirigidas à população de baixa renda, e em que o consumo de biscoitos cresce também a taxas similares à dos refrigerantes e representa importante fonte do superconsumo de calorias (Levy-Costa et al., 2005), medidas visando à ampla redução de refrigerantes e de biscoitos podem representar os primeiros passos em busca de uma alimentação mais saudável.

Pode-se concentrar as ações na redução de consumo de refrigerantes ampliando-se a proposta brasileira de cantinas saudáveis. E, ao mesmo tempo, deve-se evitar que os refrigerantes sejam substituídos pelos sucos de fruta industrializados, invariavelmente adicionados de grandes quantidades de frutose e sacarose. Associa-se a essa possibilidade o fato de que intervençôes em populações já com sobrepeso são pouco eficazes. Portanto, estudos de ampla escala que estimulem, por exemplo, redução de biscoitos e refrigerantes no Brasil, sua implementação e avaliação deveriam ser incentivados.

\section{Referências}

ALLISON, D. B. O. et al. Annual deaths attributable to obesity in the United States. Jama, 282(16): 1.5301.538, 1999.

ALMEIDA, S. S.; NASCIMENTO, P. C. B. D. \& QUAIOTI, T. C. B. Quantidade e qualidade de produtos alimentícios anunciados na televisão brasileira. Revista de Saúde Pública, 36(3): 353-355, 2002.

ANDRADE, R. G.; PEREIRA, R. A. \& SICHIERI, R. Food intake in overweight and normal-weight adolescents in the city of Rio de Janeiro. Cadernos de Saúde Pública, 19(6): 1.485-1.495, 2003.

ATKINSON, R. L. \& NITZKE, S. A. School based programmes on obesity. British Medical Journal, 323(7.320): 1.018-1.019, 2001.

BASSET, M. T. \& PERL, S. Obesity: the public health challenge of out time. American Journal of Public Health, 94(9): 1.477, 2004.

BAUR, L. A. \& O'CONNOR, J. Special considerations in childhood and adolescent obesity. Clinics in Dermatology, 22(4): 338-344, 2004.

BERKEY, C. S. et al. Sugar-added beverages and adolescent weight change. Obesity Research, 12(5): 778-788, 2004.

BORZEKOWSKI, D. L. G. \& ROBINSON, T. N. The 30-second effect: an experiment revealing the impact of television commercials on food preferences of preschoolers. Journal of the American Dietetic Association, 101(1): 42-46, 2001. 
CAMPOS, P. et al. The epidemiology of overweight and obesity: public health crisis or moral panic? International Journal of Epidemiology, 35(1): 55-60, 2006.

CAVADINI, C.; SIEGA-RIZ, A. M. \& POPKIN, B. M. US adolescent food intake trends from 1965 to 1996. Archives of the Disease in Childhood, 87(1): 85, 2002.

CUNHA, A. S. Variação Temporal do Indice de Massa Corporal em Idosos: estudo nas regiôes Nordeste e Sudeste do Brasil, 2002. Dissertação de Mestrado, Rio de Janeiro: Universidade do Estado do Rio de Janeiro.

DIETZ, W. H. \& GORTMAKER, S. L. Preventing obesity in children and adolescents. Annual Review of Public Health, 22: 337-353, 2001.

DIMEGLIO, D. P. \& MATTES, R. D. Liquid versus solid carbohydrate: effects on food intake and body weight. International Journal of Obesity and Related Metabolic Disorders, 24(6): 794-800, 2000.

DREWNOWSKI, A. \& DARMON, N. The economics of obesity: dietary energy density and energy cost. American Journal of Clinical Nutrition, 82, suppl. 1: 265S-273S, 2005.

FLEGAL, K. M. Commentary. The epidemic of obesity: what's in a name? International Journal of Epidemiology, 35(1): 72-74, 2006.

FLEGAL, K. M. et al. Excess deaths associated with underweight, overweight, and obesity. Jama, 293(15): 1.861-1.867, 2005.

FONSECA, M. J. et al. Associações entre escolaridade, renda e índice de massa corporal em funcionários de uma universidade no Rio de Janeiro, Brasil: Estudo Pró-Saúde. Cadernos de Saúde Pública, 22(11): 2.3592.367, 2006.

FONTAINE, K. R. et al. Years of life lost due to obesity. Jama, 289(2): 187-193, 2003.

FONTANIVE, R. S.; COSTA, R. S. \& SOARES, E. A. Comparison between the nutritional status of euthrophic and overweight adolescents living in Brazil. Nutrition Research, 22(6): 667-678, 2002.

GORTMAKER, S. L. et al. Television viewing as a cause of increasing obesity among children in the United States, 1986-1990. Archives of Pediatrics and Adolescent Medicine, 150(4): 356-362, 1996.

GORTMAKER, S. L. et al. Reducing obesity via a school-based interdisciplinary intervention among youth. Archives of Pediatrics and Adolescent Medicine, 153(4): 409-418, 1999.

GREGG, E. W. et al. Secular trends in cardiovascular disease risk factors according to body mass index in US adults. Jama, 293(15): 1.868-1.874, 2005.

HEYMSFIELD, S. B. The weight debate: balancing food composition and physical activity. Preface. American Journal of Clinical Nutrition, 79(5): 897S-898S, 2004.

INSTITUTO BRASILEIRO DE GEOGRAFIA E ESTATÍSTICA (IBGE). Pesquisa sobre Padrōes de Vida (PPV) 1996-1997. Rio de Janeiro: IBGE, 1997.

INSTITUTO BRASILEIRO DE GEOGRAFIA E ESTATÍSTICA (IBGE). Pesquisa de Orçamentos Familiares (POF) 2002-2003: análise da disponibilidade domiciliar de alimentos e estado nutricional no Brasil. Rio de Janeiro: IBGE, 2005.

JAMES, J. et al. Preventing childhood obesity by reducing consumption of carbonated drinks: cluster randomised controlled trial. British Medical Journal, 328(7.450): 1.237, 2004. 
JOHNSON, C. C. et al. Maintenance of the classroom health education curricula: results from the Catchon Study. Health Education and Behavior, 30: 476-488, 2003.

JOHNSON-TAYLOR, W. L. \& EVERHART, J. E. Modifiable environmental and behavioral determinants of overweight among children and adolescents: report of a workshop. Obesity, 14(6): 929-966, 2006.

LEVY-COSTA, R. B. et al. Household food availability in Brazil: distribution and trends (1974-2003). Revista de Saúde Pública, 39(4): 530-540, 2005.

LOBATO, J. C. P. Uma Visão Ecológica da Obesidade no Brasil: análise a partir da Pesquisa de Orçamentos Familiares 2002-2003, 2006. Dissertação de Mestrado, Rio de Janeiro: Núcleo de Estudos de Saúde Coletiva, Universidade Federal do Rio de Janeiro.

LUDWIG, D. S.; PETERSON, K. E. \& GORTMAKER, S. L. Relation between consumption of sugar-sweetened drinks and childhood obesity: a prospective, observational analysis. The Lancet, 357(9.255): 505-508, 2001.

MINISTÉRIO DA SAÚDE. Secretaria de Atenção à Saúde. Coordenação Geral da Política de Alimentação e Nutrição. Guia Alimentar para a População Brasileira: promovendo a alimentação saudável. Brasília: Ministério da Saúde, 2006.

MONTEIRO, C. A.; CONDE, W. L. \& POPKIN, B. M. Independent effects of income and education on the risk of obesity in the Brazilian adult population. Journal of Nutrition, 131(3): 881S-886S, 2001.

NEWBY, P. K. et al. Beverage consumption is not associated with changes in weight and body mass index among low-income preschool children in North Dakota. Journal of the American Dietetic Association, 104(7): 1.086-1.094, 2004.

PRENTICE, A. M. \& JEBB, S. A. Fast foods, energy density and obesity: a possible mechanistic link. Obesity Reviews, 4(4): 187-194, 2003.

RAMOS, M. \& STEIN, M. Desenvolvimento do comportamento alimentar infantil. Jornal de Pediatria, 76(8): S229-S237, 2000.

ROLLS, B. J. et al. Energy density not fat content of foods affected intake in lean and obese women. American Journal of Clinical Nutrition, 69: 863-871, 1999.

ROTH, J. et al. The Obesity Pandemic: where have we been and where are we going? Obesity Research, 12, suppl. 2: 88S-101S, 2004.

SAHOTA, P. et al. Evaluation of implementation and effect of primary school based intervention to reduce risk factors for obesity. British Medical Journal, 323(7.320): 1.027-1.029, 2001.

SCHULZE, M. B. et al. Sugar-sweetened beverages, weight gain, and incidence of type 2 diabetes in young and middle-aged women. Jama, 292: 927-934, 2004.

SICHIERI, R. Epidemiologia da Obesidade. Rio de Janeiro: Eduerj, 1998.

SICHIERI, R.; EVERHART, J. E. \& HUBBARD, V. S. Relative weight classifications in the assessment of underweight and overweight in the United States. International Journal of Obesity and Related Metabolic Disorders, 16(4): 303-312, 1992.

SICHIERI, R.; NASCIMENTO, S. \& COUTINHO, W. The burden of hospitalizations due to overweight and obesity in Brazil. Cadernos de Saúde Pública, 23(7): 1.721-1.727, 2007. 
STRIEGEL-MOORE, R. H. et al. Correlates of beverage intake in adolescent girls: the National Heart, Lung, and Blood Institute Growth and Health Study. Journal of Pediatrics, 148(2): 183-187, 2006.

SUTER, P. M. \& RUCKSTUHL, N. Obesity during growth in Switzerland: role of early socio-cultural factors favoring sedentary activities. International Journal of Obesity, 30, suppl. 4: S4-S10, 2006.

SUTTON, A. Childhood obesity and consumption of fizzy drinks: play outside to reduce childhood obesity. British Medical Journal, 329(7.456): 54, 2004.

UNIVERSITY OF YORK. NHS Centre for Reviews and Dissemination. The prevention and treatment of childhood obesity. Effective Health Care, 7(6): 1-11, 2002.

VAN WYMELBEKE, V. et al. Influence of repeated consumption of beverages containing sucrose or intense sweeteners on food intake. European Journal of Clinical Nutrition, 58(1): 154-161, 2004.

VEIGA, G. V. \& SICHIERI, R. Correlation in food intake between parents and adolescents depends on socioeconomic level. Nutrition Research, 26: 517-523, 2006.

VEIGA, G. V.; CUNHA, A. S. \& SICHIERI, R. Trends in overweight among adolescents living in the poorest and richest regions of Brazil. American Journal of Public Health, 94(9): 1.544-1.548, 2004.

VENTI, C. A.; TATARINNI, P. A. \& SALBE, A. D. Lack of relationship between calcium intake and body size in an obesity-prone population. Journal of the American Dietetic Association, 105(9): 1.401-1.407, 2005.

WARREN, J. M. et al. Evaluation of a pilot school programme aimed at the prevention of obesity in children. Health Promotion International, 18(4): 287-296, 2003.

WORLD HEALTH ORGANIZATION (WHO). Disponível em: <www.who.int/dietphysicalactivity/goals/en/ print.html>. Acesso em: 05 set. 2006. 



\title{
20
}

\section{Fatores Nutricionais no Diabetes}

\author{
Daniela Saes Sartorelli
}

\begin{abstract}
A história do diabetes mellitus data de vários séculos. Antigas civilizações do Egito, Roma, Grécia e Índia foram pioneiras na descrição da doença e de sua evolução. Em 1500 a.C., o papiro egípcio Ebens descreveu um distúrbio caracterizado por intensa poliúria. No entanto, o grande marco foi 70 d.C., quando o romano Arateu o denominou de diabetes, "fluir através", devido à poliúria e polidipsia características da enfermidade. Em 1675, Thomas Willis, médico inglês, introduziu o termo mellitus, "semelhante ao mel", após observar o gosto adocicado da urina dos indivíduos. As ilhotas, identificadas no século XIX por Brockman, foram descritas por Langerhans em 1869. Em 1921, o isolamento da insulina por meio de sua extração do pâncreas evitou a morte de diversos indivíduos portadores da doença. Os primeiros hipoglicemiantes orais foram desenvolvidos em 1955 (Milech \& Oliveira, 2004). Posteriormente, verificou-se a diferenciação etiológica da doença e o reconhecimento do diabetes como resultante de condições genéticas, metabólicas e ambientais. Os pontos de corte de glicemia como critério diagnóstico da doença são amplamente discutidos na atualidade, e a classificação rotineiramente empregada é: diabetes tipo 1 (anteriormente denominado insulinodependente), diabetes tipo 2 (não insulinodependente) e diabetes gestacional.

Atualmente, a indústria farmacêutica dispõe de numerosas drogas para o tratamento do diabetes, porém o controle metabólico de indivíduos com a doença em evolução consiste em um dos maiores desafios dos serviços de saúde pública (Donahue \& Ochard, 1992; Assunção, Santos \& Gigante, 2001; Assunção, Santos \& Costa, 2002).

A relevância do diabetes no perfil epidemiológico da população brasileira, a carga de doença para os sistemas públicos e seu impacto sobre a qualidade de vida dos indivíduos são indiscutíveis. Alterações na estrutura da dieta, o sedentarismo e o incremento na prevalência da obesidade são fatores de risco relevantes para o desenvolvimento do diabetes tipo 2 e, possivelmente, do diabetes gestacional. Em relação ao diabetes tipo 1, as investigações sobre a contribuição de fatores ambientais em sua etiologia são crescentes, porém escassas. $\mathrm{O}$ presente capítulo aborda dados epidemiológicos e as evidências disponíveis da contribuição de fatores nutricionais na gênese do diabetes tipo 1, diabetes gestacional e diabetes tipo 2 .
\end{abstract}

\section{Magnitude e Distribuição do Diabetes}

A prevalência global do diabetes tipo 2 (DM) tem se elevado vertiginosamente. Projeções para os próximos vinte anos estimam um incremento de $42 \%$ do número de indivíduos maiores de 65 anos acometidos pela 
doença em países desenvolvidos. Nos países em desenvolvimento, espera-se um aumento de $170 \%$ do número de indivíduos portadores da doença em todas as idades, principalmente no grupo de 45-64 anos, em que a prevalência deverá triplicar, duplicando nas faixas etárias de 20-44 e 65 e mais anos (King, Aubert \& Herman, 1998).

Dados nacionais em população urbana entre 30 e 69 anos de idade, coletados em 1988, estimaram prevalências de DM e de Tolerância à Glicose Diminuída (TGD) em 7,6 e 7,8\%, respectivamente (Malerbi \& Franco, 1992). Estudos pontuais mais recentes, com a mesma faixa etária, verificaram que $12 \%$ e $7,7 \%$ de indivíduos residentes em Ribeirão Preto, SP, eram portadores de DM e TGD, respectivamente (Torquato et al., 2003). No município do Rio de Janeiro, RJ, as prevalências de DM e TGD observadas em 1989 foram de 7,1\% e 9\%, respectivamente (Oliveira, Milech \& Franco, 1996). Nesses estudos, os principais fatores de risco identificados foram idade, história familiar de diabetes e obesidade.

Os dados disponíveis da freqüência do DM em crianças e adolescentes são escassos, mas sugerem um aumento substancial nesta faixa etária. Entre os índios Pima do Arizona, considerados a comunidade com maior coeficiente de ocorrência do DM no mundo, um estudo conduzido entre 1992 e 1996 com jovens entre 10 e 14 anos e entre 15 e 19 anos verificou prevalências de 2,2 e 5,1\%, respectivamente nas duas faixas etárias. Os dados da população norte-americana revelam uma prevalência (tipo 1 e tipo 2 ) de $0,4 \%$ entre indivíduos com idade entre 12 e 19 anos (ADA, 2000). A maior freqüência da obesidade e a crescente prevalência do diabetes gestacional estão entre os fatores relacionados à ocorrência de DM nessa faixa etária. Um estudo de rastreamento para diabetes gestacional, conduzido entre 1994 e 2002, verificou um crescimento exponencial do número de casos, independentemente da etnia, predispondo os indivíduos a um círculo vicioso, com perspectivas de aumento da prevalência da doença em todas as faixas etárias (Dabelea et al., 2005).

Em relação ao diabetes tipo 1, uma crescente incidência vem sendo evidenciada no mundo, porém discrepante em diferentes países, variando de 0,5 a 30,3 novos casos para cada cem mil indivíduos anualmente (Onkamo et al., 1999). Na América Latina, as taxas de incidência da doença são mais discretas, mas variam de 0,1/100.000 na Venezuela até 17,4/100.000 em Porto Rico (Collado-Mesa et al., 2004). No Brasil, a carência de estudos de base populacional conduzidos entre jovens limita as estimativas nacionais. No estudo conduzido em 1988, em nove capitais brasileiras, verificou-se uma freqüência de $0,1 \%$ de diabetes auto-referido entre indivíduos com idade inferior a 30 anos, sugerindo que esta seja a prevalência do diabetes tipo 1 nessa população (Malerbi \& Franco, 1992).

\section{Diabetes Tipo 1: fatores genéticos e ambientais}

O diabetes tipo 1 é uma doença crônica auto-imune, com manifestação clínica desencadeada pela falência da produção insulínica nas células $\beta$ do pâncreas. Consiste em uma doença poligênica com pelo menos 16 diferentes lócus. Entretanto, a predisposição genética mais evidente é mediada pelos genes do antígeno do leucócito humano HLA (Human Leucocyte Antigen), localizados na região do complexo principal de histocompatibilidade no braço curto do cromossomo 6, e pelo gene da insulina no cromossomo 11 . Todavia, apenas $10 \%$ das crianças com predisposição genética desenvolvem o diabetes clínico, o que sugere que fatores ambientais possam estar relacionados à história natural da doença. Entre as crianças predispostas geneticamente, a produção de auto-anticorpos já parece determinar a chance do desenvolvimento clínico da doença. Atualmente, quatro distintos auto-anticorpos foram descritos, sendo que o risco de progressão para a doença na presença de três ou quatro auto-anticorpos é de 60 a 100\% em crianças com predisposição genética (Virtanen \& Knip, 2003; Knip et al., 2005).

Outras evidências sugerem a hipótese da influência ambiental na gênese do diabetes tipo 1, tais como: a concordância de apenas $40 \%$ em estudos com gêmeos monozigóticos; valores de prevalência discrepantes entre caucasianos residindo na Europa; aumento vertiginoso da prevalência do diabetes tipo 1 nos últimos cinqüenta anos e evidências de estudos desenvolvidos com populaçôes migrantes que verificaram aumento na incidência da doença entre grupos que migraram de regiōes de baixa prevalência para regiōes de prevalência elevada (Knip et al., 2005). 
O aleitamento materno e a introdução complementar de alimentos são os fatores ambientais mais investigados na gênese do diabetes tipo 1. Evidências provenientes de estudos caso-controle sugerem que a introdução precoce do leite de vaca na alimentação infantil seja um fator de risco para o diabetes tipo 1 (Gimeno \& Souza, 1997; Virtanen \& Knip, 2003), embora estudos prospectivos recentes não tenham verificado associação positiva entre consumo de leite de vaca e detecção de auto-anticorpos relacionados à doença (Norris et al., 2003; Ziegler et al., 2003). Em contrapartida, a introdução precoce (< 3 meses de vida) de cereais na alimentação infantil foi verificada como um importante fator de risco para a auto-imunidade do diabetes tipo 1 em uma coorte de crianças alemãs (Ziegler et al., 2003). Um recente estudo de coorte que acompanhou 3.500 crianças com predisposição genética na Finlândia verificou que a introdução de frutas na alimentação de crianças menores de 4 meses representou um risco duas vezes maior para a detecção de auto-anticorpos na idade de 1 ano, quando comparado ao verificado entre crianças com aleitamento materno exclusivo. Nesse estudo, a introdução precoce de tubérculos também esteve associada a um incremento no risco da detecção de auto-anticorpos (Virtanen et al., 2006). Um dos possíveis mecanismos fisiopatológicos seria a proteção conferida pelo aleitamento materno exclusivo (Kimpimäki et al., 2001). Além disso, a introdução precoce de frutas e tubérculos, assim como de fórmulas infantis e leite de vaca, pode resultar em um aumento na oferta calórica que estaria associada a um estresse das células $\beta$, induzindo à auto-imunidade (Virtanen et al., 2006). Essa relação pode também estar fundamentada por pesquisas que verificaram uma associação positiva entre elevado ganho de peso e crescimento linear em crianças pequenas e incremento no risco de diabetes tipo 1 (Hyppönen et al., 1999, 2000).

Os estudos disponíveis ainda não conferem evidências convincentes sobre o papel da introdução precoce de alimentos na gênese do diabetes tipo 1, sendo necessário um maior número de estudos. Porém, as evidências da proteção conferida pelo aleitamento materno exclusivo até o sexto mês de vida para o desenvolvimento adequado das crianças são incontestáveis, sugerindo que esta seja a recomendação universal (WHO, 1998).

\section{Diabetes Tipo 2: estado nutricional e fatores ambientais}

A obesidade em crianças e adolescentes é um crescente problema mundial. Suas implicações na saúde infantil ainda são incertas, mas poderão repercutir nas taxas de incidência de diabetes alguns anos mais tarde, dado que o excesso de peso é considerado um fator de risco convincente para o DM (WHO/FAO, 2003).

Estudos longitudinais conduzidos entre os índios Pima verificaram que, além da obesidade na infância, o peso ao nascer (McCance et al., 1994) e a exposição intra-uterina ao diabetes gestacional foram os principais fatores preditores do desenvolvimento do DM (Dabelea \& Pettit, 2001) e da hipertensão arterial na infância e adolescência (Charles et al., 1994). A exposição intra-uterina ao diabetes gestacional vem sendo considerada como fator de risco para o desenvolvimento de obesidade, DM (Catalano et al., 2003) e síndrome metabólica na adolescência (Boney et al., 2005). De acordo com as estimativas crescentes do diabetes gestacional (Dabelea et al., 2005), um maior número de crianças deverá estar exposta ao DM em idade precoce, aumentando o risco de complicações na vida adulta.

As evidências do papel do estilo de vida na gênese do DM em adultos são crescentes. A Organização Mundial da Saúde (OMS) e a Organização das Nações Unidas para a Alimentação e Agricultura (FAO), no documento "Dieta, nutrição e prevenção de doenças crônicas", atribuíram a força das evidências científicas de fatores nutricionais em relação ao risco de doenças crônicas, com base nos critérios de causalidade de Hill: força da associação, presença do gradiente dose-resposta, associação temporal, consistência dos achados e plausibilidade biológica. As evidências foram classificadas em: convincente, provável, possível e insuficiente, e estão demonstradas no Quadro 1 (WHO/FAO, 2003).

Segundo esse documento, a associação entre excesso de peso, obesidade abdominal, sedentarismo e DM são convincentes, assim como a perda de peso voluntária em portadores de excesso de peso e a prática regular de 
atividades físicas são fatores protetores convincentes para o $\mathrm{DM}$ em adultos. $\mathrm{O}$ número de estudos epidemiológicos que incluem desenhos prospectivos e ensaios clínicos aleatorizados pode ser considerado suficiente para a demonstração da força causal desses fatores de risco para DM. Enquanto a obesidade abdominal está fortemente relacionada com a resistência à insulina, a perda de peso voluntária atua na melhoria de sua sensibilidade periférica. $\mathrm{O}$ mesmo mecanismo de proteção é conferido à prática regular de atividades físicas. Embora a prática mínima de atividades na prevenção do DM não esteja bem estabelecida, acredita-se que exercícios físicos regulares com intensidade de 80 a $90 \%$ do batimento cardíaco máximo durante vinte minutos com frequiência de cinco vezes por semana possa melhorar substancialmente a sensibilidade à insulina (WHO/FAO, 2003). Um ensaio clínico aleatorizado conduzido entre portadores de TGD verificou que a prática regular de atividades físicas de lazer e caminhadas conferiram uma redução de 65\% no risco de desenvolver o DM após quatro anos de seguimento (Laaksonen, Lindström \& Lakka, 2005).

Estudos epidemiológicos em populaçôes de diferentes origens étnicas sugerem que tanto a glicotoxicidade como a lipotoxicidade podem interferir na síntese da insulina e na sensibilidade a este hormônio. Inicialmente, níveis elevados de Ácidos Graxos Livres (AGL) circulantes foram implicados nesse processo, mas atualmente vários fatores regulatórios produzidos por adipócitos (adipocinas) foram descritos, como o fator de necrose tumoral alfa [TNF-alfa] e interleucina 6 [IL-6]. Evidências sugerem que o tecido adiposo exibe um estado de inflamação crônica de baixo grau, que interfere na ação da insulina e contribui para o desenvolvimento da resistência periférica (Zecchin \& Saad, 2006).

O consumo alimentar habitual constitui um dos principais fatores determinantes passíveis de modificação para as doenças crônicas não transmissíveis. Ressalta-se, contudo, que as limitações inerentes ao próprio método de investigação da dieta habitual restringem o número de evidências consideradas convincentes (WHO/FAO, 2003).

Estudos epidemiológicos indicam uma provável evidência de risco relacionado ao consumo excessivo de gorduras saturadas (acima de 10\% das calorias totais) e ao baixo consumo habitual de fibras da dieta (menor que $20 \mathrm{~g}$ ao dia) para o DM. Além disso, dietas hiperlipídicas (acima de 37\% das calorias totais), ricas em ácidos graxos trans, com elevado Índice Glicêmico (IG) e baixos teores de ácidos graxos ๗-3 têm sido consideradas fatores de risco possíveis para o desenvolvimento da patologia (WHO/FAO, 2003). O IG, proposto desde 1981 por Jenkins e colaboradores, consiste em uma escala de resposta glicêmica a uma quantidade fixa de carboidratos (50 g) quando comparada à resposta glicêmica de um alimento-padrão, geralmente glicose ou pães (Jenkins et al., 1981). O IG da dieta habitual é, portanto, um indicador da qualidade do carboidrato da dieta consumida, determinado por seu potencial hiperglicêmico pós-prandial (Jenkins et al., 2002).

Sugere-se ainda uma relação protetora do consumo de vitamina E, cromo, magnésio e consumo moderado de álcool para DM, mas os resultados dos estudos são ainda controversos, e essas evidências consideradas como insuficientes (WHO/FAO, 2003).

Os resultados de ensaios clínicos aleatorizados sugerem que orientações nutricionais enfocando a qualidade dos carboidratos e lipídeos da dieta, como o estímulo ao consumo de cereais integrais, frutas, verduras, legumes, azeite de oliva e peixes em detrimento do consumo de carnes e cereais refinados, associadas ao incentivo da prática de atividades físicas, podem produzir um importante impacto na prevenção primária do DM em indivíduos portadores de fatores de risco (Sartorelli, Franco \& Cardoso, 2006). 
Quadro 1 - Sumário da força das evidências da associação do estilo de vida para o desenvolvimento do diabetes tipo 2

\begin{tabular}{|lll|}
\hline Força de evidência & Fatores protetores & Fatores de risco \\
\hline Convincente & Perda de peso em sobrepesos/obeso & Sobrepeso/obesidade \\
& Prática de atividades físicas & Obesidade abdominal \\
& & Sedentarismo \\
& & História materna de DM* \\
\hline Provável & Fibra dietética & Ácidos graxos saturados \\
\hline Possível & Ácidos graxos $\varpi-3$ & Gordura total da dieta \\
& Dietas com baixo IG & Ácidos graxos trans \\
& Aleitamento materno exclusivo & \\
\hline Insuficiente & Vitamina E & Consumo excessivo de álcool \\
& Cromo & \\
& Magnésio & \\
\hline
\end{tabular}

* Incluindo DM gestacional.

Fonte: adaptado de WHO/FAO (2003).

\section{Diabetes Gestacional: estado nutricional e fatores ambientais}

O estado nutricional materno pré-gestacional é um relevante indicador no acompanhamento pré-natal, pois está associado ao desenvolvimento intra-uterino e à mortalidade infantil (Cnattingius et al., 1998). Evidências epidemiológicas sugerem, também, que o excesso de peso pré-gestacional (Nucci et al., 2001), obesidade abdominal (Branchtein et al., 1997) e ganho de peso excessivo (Seligman et al., 2006; Kac \& Velásquez-Meléndez, 2005) estariam relacionados a um maior risco de complicações, como hemorragia materna, distúrbios hipertensivos, diabetes gestacional e macrossomia fetal.

Evidências sugerem que fatores ambientais maternos que alterem o fluxo sanguíneo ou a oferta de substratos interfiram no desenvolvimento da placenta e feto (Clapp, 2002). Dados sobre o efeito da atividade física e do consumo alimentar de gestantes, o desenvolvimento fetal e o risco de complicações, como o diabetes gestacional, ainda são escassos. Estudos sugerem que a prática regular de atividades físicas moderadas atuem beneficamente no desenvolvimento placentário e na redução do risco de complicações no parto; entretanto, atividades físicas vigorosas não são recomendadas, uma vez que poderão repercutir na redução do fluxo de glicose e oxigênio para a placenta e o feto (Clapp, 2006). Por outro lado, a quantidade e a qualidade dos carboidratos da dieta habitual da gestante podem interferir na oferta de glicose para a placenta durante a prática de atividades físicas (Clapp, 2006). O consumo alimentar habitual e o aporte de diversos nutrientes têm impacto relevante na oferta de substratos para a placenta, entretanto a qualidade dos carboidratos é o principal alvo de investigaçôes do papel da dieta habitual neste processo (Clapp, 2002).

Estudos epidemiológicos recentes sugerem que a qualidade dos carboidratos constituiria importante fator preditor de dislipidemia, doenças cardiovasculares e diabetes, principalmente entre indivíduos susceptíveis à resistência à insulina, com elevado índice de massa corporal (Willett, Manson \& Liu, 2002; Liu et al., 2002, 2001, 2000). 
Em gestantes, a hiperglicemia após o consumo de alimentos com elevados teores de IG é semelhante ao observado em adultos e vem sendo associada ao maior ganho de peso materno e fetal. Em conjunto com a resistência periférica à insulina, fisiologicamente verificada durante a gestação, sugere-se que uma dieta habitual com elevados teores de IG em gestantes com excesso de peso pré-gestacional possa estar relacionada a um maior risco de diabetes gestacional e macrossomia fetal (Clapp, 2002). Por sua vez, a restrição severa de alimentos de elevados IG em mulheres eutróficas e/ou baixo peso pré-gestacional pode predispor ao baixo peso ao nascer (Scholl et al., 2004). Desta forma, a manipulação do IG e do teor de fibras da dieta poderá ser uma aliada ao controle do ganho de peso gestacional e desenvolvimento fetal adequados.

\section{Perspectivas de Risco no Brasil}

O incremento vertiginoso da prevalência do diabetes observado nas últimas décadas expressa intensas mudanças no perfil epidemiológico global na segunda metade do século XX (WHO, 2000). A influência da carga genética no desenvolvimento da doença é indiscutível; entretanto, a alarmante prevalência de alteração da homeostase glicêmica entre indivíduos geneticamente suscetíveis expostos a drásticas mudanças de estilo de vida, como os índios Pima e os nipo-brasileiros, sugere uma atuação fundamental de fatores ambientais na manifestação da doença (Gimeno et al., 2003). Além disso, os ensaios clínicos aleatorizados para prevenção do DM verificaram uma redução significativa da progressão da TGD para o DM com a adoção de um estilo de vida saudável, independentemente da predisposição genética (Uusitupa, 2005).

O envelhecimento populacional e as alterações do estilo de vida são considerados os principais determinantes do incremento na freqüência do diabetes nos últimos anos no Brasil (Sartorelli \& Franco, 2003). A elevada prevalência da obesidade poderá exercer um impacto relevante no perfil epidemiológico nos próximos anos.

Como uma tendência secular, verificou-se um incremento da prevalência de obesidade na população brasileira em todas as faixas etárias nas últimas décadas, expondo os indivíduos ao maior risco de doenças crônicas (IBGE, 2004). Entre mulheres, a prevalência do excesso de peso nas classes sociais menos favorecidas vem se intensificando (Monteiro et al., 2004), o que tem aumentado as chances de ocorrência do diabetes gestacional. Em uma coorte de gestantes, acompanhada em seis capitais brasileiras, a prevalência de excesso de peso na ocasião da concepção estava presente em $25 \%$ das mulheres e associada ao maior risco de complicações na gestação ou no parto (Nucci et al., 2001), predispondo as crianças ao desenvolvimento da doença.

Além da exposição intra-uterina ao diabetes gestacional, a obesidade na infância é relevante para as chances de desenvolvimento do DM em idades precoces. Nos Estados Unidos, a prevalência estimada de excesso de peso em indivíduos com idade entre 12 e 19 anos aumentou cerca de 3\% em um período de quatro anos, atingindo 17\% dessa população em 2004 (Ogden et al., 2006). No Brasil, os resultados da Pesquisa de Orçamentos Familiares (POF) revelam um incremento relevante da prevalência do excesso de peso em adolescentes brasileiros, que atinge cerca de $15 \%$ das meninas e $18 \%$ dos meninos com idade entre 10 e 19 anos (IBGE, 2006).

As alterações no estilo de vida dos brasileiros nas últimas décadas apresentam potencial igualmente relevante no aumento do risco de doenças crônicas. A intensa urbanização e a mecanização dos processos produtivos predispõem os indivíduos ao estilo de vida sedentário. Além disso, um estudo transversal de base populacional conduzido nos estados do Nordeste e Sudeste, em 1997, estimou que cerca de 87\% de adultos eram sedentários. A freqüência da prática de atividades físicas de lazer recomendada para prevenção de doenças crônicas, trinta minutos em cinco ou mais dias por semana, foi relatada por apenas 3,5\% dos homens e 3,2\% das mulheres (Monteiro et al., 2003).

Em relação à disponibilidade de alimentos, os dados da POF sugerem profundas mudanças nas últimas três décadas. Verificou-se um aumento importante na participação das carnes em geral (aumento de quase 50\%), carne bovina (aumento de 22\%), carne de frango (aumento de mais de 100\%), embutidos (aumento de 300\%), 
leite e derivados (aumento de 36\%), óleos e gorduras vegetais (aumento de 16\%), biscoitos (aumento de 400\%) e refeiçôes prontas (aumento de 80\%). Em contrapartida, observou-se uma tendência inversa para o consumo de arroz (redução de 23\%), feijão/leguminosas (redução de 30\%), raízes e tubérculos (redução de 30\%), peixes (redução de 50\%), ovos (redução de 84\%) e gordura animal (redução de 65\%). Em relação ao consumo do grupo de açúcares e refrigerantes, deve-se considerar que diminuiu a disponibilidade de açúcar desde o primeiro período entre 1974-75 e 1986-87, chegando a 23\% a redução no período de 1974-75 a 2003. Ao mesmo tempo, um aumento na disponibilidade de refrigerantes já vinha sendo constatado desde o primeiro período, chegando a 400\% entre $1974-75$ e 2003. O consumo de frutas, verduras e legumes permaneceu inalterado (cerca de 3 a 4\%) nas últimas três décadas (IBGE, 2004).

Quanto ao aleitamento materno, a mediana de sua duração evoluiu favoravelmente nas últimas décadas, embora ainda aquém das recomendaçôes internacionais. Entretanto, o aleitamento exclusivo é praticado por uma pequena parcela das lactantes e a introdução de outros alimentos é precoce, o que poderia predispor nossas crianças ao maior risco de diabetes tipo 1 (Venâncio et al., 2002; Kitoko et al., 2000; Venâncio \& Monteiro, 1998).

As perspectivas nacionais são de incremento da prevalência do diabetes em todas as faixas etárias, o que justifica a adoção de medidas preventivas. A Política Nacional de Alimentação e Nutrição contempla a promoção de hábitos de vida saudáveis, que se iniciam com aleitamento materno exclusivo e introdução adequada da alimentação complementar, e incluem o estímulo à alimentação saudável e à prática de atividades físicas em todos os estágios do ciclo vital (Ministério da Saúde, 2005). Os dados de estudos de prevenção primária do diabetes realizados em países em desenvolvimento são escassos, mas os resultados de um estudo brasileiro sugerem um importante impacto na melhoria da qualidade de vida de indivíduos com elevado risco metabólico obtido por meio de medidas simples de intervenção adaptadas às condições usuais de unidades básicas de saúde (Sartorelli et al., 2005).

\section{Considerações Finais}

A participação da carga genética no risco da ocorrência do diabetes é indiscutível. Entretanto, as evidências da influência de fatores ambientais em sua gênese são crescentes.

Os estudos que investigaram o papel do estado nutricional, estilo de vida e ocorrência do diabetes gestacional ainda são insuficientes, mas sugerem que o excesso de peso pré-gestacional e o ganho de peso materno estejam fortemente relacionados ao risco. A exposição intra-uterina ao diabetes gestacional, associada à elevada prevalência de excesso de peso em crianças e adolescentes, são os principais fatores associados à manifestação clínica do DM em idades precoces.

Em relação ao diabetes tipo 1, o aleitamento materno exclusivo parece exercer um efeito protetor, e a introdução precoce de alimentos pode predispor crianças geneticamente suscetíveis ao risco de desenvolvimento do diabetes clínico.

A evolução do excesso de peso, que consta das estimativas nacionais, assim como as alterações na prática de atividades físicas e no consumo alimentar, são reconhecidos fatores de risco para o diabetes em todas as faixas etárias, o que ressalta a relevância da promoção de hábitos saudáveis de vida para prevenção e controle do diabetes no Brasil.

Entretanto, segundo a OMS, a implementação de programas de mudança de estilo de vida entre indivíduos portadores de fatores de risco deve ser associada a alteraçōes ambientais que favoreçam as escolhas individuais na adoção e manutenção do estilo de vida saudável. Além disso, o estímulo à valorização cultural pela saúde constitui uma ferramenta de fundamental importância para o alcance das metas do estilo de vida saudável (WHO/ FAO, 2003). 


\section{Referências}

AMERICAN DIABETES ASSOCIATION (ADA). Type 2 diabetes in children and adolescents. Diabetes Care, 23(3): 381-389, 2000.

ASSUNÇÃO, M. C. F.; SANTOS, I. S. \& COSTA, J. S. D. Avaliação do processo da atenção médica: adequação do tratamento de pacientes com diabetes mellitus, Pelotas, Rio Grande do Sul, Brasil. Cadernos de Saúde Pública, 18(1): 205-211, 2002.

ASSUNÇÃO, M. C. F.; SANTOS, I. S. \& GIGANTE, D. P. Atenção primária em diabetes no Sul do Brasil: estrutura, processo e resultado. Revista de Saúde Pública, 35(1): 88-95, 2001.

BONEY, C. et al. Metabolic syndrome in childhood: association with birth weight, maternal obesity, and gestational diabetes mellitus. Pediatrics, 115(3): 290-296, 2005.

BRANCHTEIN, L. et al. Waist circumference and waist-to-hip ratio are related to gestational glucose tolerance. Diabetes Care, 20(4): 509-511, 1997.

CATALANO, P. M. et al. Gestational diabetes and insulin resistance: role in short and long-term implications for mother and fetus. Journal of Nutrition, 133(5), suppl. 2: 1.674S-1.683S, 2003.

CHARLES, M. et al. Familial and metabolic factors related to blood pressure in Pima Indian children. American Journal of Epidemiology, 140(2): 123-131, 1994.

CLAPP, J. F. Maternal carbohydrate intake and pregnancy outcome. The Proceedings of the Nutrition Society, 61(1): 45-50, 2002.

CLAPP, J. F. Influence of endurance exercise and diet on human placental development and fetal growth. Placenta, 27(6-7): 527-534, 2006.

CNATTINGIUS, S. et al. Prepregnancy weight and the risk of adverse pregnancy outcomes. New England Journal of Medicine, 338(3): 147-152, 1998.

COLLADO-MESA, F. et al. An ecological analysis of childhood-onset type 1 diabetes incidence and prevalence in Latin America. Revista Panamericana de Salud Publica, 15(6): 388-394, 2004.

DABELEA, D. \& PETTITT, D. J. Intrauterine diabetic environment confers risks for type 2 diabetes mellitus and obesity in the offspring, in addition to genetic susceptibility. Journal of Pediatric Endocrinology \& Metabolism, 14(8): 1.085-1.091, 2001.

DABELEA, D. et al. Increasing prevalence of gestational diabetes mellitus (GDM) over time and by birth cohort. Kaiser Permanent of Colorado GDM Screening Program. Diabetes Care, 28(3): 579-584, 2005.

DONAHUE, R. P. \& ORCHARD, T. J. Diabetes mellitus and macrovascular complications: an epidemiological perspective. Diabetes Care, 15(9): 1.141-1.155, 1992.

GIMENO, S. G. A. \& SOUZA, J. M. P. de. Insulin-dependent diabetes mellitus and milk consumption: a casecontrol study in São Paulo, Brazil. Diabetes Care, 20(8): 1.256-1.260, 1997.

GIMENO, S. G. A. et al. Prevalence and 7-year incidence of type 2 diabetes mellitus in a Japanese-Brazilian population: an alarming public health problem. Diabetologia, 45(12): 1.635-1.638, 2003.

HYPPÖNEN, E. et al. Infant feeding, early weight gain, and risk of type 1 diabetes. Diabetes Care, 22(12): $1.961-1.965,1999$. 
HYPPÖNEN, E. et al. Obesity, increased linear growth, and risk of type 1 diabetes in children. Diabetes Care, 23(12): 1.755-1.760, 2000

INSTITUTO BRASILEIRO DE GEOGRAFIA E ESTATÍSTICA (IBGE). Pesquisa de Orçamentos Familiares, 2002-2003. Análise da disponibilidade domiciliar de alimentos e do estado nutricional no Brasil. Rio de Janeiro: IBGE, 2004. Disponível em: <www.ibge.gov.br/home/estatistica/populacao/condicoesdevida/ pof/2002analise/pof2002analise.pdf>. Acesso em: 10 jul. 2006.

INSTITUTO BRASILEIRO DE GEOGRAFIA E ESTATÍSTICA (IBGE). Pesquisa de Orçamentos Familiares, 2002-2003. Antropometria e análise do estado nutricional de crianças e adolescentes no Brasil. Rio de Janeiro: IBGE, 2006. Disponível em: <www.ibge.gov.br/home/estatistica/populacao/condicoesdevida/pof/ 2003medidas/pof2003medidas.pdf>. Acesso em: 10 jul. 2006.

JENKINS, D. J. et al. Glycemic index of foods: a physiological basis for carbohydrate exchange. American Journal of Clinical Nutrition, 34(3): 362-366, 1981.

JENKINS, D. J. A. et al. Glycemic index: overview of implications in health and disease. American Journal of Clinical Nutrition, 76(1): 266S-273S, 2002.

KAC, G. \& VELÁSQUEZ-MELÉNDEZ, G. Ganho de peso gestacional e macrossomia em uma coorte de mães e filhos. Jornal de Pediatria, 81(1): 47-53, 2005.

KIMPIMÄKI, T. et al. Short-term exclusive breastfeeding predisposes young children with increased genetic risk of type 1 diabetes to progressive beta-cell autoimmunity. Diabetologia, 44(1): 63-69, 2001.

KING, H.; AUBERT, R. E. \& HERMAN, W. H. Global burden of diabetes, 1995-2025. Diabetes Care, 21(9): 1.414-1.431, 1998.

KITOKO, P. M. et al. Situação do aleitamento materno em duas capitais brasileiras: uma análise comparada. Cadernos de Saúde Pública, 16(4): 1.111-1.119, 2000.

KNIP, M. et al. Environmental triggers and determinants of type 1 diabetes. Diabetes, 54, suppl. 2: S125-S136, 2005.

LAAKSONEN, D. E.; LINDSTRÖM, J. \& LAKKA, T. A. Physical activity in the prevention of type 2 diabetes. The Finnish Diabetes Prevention Satudy. Diabetes, 54(1): 158-165, 2005.

LIU, S. et al. A prospective study of dietary glycemic load, carbohydrate intake, and risk of coronary heart disease in US women. American Journal of Clinical Nutrition, 71(6): 1.455-1.461, 2000.

LIU, S. et al. Dietary glycemic load assessed by food-frequency questionnaire in relation to plasma high-densitylipoprotein cholesterol and fasting plasma triacylglycerol in postmenopausal women. American Journal of Clinical Nutrition, 73(3): 560-566, 2001.

LIU, S. et al. Relation between a diet with a high glycemic load and plasma concentrations of high-sensitivity Creactive protein in middle-aged women. American Journal of Clinical Nutrition, 75(3): 492-498, 2002.

MALERBI, D. A. \& FRANCO, L. J. Multicenter study of the prevalence of diabetes mellitus and impaired glucose tolerance in the urban Brazilian population aged 30-69 yr. Diabetes Care, 15(11): 1.509-1.516, 1992.

MCCANCE, D. et al. Birth weight and non-insulin dependent diabetes: thrifty genotype, thrifty phenotype, or surviving baby genotype? British Medical Journal, 308(6934): 942-945, 1994. 
MILECH, A. \& OLIVEIRA, J. E. P. Diabetes: passado, presente e futuro. In: MILECH, A. \& OLIVEIRA, J. E. P. (Orgs.) Diabetes Mellitus: clinica, diagnóstico, tratamento multidisciplinar. São Paulo: Atheneu, 2004.

MINISTÉRIO DA SAÚDE. Programa Nacional de Alimentação e Nutrição. Brasília: MS, 2005.

MONTEIRO, C. A. et al. A descriptive epidemiology of leisure-time physical activity in Brazil, 1996-1997. Revista Panamericana de Salud Pública, 14(4): 246-254, 2003.

MONTEIRO, C. A. et al. Obesity and inequities in health in the developing world. International Journal of Obesity and Related Metabolic Disorders, 28(9): 1.181-1.186, 2004.

NORRIS, J. M. et al. Timing of initial cereal exposure in infancy and risk of islet autoimmunity. Jama, 290(13): 1.713-1.720, 2003.

NUCCI, L. B. et al. Nutritional status of pregnant women: prevalence and associated pregnancy outcomes. Revista de Saúde Pública, 35(6): 502-507, 2001.

OGDEN, C. L. et al. Prevalence of overweight and obesity in the United States, 1999-2004. Jama, 295(13): 1.549-1.555, 2006.

OLIVEIRA, J. E.; MILECH, A. \& FRANCO, L. J. The prevalence of diabetes in Rio de Janeiro, Brazil. Diabetes Care, 19(6): 663-666, 1996.

ONKAMO, P. et al. Worldwide increase in incidence of Type I diabetes: the analysis of the data on published incidence trends. Diabetologia, 42(12): 1.395-1.403, 1999.

SARTORELLI, D. S. \& FRANCO, L. J. Tendências do diabetes mellitus no Brasil: o papel da transição nutricional. Cadernos de Saúde Pública, 19, supl. 1: S29-S36, 2003.

SARTORELLI, D. S.; FRANCO, L. J. \& CARDOSO, M. A. Intervenção nutricional e prevenção primária do diabetes tipo 2: uma revisão sistemática. Cadernos de Saúde Pública, 22(1): 7-18, 2006.

SARTORELLI, D. S. et al. Beneficial effects of short- term nutritional counseling at the primary health care level among Brazilian overweight adults. Public Health Nutrition, 8(7): 820-825, 2005.

SCHOLL, T. O. et al. The dietary glycemic index during pregnancy: influence on infant birth weight, fetal growth, and biomarkers of carbohydrate metabolism. American Journal of Epidemiology, 159(5): 467-474, 2004.

SELIGMAN, L. C. et al. Obesity and gestational weight gain: cesarean delivery and labor complications. Revista de Saúde Pública, 40(3): 457-465, 2006.

TORQUATO, M. T. C. G. et al. Prevalence of diabetes mellitus and impaired glucose tolerance in the urban population aged 30-69 years in Ribeirão Preto (São Paulo), Brazil. São Paulo Medical Journal, 121(6): 224230, 2003.

UUSITUPA, M. Gene-diet interaction in relation to the prevention of obesity and type 2 diabetes: evidence from the finnish diabetes prevention study. Nutrition, Metabolism, and Cardiovascular Diseases, 15(3): 225233, 2005.

VENÂNCIO, S. I. \& MONTEIRO, C. A. A tendência da prática da amamentação no Brasil nas décadas de 70 e 80. Revista Brasileira de Epidemiologia, 1(1): 40-49, 1998.

VENÂNCIO, S. I. et al. Freqüência e determinantes do aleitamento materno em municípios do estado de São Paulo. Revista de Saúde Pública, 36(3): 313-318, 2002. 
VIRTANEN, S. M. \& KNIP, M. Nutritional risk predictors of b cell autoimmunity and type 1 diabetes at young age. American Journal of Clinical Nutrition, 78(6): 1.053-1.067, 2003.

VIRTANEN, S. M. et al. Age at introduction of new foods and advanced beta cell autoimmunity in young children with HLA-Conferred susceptibility to type 1 diabetes. Diabetologia, 49(7): 1.512-1.521, 2006.

WILLETT, W. C.; MANSON, J. \& LIU, S. Glycemic index, glycemic load, and risk of type 2 diabetes. American Journal of Clinical Nutrition, 76(1): 274-280, 2002.

WORLD HEALTH ORGANIZATION (WHO). Child Health and Development: evidence for the ten steps to successful breast-feeding. Geneva: WHO, 1998.

WORLD HEALTH ORGANIZATION (WHO). The World Health Report: 2000. Health Systems: improving performance. Geneva: WHO, 2000.

WORLD HEALTH ORGANIZATION/FOOD AND AGRICULTURE ORGANIZATION (WHO/FAO). Joint WHO/FAO Expert Consultation. Diet, Nutrition and the Prevention of Chronic Diseases. Geneva: WHO/FAO, 2003. (WHO Technical Report Series, 916)

ZECCHIN, H. G. \& SAAD, M. J. A. Resistência insulínica no diabetes mellitus tipo 2. In: LYRA, R. \& CAVALVANTI, N. Diabetes Mellitus. Rio de Janeiro: Diagraphic, 2006.

ZIEGLER, A. G. et al. Early infant and risk of developing type 1 diabetes-associated autoantibodies. Jama, 290(13): 1.721-1.727, 2003. 



\title{
21
}

\section{Fatores da Dieta nas Doenças Cardiovasculares}

\author{
Suely Godoy Agostinho Gimeno e Sandra Roberta Gouvea Ferreira
}

\begin{abstract}
A
partir da segunda metade do século XX, observaram-se importantes mudanças socioeconômicas e tecnológicas em todo o mundo, com conseqüentes modificações na esperança de vida ao nascer e no estilo de vida; além disso, criou-se uma capacidade sem precedentes de utilizar a ciência para prolongar e melhorar as condições de vida. Nessa transição, a mudança de saúde mais perversa foi a epidemia de Doenças Crônicas Não Transmissíveis (DCNT) e, entre elas, contribuem para a maior parte dos casos de morte ou incapacidade as Doenças Cardiovasculares (DCV), os cânceres e o Diabetes Mellitus (DM) (WHO/FAO, 2003). Mudanças nos hábitos alimentares - caracterizados por dietas com alta densidade energética, elevado consumo de gorduras e do sal de cozinha, deficientes em carboidratos complexos e micronutrientes - e no estilo de vida - caracterizado pelo sedentarismo - contribuem para a atual epidemia de excesso de peso, observada em diversas populaçóes, independentemente do seu grau de desenvolvimento (ver capítulo 25, "Transição nutricional: conceito e características").
\end{abstract}

\section{As Doenças Cardiovasculares}

A doença aterosclerótica é a principal causa de morte em várias regiōes do mundo, sendo particularmente mais prevalente nos países desenvolvidos (Cines et al., 1998). É um processo inflamatório difuso da parede arterial que começa na infância e evolui silenciosamente durante a vida adulta, quando surge mais ou menos precocemente, na dependência da presença de uma série de fatores de risco. Suas manifestações clínicas mais freqüentes e relevantes são a coronariopatia, o Acidente Vascular Cerebral (AVC) e a doença arterial periférica. Do ponto de vista anatomopatológico, o estreitamento do lúmen arterial inicia-se por acúmulo de lípides (células espumosas) no endotélio de artérias de grande e médio calibres, a partir do qual se desenvolve processo inflamatório crônico, progressivo, com formação do ateroma, sujeito à erosão e fenômenos tromboembólicos. Anormalidades também nas camadas média e adventícia dessas artérias contribuem para agravar o estreitamento luminal (Cines et al., 1998).

A aterosclerose apresenta etiologia multifatorial; alguns de seus principais fatores predisponentes são o fumo, o DM, a hipercolesterolemia, a Hipertensão Arterial (HA) e a inatividade física (Ross, 1999). Mais recentemente, outros fatores de risco foram incorporados, tais como a obesidade visceral, a Resistência à Insulina (RI), a inflamação subclínica e a hiperhomocisteinemia. Essas anormalidades, de naturezas diversas, podem comprometer a função endotelial, perpetuando a lesão por meio de mecanismo fisiopatogênico comum (Cines et al., 
1998; Ross, 1999). Dessa forma, o estresse oxidativo, a inflamação e o estado pró-trombótico estarão presentes na arteriopatia aterosclerótica instalada, independentemente do seu principal fator desencadeante.

Segundo Yokoyama (2004), o elo entre o estresse oxidativo e o processo aterogênico estabeleceu-se com base nas evidências de oxidação da Lipoproteína de Baixa Densidade (LDL) como etapa-chave na formação das células espumosas. As LDL transportam o colesterol dos locais de onde ele é absorvido (intestino) e formado (fígado) para os demais territórios, onde será utilizado para reparar membranas, produzir esteróides e cumprir outras funçōes. Essa lipoproteína é a principal transportadora do colesterol sérico ( $70 \%$ circulam ligados a ela) e fornecedora deste lipídio para os tecidos extra-hepáticos, por meio da sua ligação ao receptor de LDL na membrana plasmática. Sua remoção (clearance) da circulação ocorre por meio da ligação ao seu receptor específico, principalmente nos hepatócitos (75\%).

São conhecidos subtipos de LDL, que variam em tamanho, densidade e conteúdo lipídico; com o aumento de sua densidade, observa-se diminuição do diâmetro da partícula. As partículas pequenas e densas são reconhecidamente mais aterogênicas do que as maiores e, na literatura, documentaram-se associações entre a concentração sérica de LDL pequenas e densas e o risco de DCV. Tais partículas, quando comparadas às demais, se infiltram mais facilmente na parede arterial e são mais suscetíveis à oxidação (Engler \& Engler, 2006). O estresse oxidativo constitui-se em importante mecanismo modificador das LDL, o que compromete sua remoção da circulação e aumenta seu potencial de agressão ao endotélio.

Em concentrações normais, a LDL penetra e sai da camada íntima, mas, em quantidades excessivas, esta lipoproteína se fixa à parede arterial, podendo sofrer oxidação. In vitro, a incubação da LDL com células endoteliais e musculares lisas induz modificação oxidativa da LDL e geração de radicais livres (Parthasarathy et al., 1999).

Devido à presença de antioxidantes no plasma, a LDL circulante é habitualmente pouco oxidada. Além disso, LDL modificadas em circulação seriam rapidamente removidas por células dos sinusóides hepáticos que contêm grande quantidade de receptores. Contudo, pode haver algum grau de peroxidação lipídica no plasma, e mínimas quantidades de LDL oxidada podem desencadear rápidas modificações oxidativas e subseqüente entrada na camada íntima arterial. In vivo, a questão decisiva sobre a oxidação ou não da LDL está relacionada ao balanço entre a magnitude do processo pró-oxidante e a capacidade de defesa contra tais mecanismos. Experimentos em laboratório revelam que substâncias com propriedades antioxidantes tais como a vitamina $\mathrm{E}$ têm a capacidade de reduzir a formação de radicais livres pelas LDL modificadas (Ross, 1999; Chilson \& Steinberg, 2000). Porém, ainda não é possível afirmar que, em seres humanos, a suplementação com tais substâncias teria um papel protetor sobre o sistema cardiovascular.

Diversos fatores de risco cardiovascular encontram-se comumente agrupados sob o denominador comum da RI. O reconhecimento da freqüente associação de obesidade visceral, intolerância à glicose, HA e dislipidemia (partículas pequenas e densas de LDL, hipertrigliceridemia, níveis baixos de HDL-colesterol) levou à descrição da atualmente denominada Síndrome Metabólica (SM), tendo a RI como principal fator etiopatogênico (ver capítulo 22, "Aspectos epidemiológicos e nutricionais da síndrome metabólica”).

\section{A Epidemia das Doenças Cardiovasculares}

As DCV são responsáveis por $30 \%$ das mortes em todo o mundo e afetam todos os estratos sociais. Nos Estados Unidos, no ano de 1998, as DCV foram responsáveis por 34\% das mortes entre as mulheres e 28,2\% entre os homens. Tal cenário também ocorre em países em desenvolvimento, onde as taxas de mortalidade e de morbidade, entre as mulheres, apresentam um incremento continuado, destacando-se, em particular, o aumento no número de casos de HA, AVC e Doença Coronariana (DC) (WHO/FAO, 2003).

No Brasil, dados do Datasus, órgão do Ministério da Saúde (www.datasus.gov.br), mostram que do total de internações ocorridas em todo o país no mês de março de 2006, 9,9\% foram por doenças do aparelho circu- 
latório; entre aqueles com idade acima de 40 anos, esse valor foi de 22,3\% para o sexo masculino e de 22,1\% para o feminino. Com relação à mortalidade, do total de óbitos observados no ano de 2003, 27,3\% foram decorrentes de doenças do aparelho circulatório, com distribuição semelhante entre os sexos.

Em países em desenvolvimento, onde a transição epidemiológica avançou, há evidências de reversão do gradiente social, com indivíduos pobres sendo bastante vulneráveis às DCV. Além do aumento na incidência, a ocorrência da doença em idades cada vez menores também contribui para essa epidemia (WHO/FAO, 2003).

$\mathrm{O}$ perfil das DCV varia entre os países em desenvolvimento. Aqueles em estágios iniciais da transição têm maior número de casos de cardiopatia reumática, cardiomiopatias infecciosas e nutricionais. A HA surge como problema de saúde pública naqueles países em fase intermediária, contribuindo para a ocorrência de casos de AVC hemorrágico e doença cardíaca hipertensiva, podendo o consumo do sal de cozinha favorecer esse quadro. Em localidades com avançada transição epidemiológica, esses casos são substituídos pelo AVC isquêmico e DC, mais relacionados ao consumo elevado de gorduras e aos níveis aumentados das lipoproteínas séricas, os quais contribuem para a ocorrência da doença aterotrombótica (WHO/FAO, 2003).

\section{Nutrição como Fator de Risco para as Doenças Cardiovasculares}

A relação entre a dieta e a DC é investigada há mais de um século. De acordo com revisão da literatura feita por Hu e Willett (2002), Ignatowshi, em 1908, produziu aterosclerose em coelhos por meio de uma dieta rica em colesterol e gordura saturada. Nos anos 50, estudos experimentais mostraram que, em humanos, tanto as gorduras saturadas quanto, em menor extensão, o colesterol dietético aumentavam as concentraçôes séricas de colesterol. Além disso, estudos epidemiológicos encontraram que concentrações séricas elevadas de colesterol prediziam o risco de DC. Hoje, sabe-se que vários dos clássicos fatores de risco cardiovascular (lipoproteínas séricas, pressão arterial e adiposidade corporal) são influenciados pela dieta habitual (Bertoli et al., 2006) e que os efeitos do hábito alimentar sobre as DCV são mediados por múltiplas vias biológicas, não apenas as concentrações séricas do colesterol (Figura 1).

Figura 1 - Mecanismos pelos quais a dieta pode influenciar o risco de DCV

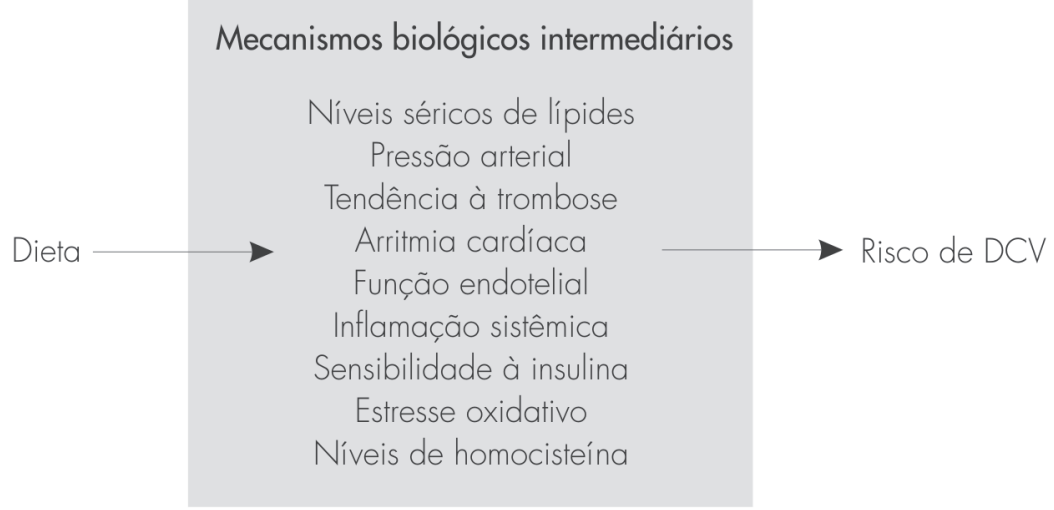

Fonte: adaptado de Hu \& Willett (2002).

O grau de adiposidade corporal, resultado do balanço energético, apresenta uma influência importante no risco de DCV. Os mecanismos pelos quais a obesidade eleva esse risco incluem a RI, hiperglicemia, HA, redução da fração HDL e aumento da LDL do colesterol (Willett, 1998).

$\mathrm{Na}$ pesquisa sobre o papel dos diferentes fatores nutricionais no desenvolvimento das DCV, vários aspectos metodológicos devem ser considerados nos estudos e na interpretação dos achados referentes a fatores na dieta: 
a) o tipo de estudo (experimental, metabólico, epidemiológico ou ensaio clínico); b) o tipo de variável resposta ou desfecho (morbidade, mortalidade ou variáveis intermediárias, como, por exemplo, a hipertensão arterial); c) problemas na aferição da exposição (dieta), que incluem a ausência de padrão-ouro para a determinação do consumo habitual de alimentos, o uso de tabelas de composição de alimentos, o desconhecimento tanto do tempo necessário para que a exposição possa provocar a doença quanto do tipo de relação que pode existir entre essas variáveis (ou seja, linear, em J, ou em U); d) o fato de a dieta não saudável com freqüência ocorrer juntamente com outros comportamentos também não saudáveis; e) o fato de os efeitos da dieta sobre o risco cardiovascular dependerem das alterações tanto do peso corporal quanto dos lípides séricos, da pressão arterial e de fatores inflamatórios e trombóticos. Esses aspectos remetem à questão de quando e como ajustar essas variáveis (variações intermediárias) na avaliação do efeito da dieta sobre as DCV (Willett, 1998).

\section{Nutrientes e Doenças Cardiovasculares}

Nas últimas décadas, diversos pesquisadores em todo o mundo investigam o papel da dieta habitual na prevenção das DCV, particularmente no que diz respeito ao consumo de gorduras, carboidratos, fibras, álcool e antioxidantes. Assim, neste capítulo, será dado maior destaque a esses componentes dietéticos.

\section{Gorduras Dietéticas}

A maior parte das gorduras naturais é composta por 98 a 99\% de triglicérides, e a grande maioria destes é de cadeias longas; o restante inclui traços de mono e diglicerídeos, ácidos graxos livres, fosfolipídeos e material não saponificável que contém esteróides. Os triglicérides são compostos por átomos de carbono, hidrogênio e oxigênio. Os ácidos graxos podem ter de quatro a trinta átomos de carbono e constituem a parte principal dos triglicérides; podem ser agrupados em saturados (AGS), monoinsaturados (AGM) e poliinsaturados (AGP). O grau de saturação pelo hidrogênio é definido como o número de duplas ligações entre os átomos de carbono na cadeia.

Os AGS não contêm duplas ligações e, geralmente, o comprimento de suas cadeias varia de 12 a 18 átomos de carbono; os mais comuns na dieta são o ácido palmítico, o esteárico, o mirístico e o láurico. Suas principais fontes incluem os laticínios, as carnes de vaca, de cordeiro, de porco e de frango.

Sabe-se que a composição lipídica da membrana celular é regulada pela composição de ácidos graxos da dieta (Haag \& Dippenaar, 2005). Os AGS aumentam a concentração da LDL plasmática pela diminuição do catabolismo da LDL; este efeito é mediado tanto pela expressão diminuída do RNAm do receptor LDL quanto pela menor fluidez da membrana (Schaefer, 2002). Além disso, como sugerido por Soinio e colaboradores (2003), o consumo elevado de alimentos ricos em gorduras saturadas pode induzir a RI, piorando o controle glicêmico.

As relações entre as gorduras da dieta e as DCV, particularmente a DC, são muito investigadas, com associaçôes fortes e consistentes geradas por um vasto corpo de evidências vindas de estudos com animais, epidemiológicos, ensaios clínicos e estudos metabólicos realizados em diferentes populações.

Inicialmente, considerou-se a relação entre as gorduras da dieta como mediada principalmente pelo seu efeito sobre os lípides séricos. De acordo com essa hipótese, o consumo elevado de AGS e colesterol e diminuído de AGP reduz os níveis sanguíneos de colesterol, importante fator causal da placa aterosclerótica (Willett, 1998; WHO/FAO, 2003). Mais recentemente, investigaram-se também os efeitos da gordura dietética sobre a função endotelial e trombose, bem como as relaçôes deste nutriente com a adiposidade corporal e as vias de inflamação.

Em diferentes populações, comprova-se a associação entre as DCV e as concentrações sangüíneas do colesterol total e da sua fração LDL. Identificou-se também a açãao protetora da HDL, e a razão entre o colesterol total e a fração HDL surgiu como um forte preditor do risco de DCV. Os níveis sanguíneos de triglicérides também se 
mostraram associados diretamente ao risco de doença aterosclerótica e a fenômenos tromboembólicos, embora esta associação não seja tão consistente como a verificada com a colesterolemia. Os efeitos das diferentes gorduras dietéticas sobre o perfil lipídico do plasma constituem o evento-chave na via causal que relaciona a dieta às DCV.

As concentrações de colesterol total no sangue e nos tecidos são influenciadas tanto pela síntese endógena como pela dieta. Lacticínios e carnes são as suas principais fontes. $\mathrm{O}$ ovo é rico em colesterol, mas, diferentemente dos outros alimentos de origem animal, não fornece AGS. O colesterol da dieta eleva os níveis dessa substância no sangue, porém seu efeito sobre a razão colesterol total/HDL, apesar de desfavorável, é pequeno. Evidências de estudos observacionais que relacionam o colesterol da dieta com as DCV são contraditórias. O limite superior recomendado para a ingestão diária de colesterol é de $300 \mathrm{mg}$; contudo, como não se trata de nutriente essencial (é sintetizado pelo organismo), sua ingestão deve ser a menor possível.

Em estudos epidemiológicos, tanto o teor total de gorduras da dieta, o consumo excessivo de AGS e de colesterol quanto a baixa ingestão de AGP associam-se consistentemente com maiores taxas de morbi-mortalidade por DCV (McGee et al., 1984; Kushi, Lew \& Stare, 1985; Joossens, Geboers \& Kesteloot, 1989; Ascherio et al., 1994; Tell et al., 1994; Albert et al., 1998) ou com o melhor perfil metabólico dos indivíduos (Apple et al., 2005; Howard et al., 2006; Nordmann et al., 2006). Estudos com animais ou de intervenção dietética também confirmaram esses achados (Dayton et al., 1968, Frantz Jr. et al., 1989, Watts et al., 1992; De Lorgeril et al., 1994).

Os AGS e os AGM podem ser sintetizados pelo organismo. Os AGP são subdivididos em n-6 e n-3, derivados, respectivamente, dos ácidos linoléico (AL) e $\alpha$-linolênico (AAL), os quais são essenciais (Lai et al., 2006).

Os AGS, como um grupo, elevam os níveis séricos do colesterol total e da fração LDL. Os ácidos mirístico e láurico têm maior efeito sobre essa elevação que o palmítico, porém tal poder torna-se muito maior quando estes são ingeridos em combinação com o colesterol da dieta. Aparentemente, o ácido esteárico não eleva o colesterol no sangue e é rapidamente convertido, in vivo, em ácido oléico.

Estudos metabólicos mostram que os AGS da dieta induzem a uma marcada elevação das frações HDL e LDL. Mudanças na razão colesterol total/HDL nem sempre são acompanhadas de alterações no colesterol total. $\mathrm{Na}$ dieta, a substituição de AGS por AGP diminui essa razão, mas quando a troca é feita por carboidratos este efeito não é observado. Uma vez que a substituição de AGS por carboidratos reduz proporcionalmente as frações LDL e HDL, esta tem pouco efeito sobre a razão LDL/HDL; considerando também o aumento que provoca nos níveis séricos de triglicérides, essa mudança na dieta tem pouco efeito sobre o risco de DC. Quando os AGM ou os AGP substituem os AGS, a LDL diminui e a HDL pouco se altera. Mais que isso, a substituição de AGS por AGP pode melhorar a sensibilidade à insulina e o DM tipo 2 (WHO/FAO, 2003; Hu \& Willett, 2002).

Uma dieta com baixo teor de gorduras e rica em carboidratos, quando comparada com outra rica em AGM, causa uma pequena queda no HDL, diminuindo a razão colesterol total/HDL. Os AGP são mais efetivos nesse aspecto do que os AGM, e nenhum deles eleva os níveis séricos dos triglicérides.

Gorduras ricas em ácido láurico (frutas tropicais) aumentam significativamente os níveis do colesterol sérico, mas, devido ao seu efeito específico sobre a HDL, a razão entre essas lipoproteínas não se altera. Destaca-se que esses efeitos podem variar com a idade dos indivíduos.

Os ácidos graxos trans são isômeros geométricos de AGM, que assumem configuração semelhante à dos AGS. A hidrogenação parcial (processo no qual são criados os ácidos graxos trans) também remove ácidos graxos essenciais como o AL e o AAL.

Estudos metabólicos mostraram que os trans são mais aterogênicos que os AGS, pois, além de aumentarem os níveis séricos da LDL, diminuem os da fração HDL. Assim, a razão LDL/HDL é maior entre indivíduos que consomem dietas com esses ácidos graxos do que entre aqueles com dieta contendo AGS ou ácido oléico. A maioria dos ácidos graxos trans da dieta vem de óleos industrializados, mas os laticínios e carnes de ruminantes também contêm este nutriente. Sua eliminação da dieta constitui estratégia importante para a prevenção das DCV (Hu \& Willett, 2002; WHO/FAO, 2003). 
O único AGM da dieta importante, do ponto de vista nutricional, é o ácido oléico, abundante nos óleos de canola, azeite de oliva e nas frutas oleaginosas. As evidências epidemiológicas que relacionam os AGM às DCV são originadas de estudos com a dieta mediterrânea, entre outros. Os AGM reduzem os níveis séricos de glicose e triglicérides em indivíduos com DM tipo 2 e podem diminuir a susceptibilidade da LDL à oxidação.

O ácido araquidônico é um importante AGP n-6. Os ácidos eicosapentanóico (EPA) e o docasaexanóico (DHA) são importantes AGP n-3. Eicosanóides, derivados do ácido araquidônico, têm propriedades metabólicas opostas àquelas dos DHA; assim, a dieta deve ser balanceada em AGP n-6 e n-3.

Um aspecto que diferencia o peixe e outros animais marinhos dos terrestres é a presença de EPA e DHA em seus lípides. Em dietas vegetarianas, é necessária a inclusão de soja e folhas verdes para atender às necessidades de AGP n-3.

Os efeitos biológicos dos AGP n-3 variam em um amplo espectro e incluem melhora do perfil lipídico do plasma, pressão arterial, função cardíaca, função endotelial, ação antiplaquetária e antiinflamatória. O DHA parece ser mais responsável pelos efeitos benéficos do peixe e óleo de peixe sobre os lípides séricos, a pressão arterial, o débito cardíaco e o controle glicêmico, ao passo que o EPA e DHA diminuem a agregação plaquetária (WHO/FAO, 2003; Engler \& Engler, 2006; Hooper et al., 2006).

Estudos mostraram que o consumo de duas ou mais porções de peixe por semana (4 g de ácidos graxos n-3) pode reduzir em $30 \%$ o risco de DCV, pois, apesar de elevar os níveis séricos tanto da HDL quanto da LDL, o aumento da LDL, aparentemente, se dá às custas de partículas maiores, menos aterogênicas (Engler \& Engler, 2006).

O AAL (ácido graxo ômega-3 encontrado nos óleos de canola e soja) pode, em humanos, ser convertido para EPA e DHA e, assim, contribuir para a prevenção das DC (Hu \& Willett, 2002).

A definição das proporções adequadas de AGS, AGM e AGP em relação ao Valor Calórico Total da dieta (VCT) é importante em função de sua forte relação com as DCV, especialmente a DC; contudo, aparentemente, o tipo de gordura é mais importante que a quantidade (a dieta mediterrânea fornece teor de gorduras $\geq 30 \%$ do VCT e os indivíduos que a consomem têm menor risco para esse grupo de doenças que os demais).

A redução dos AGS é recomendada por diversas sociedades científicas e órgãos de saúde, mas qual componente deve ser o seu substituto é matéria controversa. Tanto os AGM quanto os AGP melhoram o perfil lipídico, embora os AGP sejam mais efetivos. As recomendações dietéticas americanas indicam que os AGS representem de 7 a 8\% do VCT; os AGM, de 13 a 15\%; os AGP, de 7 a 10\% do VCT, e que as gorduras totais não ultrapassem 30\% do VCT (WHO/FAO, 2003). A prevenção (primária ou secundária) das DCV pode ser realizada por meio da redução de alimentos fontes de AGS e da eliminação dos ácidos graxos trans da dieta, com aumento do consumo de alimentos fontes de AGM e AGP e a redução do colesterol.

\section{Carboidratos e Energia}

A relação entre os carboidratos e as DCV parece ser mediada por mecanismos indiretos, incluindo sua contribuição para o VCT da dieta e seu efeito sobre o excesso de peso e distribuição da adiposidade corporal, sua influência sobre as concentrações sanguíneas de lípides, particularmente os triglicérides, e o controle glicêmico (WHO/FAO, 2003; Nordmann et al., 2006).

Dietas com alto teor de carboidratos parecem reduzir os níveis séricos de HDL e aumentar os da LDL pequenas e densas, com impacto adverso sobre a saúde cardiovascular. Tal perfil de lipoproteínas favorece ainda a elevação dos triglicérides plasmáticos. Contudo, não há evidências claras de que o risco cardiovascular seja alterado, de forma independente, pelo teor de carboidratos da dieta, pois a diminuição deste nutriente implica, em contrapartida, o aumento do consumo de lípides ou proteínas (WHO/FAO, 2003). 
O Índice Glicêmico (IG) da dieta pode ser um indicador da influência dos carboidratos no controle glicêmico (dieta com elevado IG piora o controle e está associada com mudanças nos lípides séricos). Alimentos com baixa capacidade de gelatinização do amido (grãos mais compactos), tais como o macarrão, e alto conteúdo de fibras viscosas (por exemplo, cevada, aveia e centeio) têm digestão mais lenta e, assim, menor IG. A carga glicêmica (IG $\mathrm{x}$ teor de carboidratos do alimento) é utilizada para representar tanto a qualidade quanto a quantidade do carboidrato consumido e associa-se aos níveis séricos elevados de triglicérides e diminuídos de HDL. Até o momento, os alimentos com baixo IG que podem ser recomendados são as verduras, os legumes e as leguminosas (Hu \& Willett, 2002; WHO/FAO, 2003).

\section{Fibra Dietética}

São denominadas fibras dietéticas uma mistura heterogênea de polissacarídeos e lignina que não pode ser degradada por enzimas endógenas de animais vertebrados. Podem ser solúveis em água (pectinas, gomas, mucilagens e algumas hemiceluloses) ou insolúveis (celulose e outras hemiceluloses). As fibras solúveis que têm propriedade de formar gel podem ser também chamadas de viscosas (Erkkila \& Lichtenstein, 2006).

Há evidências de que dietas ricas em fibras alimentares podem prevenir o aparecimento do DM e, possivelmente, de suas complicações (WHO/FAO, 2003). Seu efeito pode ser mediado pela digestão e absorção lenta dos carboidratos, o que leva à redução da demanda de insulina. Frutas, verduras, legumes, grãos e cereais integrais são as principais fontes de fibras na dieta.

Resultados de estudos experimentais com animais e de intervenção clínica mostram que a ingestão elevada de fibras viscosas pode reduzir as concentraçōes séricas de LDL; Wu e colaboradores (2002) atribuem esse fato à sua solubilidade e sua capacidade de se ligar ao ácido biliar e inibir a síntese de colesterol, provavelmente após fermentação no cólon intestinal.

A maioria das fibras solúveis diminui as concentrações séricas de colesterol total e LDL sem afetar as de HDL. O consumo de fibras, quando comparado ao de outros componentes da dieta, é melhor preditor do ganho de peso, dos níveis séricos de insulina, triglicérides, HDL, LDL e fibrinogênio; contudo, esse resultado pode ocorrer devido ao efeito exercido por outros determinantes da saúde cardiovascular. Recomenda-se, atualmente, de 25 a 30 gramas de ingestão diária de fibras (Erkkila \& Lichtenstein, 2006).

\section{Antioxidantes}

Oxidantes são produtos do metabolismo aeróbio normal e de resposta inflamatória; constituem um grupo diverso tanto do ponto de vista químico quanto de comportamento e, até o momento, não se sabe ao certo quais deles seriam importantes para o desenvolvimento de diversas DCNT. De forma semelhante, os antioxidantes formam um grupo de componentes com diferentes propriedades; eles atuam inibindo a formação de oxidantes ou, quando estes se formam, interrompem sua ação e reparam o dano resultante.

Uma estratégia possível para prevenir a DCV seria a de utilizar antioxidantes que atuassem ou inibindo a oxidação da LDL ou modificando a suscetibilidade ou a resistência desta lipoproteína aos oxidantes (Tribble, 1999). Porém, até o momento, os resultados de intervenções nessa linha em seres humanos não são muito animadores. Recentemente, Bleys e colaboradores (2006) mostraram, após a realização de metanálise que incluiu diversos estudos do tipo ensaio clínico com alocação aleatória dos indivíduos, que a suplementação de antioxidantes (vitaminas $\mathrm{C}, \mathrm{E}, \beta$-caroteno ou selênio) não alterou o curso da progressão da aterosclerose em humanos.

A oxidação da LDL por radicais livres é resultado de uma captação anormal da LDL por macrófagos na parede das artérias, que acelera o processo aterosclerótico. Antioxidantes dietéticos, tais como as vitaminas $\mathrm{C}$ 
(ácido ascórbico), E ( $\alpha$-tocoferol) e o $\beta$-caroteno (provitamina A), podem retirar diretamente os radicais livres (quelantes). Tais mecanismos sugerem que a ingestão aumentada ou a suplementação com esses nutrientes poderia proteger contra lesôes vasculares. Essas evidências provêm especialmente de resultados de estudos observacionais, mas os achados de ensaios clínicos com suplementos são desapontadores (WHO/FAO, 2003).

O sistema de defesa antioxidante inclui componentes tanto endógenos como exógenos que atuam sobre as lipoproteínas e, em nível molecular, protegendo a membrana celular e o DNA contra o efeito danoso dos radicais livres. Antioxidantes endógenos são enzimas naturalmente presentes no organismo, e os exógenos entram no organismo pela dieta (Rauma \& Mykkanen, 2000).

$\mathrm{O}$ papel de componentes dietéticos, tais como a vitamina $\mathrm{C}, \mathrm{E}$ e o $\beta$-caroteno, recebem atenção especial no que diz respeito à prevenção das DCV. O enriquecimento in vitro da LDL com vitamina E aumenta a resistência desta lipoproteína à oxidação, mas o mesmo não se observa para o $\beta$-caroteno (Tribble, 1999; Ricciarelli, Zingg \& Azzi, 2001).

Resultados de diferentes estudos epidemiológicos mostram associações entre a diminuição de morbidade e mortalidade por DCV e a ingestão (ou o nível sérico) de antioxidantes, tais como as vitaminas $\mathrm{C}$ e E. Na maior parte das vezes, a ingestão de antioxidantes (via alimentação ou suplementação medicamentosa) esteve associada a menor risco de desenvolver a doença (Gale et al., 1995; Klipstein-Grobusch et al., 1999; Tribble, 1999; Hirvonen et al., 2000; Liu et al., 2000, 2001; Johnsen et al., 2003; Chattopadhyay \& Bandyopadhgay, 2006).

A vitamina C é um agente redutor (doador de elétrons) e quelante de radicais livres; a vitamina $\mathrm{E}$ pode se concentrar no interior da camada fosfolipídica da membrana celular e reagir com radicais peroxil lipídico e superóxido, interrompendo, assim, a cadeia de reações de peroxidação lipídica, prevenindo o dano ao tecido (Mooradian et al., 1994; Wen et al., 1996). Após revisão do tema, Ness e Powles (1997) afirmaram que, embora os achados nulos possam estar subrelatados na literatura, os resultados dos estudos publicados são consistentes com um forte efeito protetor do consumo freqüente de frutas e vegetais para o AVC e um efeito moderado para a DC. Os autores sugerem que investigações sejam realizadas também em termos de alimentos, e não apenas de nutrientes.

Dados do Nurses Health Study, no qual mais de 85 mil mulheres foram acompanhadas por um período de até oito anos, revelaram, mesmo após o ajuste simultâneo para a idade e o hábito de fumar, menor risco de desenvolver DCV entre aquelas com maior consumo de vitamina E, quando comparadas às demais (Stampfer et al., 1993). Rimm e colaboradores (1993) encontraram resultados semelhantes com base na coorte do Health Professionals Follow-up Study, com seguimento de mais de 39 mil homens por cerca de 14 anos. Os autores também relataram - apenas entre os indivíduos fumantes ou ex-fumantes - efeito protetor estatisticamente significativo do $\beta$-caroteno. Esses achados foram consistentes com os observados em outros estudos que também relataram existência de associação entre o menor risco de DCV e o consumo de $\beta$-caroteno ou outros carotenóides, particularmente em fumantes (Gey et al., 1993; Knekt et al., 1994; Morris, Kritchvsky \& Davis, 1994; Gaziano et al., 1995; Kushi et al., 1996; Tavani et al., 1997; Kritchevsky et al., 1998). Nenhum desses estudos encontrou relação entre o consumo de vitamina C e a redução do risco de DCV. Posteriormente, Ascherio e colaboradores (1999), também utilizando dados da coorte do Health Professionals Follow-up Study, não encontraram relação entre o consumo de vitamina E, C e de vários carotenóides e a ocorrência de AVC entre homens americanos.

Embora estudos epidemiológicos observacionais embasem os benefícios à saúde dos antioxidantes (Enstrom, Kanim \& Kelvin, 1992; Will, Ford \& Bowman, 1998; Ford et al., 1999, 2003), os resultados dos estudos do tipo ensaio clínico que utilizaram terapia com antioxidantes são controversos. Contudo, até o presente momento, realizaram-se poucas pesquisas desse tipo com grande número de indivíduos; o maior deles foi o ATBC Study (Tornwall et al., 2004), em que, apesar de o principal objetivo ter sido avaliar o efeito de vitaminas antioxidantes sobre o câncer de pulmão, os pesquisadores também relataram seus efeitos sobre a DCV; tanto para o câncer de pulmão como para as DC, os autores não observaram redução no risco, após vários anos de acompanhamento. 
Mais do que isso, tanto para a vitamina $\mathrm{E}$ como para o $\beta$-caroteno, ocorreu um aumento na chance de morrer por AVC hemorrágico e por câncer de pulmão, respectivamente.

Hennekens e colaboradores (1996), após 12 anos de acompanhamento de indivíduos recebendo suplementação com o $\beta$-caroteno, não observaram efeito desta vitamina sobre a incidência de câncer e de DCV. Lonn e colaboradores (2002) não observaram benefícios sobre a ocorrência de eventos cardiovasculares e de nefropatia após 4,5 anos de utilização de suplementação com 400 UI (Unidades Internacionais) por dia de vitamina $\mathrm{E}$ em indivíduos com alto risco para DCV, quando comparados aos que utilizaram placebo; Hodis e colaboradores (2002) observaram resultados semelhantes. Apenas um ensaio clínico mostrou redução no risco de DCV após suplementação com vitamina E (Stephens et al., 1996).

Apesar de a vitamina E aumentar a resistência da LDL à oxidação e diminuir a citotoxidade da LDL oxidada, uma dificuldade em relacionar seu efeito à aterosclerose pode estar no fato de que esta doença envolve não apenas a formação da placa, mas também sua ruptura com trombose (Diaz et al., 1997). Chisolm e Steinberg (2000) sugerem ainda que talvez seja necessário o uso de antioxidantes mais potentes com diferentes distribuiçôes nos tecidos. Além disso, é provável que o início da suplementação com antioxidantes deva ocorrer precocemente, antes do início das lesões, e por longos períodos. Jha e colaboradores (1995) chamam a atenção para o fato de que, ao passo que os estudos epidemiológicos focalizaram o hábito alimentar por vários anos ou até mesmo por décadas, os ensaios clínicos utilizam a suplementação com vitaminas por um período mais curto.

Os resultados de estudos de prevenção secundária são mais consistentes em apontar benefícios das vitaminas antioxidantes (Wen et al., 1996; Antoniades et al., 2004; Kinlay et al., 2004). Sthephens e colaboradores (1996) testaram os efeitos de altas doses de $\alpha$-tocoferol (400 ou 800 UI por dia) sobre a ocorrência de eventos cardiovasculares em indivíduos com coronariopatia diagnosticada por cinecoronariografia e encontraram associação inversa entre as concentrações dessa vitamina e a ocorrência de infarto agudo do miocárdio e todos os eventos cardiovasculares em conjunto, mas não se observou impacto na mortalidade.

O possível efeito protetor da vitamina C contra a HA é abordado no capítulo 23 deste livro, "Fatores nutricionais e hipertensão arterial".

Explicaçôes para os resultados discordantes entre os diferentes estudos incluem ausência do controle do efeito de confusão exercido por outros fatores; interação (entre antioxidantes ou com outros nutrientes); isômeros com atividades diferentes no alimento e no suplemento; dissociação temporal entre os níveis sanguíneos de antioxidantes lipossolúveis quando ingeridos com gorduras na refeição e os níveis verificados quando da administração em pílula uma vez ao dia.

\section{Folato}

Folato é o termo genérico usado para componentes que têm estrutura e função semelhantes às do ácido fólico. Os mamíferos não têm a enzima necessária para sintetizar o folato e, assim, dependem inteiramente da dieta para obtê-lo. Boas fontes deste nutriente incluem os vegetais de folhas verdes, os legumes, os cogumelos e o fígado. Os alimentos crus, quando comparados aos cozidos, têm maior quantidade de folato devido ao processo de hidrólise desta vitamina durante a cocção. Nos alimentos, o folato está presente sob a forma de poliglutamato, e sua biodisponibilidade é de aproximadamente $50 \%$ daquela observada para a forma sintética, o monoglutamato (Moat et al., 2004).

O folato facilita a transferência de unidades de carbono em diversas reações biossintéticas, tais como a síntese de purinas e pirimidina, a regeneração de metionina e o metabolismo de aminoácidos. A ingestão adequada de folato é vital para a divisão e para a homeostase celular, para a produção do DNA e a regulação do metabolismo (Moat et al., 2004). 
A relação entre o folato e as DCV é explorada devido ao seu efeito sobre a homocisteína, considerada fator de risco independente para DC e, provavelmente, AVC, mas os resultados de estudos publicados são controversos (Bleys et al., 2006). O ácido fólico é necessário para a metilação da homocisteína para metionina. Níveis séricos diminuídos de folato estão associados com concentração aumentada de homocisteína; a suplementação com folato reduz esses níveis (WHO/FAO, 2003).

A homocisteína é um aminoácido sulfidril formado durante a conversão de metionina para cistina, que pode ser tóxica para o endotélio; é pró-trombótica, estimula a produção de colágeno e diminui a disponibilidade de óxido nítrico. Resultados de estudos populacionais mostram que, em geral, seus níveis séricos são maiores entre indivíduos do sexo masculino, apresentam correlação positiva com a idade, com os níveis séricos de albumina, de creatinina e de ácido úrico, e negativa com as concentrações sangüíneas de folato e vitaminas $\mathrm{B}_{6}$ (piridoxina) e $\mathrm{B}_{12}$. Aparentemente, a concentração de homocisteína é afetada pelo hábito de fumar e pelo consumo de café e de bebidas à base de cola (Lussier-Cacan et al., 1996; Giles et al., 1999; Rasmussen et al., 2000; Jacques et al., 2001).

Em estudos populacionais, os valores plasmáticos de homocisteína são inversamente associados aos níveis plasmáticos de folato, mesmo entre os valores considerados normais. Situação semelhante é observada em relação à quantidade de folato ingerida pelos indivíduos. Entretanto, as associações entre as concentrações de homocisteína e os valores das vitaminas $\mathrm{B}_{6}$ e $\mathrm{B}_{12}$ são fracas.

O folato pode reduzir os níveis séricos de homocisteína de forma eficiente, mas o mesmo não é observado em relação às vitaminas $\mathrm{B}_{6}$ e $\mathrm{B}_{12}$. Há evidências de que a riboflavina (vitaminas $\mathrm{B}_{2}$ ) é também um determinante das concentrações de homocisteína (Hustad et al., 2000; Moat et al., 2004). Baró e colaboradores (2003) observaram que, após suplementação com leite enriquecido com AGP, ácido oléico, ácido fólico e vitaminas E e $\mathrm{B}_{6}$, houve redução dos níveis séricos de homocisteína e melhora do perfil de risco cardiovascular.

A primeira evidência de que concentrações elevadas de homocisteína aumentavam o risco de DCV datam de 1969, com estudo realizado por McCully. A hiperhomocisteinemia pode ser conseqüência de deficiência de folato, de vitamina $B_{12}$ ou de enzimas envolvidas na via de remetilação desse aminoácido. Sabe-se que concentrações elevadas de homocisteína induzem à formação de PH e de LDL oxidada e podem ser citotóxicas para as células endoteliais. O tratamento com ácido fólico pode favorecer a reversão desse quadro (Cines et al., 1998; Ross, 1999; Spencer et al., 2004).

Alguns autores afirmam que a elevação dos níveis sanguíneos de homocisteína pode ser conseqüência da aterosclerose, considerando que a função renal comprometida pela doença na artéria renal contribui para a elevação dos níveis de homocisteína. De qualquer forma, se a hiperhomocisteinemia atua na promoção da trombose, a intervenção com folato torna-se atraente. Evidências recentes sugerem que a elevação da homocisteinemia resulta em disfunção endotelial, efeito que pode ser revertido com suplementação oral de folato. Sugeriu-se, ainda, que o folato poder ter efeito antioxidante. Em um ensaio clínico feito com cinqüenta indivíduos com DC, Doshi e colaboradores (2004) observaram, após a administração por seis semanas de $5 \mathrm{mg}$ por dia de ácido fólico (ou vitamina $\mathrm{B}_{9}$ ), aumento na biodisponibilidade do óxido nítrico, mas não encontraram relação com outros marcadores da função endotelial (fator Van Willebrand, selectina-E e trombomodulina). Moat e colaboradores (2004) concordam que altas doses de ácido fólico poderiam amenizar a disfunção endotelial em indivíduos assintomáticos e com hiperhomocisteinemia.

Em suma, as evidências acumuladas sugerem que o ácido fólico pode: a) prevenir a disfunção endotelial; b) reduzir a concentração plasmática de homocisteína; c) ser quelante de radicais superóxido, d) inibir a oxidação da LDL; e) tanto estabilizar quimicamente a tetraidrobiopterina quanto regenerar esse co-fator de sua forma inativa $\left(\mathrm{BH}_{2}\right)$. 


\section{Outros}

\section{Flavonóides e Outros Fitoquímicos}

Flavonóides são antioxidantes polifenólicos que estão presentes em diversos alimentos de origem vegetal (chá, maçã e alho, por exemplo). Dados de diversos estudos indicam a existência de associação inversa entre o teor de flavonóides da dieta e o risco de DCV e, provavelmente, de AVC, contudo não se deve descartar o eventual efeito de confusão por outros fatores, que pode explicar a discordância entre os resultados encontrados na literatura.

Frutas e vegetais também contêm outros fitoquímicos que podem ter propriedades protetoras (fitoestrógenos, sulfido), entretanto, até o momento, não está claro seu papel em relação às DCV.

\section{Alguns Minerais}

A elevação da pressão arterial é o principal fator de risco para as DCV, especialmente AVC. Dos muitos fatores de risco dietéticos associados à $\mathrm{HA}$, o papel de minerais, tais como o sódio, o potássio, o cálcio e o magnésio, merece destaque (ver capítulo 23, "Fatores nutricionais e hipertensão arterial").

Diversos autores sugerem que vários outros minerais, entre eles o selênio, o cobre, o zinco e o magnésio, podem atuar como protetores contra as DCV, dada sua atuação como co-fatores de enzimas com atividade antioxidante, como, por exemplo, a glutadiona peroxidase e o superóxido dismutase (Mooradian et al., 1994; Willett, 1998; Tribble, 1999).

\section{Alimentos e Doenças Cardiovasculares}

Investigações que adotaram a abordagem alimento (ou grupo de alimentos) versus aparecimento de DCV mostraram que o consumo elevado de frutas e outros vegetais promovem benefícios à saúde, particularmente em relação à sua capacidade de diminuir os níveis de pressão arterial (WHO/FAO, 2003). Joshipura e colaboradores (1999), utilizando dados do Nurses Health Study e do Health Professionals Follow-up Study observaram, após seguimento médio de 8 e 14 anos, respectivamente, que o maior consumo de frutas (em especial as cítricas) e outros vegetais (verduras cruas e de folhas verdes) associou-se ao menor risco de AVC isquêmico. Atribuiu-se tal fato ao elevado conteúdo de potássio, folato, fibras, flavonóides e vitaminas desses alimentos.

Outros efeitos positivos quanto à diminuição do risco cardiovascular registrados na literatura estão relacionados a: 1) a substituição de carne vermelha por frango ou peixe (Hu \& Willett, 2002); 2) o consumo aumentado de frutas oleaginosas - fonte de fibras, AGM e AGP que reduzem os níveis séricos de LDL (Hu \& Willett, 2002) e 3) a ingestão de soja e derivados (alimento rico em isoflavonas - estrógeno vegetal), que diminui o colesterol total e a fração LDL sem alterar os níveis séricos de HDL e de triglicérides).

Sabe-se que o consumo elevado de álcool é importante fator de risco para a saúde, porém sua ingestão em pequenas quantidades pode ser benéfica, especialmente na prevenção das DCV (Fuchs et al., 2004; Tolstrup et al., 2006). Rumpler e colaboradores (1999) destacam que o consumo moderado de álcool, assim como dietas com baixo teor de gorduras, particularmente em AGS, pode reduzir a incidência de DCV. Segundo os autores, esse impacto se deve, em grande parte, aos seus efeitos sobre os lípides e as lipoproteínas séricas; ao passo que dietas pobres em gorduras podem reduzir os níveis sangüíneos de colesterol total e da fração LDL, o consumo de álcool pode tanto reduzir os níveis de LDL quanto aumentar os de HDL.

Considera-se o consumo moderado de álcool, definido por Hu, Manson e Willet (2001) como a ingestão de cerca uma dose de bebida alcoólica ao dia, fator de proteção para o DM. Os resultados de um estudo de coorte, realizado com 84.941 mulheres acompanhadas por 16 anos, mostraram que o excesso de peso no início 
do seguimento foi o preditor mais importante para o DM; além dele, foram também importantes a ausência do consumo de álcool, o sedentarismo, o tabagismo, a dieta rica em lípides e pobre em fibras ( $\mathrm{Hu}$, Manson \& Willett, 2001).

\section{Padrōes Alimentares e Doenças Cardiovasculares}

A dieta mediterrânea, em diferentes estudos, associa-se ao menor risco cardiovascular. Baseia-se em menor consumo de carnes e derivados, elevado consumo de legumes, cereais, frutas e outros vegetais, moderado consumo de álcool e laticínios, sendo o óleo de oliva, conhecido por ter elevada razão entre AGM e AGS, utilizado no preparo dos alimentos (Engler \& Engler, 2006). Resultados semelhantes são também relatados para a dieta vegetariana e para a dieta típica japonesa (consumo reduzido de açúcar e gorduras e elevado de soja e peixe, porém também elevado em sal de cozinha) (WHO/FAO, 2003).

Em contrapartida, a dieta tipicamente ocidental, caracterizada pelo alto consumo de carnes vermelhas e processadas, frituras, açúcares e grãos refinados, está associada ao maior risco cardiovascular, independentemente de outros fatores de risco (estilo de vida) (Hu \& Willett, 2002).

Considerando o fato de que a prevenção das DCV, baseada em mudanças no estilo de vida, não é factível em um curto intervalo de tempo, Wald e Law (2003) aventaram hipoteticamente uma estratégia de prevenção das DCV baseada na chamada polipílula, que, composta por seis substâncias (estatina, aspirina, ácido fólico, mais a combinação de três drogas redutoras da pressão arterial), seria capaz de reduzir cerca de $80 \%$ dos casos dessas doenças. Em contraponto, Franco e colaboradores (2004) propuseram a polirrefeição, com efeito semelhante ao da polipílula, composta pela ingestão diária de $114 \mathrm{~g}$ de peixes de águas profundas (ricos em ácidos graxos ômega-3), $150 \mathrm{ml}$ de vinho, $100 \mathrm{~g}$ de chocolate, $400 \mathrm{~g}$ de frutas e outros vegetais, $68 \mathrm{~g}$ de frutas oleaginosas e 2,7 gramas de alho. Porém, Lennie (2006) comenta que a proposta da polirrefeição para se contrapor à polipílula, apesar de atraente, ignora o fato de que o efeito do consumo de determinados alimentos não pode ser considerado isoladamente, pois a dieta habitual consiste em um conjunto de elementos que atuam de forma sinérgica.

\section{Considerações Finais}

Como mostraram Hu e Willett (2002), numerosos aspectos do tema dieta e DCV permanecem sem esclarecimento. Desses aspectos, alguns dos principais são: a) qual a quantidade adequada de AGM e AGP (pois uma dieta rica em AGP pode aumentar o risco de câncer); b) qual a proporção ideal entre ácidos graxos ômega-3 e 6; c) qual a quantidade e o tipo de proteína na dieta, pois sabe-se que a ingestão elevada de proteínas ( $24 \%$ vs $15 \%$ ) diminui significativamente o risco cardiovascular e, para evitar o aumento de AGS, as principais fontes de proteína na dieta devem ser as frutas oleaginosas, leguminosas, frango e peixes; d) apesar de promissor, permanece incerto o papel dos fitoquímicos e antioxidantes na prevenção da DCV; e) o papel de minerais, tais como o selênio, cálcio, magnésio e zinco, no risco cardiovascular permanece inconclusivo. A maioria dos estudos que aborda o tema é do tipo ecológico ou caso-controle. São necessários mais estudos do tipo coorte ou ensaios clínicos com desfechos clínicos.

Sabe-se que pelo menos três estratégias são efetivas na redução do risco cardiovascular: a) substituir AGS e trans por AGM ou AGP; b) aumentar o consumo de alimentos ricos em ácidos graxos ômega-3 (peixes ou vegetais); c) dieta rica em frutas, vegetais, frutas oleaginosas, cereais integrais, com consumo reduzido de carboidratos refinados.

Além disso, a obesidade é uma importante condição pela qual a dieta interfere no risco cardiovascular. Entretanto, a relação entre a dieta, especialmente a gordura dietética, e a obesidade permanece controversa. 
Embora a redução de calorias seja recomendada para a perda de peso, não existem evidências oriundas de ensaios clínicos de longa duração sobre este benefício per se. O excesso de calorias (quer proveniente de gorduras, quer de carboidratos) induz ao ganho de peso, que agrava o risco cardiovascular por diversos mecanismos. É possível que uma dieta hipocalórica, com teor moderado de gorduras, restringindo as saturadas e trans, que permita maior variedade para a escolha dos alimentos, propicie maior adesão e traga mais benefícios a longo prazo do que uma dieta hipogordurosa ou aquelas muito restritas em carboidratos.

\section{Referências}

ALBERT, C. M. et al. Fish consumption and risk of sudden cardiac death. Jama, 279: 23-29, 1998.

ANTONIADES, C. et al. Vascular endothelium and inflamatory process in patients with combined type 2 diabetes mellitus and coronary atherosclerosis: the effect of vitaminan C. Diabetic Medicine, 21: 552-558, 2004.

APPLE, L. J. et al. Effects of protein, monunsaturated fat, and carbohydrate intake on blood pressure and serum lipids: results of the OmniHeart Randomized Trial. Jama, 294: 2.455-2.464, 2005.

ASCHERIO, A. et al. Acute myocardial infarction/antiplatelet and thrombolytic therapy: trans fatty acid intake and risk of myocardial infarction. Circulation, 89: 94-101, 1994.

ASCHERIO, A. et al. Relation of consumption of vitamin E, vitamin C, and carotenoids to risk for stroke among men in United States. Annals of Internal Medicine, 130: 963-970, 1999.

BARÓ, L. et al. n-3 Fatty acids plus oleic and vitamin supplemented milk consumption reduces total and LDL cholesterol, homocysteine and levels of endothelial adhesion molecules in healthy humans. Clinical Nutrition, 22: 175-182, 2003.

BERTOLI, S. et al. Nutritional status and dietary patterns in disabled people. Nutrition, Metabolism \& Cardiovascular Disease, 16: 100-112, 2006.

BLEYS, J. et al. Vitamin-mineral supplementation and the progression of atherosclerosis: a meta-analysis of randomized controlled trials. American Journal of Clinical Nutrition, 89: 880-887, 2006.

CHATTOPADHYAY, A. \& BANDYOPADHGAY, D. Vitamin E in prevention of ischemic heart disease. Pharmacology Report, 58: 179-187, 2006.

CHISOLM, G. M. \& STEINBERG, D. The oxidative modification hypothesis of atherogenesis: an overview. Free Radical Biology and Medicine, 28: 1.815-1.826, 2000.

CINES, D. B. et al. Endothelial cells in physiology and in the pathophysiology of vascular disorders. Blood, 91: 3.527-3.561, 1998.

DAYTON, S. et al. Controlled clinical trial of a diet high in unsaturated fat for prevention of atherosclerosis complications. The Lancet, 2: 1.060-1.062, 1968.

DE LORGERIL, M. et al. Mediterranean alpha-linolenic acid-rich diet in secondary prevention of coronary heart disease. The Lancet, 343: 1.454-1.459, 1994.

DIAZ, M. N. et al. Mechanism of disease: antioxidants and atherosclerotic heart disease. New England Journal of Medicine, 337: 408-416, 1997. 
DOSHI, S. N. et al. Short-term high-dose folic acid does not alter markers of endothelial cell damage in patients with coronary heart disease. International Journal of Cardiology, 94: 203-207, 2004.

ENGLER, M. M. \& ENGLER, M. B. Omega-3 fatty acids: role in cardiovascular health and disease. Journal of Cardiovascular Nursing, 21: 17-24, 2006.

ENSTROM, J. E.; KANIM, L. E. \& KELVIN, M. A. Vitamin C intake and mortality among a sample of the United States population. Epidemiology, 3: 194-202, 1992.

ERKKILA, A. T. \& LICHTENSTEIN, A. H. Fiber and cardiovascular disease risk: how strong is the evidence? Journal of Cardiovascular Nursing, 21: 3-8, 2006.

FORD, E. S. et al. Diabetes mellitus and serum carotenoids: findings from the Third National Health and Nutrition Examination Survey. American Journal of Epidemiology, 149: 168-176, 1999.

FORD, E. S. et al. The metabolic syndrome and antioxidant concentrations: findings from the Third National Health and Nutrition Examination Survey. Diabetes, 52: 2.346-2.352, 2003.

FRANCO, O. H. et al. The polymeal: more nature, safer, and probably tastier (than polypill) strategy to reduce cardiovascular disease by more than 75\%. British Medical Journal, 329: 1.447-1.450, 2004.

FRANTZ JR. I. D. et al. Test of effect of lipid lowering by diet on cardiovascular risk: the Minnesota Coronary Survey. Arteriosclerosis, 9: 129-135, 1989.

FUCHS, F. D. et al. Association between alcoholic beverage consumption and incidence of coronary heart disease in whites and blacks. American Journal of Epidemiology, 160: 466-474, 2004.

GALE, C. R. et al. Vitamin C and risk of death from stroke and coronary heart disease in cohort of elderly people. British Medical Journal, 310: 1.563-1.566, 1995.

GAZIANO, J. M. et al. A prospective study of consumption of carotenoids in fruits and vegetables and decreased cardiovascular mortality in the ederly. Annals of Epidemiology, 5: 255-260, 1995.

GEY, K. F. et al. Increased risk of cardiovascular disease at suboptimal plasma concentrations of essential antioxidants: an epidemiological update with special attention to carotene and vitamin C. American Journal of Clinical Nutrition, 57: 787-795, 1993.

GILES, W. H. et al. Distribution and correlates of elevated total homocysteine: the stroke prevention in young women study. Annals of Epidemiology, 9: 307-313, 1999.

HAAG, M. \& DIPPENAAR, N. G. Dietary fats, fatty acids and insulin resistence: short review of a multifaceted connection. Medical Science Monitor, 11: RA359-367, 2005.

HENNEKENS, C. H. et al. Lack of effect of long-term supplementation with beta-carotene on the incidence of malignant neoplasm and cardiovascular disease. New England Journal of Medicine, 334: 1.145-1.149, 1996.

HIRVONEN T. et al. Intake of flavonoids, carotenoids, vitamins $\mathrm{C}$ and $\mathrm{E}$, and risk of stroke in male smokers. Stroke, 31: 2.301-2.306, 2000.

HODIS, H. N. et al. Alpha-tocopherol supplementation in health individuals reduces low-density lipoprotein oxidation but not atherosclerosis. Circulation, 106: 1.453-1.459, 2002.

HOOPER, L. et al. Risk and benefits of omega 3 fats for mortality, cardiovascular disease, and cancer: a systematic review. British Medical Journal, 332: 752-760, 2006. 
HOWARD, B. V. et al. Low-fat dietary pattern and risk of cardiovascular disease: the women's health initiative randomized controlled dietary modification trial. Jama, 295: 655-665, 2006.

HU, F. B. \& WILLETT, W. C. Optimal diets for prevention of coronary heart disease. Jama, 288: 2.569-2.578, 2002.

HU, F. B.; MANSON, J. E. \& WILLETT, W. C. Types of dietary fat and risk of coronary heart disease: a critical review. Journal of the American College of Nutrition, 20: 5-19, 2001.

HUSTAD, S. et al. Riboflavin as a determinant of plasma total homocysteine: effect modification by the methyllenetetrahydrofolato reductase C677T polymorfism. Clinical Chemistry, 46: 1.065-1.071, 2000.

JACQUES, P. F. et al. Determinants of plasma total homocysteine concentration in the Framinghan offspring cohort. American Journal of Clinical of Nutrition, 73: 613-621, 2001.

JHA, P. et al. The antioxidant vitamins and cardiovascular disease: a critical review of epidemiologic and clinical trial data. Annals of Internal Medicine, 123: 860-872, 1995.

JOHNSEN, S. P. et al. Intake of fruit and vegetables and the risk of ischemic stroke in a cohort of Danish men and women. American Journal of Clinical Nutrition, 78: 57-64, 2003.

JOOSSENS, J. V.; GEBOERS, J. \& KESTELOOT, H. Nutrition and cardiovascular mortality in Belgium. Acta Cardiologica, 44: 157-169, 1989.

JOSHIPURA, K. J. et al. Fruit and vegetable intake in relation to risk of ischemic stroke. Jama, 282: 1.233$1.239,1999$.

KINLAY, S. et al. Long-term effect of combined vitamin $\mathrm{E}$ and $\mathrm{C}$ on coronary and peripheral endothelial function. Journal of the American College of Cardiology, 43: 626-634, 2004.

KLIPSTEIN-GROBUSCH, K. et al. Dietary antioxidants and risk of myocardial infarction in the elderly: the Rotterdan Study. American Journal of Clinical Nutrition, 69: 261-266, 1999.

KNEKT, P. et al. Antioxidant vitamin intake and coronary mortality in a longitudinal population study. American Journal of Epidemiology, 139: 1.180-1.190, 1994.

KRITCHEVSKY, S. B. et al. Provitamin A carotenoid intake and carotid artery plaques: the Atherosclerosis Risk in Communities Study. American Journal of Clinical Nutrition, 68: 726-733, 1998.

KUSHI, L. H.; LEW, R. A. \& STARE, R. J. Diet and 20-year mortality from coronary heart disease. The Ireland-Boston Diet-Heart Study. New England Journal of Medicine, 312: 811-820, 1985.

KUSHI, L. H. et al. Dietary antioxidant vitamins and death from coronary heart disease in postmenopausal women. New England Journal of Medicine, 334: 1.156-1.162, 1996.

LAI, C. Q. et al. Dietary intake of n-6 fatty acids modulates effect of apolipoprotein A5 gene on plasma fasting triglycerides remnant lipoprotein concentrations, and lipoprotein particle size: The Framinghan Heart Study. Circulation, 113: 2.062-2.070, 2006.

LENNIE, T. A. Current perspectives in nutrition and cardiovascular disease. Journal of Cardiovascular Nursing, 21: 1-2, 2006.

LIU, S. et al. Fruits and vegetable intake and risk of cardiovascular disease: the Women's Health Study. American Journal of Clinical Nutrition, 72: 922-928, 2000. 
LIU, S. et al. Intake of vegetables rich in carotenoids and risk of coronary heart disease in men: The Physicians' Health Study. International Journal of Epidemiology, 30: 130-135, 2001.

LONN, E. et al. Effects of vitamin E on cardiovascular and microvascular outcomes in high-risk patients with diabetes. Results of the Hope Study and Micro-Hope Substudy. Diabetes Care, 25: 1.919-1.927, 2002.

LUSSIER-CACAN, S. et al. Plasma total homocysteine in biological traits. American Journal of Clinical Nutrition, 64: 587-593, 1996.

MCCULLY, K. S. Vascular pathology of homocysteinemia: implications for the pathogenesis of arteriosclerosis. American Journal of Pathology, 56: 111-128, 1969.

MCGEE, D. L. et al. Ten-year incidence of coronary heart disease in the Honolulu Heart Program. Relationship to nutrient intake. American Journal of Epidemiology, 119: 667-677, 1984.

MOAT, S. J. et al. Folato, homocysteine, endothelial function and cardiovascular disease. Journal of Nutrition Biochemistry, 15: 64-79, 2004.

MOORADIAN, A. D. et al. Sellected vitamins and minerals in diabetes. Diabetes Care, 17: 464-479, 1994.

MORRIS, D. L.; KRITCHVSKY, S. B. \& DAVIS, L. E. Serum carotenoids and coronary heart disease: the lipid research clinics coronary primary prevention trial and follow-up study. Jama, 272: 1.439-1.441, 1994.

NESS, A. R. \& POWLES, J. W. Fruit and vegetables, and cardiovascular disease: a review. International Journal of Epidemiology, 26: 1-13, 1997.

NORDMANN, A. J. et al. Effects of low-carbohydrate vs low-fat diets on weight loss and cardiovascular risk factors: a meta-analysis of randomized controlled trials. Archives of Internal Medicine, 166: 285-293, 2006.

PARTHASARATHY, S. et al. Oxidants and antioxidants in atherogenesis: an appraisal. Journal of Lipid Research, 40: 2.143-2.157, 1999.

RASMUSSEN, L. B. et al. Folato intake, lifestyle factors, and homocysteine concentrations in younger and older women. American Journal of Clinical Nutrition, 72: 1.156-1.163, 2000.

RAUMA, A. L. \& MYKKANEN, H. Antioxidant status in vegetarians versus omnivores. Nutrition, 16: 111 $119,2000$.

RICCIARELLI, R.; ZINGG, J. M. \& AZZI, A. Vitamin E: protective role of a Janus molecule. The Faseb Journal, 15: 2.314-2.325, 2001.

RIMM, E. B. et al. Vitamin E consumption and the risk of coronary hearth disease in men. New England Journal of Medicine, 328: 1.450-1.456, 1993.

ROSS, R. Mechanisms of disease: atherosclerosis: an inflammatory disease. New England Journal of Medicine, 340: 115-126, 1999.

RUMPLER, W. V. et al. Changes in women's plasma lipid and lipoprotein concentrations due to moderate consumption of alcohol are affected by dietary fat level. Journal of Nutrition, 129: 1.713-1.717, 1999.

SCHAEFER, E. J. Lipoproteins, nutrition, and heart disease. American Journal of Clinical Nutrition, 75: 191$212,2002$.

SOINIO, M. et al. Dietary fat predicts coronary heart disease events in subjects with type 2 diabetes. Diabetes Care, 26: 619-624, 2003. 
SPENCER, C. G. C. et al. Lip GYH. Relationship of homocysteine to markers of platelet and endothelial activation in high risk hypertensive: a sub study of the Anglo-Scandinavian cardiac outcomes trial. International Journal of Cardiology, 94: 293-300, 2004.

STAMPFER, M. J. et al. Vitamin E consumption and the risk of cardiovascular disease in women. New England Journal of Medicine, 328: 1.444-1.449, 1993.

STEPHENS, N. G. et al. Randomised controlled trial of vitamin $\mathrm{E}$ in patients with coronary disease: Cambridge Heart Antioxidant Study. The Lancet, 347: 781-786, 1996.

TAVANI, A. et al. Beta-carotene intake and risk of non-fatal acute myocardial infarction in women. European Journal of Epidemiology, 13: 631-637, 1997.

TELL, G. S. et al. Dietary fat intake and carotid artery wall thickness. The Atherosclerosis Risk in Communities (Aric) Study. American Journal of Epidemiology, 139: 979-989, 1994.

TOLSTRUP, J. et al. Prospective study of alcohol drinking patterns and coronary heart disease in women and men. British Medical Journal, 332: 1.244-1.248, 2006.

TORNWALL, M. E. et al. Effect of a-tocopherol and $\beta$-carotene supplementation on coronary heart disease during 6-year post-trial in the ATBS study. European Heart Journal, 25: 1.171-1.178, 2004.

TRIBBLE, D. L. Antioxidant consumption and risk of coronary heart disease: emphasis on vitamin C, vitamin E and beta-carotene. Circulation, 99: 591-595, 1999.

WALD, N. J. \& LAW, M. R. A strategy to reduce cardiovascular disease by more than $80 \%$. British Medical Journal, 326: 1.419, 2003.

WATTS, G. F. et al. Effects on coronary artery disease of lipid-lowering diet, or diet plus cholestyramine, in th St Thomas' Atherosclerosis Regression Study (Stars). The Lancet, 339: 563-569, 1992.

WEN, Y. et al. Lipid peroxidation and antioxidant vitamins $\mathrm{C}$ and $\mathrm{E}$ in hypertensive patients. Ireland Journal of Medicine, 165: 210-212, 1996.

WILL, J. C.; FORD, E. S. \& BOWMAN, B. A. Serum vitamin C concentrations and diabetes: findings from the Third National Health and Nutrition Examination Survey, 1988-1994. American Journal of Clinical Nutrition, 70: 49-52, 1998.

WILLETT W. Diet and Coronary Heart Disease in Nutritional Epidemiology. New York: Oxford University Press, 1998.

WORLD HEALTH ORGANIZATION (WHO)/FOOD AND AGRICULTURE ORGANIZATION (FAO). Joint WHO/FAO Expert Consultation. Diet, Nutrition and the Prevention of Chronic Diseases. Geneva: WHO/FAO, 2003. (WHO Technical Report Series, 916)

WU, T. et al. Associations of serum C-reactive protein with fasting insulin, glucose, and glycosylated hemoglobin: the Third National Health and Nutrition Examination Survey, 1988-1994. American Journal of Epidemiology, 155: 65-71, 2002.

YOKOYAMA, M. Oxidant stress and atherosclerosis. Current Opinion on Pharmacology, 4: 110-115, 2004. 



\title{
Aspectos Epidemiológicos e Nutricionais da Síndrome Metabólica
}

\author{
Renata Damião, Bianca de Almeida Pititto, \\ Suely Godoy Agostinho Gimeno e Sandra Roberta Gouvea Ferreira
}

\section{Conceito}

A Síndrome Metabólica (SM) é um transtorno complexo representado por um conjunto de fatores de risco cardiovascular relacionados à obesidade central e resistência à insulina (I Diretriz Brasileira para Diagnóstico e Tratamento de Síndrome Metabólica, 2005). O principal marco na descrição desta síndrome são os estudos de Reaven, que sugeriu ser a Resistência à Insulina (RI) o fator comum a uma série de anormalidades, denominando-a originalmente de Síndrome X (Reaven, 1988). Resistência à insulina é uma condição genética ou adquirida em que ocorre menor utilização de glicose pelos tecidos em resposta ao estímulo insulínico. A síndrome recebeu diversas denominações quarteto mortal, síndrome de resistência à insulina, síndrome plurimetabólica (Haffner et al., 1992) -, e hoje o termo SM é recomendado pela Organização Mundial da Saúde (OMS) e mais utilizado pela comunidade científica.

Os principais componentes da SM são obesidade central, alteraçôes da homeostase glicêmica, dislipidemia (HDL-colesterol baixo e triglicéride elevado) e hipertensão arterial, estando freqüentemente presentes hiperuricemia, microalbuminúria e níveis elevados de marcadores inflamatórios e do fator inibidor do ativador do plasminogênio (PAI-1). A obesidade central decorre do acúmulo de gordura visceral, que gera RI, envolvida diretamente no desenvolvimento desta síndrome.

Estudos epidemiológicos revelaram que o ganho de peso é fator independente para desenvolvimento da SM (Ford \& Giles, 2003), sendo o tecido adiposo intra-abdominal (visceral), por suas características metabólicas, o mais implicado na gênese de RI (Egger, 1992). O adipócito do tecido visceral apresenta alta atividade lipolítica, produzindo grande quantidade de Ácidos Graxos Livres (AGL), que são lançados na circulação portal e sistêmica. $\mathrm{O}$ excesso de AGL ofertados às células hepáticas e musculares desempenha importante papel na patogênese da SM (Kelley, Goodpaster \& Storlien, 2002). No fígado, determina aumento dos metabólitos Acetil Coenzima A (AcilCOA) e diacilglicerol. Na periferia, os AGL competem com a glicose como substrato energético. A cascata de reações intracelulares, desencadeadas após a ligação da insulina ao seu receptor, está alterada, culminando com menor translocação dos transportadores da glicose para a superfície celular, o que compromete a entrada da glicose na célula.

O tecido visceral também é fonte de uma série de hormônios e citocinas (conjuntamente denominadas de adipocitocinas), sendo a maioria dotada de propriedades pró-inflamatórias e pró-aterogênicas (Shulmann, 2000; Ribeiro-Filho et al., 2006). Entre as adipocitocinas estão os hormônios como leptina, adiponectina e visfatina; 
destacam-se ainda interleucinas, o fator de necrose tumoral alfa (TNF- $\alpha$ ), a proteína quimiotáxica de monócito 1 (MCP-1), o angiotensinogênio, além de outras substâncias que têm papel na inflamação, na RI ou na aterogênese (Mohamed-Ali, Pinkney \& Coppack, 1998). A síntese de proteína C reativa pelo fígado está aumentada nesta condição, e sua concentração sérica tem sido amplamente utilizada como marcador de processo inflamatório subclínico, associado a aumento de risco cardiovascular.

Em resposta à redução na captação da glicose pelas células, ocorre aumento compensatório na produção de insulina pelas células beta, determinando hiperinsulinemia. Após esgotarem sua capacidade secretória, surgirão os diversos graus de intolerância à glicose, culminando com o diabetes mellitus.

A hiperinsulinemia está relacionada à hipertensão arterial na SM, uma vez que determina retenção renal de sódio e água e ativação simpática, que contribuem para a elevação dos níveis pressóricos (Chobanian et al., 2003). Outros autores acreditam que o aumento da pressão intra-abdominal pelo excesso de gordura visceral também poderia estimular mecanicamente os rins com ativação do sistema renina-angiotensina-aldosterona, favorecendo a retenção de sal e a hipertensão (Hall et al., 1998).

A dislipidemia da SM caracteriza-se por hipertrigliceridemia, concentrações baixas de HDL (lipoproteína de alta densidade) e presença de partículas pequenas e densas de LDL (lipoproteína de baixa densidade) (Siqueira, Abdalla \& Ferreira, 2006). O grande aporte de AGL ao fígado resulta na produção de VLDL, rica em triglicérides. A atividade da proteína transportadora de ésteres de colesterol - CETP, responsável pela remoção do colesterol dos tecidos periféricos de volta ao fígado - está aumentada na RI, o que resulta em transferência dos triglicérides da VLDL para LDL e HDL em troca de ésteres de colesterol. As LDL e HDL ricas em triglicérides sofrem ação da lipase hepática, que também está ativada na SM, gerando LDL pequenas e densas e diminuição de HDL. Este perfil lipídico típico da SM é altamente aterogênico.

Outras anormalidades como o aumento da atividade do PAI-1, proteína pró- trombogênica, e da proteína C reativa, decorrentes da diminuição da sensibilidade à insulina (Festa et al., 2000), também contribuem de modo significativo para aterosclerose e fenômenos tromboembólicos em portadores de SM.

A importância do diagnóstico da SM, da compreensão da sua fisiopatologia e da identificação de fatores de risco que sejam modificáveis (como os fatores dietéticos) baseia-se no alto risco atribuído à concomitância destes fatores de risco cardiovascular. De fato, estudos epidemiológicos revelam que a mortalidade coronariana, cardiovascular e mesmo por todas as causas está consideravelmente aumentada em portadores de SM quando comparados a indivíduos sem esta condição (Lakka et al., 2002). A SM representa, na atualidade, grande preocupação em termos de saúde pública, também devido à sua alta prevalência em várias populações mundiais, independentemente de seu nível de desenvolvimento.

\section{Prevalência no Mundo e no Brasil}

A prevalência da SM é estimada entre 20 e $25 \%$ da população geral (Dunstan et al., 2002). Estudos populacionais mostram freqüências que diferem bastante entre populações: 9,5\% em 24.329 chineses $\geq 20$ anos (Chuang, Chen \& Chou, 2004); 30,8\% em 1.091 indianos > 20 anos moradores de área urbana (Gupta et al., 2004); 31\% em 1.656 hispano-americanos entre 30 e 79 anos e 23\% em 1.081 brancos não hispânicos na mesma faixa etária (Meigs et al., 2003). Nos Estados Unidos da América, o NHANES III (National Health and Nutrition Examination Surveys III) diagnosticou SM em 23\% de 8.814 indivíduos, chegando a 42\% na população acima de 60 anos (Ford, Giles \& Mokdad, 2004). Na Europa, a prevalência foi de 9,5\% nos homens e 8,9\% nas mulheres segundo o Decode (Diabetes Epidemiology: Collaborative Analysis of Diagnostic Criteria in Europe) (Hu et al., 2004), ao passo que na cidade do Porto, Portugal, foi de 23\% (Santos, Lopes \& Barros, 2004). Essas altas prevalências são preocupantes, porque a SM é preditora de diabetes e Doença Cardiovascular (DCV), com mortalidade cerca de 2,5 vezes a de indivíduos sem a síndrome (Lakka et al., 2002). 
No Brasil, há dados regionais de prevalência de SM. O Japanese-Brazilian Diabetes Study Group, usando os critérios do National Cholesterol Education Program - Adult Treatment Panel III (NCEP-ATPIII), modificado para asiáticos, encontrou 56,8\% de SM em nipo-brasileiros com 30 anos ou mais (Rosenbaum, Gimeno \& Ferreira, 2005). Essa população caracteriza-se por Índice de Massa Corporal (IMC) médio em torno de $25 \mathrm{~kg} /$ $\mathrm{m}^{2}$, mas com alta prevalência de obesidade central e fatores de risco cardiovascular. Um outro estudo avaliou a presença de SM em 240 indivíduos > 25 anos residentes no Semi-Árido baiano. A freqüência de SM foi maior em mulheres $(38,4 \%)$ que em homens $(18,6 \%)$ e mais elevada entre aqueles com idade $\geq 45$ anos $(41,4 \%)$. Considerando sexo e idade, a maior prevalência foi registrada entre mulheres com idade $\geq 45$ anos (56,9\%) (Oliveira, Souza \& Lima, 2006). Em 753 indivíduos diabéticos estudados no Rio Grande do Sul, o diagnóstico de SM esteve presente em 671 (89\%) e 657 (87\%), utilizando-se critérios da OMS e do NCEP-ATPIII, respectivamente (Picon et al., 2006). A presença de SM também foi investigada em portadores de diabetes tipo 1. Em 524 indivíduos diabéticos tipo 1 (idade média de 20 anos), divididos de acordo com tempo de diagnóstico, encontraram-se prevalências crescentes de SM de 5,1\%, 11,2\%, 18,9\% e 31,5\% naqueles com menos de 5 anos, de 6-10 anos, de 11-15 anos e > 15 anos de diagnóstico, respectivamente (Gabbay et al., 2005).

A multifatorialidade causal e o uso de diferentes critérios diagnósticos limitam a comparação das frequiências da SM entre populaçôes. Diferenças genéticas, grupo etário, sexo e fatores ambientais (dieta e nível de atividade física) são elementos que contribuem para a variabilidade na prevalência da SM. Porém, o impacto na morbi-mortalidade está bem estabelecido, conforme descrito a seguir.

\section{Impacto da SM na Morbi-mortalidade}

A presença da SM confere ao seu portador risco três vezes maior de infarto agudo do miocárdio ou acidente vascular cerebral, em relação a indivíduos sem a síndrome (IDF, 2006). Isso decorre da gama de anormalidades presentes nos portadores da SM, anteriormente comentada. A obesidade visceral está associada à elevação de citocinas como o TNF- $\alpha$, PAI-1, interleucinas e outras que contribuem para RI, inflamação e aterogênese, e à redução da adiponectina, que melhoraria a sensibilidade à insulina. A instalação do quadro da RI gera os maiores fatores de risco cardiovascular conhecidos, que são a dislipidemia, a hipertensão e o diabetes.

O risco de desenvolver diabetes é cinco vezes maior naqueles portadores de SM (IDF, 2006). A presença de diabetes entre as anormalidades metabólicas aumenta ainda mais o risco de evento cardiovascular; estima-se que $80 \%$ dos pacientes com diabetes morram de causa cardiovascular.

Várias outras entidades clínicas integram o espectro da SM, tendo também a RI um papel central. É o caso da doença hepática gordurosa não alcoólica, na qual a RI é implicada na maior síntese e retenção de triglicerídeos nos hepatócitos, com conseqüente esteatose hepática (Carvalheira \& Saad, 2006). Também a síndrome dos ovários policísticos é freqüente em mulheres com SM; a hiperinsulinemia, atuando no tecido ovariano, estimula a produção de andrógenos.

A hiperuricemia é outra alteração metabólica associada à menor sensibilidade à insulina. A microalbuminúria - um dos critérios diagnósticos usados pela OMS na definição da SM - reflete a disfunção endotelial expressa no glomérulo. A presença de RI foi também independentemente associada a alterações cognitivas em idosos, principalmente quando somada a marcadores inflamatórios e de insuficiência cardíaca (Yaffe et al., 2004). Mais recentemente, a hiperinsulinemia crônica com aumento de TNF- $\alpha$, em humanos, mostrou-se associada à ocorrência de cânceres de cólon, pâncreas, mama e endométrio (Calle \& Kaaks, 2004).

No que se refere à mortalidade, estudo prospectivo conduzido entre 1.209 homens de 42-60 anos revelou que indivíduos com diagnóstico de SM apresentavam risco relativo de 3,77 (IC 95\%, 1,74-6,17) de morte por doença coronariana, 3,55 (IC 95\%, 1,96-6,43) de DCV e 2,43 (IC 95\% 1,64-3,61) de mortalidade por todas as causas (Lakka et al., 2002). 
No San Antonio Heart Study (Tabela 1), sendo a SM definida por critérios do NCEP-ATPIII, encontrou-se razão de risco de mortalidade por DCV de 1,96 e 2,07, para homens e mulheres sem o diagnóstico de Diabetes Mellitus (DM), respectivamente. As razões de risco correspondentes quando a SM foi definida pelos critérios da OMS, sem considerar a presença ou ausência de DM, foram de 2,83 e 1,15 para homens e mulheres respectivamente (Hunt et al., 2004). A SM teve capacidade de predizer diabetes quatro vezes maior do que a de predizer DCV (Lorenzo et al., 2003).

Tabela 1 - Razão de risco para mortalidade por DCV no San Antonio Heart Study para homens ou mulheres, considerando presença ou ausência de SM e/ou DM

\begin{tabular}{lcc}
\hline DM e/ou SM & Mulher sem DCV [HR (IC 95\%)] $]^{* *}$ & Homem sem DCV [HR (IC 95\%)] ${ }^{* *}$ \\
\hline Sem DM, sem NCEP-SM & 1,00 & 1,00 \\
\hline Sem DM, com NCEP-SM & $2,07(0,72-6,0)$ & $1,96(0,99-3,88)$ \\
\hline Com DM, sem NCEP-SM & $3,53(0,75-16,7)$ & $2,34(0,70-7,82)$ \\
\hline Com DM, com NCEP-SM & $8,19(3,51-19,1)$ & $3,09(1,49-6,43)$ \\
\hline
\end{tabular}

DM diabetes mellitus; SM síndrome metabólica; DCV doença cardiovascular; HR razão de risco; IC intervalo de confiança; NCEP-SM síndrome metabólica definida pelo National Cholesterol Education Program.

* Sem DCV no início.

* * Ajustada para idade e etnia.

Fonte: Hunt et al. (2004).

\section{Critérios Diagnósticos}

Foram vários os grupos que descreveram critérios diagnósticos: a OMS (Alberti \& Zimmet, 1998), a American Association of Clinical Endocrinologists (AACE, 2003), o European Group for the Study of Insulin Resistance (Egir) (Balkau \& Carles, 1999) e o NCEP-ATP III 2001 (Tabela 2).

O critério proposto pela OMS preconiza a avaliação da RI e do metabolismo da glicose com insulinemia, o que dificulta o diagnóstico. O NCEP-ATP III possui critérios mais simples e práticos, empregados na I Diretriz Brasileira para Diagnóstico e Tratamento de Síndrome Metabólica (I-DBSM, 2006).

$\mathrm{Na}$ I-DBSM, recomenda-se que a circunferência da cintura seja medida no meio da distância entre a crista ilíaca e a borda inferior da última costela flutuante, utilizando-se $102 \mathrm{~cm}$ para homens e $88 \mathrm{~cm}$ para mulheres como pontos de corte. Convém ressaltar, no entanto, que não existem estudos na população brasileira que certifiquem que tais valores são os mais adequados para identificar risco.

Em 2005, o NCEP e a International Diabetes Federation (IDF) modificaram o critério diagnóstico proposto pelo primeiro em 2001, instituindo a medida da cintura abdominal como critério essencial para o diagnóstico da SM (Zimmet et al., 2005). Destacaram a importância de se considerar a etnia para estabelecer os pontos de corte da circunferência da cintura. No Brasil, as sociedades científicas ainda não se posicionaram quanto aos novos valores sugeridos. 
Tabela 2 - Critérios diagnósticos de SM sugeridos pela comunidade científica

\begin{tabular}{|c|c|c|c|c|c|c|c|}
\hline & $\begin{array}{c}\text { Obesidade } \\
\text { (central/visceral) }\end{array}$ & $\begin{array}{l}\text { Triglicérides } \\
\text { (mg/dl) }\end{array}$ & $\begin{array}{c}\text { HDL-colesterol } \\
(\mathrm{mg} / \mathrm{dl})\end{array}$ & $\begin{array}{l}\text { Pressão arterial } \\
\qquad(\mathrm{mmHg})\end{array}$ & $\begin{array}{l}\text { Glicemia jejum } \\
\qquad(\mathrm{mg} / \mathrm{dl})\end{array}$ & $\begin{array}{l}\text { Glicemia de } \\
2 \mathrm{~h} \text { (mg/dl) }\end{array}$ & $\begin{array}{l}\text { Microalbuminúria } \\
\text { ou albumina/ } \\
\text { creatinina }\end{array}$ \\
\hline $\begin{array}{l}\text { OMS } \\
\text { Intolerância à } \\
\text { glicose ou DM ou } \\
\mathbb{I R}+2 \text { critérios }\end{array}$ & $\begin{array}{l}\mathrm{RCQ} \\
\sigma^{\pi}>0,85 \\
\text { \& }>0,90 \text { ou } \\
\mathrm{IMC} \geq 29,9 \mathrm{~kg} / \mathrm{m}^{2}\end{array}$ & $>150$ & $\begin{array}{l}\sigma^{x}>35 \\
+>40\end{array}$ & $>140 \times 90$ & - & - & $\begin{array}{l}>20 \mathrm{mcg} / 24 \mathrm{~h} \\
\text { ou } \geq 30 \mathrm{mg} / \mathrm{g}\end{array}$ \\
\hline $\begin{array}{l}\text { Egir } \\
\mathbb{R}+2 \text { critérios }\end{array}$ & $\begin{array}{l}C C \\
0^{x}>94 \mathrm{~cm} \\
+>80 \mathrm{~cm}\end{array}$ & $>180$ & $\begin{array}{l}\sigma^{\pi}>35 \\
+>40\end{array}$ & $>140 \times 90$ & $\begin{array}{l}>110 \\
<126\end{array}$ & - & - \\
\hline AACE & $I M C \geq 25 \mathrm{~kg} / \mathrm{m}^{2}$ & $>150$ & $\begin{array}{l}\sigma^{x}>35 \\
+>40\end{array}$ & $\geq 130 \times 50$ & $\begin{array}{l}>110 \\
<126\end{array}$ & $\begin{array}{l}>140 \\
<220\end{array}$ & - \\
\hline $\begin{array}{l}\text { NCEP / } \\
\text { IDB-SM } \\
3 \text { ou mais } \\
\text { critérios }\end{array}$ & $\begin{array}{l}\mathrm{CC} \\
\sigma^{x}>102 \mathrm{~cm} \\
+>88 \mathrm{~cm}\end{array}$ & $\geq 150$ & $\begin{array}{l}0^{x}>40 \\
q>50\end{array}$ & $\geq 130 \times 85$ & $\geq 100$ & - & - \\
\hline $\begin{array}{l}\text { NCEP / IDF } \\
\text { CC + } 2 \text { critérios }\end{array}$ & $\begin{array}{l}\mathrm{CC} \\
0^{\pi}>94 \mathrm{~cm} \\
+>80 \mathrm{~cm}\end{array}$ & $>150$ & $\begin{array}{l}\sigma^{x}>40 \\
+>50\end{array}$ & $\geq 130 \times 85$ & $\geq 100$ & - & - \\
\hline
\end{tabular}

IR resistência à insulina; DM diabetes mellitus; RCQ razão cintura-quadril; CC circunferência de cintura; OMS Organização Mundial da Saúde; Egir European Group for the Study of Insulin Resistance; AACE American Association of Clinical Endocrinologists; NCEP National Cholesterol Education Program; IDB-SM I Diretriz Brasileira para Diagnóstico e Tratamento de Síndrome Metabólica; IDF Federação Internacional de Diabetes.

\section{Envolvimento de Componentes Nutricionais na Síndrome Metabólica}

\section{Macronutrientes}

\section{Carboidratos}

Os carboidratos digeríveis incluem carboidratos simples (glicose, frutose e galactose) e complexos (amido é o principal representante). Outros podem passar imutáveis (fibras) pelo trato digestivo, mas constituem parte importante da alimentação (Nutrition and Your Health, 2000). Uma característica dos diferentes tipos de carboidratos, seu Índice Glicêmico (IG), voltou a receber atenção da comunidade científica. Este índice reflete sua capacidade de elevar a glicemia após ingestão. Quanto maior o valor do IG do alimento rico em carboidrato, maior seu potencial de elevar os níveis glicêmicos e insulinêmicos (Jenkins et al., 1981).

A classificação de carboidratos pela categoria de IG contraria a idéia de que todos os carboidratos complexos fazem bem e todos os simples fazem mal. O IG de um alimento é influenciado por vários fatores que interferem na velocidade com a qual os carboidratos são decompostos: o grau de gelatinização dos grãos de amido, o grau de processamento do alimento, a quantidade de fibras que contém e a quantidade de gordura contida no lanche ou refeição (Potter et al., 1981).

Embora seja útil, o IG de um alimento é apenas uma parte do efeito da ingestão de um alimento sobre as concentrações de glicose e insulina do sangue. Assim, desenvolveu-se o conceito de Carga Glicêmica (CG). A CG é a quantidade de carboidrato em um alimento multiplicada pelo IG de tal carboidrato. Este índice reflete melhor o efeito de um alimento nas reações metabólicas no organismo (Foster-Powell, Holt \& Brand-Miller, 2002). 
Alguns estudos exploraram a associação dos carboidratos à SM. O Framingham Offspring Study, de desenho transversal, que incluiu 2.834 participantes, observou que a ingestão de grãos integrais e fibras dos cereais associou-se à redução do risco de desenvolvimento da SM. Também verificou que a ingestão de fibra total, dos cereais, das frutas e grãos integrais associava-se a menor RI, avaliada pelo Homa-IR (modelo de acesso à homeostase - resistência à insulina), ao passo que alimentos com alto IG mostraram-se positivamente associados à RI (McKeown et al., 2004).

No que se refere à associação de hábitos alimentares a doenças isoladas, integrantes da SM, a literatura é bastante vasta. Os primeiros estudos datam da década de 1930 (Himsworth, 1936), quando se observou o papel da ingestão de carboidratos sobre a homeostase glicêmica. Em 1976, constatou-se que dietas ricas em carboidratos complexos e fibras melhoravam o controle do diabetes e o perfil lipídico (Kiehm, Anderson \& Ward, 1976).

Wirfält e colaboradores (2001), em estudo transversal envolvendo 2.040 homens e 2.959 mulheres, verificaram associação de certos padrões alimentares com componentes da SM tais como obesidade central, hiperinsulinemia, hiperglicemia, hipertensão e dislipidemia. Por meio de análise de cluster, seis padrões alimentares foram identificados com base no consumo predominante dos seguintes itens da dieta: alimentos calóricos, pão integral, pouca gordura e alto teor de fibra, pão branco, laticínios integrais e doces/bolos. $\mathrm{Na}$ análise de regressão múltipla, em ambos os sexos, os padrões alimentares dominados pelo pão integral tiveram efeitos favoráveis, ao passo que padrões dominados pelo pão branco foram associados ao maior risco para os componentes da SM.

Liese e colaboradores (2003) observaram associação inversa entre ingestão de grãos integrais e RI, que foi atenuada após ajuste pelo IMC e circunferência da cintura, sugerindo que o benefício dos grãos integrais na SM deva ser mediado pela obesidade.

Estudo realizado com amostra de nipo-brasileiros residentes em Bauru, SP, concluiu que o consumo predominante de alimentos característicos da dieta tipicamente brasileira, como arroz refinado, feijão e grandes quantidades do grupo de frutas e sucos adocicados, poderia se constituir em risco para distúrbios do metabolismo da glicose, ao passo que o maior consumo de vegetais poderia proteger contra a TGD (Tolerância à Glicose Diminuída) (Sartorelli, 2005).

Apesar dos numerosos estudos nesta linha, ainda há controvérsias em relação ao melhor tipo de carboidrato e especialmente sobre sua adequada quantidade na dieta. Independentemente disso, é consenso que efeitos metabólicos mais favoráveis são obtidos quando se dá preferência a carboidratos complexos (Davy \& Melby, 2003).

Quando os carboidratos são substituídos pelos ácidos graxos saturados, ocorre diminuição das concentrações de LDL-colesterol e do ácido graxo monoinsaturado. Porém, no caso dos ácidos graxos monoinsaturados, a substituição dos carboidratos por ácidos graxos saturados freqüentemente causa diminuição do HDL-colesterol e um aumento nos triglicérides (Knopp et al., 1997; Turley et al., 1998). Esse efeito aparentemente persiste por longo período, como sugerido pelas diferenças das concentrações de lípides nas populações na presença de diferentes hábitos alimentares (Knuiman et al., 1987; West et al., 1990).

Alguns investigadores sugerem que população resistente à insulina, com alta prevalência de SM, deva evitar dietas ricas em carboidratos e consumir mais ácidos graxos insaturados (Katan, Grundy \& Willet, 1997).

\section{Proteínas}

O papel das proteínas nas anormalidades que compõem a SM é menos estudado que o de outros nutrientes, como gorduras e carboidratos. O consumo de proteínas, em geral, tem pequeno efeito sobre as concentraçôes séricas de LDL-colesterol, embora já tenha sido relatado que a substituição de proteína animal por soja foi capaz de diminuir esta lipoproteína (Anderson, 1995). 
Pesquisas que avaliaram a relação entre o consumo de proteína e as taxas de mortalidade por DCV sugerem que quanto maior a quantidade de proteína animal na dieta, maior a incidência de morte por esta causa, e quanto maior a quantidade de proteína vegetal, menor a mortalidade (Armstrong \& Doll, 1975; Giovannucci et al., 1994; Key et al., 1996). Na mesma linha, no estudo entre adventistas do sétimo dia, observou-se que os homens que consumiam carne bovina pelo menos três vezes por semana apresentaram o dobro do risco de doença coronariana em relação àqueles que não a consumiam (Snowdon, Philips \& Fraser, 1984).

O Nurses' Health Study, que acompanhou 18 mil mulheres por 14 anos, examinou a relação entre proteína alimentar e DCV. O grupo de mulheres que ingeria a maior quantidade de proteína, cerca de um quarto das calorias diárias, apresentou probabilidade $25 \%$ menor de ter evento cardiovascular e de morrer de DCV do que o grupo daquelas que ingeriam a menor quantidade de proteína ( $15 \%$ do valor calórico total). O fato de a proteína ser de fonte animal ou vegetal não importava, e o efeito protetor aplicava-se igualmente às mulheres em dietas com baixo ou alto teor de gordura. Esses achados reforçam a idéia de que a acentuada ingestão de proteína não provoca danos ao coração (Hu et al., 1999).

Os resultados controversos relativos à associação de ingestão de proteína e risco cardiovascular devem-se ao fato de que a proteína não é encontrada isoladamente nos alimentos, mas sim associada a outros nutrientes.

\section{Gorduras}

\section{Gordura total}

A seleção adequada da quantidade e do tipo de gordura a ser consumida é importante para minimizar seu efeito deletério nos distúrbios metabólicos que compõem a SM (WHO/FAO, 2003).

Há amplas evidências na literatura que permitem recomendar a redução das calorias totais fornecidas pelas gorduras totais para o controle da obesidade (Lissner \& Heitman, 1995; Heitman et al., 1995). Tem sido observado que a alta ingestão de gordura ( $>35 \%$ das calorias totais) traz modificaçóes no metabolismo que favorecem o acúmulo de gordura corporal (Astrup et al., 1997; Nelson \& Tucker, 1996). Porém, é importante salientar que a diminuição da ingestão de gordura (<30\% das calorias totais) freqüentemente implica aumentar a ingestão de carboidrato, cujo consumo excessivo também contribui para a ocorrência de obesidade (Nutrition and Your Health, 2000). Além disso, elevada ingestão de carboidrato (> 60\% das calorias totais) em indivíduos já com sobrepeso ou obesidade pode agravar fatores de risco cardiovascular integrantes da SM, tais como a dislipidemia (hipertrigliceridemia) e a hiperglicemia do diabetes (Garg, 1998; Chen et al., 1995).

\section{Ácidos graxos saturados}

Os ácidos graxos saturados são abundantes na carne e na gordura animal, nos laticínios e em alguns óleos vegetais, como azeite de dendê e óleo de coco (Uauy, Mena \& Valenzuela, 1999). O ácido graxo saturado é o principal determinante de alterações nas concentraçōes sanguíneas do LDL-colesterol (Grundy \& Denk, 1990; Kris-Etherton \& Yu, 1997; Mensink \& Katan, 1992).

Os benefícios da baixa ingestão de ácidos graxos saturados em diminuir concentrações de LDL-colesterol estão bem documentados. O Delta Research Group investigou o efeito da redução de 15\% para 6\% na proporção dos ácidos graxos saturados fornecidos pelas calorias totais. Os autores observaram que o grupo de menor ingestão reduziu o LDL-colesterol em 11\% (Ginsberg et al., 1998). Walden e colaboradores (2000) testaram o efeito da recomendação do NCEP nos indivíduos com hipercolesterolemia, com ou sem hipertrigliceridemia. A dieta do NCEP associou-se a redução de $8 \%$ nas concentrações de LDL-colesterol. 
Alguns estudos sugerem relação entre a qualidade dos lipídios da dieta e risco de desenvolvimento de diabetes. Dados prospectivos mostraram que consumo de gorduras saturadas elevou as concentraçóes de glicemia de jejum e pós-prandial (Feskens \& Kromhout, 1990; Maron, Fair \& Haskel, 1991; Feskens et al., 1995) e insulinemia (Parker et al., 1993; Tsunehara, Leonetti \& Fujimoto, 1991), conferindo, assim, maior risco de progressão de tolerância à glicose diminuída para diabetes (Feskens, Bowles \& Kromhout, 1991).

Uma metanálise de seis estudos de coorte, totalizando 6.356 pessoas-ano, fortaleceu a hipótese de que a diminuição do nível sérico de colesterol total por meio de restrição no consumo de ácidos graxos saturados reduz o risco de DCV (Gordon, 1995). O autor observou que a diminuição das concentrações séricas de colesterol estimulada pela redução da ingestão de ácidos graxos saturados reduziu, significativamente, a incidência do evento cardiovascular em $24 \%$.

Vários estudos mostraram que o nível sérico de LDL pode ser diminuído pela redução do peso corporal de pessoas com sobrepeso (National Institutes of Health, 1998). Para maximizar a diminuição do LDL, via restrição do consumo de ácidos graxos saturados, a ingestão média deste nutriente deve passar de $11 \%$ para $<7 \%$ da energia total (NCEP, 2001).

\section{Ácidos graxos trans}

As principais fontes de ácidos graxos trans incluem produtos industrializados feitos com óleos hidrogenados, como margarina, pães, biscoitos, batata e salgadinhos fritos. Gordura proveniente de produtos lácteos fornece pequena quantidade de trans.

Estudos metabólicos, clínicos e epidemiológicos apóiam a substituição do consumo de gordura saturada e trans por insaturada no tratamento dos componentes da SM (RI, dislipidemia e intolerância à glicose) e na prevenção de doença coronariana (Purnell \& Brunzel, 1997; Hu et al., 2001; Isso et al., 2002).

Evidências de estudos controlados indicam que os ácidos graxos trans aumentam as concentraçóes de LDL-colesterol, comparados com ácidos graxos insaturados (Lichtenstein et al., 1999). Também mostraram que quando ácidos graxos trans são substituídos por ácidos graxos saturados as concentrações de HDL-colesterol no sangue se reduzem e elevam os triglicérides (Ascherio et al., 1999). Dados norte-americanos revelaram que o uso de óleo vegetal líquido ou margarina semilíquida é mais vantajoso para o perfil lipídico em termos de colesterol total, LDL-colesterol e razão colesterol total: HDL-colesterol, ao passo que o uso de manteiga ou margarina piorou tal perfil (Lichtenstein et al., 1999). Em concordância, estudos de coorte sugerem que a alta ingestão de ácidos graxos trans associa-se ao desenvolvimento de DCV (Willett et al., 1993; Kromhout et al., 1995).

\section{Ácidos graxos poliinsaturados}

Os ácidos graxos poliinsaturados têm sido subdivididos nos grupos ômega-6 e ômega-3. Os números 6 ou 3 referem-se à distância entre a primeira dupla ligação e o final da cadeia de carbono. Em temperatura ambiente são líquidos, e cada tipo desempenha uma função no organismo. Não são produzidos ácidos graxos poliinsaturados no organismo, de modo que estas gorduras essenciais devem ser obtidas de óleos vegetais como os de milho, soja, de sementes, de cereais integrais e de peixe gordurosos, como o salmão e o atum (Uauy, Mena \& Valenzuela, 1999).

O principal ácido graxo poliinsaturado da dieta é o ácido linoléico. Quando o ácido graxo saturado é substituído por ácido linoléico, ocorre redução nas concentraçōes de LDL-colesterol. A alta ingestão de ácido graxo linoléico também pode produzir pequena redução na fração HDL-colesterol e nos triglicérides, embora essas respostas sejam variáveis. Os ácidos graxos poliinsaturados causam redução pequena das concentraçôes de LDL-colesterol quando comparados aos monoinsaturados (Weggemans, Zock \& Katan, 2001). 
Pesquisas realizadas em primatas indicaram que ácidos graxos poliinsaturados eram antiaterogênicos quando comparados com os saturados (Rudel, Parks \& Sawyer, 1995). De fato, resultados de metanálises corroboram esse achado, enfatizando que os ácidos graxos poliinsaturados associavam-se à redução no risco de DCV (Gordon, 1995; Mensink \& Katan, 1992).

O ácido graxo poliinsaturado ômega-3 está presente no ácido alfalinolénico, encontrado em vegetais como a soja em grão, no óleo de canola e óleo de peixe, no ácido eicosapentenóico e no docosahexenóico (Bender \& Bender, 1997). Há indícios fortes de efeito protetor contra as DCV, embora os achados não sejam unânimes. O consumo moderado de peixe associou-se à redução de morte súbita ou coronariana em alguns estudos prospectivos (Albert et al., 1998; Daviglus et al., 1997), mas não em outros (Ascherio et al., 1995; Morris et al., 1995). Um estudo observou inclusive tendência ao aumento do risco de DCV com o ácido ômega-3. Os mecanismos pelos quais ácidos graxos poliinsaturados ômega-3 influenciariam favoravelmente no risco cardiovascular parece depender de ações benéficas na arritmia, agregação plaquetária, resposta inflamatória e concentrações de triglicérides. A capacidade da alta ingestão de ômega-3 em reduzir a trigliceridemia (Roche \& Gibney, 2000) deve decorrer da diminuição na produção de VLDL-colesterol (Harris, 1989). Em geral, o ômega-3 não revelou efeitos significativos sobre as concentrações de LDL-colesterol, exceto em grandes doses, quando aumentou o nível de LDL-colesterol em pessoas com hipertrigliceridemia (Harris, 1997).

O Diet and Reinfarction Trial foi um estudo de prevenção secundária no qual os indivíduos foram aconselhados a ingerir peixe. Em dois anos, apresentaram redução de $29 \%$ na mortalidade por todas as causas se comparados aos indivíduos do grupo controle, apesar de não ter sido observada redução na incidência de infarto do miocárdio e morte coronariana (Burr et al., 1989). Em outro estudo, pacientes infartados foram tratados com cápsulas de óleo de peixe (ácido eicosapentanóico, 1,08 g/dia) ou óleo de mostarda (ácido alfalinolénico, 2,9 g/ dia) por um ano. Eventos coronarianos foram significativamente menos freqüentes no grupo que recebeu suplementação quando comparado ao placebo (Sing et al., 1997).

\section{Ácidos graxos monoinsaturados}

Os principais ácidos graxos monoinsaturados estão contidos no azeite de oliva, óleo de amendoim, óleo de canola, abacate e a maioria das nozes (Uauy, Mena \& Valenzuela, 1999). Na dieta, a substituição do ácido graxo monoinsaturado pelo saturado resulta em aumento do nível do LDL-colesterol (Mensink \& Katan, 1992). No entanto, a substituição do ácido graxo saturado por monoinsaturado não diminui o HDL-colesterol e não eleva a trigliceridemia, como ocorre com alta ingestão de carboidrato ( $>60 \%$ das calorias totais em carboidratos) (Kris-Etherton et al., 1999).

O consumo de ácidos graxos monoinsaturados - como parte da dieta pobre em ácidos graxos saturados e colesterol e rica em vegetais, frutas e grãos - associa-se com baixa incidência de doenças cardíacas na população que consome óleo de oliva em regiōes do Mediterrâneo (Keys et al., 1986).

O Lyon Diet Heart Study objetivou reduzir o risco de um segundo ataque cardíaco ou morte em 605 homens e mulheres que haviam sobrevivido ao primeiro evento. Metade destes submeteu-se à dieta do tipo mediterrânea, isto é, que incluía grande quantidade de pão integral, tubérculos e hortaliças verdes, peixes e aves e menor quantidade de carne vermelha, frutas e azeite de oliva, retirando todo e qualquer creme e substituindo a manteiga pela margarina. Após 2,5 anos de seguimento, observou-se redução de $70 \%$ nas mortes por todas as causas (De Lorgeril et al., 1999) entre aqueles que receberam a dieta mediterrânea. Os benefícios sobre o perfil cardiometabólico têm sido verificados em estudos de menor porte e esta dieta tem sido cada vez mais prescrita por profissionais da saúde, em uma tentativa de minimizar o risco cardiovascular de pacientes de alto risco. 


\section{Colesterol total dietético}

As principais fontes de colesterol dietético incluem os produtos de origem animal, lácteos e carnes. Nas últimas décadas, houve diminuição da ingestão do colesterol na população americana, atribuída à redução no consumo de ovos, carnes e produtos lácteos integrais. Esse fato, juntamente com a redução substancial no consumo de ácidos graxos saturados, resultou em declínio da concentração sérica do colesterol da população americana (Ernst et al., 1997).

Alto consumo de colesterol dietético leva à hipercolesterolemia em animais de laboratório; porém, em humanos este efeito é controverso. Estudo conduzido por Clarke e colaboradores (1997) encontrou aumento do nível de LDL-colesterol sanguíneo por alto consumo de colesterol. Uma metanálise verificou efeito do colesterol dietético na diminuição do LDL-colesterol sanguíneo; porém, o colesterol dietético aumentou a razão do colesterol total: HDL-colesterol (Weggemans, Zock \& Katan, 2001).

O Western Electric Study sugeriu que o consumo elevado de alimentos ricos em colesterol aumenta o risco de doenças do coração, independentemente do efeito no LDL-colesterol sérico (Stamler \& Shekelle, 1988). Em contraste, dados de dois estudos prospectivos, o Nurses' Health Study e o Health Professionals Study, não encontraram associação significativa entre a frequiência da ingestão de ovos e DCV, exceto entre mulheres diabéticas (Hu et al., 1999).

\section{Micronutrientes}

Alguns micronutrientes têm recebido atenção especial no que diz respeito à prevenção das DCV. Os mais investigados, possivelmente envolvidos no processo da aterosclerose na SM, estão descritos a seguir.

\section{Ácido Fólico e Vitaminas $\mathrm{B}_{6}$ e $\mathrm{B}_{12}$}

$\mathrm{O}$ ácido fólico e as vitaminas $\mathrm{B}_{6}$ e $\mathrm{B}_{12}$ desempenham um papel no metabolismo da homocisteína, e as concentrações dessas vitaminas se correlacionam inversamente com o nível da homocisteína. O Framingham Heart Study revelou que a fortificação dos cereais com ácido fólico foi capaz de diminuir a prevalência de hiperhomocisteinemia nos indivíduos estudados (Jacques et al., 1999). Estudos transversais, casos controle e algumas coortes mostraram associação positiva entre as concentrações de homocisteína e risco de DCV (Boushey et al., 1995; Nygard et al., 1997; Stampfer et al., 1992), mas outros estudos de coorte não encontraram os mesmos resultados (Folsom et al., 1998; Alfthan et al., 1994).

Apesar da redução do nível de homocisteína com o uso de suplemento de ácido fólico, $\mathrm{B}_{6}$ e $\mathrm{B}_{12}$, não está provado que este efeito possa reduzir o risco de DCV (Stampfer et al., 1992).

\section{Antioxidantes}

A SM reúne anormalidades nas quais o estresse oxidativo está exacerbado, o que provavelmente tem papel na aterogênese. Não há dúvidas de que a oxidação do LDL-colesterol é um importante passo no desenvolvimento e progressão da doença aterosclerótica. Porém, é incerto o papel de agentes antioxidantes na redução do risco cardiovascular em seres humanos. Antioxidantes investigados em estudos com animais e seres humanos incluem ácido ascórbico (vitamina C), alfa-tocoferol (vitamina E), betacaroteno, selênio, manganês, glutationa, coenzima $\mathrm{Q}_{10}$, ácido lipóico, flavonóides, fenóis, polifenóis e fitoestrogênio (Beckman \& Ames, 1998).

Estudos em animais revelaram que alguns antioxidantes são dotados de efeitos anti-aterogênicos. Certos estudos em humanos forneceram dados metabólicos favoráveis à idéia de que os antioxidantes dietéticos poderiam reduzir o risco das DCV, mas até o momento a literatura carece de estudos que comprovem tal hipótese (National Research Council, 2000). 
Estudo chinês mostrou que a suplementação de betacaroteno $(15 \mathrm{mg} / \mathrm{d})$, vitamina $\mathrm{E}(30 \mathrm{mg} / \mathrm{d})$ e selênio $(15 \mu \mathrm{g} / \mathrm{d})$ associou-se com a diminuição de $10 \%$ na mortalidade da DCV (Blot et al., 1993). Hennekens e colaboradores (1996) não observaram benefícios quanto à incidência de DCV em 22.071 homens após 12 anos de suplementação com antioxidantes. No mesmo ano, outros autores observaram aumento não significativo (26\%) na mortalidade cardiovascular em indivíduos suplementados com betacaroteno (Omenn et al., 1996).

No Alpha-Tocoferol, Beta Carotene Cancer Prevention Study (1994), com a suplementação com pequenas doses de vitamina $\mathrm{E}$ em homens fumantes finlandeses, observou-se discreto efeito sobre a incidência de DCV e nenhum efeito na incidência de infarto do miocárdio fatal. No Cambridge Heart Antioxidant Study, de prevenção secundária, a suplementação de vitamina E (400 ou $800 \mathrm{UI} /$ dia, por 1,5 ano) reduziu significativamente o risco de novo infarto do miocárdio (77\%). Não se observou efeito na mortalidade cardiovascular, mas houve aumento não significativo na mortalidade total naqueles suplementados com vitamina E (Stephens et al., 1996). Em outros dois grandes estudos clínicos em pacientes com DCV, não se observou efeito protetor da suplementação da vitamina E no evento cardiovascular subseqüente (Gissi Prevenzione Investigators, 1999; Heart Outcomes Prevention Evaluation Study Investigators, 2000).

Assim, apesar dos efeitos benéficos de vitaminas antioxidantes no estresse oxidativo, não há evidências em humanos de que sua suplementação dietética possa reduzir o risco de DCV.

\section{Cálcio e Sódio}

Efeito protetor de laticínios na incidência da SM foi aventado em estudo prospectivo de dez anos ( $\mathrm{n}=3.000$ adultos) no qual para cada porção de leite consumida ao dia havia redução de $21 \%$ no risco da síndrome, independentemente de idade, sexo, etnia, tabagismo, consumo de álcool, atividade física, escolaridade, consumo calórico total, fibras e proteínas da dieta habitual (Pereira et al., 2002). Levantou-se a hipótese de que o elevado teor de magnésio contido nesses alimentos seja fator protetor contra o desenvolvimento de diabetes e DCV (WHO/FAO, 2003).

\section{Fibra}

As fibras podem ser classificadas em relação ao seu grau de polimerização em polissacarídeos estruturais (celulose, hemicelulose, pectina e amido resistente), não estruturais (gomas e mucilagens) e compostos não polissacarídeos (lignina e outras) (FAO/WHO, 1998). Segundo seu grau de solubilidade em água, são denominadas solúveis (ou viscosas) e insolúveis. As fibras solúveis, tais como as pectinas, gomas, mucilagens e hemicelulose tipo $\mathrm{A}$, ao contato com a água formam um retículo no qual ocorre a inclusão da água, gelificando-se a mistura. As fibras insolúveis - celulose, hemicelulose tipo B e lignina - captam pouca água, são pouco fermentáveis e formam misturas de baixa viscosidade.

Recentes estudos indicam que fibras solúveis podem reduzir as concentrações de LDL-colesterol, minimizando a absorção de gordura no trato gastrintestinal. Em contraste, as fibras insolúveis não afetam significativamente o LDL-colesterol. Ingestão média de 5-10 g de fibra solúvel por dia foi associada à redução de 5\% do LDL-colesterol (Anderson,1995). Em uma metanálise com 67 estudos, observou-se que as fibras solúveis aveia, pectina, guar e psyllium provocaram pequena, mas significativa, redução nas concentrações séricas do colesterol total e do LDL-colesterol (Brown et al., 1999). Devido ao efeito favorável da fibra solúvel nas concentrações de LDL-colesterol, o NCEP-ATP III (2001) recomenda que dietas para proteção cardiovascular sejam enriquecidas de alimentos de modo a atingir um mínimo diário de 5-10 g de fibras solúveis. 


\section{Síndrome Metabólica: evidências do papel da dieta}

\section{Dieta Ocidental versus Dieta Oriental}

Um percentual importante de indivíduos saudáveis que vivem em sociedades industrializadas desenvolverá no curso de sua vida alguma doença crônica como a obesidade, o diabetes tipo 2, a hipertensão arterial, a DCV ou mesmo a SM. Essas doenças têm origem multifatorial, envolvendo fatores genéticos e ambientais. Entre os fatores ambientais, o papel de componentes alimentares na gênese dessas doenças é há muito investigado (WHO/ FAO, 2003).

Estudos epidemiológicos que abordam padrôes de alimentação das populações possibilitam testar associações com doenças. Em particular, populações migrantes representam uma oportunidade ímpar de analisar o impacto dos novos hábitos alimentares a que estão expostos no que diz respeito ao aparecimento de agravos à saúde. As mudanças na dieta e seus riscos têm despertado grande interesse no Japão e em outros países que sofreram imigrações em larga escala, uma vez que podem fornecer subsídios importantes para a instituição de medidas de prevenção.

É grande o contraste entre a dieta dos povos orientais e a dos ocidentais. A maioria dos tradicionais pratos consumidos no Japão vem do mar, estimando-se um consumo diário de $80 \mathrm{~g}$ entre peixes e frutos do mar. O que mais distingue a culinária japonesa da ocidental é o uso de algas marinhas desidratadas (kombu), peixe seco em pó (dashico), sardinhas secas (niboshi) e produtos à base de soja, tais como o shoyu, tofu e missô, massa à base de soja fermentada (Yoshiike et al., 1996, Ministry of Health and Welfare, 1994). Tais diferenças nos padrões dietéticos se constituem no principal componente das mudanças ambientais vividas por populações japonesas, que têm sido associadas a doenças com prevalências contrastantes nos diferentes continentes. Exemplos típicos dessa situação são a DCV e o diabetes, com freqüências bem menores no Japão quando comparadas às observadas entre os japoneses e descendentes residentes nas Américas (Franco, 1996). Confrontando-se as incidências de coronariopatia na população do Japão com japoneses residentes no Havaí e na Califórnia, observou-se grande contraste nos percentuais da ingestão calórica correspondente à gordura saturada, que foram de 7\%, 23\% e 26\%, respectivamente. Em paralelo, os imigrantes sofreram aumento do peso corporal e do nível sérico de colesterol. Tais fatos devem ter contribuído para as maiores incidências de coronariopatia nos nipo-americanos (3,0/1000 no Havaí e 3,7 na Califórnia) do que nos habitantes do Japão (1,6/1000). Assim, ao lado de uma predisposição genética, também fatores ambientais - entre os quais a dieta rica em gordura saturada - parecem contribuir para tal diferença (Robertson et al., 1977).

Estudos que compararam a composição da dieta americana com a asiática caracterizaram a última como baixa em gorduras, especialmente de origem animal, e rica em fibras (Whittemore, 1989; Choi, 1990). A migração para o Ocidente fez com que asiáticos alterassem seus hábitos alimentares, que se tornaram muito próximos aos costumes locais. Yang e Read (1996), comparando a alimentação de asiáticos (51,6\% de chineses) residentes em Nevada, EUA, antes e após a imigração, verificaram aumento significativo no consumo de colesterol e gorduras, especialmente saturadas e monoinsaturadas, e redução no consumo de carboidratos e fibras totais.

Achados recentes sugerem fortemente que a dieta habitualmente consumida pelos nipo-brasileiros de Bauru exerce importante papel na gênese da SM. Os resultados favoreceram a hipótese de que a gordura total da dieta pode aumentar o risco da síndrome, ao passo que a ingestão de alimentos ricos em ácido graxo linoléico pode reduzir tal risco entre os nipo-brasileiros. O padrão alimentar deletério relacionou-se, portanto, à qualidade e quantidade de gordura, consumida, por exemplo, por meio de carne vermelha e fritura (Freire et al., 2005). A avaliação do padrão alimentar de parte dessa população revelou que o consumo da carne vermelha - provavelmente maior do que no seu país de origem - deva ser fator preditivo de SM no ambiente em que vive hoje (Damião et al., 2006). 


\section{Intervenções Nutricionais em Populações e Impacto sobre a Ocorrência da Síndrome Metabólica e seus Componentes}

Os principais objetivos da intervenção na SM são prevenir diabetes e eventos cardiovasculares. A abordagem para a SM deve iniciar com mudanças no estilo de vida (NCEP ATP III, 2002). Cada componente da SM deve ser precocemente identificado e agressivamente tratado. Freqüentemente, o uso de medicamentos específicos faz-se necessário. As seguintes metas devem ser alcançadas na abordagem dos pacientes com SM: 1) pressão arterial < 125/75 mmHg; 2) LDL-colesterol < $100 \mathrm{mg} / \mathrm{dL}$; 3) triglicérides < $150 \mathrm{mg} / \mathrm{dL}$ e 4) HDL-colesterol > $40 \mathrm{mg} / \mathrm{dL}$ para homens ou $>50 \mathrm{mg} / \mathrm{dL}$ para mulheres.

Em 1996, o Oslo Diet and Exercise Study comprovou efeitos benéficos no metabolismo glicídico e demais componentes da SM em subgrupos de indivíduos submetidos a orientação nutricional e de atividade física (Anderssen et al., 1996).

Mais recentemente, outros estudos mostraram o impacto de mudança de estilo de vida na prevenção do diabetes mellitus tipo 2. No Finnish Diabetes Prevention Study Group, 522 pacientes portadores de intolerância à glicose foram divididos em um grupo de intervenção, que recebia orientação nutricional específica e de atividade física $\geq 30 \mathrm{~min} /$ dia, e um grupo controle, para o qual era dada orientação rotineira quanto a dieta e atividade física. Após seguimento médio de 3,2 anos, os investigadores mostraram que o risco de diabetes pode ser reduzido em $58 \%$ com o programa de intervenção instituído quando comparado ao grupo controle (Tuomilehto et al., 2001).

O Diabetes Prevention Program (DPP, 2002) teve um desenho semelhante, exceto pelo fato de incluir mais um grupo de intervenção farmacológica com metformina: 1) intervenção com mudança no estilo de vida, como meta de perda de peso $\geq 7 \%$ e exercício de $150 \mathrm{~min} / \mathrm{semana}(\mathrm{n}=1.079) ; 2)$ metformina $(\mathrm{n}=1.073)$ e 3$)$ placebo $(\mathrm{n}=1.082)$. Após três anos de observação, contatou-se redução no risco de desenvolver diabetes no grupo de intervenção não farmacológica de $58 \%$, ao passo que no grupo que usou metformina esta foi de $31 \%$, quando comparados ao placebo.

Os estudos mais consistentes, que enfocaram a prevenção de componentes da síndrome por mudanças no estilo de vida em grandes grupos populacionais, dizem respeito ao diabetes tipo 2. Porém, um estudo canadense avaliou a eficácia do exercício físico sobre a presença de SM em participantes sedentários do Heritage (Health, Risk Factors, Exercise Training and Genetics) Family Study. A SM foi definida pelo critério do NCEP e diagnosticada em 16,9\% dos participantes. A intervenção consistiu em exercícios aeróbios supervisionados durante vinte semanas e foi suficiente para reduzir em 30\% a prevalência de SM nos 105 pacientes classificados como portadores da síndrome, independentemente de etnia e sexo (Katzmarzyk et al., 2003). Não se sabe se esse tipo de exercício físico seria implantável de modo duradouro no plano populacional.

Roberts, Vaziri e Barnard (2002) mostraram efeito de um programa de curto prazo (três semanas) de dieta com baixo teor de gordura, alto teor de fibras e atividade física de 45 a 60 minutos, três vezes por semana. Tal intervenção reduziu em 3,7\% o peso corporal inicial e foi capaz de melhorar a pressão arterial, o estresse oxidativo, a disponibilidade de óxido nítrico e o perfil metabólico.

Uma vez que a SM está relacionada a excesso de peso, a perda de peso é uma medida importante na abordagem de indivíduos com diagnóstico da SM. Os estudos mencionados obtiveram melhora metabólica com reduçôes de 3 a 10\% do peso inicial. Além disso, a sensibilidade à insulina sofre influência da composição da dieta. Atualmente, pode-se dizer que há subsídios na literatura para recomendar uma dieta restrita em gorduras saturadas, ao passo que o consumo de alimentos com alto teor de fibras deve ser estimulado. Quantidades moderadas de gordura monoinsaturada devem ser permitidas, já que não induzem efeitos metabólicos deletérios. 


\section{Consideraçōes Finais}

Considerando a alta prevalência da SM em diversas populaçôes e seu impacto na morbi-mortalidade dos indivíduos por ela acometidos, é de suma importância o conhecimento dos fatores causais ou de risco para essa síndrome. Sua gênese é multifatorial, incluindo fatores não modificáveis, como os genéticos, etnia e idade, e fatores modificáveis, como hábitos alimentares e de atividade física.

Há evidências de que o consumo de gorduras saturadas pode deteriorar as concentrações de glicemia de jejum e pós-prandial e insulinemia, além de conferir maior risco na progressão de TGD para diabetes. Além disso, a alta ingestão desse tipo de gordura provoca redução das concentrações de HDL-colesterol e elevação dos triglicérides, efeitos indesejáveis para o sistema cardiovascular.

A diminuição da ingestão de gordura total pode resultar em aumento da ingestão de carboidrato. É conhecido que a dieta pobre em gorduras totais e rica em carboidratos aumenta as concentrações de HDL-colesterol, provoca hipertrigliceridemia e hiperglicemia pós-prandial, exacerbando a resposta insulínica e contribuindo, portanto, para o aumento da prevalência da obesidade e o agravamento de dislipidemia e diabetes. É importante ressaltar que as consequiências metabólicas da ingestão de carboidratos dependerão não apenas da sua quantidade, mas também de sua qualidade, sendo menos deletérios os efeitos decorrentes dos carboidratos complexos.

A ingestão de grãos integrais, fibras de cereais e ácido graxo linoléico seria capaz de reduzir o risco de SM, ao passo que a de ácido graxo saturado poderia aumentar esse risco. Outros estudos indicam os benefícios da ingestão de grãos integrais, comparada com a ingestão de grãos refinados, na melhora da sensibilidade à insulina e conseqüente prevenção de diabetes tipo 2 e DCV.

Vários estudos mostraram a eficácia de programas de intervenção não farmacológica no controle da obesidade e na prevenção de diabetes, morbidades integrantes da SM. Investigações ainda são necessárias para certificar o benefício desses programas de intervenção na prevenção da SM propriamente dita e dos eventos cardiovasculares.

\section{Referências}

ALBERT, C. M. et al. Fish consumption and risk of sudden cardic death. Jama, 279: 23-28, 1998.

ALBERTI, K. G. \& ZIMMET, P. Definitions, diagnosis and classification of diabetes mellitus and its complications: provisional reports of an OMS consultation. Diabetes Care, 15: 539-553, 1998.

ALFTHAN, G. et al. Relation of serum homocycteine and lipoproteina (a) concentrations to atherosclerotic disease in a prospective Finnish population based study. Atherosclerosis, 106: 9-19, 1994.

ALPHA-TOCOPHEROL, BETA CAROTENE CANCER PREVENTION STUDY GROUP. The effect of vitamin $\mathrm{E}$ and beta carotene on the incidence of lung cancer and other cancers in male smokers. New England Journal of Medicine, 330: 1.029-1.035, 1994.

AMERICAN ASSOCIATION OF CLINICAL ENDOCRINOLOGISTS (AACE). Insulin resistance syndrome (position statement). Endocrine Practice, 9, suppl. 2: 9-21, 2003.

ANDERSON, J. W. Dietary fibre, complex carbohydrate and coronary artery disease. Canadian Journal of Cardiology, 11, suppl. G: 55-62, 1995.

ANDERSSEN, S. A. et al. Improved carbohydrate metabolism after physical training and dietary intervention in individuals with the 'atherothrombogenic syndrome'. Oslo Diet and Exercise Study (Odes). A Randomized Trial Journal of Internal Medicine, 240(4): 203-209, 1996. 
ARMSTRONG \& DOLL, R. Environmental factors and cancer incidence and mortality in different countries, with special reference to dietary practices. International Journal of Cancer, 15: 617-31,1975.

ASCHERIO, A. et al. Dietary intake of marine n-3 fatty acids, fish intake, and risk of coronary disease among men. New England Journal of Medicine, 332: 977-982, 1995.

ASCHERIO, A. et al. Trans fatty acids and coronary heart disease. New England Journal of Medicine, 340: 1.9941.998, 1999.

ASTRUP, A. et al. The role of low-fat diets and fat substitutes in body weight manage-men: what have we learned from clinical studies? Journal of the American Dietetic Association, 97, suppl. 7: S82-S87, 1997.

BALKAU, B. \& CARLES, M. A. Comment on the provisional report from the OMS Consultation of the European Group for the Study of Insulin-resistance. Diabetes Medicine, 16: 442-445, 1999.

BECKMAN, K. B. \& AMES, B. N. The free radical theory of aging matures. Physiological Reviews, 78: 547-581, 1998.

BENDER, D. A. \& BENDER, A. E. Nutrition: a reference handbook. New York: Oxford University, 1997.

BLOT, W. J. et al. Nutrition intervention trials in Linxian, China: supplementation with specific vitamin/mineral combinations, cancer incidence, and disease-specific mortality in the general population. Journal of the National Cancer Institute, 85: 1.483-1.492, 1993.

BOUSHEY, C. J. et al. A quantitative assessment of plasma homocysteine as a risk factor for vascular disease: probable benefits of increasing folic acid intakes. Jama, 274: 1.049-1.057, 1995.

BROWN, L. et al. Cholesterol-lowering effects of dietary fiber: a meta analysis. American Journal of Clinical Nutrition, 69: 30-42, 1999.

BURR, M. L. et al. Effects of changes in fat, fish and fibre intakes on death and myocardial reinfarction: Diet and Reinfarction Trial (Dart). The Lancet, 2: 757-761, 1989.

CALLE, E. E. \& KAAKS, R. Overweight, obesity and cancer: epidemiological evidence and proposed mechanisms. Nature Reviews. Cancer, 4: 579-591, 2004.

CARVALHEIRA, J. B. C. \& SAAD, M. J. A. Doenças associadas à resistência à insulina/hiperinsulinemia, não incluídas na síndrome metabólica. Arquivos Brasileiros de Endocrinologia e Metabologia, 50(2): 360-367, 2006.

CHEN, Y. D. et al. Why do low fat high carbohydrate diets accentuate postprandial lipemia in patients with NIDDM? Diabetes Care, 18: 10-16, 1995.

CHOBANIAN, A. V. et al. The Seventh Report of the Joint National Committee on Prevention, Detection, Evaluation and Treatment of High Blood Pressure. Jama, 290(2): 197, 2003.

CHOI, D. The prevalence of cardiovascular risk factors among elderly Chinese Americans. Archives of Internal Medicine, 150: 413-418, 1990.

CHUANG, S. Y.; CHEN, C. H. \& CHOU, P. Prevalence of metabolic syndrome in a large health check-up population in Taiwan [abstract]. Journal of the Chinese Medical Association, 67(12): 611-620, 2004.

CLARKE, R. et al. Dietary lipids and blood cholesterol: quantitative meta analysis of metabolic ward studies. British Medical Journal, 314: 112-117, 1997. 
DAMIÃO, R. et al. For The Japanese-Brazilian Diabetes Study Group. Dietary fat is associated with metabolic syndrome in Japanese-Brazilians. British Journal of Nutrition, 96: 532-538, 2006.

DAVIGLUS, M. L. et al. Fish consumption and the 30-year risk of fatal myocardial infarction. New England Journal of Medicine, 336: 1.046-1.053, 1997.

DAVY, B. M. \& MELBY, C. L. The effect of fiber-rich carbohydrates on features of syndrome X. Journal of the American Dietetic Association, 103: 86-96, 2003.

DE LORGERIL, M. et al. Mediterranean diet, traditional risk factors, and the rate of cardiovascular complications after myocardial infarction: final report of the Lyon Diet Heart Study. Circulation, 99: 779-785, 1999.

DIABETES PREVENTION PROGRAM RESEARCH GROUP (DPP). Reduction in the incidence of type 2 diabetes with lifestyle intervention or metformin. New England Journal of Medicine, 346: 393-403, 2002.

DIRETRIZ BRASILEIRA DE DIAGNÓSTICO E TRATAMENTO DE SÍNDROME METABÓLICA, I. Arquivos Brasileiros de Cardiologia, 84, supl. 1:1-29, 2005.

DUNSTAN, D. W. et al. The rising prevalence of diabetes and impaired glucose tolerance. The Australian Diabetes, Obesity and Lifestyle Study. Diabetes Care, 25: 829-834, 2002.

EGGER, G. The case for using waist to hip ratio measurements in routine medical checks. Medical Journal of Australia, 156: 280-285, 1992.

ERNST, N. D. et al. Consistency between U.S. dietary fat intake and serum total cholesterol concentrations: the National Health and Nutrition Examination Surveys. American Journal of Clinical Nutrition, 66, suppl.: S965-S72, 1997.

FESKENS, E. J. M. \& KROMHOUT, D. Habitual dietary intake and glucose tolerance in euglycaemic men: The Zutphen Study. International Journal of Epidemiology, 19: 953-959, 1990.

FESKENS, E. J. M.; BOWLES, C. H. \& KROMHOUT, D. Inverse association between fish intake and risk of glucose intolerance in normoglycemic elderly men and women. Diabetes Care, 14: 935-941, 1991.

FESKENS, E. J. M. et al. Dietary factors determining diabetes and impaired glucose tolerance. Diabetes Care, 18: 1.104-1.112, 1995.

FESTA, A. et al. Chronic subclinical inflammation as part of insulin resistance syndrome: the Insulin Resistance Atherosclerosis Study (Iras). Circulation, 4, 102(1): 42-47, 2000.

FOLSOM, A. R. et al. Prospective study of coronary heart disease incidence in relation to fasting total homocysteine, related genetic polymorphisms, and B vitamins: the Atherosclerosis Risk in Communities (Aric) Study. Circulation, 98: 204-210, 1998.

FOOD AND AGRICULTURE ORGANIZATION (FAO)/WORLD HEALTH ORGANIZATION (WHO). Expert consultation. Carbohydrates in Human Nutrition. Geneva: FAO, 1998. (Food and Nutrition, 66)

FORD, S. E. \& GILES, W. H. A comparison of the prevalence of the metabolic syndrome using two proposed definitions. Diabetes Care, 26: 575-581, 2003.

FORD, E. S.; GILES, W. H. \& MOKDAD, A. H. Increasing prevalence of the metabolic syndrome among US adults. Diabetes Care, 27(10): 2.444-2.449, 2004.

FOSTER-POWELL, K.; HOLT, S. H. \& BRAND-MILLER, J.C. International table of glycemic index and glycemic load values. American Journal of Clinical Nutrition, 76: 5-56, 2002. 
FRANCO, L. J. Diabetes in Japanese-Brazilians: influence of the acculturation process. Diabetes Research Clinical Practice, 34: S51-S7, 1996.

FREIRE, R. D. et al. For the Japanese-Brazilian Diabetes Study Group. Dietary fat is associated with metabolic syndrome in Japanese-Brazilians. Diabetes Care, 28(7): 1.779-1.785, 2005.

GABBAY, M. A. L. et al. Prevalence and trends of metabolic syndrome in type 1 diabetes according to duration of the disease. Diabetes, 54, suppl. 1: A176, 2005.

GARG, A. High-monounsaturated-fat diets for patients with diabetes mellitus: a meta analysis. American Journal of Clinical Nutrition, 67, suppl.: S577-S82, 1998.

GINSBERG, H. N. et al. Effects of reducing dietary saturated fatty acids on plasma lipids and lipoproteins in healthy subjects: the Delta Study, Protocol 1. Arteriosclerosis, Thrombosis and Vascular Biology, 18: 441-449, 1998.

GIOVANNUCCI, E. et al. Intake of fat, meat, and fiber in relation to risk of colon cancer in men. Cancer Research, 54: 2.390-2.397, 1994.

GISSI PREVENZIONE INVESTIGATORS. Dietary supplementation with n-3 polyunsaturated fatty acids and vitamin E after myocardial infarction: results of the GISSI Prevenzione Trial. The Lancet, 354: 447455, 1999.

GORDON, D. J. Cholesterol and mortality: what can meta-analysis tell us? In: GALLO, L. L. (Ed.) Cardiovascular Disease 2: cellular and molecular mechanisms, prevention, and treatment. New York: Plenum Press, 1995.

GRUNDY, S. M. \& DENKE, M. A. Dietary influences on serum lipids and lipoproteins. Journal Lipid Research, 31: 1.149-1.172, 1990.

GUPTA, R. et al. Prevalence of metabolic syndrome in an Indian urban population. International Journal of Cardiology, 97(2): 257-261, 2004.

HAFFNER, S. M. et al. Prospective analysis of the insulin-resistance syndrome (Syndrome X). Diabetes, 41: 715-722, 1992.

HALL, J. E. et al. Abnormal kidney function as a cause and a consequence of obesity hypertension. Clinical and Experimental Pharmacology \& Physiology, 25: 58-64, 1998.

HARRIS, W. S. Fish oils and plasma lipid and lipoprotein metabolism in humans: a critical review. Journal of Lipid Research, 30: 785-807, 1989.

HARRIS, W. S. N-e fatty acids and serum lipoproteins: human studies. American Journal of Clinical Nutrition, 65, suppl. 5: S1645-S54, 1997.

HEART OUTCOMES PREVENTION EVALUATION STUDY INVESTIGATORS. Vitamin E supplementation and cardiovascular events in high-risk patients. New England Journal of Medicine, 342: 154-160, 2000.

HEITMAN, B. L. et al. Dietary fat intake and weight gain in women genetically predisposed for obesity. American Journal of Clinical Nutrition, 61: 1.213-1.217, 1995.

HENNEKENS, C. H. et al. Lack of effect of long-term supplementation with beta carotene on the incidence of malignant neoplasms and cardiovascular disease. New England Journal of Medicine, 334: 1.145-1.149, 1996.

HIMSWORTH, H. P. Diabetes mellitus: its differentiation into insulin-sensitive and insulin-insensitive types. The Lancet, 1: 127-130, 1936. 
HU, F. B. et al. A prospective study of egg consumption and risk of cardiovascular disease in men and women. Jama, 281: 1.387-1.394, 1999.

HU, F. B. et al. Diet, lifestyle, and the risk of type 2 diabetes mellitus in women. New England Journal of Medicine, 345: 790-797, 2001.

HU, G. et al. Decode Study Group. Prevalence of metabolic syndrome and its relation to all-cause and cardiovascular mortality in nondiabetic European men and women. Archives of Internal Medicine, 24, 164(10): 1.066-1.076, 2004.

HUNT, K. J. et al. San Antonio Heart Study. National Cholesterol Education Program versus World Health Organization metabolic syndrome in relation to all-cause and cardiovascular mortality in the San Antonio Heart Study. Circulation, 110: 1.251-1.257, 2004.

INTERNATIONAL DIABETES FEDERATION (IDF). The IDF consensus worldwide definition of the metabolic syndrome, 2006.

ISSO, H. et al. Linoleic acid, other fatty acids, and the risk of stroke. Stroke, 33: 2.086-2.093, 2002.

JACQUES, P. F. et al. The effect of folic acid fortification on plasma folate and total homocysteine concentrations. New England Journal of Medicine, 340: 1.449-1.454, 1999.

JENKINS, D. J. A. et al. Glycemic index of foods: a physiological basis for carbohydrate exchange. American Journal of Clinical Nutrition, 34: 362-366, 1981.

KATAN, M. B.; GRUNDY, S. M. \& WILLETT, W. C. Should a low-fat, high-carbohydrate diet be recommended for everyone? Beyond low-fat diets. New England Journal of Medicine, 337: 563-567, 1997.

KATZMARZYK, P. T. et al. Targeting the metabolic syndrome with exercise: evidence from the Heritage Family Study. Medicine and Science in Sports and Exercise, 35(10): 1.703-1.709, 2003.

KELLEY, D. E.; GOODPASTER, B. H. \& STORLIEN, L. Muscle triglyceride and insulin resistance. Annual Review of Nutrition, 22: 325-346, 2002.

KEY, R. L. et al. Dietary habits and mortality in 11.000 vegetarians and health people: results of a 17-year follow-up. British Medical Journal, 313: 775-779, 1996.

KEYS, A. et al. The diet and 15-year death rate in the Seven Countries Study. American Journal of Epidemiology, 124: 903-915, 1986.

KIEHM, T. G.; ANDERSON, T. W. \& WARD, K. Beneficial effects of a high carbohydrate, high fiber diet on hyperglycemic diabetic men. American Journal of Clinical Nutrition, 29: 895-899, 1976.

KNOPP, R. H. et al. Long term cholesterol-lowering effects of 4 fat-restricted diets in hypercholesterolemic and combined hyperlipidemic men: the Dietary Alternatives Study. Jama, 278: 1.509-1.515, 1997.

KNUIMAN, J. T. et al. Total cholesterol and high density lipoprotein cholesterol levels in populations differing in fat and carbohydrate intake. Arteriosclerosis, 7: 612-6199, 1987.

KRIS-ETHERTON, P. M. \& YU, S. Individual fatty acid effects on plasma lipids and lipoproteins: human studies. American Journal of Clinical Nutrition, 65, suppl. 5: S1.628-S1.644, 1997.

KRIS-ETHERTON, P. M. et al. High-monounsaturated fatty acid diets lower both plasma cholesterol and triacylglycerol concentrations. American Journal of Clinical Nutrition, 70: 1.009-1.015, 1999. 
KROMHOUT, D. et al. Dietary saturated and trans fatty acids and cholesterol and 25 year mortality from coronary heart disease: the seven countries study. Preventive Medicine, 24: 308-315, 1995.

LAKKA, H. M. et al. The metabolic syndrome and the total and cardiovascular disease mortality in middle-aged men. Jama, 288: 2.709-2.716, 2002.

LICHTENSTEIN, A. H. et al. Effects of different forms of dietary hydrogenated fats on serum lipoprotein cholesterol levels. New England Journal of Medicine, 340: 1.933-1.940, 1999.

LIESE, A. D. et. al. Whole-grain intake and insulin sensitivity: the Insulin Resistance Atherosclerosis Study. American Journal of Clinical Nutrition, 78: 965-971, 2003.

LISSNER, L. \& HEITMAN, B. L. Dietary fat and obesity: evidence from epidemiology. European Journal of Clinical Nutrition, 49: 79-90, 1995.

LORENZO, C. et al. The metabolic syndrome as predictor of type 2 diabetes: the San Antonio Heart Study. Diabetes Care, 26(3): 153-159, 2003.

MARON, D. J.; FAIR, J. M. \& HASKEL, W. L. Saturated fat intake and insulin resistance in men with coronary artery disease. Circulation, 84: 2.020-2.027, 1991.

MCKEOWN, N. M. et al. Carbohydrate nutrition, insulin resistance, and the prevalence of the metabolic syndrome in the Framingham Offspring Cohort. Diabetes Care, 27: 538-546, 2004.

MEIGS, J. B. et al. Prevalence and characteristics of the metabolic syndrome in the San Antonio Heart and Framingham Offspring Studies. Diabetes Care, 52(8): 2.160-2.167, 2003.

MENSINK, R. P. \& KATAN, M. B. Effects of dietary fatty acids on serum lipids and lipoproteins: a metaanalysis of 27 trials. Arteriosclerosis and Thromobosis, 12: 911-919, 1992.

MINISTRY OF HEALTH AND WELFARE, JAPAN. Recommended dietary allowances for Japanese. 5. ed. Tokyo: Daiichi-Shuppan Co, 1994.

MOHAMED-ALI, V.; PINKNEY, J. K. \& COPPACK, S. W. Adipose tissue as an endocrine and para crine organ. International Journal of Obesity, 22: 1.145-1.158, 1998.

MORRIS, M. C. et al. Fish consumption and cardiovascular disease in the Physicians'Health Study: a prospective study. American Journal of Epidemiology, 142: 166-175, 1995.

NATIONAL CHOLESTEROL EDUCATION PROGRAM (NCEP). NCEP ATP III - Executive summary of the Third Report of the NCEP. Expert panel on detection, evaluation, and treatment of high blood cholesterol in adults (Adult Treatment Panel III). Jama, 285: 2.486-2.497, 2001.

NATIONAL INSTITUTES OF HEALTH. Clinical guidelines on the identification, evaluation, and treatment of overweight and obesity in adults the evidence report. Obesity Research, 6, suppl. 2: S51-S209, 1998.

NATIONAL RESEARCH COUNCIL. Dietary Reference Intakes for Vitamin C, Vitamin E, Selenium, and Carotenoids. Washington: National Academy Press, 2000.

NELSON, L. H. \& TUCKER, L. A. Diet composition related to body fat in a multivariate study of 203 men. Journal of the American Dietetic Association, 96: 771-777, 1996.

NUTRITION AND YOUR HEALTH. Dietary Guidelines for Americans, 2000. 5. ed. Washington: U.S. Department of Agriculture, 2000. Disponível em: <http://www.nal.usada.gov/fnic/dga/index.html>. Acesso em: 14 out. 2005. 
NYGARD, O. et al. Plasma homocysteine levels and mortality in patients with coronary artery disease. New England Journal of Medicine, 337: 230-236, 1997.

OLIVEIRA, E. P.; SOUZA, M. L. A. \& LIMA, M. D. A. Prevalência de síndrome metabólica em uma área rural do Semi-Árido baiano. Arquivos Brasileira de Endocrinologia e Metabologia, 50(3): 456-465, 2006.

OMENN, G. S. et al. Effects of a combination of beta carotene and vitamin A on lung cancer and cardiovascular disease. New England Journal of Medicine, 334: 1.150-1.155, 1996.

PARKER, D. R. et al. Relationship of dietary saturated fatty acids and body habitus to serum insulin concentrations; the Normative Aging Study. American Journal of Clinical Nutrition, 58: 129-136, 1993.

PEREIRA, M. A. et al. Dairy consumption, obesity, and the insulin resistance syndrome in young adults: the CARDIA Study. Jama, 287: 2.081-2.089, 2002.

PICON, P. X. et al. Análise dos critérios de definição da síndrome metabólica em pacientes com diabetes melito tipo 2. Arquivos Brasileiros Endocrinologia Metabologia, 50(2): 264-270, 2006.

POTTER, J. G. et al. Effect of test meals of varying dietary fiber content on plasma insulin and glucose response. American Journal of Clinical Nutrition, 34: 328-334, 1981.

PURNELL, J. Q. \& BRUNZELL, J. D. The central role of dietary fat, not carbohydrate, in the insulin resistance syndrome. Current Opinion in Lipidology, 8: 17-22, 1997.

REAVEN, G. M. Banting Lecture 1988. Role of insulin resistance in human disease. Diabetes Care, 37: 1.5951.607, 1988.

RIBEIRO-FILHO, F. F. et al. Gordura visceral e síndrome metabólica: mais que uma simples associação. Arquivos Brasileiros de Endocrinologia e Metabolismo, 50(2): 230-238, 2006.

ROBERTS, C. K.; VAZIRI, N. D. \& BARNARD, R. J. Effect of diet and exercise intervention on blood pressure, insulin, oxidative stress, and nitric oxide availability. Circulation, 106: 2.530-2.533, 2002.

ROBERTSON, T. L. et al. Epidemiologic studies of coronary heart disease and stroke in Japanese men living in Japan, Hawaii and California: incidence of myocardial infarction and death from coronary heart disease. American Journal of Cardiology, 39: 239-243, 1977.

ROCHE, H. M. \& GIBNEY, M. J. Effects of long-chain n-3 polyunsaturated fatty acids on fasting and postprandial triacylglycerol metabolism. American Journal of Clinical Nutrition, 71, suppl.: S232-S7, 2000.

ROSENBAUM, P.; GIMENO, S. G. A. \& FERREIRA, S. R. G. Analysis of criteria for metabolic syndrome in a population-based study of Japanese-Brazilians 2005. Diabetes, Obesity and Metabolism, 7: 352-359, 2005.

RUDEL, L. L.; PARKS, J. S. \& SAWYER, J. K. Compared with dietary monounsatured and satured fat, polyunsaturated fat protects African green monkeys from coronary artery atherosclerosis. Arteriosclerosis, Thrombosis and Vascular Biology, 15: 2.101-2.110, 1995.

SANTOS, A. C.; LOPES, C. \& BARROS, H. Prevalence of metabolic syndrome in city of Porto. Revista Portuguesa de Cardiologia; 23(1): 45-52, 2004.

SARTORELLI, D. S. Índice Glicêmico da Dieta Habitual e Alteração da Homeostase Glicêmica em Nipo-Brasileiros de Bauru, 2005. Tese de Doutorado, São Paulo: Faculdade de Saúde Pública, Universidade de São Paulo.

SHULMANN, G. I. Cellular mechanism of insulin resistance. The Journal of Clinical Investigation, 106(2): 171$176,2000$. 
SING, R. B. et al. Randomized, double-blind, placebo-controlled trial of fish oil and mustard oil in patients with suspected acute myocardial infarction: the Indian Experiment of Infarct survival-4. Cardiovascular Drugs and Therapy, 11: 485-491, 1997.

SIQUEIRA, A. F. A.; ABDALLA, D. S. P. \& FERREIRA, S. R. G. LDL: da síndrome metabólica à instabilização da placa aterosclerótica. Arquivos Brasileiros de Endocrinologia e Metabologia, 50(2): 334-343, 2006.

SNOWDON, D. A.; PHILLIPS, R. L. \& FRASER, G. E. Meat consumption and fatal ischemic heart disease. Preventive Medicine, 13: 490-500, 1984.

STAMLER, J. \& SHEKELLE, R. Dietary cholesterol and human coronary heart disease: the epidemiologic evidence. Archives of Pathology and Laboratory Medicine, 112: 1.032-1.040, 1988.

STAMPFER, M. J. et al. A prospective study of plasma homocysteine and risk of myocardial infarction in US physicians. Jama, 268: 877-881, 1992.

STEPHENS, N. G. et al. Randomised controlled trial of vitamin E in patients with coronary disease: Cambridge Heart Antioxidant Study (Chaos). The Lancet, 347: 781-786, 1996.

TSUNEHARA, C. H.; LEONETTI, D. L. \& FUJIMOTO, W. Y. Animal fat and cholesterol intake is high in men with IGT progressing to NIDDM. Diabetes, 40: 427, 1991.

TUOMILEHTO, J. et al. The Finnish Diabetes Prevention Study Group. Prevention of type 2 diabetes mellitus by changes in lifestyle among subjects with impaired glucose tolerance. New England Journal of Medicine, 344: 1.343-1.350, 2001.

TURLEY, M. L. et al. The effect of a low fat, high carbohydrate diet on serum high density lipoprotein cholesterol and triglyceride. European Journal of Clinical Nutrition, 52: 728-732, 1998.

UAUY, R.; MENA, P. \& VALENZUELA, A. Essential fatty acids as determinants of lipid requirements in infants, children and adults. European Journal of Clinical Nutrition, 52: 1-12, 1999.

WALDEN, C. E. et al. Differential effect of National Cholesterol Education Program (NCEP) Step II diet on HDL cholesterol, its subfractions, and apoprotein A-I in hypercholesterolemic women and men after 1 year: the be FIT study. Arteriosclerosis, Thrombosis and Vascular Biology, 20: 1.580-1.587, 2000.

WEGGEMANS, R. M.; ZOCK, P. L. \& KATAN, M. B. Dietary cholesterol from eggs increases the ratio of total cholesterol to high-density lipoprotein cholesterol in humans: a meta analysis. American Journal of Clinical Nutrition, 73: 885-891, 2001.

WEST, C. E. et al. Boys from populations with high carbohydrate intake have higher fasting triglyceride levels than boys from populations with high fat intake. American Journal of Epidemiology, 131: 271-282, 1990.

WHITTEMORE, A. S. Colorectal cancer incidence among Chinese in North America and the people's Republic of China: variation with sex, age and anatomical site. International Journal of Epidemiology, 18: 563-568, 1989.

WILLETT, W. C. et al. Intake of trans fatty acids and risk of coronary heart disease among women. The Lancet, 341: 581-585, 1993.

WIRFÄLT, E. et al. Food patterns and components of the metabolic syndrome in men and women: a crosssectional study within the Malmö diet and cancer cohort. American Journal of Epidemiology, 154: 1.150$1.159,2001$. 
WORLD HEALTH ORGANIZATION (WHO)/FOOD AND AGRICULTURE ORGANIZATION (FAO). Joint OMS/FAO Expert Consultation. Diet, Nutrition and the Prevention of Chronic Diseases. Geneva: WHO, FAO, 2003.

YAFFE, K. et al. The metabolic syndrome, inflammation, and risk of cognitive decline. Jama, 292: 2.237-2.242, 2004.

YANG, W. \& READ, M. Dietary pattern changes of Asian immigrants. Nutrition Research, 16: 1.277-1.293, 1996.

YOSHIIKE, N. et al. National nutrition survey in Japan. Journal of Epidemiology, 6: S189-S200, 1996.

ZIMMET, P. et al. The metabolic syndrome: a global public health problem and a new definition. Journal of Atherosclerosis and Thrombosis, 12(6): 295-300, 2005. 


\title{
23
}

\section{Fatores Nutricionais e Hipertensão Arterial}

\author{
Gustavo Velásquez-Meléndez, Sandhi Maria Barreto e Adriano Marçal Pimenta
}

\begin{abstract}
A pressão arterial é a força que o sangue exerce sobre a parede das artérias e é necessária para que o sangue circule por todo o organismo. Ela varia de uma pessoa para outra e em diferentes horas do dia, e tende a se elevar com a idade. Valores elevados de pressão arterial estão fortemente associados com o desenvolvimento de Doenças Cardiovasculares (DCV), cerebrovasculares e insuficiência renal. Estudos longitudinais mostram, por exemplo, que a partir de $115 \mathrm{mmHg}$ de Pressão Arterial Sistólica (PAS) e $75 \mathrm{mmHg}$ de Pressão Arterial Diastólica (PAD), o risco de um indivíduo, entre 40 e 70 anos de idade, desenvolver DCV dobra a cada incremento de $20 \mathrm{mmHg}$ na PAS e $10 \mathrm{mmHg}$ na PAD. Entretanto, para fins de diagnóstico, a Hipertensão Arterial (HA) é definida como a presença de níveis de PAS $\geq 140 \mathrm{mmHg}$ e/ou de PAD $\geq 90 \mathrm{mmHg}$ em indivíduos com 18 ou mais anos de idade. Esses valores devem expressar a média de duas ou mais medidas de pressão arterial tomadas com o indivíduo sentado e em duas ocasiōes diferentes (Aram et al., 2003).

A hipertensão é uma condição extremamente comum e de difícil controle em todo o mundo (WolfMaier et al., 2004). O estudo de Framingham estimou que o risco de uma pessoa de meia-idade ou idosa ter HA durante a vida é de 90\% (Vasan et al., 2002). Em 2000, mais de um quarto (26,4\%) da população mundial com 20 ou mais anos de idade tinha HA, o que representa em números absolutos um total de 972 milhões de pessoas. Deste total, cerca de um terço (333 milhões) residia em países desenvolvidos e os demais (639 milhōes), em países em desenvolvimento. Projeçôes para o ano de 2025 estimam que a prevalência da hipertensão poderá atingir 29,2\% do total de adultos no mundo (Kearney et al., 2005).

Apesar de o Brasil não dispor de estatísticas sobre a magnitude desta doença em todo o território nacional, estimativas realizadas com base em estudos locais de base populacional no Sul e Sudeste do país indicam que aproximadamente 20\% da população adulta brasileira têm HA (Brasil, 2001a; Passos, Assis \& Barreto, 2006). Estima-se, portanto, que existam trinta milhões de adultos com HA, dos quais metade não tem conhecimento da doença e apenas um quarto controla adequadamente sua pressão. Em um estudo regional, apenas 25,6\% dos indivíduos com hipertensão haviam controlado adequadamente o nível pressórico (Gus et al., 2004). Esses valores são próximos aos encontrados em países como os Estados Unidos, onde cerca de dois terços da população adulta com hipertensão não tratam ou tratam inadequadamente a doença (Wang \& Vasan, 2005). Em alguns países, como a China, as taxas de controle são inaceitavelmente mais baixas, chegando a apenas $8 \%$ (Gu et al., 2002).
\end{abstract}


Além da idade, fatores ambientais e genéticos influenciam a elevação da pressão arterial. Entre os fatores ambientais que afetam a pressão arterial, a dieta tem papel proeminente. Estudos observacionais e experimentais mostram que, em indivíduos com níveis pressóricos normais (inferiores a 140/90 mmHg), a adoção de uma dieta que reduza a pressão arterial pode prevenir o desenvolvimento da HA, e, naqueles com níveis pressóricos elevados, pode reduzir o risco de complicações comumente associadas à hipertensão.

A dieta e o estilo de vida são considerados complementos indispensáveis para o controle da HA, mesmo entre indivíduos que fazem tratamento medicamentoso adequado (Hoffer, 1997; Neaton et al., 1993). Em geral, o sobrepeso, o alto consumo de sal e o baixo consumo de potássio parecem ser os principais fatores relacionados à dieta passíveis de modificação e que apresentam um efeito potencialmente significativo sobre os níveis tensionais.

Em um sentido restrito, nutrição envolve todos os componentes dos alimentos que necessitamos para o desenvolvimento, funcionamento e manutenção da vida, como as proteínas, os carboidratos, os minerais, as gorduras e vitaminas. Mas as pesquisas na área de nutrição e HA contemplam também os suplementos alimentares e ingredientes não nutritivos, como as gorduras hidrogenadas, vitaminas antioxidantes, os aminoácidos etc.

O presente capítulo apresenta uma revisão dos principais nutrientes e dietas com efeito potencial sobre os níveis tensionais. Esses resultados foram obtidos, principalmente, em grandes estudos longitudinais e ensaios clínicos controlados. A grande maioria dos resultados apresentados foi corroborada em estudos de revisão sistemática ou metanálises publicadas recentemente.

\section{Evidência de Efeito Causal em Estudos Epidemiológicos}

Revisões sistemáticas de estudos epidemiológicos experimentais e observacionais permitem classificar o nível de evidência acumulado sobre o efeito de um alimento ou nutriente sobre a saúde, e, assim, guiar ou reorientar recomendaçôes para indivíduos e populações e identificar a necessidade de novos estudos sobre o tema. Em termos ideais, a classificação de um alimento ou nutriente como um fator de risco ou de proteção para a saúde deveria basear-se em evidências derivadas de múltiplos ensaios clínicos aleatórios realizados em grupos representativos das populaçôes-alvo ou relevantes para aquele alimento ou efeito postulado. Mas nem sempre é possível realizar estudos aleatórios nesta área.

Apesar do rigor e grande número de ensaios clínicos bem delineados relacionando dieta e HA, tais estudos não estão isentos de limitações. Em geral, os ensaios clínicos testam questôes bem específicas sobre o benefício potencial de uma dada dieta. Para se viabilizarem, geralmente, são feitos em populações selecionadas, especialmente com relação à motivação e condição de saúde e, não raramente, envolvem circunstâncias dietéticas artificiais, diferentes daquelas efetivamente praticadas na vida real. Estudos com pequeno tempo de seguimento deixam sem resposta os efeitos de longo prazo. Essas dificuldades podem afetar negativamente a reprodutibilidade dos resultados obtidos.

Problemas como esses não têm, entretanto, solução ideal. É inadmissível privar a população de informações potencialmente relevantes para a saúde simplesmente porque um ensaio clínico ainda está em curso. Se a diminuição do sal na dieta indicar uma redução na mortalidade, seria eticamente inaceitável guardar tal informação até o final de um estudo, só para garantir que a análise e os resultados finais sejam mais robustos. Por essas razões, os estudos observacionais constituem também importantes fontes de evidências em epidemiologia nutricional. Além de investigar efeitos de curto e longo prazos de uma dieta ou componente alimentar que não seriam eticamente passíveis de inclusão em estudos experimentais, os estudos observacionais permitem investigar interações potenciais entre um alimento e um outro fator de risco comportamental, ambiental, genético ou relacionado à própria condição de saúde. Entretanto, mesmo quando bem conduzidos, pode ser difícil identificar o verdadeiro responsável pelo efeito observado nesses estudos. Por exemplo, seria uma determinada dieta ou um nutriente nela contido? Em outras palavras, o açúcar ou o refrigerante, a vitamina $\mathrm{C}$ ou a dieta rica em frutas e legumes frescos? 
Diferentes denominaçõos são utilizadas para classificar os níveis de evidência sobre associaçõos causais biologicamente plausíveis, mas todas mantêm coerência com relação aos critérios considerados para julgar as associaçōes observadas. As orientações preconizadas em consensos americanos (Chobanian et al., 2003; Whelton et al., 2002) ou pela Organização Mundial da Saúde - OMS (WHO, 2003) geralmente se baseiam em análises criteriosas do desenho e da qualidade dos estudos que geraram aquela informação.

De forma sintética, uma evidência de associação causal é considerada 'convincente' quando está baseada em numerosos estudos observacionais prospectivos e foi confirmada por ensaios clínicos controlados com tamanho, duração e qualidade suficientes para estimarem o efeito postulado, sempre que possível. A evidência 'provável' advém de estudos que produziram associaçôes razoavelmente consistentes entre exposição e doença, mas apresentam limitações, como duração insuficiente do estudo, número insuficiente de estudos ou tamanho de amostra inadequado, seguimento incompleto ou alguma evidência em contrário que impeça um julgamento mais definitivo. Evidência 'possível' baseia-se em resultados de estudos caso controle ou transversais, que precisam ser confirmados por ensaios clínicos randomizados e/ou estudos longitudinais com desenho e tamanho suficientes. Uma evidência é considerada 'insuficiente' quando existem poucos estudos a respeito e a associação entre exposição e doença é insuficientemente estabelecida e não há evidências originadas de ensaios clínicos randomizados.

\section{Nutrientes e Dietas com Efeito Potencial sobre a Pressão Arterial}

Os níveis da pressão arterial, bem como o seu incremento com a idade e a prevalência da HA, são influenciados pela dieta. Portanto, a adoção de uma dieta saudável ajuda a prevenir e controlar esta doença. São apresentadas, aqui, evidências científicas obtidas de estudos observacionais e experimentais que sustentam esse fato.

\section{Minerais}

Sódio, potássio, magnésio e cálcio são os minerais mais freqüentemente investigados com relação a um potencial efeito sobre a pressão arterial. O potássio e o sódio são minerais essenciais para a regulação dos fluidos intra e extracelulares, atuando na manutenção da pressão sanguínea. O sal de cozinha - cloreto de sódio - é a principal fonte de sódio, sendo composto por $40 \%$ deste mineral. A necessidade humana diária de sal é cerca de 300-500 mg. A maior parte dos indivíduos, mesmo crianças, consome níveis bem além de suas necessidades deste mineral.

\section{Sódio}

O consumo de sódio está relacionado diretamente com a pressão arterial. Em geral, os ensaios clínicos mostram que reduções de $50 \%$ no consumo habitual de sódio diminuem os níveis tensionais em indivíduos normotensos e hipertensos. O impacto dessas reduções foi calculado em aproximadamente 5 e $3 \mathrm{mmHg}$ para PAD e PAS, respectivamente. Em normotensos, as reduções foram de $2 \mathrm{mmHg}$ para PAS e $1 \mathrm{mmHg}$ para PAD (He \& MacGregor, 2002; Geleijnse, Grobbee \& Kok, 2005).

Dados populacionais sugerem que uma redução de $3 \mathrm{~g} /$ dia de sódio está associada com diferenças na pressão sistólica de $5 \mathrm{mmHg}$ na faixa de 15 a 19 anos e de $10 \mathrm{mmHg}$ nas idades de 60 a 69 anos. Uma redução de $10 \mathrm{mmHg}$ na pressão sistólica, obtida com uma diminuição modesta no consumo de sal, poderia reduzir a incidência de Acidente Vascular Cerebral (AVC) em aproximadamente um terço, a doença isquêmica do coração em um quarto e a insuficiência cardíaca em mais de $25 \%$ na população entre 60 e 80 anos (He, Markandu \& MacGregor, 2005). Estima-se que a redução de $3 \mathrm{~g} /$ dia poderia levar a uma redução de $50 \%$ no número de 
indivíduos com necessidade de tratamento anti-hipertensivo, 22\% no número de mortes por AVC e 16\% nas mortes por doenças coronarianas.

Uma interessante preocupação relativa à sustentabilidade dos resultados dos estudos sistemáticos de restrição de sódio na dieta e redução dos níveis tensionais foi levantada em estudo de metanálise (Hooper et al., 2002). Os autores revisaram numerosos estudos experimentais com o objetivo de testar o efeito da restrição de sódio sobre os níveis tensionais em indivíduos normotensos e hipertensos com efeitos de longo prazo (6 a 60 meses). Apenas 11 estudos foram escolhidos por serem os mais adequados do ponto de vista metodológico, considerando a aleatorização, o controle de variáveis e a validade. Essa metanálise analisou resultados de 3.491 participantes em testes de redução de sódio na dieta. Os resultados mostram que restrição de sódio de longo prazo levou a significativa redução nos níveis de pressão arterial sistólica e que essa medida pode ajudar os pacientes que usam medicação a interromperem seu uso desde que mantenham adequado controle dos seus níveis tensionais.

Por essas razões, a OMS preconiza uma política global de redução no consumo de sal para toda a população, possível, por exemplo, pela redução do sal em produtos industrializados. Tal redução promoveria diminuições dos níveis de pressão arterial em todos os grupos populacionais, doentes e não doentes, por um período longo e sustentável. Considerando a alta prevalência da hipertensão e os riscos a ela associados, o efeito positivo sobre a morbi-mortalidade e a sobrevida seria enorme, além da redução dos gastos relacionados a DCV (Lewington et al., 2003; Selmer, Kristiansen \& Haglerod, 2000).

\section{Potássio}

Apesar de ter sido investigada em estudos observacionais, a evidência de uma relação inversa entre o consumo de potássio e a pressão arterial em indivíduos hipertensos e não hipertensos que não apresentam comprometimento renal advém principalmente de estudos de intervenção randomizados. $\mathrm{O}$ efeito redutor do potássio atinge todos os indivíduos, mas é maior em negros do que em brancos (Berenson et al., 2006). A proporção do efeito do potássio sobre a pressão arterial também depende da quantidade de sódio consumida concomitantemente: o efeito redutor é maior quando o consumo de sódio é elevado. Da mesma forma, o efeito positivo da redução do sal sobre os níveis pressóricos também é maior quando o consumo de potássio é baixo.

Em ensaios clínicos controlados, o aumento no consumo de potássio por meio de frutas e vegetais ou pela suplementação alimentar com cloreto de potássio reduz significativamente a pressão arterial, especialmente em indivíduos com níveis pressóricos aumentados (Whelton et al., 1997, He, Markandu \& MacGregor, 2005). Em um estudo de metanálise, evidenciou-se que o aumento da ingestão de 1,8 a 1,9 g de potássio por dia diminui em 4,0 $\mathrm{mmHg}$ a PAS e em $2,5 \mathrm{mmHg}$ a PAD (Whelton et al., 1997). Entretanto, indivíduos com doença renal crônica apresentam risco de hiperpotassemia quando submetidos a altas doses de potássio. As evidências acumuladas até hoje não permitem determinar o nível seguro de consumo de potássio nesses indivíduos, embora indivíduos com doença renal crônica avançada, com taxa de filtração glomerular inferior a $60 \mathrm{~mL} / \mathrm{min}$ por $1,73 \mathrm{~m}^{2}$, devam restringir seu consumo de potássio.

\section{Cálcio}

Uma metanálise com 23 estudos observacionais relatou associação inversa entre a pressão arterial e o consumo de cálcio, medido pelo recordatório de 24 horas ou pelo questionário de freqüência alimentar (Cappuccio et al., 1995). Os autores ressaltaram, entretanto, que, além de o efeito ser pequeno, os resultados dos estudos apresentavam heterogeneidade e alguns estudos não realizaram o controle adequado dos fatores de confusão. Em 1999, outro estudo indicou que o consumo de cálcio acima de $1.000 \mathrm{mg}$ por dia pode produzir uma queda de 1,4 $\mathrm{mmHg}$ na pressão arterial sistólica e de $0,8 \mathrm{mmHg}$ na pressão arterial diastólica (Griffith et al., 
1999). Contudo, revisão sistemática recente dos ensaios clínicos já realizados sobre o tema concluiu que a suplementação de cálcio na dieta contribui de forma modesta para a redução da pressão arterial e que a causalidade dessa relação foi fraca e provavelmente devida a viés (Dickinson et al., 2006a). Por essa razão, e para evitar os efeitos indesejáveis do cálcio sobre os rins (litíase renal), o consumo ou suplemento de cálcio acima da dose diária recomendada não está indicado.

\section{Magnésio}

De maneira geral, as evidências que relacionam o magnésio com a pressão arterial são insuficientes e inconsistentes. Apesar de os estudos observacionais mostrarem uma associação negativa entre magnésio na dieta e pressão arterial (Mizushima et al., 1998), esta não foi confirmada nos ensaios clínicos realizados (Jee et al., 2002). Uma revisão sistemática de vinte ensaios clínicos publicados sobre a suplementação alimentar com magnésio mostrou que os resultados desses estudos não são suficientes para confirmar uma associação causal entre o aumento do consumo de magnésio e a redução da pressão arterial (Dickinson et al., 2006b).

Finalmente, estudos de metanálise sobre o uso de suplementação conjunta de potássio, magnésio e cálcio na dieta não revelaram evidências sobre a eficácia da mesma na diminuição dos níveis tensionais em adultos (Beyer et al., 2006).

\section{Derivados do Leite}

Vários estudos observacionais mostram um efeito benéfico dos derivados do leite sobre a pressão arterial, especialmente em indivíduos com sobrepeso e idade inferior a 40 anos. Estudos em populações com meia-idade indicam uma redução de mais de 50\% no risco de desenvolver hipertensão entre indivíduos expostos a uma dieta rica em derivados do leite com baixo teor de gorduras, mas não entre os que consomem derivados integrais (Alonso et al., 2005). Em Teerã, estudo transversal também mostrou menor prevalência de hipertensão entre indivíduos que consumiam mais derivados de leite (Azadbakht et al., 2005). Mais recentemente, observou-se também menor prevalência de hipertensão entre pessoas que consumiam derivados de leite, independentemente do consumo de cálcio. Também nesse estudo o efeito foi maior entre os que consumiam menos gorduras saturadas. Os autores também não encontraram evidência de interação entre ácido linolênico e consumo de derivados de leite na HA (Djousse, et al., 2006).

\section{Álcool}

A pressão arterial aumenta progressivamente com o consumo de álcool, independentemente do tipo, especialmente quando tal consumo excede duas a três doses ao dia. A associação encontrada é independente da idade, índice de massa corporal e consumo de sal (Beilin, Puddey \& Burke, 1996). O risco de doença hipertensiva atribuível ao álcool é em torno de $16 \%$. A cada $10 \mathrm{~g}$ de álcool ingerido, a pressão arterial aumenta em torno de $1 \mathrm{mmHg}$, e tal efeito é reversível após duas a quatro semanas sem uso ou com uso reduzido de álcool (Puddey \& Beilin, 2006).

\section{Fibras}

Estudos observacionais sugerem que o consumo de fibra pode reduzir a pressão arterial sistólica e diastólica em torno de 1,6 e 2,0 mmHg, respectivamente (Alonso et al., 2006; ADA, 2006). Esses resultados não foram, no entanto, confirmados por ensaios clínicos (Whelton et al., 2005). 


\section{Carboidratos}

Em relação aos carboidratos, sua contribuição para mudanças nos níveis pressóricos mostra evidências mais convincentes em modelos animais do que em humanos. $\mathrm{O}$ aumento do consumo de carboidratos simples pode produzir uma leve e transitória elevação da pressão arterial por meio da ativação simpática, principalmente em indivíduos hipertensos (Valensi, 2005).

Os resultados dos estudos observacionais que examinaram o efeito do consumo de carboidratos sobre a pressão arterial são inconsistentes e contraditórios, ao indicarem associação positiva, inexistência de associação e associação inversa (Appel et al., 2006).

\section{Gorduras}

O efeito da quantidade e qualidade das gorduras consumidas sobre os lipídios plasmáticos e as lipoproteínas está bem documentado, mas o mesmo não se observa com relação à pressão arterial. Vários estudos investigaram a influência do consumo de gorduras sobre a pressão arterial. Apesar de alguns resultados indicarem que a pressão aumenta com um maior consumo de gorduras totais e com a elevação da razão gorduras saturadas/insaturadas, os resultados ainda são controversos (Rasmussen et al., 2006). Com exceção da gordura ômega-3 poliinsaturada, presente em peixes gordurosos de água fria como sardinha, atum e salmão, os estudos observacionais não indicam um efeito consistente entre o consumo de gorduras e a pressão arterial (Appel et al., 2005; Ascherio et al., 1992, 1996; Morris, 1994). De maneira geral, a dieta mediterrânea, rica em gorduras monoinsaturadas pela presença do azeite de oliva, parece reduzir a pressão arterial, mas a relação é confundida pela redução concomitante do consumo de carboidratos (Appel et al., 2005; Ferrara et al., 2000).

\section{Colesterol}

Os estudos longitudinais indicam uma relação positiva entre a dieta rica em colesterol e pressão arterial, mas poucos estudos examinaram esta associação, o que impede um julgamento conclusivo sobre a questão (Stamler et al., 2002).

\section{Proteínas}

Os estudos observacionais indicam uma relação inversa consistente entre o consumo de proteínas e a pressão arterial (He \& Whelton, 1999; Obarzanek, Velletri \& Cutler, 1996). Resultados de dois grandes estudos de coorte publicados recentemente mostram que apenas a proteína de origem vegetal está associada com a redução da pressão diastólica e sistólica (Elliott et al., 2006; Stamler et al., 2002).

\section{Vitamina C}

Parece existir uma associação inversa razoavelmente consistente entre o consumo de vitamina C e os níveis pressóricos. Mas tais associações advêm de estudos transversais, e, por esta razão, não permitem inferência causal (Bates et al., 1998; Ness, Chee \& Elliott, 1997). Embora haja indicações de que o uso de suplementos alimentares, tais como a vitamina $\mathrm{C}$, os ácidos graxos poliinsaturados como o ácido eicosapentanóico ou docosahexaenóico e a coenzima Q10 possam diminuir a pressão arterial, estas estão limitadas às evidências advindas de estudos clínicos adequadamente conduzidos. Estudo de metanálise contemplando 31 ensaios clínicos aleatórios com suplementação de ácidos graxos ômega-3 verificou a existência de uma relação dose-resposta significativa (Morris, 
Sacks \& Rosner, 1993). No entanto, apenas grandes doses de suplementos de ácidos graxos ômega-3 poderiam produzir modestas reduçōes nos níveis pressóricos, tornando, portanto, sua recomendação pouco prática para indivíduos hipertensos.

\section{Dietas que Reduzem a Pressão Arterial}

\section{Dieta Vegetariana}

Há algumas décadas, estudos observacionais indicam que indivíduos submetidos a dieta vegetariana apresentam pressão arterial menor do que a de não vegetarianos, com menor elevação associada ao envelhecimento (Armstrong, Van Merwyk \& Coates, 1977; Brathwaite et al., 2003; Sacks \& Kass, 1988).

Os níveis pressóricos de grupos religiosos como os adventistas do sétimo dia e os monges que consomem dietas vegetarianas são significativamente menores quando comparados aos de pessoas que consomem carne (Armstrong, Van Merwyk \& Coates, 1977; Sacks, Rosner \& Kass, 1974). Segundo estudos adequadamente controlados por peso corporal, adventistas do sétimo dia que seguiam dietas lactoovovegetarianas apresentaram prevalências de hipertensão menores $(2 \%$ vs $8,5 \%)$ e níveis pressóricos significativamente mais baixos quando comparados com aqueles de um grupo com similar estilo de vida, mas que não seguiam dietas vegetarianas (Rouse, Beilin \& Armstrong, 1983). Em um outro amplo estudo realizado na Califórnia com 34.000 adventistas, as prevalências de hipertensão foram baixas mesmo após o ajuste para efeito do peso corporal (Fraser, 1999). Nos estudos observacionais, as diferenças ajustadas por potenciais variáveis de confusão de níveis pressóricos na pressão arterial em vegetarianos, quando comparados com não vegetarianos, variaram de 5 a $10 \mathrm{mmHg}$ para PAS e de 2 a $8 \mathrm{mmHg}$ para PAD.

Negros americanos apresentam, geralmente, níveis maiores de prevalência de hipertensão quando comparados aos brancos. Porém, negros que são vegetarianos apresentavam seus níveis de PAS menores do que os dos negros não vegetarianos (Melby et al., 1989).

Resultados de ensaios clínicos aleatorizados de dietas vegetarianas durante seis semanas mostram também o efeito desse padrão alimentar na diminuição dos níveis pressóricos de 5 a $6 \mathrm{mmHg}$ para PAS e de 2 a $3 \mathrm{mmHg}$ para PAD tanto em indivíduos normotensos quanto para hipertensos quando comparados com consumidores de dietas onívoras (Margetts et al., 1986; Rouse, Beilin \& Armstrong, 1983).

Um desafio metodológico nos estudos observacionais em grupos que aderem ou não a esse tipo de dieta é a sua comparabilidade em relação a outros fatores relacionados ao estilo de vida, ou seja, entre grupos com semelhantes estilos de vida, mas com práticas dietéticas diferentes. Os estudos devem levar em consideração o fato de que os vegetarianos são geralmente mais magros que os indivíduos onívoros (Kennedy et al., 2001) e que os níveis pressóricos nas populações ocidentalizadas tendem a aumentar com o peso, uma vez que as diferenças no peso corporal de indivíduos vegetarianos e não vegetarianos pode ser um importante fator contribuinte para as diferenças de pressão arterial observadas entre esses grupos (Appleby et al., 2002). Outro fator a ser avaliado é o fato de que dietas vegetarianas apresentam menor densidade energética e maior conteúdo de fibras, embora os estudos observacionais e ensaios clínicos não tenham chegado a consenso sobre o efeito significativo das fibras nos níveis pressóricos (Burke et al., 2001; He \& Whelton, 1999).

Em geral, vários aspectos da dieta vegetariana podem influenciar a queda da pressão arterial, incluindo fatores não dietéticos, como a atividade física, e fatores dietéticos, como o menor peso corporal, o consumo aumentado de potássio e a reduzida ingestão de álcool. Além disso, a dieta vegetariana é rica em fibras e proteínas vegetais (Leitzmann, 2005). Os estudos sugerem que o efeito benéfico da dieta vegetariana sobre a pressão arterial independe da presença de outros fatores, mas as análises feitas nem sempre controlaram para todos os potenciais fatores de confusão (Appel et al., 2006). 


\section{Dieta para Controle da Hipertensão (Dash)}

Estudos de metanálise publicados em 2002 e 2003 (Geleijnse et al., 2002; Geleijnse, Kok \& Grobbee, 2003) permitem verificar o substancial impacto dos fatores dietéticos e do estilo de vida sobre os níveis pressóricos e a prevalência da HA em populações européias e americanas com ampla variação na magnitude de fatores de risco para hipertensão.

Dietas com restrição do consumo de sódio e perda de peso constituem uma efetiva e segura terapia não farmacológica anti-hipertensiva para pessoas idosas. Essas conclusões são decorrentes de um estudo clínico randomizado realizado com 975 pacientes de 60-80 anos; o grupo intervenção teve reduções de 2,8 mmHg na PAS comparado com o grupo controle (Whelton et al., 1998).

Dois recentes e importantes estudos experimentais realizados por um consórcio de quatro instituições americanas denominado The Dietary Approches to Stop Hypertension (Dash), conhecido como dieta Dash, têm produzido evidências consistentes de que dietas ricas em produtos lácteos com baixo teor de gordura, frutas e verduras têm efeito significativo na diminuição dos níveis tensionais. A aplicação das conclusões desses estudos foram incorporadas nas recomendações do comitê para prevenção, detecção e tratamento da hipertensão (Joint National Committee, 1993). Na primeira pesquisa, foram estudados 459 indivíduos igualmente distribuídos segundo sexo, dos quais 60\% eram negros e tinham em média 45 anos, a maioria apresentava sobrepeso e um terço deles era hipertenso (Appel et al., 1997).

Os participantes foram divididos aleatoriamente para o consumo de três tipos de dieta. A dieta controle foi considerada aquela semelhante à habitual da população americana, ou seja, com pouca quantidade de fibras e grande quantidade de gordura e colesterol, sendo sua composição percentual aproximada de $37 \%$ de gorduras, $15 \%$ de proteínas e $48 \%$ de carboidratos. Além disso, apresentava baixo conteúdo de potássio, magnésio e cálcio e alto conteúdo de sódio (3 a 3,5 g por dia). A mesma dieta do primeiro grupo foi acrescida de frutas e verduras, formando então o segundo grupo, o que resultou em aumento do conteúdo em três vezes de fibras (9 vs $30 \mathrm{~g}$ ), potássio (1.700 vs $4.700 \mathrm{mg}$ ), magnésio (165 vs $500 \mathrm{mg}$ ) para $2.000 \mathrm{kcal} / \mathrm{dia}$. A dieta do terceiro grupo, denominada dieta Dash, teve uma composição percentual de aproximadamente $27 \%$ de gorduras (apenas 6\% de gordura saturada), 18\% de proteínas provenientes principalmente de alimentos lácteos e 55\% de carboidratos. O conteúdo de fibra, potássio, magnésio foi similar ao do segundo grupo; entretanto, o conteúdo de cálcio foi duas vezes maior $(1.250 \mathrm{mg} / \mathrm{dia})$.

Após oito semanas de acompanhamento, verificou-se redução significativa dos níveis de pressão arterial sistólica $(-5,5 \mathrm{mmHg})$ e diastólica $(-3,0 \mathrm{mmHg})$ no grupo de dieta Dash quando comparado com o grupo controle. O resultado mais relevante desse estudo foi o fato de o impacto da dieta Dash na redução dos níveis pressóricos ter sido maior nos indivíduos hipertensos ( $\mathrm{PA} \geq 140 / 90 \mathrm{mmHg}$ ), com uma redução da PAS e da PAD de $11,4 \mathrm{mmHg}$ e $5,5 \mathrm{mmHg}$, respectivamente. Esse efeito foi similar, em magnitude, ao que se espera para o tratamento da hipertensão leve com uso da monoterapia farmacológica (Hoffer, 1997). Outros desfechos de interesse nesse estudo foram as reduções de níveis de Low Density Lipoprotein (LDL) e colesterol; entretanto houve uma redução preocupante dos níveis de High Density Lipoprotein (HDL) principalmente em mulheres.

O segundo estudo Dash (Sacks et al., 2001) teve como objetivo comparar esse tipo de dieta com a dieta habitual, tendo as duas dietas três níveis de conteúdo de sódio: baixo, intermediário e alto. Uma das hipóteses centrais era a de que haveria sinergias entre os tipos de dieta e conteúdo de sódio, o que não foi confirmado. Para esse estudo, foram recrutados 412 pacientes, sendo mulheres a maioria (56\%); a média de idade foi de 49 anos e $41 \%$ eram hipertensos.

O efeito da ingestão de sódio sobre os níveis da pressão arterial foi linear, ou seja, a dieta Dash em níveis altos e intermediários de sódio causou reduções significativas da pressão arterial; contudo, esse efeito não foi observado para o nível mais baixo quando comparado com o mesmo nível de redução de sódio da dieta habitual. Em geral, a dieta Dash e a dieta habitual com restrição de sódio (em nível $<2,5 \mathrm{~g} /$ dia) causaram significativas 
reduções dos níveis tensionais quando comparados com a dieta habitual com conteúdo alto de sódio. A dieta Dash com nível baixo de sódio foi associada às maiores reduçôes de níveis tensionais quando comparada com qualquer nível de conteúdo de sódio. Outro resultado de interesse é que a dieta Dash com níveis baixos de sódio apresentou um nível de tolerabilidade adequado, se considerada a adesão dos pacientes a esse grupo.

Quadro 1 - Fatores dietéticos e padrões alimentares que influenciam a pressão arterial

\begin{tabular}{|lcc|}
\hline Fator & Efeito postulado & Evidência \\
\hline Peso corpóreo & Direto & Convincente \\
Sal (cloreto de sódio) & Direto & Convincente \\
Potássio & Inverso & Convincente \\
Magnésio & Inverso & Possível \\
Cálcio & Inverso & Possível \\
Álcool & Direto & Convincente \\
Gorduras & & \\
Saturada & Direto & Possível \\
Ômega-3 poliinsaturada & Inverso & Convincente \\
Ômega-b poliinsaturada & Inverso & Possível \\
Monoinsaturada & Inverso & Provável \\
Colesterol & Direto & Possível \\
Proteína & & \\
Vegetal & Inverso & Provável \\
Carboidrato & Direto & Provável \\
Fibra & Inverso & Provável \\
Padrões de dieta & & \\
Vegetariana & Inverso & Convincente \\
Tipo Dash* & Inverso & Convincente \\
\hline
\end{tabular}

Níveis de evidência - Possível: indica evidência limitada ou inconsistente; Provável: evidência razoável obtida de estudos observacionais e alguns estudos clínicos; Convincente: evidência robusta, confirmada por múltiplos ensaios clínicos.

* Dash (Diet to Stop Hypertension): dieta rica em frutas e vegetais (8-10 porções por dia), em derivados do leite com baixo teor de gordura (2-3 porções por dia) e pobre em gorduras saturadas e colesterol.

Fonte: Appel et al. (2006).

\section{Considerações Finais}

Há evidências robustas sobre o efeito positivo de diversos fatores nutricionais na pressão arterial. Os mais efetivos para a redução da pressão arterial são a diminuição do sal e o aumento do consumo de potássio, um consumo moderado de álcool entre os que bebem e a adoção de um padrão de dieta do tipo Dash (Appel et al., 2006). Tendo em vista o crescimento das doenças relacionadas à HA e a elevada prevalência da hipertensão, é fundamental ampliar e otimizar as políticas de saúde voltadas para reduzir a pressão arterial não apenas entre aqueles que já têm hipertensão, mas também entre aqueles que apresentam níveis pressóricos inferiores aos estabelecidos para o diagnóstico desta condição. Quanto mais precoce e amplamente difundida, maior o impacto benéfico da dieta sobre a pressão arterial na população e maior a redução da carga de doenças a ela associadas. 
Estima-se que a queda de $2 \mathrm{mmHg}$ na pressão arterial média de uma população pode reduzir em $17 \%$ a prevalência de HA na população geral (Cook et al., 1995). Entre os normotensos, mudanças dietéticas contribuem para reduzir os níveis pressóricos médios e, dessa forma, prevenir ou retardar desenvolvimento da HA, cujo risco aumenta com o envelhecimento. Em indivíduos com hipertensão leve, ou estágio I (entre 140 e $159 \mathrm{mmHg}$ de PAS ou 90 e $99 \mathrm{mmHg}$ de PAD), mudanças dietéticas servem como uma forma de tratamento inicial, antes da medicação. Finalmente, entre aqueles em tratamento medicamentoso para a HA, a dieta é um coadjuvante essencial para se atingir um controle adequado dos níveis pressóricos e prevenir as complicações freqüentemente associadas a esta doença.

\section{Referências}

ALONSO, A. et al. Low-fat dairy consumption and reduced risk of hypertension: the Seguimiento Universidad de Navarra (SUN) cohort. American Journal of Clinical Nutrition, 82(5): 972-979, 2005.

ALONSO, A. et al. Vegetable protein and fiber from cereal are inversely associated with the risk of hypertension in a Spanish cohort. Archives of Medical Research, 37(6): 778-786, 2006.

AMERICAN DIETETIC ASSOCIATION (ADA). Nutrition fact sheet: dietary fiber. An important link in the fight against heart disease. Journal of the American Dietetic Association, 106(3): 2p, 2006.

APPEL, L. J. et al. A clinical trial of the effects of dietary patterns on blood pressure. The New England Journal of Medicine, 336(16): 1.117-1.124, 1997.

APPEL, L. J. et al. Effects of protein, monounsaturated fat, and carbohydrate intake on blood pressure and serum lipids: results of the OmniHeart randomized trial. Jama, 294(19): 2.455-2.464, 2005.

APPEL, J. L. et al. Dietary approaches to prevent and treat hypertension: a scientific statement from the American Heart Association. Hypertension, 47(2): 296-308, 2006.

APPLEBY, P. N. et al. Mortality in British vegetarians. Public Health Nutrition, 5(1): 29-36, 2002.

ARAM, V. et al. The seventh report of the Joint National Committee on Prevention, Detection, Evaluation, and Treatment of High Blood Pressure. Jama, 289: 2.560-2.571, 2003.

ARMSTRONG, B.; VAN MERWYK, A. J. \& COATES, H. Blood pressure in Seventh-day Adventist vegetarians. American Journal of Epidemiology, 105(5): 444-449, 1977.

ASCHERIO, A. et al. A prospective study of nutritional factors and hypertension among US men. Circulation, 86(5): 1.475-1.484, 1992.

ASCHERIO, A. et al. Prospective study of nutritional factors, blood pressure, and hypertension among US women. Hypertension, 27(5): 1.065-1.072, 1996.

AZADBAKHT, L. et al. Dairy consumption is inversely associated with the prevalence of the metabolic syndrome in Tehranian adults. American Journal of Clinical Nutrition, 82(3): 523-530, 2005.

BATES, C. J. et al. Does vitamin C reduce blood pressure? Results of a large study of people aged 65 or older. Journal of Hypertension, 16(7): 925-932, 1998.

BEILIN, L. J.; PUDDEY, I. B. \& BURKE, V. Alcohol and hypertension: kill or cure? Journal of Human Hypertension, 10, suppl. 2: S1-5, 1996. 
BERENSON, G. et al. Racial (black-white) contrasts of risk for hypertensive disease in youth have implications for preventive care: the Bogalusa Heart Study. Ethnicity and Disease, 16(3), suppl. 4: S4-2-9, 2006.

BEYER, F. R. et al. Combined calcium, magnesium and potassium supplementation for the management of primary hypertension in adults. Cochrane Database of Systematic Review, 3: CD004805, 2006.

BRASIL. Ministério da Saúde. Manual de Hipertensão Arterial e Diabetes Mellitus. Brasília: MS, 2001.

BRATHWAITE, N. et al. Obesity, diabetes, hypertension, and vegetarian status among Seventh-Day Adventists in Barbados: preliminary results. Ethnicity and Disease, 13(1): 34-39, 2003.

BURKE, V. et al. Dietary protein and soluble fiber reduce ambulatory blood pressure in treated hypertensives. Hypertension, 38(4): 821-826, 2001.

CAPPUCCIO, F. P. et al. Epidemiologic association between dietary calcium intake and blood pressure: a metaanalysis of published data. American Journal of Epidemiology, 142: 935-945, 1995.

CHOBANIAN, A. V. et al. The seventh report of the Joint National Committee on detection, evaluation, and treatment of high blood pressure: the JNC 7 report. Jama, 289(19): 2.560-2.572, 2003.

COOK, N. R et al. Implications of small reductions in diastolic blood pressure for primary prevention. Archives of Internal Medicine, 155: 701-709, 1995.

DICKINSON, H. O. et al. Magnesium supplementation for the management of essential hypertension in adults. Cochrane Database of Systematic Reviews, 3: CD004640, 2006a.

DICKINSON, H. O. et al. Calcium supplementation for the management of primary hypertension in adults. Cochrane Database of Systematic Review, 2: CD004639, $2006 \mathrm{~b}$.

DJOUSSE, L. et al. Influence of saturated fat and linolenic acid on the association between intake of dairy products and blood pressure. Hypertension, 48(2): 335-341, 2006.

ELLIOTT, P. et al. Relationship of dietary protein to blood pressure: the Intermap Study. Archives of Internal Medicine, 166(1): 79-87, 2006.

FERRARA, L. A. et al. Olive oil and reduced need for antihypertensive medications. Archives of Internal Medicine, 160(6): 837-842, 2000.

FRASER, G. E. Associations between diet and cancer, ischemic heart disease, and all-cause mortality in nonHispanic white California Seventh-day Adventists. American Journal of Clinical Nutrition, 70, suppl. 3: 532S-538S, 1999.

GELEIJNSE, J. M.; GROBBEE, D. E. \& KOK, F. J. Impact of dietary and lifestyle factors on the prevalence of hypertension in Western populations. Journal of Human Hypertension, 19, suppl. 3: S1-4, 2005.

GELEIJNSE, J. M.; KOK, F. J. \& GROBBEE, D. E. Blood pressure response to changes in sodium and potassium intake: a metaregression analysis of randomised trials. Journal of Human Hypertension, 17(7): 471-480, 2003 .

GELEIJNSE, J. M. et al. Blood pressure response to fish oil supplementation: metaregression analysis of randomized trials. Journal of Hypertension, 20(8): 1.493-1.499, 2002.

GRIFFITH, L. E. et al. The influence of dietary and nondietary calcium supplementation on blood pressure: an updated metaanalysis of randomized controlled trials. American Journal of Hypertension, $12(1 \mathrm{Pt}$ 1): 84-92, 1999. 
GU, D. et al. Prevalence, awareness, treatment, and control of hypertension in china. Hypertension, 40(6): 920-927, 2002.

GUS, I. et al. Prevalence, awareness, and control of systemic arterial hypertension in the state of Rio Grande do Sul. Arquivos Brasileiros de Cardiologia, 83(5): 429-433, 2004.

HE, F. J. \& MACGREGOR, G. A. Effect of modest salt reduction on blood pressure: a meta-analysis of randomized trials. Implications for public health. Journal of Human Hypertension, 16(11): 761-770, 2002.

HE, F. J. \& WHELTON, P. K. Effect of dietary fiber and protein intake on blood pressure: a review of epidemiologic evidence. Clinical and Experimental Hypertension, 21(5-6): 785-796, 1999.

HE, F. J.; MARKANDU, N. D. \& MACGREGOR, G. A. Modest salt reduction lowers blood pressure in isolated systolic hypertension and combined hypertension. Hypertension, 46(1): 66-70, 2005.

HOFFER, L. J. The Dash to lower blood pressure. Canadian Medical Association Journal, 157(12): 1.657-1.658, 1997.

HOOPER, L. et al. Systematic review of long term effects of advice to reduce dietary salt in adults. British Medical Journal, 325(7.365): 628, 2002.

JEE, S. H. et al. The effect of magnesium supplementation on blood pressure: a meta-analysis of randomized clinical trials. American Journal of Hypertension, 15(8): 691-696, 2002.

JOINT NATIONAL COMMITTEE. The fifth report of the Joint National Committee on Detection, Evaluation, and Treatment of High Blood Pressure (JNC V). Archives of Internal Medicine, 153(2): 154-83, 1993.

KEARNEY, P. M. et al. Global burden of hypertension: analysis of worldwide data. The Lancet, 365(9455): $217-$ $223,2005$.

KENNEDY, E. T. et al. Popular diets: correlation to health, nutrition, and obesity. Journal of American Dietetic Association, 101(4): 411-420, 2001.

LEITZMANN, C. Vegetarian diets: what are the advantages? Forum of Nutrition, (57): 147-156, 2005.

LEWINGTON, S. et al. Age-specific relevance of usual blood pressure to vascular mortality: a meta-analysis of individual data for one million adults in 61 prospective studies. The Lancet, 360(9.343): 1.903-1.913, 2002. Erratum in: Lancet, 361(9.362): 1.060, 2003.

MARGETTS, B. M. et al. Vegetarian diet in mild hypertension: a randomised controlled trial. British Medical Journal (Clinical Research Ed), 293(6.560): 1.468-1.471, 1986.

MELBY, C. L. et al. Relation between vegetarian/nonvegetarian diets and blood pressure in black and white adults. American Journal of Public Health, 79(9): 1.283-1.288, 1989.

MIZUSHIMA, S. et al. Dietary magnesium intake and blood pressure: a qualitative overview of the observational studies. Journal of Human Hypertension, 12(7): 447-453, 1998.

MORRIS, M. C. Dietary fats and blood pressure. Journal of Cardiovascular Risk, 1(1): 21-30, 1994.

MORRIS, M. C.; SACKS, F. \& ROSNER, B. Does fish oil lower blood pressure? A meta-analysis of controlled trials. Circulation, 88(2): 523-533, 1993.

NEATON, J. D. et al. Treatment of Mild Hypertension Study. Final results. Treatment of Mild Hypertension Study Research Group. Jama, 270(6): 713-724, 1993. 
NESS, A. R.; CHEE, D. \& ELLIOTT, P. Vitamin C and blood pressure: an overview. Journal of Human Hypertension, 11(6): 343-350, 1997.

OBARZANEK, E.; VELLETRI, P. A. \& CUTLER, J. A. Dietary protein and blood pressure. Jama, 275(20): 1.598-1.603, 1996.

PASSOS, V. M. A.; ASSIS, T. D. \& BARRETO, S. M. Hipertensão arterial no Brasil: estimativa de prevalência a partir de estudos de base populacional. Epidemiologia e Serviços de Saúde, 15(1): 35-45, 2006.

PUDDEY, I. B. \& BEILIN, L. J. Alcohol is bad for blood pressure. Clinical and Experimental Pharmacologic \& Physiology, 33(9): 847-852, 2006.

RASMUSSEN, B. M. et al. Effects of dietary saturated, monounsaturated, and n-3 fatty acids on blood pressure in healthy subjects. American Journal of Clinical Nutrition, 83(2): 221-226, 2006.

ROUSE, I. L.; BEILIN, L. J. \& ARMSTRONG, B. K. Blood-pressure-lowering effect of a vegetarian diet: controlled trial in normotensive subjects. The Lancet, 1(8.314-8.315): 5-10, 1983.

SACKS, F. M. \& KASS, E. H. Low blood pressure in vegetarians: effects of specific foods and nutrients. The American Journal of Clinical Nutrition, 48, suppl. 3: 795-800, 1988.

SACKS, F. M.; ROSNER, B. \& KASS, E. H. Blood pressure in vegetarians. American Journal of Epidemiology, 100(5): 390-398, 1974.

SACKS, F. M. et al. Effects on blood pressure of reduced dietary sodium and Dietary Approaches to Stop Hypertension (Dash) diet. The New England Journal of Medicine, 344(1): 3-10, 2001.

SELMER, R. M.; KRISTIANSEN, I. S. \& HAGLEROD, A. Cost and health consequences of reducing the population intake of salt. Journal of Epidemiology and Community Health, 54: 697-702, 2000.

STAMLER, J. et al. Eight-year blood pressure change in middle-aged men: relationship to multiple nutrients. Hypertension, 39(5): 1.000-1.006, 2002.

VALENSI, P. Hypertension, single sugars and fatty acids. Journal of Human Hypertension, 19, suppl. 3: S5-9, 2005.

VASAN, R. S. et al. Residual lifetime risk for developing hypertension in middle-aged women and men: the Framingham Heart Study. Jama, 287: 1.003-1.010, 2002.

WANG, T. J. \& VASAN, R. S. Epidemiology of uncontrolled hypertension in the United States. Circulation, 112: 1.651-1.662, 2005.

WHELTON, P. K. et al. Effects of oral potassium on blood pressure, meta-analysis of randomized controlled clinical trials. Jama, 277(20): 1.624-1.632, 1997.

WHELTON, P. K. et al. Sodium reduction and weight loss in the treatment of hypertension in older persons: a randomized controlled trial of nonpharmacologic interventions in the elderly. Tone Collaborative Research Group (Tone). Jama, 279(11): 839-846, 1998. Erratum in: Jama, 279(24): 1.954, 1998.

WHELTON, P. K. et al. Primary prevention of hypertension: clinical and public health advisory from the National High Blood Pressure Education Program. Jama, 288(15): 1.882-1.888, 2002.

WHELTON, S. P. et al. Effect of dietary fiber intake on blood pressure: a meta-analysis of randomized, controlled clinical trials. Journal of Hypertension, 23(3): 475-481, 2005. 
Epidemiologia Nutricional

WOLF-MAIER, K. et al. Hypertension treatment and control in five European countries, Canada, and the United States. Hypertension, 43: 10-17, 2004.

WORLD HEALTH ORGANIZATION (WHO). Diet, Nutrition and the Prevention of Chronic Diseases. Geneva: WHO, 2003. (WHO Technical Report Series, 916) 


\section{Parte III \\ Tópicos Especiais em Epidemiologia Nutricional}





\title{
24
}

\section{Amamentação: evidências científicas e ações para incentivar sua prática}

\author{
Marina Ferreira Rea e Tereza Setsuko Toma
}

$\mathrm{D}$ iversos são os registros históricos mostrando que a prática da amamentação ocorre há milênios e que sua substituição em escala industrial data de pouco mais de um século. Esta substituição certamente não é isenta de conseqüências, na medida em que hoje está claro quais são os vários componentes nutricionais e imunológicos específicos do leite materno, responsáveis alguns deles por atuar na fase em que o organismo do lactente passa por intenso desenvolvimento cerebral. Além disso, a prática de amamentar, que necessariamente aproxima pele-apele mãe e bebê, traz a ambos benefícios emocionais e de vínculo inigualáveis.

Serão destacados, aqui, alguns estudos selecionados sobre 'o porquê' de amamentar - quanto à morbimortalidade infantil e para a saúde da mulher - e outros sobre 'como' fazê-lo, particularmente quanto a ações de proteção, promoção e apoio ao aleitamento materno; na conclusão, serão apresentadas as situações excepcionais, em que o leite materno pode ser indicado com cuidados especiais.

\section{Amamentação: por quê?}

A singularidade tanto da prática de amamentar como do leite humano tem sido demonstrada por grande número de trabalhos científicos, em diferentes tipos de disciplinas e publicaçôes. Se antigamente pensava-se que tal singularidade levava à proteção contra doenças, principalmente porque o aleitamento materno é necessariamente uma prática higiênica e sem contaminação, mais recentemente sabe-se que o leite humano contém enorme número de leucócitos e outros fatores de proteção - lisozimas, lactoferrina, imunoglobulinas, fatores bífidos etc. que sofrem modificações do começo para o fim da mamada, nas diferentes horas do dia e com a idade pós-parto. Foi também mostrado que o recém-nascido, ao receber o colostro (leite do início da vida que em algumas culturas é descartado), recebe altas doses de Imunoglobulina A ( $\operatorname{IgA}$ ), que cai ao mínimo em poucos dias, e que o contato pele-a-pele desencadeia uma série de eventos hormonais importantes para a relação mãe-bebê. O toque, o odor e o calor estimulam o nervo vagal e isto, por sua vez, faz com que a mãe libere ocitocina. Este hormônio faz com que a temperatura das mamas aumente e aqueça o bebê. Por outro lado, a ocitocina reduz a ansiedade materna, aumenta sua tranqüilidade e responsividade social (Anderson et al., 2007).

Com a melhora das condições de vida e a crescente urbanização, o controle das velhas doenças (como as diarréias infantis) foi obtido em muitos países, mas a emergência de 'novas' causas de morbidade tem levado a investigar o papel do leite materno nessas situações. Hoje, sabe-se que amamentar protege contra doenças crônicas, 
tais como obesidade, diabetes mellitus tipo 1, doença de Crohn e linfoma, além de levar o bebê a engatinhar e andar mais precocemente (Kramer \& Kakuma, 2006).

Sem pretender esgotar o tema, detalham-se a seguir algumas das razóes que favorecem a escolha da amamentação como prática, tanto para a criança como para a mulher.

\section{Mortalidade}

Em 2003, a revista The Lancet publicou uma série de cinco artigos sobre sobrevivência de crianças menores de 5 anos de idade, resultado do trabalho do The Bellagio Study Group on Child Survival realizado por pesquisadores de vários países. $\mathrm{O}$ estudo mostrou que, apesar da redução substancial na mortalidade de crianças nos países de renda baixa e média no final do século XX, ainda morrem a cada ano mais de dez milhões de crianças no mundo, a maioria delas de causas passíveis de prevenção, tais como diarréia, pneumonia e distúrbios neonatais. O Brasil ocupava o $92^{\circ}$ lugar na classificação dos países, respondendo por 127.000 mortes de crianças abaixo de 5 anos (Black, Morris \& Bryce, 2003). Entre as intervenções direcionadas para lidar com os determinantes proximais da mortalidade de crianças, estimou-se que a 'amamentação' isoladamente seria capaz de prevenir 13\% dessas mortes - ou seja, entre as demais medidas, a prática de amamentar é a que mais contribui para a prevenção de mortes infantis (Jones et al., 2003).

As políticas de saúde deveriam contemplar entre suas metas o incremento das taxas de amamentação exclusiva nos primeiros seis meses de vida, dadas as robustas evidências científicas a seu favor. Na década de 1980, Victora e colaboradores mostraram que crianças entre 0 e 5 meses não amamentadas apresentavam um risco de morrer por diarréia e pneumonia, respectivamente sete e cinco vezes maior do que crianças amamentadas exclusivamente (Victora et al., 1987).

Betrán e colaboradores (2001), utilizando dados secundários, estimaram o potencial do aleitamento materno para reduzir a mortalidade infantil na América Latina e Caribe. O estudo incluiu 16 países e chegou à conclusão de que $13,9 \%$ das cerca de 52.000 mortes infantis anuais poderiam ser evitadas por meio da amamentação exclusiva das crianças de 0 a 3 meses de idade e amamentação parcial durante o restante do primeiro ano. Tanto para doença diarréica quanto respiratória, no Brasil e no México ocorria cerca de metade das mortes passíveis de prevenção do conjunto de países.

Mais recentemente, Bahl e colaboradores (2005), em estudo multicêntrico com mais de nove mil pares mãe-criança de Gana, da Índia e do Peru, analisaram a associação entre os diferentes padrões de amamentação com a mortalidade e internaçôes hospitalares durante os primeiros seis meses de vida. Os principais achados revelaram que não havia diferença nos riscos de morte ou hospitalização entre crianças amamentadas de maneira exclusiva ou predominante, e que crianças não amamentadas apresentavam um risco dez vezes maior de morte e três vezes maior de hospitalização quando comparadas a crianças com amamentação predominante.

O componente neonatal da mortalidade infantil representa, hoje, motivo de preocupação maior em nosso meio. Importante trabalho realizado em Gana com 10.947 recém-nascidos sobreviventes cujas mães foram visitadas no período neonatal constatou que houve marcada dose-resposta entre maior risco de morrer e retardo no início da amamentação da primeira hora até o sétimo dia de nascimento; iniciar a amamentação após o primeiro dia esteve associado a 2,4 vezes maior risco de morte neonatal. Os autores concluem que as mortes neonatais podem ser reduzidas em $16 \%$ se os bebês forem amamentados desde o primeiro dia e em $22 \%$ se o forem desde a primeira hora (Edmond et al., 2006). 


\section{Morbidade}

A preocupação com o desmame precoce e a perda da proteção contra doenças infecciosas conferida pelo leite materno, antes voltada principalmente para as crianças dos países em desenvolvimento, na última década passou a ser objeto de investigação também nos países desenvolvidos. A duração e a exclusividade da amamentação são consideradas relevantes, daí a necessidade de melhorar a qualidade dos estudos também com relação à definição clara dos padrões de amamentação adotados. A Organização Mundial da Saúde (OMS) e outros organismos no início dos anos 90 lançaram indicadores com definições e formas de coleta bastante precisas (WHO, 1991), visando a padronizar a coleta de dados sobre aleitamento materno. Isso representou um avanço e incorporação do conceito novo de 'amamentação exclusiva' e também da prática de amamentar com o uso de outros fluidos não nutritivos - fato que pode comprometer a ingesta de quantidade adequada de leite materno. Assim, ficaram estabelecidos alguns indicadores, dos quais os mais utilizados são:

- Aleitamento Materno Exclusivo (AME) - a criança recebe apenas leite humano diretamente da mama ou ordenhado, de sua própria mãe ou de uma doadora, e nenhum outro líquido ou alimento sólido, com exceção de gotas ou xarope de vitaminas, suplementos minerais ou medicamentos.

- Aleitamento Materno Predominante (AMP) - a fonte predominante de nutrição da criança é o leite humano. Entretanto, além das gotas ou xarope de vitaminas, minerais ou medicamentos, a criança pode receber também água e líquidos, tais como água açucarada ou com sabor, chás e infusôes, suco de frutas, solução de reidratação oral e fluidos utilizados em rituais (em quantidades limitadas). Com exceção de suco de frutas e água açucarada, não são aceitos sob esta definição quaisquer outros alimentos com base em água.

- Aleitamento materno pleno ou completo - é constituído pela junção do aleitamento materno exclusivo com o predominante.

- Alimentação complementar - a criança recebe tanto leite humano quanto alimentos sólidos ou semi-sólidos.

- Amamentação - a criança recebe leite humano diretamente da mama ou ordenhado.

- Alimentação com mamadeira - a criança recebe líquidos ou alimentos semi-sólidos por meio de bico de mamadeira. Este item foi incluído entre os indicadores, dada sua relevância para a prática da amamentação.

Há evidências de que, tanto em países em desenvolvimento quanto nos desenvolvidos, a amamentação protege as crianças contra infecçôes dos tratos gastrintestinal e respiratório, sendo maior a proteção quando a criança é amamentada de forma exclusiva e por tempo prolongado. Amamentação exclusiva e prolongada também tem sido associada a menor risco de síndrome da morte súbita e doença atópica. Além disso, alguns estudos sugerem uma aceleração do desenvolvimento neurocognitivo e proteção contra condições e doenças crônicas, tais como obesidade, diabetes mellitus tipo 1, doença de Crohn e linfoma (Kramer \& Kakuma, 2006).

A observação de que crianças alimentadas com leite materno apresentam menor risco de doença diarréica é antiga. Já em 1905, havia registros de diferenças na composição da microflora intestinal de crianças amamentadas em comparação a crianças desmamadas. Notava-se que as fezes de crianças amamentadas apresentavam uma predominância de lactobacilos, ao passo que a de adultos e crianças desmamadas precocemente tinham uma predominância de Escherichia coli. A partir da descoberta do fator bífido, na década de 1970, torna-se cada vez mais conhecido o mecanismo pelo qual ocorre a proteção da mucosa intestinal contra os agentes patogênicos. Sabe-se hoje que vários tipos de oligossacarídeos e glicoconjugados presentes no leite materno, conhecidos como agentes pré-bióticos, estimulam a colonização do intestino por microrganismos benéficos. Esses agentes atuam 
na primeira etapa essencial da patogênese ao impedir que um microrganismo se fixe na parede celular (Newburg, Ruiz-Palacios \& Morro, 2005).

Dois trabalhos metodologicamente bem conduzidos confirmam que um aumento nas taxas de amamentação leva ao decréscimo no risco de diarréia. Um deles, realizado no México, um experimento randomizado controlado de base comunitária, mostrou a associação entre contatos precoces e repetidos das mães com aconselhadores e incremento significativo na exclusividade e duração do aleitamento materno. Como desfecho secundário, a incidência de diarréia foi significativamente maior nas crianças do grupo controle (Morrow et al., 1999). O outro é um experimento randomizado controlado multicêntrico realizado na Bielo-Rússia, que envolveu 17.046 pares mãebebê e 34 hospitais e policlínicas associadas. Metade dessas instituições (grupo intervenção) seguia os preceitos da Iniciativa Hospital Amigo da Criança (IHAC), descritos a seguir.

As crianças do grupo intervenção apresentaram maior probabilidade de serem amamentadas aos 12 meses de idade, maior probabilidade de serem exclusivamente amamentadas aos 3 e aos 6 meses e uma redução significativa no risco de infecções do trato gastrintestinal (Kramer et al., 2001). Esse estudo, que continua em curso, promete nos trazer outros dados precisos sobre as práticas alimentares e parâmetros como peso, estatura, desenvolvimento motor, entre outros.

Os efeitos protetores da amamentação contra infecções do ouvido e pulmão têm se tornado mais evidentes nos últimos anos. A IgA secretora é um anticorpo resultante da resposta da mãe à exposição prévia a agentes infecciosos. Tem como características sobreviver nas membranas das mucosas respiratória e gastrintestinal e ser resistente à digestão proteolítica. Além de impedir que agentes patogênicos se fixem nas células da criança amamentada, ela limita os efeitos danosos do processo inflamatório (Jackson \& Nazar, 2006).

A amamentação exclusiva protege as crianças pequenas de evoluírem para quadros mais graves de infecção respiratória. Estudo de caso controle aninhado realizado em Pelotas, RS, analisou as internações por pneumonia no período pós-neonatal de uma coorte de 5.304 crianças. Crianças não amamentadas apresentaram risco 17 vezes maior de serem internadas por pneumonia do que crianças que recebiam apenas leite materno. A nãoamamentação afetou ainda mais as crianças abaixo de 3 meses de idade, cujo risco relativo para internação por pneumonia foi de 61 (César et al., 1999). A amamentação predominante por pelo menos seis meses e a amamentação parcial até um ano de idade podem reduzir também a prevalência de infecções respiratórias na infância. Estudo de uma coorte prospectiva de 2.602 crianças australianas acompanhadas desde o nascimento analisou a relação entre duração da amamentação e doenças respiratórias e infecções durante o primeiro ano de vida. Os autores relatam que a amamentação predominante por menos de seis meses mostrou ser fator protetor significativo, reduzindo a freqüência de consultas médicas e internações, particularmente por infecções respiratórias do trato superior e chiado. Interromper a amamentação antes dos 12 meses mostrou ser fator de risco para consultas médicas por doença respiratória (Oddy et al., 2003). A etiologia da asma na infância também tem sido objeto de pesquisas mais recentes. Amamentação exclusiva por pelo menos quatro meses mostrou ter efeito protetor significativo contra infecção do trato respiratório inferior com chiado, asma e atopia. Ainda não está bem esclarecido o papel da amamentação sobre a etiologia da asma, porém os estudos sugerem que ele seja decorrente de seu efeito nas infecções, na atopia e em processos inflamatórios (Oddy et al., 2002).

Há controvérsia sobre a alimentação artificial como fator de risco para morte súbita. Ao passo que alguns estudos observaram maior prevalência de alimentação artificial entre os casos do que entre os controles, outros não apontaram qualquer diferença. Alm e colaboradores (2002) observaram uma associação entre amamentação exclusiva e redução da síndrome da morte súbita, após controlar para variáveis de confusão, tais como fumo durante a gravidez, emprego paterno, posição ao dormir e idade da criança. O papel da amamentação como mecanismo de proteção contra morte súbita ainda não foi completamente elucidado. Entre as possíveis explicações de tal proteção estão a menor incidência de infecçôes, as mamadas freqüentes e o contato mais estreito entre mãe e criança. 
Os ácidos graxos poliinsaturados de cadeia longa (conhecidos pela sigla em inglês LC-PUFA), particular-

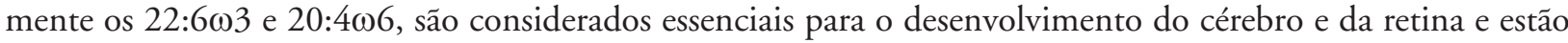
presentes no leite humano. Apesar da falta de clareza sobre a maneira pela qual os LC-PUFA atuam no desenvolvimento, vários estudos foram realizados com o objetivo de verificar as diferenças na acuidade visual e no neurodesenvolvimento, a maioria deles comparando crianças amamentadas com outras alimentadas com fórmulas infantis. Quanto à acuidade visual, parece não haver consenso entre os pesquisadores, e possivelmente isto se deve aos diferentes parâmetros utilizados (Heird \& Lapillonne, 2005). Quanto à inteligência, uma metanálise com o propósito de fazer uma revisão crítica dos estudos sobre sua associação com a amamentação encontrou apenas dois artigos com padrão de alta qualidade metodológica, sendo que um deles concluiu que a amamentação tinha efeito significativo sobre a inteligência, ao passo que o outro não. Segundo os autores, embora a maioria dos estudos analisados conclua que a amamentação tem efeito sobre a inteligência, não há evidências convincentes, e futuras investigaçôes deveriam usar métodos e critérios mais rigorosos (Jain, Concato \& Leventhal, 2002).

\section{Saúde da Mulher}

Até o presente, conforme revisão da literatura publicada por Rea (2004), aqui atualizada, sabe-se que há uma relação positiva entre amamentar e apresentar menos doenças, como o câncer de mama (Martin et al., 2005), certos cânceres ovarianos e do endométrio (Okamura et al., 2006). Indaga-se também sobre o efeito da amamentação no menor risco de morte por artrite reumatóide, e é controverso seu efeito contra certas fraturas ósseas, especialmente coxofemoral, pois há estudos mostrando que mulheres que amamentam apresentam menos osteoporose e menos fraturas (Rea, 2004). Muitos trabalhos foram publicados mostrando como a amamentação se relaciona à amenorréia pós-parto e ao conseqüente maior espaçamento intergestacional. Outros benefícios para a mulher que amamenta são o retorno ao peso pré-gestacional mais precocemente e o menor sangramento uterino pós-parto (conseqüentemente, menos anemia), devido à involução uterina mais rápida provocada pela maior liberação de ocitocina.

Uma revisão de 47 estudos realizados em trinta países envolvendo cerca de cinqüenta mil mulheres com câncer de mama e 97 mil controles sugere que o aleitamento materno pode ser responsável por 2/3 da redução estimada no câncer de mama. A amamentação foi tanto mais protetora quanto mais prolongada: o risco relativo de ter câncer decresceu 4,3\% a cada 12 meses de duração da amamentação, independentemente da origem das mulheres (países desenvolvidos vs não desenvolvidos), idade, etnia, presença ou não de menopausa e número de filhos. Estimou-se que a incidência de cânceres de mama nos países desenvolvidos seria reduzida a mais da metade (de 6,3 para 2,7\%) se as mulheres amamentassem por mais tempo (Collaborative Group on Hormonal Factors in Breast Cancer, 2002). Por sua vez, Martin e colaboradores (2005), analisando dados de uma coorte com 4.999 sujeitos, iniciada nos anos 30 do último século, além de uma extensa metanálise de outros estudos, concluíram que o fato de ter sido amamentada está relacionado a menor risco de câncer somente pré-menopausa.

Um estudo caso controle realizado em hospital japonês envolvendo 155 mulheres com câncer do endométrio e 96 controles encontrou maior risco desse câncer entre aquelas multíparas que nunca haviam amamentado; para os autores, o aumento verificado nos casos de câncer de endométrio pode estar relacionado à diminuição da prática de amamentar e à menor paridade de mulheres do Japão (Okamura et al., 2006).

A relação entre duração da amamentação e diminuição do peso pós-parto foi demonstrada em estudo brasileiro com 405 mulheres, em que a cada mês a mais de amamentação houve uma média de redução de $0,44 \mathrm{~kg}$ no peso da mãe (Kac et al., 2004). 


\section{Amamentação: como?}

No final da década de 1980, apropriando-se da informação nova de que o aleitamento materno exclusivo no início da vida é fundamental, autoridades da OMS, do Fundo das Nações para a Infância (Unicef), de organismos bilaterais e técnicos de saúde passam a se reunir para elaborar uma estratégia que levasse em conta os diversos determinantes que interferiam nessa prática, criando-se o International Group on Action on Breastfeeding (Igab).

Esse grupo procurou aprofundar a compreensão sobre como trabalhar com tais determinantes: serviços de saúde e hospitais; grupos de mães e comunidade; treinamento (destacando-se os cursos de especialização em lactação humana do Wellstart International, de San Diego, EUA, e os cursos da International Baby Food Action Network (Ibfan), África; comunicação, educação; Código Internacional de Comercialização de Substitutos do Leite Materno; mulher trabalhadora. O aprofundamento se deu em debates técnicos entre 1989 e 1990, atualizando conhecimentos e a discussão sobre a implementação de ações que visassem à melhor forma de trabalhar cada um dos temas acima, sempre tendo em vista a diminuição do desmame precoce. Diversos foram os documentos então produzidos, os quais foram levados a uma reunião final em Florença, na Itália, em um antigo hospital infantil, denominado Hospedale Del Innocenti, no dia 1 de agosto de 1990. O processo teve aí seu encerramento, com um encontro de técnicos e políticos de cerca de trinta países - o Brasil foi um deles especialmente convidados. Aí se lança, então, a chamada Declaração de Inoccenti (WHO/Unicef, 1990).

Assim, a Declaração de Inoccenti, diferentemente de qualquer outro documento internacional produzido pelas autoridades de saúde, foi o resultado de um intenso e participativo processo de análise e traz objetivo claro e metas a serem alcançadas pelos países na promoção da amamentação bem definidas. O objetivo era fortalecer a mulher na sua decisão de amamentar exclusivamente até os 6 meses $^{1}$ de vida e continuar amamentando, com alimentos complementares até o segundo ano de vida, ou mais. Assim se resumiam quatro ações fundamentais que os países deveriam realizar para que se alcançasse tal objetivo:

1) Criar e manter uma coordenação e um comitê pró-amamentação de âmbito nacional.

2) Assegurar que as maternidades cumpram os Dez Passos para o Sucesso do Aleitamento Materno, publicados em 1989.

3) Implementar todo o Código Internacional de Comercialização de Substitutos do Leite Materno (de 1981) e resoluções da Assembléia Mundial da Saúde subseqüentes e relevantes.

4) Implementar as leis trabalhistas, buscando formas criativas de proteger a mulher trabalhadora lactante e respeitando seus benefícios.

No encontro de Innocenti, foram destacadas atividades que vinham sendo desenvolvidas pelo Brasil havia uma década, como a mobilização social, as campanhas na mídia, a implementação do código com a elaboração de uma legislação nacional equivalente (em 1988), a extensão da licença-maternidade para 120 dias para a mulher trabalhadora (também em 1988) e, em especial, a existência, desde 1981, de uma equipe coordenadora nacional de todas essas açôes. Uma avaliação do programa mostrava que havíamos obtido ganhos significativos na proporção de mães que passaram a iniciar e a praticar o aleitamento materno por mais tempo. ${ }^{2}$ Mas nada havia a mostrar sobre aleitamento materno 'exclusivo' (só leite materno, sem água, chá ou qualquer outro fluido), porque isso ainda não era parte de nossos conhecimentos.

Em contrapartida, as atividades realizadas pelas maternidades ainda se restringiam à permanência de mãe e bebê no mesmo quarto - em alojamento conjunto, que já era uma norma brasileira, mas estava em processo de divulgação; os demais 'passos' para o sucesso do aleitamento materno nas maternidades só vieram a ser conhecidos efetivamente nos anos 90 . 
A OMS e o Unicef passaram, recentemente, a oferecer novas diretrizes quanto à promoção, proteção e apoio ao aleitamento materno, por meio da Estratégia Global sobre Alimentação de Lactentes e Crianças de Primeira Infância, mas sem a 'visão' que a Declaração de Innocenti conteve. De fato, OMS e Unicef, assim como outros parceiros como International Baby Food Action Network (Ibfan), World Alliance for Breastfeeding Action (Waba), International Lactation Consultant Association (Ilca) e La Leache League International (LLLI), seguem tendo em Innocenti uma referência fundamental, e reafirmaram os mesmos objetivos em 2005 durante a celebração dos 15 anos da declaração (Unicef Innocenti Research Centre, 2005).

Sabe-se que a amamentação no Brasil cresceu do final dos anos 70 até os anos 90 (Venâncio \& Monteiro, 1998); mas o crescimento foi ainda maior no final dos anos 90 e início de 2000, quando nossas autoridades da área planejaram e realizaram adequadamente ações descentralizadas de capacitação de profissionais usando os materiais de treinamento adaptados da OMS/Unicef, estratégias da Ibfan e da rede de Banco de Leite Humano. O objetivo foi implementar as metas de Innocenti com ações inovadoras de mobilização social (parcerias com Correios, Corpo de Bombeiros etc.) (Rea, 2003).

Serão detalhadas, a seguir, as principais ações de promoção, proteção e apoio à amamentação.

\section{Iniciativa Hospital Amigo da Criança}

A OMS e o Unicef lançaram a Iniciativa Hospital Amigo da Criança (IHAC), em 1992, como estratégia para atingir uma das metas estabelecidas na Declaração de Innocenti, na Cúpula Mundial para a Infância e no Plano de Ação para a Nutrição (WHO, 1998).

Desde seu lançamento, mais de 19.000 hospitais foram credenciados em 150 países. Para ser habilitado como Hospital Amigo da Criança, um hospital-maternidade deve implantar os Dez Passos para o Sucesso do Aleitamento Materno (Quadro 1) e manter a política de não aceitar doações de fórmulas infantis e outros produtos que competem com a amamentação. O processo de avaliação a que o hospital é submetido para receber o título da IHAC é padronizado e único em todo o mundo (Unicef Innocenti Research Centre, 2005).

O Brasil foi um dos 12 primeiros países a incorporar a IHAC em sua política de promoção, proteção e apoio ao aleitamento materno. Aqui, adicionalmente são exigidos outros requisitos, aos quais tem sido atribuída parte da lentidão no processo de habilitação dos hospitais interessados (Brasil, 2004; Araújo, 2005a).

Estudos realizados em diferentes países consideram a IHAC uma ação extremamente efetiva, que leva ao incremento da prevalência e duração da amamentação exclusiva e total (Lutter et al., 1997; Kramer et al. 2001; Merten, Dratva \& Ackermann-Liebrich, 2005).

$\mathrm{Na}$ Suíça, o incremento nas taxas de amamentação que o país tem vivenciado desde 1994 deve-se em parte ao número crescente de Hospitais Amigos da Criança. Segundo Merten e colaboradores (2005), os serviços utilizam o título de Amigo da Criança como forma de se promover, e isto tem influenciado a escolha das mulheres que desejam amamentar sobre o local para dar à luz.

Avaliação sobre experiências dos países com a implementação das metas da Declaração de Innocenti, conduzida em 2002, mostrou que propostas como a dos dez passos são facilmente compreendidas e aceitas, porém sua sustentabilidade parece mais efetiva quando vinculada a uma abordagem que inclui política, legislação, reforma do sistema de saúde e intervenções na comunidade (Unicef Innocenti Research Center, 2005). Os desafios para a implementação da IHAC elencados por essa avaliação incluem: grande rotatividade de profissionais da saúde; estratégias para controle e manutenção do padrão de qualidade dos hospitais credenciados; sua inclusão no orçamento dos governos; adequado investimento no apoio à mãe após a alta da maternidade; clareza sobre como lidar com as mulheres HIV positivo; aperfeiçoamento da atenção à mulher durante o trabalho de parto e o parto; integração com outras iniciativas em apoio às Metas do Milênio para o Desenvolvimento. 
A sustentabilidade da IHAC foi avaliada no Brasil em 2002 (Araújo et al., 2003) e, na análise dos questionários de $137 \mathrm{HAC}(90 \%)$ do total de 152 HAC credenciados à época, observou-se que $92 \%$ cumpriram todos os dez passos. Os passos um, três, seis, sete, oito e nove apresentaram mais de $98 \%$ de cumprimento. O passo cinco foi o menos cumprido. Comparando-se as regiões do país, observou-se que, no Nordeste, no Sul e no Sudeste, $90 \%$ dos hospitais foram aprovados em todos os dez passos. Na região Norte, apenas $50 \%$ dos hospitais os cumpriram integralmente.

Quadro 1 - Dez Passos para o Sucesso do Aleitamento Materno

1. Ter uma norma escrita sobre aleitamento, que deveria ser rotineiramente transmitida a toda a equipe de cuidados de saúde.

2. Treinar toda a equipe de cuidados de saúde, capacitando-a para implementar esta norma.

3. Informar todas as gestantes sobre as vantagens e o manejo do aleitamento.

4. Ajudar as mães a iniciar o aleitamento na primeira meia hora após o nascimento.

5. Mostrar às mães como amamentar e como manter a lactação, mesmo se vierem a ser separadas de seus filhos.

6. Não dar a recém-nascidos nenhum outro alimento ou bebida além do leite materno, a não ser que tal procedimento seja indicado pelo médico.

7. Praticar o alojamento conjunto - permitir que as mães e bebês permaneçam juntos - 24 horas por dia.

8. Encorajar o aleitamento sob livre demanda.

9. Não dar bicos artificiais ou chupetas a crianças amamentadas ao seio.

10. Encorajar o estabelecimento de grupos de apoio ao aleitamento, para onde as mães deverão ser encaminhadas por ocasião da alta do hospital ou ambulatório.

Fonte: WHO (1998).

\section{Código}

A influência da promoção comercial sobre as práticas de alimentação infantil e suas consequiências sobre o desmame precoce, a desnutrição e a mortalidade infantil foram bastante discutidas nas décadas de 1960 e 1970. Em conseqüência disso, a OMS e o Unicef realizaram a Reunião Conjunta sobre Alimentação do Lactente e da Criança Pequena em Genebra, em 1979 (OMS/Unicef, 1979). Ao final da reunião, foi recomendada a criação de um conjunto de normas, fundamentadas em princípios éticos, para nortear a promoção comercial de substitutos do leite materno: o Código Internacional de Comercialização de Substitutos do Leite Materno, o qual foi desenvolvido e aprovado em 1981 pela Assembléia Mundial da Saúde (WHO/Unicef, 1981).

O objetivo principal do Código Internacional é contribuir para o fornecimento de nutrição segura e adequada aos lactentes, por meio da proteção e promoção da amamentação e da regulação da promoção comercial dos substitutos do leite materno. O código aplica-se aos substitutos do leite materno, sejam fórmulas, leites ou alimentos complementares, a mamadeiras e bicos.

Até 2005, 64 países haviam adotado medidas para a implementação do código, dentre eles o Brasil, que o adotou como norma, em 1988, abrangendo praticamente todas as suas disposições. Entretanto, ainda há pelo menos dez países onde nenhuma medida foi tomada, além de muitos outros onde o código é voluntário ou inclui parcialmente as medidas (Sokol, 2005).

O código brasileiro foi publicado como resolução n. 5, de 20 de dezembro de 1988, do Conselho Nacional de Saúde (Ministério da Saúde, 1988). Em 1992, decidiu-se revisar essa resolução e encaminhar propostas de modificações que foram aprovadas como a Norma Brasileira para Comercialização de Alimentos para Lactentes (NBCAL), publicada também como Resolução CNS n. 31, de 12 de outubro de 1992 (Ministério da Saúde, 1993). 
Em 1999 e 2000, nova revisão foi realizada, com base em uma reflexão sobre as inconsistências e dificuldades de implementação daquele segundo texto da norma, e assim aprovou-se, com a decisiva participação da Agência Nacional de Vigilância Sanitária (Anvisa), uma versão melhorada de nosso código, agora subdividido em três textos: 1) Portaria Ministério da Saúde MS 2.051, de 8 de novembro de 2001 (Ministério da Saúde, 2001); 2) Resolução Anvisa - RDC (Resolução da Diretoria Colegiada) 221 (Anvisa, 2002a) e 3) Resolução Anvisa - RDC 222, de 5 de agosto de 2002 (Anvisa, 2002b), as quais constituem hoje a Norma Brasileira de Comercialização de Alimentos para Lactentes e Crianças de Primeira Infância, Bicos, Chupetas e Mamadeiras. Uma análise dos avanços de nosso código ou norma, desde sua primeira versão, foi realizada por Araújo et al. (2006). Em janeiro de 2006, a norma foi aprovada pelo Parlamento brasileiro e sancionada como lei n.11.265, pela Presidência da República (Brasil, 2006).

\section{Benefícios Trabalhistas e Amamentação}

Tem aumentado a participação da mulher-mãe no mercado de trabalho, e quase todos os países do mundo o reconhecem, provendo aquelas formalmente empregadas de benefícios trabalhistas. Mas são as mulheres no mercado informal, sem benefícios, a maior preocupação das autoridades de saúde. É preocupante, também, saber que dos vários benefícios trabalhistas existentes quanto à proteção da maternidade, são os referentes às possibilidades de amamentar os menos cumpridos, ou mais negociados pelos sindicatos. Diferentemente do curso da gestação e do parto, a amamentação pode ser interrompida pela mulher; se ela não tem as condições adequadas para manter a lactação, o trabalho fora é motivo, explícito ou não, para o desmame (Rea \& Cukier, 1988).

Desde o ano de sua fundação, 1919, a Organização Internacional do Trabalho (OIT) criou uma Convenção Trabalhista de Proteção à Maternidade. Mas é de 2001 a mais recente revisão dessa convenção, em que se recomenda aos países que a licença-maternidade seja de 14 semanas, que haja pausas remuneradas para amamentar durante o trabalho e que as empregadas informais sejam distinguidas com o direito a benefícios. Hoje, dos países que dão 14 semanas ou mais de licença-maternidade, temos 23/49 na África, 8/35 nas Américas, 12/40 na Ásia e Oriente Médio, 41/44 na Europa e 2/7 na Oceania (Waba, 2006).

No Brasil, esse benefício é de 120 dias (17 semanas), e vários municípios já o estenderam para seis meses para suas funcionárias; encontra-se em discussão no Parlamento um projeto de lei desta natureza. O cumprimento de todos os benefícios, incluindo a rara provisão de creche no nosso meio, não é garantia de que todas as mães trabalhadoras amamentem, embora auxilie bastante, como mostra Gomes (2006), em seu trabalho realizado em São Paulo. Entre as mulheres nessas condiçôes com crianças de 6 a 12 meses nas creches das empresas, 67\% ainda amamentavam; flexibilidade no horário, mudanças de turnos e existência de um ônibus para transporte oferecido pela empresa são fatores que facilitaram a prática de amamentar.

\section{Semana Mundial de Aleitamento Materno e Outras Campanhas}

Em fevereiro de 1991, criou-se a World Alliance for Breastfeeding Action (Waba), inicialmente composta por American Public Health Association (Apha), La Leche League International (LLLI), International Baby Food Action Network (Ibfan), International Lactation Consultants Association (Ilca), International Organization of Consumer Unions (Iocu), Wellstart International e World Council of Churches. O objetivo dessa aliança seria mobilizar a sociedade para o apoio à amamentação.

A primeira ação lançada pela Waba foi a Semana Mundial de Aleitamento Materno (Smam), em 1992. Desde então, essa estratégia de mobilização social tem levado à participação efetiva de muitos órgãos governamentais, de organizações que fazem parte das Nações Unidas e de organizações da sociedade civil. 
A Smam tem sido celebrada, na maioria dos países, durante a primeira semana de agosto. Inúmeras e criativas são as formas que os mais de cem países participantes encontraram de mobilizar a sociedade em torno dos temas anualmente definidos pela Waba. Os temas diversificados (Quadro 2) têm proporcionado a interação do aleitamento materno com outros grupos e disciplinas, tais como ecologia, economia, direitos humanos, globalização, entre outros.

Considera-se que a Smam é uma das estratégias bem-sucedidas, por seu alcance mundial, impacto, criatividade e apropriação por governos e grupos locais. O Brasil tem participado dessa iniciativa desde o princípio, inicialmente por intermédio de grupos não governamentais. Atualmente, o Ministério da Saúde tem liderado esse movimento e muitos municípios aprovaram datas comemorativas oficiais para a Smam (Unicef Innocenti Research Center, 2005; Siqueira \& Toma, 2006).

No final dos anos 90, a parceria entre Ministério da Saúde e Correios expandiu a campanha promovida na Semana para um mês. Segundo Araújo e colaboradores (2003), o ministério implantou o Projeto Carteiro Amigo da Amamentação em 1999 em oito estados do Nordeste brasileiro, onde foram treinados três mil carteiros e potencialmente beneficiadas 665.000 crianças menores de um ano e gestantes. Em 2000, o projeto treinou 6.100 carteiros das regiōes Norte, Centro-Oeste e Nordeste, que levaram informações para cerca de um milhão de mães de crianças menores de um ano e gestantes. Nos anos 2001 e 2002, o projeto aconteceu em todo o Brasil. Em 2001, participaram 16.500 carteiros, beneficiando 2.900.000 crianças menores de um ano e gestantes. Em 2002, foram treinados 23.400 carteiros, estimando-se cerca de 3.400.000 de beneficiários. Campanhas pró-amamentação pela mídia, como as realizadas pelo Brasil no início dos anos 80 , quando bem realizadas, mostram-se um importante meio de difundir o tema entre a sociedade (Rea, 1990).

Quadro 2 - Temas da Semana Mundial de Aleitamento Materno de 1992 a 2007

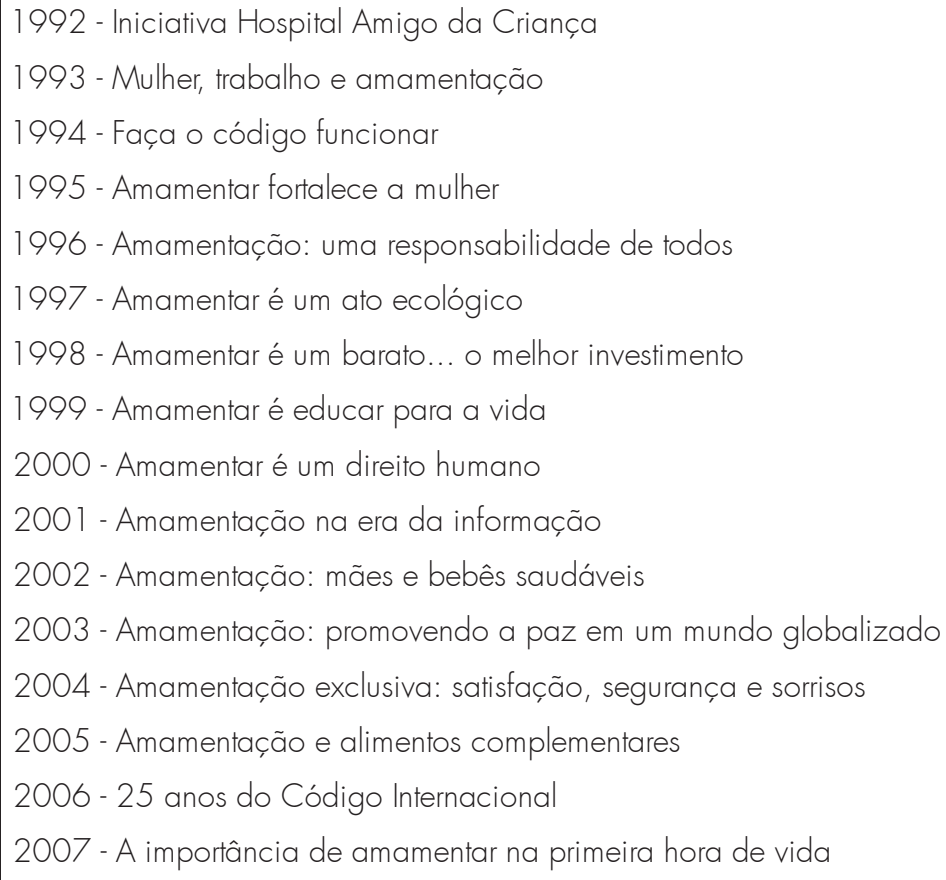

Fonte: Siqueira \& Toma (2006). 


\section{Capacitação de Profissionais da Saúde em Aleitamento Materno}

Revisão sistemática, realizada com o objetivo de avaliar as evidências sobre programas efetivos para aumentar o número de mulheres que iniciam a amamentação, selecionou 59 estudos. Estes foram agrupados segundo os temas educação em saúde; iniciativas gerais do setor Saúde; Iniciativa Hospital Amigo da Criança; capacitação de profissionais da saúde; programa de suplementação nutricional; apoio social de profissionais da saúde; apoio de pares; campanhas em meios de comunicação e outras intervenções.

Atividade em grupos pequenos durante o pré-natal, educação face a face, apoio de pares antes e após o parto mostraram efetividade como intervençōes isoladas. Pacotes de intervenção que incluem apoio de pares e/ou campanhas em meios de comunicação associados a mudanças estruturais do setor Saúde e/ou atividades educativas também se mostraram efetivos. Com relação aos serviços de saúde, mostraram-se relevantes as mudanças estruturais nas práticas de promoção do aleitamento materno nos hospitais, sendo o alojamento conjunto uma açãochave (Fairbank et al., 2000).

A Iniciativa Hospital Amigo da Criança é uma estratégia que trouxe em seu bojo a necessidade de capacitação dos trabalhadores de saúde (Passo 2) e acabou contribuindo para o surgimento de diferentes tipos de cursos. Com o propósito de favorecer a implantação dos dez passos nos hospitais, a OMS e o Unicef desenvolveram um "Curso sobre manejo do aleitamento materno", com carga horária de 18 horas. No Brasil, o manual do curso foi distribuído pelo Ministério da Saúde a todos os hospitais interessados em mudar suas rotinas em favor da amamentação. Elaborado de maneira a ser facilmente incorporado pelos serviços de saúde, esse manual traz orientaçôes sobre métodos de ensino e materiais de apoio para serem utilizados em cada uma de suas 14 sessões. Com base em experiências de especialistas em lidar com a capacitação de trabalhadores da saúde em países da África, chegou-se à conclusão de que os cursos precisam ter uma duração de pelo menos três dias para provocar uma mudança de atitudes (Brasil, 2003). O curso, que no início tinha 18 horas, foi recentemente revisto pelo Unicef e tem agora vinte horas (www.unicef.org).

A implementação da IHAC levou à constatação de que não bastava capacitar os trabalhadores dos hospitais, se não houvesse ao mesmo tempo uma sensibilização dos gestores e administradores dos serviços. Por isso, criou-se um curso de curta duração para gestores, cujo conteúdo é voltado para as necessidades e interesses dessa categoria de profissionais, incluindo-se o impacto econômico direto e indireto da incorporação dos dez passos. Uma sessão sobre planejamento permite que o participante pense sobre a situação particular do seu hospital, enumere dificuldades e facilidades, possíveis formas de contornar as dificuldades, metas e prazos (OMS/Unicef, 1999).

A dificuldade de transformar teoria em prática tem sido uma preocupação constante na área da saúde. Quando se lida com crianças, a situação é ainda mais complexa, na medida em que é necessário o passo adicional de conseguir uma comunicação apropriada com suas mães ou outros cuidadores. $\mathrm{Na}$ amamentação, há muitos pontos sensíveis, que exigiriam comportamentos, sentimentos e atitudes do profissional para lidar com a mãe de maneira confortável, denominadas "habilidades de aconselhamento" (Garrick, 1979). Essas habilidades incluem, entre outras, saber ouvir, evitar julgamentos, elogiar e oferecer poucas sugestôes relevantes. O "Aconselhamento em amamentação: um curso de treinamento" foi elaborado pela OMS com essa finalidade (OMS/Unicef, 1997). A avaliação do curso realizada em São Paulo mostrou mudança significativa na prática de médicos, enfermeiros e auxiliares de unidades básicas de saúde e concluiu pela necessidade de um período adicional de supervisão (Rea et al., 1999). Outros cursos de aconselhamento, voltados para lidar com a alimentação de crianças filhas de mães HIV positivo e alimentação complementar, foram desenvolvidos posteriormente, cada um deles com duração aproximada de quarenta horas (OMS/Unicef, 2003). 
O mais recente material de aconselhamento sobre alimentação de lactentes e crianças de primeira infância, com cerca de 35 horas, integra três cursos anteriores e foi lançado em 2006 para atender à demanda dos países por cursos mais curtos: "Integrated Infant Feeding Counselling: a training course". Esse curso traz como novidade a proposta de realizar um período de seguimento com supervisão dos profissionais após o curso e avaliá-los, introduzindo a noção de 'competências' (WHO, 2006).

A elaboração de cursos de aconselhamento como esses da OMS exige a reunião de especialistas de diversas áreas do conhecimento e, por isso, são processos longos e custosos. Assim, parece lógico deles apropriar-se desde que seja possível adaptá-los à cultura e estrutura de serviços de saúde de cada país ou região. A necessidade de adaptação e avaliação de propostas de capacitação dessa natureza repousa no fato de se questionar em que medida elas podem atender às necessidades de diferentes categorias profissionais, organização de serviços e ser utilizadas em larga escala.

O período em que houve maior número de capacitações de profissionais da saúde do país coincide com o período de maior aumento da duração da amamentação (Rea, 2003): no final dos anos 90 e início de 2000, 31.655 profissionais foram capacitados, por meio de cursos de aconselhamento (1.740 profissionais); cursos para 265 fiscais da Vigilância Sanitária sobre a NBCAL; cursos para 395 avaliadores da IHAC; cursos de 12 horas para 2.040 gestores de maternidades sobre a IHAC e 430 cursos de Bancos de Leite Humano nos 27 estados - todos eles coordenados pelo Ministério da Saúde (Araújo, 2005b). A partir de 2003 a coordenação nacional de tais cursos foi descontinuada, e não se sabe em que medida continuam sendo realizados sob a responsabilidade de municípios.

\section{Amamentação em Situações Excepcionais}

A Estratégia Global aqui mencionada aborda a necessidade de proporcionar orientação e apoio para a alimentação apropriada das crianças em situação excepcionalmente difícil. Em nosso meio, destacamos duas circunstâncias: os bebês de baixo peso ao nascer e os filhos de mães HIV positivo.

O baixo peso ao nascer tem sido uma importante razão para não amamentar, seja pela preocupação com o ganho de peso desses bebês, seja pela dificuldade de manter a lactação de suas mães. Estudos clínicos sugerem importante proteção conferida pelo leite humano contra vários tipos de infecção em recém-nascido pré-termo, sendo de particular interesse a enterocolite necrosante, uma doença inflamatória intestinal aguda que costuma ser devastadora nas unidades neonatais (Schanler, 2001; Lucas \& Cole, 1990).

No Brasil, a rede composta por cerca de 180 bancos de leite humano tem como prioridade prover o leite pasteurizado da própria mãe aos bebês pré-termo (Menconi, 2005). Além disso, o Método Mãe Canguru, cujas diretrizes foram estabelecidas pelo Ministério da Saúde em 2000, tem sido implantado de forma crescente no país e propiciado a prática do contato pele-a-pele e a participação precoce da mãe nos cuidados do recém-nascido de baixo peso. Os resultados alcançados em termos de incidência e duração da amamentação dessas crianças são surpreendentes (Lamy et al., 2005; Colameo \& Rea, 2006).

Entre as infecções virais, o principal desafio da atualidade refere-se às crianças filhas de mulheres HIV positivo. As medidas nacionais para prevenção da contaminação do HIV por meio do aleitamento materno foram publicadas na portaria n. 97, de 28 de agosto de 1995, pelo Ministério da Saúde. Nessa portaria, recomenda-se que as mães HIV positivo não amamentem seus filhos, contra-indicando o aleitamento cruzado e indicando a alternativa de utilização de leite humano pasteurizado, inclusive da própria mãe. Porém, o sistema de bancos de leite humano precisaria estar organizado de maneira a incluir essas crianças em sua lista de prioridades. Atualmente, a quase totalidade dos bancos brasileiros está sediada em hospital e atende somente à sua demanda interna. 
Para enfrentar a situação da epidemia de HIV-Aids em alguns países da África, cientistas estão estudando alternativas para tratamento do leite materno que sejam viáveis do ponto de vista prático e econômico. A técnica de pasteurização dos bancos de leite humano utiliza o aquecimento à temperatura de $62^{\circ} \mathrm{C}$ por 30 minutos e resfriamento brusco (Menconi, 2005). Outras possibilidades, que estão sendo avaliadas, incluem o método conhecido como tratamento pelo calor $\left(56^{\circ} \mathrm{C}\right.$ por 30 minutos) e o uso do pasteurizador solar $\left(60^{\circ} \mathrm{C}\right.$ por 30 minutos), além dos métodos que utilizam banho-maria (como a pasteurização de Pretória), a fervura e o método microbicida com o uso de sódio dodecil sulfato (Hartmann, Berlin \& Howett, 2006).

\section{Considerações Finais}

Em que pesem todos os conhecimentos acumulados sobre a importância de amamentar exclusivamente nos primeiros seis meses e seguir amamentando após a introdução de outros alimentos, nota-se ainda alguma resistência quanto a esta temática, como se ela fosse uma prática simples e de estudo pouco importante. Falta incorporar nos currículos das escolas de saúde muito do conhecimento atualizado ao qual se referiu aqui.

Como se sabe, a mobilização social ocorrida no Brasil desde os anos 80 foi bem-sucedida no sentido de fazer da amamentação uma norma de comportamento da sociedade, e não uma exceção. Nosso país se apropriou das políticas públicas internacionais relevantes sobre aleitamento e conseguiu traduzi-las em práticas e normas conseqüentes de aplicação local em nosso sistema de saúde.

Nossas ações em prol da amamentação têm sido observadas com interesse pelos demais países e autoridades de saúde, já que há algumas décadas mostramos que sabemos por que e como amamentar. Novas avaliações sobre aleitamento, que estão sendo realizadas, deverão mostrar como andam nossos índices de aleitamento materno e as necessidades de melhorar novas ou reviver velhas práticas.

\section{Notas}

1 Em 1990, quando a declaração foi escrita, recomendou-se de quatro a seis meses; hoje, as evidências científicas nos permitem recomendar seis meses.

2 Parte dessa documentação foi publicada em Rea (2003).

\section{Referências}

AGÊNCIA NACIONAL DE VIGILÂNCIA SANITÁRIA (ANVISA). Resolução RDC n. 221, 5 ago. 2002. Diário Oficial da União, Brasília, 6 ago. 2002a.

AGÊNCIA NACIONAL DE VIGILÂNCIA SANITÁRIA (ANVISA). Resolução RDC n. 222, 5 ago. 2002. Diário Oficial da União, Brasília, 6 ago. 2002b.

ALM, B. et al. Breast feeding and the sudden infant death syndrome in Scandinavia, 1992-95. Archives of Diseases in Childhood, 86: 400-402, 2002.

ANDERSON, G. C. et al. Early skin-to-skin contact for mothers and their healthy newborn infants (Cochrane Review). In: The Cochrane Library, Issue 1. Oxford: Update Software, 2007.

ARAÚJO, M. F. M. Iniciativa Hospital Amigo da Criança no Brasil: análise da evolução do credenciamento de hospitais no período de 1992 a 2004 e da reavaliação do cumprimento dos "Dez Passos", em 2002, 2005 a. Dissertação de Mestrado, Brasília: Universidade de Brasília. 
ARAÚJO, M. F. M. Situação e perspectivas do aleitamento materno no Brasil. In: CARVALHO, M. R. \& TAMEZ, R. N. (Org.) Amamentação: bases científicas. 2. ed. Rio de Janeiro: Guanabara Koogan, 2005 b.

ARAÚJO, M. F. M. et al. Incentivo ao aleitamento materno no Brasil: evolução do Projeto Carteiro Amigo da Amamentação de 1996 a 2002. Revista Brasileira de Saúde Materno Infantil, 3(2): 195-204, 2003.

ARAÚJO, M. F. M. et al. Avanços na norma brasileira de comercialização de alimentos para idade infantil. Revista de Saúde Pública, 40(3): 513-520, 2006.

BAHL, R. et al. Infant feeding patterns and risks of death and hospitalization in the first half of infancy: multicentre cohort study. Bulletin of the World Health Organization, 83(6): 418-426, 2005.

BETRÁN, A. P. et al. Ecological study of effect of breastfeeding on infant mortality in Latin America. British Medical Journal, 323: 303, 2001. Disponível em: <http://bmj.com/cgi/content/full/323/7308/303>. Acesso em: 06 dez. 2006.

BLACK, R. E.; MORRIS, S. S. \& BRYCE, J. Where and why are 10 million children dying every year? The Lancet, 361: 2.226-2.234, 2003.

BRASIL. Ministério da Saúde. Manejo e Promoção do Aleitamento Materno: curso de 18 horas para equipes de maternidades. Brasília: MS, 2003.

BRASIL. Ministério da Saúde. Portaria n. 756. Dispõe sobre as normas para o processo de habilitação do Hospital Amigo da Criança integrante do Sistema Único de Saúde - SUS. Diário Oficial da União, Brasília, n. 242, p. 99,17 dez. 2004. Seção 1.

BRASIL. Lei n. 11.265, de 3 de janeiro de 2006. Regulamenta a comercialização de alimentos para lactentes e crianças de primeira infância e também a de produtos de puericultura correlatos. Diário Oficial da União, Brasília, ano CXLIII n. 3, 4 jan. 2006. Seção 1.

CÉSAR, J. A. et al. Impact of breast feeding on admission for pneumonia during postneonatal period in Brazil: nested case-control study. British Medical Journal, 318: 1.316-1.320, 1999.

COLAMEO, A. J. \& REA, M. F. O Método Mãe Canguru em hospitais públicos do Estado de São Paulo, Brasil: uma análise do processo de implantação. Cadernos de Saúde Pública, 22(3): 597-607, 2006.

COLLABORATIVE GROUP ON HORMONAL FACTORS IN BREAST CANCER. Breast cancer and breastfeeding: collaborative reanalysis of individual data from 47 epidemiological studies in 30 countries, including 50.302 women with breast cancer and 96.973 women without the disease. The Lancet, 360 : 187-195, 2002.

EDMOND, K. M. et al. Delayed breastfeeding initiation increases risk of neonatal mortality. Pediatrics, 117: 380-386, 2006.

FAIRBANK, L. et al. A systematic review to evaluate the effectiveness of interventions to promote the initiation of breastfeeding: executive summary. Health Technology Assessment, 4(25), 2000.

GARRICK, C. Teaching for counselling skills. Medical Journal of Australia, 2: 358-359, 1979.

GOMES, R. G. Alimentação de Crianças de 6 a 12 Meses, Filhos de Mulheres em Trabalho Formal na Grande São Paulo, 2006. Dissertação de Mestrado, São Paulo: Programa de Pós-Graduação em Ciências, Secretaria de Estado da Saúde. 
HARTMANN, S. U.; BERLIN, C. M. \& HOWETT, M. K. Alternative modified infant-feeding practices to prevent postnatal transmission of Human Immunodeficiency Virus type 1 through breast milk: past, present and future. Journal of Human Lactation, 22(1): 75-88, 2006.

HEIRD, W. C. \& LAPILLONNE, A. The role of essential fatty acids in development. Annual Review on Nutrition, 25: 549-571, 2005.

JACKSON, K. M. \& NAZAR, A. M. Breastfeeding, the immune response, and long-term health. Journal of the American Osteopathology Association, 106: 203-207, 2006.

JAIN, A.; CONCATO, J. \& LEVENTHAL, J. M. How good is the evidence linking breastfeeding and intelligence? Pediatrics,109: 1.044-1.053, 2002.

JONES, G. et al. Bellagio Child Survival Study Group: how many child deaths can we prevent this year? The Lancet, 362: 65-71, 2003.

KAC, G. et al. Breastfeeding and postpartum weight retention in a cohort of Brazilian women. American Journal of Clinical Nutrition, 79(3): 487-493, 2004.

KRAMER, M. S. \& KAKUMA, R. Optimal duration of exclusive breastfeeding (Cochrane Review). The Cochrane Library, Issue 1, 2006. Oxford: Update software. Disponível em: <www.bireme.org.br>. Acesso em: 30 nov. 2006.

KRAMER, M. S. et al. The Probit Study Group. Promotion of Breastfeeding Intervention Trial (Probit): a randomized trial in the Republic of Belarus. Jama, 285(4): 413-420, 2001.

LAMY, Z. C. et al. Atenção humanizada ao recém-nascido de baixo peso - Método Canguru: a proposta brasileira. Ciência \& Saúde Coletiva, 10(3): 659-668, 2005.

LUCAS, A. \& COLE, T. J. Breast milk and neonatal necrotizing enterocolitis. The Lancet, 336: 1.519-1.523, 1990.

LUTTER, C. K. et al. The effectiveness of a hospital-based program to promote exclusive breast-feeding among low-income women in Brazil. American Journal of Public Health, 87: 659-663, 1997.

MARTIN, R. M. et al. Breastfeeding and cancer: The Boyd Orr Cohort and a Systematic Review with Metaanalysis. Journal of National Cancer Institute, 97(19): 1.446-1.457, 2005.

MENCONI, S. D. Banco de leite humano. In: CARVALHO, M. R. \& TAMEZ, E. R. N. Amamentação: bases cientificas. 2. ed. Rio de Janeiro: Guanabara Koogan, 2005.

MERTEN, S.; DRATVA, J. \& ACKERMANN-LIEBRICH, U. Do baby-friendly hospitals influence breastfeeding duration on a national level? Pediatrics, 116(5): 702-708, 2005.

MINISTÉRIO DA SAÚDE. Resolução CNS n. 5, de 20 de dezembro de 1988 do Conselho Nacional da Saúde: normas para comercialização de alimentos para lactentes. Diário Oficial da União, Brasília, 23 dez. 1988.

MINISTÉRIO DA SAÚDE. Resolução CNS n. 31/1992 do Conselho Nacional da Saúde: Norma Brasileira para Comercialização de Alimentos para Lactentes. Diário Oficial da Uniāo, Brasília, 12 nov. 1993.

MINISTÉRIO DA SAÚDE. Portaria n. 2051, de 8 de novembro de 2001 do Gabinete do Ministro: Norma Brasileira de Comercialização de Alimentos para Lactentes e Crianças de Primeira Infância, Bicos, Chupetas e Mamadeiras. Diário Oficial da União, Brasília, 9 nov. 2001. 
MORROW, A. L. et al. Efficacy of home-based peer counselling to promote exclusive breastfeeding: a randomised controlled trial. The Lancet, 353: 1.226-1.231, 1999.

NEWBURG, D. S.; RUIZ-PALACIOS, G. M. \& MORROW, A. L. Human milk glycans protect infants against enteric pathogens. Annual Review on Nutrition, 25: 37-58, 2005.

ODDY, W. H. et al. The effects of respiratory infections, atopy, and breastfeeding on childhood asthma. European Respiratory Journal, 19: 899-905, 2002.

ODDY, W. H. et al. Breast feeding and respiratory morbidity in infancy: a birth cohort study. Archives of Diseases in Childhood, 88: 224-228, 2003.

OKAMURA, C. et al. Lactation and risk of endometrial cancer in Japan: a case-control study. Tohoku Journal of Experimental Medicine, 208: 109-115, 2006.

ORGANIZAÇÃO MUNDIAL DA SAÚDE (OMS)/FUNDO DAS NAÇÕES UNIDAS PARA A INFÂNCIA (UNICEF). Reuniāo Conjunta OMS/Unicef sobre a Alimentação de Lactentes e Crianças Pequenas: declaração e recomendaçôes. Genebra: OMS, 1979.

ORGANIZAÇÃO MUNDIAL DA SAÚDE (OMS)/FUNDO DAS NAÇŌES UNIDAS PARA A INFÂNCIA (UNICEF). Aconselhamento em Amamentação: um curso de treinamento. Ed. e adapt. port. M. F. Rea, trad. C. M. G. Monte. São Paulo: Instituto de Saúde, 1997.

ORGANIZAÇÃO MUNDIAL DA SAÚDE (OMS)/FUNDO DAS NAÇÕES UNIDAS PARA A INFÂNCIA (UNICEF). Promoção do Aleitamento Materno nas Instituiçōes de Saúde: curso intensivo para planejadores e gestores de saúde. Ed. e adapt. port. M. F. Rea e T. S. Toma, trad. T. Ribeiro Filho e S. S. B. Silva. São Paulo: Instituto de Saúde, 1999.

ORGANIZAÇÃO MUNDIAL DA SAÚDE (OMS)/FUNDO DAS NAÇÕES UNIDAS PARA A INFÂNCIA (UNICEF). Aconselhamento em HIV e Alimentação Infantil: um curso de treinamento. Ed. e adapt. port. M. F. Rea, trad. C. M. G. Monte. São Paulo: Instituto de Saúde, 2003.

REA, M. F. The Brazilian National Breastfeeding Program: a success story. International Journal of Gynecology and Obstetrics, 31, suppl. 1: 79-82, 1990.

REA, M. F. Reflexōes sobre a amamentação no Brasil: de como passamos a 10 meses de duração. Cadernos de Saúde Pública, 19, supl. 1: 37-45, 2003.

REA, M. F. Os benefícios da amamentação para a saúde da mulher. Jornal de Pediatria, 80(5): S142-S146, 2004.

REA, M. F. \& CUKIER, R. Razōes de desmame e de introdução da mamadeira: uma abordagem alternativa para seu estudo. Revista de Saúde Pública, 22(3): 184-191,1988.

REA, M. F. et al. Counselling on breastfeeding: assessing knowledge and skills. Bulletin of the World Health Organization, 77(6): 492-498, 1999.

SCHANLER, R. J. The use of human milk for premature infants. Pediatric Clinics of North America, 48(1): $207-$ 219, 2001.

SIQUEIRA, S. R. \& TOMA, T. S. As semanas mundiais de aleitamento materno. In: REGO, J. D. 2. ed. rev. e ampl. Aleitamento Materno. São Paulo: Atheneu, 2006.

SOKOL, E. J. The Code Handbook: a guide to implementing the International Code of Marketing of Breastmilk Substitutes. 2. ed. Den Haag: ICDC, 2005. 
UNICEF INNOCENTI RESEARCH CENTRE. 1990-2005. Celebrating the Innocenti Declaration on the Protection, Promotion and Support of Breastfeeding: past achievements, present challenges and the way forward for infant and young child feeding. Nov. 2005.

VENÂNCIO, S. I. \& MONTEIRO, C. A. A tendência da prática da amamentação no Brasil nas décadas de 70 e 80. Revista Brasileira de Epidemiologia, 1(1): 40-49, 1998.

VICTORA, C. G. et al. Evidence for protection by breast-feeding against infant deaths from infectious diseases in Brazil. The Lancet, II (8554): 319-322, 1987.

WORLD ALLIANCE FOR BREASTFEEDING ACTION (WABA). Status of maternity protection by country. Update 21 May 2006. Disponível em: <www.waba.org.my>. Acesso em: 31 maio 2006.

WORLD HEALTH ORGANIZATION (WHO). Division of Diarrhoeal and Acute Respiratory Disease Control. Indicators for assessing breast feeding practices. Report of an Informal Meeting 11-12 June 1991, Geneva.

WORLD HEALTH ORGANIZATION (WHO). Evidence for the Ten Steps to Successful Breastfeeding. Geneva: WHO, 1998. (WHO/CHD/98.9)

WORLD HEALTH ORGANIZATION (WHO). Integrated Infant Feeding Counselling: a training course. Geneva: WHO, 2006.

WORLD HEALTH ORGANIZATION (WHO)/THE UNITED NATIONS CHILDREN'S FUND (UNICEF). The International Code of Marketing of Breast-Milk Substitutes. Geneva: WHO, 1981.

WORLD HEALTH ORGANIZATION (WHO)/THE UNITED NATIONS CHILDREN'S FUND (UNICEF). Innocenti Declaration on the Protection, Promotion and Support of Breastfeeding. Meeting "Breastfeeding in the 1990s: a global initiative". Cosponsored by the United States Agency for International Development (AID) and the Swedish International Development Authority (Sida), held at the Spedale degli Innocenti, Florence, Italy, on 30 July-1 August, 1990. 



\title{
Transição Nutricional: conceito e características
}

\author{
Malaquias Batista Filho, Ana Marlúcia de Assis e Gilberto Kac*
}

\section{Antecedentes e Conceitos}

A transição epidemiológica e sua representação específica na área da nutrição configuram, ainda, um conceito em processo de consolidação. Em sentido amplo, toda evolução da díade saúde-doença na história humana consiste em um processo de transição: lenta, praticamente imperceptível nos tempos pré-históricos, surpreendentemente rápida nos últimos cem anos e, sobretudo, a partir dos anos 50 do século XX (Frederiksen, 1969). Basicamente, além de sua natureza qualitativa, o que caracterizaria a transição epidemiológica seria a velocidade nas mudanças de sinais (+ e -) dos padrões de morbi-mortalidade e, por conseguinte, a substituição da agenda temática dos problemas de saúde coletiva. Este seria o aspecto, em sentido estrito, que delineia, de fato, o conceito e as implicações pragmáticas da transição epidemiológica e, por extensão, da transição nutricional (Popkin, 1993; Barreto \& Carmo, 2000; Batista Filho \& Rissin, 2003; Kac \& Velásquez-Meléndez, 2003).

Como representação simplificada, o processo de transição pode ser ilustrado como a passagem de um modelo A, demarcado pelo amplo predomínio das doenças infecciosas, parasitárias e carenciais, para um modelo Z, definido pela hegemonia praticamente absoluta (75\% e mais) das Doenças Crônicas Não Transmissíveis (DCNT), associadas ao sobrepeso/obesidade, às dislipidemias (hipercolesterolemia e desbalanço de suas frações, hipertrigliceridemia), à síndrome metabólica precursora do diabetes mellitus tipo 2 , à hiperuricemia e a outras manifestações ou fatores de risco menos relevantes. Em torno desses dois pólos gravitam conjuntos complexos e inter-relaçôes de situações nosológicas, de substratos populacionais e de ecossistemas de vida bem diferenciados. $\mathrm{Na}$ realidade, são padrões epidemiológicos que retratam perfis socioambientais, a exemplo dos habitats rurais e urbanos, da estratificação social e econômica da população, dos estilos de vida coletivos e individuais, dos níveis de escolarização, da estrutura, acesso e resolutividade dos serviços de saúde e, basicamente, da situação demográfica e sua dinâmica como expressão mais notável do processo. De forma mais concreta, o modelo A se caracteriza por populaçóes jovens, com elevadas taxas de natalidade e mortalidade, analfabetismo ou níveis muito baixos de escolaridade, desemprego/subemprego, condiçôes inadequadas de saneamento, condições socioeconômicas precárias, mortalidade infantil e pré-escolar elevada, escassa ou nula cobertura das açôes básicas de saúde, em estreita dependência das coordenadas de tempo, espaço e condições em que este estágio ocorre.

$\mathrm{O}$ aspecto mais visível da transição epidemiológica, em termos de indicadores, pode ser retratado na mudança do perfil demográfico e seus vetores proximais mais relevantes: a natalidade e a mortalidade. Dentro da 
sistematização dos estudos sobre a transição demográfica, mesmo não chegando, explicitamente, ao conceito de evento epidemiológico, uma observação histórica importante pode ser atribuída ao abade Malthus (1999), que verificou que a mortalidade na população humana tendia a cair substancialmente, ao passo que a natalidade mantinha seus padróes quantitativos, produzindo um saldo crescente e preocupante no balanço populacional. Analisando as informações disponíveis, Malthus formulou seu famoso enunciado, concluindo que a população passava a crescer em progressão geométrica, enquanto a produção de alimentos aumentaria apenas em progressão aritmética. Da dissociação desses vetores da dinâmica demográfica resultaria a visão apocalíptica da explosão demográfica. Nesse ponto, o ensaísta que formulou os fundamentos da demografia, possivelmente enfrentando sérios conflitos de consciência religiosa, adianta-se na predição de consequiências epidemiológicas e em curiosas recomendações para evitar a confirmação de suas 'profecias': crescendo a população a um ritmo exponencial explosivo, enquanto a produção alimentar aumentaria ao ritmo linear de uma contagem aritmética, o resultado final e até imediato seria a eclosão de desastrosas epidemias de fome em escala universal. Para evitar a catástrofe da fome, a solução natural seria o descarte populacional por meio das doenças de massa (endemias, epidemias e pandemias, pode-se entender) ou da destruição em massa de vidas humanas nas guerras. Um século depois da doutrina de Malthus, a história demonstrou que, por unidade de área cultivada, a produção de alimentos aumentou em ritmo geométrico, ao passo que o incremento demográfico foi sendo modelado, nos países chamados desenvolvidos, em um ritmo mais lento que as previsões de uma estimativa aritmética projetada no tempo. E isso sem contar com a ajuda das guerras ou a parceria com as doenças de massa - as grandes endemias e epidemias do passado, muitas associadas ao próprio ciclo das guerras, na observação de Josué de Castro (Castro, 1992).

A outra grande inflexão nos termos de equação demográfica foi representada pela redução marcante da natalidade, sobretudo a partir da segunda metade do século passado, quando, de fato, o processo passa a ser denominado de forma específica, mas não autônoma, de transição epidemiológica. Segundo a revisão crítica de Barreto e Carmo (2000), o marco conceitual seria a constatação de Frederiksen (1969) quanto ao valor da "caracterização dos padrōes de morbidade e mortalidade para o entendimento da transição demográfica". Em outras palavras: cada sociedade apresentaria padrões dominantes de morbidade e mortalidade que seriam modificados na medida em que se estruturavam níveis diferenciados de desenvolvimento econômico e social, estabelecendo-se, assim, uma correspondência entre os dois processos. Como expressão ilustrativa, a passagem de uma sociedade tradicional para uma sociedade moderna seria acompanhada por uma mudança no perfil de morbimortalidade dominado por doenças infecciosas para uma situação bem diferenciada, pelo predomínio de DCNT. No caso mais contemporâneo das sociedades menos desenvolvidas, essa mudança passaria a ser marcadamente determinada pela mediação da tecnologia.

Pouco depois de Frederiksen, Omran (1971) ratificou a denominação de transição epidemiológica para designar esse processo de mudança, que implicaria uma seqüência de estágios a partir das sociedades tradicionais até as sociedades modernas. Tais mudanças poderiam ocorrer segundo três modelos básicos: a) o clássico, também chamado ocidental, demarcado por uma diminuição progressiva da mortalidade e da fertilidade, levando ao envelhecimento populacional e ao domínio das doenças degenerativas e "causadas pelo homem". Seria o caso dos Estados Unidos e dos países da chamada Europa Ocidental; b) o modelo acelerado, definido, como indica sua denominação, pela rápida queda da mortalidade e rápida inversão das causas de mortes, tipificada no caso do Japão; c) finalmente, o modelo tardio ou contemporâneo, melhor configurado nos países subdesenvolvidos, tendo como elementos de caracterização uma queda mais lenta e mais recente da mortalidade, não acompanhada por um declínio tão marcante nos níveis de fertilidade. Seria pertinente esboçar um quarto estágio nessa classificação, reunindo, numa só chave, as observações de Fries (1983, 2000), que propôs uma "compressão da morbidade", com o retardamento do início das DCNT na fase adulta e na senescência e, por conseguinte, o ganho quantitativo e qualitativo de vida dos indivíduos, ou, no mesmo sentido, a idade em que a ocorrência das doenças degenerativas começa a declinar, segundo a proposição de Olshansky e Ault (1986). 
Diferenciados em seu ritmo de instalação, em sua composição nosológica e em seus contextos de determinantes, os modelos de transição teriam como etapas comuns três grandes segmentos que se sucedem: "a idade de pestilências e da fome, a idade de declínio das pandemias e a idade das doenças degenerativas aliadas às doenças criadas pelo homem” (Barreto \& Carmo, 2000: 17-18).

As perspectivas desses autores, que poderiam ser simbolizadas pelo ideal já antigo de "acrescentar anos à vida e acrescentar qualidade de vida aos anos", começa a se delinear nos objetivos políticos, doutrinários e programáticos das Naçōes Unidas, com a Estratégia Global da Alimentação e Estilos de Vida Saudáveis, fundamentada no relatório da Organização Mundial da Saúde (OMS), de 2002, e no documento aprovado pelas Nações Unidas em 2004 (WHO, 2004), já referendado por mais de cem países, inclusive o Brasil (Shandi et al., 2005). Desenha-se, concretamente, a possibilidade de deslocar (no sentido de adiar) ou suprimir parcialmente $80 \%$ da carga de morbi-mortalidade produzida pelas DCNT manejando um conjunto de fatores relacionados com a alimentação saudável, o controle do tabagismo, do alcoolismo, do sobrepeso/obesidade e do sedentarismo (Opas/OMS, 2003; Riboli \& Norat, 2003; Sandhi et al., 2005). Portanto, o retardamento das doenças crônicas, mais do que um conceito epidemiológico, é um fundamento que já se traduz em compromissos políticos e programáticos assumidos por vários países.

Evidencia-se, em todas as descrições e análises, de diferentes autores, que a transição epidemiológica constitui a face visível e mutável dos indicadores de natalidade e morbi-mortalidade, expressando, concretamente, um conjunto interativo de condições históricas e culturais, variáveis e processos socioeconômicos, alteraçôes de ecossistemas (polarização rural/urbano como exemplo), comportamentos e exposição individual e coletiva a fatores de risco, de proteção e recuperação da saúde. Representa, assim, um recorte temático e setorial de um contexto sistêmico em processo de mudanças relevantes.

\section{Passado: o cenário 'imóvel'}

Ainda que sem conferir a este elemento importância fundamental para a compreensão do processo transicional na área da alimentação e nutrição, vale mencionar, como argumentação didática, que o homem primitivo, desde seu aparecimento sobre a Terra, até a extinção de dez ou 12 de suas espécies, com a sobrevivência de uma única (o Homo sapiens), viveu precariamente no limite instável da (in)segurança alimentar. Expunha-se, como as outras espécies de animais, à disponibilidade de uma oferta natural de alimentos que, de fato, limitava o próprio crescimento populacional. A descoberta e o domínio progressivo de métodos de produção e conservação de alimentos representaram a alternativa evolucionária para ampliar em dois sentidos (pecuária e agricultura) a cadeia trófica em seu proveito.

Os achados e evidências paleontológicos, arqueológicos e antropológicos sugerem que nesse longo período da Pré-história e até de etapas relativamente recentes da história humana, a privação maior ou menor de alimentos foi ou ainda é ameaça permanente. Os fósseis humanos mais antigos teriam uma estatura média de $1,20 \mathrm{~m}$, sem correspondência, portanto, com as médias de qualquer agrupamento humano de nossos tempos. Característica étnica ou manifestação fenotípica da fome? Estima-se que a vida média dessas populações primitivas seria em torno de vinte anos. É provável que, ao lado das carências genéricas de proteínas e energia, se manifestassem, com caráter endêmico e, sobretudo, sazonalmente epidêmico, as carências nutricionais específicas de vitaminas e sais minerais, coexistindo com os momentos adversos dos ciclos naturais de oferta de alimentos ou com o fracasso de colheitas dos povos pioneiros da agricultura e do pastoreio. Era o cenário que coexistia com as doenças transmissíveis, constituindo o modelo epidemiológico que prevaleceu na longa sucessão dos milênios, com elevadíssimas taxas de natalidade e de mortalidade, resultando na inércia demográfica de um crescimento populacional próximo de zero. 
A possibilidade de uma oferta adequada de alimentos para atender à demanda potencial do consumo é um acontecimento recente na história do homem, abrangendo, seguramente, dois ou três dos sessenta séculos de testemunho escrito que documentam a saga da humanidade. O tempo de inércia demográfica do passado mais distante seria, em termos puramente conceituais, a linha de base ou estágio de aparente imobilidade para se demarcar o conceito de transição epidemiológica e nutricional que, obviamente, inclui o processo de transição nos padrôes alimentares.

\section{A Transição Nutricional}

Como enunciado simples e didático, a mudança que caracteriza a transição nutricional poderia ser definida como a passagem de um estágio bem primitivo, simbolizado pela ocorrência de formas graves de carências globais (kwashiokor, marasmo nutricional) ou específicas (hipovitaminose A, escorbuto, beribéri, raquitismo, osteomalácia, pelagra), constituindo manifestações de caráter dominantemente agudo, para outro em que predominam DCNT. Entram, também, nesse estágio os processos carenciais caracteristicamente crônicos, como o nanismo nutricional, a idiotia iodopriva, as seqüelas esqueléticas de deficiências vitamínicas e minerais e as anemias que, eventualmente, podem ser agudas. É pertinente enfatizar a associação das carências nutricionais com um variado conjunto de doenças infecciosas e parasitárias, compondo um modelo bem estabelecido de morbi-mortalidade. Em termos deliberadamente simplificados, pode-se convencionar que a redução ou desaparecimento das formas graves de desnutrição energético-protéica (kwashiorkor e marasmo) constitui o indicativo epidemiológico do processo de transição em seu estágio inicial.

Em um segundo momento, que caracterizaria a transição propriamente dita, as endemias e manifestações epidêmicas das carências nutricionais passam a apresentar uma diminuição progressiva em sua ocorrência. Em uma representação convencional, desapareceriam os casos clínicos graves de Desnutrição Energético-Protéica (DEP), de carência de iodo (idiotia e tipos mais avançados de bócio iodoprivo) e de hipovitaminose A. Pode-se eleger o início da recuperação da estatura em escala populacional como o evento mais representativo desta fase. Simultaneamente, reduz-se a incidência do Baixo Peso ao Nascer - BPN (menos de $2.500 \mathrm{~g}$ nos nascidos vivos) para valores abaixo de 10\%. Com base nos indicadores mais genéricos do processo saúde-doença, descreve-se uma redução marcante da mortalidade infantil em especial por doenças infecciosas. A base demográfica da pirâmide populacional passa a ter sua estrutura expressivamente modificada, com a queda da mortalidade por doenças facilmente evitáveis e curáveis, e da natalidade, prolongando-se a expectativa de vida a um ritmo que, em muitos países, implicou ganhos médios de cinco a dez anos, em apenas uma década. Com o prolongamento da vida, a modificação dos hábitos alimentares e a redução das atividades físicas, a população ingressa em uma nova vertente do cenário epidemiológico.

O terceiro estágio seria representado pela correção do 'déficit' estatural, resgatando-se, fenotipicamente, o potencial genético do crescimento humano, até então dificultado pelas adversidades socioambientais. Evidenciase, por tendências históricas e mudanças sociais, uma outra característica desta etapa: a instalação do sobrepeso/ obesidade, como um processo pangeográfico e transsocial. Esta etapa da transição nutricional corresponde à construção de um conjunto de co-morbidades reunidas em torno de fatores comuns de riscos: o diabetes mellitus, principalmente do tipo 2, as doenças cardio e cerebrovasculares e alguns tipos importantes de neoplasias, como o câncer de mama, da próstata, do cólon e do reto, correlacionados com o estado de nutrição, com características do regime alimentar e hábitos de vida não saudáveis. Por sua natureza e implicações, pode-se agregar a esse complexo de patologias as doenças osteoarticulares. Estima-se que as DCNT, que representam entre 70\% e 80\% da carga de morbi-mortalidade nos países desenvolvidos e já alcançam o primeiro patamar de importância epidemiológica nas nações em desenvolvimento, poderiam ser substancialmente reduzidas com a prática da alimentação e estilos de vida saudáveis (Opas/OMS, 2003; Sandhi et al., 2005). A perspectiva plenamente evidenciada de 
mudar a situação que se define no estágio 3 da transição epidemiológica constitui o próprio fundamento da Estratégia Global da Alimentação Saudável, apoiada em alguns procedimentos, como a ingestão diária de 450 a $700 \mathrm{~g}$ de frutas, verduras e legumes, redução do consumo de sal, de gorduras animais, ácidos graxos na forma trans, de açúcares industrializados e de excedente calórico da dieta em relação às necessidades normais do organismo. A aplicação, em escala populacional, dessas recomendaçôes, ao lado das medidas de promoção de hábitos de vida saudáveis, com o controle do tabagismo, do alcoolismo e do sedentarismo, poderia constituir uma variante ou uma característica peculiar da transição epidemiológica: a "compressão de morbidades crônicas", segundo a conceituação de Fries $(1983,2000)$.

A representação esquemática da transição nutricional segundo modelos ainda que bem delineados estabelece, de fato, simplificaçōes que impedem que se abranja, satisfatoriamente, a realidade em suas diferentes manifestações socioambientais e culturais. É comum, em um mesmo país e em um mesmo período, ocorrerem combinações de situaçôes diversas e até aparentemente conflitivas. Como exemplo, o caso das anemias, que escapa das tendências temporais dos outros problemas carenciais. Assim, na cidade de São Paulo, enquanto a DEP, em crianças, avaliada pelo índice estatura/idade, caiu em cerca de $70 \%$ no intervalo de duas décadas, a prevalência de anemias aumentou em $113 \%$ no mesmo período (de 1974-75 a 1995-96). Em nível mundial, foram projetadas estimativas de 3,5 bilhões de pessoas anêmicas (1999), o que corresponde a 58\% de toda a população humana, em oposição ao declínio acentuado da DEP em todos continentes, excetuados alguns países da África Subsaariana.

\section{Sinopse da Transição Nutricional no Brasil}

Como se demonstrou, a tradução mais convencional da transição nutricional se faz pelo comportamento evolutivo do estado de nutrição calórico-protéica e seu espectro de manifestações, abarcando desde as formas graves de DEP até os tipos avançados de obesidade. Nesta seção, faz-se um breve resumo dos principais eventos que caracterizam as mudanças mais relevantes no campo da nutrição registradas no Brasil, nas últimas três décadas.

As formas graves e clássicas de desnutrição infantil (o kwashiorkor, o marasmo e os tipos mistos de kwashiorkor marasmático), que tipificariam o estágio mais primitivo do processo nutricional, praticamente desapareceram como ocorrências comuns do quadro epidemiológico da desnutrição em quase todas as regiōes geográficas do Brasil. Nas décadas de 60 e 70 do último século, esses quadros eram ainda freqüentes, principalmente no Nordeste e no Centro-Norte do Brasil. Assim, as formas graves de desnutrição com edema e tipos marasmáticos apareciam nos primeiros estudos de base populacional (ICNND, 1965) e, sobretudo, entre crianças hospitalizadas, em que até $80 \%$ das internações pediátricas eram de portadores de desnutrição grave (Lucena, 1975). Já na década de 90, Saraiva (1990) teve dificuldade de encontrar crianças hospitalizadas com desnutrição. No ano de 2003, a taxa de internação por desnutrição na rede de hospitais do Sistema Único de Saúde (SUS) era de 3,08\%, caindo para 2,41\% em 2004 e para 1,86\% em 2005 (Ministério da Saúde, 2006). Mesmo nas regiōes Norte e Nordeste, essas taxas pouco ultrapassavam o percentual de $2 \%$ das admissões hospitalares.

\section{Peso ao Nascer: tendências}

Nos últimos trinta anos, a incidência do BPN, que reflete, conjuntamente, as inadequadas condições nutricionais e do estado de saúde das mães no decurso da gravidez, reduziu-se pela metade, encontrando-se agora abaixo do limite crítico estabelecido pelas Nações Unidas para a década de 90 (Unicef, 1990). Entre 1970 e 1980, a ocorrência do BPN (menos de $2.500 \mathrm{~g}$ ) prevalecia, segundo o esperado, nas regiōes pobres (Norte e Nordeste), atingindo aproximadamente $12 \%$ dos nascidos vivos. No entanto, no final da década de 1990 , registrou-se uma surpreendente alteração no quadro geográfico do evento, que passou a ser prevalente nos espaços mais desenvolvidos do Sudeste e Sul, às custas, principalmente, de um aumento da prematuridade. Essa mudança inesperada 
na cartografia do BPN representa, possivelmente, um dos aspectos mais instigantes da transição epidemiológica e nutricional do país.

Figura 1 - Distribuição percentual de nascidos vivos com baixo peso ao nascer (menos de $2.500 \mathrm{~g}$ ) segundo as regiões. Brasil, 1996 a 2000

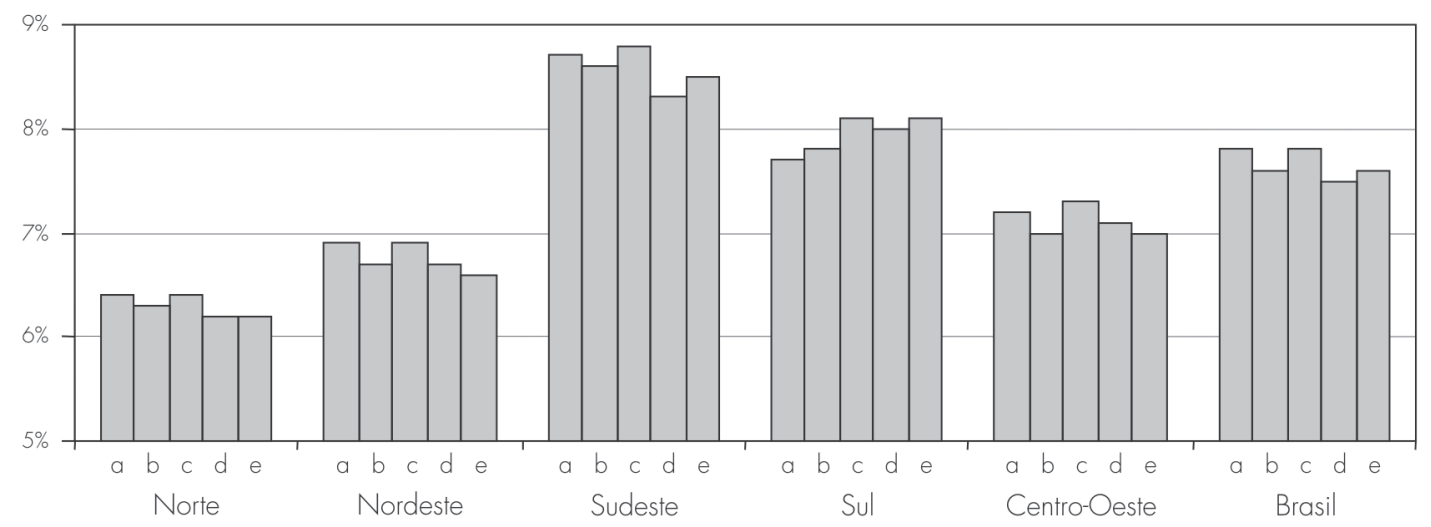

$a-1996 ; b-1997 ; c-1998 ; d-1999 ; e-2000$

Fonte: Ministério da Saúde (2004).

A propósito, estudo de uma série temporal de dez anos no município de Olinda, região metropolitana do Recife, PE, revela que a incidência do BPN apresentou redução de 47\%, entre 1991 e 2002, ao passo que os casos de prematuridade que também integram a composição deste indicador tiveram uma elevação substancial na sua ocorrência, quase 80\% (Guimarães, 2004). Seria essa duplicidade de tendências que, em escala maior, estaria ocorrendo no bloco Sul-Sudeste? Seria o primeiro registro de um novo comportamento epidemiológico, com marcantes implicações na saúde e nutrição das crianças brasileiras, considerando que a cidade de Olinda se identificaria mais com as populações meridionais do Brasil mais desenvolvido do que com as regióes Norte e Nordeste?

\section{Desnutrição em Crianças}

Estudos de prevalência que contemplaram amostras representativas do Brasil e de suas cinco macrorregiōes indicaram que, nos últimos trinta anos, a prevalência de desnutrição em crianças declinou em cerca de $80 \%$. Nas duas últimas avaliações, as regiões Sul, Sudeste e Centro-Oeste já apresentam níveis de ocorrência compatíveis com a situação dos países desenvolvidos.

Levando em conta o indicador peso/idade, discriminado no ponto de corte correspondente a - 2 desviospadrão, a prevalência de déficit antropométrico moderado e grave caiu de 16,6\% em 1974-75 para 4,6\% na avaliação mais recente (2002-2003). Nas regióes Norte e Nordeste, onde as linhas de base da série temporal indicavam as freqüências mais elevadas $(21,7 \%$ e $24,9 \%$, respectivamente), o déficit ponderal para a idade declinou, por ordem de referência, para 6,7\% e 5,4\%. Os dados da Figura 2 mostram que o ritmo mais intenso da mudança ocorreu entre 1973-74 e 1989, tendendo para a estabilização a partir desse momento, no Sul, Sudeste e Centro-Oeste. 
Figura 2 - Evolução da prevalência de déficit (a) de peso para a idade (P/I) em menores de 5 anos, segundo regiōes, no Brasil (1974-75, 1989, 1996 e 2002-3)

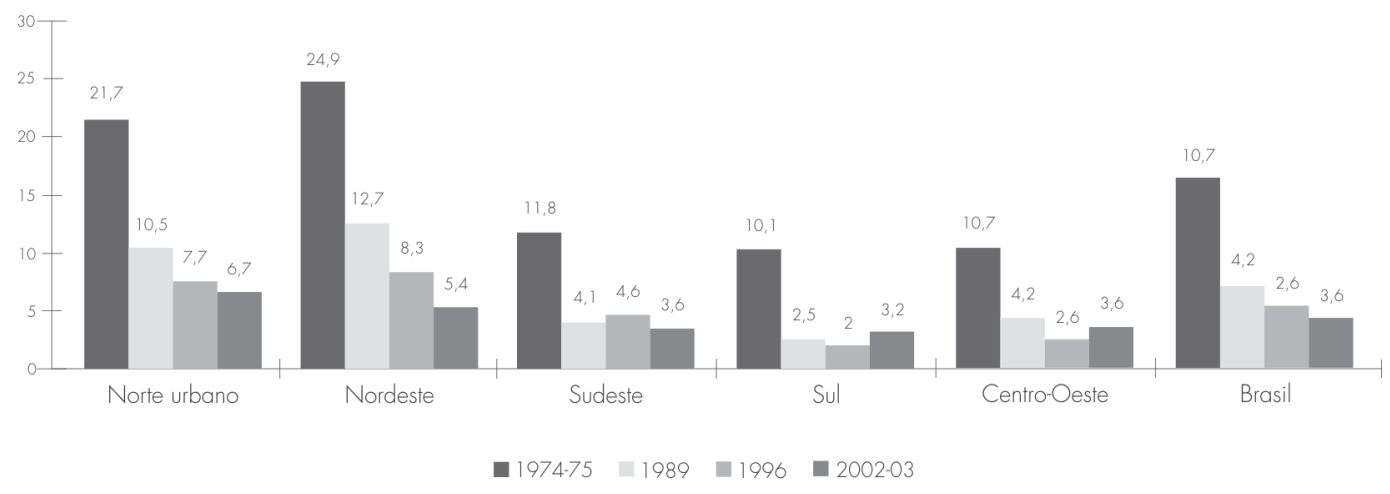

(a): déficit $\mathrm{P} / \mathrm{I}<-2$ desvios-padrão da tabela NCHS (National Center of Health and Statistics).

Fonte: IBGE (2006).

Ao lado dos aspectos geográficos, é interessante demonstrar o dinamismo social do processo, ou seja, suas tendências em função da estratificação de renda.

Observa-se que o déficit peso/idade declinou de forma marcante em todas as categorias de renda, mesmo em crianças das faixas sociais mais desfavorecidas - os $20 \%$ mais pobres ( $1^{\circ}$ quinto de renda). A partir do terceiro quinto e, de forma bem evidente, no quarto e quinto estratos de renda familiar, o déficit ponderal praticamente se estabiliza já em 1989. Os resultados da distribuição ilustrada no Figura 3 emonstram que, ao lado dos aspectos espaciais anteriormente apresentados, as mudanças do cenário epidemiológico da desnutrição em crianças implicaram ritmos diferenciados pelos padrões de renda familiar. Desde 1989, a situação das crianças menores de cinco anos a partir do quarto quintil de renda seria, pelo menos, igual à encontrada nos países considerados desenvolvidos. Em outras palavras: mesmo a mudança tendo ocorrido em todos os estratos econômicos, a renda familiar enviesou substancialmente as tendências temporais de ocorrência do problema.

Figura 3 - Evolução da prevalência do déficit (a) de peso para idade (P/I) em menores de 5 anos, segundo quintos de renda per capita no Brasil (1974-2003)

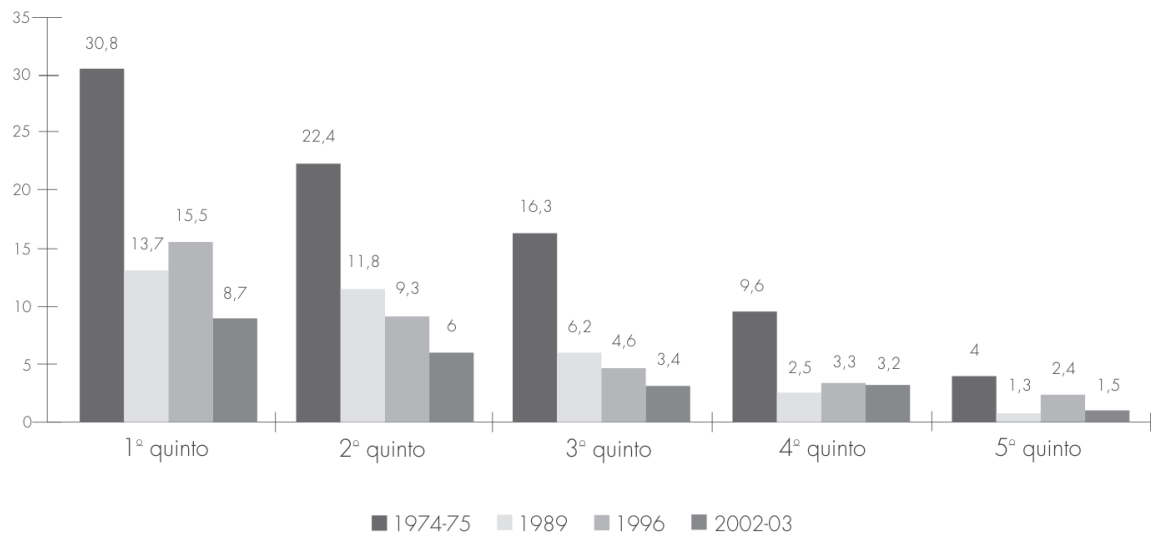

(a) Déficit $\mathrm{P} / \mathrm{I}<-2$ desvios-padrão NCHS (National Center of Health and Statistics).

Fonte: IBGE (2006). 


\section{Anemia: a grande mudança}

Lamentavelmente, não se dispõe de dados representativos que possam evidenciar, com a desejada consistência estatística, a distribuição espacial do problema das anemias no Brasil. O que se depreende dos escassos estudos publicados é que se trata do processo carencial de maior magnitude, difusão geográfica e social, afetando todos os grupos de renda e comportando-se como uma endemia pan-econômica, nas duas últimas décadas (Santos, 2002; Silva \& Batista Filho, 2005). Afetando, em maior ou menor escala, toda a população e todas as classes de renda, a ocorrência do problema tende a se concentrar nas mulheres em período reprodutivo e em crianças menores de 5 anos. De certa forma, é surpreendente assinalar que as anemias parecem evidenciar um comportamento bem diverso daquele da DEP no período mais característico da transição nutricional no Brasil, apresentando uma tendência temporal que praticamente inverte o curso epidemiológico registrado em relação à DEP em crianças. Comparadas entre si, seriam trajetórias inversamente proporcionais: as anemias aumentam sua prevalência ao mesmo tempo e em ritmo oposto ao do declínio na prevalência da desnutrição.

A figura seguinte representa as tendências das anemias entre menores de cinco anos e entre escolares de três estados do Brasil, com base em estudos selecionados para fins comparativos. São bem interessantes os resultados da cidade de São Paulo, com três inquéritos realizados nas décadas de 70, 80, 90, e do estado da Paraíba, com duas pesquisas de campo nas décadas de 80 e 90, ou, ainda, de Pernambuco, em escolares dos mesmos educandários, nos anos de 1982 e 2001.

Figura 4 - Tendências temporais de ocorrência de anemia entre menores de 5 anos e entre escolares (Recife, PE) em três estados brasileiros

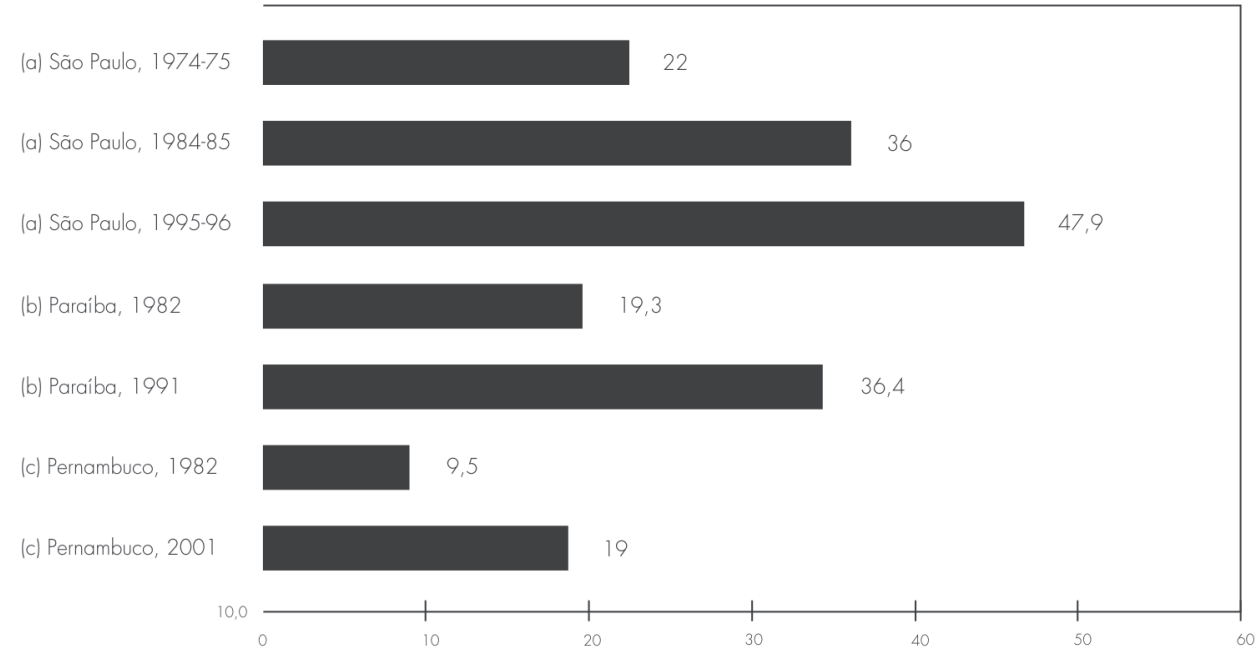

(a) Cidade de São Paulo. Fonte: Omran (1971).

(b) Amostra de oito municípios. Fonte: Lucena (1975).

(c) Avaliação de nove escolas do Recife. Fonte: Riboli \& Norat (2003).

\section{Tendências da Obesidade}

O traço predominante na caracterização da transição nutricional no Brasil é, sem dúvida, a emergência epidêmica do sobrepeso e, particularmente, da obesidade, como evento de maior visibilidade epidemiológica e de implicações correlatas com o comportamento da morbi-mortalidade. 
O acompanhamento da situação brasileira nos últimos trinta anos evidencia um processo de destacado dinamismo, com tendências claramente epidêmicas, marcado por diferenças bem nítidas entre gêneros e por evolução temporal distinta entre regiōes. Para demarcar esses aspectos, descreve-se, na Figura 5, o comportamento epidemiológico da obesidade, definida como Índice de Massa Corporal (IMC) maior do que $30 \mathrm{~kg} / \mathrm{m}^{2}$. Demonstrase que o problema aumentou cinco vezes entre os homens adultos do Nordeste e três vezes no Sudeste, entre 1974-75 e 2002-03. Entre as mulheres dessas regiōes, a trajetória foi bem mais diferenciada: a obesidade duplicou sua ocorrência entre 1974-75 e 1989, passando a declinar no período compreendido entre 1996 e 2002-03. Já no Nordeste o problema elevou-se de forma contínua até 1996, quando se inicia uma breve redução de 13,1\% para 11,7\% na avaliação realizada em 2002-03 pelo IBGE, embora no ano da base da série temporal (1974-75) a prevalência da obesidade fosse duas vezes mais elevada nas mulheres adultas do que entre os homens, tanto no Nordeste como no Sudeste. Os resultados da última observação (2002-03) indicam que a situação se tornou praticamente equivalente entre os dois sexos, na região Sudeste (Figura 5).

Figura 5 - Evolução temporal da prevalência de obesidade (IMC $\geq 30 \mathrm{~kg} / \mathrm{m}^{2}$ ) no Nordeste e no Sudeste do Brasil (1974-75, 1989, 1996 e 2002-03)

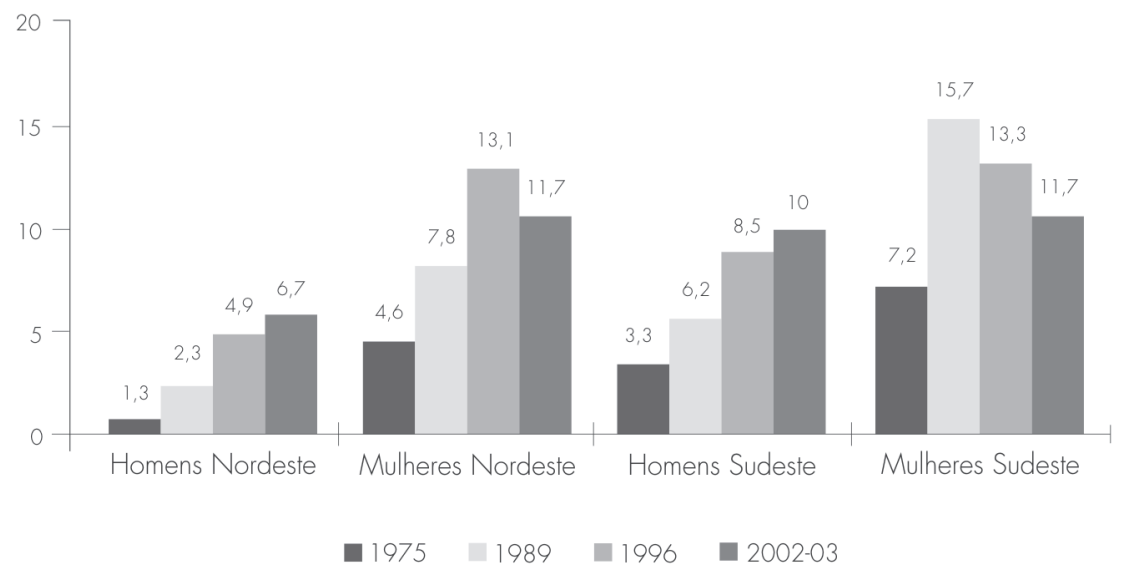

Fontes: Batista Filho \& Rissin (2003) e IBGE/MP/MS (2004).

\section{Mudanças no Perfil Alimentar}

A simples observação testemunhal ou impressionista revela evidências claras de que o perfil alimentar da população brasileira apresentou expressivas mudanças nos últimos trinta anos, o que corresponde ao período mais característico da transição nutricional no país. No entanto, com exceção do Estudo Nacional de Despesas Familiares efetuado pelo IBGE em 1974-75, não existem pesquisas representativas da situação alimentar da população que tenham utilizado metodologias de inquérito de consumo e avaliação do valor nutricional da dieta de famílias em nível geográfico (macrorregiōes e dicotomia urbano/rural) e em escala social (levando-se em consideração a renda familiar e a escolaridade de homens e mulheres adultas). Essa limitação dificulta a construção de séries espaciais, temporais e sociais que possam avaliar, com a desejada acurácia, a natureza, o ritmo e as tendências dos padrões de consumo alimentar e valor nutricional da dieta utilizada pela população brasileira.

Com essas restriçóes preliminares, apresentam-se, aqui, alguns resultados mais relevantes oriundos de estudos do IBGE nos quatro últimos decênios, a partir do inquérito nacional de 1974-75 (IBGE, 1977) e, em seguida, as pesquisas de orçamentos familiares dos anos 80 e 90 e do biênio 2002-2003, referentes às regióes metropolitanas do Norte, Nordeste, Sudeste, Sul e Centro-Oeste, considerando a avaliação em termos de macronutrientes como percentuais do conteúdo calórico. Faz-se, também, um estudo descritivo da composição macro da alimentação 
por estratos de renda. Completa-se o informe com resultados específicos de estudos de amostras pontuais que possam contribuir, ilustrativamente, com o possível detalhamento de aspectos importantes da transição nutricional no país.

Como se observa na Tabela 1, a contribuição relativa dos carboidratos decaiu entre 1974 e 2003 (61,6\% para 55,9\%), ao passo que a participação dos lipídios aumentou de $25,7 \%$ para $30,5 \%$. Em toda a seqüência temporal, a quota de ácidos graxos e de seus subgrupos (monoinsaturados, poliinsaturados e saturados) se manteve comparativamente equilibrada, e na última avaliação (2002-2003) o consumo de ácidos graxos saturados praticamente atingiu o limite ainda tolerado pelos referenciais da alimentação saudável: 9,6\%. Ressalta-se que, durante o período analisado, a contribuição das proteínas ao total energético da alimentação se manteve acima de $12 \%$, alcançando quase $14 \%$ na avaliação de 2002-2003. Ademais, desde 1987-88, a proporção de proteínas de origem animal supera, amplamente, a porção de proteínas vegetais, o que assegura uma boa qualificação em termos de valor biológico.

Observa-se ainda, como aspecto negativo, que a participação do açúcar industrializado (sacarose) no total de calorias da aquisição domiciliar de alimentos ultrapassa em muito, ao longo do período de estudo, o limite de 10\% recomendado pela OMS em seu documento sobre a alimentação saudável (WHO, 2002).

Tabela 1 - Participação relativa de macronutrientes no total de calorias estimado pela aquisição domiciliar de alimentos nas regióes metropolitanas, Brasília e Goiânia, 1974-2003

\begin{tabular}{lcccc}
\hline Macronutrientes & \multicolumn{4}{c}{ Participação relativa (\%) por ano de pesquisa } \\
\hline & $1974-75$ & $1987-88$ & $1995-96$ & $2002-03$ \\
\hline Carboidratos & 61,6 & 58,0 & 57,8 & 55,9 \\
Açúcar (sacarose) & 14,0 & 13,7 & 14,2 & 12,6 \\
Demais carboidratos & 47,6 & 44,3 & 43,6 & 43,3 \\
& & & & 13,6 \\
Proteínas & 12,6 & 12,8 & 13,8 & 7,8 \\
Animais & 6,0 & 7,0 & 8,1 & 5,8 \\
Vegetais & 6,6 & 5,8 & 5,7 & 30,5 \\
& & & & 8,0 \\
Lipídios & 25,8 & 29,2 & $7,8,4$ & 8,9 \\
Ácidos graxos monoinsaturados & 7,4 & 7,9 & 8,7 & 9,6 \\
Ácidos graxos poliinsaturados & 7,7 & 9,5 & 8,8 & 4,0 \\
Ácidos graxos saturados & 7,5 & 8,5 & 3,4 & \\
Outras fontes & 3,2 & 3,3 & & \\
\hline
\end{tabular}

Fontes: IBGE/MP/MS (2004) e Levy-Costa et al. (2005).

Os dados coletados pela Pesquisa de Orçamentos Familiares (POF, 2002-2003) evidenciam que o nível de renda atua como uma fonte importante de variação de demanda potencial de macronutrientes. Assim, a participação dos carboidratos se reduz expressivamente na proporção em que a renda se eleva, decaindo de 69,2\% no nível mais baixo para 52,2\% na faixa mais elevada. A relação entre proteínas animais e vegetais também decai com o aumento da renda, embora a combinação das duas fontes seja adequada em todas as categorias de renda.

Por outro lado, a participação relativa dos lipídios aumenta de forma consistente com a elevação do nível econômico, subindo do patamar de 19,1\% nas famílias com até 1/4 de salário mínimo per capita para 33,9\% no 
grupo constituído por famílias com renda per capita acima de cinco salários mínimos. No que se refere à composição de ácidos graxos, duas observações importantes: no estrato de renda mais alto, o componente de ácidos graxos saturados equivale praticamente ao dobro do consumo per capita familiar do escalão mais baixo de rendimento monetário, ultrapassando, ainda, o limite superior de $10 \%$ recomendado como um dos requisitos da alimentação saudável (Tabela 2).

Tabela 2 - Participação relativa de macronutrientes no total calórico estimado pela aquisição domiciliar de alimentos por classes de rendimento monetário familiar per capita em salários mínimos. Brasil, 2002-2003

\begin{tabular}{|c|c|c|c|c|c|c|}
\hline \multirow[t]{2}{*}{ Macronutrientes } & \multicolumn{6}{|c|}{ Participação relativa (\%) por faixa de renda (salário mínimo) } \\
\hline & Até $1 / 4$ & Mais de $1 / 4$ a $1 / 2$ & Mais de $1 / 2$ a 1 & Mais de 1 a 2 & Mais de 2 a 5 & Mais de 5 \\
\hline Carboidratos & 69,2 & 64,6 & 62,1 & 59,1 & 55,8 & 52,2 \\
\hline Açúcar (sacarose) & 12,9 & 14,1 & 14,8 & 14,5 & 13,2 & 11,1 \\
\hline Demais carboidratos & 56,3 & 50,5 & 47,3 & 44,6 & 42,6 & 41,1 \\
\hline Proteínas & 11,7 & 12,0 & 12,5 & 12,8 & 13,4 & 13,8 \\
\hline Animais & 5,2 & 5,9 & 6,4 & 7,0 & 7,8 & 8,4 \\
\hline Vegetais & 6,5 & 6,1 & 6,1 & 5,8 & 5,6 & 5,4 \\
\hline Lipídios & 19,1 & 23,4 & 25,4 & 28,1 & 30,8 & 34,0 \\
\hline Ácidos graxos monoinsaturados & 4,8 & 6,0 & 6,7 & 7,4 & 8,1 & 8,9 \\
\hline Ácidos graxos poliinsaturados & 6,7 & 8,2 & 8,3 & 9,1 & 9,4 & 9,1 \\
\hline Ácidos graxos saturados & 5,9 & 7,2 & 7,8 & 8,6 & 9,7 & 11,2 \\
\hline Outras fontes & 1,7 & 2,0 & 2,6 & 3,0 & 3,6 & 4,7 \\
\hline
\end{tabular}

Fontes: IBGE/MP/MS (2004) e Levy-Costa et al. (2005).

Na Tabela 3 (página seguinte), construída com base no banco de dados da POF (2002-2003), demonstrase o perfil do consumo potencial de macronutrientes da população brasileira em função dos espaços geográficos (macrorregiōes e localização urbana e rural das famílias).

Observa-se que a demanda calórica a partir de carboidratos acompanha, sistematicamente, a conhecida variação de condições econômicas que caracterizam as regiôes mais pobres (Norte e Nordeste), ou o contraste urbano/rural. De forma singular, destaca-se a elevada contribuição do açúcar (sacarose) na composição calórica do consumo potencial no Nordeste, Sudeste e Centro-Oeste (13,8\% a 15,4\%), bem acima dos referenciais mais recentemente estipulados pelos comitês técnicos (Opas/OMS, 2003).

A disponibilidade familiar de proteínas como representação percentual do total calórico ocorre de forma adequada em todas as regiōes. $\mathrm{O}$ mesmo juízo se aplica à distribuição qualitativa, entre proteínas animais e vegetais, com uma observação particular para a região Norte, onde a disponibilidade domiciliar de proteínas de origem animal apresenta predominância marcante, tanto no meio urbano como no espaço rural.

O estudo do IBGE (2002-2003) explicita mudanças de marcantes significaçóes para o entendimento da transição alimentar e nutricional do país a partir de 1974-75, quando, de fato, se caracteriza este processo no Brasil. Assim, o consumo de carnes, em geral, aumentou em 50\%, contornando uma das referências mais recorrentes dos estudos até a década de 70: a deficiência de proteínas, notadamente de origem animal. Nesse aspecto, destaca-se a disponibilidade de carne de frango na unidade familiar, com um aumento de mais de 100\%, e de 
embutidos (cerca de 300\%). Registra-se ainda o aumento de biscoitos, açúcar e refrigerantes em (400\%), indicando tendência nítida e forte na direção de produtos industrializados. Em contraponto (e em função da mesma lógica), caiu em $30 \%$ a demanda por feijões, outras leguminosas, raízes e tubérculos. Duas notificações são efetivamente positivas: a diminuição do consumo de ovos, em $84 \%$, e de gorduras animais (65\%). Embora aumentando em volume e em diversificação, a disponibilidade de frutas, legumes e verduras ainda denota uma limitação quali e quantitativa do perfil alimentar da população brasileira, não atingindo $3 \%$ do valor calórico total da dieta habitual, quando deveria alcançar $7 \%$.

Tabela 3 - Participação relativa de macronutrientes no total estimado de disponibilidade calórica de famílias brasileiras, segundo macrorregiōes geográficas e situação do domicílio (2002-2003)

\begin{tabular}{|c|c|c|c|c|c|c|c|c|c|c|}
\hline \multirow{2}{*}{ Macronutrientes } & \multicolumn{2}{|c|}{ Norte } & \multicolumn{2}{|c|}{ Nordeste } & \multicolumn{2}{|c|}{ Sudeste } & \multicolumn{2}{|c|}{ Sul } & \multicolumn{2}{|c|}{ Centro-Oeste } \\
\hline & Urb. & Rural & Urb. & Rural & Urb. & Rural & Urb. & Rural & Urb. & Rural \\
\hline Carboidratos & 60,8 & 64,2 & 62,9 & 68,7 & 56,7 & 64,3 & 54,1 & 57,9 & 57,5 & 59,1 \\
\hline Açúcar (sacarose) & 11,3 & 10,7 & 13,8 & 14,0 & 14,3 & 15,4 & 12,5 & 12,5 & 14,1 & 14,2 \\
\hline Demais carboidratos & 49,5 & 53,5 & 49,1 & 54,7 & 42,4 & 48,9 & 41,6 & 45,4 & 43,4 & 44,9 \\
\hline Proteínas & 14,0 & 13,7 & 13,6 & 12,0 & 12,3 & 10,9 & 13,8 & 14,8 & 12,0 & 11,2 \\
\hline Animais & 8,8 & 9,6 & 7,3 & 5,2 & 6,7 & 4,2 & 8,2 & 8,6 & 6,6 & 6,0 \\
\hline Vegetais & 5,2 & 4,1 & 6,3 & 6,8 & 5,6 & 6,7 & 5,6 & 6,2 & 5,4 & 5,1 \\
\hline Lipídios & 25,2 & 22,1 & 23,5 & 19,3 & 31,0 & 24,8 & 32,1 & 27,3 & 30,5 & 29,7 \\
\hline \multicolumn{11}{|l|}{ Ácidos graxos } \\
\hline monoinsaturados & 6,7 & 5,2 & 6,1 & 4,8 & 8,1 & 6,5 & 8,6 & 8,3 & 7,9 & 7,7 \\
\hline \multicolumn{11}{|l|}{ Ácidos graxos } \\
\hline poliinsaturados & 7,7 & 6,7 & 7,0 & 6,8 & 9,9 & 9,2 & 9,5 & 5,8 & 11,4 & 11,2 \\
\hline \multicolumn{11}{|l|}{ Ácidos graxos } \\
\hline saturados & 8,1 & 8,3 & 7,4 & 6,1 & 9,5 & 8,2 & 10,0 & 9,7 & 8,5 & 9,1 \\
\hline Outras fontes & 2,7 & 1,9 & 3,0 & 1,6 & 3,5 & 0,9 & 4,0 & 3,5 & 2,7 & 1,7 \\
\hline
\end{tabular}

Fontes: IBGE/MP/MS (2004) e Levy-Costa et al. (2005).

Por outro lado, embora a tendência francamente dominante nas POF seja indicativa de demanda elevada de açúcar, proteínas animais, gorduras e, entre estas, de ácidos graxos saturados, caracterizando o modelo ocidental de alimentação, na realidade o Brasil convive ainda com sérios problemas de deficiências nutricionais.

Estudos em centros metropolitanos, em populações urbanas e rurais da Bahia, em aglomerações urbanas, como Ouro Preto, Salvador e Campinas, ou, ainda, inquéritos representativos de um estudo no estado de Pernambuco demonstram a persistência de deficiências nutricionais específicas, como as de cálcio, niacina, ferro biodisponível e equivalentes de vitamina A. Coloca-se também, em uma perspectiva ainda hipotética, já sustentada por evidências consistentes, a possível deficiência de folatos e de zinco (Silva, 2005; Assis, 2000), o que diversifica o espectro de carências específicas de micronutrientes que, em anos recentes, passaram a predominar, no cenário epidemiológico, como uma das manifestaçôes da própria transição nutricional.

Essas observações e análises põem em relevo, no caso do Brasil e de outros países, a coexistência de dois modelos aparentemente conflitivos: os excessos nutricionais e inadequações alimentares, por um lado, e a 
persistência ou até mesmo o agravamento de situaçôes carenciais, por outro. Nesse contexto de dupla polarização, ficam justificadas as demandas por novos estudos e novas medidas para enfrentar as questôes emergentes que se apresentam, ao lado de velhos problemas que ainda não foram equacionados.

\section{Considerações Finais}

Embora, por dever de ofício, devamos colocar os aspectos epidemiológicos da transição nutricional em primeiro plano, sua natureza, conseqüências e projeções devem ser contextualizadas em um domínio mais amplo e estrutural: o da própria transição de padrões e estilos de vida que as geraçôes mais recentes estão experimentando. Constitui, ao mesmo tempo, um mal e um bem da civilização moderna, que mudou radicalmente, embora de forma diferenciada, num breve período, o sentido do tempo, do espaço - qual o novo pensamento geográfico?, pergunta Moreira (2006), sem fechar sua resposta - e, logicamente, o próprio homem. A transição epidemiológica e sua versão específica no campo da nutrição representam um efeito (e um pouco de causa) dessa nova e surpreendente situação. Assim, o progresso científico e tecnológico e sua difusão pelos caminhos dos mercados globalizados produziram excedentes de produção (inclusive de alimentos), migrações maciças do campo para a cidade, transferência radical de ocupações (do setor primário para o secundário e para o terciário), com poupança e substituição progressiva do trabalho físico para a produção de bens e serviços mediados por engenhos mecânicos ou eletrônicos. A vacinação, os antibióticos, a eficácia terapêutica no tratamento de muitas doenças, o saneamento ambiental, a difusão de conhecimentos sanitários e a universalização de medidas básicas de saúde minimizaram a ocorrência ou o desenlace mortal de muitas doenças. O próprio controle da natalidade banalizou-se, como prática generalizada. Além disso, a redução da atividade física, levando o homem para demandas fisiológicas próximas ao metabolismo basal, e o uso crescente de alimentos industrializados em substituição aos produtos em estado natural representam uma inflexão radical no perfil qualitativo da dieta na modernidade. E aqui surge o boom do açúcar, dos fast-foods, dos embutidos, das gorduras, dos aditivos.

Nos últimos sessenta anos, as necessidades médias de energia alimentar da população foram reduzidas de 2.800 para duas mil calorias. Neste período, o chamado metabolismo de trabalho (1.600 calorias em média) ultrapassava em $133 \%$ a taxa do metabolismo basal. Atualmente, a relação entre os dois valores é de 66\%, ou seja, a metade. Ao mesmo tempo que reduziram as demandas, por conta do sedentarismo, uma das marcas da modernidade, aumentou-se a oferta física de alimentos, baixaram-se os preços e estimulou-se o consumo de alimentos industrializados, mediante recursos de marketing que incluem atrativos organolépticos artificialmente incorporados a esses produtos. Nessa linha figuram o açúcar, o sal e as gorduras, ao lado de aditivos que alteram a cor, o odor, a textura e outros atributos dos alimentos. Na observação muito perspicaz de um analista, durante milhares de anos o homem viveu à procura dos alimentos; nos últimos quatro ou cinco anos, os alimentos 'procuram' o homem, em razão da lógica dominante dos mercados globalizados. É uma situação inteiramente nova. Em grande parte, a transição nutricional, com suas variantes mais características, representa a passagem para o modelo dos estilos de vida do mercado capitalista do Ocidente. $\mathrm{O}$ caso japonês oferece uma lição muito ilustrativa. Em 1980, quando os hábitos e estilos de vida dos japoneses ainda eram peculiares de sua cultura, a prevalência de diabetes do tipo 2 no país era de cerca de 3\% em pessoas de 40 anos. No mesmo tempo, os japoneses de 45 a 74 anos que haviam migrado para a cidade de Seatle, nos Estados Unidos, apresentavam uma prevalência dessa doença cinco a seis vezes maior, atingindo quase $20 \%$ entre os homens e mais de $16 \%$ entre as mulheres. Resultados semelhantes aos encontrados em Seatle foram obtidos em descendentes nipo-brasileiros radicados em Bauru, no estado de São Paulo (Hirai et al., 2004), o que demonstra os efeitos cruciais da ocidentalização de hábitos coletivos no processo saúde-doença. 
É oportuno registrar que a diminuição da obesidade em duas observações seqüenciais (1996 e 2002-2003) em mulheres no Sudeste e na avaliação mais recente (2002-2003) no Nordeste do Brasil pode configurar o início da “compressão de morbidade" proposta por Fries (1983, 2000), como caracterização de um quarto estágio da transição epidemiológica. Pode-se esperar que o processo ocorra em outras regiōes do Brasil e, brevemente, no grupo masculino da população adulta, no qual o problema continua em franca ascensão.

Uma referência final, mais explicativa que propriamente analítica, como conviria a um capítulo de discussão. Em sua compreensão convencional, o estudo da transição nutricional descreve e analisa a simples passagem de um modelo de situação epidemiológica representado pela DEP para um novo cenário dominado pelo sobrepeso e pela obesidade, como imagem mais representativa. Em torno desses pólos, gravitam as co-morbidades que caracterizam os respectivos padróes epidemiológicos.

No entanto, aqui, para tratar do caso brasileiro, consideramos pertinente abordar outros problemas e outros aspectos que, em nossa visão, podem e devem ser compreendidos no campo do processo transicional. Não se podem deixar de lado, por exemplo, as evidências, ainda muito limitadas mas já bem consistentes, da rápida substituição do BPN por Crescimento Intra-Uterino Restrito (CIUR) originado pela prematuridade. Além da configuração de uma mudança crucial nesses indicadores, materializa-se uma condição que redunda na dupla face da mortalidade infantil precoce e, mais tardiamente, na própria precocidade na instalação de DCNT próprias da idade adulta e da longevidade (Barker \& Martyn, 1992; Alves \& Figueira, 1998). Seriam dois modelos em posiçóes opostas do ciclo vital, agora conectados por uma linha comum. Do mesmo modo, pode-se enfocar a ocorrência das anemias. A rapidez de sua progressão, em um contexto em que os fatores de risco deveriam, em princípio, estar desaparecendo ou sendo atenuados, logicamente demanda hipóteses de que novos condicionantes passaram a atuar, no processo alimentar/nutricional recente. Ou, mais do que apenas recente: moderno ou pósmoderno. A estreita colinearidade entre a prevalência de sobrepeso/obesidade no Brasil e a ocorrência de anemia não pode passar despercebida da agenda da transição nutricional, ainda que uma condição (anemia) e a outra (sobrepeso/obesidade) apareçam em hospedeiros diferentes - crianças no primeiro caso e mulheres em idade reprodutiva, na segunda condição.

\section{Nota}

* Agradecemos a Teresa Cristina Miglioli pelas valiosas contribuições e revisões críticas de todas as versões deste capítulo.

\section{Referências}

ALVES, J. G. B. \& FIGUEIRA, F. Doenças do Adulto com Raizes na Infância. Recife: Bagaço, 1998.

ASSIS, A. M. O. et al. Condições de Vida, Saúde e Nutrição na Infância em Salvador. Salvador: Escola de Nutrição/ Instituto de Saúde Coletiva, Universidade Federal da Bahia, 2000.

BARKER, D. J. \& MARTYN, C. N. Review: maternal and fetal origins of cardiovascular disease. In: BARKER, D. J. (Ed.) Fetal and Infant Origins of Adult Disease. London: BMJ Books, 1992.

BARRETO, M. L. \& CARMO, E. H. Mudanças em padrões de morbimortalidade: conceitos e métodos. In: MONTEIRO, C. A. (Org.) Velhos e Novos Males da Saúde no Brasil. 2. ed. São Paulo: Hucitec, 2000.

BATISTA FILHO, M. \& RISSIN, A. A transição nutricional no Brasil: tendências regionais e temporais. Cadernos de Saúde Pública, 19, supl. 1: 181-191, 2003.

CASTRO, J. de. Geografia da Fome. 11. ed. Rio de Janeiro: Griphus, 1992. 
FREDERIKSEN, H. Feedbacks I economic and demographic transition. Science, 166: 837-847, 1969.

FRIES, J. F. The compression of morbidity. Health and Society, 61(3): 397-419, 1983.

FRIES, J. F. Compression of morbidity in the elderly. Vaccine, 18: 1.584-1.589, 2000.

FUNDO DAS NAÇÕES UNIDAS PARA A INFÂNCIA (UNICEF). Declaração Mundial sobre a Sobrevivência, a Proteção e Desenvolvimento da Criança. Nova York: Unicef, 1990.

GUIMARÃES, T. M. R. Avaliação de Resultados do PSF em Olinda na Saúde Infantil: um estudo de série temporal, 1990-2002, 2004. Dissertação de Mestrado, Recife: Instituto Materno Infantil de Pernambuco.

HIRAI, A. et al. Diabetes Mellitus e Doenças Associadas em Nipo-Brasileiros. São Paulo: Green Forest do Brasil, 2004 .

INSTITUTO BRASILEIRO DE GEOGRAFIA E ESTATÍSTICA (IBGE). Endef(Estudo Nacional de Despesas Familiares): resultados preliminares. Brasília: IBGE, 1977.

INSTITUTO BRASILEIRO DE GEOGRAFIA E ESTATÍSTICA (IBGE). Pesquisa de Orçamentos Familiares no Brasil, 2002/2003: antropometria e análise do estado nutricional de crianças e adolescentes no Brasil. Rio de Janeiro: IBGE, 2006.

INSTITUTO BRASILEIRO DE GEOGRAFIA E ESTATÍSTICA (IBGE)/MINISTÉRIO DO PLANEJAMENTO (MP)/MINISTÉRIO DA SAÚDE (MS). Pesquisa de Orçamentos Familiares, 2002-2003: análise da disponibilidade domiciliar de alimentos e do estado nutricional no Brasil. Rio de Janeiro: IBGE, 2004.

INTERDEPARTMENTAL COMMITTEE ON NUTRITION FOR NATIONAL DEFENSE (ICNND). Northeast Brazil, Nutrition Survey, March/May, 1963. Washington: ICNND, 1965.

KAC, G. \& VELÁSQUEZ-MELÉNDEZ, J. G. A transição nutricional e a epidemiologia da obesidade na América Latina. Cadernos de Saúde Pública, 19, supl. 1: S4-S5, 2003.

LEVY-COSTA, R. B. et al. Disponibilidade domiciliar de alimentos no Brasil: distribuição e evolução (19742003). Revista Saúde Pública, 39: 530-540, 2005.

LUCENA, M. A. F. Estudo Antropométrico Comparativo de Crianças de 1 a 60 meses em Duas Cidades do Nordeste: Recife (PE) e São Luis (MA), 1975. Dissertação de Mestrado, Recife: Departamento de Nutrição, Universidade Federal de Pernambuco.

MALTHUS, T. R. An Essay on the Principle of Population (1798). Reprint. Oxford: University Press, 1999.

MINISTÉRIO DA SAÚDE. Disponível em: <http://dtr2004.saude.gov.br/nutricao//bs_2/documentos/ nota_bolsa_familia.pdf>, atualizada em 16 jan. 2006. Acesso em: 16 out. 2006.

MOREIRA, R. Para Onde Vai o Pensamento Geográfico? Por uma epistemologia crítica. São Paulo: Contexto, 2006.

OLSHANSKI, S. J. \& AULT, A. B. The fourth stage of the epidemiologic transition: the age of delayed degenerative diseases. Milbank Memorial Fundation Quartely, 64(3): 355-391, 1986.

OMRAN, A. R. The epidemiologic transition: a theory of the epidemiology of population change. Milbank Memorial Fundation Quarterly, 49: 509-538, 1971.

ORGANIZAÇÃO PAN-AMERICANA DA SAÚDE (OPAS)/ORGANIZAÇÃO MUNDIAL DA SAÚDE (OMS). Doenças crônico-degenerativas e obesidade: estratégia mundial sobre alimentação saudável, atividade física e saúde. Brasília, 2003. Disponível em: <http://www.opas.org.br/sistema/arquivos/ d_cronic.pdf >. Acesso em: out. 2006. 
POPKIN, B. M. Nutritional patterns and transition. Population and Development Review, 19: 138-157, 1993.

RIBOLI, E. \& NORAT, T. Epidemiologic evidence of the protective effect of fruit and vegetables on cancer risk. American Journal of Clinical Nutrition, 78, suppl. 3: S559-S569, 2003.

SANDHI, M. B. et al. Análise da estratégia global para alimentação, atividade física e saúde, da Organização Mundial da Saúde. Epidemiologia e Serviços de Saúde, 14(1): 41-68, 2005.

SANTOS, L. M. P. (Org.) Bibliografia sobre a Deficiência de Micronutrientes no Brasil: 1990-2000. Brasília: Opas, 2002. v. 2.

SARAIVA, L. Estudo do Coração de Crianças Desnutridas com Edema: aspectos clínicos, eletrocardiográficos e ecográficos, 1990. Dissertação de Mestrado, Recife: Departamento de Nutrição, Universidade Federal de Pernambuco.

SILVA, S. C. L. \& BATISTA FILHO, M. Anemia em Mães e Filhos no Estado e Pernambuco. Recife: Instituto Materno Infantil Prof. Fernando Figueira (Imip), 2005. (Publicações Científicas, 9)

SILVA, P. S. Estado Nutricional de Zinco em Crianças Pré-Escolares de Creches Públicas da Cidade do Recife, 2005. Dissertação de Mestrado, Recife: Departamento de Nutrição, Universidade Federal de Pernambuco.

WORLD HEALTH ORGANIZATION (WHO). World Health Report 2002: reducing risks, promoting healthy life. Geneva: Who, 2002.

WORLD HEALTH ORGANIZATION (WHO). Global strategy on diet, physical activity and health. Food and Nutrition Bulletin, 25(3): 292-302, 2004. 


\title{
26
}

\section{Epidemiologia da Atividade Física}

\author{
Pedro Curi Hallal e Luiz Antonio dos Anjos
}

\section{Conceitos e Definições na Área de Atividade Física}

Embora a noção de que o exercício físico está relacionado com a saúde exista há muito tempo, os estudos científicos sobre a associação entre atividade física e saúde foram iniciados na década de 1950, com a pesquisa de Jerry Morris e colaboradores na Inglaterra (Morris et al., 1953), que observou que o risco de doença coronariana em condutores de ônibus era maior do que o dos cobradores, os quais, pelas características dos ônibus ingleses de dois andares, precisavam ficar se movimentando constantemente, subindo e descendo escadas. Desde então, um forte corpo de evidências foi se solidificando e confirmando o importante papel exercido pela atividade física sobre a saúde (Caspersen, 1989; U.S. Department of Health and Human Services, 1996).

Tendo em vista que a terminologia utilizada na área muitas vezes se revela inconsistente, é fundamental definir os conceitos a serem utilizados ao longo deste capítulo. Atividade física pode ser entendida como qualquer movimento produzido pela contração da musculatura esquelética que resulte em dispêndio de energia. O exercício físico, por sua vez, é uma atividade física planejada, estruturada, repetitiva que objetiva o desenvolvimento de algum componente da aptidão física. Assim, de acordo com essas definições (Caspersen, Powell \& Christensen, 1985), o exercício físico é apenas um subgrupo da atividade física. Em outras palavras, todo exercício físico é uma atividade física, mas nem toda atividade física se constitui em um exercício físico. Já a aptidão física pode ser entendida como um conjunto de atributos que um indivíduo apresenta e que lhe confere a capacidade de realizar as atividades cotidianas sem fadiga excessiva.

$\mathrm{Na}$ pesquisa em atividade física e saúde, é freqüente a utilização de termos que indiquem baixos níveis de atividade física. $\mathrm{O}$ termo sedentarismo é um dos mais empregados. Alguns autores utilizam ainda termos como atividade física insuficiente para obtenção de benefícios à saúde, inatividade física, atividade física irregular, entre outros. Embora existam várias propostas de padronização e diferenciação desses termos, não há até o presente momento consenso na literatura especializada sobre a terminologia utilizada para indicar sedentarismo. Isso se deve, em parte, à dificuldade em medir, de forma precisa, todos os domínios da atividade física (atividades ocupacionais, serviços domésticos, atividades de deslocamento, de lazer).

A recomendação hegemônica atual para a prevenção de doenças na população mundial divulgada por organizações internacionais sugere que os indivíduos devem acumular pelo menos trinta minutos de atividade física de intensidade moderada na maioria, preferencialmente todos os dias da semana. Essa recomendação teve 
origem na proposta feita pelo Colégio Americano de Medicina Esportiva (ACSM) e pelo Centro de Controle e Prevenção de Doenças (CDC) dos Estados Unidos no meio da década passada (Pate et al., 1995). Atividade moderada foi definida como a que faz com que se gaste em torno de $200 \mathrm{kcal}$ em trinta minutos, o equivalente a uma caminhada de 4,8 a $6,4 \mathrm{~km} / \mathrm{h}$. Seguindo esse modelo, usa-se com freqüência o ponto de corte de 150 minutos por semana de atividades moderadas como critério para indicar o indivíduo sedentário. As recomendaçôes ainda indicam que no caso de atividade física intensa, um mínimo de vinte minutos, três vezes por semana, pode ser suficiente para a obtenção de benefícios à saúde. A ênfase por atividades moderadas baseou-se, em parte, na idéia de que a maioria dos americanos simplesmente não manteria atividades intensas que os fizesse suar ou aumentar consideravelmente a respiração (Erlichman, Kerbey \& James, 2002a).

A recomendação atual pode ser adequada para a prevenção de várias doenças crônicas na população em geral, mas provavelmente não se aplica a todos os objetivos das pessoas que praticam atividade física. A dose de atividade física necessária para diminuir o risco de infarto agudo do miocárdio pode ser bastante diferente daquela necessária para melhorar a saúde mental, por exemplo. Recomendações recentes também indicam que a dose de atividade física necessária para atingir as recomendaçôes atuais pode não ser suficiente para criar déficit energético e, conseqüentemente, perda de peso corporal. Para esse fim, serão necessárias intensidades ou durações maiores (Jakicic et al., 2001; IOM, 2002; Erlichman, Kerbey \& James, 2002b; Serdula, Khan \& Dietz, 2003; FAO/ WHO/UNU, 2004). Para crianças e adolescentes, a recomendação é de que se deva realizar pelo menos uma hora por dia de atividade física de intensidade moderada a intensa (Strong et al., 2005).

\section{O Papel da Atividade Física na Prevenção e Tratamento de Doenças}

Logo após o estudo pioneiro de Morris e colaboradores (1966), outros pesquisadores iniciaram pesquisas sobre a relação entre atividade física e saúde. Os estudos do prof. Ralph Paffenbarger entre ex-alunos da Universidade de Harvard reforçaram o conhecimento científico de que a atividade física pode, além de auxiliar na prevenção de doenças coronarianas, exercer efeito sobre outras enfermidades (Paffenbarger et al., 1986, 1993). Em 1990, metanálise publicada por Berlin e Colditz reuniu toda a literatura disponível até então e concluiu que indivíduos ativos apresentavam risco menor de desenvolver doenças coronarianas em comparação com os sedentários (Berlin \& Colditz, 1990).

Em 1995, uma publicação histórica resumiu o conhecimento acumulado até aquele momento sobre os efeitos da atividade física na prevenção de doenças. O autor classificou como "conclusivas" as evidências que associavam a prática de atividade física com um risco reduzido de doença cardíaca coronariana, hipertensão arterial, doença renal, diabetes tipo 2, osteoporose, câncer de cólon e mama, depressão, ansiedade, entre outras. Para alguns desfechos, como, por exemplo, reumatismo, doença pulmonar obstrutiva crônica, entre outras, as evidências foram consideradas pelo autor como "sugestivas" até aquele momento, ao passo que para outros (dores lombares, função imunológica e outras), as evidências foram classificadas como "insuficientes" (Shepard, 1995).

Outro marco definitivo foi a publicação do livro Atividade Física e Saúde pelo CDC (U.S. Department of Health and Human Services, 1996), que revisou e analisou toda a literatura na área até então, fornecendo a base técnico-científica para as recomendações populacionais sobre a prática de atividade física. Uma das principais mensagens dessa publicação é que a atividade física não precisa ter intensidade alta para trazer benefícios à saúde; atividades físicas de intensidade moderada são igualmente importantes. Além disso, fica claro que os maiores benefícios são atingidos quando uma pessoa sedentária torna-se moderadamente ativa, o que torna fundamental o estímulo à atividade física para indivíduos sedentários. Em idosos, a capacidade de viver com independência é claramente maior entre os fisicamente ativos. 
Recentemente, Hallal e colaboradores (2006a) propuseram um modelo conceitual das formas como a atividade física pode se associar com morbidade e mortalidade ao longo da vida (Figura 1). Os autores demonstram que a atividade física na infância ou adolescência pode exercer, além de um efeito direto sobre a morbidade na própria adolescência, um efeito direto sobre a morbi-mortalidade na idade adulta, e também um efeito indireto, mediado pelo nível de atividade física em adultos. Isso se deve ao acúmulo de evidências indicando que jovens fisicamente ativos têm maior probabilidade de serem adultos ativos. Os autores demonstram ainda que a prática de atividade física na adolescência pode auxiliar tanto na prevenção quanto no tratamento de várias morbidades, exercendo inclusive um efeito protetor duradouro contra osteoporose na idade adulta. Outro aspecto discutido na publicação é que a quantidade e a intensidade de atividade física necessárias para cada objetivo podem variar dependendo do desfecho em questão (Hallal et al., 2006a).

Figura 1 - Modelo conceitual dos possíveis efeitos diretos (A-D) e indiretos (E-I) da atividade física na adolescência na saúde de adolescentes e adultos

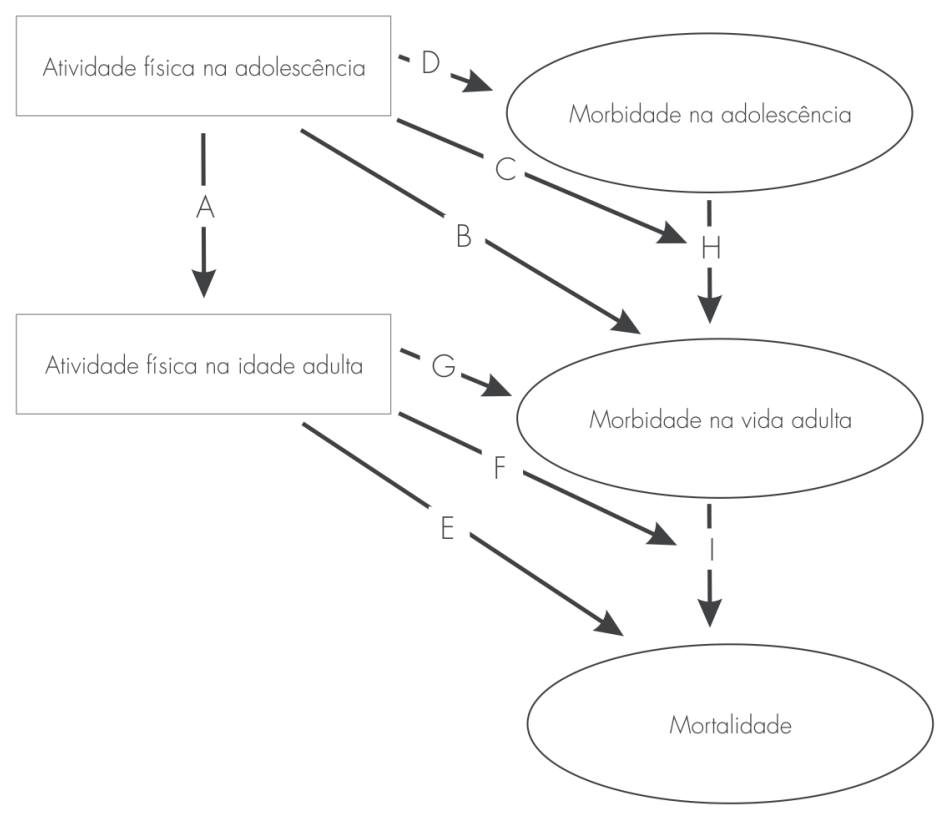

Fonte: adaptada de Hallal et al. (2006a).

Entretanto, alguns pontos polêmicos devem ser discutidos quando se fala em atividade física e saúde. Uma primeira pergunta que freqüentemente surge é: os benefícios da prática de atividade física para a saúde têm duração por longos períodos? Uma variação dessa pergunta é: uma pessoa fisicamente ativa na adolescência, mas que parou de se exercitar na idade adulta, tem menor risco de desenvolver uma doença crônica em comparação a outro indivíduo que sempre foi sedentário? Infelizmente, as evidências indicam que pessoas ativas na adolescência, mas que se transformaram em sedentárias na idade adulta, têm um risco de desenvolver doença coronariana similar ao de pessoas que eram sedentárias na adolescência e na idade adulta. No entanto, essa pergunta pode ter respostas diferentes dependendo da morbidade em questão. Por exemplo, existe um consistente corpo de evidências indicando que a atividade física na adolescência exerce um efeito de longo prazo sobre o risco de osteoporose (Kohrt et al., 2004).

Além do papel preventivo, a atividade física também é recomendada como agente terapêutico para várias enfermidades crônicas. Por exemplo, as organizaçōes responsáveis pelo tratamento do diabetes sempre incluem a atividade física como uma das intervençōes centrais para o tratamento da morbidade. Ensaios clínicos randomizados 
mostram que o exercício físico é tão eficaz quanto mudanças na dieta para o tratamento do diabetes (Pan et al., 1997; Orchard et al., 2005).

No que se refere à hipertensão arterial, as recomendações atuais também indicam que a prática de atividade física é fundamental no tratamento da morbidade (The Sixth Report of the Joint National Committee on Prevention, Detection and Treatment of High Blood Pressure, 1997). A literatura mostra ainda que a atividade física pode tanto prevenir quanto adiar o aparecimento de hipertensão arterial (U.S. Department of Health and Human Services, 1996).

Outras doenças também podem incluir a prática de atividade física no seu tratamento. $\mathrm{Na}$ asma, por exemplo, a prática de atividades aquáticas é recomendada no tratamento (Rosimini, 2003). Na área da saúde mental, são cada vez mais freqüentes os estudos que mostram a eficácia da inclusão da prática de atividades físicas no tratamento de morbidades psiquiátricas (Ekeland et al., 2004).

\section{Níveis Populacionais de Atividade Física}

A evolução da produção científica na área de atividade física e saúde é notória no Brasil. Em 1990, um estudo que avaliou a ocorrência de diversos fatores de risco para doenças crônicas forneceu a primeira estimativa da prevalência de sedentarismo em uma amostra de adultos brasileiros (Rego et al., 1990). Nos anos seguintes, vários inquéritos auxiliaram no diagnóstico da situação brasileira quanto aos níveis de atividade física.

$\mathrm{Na}$ Pesquisa sobre Padrões de Vida (PPV) realizada em 1997 em amostra probabilística da população do Nordeste e Sudeste brasileiros, somente $20 \%$ da população indicaram a prática de exercício físico ou esporte, havendo um grande diferencial entre homens $(27,3 \%)$ e mulheres $(13,1 \%)$, nas duas regióes e diversas faixas etárias (Anjos, 2006). Deve-se ressaltar que esses dados são baseados em uma pergunta simples: "O(A) Sr.(a) pratica exercício físico/esporte todas as semanas?”, ou seja, a avaliação é de apenas um dos domínios da atividade física - a atividade física de lazer. Os resultados mostraram que o grupo etário mais ativo foi o de 10 a 15 anos de vida tanto para homens quanto para mulheres (Figura 2), que apresenta uma dramática redução após os 20 anos de idade, com os níveis se mantendo em toda a vida adulta.

Figura 2 - Prevalência (\%) de prática de esportes ou exercício físico em função da idade e sexo, avaliada na Pesquisa sobre Padrōes de Vida (PPV). Brasil (Nordeste e Sudeste), 1997

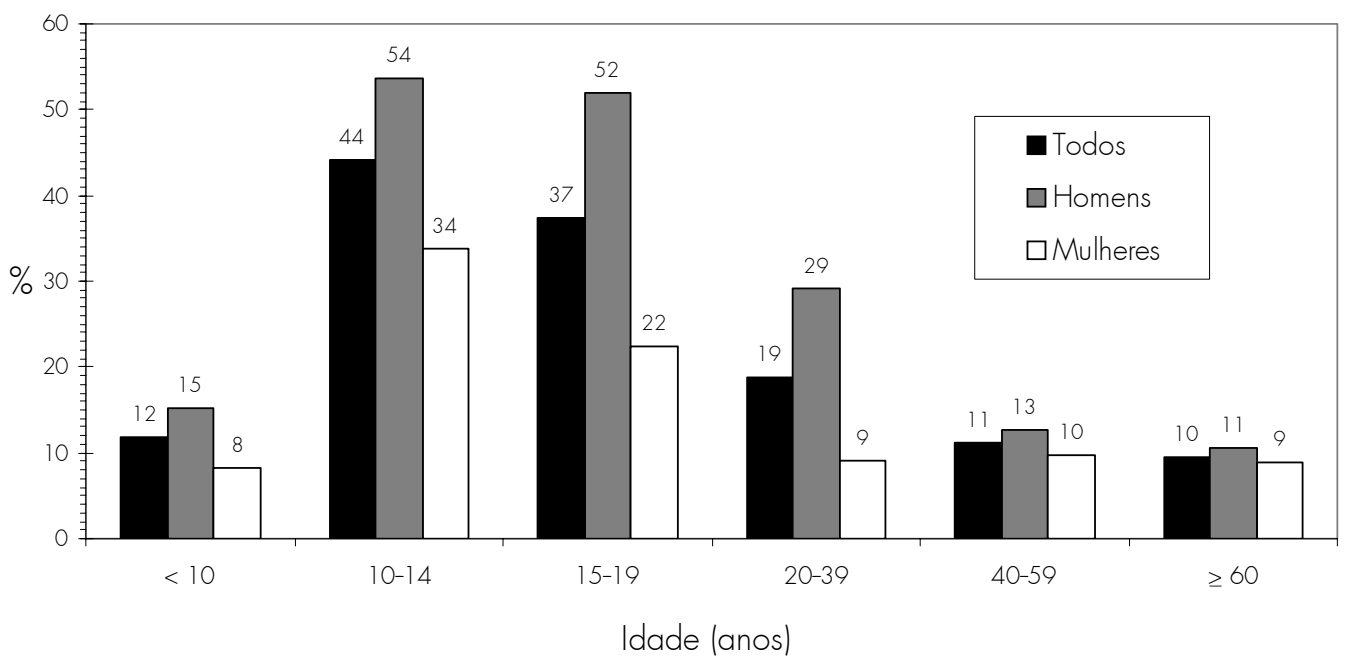

Fonte: reproduzida de Anjos (2006). 
Entre as práticas esportivas ou exercícios físicos relatados, destacam-se os esportes coletivos (futebol, vôlei, basquete) para os indivíduos mais jovens, principalmente homens, e a caminhada para os adultos e idosos (Figura 3). Em geral, o padrão é semelhante na população das duas regiōes, sendo os esportes coletivos e as corridas praticados mais freqüentemente pelos homens jovens e as caminhadas e o ciclismo pelas mulheres, independentemente da idade. Fica evidente o papel da caminhada como forma de atividade física praticada pelos indivíduos adultos, particularmente após os 40 anos de vida.

Figura 3 - Prevalência (\%) de prática de esportes ou exercício físico, por modalidade, em função da idade e sexo, avaliada na Pesquisa sobre Padrões de Vida (PPV). Brasil (Nordeste, NE e Sudeste, SE), 1997

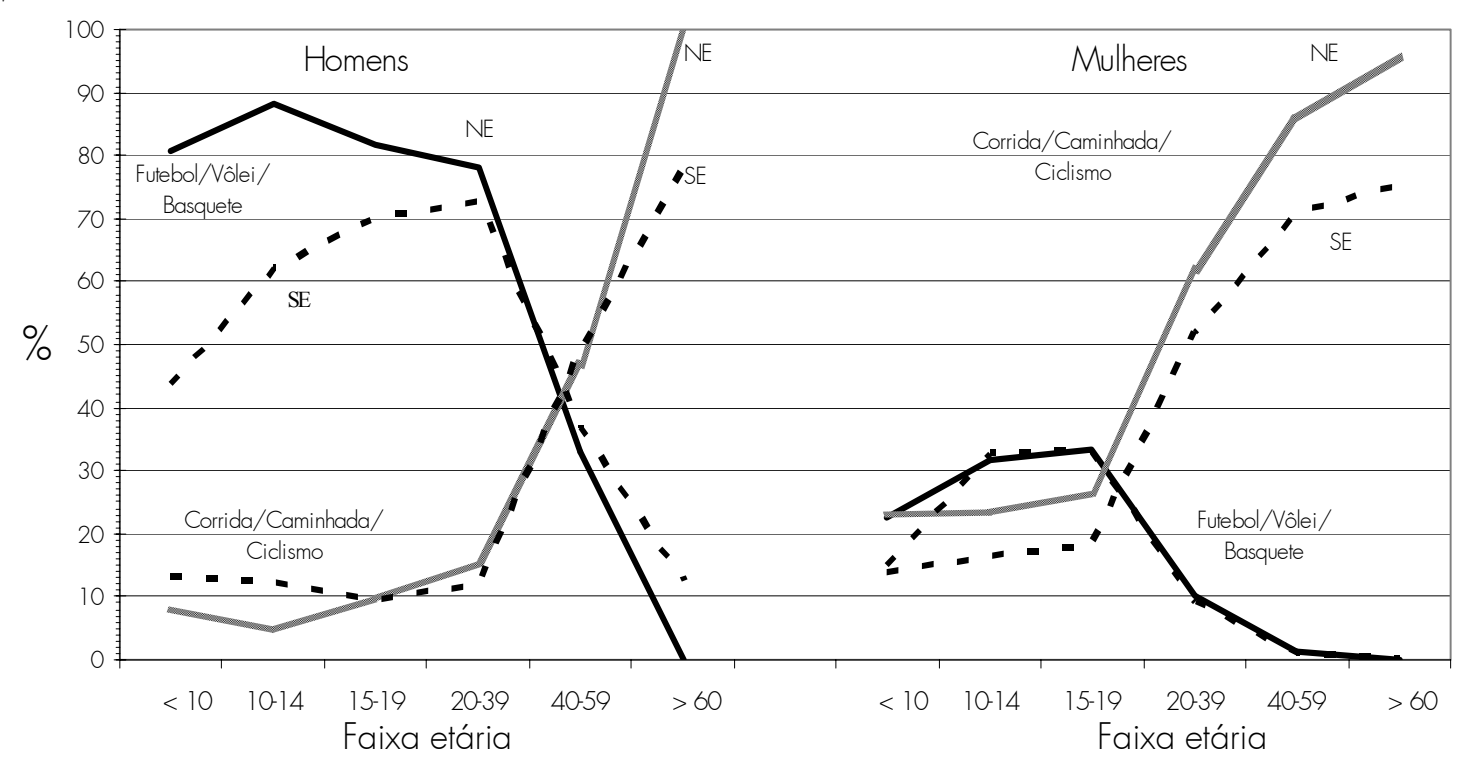

Fonte: reproduzida de Anjos (2006).

$\mathrm{Na}$ PPV, apenas 42,3\% das pessoas relataram ter ocupação, informação que foi usada para classificar, segundo o Código Brasileiro de Ocupações, o Nível de Atividade Física Ocupacional (Nafo) em três níveis: leve, moderado e pesado (Ribeiro, 1994). Dos que afirmaram ter ocupação, 29\% tinham Nafo leve e 23,6\%, Nafo pesado. As mulheres tinham mais Nafo leve (homens = 22,1 e mulheres $=40,5 \%$ ), e os homens mais Nafo pesado (homens $=30,5$ e mulheres $=12 \%$ ). A diferença mais importante entre regiōes foi para o Nafo pesado em mulheres (Nordeste $=36,1$ e Sudeste $=5,6 \%$ ). Entre as pessoas que não praticavam esportes ou exercício físico, $23 \%$ e $49,3 \%$ tinham Nafo pesado e moderado, respectivamente.

Assim, se forem somados os indivíduos com Nafo moderado e pesado aos que praticavam exercício físico, o total de ativos sobe para 44,2\% (Anjos, 1999). Apesar da limitação na pergunta sobre a prática de esportes ou exercício físico, a PPV foi a primeira pesquisa de base populacional em regiōes brasileiras que obteve tal informação.

Dados mais recentes, obtidos no Inquérito Domiciliar sobre Comportamentos de Risco e Morbidade Referida de Doenças e Agravos Não Transmissíveis, realizado pelo Instituto Nacional de Câncer (Inca) em amostra da população de 15 capitais e do Distrito Federal, em 2004 (Inca, 2004), indicam uma média de indivíduos com idade entre 15 e 69 anos insuficientemente ativos (prática de atividade física inferior a 150 minutos por semana) da ordem de 37\% (Figura 4), com variação expressiva entre as capitais, sendo João Pessoa a capital com menor população ativa (45\%), e Belém com a mais ativa (72\%). 
Figura 4 - Percentual de indivíduos com idade entre 15 e 69 anos insuficientemente ativos (sedentários + irregularmente ativos) por capital avaliada (mais Distrito Federal) no Inquérito Domiciliar sobre Comportamentos de Risco e Morbidade Referida de Doenças e Agravos Não Transmissíveis, Instituto Nacional de Câncer, em 2004

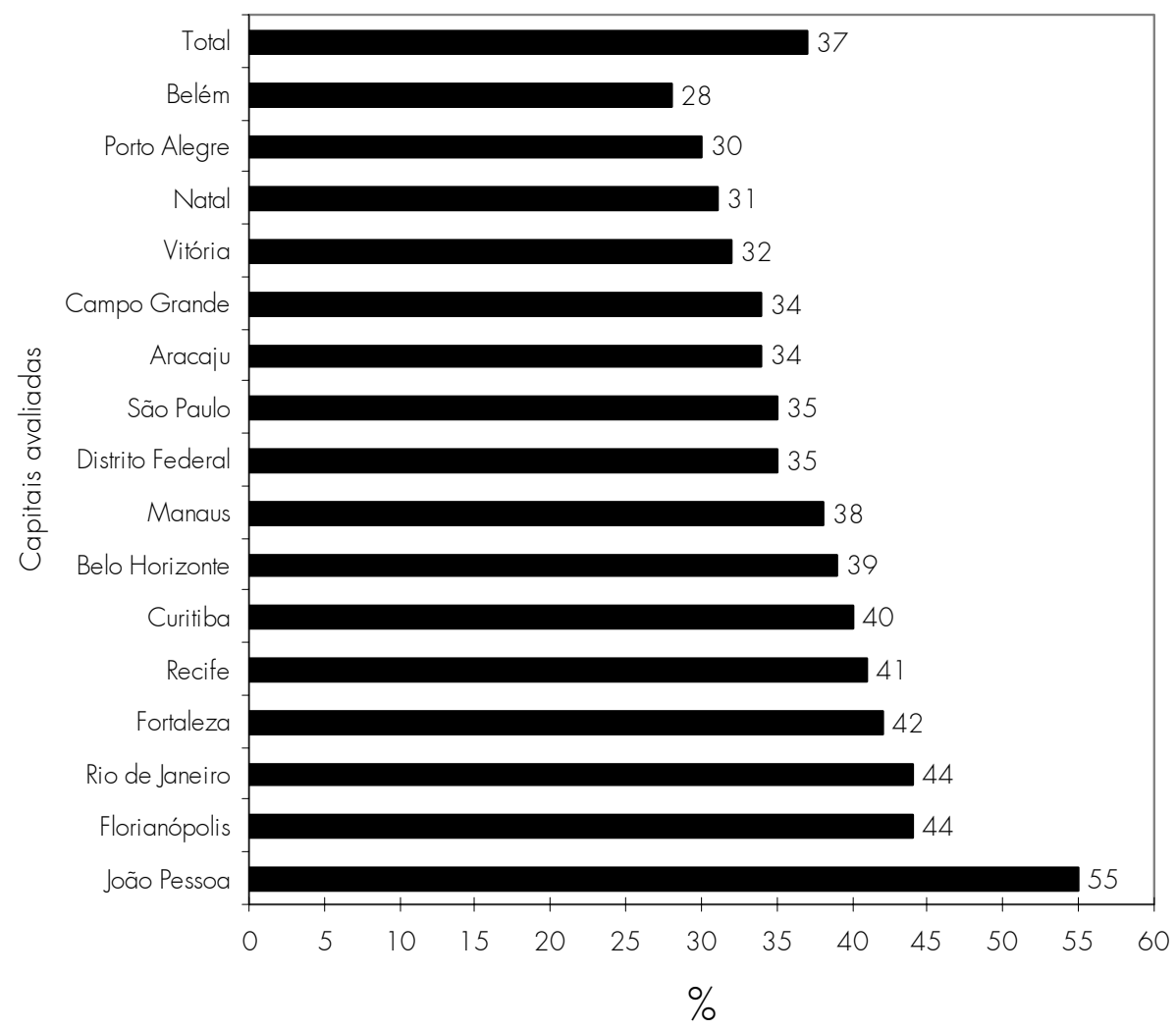

Fonte: reproduzida de Anjos (2006).

Os dados da pesquisa do Inca foram obtidos usando-se o Questionário Internacional sobre Atividade Física (Ipaq), com o qual se procura obter informações sobre todos os domínios da atividade física (lazer, trabalho, transporte, deslocamentos). Em países ainda em desenvolvimento, não só a atividade física laboral como também as atividades dos outros domínios, particularmente a associada ao transporte, ganham contornos importantes por poderem contribuir no total de atividade diária da população. No Brasil, deve-se atentar para esse fato, mas não existem dados disponíveis sobre o padrão de uso de meios de transporte na população em geral. Um dado importante diz respeito à posse de veículos automotores nos domicílios. Nos EUA, apenas 5\% dos domicílios 'não' têm automóveis, ao passo que os dados do mais recente censo demográfico brasileiro indicam que os residentes de apenas 32,7\% dos domicílios brasileiros possuíam automóveis: 35,3\% na região urbana e 19,1\% na regiāo rural (Anjos, 2006). Especula-se hoje sobre uma possível associação entre o tempo gasto dirigindo automóveis para o trabalho e os níveis de atividade física na população. Em uma amostra de 6.810 australianos, Wen e colaboradores (2006) documentaram que os indivíduos que dirigiam para o trabalho tinham menor chance de alcançar níveis recomendados de atividade física do que os que não usavam o carro. Além disso, houve associação positiva entre dirigir para o trabalho e obesidade na amostra. Portanto, é fundamental que todos os domínios da atividade física sejam avaliados.

Vários estudos locais também estão disponíveis e contribuem para o conhecimento dos níveis de atividade física dos brasileiros. Na cidade de Pelotas, RS, por exemplo, vários estudos sobre a epidemiologia da atividade 
física foram realizados nos últimos anos. Em 2003, Hallal e colaboradores mostraram que $41 \%$ dos adultos da cidade não praticavam a quantidade mínima de atividade física recomendada para a obtenção de benefícios à saúde (Hallal et al., 2003). Com o mesmo banco de dados, Hallal e Siqueira (2004) demonstraram que apenas $29 \%$ dos entrevistados atingiam o ponto de corte recomendado para atividades físicas de intensidade alta. No que se refere à atividade física realizada no deslocamento para o trabalho, um estudo, também realizado em Pelotas (Bacchieri, Gigante \& Assunção, 2005), mostrou que a bicicleta foi o modo de transporte mais utilizado por homens trabalhadores nessa cidade (27\%) e, embora o ônibus tenha sido o modo de transporte mais utilizado entre as mulheres, $28 \%$ delas deslocavam-se a pé para o trabalho.

No estado de São Paulo, Matsudo e colaboradores (2002) encontraram prevalência de sedentarismo de 45\% também utilizando a versão curta do Ipaq. Em outra publicação, Hallal e colaboradores (2005) compararam os percentuais de caminhada por lazer e no geral, constatando que apenas $15 \%$ dos entrevistados atingiam a recomendação de 150 minutos por semana por meio de caminhadas no lazer, mas esse valor era de $41 \%$ quando consideradas as caminhadas realizadas em geral, principalmente deslocamento para o trabalho.

Entre adolescentes, os estudos em diversos lugares do Brasil também concordam em demonstrar elevadas taxas de sedentarismo, embora as estimativas sejam muito distintas em decorrência dos diferentes pontos de corte e instrumentos utilizados. As recomendações atuais sugerem que os adolescentes devem praticar pelo menos sessenta minutos diários de atividades físicas de intensidade moderada a vigorosa (Strong et al., 2005). Hallal e colaboradores (2006b) mostraram que 58\% dos adolescentes de 10 a 12 anos da cidade de Pelotas não praticavam a quantidade recomendada de atividade física para a sua idade. Outro estudo, conduzido na mesma cidade, com adolescentes de 15-19 anos, encontrou uma prevalência de sedentarismo de 39\%, com um ponto de corte de sessenta minutos por semana (Oehlschlaeger et al., 2004).

\section{O Futuro da Mensuração da Atividade Física em Estudos Populacionais}

Como as atividades de intensidade moderada são importantes não só para o total do gasto energético diário, mas também na prevenção de diversos agravos à saúde, e constituem as modalidades de mais difícil captação por questionários, há, atualmente, um relativo consenso de que é necessário tentar avaliar a atividade física de forma mais objetiva em estudos populacionais (Freedson \& Miller, 2000; Wareham \& Rennie, 1998). Além disso, vários estudos demonstram a baixa validade de diversos questionários de atividade física disponíveis (Kriska \& Caspersen, 1997) em comparação com métodos mais diretos de mensuração. Além disso, muitas vezes os estudos de validação são analisados de forma polêmica (Hallal \& Victora, 2004).

A busca de métodos tem se concentrado em monitoração da freqüência cardíaca (Wareham et al., 1997) e no uso de acelerômetros (Yoshioka et al., 2005) ou em uma combinação desses métodos (Brage et al., 2006; Johansson et al., 2006). Quando há interesse em documentar a atividade de caminhada, pode-se também usar pedômetros, aparelhos mais simples e baratos do que os acelerômetros. De fato, um estudo em uma amostra probabilística de adultos de Niterói, RJ, documentou, recentemente, a importância da medição objetiva da atividade física em estudos populacionais. Por meio de questionário, obteve-se a freqüência de realização de atividade física no lazer em $23,1 \%$ e $42,4 \%$ das mulheres e homens, respectivamente. No entanto, a mediana do número de passadas diárias, obtida por meio de pedômetro usado durante as horas em que os indivíduos permaneciam acordados, foi de 8.977 e 10.061 para mulheres e homens, respectivamente. Assim, 39 e 52\% de mulheres e homens, respectivamente, ultrapassaram a marca recomendada de dez mil passadas diárias, usada como critério para se considerar a atividade física suficiente (Anjos, 2004; Anjos, Wahrlich \& Vasconcellos, 2006). 


\section{Considerações Finais}

O acúmulo de evidências científicas sobre os benefícios da atividade física para a saúde tem despertado a atenção de várias agências de saúde pública para o problema do sedentarismo. Diversas iniciativas têm sido idealizadas para um aumento do nível de atividade física da população, desde estratégias de aconselhamento e conscientização até mudanças ambientais. A literatura nacional sobre atividade física e saúde tem crescido nos últimos anos, e a inserção dos pesquisadores desta área na comunidade da saúde coletiva é cada vez mais presente. A mensuração de atividade física em estudos populacionais sempre foi, e continua sendo, um desafio. Novos métodos têm sido propostos, e sua utilização é crescente em nosso meio.

\section{Referências}

ANJOS, L. A. Prevalência da inatividade física no Brasil. In: CONGRESSO BRASILEIRO DE ATIVIDADE FÍSICA E SAÚDE, 2, 1999, Florianópolis. Anais... Florianópolis, Santa Catarina: Centro de Desportos, Universidade Federal de Santa Catarina, 1999.

ANJOS, L. A. Avaliação da atividade física diária através de pedômetro em adultos de Niterói, Rio de Janeiro. In: CONGRESSO BRASILEIRO DE EPIDEMIOLOGIA, VI, 2004, Recife. Revista Brasileira de Epidemiologia, n. especial, jun. 2004. Versão eletrônica.

ANJOS, L. A. Obesidade e Saúde Pública. Rio de Janeiro: Editora Fiocruz, 2006.

ANJOS, L. A.; WAHRLICH, V. \& VASCONCELLOS, M. T. L. Association of daily pedometer count and nutritional status in a household survey in Niterói, Rio de Janeiro, Brazil. Obesity Reviews, 7, suppl. 2: 273, 2006.

BACCHIERI, G.; GIGANTE, D. P. \& ASSUNÇÃO, M. C. Determinantes e padrões de utilização da bicicleta e acidentes de trânsito sofridos por ciclistas trabalhadores da cidade de Pelotas, Rio Grande do Sul, Brasil. Cadernos de Saúde Pública, 21: 1.499-1.508, 2005.

BERLIN, J. A. \& COLDITZ, G. A. A meta-analysis of physical activity in the prevention of coronary heart diseases. American Journal of Epidemiology, 132: 612-628, 1990.

BRAGE, S. et al. Effect of combined movement and heart rate monitor placement on physical activity estimates during treadmill locomotion and free-living. European Journal of Applied Physiology, 96: 517-524, 2006.

CASPERSEN, C. J. Physical activity epidemiology: concepts, methods, and applications to exercise science. Exercise and Sport Sciences Reviews, 17: 423-473, 1989.

CASPERSEN, C. J.; POWELL, K. E. \& CHRISTENSEN, G. M. Physical activity, exercise, and physical fitness: definitions and distinctions for health-related research. Public Health Reports, 100: 126-131, 1985.

EKELAND, E. et al. Exercise to improve self-steem in children and young people. Cochrane Database of Systematic Reviews, 2004: CD002683.

ERLICHMAN, J.; KERBEY, A. L. \& JAMES, W. P. T. Physical activity and its impact on health outcomes. Paper 1: The impact of physical activity on cardiovascular disease and all-cause mortality: an historical perspective. Obesity Reviews, 3: 257-271, 2002a.

ERLICHMAN, J.; KERBEY, A. L. \& JAMES, W. P. T. Physical activity and its impact on health outcomes. Paper 2: Prevention of unhealthy weight gain and obesity by physical activity: an analysis of the evidence. Obesity Reviews, 3: 273-287, 2002 b. 
FOOD AND AGRICULTURE ORGANIZATION (FAO)/WORLD HEALTH ORGANIZATION (WHO)/ UNITED NATIONS UNIVERSITY (UNU). Human Energy Requirements: report of a joint FAO/WHO/ UNU Expert Consultation. Rome: FAO, 2004. (FAO Technical Report Series 1)

FREEDSON, O. S. \& MILLER, K. Objective monitoring of physical activity using motion sensors and heart rate. Research Quarterly for Exercise and Sport, 71: 21-29, 2000.

HALLAL, P. C. \& SIQUEIRA, F. C. Compliance with vigorous physical activity guidelines in Brazilian adults: prevalence and correlates. Journal of Physical Activity and Health, 1: 389-397, 2004.

HALLAL, P. C. \& VICTORA, C. G. Reliability and validity of the International Physical Activity Questionnaire (Ipaq). Medicine \& Science in Sports \& Exercise, 36: 556, 2004.

HALLAL, P. C. et al. Physical inactivity: prevalence and associated variables in Brazilian adults. Medicine \& Science in Sports \& Exercise, 35: 1.894-1.900, 2003.

HALLAL, P. C. et al. Who, when, and how much? Epidemiology of walking in a middle-income country. American Journal of Preventive Medicine, 28: 156-161, 2005.

HALLAL P. C. et al. Adolescent physical activity and health: a systematic review. Sports Medicine, 36: 1.0191.030, $2006 a$.

HALLAL, P. C. et al. Early determinants of physical activity in adolescence: prospective birth cohort study. British Medical Journal, 332(7548): 1.002-1.007, $2006 \mathrm{~b}$.

INSTITUTO NACIONAL DE CÂNCER (INCA). Inquérito Domiciliar sobre Comportamentos de Risco e Morbidade Referida de Doenças e Agravos Não Transmissiveis: Brasil, 15 capitais e Distrito Federal, 20022003. Rio de Janeiro: Inca, 2004.

INSTITUTE OF MEDICINE OF THE NATIONAL ACADEMIES (IOM). Dietary Reference Intakes for Energy, Carbohydrate, Fiber, Fat, Fatty Acids, Protein, and Amino Acids. Part 1. Washington: The National Academy Press, 2002.

JAKICIC, J. M. et al. ACSM Position stand on the appropriate intervention strategies for weight loss and prevention of weight regain for adults. Medicine \& Science in Sports \& Exercise, 33: 2.145-2.156, 2001.

JOHANSSON, H. P. et al. Accelerometry combined with heart rate telemetry in the assessment of total energy expenditure. British Journal of Nutrition, 95: 631-639, 2006.

KOHRT, W. M. et al. American College of Sports medicine position stand: physical activity and bone health. Medicine \& Science in Sports \& Exercise, 36: 1.985-1.996, 2004.

KRISKA, A. M. \& CASPERSEN, C. J. Introduction to collection of physical activity questionnaires. Medicine and Science in Sports and Exercise, 29: S5-S9, 1997.

MATSUDO, S. M. et al. Nível de atividade física da população do estado de São Paulo: análise de acordo com o sexo, idade, nível socioeconômico, distribuição geográfica e de conhecimento. Revista Brasileira de Ciência \& Movimento, 10: 41-50, 2002.

MORRIS, J. N. et al. Coronary heart disease and physical activity of work. The Lancet, 2: 1.111-1.120, 1953.

MORRIS, J. N. et al. Incidence and prediction of ischemic heart disease in London busmen. The Lancet, 2: 553$559,1966$. 
OEHLSCHLAEGER, M. H. K. et al. Prevalência de sedentarismo e fatores associados em adolescentes de área urbana. Revista de Saúde Pública, 38: 157-163, 2004.

ORCHARD, T. J. et al. Diabetes Prevention Program Research Group. The effect of metformin and intensive lifestyle intervention on the metabolic syndrome: the Diabetes Prevention Program randomized trial. Annals of Internal Medicine, 142: 611-619, 2005.

PAFFENBARGER JR., R. S. et al. Physical activity, all-cause mortality, and longevity of college alumni. New England Journal of Medicine, 314: 605-613, 1986.

PAFFENBARGER JR., R. S. et al. The association of changes in physical activity level and other lifestyle characteristics with mortality among men. New England Journal of Medicine, 328: 538-545, 1993.

PAN, X. R. et al. Effects of diet and exercise in preventing NIDDM in people with impaired glucose tolerance: the Da Qing IGT and Diabetes Study. Diabetes Care, 20: 537-544, 1997.

PATE, R. R. et al. Physical activity and public health: a recommendation from the Centers for Disease Control and Prevention and the American College of Sports Medicine. Jama, 273(5): 402-407, 1995.

REGO, R. A. et al. Fatores de risco para doenças crônicas não-transmissíveis: inquérito domiciliar no município de São Paulo, SP (Brasil). Metodologia e resultados preliminares. Revista de Saúde Pública, 24: 277-285, 1990.

RIBEIRO, F. S. N. Da Identidade do Pesquisado à Identidade da Pesquisa: os trabalhadores na Pesquisa Nacional sobre Saúde e Nutrição, 1994. Dissertação de Mestrado, Rio de Janeiro: Escola Nacional de Saúde Pública Sergio Arouca, Fundação Oswaldo Cruz.

ROSIMINI, C. Benefits of swim training for children and adolescents with asthma. Journal of the American Academy of Nurse Practioners, 15: 247-252, 2003.

SERDULA, M. K.; KHAN, L. K. \& DIETZ, W. H. Weight loss counseling revisited. Jama, 289: 1.747-1.750, 2003.

SHEPARD, R. J. Physical activity, Fitness and health. The Current Consensus. Quest, 47: 288-303, 1995.

STRONG, W. B. et al. Evidence based physical activity for school-age youth. Journal of Pediatrics, 146: 732-737, 2005.

THE SIXTH REPORT of the Joint National Committee on Prevention, Detection and Treatment of High Blood Pressure, 1997. (NIH Publication, 984080)

U.S. DEPARTMENT OF HEALTH AND HUMAN SERVICES. Physical Activity and Health: a report of the Surgeon General. Atlanta: U.S. Department of Health and Human Services, Center for Disease Control and Prevention, National Center for Chronic Disease Prevention and Health Promotion, 1996.

WAREHAM, N. J. \& RENNIE, K. L. The assessment of physical activity in individuals and populations: why try to be more precise about how physical activity is assessed? International Journal of Obesity, 22, suppl. 2: S30-38, 1998.

WAREHAM, N. J. et al. Feasibility of heart-rate monitoring to estimate total level and pattern of energy expenditure in a population-based epidemiological study: the Ely Young Cohort Feasibility Study 1994-5. British Journal of Nutrition, 78: 889-900, 1997. 
WEN, L. M. et al. Driving to work and overweight and obesity: findings from the 2003. New South Wales Health Survey, Australia. International Journal of Obesity, 30: 782-786, 2006.

YOSHIOKA, M. et al. Long-period accelerometer monitoring shows the role of physical activity in overweight and obesity. International Journal of Obesity, 29: 502-508, 2005. 



\title{
Obesidade e Saúde Mental: evidências e controvérsias
}

\author{
Claudia de Souza Lopes
}

\begin{abstract}
A avaliação do papel do sobrepeso/obesidade na saúde dos indivíduos tem sido objeto de diversos estudos científicos, principalmente nas duas últimas décadas. Se, por um lado, as consequiências deletérias do sobrepeso/ obesidade na morbidade física são hoje amplamente conhecidas, ainda há bastante controvérsia sobre o impacto da obesidade na saúde mental dos indivíduos. Embora a obesidade seja entendida como um produto da suscetibilidade genética associada a um ambiente obesogênico, não existe um claro paradigma na sua abordagem que justifique a freqüência com que a obesidade tem sido associada a transtornos mentais, principalmente a depressão.

Provavelmente, a existência de uma gama de outros fatores que se associam tanto à obesidade como à saúde mental torna a evidência desta associação bem mais complexa do que a encontrada para morbidade física. Assim, a avaliação da associação entre obesidade e saúde mental deve levar em conta o contexto social e cultural dos indivíduos, e questões relativas à percepção do peso corporal, auto-estima, discriminação, estigma, entre outras, devem ser consideradas na construção de modelos teóricos causais. Além disso, diferenças relativas aos critérios utilizados para a definição de transtorno mental e obesidade também contribuem para diferenças encontradas nos estudos.
\end{abstract}

\section{Contexto Social versus Fatores Psicológicos e Biológicos}

As mudanças ocorridas nas últimas décadas nos padróes culturais e de estilo de vida, principalmente nos países ocidentais, têm tido repercussões importantes nos padróes estéticos aceitos como adequados. Neste contexto, juventude, perfeição física e magreza aparecem como os modelos socialmente mais difundidos. Assim, o padrão de peso 'ideal' tem sido apresentado como referencial não apenas de saúde, mas como uma importante medida de valor pessoal, e indivíduos que estão fora desse padrão, principalmente aqueles com sobrepeso, apresentam maior risco de sofrer algum tipo de discriminação e exclusão social. A necessidade de ajuste a esse modelo tem levado, principalmente as mulheres, à busca pelo corpo 'ideal' e à crença de que isto pode ser atingido apenas pelo esforço pessoal. Reforçando essa crença, temos a mídia e a indústria cosmética, alimentícia e farmacêutica difundindo temas relacionados à beleza e à aquisição de um corpo ideal em campanhas publicitárias e em artigos de revistas femininas especializadas.

Uma série de explicações para a relação entre obesidade e saúde mental, particularmente depressão, tem sido oferecida, incluindo o possível papel de fatores psicológicos, sociológicos e biológicos. Assim, uma parcela 
considerável de estudos tem avaliado o papel do estigma, da adequação às normas de aparência, da auto-imagem corporal, o modo como estes fatores interagem entre si e com o ambiente social e sua importância na mediação da associação entre obesidade e transtornos mentais.

\section{O Papel do Estigma}

De acordo com Sarlio-Lahteenkorva, Stunkard e Rissanen (1995), o estigma associado à obesidade na cultura ocidental pode ser ainda mais danoso do que aquele relacionado às questôes raciais ou mesmo de incapacidade física. Estudos têm demonstrado que indivíduos obesos, particularmente as mulheres, têm menos probabilidade de serem aceitos em boas universidades (Canning \& Mayer, 1966) e de obterem bolsas de estudo (Crandall, 1994). A obesidade também afeta negativamente a capacidade de obter emprego (Rothblum et al., 1990) e o status socioeconômico (Sobal \& Stunkard, 1989).

Entretanto, apesar de haver evidência empírica sobre os efeitos da obesidade na estigmatização dos indivíduos, pouco ainda se sabe sobre as conseqüências psicológicas da estigmatização relacionada à obesidade ou em que sentido indivíduos obesos internalizam as visōes culturais sobre o peso (Falkner et al., 1999; Crossrow, Jeffery \& McGuire, 2001). Friedman e colaboradores (2005), com o objetivo de avaliar a relação entre estigmatização relacionada com o peso, crenças ideológicas sobre o peso e funcionamento psicológico, investigaram 93 indivíduos obesos em início de tratamento. Os resultados mostraram que a experiência de estigmatização associava-se positivamente com depressão, sintomas psiquiátricos gerais e transtorno da auto-imagem, e negativamente com autoestima. Myers e Rosen (1999) também encontraram que a estigmatização era uma experiência comum para indivíduos obesos e que uma maior freqüência de experiências estigmatizantes associava-se com maior Índice de Massa Corporal (IMC), pior funcionamento psicológico, maior insatisfação com a auto-imagem e reduzida auto-estima. Esses dados sugerem que a estigmatização relacionada ao peso provavelmente apresenta conseqüências psicológicas negativas.

Outra abordagem do estigma diz respeito ao modo como os próprios indivíduos obesos internalizam o preconceito e crenças de determinada cultura com relação à obesidade e como estas crenças associam-se à saúde mental. Segundo alguns autores (Crandall \& Biernat, 1990; Ross, 1994), essa associação se verifica na baixa auto-estima e no preconceito que os indivíduos obesos têm contra seu próprio grupo. Contudo, o grau em que a internalização de tais crenças age na associação entre experiências estigmatizantes e funcionamento psicológico se mantém desconhecido.

Um foco também pouco explorado e interessante é o papel do controle do peso como mediador da associação entre estigmatização e funcionamento psicológico. Esse papel se basearia na crença corrente de que os indivíduos podem controlar o seu peso e de que tal controle seria apenas uma questão de autodisciplina (Maddox, Back \& Liederman, 1968). Essa visão normativa pode, em parte, explicar por que indivíduos obesos tendem a ser avaliados mais negativamente do que indivíduos que não têm controle sobre suas características estigmatizantes (por exemplo, raça) (Dejong, 1980). De fato, estudos que investigaram a associação entre crença na capacidade de controle de peso e funcionamento psicológico mostraram que crenças maiores de autocontrole de peso associavam-se a auto-estima e funcionamento psicológico debilitados em mulheres obesas (Tiggemann \& Rothblum, 1997).

Ross (1994), por exemplo, desenhou duas explicações possíveis para a associação entre obesidade e depressão. Uma, na perspectiva reflected self-appraisal, argumenta que o estigma e a desvalorização do obeso podem levar indivíduos com sobrepeso a sofrer baixa auto-estima, ter uma auto-imagem mais negativa, sentir-se menos queridos pelos outros e apresentar níveis mais elevados de depressão. Quanto menos comum e aceitável for o sobrepeso em um determinado grupo, maior a possibilidade de haver um impacto psicológico negativo. A segunda, baseada na perspectiva de adequação às normas de aparência, argumenta que, para aqueles que são obesos, adequar-se à norma do peso 'ideal' pode ser estressante, pois estar em dieta pode acarretar mais estresse do que a obesidade em 
si. Isso deve ser particularmente verdadeiro nas situações em que o controle de peso não é satisfatório, o que ocorre comumente. Ross apresenta dados que sustentam a hipótese de adequação às normas de aparência, mas encontrou pouco suporte para a hipótese reflected appraisal. Essas perspectivas que competem entre si oferecem explicações plausíveis para os processos socioculturais que associam obesidade com disfunção psicológica. Entretanto, até o momento não houve nenhuma tentativa de replicar ou estender a pesquisa de Ross.

\section{A Hipótese do Jolly Fat}

A hipótese do jolly fat, que postula que pessoas com sobrepeso, de ambos os sexos, têm baixo risco de depressão, foi propalada por muitas décadas, a despeito da falta de evidência empírica consistente para isso. Em um dos primeiros estudos sobre o tema, Crisp e McGuiness (1976) verificaram que a obesidade estava relacionada com baixos níveis de ansiedade tanto em mulheres como em homens de meia-idade e baixos níveis de depressão em homens. Estudo subseqüente, em uma amostra mais rural, mostrou resultados semelhantes para os homens de meia-idade.

No entanto, a associação era muito mais fraca para as mulheres de forma geral, sendo a obesidade relacionada com baixa ansiedade em mulheres mais velhas e trabalhadoras manuais e com baixos níveis de depressão em mulheres mais jovens e da classe média. Não foi encontrada associação entre obesidade e depressão em homens mais jovens (Crisp et al., 1980). Palinkas, Wingard e Barret-Connor (1996) verificaram que obesidade não se associava a maior risco de depressão em mulheres entre 50 e 89 anos, mas, entre os homens, depressão estava inversamente associada à obesidade, o que confirma parcialmente a hipótese do jolly fat. Mais recentemente, Jasienska e colaboradores (2005), em estudo com mulheres entre 45 e 64 anos, mostraram que mulheres na prémenopausa e com baixo nível educacional apresentavam uma relação inversa entre IMC e níveis de depressão; esta associação não se confirmou entre aquelas com melhor nível educacional.

\section{Epidemiologia: principais estudos e abordagens metodológicas}

A obesidade é um fator de risco já bem estabelecido para uma série de doenças crônicas, como diabetes mellitus tipo 2, doenças cardiovasculares e doenças articulares, entre outras. Entretanto, o papel da obesidade no desenvolvimento de transtornos mentais, particularmente a depressão, ainda não está plenamente estabelecido. Depressão associa-se com condiçōes médicas crônicas, baixa adesão a tratamentos médicos, elevada utilização de serviços de saúde e desfechos de saúde desfavoráveis. Portanto, a melhor compreensão da relação entre obesidade e depressão é importante para clínicos, pesquisadores e gestores na área da saúde (Onyike et al., 2003).

Existe hoje um conjunto de estudos clínicos e epidemiológicos que investigaram o tema. Entre os estudos epidemiológicos, há uma gama de questôes metodológicas relacionadas aos desenhos utilizados, amostras de população e medidas para avaliação de psicopatologia e pontos de corte para obesidade, que tornam a comparação dos achados difícil e podem contribuir para a inconsistência dos resultados.

A maioria dos estudos epidemiológicos baseia-se em desenhos transversais ou estudos de prevalência, e poucos estudos investigaram a questão prospectivamente. Uma outra questão refere-se ao fato de que muitos estudos baseiam-se em amostras clínicas, em tratamento. Tais estudos são mais vulneráveis a vieses relacionados aos efeitos do tratamento propriamente dito ou mesmo de comportamentos diferenciados entre aqueles que buscam tratamento. A não-estratificação por sexo pode também subestimar a associação.

Alguns estudos encontraram associação entre obesidade e depressão em mulheres, mas não em homens (Noppa \& Hallstrom, 1981; Istvan, Zavela \& Weidner, 1992); outros reportaram associações inversas entre obesidade e depressão em homens e mulheres (Carpenter et al., 2000; Palinkas, Wingard \& Barret-Connnor, 1996; Crisp \& McGuiness, 1976). Entre os estudos transversais, o principal problema relaciona-se à possibilidade de 
causalidade reversa, uma vez que tanto indivíduos obesos podem apresentar um risco mais elevado para depressão como indivíduos deprimidos podem apresentar um maior risco para obesidade. Além disso, tanto a obesidade como a depressão são condições de saúde que resultam de um conjunto de fatores de risco ou protetores que se acumulam ao longo da vida. Portanto, estudos longitudinais prospectivos são as melhores ferramentas para a investigação da direção da associação.

Outra questão diz respeito à heterogeneidade de medidas utilizadas na avaliação de transtornos mentais. Friedman e Brownell (1995), em uma ampla revisão do tema, chamaram atenção para o fato de que a maioria dos estudos populacionais não utiliza critérios diagnósticos estabelecidos em suas definições de depressão. A definição de obesidade também tem variado. Alguns estudos utilizam o IMC como variável contínua, outros usam pontos de corte, que, dependendo da recomendação, podem ser diferentes.

\section{Que Subgrupos Estão sob Maior Risco?}

Entre os estudos que avaliaram a possível associação entre obesidade e transtornos mentais, uma parcela considerável abordou a possibilidade de determinados subgrupos de indivíduos obesos apresentarem risco mais elevado do que outros. Existem hoje evidências da importância da genética e de componentes fisiológicos na etiologia da obesidade. Por outro lado, fatores sociais, culturais e ambientais também têm sido implicados de forma indiscutível nesta etiologia. Assim, é lógico que se examine em que medida os correlatos psicológicos da obesidade variam entre indivíduos e que fatores desempenham um papel central nessa variação.

Diversos estudos observaram que as mulheres apresentam prevalências mais elevadas de sobrepeso e que tal prevalência é maior entre aquelas com baixa escolaridade e com mais idade (James et al., 2001, Gigante et al., 2006; Fonseca et al., 2006). Da mesma forma, o sexo feminino apresenta risco mais elevado de transtornos mentais, particularmente ansiedade e depressão (Somers et al., 2006; Waraich et al., 2004; Lopes, Faerstein \& Chor, 2003). A pressão da sociedade para a manutenção do "peso ideal" é muito maior para as mulheres do que para os homens. Por sua vez, a entrada na menopausa acarreta uma série de modificações hormonais que, além do aumento de peso, freqüentemente modificam a deposição de gordura no corpo, com predominância na região abdominal (Avis \& Crawford, 2001). Além disso, há um aumento da labilidade emocional, distúrbios de humor e queixas de insônia. Acredita-se, assim, que o papel da obesidade no risco de transtornos mentais, particularmente da depressão, seja maior entre as mulheres do que entre os homens e que este risco possa aumentar no período do climatério e menopausa. Contudo, os resultados dos estudos ainda apresentam controvérsias (Lee et al., 2005; Medeiros, Medeiros \& Oliveira, 2006).

Estudos de base populacional conduzidos recentemente nos EUA e Canadá mostraram associação entre obesidade e depressão. Vários destes inquéritos observaram diferenças entre sexos, com associações positivas entre obesidade e depressão entre as mulheres e associações negativas ou inexistentes entre os homens (Palinkas, Wingard \& Barret-Connor, 1996; Istvan, Zavela \& Weidner, 1992; Carpenter et al., 2000; Onyike et al., 2003; Heo et al., 2006).

Han e colaboradores (1998) avaliaram associação entre obesidade e saúde mental mensurada por meio do Short Form-36 Health Survey Questionnaire (SF-36), em uma amostra de indivíduos com idades entre 20 e 59 anos na Holanda. O estudo mostrou que homens no tercil superior de obesidade apresentavam maior probabilidade de relatar não se sentirem felizes e mulheres no tercil superior de obesidade apresentavam maior probabilidade de relatar humor depressivo.

Faith e colaboradores (2001) encontraram uma diferença entre sexos na associação entre 'neuroticismo' (um correlato da depressão) e IMC em uma amostra de base populacional inglesa. Não foi observada associação significativa entre os homens, ao passo que IMC maior associava-se significativamente com maiores níveis de 'neuroticismo' em mulheres. Simon e colaboradores (2006), entretanto, em inquérito recente na população americana adulta, 
mostraram associação entre obesidade e diagnóstico de depressão, mas não observaram diferenças significativas entre homens e mulheres. Outras variáveis sociodemográficas como etnia, escolaridade e renda foram avaliadas como possíveis mediadoras da associação entre obesidade e saúde mental.

Reed (1985), usando dados do First National Health and Nutrition Examination Survey (NHANES I), verificou que a obesidade estava relacionada à debilitação da saúde mental em mulheres negras e brancas. Mostrou também que o subgrupo de mulheres obesas, com níveis mais elevados de educação e mais jovens era o que apresentava piores níveis de saúde mental, principalmente sintomas de depressão e ansiedade. Hällstrom e Noppa (1981) estudaram mulheres entre 38 e 54 anos e não encontraram associação entre obesidade e transtornos mentais correntes ou passados, incluindo ansiedade, fobias, depressão, contato com psiquiatras ou uso de medicamentos psicotrópicos. Ross (1994), utilizando dados de uma amostra representativa de 2.020 adultos com 18 anos ou mais, não encontrou nenhum efeito direto relacionado ao sobrepeso na maioria dos subgrupos. Pessoas com sobrepeso tinham maior probabilidade de estar em dieta e apresentar saúde física mais debilitada, ambos associados à depressão. Entretanto, o sobrepeso aumentava o risco de depressão entre aqueles com escolaridade mais alta.

No Brasil, estudo longitudinal conduzido entre mulheres acompanhadas por nove meses no pós-parto em um centro de saúde no Rio de Janeiro mostrou que, após ajuste por renda e escolaridade, mulheres com gordura corporal (estimada por meio de bioimpedância elétrica) igual ou maior que 30\% tinham maior chance de apresentar transtornos mentais comuns - Odds Ratio (OR) = 1,66; Intervalo de Confiança (IC) 95\% 1,03-2,65. Entretanto, os autores não encontraram associação entre sobrepeso e obesidade, medidos pelo IMC, e transtornos mentais comuns (Kac et al., 2006).

Outra linha de estudos procura avaliar o papel da autopercepção do peso corporal na ocorrência de transtornos mentais (Buddeberg-Fischer, Klaghofer \& Reed, 1999; Kaplan, Busner \& Pollac, 1988). No Brasil, Veggi e colaboradores (2004) avaliaram a associação entre transtornos mentais comuns, IMC e autopercepção do peso corporal por meio de um estudo transversal realizado com uma população de funcionários de uma universidade pública no Rio de Janeiro (Estudo Pró-Saúde, 2006), tendo encontrado associação entre a presença de transtornos mentais comuns e a percepção de peso muito acima do ideal somente entre as mulheres $(\mathrm{OR}=1,84 ;$ IC $95 \%$ 1,22-2,76).

Estudo longitudinal subseqüente após dois anos de seguimento da população confirmou esses achados, mostrando que após ajuste por sexo, idade, renda, IMC na linha de base e alteração de peso no período de seguimento, perceber-se muito acima do peso ideal aumentava o risco de transtornos mentais comuns - Risco Relativo $(\mathrm{RR})=1,42$; IC95\% 1,02-1,98. A estratificação por sexo não mostrou diferenças significativas com relação ao risco de transtornos mentais entre aqueles com percepção de peso acima do ideal. Com relação à associação entre IMC e transtornos mentais comuns, esse estudo, a exemplo do estudo conduzido por Kac e colaboradores (2006), também não encontrou associação entre níveis de IMC e incidência de transtornos mentais comuns. Uma possibilidade a ser considerada é o critério para definição de transtornos mentais, já que o instrumento utilizado em ambos os estudos (General Health Questionnaire 12) é um instrumento de rastreamento, que não permite a realização de diagnósticos psiquiátricos mais graves.

Para Friedman e Brownell (1995), sexo e idade são os fatores que desempenham papel mais importante na associação entre obesidade e sofrimento psíquico, de forma geral. Além desses, distúrbio da auto-imagem e baixa auto-estima podem ser uma forma subclínica de sofrimento psíquico, e pode-se especular sobre a possibilidade de que estes fatores venham a agir como fatores de risco para psicopatologia. Para esses autores, apenas estudos prospectivos podem, com base nas associaçóes encontradas entre fatores de risco específicos e características psicológicas em indivíduos obesos, estabelecer nexos causais. Os principais estudos longitudinais conduzidos até o momento mostraram que a obesidade é um fator de risco para o desenvolvimento de depressão (Roberts et al., 2003, 2000), que a depressão é um fator de risco para obesidade (Hasler et al., 2004; Goodman \& Whitaker, 2002; Noppa \& Hallstrom, 1981), que o sucesso na perda de peso associa-se à diminuição de sintomas de 
depressão (Dixon, Dixon \& O’Brien, 2003) e que a depressão é um preditor para o insucesso na tentativa de perda de peso (Linde et al., 2004; McGuire et al., 1999).

\section{Obesidade e Transtornos Alimentares}

Outro subgrupo importante e avaliado principalmente em amostras clínicas é o dos indivíduos obesos que estão em tratamento para perda de peso. Estudos têm demonstrado que esses indivíduos apresentam uma prevalência elevada de transtornos alimentares, particularmente Compulsão Alimentar Periódica (CAP) ${ }^{1}$ e, menos freqüentemente, Transtorno da Compulsão Alimentar Periódica (TCAP). ${ }^{2}$ Em obesos que procuram programas para controle de peso, foram observadas freqüências em torno de $30 \%$ para TCAP e $46 \%$ para CAP, estando o TCAP associado a sintomas psicopatológicos em geral, especialmente à depressão, a uma maior gravidade da obesidade e ao prejuízo no funcionamento social e ocupacional (Spitzer et al., 1992, 1993). No Brasil, Appolinario, Coutinho e Povoa (1995) e Borges e colaboradores (2002) encontraram prevalências de TCAP entre 16\% e 27\% em pacientes que procuravam tratamento para emagrecer. Na população geral, a prevalência de TCAP é baixa; entretanto, a ocorrência de episódios de compulsão é muito mais freqüente e tem sido associada à obesidade. Siqueira, Appolinario e Sichieri (2005) estudaram 2.855 adultos freqüentadores de shopping centers em diferentes capitais do Brasil e observaram que a prevalência de episódios de compulsão alimentar entre homens com sobrepeso comparados com os sem sobrepeso foi aproximadamente três vezes maior e que nas mulheres esta razão foi duas vezes maior.

\section{Obesidade e Transtornos Mentais em Populações de Crianças e Adolescentes}

Estudos conduzidos em populações de crianças e adolescentes com o objetivo de investigar associação entre obesidade e problemas psicológicos, a exemplo dos estudos conduzidos em populações adultas, também têm apresentado dificuldade de chegar a resultados consistentes. Renman e colaboradores (1999) não encontraram diferenças entre adolescentes obesos e eutróficos com relação a auto-estima, desempenho social e saúde mental. Lamertz e colaboradores (2002), em inquérito de base populacional conduzido entre adolescentes e adultos jovens de 15 a 24 anos em Munique, não encontraram associação entre IMC e transtornos mentais mensurados por meio do Diagnostic and Statistical Manual of Mental Disorders, fourth edition (DSM-IV).

Erickson e colaboradores (2000), em amostra escolar de pré-adolescentes, também não encontraram associação entre obesidade e depressão após controle por preocupações relacionadas ao peso. Em contraste, outros estudos encontraram mais transtornos mentais em adolescentes obesos (Buddeberg-Fischer, Klaghofer \& Reed, 1999). Alguns autores reportam maior ocorrência de sintomas depressivos (Hammar et al., 1972; Strauss et al., 1985) e baixa auto-estima (Strauss et al., 1985), e outros não encontraram diferenças com relação à depressão (Wadden, 1989) e auto-estima (Pastore, Fisher \& Friedman, 1996) entre adolescentes obesos e controles. Da mesma forma, a associação entre obesidade e ansiedade em adolescentes tem sido pouco consistente, com resultados divergentes: três estudos mostraram não haver associação (Britz et al., 2000) e outro mostrou níveis mais elevados de ansiedade em adolescentes obesos (Hammar et al., 1972). Com relação à associação entre depressão e obesidade, Goodman e Whitaker (2002), em estudo prospectivo de base populacional entre adolescentes, confirmaram que humor depressivo na linha de base aumentava o risco de desenvolvimento e persistência de obesidade após um ano de seguimento.

Poucos estudos avaliaram a associação entre depressão e obesidade na infância e efeitos na idade adulta. Pine e colaboradores (1997) avaliaram a associação entre sintomas psiquiátricos na adolescência e obesidade em adultos jovens e encontraram que IMC estava inversamente relacionado com sintomas depressivos em homens, mas não entre as mulheres, e que IMC na idade adulta associava-se positivamente com transtorno de conduta em 
adolescentes de ambos os sexos. Estudo mais recente no mesmo grupo mostrou que crianças e adolescentes (6-17 anos), com depressão maior, apresentavam IMC significativamente mais elevado na idade adulta do que aqueles sem depressão maior (IMC $=26,1 \mathrm{~kg} / \mathrm{m}^{2}$ e $24,2 \mathrm{~kg} / \mathrm{m}^{2}$, respectivamente). Barefoot e colaboradores (1998) encontraram que o efeito da depressão na adolescência na mudança de peso ao longo de vinte anos depende do peso relativo (peso ajustado para estatura). Entre os adolescentes no quintil mais elevado de IMC, aqueles que eram deprimidos apresentavam, significativamente, maior probabilidade de ganhar pelo menos $10 \mathrm{~kg}$ ao longo de vinte anos se comparados aos adolescentes não deprimidos $(\mathrm{OR}=2,2)$.

Tais achados chamam a atenção para a necessidade de estudos mais específicos para a avaliação de psicopatologia em crianças e adolescentes. São poucas as escalas e questionários para avaliação de transtornos mentais voltados exclusivamente para essas populações, e há também necessidade de estudos que se baseiem mais em critérios diagnósticos do que em avaliações quantitativas globais. Outra questão relaciona-se ao fato de crianças e adolescentes obesos serem avaliados muitas vezes em início de tratamento, quando o desgaste relativo à adequação à dieta e ao esforço associado a tentativas recorrentes e muitas vezes frustradas de perder peso pode ainda não estar presente. Como já discutido anteriormente, esse fator pode, mais do que a obesidade em si, relacionar-se a sintomas de ansiedade e depressão.

\section{Considerações Finais}

Até este momento, a preponderância da evidência sugere que a obesidade pode estar implicada na etiologia da depressão. Entretanto, há ainda uma série de razões que nos levam a avaliar a questão com cuidado. Em primeiro lugar, ainda há poucos estudos cujo foco tenha sido a avaliação da obesidade e depressão. Em segundo, apenas três estudos que evidenciaram associação entre obesidade e ocorrência de depressão basearam-se em dados prospectivos. Esta é uma questão central, porque se por um lado estudos de prevalência podem fornecer evidência de co-variação para obesidade e depressão, por outro eles não permitem que se avalie em que medida a obesidade associa-se com início de depressão. Para responder a essa pergunta, precisamos de estudos prospectivos que examinem a ocorrência de depressão futura naqueles com e sem depressão na linha de base. Esta questão é crítica, já que podemos assumir que a estrutura causal que produz morbidade é diferente antes e depois da ocorrência da depressão. Em outras palavras, fatores que causam a depressão podem ser diferentes daqueles que a mantêm ou prolongam.

Outros mecanismos na associação entre obesidade e depressão foram explorados em diferentes estudos. Indivíduos obesos apresentam menor probabilidade de praticar exercícios, e atividade física reduz o risco de depressão por meio do aumento dos níveis de endorfinas, melhorando a regulação de norepinefrina e elevando a auto-estima.

\section{Notas}

1 Comportamento alimentar caracterizado pela ingestão de grande quantidade de comida em um período delimitado (até duas horas), acompanhado da sensação de perda de controle sobre o que ou o quanto se come, é conhecido em inglês como binge eating (Stunkard, 1959).

2 Quando os episódios de CAP ocorrem pelo menos dois dias por semana nos últimos seis meses, associados a algumas características de perda de controle, e não são acompanhados de comportamentos compensatórios dirigidos para a perda de peso, compõem uma síndrome denominada atualmente de Transtorno da Compulsão Alimentar Periódica (TCAP) - binge eating disorder (DSM-IV) (APA, 1994). 


\section{Referências}

AMERICAN PSYCHIATRIC ASSOCIATION (APA). Diagnostic and Statistical Manual of Mental Disorders. 4. ed. Washington: American Psychiatric Press, 1994.

APPOLINARIO, J. C.; COUTINHO, W. \& POVOA, L. C. O transtorno do comer compulsivo no consultório endocrinológico: comunicação preliminar. Jornal Brasileiro de Psiquiatria, 44, supl. 1: S46-S9, 1995.

AVIS, N. E. \& CRAWFORD, S. L. Menopause and weight. Menopause, 8(4): 239-244, 2001.

BAREFOOT, J. C. et al. Symptom of depression and changes in body weight in patients with major depression. International Journal of Obesity and Metabolic Disorders, 22: 688-694, 1998.

BORGES, M. B. F. et al. Binge-eating disorder in Brazilian women on a weight-loss program. Obesity Research, 10(11): 1.127-1.134, 2002.

BRITZ, B. et al. Rates of psychiatric disorders in a clinical study group of adolescents with extreme obesity and in obese adolescents ascertained via a population based study. International Journal of Obesity; 24: 1.707$1.714,2000$.

BUDDEBERG-FISCHER, B.; KLAGHOFER, R. \& REED, V. Associations between body weight, psychiatric disorders and body image in female adolescents. Psychotherapy and Psychosomatics; 68(6): 325-332, 1999.

CANNING, H. \& MAYER, J. Obesity: its possible effect on college acceptance. New England Journal of Medicine, 275: 1.172-1.174, 1966.

CARPENTER, K. M. et al. Relationships between obesity and DSM-IV major depressive disorder, suicide ideation, and suicide attempts: results from a general population study. American Journal of Public Health; 90(2): 251-257, 2000.

CRANDALL, C. S. Prejudice against fat people: ideology and self-interest. Journal of Personality and Social Psychology, 66: 882-894, 1994.

CRANDALL, C. S. \& BIERNAT, M. The ideology of anti-fat attitudes. Journal of Applied Social Psychology, 20: 227-243, 1990.

CRISP, A. H. \& MCGUINESS, B. Jolly fat: relation between obesity and psychoneurosis in general population. British Medical Journal, 1: 7-9, 1976.

CRISP, A. H. et al. "Jolly fat” revisited. The Journal of Psychosomatic Research, 24: 233-241, 1980.

CROSSROW, N. H. F.; JEFFERY, R. W. \& MCGUIRE, M. T. Understanding weight stigmatization: a focus group study. Journal of Nutrition and Education Behavior, 3: 208-214, 2001.

DEJONG, W. The stigma of obesity: the consequences of naïve assumptions concerning the causes of physical deviance. Journal of Health and Social Behavior, 21: 75-87, 1980.

DIXON, J. B.; DIXON, M. E. \& O'BRIEN, P. E. Depression in association with severe obesity. Archives of Internal Medicine, 163: 2.058-2.065, 2003.

ERICKSON, S. J. et al. Are overweight children unhappy?: body mass index, depressive symptom, and overweight concerns in elementary school children. Archives of Pediatrics \& Adolescent Medicine, 154(9): 931-935, 2000.

FAITH, M. S. et al. Gender differences in the relationship between psychological well-being and relative body weight: results from a British population-based sample. Obesity Research, 9: 647-650, 2001. 
FALKNER, N. H. et al. Mistreatment due to weight: prevalence and sources of perceived mistreatment in women and men. Obesity Research, 7: 572-576, 1999.

FONSECA, M. J. M. et al. Associações entre escolaridade, renda e índice de massa corporal em funcionários de uma universidade no Rio de Janeiro, Brasil: Estudo Pró-Saúde. Cadernos de Saúde Pública, 22(11): 2.3592.367, 2006 .

FRIEDMAN, M. A. \& BROWNELL, K. D. Psychological correlates of obesity: moving to the next research generation. Psychological Bulletin, 117(1): 3-20, 1995.

FRIEDMAN, K. E. et al. Weight stigmatization and ideological beliefs: relation to psychological functioning in obese adults. Obesity Research, 13(5): 907-916, 2005.

GIGANTE, D. P. et al. Obesidade da população adulta de Pelotas, Rio Grande do Sul, Brasil e associação com nível sócio-econômico. Cadernos de Saúde Pública, 22(9): 1.873-1.879, 2006.

GOODMAN, E. \& WHITAKER, R. A prospective study of the role of depression in the development and persistence of adolescent obesity. Pediatrics, 110: 497-504, 2002.

HÄLLSTROM, T. \& NOPPA, H. Obesity in women in relation to mental illness, social factors and personality traits. Journal of Psychosomatic Research, 25(2):75-82, 1981.

HAMMAR, S. L. et al. An interdisciplinary study of adolescent obesity. Journal of Pediatrics, 80(3): 373-383, 1972.

HAN, T. S. et al. Quality of life in relation to overweight and body fat distribution. American Journal of Public Health, 88: 1.814-1.820, 1998.

HASLER, G. et al. The associations between psychopathology and being overweight: a 20 year prospective study. Psychological Medicine, 34: 1.047-1.057, 2004.

HEO, M. et al. Depressive mood and obesity in US adults: comparison and moderation by sex, age, and race. International Journal of Obesity, 30: 513-519, 2006.

ISTVAN, J.; ZAVELA, K. \& WEIDNER, G. Body weight and psychological distress in NHANES, I. International Journal of Obesity and Related Metabolic Disorders, 16: 999-1.003, 1992.

JAMES, P. T. et al. The worldwide obesity epidemic. Obesity Research, 9, suppl. 4: 228S-233S, 2001.

JASIENSKA, G. et al. Body mass, depressive symptoms and menopausal status: an examination of the "jolly fat" hypothesis. Women's Health Issues, 15: 145-151, 2005.

KAC, G. et al. Fatores relacionados à prevalência de morbidades psiquiátricas menores em mulheres selecionadas em um centro de saúde no Rio de Janeiro, Brasil. Cadernos de Saúde Pública, 22(5): 999-1.007, 2006.

KAPLAN, S. L.; BUSNER, J. \& POLLAC, S. Perceived weight, actual weight and depressive symptoms in a general adolescent sample. International Journal of Eating Disorders; 7: 107-113, 1988.

LAMERTZ, C. M. et al. Are obese adolescents and young adults at higher risk for mental disorders? A community survey. Obesity Research, 10(11): 1.152-1.160, 2002.

LEE, E. S. et al. Depressive mood and abdominal fat distribution in overweight premenopausal women. Obesity Research, 13: 320-325, 2005. 
LINDE, J. A. et al. Binge eating disorder, weight control self-efficacy, and depression in overweight men and women. International Journal of Obesity and Related Metabolic Disorders, 28(3): 418-425, 2004.

LOPES, C. S.; FAERSTEIN, E. \& CHOR, D. Eventos de vida produtores de estresse e transtornos mentais comuns: resultados do Estudo Pró-Saúde. Cadernos de Saúde Pública, 19(6): 1.713-1.720, 2003.

MADDOX, G. L.; BACK, L. \& LIEDERMAN, V. Overweight as social deviance and disability. Journal of Health and Social Behavior, 9: 289-298, 1968.

MCGUIRE, M. T. et al. What predicts weight regain in a group of successful weight losers? Journal of Consulting and Clinical Psychology, 67(2): 177-185, 1999. Erratum in: Journal of Consulting and Clinical Psychology, 67(3): 282, 1999.

MEDEIROS, S. F.; MEDEIROS, M. M. W. Y. \& OLIVEIRA, V. N. Climateric complaints among very lowincome women from tropical region of Brazil. São Paulo Medical Journal, 124(4): 214-218, 2006.

MYERS, A. \& ROSEN, J. C. Obesity stigmatization and coping: relation to mental health symptoms, body image, and self-esteem. International Journal of Obesity, 23: 221-230, 1999.

NOPPA, H. \& HALLSTROM, T. Weight gain in adulthood in relation to socioeconomic factors, mental illness, and personality tracts: a prospective study of middle-aged women. Journal of Psychosomatic Research, 25: 83-89, 1981.

ONYIKE, C. U. et al. Is obesity associated with major depression? Results from the Third National Health and Nutrition Examination Survey. American Journal of Epidemiology, 158(12): 1.139-1.147, 2003.

PALINKAS, L. A.; WINGARD, D. L. \& BARRET-CONNOR, E. Depressive symptoms in overweight and obese older adults: a test of the "jolly-fat" hypothesis. Journal of Psychosomatic Research, 40(1): 59-66, 1996.

PASTORE, D. R.; FISHER, M. \& FRIEDMAN, S. B. Abnormalities in weight status, eating attitudes, and eating behaviors among urban high school students: correlations with self-esteem and anxiety. The Journal of Adolescent Health, 18(5): 312-319, 1996.

PINE, D. S. et al. Psychiatric symptoms in adolescence as predictors of obesity in early adulthood: a longitudinal study. American Journal of Public Health, 87(8): 1.303-1.310, 1997.

REED, D. B. The relationship between obesity and psychological general well-being in United States women (Abstract). Dissertation Abstracts International, 46: 3.791, 1985.

RENMAN, C. et al. Mental health and psychosocial characteristics in adolescent obesity: a population-based case-control study. Acta Paediatrica, 88(9): 998-1.003, 1999.

ROBERTS, R. E. et al. Are the obese at greater risk for depression? American Journal of Epidemiology, 152(2): 163-170, 2000.

ROBERTS, R. E. et al. Prospective association between obesity and depression: evidence from the Alameda County Study. International Journal of Obesity, 27: 514-521, 2003.

ROSS, C. E. Overweight and depression. Journal of Health and Social Behavior, 35: 63-78, 1994.

ROTHBLUM, E. D. et al. The relationship between obesity, employment discrimination, and employmentrelated victimization. Journal of Vocational Behavior, 37: 251-266, 1990. 
SARLIO-LAHTEENKOORVA, S.; STUNKARD, A. \& RISSANEN, A. Psychosocial factors and quality of life in obesity. International Journal of Obesity, 6: S1-5, 1995.

SIMON, G. E. et al. Association between obesity and psychiatric disorders in the US adult population. Archives of General Psychiatry, 63: 824-830, 2006.

SIQUEIRA, K. S.; APPOLINARIO, J. C. \& SICHIERI, R. Overweight, obesity, and binge eating in a nonclinical sample of five Brazilian cities. Obesity Research, 12(12): 1.921-1.924, 2005.

SOBAL, J. \& STUNKARD, M. J. Socioeconomic status and obesity: a review of the literature. Psychological Bulletin, 105: 260-275, 1989.

SOMERS, J. M. et al. Prevalence and incidence studies of anxiety disorders: a systematic review of the literature. Canadian Journal of Psychiatry, 51(2): 100-113, 2006.

SPITZER, R. L. et al. Binge eating disorder: a multisite field trial of the diagnostic criteria. International Journal of Eating Disorders, 11: 191-203, 1992.

SPITZER, R. L. et al. Binge eating disorder: its further validation in a multisite study. International Journal of Eating Disorders, 13: 137-153, 1993.

STRAUSS, C. C. et al. Personal and interpersonal characteristics associated with childhood obesity. Journal of Pediatric Psychology, 10(3): 337-343, 1985.

STUNKARD, A. J. Eating patterns and obesity. Psychiatric Quarterly, 33: 284-292, 1959.

TIGGEMANN, M. \& ROTHBLUM, E. D. Gender differences in internal beliefs about weight and negative attitudes towards self and others. Psychology Women Quarterly, 21: 581-593, 1997.

VEGGI, A. B. et al. Body weight perception and common mental disorders: Pró-Saúde Study. Revista Brasileira de Psiquiatria, 26(4): 242-247, 2004.

WADDEN, T. A. et al. Dissatisfaction with weight and figure in obese girls: discontent but not depression. International Journal of Obesity, 13(1): 89-97, 1989.

WARAICH, P. et al. Prevalence and incidence studies of mood disorders: a systematic review of the literature. Canadian Journal of Psychiatry, 50(9): 569-70, 2004. 



\title{
Segurança Alimentar e Nutricional: concepções e desenhos de investigação
}

\author{
Luciene Burlandy e Rosana Salles da Costa
}

\begin{abstract}
A
Segurança Alimentar e Nutricional (SAN) vem ocupando de forma crescente a agenda pública no Brasil, e neste processo convivem diferentes compreensões sobre o tema, cada qual com implicações específicas para a construção de políticas públicas e a definição de indicadores e desenhos de investigação.

No sentido de contribuir para o debate sobre concepçóes e usos de indicadores e métodos de investigação neste campo, este capítulo tem como objetivo problematizar limites e possibilidades de utilização da Escala Brasileira de Insegurança Alimentar (Ebia) à luz do conceito de SAN consagrado na II Conferência Nacional de Segurança Alimentar e Nutricional (CNSAN), realizada em 2005 (Consea, 2004). Visando a aprofundar esta análise por meio de um exemplo de utilização da escala no país, apresentamos os resultados do estudo de caso do município de Duque de Caxias, no estado do Rio de Janeiro, que correlacionam o grau de Insegurança Alimentar (IA), mensurado com base na escala, com indicadores socioeconômicos.

\section{Conceito de Segurança Alimentar e Nutricional: potencialidades e desafios}

Como fruto de um processo histórico transcorrido tanto no Brasil como em diversos países do mundo (Pessanha, 1998; Maluf, Menezes \& Valente, 1996), a SAN constitui-se em um campo em construção, seja no plano teórico-conceitual, seja no âmbito da formulação e implementação de políticas públicas, apresentando diferentes possibilidades em termos de mensuração e análise.

A expressão mais ampla que se consagra no país sobre este tema emerge na II CNSAN, realizada em março de 2005, e expressa a compreensão de um segmento importante da sociedade brasileira, incluindo gestores, técnicos de governo, instituições acadêmicas e organizações sociais: "Segurança Alimentar e Nutricional (SAN) é a realização do direito de todos ao acesso regular e permanente a alimentos de qualidade, em quantidade suficiente, sem comprometer o acesso a outras necessidades essenciais, tendo como base práticas alimentares promotoras de saúde, que respeitem a diversidade cultural e que sejam social, econômica e ambientalmente sustentáveis" (Consea, 2004).

Esse enfoque ampliado de SAN articula a 'dimensão alimentar' (da produção, comercialização e consumo) e a 'dimensão nutricional' (da utilização do alimento pelo organismo e sua relação com a saúde), pressupondo
\end{abstract}


que a forma como o alimento é produzido, comercializado e consumido é parte de um todo integrado. Sendo assim, por exemplo, a promoção de um perfil de 'consumo' alimentar saudável, não só na dimensão orgânica, biológica, mas também na vida ambiental e social, implica uma forma diferente de 'produzir e comercializar' esse alimento.

Portanto, são várias as questões que ocupam o campo da SAN no Brasil: aquelas referentes ao comércio internacional que geram condiçôes desiguais de comercialização; a privatização dos recursos ambientais e da base genética do sistema agroalimentar; o uso indiscriminado de agrotóxicos na produção de alimentos; problemas ambientais gerados pelo processo produtivo; o desperdício de alimentos; as desigualdades de acesso à terra, à água, à renda, ao emprego e a serviços públicos e suas implicaçóes no acesso à alimentação e na vulnerabilidade socioeconômica, alimentar e nutricional de determinados segmentos da população; os riscos sanitários; a desnutrição e demais doenças relacionadas às carências nutricionais e ao não-atendimento de necessidades alimentares especiais; o perfil de consumo alimentar de risco à saúde, a obesidade, a fome, entre outras (FBSAN, 2006). Trata-se de um quadro bastante complexo que expressa a realidade de um país marcado por situações de privação e fartura, conflitos e profundas desigualdades.

Essa concepção ampliada, no entanto, convive com outros enfoques que enfatizam dimensóes específicas do tema, como, por exemplo, o combate à fome ou a segurança do alimento (em termos de inocuidade, riscos sanitários).

Ainda que a fome seja uma face da IA e que seja possível estabelecer recortes com base em um conceito amplo, a concepção de SAN acima descrita impõe um olhar diferenciado sobre cada dimensão específica que a constitui. Tal diferenciação refere-se principalmente a uma análise integrada de todos esses componentes.

Quando, por exemplo, a fome é abordada em uma perspectiva reducionista, ou seja, não integrada aos demais componentes que constituem a concepção ampliada de SAN, o foco das ações volta-se 'apenas' para os aspectos biológicos, ou para os segmentos que passam privação de alimentos e para intervenções de caráter compensatório e emergencial. Mesmo que medidas desse tipo sejam necessárias, elas não são suficientes para superar o problema, pois não afetam seus determinantes. De igual modo, os indicadores utilizados para mensurar a fome, quando partem de uma concepção restrita, tendem a expressar apenas uma dimensão específica desse quadro. Assim, a fome foi por muito tempo mensurada com base na insuficiência de renda e também, em alguns estudos, por indicadores antropométricos, como será tratado posteriormente; trata-se, no entanto, de um fenômeno muito mais complexo, ainda que a renda seja um elemento fundamental em sua determinação.

As desigualdades inerentes ao sistema econômico e ao processo produtivo, inclusive de alimentos, são fatores determinantes da fome. Portanto, precisam ser enfrentados para que os programas neste campo deixem de ser apenas medidas compensatórias de um problema continuamente gerado pela dinâmica socioeconômica e pelos valores que marcam as relaçôes sociais cotidianas, reforçando e perpetuando as desigualdades. Superar a fome implica, portanto, considerá-la parte de políticas universais que garantam direitos, incluindo a qualidade sanitária e nutricional daquilo que se come, as condições de vida, saúde, educação, trabalho, cultura, ou seja, tendo em vista o controle de todos os riscos econômicos, sociais, ambientais e de saúde que marcam o processo de produção, comercialização e consumo de alimentos.

O enfoque ampliado de SAN impõe mudanças radicais voltadas para o enfrentamento dessas desigualdades, seja por seu caráter universalista, seja porque pressupóe o alcance de bens públicos como a sustentabilidade social, econômica e ambiental, o direito humano, os direitos de cidadania, a alimentação adequada e saudável e a cultura. Nesta perspectiva, necessariamente os determinantes da fome são enfrentados e o enfoque sobre o tema muda. Ou seja, não basta superar a fome se os processos pelos quais as ações são implementadas violam direitos, se os programas são vistos como favores, se agridem os valores culturais dos grupos, se reforçam relaçôes assistencialistas, paternalistas, de dominação. Se temporariamente as pessoas deixam de passar fome, mas continuam sendo violadas em seus direitos fundamentais e permanentemente submetidas aos mesmos processos que geram estas violaçóes, não se pode dizer que a SAN tenha sido garantida. 
Essa mesma perspectiva pode ser pensada para o enfoque que restringe a compreensão de SAN como alimento seguro, porque considera apenas a qualidade sanitária do alimento. Não há como pensar o alimento fora da relação humana e de todos os processos culturais, psicossociais e econômicos que a marcam. Alimento seguro, do ponto de vista sanitário, não é necessariamente adequado nutricionalmente, culturalmente, socialmente. Se os processos pelos quais esse alimento é produzido geram desigualdades sociais e econômicas e agridem culturas estabelecidas, não se pode considerar que a SAN tenha sido alcançada.

Diante das questôes aqui destacadas, pode-se considerar que o enfoque ampliado de SAN, consagrado na II CNSAN, contribui para reforçar determinados princípios e valores na sociedade ao questionar os processos referentes à conquista de direitos; à ampliação dos riscos ambientais, sociais e econômicos; à violação da identidade cultural dos povos e de suas formas de apropriação dos recursos; às desigualdades que vêm sendo geradas na sociedade e ao modo como o sistema alimentar constitui parte dessa dinâmica. A SAN torna-se, assim, um componente decisivo para a construção de um projeto de desenvolvimento que articule e integre crescimento econômico, social e humano, contribuindo para o resgate de valores éticos, de eqüidade, de cidadania e cultura.

\section{Indicadores de Segurança Alimentar e Nutricional}

A discussão em torno dos indicadores de SAN vem acompanhando o debate conceitual, e no plano internacional o Comitê de Segurança Alimentar Mundial (FAO, 2001) propôs um conjunto de indicadores para monitorar a situação de SAN no mundo, incluindo dados sobre disponibilidade de alimentos; estado de saúde e nutrição; condiçōes demográficas, ambientais, econômicas, políticas, sociais, climáticas; acesso aos alimentos; renda; gastos com alimentação; condições de moradia; saneamento; hábitos alimentares e acesso à atenção à saúde.

No Brasil, foram propostos os seguintes parâmetros para monitorar a situação de SAN no plano nacional: 1) Disponibilidade física de alimentos per capitalano; 2) Nível de autonomia do país na oferta de alimentos (auto-suficiência); 3) Poder de compra do salário mínimo e da renda familiar; 4) Poder de compra dos estratos mais pobres da população; 5) Proporção de população assistida por programas de segurança alimentar; 6) Perfil do consumo alimentar por faixa etária ou estrutura de consumo alimentar; 7) Prevalência estimada de baixo peso, sobrepeso e obesidade na população maior de 18 anos, segundo o Índice de Massa Corporal (IMC), por sexo; 8) Prevalência de déficit antropométrico, de peso e estatura, para menores de 5 anos; 9) Índice de indigência ou proporção de indigentes (Consea, 2004).

Esse conjunto de indicadores possibilita acessar tanto os determinantes da SAN (ou parte deles) como, entre outros, a disponibilidade de alimentos e a renda quanto suas conseqüências (ou parte delas), por exemplo, no estado nutricional. O atual Conselho Nacional de Segurança Alimentar e Nutricional (Consea) dispõe de um grupo de trabalho que vem discutindo o tema com o objetivo de propor também um conjunto de indicadores que possa ser parte de um sistema de monitoramento da situação alimentar e nutricional do país. A matriz definida pelo Consea para seleção e análise dos indicadores de monitoramento engloba as seguintes dimensões de SAN: 1) produção e disponibilidade de alimentos; 2) renda e condiçôes de vida; 3) acesso à alimentação e tendências de consumo; 4) saúde e acesso aos serviços de saúde; 5) perfil nutricional dos grupos populacionais segundo vários critérios (de renda, etário, étnico-racial); 6) acesso à educação; 7) políticas e programas públicos relacionados com a SAN; 8) segurança dos alimentos quanto a resíduos químicos e nutrientes (Consea, 2007).

Por se tratar de um conceito multidimensional, ou seja, que envolve múltiplas dimensões de análise, como a econômica, a social, a cultural, a política, a biológica, entre outras, seria possível pensar em um indicador sintético que contemplasse as múltiplas variáveis que o constituem. Esses indicadores, no entanto, referem-se ao âmbito da nação, cabendo, então, pensar como acessar a SAN no nível individual ou familiar. 


\section{Fome e Insegurança Alimentar: implicações para definição de indicadores e desenhos de investigação}

Aproximar-se de processos tão entrelaçados como a fome, a pobreza, a indigência e a insegurança alimentar, com o intuito de compreender suas especificidades e formular intervençôes mais adequadas ao seu enfrentamento, impõe delimitar com maior precisão as fronteiras entre diferentes conceitos e indicadores utilizados para expressá-los. Cabe, portanto, rever distintas abordagens teórico-conceituais que vêm sendo construídas em torno desses problemas e analisar de que forma afetam o desenho de investigações neste campo.

\section{Diferenciações entre Fome, Pobreza, Indigência e Insegurança Alimentar}

A alimentação é uma dimensão humana inalienável e, portanto, a não-satisfação neste âmbito da vida é sempre considerada expressão gritante da pobreza. Essa relação é tão estreita que os indicadores de indigência (condição ainda mais adversa que a pobreza) comumente adotados se confundem com o dimensionamento da fome. $\mathrm{O}$ valor da linha de indigência corresponde à renda necessária para a aquisição de uma cesta básica alimentar capaz de suprir necessidades nutricionais de um indivíduo, na verdade as necessidades energéticas (Rocha, 1998, 2005). Diante disso, caberia perguntar: quem não dispõe de renda para se alimentar não estaria passando fome? Como diferenciar, então, indigência e fome? Além disso, considerando-se as possíveis carências de micronutrientes, a qualidade sanitária e nutricional, além dos demais aspectos referentes à cultura e à dimensão simbólica da alimentação, não se pode afirmar que a satisfação de necessidades energéticas significa SAN. Cabe considerar também que as preferências cotidianas de consumo não seguem uma lógica otimizadora, como os procedimentos metodológicos que definem a cesta básica de forma normativa com base nos alimentos mais baratos que permitem cobrir as necessidades nutricionais. Ao contrário, superam tanto os preceitos estritamente nutricionais quanto os econômicos, levando em conta a praticidade dos alimentos e seu valor simbólico.

Na realidade, há situaçôes em que as pessoas podem não dispor de renda monetária para suprir suas necessidades alimentares e nutricionais, mas têm acesso a recursos não monetários que as impedem de passar fome (doações, inserção em programas sociais e redes de apoio, plantio para consumo próprio etc.). Por isso, uma definição de fome amplamente aceita refere-se à falta de disponibilidade e de acesso ao alimento em quantidade e qualidade que atenda às necessidades nutricionais, estando diretamente associada à relação que as pessoas estabelecem, com base em suas capacidades, com os diferentes recursos (não só monetários) e mercadorias disponíveis na sociedade (Sen, 1981). É importante destacar que, do ponto de vista da SAN, o comprometimento de outras necessidades essenciais (para além das nutricionais) na garantia do acesso à alimentação é igualmente inaceitável.

Certamente, em uma sociedade de mercado, o principal recurso para o acesso ao alimento é a renda e, por isso, ele vem sendo amplamente utilizado para dimensionar situações de IA ou de vulnerabilidade à fome (Lavínas, 1998). Assim, na prática os dois fenômenos (fome e indigência) se confundem.

No sentido de definir indicadores que diferenciem fome e indigência, a fome crônica tem sido associada a situações em que a alimentação habitual não garante as necessidades energéticas do organismo, mensuradas por meio de indicadores antropométricos. $\mathrm{O}$ recurso a este tipo de indicador também vem sendo utilizado como resposta às dificuldades técnicas de avaliar o consumo alimentar habitual dos indivíduos e suas correspondentes necessidades energéticas (Monteiro, Mondini \& Costa, 2000).

Nesses termos, a fome vem sendo dimensionada com base em valores de reservas energéticas na população adulta, sendo o valor do IMC inferior aos $18,5 \mathrm{~kg} / \mathrm{m}^{2}$ preconizados como indicador para este dimensionamento. A associação da fome com déficits energéticos em adultos (magreza) é justificada pelo argumento de que nem sempre a desnutrição infantil é originária da deficiência energética das dietas, podendo ser ocasionada por deficiência específica de macro e micronutrientes, desmame precoce e infecções comuns à infância (Monteiro, 1995; WHO, 1995). 
Algumas questões se colocam quando se opta por usar esse tipo de indicador. Por que associar fome apenas à deficiência energética em adultos? Por que a carência de outros nutrientes (vitaminas, minerais) não caracteriza fome? Josué de Castro considerava que a fome incluía não apenas a inanição, ou seja, "O que os povos de língua inglesa chamam de starvation", mas também a "fome parcial", a chamada "fome oculta, na qual pela falta permanente de determinados elementos nutritivos, em seus regimes habituais, grupos inteiros de populações se deixam morrer lentamente de fome, apesar de comerem todos os dias" (Castro, 1946: 21).

Se os déficits nutricionais também na infância não são apenas causados por aporte energético insuficiente das dietas, não há por que dimensionar a fome em uma população apenas com base em indicadores de déficits energéticos em adultos.

Mesmo considerando fome como deficiência energética, também não caberia avaliá-la apenas com base em dados antropométricos (déficits de peso e estatura para idade), porque ela não se expressa unicamente por meio de déficits de crescimento e peso. Os dados antropométricos, especialmente os de estatura, refletem um momento tardio, quando a conseqüência de privaçôes alimentares crônicas já está instalada. Isso não significa que o indivíduo, ou a família, não tenha passado por circunstâncias de privação alimentar, ainda que temporária. A antropometria não seria, portanto, um parâmetro razoável para definir 'por si só' a população assistida por uma estratégia de combate à fome.

Aceitar que a ausência de déficits antropométricos significa inexistência da fome implica desconsiderar adaptaçôes biológicas, comportamentais e sociais que tornam as crianças submetidas a estresse nutricional no início da vida mais eficientes metabolicamente e levam, em algumas circunstâncias, à redução de atividades espontâneas para poupar energia (Anjos et al., 1992). Trata-se de elementos que têm permitido associar a IA inclusive à obesidade (Alaimo, Olson \& Frongillo, 2001).

O sobrepeso e a obesidade indicam que o organismo apresenta já por longo período um balanço energético positivo, ou seja, uma diferença positiva entre a ingestão energética e o gasto energético. $O$ gasto energético tem três componentes: a Taxa Metabólica Basal (TMB), que corresponde a 50 a $70 \%$ do gasto total, dependendo do nível de atividade física do indivíduo; a ação dinâmica específica dos alimentos (10\%) e a atividade física. A redução na ingestão alimentar causa uma redução tanto na TMB, por um mecanismo de adaptação biológica, quanto na atividade física, por processos de adaptação comportamental/social, embora este não seja o determinante único nem principal do problema. Mas o gasto se reduz, gerando um balanço energético positivo, sem que necessariamente isso signifique um consumo alimentar adequado (Wahrlich \& Anjos, 2001).

Além disso, a fome e a IA não são fenômenos meramente biológicos, da mesma forma que pobreza não é apenas uma questão monetária. Quem é capaz de afirmar que um ser humano forçado a sobreviver de restos de alimentos ou de ração animal, ainda que não tenha sido afetado biologicamente, de forma que os indicadores antropométricos ou clínicos sejam capazes de detectar, não passa fome ou não se encontra em situação de IA? (Valente, 2002). Ou, ao contrário, quem pode afirmar que uma pessoa com excesso de peso não passe também por privaçôes?

Essas consideraçôes reforçam, por um lado, a pertinência de compreender a IA e a fome como questôes acima de tudo sociais e humanas em todas as suas dimensões. São inseguras as situações em que não há disponibilidade e acesso temporário ou permanente a uma alimentação que não constitua risco à saúde, seja adequada às necessidades nutricionais tanto em termos quantitativos quanto qualitativos e se baseie em hábitos saudáveis e digna do ponto de vista humano e social.

Além disso, destaca-se a importância de construir indicadores de fome e IA, no âmbito individual e familiar, que sejam capazes de perscrutar dimensões que a renda e a antropometria não permitem. Mais ainda, para além de um indicador ou outro é importante considerar as múltiplas situaçōes de vulnerabilidade vividas pelas famílias.

Quais são as alternativas ao recurso a indicadores que dimensionem a acessibilidade alimentar com base na renda ou na antropometria? 
A mensuração da fome no contexto da rede de segurança nutricional nacional dos Estados Unidos, integrada por um conjunto de 15 programas a cargo do Serviço Nacional de Nutrição do Departamento de Agricultura Americana, baseou-se no auto-relato da condição de segurança alimentar familiar, em resposta a questôes incluídas nas pesquisas nacionais de consumo a partir de 1977. Essas questôes referiam-se à suficiência e qualidade da alimentação (quantidade e tipo de alimento consumido) e à sustentabilidade dessa condição ao longo do tempo, segundo a percepção e concepção da família (Bickel \& Andrews, 2002).

Os domicílios foram agrupados em três segmentos, de acordo com o tipo de resposta: aqueles que relataram uma alimentação adequada em termos de quantidade e qualidade; os que relataram quantidade suficiente, mas comprometimento da qualidade (não consumiam o tipo de alimento que deveriam, segundo sua concepção) e os que relataram que a suficiência em termos de quantidade não era sustentável ao longo do tempo, ou seja, em determinados períodos a alimentação disponível para a família era insuficiente. Essas informações possibilitaram identificar em que medida as alteraçôes na renda familiar ao longo do tempo refletiam modificações na quantidade e qualidade da alimentação. Os dados permitem, assim, não só uma aproximação à percepção subjetiva da família em relação à alimentação, mas também aos aspectos comportamentais objetivos ao longo do tempo (Bickel \& Andrews, 2002).

Os principais resultados dessa pesquisa sinalizaram que o comportamento em termos de consumo responde, de modo seqüencial e ordenado, à renda familiar disponível, ou seja, quando há uma redução da renda, a primeira atitude da família é consumir alimentos mais baratos, visando a manter a quantidade (a qualidade é comprometida). Uma vez esgotadas essas possibilidades, diante de uma retração mais drástica da renda, a quantidade de alimentos consumidos então se reduz.

Essas informações permitem compreender como as famílias gerenciam a situação de IA a que são submetidas e alertam para o fato de que a fome pode ser uma realidade mesmo na ausência de sintomas clínicos (Bickel \& Andrews, 2002).

Seguindo princípios semelhantes, o Centro de Pesquisa Alimentar e Ação de Washington D.C. desenvolveu um projeto de identificação da fome na comunidade infantil que deu origem a uma escala de risco, baseada em indicadores que refletiam aspectos da IA dos domicílios (alteração na quantidade e qualidade da alimentação) (Bickel \& Andrews, 2002).

A partir da experiência desses estudos conjugados à análise de outras estratégias de mensuração da IA, um questionário de segurança alimentar passou a constituir suplemento da Pesquisa Populacional dos Estados Unidos (anual), o que permitiu produzir escalas de medidas da severidade de privações alimentares, classificando-se os domicílios segundo as seguintes condições: com segurança alimentar; com IA sem fome e com IA com fome. Com base nessa metodologia, constatou-se que $90 \%$ dos domićlios americanos encontravam-se em situação de segurança alimentar, os demais enfrentavam situação temporária de insegurança ao longo do ano e, destes, 3,1\% chegavam a passar fome em determinados períodos pela impossibilidade de comprar alimentos em quantidade suficiente.

Dados da Pesquisa Nacional de Saúde da População do Canadá, baseados no auto-relato das famílias, indicam que, em 2001, $8 \%$ da população haviam comprometido a qualidade e a quantidade do consumo alimentar por falta de recursos financeiros. A situação não se limitava a famílias de baixa renda, pois $12 \%$ dos domicílios de renda média apresentaram algum comprometimento alimentar (Koc, 2002).

O uso desse tipo de método no Brasil, suas potencialidades e limites serão aqui problematizados. Cabe, por ora, destacar que, em síntese, embora as informações antropométricas possam indicar condições severas em termos de privação alimentar, por refletirem as conseqüências de um processo de mais longo prazo, elas não são suficientes para abordar o fenômeno da fome em todas as suas dimensões. De igual modo, não possibilitam que o problema seja tratado como um processo, pois expressam uma situação já instalada. Metodologias que reflitam situações de risco diferenciado, e que, portanto, caracterizem de fato diferentes momentos de vulnerabilidade avançam tanto em seu potencial explicativo quanto nos caminhos que abrem em termos de identificação de grupos de risco. 


\section{Diferenciações entre Pobreza e Desigualdade de Renda}

$\mathrm{Na}$ abordagem das relações entre indicadores socioeconômicos e SAN, outra diferenciação que pode ser feita em termos analíticos é entre pobreza e desigualdade de renda. Em contextos em que há pobreza generalizada, o acesso a bens e serviços tende a ser comprometido de forma mais generalizada também. Em contexto de desigualdade mais acentuada, como no caso brasileiro, a localização das famílias tende a ser um dado importante, mesmo no âmbito municipal, pois entre famílias de baixa renda pode haver diferenças no acesso a bens e serviços públicos de acordo com a localização do domicílio. As famílias residentes nas áreas urbanas, ou em determinados bairros do município, tendem a ter mais acesso a bens e serviços mesmo sendo tão pobres quanto outras que residam em áreas onde há menor disponibilidade destes bens. Isso ocorre porque existe um volume de riquezas circulantes que está distribuído de forma desigual (ou seja, não é um país pobre de forma generalizada, mas desigual), e mesmo alguns segmentos dentre os pobres podem usufruir de forma indireta desse desenvolvimento econômico.

Feitas, então, essas diferenciações entre fome, desnutrição, pobreza, desigualdade e insegurança alimentar e nutricional, cabe analisar as possibilidades e os desafios no uso da Escala de Insegurança Alimentar, como uma alternativa a todos os indicadores acima descritos. O que de fato este indicador possibilita mensurar? Qual a sua correlação com os indicadores socioeconômicos que constituem determinantes da insegurança alimentar e nutricional e vêm sendo utilizados para mensurar a fome? Qual a concepção de SAN que sustenta este indicador, e como ela se correlaciona com o conceito da II CNSAN?

\section{A Escala de Segurança Alimentar e Nutricional à Luz do Conceito de SAN}

A metodologia desenvolvida e utilizada pela Universidade de Cornell para avaliação da segurança alimentar em nível familiar foi adaptada e validada, no Brasil, pela Universidade Estadual de Campinas (Unicamp) e pelo Observatório de Políticas de Segurança Alimentar e Nutrição da Universidade de Brasília (UnB), além de outras instituições (universidades federais da Paraíba e de Mato Grosso e Instituto de Pesquisas da Amazônia), com apoio técnico e financeiro dos ministérios da Saúde e do Desenvolvimento Social e Combate à Fome e da Organização Pan-Americana da Saúde (Opas).

Este método possibilita o diagnóstico rápido da situação de segurança alimentar familiar, constituindo-se em uma ferramenta importante para a avaliação de políticas públicas. Consiste em um questionário contendo 15 perguntas que medem níveis diferentes de IA. Classifica-se a IA utilizando-se o somatório do número de respostas afirmativas às questôes, resultando em um escore, que categoriza as famílias (Unicamp, 2004).

A Ebia (Segall-Corrêa et al., 2004) classifica os distintos graus de segurança alimentar na família em:

I) Situação de segurança alimentar.

II) Insegurança alimentar leve - receio ou medo de sofrer insegurança alimentar no futuro próximo, reflete o componente psicológico da insegurança e o problema de qualidade da alimentação da família.

III) Insegurança alimentar moderada - restrição na quantidade de alimentos na família.

IV) Insegurança alimentar grave - fome entre adultos e/ou crianças da família.

O questionário adaptado da Ebia consta de 15 perguntas centrais fechadas, com resposta do tipo sim ou não, sobre a experiência nos últimos três meses de insuficiência alimentar em seus diversos níveis de intensidade, que vão da preocupação de que a comida possa acabar até a vivência de passar todo o dia sem comer. Das 15 perguntas, sete referem-se a membros da família menores de 18 anos. 
Cada resposta afirmativa do questionário de IA corresponde a 1 ponto, sendo a pontuação da escala sua soma, variando em uma amplitude de 0 a 15 pontos:

a) Segurança alimentar $=0$.

b) Insegurança alimentar leve $=1-5$ pontos em famílias com menores de 18 anos; 1-3 pontos em famílias apenas com adultos.

c) Insegurança alimentar moderada = 6-10 pontos em famílias com menores de 18 anos; 4-6 pontos em famílias apenas com adultos.

d) Insegurança alimentar grave $=11-15$ pontos em famílias com menores de 18 anos; 6-10 pontos em famílias apenas com adultos;

Os pontos de corte da IA foram definidos por critério da assinação eqüidistante, isto é, a cada nível corresponde um mesmo número de pontos: cinco para cada nível nas famílias com menores e três nas famílias sem menores, sendo que à IA grave correspondem dois pontos, por serem oito as perguntas dirigidas a adultos (Marín-León et al., 2005).

A escala parte do mesmo pressuposto do método utilizado nos Estados Unidos, qual seja, a diferenciação entre situaçôes de fome que implicam o consumo insuficiente de alimentos, ou seja, não ter o suficiente para se alimentar ou não ter nada para se alimentar - incluindo a sensação física da fome (identificada pela escala como grau severo de IA) -, e a IA mais ampla, que pode ser identificada, por exemplo, com o fato de ter de comer as mesmas coisas durante toda a semana ou de cortar as porções um pouco menores a cada dia, o que envolve também a ansiedade por ter o alimento suficiente e o fato de o alimento ser adquirido de formas socialmente aceitáveis. Assim, a escala possibilita diferenciar a IA com fome e sem fome e pressupõe que a mensuração da IA envolve a avaliação de aspectos quantitativos, qualitativos, psicológicos e sociais (Olson, Frongillo \& Kendall, 1994).

\section{Questóes sobre a Escala}

A concepção que subsidia a escala de SAN refere-se mais à escassez alimentar e menos à segurança alimentar e nutricional de forma mais ampla, tal como proposta pela II CNSAN. Ela acessa, portanto, dimensões específicas do conceito, particularmente as situações que culminam em problemas de acesso à alimentação: "As medidas de IA devem ser capazes de refletir os diferentes níveis e possibilidades de acesso aos alimentos" (Unicamp, 2004: 9). Para além da situação de privação alimentar em diferentes graus, medidos pela escala, outra dimensão do conceito que também está presente é a qualidade da alimentação da família. No entanto, trata-se da concepção de qualidade na percepção da família, que não necessariamente representa a dimensão de qualidade presente no conceito de SAN, que envolve qualidade nutricional e sanitária.

Em todos os grupos focais que foram operacionalizados para validar a escala no contexto brasileiro, a questão da segurança alimentar esteve correlacionada a alimentos livres de agrotóxicos e higienicamente seguros (Unicamp, 2004). No estudo americano, as questôes referentes à qualidade estiveram correlacionadas principalmente com a monotonia da dieta (Olson, Frongillo \& Kendall, 1994).

Ainda que a validação da escala, tanto no Brasil quanto nos EUA, tenha contemplado uma análise da concepção das famílias sobre o que seria alimento de qualidade ou alimentação saudável, com base em grupos focais, este tipo de método não possibilita inferir que tal concepção seja representativa de qualquer outra população além daquela que participou do processo de validação. Ela serve, no entanto, para garantir que as questões incluídas no questionário contemplem essas diferentes perspectivas. Isso resultou na necessidade de formular várias perguntas de modo a garantir informação suficiente para a análise da segurança alimentar, tanto na perspectiva da família quanto na dos indivíduos (Briefel \& Sempos, 1992). 
Pode-se considerar que a escala possibilita uma abordagem da segurança alimentar capaz de identificar situações prévias de privação vividas pelas famílias, antes que se instalem quadros de desnutrição, que já expressam um percurso mais crônico de fome. Permite, assim, identificar diferentes gradientes de IA, recuperando de certa forma fases de um processo (ou retratos de diferentes fases de um processo vivido pelas famílias), e não apenas situações estáticas. Nesse sentido, em sua concepção, a escala avança em relação à mensuração da fome com base em indicadores antropométricos.

No entanto, é sempre importante destacar que se trata da concepção da família do que seja segurança ou IA, e as perguntas feitas direcionam-se fundamentalmente para problemas de acesso ao alimento ou para dificuldades da família em manter um perfil próprio de consumo alimentar impostas por tais problemas. Continua a pergunta sobre qual seria esse perfil de consumo.

\section{Um Exemplo de Utilização da Ebia: estudo de Campos Elíseos no município de Duque de Caxias, RJ}

Para exemplificar a utilização da Ebia em estudos desenvolvidos no país, recentemente foi realizada uma pesquisa no segundo distrito do município de Duque de Caxias denominado Campos Elíseos, situado na área metropolitana do Rio de Janeiro, com o objetivo de avaliar o grau de IA e nutricional na população. Trata-se de uma amostra representativa de Campos Elíseos (1.085 domicílios), conglomerada em três estágios de seleção, distribuídos em 75 setores censitários.

Como característica dessa população, destaca-se que, apesar de a maioria das famílias ter acesso às condições básicas de saneamento, um percentual significativo dos domicílios não se beneficiava da distribuição pública de água $(35,7 \%)$ e do consumo de água filtrada (36,4\%). É importante ressaltar que o acesso à água constitui um elemento importante no âmbito da SAN, considerando inclusive que se trata de um alimento. No entanto, os problemas relacionados ao acesso à água não são necessariamente associados pelas famílias à IA, ou seja, as suas "condições para comprar, receber ou produzir sua alimentação" e "oferecer uma alimentação saudável, variada e em quantidade suficiente", conforme expresso no questionário da Ebia. De modo geral, os domicílios eram compostos por famílias numerosas, com a escolaridade do chefe da família em sua maioria inferior a oito anos de estudos e com quase a metade da população estudada composta por indivíduos com cor da pele não-branca (Tabela 1).

Tabela 1 - Prevalências expandidas das características dos domicílios avaliados. Campos Elíseos, Duque de Caxias, RJ, 2005

\begin{tabular}{lcc}
\hline \multicolumn{1}{c}{ Indicadores socioeconômicos } & $\%$ & Intervalo de confiança (95\%) \\
\hline Renda familiar mensal per capita em tercis (reais) & 33,6 & \\
O a 138,00 & 32,9 & \\
138,10 a 270,00 & 33,5 & \\
Acima de 270,00 & & $3,8-7,8$ \\
Escolaridade do chefe da família & 5,8 & $46,1-56,6$ \\
Analfabeto & 51,4 & $18,1-26,9$ \\
Básico incompleto (<8 anos) & 22,5 & $15,7-23,4$ \\
Básico completo (8-10 anos) & 19,6 & $-0,07-1,2$ \\
Fundamental completo (1 1-14 anos) & 0,7 & \\
Universitário (> 15 anos) &
\end{tabular}


Tabela 1 - Prevalências expandidas das características dos domicílios avaliados. Campos Elíseos, Duque de Caxias, RJ, 2005 (continuação)

\begin{tabular}{|c|c|c|}
\hline Indicadores socioeconômicos & $\%$ & Intervalo de confiança (95\%) \\
\hline \multicolumn{3}{|l|}{ Classificação Abipeme' } \\
\hline A & 0,1 & $-0,03-0,20$ \\
\hline$B$ & 6,2 & $3,5-9,0$ \\
\hline C & 44,6 & $38,5-50,7$ \\
\hline D & 38,8 & $32,9-44,8$ \\
\hline E & 10,3 & $6,8-13,3$ \\
\hline \multicolumn{3}{|l|}{ Saneamento básico } \\
\hline \multicolumn{3}{|l|}{ Lixo } \\
\hline Serviço público & 89,5 & $84,9-94,1$ \\
\hline Outros & 10,5 & $5,8-15,0$ \\
\hline \multicolumn{3}{|l|}{ Água } \\
\hline Serviço público & 64,3 & $56,1-72,5$ \\
\hline Outros & 35,7 & $27,4-43,9$ \\
\hline \multicolumn{3}{|l|}{ Presença de filtro } \\
\hline $\operatorname{Sim}$ & 63,6 & $58,5-68,6$ \\
\hline Não & 36,4 & $31,3-41,4$ \\
\hline \multicolumn{3}{|l|}{ Esgoto } \\
\hline Serviço público & 80,4 & $73,9-86,8$ \\
\hline Outros & 19,6 & $13,1-26,0$ \\
\hline \multicolumn{3}{|l|}{ Número de pessoas por domicílio } \\
\hline $1-4$ & 55,9 & $51,0-60,9$ \\
\hline $5-8$ & 40,2 & $35,2-45,1$ \\
\hline$>8$ & 3,9 & $2,1-5,5$ \\
\hline \multicolumn{3}{|l|}{ Cor da pele ${ }^{2}$} \\
\hline Branco & 30,9 & $26,2-35,5$ \\
\hline Não-branco & 69,1 & $64,4-73,7$ \\
\hline
\end{tabular}

1 - Associação Brasileira de Institutos de Mercado; 2 - Avaliação realizada pelos entrevistadores, considerando não-brancos os indivíduos com cor da pele parda, negra, indígena e amarela.

Aplicando a Ebia nas famílias residentes em Campos Elíseos, foi possível constatar (Figura 1) que mais da metade apresentou algum grau de IA, principalmente nos domicílios com crianças e adolescentes. Apenas 38,6\% das famílias responderam que não apresentavam IA, ou seja, restrições quanto ao acesso à aquisição e consumo de alimentos. 
Figura 1 - Prevalências expandidas de Segurança e Insegurança Alimentar (IA) classificadas pela Escala Brasileira de Insegurança Alimentar (Ebia). Campos Elíseos, Duque de Caixas, RJ, 2005

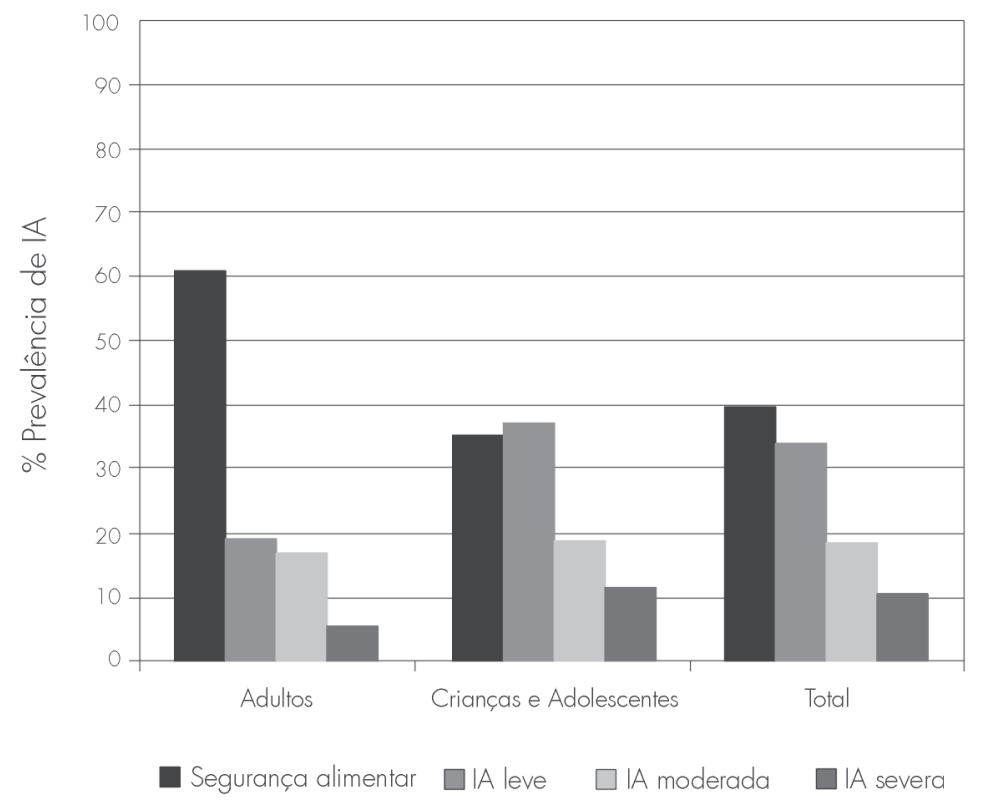

Fonte: Unicamp (2004).

Comparando-se os resultados encontrados com os dados da Pesquisa Nacional por Amostragem de Domicílios (PNAD) de 2004, observou-se que essa população apresenta um grau de segurança alimentar (38,6\%) inferior aos valores encontrados para a área urbana do Brasil (66,7\%) e para o Rio de Janeiro (71,7\%). Esses resultados revelam que um percentual elevado de famílias apresenta percepção de fome e privação de alimentos, apesar de o distrito de Campos Elíseos se localizar muito próximo ao centro da cidade do Rio de Janeiro e ser considerado um importante pólo de indústrias do estado, que abriga a segunda refinaria do país, a Duque de Caxias (Reduc). O município de Duque de Caxias ocupa o segundo lugar em arrecadação de ICMS no estado, perdendo apenas para a capital, de acordo com as informaçôes da Fundação Cide (Cide, 2007).

Para tentar entender os possíveis fatores associados à IA nessa população, avaliou-se a associação entre as variáveis socioeconômicas utilizadas de acordo com o grau de IA, como apresentado na Tabela 2.

Tabela 2 - Prevalências expandidas do grau de Insegurança alimentar (IA) classificada pela Ebia ${ }^{1}$ de acordo com variáveis socioeconômicas. Campos Elíseos, Duque de Caxias, RJ, 2005

\begin{tabular}{|c|c|c|c|c|c|}
\hline Características dos domicílios (n) & SAN \% & IA leve \% & A moderada \% & A severa \% & $\begin{array}{c}\text { p-valor }{ }^{2} \\
\left(X^{2}\right)\end{array}$ \\
\hline $\begin{array}{l}\text { Renda familiar mensal per capita em tercis - reais } \\
\text { ( } n=1.065 \text { domicílios) }\end{array}$ & & & & & $<0,0001$ \\
\hline 0 a 138,00 & 21,1 & 40,8 & 24,6 & 13,5 & \\
\hline 138,10 a 270,00 & 47,8 & 32,6 & 16,5 & 3,1 & \\
\hline Acima de 270,00 & 70,6 & 21,5 & 6,2 & 1,7 & \\
\hline
\end{tabular}


Tabela 2 - Prevalências expandidas do grau de Insegurança alimentar (IA) classificada pela Ebia ${ }^{1}$ de acordo com variáveis socioeconômicas. Campos Elíseos, Duque de Caxias, RJ, 2005 (continuação)

\begin{tabular}{|c|c|c|c|c|c|}
\hline Características dos domicílios (n) & SAN $\%$ & IA leve \% & A moderada \% & A severa \% & $\begin{array}{c}\text { p-valor }{ }^{2} \\
\left(X^{2}\right)\end{array}$ \\
\hline $\begin{array}{l}\text { Escolaridade do chefe da família } \\
\text { ( } n=1.094 \text { pessoas) }\end{array}$ & & & & & 0,01 \\
\hline Analfabeto & 42,6 & 24,9 & 15,6 & 16,9 & \\
\hline Fundamental incompleto & 40,4 & 32,8 & 20,6 & 6,2 & \\
\hline Fund. compl. + Ensino Médio incompleto & 55,8 & 28,4 & 9,7 & 6,1 & \\
\hline Ensino Médio completo & 63,4 & 29,5 & 6,3 & 0,8 & \\
\hline Universitário completo & 50,5 & 49,5 & 0 & 0 & \\
\hline $\begin{array}{l}\text { Classificação Abipeme }^{3} \\
\text { ( } \mathrm{n}=805 \text { domićlilios) }\end{array}$ & & & & & $<0,0001$ \\
\hline A & 45,6 & 54,4 & 0 & 0 & \\
\hline B & 82,8 & 16,7 & 0,5 & 0 & \\
\hline C & 62,7 & 26,8 & 9,0 & 1,5 & \\
\hline D & 29,0 & 39,3 & 22,7 & 9,0 & \\
\hline E & 33,8 & 25,3 & 24,4 & 16,5 & \\
\hline \multicolumn{6}{|l|}{$\begin{array}{l}\text { Saneamento básico } \\
\text { ( } \mathrm{n}=1.085 \text { domicílios) }\end{array}$} \\
\hline Lixo & & & & & 0,60 \\
\hline Rede pública & 47,5 & 31,5 & 15,7 & 5,3 & \\
\hline Outro & 47,1 & 28,8 & 14,6 & 9,5 & \\
\hline Água & & & & & 0,70 \\
\hline Rede pública & 49,4 & 30,4 & 14,6 & 5,6 & \\
\hline Outro & 43,9 & 32,8 & 17,5 & 5,8 & \\
\hline Esgoto & & & & & 0,27 \\
\hline Rede pública & 49,2 & 31,2 & 14,7 & 4,9 & \\
\hline Outro & 39,6 & 31,6 & 19,5 & 9,3 & \\
\hline Presença de filtro & & & & & 0,01 \\
\hline Sim & 52,7 & 27,5 & 15,6 & 4,2 & \\
\hline Não & 36,9 & 38,5 & 16,1 & 8,5 & \\
\hline $\begin{array}{l}\text { № de pessoas/domicílio } \\
(\mathrm{n}=1.085 \text { domicílios })\end{array}$ & & & & & $<0,0001$ \\
\hline $1-4$ & 54,8 & 26,6 & 14,7 & 3,9 & \\
\hline $5-8$ & 25,9 & 45,9 & 18,5 & 9,7 & \\
\hline$>8$ & 29,2 & 13,0 & 15,1 & 42,7 & \\
\hline
\end{tabular}


Tabela 2 - Prevalências expandidas do grau de Insegurança alimentar (IA) classificada pela Ebia ${ }^{1}$ de acordo com variáveis socioeconômicas. Campos Elíseos, Duque de Caxias, RJ, 2005 (continuaçãa)

\begin{tabular}{lccccc}
\hline Características dos domićlios $(\mathrm{n})$ & SAN \% & IA leve \% & $\mid$ A moderada \% & $\begin{array}{c}\mid \text { A severa \% } \\
\text { P-valor }{ }^{2} \\
\left(X^{2}\right)\end{array}$ \\
\hline $\begin{array}{l}\text { Cor de pele } \\
\text { (n=1.257 pessoas) }\end{array}$ & & & & 0,01 \\
$\quad$ Branca & 48,3 & 37,3 & 11,9 & 2,5 & \\
$\quad$ Não-branca & 47,5 & 28,1 & 17,0 & 7,4 & \\
\hline
\end{tabular}

1 - Escala Brasileira de Segurança Alimentar; 2 - Comparação entre os níveis de classificação da Ebia; 3 - Associação Brasileira de Institutos de Pesquisa de Mercado; 4 - Avaliação realizada pelos entrevistadores, considerando não-brancos os indivíduos com cor da pele parda, negra, indígena e amarela.

Com base nesses resultados, observou-se que menor renda familiar per capita, menor escolaridade do chefe da família, menor aquisição de bens de consumo, maior número de pessoas no domicílio, ausência de filtro e chefe da família não-branco são fatores associados ao aumento significativo na freqüência de algum grau de IA ( $p$-valor < 0,05) na família. Esses resultados foram semelhantes aos dados coletados na PNAD 2004, ou seja, famílias com insegurança alimentar e nutricional apresentam condiçōes insatisfatórias quanto aos indicadores socioeconômicos. Também no estudo de validação da Ebia foi encontrada uma relação inversa entre IA e o nível de rendimento monetário das famílias (Unicamp, 2004), e em estudos que utilizaram a escala em meio urbano também foi encontrada uma associação entre IA e raça/cor, densidade demográfica intradomiciliar, escolaridade e condições precárias de moradia (Leão, 2005; Panigassi, 2005).

No entanto, cabe considerar que $21,1 \%$ das famílias com renda per capita inferior a $\mathrm{R} \$ 138,00$ (que representa menos da metade do salário mínimo atual) apresentam situação de SAN, indicando que outros fatores, além da renda, estão contribuindo para a ampliação do acesso à alimentação. Ainda assim, isso não significa que essas famílias não estejam comprometendo o acesso a outros bens ou serviços essenciais para garantir a alimentação, situação igualmente indesejável do ponto de vista da SAN entendida de forma mais ampliada.

Por sua vez, aproximadamente $30 \%$ das famílias com renda superior a $\mathrm{R} \$ 270,00$ (que representa em torno de 2/3 do salário mínimo atual) também foram classificadas em condição de IA. Esses dados podem indicar uma situação conjuntural crítica, que compromete a estrutura econômica familiar, bem como a própria utilização da renda disponível e, conseqüentemente, a aquisição de alimentos, transpondo as famílias para condições de IA temporária.

Outra questão que deve ser considerada é que a percepção de IA por parte das famílias é relativa, e não absoluta. Mesmo dispondo de renda acima do último tercil de renda familiar mensal per capita, essas famílias se consideram em situação de IA. Sua percepção é marcada pelos perfis de acesso e consumo compartilhados no contexto social em que vivem e também ao longo de sua própria trajetória de vida. Portanto, a concepção atual se constrói com base em uma comparação com situações distintas previamente experimentadas, quando podem ter vivenciado condições mais seguras do ponto de vista alimentar do que as atuais, além da própria influência do perfil de consumo urbano, marcado pelos valores disseminados nos meios de comunicação.

Um resultado importante observado relaciona-se à associação significativa entre cor da pele e IA. Na Tabela 2, é possível constatar que indivíduos com cor da pele branca têm menor probabilidade de serem classificados com IA, principalmente nos graus moderado e severo. Por sua vez, indivíduos com cor da pele não-branca têm probabilidade maior de serem classificados nos estágios mais severos de IA. 
Raça ou cor da pele tem sido extensivamente utilizada na literatura médica e de saúde pública para medir as diferenças sociais nos desfechos de saúde, principalmente nas últimas décadas e especialmente nos Estados Unidos, onde há uma vasta literatura que relaciona raça e disparidades sociais em desfechos de saúde, indicando que a raça é um importante preditor para a saúde (Travassos \& Williams, 2004). Naquele país, negros são tidos, nos termos da maioria dos indicadores socioeconômicos e de saúde, como pessoas em desvantagem em relação a brancos. No Brasil, são ainda escassas, porém crescentes, as publicaçôes que avaliam as desigualdades socioeconômicas que caracterizam as relaçôes raciais e étnicas no país (Coimbra Jr. \& Santos, 2000; Olinto \& Olinto, 2000; Telles, 2003), indicando que indivíduos não-brancos, mesmo com alto nível educacional, não dispõem das mesmas oportunidades de emprego e salários que os brancos. Portanto, as desigualdades não são determinadas apenas pela educação formal (embora seja um fator importante, como destacado a seguir), mas também por outros fatores, como, por exemplo, valores e práticas que reforçam os preconceitos raciais nas relaçôes sociais cotidianas e, conseqüientemente, as dificuldades de acesso a bens e serviços e ao próprio emprego para indivíduos não-brancos. Os resultados encontrados em Campos Elíseos instigam para o debate na sociedade sobre as disparidades sociais relacionadas a raça ou cor da pele no nosso país e seus determinantes.

Por fim, não há como deixar de ressaltar a forte associação entre os fatores aqui estudados - por exemplo, o efeito da renda familiar e da escolaridade do chefe da família na aquisição dos bens de consumo -, avaliada por meio da classificação da Associação Brasileira de Institutos de Pesquisa de Mercado (Abipeme). Para que os resultados encontrados possam contribuir na discussão dos possíveis determinantes da SAN, serão necessárias novas análises que controlem, ou pelo menos minimizem, o efeito de colinearidade entre essas variáveis, ou seja, é preciso buscar modelos de análise, como os modelos de equaçóes estruturadas, que estimem exatamente o quanto cada variável socioeconômica se associa com a SAN, isoladamente e/ou combinadas entre si.

Em síntese, observou-se que a questão da SAN ultrapassa o limite do acesso das famílias a uma alimentação adequada, tanto do ponto de vista quantitativo como qualitativo, incluindo as condiçóes diferenciadas que apresentam na utilização da própria renda e a relação com cada contexto de vida. Além disso, o quadro de desigualdades sociais descrito, que indica a importância de questōes relacionadas, por exemplo, a raça/cor, merece ser considerado de forma mais aprofundada para que seja possível compreender a interação entre os diferentes fatores correlacionados com a SAN.

\section{Considerações Finais}

A Ebia apresenta uma alternativa às tradicionais formas de mensuração da fome, apoiadas em indicadores antropométricos de desnutrição em adultos ou na superposição entre indigência (baseada em dados de renda) e fome. Essa escala reforça a perspectiva processual das múltiplas condições de insegurança às quais as famílias estão submetidas, permitindo a identificação de diferentes gradientes de severidade nesse quadro.

Um possível limite que vem sendo associado ao método refere-se ao fato de ele captar a situação de IA na ótica das famílias, ou seja, as questôes identificadas referem-se à percepção das famílias sobre seu próprio quadro de insegurança, não estando baseadas em indicadores 'objetivos' como os antropométricos, ou de consumo alimentar.

No entanto, se, por um lado, a Ebia permite conclusões referenciadas, a percepção das famílias, ao basearse na concepção que fundamenta esta escala, possibilita também uma abordagem relativa, e não absoluta, da segurança alimentar. $\mathrm{O}$ acesso à alimentação e as decisões em torno da quantidade e da qualidade dos alimentos que seriam necessárias para estar livre da fome ou da IA são socialmente construídos e vão além da definição biológica de um mínimo absoluto de sobrevivência. A definição de uma cesta básica alimentar (como a que pauta o conceito de indigência) é uma arbitrariedade, pois nem mesmo as necessidades biológicas dos indivíduos são as mesmas, considerando as diferentes características etárias, de sexo, de atividade física, além de outras variáveis. Mais ainda, há múltiplas necessidades sociais, culturais, psicológicas e simbólicas que condicionam a alimentação 
e se constroem tendo em vista uma referência não absoluta, mas relativa, uma vez que se baseiam na comparação da quantidade e qualidade de alimentos de que indivíduos e grupos sociais dispõem de acordo com o estilo de vida compartilhado em cada sociedade. O perfil de consumo alimentar é socialmente compartilhado e, portanto, o senso de privação e de insegurança está intimamente relacionado a expectativas e a pontos de vista sociais sobre o que é justo e quem tem direito de desfrutar o que em cada contexto. Em áreas metropolitanas especialmente marcadas por forte desigualdade social (como no caso aqui analisado), a disponibilidade de determinados alimentos e produtos cria expectativas de consumo que não são acessíveis a todos e podem se expressar em formas de privação relativa, identificadas pelas famílias como situações de IA. Como os gradientes de privação são diferenciados, bem como as múltiplas vulnerabilidades, mesmo algumas famílias que em determinado corte temporal não seriam classificadas como em condição de insegurança podem estar vulneráveis a ela e se ver, em uma conjuntura subseqüente, submetidas a algum tipo de privação, ainda que temporária.

Acessar a percepção de IA pode ser um avanço, na medida em que permite uma aproximação com a subjetividade e, portanto, com a relatividade da situação vivida por cada família, de modo a enriquecer a análise de variáveis objetivas ou diferenciações mais estanques que classificam os grupos com base apenas na distinção entre os que passam e os que não passam por privação.

Foi possível perceber que as condições socioeconômicas são fatores que se correlacionam fortemente com a IA avaliada com base na Ebia. As variáveis utilizadas corroboram a hipótese de que para erradicar a fome e a pobreza é primordial o investimento em uma distribuição mais eqüitativa da renda, do trabalho e do acesso a bens e serviços públicos.

Enfim, a utilização da Ebia como instrumento que enriquece a compreensão sobre a fome e o acesso aos alimentos, aliada a outros tipos de análises, tende a contribuir no planejamento de políticas públicas para o combate à IA.

\section{Referências}

ALAIMO, K; OLSON, C. M. \& FRONGILLO JR., E. A. Low family income and food insufficiency in relation to overweight in US children. Archives of Pediatrics \& Adolescent Medicine, 155: 1.161-1.167, 2001.

ANJOS, L. A. et al. Vigilância nutricional em adultos: experiência de uma unidade de saúde atendendo população favelada. Cadernos de Saúde Pública, 8: 50-56, 1992.

BICKEL, G. W. \& ANDREWS, M. A evolução do programa de cupom alimentação e a mensuração da fome dos Estados Unidos. In: TAKAGI, M.; SILVA, J. G. \& BELIK, W. (Orgs.) Combate à Fome è̀ Pobreza Rural. São Paulo: Instituto de Cidadania, 2002.

BRIEFEL, R. R. \& SEMPOS, C. T. Dietary methodology workshop for the Third National Health and Nutrition Examination Survey. March 1986. Vital Health Stat, 4(27):1-108, Mar 1992.

CASTRO, J. de. Geografia da Fome. 1. ed. Rio de Janeiro: O Cruzeiro, 1946.

CENTRO DE INFORMAÇÕES DE DADOS DO RIO DE JANEIRO (CIDE). Disponível em: <www.cide.rj.gov.br>. Acesso em: 26 fev. 2007.

COIMBRA JR., C. E. A. \& SANTOS, R. V. Saúde, minorias e desigualdade: algumas teias de inter-relações, com ênfase nos povos indígenas do Brasil. Ciência e Saúde Coletiva, 5: 125-130, 2000.

CONSELHO NACIONAL DE SEGURANÇA ALIMENTAR E NUTRICIONAL (CONSEA). Documento de Referência da II Conferência Nacional de Segurança Alimentar e Nutricional. Brasília: Consea, 2004. 
CONSELHO NACIONAL DE SEGURANÇA ALIMENTAR E NUTRICIONAL (CONSEA). Documento Base da III Conferência Nacional de Segurança Alimentar e Nutricional. Brasília: Consea, 2007.

FOOD AND AGRICULTURE ORGANIZATION (FAO). Evaluación de la Situación de la Seguridad Alimentaria Mundial. Comitê de Seguridad Alimentaria Mundial. Roma: FAO, 2001.

FÓRUM BRASILEIRO DE SEGURANÇA ALIMENTAR E NUTRICIONAL (FBSAN). Carta do V Encontro do Fórum Brasileiro de Segurança Alimentar e Nutricional. Belo Horizonte, 2006. Disponível em: <www.fbsan.org.brlcartadacidadedebelohorizonte.doc>. Acesso em: 20 set. 2006.

KOC, M. Revisitando a segurança alimentar: perspectives canadenses. In: TAKAGI, M.; SILVA, J. G. \& BELIK, W. (Orgs.) Combate à Fome e à Pobreza Rural. São Paulo: Instituto de Cidadania, 2002.

LAVINAS, L. Acessibilidade Alimentar e Estabilização Econômica no Brasil nos Anos 90. Brasília: Ipea, 1998. (Textos para Discussão, 591)

LEÃO, M. Fome e Insegurança Alimentar no Distrito Federal, 2005. Dissertação de Mestrado, Brasília: Departamento de Nutrição, Faculdade de Ciências da Saúde, Universidade de Brasília.

MALUF, R.; MENEZES, F. \& VALENTE, F. Contribuição ao tema da segurança alimentar no Brasil. Revista do Núcleo de Estudos e Pesquisas em Alimentação Nepa/Unicamp. Cadernos de Debate, 4: 66-88, 1996.

MARÍN-LEÓN et al. A percepção de insegurança alimentar em famílias com idosos em Campinas, São Paulo, Brasil. Cadernos de Saúde Pública, 21(5): 1.433-1.440, 2005.

MONTEIRO, C. A. A dimensão da pobreza, da fome e da desnutrição no Brasil. Estudos Avançados, 9(24): 195207, 1995.

MONTEIRO, C. A.; MONDINI, L. \& COSTA, R. B. L. Mudanças na composição e adequação nutricional da dieta familiar nas áreas metropolitanas do Brasil (1988-1996). Revista de Saúde Pública, 34: 251-258, 2000 .

OLINTO, M. T. A. \& OLINTO, B. A. Raça e desigualdades entre as mulheres: um exemplo no sul do Brasil. Cadernos de Saúde Pública, 16: 1.137-1.142, 2000.

OLSON, C. M; FRONGILLO, E. A. \& KENDALL, A. Measuring the prevalence of hunger and food insecurity in communities: principles and methods. In: LEIDENFROST, N. B. \& WILKINS, J. L. (Eds.) Food Security in the United States: a guidebook for public issues education. Washington: USDA, 1994.

PANIGASSI, G. Inquérito Populacional sobre a Percepção da Segurança Alimentar Intra-Familiar no Município de Campinas, SP, 2005. Tese de Doutorado, Campinas: Universidade Estadual de Campinas.

PESSANHA, L. Segurança Alimentar como um Princípio Orientador de Politicas Públicas: implicaçôes e conexōes para o caso brasileiro, 1998. Tese de Doutorado, Rio de Janeiro: Programa de Pós-Graduação de Ciências Sociais em Desenvolvimento, Agricultura e Sociedade, Universidade Federal Rural do Rio de Janeiro.

ROCHA, S. On Statistical Mapping of Poverty. Rio de Janeiro: Ipea, 1998. (Textos para Discussão, 553)

ROCHA, S. Pobreza no Brasil: afinal, de que se trata? Rio de Janeiro: Fundação Getulio Vargas, 2005.

SEGALL-CORRÊA et al. Projeto Acompanhamento e Avaliação da Segurança Alimentar de Famílias Brasileiras: validação de metodologia e de instrumento de coleta de informação. Campinas: Departamento de Medicina Preventiva e Social/Unicamp, Opas, Ministério de Saúde, 2004. (Relatório Técnico) 
SEN, A. Poverty and Famines: an essay on entitlement and deprivation. Oxford: Clarendon Press, 1981.

TELLES, E. Racismo à Brasileira: uma nova perspectiva sociológica. Rio de Janeiro: Relume Dumará, 2003.

TRAVASSOS, C. \& WILLIAMS, D. R. The concept and measurement of race and their relationship to public health: a review focused on Brazil and the United States. Cadernos de Saúde Pública, 20(3): 660-678, 2004.

UNIVERSIDADE ESTADUAL DE CAMPINAS (UNICAMP). Acompanhamento e Avaliação da Segurança Alimentar de Famílias Brasileiras: validação de metodologia e de instrumento de coleta de informação- urbanol rural, 2004. (Relatório Técnico)

VALENTE, F. Direito Humano à Alimentação: desafios e conquistas. São Paulo: Cortez, 2002.

WAHRLICH, V. \& ANJOS, L. A. Aspectos históricos e metodológicos da medição e estimativa da taxa metabólica basal: uma revisão da literatura. Cadernos de Saúde Pública, 7(4): 801-817, 2001.

WORLD HEALTH ORGANIZATION (WHO). Physical Status: the use and interpretation of anthropometry. Geneva: WHO, 1995. (WHO Technical Report Series) 



\title{
Alimentação e Nutrição dos Povos Indígenas no Brasil
}

\author{
Maurício Soares Leite, Ricardo Ventura Santos, \\ Carlos Everaldo Álvares Coimbra Jr. e Silvia Ângela Gugelmin
}

\begin{abstract}
A ntes de qualquer discussão sobre o perfil nutricional dos povos indígenas, é importante enfatizar a considerável sociodiversidade envolvida. No Brasil, são mais de duzentas etnias, que somam uma população estimada de 450.000-600.000 pessoas, a depender da fonte, e falam aproximadamente 170 línguas diferentes. As 611 terras indígenas ocupam 15\% do território nacional (Figura 1). Assim, estamos lidando com povos socioculturalmente diferenciados em relação à sociedade envolvente e também entre si, com cosmologias, línguas, formas de subsistência, organização social e sistemas políticos próprios. Em contraste com essa diversidade, os indígenas constituem menos de $1 \%$ do contingente populacional total do país, embora se encontrem em franco crescimento demográfico (IBGE, 2005; Pagliaro, Azevedo \& Santos, 2005; Ricardo \& Ricardo, 2006).

No passado, os povos indígenas que hoje habitam o que é o território brasileiro dependiam, em menor ou maior grau, da agricultura, caça, pesca e colheita para a obtenção de alimentos. A interação com as frentes de expansão, ocasionando a instalação de novos regimes econômicos e a diminuição dos territórios, entre outros fatores, levou a drásticas alterações em seus sistemas de subsistência. Além das etnias com parcelas expressivas de suas populações vivendo em áreas urbanas, portanto não mais produzindo diretamente os alimentos consumidos, há atualmente outras habitando áreas nas quais as pressões populacionais, aliadas a ambientes degradados, comprometem a manutenção da segurança alimentar. Há significativas diferenças na extensão das terras indígenas, em geral com aquelas localizadas em áreas de mais antiga colonização (como no Nordeste, Sudeste e Sul) bastante reduzidas em tamanho (Figura 1). Há de se mencionar também a utilização da mão-de-obra indígena em muitas regiōes, como no corte manual da cana-de-açúcar no Sudeste ou na extração de borracha nativa na Amazônia, em troca de remuneraçôes que não garantem a aquisição de alimentos em quantidade e qualidade satisfatórias. Assim, além da sociodiversidade, a compreensão da dimensão alimentar e nutricional dos povos indígenas precisa levar em consideração o padrão de intensa transformação cultural, social e econômica em curso.
\end{abstract}


Figura 1 - Distribuição das terras indígenas no Brasil

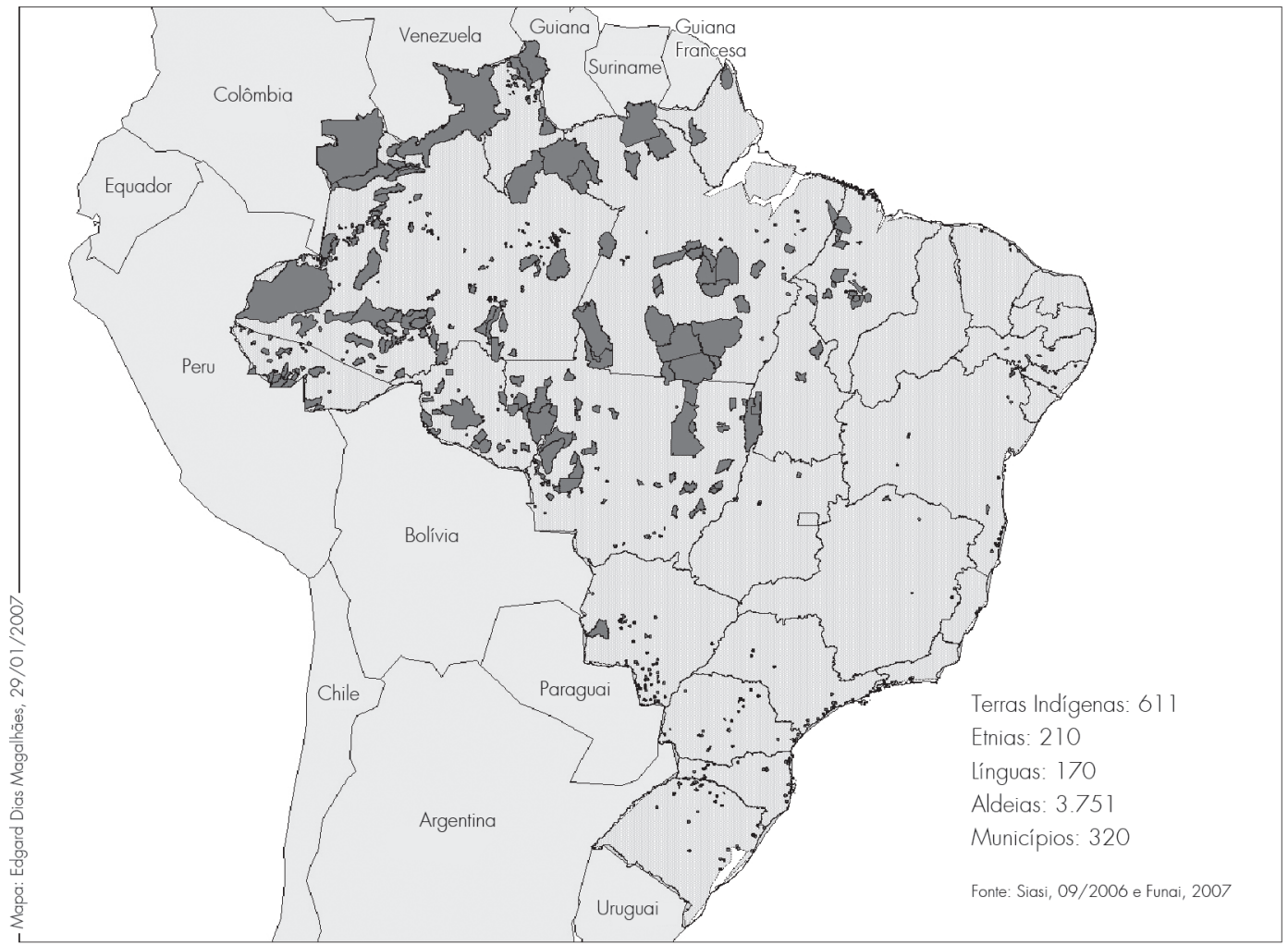

\section{Fontes de Dados e Aspectos Metodológicos}

O conhecimento das condições de alimentação e nutrição do conjunto dos povos indígenas esbarra em uma série de obstáculos. Um dos principais é o ainda incipiente sistema de coleta de dados em saúde responsável por essa parcela da população brasileira. A escassez de dados não se limita às dimensões alimentar e nutricional, e resulta naquela que já foi descrita como uma "danosa invisibilidade demográfica e epidemiológica" (Coimbra Jr. \& Santos, 2000: 131), que acaba por comprometer o planejamento, a execução e a avaliação das ações em saúde entre as sociedades indígenas. Garnelo, Macedo e Brandão (2003) e Santos e Coimbra Jr. (2003) chamam a atenção para o fato de que mesmo os mais básicos indicadores demográficos, como taxas de mortalidade infantil, esperança de vida ao nascer e principais causas de morbidade e mortalidade, não estão disponíveis, de maneira fidedigna, nas bases de dados oficiais. Soma-se a isso o fato de que apenas a partir do Censo Populacional de 1991 foi incluída a categoria "indígena", mas ainda assim sem especificação da etnia do entrevistado. O resultado é que mesmo as grandes bases de dados demográficos apresentam limitações para a realização de análises mais detalhadas sobre as condiçōes de vida e saúde dos povos indígenas (Garnelo, Macedo \& Brandão, 2003; IBGE, 2005; Pagliaro, Azevedo \& Santos, 2005; Santos \& Coimbra Jr., 2003).

Em 2000, um ano depois de assumir a responsabilidade pelas ações em saúde entre os povos indígenas, a Fundação Nacional de Saúde (Funasa) iniciou a estruturação do Sistema de Informação da Atenção à Saúde Indígena (Siasi), que proveria sistematicamente informaçōes sobre saúde indígena. No entanto, seis anos depois, o sistema funciona apenas parcialmente, com sérios problemas de cobertura e qualidade das informações (Sousa, Scatena \& Santos, 2007). Mais recentemente, a Funasa deu início à implantação de um Sistema de Vigilância 
Alimentar e Nutricional (Sisvan). Até o momento não há, contudo, uma avaliação da cobertura do sistema, da qualidade ou da representatividade dos dados por ele reunidos.

Além dos problemas relativos à coleta sistemática de dados entre essas populações, chama a atenção a inexistência de inquéritos abrangentes, que possam descrever o perfil nutricional. Exceçóes a este quadro correspondem à elaboração do I e do II Mapas da Fome em Terras Indígenas (Verdun, 1994; Inesc/Peti-MN/ Anaí-BA, 1995), que buscaram identificar a ocorrência de problemas nutricionais entre os povos indígenas do país e alguns de seus determinantes. No entanto, os estudos basearam-se na coleta de informaçóes por meio de questionários enviados às comunidades, não envolvendo inquéritos nutricionais propriamente ditos. A despeito das limitaçôes, ambos os levantamentos revelaram um quadro caracterizado pela precariedade, no qual dificuldades na obtenção de alimentos eram enfrentadas por grande parte das populações descritas. Entre as causas do problema, a escassez de terras e o aumento da pressão sobre os recursos naturais configuravam-se como primordiais.

Outrossim, contamos com os resultados das pesquisas realizadas em diversas comunidades indígenas. Essas pesquisas são, em sua maioria, estudos de caso, ou seja, trabalhos realizados com uma única ou poucas comunidades, geralmente durante curtos períodos. Embora possam sugerir a existência de tendências ou padrôes epidemiológicos específicos, são limitadas as possibilidades de generalização. Quaisquer extrapolaçôes para outros grupos devem, portanto, ser vistas com extrema cautela, diante não apenas do grande número de etnias indígenas, mas também do elevado grau de diversidade que apresentam. Considerando-se ainda o papel dos contextos locais na determinação dos perfis de saúde e nutrição e a notável heterogeneidade que daí resulta mesmo quando se avaliam subgrupos de uma mesma etnia -, compreende-se por que ainda hoje não é possível traçar um panorama satisfatório das condições nutricionais do conjunto dos povos indígenas.

Quando se examina a literatura existente sobre o assunto, revela-se, portanto, um contraste marcante entre o número de sociedades indígenas existentes no país e a pequena quantidade de estudos realizados. A década de 1990, contudo, caracterizou-se por um incremento significativo no número de estudos que visavam à descrição do estado nutricional propriamente dito, de modo geral por meio da antropometria. Até então, apenas uma pequena parte das pesquisas que envolviam a análise de dados antropométricos entre populações indígenas tinha na caracterização do perfil nutricional seu objetivo principal (Santos, 1993).

Em um esforço de consolidação dos dados disponíveis, no início da década de 1990 foram feitas as primeiras revisões da literatura, com enfoques distintos. Dufour $(1991,1992)$ sumariza os dados disponíveis sobre alimentação e nutrição de populações indígenas amazônicas, o que incluiu dados antropométricos e a descrição geral de suas dietas e, para alguns grupos, a adequação em termos calóricos e de nutrientes. Santos (1993) aborda a literatura sobre crescimento físico de crianças indígenas no Brasil, discutindo, entre outros aspectos, o impacto nutricional dos processos de mudanças socioeconômicas decorrentes do contato com não-índios e as possibilidades de interpretação dos dados antropométricos.

Em termos metodológicos, os estudos disponíveis à época foram descritos como numericamente reduzidos, referindo-se essencialmente a grupos amazônicos, incluindo crianças e adultos e baseando-se em inquéritos transversais e na análise de medidas de peso, estatura, perímetro braquial e dobras cutâneas (Santos, 1993). Essa descrição ainda é, de modo geral, válida, embora desde então tenham se multiplicado os estudos sobre alimentação e nutrição entre populaçōes indígenas no país. Os estudos mais recentes ainda se caracterizam por seu caráter transversal e, embora em alguns casos incluam outros métodos de avaliação nutricional, como a impedância bioelétrica (Hurtado-Guerrero et al., 2003; Fagundes et al., 2004; Lourenço, 2006) e a análise do consumo alimentar (Ribas et al., 2001; Lima, 2004; Schweighofer, 2006), a antropometria é o método adotado na maior parte deles. O conceito de segurança alimentar avaliada com base em escores vem sendo também utilizado em alguns estudos (Schweighofer, 2006). Uma mudança significativa diz respeito à ampliação das pesquisas para outras regiōes além da Amazônia (Cardoso et al., 2003; Ribas \& Philippi, 2003; Menegolla et al., 2006; Meyerfreund, 2006; Pícoli, Carandina \& Ribas, 2006) e à diversificação das faixas etárias avaliadas, em alguns 
casos incluindo adolescentes e idosos como segmentos específicos de análise (Capelli \& Koifman, 2001; HurtadoGuerrero et al., 2003; Leite et al., 2006; Lourenço, 2006).

Um problema registrado nas revisões da década de 1990 dizia respeito à dificuldade de determinar a comparabilidade dos resultados devido à heterogeneidade das formas de apresentação (Santos, 1993). Variavam, entre outros aspectos, as formas de apresentação dos dados, as populações-referência e os pontos de corte adotados para o diagnóstico nutricional. Nesse aspecto, houve um progresso significativo: a maior parte dos estudos desenvolvidos após meados da década de 1990 tem se baseado, para fins de avaliação nutricional, na populaçãoreferência e nos pontos de corte recomendados pela Organização Mundial da Saúde (OMS) (WHO, 1995). Algumas publicações, como Fagundes et al. (2004), Lima (2004) e Menegolla et al. (2006), já fazem uso das curvas propostas pelo Centers for Disease Control and Prevention (CDC) (Kuczmarski et al., 2000), e é provável que um número crescente de estudos passe a utilizar as novas curvas de crescimento divulgadas pela OMS (WHO, 2006), o que pode em alguma medida afetar a comparabilidade dos dados disponíveis (ver capítulo 3 , "Referências antropométricas"). Nos estudos mais recentes, ainda variam significativamente as faixas etárias sob análise, além do detalhamento dos resultados observados. Portanto, as dificuldades relativas à comparabilidade dos resultados ainda não foram de todo superadas.

\section{Perfil Nutricional dos Povos Indígenas}

Embora persista uma relativa escassez de dados, os estudos mais recentes sobre a situação nutricional confirmam, em linhas gerais, o quadro que se delineava no início da década de 1990 (Santos, 1993). Ao mesmo tempo, porém, os trabalhos reafirmam a heterogeneidade e a importância dos contextos locais na determinação dos perfis nutricionais. Ainda hoje observam-se altas prevalências de desnutrição infantil. No segmento adulto, por sua vez, parece estar em curso uma mudança importante do perfil nutricional, com o surgimento de casos de sobrepeso e obesidade, por vezes em números significativos.

Por si só, esta breve descrição já permite supor a complexidade do perfil nutricional que buscamos delinear aqui. Por outro lado, ela corresponde a uma simplificação da real diversidade de situaçóes registradas pelos estudos. Observam-se grandes variaçóes na importância relativa de cada problema de uma comunidade para outra, situação descrita nas próximas seções.

\section{Crianças e Adolescentes}

No que se refere ao perfil nutricional de crianças, as primeiras revisões evidenciavam crianças com peso e estatura mais baixos que os de crianças não-indígenas da mesma idade, embora mantendo uma relativa adequação de suas proporções corporais, quando avaliadas por meio do índice peso/estatura. Santos (1993) chamou a atenção para o fato de que, adotados os critérios diagnósticos recomendados pela OMS (WHO, 1995), as prevalências de desnutrição encontradas superavam mesmo aquelas encontradas nas regiões Norte e Nordeste do país. Sinais clínicos de desnutrição seriam, ainda, encontrados em alguns estudos (Dufour, 1991).

As investigações ainda hoje revelam prevalências moderadas ou elevadas de desnutrição infantil, por vezes superiores àquelas registradas nas camadas mais pobres da população brasileira (Coimbra Jr. \& Santos, 1991; Escobar, Santos \& Coimbra Jr., 2003; Ribas \& Philippi, 2003; Leite et al., 2003, 2006; Menegolla et al., 2006; Orellana et al., 2006). A Tabela 1 apresenta as prevalências de baixo peso e baixa estatura para a idade identificadas em estudos publicados a partir da década de 1990. A título de exemplo, quando adotados os critérios diagnósticos recomendados pela OMS (WHO, 1995), entre os menores de 5 anos os déficits de estatura podem variar de 10\% (Capelli \& Koifman, 2001) a mais de 50\% (Martins \& Menezes, 1994; Leite, 2007). Entre os menores de cinco anos, considerando-se que os inquéritos de âmbito nacional mais recentes revelam prevalências médias de baixa 
estatura e de baixo peso para a idade da ordem de 10,5\% (Bemfam/DHS, 1997) e 4,6\% (IBGE, 2005), respectivamente, o registro de déficits estaturais e ponderais da ordem de 50\% e 60\% evidenciam a gravidade do quadro. Se em alguns estudos as prevalências assemelham-se às médias nacionais e/ou regionais, na maior parte dos casos elas são mais elevadas.

Em várias comunidades investigadas, os déficits em estatura e peso registrados entre crianças indígenas podem refletir condições de alimentação e nutrição amplamente desfavoráveis. Embora haja autores que sugerem que as crianças indígenas poderiam apresentar potenciais de crescimento distintos, de modo que as curvas internacionais não sejam adequadas (ver discussão em Santos, 1993), há fartas indicações de que as alterações antropométricas encontradas refletem em larga medida condições de vida precárias, nas quais prevalecem problemas de ordem nutricional. O Ministério da Saúde declarava, em 2003: "os dados disponíveis indicam, em diversas situações, taxas de morbidade e mortalidade três a quatro vezes maiores que aquelas encontradas na população brasileira geral" (Funasa, 2002: 10). Além disso, no perfil de morbidade dessas comunidades predominam as doenças infecciosas e parasitárias (Funasa, 2003), o que pode comprometer de modo importante o estado nutricional (Santos \& Coimbra Jr., 2003).

O sobrepeso e a obesidade em crianças indígenas, por outro lado, ainda parecem problemas distantes, mas devem ser monitorados, particularmente naquelas comunidades em que há casos diagnosticados entre os adultos ou já entre os adolescentes. Há registros de sobrepeso infantil em alguns estudos (Capelli \& Koifman, 2001; Ribas et al., 2001; Lima, 2004; Menegolla et al., 2006; Orellana et al., 2006).

Se há um número expressivo de estudos sobre crianças indígenas, o estado nutricional de adolescentes tem sido avaliado em um número muito restrito de investigações (Capelli \& Koifman, 2001; Gugelmin, 2001; Leite et al., 2003, 2006; Lima, 2004), o que limita sobremaneira as análises comparativas. Tal como veremos no caso dos adultos, o sobrepeso é uma questão que tem sido destacada em alguns trabalhos, notando-se, contudo, muita variação. Assim, entre os Xavánte, o sobrepeso atinge 27,5\% dos indivíduos entre 10 e 17 anos (Leite et al., 2006); entre os Baré, 7,1\% (Lima, 2004).

Tabela 1 - Freqüência de baixa estatura e baixo peso para a idade ( $\leq-2$ escores z das medianas da populaçãoreferência do National Center of Health and Statistics (NCHS) em crianças indígenas menores de 5 anos, reportadas em estudos selecionados

\begin{tabular}{lcccc}
\hline \multicolumn{1}{c}{ Fonte } & Etnia (localização) & Ano de coleta & \multicolumn{2}{c}{ Percentual de déficit } \\
\hline & & & Peso/idade & Estatura/idade \\
\hline Martins \& Menezes (1994) & Parakanã (PA) & 1991 & 10,1 & 50,6 \\
Capelli \& Koifman (2001) & Parakateiê (PA) & 1994 & - & 10,0 \\
Ribas et al. (2001) & Teréna (MS) & 1999 & 8,0 & 16,0 \\
Alves, Morais \& Fagundes-Filho (2002) & Teréna (MS) & 1996 & 5,5 & 20,7 \\
Morais et al. (2003) & Alto Xingu (MT) & 1992 & 5,0 & 20,4 \\
Weiss (2003) & Enawenê-Nawê (MT) & 1990 & 50,0 & 17,8 \\
Leite (2007) & Pakaanóva-Warí (RO) & 2003 & 52,5 & 62,7 \\
Leite et al. (2006) & Xavánte (MT) & 1997 & 17,2 & 31,7 \\
Pícoli, Carandina \& Ribas (2006) & Guaraní (MS) & 2003 & 18,2 & 34,1 \\
Schweighofer (2006) & Teréna (MS) & 2004 & 5,9 & 11,8 \\
Orellana et al. (2006) & Suruí (RO) & 2005 & 12,4 & 31,4 \\
\hline
\end{tabular}




\section{Adultos}

O que desponta na literatura produzida sobre a situação nutricional de adultos indígenas em anos recentes é o aumento dos casos de obesidade e de doenças associadas, como hipertensão arterial, diabetes mellitus e dislipidemias (Vieira Filho, Russo \& Novo, 1983; Fleming-Moran et al., 1991; Santos \& Coimbra Jr., 1996; Cardoso et al., 2001; Gugelmin \& Santos, 2001; Lima et al., 2001; Leite et al., 2003; Lourenço, 2006; Meyerfreund, 2006). Este cenário tem sido interpretado como resultante de transformaçōes socioeconômicas que vêm tendo lugar entre essas sociedades.

Em parte, tais achados podem ser atribuídos à associação entre as modificaçôes por que passam as dietas tradicionalmente consumidas e aquelas referentes aos padrões de atividade física. No tocante à alimentação, as mudanças observadas indicam a redução do consumo de alimentos tradicionais, em favor do consumo de alimentos industrializados e mesmo de cultivos introduzidos. Por outro lado, parecem se alterar também os padrões tradicionais de atividade física, como decorrência de alterações importantes nas estratégias de subsistência e nos padrōes de assentamento. Uma fração ainda mais reduzida das análises aborda esse tipo de aspecto (Santos \& Coimbra Jr., 1996; Gugelmin \& Santos, 2001). De modo geral, os dados indicam uma redução nos níveis de atividade física, devida, em parte, a um maior engajamento em novas formas de trabalho remunerado que requerem níveis de atividade menos intensos do que aqueles necessários às estratégias de subsistência anteriormente praticadas.

Tabela 2 - Freqüência de sobrepeso e obesidade (IMC $\geq 25 \mathrm{~kg} / \mathrm{m}^{2}$ ) em adultos indígenas, reportada em estudos selecionados

\begin{tabular}{|c|c|c|c|c|c|c|}
\hline Fonte & Etnia & Ano de coleta & $\begin{array}{l}\text { Faixa etária } \\
\text { (anos) }\end{array}$ & Sexo & $\begin{array}{c}\text { Sobrepeso } \\
(\%)\end{array}$ & Obesidade $1 \%$ \\
\hline \multirow{2}{*}{ Capelli \& Koifman (200 1) } & \multirow{2}{*}{ Parakatejê (PA) } & \multirow{2}{*}{1994} & \multirow{2}{*}{$\geq 20$} & M & 23,7 & 1,7 \\
\hline & & & & $\mathrm{F}$ & 50,0 & 12,5 \\
\hline \multirow{5}{*}{ Gugelmin \& Santos (2001) } & Xavánte (MT) & \multirow{5}{*}{1994 e 1998} & \multirow{5}{*}{$24-64$} & M & 41,6 & 24,6 \\
\hline & Aldeia São José & & & $F$ & 49,2 & 41,3 \\
\hline & & & & & & \\
\hline & Xavánte (MT) & & & M & 47,5 & 2,5 \\
\hline & Aldeia Etéñitépa & & & F & 42,8 & 4,8 \\
\hline \multirow{6}{*}{ Cardoso et al. (2001) } & \multirow{6}{*}{ Guaraní-Mbya (RJ) } & \multirow{6}{*}{1999} & \multirow{2}{*}{$15-29$} & M & 7,1 & 2,4 \\
\hline & & & & $\mathrm{F}$ & 18,8 & 6,2 \\
\hline & & & \multirow{2}{*}{$30-49$} & M & 38,9 & 11,1 \\
\hline & & & & $F$ & 46,2 & 0,0 \\
\hline & & & \multirow{2}{*}{$\geq 50$} & M & 11,8 & 0,0 \\
\hline & & & & $\mathrm{F}$ & 33,4 & 8,3 \\
\hline \multirow{2}{*}{ Leite (2007) } & \multirow{2}{*}{$\begin{array}{c}\text { Pakaanóva-Warí } \\
\text { (RO) }\end{array}$} & \multirow{2}{*}{2002} & \multirow{2}{*}{$\geq 20$} & M & 12,5 & 2,0 \\
\hline & & & & $F$ & 1,8 & 0,0 \\
\hline \multirow{4}{*}{ Lourenço (2006) } & \multirow{4}{*}{ Suruí (RO) } & \multirow{4}{*}{2004} & \multirow{2}{*}{$20-49$} & M & 50,5 & 11,9 \\
\hline & & & & $\mathrm{F}$ & 34,0 & 24,5 \\
\hline & & & \multirow{2}{*}{$\geq 50$} & M & 12,5 & 0,0 \\
\hline & & & & $F$ & 38,1 & 9,5 \\
\hline \multirow{4}{*}{ Saad (2005) } & \multirow{4}{*}{ Teréna (MS) } & \multirow{4}{*}{2003} & \multirow{2}{*}{$20-59$} & $M$ & 42,7 & 11,6 \\
\hline & & & & $F$ & 41,5 & 18,7 \\
\hline & & & \multirow{2}{*}{$\geq 60$} & M & 19,1 & 14,3 \\
\hline & & & & $\mathrm{F}$ & 8,7 & 39,1 \\
\hline
\end{tabular}


A obesidade, embora de magnitude desconhecida no conjunto da população indígena, alcança prevalências preocupantes em comunidades específicas. Exemplos podem ser observados na Tabela 2, em que a proporção de adultos com Índice de Massa Corporal (IMC) $\geq 25 \mathrm{~kg} / \mathrm{m}^{2}$ supera os $50 \%$ em determinadas faixas etárias (Capelli \& Koifman, 2001; Cardoso et al., 2001; Gugelmin \& Santos, 2001; Lourenço, 2006; Saad, 2005), embora por vezes não alcance prevalências significativas (Leite, 2007). Gugelmin e Santos (2001) diagnosticaram como obesos 39,6\% dos adultos Xavánte entre 24 e 64 anos de idade. Embora poucos estudos analisem a situação dos adolescentes indígenas, há indícios de que o ganho de peso inicia-se ainda nesse grupo de idade (Gugelmin, 2001; Lima, 2004; Leite et al., 2006).

Esses achados assumem um significado especial, por refletirem uma gradual e importante mudança no perfil epidemiológico dessas populações, em que as Doenças Crônicas Não Transmissíveis (DCNT) começam a assumir um papel expressivo. Elas são consideradas um grave problema entre as populações indígenas de outras partes das Américas (Young, 1994). Há que se considerar, ainda, os estudos que atestam a associação entre a desnutrição na infância e a obesidade e desordens associadas na idade adulta (Barker, 2000).

\section{Dieta e Diversidade Alimentar}

No que se refere à dieta, há menos informações que aquelas relativas ao perfil nutricional. Quanto a este aspecto, não mudou significativamente o panorama observado no início da década de 90 . A revisão de Dufour (1991) inclui poucos estudos realizados no Brasil, o que resulta em um quadro bastante fragmentado, em especial quando as análises avaliam a adequação da dieta. Apesar disso, a autora atesta uma ingestão geralmente adequada, em termos protéicos e calóricos, entre os adultos. A situação seria menos favorável para as crianças, devido à baixa densidade nutricional dos alimentos.

Uma descrição, ainda que geral, das dietas dos povos indígenas exige que se façam algumas ressalvas. Há uma tal diversidade, que quaisquer generalizações resultam problemáticas. Por exemplo, há os diferentes ecossistemas ocupados pelos povos indígenas, que incluem ambientes tão distintos como áreas de floresta de terra firme e de várzea nos estados amazônicos, extensas áreas de cerrado em Roraima e na região Centro-Oeste, de caatinga no Semi-Árido nordestino, de mata atlântica nas regiōes litorâneas, e assim por diante (para não mencionar as populaçôes localizadas em ambientes urbanos em todo o país). A imensa diversidade cultural dos povos indígenas exerce papel importante também nesse contexto, na medida em que multiplica as possibilidades apresentadas pelos contextos ambientais, fundiários e socioeconômicos em que se inserem. Algumas das formas contemporâneas de obtenção de alimentos remontam a momentos anteriores ao contato com não-índios. A maior parte dos povos indígenas praticava a agricultura, combinada com a coleta de produtos silvestres e com a caça e/ou a pesca. De modo geral, essas atividades hoje incluem novos elementos, como equipamentos, cultivos, técnicas e mesmo objetivos, já que agora, em alguns casos, incluem a comercialização da produção. No presente, a agropecuária é amplamente praticada por diversos povos, como o são a exploração da madeira, as atividades de mineração, a piscicultura, entre outras. Portanto, os povos indígenas têm uma inserção em uma economia de mercado já, em menor ou maior grau, globalizada.

A questão do acesso aos alimentos entre populações indígenas não pode, contudo, se limitar à discussão das formas pelas quais são produzidos pelas próprias comunidades, devendo obrigatoriamente estender-se a outras formas de obtê-los. A aquisição comercial é uma realidade para a maioria desses povos. O acesso aos recursos monetários que isso exige, por sua vez, inclui o comércio com não-índios, o trabalho remunerado, o recebimento de benefícios sociais (por exemplo, aposentadorias e programas de redistribuição de renda, como o Bolsa Família) e, em alguns casos, a exploração madeireira e mineral. Além disso, não pode ser desconsiderado o acesso a alimentos por intermédio da alimentação escolar e, ainda, de programas de cunho emergencial, como a distribuição de cestas básicas, que hoje se estende a um número significativo de comunidades indígenas. 
De modo geral, os estudos que abordam a questão nutricional mencionam aspectos da dieta dos grupos avaliados, mas usualmente se limitam a descriçóes pouco detalhadas, se considerada a perspectiva das pesquisas nutricionais. É restrito o número de trabalhos cujas análises investigam sistematicamente o consumo de alimentos. Em termos metodológicos, observa-se uma significativa diversidade: são utilizadas técnicas como o recordatório de 24 horas (Ribas et al., 2001; Ribas \& Philippi, 2003; Lima, 2004; Schweighofer, 2006) ou referentes a períodos maiores (Schuch, 2001), observação direta, incluindo ou não pesagens de alimentos (Santos et al., 1997; Forline, 1997; Leite, 2007), e questionários de freqüência alimentar (Lima et al., 2001; Lima, 2004). Variam, além disso, as perspectivas nas quais as análises das dietas se inserem. Algumas enfocam mais diretamente a avaliação da adequação da dieta ou de suas relações com perfil de saúde (Lima et al., 2001; Ribas et al., 2001; Ribas \& Philippi, 2003; Lima, 2004; Schweighofer, 2006), ao passo que outras se voltam para um diálogo com a ecologia humana e a etnologia na discussão dos processos de mudanças socioeconômicas e culturais (Santos et al., 1997; Forline, 1997; Leite, 2007).

De modo semelhante ao observado entre populações nativas de outras partes do mundo (Wirsing, 1985), são múltiplos os relatos de redução da diversidade alimentar rumo a uma dieta rica em carboidratos, gorduras e sódio e pobre em proteínas, principalmente as de origem animal, fibras e micronutrientes (Cardoso et al., 2001; Santos et al., 1997; Vieira Filho et al., 1997). Chama a atenção o registro, entre os Xavánte, de casos de beribéri concomitantemente à descrição de uma dieta monótona e quase exclusivamente limitada ao consumo de arroz polido (Vieira Filho et al., 1997).

Os estudos mais recentes delineiam, assim, um panorama de modo geral menos favorável que aquele descrito no início da década de 90 (Dufour, 1991). Entre os Teréna, os estudos sugerem uma ampla inadequação da dieta, sobretudo em relação a calorias, proteínas e micronutrientes (Ribas et al., 2001; Ribas \& Philippi, 2003; Schweighofer, 2006). Perfil semelhante é registrado por Schuch (2001) entre os Kaingáng, em que mais de 90\% das famílias não atingiam $80 \%$ de adequação da ingestão de cálcio e vitamina $\mathrm{A}$. Como era de esperar, contudo, o quadro não é homogêneo: entre os Guajá, no Maranhão, Forline (1997) encontra uma realidade distinta, em que tanto o aporte calórico como o protéico superam as necessidades nutricionais de crianças, adolescentes e adultos.

\section{Deficiência de Micronutrientes}

Apesar das evidências de inadequação das dietas no caso de muitos povos indígenas, em particular aqueles experimentando rápidos processos de mudanças, os estudos sobre deficiências de micronutrientes praticamente limitam-se à investigação da anemia. Não há levantamentos abrangentes para o conjunto das populações indígenas do país, mas os inquéritos já realizados revelam prevalências alarmantes. Embora o problema não atinja exclusivamente as crianças, é particularmente importante nesta faixa etária.

As crianças mais novas são geralmente mais afetadas: entre os Xavánte, 74\% das crianças menores de 10 anos tiveram anemia diagnosticada, percentual que se elevava a 97\% entre os 6 e 24 meses (Leite et al., 2003). Nesta mesma faixa etária, 82\% das crianças Guaraní (Serafim, 1997), 86\% das Teréna (Morais, Alves \& Fagundes Neto, 2005) e 92\% das Suruí encontravam-se anêmicas (Orellana et al., 2006).

Em pesquisa que abordou a anemia em adolescentes Xavánte, Leite e colaboradores (2003) observaram que esta atinge sobremaneira o sexo feminino, e em especial as mais jovens: entre 10 e 14 anos, 87,5\% das adolescentes encontravam-se anêmicas, em comparação a 50\% dos rapazes. Dos 15 aos 19 anos nenhum rapaz teve diagnóstico de anemia, ao passo que 44,4\% das adolescentes eram anêmicas (Leite et al., 2003).

Entre os adultos, o problema parece atingir especialmente as mulheres em idade reprodutiva. As maiores necessidades nutricionais nessa faixa de idade colocam esse grupo populacional sob maior risco para o desenvolvimento da anemia. Inquérito realizado entre os Xavánte não identificou nenhum caso entre os homens com 
idades entre 15 e 40 anos, ao passo que, na mesma faixa etária, quase um terço das mulheres examinadas (29,4\%) tiveram anemia diagnosticada (Leite et al., 2003). Em alguns estudos os idosos apresentam prevalências expressivas (Hurtado-Guerrero et al., 2003), embora em outros não sejam particularmente atingidos (Leite et al. 2003). De todo modo, devem ser vistos com atenção, por constituírem um grupo etário potencialmente vulnerável à desnutrição energético-protéica, à anemia ferropriva e, naquelas populaçōes em que a obesidade já constitui um problema, também à sua ocorrência.

As condiçōes de vida descritas pelos estudos que incluíram a anemia em suas análises revelam uma etiologia multicausal, em que interagem as deficiências nutricionais e as doenças infecciosas e parasitárias. Em algumas comunidades, a malária pode ser um fator preponderante. As elevadas prevalências registradas entre os menores de 2 anos e entre as mulheres em idade reprodutiva chamam ainda a atenção para o fato de que em muitos casos as mulheres iniciam suas gestações já anêmicas ou com baixas reservas de ferro (Leite et al., 2003).

No que se refere a outros micronutrientes, chama a atenção a ausência de estudos sobre a hipovitaminose A entre sociedades indígenas, considerando-se a existência de etnias situadas em áreas consideradas endêmicas para a carência (Santos \& Coimbra Jr., 2003).

\section{Tendências do Perfil Nutricional Indígena}

Diante da escassez de dados epidemiológicos para os povos indígenas, não é possível descrever, de modo semelhante ao que tem sido feito para a população não indígena, uma trajetória de suas condições nutricionais. Os inquéritos de abrangência nacional - o Estudo Nacional de Despesas Familiares (Endef) realizado em 19741975; a Pesquisa Nacional sobre Saúde e Nutrição (PNSN) desenvolvida em 1989; a Pesquisa Nacional de Demografia e Saúde (PNDS) que aconteceu em 1996 e a Pesquisa de Orçamento Familiar (POF) executada em 2002-2003 - vêm registrando, ao longo das últimas décadas, importante diminuição das prevalências de desnutrição infantil em todo o país (para análises mais detalhadas, ver Monteiro, 2000 e Monteiro, Conde \& Konno, 2005). Em contrapartida, entre os adultos as prevalências de obesidade têm aumentado consistentemente (Kac \& Velásquez-Meléndez, 2003; Monteiro, Conde \& Konno, 2005).

Há um pequeno conjunto de estudos que analisaram a situação nutricional de uma mesma comunidade indígena em diferentes ocasiões. Esses estudos têm revelado, em alguns casos, importantes mudanças, embora não seja possível extrapolar os resultados para o universo das sociedades indígenas do país. Morais e colaboradores (2003) registram, entre crianças do Alto Xingu, em Mato Grosso, o agravamento das condições nutricionais, segundo o índice estatura/idade, entre os anos de 1982 e 1990. Entre os 12 e os 59 meses, a prevalência de baixa estatura dobrou no período (de 10\% para 22\%). Em crianças Teréna, do Mato Grosso do Sul, avaliadas em 1995 e 2002, observou-se uma melhora de alguns indicadores, com um aumento nas medianas dos índices peso/idade peso/estatura nos menores de 24 meses e nos índices peso/estatura e estatura/idade nas crianças entre 24 e 59 meses (Morais, Alves \& Fagundes Neto, 2005). Baruzzi e colaboradores (2001) registraram melhora significativa na magnitude das prevalências de anemia em crianças Panará (Mato Grosso) entre 6 e 59 meses de idade avaliadas em 1978 e em 1998 (de 68\% para 48\%).

Em estudo recente sobre os Suruí de Rondônia, Orellana e colaboradores (2006) registraram uma redução significativa dos déficits de estatura entre os menores de 9 anos (de 46,3\% para 26,7\%), entre 1987 e 2005 . No entanto, o mesmo estudo assinala a persistência de elevadas prevalências de anemia. Concomitantemente, registram o surgimento de casos de sobrepeso entre os menores de 10 anos (3,9\%), diagnóstico ausente no primeiro inquérito. Situando os dados na trajetória histórica do grupo, os autores chamam a atenção para mudanças importantes na realidade suruí. A década de 1980 é caracterizada como um período crítico, em que o envolvimento do grupo com a economia regional resultou no comprometimento das atividades de subsistência e em uma crise na produção de alimentos. Para os últimos anos, por outro lado, os autores registram novas oportunidades de acesso à renda, como 
o trabalho remunerado como agentes de saúde e professores, e ainda o recebimento de aposentadorias, o que possibilita a aquisição comercial de alimentos. Além disso, assinalam a ampliação do acesso aos serviços de saúde, o que pode também haver contribuído para a mudança do perfil.

Entre os adultos, um caso especialmente bem documentado de alterações nutricionais ao longo do tempo diz respeito aos Xavánte, de Mato Grosso. A comparação entre dados antropométricos da década de 1970 e de 1998 revelou uma mudança drástica do perfil de nutrição, com aumento marcante dos valores de peso tanto entre os homens como entre as mulheres, mudança que se reflete no surgimento de casos de hipertensão arterial e diabetes mellitus não insulinodependente (Coimbra Jr., Flowers \& Salzano, 2002; Gugelmin \& Santos, 2001). Uma nuance importante diz respeito ao fato de que duas comunidades com diferentes trajetórias de interação com não-índios foram avaliadas, e apresentaram resultados bastante distintos. Em um intervalo de cerca de trinta anos, as médias de estatura se mantiveram inalteradas em ambas; as médias de peso, contudo, passaram a diferir em cerca de cinco quilos entre os homens, e de 13 quilos entre as mulheres. A mudança do perfil parecia estar atrelada, segundo os autores, à intensidade das transformações socioeconômicas, culturais e ambientais, afetando especialmente a comunidade em que se registraram as maiores modificações no estilo de vida.

Processo semelhante teve lugar entre os Suruí, avaliados em 1988 (Santos \& Coimbra Jr., 1996) e 2005 (Lourenço, 2006). Nesse espaço de tempo, as médias de peso entre os adultos aumentaram em $11 \mathrm{~kg}$ nos homens e em 8,4 kg entre as mulheres, resultando em um quadro em que 60,5\% dos indivíduos com idades entre 20 e 49 anos apresentavam algum grau de sobrepeso. A mudança no perfil antropométrico ocorre concomitantemente com alteraçôes significativas nas práticas de subsistência e na dieta do grupo, com a redução dos níveis de atividade física e o aumento do consumo de alimentos industrializados. O caso suruí também reafirma, desse modo, o papel das mudanças no estilo de vida das populaçóes nativas no surgimento da obesidade e exemplifica uma dinâmica possivelmente presente em um número significativo de etnias, embora ainda não documentada em toda a sua extensão.

\section{Considerações Finais}

As informações aqui apresentadas revelam um quadro preocupante, no qual as crianças parecem ser particularmente atingidas, mas em que adolescentes e adultos não estão livres de problemas de ordem nutricional. Além disso, chama a atenção a ocorrência de problemas tão distintos como a desnutrição nas crianças e a obesidade nos adultos.

Um elemento central para a compreensão desse quadro é a constatação de que as populações indígenas vêm sendo submetidas, desde seus primeiros contatos com não-índios, a um acelerado e complexo processo de mudanças, que atinge os mais diversos aspectos de suas vidas. Para alguns povos, essas mudanças se iniciaram há séculos; para outros, a partir dos anos 60 do século XX ou ainda mais recentemente. Ainda que seja difícil 'medir' exatamente o impacto das mudanças, seus efeitos têm sido descritos por muitos autores (ver Hemming, 1978 para um panorama amplo) e parece evidente que, em diversos aspectos, exercem uma influência negativa sobre o estado nutricional das populações afetadas (Wirsing, 1985).

Elementos comuns nesse quadro de transformações são a restrição territorial, o progressivo esgotamento dos recursos naturais e o comprometimento das atividades de subsistência. À instabilidade na produção de alimentos somam-se ainda precárias condições sanitárias, o que contribui para as elevadas prevalências de doenças infecciosas e parasitárias que, de modo geral, caracterizam os perfis de saúde registrados entre essas populaçóes (Garnelo, Macedo \& Brandão, 2003; Santos \& Coimbra Jr., 1993). A interação entre a desnutrição e as infecções é bem conhecida, e as crianças são particularmente vulneráveis aos seus efeitos.

As implicaçôes nutricionais de todas essas mudanças não estão relacionadas somente à ocorrência da desnutrição energético-protéica, à anemia ferropriva ou às deficiências de vitaminas, mas também ao aumento dos 
casos de obesidade, de hipertensão arterial e de diabetes. Nesse âmbito, chama a atenção o papel das transformaçôes socioeconômicas, culturais e ambientais, e mais especificamente das modificações relativas ao estilo de vida dessas populações. No tocante à alimentação, o maior consumo de alimentos industrializados resulta em uma dieta mais calórica, rica ainda em sódio e em açúcar e gorduras, e pobre em fibras. Tais mudanças, associadas a níveis menos intensos de atividade física, favorecem, como já mencionamos, o surgimento de casos de obesidade e de doenças cardiovasculares e metabólicas. Trata-se, aqui, de uma importante mudança dos perfis de morbimortalidade: às doenças infecciosas e parasitárias, que predominam no perfil de saúde das populaçóes indígenas, somam-se agora, em proporção crescente, as DCNT.

Os conhecimentos sobre as condições de alimentação e nutrição das sociedades indígenas do Brasil são ainda hoje muito limitados, a despeito do aumento do número de pesquisas sobre o tema nas últimas duas décadas. A comparação com a situação registrada para o restante da população brasileira evidencia uma notável desigualdade, que se inicia pela própria escassez de dados demográficos e epidemiológicos sobre o segmento indígena e se estende aos seus indicadores de saúde e nutrição, invariavelmente piores que aqueles registrados entre o restante da população do país. Mesmo quando não se dispõe de dados sobre nutrição, a elevada freqüência com que se observam, entre essas comunidades, condições sanitárias inadequadas, problemas com a produção e o acesso a alimentos, níveis elevados de morbi-mortalidade por doenças infecciosas e parasitárias, entre outros fatores, expressa um panorama amplamente favorável à ocorrência de problemas nutricionais entre os povos indígenas.

\section{Referências}

ALVES, G. M. S.; MORAIS, M. B. \& FAGUNDES-FILHO, U. Estado nutricional e teste de hidrogênio no ar expirado com lactose e lactulose em crianças indígenas Terena. Revista de Pediatria, 78(2): 138-143, 2002.

BARKER, D. J. P. In utero programming of cardiovascular disease. Theriogenology, 53: 555-574, 2000.

BARUZZI, R. G. et al. Saúde e doença em índios Panará (Kreen-Akarôre) após vinte anos de contato com o nosso mundo, com ênfase na ocorrência de tuberculose (Brasil Central). Cadernos de Saúde Pública, 17: 407-412, 2001.

BEM-ESTAR FAMILIAR NO BRASIL (BEMFAM)/DEMOGRAPHIC HEALTH SURVEY (DHS). Pesquisa Nacional sobre Demografia e Saúde, 1996. Rio de Janeiro: Bemfam, DHS, IBGE, Usaid, MS, FNUAP, Unicef, 1997.

CAPELLI, J. C. S. \& KOIFMAN, S. Avaliação do estado nutricional da comunidade indígena Parkatêjê, Bom Jesus do Tocantins, Pará, Brasil. Cadernos de Saúde Pública, 17(2): 433-437, 2001.

CARDOSO, A. M. et al. Prevalência de fatores de risco para doenças cardiovasculares na população GuaraníMbyá do estado do Rio de Janeiro. Cadernos de Saúde Pública, 17(2): 345-354, 2001.

CARDOSO, A. M. et al. Prevalência de diabetes mellitus e da síndrome de resistência insulínica nos índios Guarani do estado do Rio de Janeiro. In: COIMBRA JR., C. E. A.; SANTOS, R. V. \& ESCOBAR, A. L. (Orgs.) Epidemiologia e Saúde dos Povos Indígenas no Brasil. Rio de Janeiro: Editora Fiocruz, 2003.

COIMBRA JR., C. E. A. \& SANTOS, R. V. Avaliação do estado nutricional num contexto de mudança sócioeconômica: o grupo indígena Suruí do Estado de Rondônia, Brasil. Cadernos de Saúde Pública, 7: 538-562, 1991.

COIMBRA JR., C. E. A. \& SANTOS, R. V. Saúde, minorias e desigualdade: algumas teias de inter-relações, com ênfase nos povos indígenas. Ciência \& Saúde Coletiva, 5: 125-132, 2000. 
COIMBRA JR., C. E. A.; FLOWERS, N. M. \& SALZANO, F. M. The Xavante in Transition: health, ecology and bioanthropology in Central Brazil. Ann Arbor: University of Michigan Press, 2002.

DUFOUR, D. L. Diet and nutritional status of Amazonian peoples. Cadernos de Saúde Pública, 7: 481-502, 1991.

DUFOUR, D. L. Nutritional ecology in the tropical rainforests of Amazonia. American Journal of Human Biology, 4: 197-207, 1992.

ESCOBAR, A. L.; SANTOS, R. V. \& COIMBRA JR., C. E. A. Avaliação nutricional de crianças indígenas Pakaanóva (Wari'), Rondônia, Brasil. Revista Brasileira de Saúde Materno Infantil, 3(4): 457-461, 2003.

FAGUNDES, U. et al. Avaliação do estado nutricional e da composição corporal de crianças índias do Alto Xingu e da etnia Ikpeng. Jornal de Pediatria, 80: 483-489, 2004.

FLEMING-MORAN, M. et al. Blood pressure levels of the Suruí and Zoró Indians of the Brazilian Amazon: group and sex-specific effects resulting from body composition, health status, and age. Human Biology, 63: 835-861, 1991.

FORLINE, L. C. The Persistence and Cultural Transformation of the Guajá Indians, Foragers of Maranhão State, Brazil, 1997. Ph.D. Dissertation, Gainesville: University of Florida.

FUNDAÇÃO NACIONAL DE SAÚDE (FUNASA). Política Nacional de Atenção à Saúde dos Povos Indígenas. Brasília: Funasa, 2002.

FUNDAÇÃO NACIONAL DE SAÚDE (FUNASA). Relatório Morbimortalidade, 2002. Brasília: Funasa, 2003.

GARNELO, L.; MACEDO, G. \& BRANDÃO, L. C. Os Povos Indígenas e a Construção das Políticas de Saúde no Brasil. Brasília: Organização Pan-Americana da Saúde, 2003.

GUGELMIN, S. A. Antropometria Nutricional e Ecologia Humana dos Xavante de Sangradouro-Volta Grande, Mato Grosso, 2001. Tese de Doutorado, Rio de Janeiro: Escola Nacional de Saúde Pública, Fundação Oswaldo Cruz.

GUGELMIN, S. A. \& SANTOS, R. V. Ecologia humana e antropometria nutricional de adultos Xavante, Mato Grosso, Brasil. Cadernos de Saúde Pública, 17(2): 313-322, 2001.

HEMMING, J. Red Gold: the conquest of the Brazilian indians. London: MacMillan, 1978.

HURTADO-GUERRERO, A. F. et al. Condição nutricional de um grupo de idosos indígenas no Distrito Sanitário Leste de Roraima. In: COIMBRA JR., C. E. A.; SANTOS, R. V. \& ESCOBAR, A. L. (Orgs.) Epidemiologia e Saúde dos Povos Indígenas no Brasil. Rio de Janeiro: Editora Fiocruz, 2003.

INSTITUTO BRASILEIRO DE GEOGRAFIA E ESTATÍSTICA (IBGE). Tendências Demográficas: uma análise dos indígenas com base nos resultados da amostra dos censos demográficos 1991 e 2000. Rio de Janeiro: IBGE, 2005.

INSTITUTO DE ESTUDOS SOCIOECONÔMICOS (INESC). PROJETO ESTUDOS SOBRE TERRAS INDÍGENAS/MUSEU NACIONAL (PETI/MN). ASSOCIAÇÃO NACIONAL DE AÇÃO INDIGENISTA (ANAÍ-BA). Mapa da Fome II. Brasília: Inesc/PetI-MS/Anaí-BA, 1995.

KAC, G. \& VELÁSQUEZ-MELÉNDEZ, G. (Orgs.) A transição nutricional e a epidemiologia da obesidade na América Latina. Cadernos de Saúde Pública, 19, supl.: S4, 2003. 
KUCZMARSKI, R. J. et al. CDC growth charts: United States. Advance Data, 8: 1-27, 2000.

LEITE, M. S. Transformação e Persistência: antropologia da alimentação e nutrição em uma sociedade indígena amazônica. Rio de Janeiro: Editora Fiocruz, 2007.

LEITE, M. S. et al. Perfis de saúde indígena, tendências nacionais e contextos locais: reflexões a partir do caso Xavante, Mato Grosso. In: COIMBRA JR., C. E. A.; SANTOS, R. V. \& ESCOBAR, A. L. (Orgs.) Epidemiologia e Saúde dos Povos Indígenas no Brasil. Rio de Janeiro: Editora Fiocruz, 2003.

LEITE, M. S. et al. Crescimento físico e perfil nutricional da população indígena Xavante de Sangradouro-Volta Grande, Mato Grosso, Brasil. Cadernos de Saúde Pública, 22(2): 265-276, 2006.

LIMA, M. G. et al. Fatores de risco para câncer de mama em mulheres indígenas Terena de área rural, Estado do Mato Grosso do Sul, Brasil. Cadernos de Saúde Pública, 17: 1.537-1.544, 2001.

LIMA, R. V. Avaliação do Estado Nutricional da População Indígena da Comunidade Terra Preta, Novo Airão, Amazonas, 2004. Dissertação de Mestrado, Manaus: Universidade Federal do Amazonas, Fundação Oswaldo Cruz.

LOURENÇO, A. E. P. Avaliação do Estado Nutricional em Relação a Aspectos Socioeconômicos de Adultos Indígenas Suruí, Rondônia, Brasil, 2006. Dissertação de Mestrado, Rio de Janeiro: Escola Nacional de Saúde Pública, Fundação Oswaldo Cruz.

MARTINS, S. J. \& MENEZES, R. C. Evolução do estado nutricional de menores de 5 anos em aldeias indígenas da tribo Parakanã, na Amazônia Oriental Brasileira. Revista de Saúde Pública, 28(1): 1-8, 1994.

MENEGOLLA, I. A. et al. Estado nutricional e fatores associados à estatura de crianças da terra indígena Guarita, Sul do Brasil. Cadernos de Saúde Pública, 22: 395-406, 2006.

MEYERFREUND, D. Estudo da Hipertensão Arterial e de Outros Fatores de Risco Cardiovascular nas Comunidades Indígenas do Espírito Santo - BR, 2006. Tese de Doutorado, Vitória: Centro de Ciências da Saúde, Universidade Federal do Espírito Santo.

MONTEIRO, C. A. (Org.) Velhos e Novos Males da Saúde no Brasil: a evolução do país e de suas doenças. São Paulo: Hucitec, Nupens, 2000.

MONTEIRO, C. A.; CONDE, W. L. \& KONNO, S. C. Análise do inquérito Chamada Nutricional 2005. Cadernos de Estudos. Desenvolvimento Social em Debate, 4: 29-36, 2005.

MORAIS, M. B.; ALVES, G. M. \& FAGUNDES NETO, U. L. Estado nutricional de crianças índias terenas: evolução do peso e estatura e prevalência atual de anemia. Jornal de Pediatria, 81: 383-389, 2005.

MORAIS, M. B. et al. Estado nutricional de crianças índias do Alto Xingu em 1980 e 1992 e evolução ponderoestatural entre o primeiro e o quarto anos de vida. Cadernos de Saúde Pública, 19: 543-550, 2003.

ORELLANA, J. D. Y. et al. Estado nutricional e anemia em crianças Suruí, Amazônia, Brasil. Jornal de Pediatria, 82: 383-388, 2006.

PAGLIARO, H.; AZEVEDO, M. \& SANTOS, R. V. Demografia dos Povos Indígenas no Brasil. Rio de Janeiro: Editora Fiocruz, Abep, 2005.

PÍCOLI, R. P.; CARANDINA, L. \& RIBAS, D. B. Saúde materno-infantil e nutrição de crianças Kaiowá e Guaraní, área indígena de Caarapó, Mato Grosso do Sul, Brasil. Cadernos de Saúde Pública, 22: 223-227, 2006. 
RIBAS, D. L. B. \& PHILIPPI, S. T. Aspectos alimentares e nutricionais de mães e crianças indígenas Terena, Mato Grosso do Sul. In: COIMBRA JR., C. E. A. et al. Epidemiologia e Saúde dos Povos Indígenas no Brasil. Rio de Janeiro: Editora Fiocruz, 2003.

RIBAS, D. L. B. et al. Nutrição e saúde infantil em uma comunidade indígena Terena, Mato Grosso do Sul, Brasil. Cadernos de Saúde Pública, 17(2): 323-322, 2001.

RICARDO, B. \& RICARDO, F. Povos Indígenas no Brasil, 2001-2005. São Paulo: Instituto Socioambiental, 2006.

SAAD, M. N. L. Saúde e Nutrição Terena: sobrepeso e obesidade, 2005. Dissertação de Mestrado, Campo Grande: Universidade Federal do Mato Grosso do Sul.

SANTOS, R. V. Crescimento físico e estado nutricional de populações indígenas brasileiras. Cadernos de Saúde Pública, 9, supl. 1: 46-57, 1993.

SANTOS, R. V. \& COIMBRA JR., C. E. A. Socioeconomic differentiation and body morphology in the Suruí of Southwestern Amazonia. Current Anthropology, 37(5): 851-856, 1996.

SANTOS, R. V. \& COIMBRA JR., C. E. A. Cenários e tendências da saúde e da epidemiologia dos povos indígenas no Brasil. In: COIMBRA JR., C. E. A.; SANTOS, R. V. \& ESCOBAR, A. L. (Orgs.) Epidemiologia e Saúde dos Povos Indígenas no Brasil. Rio de Janeiro: Editora Fiocruz, 2003.

SANTOS, R. V. et al. Tapirs, tractors and tapes: the changing economy and ecology of the Xavante Indians of Central Brazil. Human Ecology, 25(4): 545-566, 1997.

SCHUCH, I. Perfil Socioeconômico e Alimentar das Familias Indigenas da Terra Indígena Guarita - RS, 2001. Dissertação de Mestrado, Campinas: Departamento de Planejamento Alimentar e Nutrição, Faculdade de Engenharia de Alimentos, Universidade Estadual de Campinas.

SCHWEIGHOFER, T. R. F. Segurança Alimentar e Nutricional em Famílias Indígenas Terena, Mato Grosso do Sul, Brasil, 2006. Dissertação de Mestrado, Campo Grande: Universidade Federal de Mato Grosso do Sul.

SERAFIM, M. G. Hábitos Alimentares e Nivel de Hemoglobina em Crianças Indígenas Guarani, Menores de 5 anos, dos Estados de São Paulo e do Rio de Janeiro, 1997. Dissertação de Mestrado, São Paulo: Escola Paulista de Medicina.

SOUSA, M. C.; SCATENA, J. H. G. \& SANTOS, R. V. O Sistema de Informação da Atenção à Saúde Indígena (Siasi): criação, estrutura e funcionamento. Cadernos de Saúde Pública, 23(4): 853-861, 2007.

VERDUN, R. Mapa da Fome entre os Povos Indígenas no Brasil (I): uma contribuição à formulação de políticas de segurança alimentar. Brasília: Ines, 1994.

VIEIRA FILHO, J. P. B.; RUSSO, E. M. K. \& NOVO, N. F. A hemoglobina glicosilada (HbA1) dos índios xavantes. Arquivos Brasileiros de Endocrinologia e Metabologia, 27: 153-156, 1983.

VIEIRA FILHO, J. P. B. et al. Polineuropatia nutricional entre os índios xavantes. Revista da Associação Médica Brasileira, 43(1): 82-88, 1997.

WEISS, M. C. Contato interétnico, perfil saúde-doença e modelos de intervenção em saúde indígena: o caso enawenê-nawê, Mato Grosso. In: COIMBRA JR., C. E. A.; SANTOS, R. V. \& ESCOBAR, A. L. (Orgs.) Epidemiologia e Saúde dos Povos Indígenas no Brasil. Rio de Janeiro: Editora Fiocruz, 2003. 
WIRSING, R. L. The health of traditional societies and the effects of acculturation. Current Anthropology, 26: 303-322, 1985.

WORLD HEALTH ORGANIZATION (WHO). Physical Status: the use and interpretation of anthropometric indicators of nutritional status. Geneva: WHO, 1995. (WHO Technical Report Series, 854)

WORLD HEALTH ORGANIZATION (WHO). WHO Child Growth Standards. Length/height-for-age, weightfor-age, weight-for-length, weight-forheight and body mass index-for-age: methods and development. Geneva: WHO, 2006.

YOUNG, T. K. The Health of Native Americans: towards a biocultural epidemiology. Oxford: Oxford University Press, 1994. 



\title{
30
}

\section{Políticas Públicas de Alimentação e Nutrição}

\author{
Marília Mendonça Leão e Inês Rugani Ribeiro de Castro
}

\section{O Contexto Político-Institucional das Políticas de Alimentação e Nutrição a partir da Década de 1980}

Em meados da década de 1980, o país vivia o processo de reconstrução do Estado democrático, após vinte anos de governo militar (1964-1984). Na área da saúde pública, foi intensa a movimentação durante o ano de 1986, com a realização da VIII Conferência Nacional de Saúde, evento-síntese da democratização da saúde no país. Seus resultados foram decisivos para o lançamento dos pilares que construiriam o Sistema Único de Saúde (SUS) e que ainda hoje o sustentam.

Como desdobramento da VIII Conferência, foi realizada, em novembro de 1986, a I Conferência Nacional de Alimentação e Nutrição, sob a coordenação do Instituto Nacional de Alimentação e Nutrição (Inan), autarquia então vinculada ao Ministério da Saúde. A conferência contou com representatividade da sociedade civil e de diferentes esferas de governos e pode ser considerada o primeiro evento, após o governo militar, da área de alimentação e nutrição com participação democrática. As recomendaçôes do documento final dessa I Conferência deixam claro o pressuposto de que os problemas de alimentação e nutrição tinham caráter estrutural e vínculos estreitos com as condições de vida e renda da população e explicitam o reconhecimento da alimentação como um direito: "Ao reconhecer a alimentação como um direito de todos, a Conferência estabelece as responsabilidades do Estado de assegurar a disponibilidade interna de alimentos, bem como as condições de acesso ao consumo através, sobretudo, de uma política de salários justos e promoção de pleno emprego" (Inan, 1986: 2).

$\mathrm{Na}$ análise desse e de outros documentos da época (Inan, 1973; Kruse, 1979; Coimbra, 1982; Peliano, 1983; Musgrove, 1985), é notório que prevalecia na esfera do governo federal o entendimento de que os principais problemas de nutrição e saúde pública referiam-se à privação alimentar, cuja conseqüência mais grave é a desnutrição. A despeito de os gestores reconhecerem o caráter estrutural da fome e da desnutrição, a tônica da intervenção governamental foi, sistematicamente, a de creditar a solução dos problemas na conta do crescimento econômico e de seus impactos positivos no acesso satisfatório aos alimentos básicos pela parcela da população em situação de pobreza.

Em uma economia de mercado como a brasileira, o acesso aos alimentos é diretamente determinado pela disponibilidade de renda das famílias. Assim, supunha-se que o crescimento econômico, qualquer que fosse sua 
trajetória, resolveria os principais problemas alimentares e nutricionais da população, com o aumento do emprego e da renda. Orientada por essa lógica, a agenda governamental privilegiava as ações no plano econômico, e as açôes da área social tinham caráter apenas compensatório, destinadas a aliviar a pobreza das populaçôes que viviam à margem do mercado. As principais políticas dessa fase foram, muitas vezes, estruturadas de acordo com os interesses econômicos do político com prestígio no momento e visavam à compra de alimentos básicos, industrializados ou "formulados" para distribuição entre as populações "biológica e socialmente" vulneráveis.

O Inan foi um órgão forte na esfera federal, pois, como coordenador e articulador da Política Nacional de Alimentação e Nutrição (PNAN), interagia com desenvoltura entre os ministérios da Agricultura e órgãos de abastecimento, Educação, Trabalho, Previdência e ainda com a Secretaria de Planejamento da Presidência da República (Seplan), órgão da estrutura federal mais próximo do presidente da República. Em verdade, o Inan era o braço executivo da política social do governo e, durante alguns anos, seu orçamento foi maior do que o do Ministério da Saúde, em função da extensão de alguns de seus programas de distribuição de alimentos.

Nesse contexto, teve igual importância política e programática o Ministério da Educação, representado pela Fundação de Assistência ao Estudante (FAE), então o órgão coordenador do Programa Nacional de Alimentação Escolar (PNAE). A FAE implementou uma estratégia de descentralização, nos anos 90, desmontando a estrutura centralizada do programa mediante a transferência de atribuiçôes e do poder decisório da gestão do nível federal para os estados e municípios. A FAE foi extinta em 1997 e substituída pelo Fundo Nacional de Desenvolvimento da Educação (FNDE), que, atualmente, coordena o PNAE. O Quadro 1 demonstra a predominância dos programas de distribuição de alimentos entre os anos 80 e 90.

Quadro 1 - Principais políticas públicas de alimentação e nutrição no Brasil implementadas ou vigentes no período de 1984 a 2006

\begin{tabular}{|c|c|c|}
\hline Tipo de ação & Órgão responsável & Início-término \\
\hline \multicolumn{3}{|l|}{ 1. Suplementação alimentar } \\
\hline Programa de Nutrição em Saúde & Inan & 1976-1984 \\
\hline Programa de Suplementação Alimentar (PSA) & Inan & 1985-1989 \\
\hline Programa Leite é Saúde & Inan & 1993-1998 \\
\hline Programa de Complementação Alimentar (PCA) & $\mathrm{LBA}$ & 1976-1990 \\
\hline Incentivo ao Combate às Carências Nutricionais (ICCN) & Ministério da Saúde & 1998-2002 \\
\hline Programa de Alimentação Escolar & FNDE/MEC & 1954-presente \\
\hline Programa de Alimentação do Trabalhador (PAT) & Ministério do Trabalho & 1976-presente \\
\hline Programa de Aquisição de Alimentos (PAA) & MDS/Conab & 2003-presente \\
\hline Programa de Distribuição de Cestas & MDS & 2003-presente \\
\hline Restaurantes Populares & MDS & 2003-presente \\
\hline Hortas Comunitárias & MDS & 2003-presente \\
\hline Cozinhas Comunitárias & MDS & 2003-presente \\
\hline Banco de Alimentos & MDS & 2003-presente \\
\hline
\end{tabular}


Quadro 1 - Principais políticas públicas de alimentação e nutrição no Brasil implementadas ou vigentes no período de 1984 a 2006 (continuação)

\begin{tabular}{|lcc|}
\hline Tipo de ação & Órgão responsável & Início-término \\
\hline 2. Prevenção e controle de doenças & Ministério da Saúde & 1954-presente \\
\hline Prevenção e Controle das Deficiências de lodo & Ministério da Saúde & 1983-presente \\
\hline Prevenção e Controle das Deficiências de Ferro & Ministério da Saúde & 1983-presente \\
\hline Prevenção e Controle das Deficiências de Vitamina A & Ministério da Saúde & 1976-presente \\
\hline Sistema de Vigilância Alimentar e Nutricional & MDS & 2003-presente \\
\hline Construção de cisternas no Semi-Árido & Ministério da Educação & 2001-2004 \\
\hline 3. Transferência de renda & Ministério da Saúde & 2004-2004 \\
\hline Bolsa Escola & MDS & 1995-presente \\
\hline Bolsa Alimentação & MDS \\
\hline Bolsa Família & Ministério da Saúde & Ministério da Saúde \\
\hline Benefício de Prestação Continuada (BPC) & MDS & 1999-presente \\
\hline 4. Promoção da saúde & 2003-presente \\
\hline Incentivo ao Aleitamento Materno & & \\
\hline Alimentação Saudável & & \\
\hline Educação Alimentar & & \\
\hline
\end{tabular}

Inan - Instituto Nacional de Alimentação e Nutrição

LBA - Legião Brasileira de Assistência

FNDE/MEC - Fundo Nacional de Desenvolvimento da Educação/Ministério da Educação

MDS - Ministério do Desenvolvimento Social e Combate à Fome

Conab - Companhia Nacional de Abastecimento

A partir da década de 1990, novos ventos anunciam a necessidade de mudança de rota em alguns setores governamentais, diante da constatação da transição demográfica e nutricional e seus impactos negativos na saúde e na economia da população. Os resultados da Pesquisa Nacional sobre Saúde e Nutrição - PNSN (Ministério da Saúde, 1989) foram os primeiros a chamar a atenção dos gestores e planejadores federais para a questão da transição nutricional. Além de demonstrarem a franca redução da desnutrição infantil, quando comparados com estudos da década de 1970, evidenciaram o aumento dos casos de excesso de peso e obesidade entre os adultos (Coitinho, 1991; Monteiro, 2000). Iniciou-se, a partir daí, no âmbito do Ministério da Saúde, um tímido discurso oficial, sobre a coexistência das duas dimensões do problema alimentar e nutricional: a privação alimentar e o aumento da obesidade e de outras DCNT associadas à alimentação inadequada e/ou excessiva.

No entanto, o início dos anos 90 não foi nada favorável à formulação e implementação de políticas públicas coerentes com o novo perfil alimentar e nutricional que se anunciava. Os anos de 1990 a 1992 foram marcados pela desastrosa tentativa de implementação das idéias neoliberais do governo Collor, com a extinção de órgãos públicos federais e a redução de recursos para programas sociais, sob o argumento da promoção da estabilização da economia e da modernização do Estado. Na época, iniciou-se um lento e eficiente processo de destruição organizacional no Inan, e, na falta de um plano político-institucional para o futuro, o órgão foi perdendo os seus melhores quadros técnicos. Praticamente todos os programas de alimentação e nutrição foram desativados, e em 1997 o Inan foi extinto (Ministério das Relações Exteriores, 1996). 
O Inan sempre foi considerado um corpo estranho à estrutura do Ministério da Saúde, pois sua missão de coordenação do Pronan (Programa Nacional de Alimentação e Nutrição) transcendia a esfera da Saúde, na medida em que se articulava com as estruturas de comando de vários outros ministérios. O desaparecimento do Inan deixou um vácuo institucional e programático na área da alimentação e nutrição.

A partir de 1997, os poucos programas remanescentes do Inan foram distribuídos por diferentes instâncias do Ministério da Saúde. A discussão sobre a interação da alimentação com as DCNT permanecia incipiente, embora já presente nas coordenações técnicas de diabetes e hipertensão, todavia sem qualquer articulação com programas de nutrição. A abordagem fragmentada e desarticulada das questôes relacionadas à alimentação e nutrição gerou descontentamento na comunidade de técnicos de governo e pesquisadores, com repercussões nos organismos internacionais ligados à área (Ministério da Saúde, 2006c).

Transcorria, à época, o primeiro mandato do governo Fernando Henrique (1995-1998), período em que se implementou, com o auxílio da consolidação do Plano Real, uma nova política fiscal no país. Na área de segurança alimentar, o principal legado do governo anterior, já então sob a gestão de Itamar Franco, foram as propostas para uma Política de Segurança Alimentar, referendadas pela I Conferência Nacional de Segurança Alimentar, realizada em 1994. Note-se aqui que o 'nutricional' não compunha ainda o conceito de segurança alimentar. Essa conferência foi promovida pelo Conselho Nacional de Segurança Alimentar (Consea) em parceria com a Ação da Cidadania contra a Fome, a Miséria e pela Vida, em julho de 1994 (Consea, 1994). No entanto, o Consea foi extinto no início de 1995, e com esta decisão romperam-se laços importantes com movimentos da sociedade civil (Valente, 2004).

Em contrapartida, a estabilização da economia criou um ambiente favorável ao gerenciamento das políticas públicas, permitindo mais profissionalismo e transparência à formulação, implementação, planejamento e orçamento das ações de governo. Foi nesse contexto que um grupo de técnicos do Ministério da Saúde deflagrou, em 1998, um processo democrático de consulta e discussão para a elaboração de uma nova política para a área de alimentação e nutrição, que definisse as obrigaçōes do setor Saúde para o alcance da segurança alimentar e nutricional. Essa iniciativa contou com a participação da sociedade civil, por intermédio de várias organizações, instituiçôes acadêmicas e de pesquisa na área, do setor produtivo da área de alimentos, dos diferentes órgãos e instâncias de governo, além da comunidade internacional. O processo culminou com a aprovação, em 1999, da PNAN (Ministério da Saúde, 1999b). Iniciou-se, aí, um novo ciclo de gestão governamental na área da alimentação e nutrição, introduzindo-se um discurso mais coerente e pertinente à problemática da transição nutricional (Ministério da Saúde, 2006c).

São sete as diretrizes programáticas da PNAN: 1. Estímulo a ações intersetoriais; 2. Garantia da segurança e qualidade dos alimentos; 3. Monitoramento da situação alimentar e nutricional; 4. Promoção de práticas alimentares e estilos de vida saudáveis; 5 . Prevenção e controle dos distúrbios e doenças nutricionais; 6 . Promoção do desenvolvimento de linhas de investigação e desenvolvimento; 7. Capacitação de recursos humanos em saúde e nutrição. Tais diretrizes deixam claro que o entendimento do governo federal sobre o problema alimentar e nutricional do país passou a transcender a visão segundo a qual a questão da privação alimentar tem como causa básica a pobreza e ampliou sua abordagem para os problemas relacionados ao aumento de peso da população, propondo como estratégia fundamental a promoção da alimentação saudável. A PNAN reforça a abordagem da dupla carga de doenças, ressalta a importância da abordagem multidisciplinar e intersetorial e antecipa a discussão sobre temas e recomendações que só mais tarde, em 2004, viriam a ser apresentadas, formalmente, pela Organização Mundial da Saúde (OMS), quando da divulgação da Estratégia Global para a Alimentação Saudável e Atividade Física (WHO, 2004).

Durante o processo de discussão e elaboração da PNAN (1998-1999), foi criada a Área Técnica de Alimentação e Nutrição (Atan), que alcançou, em 2001, o status de Coordenação Geral da Política de Alimentação e Nutrição (CGPAN), no âmbito do Departamento de Atenção Básica à Saúde do Ministério da Saúde. 
Para aferir a coerência entre o discurso e a prática de um governo, é preciso buscar a programação orçamentária, que traduz as reais intenções dos gestores governamentais. Nota-se, por exemplo, a importância dada ao tema da alimentação e nutrição no Ministério da Saúde com a criação do Programa Alimentação Saudável, no Plano Plurianual (PPA) do governo federal para o período de 2000 a 2003. No ano de 2002, o orçamento desse programa aprovado pelo Congresso Nacional atingiu o seu valor máximo, com o montante de 412,9 milhões de reais, e o total executado nesse exercício foi de 253,7 milhōes (61\%). Esse programa foi continuado para o PPA seguinte (2004-2007), embora com recursos bastante inferiores: 21,7 milhōes para o exercício de 2006 (Siafi, 2003). Observe-se que aqui estão sendo citados apenas os recursos alocados para as ações de alimentação e nutrição (Programa Alimentação Saudável), sob coordenação da CGPAN do Ministério da Saúde. Cabe esclarecer, ainda, que a redução expressiva se deu, a partir de 2004, em função da transferência dos recursos do então Programa Bolsa Alimentação (PBA) para o Bolsa Família (PBF), coordenado pelo Ministério do Desenvolvimento Social e Combate à Fome (MDS) (CGPAN, 2004).

Desde 2003, novas estratégias vêm compondo a agenda do governo federal na área de alimentação e nutrição e ampliando-se para outros setores, principalmente no MDS. Assumiu-se um discurso de combate à pobreza e eliminação da fome, enfatizando-se a sinergia entre ambas. Durante o primeiro mandato do presidente Lula (2003-2006), priorizou-se um conjunto de ações conhecido como Programa Fome Zero, cuja ação mais importante, tanto em termos orçamentários como políticos, é o programa de transferência de renda Bolsa Família. Nesse período, nota-se um deslocamento das prioridades em alimentação e nutrição, da esfera da saúde para os setores responsáveis pela política social, e novos conceitos são incorporados ao discurso oficial, tais como segurança alimentar e nutricional, direito humano à alimentação adequada, soberania alimentar, desenvolvimento social e inclusão produtiva.

A criação do MDS, em janeiro de 2004, teve como objetivos a integração das políticas de assistência social e a redução da pobreza, conforme explicitado na lei de criação do órgão (Brasil, 2004). Esse ministério nasceu com forte prestígio político e ocupou, em certo sentido, o espaço político que nos anos 70 foi ocupado pelo Inan, como órgão coordenador dos principais programas sociais de então. Entretanto, a desejável articulação com outros setores como Saúde e Educação, em prol de uma agenda harmonizada e complementar de combate à pobreza, inclusão social e promoção da saúde, ainda não se efetivou. As três pastas - Saúde, Educação e Desenvolvimento Social - executaram, em 2005, um orçamento total de R 76 bilhōes de reais (cerca US\$ 34,8 bilhôes), o correspondente a 3,9\% do PIB (Vaitsman, 2006). Tais valores representam, sem dúvida nenhuma, um enorme potencial institucional para a promoção do desenvolvimento social, a depender da capacidade de articulação dos seus gestores e de sua correta destinação.

Cabe ressaltar que o Consea, recriado no primeiro ano de governo Lula (2003) como Conselho Nacional de Segurança Alimentar e Nutricional, tem feito diversas tentativas de articulação entre os ministérios e de participação democrática na ampliação da segurança alimentar e nutricional no país. Nesse processo, teve atuação importante na formulação e aprovação da Lei de Segurança Alimentar e Nutricional e na construção do Sistema Nacional de Segurança Alimentar e Nutricional (Brasil, 2006f). A criação dessa lei e desse sistema integra um cenário propício para a construção de uma agenda intersetorial mais articulada e complementar na área.

\section{Os Programas Federais de Alimentação e Nutrição}

A seguir estão descritos alguns dos principais programas existentes ou desenvolvidos a partir de meados dos anos 80. Alguns desses programas já foram extintos, mas julgou-se importante incluí-los neste capítulo pela dimensão e relevância que assumiram à época. Outros programas estão citados porque ainda vigentes e por se constituírem em espaço potencial para a abordagem da promoção da alimentação saudável, se reordenados para a incorporação de intervenções mais efetivas no enfretamento dos problemas advindos da transição nutricional. 


\section{O Programa Nacional de Incentivo ao Aleitamento Materno (Pniam)}

A promoção da amamentação é uma ação prioritária no campo das políticas públicas de alimentação e nutrição e está detalhada no capítulo 24, "Amamentação: evidências científicas e ações para incentivar sua prática".

Desde os anos 70, esforços governamentais vêm sendo empreendidos no sentido de resgatar a amamentação no Brasil, a exemplo de movimentos internacionais similares. Em 1981, foi criado o Programa Nacional de Incentivo ao Aleitamento Materno (Pniam), coordenado pelo Inan e, desde então, diversas ações de promoção do aleitamento materno vêm sendo desenvolvidas em todo o país. O Pniam articula ações governamentais e da sociedade civil nas áreas da saúde, nutrição, educação, comunicação, legislação e trabalho, visando ao estímulo ao aleitamento materno no Brasil. O êxito desse programa é reconhecido internacionalmente (Jelliffe \& Jelliffe, 1988; Brasil, 2003).

O Brasil teve papel protagonista na 54a Assembléia Mundial de Saúde, em 2001, quando apresentou uma proposta de resolução recomendando o aleitamento materno exclusivo por seis meses, e não mais por um período variável de quatro a seis meses. A proposta brasileira foi aprovada por unanimidade pelos estadosmembros presentes.

Entre as ações que vêm sendo desenvolvidas pelo Ministério da Saúde em conjunto com as secretarias de Saúde e a sociedade civil, além de açôes de marketing social e campanhas educativas, destacam-se a Iniciativa Hospital Amigo da Criança - IHAC (Brasil, 2005a), a Rede de Bancos de Leite Humano (BLH), a Iniciativa Unidade Básica Amiga da Amamentação (Iubaam) e a Norma Brasileira de Comercialização de Alimentos para Lactentes (NBCAL).

A IHAC, lançada pela OMS e pelo Fundo das Nações Unidas para a Infância (Unicef) em 1992 em âmbito mundial, visa ao estímulo ao cumprimento, nas maternidades, de medidas básicas e fundamentais para promover a amamentação desde o momento do nascimento (WHO/Unicef, 1992). No Brasil, atualmente 335 unidades hospitalares estão credenciadas como Hospitais Amigos da Criança.

A Rede de BLH tem por objetivo apoiar as mães na promoção e no manejo do aleitamento materno, realizando atividades de coleta do excedente da produção láctea, pasteurização e controle de qualidade do leite humano coletado e sua posterior distribuição gratuita para recém-nascidos de baixo peso, prematuros e enfermos, impedidos de ser amamentados por suas próprias mães (Maia, 2006). A Rede de Bancos de Leite Humano (BLH) do Brasil é a maior e mais complexa do mundo, contando com 187 bancos e 29 postos de coleta de leite humano em funcionamento no país.

A Iubaam visa a complementar a IHAC e propõe para a rede básica de saúde um conjunto de procedimentos e rotinas para a promoção da amamentação (Oliveira \& Camacho, 2002; Secretaria de Estado de Saúde do Rio de Janeiro, 2006).

A NBCAL constitui-se em importante instrumento legal para a regulação da promoção comercial e o uso apropriado dos alimentos que estão à venda como substitutos ou complementos do leite materno, bem como de bicos, chupetas e mamadeiras (Conselho Nacional de Saúde, 1992).

Uma recente conquista de todos os profissionais e entidades que atuam na promoção do aleitamento materno foi a promulgação da lei n. 11.265, em 4 de janeiro de 2006, que regulamentou a comercialização de alimentos para lactentes e crianças de primeira infância e também de produtos de puericultura correlatos.

\section{A Distribuição de Alimentos e a Promoção de Acesso aos Serviços de Atenção Básica à Saúde: o Programa Leite é Saúde (PLS) e o Incentivo ao Combate às Carências Nutricionais (ICCN)}

O Programa Leite é Saúde (PLS), criado pelo Ministério da Saúde em 1993, visava ao controle da desnutrição em crianças com idade abaixo de dois anos e do baixo peso em gestantes por meio da suplementação 
alimentar com leite integral e óleo de soja para grupos em risco nutricional, definido com base em indicadores antropométricos. Essa suplementação era feita pela rede básica de saúde, associada às ações de cuidados básicos e acompanhamento nutricional. A aquisição dos alimentos era feita pelos municípios com recursos advindos do governo federal (Ministério da Saúde, 1993).

O desenho do PLS concretizou dois avanços importantes, que programas anteriores não alcançaram: definiu um grupo populacional mais focalizado, de maior vulnerabilidade biológica, com maior capacidade de resposta à intervenção, e vinculou a suplementação às açōes básicas de saúde. Com isso, contribuiu para o desenvolvimento de uma cultura institucional segundo a qual o controle da desnutrição não dependia exclusivamente da melhoria das condiçôes de vida da população e cabia ao sistema de saúde a missão intransferível de cuidar de forma diferenciada dos grupos em maior risco nutricional (Castro, 1999).

Em 1998, o PLS foi substituído pelo Incentivo de Combate às Carências Nutricionais (ICCN), que preservou, em linhas gerais, o desenho programático de seu antecessor e o aperfeiçoou em vários aspectos (Brasil, 1997, 1998a, 1998b). Em primeiro lugar, o montante de recursos a ser repassado a cada município passou a ser calculado nos termos de modelos preditivos de desnutrição, baseados em dados de censos demográficos e em pesquisas epidemiológicas. O resultado foi a diminuição (em termos proporcionais e absolutos) do montante repassado a grandes centros urbanos e o aumento daquele repassado a municípios onde a prevalência da desnutrição era alta. Garantia-se, assim, uma mudança histórica na distribuição de recursos voltados para programas de nutrição que contribuía para a diminuição das desigualdades entre cidades, estados e regiōes.

Segundo, o repasse dos recursos federais passou a ser feito não mais por intermédio de convênios, mas sim diretamente do Fundo Nacional de Saúde para os fundos municipais de Saúde, como parte integrante do Piso de Atenção Básica (PAB), com acompanhamento dos conselhos municipais de Saúde. Isso implicou maior agilidade na transferência do recurso, garantindo continuidade e regularidade das aquisições dos alimentos, e extinguiu procedimentos burocráticos e conflitos de interesses entre gestores.

Um terceiro avanço foi a inclusão de uma ação de nutrição no $\mathrm{PAB}$, fortalecendo a premissa de que o cuidado oferecido a grupos em risco nutricional é um componente central desta atenção.

O quarto avanço do ICCN em relação ao PLS foi o fato de prever que uma parcela dos recursos repassados poderia ser utilizada para a suplementação com ferro ou outros micronutrientes, para a promoção do aleitamento materno e para ações que beneficiavam outros grupos de risco nutricional, como filhos de mulheres com diagnóstico de HIV positivo e idosos de baixo peso.

Dados provenientes do Sistema de Informação da Atenção Básica (Siab) para a região Nordeste mostraram uma aceleração no declínio das taxas de desnutrição na região após a implantação do ICCN. Entre abril de 1999 e maio de 2000, o risco nutricional foi reduzido em $15 \%$, quando a tendência histórica então verificada era de um declínio médio de 5\% ao ano (Ministério da Saúde, 2002).

Em contrapartida, um estudo encomendado pelo Ministério da Saúde demonstrou que o leite era o alimento básico e não um alimento adicional, como se esperava, constituindo-se na principal fonte de nutrientes e energia para as crianças. Como conseqüência, a dieta era monótona, hiperprotéica, rica em cálcio e marcadamente deficiente em ferro e zinco (Santos, 2003). Estudos como esse corroboraram a necessidade de modernização e ampliação do programa para que este, além da recuperação nutricional, promovesse uma dieta diversificada e saudável. O desdobramento disso foi a formulação de um programa que promovesse a autonomia das famílias, garantindo, no lugar da distribuição de alimentos, a transferência direta de recursos, para que as próprias famílias pudessem adquirir os alimentos necessários ao reforço da alimentação de crianças, gestantes e nutrizes. Como resultado, foi criado em 2001 o Programa Nacional de Renda Mínima vinculado à Saúde, chamado Programa Bolsa Alimentação (Brasil, 2001). 


\section{As Políticas de Transferência de Renda: os programas Bolsa Alimentação (PBA) e Bolsa Família (PBF)}

Programas de transferência monetária já existem no Brasil desde a década de 90 do último século, especialmente se considerados nesta categoria aqueles que contemplam os direitos sociais estabelecidos na Constituição de 1988, como os Benefícios de Prestação Continuada (BPC) e a Renda Mensal Vitalícia (RMV). Os dois primeiros programas de renda mínima do país foram implementados na área da Educação, pela prefeitura de Campinas, SP, e pelo governo do Distrito Federal, em 1995. Em 2001, o governo federal formulou um programa nacional, com função diversa daquela estritamente atribuída à previdência social, o Programa Bolsa Escola. Este programa era vinculado ao Ministério da Educação e tinha como objetivos fomentar a freqüência da criança na escola e contribuir com a redução da pobreza. Abriu-se aí uma janela de oportunidade política para a formulação do PBA, no Ministério da Saúde, com objetivo semelhante ao da Educação, qual seja, reforçar o vínculo dos participantes com os serviços de atenção básica à saúde.

O PBA representou uma mudança de paradigma na intervenção governamental no campo da alimentação e nutrição, a qual, conforme já mencionado, se dava por intermédio de programas de distribuição de alimentos e/ou suplementos. O PBA visava à redução e à prevenção da desnutrição e da mortalidade infantil por meio da transferência direta de renda vinculada à contrapartida da família na forma de participação em ações básicas de saúde tais como imunização, pré-natal, atividades educativas em saúde e nutrição e acompanhamento do crescimento e do desenvolvimento. Os critérios de elegibilidade do programa combinavam renda per capita com o risco nutricional dos potenciais titulares de direito (gestantes, nutrizes e crianças de até 6 anos de idade).

O PBA trouxe importantes inovações em termos de desenho programático, na medida em que apresentou uma nova estratégia para estreitar o vínculo entre as famílias e os serviços de atenção básica à saúde e valorizou o protagonismo feminino na família, uma vez que o cartão magnético para o saque, na rede bancária local, do recurso mensal repassado era entregue preferencialmente para a mulher. Cada família participante do programa recebia uma transferência mensal de $\mathrm{R} \$ 15,00$ a $\mathrm{R} \$ 45,00$, dependendo do número de filhos. Em 2002, penúltimo ano de implementação do programa, a CGPAN teve alocado no seu orçamento para este programa um total de R \$ 300 milhões, atendendo cerca de 1,3 milhão de famílias (Siafi, 2003). Esse foi, desde a extinção do Inan, o maior orçamento que a área de alimentação e nutrição recebeu no âmbito do orçamento geral do Ministério da Saúde.

$\mathrm{O} P B F$ promove o acesso à alimentação por meio da garantia de uma renda mínima mensal às famílias. Ele transfere renda direta às famílias, condicionando a transferência ao cumprimento de açōes básicas de saúde e educação. Está destinado às famílias com renda per capita de até R \$ 120,00 mensais, e o valor do benefício pode variar entre R \$ 15,00 e R \$ 95,00 por mês, a depender da situação de renda e da existência de crianças, adolescentes, gestantes e/ou nutrizes.

$\mathrm{O}$ PBF é uma política prioritária do governo Lula para o combate à fome e à pobreza, e foi organizado a partir da reestruturação e unificação dos programas de transferência então existentes (Bolsa Escola, Bolsa Alimentação, Auxílio Gás e Programa Nacional de Acesso à Alimentação), mantendo-se a mesma lógica de captação, cadastramento e repasse de recursos aos titulares de direito do programa. Até fins de 2006, o programa atendia 11,1 milhōes de famílias, totalizando cerca de 45 milhões de pessoas, ou $25 \%$ da população do país. As famílias inscritas no programa recebem um valor médio de $\mathrm{R} \$ 60,00$ por mês; destas, cerca de $94 \%$ pertencem ao dois quintis de mais baixa renda, o que demonstra uma adequada focalização do programa (Ministério do Desenvolvimento Social, 2006a).

Os resultados da Chamada Nutricional, realizada em 2005 pelo MDS, sugerem um efeito protetor do programa no estado nutricional das crianças da regiāo do Semi-Árido. Entre as crianças menores de 5 anos que recebiam transferência de renda, a prevalência da desnutrição era $30 \%$ menor do que a daquelas não contempladas por 
este programa. O grupo etário de 6 a 11 meses pareceu ser o mais beneficiado, pois apresentou uma prevalência 62\% menor (Ministério do Desenvolvimento Social, 2006b).

Além do PBF, o MDS desenvolve outros programas relacionados à promoção da segurança alimentar e nutricional. São eles: Programa de Erradicação do Trabalho Infantil (Peti); Benefício de Prestação Continuada (BPC); Programa de Aquisição de Alimento (PAA); Construção de Cisternas; Distribuição de Cestas de Alimentos; Hortas Comunitárias; Cozinhas Comunitárias; Restaurantes Populares; Educação Alimentar e Bancos de Alimentos.

\section{Programas de Fornecimento de Refeições a Públicos Específicos: o Programa Nacional de Alimentação Escolar (PNAE) e o Programa de Alimentação do Trabalhador (PAT)}

O PNAE é o mais antigo programa da área de alimentação e nutrição. Foi criado em 1954, no fim do governo Vargas. O direito à alimentação escolar para todos os alunos do Ensino Fundamental foi assegurado pela Constituição de 1988. Em 1997, o PNAE passou a ser gerenciado pelo Fundo Nacional de Desenvolvimento da Educação (FNDE), vinculado ao Ministério da Educação, quando foi extinta a Fundação de Assistência ao Estudante (FAE).

O PNAE era executado de forma centralizada, isto é, a compra e a distribuição de alimentos eram feitas pelo órgão nacional. Essa estratégia se mostrou altamente ineficiente, pois o controle de qualidade, o armazenamento e o transporte dos produtos eram atividades de custos altíssimos. Além disso, o programa era suscetível a desvios e corrupção, acarretando falta da merenda nas escolas e reduzindo o número de dias de atendimento. Em 1993, iniciou-se um processo de descentralização do PNAE, passando-se a transferir, automaticamente, os recursos financeiros aos estados e municípios, sem necessidade de convênio.

O PNAE é um dos programas federais com enorme potencial para o desenvolvimento de uma agenda de promoção da saúde e da alimentação saudável. Esforços consistentes vêm sendo feitos pelo programa, o que pode ser comprovado pelas seguintes medidas:

1) Aumento substancial dos valores per capita para fins do repasse dos recursos para alunos de ensino pré-escolar e fundamental (de $\mathrm{R} \$ 0,06$ para $\mathrm{R} \$ 0,13$ ), com valores superiores para alunos de comunidades indígenas ( $\mathrm{R} \$ 0,34$ per capita) e de creches públicas e filantrópicas ( $\mathrm{R}$ \$ 0,18 per capita).

2) Publicação da portaria interministerial n. 1.010, de 8 de maio de 2006, assinada pelos ministros da Saúde e da Educação, instituindo as diretrizes para a promoção da alimentação saudável nas escolas de Educação Infantil, Fundamental e de Ensino Médio das redes pública e privada, em âmbito nacional, detalhada adiante.

3) Envio ao Congresso Nacional de projeto de lei da Alimentação Escolar, que propõe a extensão da alimentação escolar para a educação de jovens e adultos e de alunos de Ensino Médio, além de incluir como responsabilidade do Estado as escolas comunitárias pertencentes às organizações da sociedade civil pública.

4) Os esforços dos seus atuais gestores, no âmbito administrativo, para a inclusão do PNAE no próximo plano plurianual do governo federal como um programa específico, e não como componente de um outro programa (no caso, o Programa Brasil Escolarizado), como ocorre atualmente, visando ao fortalecimento e à ampliação de suas atividades. A situação atual tem restringido as atividades, basicamente, à compra de gêneros alimentícios. As novas ações pretendidas buscam priorizar: 
a) Capacitação dos agentes envolvidos no PNAE.

b) Desenvolvimento de projetos e pesquisas para subsidiar as ações do PNAE.

c) Implementação, desenvolvimento e ampliação dos centros colaboradores de alimentação escolar para desenvolvimento de ações intersetoriais, especialmente das áreas de educação e saúde.

d) Ampliação da rede de cooperação técnica internacional para implementação de programas de alimentação escolar em países latino-americanos e africanos.

O PAT, instituído em 1976, foi destinado ao atendimento de trabalhadores de baixa renda. É, a exemplo do PNAE, um dos mais antigos programas da área ainda vigentes. Está estruturado na parceria entre governo, empresa privada e trabalhador, e tem como unidade gestora a Secretaria de Inspeção do Trabalho do Departamento de Segurança e Saúde do Ministério do Trabalho. Ele faculta às pessoas jurídicas e físicas a dedução das despesas com alimentação dos seus trabalhadores em até 4\% do Imposto de Renda devido. Seu objetivo é melhorar as condiçõos nutricionais dos trabalhadores, esperando-se impactos positivos na qualidade de vida, na redução de acidentes de trabalho e no aumento da produtividade laboral. $\mathrm{O}$ benefício concedido ao trabalhador não pode ser em espécie (dinheiro). Em outubro de 2006, o programa contava com a adesão de 104.084 empresas e com 5.644 fornecedores atendendo a 9.062 .837 trabalhadores, dos quais cerca de $40 \%$ residentes no estado de São Paulo (Ministério do Trabalho, 2006).

Merece destaque uma mudança recente no desenho do programa: os parâmetros nutricionais para as refeiçôes fornecidas em seu âmbito foram atualizados de forma a se adequarem ao atual perfil nutricional da população (Brasil, 2006e). Este programa representa uma importante janela de oportunidade para a promoção da alimentação saudável no ambiente de trabalho, ainda não suficientemente explorada.

\section{Programas de Controle e Prevenção de Carências de Micronutrientes: ferro, vitamina A e iodo}

A descrição da relevância das carências de ferro e vitamina A na agenda da saúde pública está detalhada em capítulos deste livro intitulados "Epidemiologia da anemia ferropriva" e "Epidemiologia da hipovitaminose A e xeroftalmia”.

O controle da anemia por deficiência de ferro, embora previsto em todos os planos de governo da área de alimentação e nutrição, nunca foi implantado em escala nacional e nem obteve resultados animadores. Todas as açõos então propostas estavam baseadas na prática clínica na rede básica de saúde, ou seja, o foco da suplementação era o tratamento, e não a prevenção da anemia.

Em 1999, o governo brasileiro, as sociedades civil e científica, alguns organismos internacionais e as indústrias brasileiras firmaram o Compromisso Social para a Redução da Anemia Ferropriva no Brasil. As açôes decorrentes desse pacto foram reforçadas pela PNAN, aprovada nesse mesmo ano, que definiu como açôes prioritárias a fortificação das farinhas de trigo e de milho com ferro, a suplementação com sais de ferro para grupos vulneráveis e atividades voltadas para a orientação alimentar e nutricional, em consonância com o recomendado por organismos internacionais (Unicef/UNU/WHO, 1998; Ministério da Saúde, 1999a; WHO, 2001).

Em relação à ação de fortificação, foi publicada, em 2002, a resolução n. 344 da Anvisa, que tornou obrigatória a adição de ferro e de ácido fólico nas farinhas de trigo e nas farinhas de milho pré-embaladas e prontas para oferta ao consumidor e nas destinadas a uso industrial, incluindo as de panificação e as farinhas adicionadas nas pré-misturas, devendo cada $100 \mathrm{~g}$ de farinha fornecer no mínimo 4,2 mg de ferro e $150 \mathrm{mcg}$ de 
ácido fólico (Anvisa, 2002). A medida só entrou em vigor em junho de 2004, em função de prazos estipulados para as empresas se adequarem ao processo de fortificação.

Quanto à ação de suplementação com sais de ferro, iniciou-se, em 2006, a implementação do Programa Nacional de Suplementação de Ferro (Ministério da Saúde, 2005). Coordenado pela CGPAN, consiste na suplementação universal profilática com sulfato ferroso em dose-padrão dirigida a todas as crianças de 6 a 18 meses de idade, gestantes a partir da vigésima semana e mulheres até o terceiro mês pós-parto. A distribuição do produto é feita na rotina das unidades de saúde.

Está prevista a distribuição dos suplementos de ferro às unidades de saúde do SUS em todos os municípios brasileiros, com base no número estimado de crianças e mulheres a serem abrangidas pela ação. Este programa traz duas inovações que merecem destaque. A primeira foi a adoção de um novo sulfato ferroso, desenvolvido por Farmanguinhos/Fiocruz e apresentado na forma de xarope, com características sensoriais (sabor, textura, cor) melhores que as dos produtos tradicionalmente usados na rotina na rede básica de saúde. Essa inovação teve por objetivo melhorar a adesão dos usuários à suplementação.

A segunda inovação foi a definição de que a suplementação seria universal (sem triagem prévia de casos de risco) e profilática, com uma dosagem padrão. Isso simplificou enormemente sua operacionalização, modificando a tradição de suplementação na rede básica de saúde que, conforme já comentado, estava focada exclusivamente no tratamento da anemia.

Para que o programa atinja plenamente seus objetivos, é necessário que: a) sua implementação se dê, em todas as esferas de governo, por meio da integração das áreas de nutrição, saúde da criança e atenção básica (incluindo o PSF, Programa Saúde da Família), que ainda estão pouco articuladas para esta ação; b) seja ampliada a escala de produção do sulfato ferroso adotado pelo programa, de forma a garantir cobertura e regularidade no fornecimento do produto; c) sejam desenvolvidos e difundidos instrumentos facilitadores de práticas de orientação alimentar que complementem a suplementação e d) sejam revisados aspectos de seu desenho em função de estudos de avaliação de operacionalização e de impacto do programa (Engstrom, 2006).

O controle da hipovitaminose A vem sendo feito, desde os anos 80 , por meio de suplementação com megadoses de vitamina A, hoje estruturada no Programa Nacional de Suplementação de Vitamina A (Brasil, 2005b, 2005c). Este programa é executado pelos estados e municípios com o objetivo de erradicar a deficiência nutricional de vitamina A em crianças de 6 a 59 meses de idade e mulheres no pós-parto imediato (antes da alta hospitalar), residentes em regiōes consideradas de risco. No Brasil, são consideradas áreas de risco a região Nordeste, o Vale do Jequitinhonha, em Minas Gerais, e o Vale do Ribeira, em São Paulo. O programa está regulamentado pela portaria ministerial n.729, publicada em 13 de maio de 2005, pelo Ministério da Saúde.

O controle da deficiência de iodo é feito por meio da iodação de todo o sal produzido no país, mediante parceria entre a CGPAN, a Anvisa e o setor produtivo (Brasil, 2005d, 2006c). A portaria n. 2.362, de 1 de dezembro de 2005, do Ministério da Saúde, estrutura o Programa Nacional de Prevenção e Controle dos Distúrbios por Deficiência de Iodo (DDI) e define as atribuições de cada órgão.

Desde que a adição de iodo no sal foi determinada na década de 1950, o Ministério da Saúde realizou quatro pesquisas para avaliar o impacto e a eficácia das conseqüências desta intervenção no Brasil. Tais pesquisas registraram significativa redução nas prevalências de bócio em todo o país (Opas, 2002). No entanto, há ainda necessidade de aperfeiçoamento das ações de prevenção, controle e monitoramento do programa.

A OMS aprovou na 58ª Assembléia Mundial de Saúde a resolução WHA 58.60, que recomenda aos países o monitoramento da situação nutricional referente ao iodo a cada três anos (WHO/Unicef/ICCIDD, 2001; WHO, 2005). A CGPAN está propondo a realização de um novo estudo de base populacional, de abrangência nacional, com a finalidade de avaliar o impacto da iodação do sal produzido no Brasil. A pesquisa permitirá avaliar se a iodação do sal oferecido à população é capaz de fornecer a quantidade necessária de iodo para prevenir e controlar os DDI sem risco de ocorrência de doenças associadas ao consumo excessivo deste micronutriente. 


\section{As Políticas Públicas de Alimentação e Nutrição diante da Transição Nutricional no Brasil: desafios e possibilidades}

Como em outros países em desenvolvimento, a transição nutricional no Brasil é marcada pela presença concomitante de desnutrição, obesidade e doenças carenciais específicas ligadas à má alimentação. No campo das políticas públicas, a resposta mais adequada a esse cenário é a construção de uma agenda única de promoção da alimentação saudável, entendendo-se tal estratégia como a que melhor condiz com o complexo perfil nutricional de nossa população. Em linhas gerais, essa agenda única abarca basicamente a promoção da amamentação e da alimentação complementar oportuna e adequada, do aumento do consumo de Frutas, Legumes e Verduras (FLV), do consumo de feijão com arroz, da diminuição do consumo de alimentos ricos em gorduras saturadas e trans, açúcares e sal e a valorização dos alimentos regionais e da cultura alimentar local (Ministério da Saúde, 2006b). Além da alimentação saudável, promover atividades físicas no cotidiano é ação amplamente reconhecida como imprescindível para a prevenção e o controle da obesidade e para a promoção de uma vida saudável (WHO/FAO, 2003).

Dada a complexidade do quadro epidemiológico atual e de seus determinantes, uma única medida não é suficiente para melhorar o perfil nutricional de nossa população. Ao contrário, para que as políticas públicas de promoção da alimentação saudável sejam efetivas, elas devem integrar açôes de incentivo, apoio e proteção às escolhas saudáveis (Ministério da Saúde, 2006a). Entendem-se aqui como de 'incentivo' as ações que difundem informação e motivam os indivíduos para a adoção de práticas saudáveis; como ações de 'apoio', aquelas que visam a facilitar opções saudáveis entre pessoas que já estejam motivadas, e como ações de 'proteção' aquelas que visam a evitar a exposição de indivíduos e coletividades a fatores que estimulem práticas não saudáveis.

Além da integração das vertentes aqui citadas, a efetividade dessas políticas públicas pressupõe, também, que elas abarquem ações dirigidas tanto ao ambiente quanto aos indivíduos, superando duas concepções que, tradicionalmente, permeiam as ações desenvolvidas nesta área. A primeira vê os determinantes estruturais como dados que não podem ser mediados ou modificados. São expressões desta concepção as seguintes assertivas: por um lado, em um contexto de pobreza, não há como melhorar os hábitos alimentares nem o estado nutricional da população; por outro, no contexto da família urbana contemporânea, não há como interferir na globalização da produção e oferta de alimentos e na ampliação da sociedade de consumo.

De acordo com a segunda concepção, uma vez garantidas condições minimamente dignas de vida, as práticas alimentares inadequadas e suas conseqüências são fruto, exclusivamente, da vontade (força/falta de) de cada pessoa. A superação dessas concepções implica reconhecer a função do Estado e a capacidade das políticas públicas em diminuir as iniqüidades sociais em favor do bem comum, da saúde da população e da sustentabilidade do planeta, mesmo que para isso sejam necessárias medidas que se contraponham aos interesses econômicos de grandes corporações. Implica, também, reconhecer que as escolhas alimentares são fruto de processos complexos construídos em diferentes contextos históricos e influenciados pelas dimensões física, econômica e sociocultural do ambiente (Swinburn et al., 1999; Valente, 2002).

Nessa perspectiva, as medidas dirigidas ao ambiente devem promover práticas ecologicamente sustentáveis na cadeia alimentar (Consea, 2004) e, ao mesmo tempo, transformar o ambiente obesogênico em que as pessoas vivem em um ambiente promotor da saúde. Alguns exemplos de medidas de promoção da alimentação saudável dirigidas ao ambiente são: a taxação e o conseqüente aumento de preço dos produtos ricos em gorduras, açúcares e sal; a revisão dos subsídios à produção de alimentos, valorizando-se a produção de FLV e os processos produtivos ecologicamente sustentáveis; a regulamentação da publicidade de alimentos; a regulamentação da venda e propaganda de alimentos no ambiente escolar e a implementação de medidas que facilitem o acesso físico a FLV em programas públicos de alimentação (como o PNAE), em ambientes de trabalho e em áreas (bairros, comunidades) com pouco ou nenhum acesso a esses alimentos. 
As medidas dirigidas aos indivíduos, por sua vez, devem abranger ações que visem à ampliação do nível de conhecimento da população sobre alimentação, à valorização da cultura alimentar, à promoção da cidadania e ao desenvolvimento de habilidades que ampliem sua autonomia nas escolhas alimentares e na preparação de refeiçōes saudáveis.

Esses são alguns exemplos de ações possíveis. Os diferentes setores da sociedade (poderes Executivo, Legislativo, Judiciário, sociedade civil organizada, instituiçôes acadêmicas) desempenham papéis distintos e complementares no planejamento e implementação dessas medidas de incentivo, apoio e proteção à alimentação saudável. A experiência tem demonstrado que a ação em parceria contribui para a consolidação de medidas consistentes, inovadoras e condizentes com o complexo perfil epidemiológico de nossa população.

\section{Alguns Exemplos de Ações já Desenvolvidas}

Inúmeras e inovadoras ações vêm sendo desenvolvidas em diferentes locais do país. No campo das ações de 'incentivo’ à alimentação saudável, merece destaque a publicação do Guia Alimentar para a População Brasileira (Ministério da Saúde, 2006b). Assemelhado a guias publicados nos últimos anos em outros países e lançado pela CGPAN em 2005, esse documento estabelece as diretrizes alimentares a serem utilizadas na orientação de escolhas mais saudáveis de alimentos da população. Sua construção partiu dos seguintes princípios: abordagem integrada (visando à prevenção da desnutrição e de outras deficiências nutricionais bem como da obesidade e ao aumento da resistência a muitas doenças infecciosas); referencial científico e cultura alimentar (evidências científicas em relação aos princípios de uma alimentação adequada); referencial positivo (ênfase nos atributos, vantagens e ações factíveis para a adoção de uma alimentação saudável, em vez de enfocar ações que não devem ser realizadas); explicitação e variação de quantidades (sempre que possível, as recomendações são quantificadas e expressas com uma margem de variação); alimentos como referência (foco em alimentos e bebidas mais do que em componentes nutricionais); sustentabilidade ambiental (valorização da produção e do processamento de alimentos que empreguem tecnologias e recursos ambientalmente sustentáveis); originalidade (dirigido à população brasileira com base em sua cultura alimentar); abordagem multifocal (recomendações dirigidas à população em geral, aos governos ou indústrias, a profissionais da saúde e a famílias).

No campo das açôes de 'apoio', merece destaque a 'rotulagem nutricional obrigatória para alimentos e bebidas embalados'. Regulamentada pela Agência Nacional de Vigilância Sanitária (Anvisa), inicialmente em março de 2001, essa iniciativa visa a facilitar a escolha de alimentos saudáveis por meio de informaçôes contidas nos rótulos, permitindo ao consumidor exercer o direito de conhecer a composição do alimento que está comprando e o que está comendo (Anvisa, 2001a, 2001b, 2003a). Ajustes foram feitos nos últimos anos com a intenção de tornar essa iniciativa mais adequada à inclusão de novos itens nos componentes nutricionais listados (p. ex., gordura trans) e aos mecanismos comerciais internacionais (exemplo: regras do Mercosul) (Anvisa, 2003b).

No campo das ações de 'proteção', cabe destacar a publicação de 'regulamento' técnico da Anvisa que se aplica "à oferta, propaganda, publicidade, informação e a outras práticas correlatas cujo objetivo seja a divulgação ou promoção de alimentos com quantidades elevadas de açúcar, de gordura saturada, de gordura trans, de sódio e de bebidas com baixo teor nutricional" (Anvisa, 2006, grifos nossos).

As açōes aqui citadas são exemplos concretos da implementação de pelo menos duas diretrizes da PNAN, a promoção de práticas alimentares e estilos de vida saudáveis e a prevenção e controle dos distúrbios nutricionais e de doenças associadas à alimentação e nutrição. São exemplos, também, da implementação das diretrizes de promoção da alimentação saudável inseridas na Estratégia Global de Alimentação, Atividade Física e Saúde, aprovada em maio de 2004 na 57a Assembléia Mundial da Saúde, da qual o Brasil foi signatário (WHO, 2004). 


\section{Ações de Monitoramento do Estado Nutricional da População e de Fatores a Ele Associados}

O conhecimento da magnitude e da distribuição social e geográfica dos eventos de interesse para a área de alimentação e nutrição, bem como o monitoramento das tendências temporais desses eventos são ações fundamentais para o planejamento, a avaliação e o redirecionamento de políticas públicas. No Brasil, essas ações vêm sendo desenvolvidas mediante a combinação de duas vertentes de iniciativas: por um lado, a realização de estudos nacionais e regionais de base populacional e, por outro, a implementação de sistemas de informação, vigilância e monitoramento de eventos específicos ou de implementação de políticas e programas (Quadro 2).

Quadro 2 - Inquéritos de base populacional sobre alimentação, nutrição e saúde segundo evento estudado e ano do estudo. Brasil, 1974-2007

\begin{tabular}{|c|c|c|c|c|c|}
\hline Ano & $\begin{array}{l}\text { Carências de } \\
\text { micronutrientes }\end{array}$ & $\begin{array}{l}\text { Consumo } \\
\text { alimentar }\end{array}$ & $\begin{array}{l}\text { Disponibilidade de } \\
\text { alimentos }\end{array}$ & Antropometria & Indicadores de saúde \\
\hline 1974 & & Endef & & Endef & \\
\hline 1976 & & & & & AMS \\
\hline 1986 & & & & PNDS/DHS 1 & PNDS/DHS 1 \\
\hline 1987 & & & POF & & \\
\hline 1989 & & & & PNSN & PNSN \\
\hline 1990 & & & & & AMS \\
\hline 1991 & & & & PNDS/DHS 2 & PNDS/DHS 2 \\
\hline 1992 & & & & & AMS \\
\hline 1996 & & Multicêntrico & POF & PNDS/DHS 3 & PNDS/DHS 3 \\
\hline 1997 & & & & PPV & \\
\hline 1998 & & & & & PNAD \\
\hline 1999 & & & & & AMS \\
\hline 2002 & & & & & AMS \\
\hline 2003 & & PMS/WHS & $\mathrm{POF}$ & $\begin{array}{c}\text { POF } \\
\text { PMS/WHS }\end{array}$ & PMS/WHS \\
\hline \multicolumn{6}{|l|}{2004} \\
\hline 2005 & & & & $\begin{array}{c}\text { Chamada } \\
\text { Nutricional-MDS }\end{array}$ & \\
\hline 2006 & PNDS/DHS $4^{(a)}$ & & & & PNDS/DHS $4^{(a)}$ \\
\hline 2007 & & $P O F^{(b)}$ & $P O F^{(b)}$ & & \\
\hline Total & 1 & 3 & 4 & 8 & 12 \\
\hline
\end{tabular}

AMS - Assistência Médico-Sanitária (IBGE, 2005).

Endef - Estudo Nacional de Despesas Familiares (IBGE, 1980).

Multicêntrico (Galeazzi, Domene \& Sichieri, 1997).

PMS/WHS - Pesquisa Mundial de Saúde, World Health Survey (Szwarcwald et al., 2004). 
PNAD - Pesquisa Nacional de Amostras por Domicílio (IBGE, 2006).

PNDS/DHS - Pesquisa Nacional de Demografia e Saúde/Demographic and Health Survey (Bemfam/

IBGE/MS/DHS/FNUAP/Unicef, 1997).

PNSN - Pesquisa Nacional sobre Saúde e Nutrição (Ministério da Saúde, 1989).

POF - Pesquisa de Orçamentos Familiares (IBGE/MS, 2004, 2006).

PPV - Pesquisa de Padrões de Vida (IBGE, 1997).

(a) Inquérito em fase de análise dos dados, conclusão prevista para 2007.

(b) Inquérito em planejamento, previsto para ir a campo em 2007-2008.

Os estudos de base populacional vêm documentando o processo de transição nutricional principalmente no que diz respeito a indicadores de produção/disponibilidade dos alimentos e a indicadores antropométricos. Estudos sobre consumo alimentar efetivo e de diagnóstico por carência de micronutrientes, de abrangência nacional, embora muito importantes, são raros e devem ser considerados como prioridade em pesquisa. Encontra-se em fase de análise de dados a Pesquisa Nacional sobre Demografia e Saúde (PNDS-DHS), inquérito planejado e financiado pelo Ministério da Saúde, que possui um módulo para estudar a anemia e hipovitaminose A, em amostra nacional composta por famílias que têm mulheres em idade fértil e crianças menores de 5 anos.

Não serão detalhadas, aqui, informações sobre os estudos já realizados, mas, a fim de oferecer um panorama resumido sobre eles, estão apresentados no Quadro 2 os principais inquéritos de base populacional realizados ou em curso entre os anos de 1974 e 2007, segundo o ano de realização e evento estudado, com a indicação de fontes bibliográficas para consulta. Quanto aos sistemas de informação, vigilância e monitoramento, cabe destacar, inicialmente, o Sistema de Vigilância Alimentar e Nutricional (Sisvan), que é coordenado pelo Ministério da Saúde e tem se constituído em importante instrumento de monitoramento da situação alimentar e nutricional, em nível local.

São de meados da década de 1970 os primeiros esforços de implantação do Sisvan pelo Ministério da Saúde, vinculando-o a programas de nutrição (Castro, 1995). Em 1993, a implementação do Sisvan foi estabelecida como requisito para a adesão dos municípios ao Programa Leite é Saúde. Da mesma forma, em 1998, esse sistema foi considerado um dos pré-requisitos para adesão ao ICCN. O requisito para a permanência do município no programa era o envio regular de dados provenientes do Sisvan municipal. A partir de 1999, com aprovação da PNAN, o Sisvan foi ampliado e aperfeiçoado, de modo a estender sua cobertura a todo o país.

Com a criação do PBA em 2001, foi iniciada a construção de um sistema informatizado para a coleta de informaçōes referentes à população usuária do SUS e beneficiária do programa a partir dos municípios. Em 2004, a CGPAN concluiu o projeto do sistema informatizado e publicou portaria (Ministério da Saúde, 2004) que instituiu e divulgou as orientações para a implementação do Sisvan, no âmbito das ações básicas de saúde do SUS, em todo o território nacional. Em agosto de 2007, o site do Sisvan informou que 5.222 municípios estavam incluindo dados sobre o acompanhamento das condicionalidades de saúde do Programa Bolsa Família, e durante o primeiro semestre deste ano foram monitoradas 4.425.320 de famílias do programa (CGPAN, 2007; Ministério da Saúde, 2007).

Outro sistema relevante é o Sistema de Nascidos Vivos (Sinasc), que, estruturado no início da década de 1990, vem sendo aperfeiçoado desde então. Ele fornece informações sobre o peso ao nascer do universo de crianças nascidas em unidades de saúde e sobre alguns fatores associados a este desfecho como, por exemplo, idade e escolaridade maternas e idade gestacional (Mello-Jorge et al., 1993).

Nos últimos anos, inspirando-se na experiência de outros países e em recomendações da OMS sobre o tema, o Brasil começou a estruturar a implementação de sistemas de monitoramento de fatores de risco à saúde com foco naqueles associados às DCNT, entre eles o consumo alimentar e a prática regular de atividades físicas. 
No momento, sob coordenação da Secretaria de Vigilância em Saúde do Ministério da Saúde (SVS), estão em fase de estruturação dois sistemas, ambos baseados em amostras probabilísticas da população de interesse: um dirigido à população adulta e baseado em informações coletadas em entrevistas telefônicas, e outro dirigido à população adolescente e baseado em informações coletadas por meio de questionários preenchidos pelos próprios respondentes, aplicados na rede de ensino fundamental.

Também nos últimos anos, vem sendo implantada a Política de Avaliação e Monitoramento do MDS, iniciada desde a criação deste ministério, em 2004. A Secretaria de Avaliação e Gestão da Informação (Sagi) do MDS é o órgão responsável pelo sistema de avaliação e monitoramento das políticas desta pasta, cujo objetivo central é melhorar a gestão e o desempenho das políticas de desenvolvimento social.

Pelo exposto, várias iniciativas vêm sendo feitas para o monitoramento e a documentação da situação nutricional da população brasileira. Entretanto, muito ainda há que avançar e aprimorar, de modo a agilizar os processos de análise, disseminação e aplicação prática dos resultados obtidos.

\section{Avanços Recentes na Definição de Diretrizes Nacionais para a Promoção da Saúde}

Três documentos oficiais publicados recentemente expressam importantes avanços em termos de definição de diretrizes nacionais no campo da promoção da saúde. Neles, a promoção da alimentação saudável é considerada ação prioritária. De certa forma, esses dois documentos concretizam diretrizes estabelecidas na PNAN, que, como já comentado, foi um marco histórico em termos de redefinição do escopo das políticas públicas em alimentação e nutrição diante da transição nutricional.

O primeiro documento é a Política Nacional de Promoção da Saúde, publicado em março de 2006 (Brasil, 2006b). Suas diretrizes são: reconhecer na promoção da saúde uma parte fundamental da busca da eqüidade e da melhoria da qualidade de vida e de saúde; estimular as açóes intersetoriais, buscando parcerias que propiciem o desenvolvimento integral das ações de promoção da saúde; fortalecer a participação social como fundamental na consecução de resultados de promoção da saúde, em especial a eqüidade e o empoderamento individual e comunitário; promover mudanças na cultura organizacional, com vistas à adoção de práticas horizontais de gestão e ao estabelecimento de redes de cooperação intersetoriais; incentivar a pesquisa em promoção da saúde, avaliando eficiência, eficácia, efetividade e segurança das ações prestadas; divulgar e informar iniciativas voltadas para a promoção da saúde entre profissionais da saúde, gestores e usuários do SUS, considerando metodologias participativas e os saberes populares e tradicionais.

O segundo documento é a Política Nacional de Atenção Básica, publicado em 28 março de 2006 (Brasil, 2006a), que estabelece as diretrizes e normas para a organização da Atenção Básica para o PSF e o Programa Agentes Comunitários de Saúde (Pacs). Este é um lócus estratégico, no âmbito do setor Saúde, para a implementação das ações de alimentação e nutrição.

O terceiro documento é a portaria n. 1.010, publicada em maio de 2006 pelo Ministério da Saúde em conjunto com o Ministério da Educação, que apresenta diretrizes para a promoção da alimentação saudável nas escolas (Brasil, 2006d). É dirigido a escolas públicas e privadas e apresenta cinco eixos: Educação nutricional (ações dirigidas ao currículo e ações de mobilização); Hortas comunitárias; Segurança alimentar (boas práticas tanto no programa de alimentação escolar quanto nas cafeterias/cantinas); Restrição de venda e propaganda de alimentos nas cantinas escolares; Monitoramento do estado nutricional dos estudantes.

Primeiro documento legal sobre o tema publicado em conjunto por esses dois ministérios, essa portaria fornece diretrizes muito claras para a atuação dos diferentes atores sociais no ambiente escolar, espaço privilegiado para a promoção da alimentação saudável. 


\section{Considerações Finais}

A análise das políticas públicas desde os anos 80 até o presente demonstra, sem dúvida, avanços na ação governamental. Movimentos sucessivos pela descentralização da gestão foram desencadeados, acompanhados das respectivas regulamentaçóes para o repasse direto dos recursos financeiros em nível local. Verifica-se uma mudança de paradigma no combate à pobreza e na promoção da segurança alimentar e nutricional, com a substituição de programas de distribuição de alimentos pela transferência direta de renda. Esforços concretos para a melhoria do delineamento dos programas e para a construção de uma agenda de promoção da saúde e da alimentação saudável foram feitos, embora não tenham ainda apresentado repercussão programática na maioria dos municípios do país. Contudo, é evidente que as políticas públicas não dialogam entre si e que não buscam juntar suas forças institucionais para uma agenda única mais efetiva e coerente com os problemas existentes.

O desafio que está posto para os gestores das políticas públicas de alimentação e nutrição no âmbito da saúde é, portanto, o de desenvolver, fomentar e articular ações que respondam de forma resolutiva ao dinâmico processo de transição nutricional, em um cenário socioeconômico de profundas desigualdades sociais. Para isso, é necessário aprofundar e consolidar a atuação em dois grandes eixos: o primeiro no âmbito do SUS, e o segundo em âmbito intersetorial. No contexto do SUS, a agenda que se coloca é a de estruturação e ampliação da cobertura de ações que:

a) subsidiem e instrumentalizem a atuação dos gestores e profissionais da saúde no acompanhamento nutricional da população, permitindo o diagnóstico precoce e o manejo dos agravos nutricionais, e na promoção da saúde e da alimentação saudável;

b) apóiem os gestores locais nas ações de promoção da segurança alimentar e nutricional, inclusive com incentivos financeiros que facilitem aos gestores cumprir as condicionalidades de saúde dos programas de transferência de renda, importantes janelas de oportunidade para a promoção da saúde e da alimentação saudável;

c) disponibilizem mais recursos humanos e financeiros para atender às novas demandas da população que emergem do cenário da transição nutricional e desembocam nos diversos níveis de complexidade dos serviços de saúde.

No âmbito intersetorial, cabe ao setor Saúde protagonizar e influenciar processos decisórios que visem à formulação e implementação de políticas públicas voltadas para os determinantes dos agravos nutricionais, e não simplesmente para os seus desfechos, como a desnutrição e a obesidade. Para tanto, é imperativa a definição de uma instância coordenadora de uma agenda governamental, desenvolvida com enfoque multidisciplinar, coerente com o perfil epidemiológico da população e integrada às políticas já estabelecidas e reconhecidamente efetivas. Os esforços para o enfrentamento da transição nutricional devem ser concomitantes aos da redução da desigualdade social e permear a ação dos governos, do setor produtivo e da sociedade civil. O desafio é para todos. 


\section{Referências}

AGÊNCIA NACIONAL DE VIGILÂNCIA SANITÁRIA (ANVISA). Resolução RDC n. 39, 21 mar. 2001. Aprova a tabela de valores de referência para porções de alimentos e bebidas embalados para fins de rotulagem nutricional. Diário Oficial da União, Brasília, 22 mar. 2001, 2001a.

AGÊNCIA NACIONAL DE VIGILÂNCIA SANITÁRIA (ANVISA). Resolução RDC n. 40, 21 mar. 2001. Aprova o regulamento técnico para a rotulagem nutricional obrigatória de alimentos e bebidas embalados. Diário Oficial da União, Brasília, 22 mar. 2001, 2001 b.

AGÊNCIA NACIONAL DE VIGILÂNCIA SANITÁRIA (ANVISA). Resolução RDC n. 344, 13 dez. 2002. Aprova o regulamento técnico para a fortificação das farinhas de trigo e das farinhas de milho com ferro e ácido fólico. Diário Oficial da União, Brasília, 18 dez. 2002. Disponível em: <www.anvisa.gov.br/alimentos>. Acesso em: jan. 2007.

AGÊNCIA NACIONAL DE VIGILÂNCIA SANITÁRIA (ANVISA). Resolução RDC n. 359, 23 dez. 2003. Aprova o Regulamento Técnico sobre Rotulagem Nutricional de Alimentos Embalados, tornando obrigatória a rotulagem nutricional. Diário Oficial da Uniāo, Brasília, 26 dez. 2003a.

AGÊNCIA NACIONAL DE VIGILÂNCIA SANITÁRIA (ANVISA). Resolução RDC n. 360, 23 dez. 2003. Aprova o Regulamento Técnico sobre Rotulagem Nutricional de Alimentos Embalados, tornando obrigatória a rotulagem nutricional. Diário Oficial da Uniāo, Brasília, 26 dez. 2003 b.

AGÊNCIA NACIONAL DE VIGILÂNCIA SANITÁRIA (ANVISA). Consulta Pública n. 71, 10 nov. 2006. Regulamento dirigido à oferta, propaganda, publicidade, informação e a outras práticas correlatas cujo objeto seja a divulgação ou promoção de alimentos com quantidades elevadas de açúcar, de gordura saturada, de gordura trans, de sódio e de bebidas com baixo teor nutricional, quaisquer que sejam as formas e meios de sua veiculação. Diário Oficial da Uniāo, Brasília, 13 nov. 2006.

BEM-ESTAR FAMILIAR NO BRASIL (BEMFAM)/INSTITUTO BRASILEIRO DE GEOGRAFIA E ESTATÍSTICA (IBGE)/MINISTÉRIO DA SAÚDE (MS)/DEMOGRAPHIC AND HEALTH SURVEYS (DHS)/FUNDO DE POPULAÇÃO DAS NAÇŌES UNIDAS (FNUAP)/FUNDO DAS NAÇŌES UNIDAS PARA A INFÂNCIA (UNICEF). Pesquisa Nacional sobre Demografia e Saúde: relatório preliminar. Rio de Janeiro: Bemfam, 1997.

BRASIL. Portaria n. 1.882, 18 dez. 1997. Estabelece o Piso de Atenção Básica - PAB e sua composição. Diário Oficial da Uniāo, Brasília, 22 dez., n. 247-E, p. 10-11, 1997. Seção 1.

BRASIL. Portaria n. 2.091, 26 fev. 1998. Altera dispositivos da Portaria n. 1882 de 18/12/97, que estabelece o Piso de Atenção Básica - PAB e sua composição. Diário Oficial da União, Brasília, 3 mar., n. 41, p. 248, 1998a. Seção 1.

BRASIL. Portaria n. 2.409, 23 mar. 1998. Estabelece critérios e requisitos para implementação de ações de combate às carências nutricionais nos municípios. Diário Oficial da União, Brasília, 27 mar. 1998, n. 59, p. 33-62, 1998b. Seção 1.

BRASIL. Medida Provisória n. 2.206. Cria o Programa Nacional de Renda Mínima vinculado à Saúde: Bolsa Alimentação. Diário Oficial da União, Brasília, 13 ago. 2001.

BRASIL. Ministério das Relaçôes Exteriores. Convenção sobre os direitos da criança. Relatório consolidado ao Comitê sobre os Direitos da Criança. Brasília, 2003. 
BRASIL. Presidência da República. Medida Provisória n. 163/2004 convertida na Lei n. 10.869 de 13 maio 2004. Brasília, 2004.

BRASIL. Ministério da Saúde. Normas para o processo de habilitação do Hospital Amigo da Criança. Brasília, 2005 a.

BRASIL. Ministério da Saúde. Portaria n. 729. Institui o Programa Nacional de Suplementação de Vitamina A e dá outras providências. Diário Oficial da Uniāo, Brasília, 13 maio 2005, 2005 b.

BRASIL. Ministério da Saúde. Coordenação Geral da Política de Alimentação e Nutrição. Condutas gerais do Programa Nacional de Suplementação de Vitamina A. Série A. Normas e Manuais Técnicos Brasília, 2005c.

BRASIL. Ministério da Saúde. Portaria n. 2.362, 01 dez. 2005. Reestrutura o Programa Nacional de Prevenção e Controle dos Distúrbios por Deficiência de Iodo - DDI, designado por Pró-Iodo. Diário Oficial da Uniāo, Brasília, 01 dez. 2005, 2005d.

BRASIL. Ministério da Saúde. Portaria n. 648, 28 mar. 2006. Aprova a Política Nacional de Atenção Básica, estabelecendo a revisão de diretrizes e normas para a organização da Atenção Básica para o Programa Saúde da Família (PSF) e o Programa Agentes Comunitários de Saúde (PACS). Brasília, 2006a.

BRASIL. Ministério da Saúde. Portaria n. 687, 30 mar. 2006. Aprova a Política de Promoção da Saúde. Diário Oficial da União, Brasília, 31 mar. 2006b, n. 63, p. 138. Seção 1.

BRASIL. Ministério da Saúde. Coordenação Geral da Política de Alimentação e Nutrição. Manual Técnico e Operacional do Programa Nacional de Prevenção e Controle dos Distúrbios por Deficiência de Iodo. Brasília: MS, 2006c.

BRASIL. Ministérios da Saúde e da Educação. Portaria Interministerial n. 1.010, 8 maio 2006. Institui as diretrizes para a promoção da alimentação saudável nas escolas de educação infantil, fundamental e nível médio das redes públicas e privadas, em âmbito nacional. Diário Oficial da União, Brasília, 9 maio 2006d, n. 87, p. 70. Seção 1.

BRASIL. Ministério do Trabalho e Emprego. Portaria Interministerial n. 66, 25 ago. 2006. Altera os parâmetros nutricionais do Programa de Alimentação do Trabalhador. Diário Oficial da União, Brasília, 28 ago. 2006e.

BRASIL. Lei n. 11.346, 15 set. 2006. Cria o Sistema Nacional de Segurança Alimentar e Nutricional - Sisan com vistas em assegurar o direito humano à alimentação adequada e dá outras providências. Brasília, $2006 f$.

CASTRO, I. R. R. Vigilância Alimentar e Nutricional: limitaçôes e interfaces com a rede de saúde. Rio de Janeiro: Editora Fiocruz, 1995.

CASTRO, I. R. R. Efetividade da Suplementação Alimentar na Recuperação Nutricional de Crianças: avaliação do programa "Leite éSaúde" no município do Rio de Janeiro, 1999. Tese de Doutorado, São Paulo: Faculdade de Saúde Pública, Universidade de São Paulo.

COIMBRA, M. A. Alimentação no Brasil. Belo Horizonte, 1982. (Mimeo.)

COITINHO, D. C. et al. Condiçôes Nutricionais da População Brasileira: adultos e idosos. Pesquisa Nacional sobre Saúde e Nutrição. Brasília: Inan/MS, 1991.

CONSELHO NACIONAL DE SAÚDE (CNS). Resolução 31, de 12 de outubro de 1992. Aprova a Norma Brasileira para a Comercialização de Alimentos para Lactentes. Brasília, 1992. 
CONSELHO NACIONAL DE SEGURANÇA NACIONAL (CONSEA). I Conferência Nacional de Segurança Alimentar e Nutricional. Conselho Nacional de Segurança Alimentar e Ação da Cidadania. Relatório Final. Brasília, 1994.

CONSELHO NACIONAL DE SEGURANÇA NACIONAL (CONSEA). Princípios e diretrizes de uma política de segurança alimentar e nutricional. Textos de referência da II Conferência Nacional de Segurança Alimentar e Nutricional. Conselho Nacional de Segurança Alimentar e Nutricional. Brasília, 2004.

COORDENAÇÃO GERAL DA POLÍTICA DE ALIMENTAÇÃO E NUTRIÇÃO (CGPAN). Relatório de Gestão - 2003. Brasília, 2004. Disponível em: <www.saude.gov.br/nutricao>. Acesso em: jan. 2007.

COORDENAÇÃO GERAL DA POLÍTICA DE ALIMENTAÇÃO E NUTRIÇÃO (CGPAN). Sisvan, Módulo de Gestão, Relatórios Consolidados, 2a Vigência 2006. Brasília, 2007. Disponível em: <www.saude.gov.br/ nutricao> Acesso em: jan. 2007.

ENGSTROM, E. M. Efetividade da Suplementação Diária e Semanal com Sulfato Ferroso na Prevenção da Anemia em Crianças Menores de Um Ano de Idade: um ensaio clinico randomizado por grupos, 2006. Tese de Doutorado, Rio de Janeiro: Escola Nacional de Saúde Pública Sergio Arouca, Fundação Oswaldo Cruz.

GALEAZZI, M. A.; DOMENE, S. M. A. \& SICHIERI, R. (Orgs.) Estudo Multicêntrico de Consumo Alimentar. Campinas: Nepa, 1997. (Cadernos de Debate, vol. especial).

INSTITUTO BRASILEIRO DE GEOGRAFIA E ESTATÍSTICA (IBGE). Estudo Nacional da Despesa Familiar. Brasília: Endef, 1980.

INSTITUTO BRASILEIRO DE GEOGRAFIA E ESTATÍSTICA (IBGE). Pesquisa sobre Padröes de Vida. Rio de Janeiro: IBGE, 1997.

INSTITUTO BRASILEIRO DE GEOGRAFIA E ESTATÍSTICA(IBGE). Estatísticas de Saúde, Assistência Médico-Sanitária. Rio de Janeiro: IBGE, 2005.

INSTITUTO BRASILEIRO DE GEOGRAFIA E ESTATÍSTICA (IBGE). Pesquisa Nacional por Amostra de Domicílios: segurança alimentar, 2004. Rio de Janeiro: IBGE, 2006.

INSTITUTO BRASILEIRO DE GEOGRAFIA E ESTATÍSTICA (IBGE)/MINISTÉRIO DA SAÚDE (MS). Pesquisa de Orçamentos das Famílias 2002-2003: análise da disponibilidade domiciliar de alimentos e do estado nutricional no Brasil. Rio de Janeiro: POF, 2004.

INSTITUTO BRASILEIRO DE GEOGRAFIA E ESTATÍSTICA (IBGE)/MINISTÉRIO DA SAÚDE (MS). Pesquisa de Orçamentos das Famílias 2002-2003: antropometria e análise do estado nutricional de crianças e adolescentes no Brasil. Rio de Janeiro: POF, 2006.

INSTITUTO NACIONAL DE ALIMENTAÇÃO E NUTRIÇÃO (INAN). I Programa Nacional de Alimentação e Nutrição - Pronan 1973/1974. Brasília, 1973. Biblioteca do Ministério da Saúde sob o registro MF 0784 cod. 100020073/3.

INSTITUTO NACIONAL DE ALIMENTAÇÃO E NUTRIÇÃO (INAN). Relatório final da I Conferência Nacional sobre Saúde e Nutrição. Brasília, 1986.

JELLIFFE, E. P. F. \& JELLIFFE, D. B. Programmes to Promote Breastfeeding. Oxford: Oxford Medical Publications, 1988.

KRUSE, B. G. A. O Pronan e as perspectivas no campo da alimentação e nutrição. Conferência pronunciada no III Encontro de Ciência e Tecnologia de Alimentos, promovido pela Universidade Federal Rural do Rio de 
Janeiro. Rio de Janeiro, 1979. (Mimeo.)

MAIA, P. R. S. et al. Rede Nacional de Bancos de Leite Humano: gênese e evolução. Revista Brasileira de Saúde Materno Infantil, 6(3): 285-292, 2006.

MELLO-JORGE, M. H. P. et al. Avaliação do Sistema de Informações sobre Nascidos Vivos e o uso de seus dados em epidemiologia e estatísticas de saúde. Revista de Saúde Pública, 27, supl.: 1-44, 1993.

MINISTÉRIO DO DESENVOLVIMENTO SOCIAL E COMBATE À FOME. Programa Bolsa Família. Brasília, 2006a. Disponível em: <www.mds.gov.br/bolsafamilia>. Acesso em: dez. 2006.

MINISTÉRIO DO DESENVOLVIMENTO SOCIAL E COMBATE À FOME. Secretaria de Avaliação e Gestão da Informação. Chamada Nutricional: um estudo sobre a situação nutricional das crianças do SemiÁrido brasileiro. Brasília: MDS, 2006b. (Cadernos de Estudo, 4)

MINISTÉRIO DAS RELAÇÕES EXTERIORES. Relatório nacional brasileiro para a Cúpula Mundial da Alimentação. Roma, 1996.

MINISTÉRIO DA SAÚDE. Instituto Nacional de Alimentação e Nutrição. Pesquisa Nacional sobre Saúde e Nutrição. Brasília: MS, 1989.

MINISTÉRIO DA SAÚDE. Programa de Atendimento aos Desnutridos è̀s Gestantes em Risco Nutricional: Leite éSaúde. Brasília: MS, 1993.

MINISTÉRIO DA SAÚDE. Compromisso Social no Controle da Anemia por Carência de Ferro no Brasil. Brasília: MS, 1999a.

MINISTÉRIO DA SAÚDE. Politica Nacional de Alimentação e Nutrição. 1. ed. Brasília: MS, 1999b.

MINISTÉRIO DA SAÚDE. Secretaria de Políticas de Saúde. Balanço das atividades na área de alimentação e nutrição a partir de 1998. Documento interno. Brasília, 2002.

MINISTÉRIO DA SAÚDE. Portaria Ministerial n. 2.246 de 18 de outubro de 2004. Institui e divulga orientações básicas para o Sisvan. Diário Oficial da União, Brasília, 20 out. 2004. Disponível em: <www.saude.gov.br/ nutrição>. Acesso em: dez. 2006.

MINISTÉRIO DA SAÚDE. Secretaria de Atenção à Saúde. Departamento de Atenção Básica. Manual Operacional do Programa Nacional de Suplementação de Ferro. Brasília: MS, 2005.

MINISTÉRIO DA SAÚDE. Secretaria de Atenção à Saúde. Departamento de Atenção Básica. Obesidade. Série A. Normas e Manuais Técnicos. Brasília: MS, 2006a. (Cadernos de Atenção Básica, 12)

MINISTÉRIO DA SAÚDE. Secretaria de Atenção à Saúde. Departamento de Atenção Básica. Coordenação Geral da Política de Alimentação e Nutrição. Guia Alimentar para a População Brasileira: promovendo a alimentação saudável. Brasília: MS, $2006 \mathrm{~b}$.

MINISTÉRIO DA SAÚDE. Secretaria de Vigilância em Saúde. Departamento de Análise de Situação de Saúde. Mapeamento das Iniciativas de Vigilância, Prevenção e Controle das Doenças Crônicas Não Transmissiveis no Brasil, 1999-2005: subsidios para a formulação de uma política nacional de vigilância integrada. Brasília: MS, 2006c.

MINISTÉRIO DA SAÚDE. Secretaria de Atenção à Saúde. Departamento de Atenção Básica. Coordenação Geral da Política de Alimentação e Nutrição. Sistema de Vigilância Alimentar e Nutricional, 2007. Disponível em <http://dtr2004.saude.gov.br/nutricao/sisvan.php>. Acesso em: agosto 2007. 
MINISTÉRIO DOTRABALHO. Programa de Alimentação do Trabalhador. Disponível em: <www.trabalho.gov.br>. Acesso em: dez. 2006.

MONTEIRO, C. A. (Org.) Velhos e Novos Males da Saúde no Brasil: a evolução do país e de suas doenças. 2. ed. aum. São Paulo: Hucitec, Nupens/USP, 2000.

MUSGROVE, P. Programas Destinados a Mejorar el Consumo Alimentício de Familias Pobres en el Brasil: evaluación parcial del PROAB, PNS y PCA. Washington: OPS, 1985.

OLIVEIRA, M. I. C. \& CAMACHO, L. A. B. Impacto das unidades básicas de saúde na duração do aleitamento materno exclusivo. Revista Brasileira de Epidemiologia, 5(1): 41-51, 2002.

ORGANIZAÇÃO PAN-AMERICANA DA SAÚDE (OPAS). Bibliografia sobre Deficiência de Micronutrientes no Brasil - 1990-2000. Vol. III - Iodo e bócio endêmico. Brasília: OPS, 2002.

PELIANO, A. M. et al. O Problema Alimentar Brasileiro: situação atual, perspectivas e propostas de políticas. Brasília: Ipea/CNRH, 1983. (Documento de Trabalho, 11)

SANTOS, I. S. Use of isotope method to measure the impact on child growth of a nutritional program delivered to underweight children in Northeast, Brazil. Final report of Project RLA 7/008 IAEA. Brazil, 2003.

SECRETARIA DE ESTADO DE SAÚDE DO RIO DE JANEIRO. Iniciativa Unidade Básica Amiga da Amamentação: manual de capacitação de multiplicadores. Rio de Janeiro, 2006.

SISTEMA INTEGRADO DE ADMINISTRAÇÃO FINANCEIRA DO GOVERNO FEDERAL (SIAFI). Programa Alimentação Saudável, Unidade 36901, Fundo Nacional de Saúde. Base de dados de 19 de janeiro de 2003. Pesquisa feita em dezembro de 2006.

SWINBURN, B. et al. Dissecting obesogenic environments: the development and application of a framework for identifying and prioritizing environmental interventions for obesity. Preventive Medicine, 29: 563-570, 1999.

SZWARCWALD, C. L. et al. Pesquisa Mundial de Saúde: o Brasil em números. Radis: comunicação em saúde, (23): 14-23, 2004.

UNITED NATIONS CHILDREN'S FUND (UNICEF)/UNITED NATIONS UNIVERSITY (UNU)/ WORLD HEALTH ORGANIZATION (WHO). Preventing Iron Deficiency in Women and Children: technical consensus on key issues and resources for programme advocacy, planning and implementation. New York: Unicef, 1998. (MI Technology Workshop)

VAITSMAN, J. et al. O Sistema de Avaliação e Monitoramento das Políticas e Programas Sociais: a experiência do Ministério do Desenvolvimento Social e Combate à Fome. Brasília: Unesco, 2006. (Policy Papers, 17)

VALENTE, F. L. S. Direito Humano à Alimentação: desafios e conquistas. São Paulo: Cortez, 2002.

VALENTE, F. A Política de Insegurança Alimentar e Nutricional. Brasília: Inesc, 2004.

WORLD HEALTH ORGANIZATION (WHO). Iron Deficiency Anaemia Assessment, Prevention and Control: a guide to programme managers. Geneva: WHO, 2001.

WORLD HEALTH ORGANIZATION (WHO). Global Strategy on Diet, Physical Activity and Health. Geneva: WHO, 2004.

WORLD HEALTH ORGANIZATION (WHO). WHA 58.24, Fifty-Eighth World Health Assembly. Sustaining the Elimination of Iodine Deficiency Disorders, May, Geneva, 2005. 
WORLD HEALTH ORGANIZATION (WHO)/FOOD AND AGRICULTURE ORGANIZATION OFTHE UNITED NATIONS (FAO). WHO/FAO Expert Consultation. Diet, Nutrition and the Prevention of Chronic Diseases. Geneva: WHO, 2003. (WHO Technical Report Series, 916)

WORLD HEALTH ORGANIZATION (WHO)/THE UNITED NATIONS CHILDREN'S FUND (UNICEF). The Global Criteria for the Baby Friendly Hospital Iniciative. Geneva: WHO, 1992.

WORLD HEALTH ORGANIZATION (WHO)/THE UNITED NATIONS CHILDREN'S FUND (UNICEF)/ INTERNATIONAL COUNCIL FOR THE CONTROL OF IODINE DEFICIENCY DISORDERS (ICCIDD). Assessment of Iodine Deficiency Disorders and Monitoring their Elimination. Geneva: WHO, 2001. (WHO/NHD/01.1) 



\title{
Janelas Críticas para Programação Metabólica e Epigênese Transgeracional
}

\author{
Aníbal Sanchez Moura
}

$\mathrm{E}$ studos recentes em epidemiologia e biologia experimental demonstram que o desenvolvimento biológico é sempre resultado da interação entre o ser biológico e o meio ambiente. Modificações no meio (nutrição, temperatura e estresse) interagem com as características biológicas (genética, idade e sexo) determinando o surgimento de fenótipos específicos. Tais fenótipos, por sua vez, representam o produto da organização de indivíduos adaptados (ou não) a situações ambientais diversas, refletindo-se, em última instância, como indivíduos saudáveis ou doentes. Esse conceito, embora de senso comum, somente nas últimas décadas obteve atenção sistemática no meio científico.

Alguns estudos epidemiológicos são seminais no desenvolvimento da teoria que aborda o poder de determinação pregressa no surgimento de doenças crônicas. Nesses trabalhos estudou-se, basicamente, a associação entre baixo peso ao nascer e desenvolvimento de patologias na idade adulta. Nesta categoria encontram-se os estudos realizados em Wales, na Inglaterra, por David Barker e Clive Osmond em 1986 em coortes de crianças nascidas no início do século XX ( 1920) e estudadas quando adultas $(\sim 1980)$. Os autores concluem nesses trabalhos que a nutrição no início da vida associa-se a Doenças Cardiovasculares (DCV) na idade adulta. Deriva desses estudos a teoria da "origem fetal das doenças", que marca decisivamente os estudos epidemiológicos e de biologia experimental nos últimos trinta anos (Barker, 2004).

Essa teoria tem se confirmado em uma série de outros trabalhos nos quais se demonstra a existência de um padrão de desenvolvimento dependente das condições de desenvolvimento fetal, assim como do ambiente e das condiçôes perinatais. Para sua consolidação, tornou-se necessário estabelecer critérios para se determinar, entre outros, se tais doenças são ou não reversíveis. Alguns estudos permitiram a avaliação dessa teoria seguindo critérios e metodologias mais acuradas. Por exemplo, registros médicos em diferentes momentos no início da vida de populaçôes permitiram observar se causas pregressas eram determinantes de doenças a longo prazo (Waterland \& Garza, 1999). No clássico estudo da população holandesa adulta, que durante a Segunda Guerra Mundial passou por períodos de desnutrição, foi possível, por meio do controle de um amplo conjunto de variáveis, confirmar a relação entre a disponibilidade de nutrientes durante a gestação e a reversibilidade ou não de algumas doenças crônicas. A particular situação dessa população deveu-se ao fato de que nas proximidades do final da Segunda Guerra Mundial o governo holandês no exílio determinou que a resistência holandesa colaborasse com as tropas aliadas em diferentes ataques aos alemães. Como retaliação, os nazistas determinaram o cerco da Holanda, proibindo a entrada de comida e energia. Mais tarde foi permitida a entrada de comida; entretanto, por 
motivos de estratégia de guerra, a comida deveria ser distribuída através dos rios, onde o controle nazista se dava de forma mais eficiente. A chegada da comida aos holandeses foi impossibilitada pela imprevisibilidade do clima. Naquele ano de 1944, o inverno se antecipou. Os rios congelaram, a natureza e os homens em guerra produziram um grande episódio de fome conhecido como The 1944-1945 Dutch Famine. A existência de um sistema de registro e a organização da população na guerra, fazendo uma distribuição de alimentos conforme as demandas necessárias para a defesa militar da Holanda, a despeito do caráter trágico desse evento, gerou uma rica fonte de dados. Pode-se, hoje, afirmar que grande parte dos estudos sobre efeitos da nutrição no início da vida no desenvolvimento de doenças crônicas, tais como doenças cardiovasculares, metabólicas e câncer, baseia-se nas evidências provenientes de estudos dessas populações anos após o inverno de 1944-1945. No caso do câncer de mama, fortes evidências demonstram que o desenvolvimento da doença deve-se à desnutrição, assim como ao processo de realimentação. Ou seja, o período e a magnitude do processo de realimentação determinariam a reorganização celular em um padrão que se desenvolveria em direção a determinadas patologias (Susser \& Stein, 1994).

As informações provenientes dessas populações permitem, hoje, demonstrar com mais ênfase que a interação entre o meio ambiente e o ser biológico opera constantes alteraçōes, gerando ou não adaptações fisiológicas. Tais adaptações refletem o equilíbrio dinâmico entre o meio interno e o meio externo. Pode-se dizer, portanto, que o desenvolvimento biológico é o desenvolvimento dessas interações e suas resultantes e originais adaptações. Ou seja, alterações decorrentes da participação desproporcional (por falta ou excesso) dos fatores constituintes dessa delicada dinâmica geram desvios do desenvolvimento normal, fazendo surgir novos padrôes de equilíbrio metabólico e, por incapacidade de fazer emergir e manter tais padrôes, a doença surge. Diversos estudos epidemiológicos e experimentais mostram que, nas interações com o ambiente, o organismo pode responder agudamente, ou seja, identificando a interação, reagindo e se reconstituindo, ou também, cronicamente, adaptando-se mediante modificações fisiológicas permanentes.

\section{O Conceito de Impressão Metabólica: janela de exposição (critical window)}

As modificações geradas nos indivíduos na idade adulta e decorrentes de ação ambiental (p. ex., disponibilidade de nutrientes) podem ser de duas ordens: 1) mantidas como resposta à manutenção do estímulo (negativo ou positivo) externo (ex: condições sociais) ou por modificaçôes estruturais do meio interno (p. ex., acidentes); 2) permanentes após a retirada do agente indutor do processo adaptativo. Assim, alguns processos adaptativos gerados em resposta a insulto externo, como a desnutrição, são mantidos mesmo quando a nutrição normal é restituída. Nessa perspectiva, diversos autores têm mostrado que o diabetes e as DCV podem ter etiopatogenias constituídas pelo desequilíbrio na interação entre o indivíduo e variáveis ambientais (p. ex., nutrição) em determinado período da vida. Assim, para a compreensão do desenvolvimento das doenças tem-se utilizado como conceito a idéia de janela de exposição (momento de maior risco), ou seja, o momento no qual ocorre a impressão ou estampagem e, com o seu desdobramento, a programação metabólica.

Em relação à janela de exposição, são características de sua potencialidade na determinação de doenças na idade adulta o período da vida em que ocorre e a sua intensidade. Por exemplo, em relação a determinadas doenças a ocorrência de desnutrição na gestação determina efeitos prospectivos muito mais amplos que a desnutrição na idade adulta. Entretanto, tal afirmativa não restringe a idéia de janela de exposição ao período gestacional, já que é possível determinar períodos de intensa vulnerabilidade em outras idades - por exemplo, na adolescência. Outros determinantes podem conferir maior ou menor capacidade de programação biológica. Por exemplo, características dos indivíduos podem ampliar ou reduzir a ação do meio durante a janela de 
exposição. É, entretanto característica temporalmente marcada dos organismos a sua capacidade de adaptação metabólica. Em condições fora da normalidade, pode ocorrer a produção ou inibição de proteínas responsáveis pela regulação de hormônios. Condições nutricionais diferenciadas podem induzir mecanismos voltados para a inibição da expressão de determinados genes. Adicionalmente, a interação entre os fatores ambientais e o ser biológico depende de perfil genômico. Por exemplo, são conhecidas as diferenças de resposta metabólica entre caucasianos, negros e outras etnias submetidas às mesmas condiçõos ambientais em relação ao desenvolvimento de doenças crônicas não transmissíveis. Ou seja, os fatores ambientais interagem com as características dos indivíduos, o que dimensiona, de certa forma, a relação entre momento e intensidade na configuração do efeito tardio.

\section{Janelas de Exposição e Sistemas Controladores}

O ambiente penetra nos indivíduos, basicamente, por intermédio de estímulos sobre o sistema nervoso, determinando, por exemplo, por meio de nutrientes ou ausência de nutrientes, particulares respostas. Ao sistema nervoso associa-se o sistema endócrino e, por conseguinte, as relações entre os dois sistemas dão seguimento às instruções ambientais no interior do organismo. A combinação de meio ambiente (nutrientes disponíveis), recepção do sistema nervoso e modulação do sistema endócrino gerará diferentes efeitos, dependendo da fase de desenvolvimento. Em períodos específicos do desenvolvimento - por exemplo, no período fetal e durante a lactação -, são estabelecidos os mecanismos de controle do sistema nervoso e hormonal que desenvolvem as suas configurações e inter-relações. A integração entre os dois sistemas é tema de uma série de estudos em animais e em humanos que demonstram a importância de modificaçôes neuro-hormonais no início da vida no surgimento de diferentes patologias na idade adulta. Demonstra-se que a modulação da ingestão de nutrientes, armazenamento e utilização de fontes energéticas na idade adulta depende de configuraçôes nervosas e hormonais desenvolvidas no hipotálamo no início da vida. No período fetal, ou mesmo no início da lactação, caso tal circuitaria neuro-hormonal seja obrigada à adaptação a situações de desnutrição, seu desenvolvimento morfológico e fisiológico modifica-se, podendo ficar permanentemente alterado, mesmo quando a alimentação retorne à normalidade. No caso específico da desnutrição na gestação e/ou lactação, as adaptações do organismo geradas como respostas a condições de carência nutricional induzem, entre outros ajustes, o aumento da sua capacidade de utilização dos nutrientes. $\mathrm{O}$ resultado de tais adaptações pode ser observado quando estudamos hormônios, tais como a insulina, para os quais o organismo aumenta a sua sensibilidade no momento em que ocorre inibição de sua secreção. Entretanto, ao serem restabelecidas as condições normais de alimentação, a circuitaria hipotalâmica e seu controle sobre as vias neuro-hormonais se mantêm em descompasso com a utilização adaptada de nutrientes e seu provimento normal (Moura et al., 2002).

Por meio do estudo em humanos e diferentes modelos experimentais, busca-se explicar as situações observadas em humanos nas quais modificações nutricionais em janelas de exposição determinam padrôes diferentes de fome e saciedade. Distúrbios alimentares encontrados em adultos, tais como os expressos em obesos, têm sido associados com anormalidades nutricionais ocorridas durante determinadas janelas de exposição na infância e na adolescência. A descoberta de uma série de hormônios dependentes de certos aportes nutricionais que ocorrem em fases específicas do desenvolvimento e que agem em área específica do cérebro, tais como a colecistocinina, grelina, Neuropeptídeo Y (NPY), adiponectina e insulina, permite estudos em bases científicas mais rigorosas (Bouret \& Simerly, 2006). Especial interesse tem despertado a descoberta da leptina (Zhang et al., 1994). Este hormônio, produzido por adipócitos, exerce ação sobre a modulação do processo de fome-saciedade no hipotálamo, assim como controlador da partição energética periférica. Interessante observar também que a síntese desses hormônios depende da ação de nutrientes em seus respectivos genes, e principalmente que tal ação modulatória nutricional ocorre em momentos particulares do desenvolvimento. Por exemplo, a descoberta de neurotransmissores, tais como NPY, Agouti-Related Peptide (AGRP), Proopiomelanocortin 
(POMC) e Cocaine inducible element (CART), reveste-se de importância porque constituem, conjuntamente com a leptina, hormônios que organizam os circuitos neuronais hipotalâmicos, determinantes da modulação fina do processo de fome-saciedade (Berthoud, 2002). Sabemos, hoje, que a leptina e a insulina, cuja secreção e ação no início da vida são determinadas pelo aporte nutricional, têm vital importância no desenvolvimento morfológico dessa circuitaria. Ou seja, a leptina age diretamente não só no metabolismo, mas também na configuração da circuitaria neural responsável pelo controle da fome-saciedade.

A presença ou ausência de nutrientes em janelas críticas do desenvolvimento, por meio de estímulo ou inibição da secreção de hormônios, altera a funcionalidade dos órgãos. Tais órgãos alterados, por sua vez, dependem de padrões de ação hormonal específicos para utilização desses mesmos nutrientes. Fecha-se, assim, um ciclo inaugurado pelo processo de estampagem ou imprinting, induzido por alteração nutricional e mantido pelas demandas de suas alteraçôes pregressas em um processo denominado programação metabólica.

\section{Janela de Exposição e Programação de Doenças}

Trabalhos pioneiros demonstraram associação entre variações nutricionais em períodos específicos do início da vida (janelas de exposição), como causa de efeitos prospectivos no metabolismo energético nos indivíduos quando adultos. Demonstrou-se, basicamente, que a resistência à insulina, assim como a sua secreção, encontram-se alteradas nos adultos desnutridos na gestação. Tal associação reveste-se de importância porque o efeito da insulina, associada a outros hormônios, entre os quais a leptina, no crescimento e metabolismo celular é decisivo. Sabe-se, por exemplo, que integrando-se os dois hormônios, a insulina estimula a adipogênese (Barr et al., 1997), modificando a disponibilização e ação da leptina. Por sua vez, os receptores da leptina presentes nas células betapancreáticas inibem secreção de insulina (Emilsson et al., 1997), determinando a existência de um eixo adipoinsular, no qual a secreção de insulina estimula a adipogênese, com concomitante aumento da produção de leptina. Também, por meio de mecanismo de retroalimentação, a leptina produzida reduziria a secreção de insulina, reduzindo, por sua vez, a adipogênese.

Estudos epidemiológicos realizados em países como Inglaterra, Estados Unidos e Suécia mostram que o Baixo Peso ao Nascer (BPN) associa-se a modificações na homeostase glicêmica dos indivíduos quando adultos. Sabe-se também que a redução de nutrientes na fase fetal programa prospectivamente alterações na secreção e ação da insulina. Basicamente, em estudos em humanos e experimentais em animais, o BPN como resultado da redução da disponibilidade de nutrientes ao feto determina adaptação metabólica. Dessa forma, por exemplo, a baixa estatura na idade adulta pode ser considerada um indicador epidemiológico de nutrição pregressa, assim como resultado de adaptação metabólica construída como resposta à carência nutricional na infância.

O crescimento da criança depende da interação entre o ambiente fetal e a plasticidade metabólica do feto. Ou seja, durante o desenvolvimento fetal as determinações genéticas indutoras do crescimento dependem, para sua expressão, por exemplo, do aporte e disponibilidade, assim como da capacidade de utilizar nutrientes. A determinação materna desse processo pode ser considerada preponderante nesta fase (ou janela) do desenvolvimento. Por exemplo, o implante de óvulo proveniente de mães altas em mães de baixa estatura, em condições ambientais similares, fez com que os fetos se desenvolvessem em crianças de baixa estatura. Pode-se, assim, dizer que as determinações genéticas do crescimento podem ser relativizadas pelos fatores ambientais conferidos ao feto pela mãe. Ou seja, o ambiente gerado pela relação mãe-feto-nutriente constitui-se em forte determinante da plasticidade do feto e, portanto, de sua adaptabilidade (Jones, 2005).

É evidente que a plasticidade conferida pelo ambiente fetal pode ser também entendida como uma forma de priorização de respostas metabólicas. Ou seja, os nutrientes fluem para sistemas essenciais à manutenção da vida em prejuízo de outros não tão essenciais. Dessa forma, o organismo se adapta, aperfeiçoa determinados sistemas e sobrevive. Entretanto, tal processo gera um custo. Por exemplo, o organismo reduz o número de 
células. Tal redução, importante como resposta adaptativa no período fetal, induz deficiências fundamentais na idade adulta (Moura et al., 2002).

Também clássicos são os estudos que associam variações nutricionais durante a janela de exposição e alteração do desenvolvimento do coração e do sistema circulatório. Em biologia experimental, na tentativa da criação de modelos experimentais que contemplem tal interação, diferentes animais geneticamente modificados foram desenvolvidos.

A origem dessas doenças parece ter também uma explicação na alteração neuro-hormonal desencadeada durante a janela de exposição, quando ocorre variação de provimento nutricional. Além do que foi anteriormente assinalado, sabemos que o efeito prospectivo da desnutrição na gestação leva à obesidade, que, por sua vez, reduz a secreção de insulina, alterando a adipogênese. Tal obesidade adquirida determina um processo de dessensibilização do receptor de leptina hipotalâmico, constituindo-se em importante fator causal da hiperfagia, que, por sua vez, determinaria a redução da sensibilidade à insulina, induzindo aumento na secreção da insulina. Esse raciocínio oferece uma interessante ligação para a observada associação entre obesidade, diabetes e DCV.

A determinação de alterações dos sistemas hormonais, tais como o sistema insulina-leptina induzido por variações nutricionais durante a janela de exposição, se reflete nas DCV. Demonstra-se, por exemplo, que concentrações elevadas de leptina se associam ao aumento da freqüência cardíaca e da pressão arterial e também ao aumento da espessura do miocárdio, independentemente da composição corpórea e dos níveis de pressão sangüínea. Em modelo experimental, comparando-se animais controle obesos e hipertensos espontâneos, também se verifica que a leptina induz inibição da contração de cardiomiócitos nos animais controle e é incapaz de agir nos miócitos dos ratos obesos e hipertensos (Casto, Vanness \& Overton, 1998; Shek, Brands \& Hall, 1998; Paolisso et al., 1999). Ou seja, na obesidade, a ação da leptina nos cardiomiócitos pode ser inibida. Sugere-se que tal processo ocorra nos cardiomiócitos através de modificações na cascata de sinalização do hormônio, especificamente por alteração de proteínas da cascata de sinalização da insulina, relacionadas ao metabolismo energético e crescimento celular, como as da via Janus Tyrosine Kinase/Signal Transducer and Activator of Transcription (JAK/Stat) e Mitogen-Activated Protein kinase (MAP kinase). Ou seja, provavelmente alterações no diálogo molecular induzido por desnutrição no início da vida entre a leptina e a insulina durante o processo de sinalização hormonal em seus estágios pós-receptores participam na etiopatogenia da hipertrofia ventricular cardíaca em obesos (Pereira et al., 2006).

O aumento da resistência à insulina desenvolvido a partir de alteração nutricional no início pode induzir uma maior demanda na secreção de insulina. Tal processo se dá inicialmente e se constitui em forma adaptativa voltada para a proteção contra o surgimento do diabetes tipo 2. Entretanto, outros fatores se associam à hiperinsulinemia, como hipertensão, dislipidemia com aumento de triglicerídeos e redução de lipoproteínas de baixa densidade (HDL-C).

Recentes evidências têm demonstrado relação entre a desnutrição no início da vida e o desenvolvimento de câncer na idade adulta. Por exemplo, mulheres que foram submetidas à desnutrição no início da gestação durante a fome holandesa de 44-45 apresentaram risco de câncer de mama cinco vezes maior quando comparadas com mulheres não expostas à fome no período perinatal. Acrescenta-se ainda que o surgimento do câncer de mama nessas mulheres não está associado aos fatores de risco comuns desta doença. A despeito da exigüidade de estudos que especificamente abordem os mecanismos indutores desse processo, algumas hipóteses têm sido levantadas, como, por exemplo, a de que a retomada de uma alimentação normal e crescimento físico nessa população levaria a uma rápida proliferação celular, acarretando a produção maior e desequilibrada de fatores de crescimento, que prospectivamente poderia determinar o surgimento do câncer. Mais ainda, sugere-se que, determinada por condições nutricionais, ocorreria redução do processo proliferativo, por exemplo, de células-tronco, conservando-se, entretanto, a potência proliferativa. Assim, por ocasião do processo de alimentação normal, as células retomariam a sua capacidade proliferativa em um ambiente estranho ao seu próprio desenvolvimento. As observações sobre a 
associação entre peso ao nascer, velocidade de crescimento na infância e surgimento de câncer de mama na idade adulta poderiam ser explicadas não apenas pelo processo carencial, mas também por um sistema que integre a carência e a normalização nutricional. Ou seja, nessas populaçôes desnutridas no início do processo gestacional e depois nutridas de forma normal, o catch-up determinaria as condiçôes para o estabelecimento do câncer (Elias et al., 2005). Alguns autores sugerem que mecanismos celulares responsáveis pela ativação do sistema de coagulação extrínseco acompanham a normalização nutricional e a cascata fibrinolítica. Tais processos, por sua vez, estando também associados ao crescimento, invasão e metástase, facilitariam o desenvolvimento de câncer. Por exemplo, as altas concentraçōes de fibrinogênio, um potente marcador de câncer presente nas mulheres holandesas, sugerem que o processo de programação metabólico voltado para a recuperação do crescimento gera também agentes aterogênicos (Roseboom et al., 2000a, 2000b).

\section{As Janelas de Exposição e Epigênese Transgeracional Nutricional}

Hoje, pode-se dizer que o poder de programação metabólica induzido por alterações nutricionais em determinadas fases da vida encontra-se bem caracterizado. Entretanto, novas questōes têm sido apresentadas aos estudiosos deste campo. No caso da origem fetal da programação metabólica, seriam as programações desenvolvidas decorrentes de específicos nutrientes ou da interação destes com a fisiologia materna? Acrescenta-se ainda a discussão sobre a possibilidade de um provável processo de transmissão transgeracional da totalidade ou parte da variabilidade metabólica obtida.

Nos estudos epidemiológicos, a interação entre a saúde da mãe e o aporte nutricional durante a gestação se mostra relevante. Os dados atuais revelam que uma parcela importante das mulheres gestantes é portadora de sobrepeso, o que dificulta a interpretação de uma 'origem fetal' de doenças. É preciso separar a programação metabólica adquirida pelos filhos daquela que decorre da associação entre nutrientes específicos ou de outras determinações da obesidade dessas mães. Novas indagações científicas sobre o conceito de 'janela de exposição' têm determinado redefinições que permitam a absorção de novos e complexos conjuntos de variáveis.

Atendendo às demandas teóricas aqui apresentadas, recentemente, com a ampliação de instrumental teórico e técnico em biologia, tais como o desvendamento tanto do genoma quanto de sua fisiologia, têm sido abertas novas possibilidades da análise da determinação prospectiva de certas doenças. Neste contexto, avanços têm sido obtidos com disciplinas que privilegiam como centro de investigação a progressão de um fenótipo sadio a um fenótipo característico de uma doença crônica, como resultante de modificações na expressão gênica. Mais especificamente, como resultante da atividade de proteínas, enzimas e outras substâncias químicas. Parte-se do princípio de que a informação genômica pode ser modulada diferentemente por variações quantitativas e qualitativas de nutrientes. Assim, uma expressiva produção científica demonstra que diferentes moléculas químicas dos alimentos agiriam de forma particular no gene. Por exemplo, no milho, um alimento mundialmente utilizado, tem-se demonstrado que diferentes ácidos graxos livres, triglerídeos, tocoferol, esteróis e outras substâncias exercem ação individualizada no interior da célula e, em particular, na fisiologia gênica. Também no leite humano tem-se demonstrado que substâncias químicas nele presentes alteram e modulam a expressão gênica (Kaput \& Rodriguez, 2004).

Durante os períodos de alta sensibilidade às influências ambientais, as alterações metabólicas prospectivamente induzem programações metabólicas, e os fatores indutores de impressão provavelmente são constituídos por eventos combinados de relação imediata com o meio, assim como com fatores provenientes de mães anteriormente modificadas. Tais modificações, por sua vez, podem gerar alterações gênicas que podem ou não ser transferidas aos filhos, ou seja, de forma transgeracional (Anway et al., 2005; Newbold et al., 1998, 2000). Por exemplo, sabemos que a expressão de um gene pode ser afetada direta ou indiretamente. Ou seja, os nutrientes podem agir ligando-se aos fatores de transcrição e determinar qualitativamente a fisiologia gênica. Também, o provimento desbalanceado de nutrientes pode alterar as concentraçóes de substratos necessários para 
a ativação de vias metabólicas de sustentação da maquinaria gênica. No caso de modificação do balanço energético intracelular por meio de alteração da presença de ácidos graxos livres, encontram-se modificadas as vias

$\beta$-oxidação, que alteram a homeostase celular do Nicotinamide Adenine Dinuleotide (NAD). Sabe-se que, em tal processo, a reoxidação do NAD determinará modificação na atividade de transporte mitocondrial de elétrons, que se constitui em um co-fator das proteínas responsáveis pela remodelação da cromatina. $\mathrm{Ou}$ seja, partindo-se de alterações na disponibilidade de ácidos graxos, obtém-se modificação na expressão gênica. Mais ainda, a remodelação da cromatina determina efeitos crônicos na expressão e regulação gênica por meio da acetilação de histonas, ou mesmo da metilação do DNA. A capacidade de transmissão de modulação da informação

gênica de uma geração a outra determinaria a manutenção ou não de uma programação específica.

O conceito de epigênese foi inicialmente definido como "o desenvolvimento do processo de transformação de um genótipo num fenótipo", e mais recentemente como "herança de informação baseada na expressão gênica e não na seqüência de genes (genética)". Alguns autores têm também chamado "código epigenético" ao fenômeno determinante da escolha seletiva de alguns poucos genes para determinada expressão. Por exemplo, todo tecido contém os mesmos trinta mil genes, mas apenas alguns são selecionados para gerar o fenótipo específico. Adicionalmente, esse código epigênico é constituído de subcódigos, como, por exemplo, o código de metilação do DNA, o código de metilação/acetilação/fosfolorização das histonas e o código da coregulaçãa. Esses códigos interagem, definindo meticulosamente a remodelação da cromatina. Ou seja, permitem que ocorram ativação e regulação de fatores de transcrição que, por sua vez, realizam o reconhecimento, ativação ou silenciamento transitório ou permante de determinados genes. O processo mantido ou alterado de remodelação da cromatina pode ser transitória ou permanentemente propagado por mitose ou meiose, tendo, portanto, a capacidade de determinar a estabilização de transmissão de novos estados regulatórios para a célula e, por conseguinte, para o organismo (Jablonga \& Lamb, 2002). Tal mecanismo reforça a possibilidade de que a ação de nutrientes em períodos críticos (janelas de exposição) modifique, por meio da integração diferenciada de diferentes genes com mecanismos epigênicos, a cromatina e respectivos fatores de transcrição. Nutrientes determinariam a desorganização do processo epigênico, podendo gerar prospectivamente o surgimento de doenças como o câncer e o diabetes, e explicariam também o caráter transgeracional hoje observados nestas doenças (Crews \& McLachlan, 2006).

A potência do processo é dependente do momento do desenvolvimento. Por exemplo, a leptina, que tem, entre outras funções, a de regular o processo de fome e saciedade, como já descrito aqui, tem esta ação estabelecida em um breve período pós-natal. A interação entre nutrientes específicos e a leptina na determinação do comportamento alimentar depende do momento do desenvolvimento em que se dá a remodelação da cromatina. O período determinante da ação prospectiva da leptina não coincide com o da ação de outros hormônios, tais como o Insulin Growth Factor (IGF) ou receptores de glicocorticóides e seus respectivos promotores, o que explica a complexidade desse fenômeno.

\section{Considerações Finais}

As idéias de janela de exposição, impressão e programação metabólica, epigênese, assim como de epigênese transgeracional, permitem, hoje, que a relação entre o meio ambiente e o ser biológico seja vista de forma renovada. A despeito do progresso multidisciplinar que tem permitido o avanço dessas idéias, ainda persistem intricados problemas teóricos e experimentais. Por exemplo, a caracterização temporal das janelas de exposição a grande variação no tempo para o surgimento e amadurecimento dos sistemas. Alguns sistemas apresentam alta vulnerabilidade durante a gestação, outros durante a lactação, na adolescência, ou mesmo em adultos. A irreversibilidade da programação e a transferência epigênica transgeracional continuam a desafiar os cientistas 
como idéias que ainda procuram métodos mais vigorosos para sua averiguação. Entretanto, a conexão entre a epidemiologia e a biologia e o seu recíproco enriquecimento seguramente permitem caminhar em direção a políticas de saúde pública cada vez mais efetivas.

\section{Referências}

ANWAY, M. D. et al. Epigenetic transgerational actions of endocrine disruptors and male fertility. Science, 308(5.727): 1.466-1.469, 2005.

BARKER, D. J. P. The developments origins of well-being. Philosophical Transactions of the Royal Society B: biological sciences, 359(1.449): 1.359-1.366, 2004.

BARR, V. A. et al. Insulin stimulates both leptin secretion and production by rat white adipose tissue. Endocrinology, 138(10): 4.463-4.472, 1997.

BERTHOUD, H. R. Multiple neural systems controlling food intake and body weight. Neuroscience and Biobehavior Reviews, 26(4): 393-428, 2002.

BOURET, S. G. \& SIMERLY, R. B. Developmental programming of hypothalamic feeding circuts. Clinical Genetic, 70(4): 295-301, 2006.

CASTO, R. M.; VANNESS, J. M. \& OVERTON, J. M. Effects of central leptin administration on blood pressure in normotensive rats. Neuroscience Letters, 246(1): 29-32, 1998.

CREWS, D. \& MCLACHLAN, J. A. Epigenetics, evolution, endocrine disruption, health, and disease. Endocrinology, 147, suppl. 6: S4-S10, 2006.

ELIAS, S. G. et al. The 1944-1945 Dutch Famine and subsequent overall cancer incidence. Cancer Epidemiology Biomarkers \& Prevention, 14(8): 1.981-1.985, 2005.

EMILSSON, V. et al. Expression of the functional leptin receptor mRNA in pancreatic islets and direct inhibitory action of leptin on insulin secretion. Diabetes, 46(2): 313-316, 1997.

JABLONGA, E. \& LAMB, M. J. The changing concept of epigenetics. Annals New York Academy Sciences, 981: 82-96, 2002.

JONES, J. H. Fetal programming: adaptative life-history tactics or making the best of a bad start. American Journal of Human Biology, 17(1): 22-33, 2005.

KAPUT, J. \& RODRIGUEZ, R. L. Nutritional genomics: the next frontier in the postgenomic era. Physiological Genomics, 16(2): 166-177, 2004.

MOURA, A. S. et al. Malnutrition during lactation as a metabolic imprinting factor inducing the feeding pattern of offspring rats when adults: the role of insulin and leptin. Brazilian Journal of Medical and Biological Research, 35(5): 617-622, 2002.

NEWBOLD, R. R. et al. Increased tumors but uncompromised fertility in the female descendents of mice exposed developmentally to diethylstilbestrol. Carcinogenesis, 19(9): 1.655-1.663, 1998.

NEWBOLD, R. R. et al. Proliferative lesions and reproductive tract tumors in male descendants of mice exposed developmentally to diethylstilbestrol. Carcinogenesis, 21(7): 1.355-1.363, 2000.

PAOLISSO, G. et al. Plasma leptin level is associated with myocardial wall thickness in hypertensive insulin- 
resistant men. Hypertension, 34(5): 1.047-1.052, 1999.

PEREIRA, R. O. et al. Overfeeding during lactation modifies insulin and leptin signaling cascade in rats' hearts. Regulatory Peptides, 136(1-3): 117-121, 2006.

ROSEBOOM, T. J. et al. Plasma lipid profile in adults after prenatal exposure to Dutch famine. American Journal of Clinical Nutrition, 72(5): 1.101-1.106, 2000a.

ROSEBOOM, T. J. et al. Plasma fibrinogen and factor VII concentration in adults after prenatal exposure to famine. British Journal of Haematology, 111(1): 112-117, 2000b.

SHEK, E. W.; BRANDS, M. W. \& HALL, J. E. Chronic leptin infusion increases arterial pressure. Hypertension, 31(1 Pt 2): 409-414, 1998.

SUSSER, M. \& STEIN, Z. Timing in prenatal nutrition: a reprise of Dutch Famine Study. Nutrition Reviews, 52(3): 84-94, 1994.

WATERLAND, R. A. \& GARZA, C. Potential mechanisms of metabolic imprinting that lead to chronic disease. American Journal Clinical Nutrition, 69(2): 179-197, 1999.

ZHANG, Y. et al. Positional cloning of the mouse obese gene and its human homologue. Nature, 372(6.505): 425-432, 1994. 



\title{
32 \\ Efeitos a Longo Prazo da Nutrição na Infância
}

\author{
Bernardo Lessa Horta
}

$\mathrm{N}$ os últimos anos, tem havido um grande interesse na avaliação dos fatores de risco para a ocorrência de doenças crônicas na perspectiva do ciclo vital (Ben-Shlomo \& Kuh, 2002). Grande parte desse interesse foi despertada pelos achados de Barker (1992) de que o peso ao nascer estava associado com o desenvolvimento de doenças crônicas, tais como diabetes, hipertensão e cardiopatia isquêmica. Estudos subseqüentes, realizados em diferentes países, também encontraram um maior risco de doenças crônicas em adultos que nasceram com baixo peso (Rich-Edwards et al., 1997; Newsome et al., 2003; Horta et al., 2003). Tais evidências levaram ao desenvolvimento da hipótese da origem fetal das doenças, também conhecida como hipótese de Barker, que propôs que o feto seria programado intra-útero, principalmente por fatores nutricionais que influenciariam o metabolismo e a fisiologia desse indivíduo por toda a vida. De acordo com a hipótese de Barker, a desnutrição fetal provocaria mudanças na estrutura e função de certos órgãos, aumentando a chance de o feto sobreviver, que por outro lado aumentaria o risco do desenvolvimento de doenças na idade adulta. Atualmente, esta hipótese tem sido reconhecida como teoria desenvolvimentista da origem da saúde e doença (Gluckman \& Hanson, 2004). A maioria dos estudos iniciais sobre a hipótese de Barker utilizou o peso ao nascer como um indicador da nutrição intra-uterina (Adair \& Dahly, 2005), embora seja determinado tanto pela duração da gestação como pelo crescimento intrauterino (Horta et al., 1997).

A afirmação da existência de uma relação causal entre peso ao nascer e doença crônica tem sido criticada por alguns autores. A maioria dos primeiros estudos é suscetível a um confundimento residual, principalmente pelo nível socioeconômico, e ao viés de seleção, pois as perdas no acompanhamento foram elevadas (Joseph \& Kramer, 1996). Além disso, Lucas, Fewtrell e Cole (1999) demonstraram que a maioria dos estudos, ao controlar o efeito do peso ao nascer para uma medida posterior de peso na infância ou na adolescência, estava avaliando o efeito do ganho de peso e não do peso ao nascer, pois, no momento em que é controlado para uma medida posterior de peso, o coeficiente de regressão da variável peso ao nascer não reflete mais o efeito do peso ao nascer, mas sim o da mudança de peso no período.

Lucas, Fewtrel e Cole (1999) também chamaram a atenção para o fato de que esses erros nos estudos sobre os efeitos do peso ao nascer desviaram a atenção de outras importantes exposições nutricionais ocorridas nos primeiros anos de vida - tais como duração da amamentação e dieta -, que podem estar associadas ao desenvolvimento de doenças crônicas. O presente capítulo pretende revisar as evidências sobre os efeitos a longo prazo da amamentação e do crescimento acelerado (catch-up) nos primeiros anos de vida. 
houve concordância entre o peso ao nascer auto-relatado e o consignado nos registros das maternidades. A concordância foi independente de características da entrevistada ou dos pais.

Enquanto o auto-relato do peso ao nascer apresenta baixa acurácia, o recordatório materno é relativamente acurado e independente de características das mães ou dos seus filhos (O’Sullivan, Pearce \& Parker, 2000; Walton et al., 2000). Portanto, ao contrário do observado para a duração da amamentação, o erro de informação é não diferencial. Por outro lado, o elevado erro observado com o peso auto-relatado reduz drasticamente o poder estatístico do estudo.

\section{Confundimento}

O nível socioeconômico é um dos principais fatores de confusão, mas a direção do confundimento varia com o local onde está sendo realizado o estudo. Enquanto nos países desenvolvidos, geralmente, haverá uma tendência a superestimar o efeito benéfico da amamentação, nos países em desenvolvimento a direção do viés vai depender do desfecho que está sendo estudado. Nestas localidades, a duração da amamentação é maior entre as crianças de menor nível socioeconômico (Horta et al., 1996), ao contrário do observado nos países desenvolvidos (Bauchner, Leventhal \& Shapiro, 1986), e a direção do viés vai depender da associação entre nível socioeconômico e o desfecho. Para a escolaridade, haverá uma tendência a subestimar um efeito benéfico da amamentação, uma vez que as crianças de menor nível socioeconômico apresentam menor escolaridade do que as mais ricas. Por outro lado, para o colesterol, a confusão pelo nível socioeconômico tenderá a superestimar o efeito benéfico da amamentação.

\section{Controle para Possíveis Fatores Mediadores}

Muitos dos estudos que avaliam os efeitos a longo prazo da nutrição na infância têm controlado as suas estimativas para possíveis fatores mediadores, especialmente o peso ou o Índice de Massa Corporal (IMC) na idade adulta. $\mathrm{O}$ controle para um fator mediador reduzirá a magnitude da medida de associação, que passará a refletir, apenas, o efeito que não decorre desse fator mediador que está sendo controlado na análise (Victora et al., 1997).

\section{Ano de Nascimento}

Para os estudos que avaliam os efeitos a longo prazo da amamentação, o ano de nascimento pode ser uma fonte de heterogeneidade. Na maioria dos países desenvolvidos, ao longo do último século, ocorreu uma grande mudança na dieta das crianças que não eram amamentadas. Nas primeiras décadas do século XX, as crianças que não estavam sendo amamentadas geralmente recebiam preparaçôes baseadas em leite integral (Barr et al., 2000), com altas concentrações de sódio e de colesterol e ácidos graxos similares aos encontrados no leite materno. As primeiras apresentações de leite artificial também continham alta concentração de sódio. Apenas a partir dos anos 80 é que foi reduzida a quantidade de sódio no leite artificial, e hoje esta concentração é similar àquela observada no leite materno.

\section{Local do Estudo}

A maioria dos estudos que avaliaram os efeitos a longo prazo da nutrição na infância foi realizada em países desenvolvidos. Os achados desses estudos podem não ser generalizáveis para indivíduos expostos a diferentes condiçôes nutricionais e ambientais, como, por exemplo, as populações de países em desenvolvimento. Por esse motivo, considera-se que o fato de não terem sido realizados no mesmo local é uma potencial fonte de heterogeneidade entre os estudos. 


\section{Efeitos a Longo Prazo da Nutrição na Infância}

A amamentação e o crescimento acelerado (catch-up) são os principais aspectos da nutrição na infância que têm tido o seu efeito a longo prazo avaliado. No que diz respeito aos possíveis efeitos da amamentação, obesidade, pressão arterial, colesterol sérico e desenvolvimento intelectual têm sido os principais desfechos avaliados. Inicialmente, serão revisadas as evidências a respeito dos efeitos a longo prazo da amamentação sobre esses desfechos.

\section{Amamentação}

\section{Pressão Arterial}

Numerosos estudos têm sugerido que a pressão arterial na idade adulta pode ser influenciada pela nutrição na infância, e existem três possíveis mecanismos para um efeito da amamentação sobre a pressão arterial na idade adulta. A seguir, vamos discutir brevemente estes mecanismos.

\section{Menor quantidade de sódio no leite materno}

Como a ingestão de sódio está diretamente relacionada com a pressão arterial (Brunner et al., 2005) e até o final do século passado a quantidade de sódio no leite materno era muito menor do que aquela encontrada na maioria das fórmulas (Fomon, 2001), tem-se sugerido que a menor quantidade de sódio no leite materno programaria o indivíduo para ter menor pressão arterial na idade adulta. Contudo, as evidências a respeito de um efeito a longo prazo da ingestão de sal sobre a pressão arterial são controversas. Ao passo que dois estudos (Whitten \& Stewart, 1980; Singhal, Cole \& Lucas, 2001) não observaram um efeito a longo prazo da ingestão de sódio na infância, Geleijnse e colaboradores (1997) observaram que a pressão arterial aos 15 anos era 3,6 mmHg (Intervalo de Confiança [IC] de 95\%: - 6,6 a - 0,5) menor entre os indivíduos que nos primeiros seis meses de vida receberam dieta com menor quantidade de sódio.

\section{Presença de ácidos graxos no leite materno}

Os ácidos graxos poliinsaturados de cadeia longa estão presentes no leite materno, mas não são encontrados na maior parte dos leites artificiais (Koletzko et al., 2001). Em indivíduos hipertensos, com a suplementação com ácidos graxos de cadeia longa consegue-se reduzir a pressão arterial (Morris, Sacks \& Rosner, 1993). Além disso, Forsyth e colaboradores (2003) observaram que a pressão arterial aos 6 anos de idade era menor naquelas crianças que, ao nascer, haviam sido alocadas para receber uma suplementação com ácidos graxos de cadeia longa e que a pressão arterial dessas crianças foi similar à das amamentadas.

\section{Obesidade}

Como o peso na idade adulta é um fator associado à ocorrência de hipertensão (Perry, Whincup \& Shaper, 1994) e a amamentação estaria associada a um menor risco de obesidade e sobrepeso (Arenz et al., 2004; Owen et al., 2005a; Harder et al., 2005), tem-se sugerido que o efeito protetor da amamentação seria mediado pela obesidade. Porém, em decorrência do pequeno efeito protetor da amamentação para a obesidade, é pequena a probabilidade de que este seja o principal mecanismo para um efeito a longo prazo da amamentação sobre a pressão arterial.

$\mathrm{Na}$ revisão da literatura, foram identificadas duas metanálises que avaliaram o efeito a longo prazo da amamentação sobre a pressão arterial (Owen et al., 2003; Martin, Gunnell \& Smith, 2005). Owen e colaboradores (2003) incluíram 25 estudos que avaliaram o efeito da amamentação sobre a pressão arterial em qualquer idade. 
O efeito médio da amamentação foi estatisticamente significativo para a pressão sistólica [diferença: - 1,10 $\mathrm{mmHg}$ (IC de 95\%: - 1,79 a - 0,42 mmHg)], mas não para a pressão diastólica [diferença: - 0,36 mmHg (IC de 95\%: 0,79 a $0,08 \mathrm{mmHg}$ )]. Os resultados dos estudos eram heterogêneos, e para a pressão sistólica houve claramente um viés de publicação com os estudos pequenos (<300 participantes), mostrando um maior efeito protetor da amamentação.

A metanálise publicada por Martin e colaboradores em 2005 incluiu 15 estudos em que a pressão arterial foi avaliada em indivíduos com mais de 1 ano de idade. Similarmente ao observado por Owen e colaboradores (2003), a amamentação esteve associada com menor pressão sistólica [diferença: - 1,4 mmHg (IC de 95\%: - 2,2 a - 0,6 mmHg)] e o efeito protetor foi maior nos estudos com menor tamanho da amostra. Além disso, a proteção da amamentação foi maior nos estudos cuja população nasceu antes de 1980 (diferença média: - 2,7 mmHg) do que naqueles que nasceram depois de 1980 (diferença média: - 0,8 mmHg).

As metanálises sugerem que a amamentação tem pequeno efeito protetor sobre a pressão arterial, mas parte deste efeito parece decorrer de um viés de publicação, uma vez que estudos pequenos com resultados negativos apresentaram menor probabilidade de serem publicados. Por outro lado, é importante salientar que mesmo um pequeno efeito protetor da amamentação é relevante do ponto de vista da saúde pública. De acordo com Martin, Gunnell e Smith (2005), uma redução de cerca de $2 \mathrm{mmHg}$ na pressão sistólica em nível populacional reduziria a prevalência de hipertensão em aproximadamente $17 \%$ e a incidência de cardiopatia isquêmica e acidente vascular cerebral em 6 e $15 \%$, respectivamente.

\section{Colesterol}

O efeito a longo prazo da amamentação sobre o colesterol sérico também tem despertado muito interesse. Estudos realizados na infância indicam que as crianças amamentadas apresentam maiores concentraçóes de colesterol total (Owen et al., 2002), em decorrência da maior quantidade de colesterol encontrada no leite materno. A elevada ingestão de colesterol na infância pode ter um efeito a longo prazo sobre o colesterol sérico, reduzindo a síntese de colesterol no fígado, por meio da inibição da síntese da Hidroximetil-Glutaril Coenzima A (HMG -CoA) redutase, enzima essencial para a produção de colesterol (Jones et al., 1990). Estudos com animais têm relatado presença de maiores níveis dessa enzima naqueles que não foram amamentados (Devlin et al., 1998).

As evidências da literatura sugerem que na idade adulta o colesterol total é menor entre os indivíduos que foram amamentados (diferença média: - 0,18 mmol/L; IC de 95\%: - 0,30 a - 0,06 mmol/L) (Owen et al., 2002). Além dessas evidências oriundas de estudos observacionais, Singhal e colaboradores (2004) observaram que a relação Low Density Protein/High Density Protein (LDL/HDL) era menor entre adolescentes que nasceram prematuros e que foram alocados para receber leite materno, comparados aos que foram alocados para receber fórmula.

O efeito da amamentação sobre o colesterol total é superior ao que tem sido relatado pelos estudos que avaliaram o impacto de intervenções comportamentais na idade adulta, tais como mudança na dieta (Brunner et al., 2005), atividade física, interrupção do tabagismo e perda de peso (Ebrahim \& Smith, 1997).

\section{Obesidade}

Vários estudos têm sido publicados a respeito dos efeitos a longo prazo da amamentação sobre a obesidade, e três mecanismos biológicos têm sido propostos para explicar um possível efeito protetor da amamentação. Diferenças na ingestão de proteínas e no metabolismo poderiam ser um desses mecanismos, pois o leite materno apresenta menor teor protéico comparado a outros leites (Whitehead, 1995) e a elevada ingestão de proteínas nos primeiros meses de vida está associada com maior risco de obesidade aos 8 anos de vida (Rolland-Cachera et al., 1995). 
Outra explicação biológica seria que a maior secreção de insulina pelas crianças que não são amamentadas poderia resultar em um aumento no número de adipócitos, que estaria associado ao maior risco de obesidade na idade adulta (Lucas et al., 1980). Finalmente, Birch e Fisher (1998) sugeriram que as crianças que foram amamentadas teriam maior facilidade de consumir novos alimentos como, por exemplo, os vegetais, reduzindo, subseqüentemente, a ingestão calórica.

Quatro metanálises foram publicadas nos últimos anos, das quais três avaliaram o efeito da amamentação sobre a prevalência de sobrepeso/obesidade e uma teve como desfecho o IMC. Arenz e colaboradores (2004) incluíram nove estudos com mais de 69.000 participantes. Os mesmos autores excluíram 19 estudos, principalmente por não terem ajustado as suas estimativas para potenciais fatores de confusão ou por terem usado uma definição de obesidade diferente daquela utilizada na metanálise. A prevalência de obesidade mostrou-se menor entre os indivíduos que foram amamentados (razão de odds combinada: 0,78; IC de 95\%: 0,71 a 0,85). Resultados dos estudos incluídos foram homogêneos, mas há evidências de viés de publicação, com os estudos de pequeno tamanho da amostra apresentando maior efeito protetor da amamentação.

Owen e colaboradores (2005a) não utilizaram critérios de inclusão tão restritivos, como Arenz e colaboradores (2004), e por este motivo incluíram 28 estudos em sua metanálise. Também observaram um efeito protetor da amamentação (razão de odds combinada: 0,87; IC de 95\%: 0,85 a 0,87), que foi de menor magnitude (razão de odds combinada: 0,93 ) nos estudos que controlaram para confundimento por variáveis socioeconômicas, antropometria dos pais e tabagismo materno nos primeiros anos de vida. Como o efeito protetor da amamentação foi de maior magnitude nos estudos de menor tamanho, a ocorrência de viés de publicação também não pode ser descartada.

Em outra metanálise, Harder e colaboradores (2005) tentaram avaliar a existência de uma relação de doseresposta e incluíram 14 estudos, descrevendo o efeito de mais de uma categoria da amamentação sobre o risco de obesidade. Eles observaram um efeito dose-resposta estatisticamente significativo, e o risco de obesidade diminuiu 4\% para cada mês de aumento na duração da amamentação.

Finalmente, Owen e colaboradores (2005b), ao avaliarem o efeito da amamentação sobre a média do IMC, incluíram 36 estudos. Aqueles indivíduos que foram amamentados apresentaram menor IMC (diferença média: - 0,04; IC de 95\%: - 0,05 a - 0,02). Em uma clara demonstração do viés introduzido pelos fatores de confusão, nos 11 estudos que forneceram estimativas que estavam ajustadas para idade, nível socioeconômico, tabagismo materno e IMC, a diferença média reduziu de - 0,12 para - 0,01, após ajuste para os fatores de confusão. Além disso, similarmente ao observado nas outras três metanálises, o viés de publicação foi evidente.

Os estudos que avaliaram o efeito da amamentação sobre a prevalência de sobrepeso/obesidade sugerem que a amamentação pode ter um pequeno efeito protetor a longo prazo. Apesar de claramente haver um viés de publicação, um efeito protetor da amamentação ainda foi observado nos estudos de maior tamanho da amostra, o que sugere que tal efeito não é decorrente apenas daquele viés.

\section{Desenvolvimento Intelectual}

Muitos estudos têm observado um efeito positivo da amamentação sobre o desenvolvimento cognitivo. O leite materno é rico em ácidos graxos de cadeia longa, principalmente o ácido araquidônico e o ácido docosahexaenóico (DHA), que são importantes para o desenvolvimento do córtex cerebral e da retina (Koletzko et al., 2001; Crawford, 1993; Birch et al., 1992). Em 1999, Anderson, Johnstone e Remley revisaram estudos que avaliaram crianças com idades entre 6 meses e 15 anos e observaram que, mesmo após ajuste para possíveis fatores de confusão, a amamentação esteve associada com um aumento de 3,2 pontos no quociente de inteligência.

$\mathrm{O}$ viés de auto-seleção é uma importante limitação dos estudos que avaliam os efeitos da amamentação sobre o desenvolvimento intelectual, visto que o desempenho em testes cognitivos está relacionado à qualidade 
da estimulação recebida pela criança (Johnson et al., 1993) e que as mães que decidem amamentar tendem a estimular mais os seus filhos (Fergusson, Beautrais \& Silva, 1982). Jain, Concato e Leventhal (2002) buscaram evitar esse viés, revisando estudos que controlaram para a estimulação recebida pela criança: dos nove estudos incluídos, apenas quatro observaram que o efeito da amamentação sobre o desempenho cognitivo era estatisticamente significativo. Os autores não descreveram a direção da associação para os estudos que não encontraram uma associação estatisticamente significativa e, além disso, não obtiveram uma estimativa global do efeito da amamentação.

Confundimento residual pelo nível socioeconômico tem sido apontado como outra explicação para o efeito positivo da amamentação sobre o desempenho em testes de inteligência, pois nos países desenvolvidos a duração da amamentação é maior nas famílias de melhor nível socioeconômico. Porém, um efeito positivo da amamentação sobre a escolaridade ou o desempenho em testes de inteligência também foi observado em estudos realizados nas Filipinas (Daniels \& Adair, 2005) e no Brasil (Victora et al., 2005), onde a duração da amamentação é inversamente relacionada ao nível socioeconômico. Não se pode atribuir, portanto, essa associação a um confundimento pelo nível socioeconômico.

As evidências sugerem que a duração da amamentação tem um efeito a longo prazo sobre o desenvolvimento intelectual. No estudo de Lucas e colaboradores (1992), as crianças prematuras que haviam sido aleatorizadas para receberem leite do banco de leite humano apresentaram melhor desempenho no teste Wechsler Intelligence Scale for Children - Revised (WISC-R), o que reforça a hipótese de existência de uma relação causal.

\section{Catch-up}

Tanner (1981) definiu catch-up como o período de aceleração no crescimento, que ocorre quando um período de retardo de crescimento é encerrado e as condições favoráveis são restauradas. $\mathrm{O}$ catch-up começa assim que o fator responsável pelo atraso no crescimento é retirado. Em geral, tende a ser incompleto, e o indivíduo não consegue alcançar na idade adulta a estatura que teria alcançado se não tivesse ocorrido o período de atraso no crescimento.

A maioria dos estudos tem usado o peso do indivíduo como indicador antropométrico da ocorrência ou não de catch-up. Mas diferentes critérios têm sido usados para avaliar a ocorrência dessa recuperação acelerada. Enquanto alguns autores consideram que houve catch-up naqueles indivíduos cujo incremento no peso ou estatura foi maior do que a média, em outros estudos considera-se o incremento de escore $\mathrm{z}$, com um ponto de corte definido.

O catch-up tem claros benefícios a curto prazo. Victora e colaboradores (2001) observaram que entre as crianças que nasceram pequenas para a idade gestacional e que apresentaram catch-up nos primeiros vinte meses de vida (aumento de pelo menos 0,66 desvios-padrão no escore z de peso-para-idade), a incidência de hospitalização no terceiro ano de vida foi $65 \%$ menor do que a observada entre as crianças que também nasceram pequenas para a idade gestacional mas não apresentaram catch-up. A mortalidade nos primeiros cinco anos também foi menor entre as crianças que fizeram catch-up.

Entretanto, há uma controvérsia a respeito dos efeitos a longo prazo do catch-up. Recentemente, Fisher e colaboradores (2006) revisaram as evidências sobre o efeito do crescimento e do tamanho na infância sobre o risco de adoecer na idade adulta, e concluíram que não havia um padrão de crescimento na infância que estivesse associado com a redução no risco de doença em adultos.

Em uma clara demonstração da importância de estudar o efeito do catch-up em diferentes períodos da infância, Barker e colaboradores (2005) observaram que a incidência de cardiopatia isquêmica foi maior entre aqueles indivíduos que apresentaram um crescimento lento nos dois primeiros anos de vida, mas entre os 2 e 11 anos de idade tiveram um crescimento acelerado, e que esta associação foi mediada pela resistência à insulina. 
Estudos realizados no Brasil e nas Filipinas também observaram que o ganho de peso na infância não estava associado com maior pressão arterial em idade posterior, ao passo que o ganho de peso entre a infância e a adolescência estava relacionado com maior risco de elevação na pressão arterial (Horta et al., 2003; Adair \& Cole, 2003). Por sua vez, Law e colaboradores (2002) relataram que o crescimento no primeiro ano de vida não estava associado com a pressão arterial na idade adulta, ao passo que o ganho de peso entre 1 e 5 anos estava positivamente associado com a pressão arterial na idade adulta.

É importante que os estudos procurem avaliar o efeito do crescimento em diferentes períodos do ciclo vital, colaborando assim para a identificação de períodos críticos, em que o catch-up pode ter um efeito negativo ou positivo sobre a saúde. Além disso, deve-se buscar avaliar a interação entre crescimento e estado nutricional no início do período.

\section{Consideraçōes Finais}

Além da pressão arterial, a amamentação também tem um efeito protetor a longo prazo sobre outros importantes fatores de risco cardiovascular: o colesterol e a obesidade. Apesar de a magnitude do efeito protetor da amamentação ser pequeno, este, como visto anteriormente, é similar ao observado para intervenções comportamentais implementadas na idade adulta. Além do efeito protetor cardiovascular, a amamentação também tem efeito sobre o desenvolvimento intelectual.

As evidências sobre os efeitos do crescimento na infância sugerem que o catch-up é capaz de programar o aparecimento de doenças na idade adulta, reduzindo, portanto, o risco de aparecimento de doenças cardiovasculares.

\section{Referências}

ADAIR, L. S. \& COLE, T. J. Rapid child growth raises blood pressure in adolescent boys who were thin at birth. Hypertension, 41(3): 451-416, 2003.

ADAIR, L. \& DAHLY, D. Developmental determinants of blood pressure in adults. Annual Review of Nutrition, 25: 407-434, 2005.

ANDERSON, J. W.; JOHNSTONE, B. M. \& REMLEY, D. T. Breast-feeding and cognitive development: a meta-analysis. American Journal of Clinical Nutrition, 70(4): 525-535, 1999.

ANDERSSON, S. W. et al. Poor agreement between self-reported birth weight and birth weight from original records in adult women. American Journal of Epidemiology, 152(7): 609-616, 2000.

ARENZ, S. et al. Breast-feeding and childhood obesity-a systematic review. International Journal of Obesity and Related Metabolic Disorders, 28(10): 1.247-1.256, 2004.

BARKER, D. J. P. Fetal and Infant Origins of Adult Disease. London: BMJ Publishing, 1992.

BARKER, D. J. et al. Trajectories of growth among children who have coronary events as adults. New England Journal of Medicine, 353(17): 1.802-1.809, 2005.

BARR, S. I. et al. Effects of increased consumption of fluid milk on energy and nutrient intake, body weight, and cardiovascular risk factors in healthy older adults. Journal of the American Dietetic Association, 100(7): 810$817,2000$.

BAUCHNER, H.; LEVENTHAL, J. M. \& SHAPIRO, E. D. Studies of breast-feeding and infections: how good is the evidence? Jama, 256(7): 887-892, 1986. 
BEN-SHLOMO, Y. \& KUH, D. A life course approach to chronic disease epidemiology: conceptual models, empirical challenges and interdisciplinary perspectives. International Journal of Epidemiology, 31(2): 285293, 2002.

BIRCH, E. E. et al. Dietary essential fatty acid supply and visual acuity development. Investigative Ophthalmology \&Visual Science, 33(11): 3.242-3.253, 1992.

BIRCH, L. L. \& FISHER, J. O. Development of eating behaviors among children and adolescents. Pediatrics, 101(3): 539-549, 1998.

BRUNNER, E. J. et al. Dietary advice for reducing cardiovascular risk. Cochrane Database of Systematic Reviews, CD002128, 2005.

CHALMERS, I. Unbiased, relevant, and reliable assessments in health care: important progress during the past century, but plenty of scope for doing better. British Medical Journal, 317(7.167): 1.167-1.168, 1998.

CRAWFORD, M. A. The role of essential fatty acids in neural development: implications for perinatal nutrition. American Journal of Clinical Nutrition, 57, suppl. 5: 703S-709S, 1993.

DANIELS, M. C. \& ADAIR, L. S. Breast-feeding influences cognitive development in Filipino children. Journal of Nutrition, 135(11): 2.589-2.595, 2005.

DEVLIN, A. M. et al. Early diet influences hepatic hydroxymethyl glutaryl coenzyme A reductase and 7alphahydroxylase mRNA but not low-density lipoprotein receptor mRNA during development. Metabolism, 47(1): 20-26, 1998.

EBRAHIM, S. \& SMITH, G. D. Systematic review of randomised controlled trials of multiple risk factor interventions for preventing coronary heart disease. British Medical Journal, 314(7.095): 1.666-1.674, 1997.

FERGUSSON, D. M.; BEAUTRAIS, A. L. \& SILVA, P. A. Breast-feeding and cognitive development in the first seven years of life. Social Science \& Medicine, 16(19): 1.705-1.708, 1982.

FISHER, D. et al. Are infant size and growth related to burden of disease in adulthood? A systematic review of literature. International Journal of Epidemiology, 35(5): 1.196-1.210, 2006.

FOMON, S. Infant feeding in the 20th century: formula and beikost. Journal of Nutrition, 131(2): 409S-420S, 2001.

FORSYTH, J. S. et al. Long chain polyunsaturated fatty acid supplementation in infant formula and blood pressure in later childhood: follow up of a randomised controlled trial. British Medical Journal, 326(7.396): 953, 2003.

GELEIJNSE, J. M. et al. Long-term effects of neonatal sodium restriction on blood pressure. Hypertension, 29(4): 913-917, 1997.

GLUCKMAN, P. D. \& HANSON, M. A. Living with the past: evolution, development, and patterns of disease. Science, 305(5691): 1.733-1.736, 2004.

HARDER, T. et al. Duration of breastfeeding and risk of overweight: a meta-analysis. American Journal of Epidemiology, 162(5): 397-403, 2005.

HORTA, B. L. et al. Breastfeeding and feeding patterns in two cohorts of children in Southern Brazil: trends and differences. Cadernos de Saúde Pública, 12, supl. 1: 43-48, 1996. 
HORTA, B. L. et al. Low birthweight, preterm births and intrauterine growth retardation in relation to maternal smoking. Paediatric and Perinatal Epidemiology, 11(2): 140-151, 1997.

HORTA, B. L. et al. Early and late growth and blood pressure in adolescence. Journal of Epidemiology and Community Health, 57(3): 226-230, 2003.

HUTTLY, S. R. et al. Do mothers overestimate breast feeding duration? An example of recall bias from a study in southern Brazil. American Journal of Epidemiology, 132(3): 572-575, 1990.

JAIN, A.; CONCATO, J. \& LEVENTHAL, J. M. How good is the evidence linking breastfeeding and intelligence? Pediatrics, 109(6): 1.044-1.053, 2002.

JOHNSON, D. L. et al. Does HOME add to the prediction of child intelligence over and above SES? The Journal of Genetic Psychology; Child Behavior, Animal Behavior, and Comparative Psychology, 154(1): 33-40, 1993.

JONES, P. J. et al. Comparison of breast-feeding and formula feeding on intestinal and hepatic cholesterol metabolism in neonatal pigs. American Journal of Clinical Nutrition, 51(6): 979-984, 1990.

JOSEPH, K. S. \& KRAMER M. S. Review of the evidence on fetal and early childhood antecedents of adult chronic disease. Epidemiology Review, 18(2): 158-174, 1996.

KOLETZKO, B. et al. Long chain polyunsaturated fatty acids (LC-PUFA) and perinatal development. Acta Paediatrica, 90(4): 460-464, 2001.

LAW, C. M. et al. Fetal, infant, and childhood growth and adult blood pressure: a longitudinal study from birth to 22 years of age. Circulation, 105(9): 1.088-1.092, 2002.

LUCAS, A.; FEWTRELL M. S. \& COLE, T. J. Fetal origins of adult disease-the hypothesis revisited. British Medical Journal, 319(7.204): 245-249, 1999.

LUCAS, A. et al. Breast vs bottle: endocrine responses are different with formula feeding. The Lancet, 1(8.181): 1.267-1.269, 1980.

LUCAS, A. et al. Multicentre trial on feeding low birthweight infants: effects of diet on early growth. Archives of Diseases in Childhood, 59(8): 722-730, 1984.

LUCAS, A. et al. Breast milk and subsequent intelligence quotient in children born preterm. The Lancet, 339(8.788): 261-264, 1992.

MARTIN, R. M.; GUNNELL, D. \& SMITH, G. D. Breastfeeding in infancy and blood pressure in later life: systematic review and meta-analysis. American Journal of Epidemiology, 161(1): 15-26, 2005.

MORRIS, M. C.; SACKS, F. \& ROSNER, B. Does fish oil lower blood pressure? A meta-analysis of controlled trials. Circulation, 88(2): 523-533, 1993.

NEWSOME, C. A. et al. Is birth weight related to later glucose and insulin metabolism? A systematic review. Diabetes in Medicine, 20(5): 339-348, 2003.

O'SULLIVAN, J. J.; PEARCE, M. S. \& PARKER, L. Parental recall of birth weight: how accurate is it? Archives of Diseases in Childood, 82(3): 202-203, 2000.

OWEN, C. G. et al. Infant feeding and blood cholesterol: a study in adolescents and a systematic review. Pediatrics, 110(3): 597-608, 2002. 
OWEN, C. G. et al. Effect of breast feeding in infancy on blood pressure in later life: systematic review and metaanalysis. British Medical Journal, 327(7.425): 1.189-1.195, 2003.

OWEN, C. G. et al. Effect of infant feeding on the risk of obesity across the life course: a quantitative review of published evidence. Pediatrics, 115(5): 1.367-1.377, 2005a.

OWEN, C. G. et al. The effect of breastfeeding on mean body mass index throughout life: a quantitative review of published and unpublished observational evidence. American Journal of Clinical Nutrition, 82(6): 1.298$1.307,2005 b$.

PERRY, I. J.; WHINCUP, P. H. \& SHAPER, A. G. Environmental factors in the development of essential hypertension. British Medical Bulletin, 50(2): 246-259, 1994.

RICH-EDWARDS, J. W. et al. Birth weight and risk of cardiovascular disease in a cohort of women followed up since 1976. British Medical Journal, 315(7.105): 396-400, 1997.

ROLLAND-CACHERA, M. F. et al. Influence of macronutrients on adiposity development: a follow up study of nutrition and growth from 10 months to 8 years of age. International Journal of Obesity and Related Metabolic Disorders, 19(8): 573-578, 1995.

SINGHAL, A.; COLE, T. J. \& LUCAS, A. Early nutrition in preterm infants and later blood pressure: two cohorts after randomised trials. The Lancet, 357(9.254): 413-419, 2001.

SINGHAL, A. et al. Breastmilk feeding and lipoprotein profile in adolescents born preterm: follow-up of a prospective randomised study. The Lancet, 363(9.421): 1.571-1.578, 2004.

TANNER, J. M. Catch-up growth in man. British Medical Bulletin, 37(3): 233-238, 1981.

VICTORA, C. G. et al. The role of conceptual frameworks in epidemiological analysis: a hierarchical approach. International Journal of Epidemiology, 26(1): 224-227, 1997.

VICTORA, C. G. et al. Short-term benefits of catch-up growth for small-for-gestational-age infants. International Journal of Epidemiology, 30(6): 1.325-1.330, 2001.

VICTORA, C. G. et al. Breastfeeding and school achievement in Brazilian adolescents. Acta Paediatrica, 94(11): $1.656-1.660,2005$.

WALTON, K. A. et al. Parental recall of birthweight: a good proxy for recorded birthweight? European Journal of Epidemiology, 16(9): 793-796, 2000.

WHITEHEAD, R. G. For how long is exclusive breast-feeding adequate to satisfy the dietary energy needs of the average young baby? Pediatric Research, 37(2): 239-243, 1995.

WHITTEN, C. F. \& STEWART, R. A. The effect of dietary sodium in infancy on blood pressure and related factors. Studies of infants fed salted and unsalted diets for five months at eight months and eight years of age. Acta Paediatrica, 279, suppl. 1: 1-17, 1980.

WHO COLLABORATIVE STUDY Team on the Role of Breastfeeding on the Prevention of Infant Mortality. Effect of breastfeeding on infant and child mortality due to infectious diseases in less developed countries: a pooled analysis. The Lancet, 355(9.202): 451-455, 2000. 



\section{Índice}

\section{Símbolos}

25-hidroxicolecalciferol 129,143

á-caroteno 137 ver tb provitamina $\mathrm{A}$

á-tocoferol ver vitamina $\mathrm{E}$

á-TTP ver proteína de transferência de á-tocoferol

\section{A}

AACE ver American Association of Clinical Endocrinologists AAL ver ácido á-linolênico

absorptiometria de raios $\mathrm{X}$ de dupla energia ver Dexa

Ação da Cidadania contra a Fome, a Miséria e pela Vida 522

acelerômetro ver métodos de medição de gasto energético

acidente vascular cerebral 371-373, 378, 380-381, 391, 413, 557

ácido araquidônico 376,558

ácido ascórbico ver vitamina $\mathrm{C}$

ácido biliar 377

ácido eicosapentanóico 141, 376, 397, 416

ácido esteárico 140, 374-375

ácido fítico 108

ácido fólico 223, 271, 299, 303, 313-316, 379-382, 398, 528-529

ácido láurico 374, 375

ácido lipóico 398

ácido mirístico 374-375

ácido oléico 140, 375-376, 380

ácido oxálico 108, 136

ácido palmítico $140,374-375$

ácido úrico 380

ácido á -linolênico 140, 375-376, 397, 415

ácido docosahexaenóico 376, 397, 416, 458

ácido graxo 132, 138-142, 195, 374-376, 396, 417, 449, 454-455, $457,549,555-556,558$ ácido graxo insaturado $132,140,394,396$

ácido graxo linoléico 139-140, 375-376, 396, 400, 402

ácido graxo linolênico 415

ácido graxo livre 362, 374, 389-390, 548

ácido graxo monoinsaturado 139, 374-376, 382-383, 394-397,

$$
\text { 454-456 }
$$

ácido graxo ômega-3 362, 376, 396-397, 382, 416-417, 419

ácido graxo ômega-6 382, 396, 419

ácido graxo poliinsaturado 139-140, 141-143, 374-377, 380, 382-383, $396-397,416-417,454-456,556$

ácido graxo saturado 108, 118, 120, 139, 363, 374-376, 383, 394-398, $402,454-456$

ácido graxo transinsaturado $139,353,362-363,375-376,382-383$, 396, 449, 530-531

acilCOA ver metabólitos acetil coenzima A

acompanhamento nutricional 37, 525-535

aconselhamento nutricional 264-265, 267-268

ACP ver análise dos componentes principais

açúcar 107, 187-189, 191-192, 222, 263-265, 270, 273, 313, $350-353,365,382,412,449,455-458,503,513,530-531$

adipócitos 362, 558

adiponectina 389,391

adiposidade ver obesidade

adolescência 66, 79, 82, 85, 157, 309, 361, 463, 478-479, 545, 553, 560

AFC ver análise de fator comum

AFC ver análise de fatores confirmatória

AFE ver análise de fatores exploratória

AGL ver ácido graxo livre

agregação plaquetária 376, 397

agrotóxicos 486, 492

água corporal total 150-153, 156-158 
Água Duplamente Marcada ver métodos de medição de gasto energético

AIC ver Critério de Informação de Akaike

Aids 261, 290-,291, 439

albumina 116, 120, 205, 380, 393

álcool 101, 117, 133, 142, 156, 181, 197, 362-263, 374, 381-382, $399,415,419$

consumo 101, 142, 381-382, 399, 415

alcoolismo 131, 447, 449

aleitamento materno 17, 62, 68-72, 75, 292, 309, 314, 316, 322, $338,361,363,365,367-368,427-440,442,521,524-525$

algoritmo de Gauss-Newton 254

algoritmo de Newton-Raphson 254

algoritmo Fisher-scoring 254

algoritmo Lindstrom \& Bates 254

alimentação

complementar 261, 264-265, 267, 273, 310, 365, 429, 437, 530

crianças $315,361,437,440,525$

inadequada $106,326,521$

indígena $504,505,507,508,513$

saudável 312, 351, 353, 356, 365, 447, 449, 454, 455, 492-493, 521-523, 527-528, 530-531, 534-535

alpha de Cronbach 221-222

amamentação 21, 68, 176, 246-247, 259-260, 261, 264-266, 273, $309,368,427-439524,530,553-560$ ver tb aleitamento materno

American Association of Clinical Endocrinologists 392, 393

amido 262, 377, 393, 399

aminoácido 132, 142, 181, 269, 379-380, 412

análise de agrupamento 214,394

análise de consumo alimentar 505

análise de fator comum 215, 389

análise de fatores exploratória 232-233

análise de fatores confirmatória 233-234

análise fatorial 214-217, 223

análise longitudinal 248, 260

ancilostomíase ver doenças parasitárias

anemia

em crianças $270,302-307,311$

em gestantes 307-308

em idosos 307

em indígenas 511-513

em lactentes 303

em mulheres 303, 307-308

em puérperas 307-308

materna 311

no Brasil 302-306

nos lactentes 310

nutricional 302

por deficiência

de ferro ver anemia ferropriva de ácido fólico 299

de vitamina B12 299

por destruição de células vermelhas 299

anemia falciforme 299

anemia ferropriva 17, 20, 31, 134-135, 268, 271-272, 297-299, $301,303,305,307,309-317,512-513,515,528$

anemia hipocrômica 134, 299

anemia macrocítica 299

anemia megaloblástica 133

anemia microcítica 134, 299

anemia normocítica 299

anemia normocrômica 299

angiotensinogênio 390

antioxidante $132,137,141-142,205,372,374,377-382,398-399,412$

antropometria $20,31,37,49-50,53,57,62,68,69,71,81,93,112$,

118, 153 489, 505, 558 ver tb métodos de medição da composição corporal

Anvisa 529, 531

aproximação adaptativa gaussiana 254

aproximação laplaciana 254

arritmia 397

arteriopatia aterosclerótica 372

ascaridíase 328

aspirina 26,382

ataque cardíaco 397

ATBC Study 379

atenção básica 529, 534

aterogênese 390-391, 398

ateroma $142-143,371$

aterosclerose $371,373,378-379,390,398$

atividade física 19, 21, 79, 102, 154, 165-166, 169-170, 172$173,177,182,195-196,362-366,391,399,401-402$, 418, 508-509, 513, 558

auto-anticorpos 360-361

avaliação clínico-nutricional 117

avaliação dietética 120

avaliação global subjetiva 118

avaliação nutricional $68,118-119,131,505,506$

de adolescentes 79, 81, 83, 85, 87-88, 348

de adultos 82, 93

de crianças $50-51,53,55,57,59,61,65,76,282$

do idoso 116-117

AVC ver acidente vascular cerebral

\section{B}

betacaroteno 26, 137, 142, 187, 205, 272, 327, 341, 377-379, 398-399 ver tb provitamina A

biomarcadores de exposição nutricional 137

baixa estatura ver estatura

baixo peso ao nascer 33-34, 36-37, 43, 309-311, 314, 338, 364, $438,448,450,458,543$ ver tb peso corporal 
balanço energético 138, 165, 172, 289, 352, 373, 489, 548

Bancos de Leite Humano 433, 438-439, 524, 559

Baré ver populaçōes indígenas

Baysean Information Criterion ver Critério Bayesiano de Schwartz

beribéri ver desnutrição, classificação da

BHT ver butil hidroxitolueno

bioimpedância ver métodos de medição da composição

biomarcadores de exposição nutricional 127, 135, 141-142

biopsia hepática 335, 336

bócio iodoprivo 448, 529

bolsa família ver Programa Bolsa Família

BPN ver baixo peso ao nascer

butil hidroxitolueno 132

\section{C}

cafeína

consumo de 108, 133

cálcio $79,106,108,143,150,197,205,210,300,315,381,383,399$, 413, 415, 418, 457

calorimetria direta ver métodos de medição de gasto energético calorimetria indireta ver métodos de medição de gasto energético

Caltrac 172

Cambridge Heart Antioxidant Study 399

caminhada 168, 171, 362, 462, 465, 467

câncer 26, 114, 137, 139, 143, 185, 195, 197, 198, 379, 383, 544, $547,548,549$

câncer da próstata 448

câncer de cólon 391, 448, 462

câncer de endométrio 391

câncer de mama 26, 185, 198, 391, 448, 462

câncer de pâncreas 391

câncer de pulmão 379

câncer do reto 448

CAP ver compulsão alimentar periódica

carboidratos 139, 166-167, 181, 362-364, 374, 377, 383, 393-395, $397,400,402,412,416,418$

carbono 380

cardiomiopatia

infecciosa 373

nutricional 373

isquêmica $553,557,560$

reumática 373

carências nutricionais

diagnóstico laboratorial de 31

identificação de 118

carga glicêmica 393

cárie dentária 26

carne $25,143,191,198,209,347,375-376,382,400,417$

carotenóides 132, 142, 327-328, 337, 341, 379

biodisponibilidade dos 137 biomarcadores de exposição nutricional 137

catarata 118

catch-up (crescimento acelerado) 548, 553, 556, 559-560

CC ver circunferência da cintura

CDC ver Centro de Controle e Prevenção de Doenças

cegueira noturna 325-326, 328-329, 330, 332, 334 ver tb xeroftalmia centeio 377

Centro de Controle e Prevenção de Doenças 68-69, 81, 83, 85-86, $115,462,506$

Centro Latino-Americano de Perinatologia 37

Centro Nacional de Estatísticas de Saúde dos Estados Unidos 68-72, $75,77,81,282,338,451,507$

ceratomalacia 325,332 ver $t b$ xeroftalmia

cereais $262,377,382$

cesta básica alimentar 488,498

CG ver carga glicêmica

CGPAN ver Coordenação Geral da Política de Alimentação e Nutriçãa chá 381, 429, 432

Childhood Obesity Working Group of the Internation Obesity Task Force 348

chocolate 382

CIC ver citologia de impressão conjuntival

cicatrizes corneais $326,332,341$ ver tb xeroftalmia

citocina 389,391

citologia de impressão conjuntival 329, 335

CIUR ver crescimento intra-uterino restrito

cloreto de potássio

suplementação 414

cloreto de sódio 413

clorose ver ferro, deficiência de

cluster ver análise de agrupamento

CNSAN ver Conferência Nacional de Segurança Alimentar

cobre $79,136,381$

coenzima Q10 398

cogumelo 379

colelitíase 349

colesterol 120,135, 137-141, 159, 189, 191, 197, 205, 209, 281, $372-373,375,377,382$, 389-390, 393-402, 416, 418-420, $555-557,560$

consumo $108,398,401$

dieta rica em 416

dietético 398

redução nos níveis de 419

sérico 372, 396, 398-399

total $396,398,399$

colostro 427

composição corporal $20,79,98,110,149-160,166,168,172$

ver tb métodos de medição da composição corporal

aplicação em diagnósticos nutricionais 158-159

avaliação da 93

conceituação de 149-150 
histórico 150-151

medição da 149

modificação ao longo da vida 157-158

Compromisso Social para a Redução da Anemia Ferropriva no Brasil 528

compulsão alimentar periódica 478-479 ver tb transtorno da compulsão alimentar periódica

conceptualização dimensional 227, 232, 236

condiçôes nutricionais 81

Conferência Nacional de Alimentação e Nutrição 519

Conferência Nacional de Saúde 519

Conferência Nacional de Segurança Alimentar 485, 487, 491-492, 522

Conselho Nacional de Segurança Alimentar e Nutricional 487, 522-523

contínuo da variável latente 234, 236

controle glicêmico 374, 376-377

Coordenação Geral da Política de Alimentação e Nutrição 522-523, 526, 529, 531, 533

coronariopatia ver doença coronariana

crescimento

anormal 51

acelerado ver catch-up

fetal $31,34,36$

infantil 49, 66-67, 246-247, 253, 259, 266-267, 269, 554 ver tb Estudo de Crescimento Harpenden

adolescência 81 ver tb Estudo de Crescimento Harpenden

crescimento intra-uterino restrito 33, 35-36, 43, 458

critério bayesiano de Schwartz 254

critério de informação de Akaike 253,259

cromo, consumo de 363

curva de Atalah 39

curva de Rosso 36-37

\section{D}

dados antropométricos ver indicadores antropométricos

Dash ver dietary approches to stop hypertension

data da última menstruação 43

débito cardíaco 376

Decode ver Diabetes Epidemiology: Collaborative Analysis of Criteria in Europe

déficit antropométrico 290, 451

déficit de crescimento 17

déficit de estatura-para-idade 282-283, 286-288

déficit de peso-para-estatura 282, 286, 288

déficit de peso-para-idade 50, 69-70, 282-287, 291-292

déficit nutricional 49, 97, 116, 281-285, 289-292

déficit ponderal 284, 450-451

Delta Research Group 395

demanda metabólica 117-118, 328

densidade corporal 98, 151-152, 154, 158, 163, 380

densitometria corporal ver métodos de medição da composição corporal depleção nutricional 117,128 depressão 462, 473-479

derivados de leite 415, 418-419

desenho de itens 230, 232

desidratação 106,304

Design Concepts in Nutritional Epidemiology 19

desmame 17, 136, 310, 429, 432, 434-435

desnutrição $17,19-21,49,61,79,81,115-116,118,120,261,267$, $297,338,340,348,350,486,489,491,493,499,506,509$, $511-513,519,521,524-526,530-531,535$

aguda ver emaciação

crônica 53, 57

exposição à 112

indicador de 87

indígena 506, 511, 513

desnutrição energético-protéica 19, 281, 338, 448-449, 452, 458, 511-512

desnutrição infantil 17, 261, 282, 288, 450, 451, 506, 512, 521, 524

desnutrição, classificação da

formas graves

kwashiokor 281, 448-449

marasmo nutricional 281, 448

formas específicas

beribéri $24,448,510$

escorbuto 23, 24, 448

hipovitaminose A 20, 325 326, 329, 334, 336, 338, $448,529,533$
osteomalácia 448
pelagra $24,25,448$
raquitismo 448

Dexa ver métodos de medição da composição corporal

DHA ver ácido docasaexanóico

diabetes 20, 114, 117, 139, 364, 458, 462, 464, 544, 547, 549, 553

agravamento do 402

em adolescentes 360

em adultos 362

em crianças 360

em indígenas 508, 512-513

fatores de risco do 361-362, 365-366

gestacional 34-36, 359-361, 363-365

prevenção e controle 362-366, 394, 401-402

diabetes mellitus 85, 116, 213, 359-364, 371, 375-377, 390, 392-393, 400-402, 405-406, 410, 428-429, 445, 448, 475

tipo 1 359-361, 366, 391

tipo 2 87-88, 349, 359, 361, 368, 402

Diabetes Epidemiology: Collaborative Analysis of Criteria in Europe 390

Diabetes Prevention Program 401

diacilglicerol 389

diagnóstico nutricional 39, 57, 58, 62, 153, 158, 506

em gestantes 31,36

em idosos 118, 120

diário alimentar ver métodos de avaliação do consumo alimentar 
diarréia 58, 117, 118, 261, 272, 290, 292, 311, 314, 328, 339, 340, $427-430$

Diet and Reinfarction Trial 397

dieta 17, 19-20, 23-26, 135, 138-140, 146-147, 165-166, 181-182, 186-187, 189-190, 194-206, 208-212, 362-363, 391, 397, $412-420,505,508-511,513,553,555-557$

com alto teor de gordura 395,401

com baixo teor de gordura 395, 401-402

e doenças $19,20,25,201,214,223$

habitual 399

hipocalórica 383

hiperlipídica 108,362

hiperprotéica 108

lactoovovegetariana 41

pobre em gorduras totais 402

rica em carboidratos 394, 402

rica em fibras 394, 401, 402

vegetariana $376,382,417-418$

dietary approches to stop hypertension 418

Diretriz Brasileira para Diagnóstico e Tratamento de Síndrome Metabólica 389, 392-393

Diretrizes Nacionais para a Promoção da Saúde

Política Nacional de Atenção Básica 534

Política Nacional de Promoção da Saúde 534

dislipidemia 87, 101, 116, 363, 372, 389-391, 394-396, 402, 445, 508,547

dispêndio de energia ver gasto energético

distúrbios nutricionais 20,79, 531

dobra cutânea ver indicadores antropométricos

doença arterial periférica 371

doença aterosclerótica 371, 375, 398

doença coronariana 371-376, 378-379, 380, 391, 395-396, 400, 414, $461-463$

infarto do miocárdio 26, 141, 379, 391, 397, 399, 462

doença de Crohn 428-429

doença pulmonar obstrutiva crônica 462

doença renal 414, 462

doença respiratória 428

doenças cardiovasculares $20,85,87-88,114,116-117,133,137-139$, $141-142,159,213,349,363,371,372-382,390-392,395-402$, $411,414,475,513,543-544,547,560$ ver tb doença coronariana

biomarcadores de exposição nutricional 141-142

doenças carenciais $19,20,23,26,530$

doenças cerebrovasculares 411,448

doenças crônicas 26, 50,110,117, 121, 128, 138-139, 141-142, 213 , $310,312,354,361,364,427,429,447-448,462,464,475$, $543-544,553$

doenças crônicas não transmissíveis 19-21, 26-27, 101, 107-108, 117, $201,213,222,362,371,377,445-448,458,509,513$, $521-522,533,545$

doenças gastrointestinais 117

doenças infecciosas 213, 289, 290, 292, 310, 311, 325, 429, 445, 446, $448,507,511,512,513,531$ doenças metabólicas 391, 513, 544,

doenças parasitárias 300, 302, 445, 448, 507, 511- 513

ancilostomíase 312

ascaridíase 328

esquistossomose 310,312

estrongiloidíase 328

giardíase 328

doenças osteoarticulares 448

DPP ver Diabetes Prevention Program

DPT ver vacina tríplice

DUM ver data da última menstruação

E

Ebia ver Escala Brasileira de Insegurança Alimentar

educação alimentar 312, 527

educação nutricional $227,312,534$

efeitos aleatórios 245, 251-252, 254-258

efeitos fixos 245, 251-252, 260

Egir ver European Group for the Study of Insulin Resistance

$\mathrm{E} / \mathrm{I}$ ver estatura para idade

EIMCC ver Estudo Internacional Multicêntrico

emaciação 58

Encontro Mundial de Cúpula pela Criança 297

Endef ver Estudo Nacional da Despesa Familiar

envelhecimento 105-108, 110, 113-114, 117-118, 157-158, 213, 307, $310,316,364,417,420,446$

EPA ver ácido eicosapentanóico

epidemiologia da amamentação 21

epidemiologia da anemia ferropriva 31, 297, 528

epidemiologia da atividade física 461, 466,

epidemiologia da desnutrição 20

epidemiologia da desnutrição infantil 281, 350

epidemiologia da hipovitaminose A 31, 325, 326, 528

epidemiologia da obesidade 347

epidemiologia da xeroftalmia 31,325

epidemiologia das alterações nutricionais na adolescência 85

epidemiologia das DCNT 20

epigênese transgeracional 543, 548, 549

Equamax ver procedimento de rotação ortogonal

equivalente da atividade de retinol 327

Escala Brasileira de Insegurança Alimentar 485, 491, 493-495, 497, 498, 499

escalas formadoras do construto 232

escorbuto ver desnutrição, classificação da

escore Z de comprimento para idade 262-264, 266

escore $Z$ de peso para idade 263,559

Escherichia coli 429

espaço de conteúdo 230-232

espaço do desfecho 231, 232

esquistossomose ver doenças parasitárias 


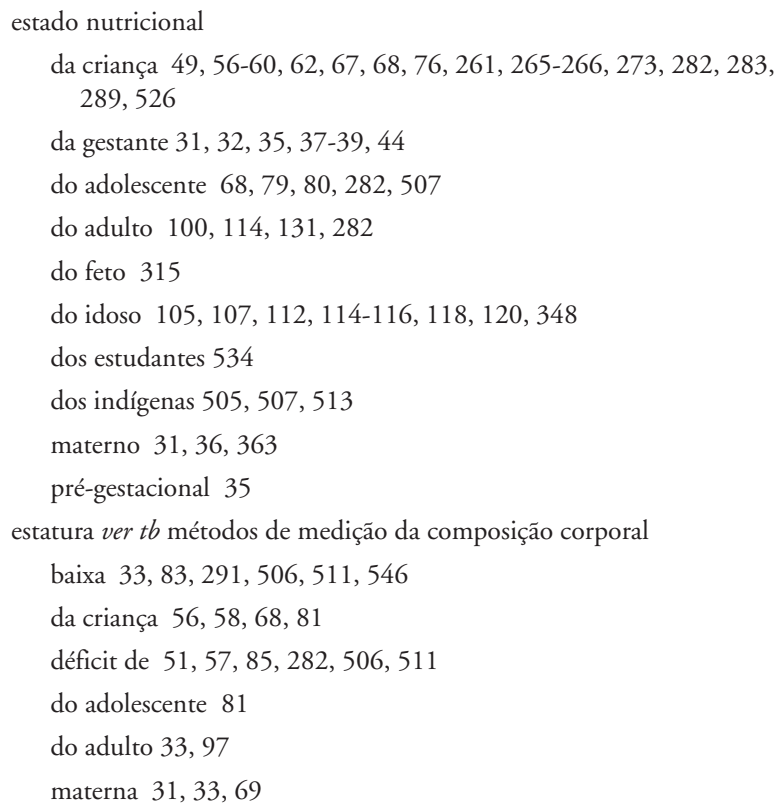

\section{F}

FAO ver Organização das Naçōes Unidas para Agricultura e Alimentação farinha de milho 25,313

farinha de trigo 313

fator bífido 427,429 fator inibidor do ativador do plasminogênio 389, 390, 391

fator Van Willebrand 380

ferritina $134,142,205,267,268,300-302,311,316$

ferro $128,132,134-136,142$

absorção de 268, 271, 300, 315

biomarcadores de exposição nutricional 136

indicadores bioquímicos de estado nutricional 134, 135

deficiência de 134-136, 269-271, 297-302, 309-316, 528

heme $134,136,270,300,313$

não-heme $106,134,268,300,313,315$

suplementação de $267,238,311,312,315,525,529$

ferropenia ver deficiência de ferro

fibras $138,347,362,364,374,381-382,393,399-401,417-418,513$

consumo de 106, 208-209, 377, 394, 402, 415

fibrinogênio 377,548

Finnish Diabetes Prevention Study Group 401

fitatos 136, 269, 300, 315

fitoestrogênio 381,398

flavonóides $135,381,398$

flúor 25,26

FNDE ver Fundo Nacional de Desenvolvimento da Educação

folato 128, 132-136, 142, 379-381, 456

biomarcadores de exposição nutricional 136

indicadores bioquímicos de estado nutricional 133, 134

folha de balanço de alimentos ver métodos de avaliação do consumo alimentar

fome 289-291, 326, 446-447, 486, 488-493, 495, 498-499, 519, $521-523,526,535,545-547,549$

fortificação de alimentos 135, 136, 267-271, 273, 313, 341

fotofobia 330

Framingham Heart Study 398

Framingham Offspring Study 394

freqüência cardíaca 467, 547 ver tb métodos de medição de gasto energético

fritura $382,396,400$

frutas $17,23,25,72,106-109,136,142,185-186192,197,205$, 208-209, 222, 265, 272, 281, 315, 341, 350, 352-353, 361-362, $365,375-378,381-382,394,397,412,414,418-419,429$, 449, 456,530

fumo 300, 371, 430 ver tb

Fundação Nacional de Saúde 504

Fundo Nacional de Desenvolvimento da Educação 520, 521, 527

\section{G}

ganho de peso ver indicadores antropométricos e peso corporal, aumento de ganho ponderal ver ganho de peso

ganho ponderal gestacional ver indicadores antropométricos $e$ peso corporal gestacional

gasto energético 165, 167-171, 176, 195-196, 347, 351, 461, 467, 489 ver tb métodos de medição de gasto energético

General Health Questionnaire 12477

Geografia da Fome 326 
giardíase ver doenças parasitárias

glicemia 359, 393, 396, 402

glicose

metabolismo da 392, 394

intolerância à 87, 372, 390, 396, 401

goma 377,399

gordura corporal $33-34,54,79,81-83,85,97-102,112,114,150$

$152-153,157-159,195,395,477$

gordura hidrogenada 139,412

gordura insaturada 396, 416

gordura monoinsaturada 400, 401, 416

gordura ômega-3 poliinsaturada 416

gordura saturada $373,396,400,418,531$

gordura trans $382,396,530,531$

gráfico de sedimentação de Cattell 219

grãos $143,263,265,350,377,382,393,394,397,402$

Guajá ver populaçôes indígenas

guar 399

Guaraní ver populações indígenas

Guia Alimentar para a Populaçāo Brasileira 531

\section{$\mathrm{H}$}

hábitos alimentares 50,107, 110, 118, 182, 186, 188, 190, 192, $194,201,203,221,312,341,351,353-354,371,373,379$, $394,400,402,448,487,530$

Harpenden Growth Study ver Estudo de Crescimento Harpenden HAZ ver escore $Z$ de comprimento para idade HDL ver lipoproteína de alta densidade

Health Professionals Study 398

Health Professionals Follow-up Study 378, 381

hematócrito 116, 299, 302

hemoglobina 116, 133, 134, 267-270, 298-302, 310-312, 316

Heritage Family Study 401

hidrometria ver métodos de medição da composição corporal

hipercolesterolemia 349, 371, 395, 398, 445

hiperglicemia 87, 364, 373, 394-395, 402

hiperhomocisteinemia 133, 142, 371, 380, 398

hiperinsulinemia 87, 390, 391, 394, 547

hiperpotassemia 414

hipertensão arterial 20-21, 34, 58, 87, 101, 117 133, 349, 361, 371-374, $379,381,389-391,394,400,411-415,417-420,462,464,508$, $512-513,522,547,553,556-557$

hipertrigliceridemia 87, 101, 372, 390, 395, 397, 402, 445

hiperuricemia 389, 391, 445

hipervitaminose 136

hipótese do jolly fat 475

hipótese reflected appraisal 474-475

hipovitaminose A ver vitamina A, deficiência de $e$ desnutrição, classificação da história dietética 109, 117

HIV 245-246, 261, 288-291, 433, 437-439, 525

HLA ver Human Leucocyte Antigen
Homa-IR 87, 394

homocisteína, concentração de 133-134, 142, 380, 398

homocisteinemia 133, 142, 371, 380, 398

Human Leucocyte Antigen 360

\section{I}

IA ver insegurança alimentar

IBGE 186, 348, 453, 455

ICCN ver Incentivo de Combate às Carências Nutricionais

idade gestacional 31, 33-37, 40, 42-43, 71, 258, 302, 533, 559

IDF ver International Diabetes Federation

idiotia iodopriva ver iodo, carência de

IG ver idade gestacional

IG ver índice glicêmico

IGF ver insulin growth factor

IHAC ver Iniciativa Hospital Amigo da Criança

IMC ver índice de massa corporal

impedância bioelétrica 505

impressão metabólica 544, 548-549

Inan ver Instituto Nacional de Alimentação e Nutrição

Inca ver Instituto Nacional de Câncer

Incap ver Instituto de Nutrición de Centroamérica y Panamá

Incentivo de Combate às Carências Nutricionais 524-525, 533

indicadores antropométricos

altura uterina 31,35

altura do joelho 113-114

circunferência cefálica 34, 50, 53-54, 69, 263,

circunferência da cintura 99, 100-102, 115-116, 187, 392-394,

circunferência da panturrilha $33,113,116,120$,

circunferência do braço (braquial) 31, 33, 112-113, 115-116, 120, 263,505

circunferência do quadril 99

circunferência do tronco 99

dobra cutânea 31, 33-34, 50, 55-58, 70, 83, 94, 96-99, 112 -

$113,115-117$

estatura materna 31,33

estatura-para-idade 68-70, 80, 282, 292

ganho de peso $31,32,35-37,39,44,51,80,112,258,259,262$, $264,311,349,351-353,361-363,383,389,476,438,509,522$, 553,560

índice de massa corporal pré-gestacional 31, 34-35, 37-38

peso-para-comprimento 69-71, 74

peso-para-estatura 35-38, 68-71, 81-82, 292

peso-para-idade 68-70, 74, 80-82, 282-284, 288, 292

perímetro do braço (braquial) 31, 33

perímetro da panturrilha 31,33

peso pré-gestacional 31-34, 36-37, 39, 42, 363-365, 431

indicadores bioquímicos 127, 128, 129, 130, 131, 132, 135, 136

de estado nutricional $127,128,129$

de exposição nutricional 128 
especificidade dos 131

estáticos 127,128

faixas de normalidade 129,132

funcionais $127,128,129$

pontos de corte 129,132

sensibilidade dos 131

valores de referência 129,132

indicadores bioquímicos de estado nutricional 127, 135, 136

índice antropométrico ver indicadores antropométricos índice de massa corporal 83-84, 87-88, 111, 120, 155, 158-159, $169,187-189,195,349-350,394,415,453,474,476$

em adolescentes 82, 85-86, 348, 478-479

em adultos 100-102, 114 , 391, 475, 477-478, 487-488, 508-509, 555

em crianças $61,68-69,281,352,479,555,558$

em idosos 112, 114-117, 154, 348

pré-gestacional 31,32, 33, 35, 36, 40-44, 245, 364-365

ver tb indicadores antropométricos

índice energético integrado 170-171, 174

índice glicêmico 362, 364, 377, 393, 394

infarto do miocárdio ver doença coronariana

infância $58,65,69,151,157,267-269,273,286,291-292,311$, 338-339, 342, 350, 361, 364, 430, 463, 478, 488-489, 509, 545-546, 553-557, 559-560,

Iniciativa Hospital Amigo da Criança 430, 433, 437, 439, 524

Iniciativa Unidade Básica Amiga da Amamentação 524

inquéritos alimentares ver métodos de avaliação do consumo alimentar

inquéritos recordatórios de 24 horas ver métodos de avaliação do consumo alimentar

insegurança alimentar $106,485-486$, 488-499

insegurança nutricional 491, 497

Institute of Medicine (Estados Unidos) 34-35, 39, 42, 327

Instituto de Nutrición de Centroamérica y Panamá 262

Instituto Nacional de Alimentação e Nutrição 519-524, 526

Instituto Nacional de Câncer 465-466

insuficiência cardíaca 391, 413

insuficiência renal 133,411

insulina 87-88, 116, 359-360, 362-364, 375, 377, 389-391, 393, 401402, 545-547, 558 ver tb Resistência à Insulina

insulin growth factor 116, 549

insulinemia 392, 396, 402

International Diabetes Federation 392-393

International Journal of Body Composition Research 151

International Obesity Task Force 82, 348

intolerância à glicose 87, 372, 396, 401

inventário ver métodos de avaliação do consumo alimentar

iodo 528

carência de 448

deficiência de 529

IOM ver Institute of Medicine (Estados Unidos)

IOTF ver International Obesity Task Force

IR24h ver inquéritos recordatórios de 24 horas
$\mathrm{J}$

janela de exposição 544, 546, 547, 548, 549

Japanese-Brazilian Diabetes Study Group 391

\section{K}

Kaingáng ver populaçôes indígenas

KMO ver teste de Kaiser-Meyer-Olkin 216-217

kwashiokor ver desnutrição, classificação da

\section{L}

lactação 71, 75, 128, 131, 262, 300, 315, 432, 435, 438, 545, 549

lactobacilos 429

lactose, intolerância à 108

laticínio 208, 374-375, 394-395, 399

LDL ver lipoproteína de baixa densidade

legumes 208, 265, 281, 350, 362, 365, 377, 379, 382, 412, 449, 456,530

leguminosas 25, 377, 382, 456

Lei de Segurança Alimentar e Nutricional 523

leite artificial 555-556

leite desnatado 221-222, 326,

leite consumo 352,361

leite enriquecido com ferro 270

leite enriquecido com AGP 380

leite integral 222, 266, 272, 315, 361, 525, 555,

leite pasteurizado 438

leite materno 262, 265, 267, 272-273, 309, 315, 325, 336, $427-432,434,438-439,524,548,554-559$

leite pó $262-264,266,268,269,271$

leite semidesnatado 270

leucócitos 128, 427

linfócitos totais 116

lipídios 108, 138-141, 167, 181, 396, 416, 454

biomarcadores de exposição nutricional $139,140,141$

lipoproteína de alta densidade 87, 101, 372-377, 381, 389, 390, 394, 396-398, 401-402, 418, 547, 557

lipoproteína de baixa densidade 138-139, 159, 205, 372, 390, 394-399, 401, 418, 557

Lisrel 8 ver software 234

litíase renal 415

Lyon Diet Heart Study 397

\section{M}

macronutrientes 189, 201, 282, 393, 453-456

macrossomia fetal 36, 363, 364

mácula, degeneração da 137

magnésio 363, 381, 383, 413, 418

consumo 415

suplementação 415 
magreza $85,121,473$

malária 261, 272, 301-302, 310, 312, 511

MAN ver Mini-Avaliação Nutricional

manchas de Bitot 326, 330, 332, 334 ver tb xeroftalmia

mapa do construto 230, 232

mapas da fome em terras indígenas 505

marasmo nutricional ver desnutrição, classificação da

marcadores antropométricos ver indicadores antropométricos

marcadores bioquímicos ver indicadores bioquímicos

massa corporal 51, 82, 282

total 96

magra $40,44,101,110,115-116$

massa gorda 112

massa corporal livre de gordura 112, 114

massa muscular 79, 82, 112, 116, 118, 157-158

massa óssea 79

matriz de co-variância 258

simétrica composta 254

uniforme 254

matriz de variância 252, 258

maturidade química 151

medidas antropométricas ver indicadores antropométricos

menarca 81

menopausa 475-476

metabólitos acetil coenzima A

metilação 549

metionina 133-134, 379-380

método antropométrico ver antropometria

método de Atalah 39

método de Teoria de Resposta ao Item 234

método do Gradiente 254

método DUD (doesn't use derivatives) 254

método Fatorial ver métodos de medição de gasto energético

método Fescina 37

método mãe canguru 438

método Payette ver questionário Payette

métodos bioquímicos 127, 131-132

especificidade dos 131

sensibilidade dos 131

métodos de avaliação do consumo alimentar 109, 127, 183, 201, 210

diário alimentar 183, 186-187

folha de balanço de alimentos 183-185

inquéritos alimentares $127,131,138-139,141,213$

inventário 183-185

recordatório 24 horas 183, 187, 189-190, 194, 196-197, 414, 510

recordatório 72 horas 187

Pesquisa de Orçamento Familiar 86-88, 107, 110-112, 115, 186, 282-293, 348, 350, 352-353, 355-356, 365, 511

questionário de freqüência alimentar 109-110, 183,189-195, $197,200-210,214,216-219,221-222,224,415,510$ registro alimentar 109-110, 186

métodos de medição da composição corporal 34, 49-50, 59, 69,

$74,81,93,112,118,149,151,153,156,489-490,505$

antrometria 153

bioimpedância 156

densitometria corporal 151, 153

Dexa 152-153, 159

dobra cutânea 153

hidrometria 152,157

pesagem hidrostática $150-151$

peso corporal e estatura 149, 154, 473, 477

potássio corporal total 152

métodos de medição de gasto energético

acelerômetro 169, 171-172, 467

água duplamente marcada 166-169, 173, 176, 187, 194-196

calorimetria direta 166-167, 169

calorimetria indireta 166-167, 169, 173

freqüência cardíaca 167-169, 172

método fatorial 170,172

métodos recordatórios ver métodos de avaliação do consumo alimentar Metropolitan Life Insurance Company, padrão de referência do 35 micronutrientes 261-265, 267-270, 274, 282, 290, 510-511, 525, 533

baixa ingestão de 108

deficiência de 31, 340, 510

dosagens séricas de 117

minerais $381,383,412-413$

consumo 108

mini-avaliação nutricional 118, 120

mini-exame de estado mental 118

Ministério da Agricultura 520

Ministério da Educação 520-521, 523, 526-527, 534

Ministério da Previdência 520

Ministério da Saúde 37, 266, 273, 507, 519-526, 529, 533-534

Ministério do Desenvolvimento Social e Combate à Fome 521, 523, $526-527,534$

Ministério do Trabalho 520, 528

modelo alimentar protótipo 221

modelo de dados longitudinais 255

modelo de efeitos aleatórios 259

modelo de efeitos fixos 260

modelo de efeitos mistos 246, 248, 250, 251, 252, 254, 255, 257 258,260

modelo de mensuração 232

modelo de regressão assintótico 259

modelo não linear 234, 251

modelos polinomiais 251

monoglicerídeo 374

monoglutamato 380

mortalidade fetal 34

mortalidade infantil 32, 71, 246, 291, 338, 363, 427-428, 434, 445, $448,458,501,526$ 
morte materna 310

mucilagem 377

musculatura total corporal 151

\section{$\mathrm{N}$}

NAF ver nível de atividade física

Nafo ver nível de atividade física ocupacional

nanismo nutricional 448

National Cholesterol Education Program Adult Treatment Panel III 87, 391-393

National Health and Nutrition Examination Survey 69-70, 83, 112, 114115

NBCAL ver Norma Brasileira para Comercialização de Alimentos

NCEP-ATPIII ver National Cholesterol Education Program Adult Treatment Panel

NCHS ver Centro Nacional de Estatísticas de Saúde dos Estados Unidos neuroticismo 476

NHANES ver National Health and Nutrition Examination Survey niacina 25-26, 106, 456

consumo de 106

consumo inadequado em idosos 109

nitrogênio 24, 132, 150-151, 188, 194-195, 203

níveis tensionais $412-415,418-419$

níveis tensionais $412-415,418-419$

nível de atividade física 34, 170-176, 182, 196

nível de atividade física ocupacional 465

Norma Brasileira para Comercialização de Alimentos 435, 438, 524

normotensos 413-414, 417, 420

NSI ver Nutrition Screening Initiative

Nurses Health Study 378, 381

nutrientes

aumento da necessidade 79

consumo inadequado 108

ingestão 106

Nutrition Screening Initiative 115

\section{$\mathrm{O}$}

obesidade 17, 19-21, 35-36, 39, 49, 79, 82-87, 102, 111-115, 151, $154,158-160,213,359-361,364,428-429,445,447-449$, 453, 458, 467, 486-487, 489, 512, 521, 530-531, 535, $547-548,556,558,560$

abdominal 362, 363

avaliação de 82

caráter epidêmico da 350

conseqüências da 349

em crianças 351-352, 361, 364

morbidades associadas à 86

no Brasil 165, 348, 349, 350-351, 353

pós-parto 34

pré-gestacional 35

risco de 85,97 visceral $371-372$

obesidade, diagnóstico da 51

em adolescentes $82,83,361$

em adultos 351

em homens 348

em idosos 107, 111, 113

em indígenas 506-509, 511, 513

em mulheres 353

obesidade, fatores associados à 350

ambientais 350

sociodemográficos 350

socioeconômicos 350

Oblimin direto ver procedimento de rotação oblíqua

ocitocina 427,431

oesteoartrite 349

óleo de canola 376

óleo de peixe 376

óleo de soja 265-266, 376, 525

óleo industrializado 376

OMS ver Organização Mundial da Saúde

Organização das Nações Unidas 185

Organização das Nações Unidas para Agricultura e Alimentação 174, $176,183,185,361$

Organização Mundial da Saúde 17-18, 33, 35, 44, 67-72, 74-75, 77, 79-80, 82-83, 85, 87-88, 100, 102-103, 111-112, 114, 172, 261, 281-283, 286-288, 291, 297, 299, 302, 307, 314-316, $325,353,362,366,429,437-438,447,450,506-507$, $522,524,529,533$

Organização Pan-Americana da Saúde 491

osteomalácia ver desnutrição, classificação da

osteopenia 108

osteoporose 108, 141, 143, 160, 462, 463

biomarcadores de exposição nutricional 143

ovo $27,265,326,375$

óxido nítrico 380,381

oxigênio $132,134,142,150,167,297,316,363,374$

\section{$P$}

PAB ver Piso de Atenção Básica

PAD ver pressão arterial diastólica

padrão alimentar 20, 27, 195, 213-215, 220-222, 224, 419

análise de componentes principais do 213-224

de risco 222

mudanças no 107-108, 117

saudável 222

padrão dietético ver padrão alimentar

PAI-1 ver inibidor do ativador do plasminogênio

part-whole correlation 44

parto

a termo 44

cirúrgico 33 
complicações no operatório 34, 36, 364

pós-termo 44

prematuro 44

trabalho de 33

PAS ver pressão arterial sistólica

PAT ver Programa de Alimentação do Trabalhador

Payette ver questionário Payette

PC ver peso corporal

PCr ver proteína-C reativa

pectina 377,399

peixe, consumo de 185, 193, 265

efeitos benéficos do 376, 378, 397

na dieta japonesa 382,400

pelagra ver desnutrição, classificação da

perda ponderal recente ver peso corporal, perda de

perda ponderal ver peso corporal, perda de

perímetro ver circunferência

pesagem hidrostática ver métodos de medição da composiçāo corporal peso atual ver peso corporal atual

peso corporal 34, 42-43, 50-51, 58, 60, 69-71, 73, 81-83, 96-97, 112-114, 417-418 ver tb métodos de medição da composição corporal

aferido $43,97,121$

atual 118,418

aumento de $36-37,44,52,80,87,363$

baixo $39-40,73,79,82-83,85,87-88,115,118$

curvas de 36

déficit de 60-62, 111-112

definitivo 79

em adultos 96

em recém-nascidos 32, 34, 39, 42, 44, 361, 553, 554-555

excesso de ver sobrepeso

fetal 36,42

gestacional $31-34,36-37,42-43,364$

hidrostático

ideal $473,475-477$

materno 33-34, 36, 43, 365

mudanças no 120

no momento da consulta 36

normal 43

perda de 43, 113, 117-118, 120-121, 362, 418, 558

referido $43,97,121$

relativamente normal 113

retenção de 36

variação de 96,117

peso de gordura $150-152,159$

peso livre de gordura 149-153, 156-159

peso magro ver peso livre de gordura

peso-para-comprimento ver indicadores antropométricos

peso-para-estatura ver indicadores antropométricos

peso-para-idade ver indicadores antropométricos
Pesquisa de Orçamento Familiar ver métodos de avaliação do consumo alimentar

Pesquisa de Padrōes de Vida 111-112, 348, 353, 355, 464-465

Pesquisa Estadual de Saúde e Nutrição de Pernanbuco 303

Pesquisa Nacional por Amostragem de Domicílios 110, 497

Pesquisa Nacional sobre Demografia e Saúde 293, 511, 533

Pesquisa Nacional sobre Saúde e Nutrição 81-84, 87, 110-112, 115 , $293,348,511,521$

pesquisas de orçamento familiar ver métodos de avaliação do consumo alimentar

PG ver peso de gordura

Physicians' Health Study 26

piridoxina ver vitamina B6

pirimidina 379

pirogalol 132

Piso de Atenção Básica 525

Plano de Frankfurt 53, 54, 55, 97

PLG ver Peso Livre de Gordura

plicômetro 56-57

PLS ver Programa Leite é Saúde

PM ver peso magro

PNAD ver Pesquisa Nacional por Amostragem de Domicílios

PNAE ver Programa Nacional de Alimentação Escolar

PNDS ver Pesquisa Nacional sobre Demografia e Saúde

PNAN ver Política Nacional de Alimentação e Nutrição

pneumonia 261, 290-291, 428, 430

Pniam ver Programa Nacional de Incentivo ao Aleitamento Materno

PNSN ver Pesquisa Nacional sobre Saúde e Nutrição

POF ver Pesquisa de Orçamento Familiar

polidipsia 359

poliglutamato 380

polipílula 382

polissacarídeo 377

Política de Segurança Alimentar 522

Política Nacional de Alimentação e Nutrição 365, 520, 522, 528, 531, 533,534

poliúria 359

populações indígenas $347,360-361,364,507,509-512$

Baré 507

Guajá 511

Guaraní 511

Kaingáng 510

Suruí 510-512

Teréna 510-511

Xavánte 507, 509-510, 512

potássio 381, 382, 413-414, 418

consumo de 412, 414-415, 418, 420

potássio corporal total ver métodos de medição da composição corporal potencial hiperglicêmico pós-prandial 363

PPR ver perda ponderal recente

PPV ver Pesquisa de Padrōes de Vida 
pranchas de Tanner 80

pré-albumina 117

pré-eclampsia 36

prega cutânea ver dobra cutânea

pressão arterial 281, 373, 376, 381-382, 411-417, 419-420, 556-557, 560

diferenças de 418

elevação da 412, 416

em vegetarianos 417

medidas de 411

níveis da 390, 412-413, 416-420

queda da 418

redução da 414-417, 419-420

valores elevados de 411

média 420

pressão arterial sistólica 41 1, 413-414, 417-418, 420, 557

pressão arterial diastólica 411, 413-420, 557

procedimento de rotação oblíqua

Oblimin direto 220

Promax 220

procedimento de rotação ortogonal

Equamax 220

Quartimax 220

Varimax 220-222, 233

processo aterogênico 372

processo de grupos focais 230

processo de grupos nominais 230

Programa Agentes Comunitários de Saúde 534

Programa Alimentação Saudável 523

Programa Auxílio Gás 526

Programa Benefícios de Prestação Continuada 526

Programa Bolsa Alimentação 266, 523, 525-526, 533

Programa Bolsa Escola 526

Programa Bolsa Família 303, 523, 526-527, 533

Programa Brasil Escolarizado 527

Programa de Alimentação do Trabalhador 527-528

Programa de Atenção Integral às Doenças Prevalentes na Infância 265

Programa de Renda Mensal Vitalícia 526

Programa Fome Zero 523

Programa Leite é Saúde 524, 525

Programa Nacional de Acesso à Alimentação 526

Programa Nacional de Alimentação e Nutrição 522

Programa Nacional de Alimentação Escolar 520, 527, 528

Programa Nacional de Imunização 340

Programa Nacional de Incentivo ao Aleitamento Materno 524

Programa Nacional de Prevenção e Controle dos Distúrbios por Deficiência de Iodo 529

Programa Nacional de Renda Mínima ver Programa Bolsa Alimentação 525

Programa Nacional de Suplementação de Ferro 529

Programa Nacional de Suplementação de Vitamina A 529
Programa Nacional do Leite 266

Programa Saúde da Família 303, 316, 529, 534, 537

Programa de Controle e Prevenção de Carências de Micronutrientes 528

programas de promoção da saúde e da alimentação saudável 527, 535

programas de promoção da segurança alimentar e nutricional 527, 535 programação metabólica 350, 543-544, 546, 548-549

Promax ver procedimento de rotação oblíqua proteína 106, 108, 117, 377, 383, 412, 416, 418, 447, 454-558

proteína $\mathrm{C}$ reativa 117

proteína de transferência de á-tocoferol 138

proteína ligante de retinol 137, 328, 335, 336

proteína transportadora de retinol 117

proteína de origem vegetal 417

protoporfirina 134

provitamina A 137, 327, 378

PSF ver Programa Saúde da Família

psicometria 232, 238

análises psicométricas 232, 234

enfoque psicométrico 232, 233, 234, 235, 236, 237

evidências psicométricas 230

modelagem psicométrica 232

propriedades psicométricas 215, 233-234

trajetória psicométrica 230

purina 379

\section{Q}

Quartimax ver procedimento de rotação ortogonal

QFA ver Questionário de Freqüência Alimentar

Questionário de FrequiênciaAlimentar ver métodos de avaliação do consumo alimentar

Questionário Internacional sobre Atividade Física 466

Questionário Payette 118-120

\section{R}

$\mathrm{R}$ ver software

r24 ver recordatório 24 horas

raf ver razão de atividade física

raquitismo ver desnutriçāo, classificação da

razão cintura/quadril 99, 100-103, 116

razão de atividade física 170

rbp ver proteína ligante de retinol

rcq ver razão cintura/quadril

rdr ver teste de resposta a uma dose de retinol

re ver requerimentos energéticos

recordatório 24 horas ver métodos de avaliação do consumo alimentar recordarório 72 horas ver métodos de avaliação do consumo alimentar referência de crescimento 69

referência do NCHS 69

referência do Reino Unido 68 
referência NCHS-OMS 77

referência NCHS/CDC 69

reflected appraisal ver hipótese reflected appraisal

registro alimentar ver métodos de avaliação do consumo alimentar registro dietético ver métodos de avaliação do consumo alimentar relação cintura/quadril ver razão cintura/quadril

relação colesterol/HDL 101

relação colesterol total/HDL 101

Relatório Mundial de Saúde 17

requerimentos energéticos 172,176

resistência à insulina 87-88, 362-363, 371-374, 389-394, 396, 403, 546547,559

resposta glicêmica 362

retinol activity equivalent ver equivalente da atividade de retinol

retinol ver vitamina $\mathrm{A}$

retinolemia 327

reumatismo 462

Revised Conflict Tactics Scales 231

RI ver resistência à insulina

riboflavina 26, 109, 129-130, 262, 380

risco cardiovascular 101, 102, 113

risco nutricional 34, 106, 121

alto 121

baixo 121

em gestantes 37

grupo de 79,110

moderado 121

situações de 49

$S$

S-Plus/R ver software

sais de ferro 298, 312, 313, 314, 315, 316

sais minerais 447

sal $449,458,556$

alto consumo de 412, 416

de cozinha 313,413

diminuição do 412, 414, 420

necessidade humana diária de 413

sarampo 261, 272, 290, 336, 338, 340-341

SAS ver software

saúde bucal 106, 107, 117

saúde coletiva 297, 309

saúde da criança 261, 265, 529

saúde indígena 504, 513

saúde pública 221, 271, 299, 302, 316, 325-326, 337, 350, 359 , 519,528

scree plot ver teste gráfico de Cattel 219

sedentarismo 107, 112, 359, 362, 382, 449, 457, 461, 464, 467, 468

segurança alimentar e nutricional 21, 106, 265, 288, 312, 447 , 485-487, 490-495, 497, 498, 499, 503-505, 522-523, 527, 534

selectina-E 381 selênio $116,132,205,377,381-382,398-399$

Serviço de Saúde Pública (Estados Unidos) 24, 25

Short Form-36 Health Survey Questionnaire 476

síndrome da morte súbita 429, 430

síndrome dos ovários policísticos 391

síndrome metabólica 20-21, 26, 87-88, 101, 117, 203, 372

aspectos epidemiológicos da 87,101

aspectos nutricionais da 87,101

na adolescência 361

síndrome xeroftálmica 328-329, 332, 338

Sistema de Informação da Atenção à Saúde Indígena 504

Sistema de Informação da Atenção Básica 525

Sistema de Nascidos Vivos 533

Sistema de Vigilância Alimentar e Nutricional 505, 533

Sistema Nacional de Segurança Alimentar e Nutricional 523

Sistema Único de Saúde 21, 519, 529, 533-535

skinfolder caliper ver plicômetro

sobrepeso 17, 19, 21, 26, 34-36, 39-40, 43, 49, 61, 70, 82-88, 102, $115,154,159,187,209,213,377,412,415,418,445$, $447-448,453,458,473-478,487,489,506-507,509$, $512,521,556,558$

declínio de 87 em adolescentes 82, 83, 86, 87, 88, 101, 348, 365-366 em crianças $61,69,351,366$

em idosos 107

morbidades associadas ao 86

no Brasil 165, 348

pós-parto 34

pré-gestacional 365

risco de 83

sódio $143,150,195,197,203,381,413,414,418,419,555,556$

consumo 413,414

conteúdo 419

efeito da ingestão de 419

níveis de 419

redução no consumo 413

restrição de 414, 418, 419

testes de redução de 414

software

Lisrel 8234

R 234, 249, 258

S-Plus/R 254

SAS 254

Stata 234

Winbugs 254

soja $139,220,222-223,262-266,376,381-382,394,396-397,400,525$

solução de reidratação oral 429

soma de quadrado residual $253-254$

Stata ver software

subnutrição ver déficit de peso-para-idade

sulfido 381 
superóxido dismutase 381

suplemento alimentar 261-267, 269, 417

Suruí ver populações indígenas

SUS ver Sistema Único de Saúde

\section{$\mathrm{T}$}

tabagismo 102, 131, 134, 143, 349, 350, 382, 447, 449, 558

talassemia minor 272

taxa de ganho de peso 42

taxa líquida de peso 42

taxa metabólica basal 165-166, 168-178, 180, 489

TCAP ver transtorno da compulsão alimentar periódica

técnica de aferição, padronização da 93, 96

técnica Delphi 230

teoria da generalização 234

teoria de resposta ao item 234

teoria desenvolvimentista da origem da saúde e doença 553

Terceiro Estudo para Investigação de Saúde e Nutrição ver NHANES

Teréna ver populações indígenas

teste de esferecidade de Bartlett 216, 217

teste de Kaiser-Meyer-Olkin 216

teste de resposta a uma dose de retinol 335,336

teste gráfico de Cattel 219

tetraidrobiopterina 381

TG ver Teoria da Generalização

TGD ver tolerância à glicose diminuída

TGP ver taxa de ganho de peso

The Surgeon General's Report on Nutrition and Health 27

tiamina 24, 26, 109, 262

TLP ver taxa líquida de peso

TMB ver taxa metabólica basal

TNF-alfa ver fator de necrose tumoral alfa

tolerância à glicose diminuída 360, 362, 364

transferrina 117, 134, 135, 136, 301

transição demográfica $105,213,521$

transição epidemiológica 26, 213, 302, 316, 445-450, 457-458

transição nutricional 17, 20-21, 26, 107, 213, 302, 316, 521-523, 530, 533-535

transtorno da compulsão alimentar periódica 478-479

transtornos mentais 473-479

Treatise of the Scurvy in Three Parts 23

TRI ver teoria de resposta ao item

triagem nutricional 50, 115

triglicéride 374- 377

trombomodulina 381

trombose $374,379,380$

\section{U}

ulceração corneal 325 ver tb xeroftalmia

ultra-sonografia 44
Unicef 74-75, 273, 277, 297, 314, 316, 437, 514, 524

Universidade de Southampton 19

USG ver ultra-sonografia

\section{V}

vacina anti-sarampo 340

vacina Sabin 340

vacina tríplice 272,340

vacinação 272,340

validação 20, 135, 151, 191-192, 195-196, 202-208, 210

validade concorrente 236

validade de construto 232, 236

validade de critério 236, 237

validade de mensuração 228, 229

validade dimensional 232, 233

validade operacional 228, 229

validade preditiva 236

valor antropométrico ver índice antropométrico

valor calórico total 376

variância acumulada 219

variância compartilhada 215

variância exclusiva 215

variância explicada 218, 219

variância residual 250

variância total 217, 218, 219

variância total explicada 218, 219

Varimax ver procedimento de rotação ortogonal

VCT ver valor calórico total

vegetais $222,378,380,381,382,383,419$

verduras $17,25,186,198,209,377,382,418,449,456$

vinagre 23

vinho 382

vitamina A 17, 31, 116-117, 132, 136-137, 142, 189, 192, 202, 205, 262, 272, 300, 325, 327-329, 334-336, 338, 341, 457

absorção de 328

administração compulsória de 326

biomarcadores de exposição nutricional 136,137

concentrações de 325, 335-336

consumo deficiente de 109

deficiência de 20, 31, 118, 261, 272-274, 325-328, 334, 336$338,341-342,448,511,528,529,533$

megadoses 340, 341, 529

suplementação de 340

toxicidade da 340

vitamina $\mathrm{A}$, distúrbios da deficiência de 325

xeroftalmia 272, 325-330, 334, 336, 337, 339, 341-342

em crianças 341

no Brasil 326-327

vitamina A pré-formada 327, 328, 341

vitamina B2 380 
vitamina B6 134, 380

vitamina B9 ver ácido fólico

vitamina B12 133, 134, 135, 380

vitamina C 23, 24, 26, 106, 117, 132, 136, 142, 188, 189, 262, $268-269,270,271,300,378,379,398413,417$

alta ingestão de 109

baixo consumo de 109

deficiência de 117

vitamina D 143

vitamina E 117, 132, 137-138, 141-142, 205, 363, 372, 378-379, 398-399

biomarcadores de exposição nutricional 138

VLDL ver lipoproteínas de densidade muito baixa

\section{W}

WAZ ver escore $\mathrm{Z}$ de peso para idade

Weanimix (suplemento alimentar) 263

Wechsler Intelligence Scale for Children - Revised 559

Winbugs ver software

\section{$\mathrm{X}$}

Xavánte ver populaçōes indígenas

xeroftalmia ver vitamina A, distúrbios da deficiência de $e$ síndrome xeroftálmica

xerose $330,332,334$

xerostomia 106

\section{$\mathrm{Z}$}

zinco 17, 79, 109, 116, 132, 136, 273, 381-382, 456, 525

aporte adequado de 109

consumo insuficiente de 109 
Formato: $21 \times 26 \mathrm{~cm}$

Tipologia: Adobe Garamond e Mudos Light

Papel: Offset $70 \mathrm{~g} / \mathrm{m}^{2}$

Cartão Supremo $250 \mathrm{~g} / \mathrm{m}^{2}$

Fotolito: Engenho e Arte Editoração Ltda. (capa)

Reimpressão e acabamento: Imprinta Express Gráfica e Editora Ltda.

Rio de Janeiro, dezembro de 2009.

Não encontrando nossos títulos em livrarias, contactar:

\section{EDITORA FIOCRUZ}

Av. Brasil, 4036 - 1aadar - sala 112 - Manguinhos

21040-361 - Rio de Janeiro, RJ

Tel.: (21) 3882-9039 e 3882-9041

Telefax: (21) 3882-9006

www.fiocruz.br/editora

editora@fiocruz.br

EDITORA ATHENEU

$0800267753 \cdot$ www.atheneu.com.br 